FAGULTAD DE GIENGIAS SOGIALES

UNIVERSIDAD DE SALAMANGA

\title{
MORTALIDAD E HIGIENE URBANA EN MADRID EN EL PRIMER TERGIO DEL SIGLO XX
}

Yolanda Piedad Casado Ruiz

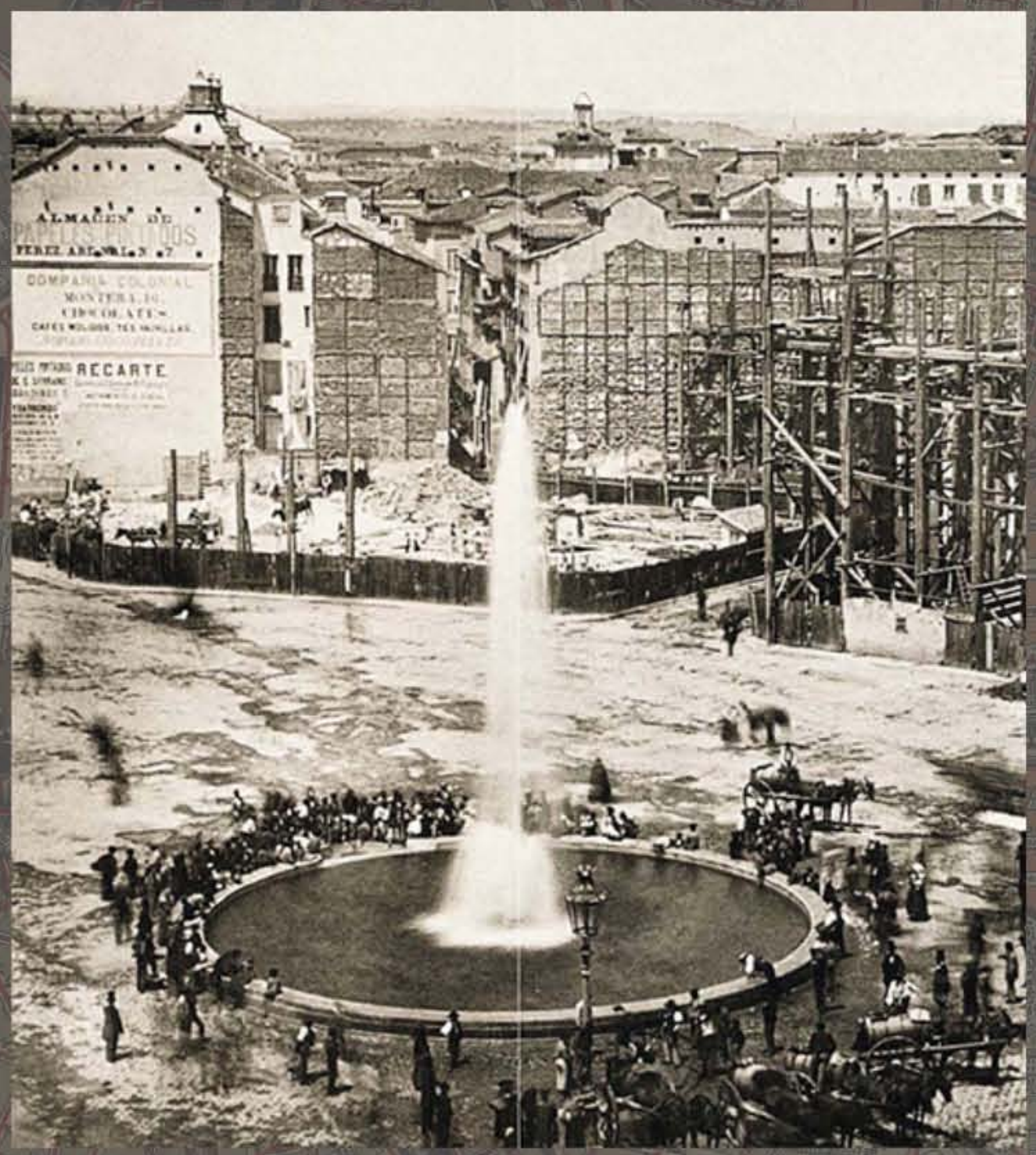

Tesis doctoral dirigida por:

Diego Ramiro Fariñas

Alberto del Rey Poveda

DEPARTAMENTO DE SOGIOLOGÍA FACULTAD DE CIENCIAS SOGIALES UNIVERSIDAD DE SALAMANGA 


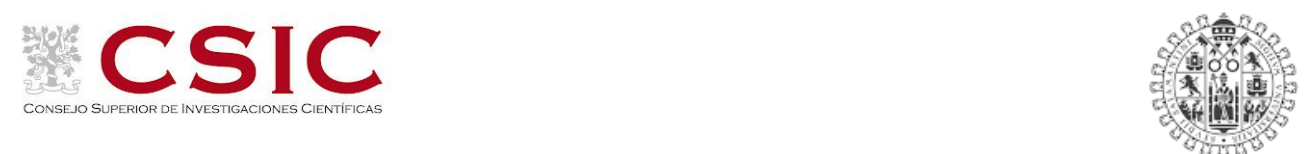

VNiVERSIDAD

BSALAMANCA

\title{
MORTALIDAD E HIGIENE URBANA EN MADRID EN EL PRIMER TERCIO DEL SIGLO XX
}

\author{
MEMORIA PARA OPTAR AL GRADO DE DOCTOR \\ PRESENTADA POR \\ Yolanda Piedad Casado Ruiz
}

Bajo la dirección de los doctores:

Diego Ramiro Fariñas

Alberto del Rey Poveda

DEPARTAMENTO DE SOCIOLOGÍA

FACULTAD DE CIENCIAS SOCIALES

UNIVERSIDAD DE SALAMANCA.

Salamanca, 2021 



\section{Agradecimientos}

Mis agradecimientos deben comenzar, de manera obligatoria, hacia las instituciones y proyectos que han hecho posible el desempeño de la presente tesis doctoral. Tanto desde el punto de la financiación, como de la posibilidad de acceso a las fuentes de datos empleadas, así como por la oportunidad de conocer al personal más cualificado en diversas áreas del conocimiento; desde la demografía, la historia o la sociología a la medicina o la epidemiología.

En este sentido, en primer lugar, a mi adscripción al proyecto de $\mathrm{I}+\mathrm{D}+\mathrm{i}$ "Mortalidad infecciosa $y$ condiciones de vida en áreas urbanas: el ejemplo de Madrid" (Referencia proyecto CSO2011-29970), con la beca de Formación de Personal Investigador, de 2013 a 2016, en Departamento de Población del Centro de Ciencias Humanas y Sociales del CSIC, bajo la dirección del Dr. Diego Ramiro Fariñas. Vinculado al proyecto anterior, pude disfrutar de la ayuda para realización de estancias breves en otros centros de investigación (Referencia ayuda BES-2012-055279), que me permitió asistir como personal visitante en el Departamento de Estadísticas Sociales y Demográfica, de la Facultad de Ciencias Sociales de la Universidad de Southampton (Reino Unido), bajo dirección del Doctor Andrew Hinde, durante tres meses en el año 2014. Asimismo, destacar los proyectos "Supervivencia y salud a lo largo del ciclo de vida $y$ diferencias generacionales en el envejecimiento: un análisis por edad, momento y generación” (RTI2018-097812-B-I00) del Ministerio de Ciencia, Innovación y Universidades y "Los efectos de la salud en la primera infancia sobre la salud y mortalidad adulta" (CSO201569834-R), del Ministerio de Economía y Competitividad, que han subvencionado parte de mis actividades científicas, tales como asistencia a congresos y cursos de formación especializada.

Una vez finalizado mi periodo de beca FPI, tuve la suerte de continuar dentro del Grupo de Investigación del CCHS-CSIC dirigido por Diego Ramiro Fariñas, bajo varios contratos. De 2017 a 1918 dentro del Proyecto Europeo Methodologies and Data mining techniques for the analysis of Big Data based on Longitudinal and Epidemiological Registers (LONGPOP) (Contract 676060. Entidad financiadora: European Commission, H2020 Programme, H2020MSCA-ITN-2015) y de 2018 a 2019 con un contrato en el marco del Proyecto "Contrato Tecnológico entre el CSIC-IEGD y la Fundación BBVA para el proyecto "Demografía hoyDemography-today”.

Por todo ello, mi más sincero a agradecimiento a las instituciones mencionadas y al personal de las mismas. De manera especial e ineludible a Diego Ramiro, pues sin él, nada de lo anterior hubiera sido posible. Gracias por creer en mí y darme la posibilidad de disfrutar de tantas oportunidades. Del mismo modo, agradecer a Alberto del Rey no sólo su ayuda en esta tesis, 
sino también su intenso apoyo y confianza en mí. Sus palabras, tan adecuadas, en el momento oportuno han supuesto un gran revulsivo para que esta tesis se haya podido finalizar. Los dos han sido unos directores de tesis envidiables, por lo que debo resaltar mi agradecimiento, por su apoyo y consejo en este largo recorrido que ha supuesto mi tesis doctoral. Me han ayudado a superar importantes baches, especialmente en los últimos momentos. Siempre les estaré agradecida por ello.

Agradecer a los miembros del Grupo de Dinámicas Demográficas y del Instituto de Economía, Geografía y Demografía su compañía durante todos estos años. Especialmente a Belén, Sara y Begoña, que, en la que podría denominar como "mi primera etapa", fueron las mejores compañeras que se puede tener. Asimismo, agradecer a Dariya, Laura, Mathias y María el apoyo ofrecido durante el disfrute de su estancia en el CSIC. Particularmente, quiero aprovechar para resaltar mi gratitud hacia Dariya, por toda la ayuda prestada en esta tesis doctoral.

De igual modo, debo dar las gracias a Pilar, por su capacidad para animarme en los momentos en que más lo necesitaba; a Bárbara, por deleitarme con su brillante capacidad académica de manera tan altruista y a Antonia, por hacerme llegar siempre los mejores deseos durante toda esta etapa.

En el plano personal, mi agradecimiento se extiende a varias personas y se basa, de manera general, en la comprensión de las ausencias y en haber creído siempre en mí. Mis amigos y familiares han sido un pilar fundamental desde el primer al último momento. En especial, agradecer a mis padres y hermanos el acompañamiento, los ánimos y la fuerza.

Por último, mi gratitud debe ir dirigida a la persona que más me ha inspirado $\mathrm{y}$, sobre todo, animado a continuar. Dani, mi marido, por tantos años a mi lado, siempre transmitiéndome lo mejor en cada momento. Pues nada de esto hubiera sido posible sin ti.

A todos, mi más sincero agradecimiento.

Yolanda Casado Ruiz

Septiembre de 2021 


\section{Índice}

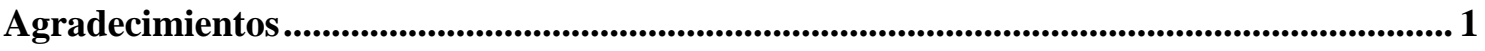

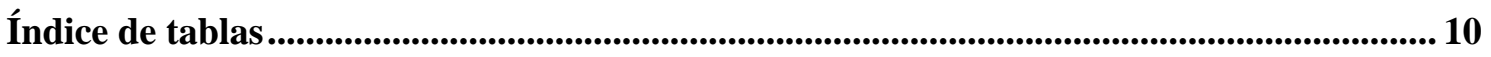

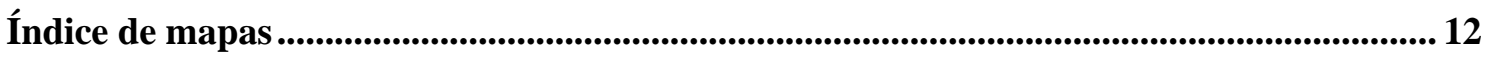

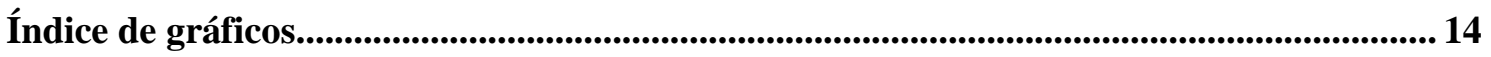

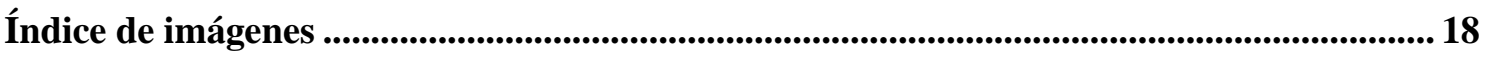

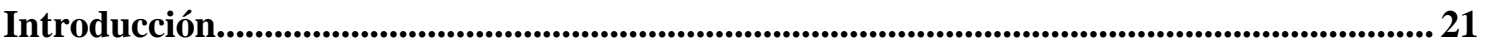

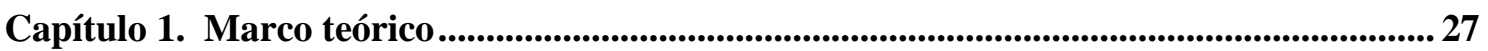

1.1 Los debates sobre la disminución de la mortalidad..................................................... 28

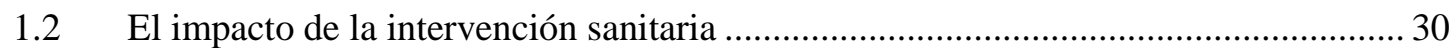

1.2.1 Procesos de calidad de las aguas: la filtración y la cloración............................... 33

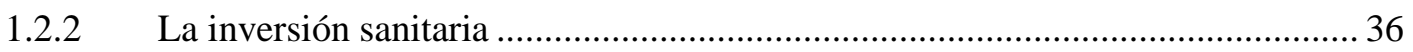

1.2.3 Mortalidad infantil y mejoras en higiene urbana................................................. 38

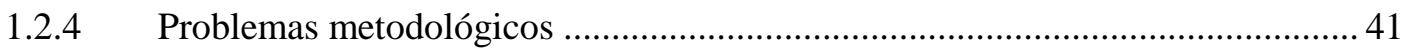

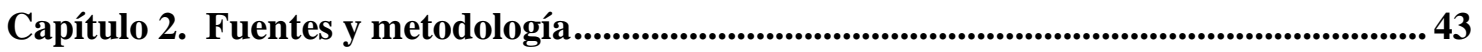

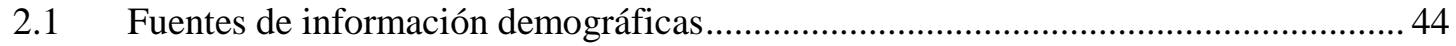

2.1.1 Los partes de nacimiento y defunción del Registro Civil..................................... 44

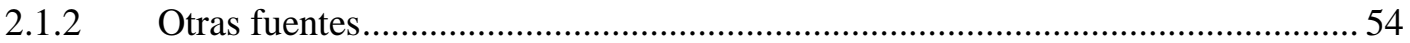

2.2 Las fuentes de información cartográficas y las Guías de la ciudad de Madrid. ........... 55

2.2.1 El Plano y Guía de Facundo Cañada ................................................................... 56

2.2.2 La Guía práctica de Madrid (González e Iribas, 1906), ....................................... 63

2.2.3 La Guía de las vías públicas de Madrid. .............................................................. 67

2.2.4 La elaboración de callejeros históricos de viales ................................................... 68

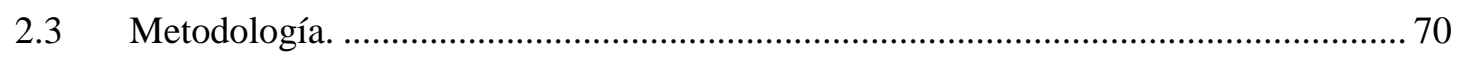

2.3.1 Información cartográfica: construcción de Mapas en el Proyecto HISDI-MAD 70

2.3.2 El uso de mapas de cobertura de agua y alcantarillado...................................... 74

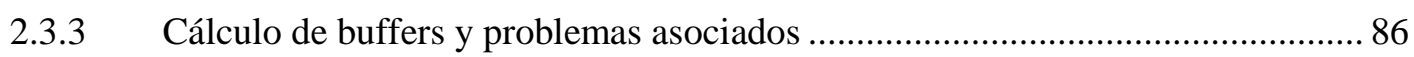

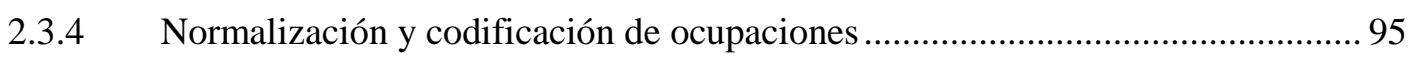

2.3.4.3 El proceso de codificación de las ocupaciones de los partes de defunción del

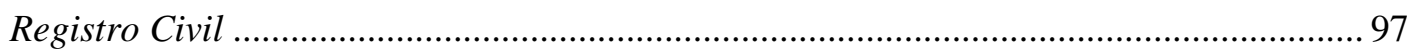

2.3.5 Normalización y codificación de causas de muerte. .......................................... 101 


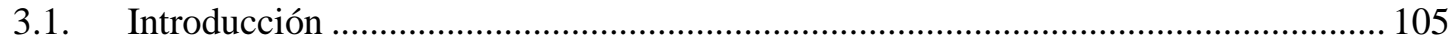

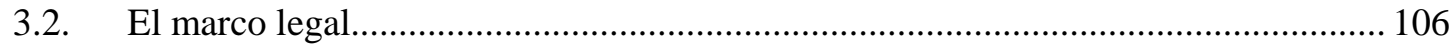

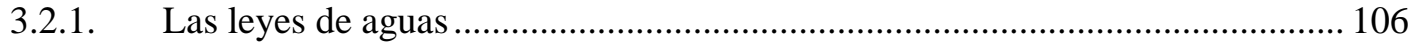

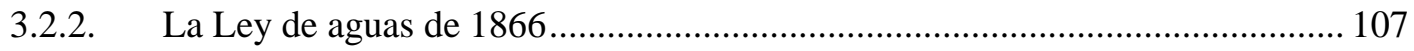

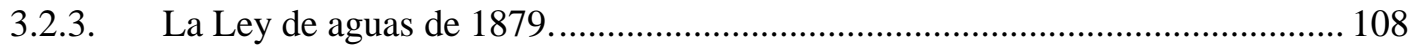

3.2.4. La progresiva municipalización del servicio de aguas potables......................... 108

3.2.5. El Estatuto Municipal de 1924 y el Reglamento de Obras, Servicios y Bienes

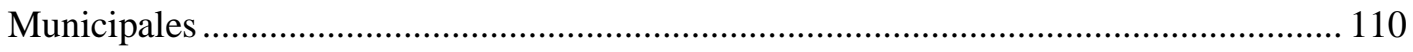

3.2.6. El Canal de Isabel II como ejemplo de Empresa Pública................................... 111

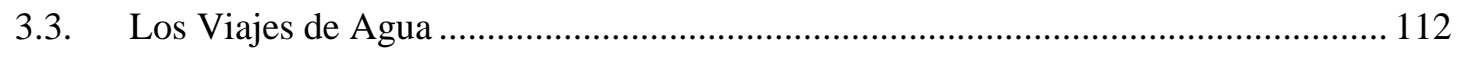

3.3.1. Los viajes de agua en Madrid hasta mediados del siglo XIX ............................ 112

3.3.2. Descripción de los viajes de agua.................................................................... 113

3.3.3. La insuficiencia del servicio. La necesidad de mejora del abastecimiento de agua

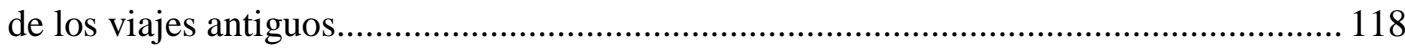

3.3.4. Proyectos anteriores al Canal de Isabel II y los viajes de agua .......................... 120

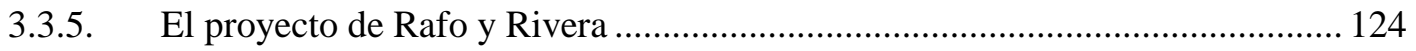

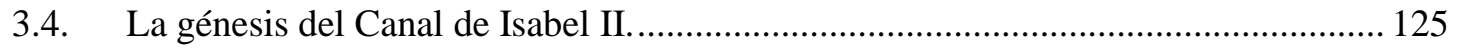

3.4.1. La primera etapa del Canal de Isabel II (1851-1865)....................................... 125

3.4.2. La segunda etapa del Canal de Isabel II (1865-1907) ...................................... 131

3.4.3. La tercera etapa del Canal de Isabel II (1907-1930) ......................................... 136

3.4.4. ¿Municipalización del Servicio de agua en Madrid? .......................................... 143

3.5. Las cuentas económicas del Canal de Isabel II ......................................................... 144

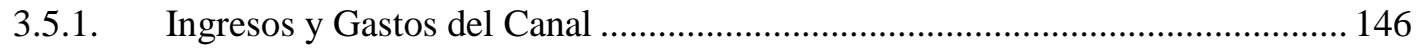

3.5.2. La cuenta de explotación: ingresos. …….......................................................... 147

3.5.3. La cuenta de explotación: gastos........................................................................ 149

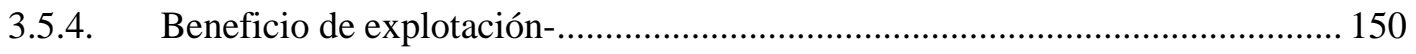

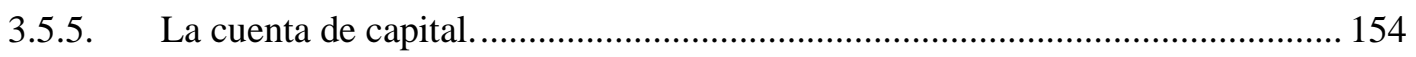

3.5.6. Consideraciones finales sobre las Cuentas del Canal de Isabel II ...................... 157

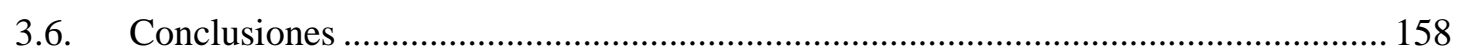

Capítulo 4. La calidad de las aguas de abastecimiento................................................... 159

4.1. Los primeros análisis de las aguas de consumo. Los análisis no sistemáticos............... 159

4.2. La sistematización de los análisis del agua de consumo .......................................... 161

4.3. Las condiciones higiénicas de las aguas de consumo y su composición química..... 162

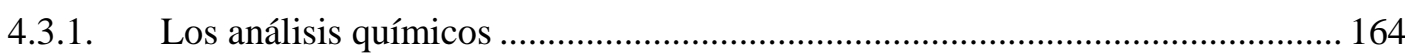


4.3.2. Las condiciones del agua destinada a la alimentación. Características mínimas

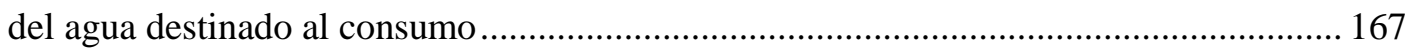

4.4. Los medios de tratamiento y purificación de las aguas............................................... 169

4.4.1. Las estaciones depuradoras en la ciudad de Madrid. ......................................... 172

4.4.2. Estaciones de depuración de aguas por ozono. …………………….................. 176

Capítulo 5. El consumo de agua en una ciudad en crecimiento .......................................... 180

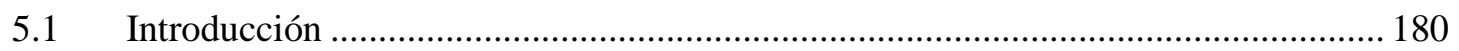

5.2 El abastecimiento de agua en una ciudad en crecimiento ......................................... 180

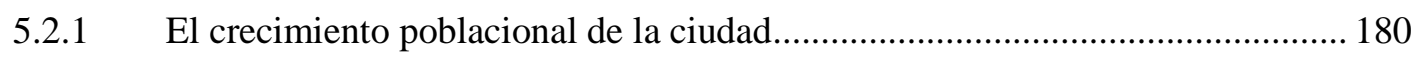

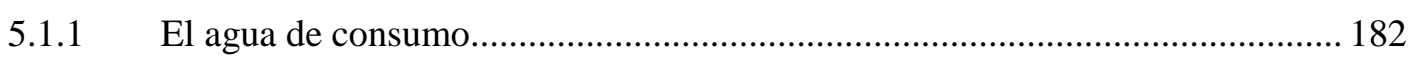

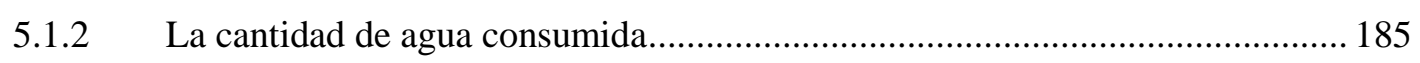

5.2 La expansión de la ciudad y los problemas de distribución...................................... 197

5.2.1 El problema de la distribución de agua de consumo ......................................... 200

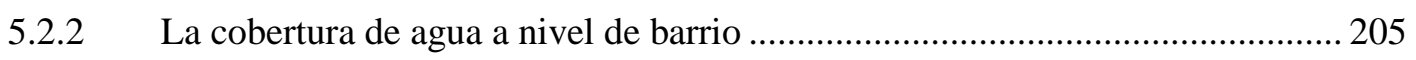

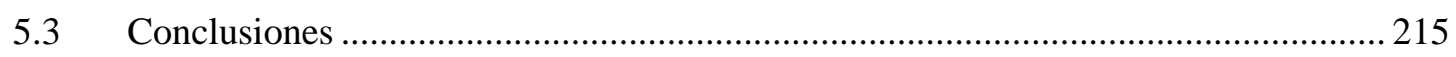

Capítulo 6. La red de alcantarillado y el sistema de evacuación de aguas......................... 217

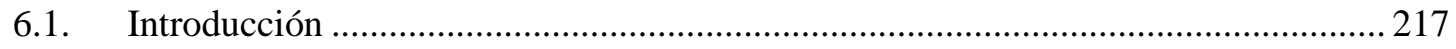

6.2. Las alcantarillas antiguas. Breve bosquejo histórico.................................................. 218

6.3. La primera construcción del alcantarillado moderno en Madrid. 1856 y $1865 \ldots \ldots . . . .220$

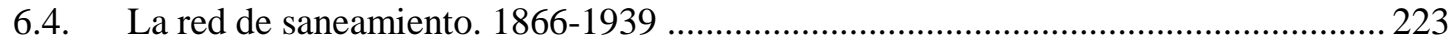

6.4.1. La reorganización del ramo de alcantarillas de Madrid (1866-1885). ............... 224

6.4.2. La integración al saneamiento. 1885-1930..................................................... 225

6.4.3. Los nuevos planes de obras. El Plan general de saneamiento del subsuelo de Madrid. 236

6.4.4. El Plan General de Saneamiento del Subsuelo a la altura de 1923 y el Proyecto de obras de saneamiento del subsuelo de los barrios extremos de Madrid de 1924.......... 242

6.4.5. La red de evacuación de aguas a la altura de 1929 …......................................... 247

6.5. Canalización y saneamiento del Río Manzanares ..................................................... 249

6.5.1. Proyectos de Canalización del Rio ..................................................................... 251

Capítulo 7. El Laboratorio Municipal de Madrid.................................................................. 257

7.1. La creación de los Laboratorios Municipales de Higiene. ......................................... 257 
7.2. Las normativas comunes en el contexto español..................................................... 262

7.3. La génesis del Laboratorio Municipal de Madrid ......................................................... 263

7.3.1. La reorganización del Laboratorio Químico de Madrid desde 1898 .................. 267

7.4. Las funciones y servicios del Laboratorio................................................................. 270

7.4.1. El funcionamiento del laboratorio y sus dependencias .................................... 270

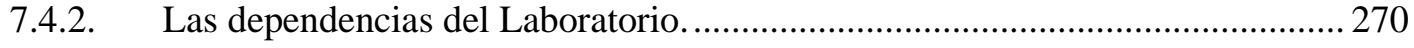

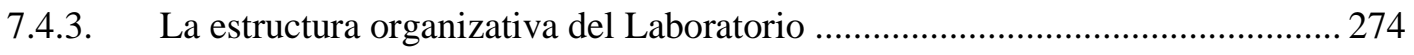

7.4.4. Los servicios a la ciudadanía. Servicio de de pago y los servicios gratuitos. Las

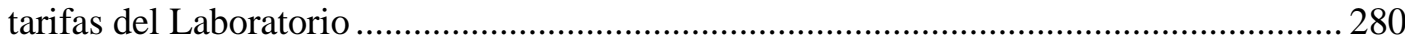

7.5. El servicio de inspección de subsistencias del laboratorio ............................................. 291

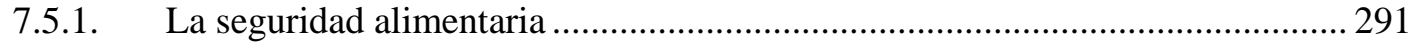

7.5.2. Los peritos veterinarios y los peritos químicos del laboratorio...........................2295

7.5.3. Número de inspección de subsistencias ............................................................ 297

7.5.4. Mercados de abastos en la ciudad ................................................................... 299

7.6. El servicio de defensa contra las enfermedades infectocontagiosas del laboratorio.

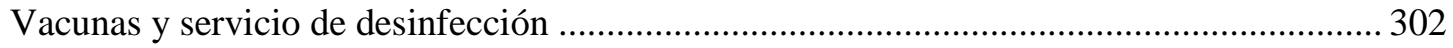

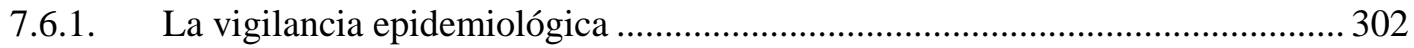

7.6.2. La ampliación de los servicios del laboratorio y la Sección de Epidemiología. 304

7.6.3. El funcionamiento de la Sección de Epidemiología.............................................. 306

7.7. El servicio de vacunación como medida profiláctica contra las enfermedades

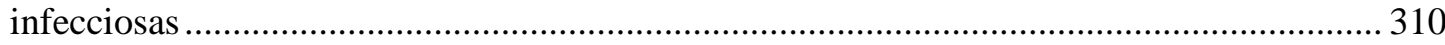

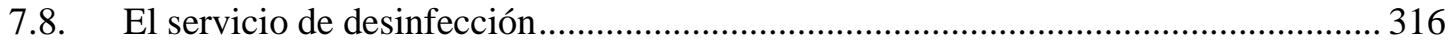

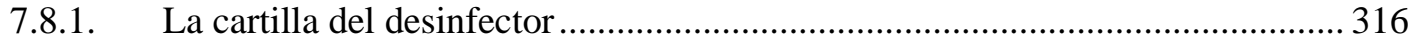

7.8.2. Servicio de desinfección ante las enfermedades infecciosas.............................. 326

7.8.3. El Campamento de Desinfección ...................................................................... 333

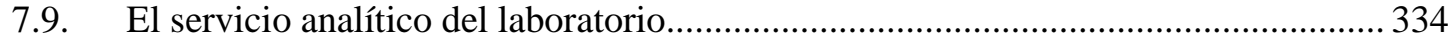

7.9.1. Condiciones mínimas de las sustancias ................................................................. 341

7.9.2. La institucionalización de los análisis de agua.................................................... 344

Capítulo 8. Características sociales y demográficas del espacio urbano madrileño ........ 371

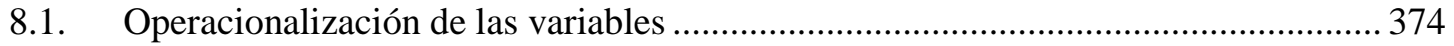

8.2. La estructura socioprofesional de Madrid y su distribución en la ciudad en el año 1915 376

8.3. La distribución espacial de las ocupaciones profesionales........................................... 380

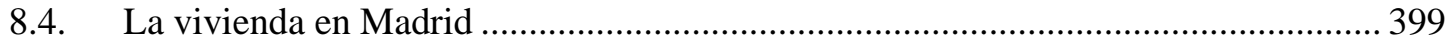

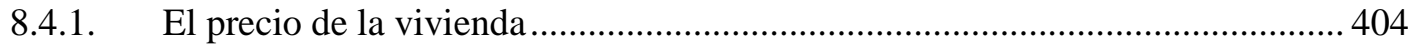

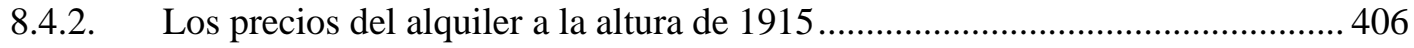


8.4.3. El problema de la habitación: el hacinamiento.

8.4.4. La salubridad de la vivienda

Capítulo 9. La Fiebre tifoidea

9.1. La Fiebre tifoidea como enfermedad endémica. ................................................ 422

9.1.1. Aspectos clínicos de la fiebre tifoidea.................................................. 422

9.1.1. Pequeño bosquejo histórico de la fiebre tifoidea.........................................4 423

9.1.2. Descripción y epidemiología de la fiebre tifoidea........................................4 423

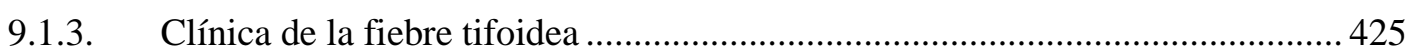

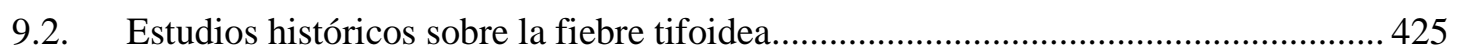

9.3. La calidad de las aguas y la transmisión de fiebre tifoidea .................................... 428

9.3.1. Epidemias tíficas y el teorema de Hazen. Contexto español y mundial ............ 432

9.4. El problema de la fiebre tifoidea en España.................................................... 440

9.5. Estado sanitario de Madrid y las fiebres tifoideas. Epidemia de 1920...................451

9.5.1. Origen de la epidemia. .................................................................. 452

9.5.2. Las medidas defensivas contra la fiebre tifoidea: medidas higiénicas dirigidas a la población y la vacunación antitífica

9.5.3. Las medidas defensivas contra la fiebre tifoidea: el estudio de las aguas de abastecimiento.....

Capítulo 10. La mortalidad en Madrid durante el primer tercio del siglo XX................. 456

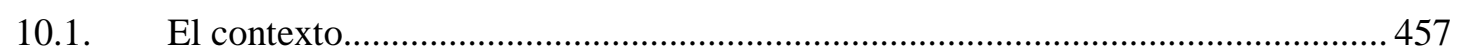

10.2. La evolución de la mortalidad general en la ciudad de Madrid.............................. 460

10.3. La mortalidad de niños menores de cinco años a nivel de barrio........................... 471

10.3.1. Distribución de mortalidad por causas y factores explicativos

10.3.2. Mortalidad por enfermedades transmitidas a través del agua y alimentos y evolución de la infraestructura de saneamiento

10.4. Las mejoras en la infraestructura urbana de saneamiento como elementos explicativos de la mortalidad por enfermedades transmitidas a través del agua y alimentos. 489

10.4.1. Modelos explicativos de la mortalidad por enfermedades transmitidas a través del agua y alimentos. 490

10.5. Conclusiones 503

11. Conclusiones 506

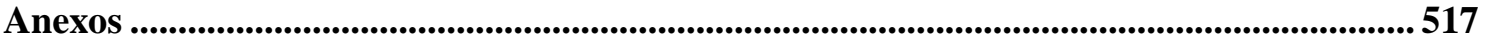

Bibliografía 


\section{Índice de tablas}

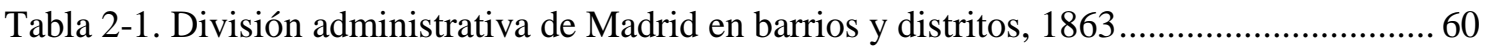

Tabla 2-2. División administrativa del Conde de Romanones, 1898 .......................................... 61

Tabla 2-3. Capítulos Generales de la Nomenclatura Internacional de Enfermedades y Causas de

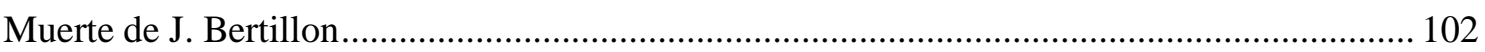

Tabla 2-4. Clasificación de causas de mortalidad modificada a partir de la propuesta por

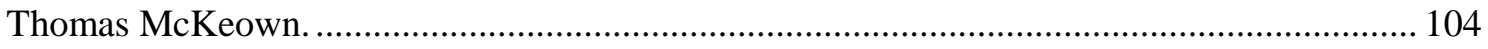

Tabla 5-1. Consumo de agua procedente del Canal de Isabel II. 1920-1932 _......................... 187

Tabla 5-2. Consumo de agua procedente de la Sociedad Hidráulica Santillana. 1920-1932 .... 188

Tabla 5-3. Concesiones de agua de los Viajes Antiguos realizadas por el Ayuntamiento de

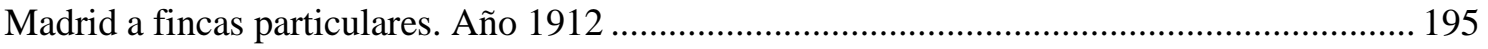

Tabla 5-4. Concesiones de las aguas sobrantes realizadas por el Ayuntamiento de Madrid hasta

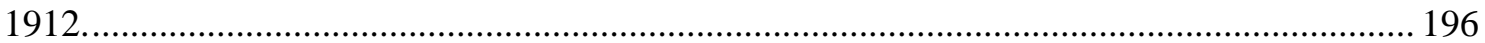

Tabla 5-5. Coste de la licencia de aguador en la ciudad de Madrid........................................... 197

Tabla 5-6. Barrios con una superficie de cobertura de red de agua por el Canal de Isabel II

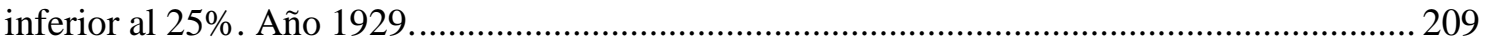

Tabla 5-7. Barrios con una superficie de cobertura de red de agua por el Canal de Isabel II

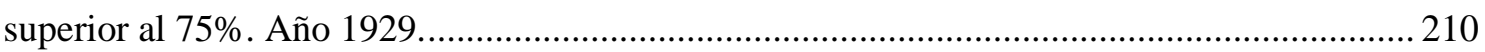

Tabla 6-1. Alcantarillas y cuencas que desembocaban en el río Manzanares............................250

Tabla 7-1. Las tarifas de los análisis cuantitativos del Laboratorio Municipal de Madrid, ...... 282

Tabla 7-2. Las tarifas de los análisis cuantitativos sobre productos patológicos del Laboratorio

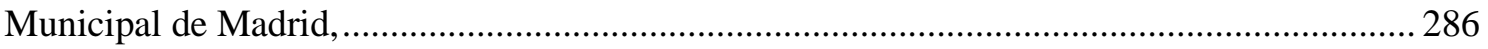

Tabla 7-3. Las tarifas de vacunas y sueros del Laboratorio Municipal de Madrid, ................... 287

Tabla 7-4. Tarifas del Servicio de desinfección del Laboratorio Municipal de Madrid. ........... 290

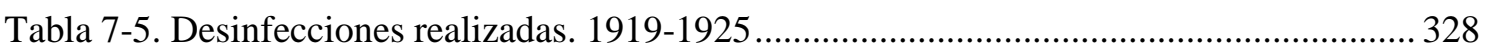

Tabla 7-6. Niveles máximos permitidos de los componentes del agua destinados al consumo.

Tabla 7-7. Muestras analizadas según su naturaleza en los años 1917 y 1932 ........................... 343

Tabla 7-8. Muestras analizadas según su procedencia en los años 1917 y 1932 ....................... 344

Tabla 7-9. Composición química de las aguas alimenticias de Madrid, en su estado normal:

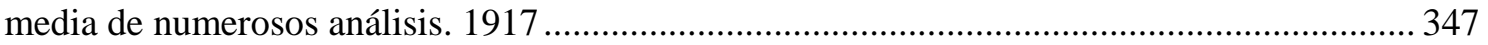

Tabla 7-10. Composición química normal de las aguas del Lozoya, año 1932 ........................ 350

Tabla 7-11. Composición química normal de las aguas del Manzanares, año 1932 .................. 351

Tabla 7-12. Composición química normal de las aguas del viaje del Abroñigal Alto, año 1932.

Tabla 7-13. Composición química normal de las aguas del viaje del viaje del Retamar, año

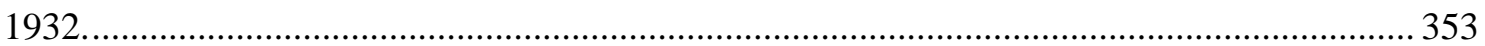

Tabla 7-14. Composición química normal de las aguas del viaje de la Alcubilla, año 1932 .... 354

Tabla 7-15. Composición química normal de las aguas del viaje del Abroñigal Alto, año 1932

Tabla 7-16. Composición química normal de las aguas del viaje de Amaniel, año 1932 .......... 356

Tabla 7-17. Composición química normal de las aguas del viaje de la fuente del Berro, año 1932

Tabla 7-18. Bacterias encontradas en las aguas del Lozoya de las muestras recogidas en el

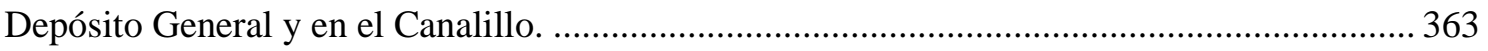

Tabla 7-19. Bacterias encontradas en las aguas del Manzanares. ................................................ 365 
Tabla 7-20. Bacterias encontradas en el agua de los Viajes antiguos 366

Tabla 8-1. Número de cuartos por precio del alquiler. Varios años

Tabla 8-2. Número edificios con más de 200 y 300 habitantes. Por distritos ......

Tabla 10-1. Probabilidad de morir por diarrea y enteritis. Mortalidad infantil. 1905-1907 ...... 492

Tabla 10-2. Probabilidad de morir por diarrea y enteritis. Mortalidad infantil. 1918-1922 ...... 494

Tabla 10-3. Probabilidad de morir por diarrea y enteritis. Menores de cinco años. 1905-1907495

Tabla 10-4. Probabilidad de morir por diarrea y enteritis. Menores de cinco años. 1918-1922496

Tabla 10-5. Probabilidad de morir por diarrea y enteritis. 1905-1907. (Conjunto de la base de datos).

Tabla 10-6. Probabilidad de morir por diarrea y enteritis. 1918-1922. (Conjunto de la base de datos)

Tabla 10-7. Probabilidad de morir por fiebre tifoidea. 1905-1907. (Conjunto de la base de datos)

Tabla 10-8. Probabilidad de morir por fiebre tifoidea. 1922-1918. (Conjunto de la base de datos).

Tabla Anexos -1. Relación de los barrios y su numeración. 


\section{Índice de mapas}

Mapa 2-1. Composición del Plano de Facundo Cañada.............................................................. 57

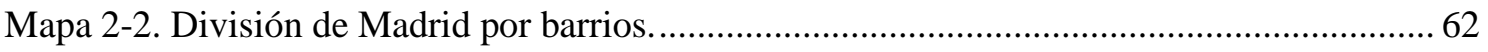

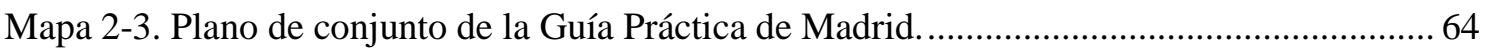

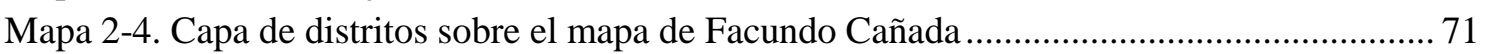

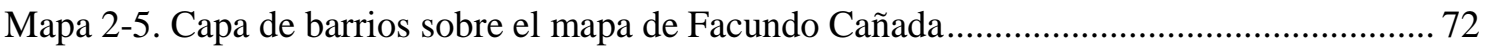

Mapa 2-6. Capa de ejes de calle sobre el mapa de Facundo Cañada ......................................... 73

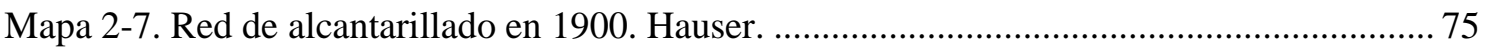

Mapa 2-8. Plano del Plan General del Saneamiento del Subsuelo de Madrid. 1913-1923 ......... 76

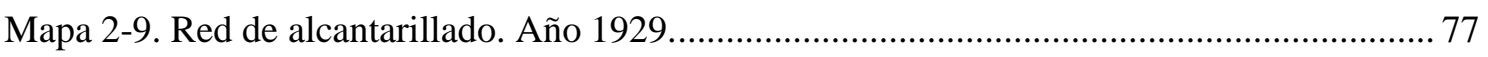

Mapa 2-10. Red de abastecimiento de agua. Canal de Isabel II. Año 1929............................... 78

Mapa 2-11. Red de abastecimiento de agua. Hidráulica Santillana y Viajes antiguos. Año 1929.

79

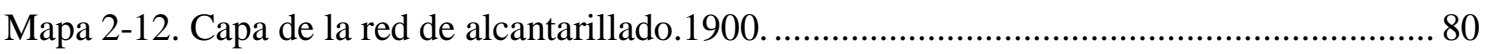

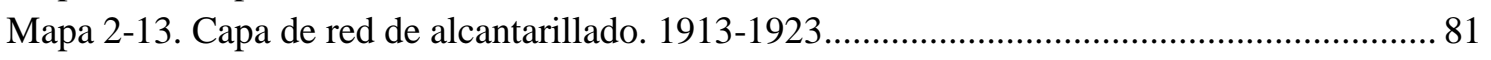

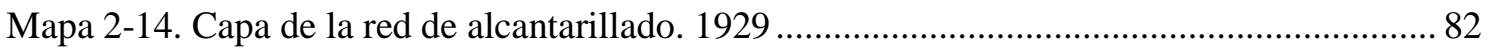

Mapa 2-15. Capa de la red de abastecimiento de agua. Canal de Isabel II. 1929....................... 83

Mapa 2-16. Capa de la red de abastecimiento de agua. Hidráulica Santillana. 1929.................... 84

Mapa 2-17. Capa de la red de abastecimiento de agua. Viajes de agua. 1929........................... 85

Mapa 2-18. Proporción de alcantarillado con buffer de 25 metros. Años 1900, 1913-1923 y

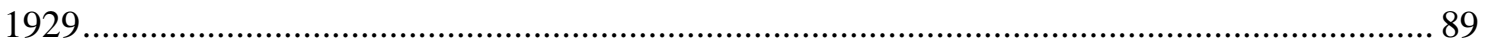

Mapa 2-19. Proporción de alcantarillado con buffer de 50 metros. Años 1900, 1913-1923 y 1929.

Mapa 2-20. Proporción de la red de alcantarillado 1900, 1923 y 1929 teniendo en cuenta la

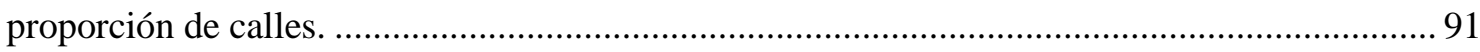

Mapa 2-21. Proporción de la red de agua con buffer de 25 metros. Año 1929........................... 92

Mapa 2-22. Proporción de la red de agua con buffer de 50 metros. Año 1929........................... 93

Mapa 2-23. Proporción de la red de agua teniendo en cuenta la proporción de calles .Año 1929.

Mapa 3-1. Los Viajes de Agua en Madrid, año 1750............................................................ 115

Mapa 3-2. Plano del Proyecto de Conducción de aguas a Madrid de Rafo y Rivera. Año 1848.

Mapa 3-3. Plano general del Canal de Isabel II y perfiles de las presas ................................... 142

Mapa 5-1. Distribución de agua de consumo por Zona Urbana. Año 1929 ............................... 202

Mapa 6-1. Plano General de la Cuenca del río Manzanares...................................................... 252

Mapa 8-1. Mapas de la distribución ocupacional de los hombres. 1915 ................................... 388

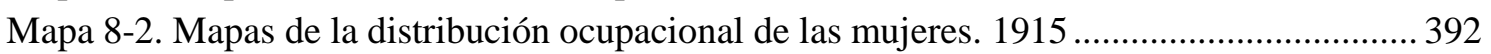

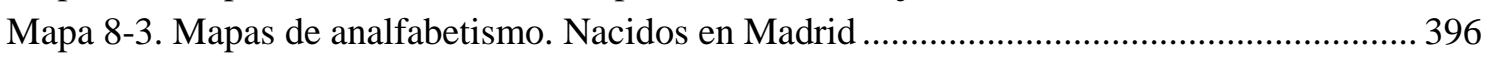

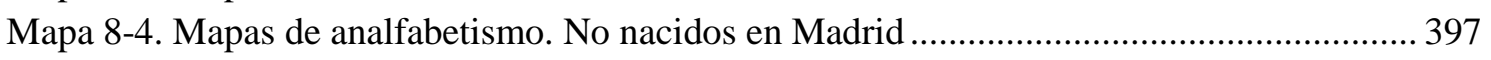

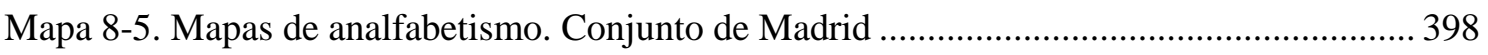

Mapa 8-6. Precio medio del alquiler por Barrios. 1915 ............................................................ 407

Mapa 8-7. Distribución del número de personas por edificio. Barrios de Madrid, año 1915 ... 415

Mapa 8-8. Distribución de la superficie disponible por habitante. Barrios de Madrid, año 1915

Mapa 8-9. Distribución del número de personas por vivienda. Barrios de Madrid, año 1915.. 420

Mapa 8-10. Distribución del número de cuartos por edificio. Barrios de Madrid, año 1915.... 421 
Mapa 10-1. ECMR (5q0) estandarizado para la ciudad de Madrid. 1905-1907

Mapa 10-2. ECMR (5q0) estandarizado para la ciudad de Madrid. 1920-1922

Mapa 10-3. ECMR (5q0) Estandarizada por enfermedades infecciosas y cobertura del sistema

de alcantarillado en la ciudad de Madrid, 1905-1907 y 1920-1922.

Mapa 10-4. ECMR (5q0) estandarizado por enfermedades transmitidas por agua y alimentos para la ciudad de Madrid. 1905-1907.

Mapa 10-5. ECMR (5q0) estandarizado por enfermedades transmitidas por agua y alimentos para la ciudad de Madrid. 1920-1922.

Mapa 10-6. ECMR (5q0) Estandarizada por enfermedades transmitidas a través del agua y alimentos y cobertura del sistema de alcantarillado en la ciudad de Madrid, 1905-1907 y 19201922

Mapa 10-7. ECMR (5q0) estandarizado por diarrea y enteritis para la ciudad de Madrid. 19051907.

Mapa 10-8. ECMR (5q0) estandarizado por diarrea y enteritis para la ciudad de Madrid. 19201922

Mapa 10-9. ECMR (5q0) Estandarizada por diarrea y enteritis y cobertura del sistema de alcantarillado en la ciudad de Madrid, 1905-1907 y 1920-1922.

Mapa 10-10. ECMR (5q0) Estandarizada por diarrea 1905-1907 y 1920-1922 y cobertura del sistema de alcantarillado y de agua en 1929 en la ciudad de Madrid..... 486 


\section{Índice de gráficos}

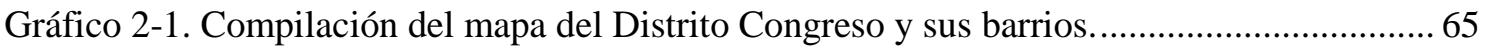

Gráfico 2-2. Compilación de los mapas de los barrios del distrito Congreso ................................66 66

Gráfico 3-1. Medidas de agua de los cuatro principales Viajes, en reales fontaneros. Años 1699-

1828.

Gráfico 3-2. Reales Fontaneros de agua de los cuatro viajes de agua principales en reales

fontaneros. Años 1699-1828

Gráfico 3-3. Diferencia del gasto en obras del Canal de Isabel II. Años 1921 y 1929

Gráfico 3-4. Representación gráfica de la población y abastecimiento de agua con cálculos

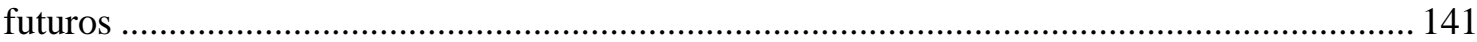

Gráfico 3-5. Cuenta de ingresos del Canal de Isabel II entre los años 1908-1929..................... 146

Gráfico 3-6. Cuenta de gastos del Canal entre 1907-1929..................................................... 147

Gráfico 3-7. Evolución de los ingresos anuales por venta de agua, venta de energía eléctrica y

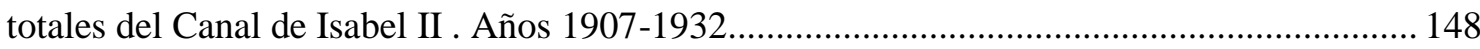

Gráfico 3-8. Precio del metro cúbico de agua en domicilios para varias ciudades................... 149

Gráfico 3-9. Evolución de los gastos del Canal de Isabel II, por tipo de gasto. Años 1907-1932

Gráfico 3-10. Evolución anual de los gastos, ingresos y beneficios del Canal de Isabel II. 1907-

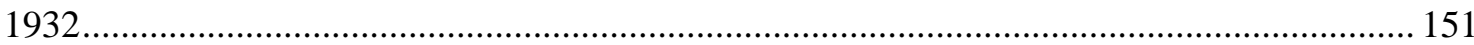

Gráfico 3-11. Evolución del coeficiente de explotación del Canal de Isabel II. Años 1907-1932

Gráfico 3-12. Evolución del gasto, ingreso y beneficio por habitante y año del Canal de Isabel

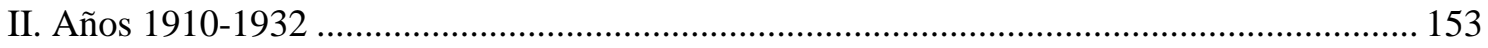

Gráfico 3-13. Evolución del agua vendida por el Canal de Isabel II. Años 1921-1932 _............ 153

Gráfico 3-14. Evolución de la tarifa media, gastos y beneficios por metro cúbico de agua. Canal

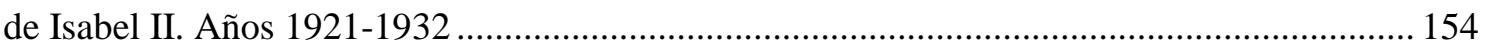

Gráfico 3-15. Capital, beneficios líquidos y rentabilidad del Canal de Isabel II ....................... 155

Gráfico 4-1. Contaminación del Río Lozoya en su transcurso desde el Paular hasta la Presa de la

Parra. Paular, Lozoya, Cruce, Buitrago, Embalse, Presa del Villar, Presa de la Parra............... 164

Gráfico 4-2. Estaciones depuradoras del Ayuntamiento de Madrid. Año 1929.......................... 176

Gráfico 5-1. Evolución del número de habitantes de la ciudad de Madrid. Años 1857-1930 .. 182

Gráfico 5-2. Mínimo de litros d agua necesarios para el abastecimiento de las poblaciones para

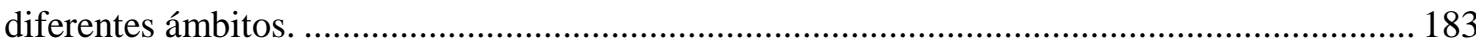

Gráfico 5-3. Evolución del consumo máximo de agua por habitante y día (1858-1930)........... 186

Gráfico 5-4. Evolución anual de la conducción máxima de agua del Canal de Isabel II (1858-

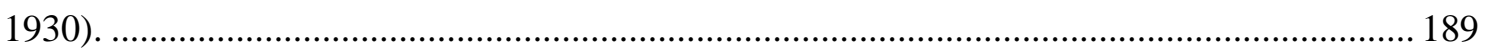

Gráfico 5-5. Evolución anual de los abonados del Canal de Isabel II (1903-1933)................... 189

Gráfico 5-6. Consumo de agua por persona y día en litros para varias ciudades del mundo

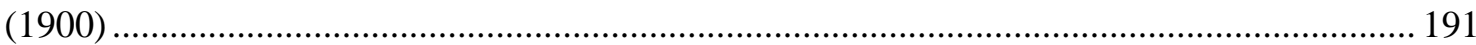

Gráfico 5-7. Consumo de agua del Canal de Isabel II, tomado por meses, en el espacio de un

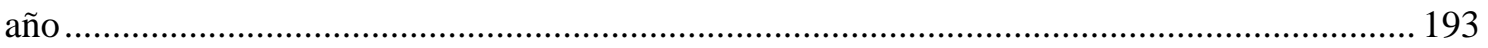

Gráfico 5-8. Metros cúbicos de agua según río de abastecimiento ............................................ 193

Gráfico 5-9. Número de habitantes por distritos. Años 1905, 1915 y 1920 .............................. 200

Gráfico 5-10. Variación en el número de habitantes por distrito. Años 1905 y 1920_............... 200

Gráfico 5-11. Superficie abastecida por redes de agua en función de la superficie del barrio.

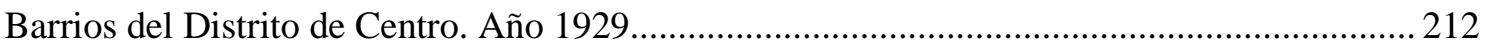


Gráfico 5-12. Superficie abastecida por redes de agua en función de la superficie del barrio.

Barrios del Distrito de Buenavista. Año 1929

Gráfico 5-13. Superficie abastecida por redes de agua en función de la superficie del barrio.

Barrios del Distrito de Chamberí. Año 1929

Gráfico 5-14. Superficie abastecida por redes de agua en función de la superficie del barrio.

Barrios del Distrito de Congreso. Año 1929.

Gráfico 5-15. Superficie abastecida por redes de agua en función de la superficie del barrio.

Barrios del Distrito de Hospicio. Año 1929.

Gráfico 5-16. Superficie abastecida por redes de agua en función de la superficie del barrio.

Barrios del Distrito de Hospital. Año 1929.

Gráfico 5-17. Superficie abastecida por redes de agua en función de la superficie del barrio.

Barrios del Distrito de Inclusa. Año 1929.

Gráfico 5-18. Superficie abastecida por redes de agua en función de la superficie del barrio.

Barrios del Distrito de Latina. Año 1929.

Gráfico 5-19. Superficie abastecida por redes de agua en función de la superficie del barrio.

Barrios del Distrito de Palacio. Año 1929.

Gráfico 5-20. Superficie abastecida por redes de agua en función de la superficie del barrio.

Barrios del Distrito de Universidad. Año 1929

Gráfico 6-1. Número de fosas y pozos negros por distritos, año 1929................................... 245

Gráfico 6-2. Zonas a alcantarillar según el Proyecto de obras de saneamiento del subsuelo de los

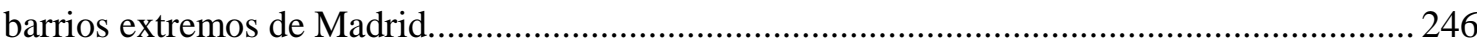

Gráfico 6-3. Evolución de los kilómetros de alcantarillas existentes para diferentes años....... 249

Gráfico 7-1. Servicios del Laboratorio de Madrid en su fundación............................................ 265

Gráfico 7-2. Funciones de los Inspectores veterinarios y los Inspectores químicos .................. 275

Gráfico 7-3. Organización de los servicios del Laboratorio Municipal, por acuerdo de 20 de

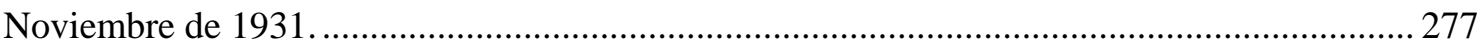

Gráfico 7-4. Servicios del Laboratorio Municipal de Madrid...................................................... 280

Gráfico 7-5. Sustancias susceptibles de análisis por el Laboratorio Municipal.......................... 281

Gráfico 7-6. Funciones de los Inspectores veterinarios y los Inspectores químicos................. 296

Gráfico 7-7. Visitas realizadas a los establecimientos por los inspectores químicos y veterinarios

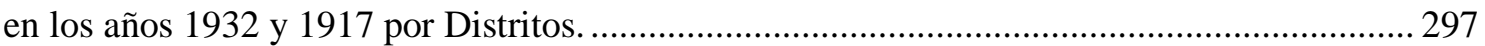

Gráfico 7-8. Muestras tomadas en los establecimientos por los inspectores químicos y

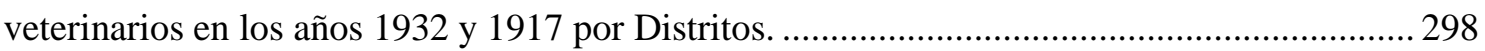

Gráfico 7-9. Inutilizaciones realizadas en los establecimientos en los años 1932 y 1917 por

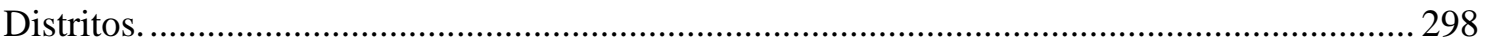

Gráfico 7-10. Denuncias realizadas a los establecimientos en los años 1932 y 1917 por Distritos.

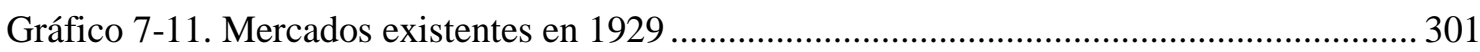

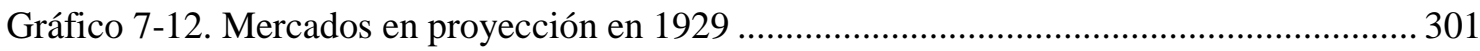

Gráfico 7-13. Información necesaria en la Sección de Epidemiología del Laboratorio Municipal.

Gráfico 7-14. Tasa de mortalidad por difteria (\%) en Madrid. 1904-1929 .............................. 311

Gráfico 7-15. Tasa de mortalidad por viruela(\%) en Madrid. 1904-1929................................ 312

Gráfico 7-16. Vacunas y sueros del Laboratorio Municipal. ................................................... 314

Gráfico 7-17. Clases de desinfección en función de la enfermedad. Servicio de desinfección del

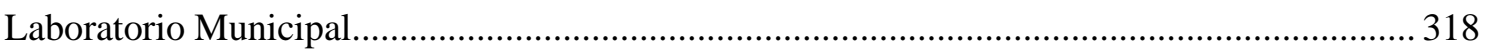

Gráfico 7-18. Tipos de desinfectantes. Servicio de desinfección del Laboratorio Municipal... 318

Gráfico 7-19. Elementos susceptibles de ser desinfectados y mecanismos a emplear............. 322 
Gráfico 7-20. Precauciones y obligaciones de los desinfectores.

Gráfico 7-21. Mecanismos de contaminación por enfermedades infectocontagiosas................ 327

Gráfico 7-22. Número de desinfecciones realizadas según la iniciativa ante la desinfección. . 328

Gráfico 7-23. Desinfecciones realizadas por el servicio de desinfección del Laboratorio

Municipal por distritos. Proporción de desinfecciones según el distrito.

Gráfico 7-24. Desinfecciones realizadas por el servicio de desinfección del Laboratorio

Municipal por distritos. Proporción de desinfecciones según el año. ......................................329

Gráfico 7-25. Desinfecciones totales realizadas en viviendas. Por meses y distritos. ............... 330

Gráfico 7-26. Desinfecciones realizadas en viviendas por fiebre tifoidea e infecciones

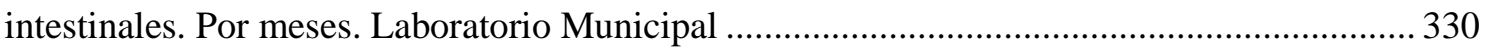

Gráfico 7-27. Desinfecciones realizadas en viviendas por gripe. Por meses. Laboratorio

Municipal

Gráfico 7-28. Desinfecciones realizadas en viviendas por difteria. Por meses. Laboratorio

Municipal

Gráfico 7-29. Desinfecciones realizadas en viviendas por viruela. Por meses. Laboratorio

Municipal

Gráfico 7-30. Desinfecciones realizadas en viviendas por tuberculosis. Por meses. Laboratorio

Municipal

Gráfico 7-31. Desinfecciones realizadas en viviendas por sarampión. Por meses. Laboratorio

Municipal

Gráfico 7-32. El Servicio analítico del Laboratorio Municipal de Higiene de Madrid. 1917... 335

Gráfico 7-33. Secciones y funciones del Laboratorio Municipal. 1932..................................... 338

Gráfico 7-34. Elementos del agua susceptibles de análisis químicos. ....................................... 360

Gráfico 7-35. Proporción de la contaminación de muestras por fuente de abastecimiento de

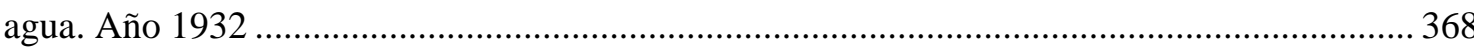

Gráfico 7-36. Bacterias encontradas por centrímetro cúbico de agua por fuente de

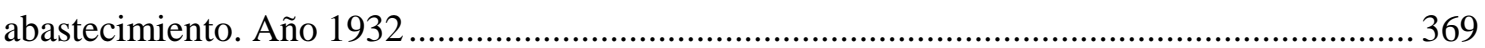

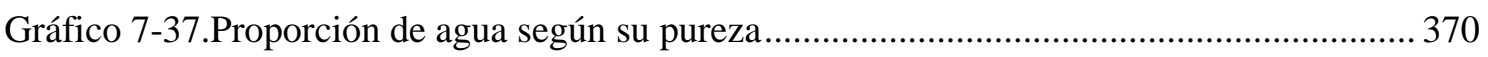

Gráfico 8-1. Estructura socioprofesional de Madrid. Hombres. Año 1915 ................................ 377

Gráfico 8-2. Estructura socioprofesional de Madrid. Mujeres. Año 1915 .................................. 379

Gráfico 8-3. Proporción de los precios del alquiler en la ciudad de Madrid en el año 1915.

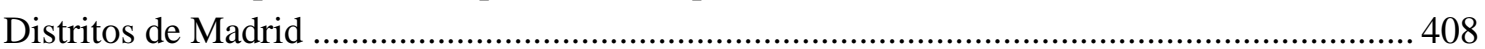

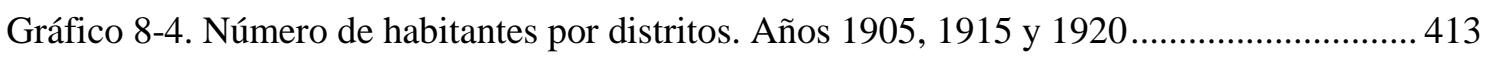

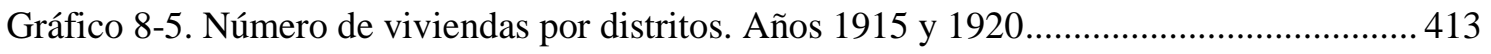

Gráfico 8-6. Número de habitantes por vivienda, según distritos. Años 1915 y $1920 \ldots \ldots \ldots \ldots \ldots . . . .413$

Gráfico 8-7. Diferencial del número de habitantes por distritos entre los años 1905 y 1920 .. 414

Gráfico 8-8. Evolución del número de habitantes y del número de viviendas por distritos. Años

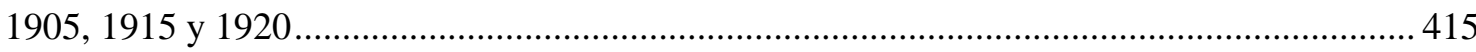

Gráfico 9-1. Tiempo de supervivencia del bacilo tífico en condiciones naturales del agua. .... 426

Gráfico 9-2. Medios de transmisión de la fiebre tifoidea........................................................... 427

Gráfico 9-3. Término medio de defunciones por fiebres tifoideas por distritos y meses, en relación con los máximos de bacilus coli encontrados en los depósitos del Canal y el consumo

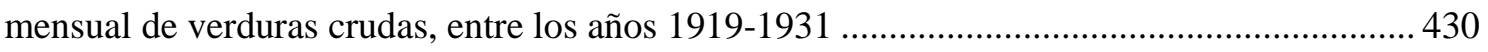

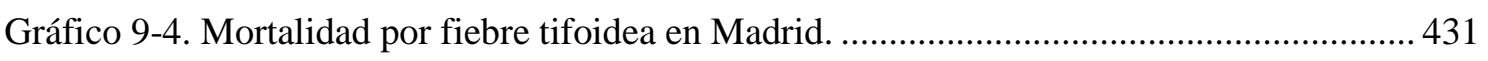

Gráfico 9-5. Mortalidad por fiebre tifoidea por 100.000 habitantes en relación con el sistema de abastecimiento de agua en algunas ciudades europeas y norteamericanas ............................... 438

Gráfico 9-6. Mortalidad por fiebre tifoidea (\%) registradas en capitales de provincia y

provincias de España en el decenio de 1910-1919. 
Gráfico 9-7. Las ocho capitales de mayor y menor mortalidad por 100000 habitantes, entre 1917-1919.

Gráfico 9-8. Evolución de la mortalidad por fiebre tifoidea en Madrid. 1904-1929 ................. 45

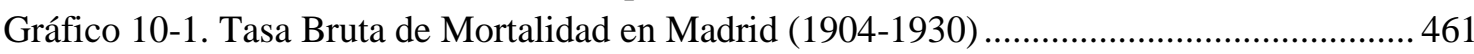

Gráfico 10-2. Tasa Bruta de Mortalidad de Madrid a nivel de distrito (1904-1929) ................. 462

Gráfico 10-3. Tasa Bruta de Mortalidad de los Barrios de Madrid (1904-1930)....................... 464

Gráfico 10-4. Distribución por edades de la mortalidad por diarrea y enteritis en Madrid, 1905-

1921

Gráfico 10-5. Distribución por edades de la mortalidad por agua y alimentos como proporción

del grupo de edad. Madrid (1905-1907 Y 1918-1922). 466

Gráfico 10-6. Proporción de las defunciones por enfermedades transmitidas por agua y alimentos por barrio. Como porcentaje de las muertes totales de cada barrio, por años. Mortalidad institucional y no institucional.

Gráfico 10-7. Proporción de las defunciones por enfermedades transmitidas por agua y

alimentos por barrio. Como porcentaje de las muertes totales de cada barrio, por años.

Mortalidad no institucional

Gráfico 10-8. Proporción de las defunciones por fiebre tifoidea por barrio. Como porcentaje de

las muertes totales de cada barrio, por años. Mortalidad institucional y no institucional.

Gráfico 10-9. Proporción de las defunciones por fiebre tifoidea por barrio. Como porcentaje de

las muertes totales de cada barrio, por años. Mortalidad no institucional 469

Gráfico 10-10. Proporción de las defunciones por diarrea y enteritis por barrio. Como porcentaje de las muertes totales de cada barrio, por años. Mortalidad institucional y no institucional. ... 470 Gráfico 10-11. Proporción de las defunciones por diarrea y enteritis por barrio. Como porcentaje de las muertes totales de cada barrio, por años. Mortalidad no institucional ............................. 470

Gráfico 10-12. Mortalidad por Diarrea y enteritis de menores de 2 años, años 1904-1929...... 483

Gráfico 10-13. Mortalidad por fiebre tifoidea en Madrid por distrito entre 1904-1929 ........... 487

Gráfico 10-14. Tasa de mortalidad por fiebre tifoidea, nivel de barrio. (1904-1930)................ 488

Gráfico 10-15. Distribución por edades de la mortalidad por fiebre tifoidea ..............................489

Gráfico Anexos-1. Compilación del mapa del Distrito Buenavista y sus barrios ...................... 518

Gráfico Anexos -2. Compilación de los mapas de los barrios del distrito Buenavista............... 519

Gráfico Anexos -3. Compilación del mapa del Distrito Centro y sus barrios .............................520

Gráfico Anexos -4. Compilación de los mapas de los barrios del distrito Centro. ..................... 521

Gráfico Anexos -5. Compilación del mapa del Distrito Chamberi y sus barrios ........................ 522

Gráfico Anexos -6. Compilación de los mapas de los barrios del distrito Chamberi.................5 523

Gráfico Anexos -7. Compilación del mapa del Distrito Hospicio y sus barrios .........................524

Gráfico Anexos -8. Compilación de los mapas de los barrios del distrito Hospicio....................525

Gráfico Anexos -9. Compilación del mapa del Distrito Hospital y sus barrios ...........................526

Gráfico Anexos -10. Compilación de los mapas de los barrios del distrito Hospital.................527

Gráfico Anexos -11. Compilación del mapa del Distrito Inclusa y sus barrios .........................528

Gráfico Anexos -12. Compilación de los mapas de los barrios del distrito Inclusa....................529

Gráfico Anexos -13. Compilación del mapa del Distrito Latina y sus barrios............................530

Gráfico Anexos -14. Compilación de los mapas de los barrios del distrito Latina .....................531

Gráfico Anexos -15. Compilación del mapa del Distrito Palacio y sus barrios ........................... 532

Gráfico Anexos -16. Compilación de los mapas de los barrios del distrito Palacio.................... 533

Gráfico Anexos -17. Compilación del mapa del Distrito Universidad y sus barrios ................. 534

Gráfico Anexos -18. Compilación de los mapas de los barrios del distrito Universidad........... 535 


\section{Índice de imágenes}

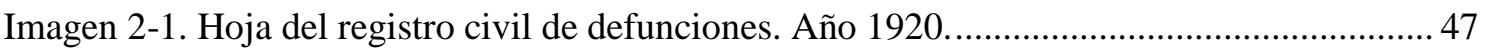

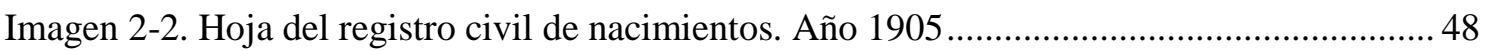

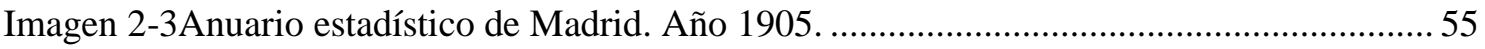

Imagen 2-4. Ampliación de la zona del Retiro. Plano de Facundo Cañada. ................................... 58

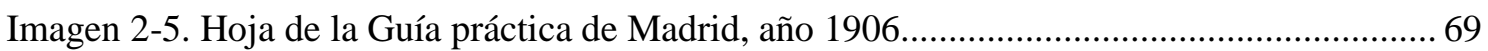

Imagen 3-1. Fotografía de un aguador en el denominado Cerro del Tío Pío, Madrid ................ 117

Imagen 3-2. Portada del proyecto de Francisco Javier Barra. "Proyecto y Memoria sobre

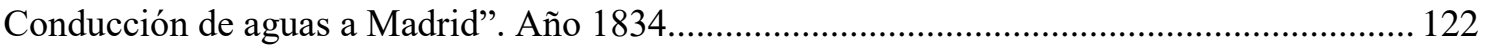

Imagen 3-3. Litografía de la Fuente de Puerta Cerrada. ............................................................ 123

Imagen 3-4. Colocación de la primera piedra en el Pontón de la Oliva ........................................ 127

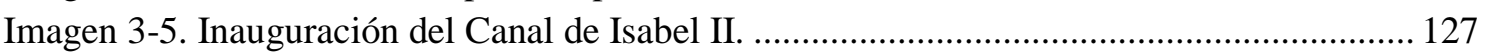

Imagen 3-6. Llegada de aguas a Madrid. Calle San Bernardo ................................................ 128

Imagen 3-7. Obras de la Presa del Pontón de la Oliva.......................................................... 130

Imagen 4-1. Plano de conjunto con los puntos de vertimiento de las aguas depuradas. Año 1930

Imagen 4-2. Plano del anteproyecto de riego con las aguas depuradas. Año 1930.................... 179

Imagen 5-1. Fotografía de anuncio de prensa del jabón Heno de Pravia ................................... 184

Imagen 5-2. Caricatura del siglo XVIII mostrando diferentes aseos según el país..................... 185

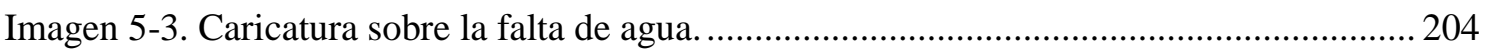

Imagen 6-1. Fotografía de la Instrucción de Sabatini sobre el empedrado y limpieza de calles de

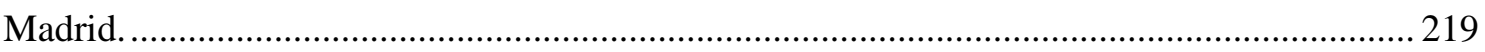

Imagen 6-2. Fotografía de la firma de la escritura de adjudicación de las Obras de saneamiento

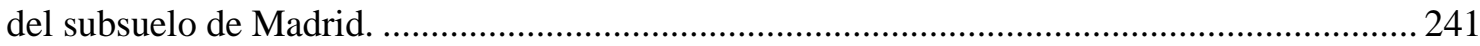

Imagen 6-3. Fotografía de las obras de alcantarillado en la Gran Vía madrileña en el año 1912.

Imagen 6-4. Fotografía de la primera piedra colocada por el Ministro de Fomento para la

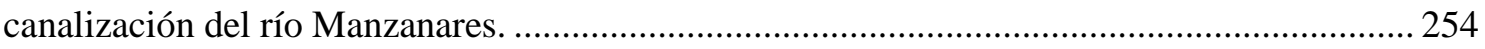

Imagen 7-1. Fotografía de un funcionario de la Food and Drugs Administration inspeccionando

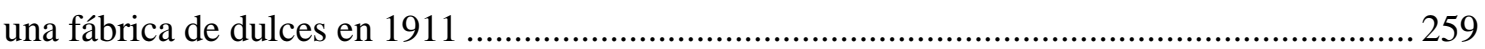

Imagen 7-2. Fotografía de una laboratorio de inspección de alimentos adulterados. ................. 259

Imagen 7-3. Fotografía de la fachada principal del Laboratorio Municipal de Madrid............ 270

Imagen 7-4. Fotografía del Parque o puesto de desinfección de la plaza de San Francisco ..... 271

Imagen 7-5. Fotografía del Parque de desinfección de Huerta Segura. .................................... 272

Imagen 7-6. . Fotografía de Sucursal de la calle de Ferrer del Río. ............................................ 273

Imagen 7-7. Fotografía del Campamento de desinfección. Paseo de las Yeserías, números 13 y

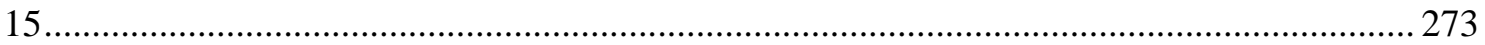

Imagen 7-8. Fotografía de los Golfillos recogidos en el Campamento de Desinfección.......... 274

Imagen 7-9. Expediente relativo al concurso de cuatro automóviles sanitarios con destino a los

servicios de transporte de enfermos infecciosos y de desinfección, 1922. ...............................279

Imagen 7-10. Fotografía de la vacunación de unas niñas mordidas por un animal rabioso, 1916

Imagen 7-11. Fotografía de los puestos de venta contiguos al Mercado de Santa Isabel. ......... 300 Imagen 7-12. Modelo de formulario del Laboratorio Municipal. Sección de Epidemiología (Hoja número uno) 
Imagen 7-13. Modelo de formulario del Laboratorio Municipal. Sección de Epidemiología

(Hoja número dos) 308

Imagen 7-14. Modelo de formulario del Laboratorio Municipal. Sección de Epidemiología

(Hoja número tres)

Imagen 7-15. Portada del libro Moderna Terapéutica biológica. Las vacunas y sueros del Laboratorio Municipal. 1916

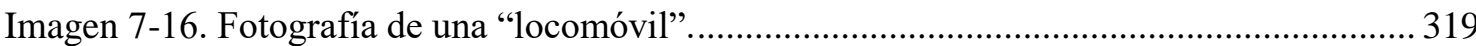

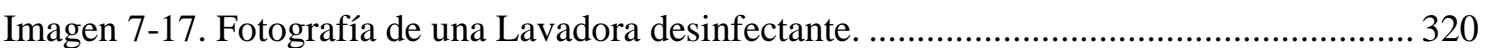

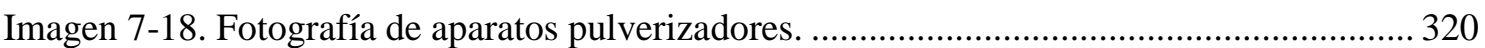

Imagen 7-19.Fotografía del personal con la herramienta de desinfección de la vía pública.... 321

Imagen 8-1. Fotografías del llamado Barrio de las Injurias ...................................................... 372

Imagen 8-2. Fotografía de la Calle Alcalá con Conde de Peñalver........................................... 373

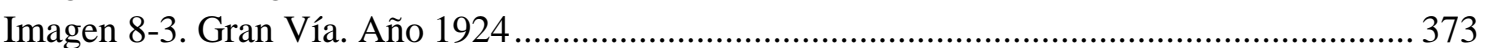

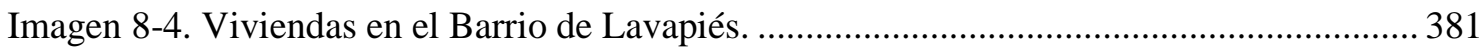

Imagen 8-5. Viviendas en el Barrio de Arganzuela. Distrito de Latina. ..................................... 382

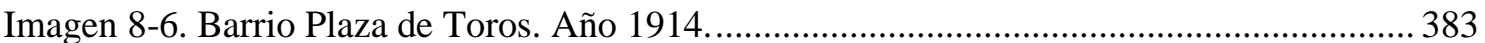

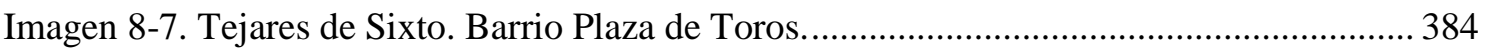

Imagen 8-8. Chozas en el Barrio de Lozoya. Año 1914. ………................................................... 385 


\section{Introducción}

Desde finales del siglo XIX, en buena parte de las capitales europeas, comenzaron a implantarse mejoras orientadas al saneamiento urbano con el objetivo principal de mejorar la salud de sus habitantes y reducir la mortalidad. Concretamente, el desarrollo del suministro de agua potable en las poblaciones y la gestión de las aguas residuales, pueden tomarse como indicadores del proceso de modernización urbana que tuvo lugar en las ciudades occidentales a partir de mediados del siglo XIX.

La presente tesis doctoral aborda el estudio de la influencia que tuvieron determinadas mejoras en el saneamiento urbano, como elemento de la transformación urbana acaecida en una gran capital europea, Madrid en el primer tercio del siglo XX, en la salud de la población y, de manera particular, en la mortalidad. Las variaciones, que se produjeron tanto en el desarrollo como en el consumo y disposición de estos elementos, pueden servir como reflejo de la transformación urbana sufrida a lo largo de nuestro periodo de estudio.

Pese a la importancia de tomar estos factores como elementos explicativos de la modernización urbana y su influencia en la mortalidad, lo cierto es que, en el contexto español, apenas se han realizado estudios que atiendan a la modernización de los servicios de agua y de evacuación desde finales del siglo XIX y primer tercio del siglo XX y, mucho menos, a la influencia de éstos en la mortalidad experimentada. Asimismo, también son escasos los trabajos que a nivel internacional lo abordan para grandes urbes y menos aún aquellos que usan registros individuales, tanto de defunciones, nacimientos como procedentes del padrón de habitantes.

Así, el objetivo principal de la presente tesis será cuantificar la importancia que tuvieron la mejora y extensión de la provisión de agua de consumo y de las redes de evacuación de agua en la mortalidad de la ciudad de Madrid en el primer tercio del siglo XX. En algunos casos, se realizarán análisis centrados en la mortalidad general, en otros, en la mortalidad infantil y/o en la mortalidad de niños menores de cinco años. Todo ello, haciendo especial hincapié en la mortalidad por enfermedades trasmitidas a través del agua y alimentos, partiendo de la hipótesis de su relación con los sistemas de saneamiento urbano. 
Para poder investigar el impacto del abastecimiento de agua y saneamiento en la mortalidad, se ahonda en la evolución de los modelos de organización, gestión y distribución del servicio de abastecimiento de agua y la red de alcantarillado entre la segunda mitad del siglo XIX y principios del XX, tomando como caso de estudio la ciudad de Madrid.

Uno de los potenciales de este trabajo de investigación radica en que se ha llevado a cabo empleando fuentes estadísticas que permiten dotar de una perspectiva espacial al estudio de la influencia de las mejoras en la infraestructura de red de agua de consumo y de la red de evacuación de agua. Para ello, se usan tanto mapas, cartografía y callejeros de la época, como una infraestructura de datos espaciales, que nos permitirán conocer cuál fue el alcance real de las citadas redes a nivel de áreas pequeñas dentro de la ciudad. Asimismo, seremos capaces de dibujar la distribución de la mortalidad por diferentes causas y grupos de población en función de la edad, y otra serie de variables que nos permitirán obtener una panorámica de la estructura social de la época y la segregación y fragmentación del espacio urbano.

Respecto a las fuentes de información de orden demográfico, emplearemos los registros individuales de partes de defunción y de nacimientos del Registro Civil de 1905-1907 y de 1920-1922 para los cálculos de la mortalidad infantil y de menores de cinco años. Para el resto de cálculos, se usarán, añadido a los datos anteriores, los correspondientes a los años 1918-1920. Se trata de fuentes de información de suma importancia en los análisis dentro del ámbito de la demografía histórica. La valoración de los mismos radica en dos motivos principales: el primero de ellos, descansa en la importancia de la propia rica información recogida en las partidas y, la segunda, en que se trata de registros individuales de defunciones, o nacimientos que nos permiten seguir un registro diario de eventos. A lo anterior hay que añadir que para estas fuentes de información de orden individual, la perspectiva espacial ha sido muy relevante, al contar con la dirección postal de la muerte y el nacimiento, permitiendo la geolocalización de los eventos, si bien esta información no ha podido ser obtenida de manera directa en todos los casos, dada la estructura e información de la fuente original. En este sentido, dado que buena parte de nuestros análisis se centran en el nivel de barrio, ha sido necesario disponer de callejeros históricos de la ciudad con especificaciones concretas de viales y su asociación a un barrio, con el objetivo de vincular éstos a nuestras bases de datos. 
Tanto la recolección del gran volumen de datos individuales, su tratamiento de depuración normativa y codificación, como la operacionalización de los indicadores sobre los sistemas de redes de alcantarillado y de agua y su posterior integración vinculada a la base de datos demográfica ha supuesto un intenso trabajo, tanto temporal como metodológico.

También se emplearán fuentes de datos agregados con el objetivo de obtener una panorámica general del periodo de estudio. Para tratar la situación sociodemográfica, se emplearán los datos de Resúmenes de Padrón y, en aras de disponer de una imagen de la mortalidad en el periodo de 1900 a 1930, se emplearán datos de los Anuarios Estadísticos de la ciudad.

Además, para llevar a cabo nuestros análisis, se ha utilizado información diversa, tanto documental como cartográfica, sobre la evolución de los sistemas de alcantarillado urbano y abastecimiento de agua de consumo en Madrid, con el objetivo de conocer el estado, lo más cerca de la realidad posible, del sistema de alcantarillado y de la red de agua para cada uno de los dos periodos.

Hay que tener en cuenta que la obtención de indicadores que permitan conocer el estado distributivo en el que se encontraban las redes de abastecimiento de agua de consumo y de los sistemas de evacuación de aguas residuales en los contextos pasados resulta complicado. En buena medida, de ahí radica la importancia del presente estudio, en tanto en cuanto se ha logrado extraer indicadores a nivel de barrio que lo permiten, mediante la combinación de mapas históricos y el uso de infraestructuras de datos espaciales.

El lector del presente trabajo, va a encontrar en sus manos un estudio acerca del desarrollo de los sistemas de distribución de agua y de redes de evacuación de aguas residuales en la ciudad de Madrid y su influencia en la mortalidad. Quizá, en ocasiones demasiado descriptivo, pero se ha considerado que para tratar de una manera óptima el proceso hay que entender y atender al contexto.

Por ello, se tratará la evolución histórica de la modernización del sistema de distribución de agua en Madrid, así como se hará con el sistema de canalización de las redes de evacuación. También se atenderá a la temática relativa a la depuración de las aguas de consumo que tuvo como objetivo mejorar su calidad, así como a la evolución del agua 
consumida. Asimismo, como manifestación institucional de la importancia de la higiene urbana, nos centraremos en la relevancia que tuvo el Laboratorio Municipal en estos cometidos. Para finalizar, como preludio del análisis centrado en la mortalidad, se realiza un estudio descriptivo tanto de la vivienda, como de las principales características sociales y demográficas de la ciudad de Madrid.

En síntesis, cabe decir que, en línea con otros estudios que atienden al impacto de la provisión de agua potable y la mejora en la gestión de residuos urbanos en el riesgo de mortalidad (en los que algunos han evidenciado tal impacto, mientras que otros no han reportado un efecto unívoco) los resultados obtenidos en el presente trabajo alientan a la apertura de un camino importante en el debate acerca del impacto real que el desarrollo de las infraestructuras de saneamiento tuvieron en el inicio del declive de la mortalidad en el pasado y tuvieron en la salud y la mortalidad en el contexto español de principios del siglo XX, que permitan ampliar el espectro de estudio acerca de los factores influyentes en el proceso de transición sanitaria y epidemiológica mediante el empleo de datos individuales.

En lo que respecta a la estructura formal de la presente tesis doctoral, atenderemos primeramente a la historiografía que ha tratado la temática relativa a la higiene urbana e infraestructuras sanitarias y su influencia en la mortalidad. Posteriormente, se señalará de manera pormenorizada las fuentes y metodología empleadas.

Los capítulos tres, cuatro y cinco están dedicados a la temática del agua, desde diferentes ámbitos. Así, en el capítulo tres trataremos la temática relativa a la evolución de los modelos de organización, gestión y distribución del servicio de abastecimiento de agua entre la segunda mitad del siglo XIX y principios del XX, tomando como caso de estudio la ciudad de Madrid. El capítulo cuatro versará sobre la calidad de las aguas de consumo y los medios de análisis de agua y de tratamiento de las mismas y en el capítulo cinco atenderemos a la evolución del consumo de agua en la ciudad de Madrid y su estrecha vinculación con el crecimiento poblacional y en extensión experimentado.

En el capítulo seis se hará alusión a la evolución del sistema de alcantarillado, desde el periodo previo a la construcción del primer alcantarillado moderno, de manos del Canal 
de Isabel II, hasta los años treinta del siglo XX. También se hará mención explícita al Proyecto sobre la Canalización y Saneamiento del Río Manzanares.

El capítulo siete estará dedicado a la historia, organización y funcionamiento del Laboratorio Municipal de Madrid, como manifestación institucional palpable de los preceptos higienistas de la época.

En el siguiente capítulo analizaremos las principales características sociales y demográficas de la ciudad de Madrid, desde un punto de vista tanto temporal como espacial, con el objetivo de obtener una panorámica de la realidad social del periodo de estudio.

El capítulo nueve estará dedicado a la realización de un bosquejo histórico de la fiebre tifoidea y a la manifestación de la relación existente entre la calidad de las aguas y la transmisión de la enfermedad. También se atenderá a la manifestación de la misma en el contexto español y mundial, así como a los debates surgidos en la época en torno a la epidemia de fiebre tifoidea de 1920 en Madrid.

En el capítulo diez se aborda el estudio de la mortalidad en la ciudad de Madrid durante el primer tercio del siglo XX, tomando como elementos explicativos la cobertura de la red de alcantarillado y de agua de consumo. En este sentido, para atender de forma óptima a los patrones de mortalidad y obtener una visión temporal y espacial del fenómeno, se analiza la evolución de la mortalidad en la ciudad de Madrid desde dos perspectivas y a través de dos tipos de fuentes. Mediante la reconstrucción de series anuales con datos individuales agregados para el análisis de la mortalidad general y por causas transmitidas a través del agua y alimentos y, además, se realiza una comparativa entre dos periodos (1905-1907 y 1920-1922) para el análisis de la mortalidad de niños menores de cinco años mediante datos individuales procedentes del Registro Civil de Nacimientos y del Registro Civil de Defunciones de la ciudad que serán representados en la Infraestructura de Datos Espaciales histórica de la ciudad de Madrid (HISDI$\mathrm{MAD}^{1}$ ). Asimismo, trataremos de ver si las mejoras implementadas en la infraestructura

\footnotetext{
1 HISDIMAD fue un producto del proyecto dirigido por Diego Ramiro Fariñas titulado, “Creación de una infraestructura de datos espaciales urbanos como plataforma de información geoespacial y sociodemográfica (IDEURBANA)" (CSO2010-11485-E) y la información de base de los proyectos de investigación CSO2008-06130/SOCl y CSO2011-29970 del Plan Nacional (I+D) del Ministerio de Economía Competitividad. Se trata de un geoportal de cartografía y demografía histórica para la ciudad de Madrid realizado siguiendo los estándares y normativa de interoperabilidad del Open Geospatial Consortium (OGC). Esta Infraestructura de Datos Espaciales utiliza como cartografía histórica el "Plano de Madrid y pueblos colindantes" de 1900 del cartógrafo español Facundo Cañada
} 
urbana de saneamiento de la ciudad de Madrid, influyeron en la probabilidad de morir por enfermedades transmitidas a través del agua y alimentos en dos periodos temporales, empleando, para ello, los datos individuales recogidos del registro civil de defunciones (1905-1906-1907 y 1918-1919-1920-1921-1922) mediante análisis de regresión logística binaria.

Por último se realizarán unas breves conclusiones acerca de los resultados obtenidos en el presente trabajo, así como sobre las debilidades y potencialidades del mismo. 


\section{Marco teórico}

La presente tesis doctoral se centra en el impacto que tuvieron las reformas y mejoras en infraestructura sanitaria en la mortalidad urbana, tomando como caso de estudio la ciudad de Madrid a principio del siglo XX.

De este modo, el enfoque historiográfico presente se centra especialmente en el efecto de las mejoras en el abastecimiento de agua y de alcantarillado en la mortalidad, así como en la implementación de mecanismos de tratamiento de las aguas de consumo. ${ }^{2}$.

La importancia que tuvieron las reformas de saneamiento en la reducción de la mortalidad desde el siglo XIX y principios del siglo XX ha sido objeto de estudio de la demografía histórica y corrientes médicas y epidemiológicas, principalmente. Si bien, es necesario señalar que los resultados obtenidos no ofrecen resultados claros, en la medida en que la influencia del saneamiento en la mortalidad no ha podido ser siempre demostrada.

McKeown (McKeown 1976:253), por ejemplo, asignaba un papel secundario a la importancia del suministro de agua y al saneamiento como factores influyentes en la reducción de las tasas de mortalidad, focalizando la nutrición como elemento primordial a la hora de relacionar las mejoras en los niveles de vida con la reducción de las tasas de mortalidad. Otra serie de estudios posteriores fueron incorporando un conjunto más amplio de factores, relacionados con los niveles de vida, como argumentos para explicar la disminución de la mortalidad (Grundy 2004; Murray, Chen and CHEN 1993; Riley 2001; Schofield and Reher 1991).

Asimismo, se debe tener en consideración la posible influencia indirecta en la mortalidad por otras causas, tal y como manifiestan autores como Preston y Van de Walle o Ferrie y Troesken (Preston \& Van de Walle, 1978; Troesken, 2004).

A lo anterior, hay que añadir el hecho de la inexistencia de un consenso sobre las causas de muerte que, de facto, son afectadas por el estado en el abastecimiento de agua y del alcantarillado, en la medida en que existe variedad de puntos de vista sobre la mejor

\footnotetext{
${ }^{2}$ Un análisis exhaustivo sobre el estudio de la caída general de la mortalidad en Madrid y en zonas urbanas en España puede consultarse en (Pérez Moreda, Reher, \& Sanz Gimeno, 2015; Sanz Gimeno, 2001)
} 
manera de identificar las enfermedades que tenían más probabilidades de responder a las mejoras sanitarias (Harris \& Helgertz, 2019).

Las enfermedades clásicas por excelencia relacionadas con la transmisión a través del agua son la fiebre tifoidea y el cólera. Si bien, hay que tener en cuenta que, en ocasiones, la nomenclatura de tifus o tifoidea se empleaba de manera indistinta, cuando se trata de enfermedades totalmente diferentes (de Looper, Booth, \& Baffour, 2019). La gastroenteritis también ha sido incluida en algunos estudios (de Looper et al., 2019; Helgertz \& Önnerfors, 2019), entre otras enfermedades tales como la pirexia.

\subsection{Los debates sobre la disminución de la mortalidad.}

Las causas del descenso de la mortalidad urbana han sido objeto de estudio desde tiempo pasado. En los últimos años, la importancia de este objeto de estudio ha cobrado un destacable interés, especialmente las investigaciones centradas en la influencia de la contaminación atmosférica, así como la influencia de la mejora en la dieta. Sin embargo, el papel que juegan las mejoras sanitarias, no es menor importante. Estudios recientes han tratado de desentrañar la importancia de éstas en la mortalidad desde mediados del siglo XIX en distintos contextos, países y continentes (Davenport, Satchell, \& Shaw-Taylor, 2019; de Looper et al., 2019; Esteve Palos \& Recaño Valverde, 2006; Harris \& Hinde, 2019; Helgertz \& Önnerfors, 2019; Hinde \& Harris, 2019; Peltola \& Saaritsa, 2019).

En este sentido, las líneas de debate que giran en torno a la disminución de la mortalidad siguen teniendo suma importancia en las esferas sociales, demográficas, económicas y médicas, entre otras. El abanico de líneas de investigación que han abordado y abordan este tema van desde el impacto que los factores medioambientales en la mortalidad, centrándose en la contaminación atmosférica (Bailey, Hatton, \& Inwood, 2018; Beach \& Hanlon, 2018), al impacto de los avances en saneamiento (Chapman, 2019; Kesztenbaum \& Rosenthal, 2014, 2017), mientras que otros siguen manteniendo la nutrición y la dieta como aspectos más relevantes (Floud, Fogel, Harris, \& Hong, 2011; Fogel, 2004). A día de hoy, el alcance de los distintos factores en la disminución de la mortalidad, sigue siendo objeto de discusión. 
Y esta discusión es relevante, porque en la actualidad, según el Banco Mundial, el 56,71 por ciento de la población mundial pueden ser clasificada como población urbana

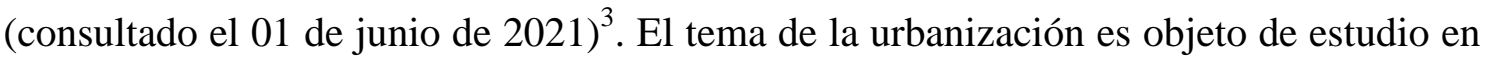
sí mismo desde distintas esferas del conocimiento: la demografía, la sociología urbana, entre otras, siendo elemental para los estudios sobre el cambio de la mortalidad. Son tradicionales los estudios y la preocupación sobre la sobremortalidad urbana, sobre todo durante el proceso de modernización demográfica, cuando se producen los principales flujos de migración a las zonas urbanas (Pérez Moreda et al. ,2008)).

Otros autores han destacado la importancia del estudio de la disminución de la mortalidad como elemento clave para comprender el proceso de crecimiento económico, fruto de la disminución de la mortalidad en la infancia y el aumento de la longevidad (Lee, 2003), así como de las mejoras en la salud en edades avanzadas, que contribuye a la mejora de la productividad económica (Floud et al., 2011).

El debate acerca de los factores que provocaron la caída de la mortalidad ha sido muy intenso en las últimas décadas. Una de las tesis más conocidas sobre las causas de la caída de la mortalidad es la de Thomas McKeown, que mantenía que la disminución en la mortalidad en Inglaterra, durante la segunda mitad del siglo XVIII, estaba asociada con la disminución de la mortalidad por enfermedades infecciosas. En términos generales, McKeown consideraba que las mejoras producidas en la nutrición y en la dieta eran los factores más relevantes a la hora de atender a la disminución de la mortalidad, por delante de otros como las mejoras médicas, mejoras en saneamiento, la disminución de la virulencia de los organismos infecciosos y el aumento en la inmunidad de la especie humana (McKeown, 1976; McKeown, Brown, \& Record, 1972; McKeown \& Record, 1962).

El trabajo de McKeown es polémico en algunas de sus explicaciones, en la medida en que, supone una subestimación de la influencia que tuvieron las mejoras sanitarias implementadas desde el siglo XIX (Szreter, 1988). Uno de los puntos de crítica a las tesis de la teoría de McKeown radica en torno a la vinculación existente entre nutrición e infección, en tanto en cuanto si bien las mejoras en la nutrición pueden fomentar una mayor resistencia a las infecciones, la disminución a la exposición a las enfermedades puede ser un componente de las mejoras en el estado nutricional (Scrimshaw \&

\footnotetext{
${ }^{3}$ https://data.worldbank.org/indicator/SP.URB.TOTL.IN.ZS
} 
SanGiovanni, 1997). A su vez, la disminución de la exposición a la infección depende de factores relacionados con las medidas sanitarias implementadas (Harris, 2004).

Tradicionalmente, desde las esferas de la economía, la historia y la demografía, para investigar la influencia de la nutrición en la disminución de la mortalidad, se han empleado indicadores relacionados con la estatura o la talla. Un estudio intensivo sobre este tema es el realizado por Fogel et al (2007), quienes manifestaban que la disposición de datos sobre la estatura de la población permite obtener información sobre el estado de nutrición de dicha población, lo que suponía un avance respecto a los análisis de McKeown. Sin embargo, los autores también muestran que el "estado nutricional neto", medido a través de los datos de estatura, es la manifestación no sólo de la dieta, sino también de la enfermedad. Otro de los estudios destacables es el de Harris et al (Harris, Floud, \& Hong, 2015), que mantienen que las mejoras en salud pública jugaron también un papel importante en la disminución de la mortalidad.

Es en este aspecto en el que nos vamos a centrar, cómo se ha abordado en la literatura la caída de la mortalidad en zonas urbanas gracias a las mejoras en higiene pública, en el abastecimiento de aguas y el saneamiento público.

\subsection{El impacto de la intervención sanitaria}

Hay que tener en cuenta que la mayor inversión en mejoras en el suministro de agua no tuvo por objetivo primario la mejora de la salud pública vinculada a los problemas sanitarios que acuciaban a buena parte de la población de las grandes ciudades desde finales del siglo XVIII (Ogasawara \& Inoue, 2015; Wohl, 1983). La salud pública se vio, de este modo, beneficiada de manera indirecta, en tanto en cuanto los motivos iniciales estaban vinculados, especialmente, a mejoras en el valor de las propiedades, el uso industrial del agua... etc. Sin embargo, la combinación de medidas relacionadas con la mejora del suministro de agua y las de eliminación de residuos no se llevó a cabo al unísono en casi ningún caso (Hassan, 1985).

Las primeras críticas ante la inexistencia de un alcantarillado suficiente y eficiente, venían abaladas por la Teoría miasmática de la enfermedad (Hauser, 1902b), basada, en términos generales, en la propagación de enfermedades infecciosas por el "aire impuro 
o malo" emanado por las materias en descomposición. Con el paso de los años y la llegada de nuevas teorías, se demostró que la teoría miasmática de la enfermedad era errónea, aun así tuvo implicaciones prácticas beneficiosas (Flinn, 1965). Un punto de inflexión importante ante la comprensión de la transmisión de enfermedades infecciosas tuvo por origen la epidemia de cólera sufrida en Londres en 1854, con las investigaciones de John Snow y el posterior desarrollo de la teoría bacteriológica de la enfermedad (Harris \& Helgertz, 2019). A partir de este momento, la calidad de las aguas comenzó a jugar un papel importante en la implementación de medidas orientadas a la consecución de la misma.

En relación a la pregunta de investigación planteada en la presente tesis doctoral (cómo las reformas sanitarias afectaron la mortalidad urbana durante este período), el análisis bibliográfico sobre la influencia de las reformas sanitarias en la mortalidad urbana nos ofrece resultados bastante disímiles unos de otros. Algunos autores llegan a la conclusión del efecto de la inversión en saneamiento en la disminución de la mortalidad (para el contexto británico (Hinde \& Harris, 2019)) y la introducción de nuevos suministros de agua en la mortalidad por enfermedades trasmitidas a través del agua (Sydney, (de Looper et al., 2019), así como el impacto de las reformas sanitarias en la disminución de la mortalidad infantil (Finlandia, (Peltola \& Saaritsa, 2019)).

Esteve y Recaño (Esteve Palos \& Recaño Valverde, 2006), en su estudio sobre el análisis de la mortalidad en la ciudad de Barcelona a finales del siglo XIX (1880-1889), muestran la influencia de factores ambientales y espaciales en las causas de muerte de los 53 barrios que constituían la ciudad de Barcelona. Concretamente, encuentran diferencias significativas por barrios en lo que respecta a las enfermedades transmitidas por el agua y los alimentos.

Destacable también el estudio de Meckel (Meckel 1985) sobre la introducción de los sistemas centrales de suministro de agua y alcantarillado en la ciudad de Boston entre 1840 y 1880. Los resultados de su investigación también advierten que la sustitución del antiguo sistema de abastecimiento por la canalización de agua por tubería contribuyó a la reducción de mortalidad por enfermedades infecciosas transmitidas a través del agua.

Otros autores no encuentran evidencias significativas, o llegan a resultados bastante más modestos a la hora de establecer una relación explicativa entre las reformas sanitarias y la disminución de la mortalidad (Suecia, (Helgertz \& Önnerfors, 2019) y Suiza, (Floris 
\& Staub, 2019)). Castensson et al. (Castensson, Löwgren and Sundin 1988:273-298) utilizaron un argumento similar para comparar la tendencia de las tasas brutas de mortalidad que siguieron a la introducción de un sistema de suministro de agua y alcantarillado en cuatro ciudades suecas entre 1860 y 1920. El análisis no reveló cambios en la mortalidad que pudieran conectarse a los años en que se construyeron las instalaciones.

Además, hay que tener en cuenta que Los cambios producidos en la mortalidad urbana están estrechamente vinculados al tema de la urbanización de los espacios. En general, se acepta que la urbanización desordenada agravó los problemas de salud pública existentes y esto implica que existía una necesidad específica de abordar los problemas asociados con esas áreas (Harris \& Helgertz, 2019).

En este sentido, un aspecto adicional que debemos tener en consideración es el relativo a la posible relación entre el impacto de la mejora del suministro de agua y el tamaño de los núcleos urbanos. Hinde y Harris (2019), en su estudio sobre la mortalidad en Inglaterra y Gales desde mediados del siglo XIX hasta la primera década del siglo XX, mantienen que si bien existían diferencias en las tasas de mortalidad atendiendo a la densidad de población, también concluyen que la disminución de las tasas de mortalidad era similar independientemente del tipo de área.

Helgertz y Önnerfors (2019), mantienen que la implementación de medidas de mejora de abastecimiento de agua y de las redes de evacuación en entornos poblacionales más pequeños supone que una mayor parte de la población en cuestión podría beneficiarse de manera más rápida, por lo que la estimación del impacto de la puesta en marcha de tales medidas, sería estimada de manera más precisa. Los autores también muestran en su estudio que las diferentes vías por las que se pueden transmitir enfermedades infecciosas por el agua y/o por los alimentos (trasmisión del agua y/o alimentos a las personas, transmisión de persona-persona y la transmisión de persona a otra persona a través de la trasmisión de persona a los alimentos y/o al agua), vendría determinada por la densidad y el tamaño de la población. En este sentido, los autores abogan por estudios centrados en núcleos de población más pequeños, en aras de una mejor comprensión de la influencia de las medidas implementadas ante la trasmisión de enfermedades infecciosas transmitidas por el agua y alimentos en áreas urbanas. 


\subsubsection{Procesos de calidad de las aguas: la filtración y la cloración}

La filtración y la cloración fueron los principales mecanismos de que se dispuso para mejorar la calidad de las aguas (D. Cutler \& Miller, 2005). En cuanto a la cloración, había dos tipos; la filtración por arena y la filtración rápida. El primer mecanismo se basaba en "colar" el agua con una base de arena u otra materia porosa, de manera que las bacterias quedaban en la superficie de la materia porosa empleada (arena o grava, generalmente). La filtración rápida era parecida al anterior proceso, con la salvedad de que se empleaba agua a presión para que la filtración a través de la arena tuviera mayor fortaleza. Respecto al proceso de cloración de las aguas, su generalización tuvo lugar tiempo más tarde, entrado el siglo $\mathrm{XX}$, fruto, en buena medida, de reticencias por parte de la población (Peltola \& Saaritsa, 2019).

Uno de los principales estudios que se centra en la relación existente entre la calidad de las aguas y la mortalidad es el de Meeker (Meeker 1971), que se centró en la influencia que tuvo la introducción de métodos de filtración de agua en diferentes ciudades americanas entre 1850 y 1915 , concluyendo que dichas mejoras en obra pública sanitaria fueron continuadas por una disminución de la mortalidad por fiebre tifoidea.

Ferrie y Troesken (Ferrie and Troesken 2005, 2008) tomaron como elemento importante en la explicación de la transición de la mortalidad los mecanismos de purificación y cloración del agua junto con la conducción de agua por tubería. Estos elementos influyeron, según sus estudios, a la reducción de la mortalidad por enfermedades transmitidas por agua en la ciudad de Chicago entre 1850 y 1925. Según sus estimaciones, entre el 30 y el 50 por ciento de la disminución de la tasa de mortalidad de Chicago podría atribuirse a la purificación del agua ya la subsiguiente erradicación de la fiebre tifoidea.

La influencia de los medios de filtración y cloración también fueron estudiados por Cutler y Miller (2005) para trece ciudades de los Estados Unidos, concluyendo que más del sesenta por ciento de la reducción de la mortalidad infantil, podía ser explicada por la introducción de los medios de purificación de las aguas. En relación al estudio de Cutler y Miller, autores como Anderson, Charles y Rees (Anderson, Charles, \& Rees, 2018) mantuvieron que la reducción estaba sobrestimada. En esta misma línea, encontramos el estudio de Alsan y Goldin (Alsan \& Goldin, 2015), quienes 
argumentaron que los medios de filtración y cloración no podían tener el impacto declarado en la mortalidad infantil.

Atendiendo a los estudios que tuvieron como objeto de estudio poblaciones europeas, cabe destacar el realizado por Preston y Van de Walle (Preston and Van de Walle 1978), quienes focalizaron su atención en la relación entre la calidad del suministro de agua y la presencia de mecanismos de gestión de aguas residuales y la mortalidad diferencial en diferentes regiones francesas. Nilsson (Nilsson 1994) realizó un estudio sobre Linköping (Suecia), demostrando que las áreas de la ciudad que estuvieron abastecidas más tempranamente por sistemas centrales de agua fueron las que experimentaron una disminución de la mortalidad más rápida.

Un aspecto más a tener en consideración añadido a la calidad, es el relativo a la cantidad de las aguas. Autores como Ewal (1991) defendían la teoría de que cada una de las dos características actuaba como elemento protector de un tipo de infecciones. Así, una mayor cantidad disponible de agua, favorecía la protección ante patógenos más "benignos" como V. cholerae, shigella sonnei y E.coli enterotoxigénica. Respecto a las mejoras en la calidad del agua, éstas fomentaban la probabilidad de reducir la mortalidad por "patógenos graves" como V. cholera clásico, salmonella typhi y shigella dysenteriae.

Si bien el empleo de tecnología que tuvo por objetivo la limpieza de las aguas, como la filtración y la cloración, con la pretensión de mejorar su calidad fue un aspecto relevante, tal y como demostraron autores como Cutler y Miller (2005), otros autores mantienen que es necesario partir de la premisa de que dicho agua sin tratar ya estuviera contaminada (Ogasawara \& Inoue, 2015).

La importancia de tomar agua de tramos de río en su nacimiento o cercanos al mismo como elemento protector de la mortalidad por enfermedades transmitidas a través del agua ha sido demostrada por algunos autores. De Looper, Booth y Baffour (2019), en su estudio sobre las mejora sanitarias y la mortalidad en Sydney entre 1857-1906, mantienen que el hecho de comenzar a suministrar agua de las zonas altas del río Nepean, es el factor explicativo más relevante del cambio experimentado en la mortalidad por enfermedades transmitidas a través del agua. Hay que tener en consideración, que los autores enfatizan, también, el hecho de que la generalización de las conexiones a la red de agua potable se produjo de manera muy rápida. Así, en 1888, 
dos años después de que llevasen a cabo los reemplazos del suministro con agua de los tramos altos del río, el ochenta y cinco por ciento de la población disponía de conexión a la red.

Los estudios anteriormente descritos, están caracterizados por haber hallado una relación causal basada en una reducción de la mortalidad. Pero, tal y como señalamos, existen otra serie de estudios cuyos resultados no detectan una relación clara entre el desarrollo y mejora de las infraestructuras de saneamiento, de abastecimiento de aguas y tratamiento de las mismas y la reducción de la mortalidad.

Las investigaciones de Gaspari y Woolf (Gaspari and Woolf 1985) se centraron en la relación existente entre el ingreso y gasto en obras públicas y mortalidad en ciudades americanas de principios del siglo XX, empleando métodos de regresión lineal para analizar los efectos del suministro de agua sobre las diferencias transversales en la tasa de mortalidad de 122 ciudades en los Estados Unidos que tenían una población de 30.000 o más en 1910. Los resultados de su investigación señalan que, si bien aquellas ciudades que invirtieron en sistemas de alcantarillado tuvieron menor mortalidad, no hallaron asociaciones entre la instalación de un sistema urbano de filtración de agua y una disminución de la mortalidad.

Ante la necesidad dar explicación a la ausencia unívoca de resultados que permitieran relacionar las mejoras en los sistemas de saneamiento y la mortalidad, Gaspari y Woolf (Gaspari and Woolf 1985) hicieron hincapié en la deficiente información sobre la calidad del agua y la cobertura del sistema de agua filtrada en las 122 ciudades que estudiaron. Algunas de las ciudades estudiadas pudieron haber tenido provisiones de agua sin que ello significase que se implementaran de forma conjunta con sistemas de filtración.

Resultados similares ofrecieron los estudios de Massey, Condran and Denton (Massey, Condran and Denton 1987), quienes investigaron el impacto de los cambios en el suministro de agua de Filadelfia entre 1890 y 1920. Los métodos de filtración de agua se instalaron en diferentes áreas de la ciudad en diferentes momentos durante estos 30 años y, si bien la filtración de agua puso fin de inmediato a las epidemias de fiebre tifoidea, los resultados de la investigación muestran que no tuvo un efecto tan claro 
sobre las muertes por otras enfermedades transmitidas por el agua, como la diarrea infantil, la diarrea infantil, la disentería y la enteritis.

\subsubsection{La inversión sanitaria}

Otra línea de investigación se ha entrado en la historia de las reformas sanitarias a través del estudio del gasto público en estas medidas. Estudios realizados para Inglaterra y Gales (Bell \& Millward, 1998; Chapman, 2019; Szreter, 1988), se centran en los préstamos que las autoridades asumieron como proxi para medir la intervención sanitaria. Cercano a estos análisis, encontramos el llevado a cabo por Harris and Hinde (2019), quienes atienden al impacto de los préstamos del gobierno central o del Parlamento en la disminución de la mortalidad. Sus resultados apuntan a que la mortalidad por enfermedades transmitidas a través del agua se redujo a medida que aumentaba el valor de los préstamos. Sin embargo, también señalan que los resultados no son símiles entre lugares, por lo que es necesario tomar los contextos particulares de cada zona local.

Para Inglaterra, cabe destacar el estudio de Bell y Millward (Bell and Millward 1998), quienes se centraron en la relación entre las tasas de mortalidad infantil y general con el nivel y momento del gasto del gobierno local en la infraestructura de saneamiento, para 36 ciudades de Inglaterra y Gales entre 1870-1914. Ellos encontraron que el momento de un pico de inversión en saneamiento y el inicio de una disminución general de la mortalidad infantil coincidió, lo que sugiere una relación causal.

Destacables son los estudios sobre la influencia de pequeñas mejoras sanitarias implementadas como elementos claves para la reducción de la mortalidad infantil, previo a la inversión pública en implementación o mejora de las redes de agua y de alcantarillado (Jaadla \& Puur, 2016). Sin embargo, la mayoría de estudios que versan sobre esta línea, argumentan que el papel que jugaron las grandes inversiones públicas en estas materias fue clave para la reducción de la mortalidad, especialmente de la mortalidad específica por enfermedades transmitidas a través del agua.

Teniendo como objeto de estudio el entorno anglosajón, autores como Szreter y Chapman (Chapman, 2019; Szreter, 1988) estudiaron la influencia de las 
intervenciones sanitarias llevadas a cabo en municipios de Inglaterra y Gales. Mientras que Szreter se centró en el análisis de la influencia del valor de los préstamos aprobados en materia de sanidad municipal y su influencia en la caída de la mortalidad desde 1870, Chapman atendió a la relevancia del valor de la deuda municipal y la disminución de la mortalidad entre 1891 y 1900 . Ambos mantienen que la disminución de la mortalidad se vio influida por los dos indicadores descritos, respectivamente por cada autor.

En el contexto estadounidense, Cain y Rotella (Cain \& Rotella, 2001) estudiaron el gasto en saneamiento llegando a la conclusión de que en 48 ciudades de los Estados Unidos, la reducción en la mortalidad por enfermedades transmitidas a través del agua, se vio influida por el aumento del gasto público en saneamiento urbano.

Si bien, hay que tener en consideración que cuando se trata la temática de la inversión pública en saneamiento urbano, es difícil obtener información desagregada sobre la inversión por clase de actividad de obra pública. A su vez, hay que tener en consideración las diferencias entre obras vinculadas al abastecimiento de agua, obras relativas al sistema de evacuación de residuos y las referentes a la calidad de las aguas.

En este sentido, es de suma importancia conocer la sucesión de las diferentes obras implementadas, como veremos más adelante teniendo en cuenta el caso de la ciudad de Madrid. Algunos estudios mantienen que la secuencia en la implementación de medidas tuvo una influencia significativa en la mortalidad, de manera que pudo ser perjudicial en algunos casos. Un ejemplo de ello es el estudio de Hassan (1985), quien mantiene que, en algunos municipios de Inglaterra y Gales, la primera inversión en abastecimiento de agua no se acompañó de la correspondiente en el sistema de evacuación, lo que conllevó a que algunas zonas se vieran perjudicadas, o expuestas a un mayor riesgo, con las medidas de abastecimiento.

En esta misma línea se encuentra el estudio de Hubbard (2000), en su estudio sobre Bergen y Oslo, en Noruega. En líneas generales, el autor compara las medidas implementadas en ambas ciudades en torno a 1860, llegando a la conclusión de que la mayor disminución de la mortalidad en Bergen respecto a Oslo, vino determinada porque en esta ciudad se implementaron a la par medidas de abastecimiento y evacuación de residuos, mientras que en Oslo las medidas adoptadas sólo tuvieron por objetivo el suministro de agua. En esta línea explicativa encontramos los estudios de Gallardo y Kesztenbaum \& Rosenthal (Gallardo Albarrán, 2018; Kesztenbaum \& 
Rosenthal, 2017) . Gallardo estudia el contexto alemán, llegando a la conclusión de que la mortalidad se redujo entre un 19 y un 23 por ciento entre 1877 y 1913 fruto de la combinación de medidas de abastecimiento de aguas y evacuación de residuos. Por su parte, Kesztenbaum \& Rosenthal, mantienen que una conexión directa a la red de alcantarillado fue determinante para esa caída de la mortalidad.

A diferencia de lo que sucedió en Madrid, donde las reformas de abastecimiento y evacuación de aguas se extendieron de manera muy lenta a toda la población, Helgertz y Önnerfors (2019) en su estudio sobre Suecia, afirman que, el año siguiente a la introducción de reformas de suministro de agua, se conectaron más de mitad de los hogares y, en los cinco años siguientes, ya aparecían conectados más de las tres cuartas partes. Respecto a la red de evacuación de aguas, las proporciones resultaron muy similares a las de la conexión a la red de abastecimiento.

\subsubsection{Mortalidad infantil y mejoras en higiene urbana.}

El estudio de la mortalidad infantil en general y por causas específicas como la mortalidad por diarrea y disentería, en áreas urbanas entraña serias dificultades. Atendiendo a la mortalidad infantil por estas causas, si bien estudios contemporáneos parecen defender la hipótesis de que el saneamiento y el abastecimiento de agua influyen en la misma (Cairncross et al., 2010), los análisis históricos no parecen encontrar evidencias significativas clara. Un ejemplo de ello lo muestra el estudio de Davenport, Satchell y Shaw-Taylor (Davenport et al., 2019) en su investigación sobre el cólera en varias ciudades británicas entre los años 1831 y 1866, quienes mantienen que la calidad del suministro de agua no podía tomarse como factor explicativo de la mortalidad infantil general ni por diarrea.

El ya citado estudio de Cutler y Miller (2005) toma la influencia de los sistemas de cloración y filtración de agua para explicar la mortalidad infantil. Si bien, el hecho de que la mortalidad infantil se use como variable dependiente es controvertido. Así lo manifestaron los propios autores en un posterior estudio (D. M. Cutler \& Miller, 2019) afirmando que se tiende a considerar que la mortalidad infantil es menos susceptible a variaciones en la calidad de las aguas, por estar mayor condicionada a factores relacionados con el nacimiento (especialmente en los 28 primeros días de vida) y la 
lactancia, de modo que otra serie de factores explicativos, como los relacionados con la obstetricia, podrían ser más influyentes que las mejoras en la calidad de las aguas.

En cuanto a la influencia de la calidad del agua y la mortalidad infantil, Davenport et al. (Davenport et al., 2019) mantienen que, según sus análisis para el contexto británico, la mortalidad por diarrea y la mortalidad infantil no estuvieron relacionados con los instrumentos empleados para la mejora de la calidad del agua. En este sentido, es ineludible la importancia de continuar atendiendo a la comprensión de la etiología de la mortalidad por diarrea (Peltola \& Saaritsa, 2019), así como a las pautas de alimentación infantiles, en aras de poder comprender los cambios en la mortalidad infantil y por diarrea y sus causas asociadas. En este sentido, Condran (Massey et al. 1987) hizo hincapié en la influencia que hubiera podido tener las mejoras en la calidad de la oferta de leche, que coincidieron temporalmente con una marcada disminución de la mortalidad infantil. El estudio de Edvinsson (Brändström and Tedebrand 1993) mantuvo que la falta de capacidad explicativa para establecer una relación entre las mejoras de saneamiento y la mortalidad infantil por enfermedades gastrointestinales radicaba en la existencia de una mala calidad del agua canalizada de Sundsvall en la década de 1880 (documentada por los contemporáneos) y a las prácticas de lactancia materna, que podrían haber influido de manera más acusada en la mortalidad que los efectos ofrecidos por las condiciones de saneamiento.

Brändström and Tedebrand (Brändström and Tedebrand 1993:55-108) utilizaron un análisis a nivel individual con el objetivo de medir el efecto de las mejoras de saneamiento en Sundsvall, el norte de Suecia en la década de 1880. En 1879, los que vivían en las partes internas de la ciudad obtuvieron acceso a agua corriente y un sistema de alcantarillado, mientras que los residentes de otros lugares seguían dependiendo de un sistema mediante pozos. Usando modelos de riesgo, Edvinsson demostró que, mientras que la mortalidad infantil era realmente más alta en las áreas donde las mejoras de saneamiento no habían sido implementadas, la diferencia no era estadísticamente significativa, ni era el resultado de una mayor mortalidad por enfermedades gastrointestinales.

Sin embargo, la investigación sobre las diferencias espaciales en la mortalidad diarreica en niños en Estocolmo, 1878-1925, reveló que la mortalidad infantil era menor en áreas 
donde más hogares recibían agua corriente (Macassa, Ponce de Leon and Burström 2006).

Por su parte, Peltola y Saaritsa (2019), toman como objeto de estudio las mejoras introducidas en el abastecimiento de agua, en los sistemas de alcantarillado y la aplicación de medidas de cloración en treinta y siete ciudades de Finlandia entre los años 1870 y 1938 y su influencia en la mortalidad infantil. En sus análisis, encuentran una relación estadísticamente significativa, de modo que consiguen explicar cerca del veintiséis por ciento de la mortalidad infantil para el periodo de estudio. Además, observan que el efecto del desarrollo de las medidas implementadas es mayor en caso de que éstas se lleven a cabo en ciudades pequeñas y medianas, que en núcleos de población mayores. Tal y como hemos señalado en líneas precedentes (Floris \& Staub, 2019), Peltola and Saaritsa (2019) también mantienen que es necesario tener en consideración factores adicionales a la hora de explicar la disminución de la mortalidad cuando intentan explicar la influencia de las reformas de saneamiento y de suministro de agua en la mortalidad en Finlandia, de manera general. En este sentido, advierten que, si bien las reformas sanitarias tuvieron un impacto positivo en la reducción de la mortalidad urbana, en el periodo de estudio analizado, 1870-1938, la mayoría de la población en Finlandia no tenía su residencia en núcleos urbanos.

Cabe destacar, también, la investigación llevada a cabo por Helgertz and Önnerfors (2019) en 84 ciudades suecas entre 1875 y 1930. Los autores se centran en la influencia de la implementación de sistemas de agua corriente y alcantarillado, como reformas introducidas de manera paralela, en su caso. Tras el análisis del impacto de las medidas en la mortalidad infantil, ésta tan sólo se vio reducida en un seis por ciento, siendo de un nueve por ciento teniendo en consideración la mortalidad por enfermedades transmitidas a través del agua y de un cinco por ciento para la mortalidad general. Los autores manifiestan, como posible explicación a sus resultados, la influencia de haber tomado como objeto de estudio ciudades de reducido tamaño. Esta hipótesis entra en conflicto con las de otros autores que afirman que el impacto de la implementación de medidas sanitarias es mayor en núcleos de población de medio y pequeño tamaño (Peltola \& Saaritsa, 2019). Esta contraposición, pone de manifiesto la necesidad de atender a los elementos característicos de cada entorno urbano de manera pormenorizada, atendiendo de manera exhaustiva al contexto individual en que se implementen las medidas sanitarias. 


\subsubsection{Problemas metodológicos}

A los debates expuestos, hay que sumar otros que giran en torno a la metodología y la selección de variables adecuadas. Así, en su revisión de la literatura anterior, Van Poppel y Van der Heijden (Van Poppel and Van der Heijden 1997:113-148) pusieron el foco de atención sobre una serie de problemas metodológicos que pudieron haber complicado los análisis empíricos y contribuyeron a este escenario de resultados mixtos mostrado en las líneas anteriores. Uno de estos problemas es el nivel de análisis. Los estudios históricos a menudo se llevaron a cabo a escala agregada, utilizando ciudades o distritos urbanos como unidades de análisis, ocultando así gran parte de la variación, tanto en las tasas de mortalidad como en la provisión de un ambiente sanitario, y sesgando cualquier correlación entre ellos a la baja. Cuando los datos agregados se derivan de fuentes publicadas, los investigadores se limitan a tabulaciones cruzadas y clasificaciones que no fueron diseñadas para cumplir con las agendas de investigación modernas. El análisis de los datos agregados también se basa en correlaciones ecológicas: produce asociaciones espaciales que pueden ser erróneamente interpretadas como enlaces causales.

Otro problema señalado por Van Poppel y Van der Heijden fue el control inadecuado de los factores de confusión que, a su vez, puede ser generalizable al conjunto de estudios en demografía histórica. Esrey y Habicht (Esrey and Habicht 1985) proporcionan una larga lista de esas variables a considerar en los análisis que tienen como objeto de estudio el abastecimiento de agua el saneamiento, incluyendo edad y sexo, educación, ingreso, dieta, patrones de lactancia materna, condiciones de vivienda y acceso a la atención médica. Las intervenciones en el abastecimiento de agua y el saneamiento pueden ir acompañadas de cambios en otros factores y la falta de control de sus efectos podría impedir la estimación de los verdaderos beneficios de las intervenciones. Otra dificultad con los estudios históricos fue la inadecuada especificación de las variables dependientes. Es probable que algunas causas de muerte, como la diarrea, la fiebre tifoidea y el cólera, se vean directamente afectadas por el desarrollo de obras sanitarias y sistemas de alcantarillado, pero otras no. Cuando las medidas globales de mortalidad resultan inadecuadas, las muertes pueden tener que desglosarse en categorías de causa de muerte. 
Para nuestro caso de estudio, a la hora de atender a la evaluación del efecto que las intervenciones sanitarias tuvieron en la mortalidad urbana (medidas a través de la inversión en obras públicas de saneamiento, implementación o desarrollo de sistemas de agua corriente, desarrollo y/o extensión de redes de alcantarillado) para el caso de Madrid, con la información disponible se ha de asumir que existen lagunas que impiden que los análisis lleguen a alcanzar un mayor grado de exhaustividad sobre el alcance real de las iniciativas. Otro aspecto importante a tener en cuenta, es la falta de una conclusión unánime en la literatura sobre la identificación de variables apropiadas y sobre qué mortalidad tuvo mayor efecto esas mejoras en el saneamiento público, bien sobre la mortalidad por causas específicas y/o la mortalidad general y/o la mortalidad infantil (Harris \& Helgertz, 2019). 


\section{Fuentes y metodología}

Teniendo en cuenta que el objetivo principal de nuestro trabajo es el estudio de la mortalidad en la ciudad de Madrid, tomando como hipótesis la influencia que la implementación de mejoras en los sistemas abastecimiento de agua de consumo y de alcantarillado tuvieron en la misma, para llevarlo a cabo, se necesita disponer, por un lado, de información de demográfica y, por otro, de aquella relativa a los sistemas de higiene en infraestructura urbana.

Para la información sobre eventos vitales, recurriremos, como fuente de datos principal, a los partes de nacimientos y defunciones de la ciudad de Madrid en dos periodos temporales. En el primer caso, se dispone de información individual sobre los años 1905-1907 y 1920-1922. En cuanto a los partes de defunciones, disponemos de información individual de los registros de los años 1905-1907 y 1918-1922. También se emplearán fuentes de datos agregados de información demográfica, como los Anuarios Estadísticos de la ciudad de Madrid y los Resúmenes de padrón.

Respecto a los sistemas de abastecimiento de agua y red de alcantarillado, además de información histórica extensa sobre su evolución desde mediados del siglo XIX hasta los años treinta del siglo XX, se emplearán como elemento indispensable mapas históricos sobre dichos sistemas. Éstos, se someterán a un tratamiento mediante herramientas de Sistemas de Información Geográfica sobre la Infraestructura de Datos Espaciales de la Ciudad de Madrid, con el objetivo de poder crear indicadores que nos permitan operacionalizar la cobertura de red de agua y de alcantarillado como variables susceptibles de ser sometidas a análisis.

Asimismo, dado que otro de nuestros objetivos es atender a la posible variabilidad espacial de la mortalidad a nivel de barrio en la ciudad de Madrid, se emplearán callejeros históricos de la época, que nos permitirán obtener esta referencia espacial vinculada a nuestra base de datos de registros individuales. 


\subsection{Fuentes de información demográficas}

\subsubsection{Los partes de nacimiento y defunción del Registro Civil}

La instauración del Registro Civil en España tuvo lugar mediante la Ley de 17 de junio de 1870, tras varios intentos previos en pro de la ordenación civil del Registro desde 1823 (David Sven Reher, Lobo, \& Sestafe, 1995). Con la Constitución de 1869 y la promulgación de la libertad religiosa, se dio paso a la secularización del Registro. Finalmente, la declaración obligatoria de los nacimientos, defunciones y matrimonios quedaron establecidos por Reglamento de 13 de diciembre de 1870, con aplicación en el día primero del siguiente año.

Pese a constituirse como elemento de registro obligatorio de los nacimientos, defunciones y matrimonios, lo cierto es que su obligatoriedad no eximió para que no fuera un instrumento y fuente demográfica de fiabilidad plena hasta pasados los primeros años del siglo XX. Un ejemplo de ello es que los fallecimientos antes de las veinticuatro horas de los nacidos vivos no aparecían registrados en el Registro, sino en cuadernos separados que recogían la mortalidad fetal, donde se incluían los muertos en las primeras 24h, cuadernos que posteriormente eran destruidos (Ramiro, 1998). De este modo, las estadísticas oficiales no recogían éstos fallecimientos en los apartados de los fallecimientos de menores de un año de vida (Dopico, 1985). Añadido a este subregistro de la mortalidad, estaba el hecho del subregistro de nacimientos, especialmente producido cuando el tiempo entre el nacimiento biológico y la adquisición de personalidad jurídica del nacido era amplio (Dopico, 1985).

Pese a las problemáticas descritas, la riqueza del Registro Civil de defunciones como de nacimientos como fuente de información sociodemográfica es indiscutible. Tal y como veremos más adelante, ya no sólo se trata del hecho de la obligatoriedad de registrar el evento de mortalidad, sino que los partes de defunción y nacimientos del Registro Civil contienen información adicional de relevancia, tal como el lugar de nacimiento o de residencia de la persona fallecida o la enfermedad causante del fallecimiento. Respecto a ésta última, hay que tener en consideración que ésta se registraba mediante presentación obligatoria de un parte médico que constatase la causa de defunción. Asimismo, pese a que en el Registro se solicitase un lugar de residencia, eran registradas todas las defunciones ocurridas en la ciudad por lugar de inscripción, aunque 
el fallecido no tuviera residencia en la misma. Esto tiene especial importancia, en la medida en que Madrid era ciudad de tránsito para un buen número de personas; los denominados y registrados como "transeúntes".

Hay que señalar que el hecho de que, pese a que hubiera que constatarse de manera obligatoria un domicilio (con nombre de calle, número y cuarto) el análisis exhaustivo de los registros de defunciones, revela una de las problemáticas asociadas al tener un registro realizado por lugar de inscripción, que no siempre se trata de un domicilio que corresponde a un hogar, sino que, en ocasiones, se trata de la dirección postal de una institución de salud o beneficencia. Si bien, en algunos casos, sí aparece especificada una dirección postal que corresponde a una vivienda y en el campo de "observaciones" aparece que el lugar de fallecimiento se produce en una institución de salud. Hay que tener en cuenta que la mortalidad hospitalaria infiere en los cálculos de mortalidad que toman como variable independiente una entidad geográfica en cuestión para análisis de distribución espacial, generalmente. Es por ello que, pese al arduo trabajo añadido, se ha creído necesario identificar aquellas direcciones postales que no corresponden a un domicilio como tal, sino a una institución. Este aspecto será tratado más adelante de manera pormenorizada.

En las partidas de defunciones también aparecen explicitados los datos nominales de la persona fallecida, con nombre y dos apellidos, por lo que se presta a ser una fuente de información perfecta para análisis longitudinales, mediante el enlace de registros con los de nacimientos, donde aparecen los nombres de los padres, sus edades, status migratorio y civil, o con el padrón de habitantes.

Respecto a la enfermedad causa del fallecimiento, a pesar de las posibles modas diagnósticas, podemos afirmar, en términos generales, que la fiabilidad del diagnóstico referido era buena, en la medida en que se registraba teniendo en consideración la comunicación del director del establecimiento, en caso de tratarse de instituciones de carácter médico asistenciales, y de la certificación facultativa remitida, con el doble reconocimiento de manos del médico del registro (García Ferrero, 2018, p. 114).

Una problemática adicional es la referente a la accesibilidad de los datos de Registro Civil. En la medida en que se trata de registros individuales con filiación nominal, el acceso se ve limitado. 
Tal y como se ha mencionado, la principal fuente de información demográfica empleada en este trabajo han sido los partes de defunciones y de nacimientos del Registro Civil de la ciudad de Madrid.

En este sentido, se ha vaciado de manera manual un total 135.191 casos de defunciones. En el primer periodo de estudio, han sido vaciados 15.918 registros para $1905 ; 16.162$ para 1906 y 15.239 para 1907. Correspondientes al segundo periodo, se han vaciado 18.974 registros para $1918 ; 18.281$ para el año $1919 ; 18.152$ para $1920 ; 16.179$ para 1921 y 16.286 para 1922.

Respecto a la creación de la base de datos de nacimientos, hemos dispuesto un total de entre 16.000 y 18.000 casos individuales por año de estudio.

Como puede intuirse, dado el volumen numérico de registros, añadido que la grafía propia de los registros no siempre resulta fácilmente legible, el tiempo requerido para la informatización manual de toda la información es difícil de calcular, pero ha sido considerablemente amplio.

Las variables anotadas en cada una de las hojas de los partes de defunción corresponden exclusivamente al fallecido ${ }^{4}$. Los campos de registro, tal y como puede verse en las imagen adjunta (Imagen 2-1), eran el nombre y apellidos, la edad, su lugar de nacimiento (denominado como "naturaleza") con el registro del pueblo y provincia, la profesión, la fecha completa de fallecimiento, el domicilio (con la especificación de calle, número y cuarto), la causa de enfermedad que dio origen al fallecimiento, el cementerio de inhumación y un campo de observaciones. Respecto a éste último, no contiene información estandarizada, sino que algunas veces aparece vacío y otras con información sobre el lugar de fallecimiento, para aquellos casos en que la dirección es un domicilio y el lugar de la muerte es una institución; para aquellos casos en que la dirección es una institución y la muerte es la propia institución u otra; para aquellos casos en que la muerte se produce de manera "traumática" en la vía pública y viene acompañado de la explicitación de "judicial".

\footnotetext{
${ }^{4}$ En un periodo anterior al del presente estudio, en las hojas de inscripción de defunciones aparecía, adicionalmente, diversa información acerca del padre de familia; tal como la edad, el estado civil, lugar de nacimiento, razón de parentesco, ocupación y lugar de residencia.
} 
Imagen 2-1. Hoja del registro civil de defunciones. Año 1920.

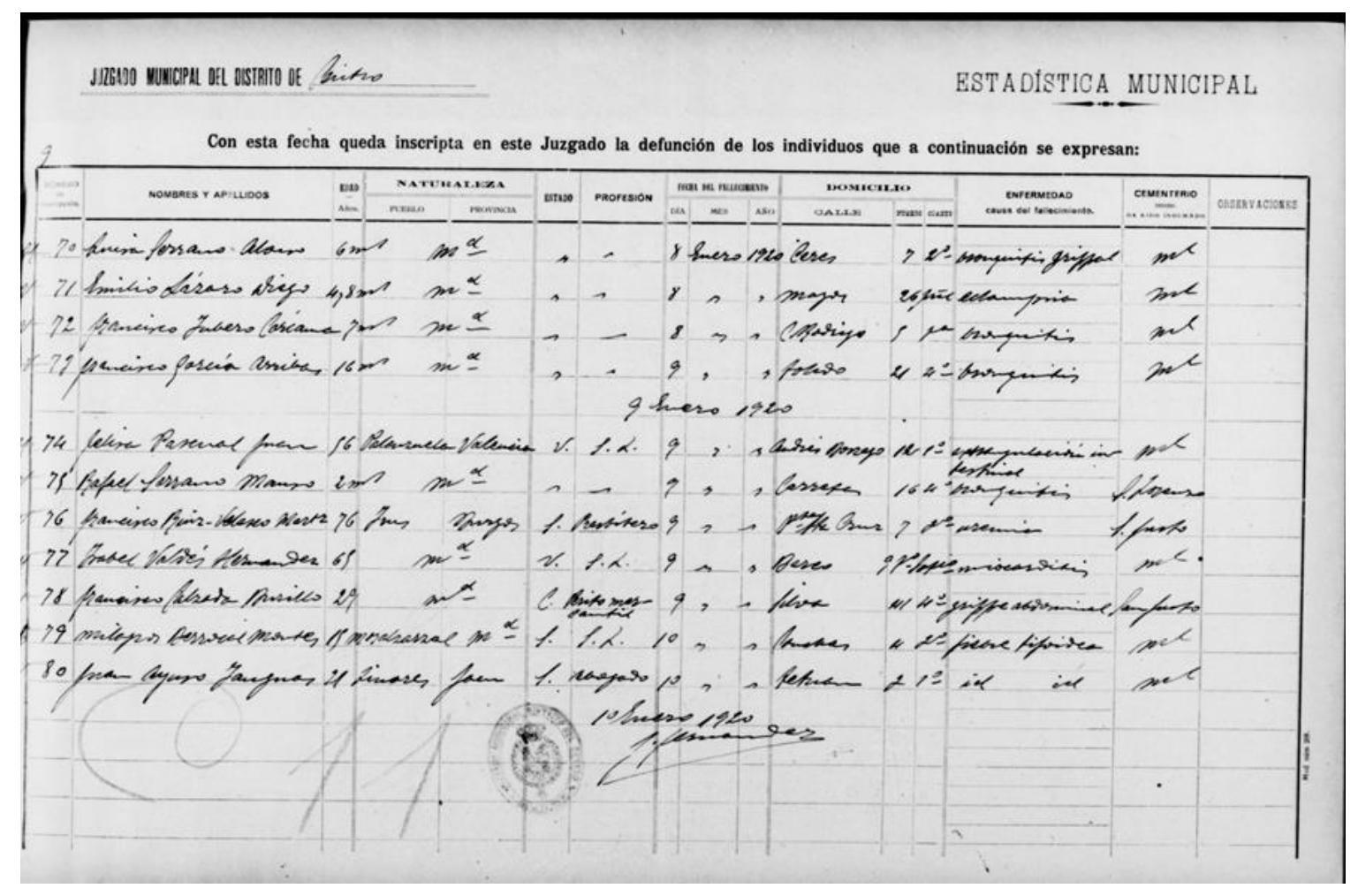

En el caso de los nacimientos, aparte del nombre de pila del nacido, aparece también el nombre y apellidos de los padres, su edad, estado civil y su naturaleza (Imagen 2-2). En el caso de niños nacidos de madre soltera solo el nombre de la madre aparece cuando el padre es desconocido. 


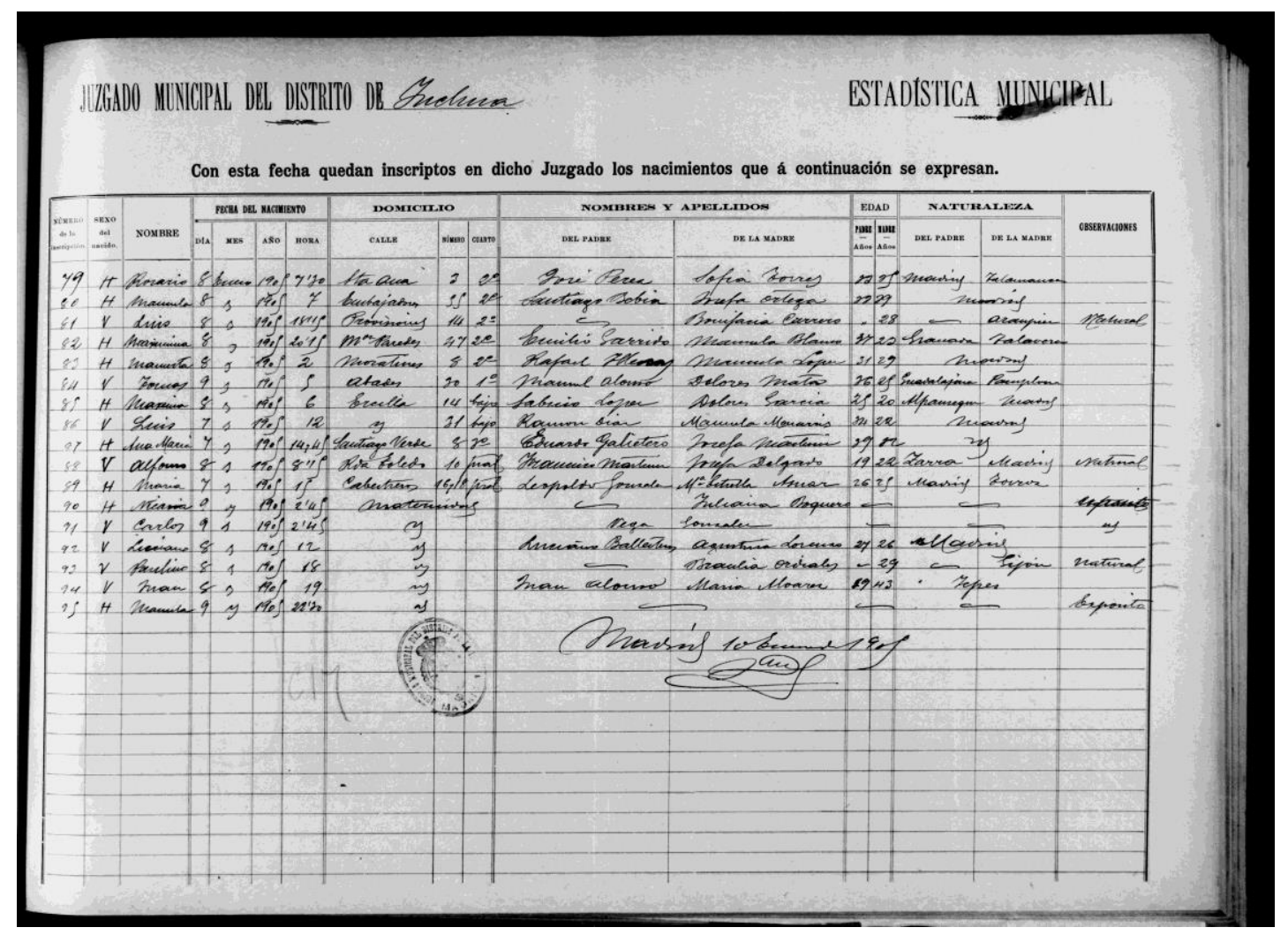

\subsubsection{Problemáticas con la base de datos del registro civil de defunciones.}

Es necesario reseñar que el registro civil de defunciones contiene información geográfica en diferentes campos. Ésta puede ser encontrada en el campo "domicilio", en el campo "cuarto" y/o en el campo observación.

Situaciones encontradas:

- Registros en que en el campo "domicilio" aparece una dirección que corresponde a la de un domicilio de residencia.

- Registros en que en el campo "domicilio" aparece una dirección que corresponde a la de un domicilio de residencia y en el campo de "observación" aparece el lugar en el que se produjo el fallecimiento, siendo diferente uno del otro. En estos casos, el campo observación suele indicar que el fallecimiento se produce en una institución.

- Transeúntes o personas sin domicilio. No disponemos del domicilio, sino del lugar donde se produce el fallecimiento. Esta información, aparece 
indistintamente en el campo en el campo "cuarto" y/o en el campo observación. Para poder identificarlos, hemos de recurrir al campo "domicilio", donde aparece especificado que es un "transeúnte", o "sin domicilio" o "en su pueblo". Para esta situación particular, éstas personas mueren o bien en la vía pública o en instituciones de salud.

- Registros en que en el campo "domicilio" aparece una dirección que corresponde a la de una institución, y no a la de un domicilio de residencia. En estos casos, no disponemos de información alguna sobre la dirección de domicilio de la persona, sino del lugar donde se produce el fallecimiento, que es una institución.

- Registros en que en el campo "domicilio" aparece el nombre de una institución. Para estos casos, hemos de asignar una dirección postal a la institución y, posteriormente, el barrio correspondiente a la misma.

- Registros en que en el campo "domicilio" aparece una localización identificada como tejar, huerta, casa o similar.

- Registros que corresponden a personas que no tienen residencia en el término municipal de Madrid, sino que la dirección de domicilio corresponde a lugares colindantes; tales como el término municipal de Carabanchel, el término municipal de Vallecas o el de Chamartín, entre otros. Estos casos eran registrados en los distritos de Madrid porque el lugar de fallecimiento era Madrid.

Teniendo en cuenta las diversas situaciones planteadas arriba, es condición necesaria la creación de ficheros de bases de datos de normalización y codificación adicionales al callejero de vías públicas de la ciudad, que contuvieran información sobre la dirección postal y barrio correspondiente a la misma, acerca de la ubicación de los Tejares, huertas, cerros, entre otros lugares, así como sobre las instituciones de salud existentes en la ciudad de Madrid.

Respecto a las ubicaciones de las localizaciones con denominación tejares, huertas, casas, entre otras, se ha logrado crear una base de datos con la identificación postal y barrio asociado a más de 200 localizaciones de este tipo. Entre éstas, podemos encontrarnos diferentes denominaciones de tejares (tales como "el Tejar de Sixto", o el "Tejar de Blas", entre otros), de huertas (tal como "Huerta del Cura", "Huerta de los Mochuelos", entre otras), “casas" (tal como la "Casa de Francisco Bajo", "Casa de Don 
Ignacio Nieto", "Casas de Cabrero", entre otras), casillas (“Casilla de vecindad de Don Cecilio Gurrea", "Casilla de Juan Pérez", entre otras), cerros ("Cerro de la Plata", "Cerro del Cuervo", entre otros), corrales ("Corral de la Villa", "Corral de Rubio", entre otros), quintas (tal como la "Quinta de los Ángeles", “Quinta de Moreno”, entre otras), Alfares (tales como el "Alfar de Sotero" el "Alfar de Manuel Pradillo", entre otros), merenderos (tales como el "Merendero de Juan Pérez" o el "Merendero de Santiago Florín", entre otros), posesiones ("Posesión de Caño Gordo", "Posesión de Doña Francisca Martínez", entre otras), ventorros ("Ventorro del Jaro", "Ventorro del pico del pañuelo", entre otros), villas ("Villa Blanca", "Villa Asunción”, entre otras). También se han encontrado diferentes denominaciones de Barrio que, en realidad, no lo son como tal desde el punto de vista administrativo; un ejemplo de ello lo constituyen el "Barrio del Cabrero", el "Barrio de Carbonel" o el "Barrio de las Injurias". También tenemos 124 casos en que la denominación son chozas, entre las que cabe destacar las "Chozas de la Alhóndiga", situadas en el Barrio de Peñuelas.

También nos encontramos con casos en que una misma institución cambia de dirección postal o que, pese a no sufrir un traslado físico, la denominación de la calle varía en función del periodo de estudio (por ejemplo, el Asilo de San Luis de Gonzaga, situado en el Paseo de Ronda, 19 o en Doctor Esquerdo, 19). En estos casos, hemos de realizar una combinación adicional teniendo en cuenta el año para el caso de referencia. En buena medida, el hecho de haber realizado una compilación de información sobre instituciones de salud de la ciudad de Madrid con diferentes fuentes, y para distintos años (como se verá más adelante), nos permite salvaguardar, en la medida de lo posible, los cambios y crecimiento sufrido en la ciudad a lo largo del periodo de estudio.

Existen algunos casos en que los calificados como transeúntes o personas sin domicilio aparece en la observación como "muerto en el depósito de aguas", por lo que, en estos casos, la asignación de barrio es Lozoya, dada la localización del depósito de agua. Una situación similar sucede cuando se señala que el fallecimiento se produce en una de las estaciones de ferrocarril de la ciudad. En estos casos, se ha asignado el barrio correspondiente a la de la estación de ferrocarril en cuestión. Otra serie de situaciones ante las que nos encontramos, es cuando se señala de manera explícita que el fallecimiento se produce en la vía pública. En estos casos, se ha asignado el barrio correspondiente a la calle en la que se produce el fallecimiento, para aquellos casos en que una calle completa corresponde a un solo barrio. En los casos en que una calle 
disponga de números postales que no corresponden a un solo barrio, no podemos asignarles ninguno, en la medida en que no disponemos de información suficiente como para hacerlo sin llevar a equívocos.

\subsubsection{El registro de la mortalidad hospitalaria}

Tal y como se ha señalado en líneas precedentes, uno de los potenciales de los partes de defunción del registro civil es la alusión a si ésta se produjo o no en una institución. Sin embargo, con el enlace de los campos referidos al domicilio al callejero histórico de la ciudad y al directorio histórico de instituciones de salud y beneficencia, se han identificado, también, direcciones postales en el campo domicilio, que realmente corresponden a una institución benéfico-asistencial. Esta situación es fruto de la discreción del registrador en el hecho de anotar el nombre de la misma o la dirección postal. Sin en enlace del campo de dirección al callejero histórico y al directorio de instituciones de salud y beneficencia, éstos casos de mortalidad institucional quedarían enmarcados dentro de la mortalidad domiciliaria, en la medida en que, en ocasiones, no se dispone de una referencia explícita al fallecimiento institucional.

Entendiendo que el objetivo del trabajo es tratar de desentrañar diferencias espaciales a nivel de barrio en la mortalidad, el lugar de residencia se convierte en una variable clave para el propio análisis. Si partimos de la hipótesis de que las divergencias en infraestructura urbana y las características sociales y demográficas definitorias de los barrios influyen en la mortalidad, se hace necesario poder diferenciar la mortalidad domiciliaria de la hospitalaria, por un lado y, por otro, aislar los casos en que no se disponga del domicilio del fallecido.

Por tanto, pese a que en un principio pudiera pensarse que disponemos del lugar de residencia de todos los fallecidos, dada la estructura de campos incluidos en los partes de defunción del registro civil, hemos de tener en consideración que en un porcentaje relevante de casos el domicilio del que disponemos información corresponde a una institución.

También se ha logrado crear una base de datos de instituciones de salud con las direcciones postales y barrios asociados para el conjunto de instituciones de salud de 
Madrid $^{5}$. En este segundo caso, se dispone de información de Hospitales, Asilos, Casas de Socorro, Gotas de Leche, Dispensarios, Gabinetes Médicos, Clínicas y Policlínicas, Sanatorios, entre otras. Para la creación de la base de datos sobre estas instituciones, se ha recopilado información de diversas fuentes, con el objetivo de disponer de una panorámica lo más real posible de todo el periodo de estudio; La Guía asociada al Plano de Facundo Cañada de 1902, el Callejero de González e Iribas de 1906, la Guía de las Vías Públicas de la Ciudad de Madrid de 1916 y la Memoria de la Ciudad de 1929.

Un ejemplo de la importancia de la utilización de diferentes fuentes de información acerca de la localización (Nombre del edificio y su dirección postal asociada) de diferentes instituciones de salud es que si bien en la Guía del Facundo Cañada sólo se dispone de información correspondiente a nueve Hospitales de la ciudad, atendiendo a la información proporcionada en la sección de Directorio General (Hospital de mujeres incurables de Jesús Nazareno, el Hospital de Epidémicos, el Hospital de hombres, el Hospital de la Princesa, Hospital de la V.O.T de San Francisco, el Hospital de San Juan de Dios, el Hospital de San Luis el Hospital Homeopático de San José y el Hospital Provincial). En la Guía de las Vías Públicas de 1916, ya se dispone de información sobre quince hospitales.

Si bien, es necesario destacar algunas de las problemáticas encontradas. Una de éstas es la referida a las denominaciones de las instituciones de salud, ya que, en los registros de defunciones, no siempre aparece el nombre "oficial", sino el nombre coloquial con el que se referían a la misma. Un ejemplo de ello sucede con la denominación general de "asilo de ancianos", dado que existían varios en toda la ciudad. En aquellos casos en que sólo se especifique dicha denominación sin ninguna información adicional en ningún campo del registro, no podemos ser capaces de asignar una dirección postal y barrio a ese caso concreto. Sin embargo, para aquellos casos en los que se disponga de información postal en alguno de los campos (bien sea en el "domicilio", "cuarto" u “observación”), podemos ser capaces de identificar en qué institución concreta se produce el fallecimiento, gracias a la creación de la base de datos sobre instituciones de salud y beneficencia de la ciudad. Esta serie de situaciones particulares nos ponen en la antesala de valorar la importancia de recurrir al análisis de los diferentes campos del

\footnotetext{
5 Asimismo, se ha logrado la identificación del trinomio Denominación de la localización-dirección postal-Barrio asociado, de otra serie de lugares que, si bien no corresponden a una institución, sí son lugares que aparecen en el registro civil de defunciones de la ciudad como lugares de muerte en diversos casos. Entre éstos, cabe destacar las estaciones de Ferrocarril.
} 
registro civil de defunciones, pese a la dificultad añadida que supone la depuración, normalización y asignación de dirección postal y de barrio de cada uno de los campos.

Otra problemática con la que nos hemos encontrado, a la hora de asignar una dirección postal a las instituciones de salud, ha sido para los casos en que éstos suceden en las Casas de Socorro. Hay que tener en consideración que éstas se distribuían en la ciudad de Madrid con una gestión administrativa a nivel de Distrito. A su vez, cada Distrito de la ciudad disponía de un mínimo de dos Casas de Socorro; una "Casa de Socorro" y una "Casa de Socorro Sucursal", con direcciones postales diferentes y, en consecuencia, barrios diferentes también. Para estos casos, en general, en el campo que indica que el fallecimiento se ha producido en una Casa de Socorro, no se especifica en cuál, remitiendo simplemente a que el fallecimiento se produce en esta clase de institución. Para la identificación de la dirección postal y barrio, se ha tenido en consideración el Distrito de Registro, con el objetivo de identificar a qué Casa de Socorro se refiere cada situación particular. Asimismo, como se ha señalado más arriba, convivían, en un mismo Distrito, las Casas de Socorro con las Sucursales de las Casas de Socorro. Por ello, se ha asignado la dirección de las Sucursales para aquellos casos en que aparece especificado como tal. Para el resto, se ha asignado la correspondiente a la Casa de Socorro del Distrito de Inscripción.

Otras situaciones particularmente problemáticas, las encontramos en los casos en que en la dirección postal aparece el nombre de una calle, sin numeración. Si no disponemos de información adicional en ninguno de los otros campos del registro, nos vemos ante la dificultad de asignar un correspondiente barrio. Sin embargo, si sí existe dicha información adicional, la combinación de la misma en los diferentes campos, nos ofrecen la posibilidad de conocer el lugar al que se refiere el registro. Un ejemplo de ello es el caso de algunos fallecidos en los hospitales. Particularmente, nos encontramos con diversos registros en que en el campo domicilio aparece "Atocha" y el campo número aparece vacío. Sin embargo, en el campo cuarto se especifica "hospital". Con esta información, somos capaces de inferir que se trata de casos en que el fallecimiento se produce en el Hospital de Nuestra Señora de El Carmen, ubicado en Atocha. Así, una vez identificados los casos en el Hospital de Nuestra Señora de El Carmen, podemos realizar la asignación de dirección postal y barrio con la base de datos de instituciones de salud que ha sido creada. 
Asimismo, algunas instituciones que aparecen en el campo de observaciones, hemos sido capaces de ubicarlas en un barrio concreto en el caso de que aparezca el nombre de la calle y el número postal de manera explícita (por ejemplo, "fallecido en Guzmán el bueno 50, sanatorio"). Sin embargo, en ocasiones no somos capaces de conocer a qué institución se refiere, por no aparecer en nuestra base de datos sobre instituciones de salud. En el caso en que no nos aparezca la especificación concreta de calle+número+especificación de institución, pensaríamos que se trata de un fallecimiento en la vía pública, al no aparecer dicha dirección en nuestra base de datos de instituciones de salud y beneficencia. Situaciones similares ocurren cuando simplemente aparece especificado en el campo observación denominaciones tales como "asilo", de manera única. Si no disponemos de información adicional que nos permita conocer a qué asilo se refiere, únicamente seremos capaces de saber que se trata de un caso de mortalidad institucional, pero nos hallamos ante la imposibilidad de conocer la ubicación del fallecimiento.

Por el contrario, en otras ocasiones, nos encontramos casos en que en observación aparece, por ejemplo, “falleció en Calle San Bernardo 101, hospital". En ocasiones como esta, en que sí disponemos de la dirección asociada a una institución, estamos en la tesitura de otorgarle el nombre oficial de la misma ("Hospital de San Pedro" y su Barrio y distrito; Vallehermoso-Universidad").

\subsubsection{Otras fuentes}

Pese a que la fuente de datos principal empleada en el presente estudio han sido los datos individuales procedentes de los partes de defunciones y nacimientos del Registro Civil, también se ha recurrido a otras fuentes de datos agregados con el objetivo principal de darle valor añadido a la información contextual sobre la realidad del Madrid del primer tercio del siglo XX. En este sentido, se ha hecho uso de la información recogida en los Anuarios Estadísticos de la ciudad de Madrid (Imagen 2-3) y los Boletines de Estadística Demográfica del Ayuntamiento de Madrid, que, de periodicidad anual, ofrecen información a nivel de distrito, y en algunos casos a nivel de barrio, de eventos demográficos como nacimientos y defunciones por edad y causa de 
muerte de una forma más detallada a como aparecen en los Movimientos Naturales de la Población de la época para la misma capital.

Asimismo, se ha usado la información del Resumen de Padrón correspondiente a los datos recogidos en 1915 en la capital. Éstos contienen información sobre características sociodemográficas a nivel de barrio.

Imagen 2-3Anuario estadístico de Madrid. Año 1905.

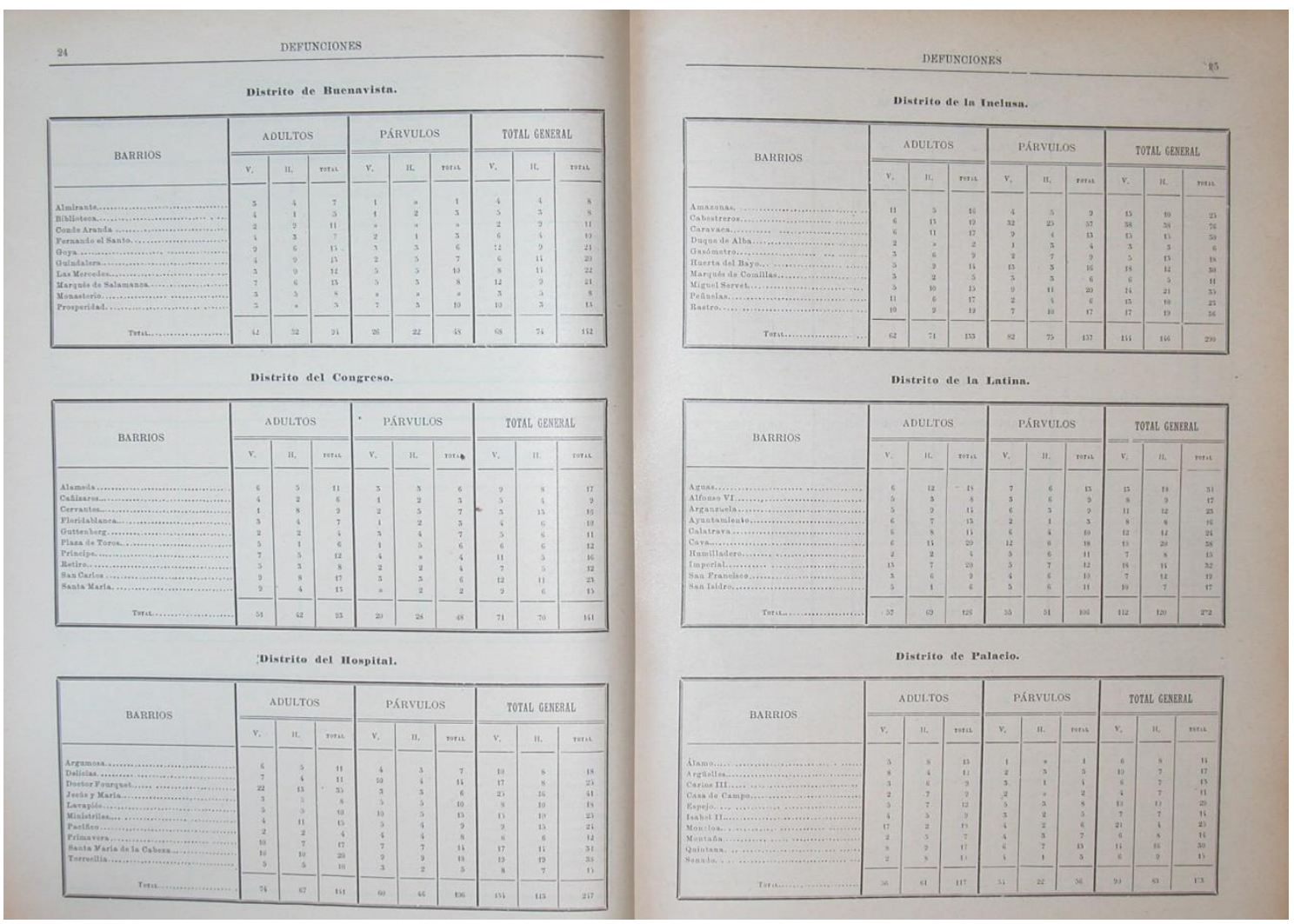

\subsection{Las fuentes de información cartográficas y las Guías de la ciudad de Madrid.}

Dado que nos interesa realizar el análisis de la mortalidad a nivel de barrio, uno de los problemas principales con el que nos encontramos es el hecho de que en la información proporcionada por Registro Civil de defunciones de la ciudad no aparece de manera explicitada la referencia al barrio, tal y como puede verse en la Imagen 2-1, donde se 
muestra, a modo de ejemplo, una hoja del Registro Civil de defunciones. En relación a esta circunstancia, otra problemática añadida era el hecho de disponer de un callejero que nos sirviera de base para poder realizar las asignaciones de los domicilios a los correspondientes barrios. Ante este hecho, en un principio, se decidió utilizar la Guía de Madrid y Pueblos Colindantes (Cañada López, 1902), pero nos encontramos con que buena parte de las direcciones postales que aparecían en los datos del Registro Civil no se encontraban en el callejero proporcionado por la Guía de Madrid y Pueblos Colindantes. La explicación a este hecho radicaba en que el periodo de estudio comprende fechas más tardías a la del trabajo de Facundo Cañada y, debido al crecimiento de la ciudad y las reformas viarias implementadas, nos encontramos con direcciones postales que bien eran de nueva creación o habían sufrido algún tipo de modificación en su denominación nominal. Asimismo, la Guía de Madrid y Pueblos colindantes sufre la limitación de que algunas numeraciones no aparecen contenidas.

Por ello, se decidió recurrir a guías y callejeros alternativos, que abarcasen periodos temporales posteriores al de la Guía de Madrid y Pueblos Colindantes y que permitieran solventar las limitaciones de ésta. Hay que tener en consideración que si bien sí existen varias guías-callejeros de la ciudad, en la mayoría de ellas no se especifica el barrio correspondiente a la dirección de calle en cuestión, de manera que no eran de utilidad para nuestro cometido. Finalmente, se encontraron dos guías que contenían las direcciones postales con la asociación de barrio correspondiente, así como diversa información de relevancia, tal como información sobre variaciones sufridas en las denominaciones de calle, nomenclátores de instituciones de salud y beneficencia, entre otras. Éstas han sido la Guía práctica de Madrid (González e Iribas, 1906) y la Guía de las Vías Públicas de Madrid (Ayuntamiento de Madrid, 1916).

\subsubsection{El Plano y Guía de Facundo Cañada}

La Guía de Madrid y Pueblos Colindantes, que viene acompañada de un "Plano de Madrid y Pueblos colindantes al principiar el Siglo $X X^{6}$, fue obra del cartógrafo militar Facundo Cañada López, data de 1902, pero su ejecución comenzó a gestarse en el año 1898 (del Bosque González, García Ferrero, Gómez Nieto, Martín-Forero

\footnotetext{
${ }^{6}$ El Plano de Madrid y pueblos colindantes, de Facundo Cañada, puede consultarse en http://hdl.handle.net/10261/28971
} 
Morente, \& Ramiro Fariñas, 2010b; García Ferrero, 2018). Realizado a escala 1:7.500, el plano está dividido en seis hojas, cuyas dimensiones conjuntan alcanzan 1,44 metros de ancho por 1,77 de alto (Cañada López, 1902).

Mapa 2-1. Composición del Plano de Facundo Cañada

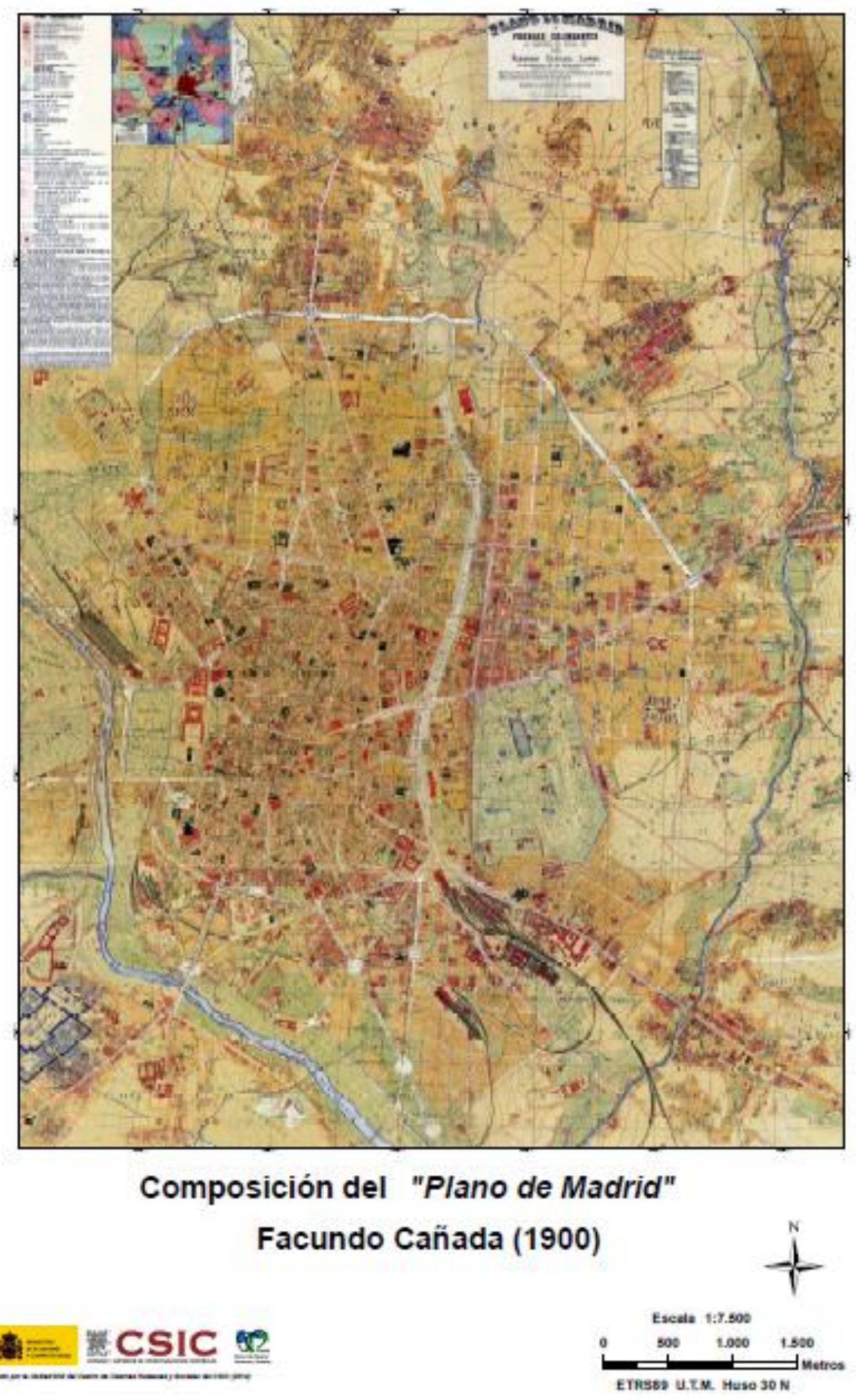

Fuente: Digital CSIC 
En el propio plano figura información diversa, que va desde los nombres de las plazas, calles y otra tipología de vías, a la numeración de las mismas a nivel de manzana mediante la señalización de los tramos de numeración de principio y fin. Asimismo, se recoge la asociación de diferentes instituciones presentes en la ciudad; tal como edificios administrativos de nivel tanto estatal como municipal, instituciones religiosas, benéfico-asistenciales y de salud. También se encuentran fijados otra serie de elementos que conforman el escenario cartográfico de la ciudad, como son los parques, jardines, red de transporte pública, entre otros. Todo ello hace que el Plano y Guía de Facundo Cañada sea considerado por muchos como uno de los documentos cartográficos de carácter histórico de mayor importancia desde el punto de vista y objetivo catastral para la ciudad de Madrid (del Bosque González, García Ferrero, Gómez Nieto, MartínForero Morente, \& Ramiro Fariñas, 2010a). El mapa de Facundo Cañada de Madrid y toda su información está disponible en una Infraestructura de Datos Espaciales pública que puede ser accesible en http://www.idehistoricamadrid.org/hisdimad/index.htm

Imagen 2-4. Ampliación de la zona del Retiro. Plano de Facundo Cañada.

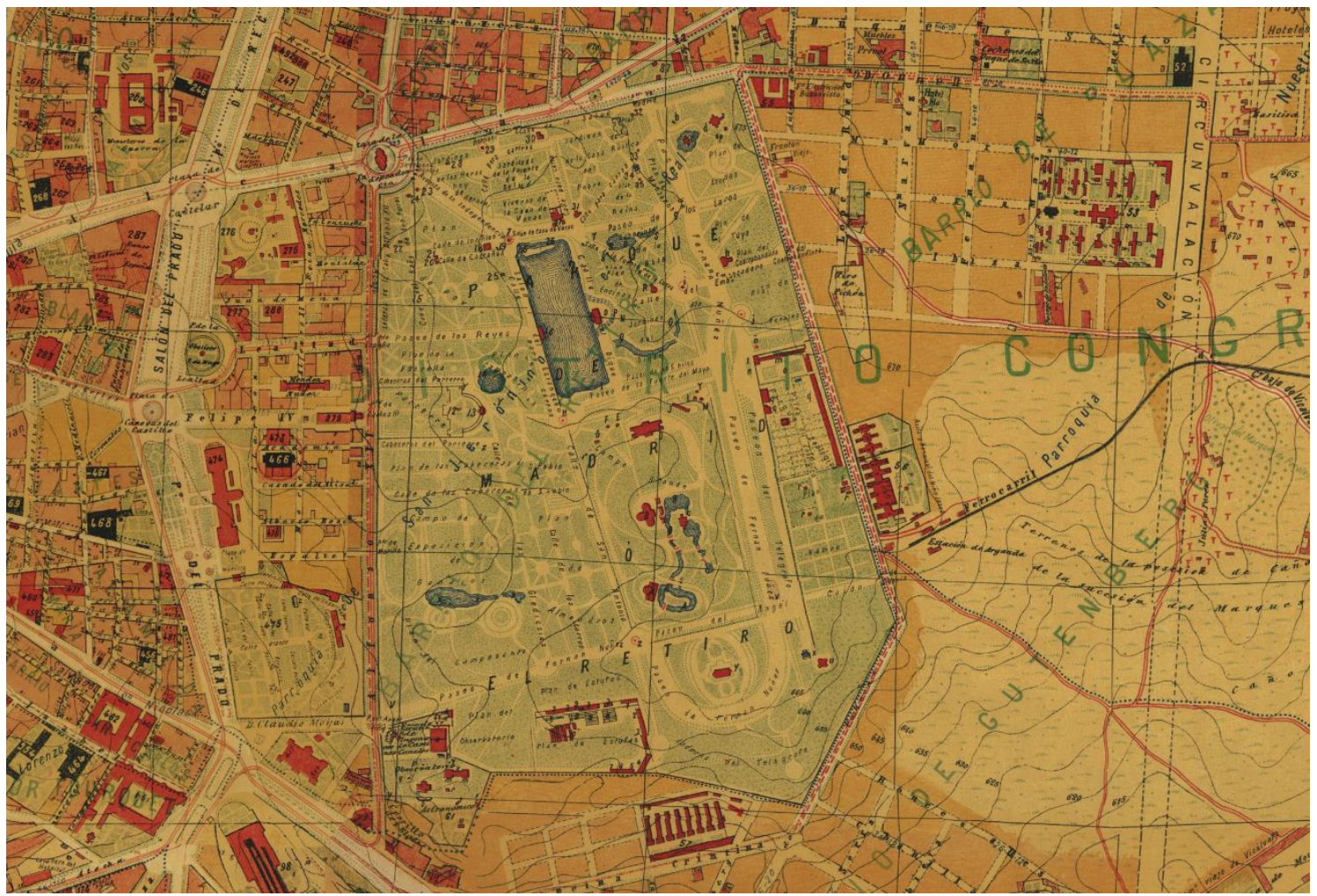

Fuente: Elaboración propia 
La Guía de Madrid y Pueblos Colindantes, asociada al Plano de Facundo Cañada, complementa y completa ampliamente la información referida al Plano. Entre la información recogida a destacar encontramos el listado de vías públicas ordenado alfabéticamente, la relación de calles que sufrieron variaciones nominales, directorios de instituciones de orden administrativo, educativo, de salud, entre otros, el directorio de las alcaldías de barrio, las campanas destinadas al aviso en caso de incendio, los conjuntos escultóricos y estatuas existentes en la ciudad. Aparece, también, la referencia a las divisiones administrativas de la ciudad de Madrid, seccionadas en Distritos y Barrios. Especialmente importante fue la promulgada por el Conde de Romanones en 1898, aprobada en 1902, que rompió con la división administrativa existente desde 1863. 
Tabla 2-1. División administrativa de Madrid en barrios y distritos, 1863

\begin{tabular}{|c|c|}
\hline \multirow{10}{*}{ 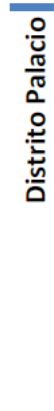 } & 11. Álamo \\
\hline & 12. Amaniel \\
\hline & 13. Bailen \\
\hline & 14. Conde Duque \\
\hline & 15. Florida \\
\hline & 16. Leganitos \\
\hline & 17. Platerías \\
\hline & 18. Argüelles \\
\hline & 19. Quiñones \\
\hline & 20. Vergara \\
\hline
\end{tabular}

\begin{tabular}{|c|c|}
\hline \multirow{10}{*}{ 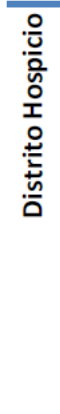 } & 41 Barco \\
\hline & 42 Beneficencia \\
\hline & 43 Chamberí \\
\hline & 44 Colmillo \\
\hline & 45 Desengaño \\
\hline & 46 Fuencarral \\
\hline & 47 Hernán cortes \\
\hline & 48 Pelayo \\
\hline & 49 Santa Bárbara \\
\hline & 410 Valverde \\
\hline
\end{tabular}

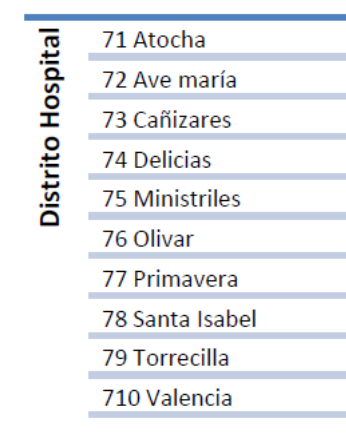
. 101 Cava
¿ 102 Carretas
Oे 103 Concepción
104 Constitución
105 Estudios
O. 106 Juanelo
107 Progreso
108 Puente de Segovia
109 Puerta cerrada
1010 Segovia

Fuente: (Cañada López, 1902)

\begin{tabular}{|c|c|}
\hline \multirow{10}{*}{. } & 21 Pozas \\
\hline & 22 Colon \\
\hline & 23 Corredera \\
\hline & 24 Daoiz \\
\hline & 25 Dos de mayo \\
\hline & 26 Escorial \\
\hline & 27 Estrella \\
\hline & $28 \mathrm{Pez}$ \\
\hline & 29 Pizarro \\
\hline & 210 Rubio \\
\hline
\end{tabular}

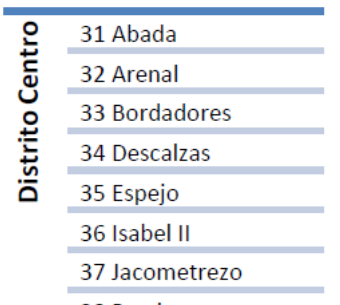
38 Postigo

39 Puerta del sol

310 Silva

\begin{tabular}{|c|c|}
\hline \multirow{10}{*}{ 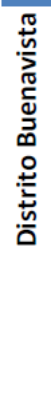 } & 51 Alcalá \\
\hline & 52 Almirante \\
\hline & 53 Belén \\
\hline & 54 Caballero de gracia \\
\hline & 55 Libertad \\
\hline & 56 Montera \\
\hline & 57 Plaza de toros \\
\hline & 58 Reina \\
\hline & 59 San marcos \\
\hline & 510 Salamanca \\
\hline
\end{tabular}

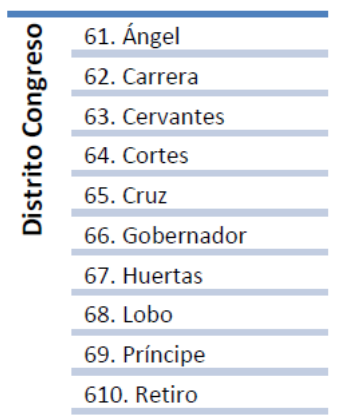

\begin{tabular}{|c|c|}
\hline \multirow{10}{*}{ 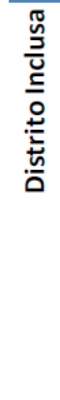 } & 81 Cabestreros \\
\hline & 82 Caravaca \\
\hline & 83 Comadre \\
\hline & 84 Embajadores \\
\hline & 85 Encomienda \\
\hline & 86 Huerta del bayo \\
\hline & 87 Peñón \\
\hline & 88 Peñuelas \\
\hline & 89 Provisiones \\
\hline & \\
\hline
\end{tabular}

\begin{tabular}{|c|c|}
\hline \multirow{10}{*}{ 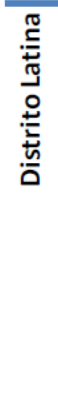 } & \multirow{2}{*}{$\begin{array}{l}1 \text { Aguas } \\
2 \text { Arganzuela }\end{array}$} \\
\hline & \\
\hline & 93 Calatrava \\
\hline & 94 Cebada \\
\hline & 95 Don pedro \\
\hline & 96 Humilladero \\
\hline & 97 Puente de Toledo \\
\hline & 98 Puerta de moros \\
\hline & 99 Solana \\
\hline & \\
\hline
\end{tabular}


Tabla 2-2. División administrativa del Conde de Romanones, 1898

\begin{tabular}{|c|c|}
\hline \multirow{10}{*}{$\begin{array}{l}\text { o } \\
\text { b } \\
\text { o } \\
\text { g } \\
\frac{2}{2} \\
\frac{5}{0}\end{array}$} & 11 Carmen \\
\hline & 12 Constitución \\
\hline & 13 Correos \\
\hline & 14 Estrella \\
\hline & 15 Jardines \\
\hline & 16 Muñoz torrero \\
\hline & 17 Puerta del sol \\
\hline & 18 San Luis \\
\hline & 19 San Martín \\
\hline & 110 Tudescos \\
\hline \multirow{10}{*}{ 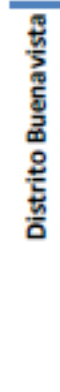 } & 41 Almirsnte \\
\hline & 42 Biblioteca \\
\hline & 43 Conde de Aranda \\
\hline & 44 Monasterio \\
\hline & 45 Fernando el santo \\
\hline & 46 Goys \\
\hline & 47 Guindslers \\
\hline & 48 Las mercedes \\
\hline & $49 \mathrm{M}$. de Salamanca \\
\hline & 410 Prosperidad \\
\hline \multirow{10}{*}{$\begin{array}{l}\frac{\text { g }}{3} \\
\frac{3}{4} \\
\frac{8}{2} \\
\frac{5}{0}\end{array}$} & 71 Amazonas \\
\hline & 72 Cabestreros \\
\hline & 73 Caravsca \\
\hline & 74 Duque de albs \\
\hline & 75 Gssómetro \\
\hline & 76 Huerta del bayo \\
\hline & 77 Marqués de comillas \\
\hline & 78 Miguel Servet \\
\hline & 79 Peñuelas \\
\hline & 710 Rastro \\
\hline \multirow{10}{*}{ 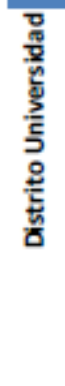 } & 101 Amaniel \\
\hline & 102 Bellas vistas \\
\hline & 103 Conde duque \\
\hline & 104 Conde Toreno \\
\hline & 105 Guzmán el bueno \\
\hline & 106 Lozoya \\
\hline & 107 Minas \\
\hline & 108 Quiñones \\
\hline & 109 Santa Lucia \\
\hline & 1010 Vallehermoso \\
\hline
\end{tabular}
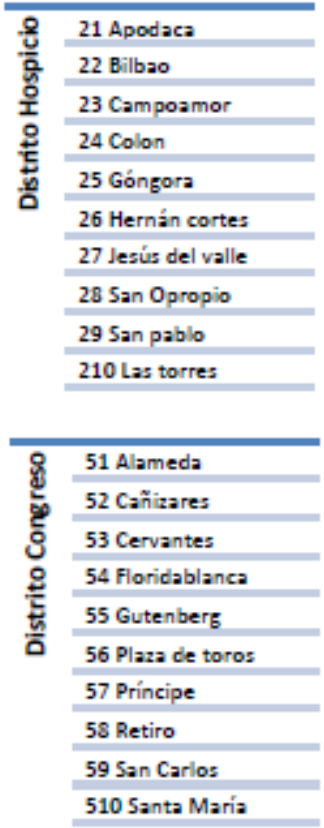

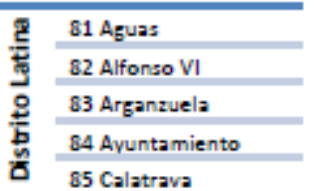

86 Cava

87 Humilladero

SB Imperial

89 San Franciaco

810 San laidro

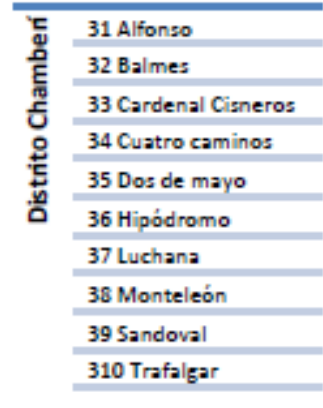

\begin{tabular}{|c|c|}
\hline \multirow{10}{*}{ 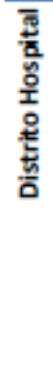 } & 61 Argumosa \\
\hline & 62 Delicias \\
\hline & 63 Doctor Fourquet \\
\hline & 64 Jesús y Maris \\
\hline & 65 Lavapiés \\
\hline & 66 Ministriles \\
\hline & 67 Pacifico \\
\hline & 68 Primsvera \\
\hline & 69 Sonta María la Cabeza \\
\hline & 610 Torrecills \\
\hline
\end{tabular}

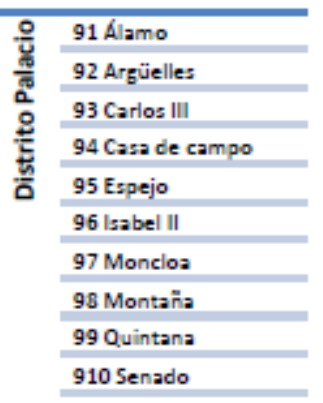

Fuente: (Cañada López, 1902) 
Mapa 2-2. División de Madrid por barrios ${ }^{7}$.

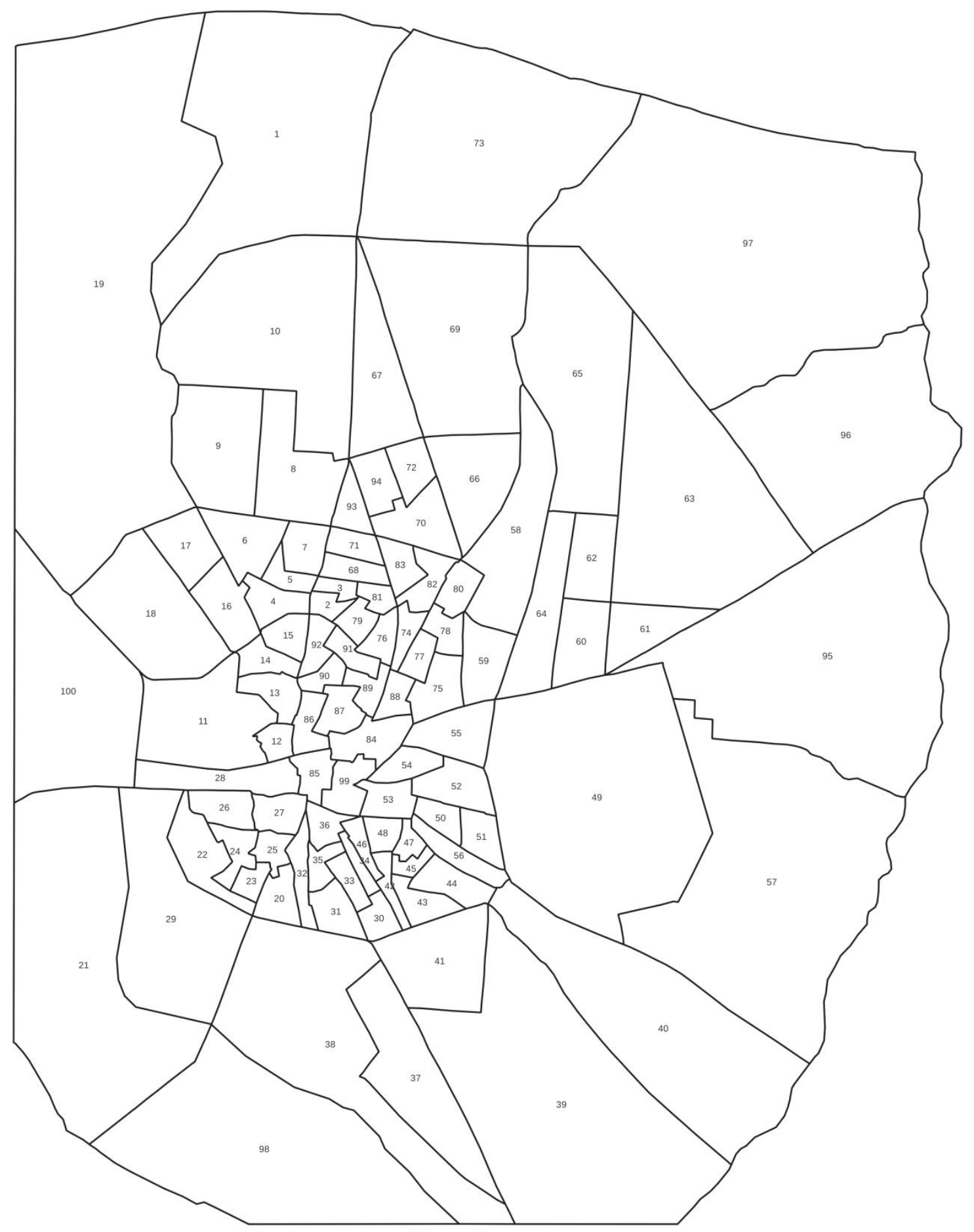

Fuente: Elaboración propia

${ }^{7}$ En la sección de anexos puede consultarse la relación numérica con la correspondencia al barrio. 


\subsubsection{La Guía práctica de Madrid (González e Iribas, 1906),}

La denominada Guía práctica de Madrid, de 1906, ha sido una fuente de recurso de indiscutible valor para el presente estudio dada la información viaria que contiene. Ésta aparece dividida en dos tomos. El primero de ellos, con un volumen de 608 páginas, contiene la información correspondiente a los distritos de Buenavista, Centro, Chamberí, Congreso, Hospicio y Hospital. En el segundo se recoge la información sobre los distritos de Inclusa, Latina, Palacio y Universidad, con un volumen de 417 páginas. Las reseñas que contiene esta guía versa desde la numeración de los edificios por manzanas, la ubicación de los solares o localización de establecimientos oficiales y públicos hasta información tal como las tarifas aplicadas por la utilización de los carruajes de plaza que circulaban a nivel de Distrito. Asimismo, dicha guía viene enriquecida con planos de los diez distritos de la ciudad y de los cien barrios, todos a escala $1 / 5000^{9}$. En una segunda edición de la Guía, denominada de manera extensa como Guía práctica de Madrid con arreglo a la nueva división administrativa y judicial (González e Iribas, 1907), se incluye un plano de la ciudad de Madrid ${ }^{10}$ que presumía se ser el único que, hasta el momento, abarcaba en su representación todo el término municipal. Como puede observarse, el plano corresponde al periodo previo a la reforma de la Gran Vía y sus demoliciones consecuentes. Sin embargo, ésta calle aparece coloreada en rosa, demarcando los inmuebles que serían derribados para la reforma. Otros aspectos interesantes que aparecen en el plano, son la señalización de elementos que podrían resultar de interés para los ciudadanos, tales como monumentos, instituciones de diverso tipo, transportes públicos, entre otros.

\footnotetext{
${ }^{8}$ La Guía completa y sus objetos digitales, pueden consultarse en la Biblioteca Digital de la Comunidad de Madrid:

https://bibliotecavirtualmadrid.comunidad.madrid/bvmadrid_publicacion/es/consulta/registro.do?id=130

${ }^{9}$ Tanto la obra de Facundo Cañada como la González e Iribas, fueron elaboradas atendiendo a la nueva división administrativa y judicial, aprobada por las Reales Órdenes de 5 de junio y de 14 de julio y de 19 de octubre de 1902. Propuesta por el Conde de Romanones en 1898, la nueva división administrativa de la ciudad revistió de especial importancia, en la medida que, por primera vez, la división municipal de Madrid rompía con el límite de la zona del interior y del Ensanche con la inclusión de la zona del Extrarradio. De este modo, a los 7,78 km2 del Casco Antiguo y los 15,16 km2 del Ensanche, se sumaron un total de 43,81 km2 correspondientes al Extrarradio (Gavira Golpe \& Ruiz Varela, 1991, p. 68).

${ }^{10}$ El plano de González e Iribas puede consultase en

http://www.memoriademadrid.es/buscador.php?accion=VerFicha\&id=21689
} 
Mapa 2-3. Plano de conjunto de la Guía Práctica de Madrid.

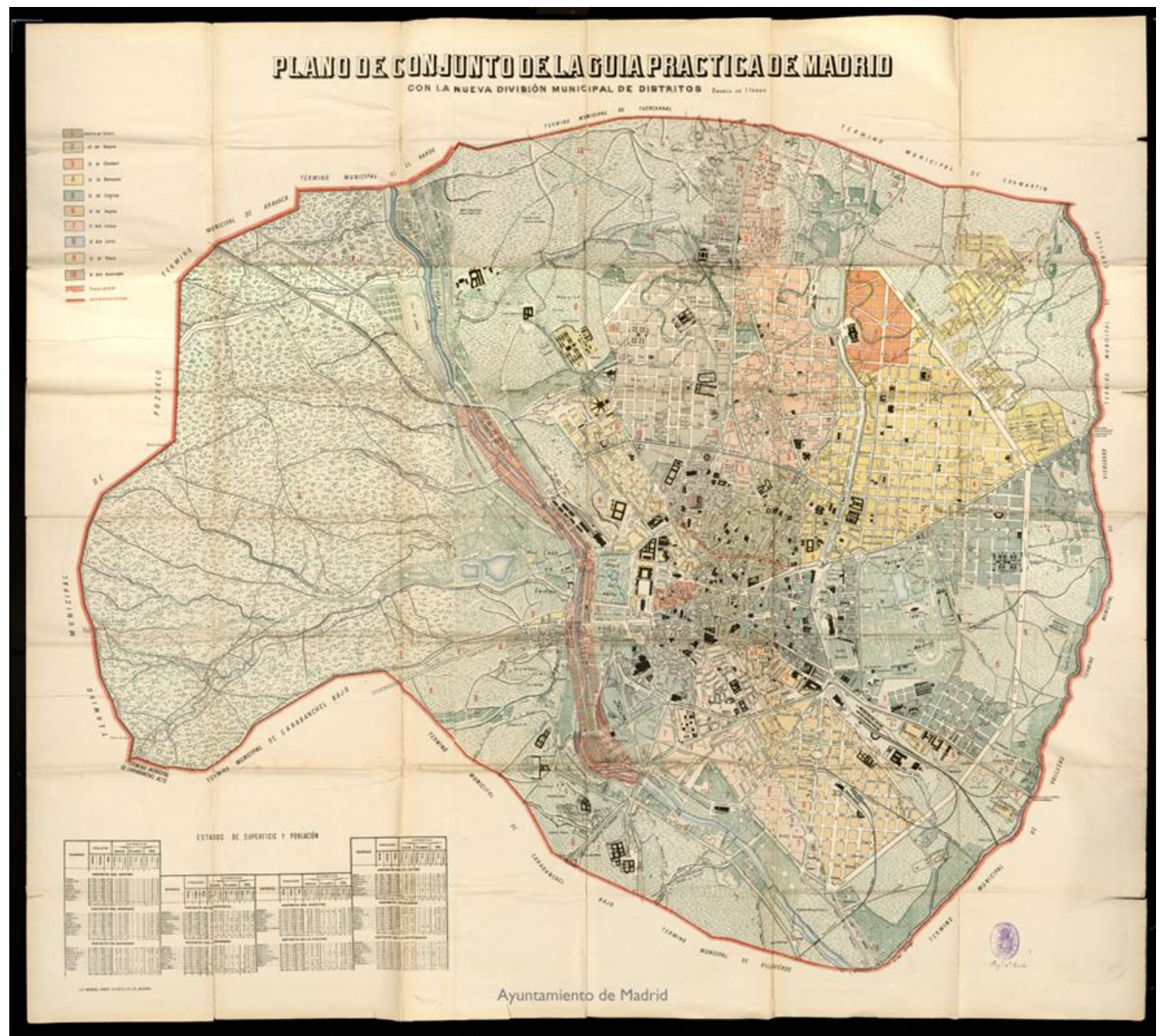


Gráfico 2-1. Compilación del mapa del Distrito Congreso y sus barrios ${ }^{11}$.

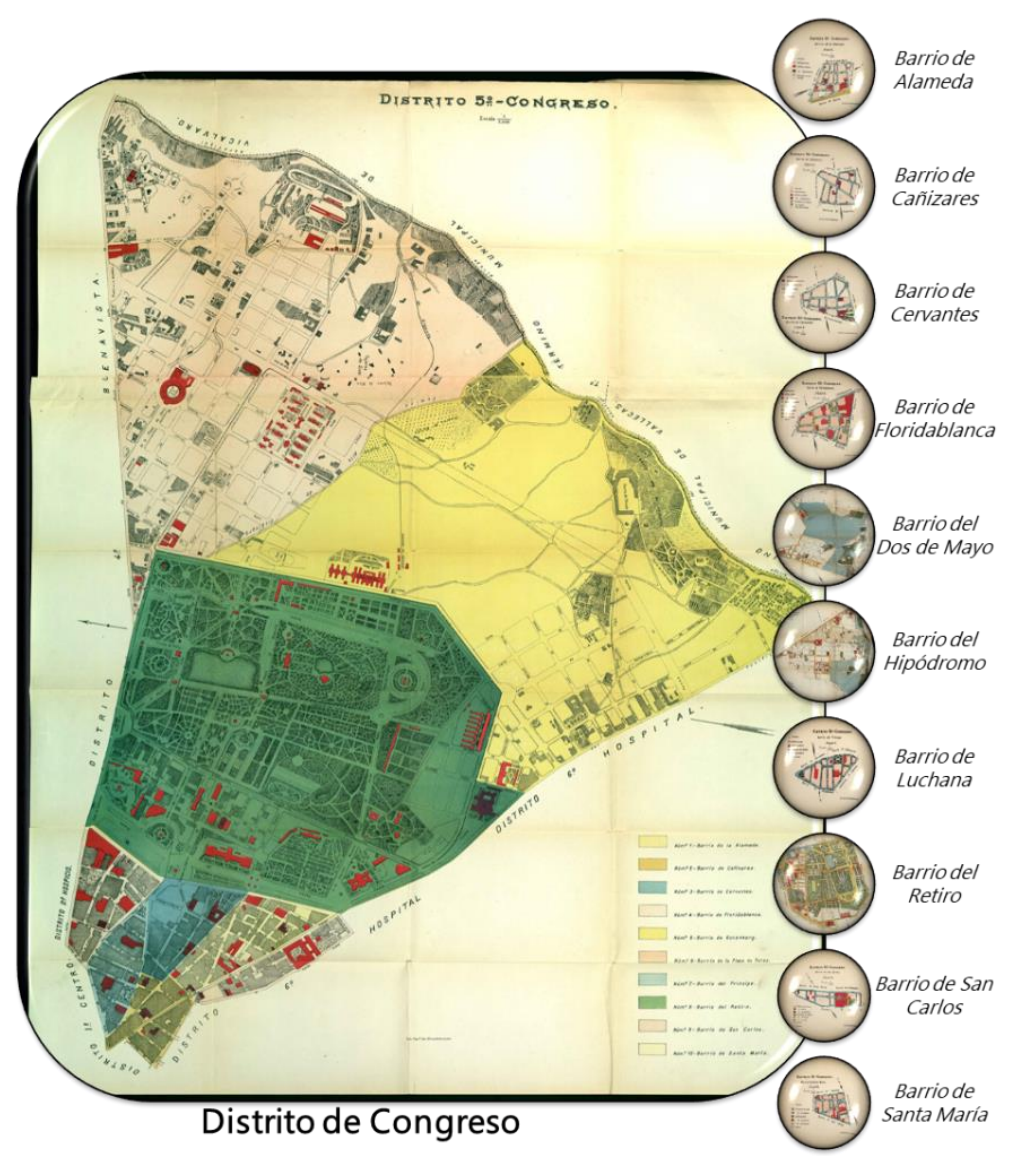

Fuente: Elaboración propia. Imágenes obtenidas de (González e Iribas, 1906)

${ }^{11}$ Las compilaciones correspondientes al resto de distritos pueden consultarse en la sección de anexos. 
Gráfico 2-2. Compilación de los mapas de los barrios del distrito Congreso ${ }^{12}$

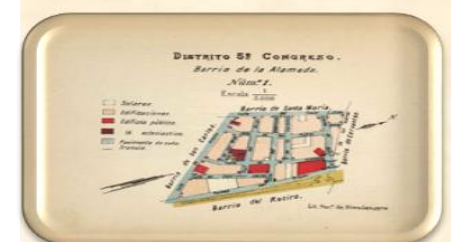

Barrio de Alameda

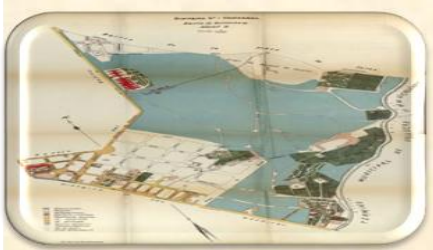

Barrio del Dos de Mayo

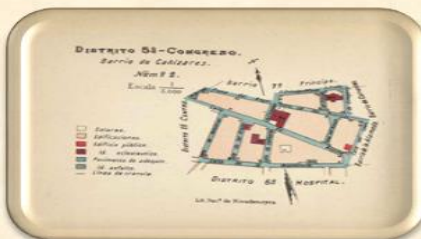

Barrio de Cañizares

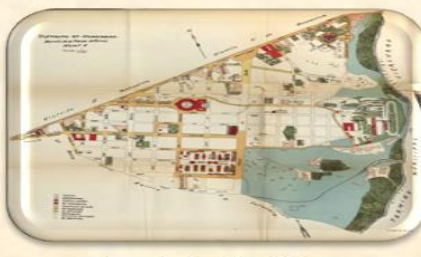

Barrio del Hipódromo

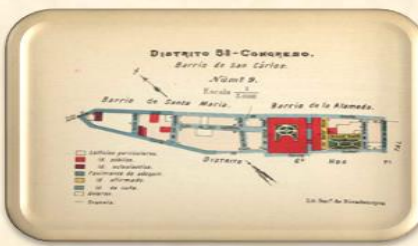

Barrio de San Carlos

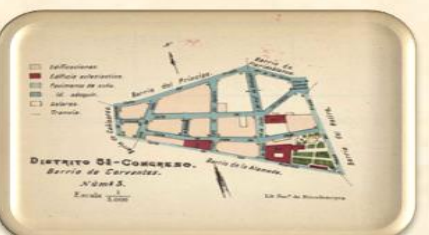

Barrio de Cervantes

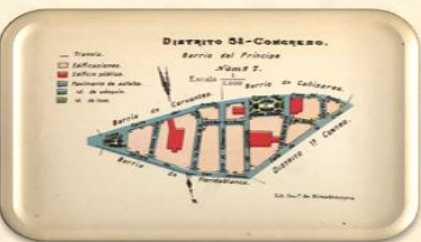

Barrio de Luchana

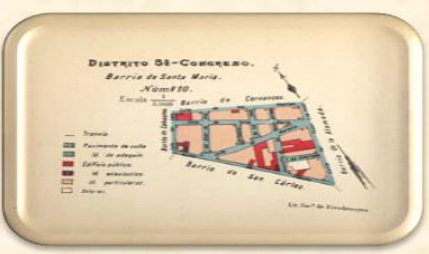

Barrio de Santa María

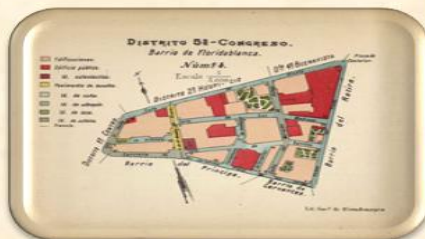

Barrio de Floridablanca

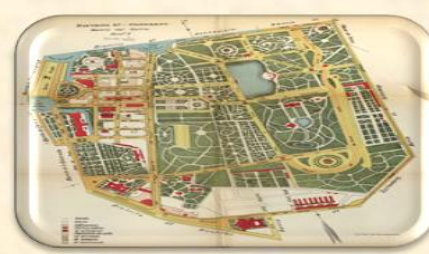

Barrio del Retiro

Fuente: Elaboración propia. Imágenes obtenidas de (González e Iribas, 1906)

\footnotetext{
${ }^{12}$ Las compilaciones correspondientes al resto de barrios pueden consultarse en la sección de anexos.
} 


\subsubsection{La Guía de las vías públicas de Madrid.}

La Guía de las Vías Públicas de Madrid (Ayuntamiento de Madrid, 1916), denominada de forma secundaria como Vías Públicas. Sus límites, barrio, distrito, zona municipal y militar, parroquia y sección hipotecaria a la que corresponden, ha sido otra de las fuentes de información viaria utilizadas. Contiene información de los Distritos y Barrios de la ciudad y las Vías Públicas que comprenden. En cuanto a su estructura, los nombres de las calles aparecen por orden alfabético, con la especificación de donde empieza y donde termina. Respecto a la numeración, aparecen los tramos de números, pares e impares. En el caso que sólo se contenga uno de los tramos (par o impar), es porque el omitido corresponde a un barrio distinto.

La Guía de 1916 contiene otra serie de información que reviste especial importancia a la hora de poder conocer de la manera más real posible la estructura viaria de la ciudad de Madrid. Por ejemplo, contiene una relación de las variaciones sufridas en la denominación de las vías públicas, con la especificación de su denominación a la altura de 1916, el nombre anterior y la fecha del acuerdo de modificación, por lo que, con esta información, podemos ser capaces de identificar las mismas. Hay que tener en consideración que a lo largo del periodo de estudio que comprende la presente tesis, la ciudad de Madrid sufrió un continuo de reformas urbanas que, consecuentemente, repercutían en la estructura y denominación viaria. Un ejemplo de ello fueron las calles desaparecidas con la reforma de la Gran Vía. La Guía de las Vías Públicas de Madrid contiene la relación de las mismas, por lo que resulta un valor añadido realmente importante.

Otra información de relevancia que aparece en la Guía de 1916 es la especificación de lo que se denomina "población diseminada" para referirse a estructuras habitacionales como caseríos, edificios y albergues, que estaban situados en la zona del Extrarradio, fuera de las vías públicas. La referencia a éstos, al no estar situadas en una vía pública, viene estructurada con el nombre de la edificación, caserío, tejar... y el correspondiente barrio en el que están situadas. Esta información revierte especial importancia, en la medida en que en los registros individuales que serán empleados en el análisis, en numerosas ocasiones aparece una referencia explícita a esta clase de localizaciones. 
Aparece también un directorio de Servicios Municipales (Tenencias de Alcaldía, Casas de Socorro, Gota de Leche, Servicio contra incendios y otras Dependencias municipales), de Asilos, hospitales y otros establecimientos benéficos, de cementerios y de estaciones de ferrocarril.

\subsubsection{La elaboración de callejeros históricos de viales}

La información de las guías arriba señaladas ha sido transformada a una base de datos, con el objetivo de poder utilizarlas como base de datos de normalización y codificación de las entidades geográficas que aparecen en las hojas del registro civil de defunciones, dado que las guías contienen una relación de calle y número con el barrio correspondiente, para todo el conjunto de la ciudad de Madrid.

Uno de los problemas que nos encontramos a la hora de crear una base de datos con todos los viales de la ciudad, y su información asociada, a partir de las Guías descritas arriba, radica en la dificultad de poder extraer las numeraciones singulares de portal, dada la estructura de numeraciones por tramos que aparece en las Guías, tal y como puede apreciarse en la imagen adjunta (Imagen 2-5). 


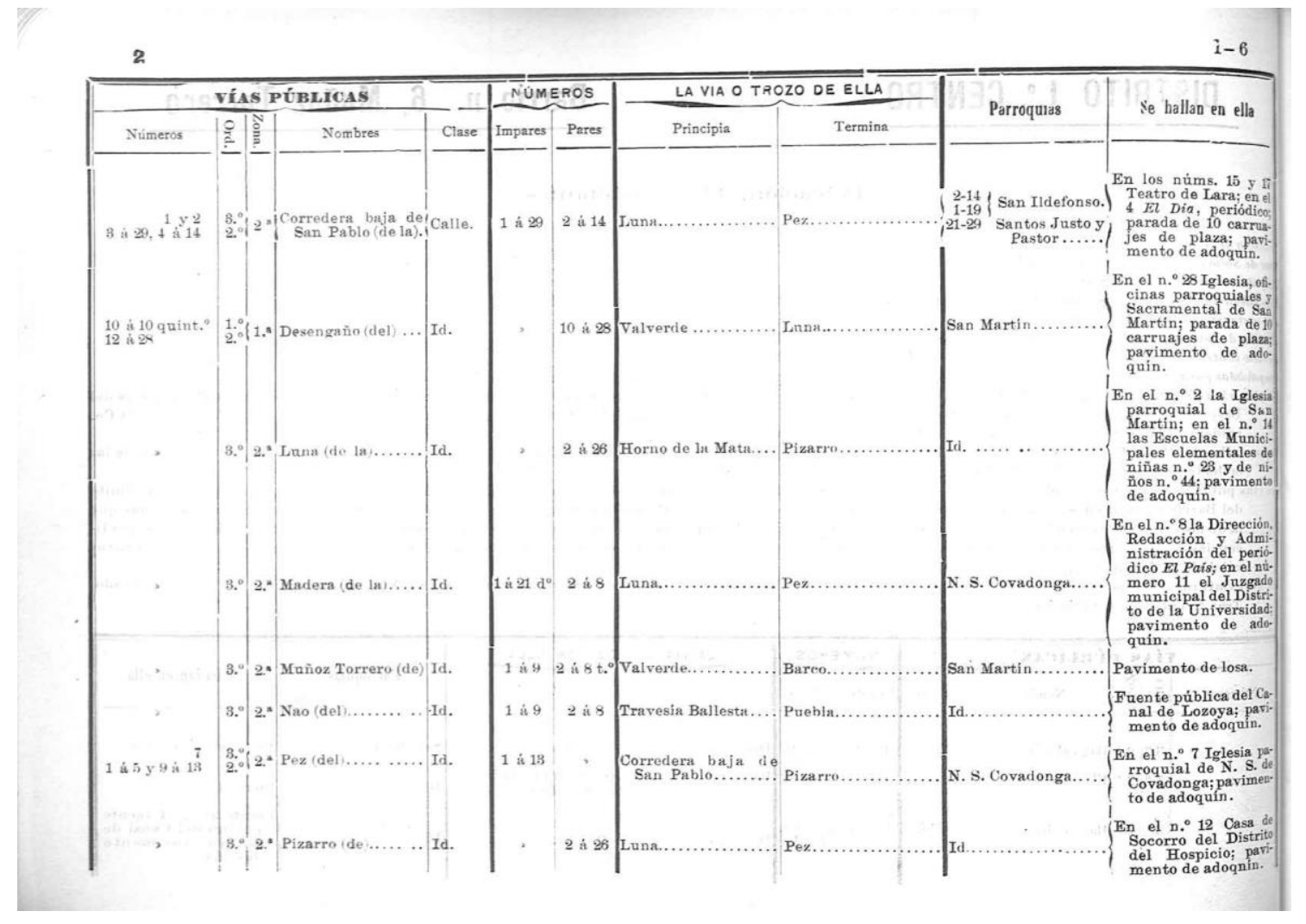

Fuente: (González e Iribas, 1906)

Para el caso de la Guía práctica de Madrid, de González e Iribas, ésta aparece dividida en diez secciones, una por cada distrito. En cada sección, las vías públicas aparecen por orden alfabético y se corresponden a la totalidad de las comprendidas en los diez Barrios que conforman el Distrito. A la hora de extraer la información viaria, hay que tener en cuenta consideraciones tales como que cuando las calles, plazas, paseos (o cualquier tipo de vía) o trozo de las mismas, aparecen acompañadas de una sola numeración (ya sea impar o par) es debido a que se corresponden con el límite del Barrio. En el caso de que aparezcan designadas las dos numeraciones (pares e impares), significa que están en el interior del barrio. Además, para el caso de la numeración de las plazas, la numeración es siempre correlativa (en este caso, si aparece de manera separada la numeración par e impar es simplemente por cuestión de estructura de la Guía). La clasificación por orden y zonas, es solo para el pago de arbitrios, por licencias de obras, aperturas de establecimientos, etc. Cuando no figuran los números en la casilla de la izquierda, es porque son los de la numeración natural de la calle y se expresan en las casillas de la derecha (González e Iribas, 1906). 
La Guía de las Vías Públicas de Madrid (Ayuntamiento de Madrid, 1916), tiene una estructura similar a la Guía de González e Iribas, de manera que la estructura de la denominación viaria viene especificada por los nombres de las calles ordenados alfabéticamente, con la especificación de donde empieza y donde termina. Respecto a la numeración, aparecen los tramos de números, pares e impares. En el caso que sólo se contenga uno de los tramos (par o impar), es porque el omitido corresponde a un barrio distinto.

\subsection{Metodología.}

\subsubsection{Información cartográfica: construcción de Mapas en el Proyecto HISDI-MAD}

En líneas precedentes se ha atendido a la descripción detallada del Plano de Facundo Cañada López y su relevancia como elemento cartográfico. Dando buena cuenta de su potencial, el Dr. Diego Ramiro Fariñas y su grupo de investigación del Departamento de Población del CCHS-CSIC y la unidad de Sistemas de Información Geográfica de la misma institución, pusieron en marcha un ambicioso proyecto denominado HISDI$\mathrm{MAD}^{13}$, cuyo objetivo principal queda descrito por el propio título del mismo "Creación de una infraestructura de datos espaciales urbanos como plataforma de información geoespacial y sociodemográfica", usando, para ello, el plano de Madrid de Facundo Cañada ${ }^{14}$.

Los Sistemas de Información Geográfica y su relevancia como herramienta de uso en las Ciencias Sociales resulta indiscutible. En el caso presente, para lograr el objetivo de poder realizar análisis a nivel de barrio teniendo en cuenta la cobertura de la red de agua y de las redes de evacuación/alcantarillado, era necesario emplear herramientas de análisis espacial. El proyecto HISDI-MAD contiene un total de 16 capas vectoriales con información geográfica del plano de Facundo Cañada López. De éstas, han sido utilizadas en el presente trabajo la capa de distritos (Mapa 2-4), la capa de barrios (Mapa 2-5) y la capa de ejes de calles (Mapa 2-6).

\footnotetext{
${ }^{13}$ Toda la información relativa al proyecto, puede consultarse en: http://www.idehistoricamadrid.org/hisdimad/index.htm

${ }^{14}$ Para conocer la metodología y técnicas aplicadas, puede consultarse el informe realizado por los autores (del Bosque González et al., 2010a)
} 
Mapa 2-4. Capa de distritos sobre el mapa de Facundo Cañada

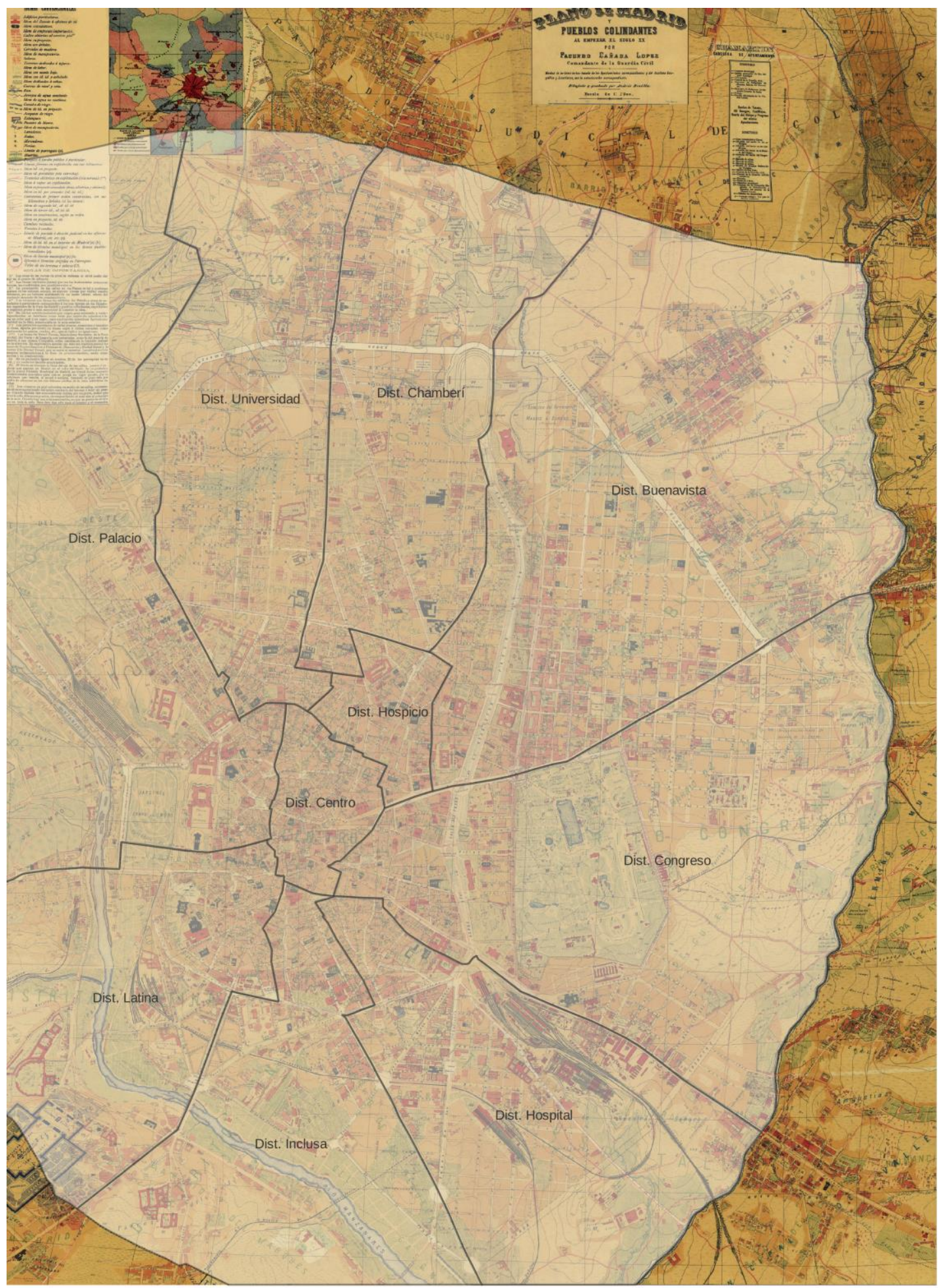

Fuente: Elaboración propia 
Mapa 2-5. Capa de barrios sobre el mapa de Facundo Cañada

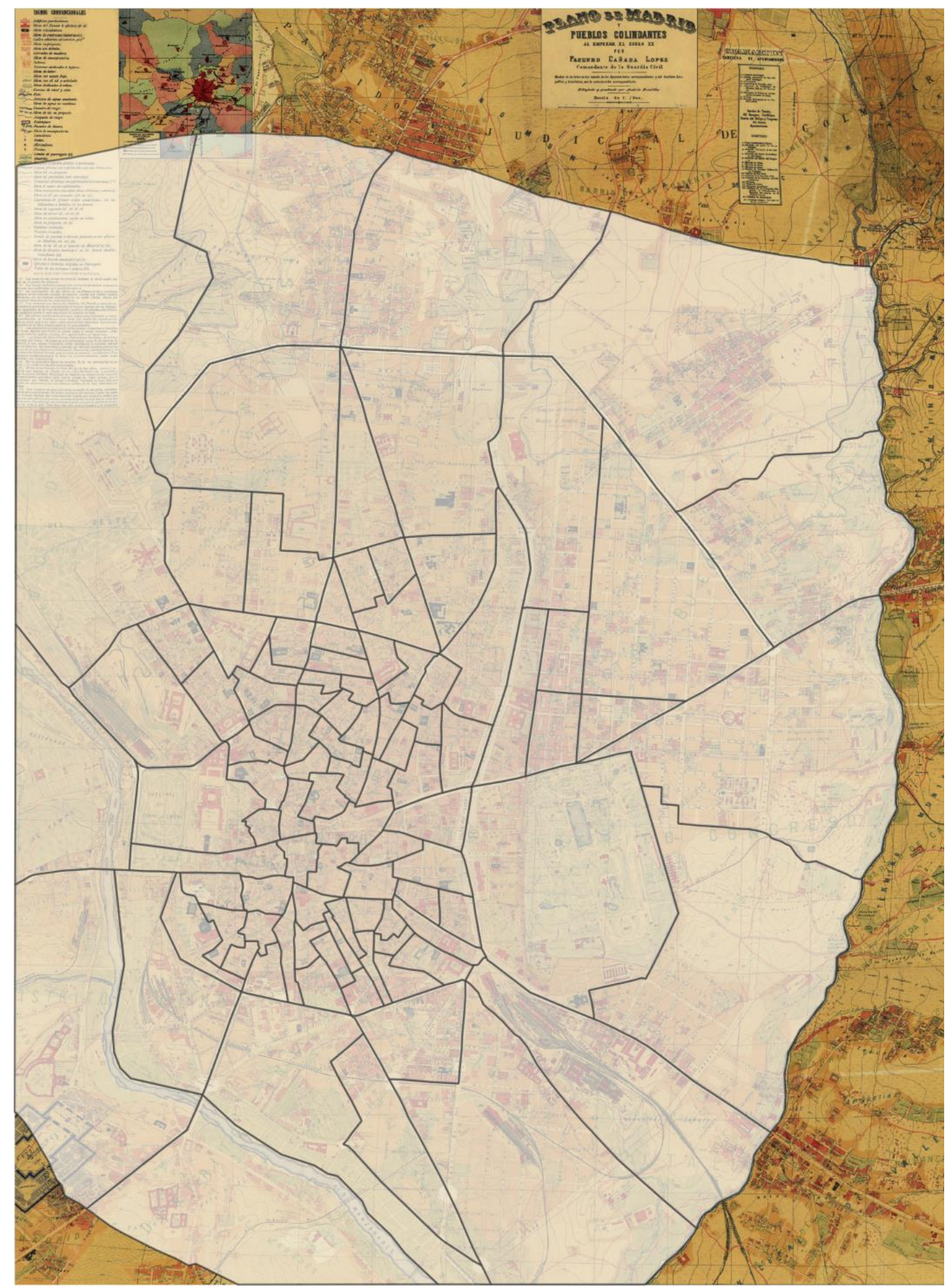

Fuente: Elaboración propia 
Mapa 2-6. Capa de ejes de calle sobre el mapa de Facundo Cañada

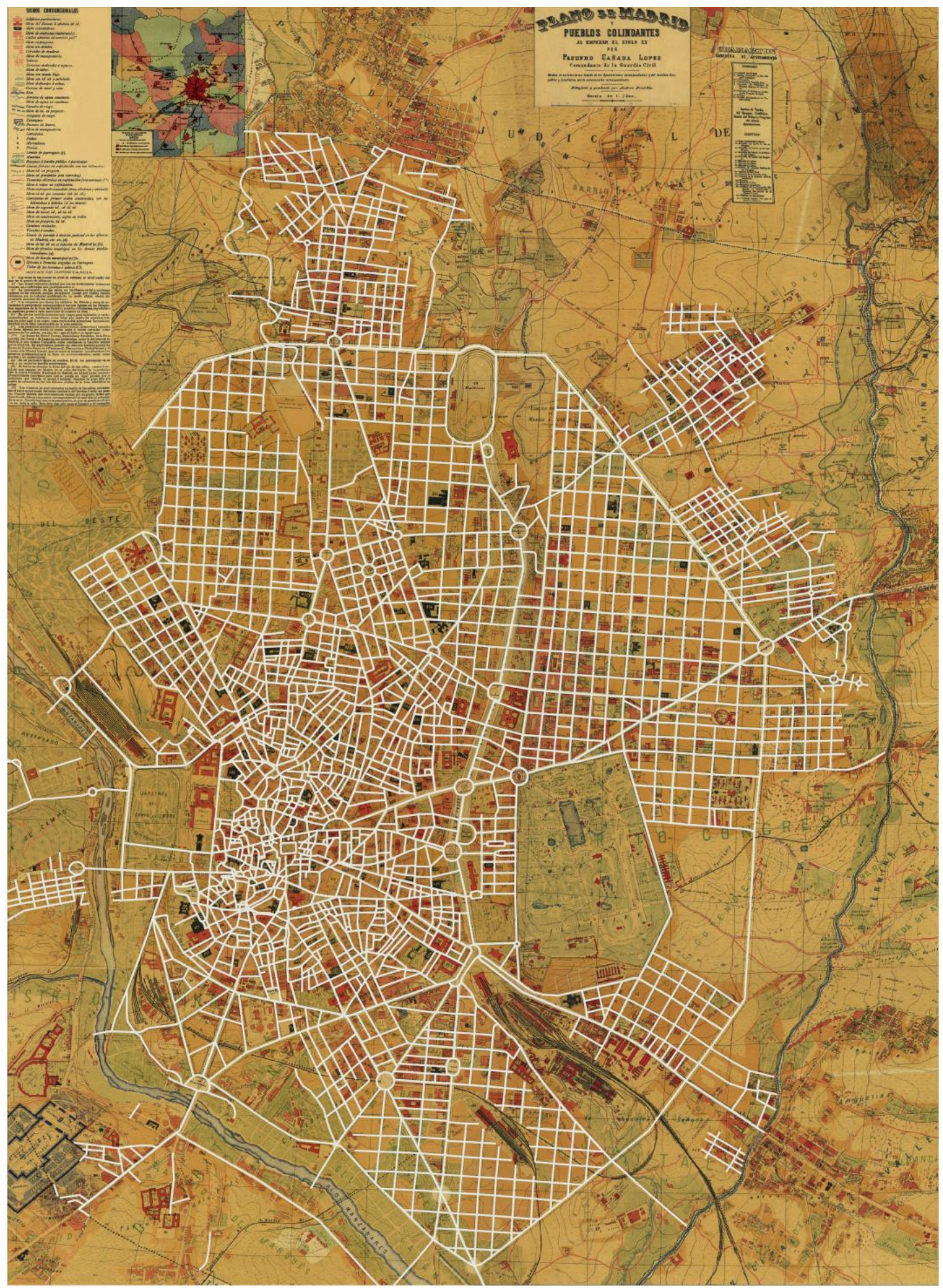

Fuente: Elaboración propia 


\subsubsection{El uso de mapas de cobertura de agua y alcantarillado.}

Con el objetivo de poder conocer el estado de las infraestructuras de abastecimiento de agua y de la red de alcantarillado en la cuidad de Madrid, se ha empleado información diversa histórica sobre la evolución de los sistemas de alcantarillado urbano y de la red de agua de Madrid en fechas que abarcan nuestro periodo de estudio.

Uno de los potenciales de la presente investigación radica en que, a partir de mapas antiguos sobre alcantarillado y agua, hemos sido capaces de extraer indicadores a nivel de barrio que nos permiten obtener un proxi de la superficie cubierta por los anteriores. Respecto al alcantarillado, se ha usado el mapa sobre la cobertura de alcantarillado de 1900 de Hauser (Hauser, 1902a), el mapa correspondiente a la red de evacuación del Plan General del Saneamiento del Subsuelo de Madrid de 1913-1923, obtenido del libro sobre Historia del Saneamiento (V. G. R. Pinto Crespo, Rafael; Velasco Medina, Fernando, 2015) y el mapa de la red de alcantarillado que aparece en la Memoria de la Ciudad de Madrid del año 1929 (Ayuntamiento de Madrid, 1929). 


\section{Mapa 2-7. Red de alcantarillado en 1900 . Hauser.}

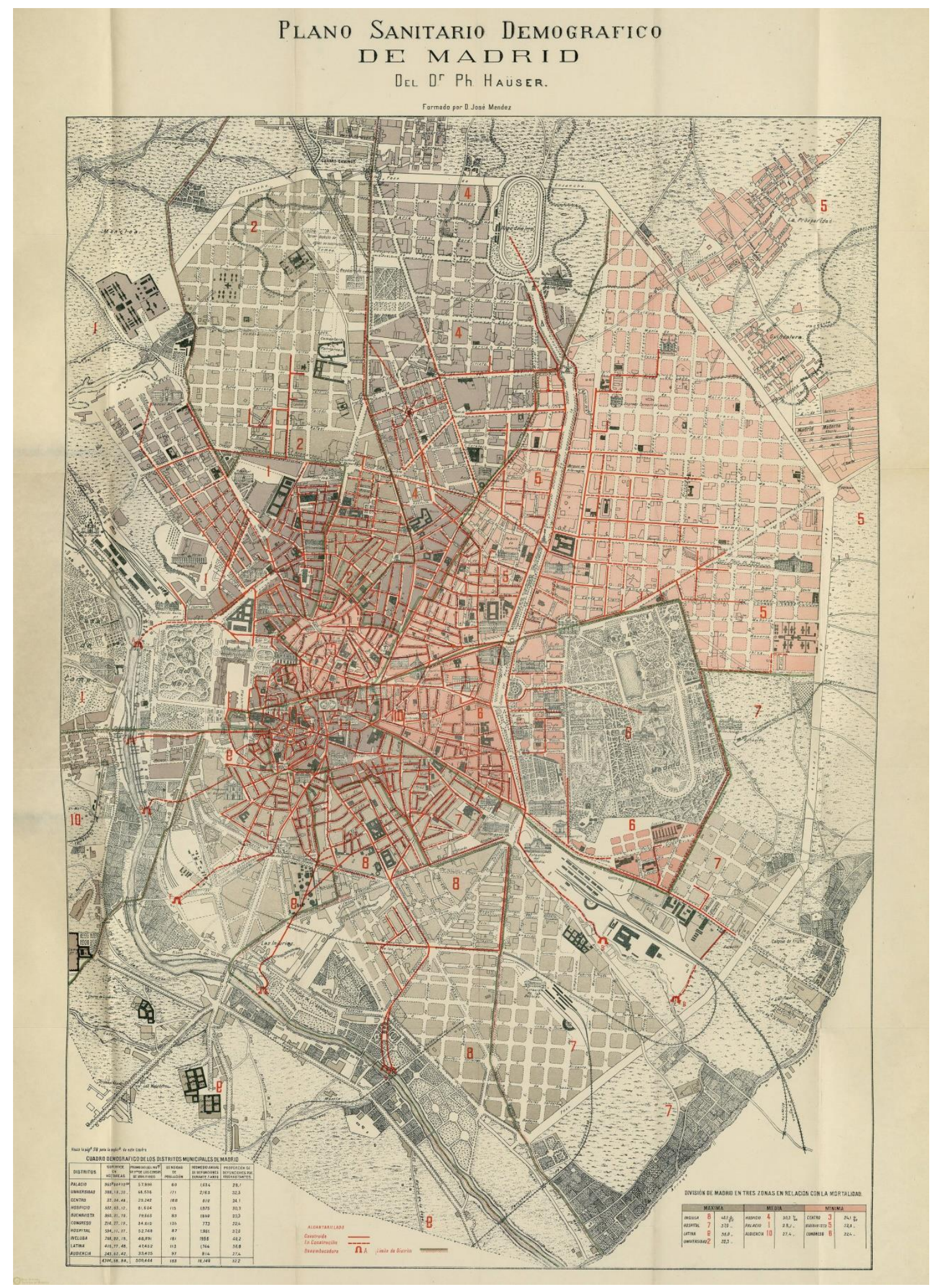

Fuente:(Hauser, 1902a) 
Mapa 2-8. Plano del Plan General del Saneamiento del Subsuelo de Madrid. 1913-1923

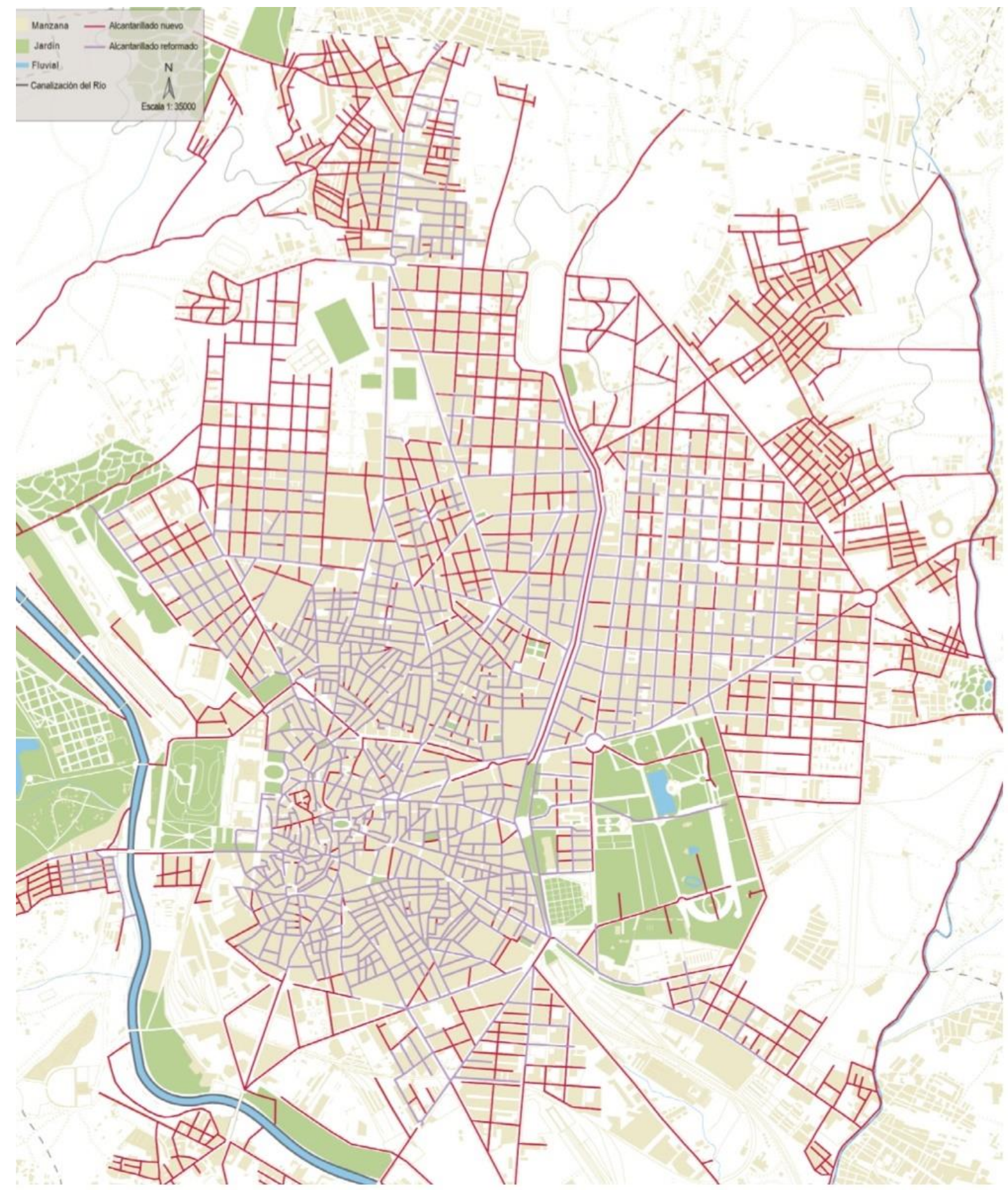

Fuente: (V. G. R. Pinto Crespo, Rafael; Velasco Medina, Fernando, 2015) 


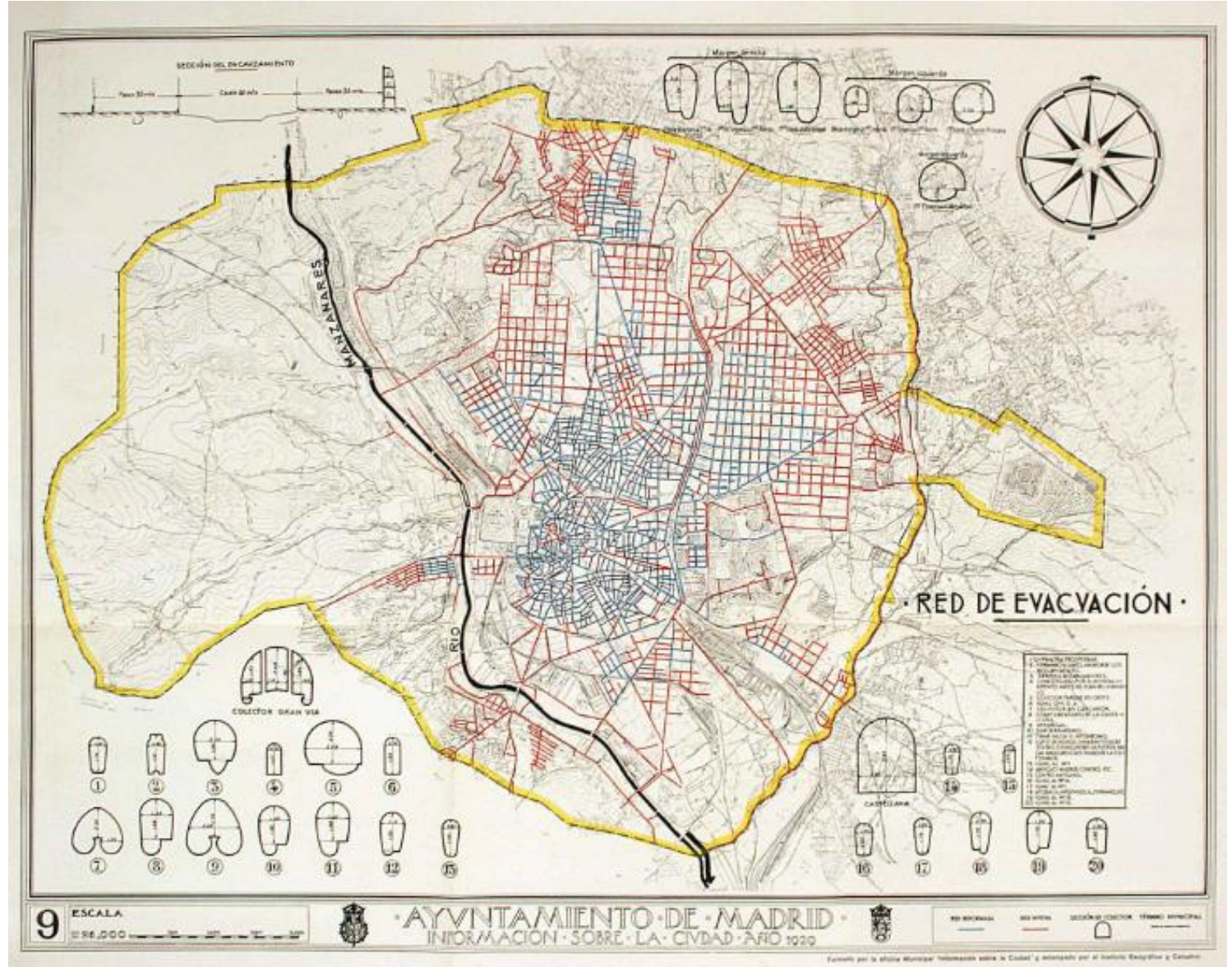

Fuente: (Ayuntamiento de Madrid, 1929)

Respecto al sistema de abastecimiento de agua, se han usado los mapas de distribución de la red para el año 1929, obtenidos de la Memoria de la ciudad (Ayuntamiento de Madrid, 1929), para las tres fuentes de abastecimiento existentes en ese momento; el Canal de Isabel II (Mapa 2-10), la Sociedad Hidráulica Santillana y los Viajes antiguos (Mapa 2-11). 
Mapa 2-10. Red de abastecimiento de agua. Canal de Isabel II. Año 1929.

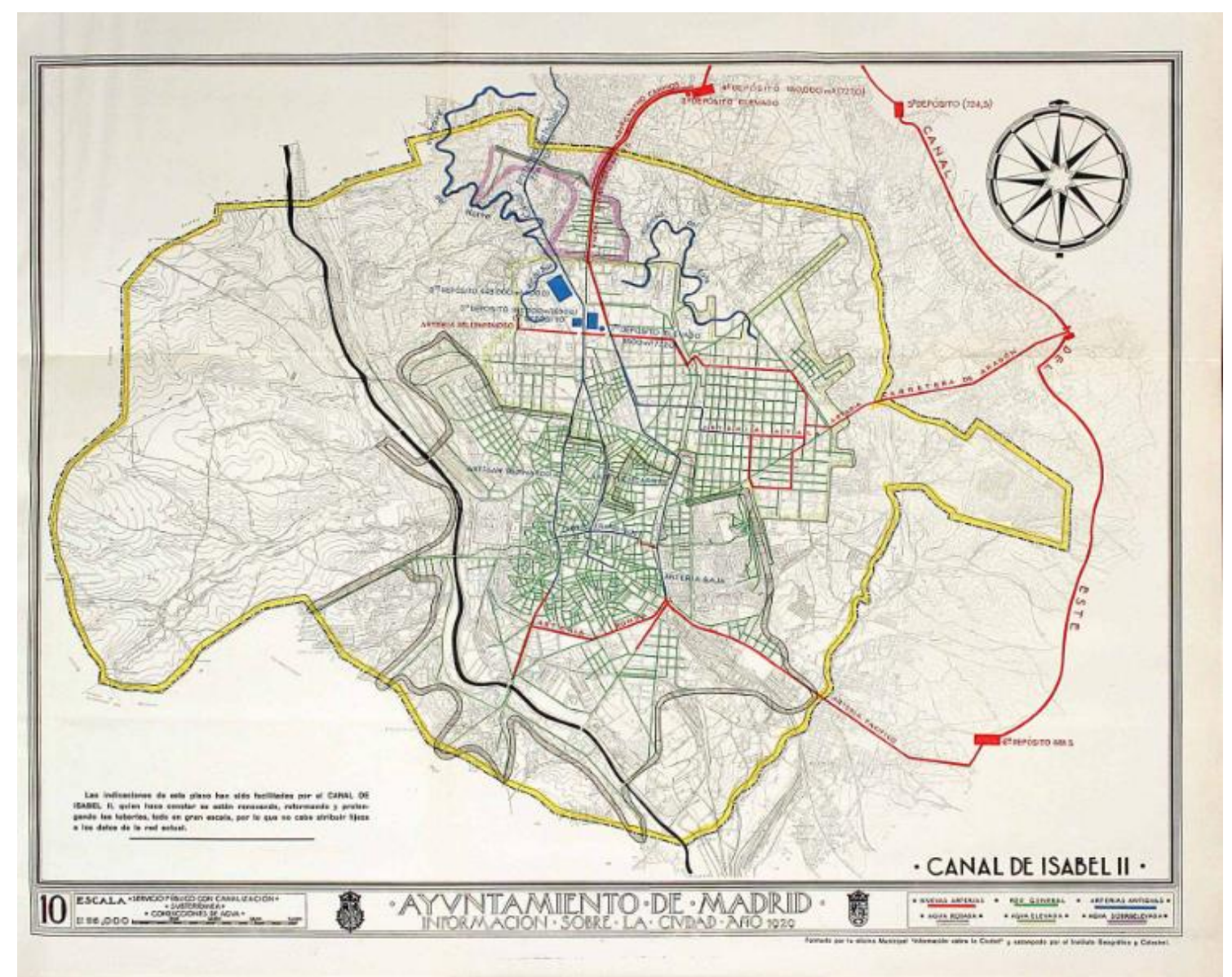

Fuente: (Ayuntamiento de Madrid, 1929) 


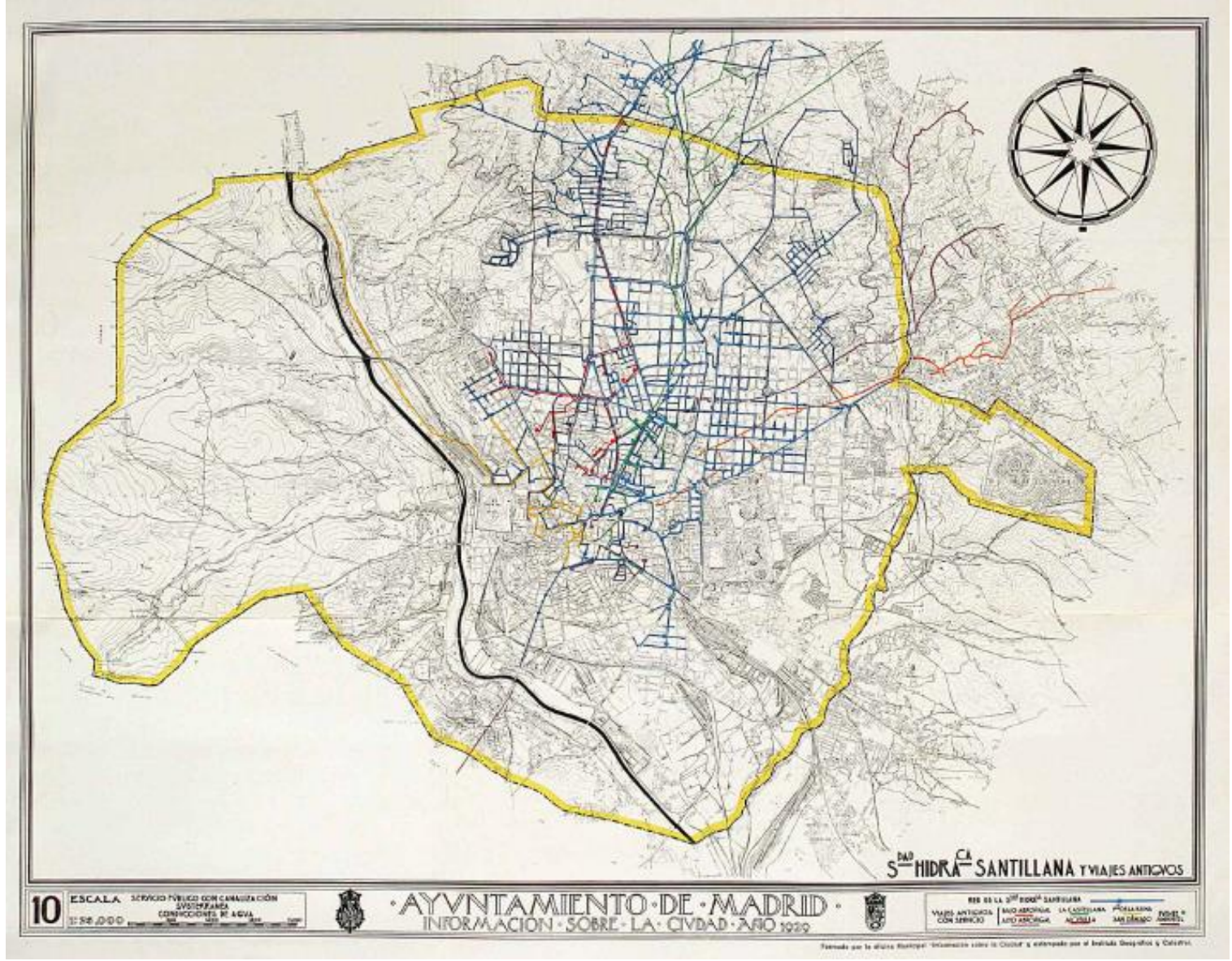

Fuente: (Ayuntamiento de Madrid, 1929)

Una vez obtenidas las imágenes, es necesario realizar la conversión de nuestro elemento de estudio a capas vectoriales.

Con el objetivo de poder realizar la digitalización y vectorización de los mapas de líneas de agua y de líneas de alcantarillado, se han empleado diferentes herramientas de los programas ArcGis y Qgis. Para ello, se ha empleado como capas base las capa vectoriales de barrios y la de ejes de calles de la IDE Histórica de Madrid.

El primer paso ha sido proceder a la georreferenciación de las imágenes de los mapas de agua y de alcantarillado de la ciudad, con el objetivo de poder superponer estas imágenes con la capa de líneas de calle de la IDE Histórica de la ciudad de Madrid.

Teniendo en cuenta que las redes de agua y alcantarillado de la ciudad tienen una dimensión espacial lineal, el proceso de vectorización de las mismas se convirtió en una tarea ardua, pues se ha elaborado de manera manual. De este modo, se ha procedido a 
vectorizar todas las líneas de las redes de distribución de agua y del sistema de evacuación de aguas, con el objetivo de crear las capas vectoriales de líneas de agua y de alcantarillado, con idéntica proyección a la de las capas vectoriales de la IDE Histórica de la ciudad (ETSR89/UTM zone 30).

El resultado de la creación las capas, se muestra en las imágenes a continuación.

Mapa 2-12. Capa de la red de alcantarillado.1900.

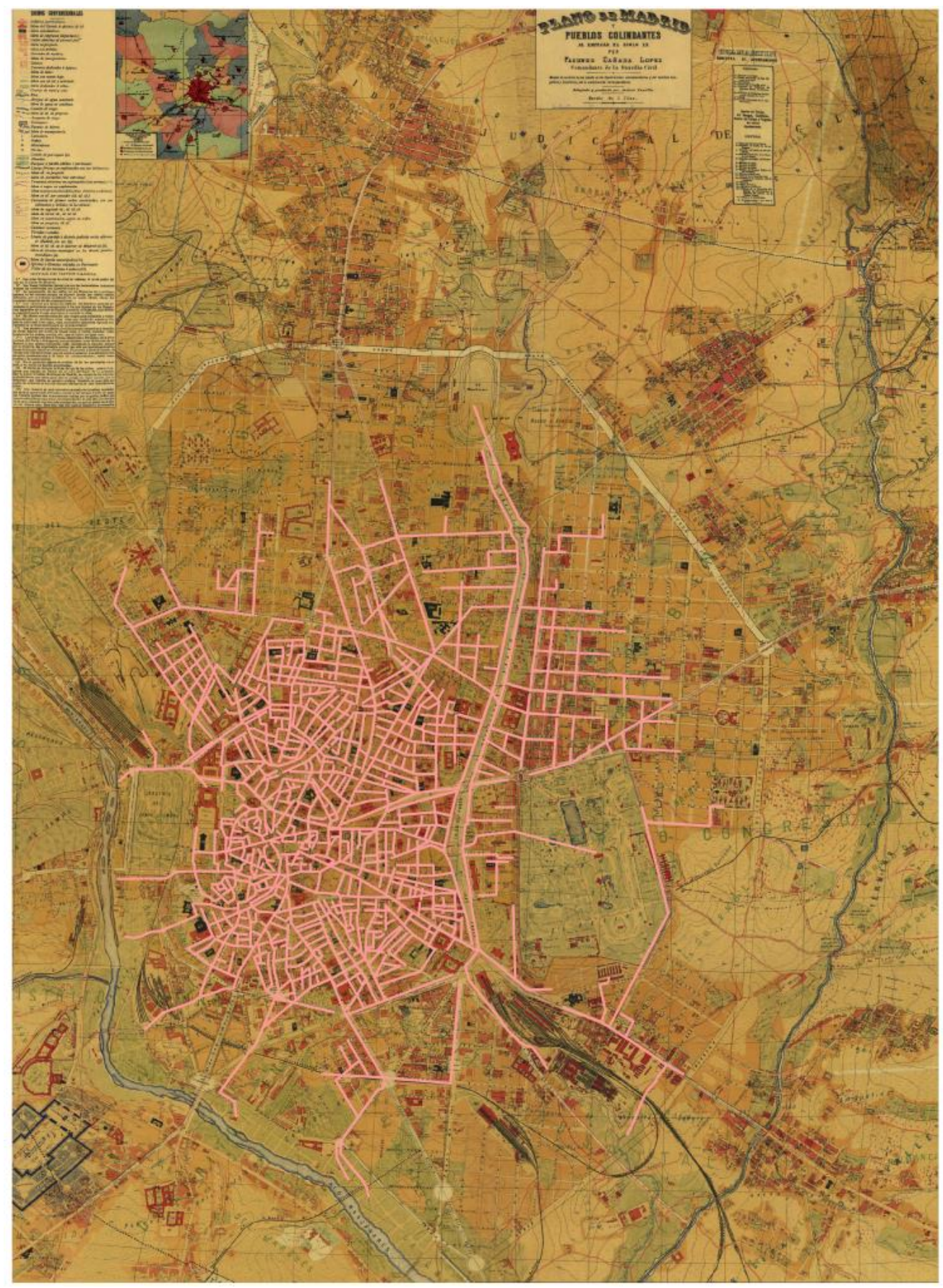

Fuente: Elaboración propia. 
Mapa 2-13. Capa de red de alcantarillado. 1913-1923

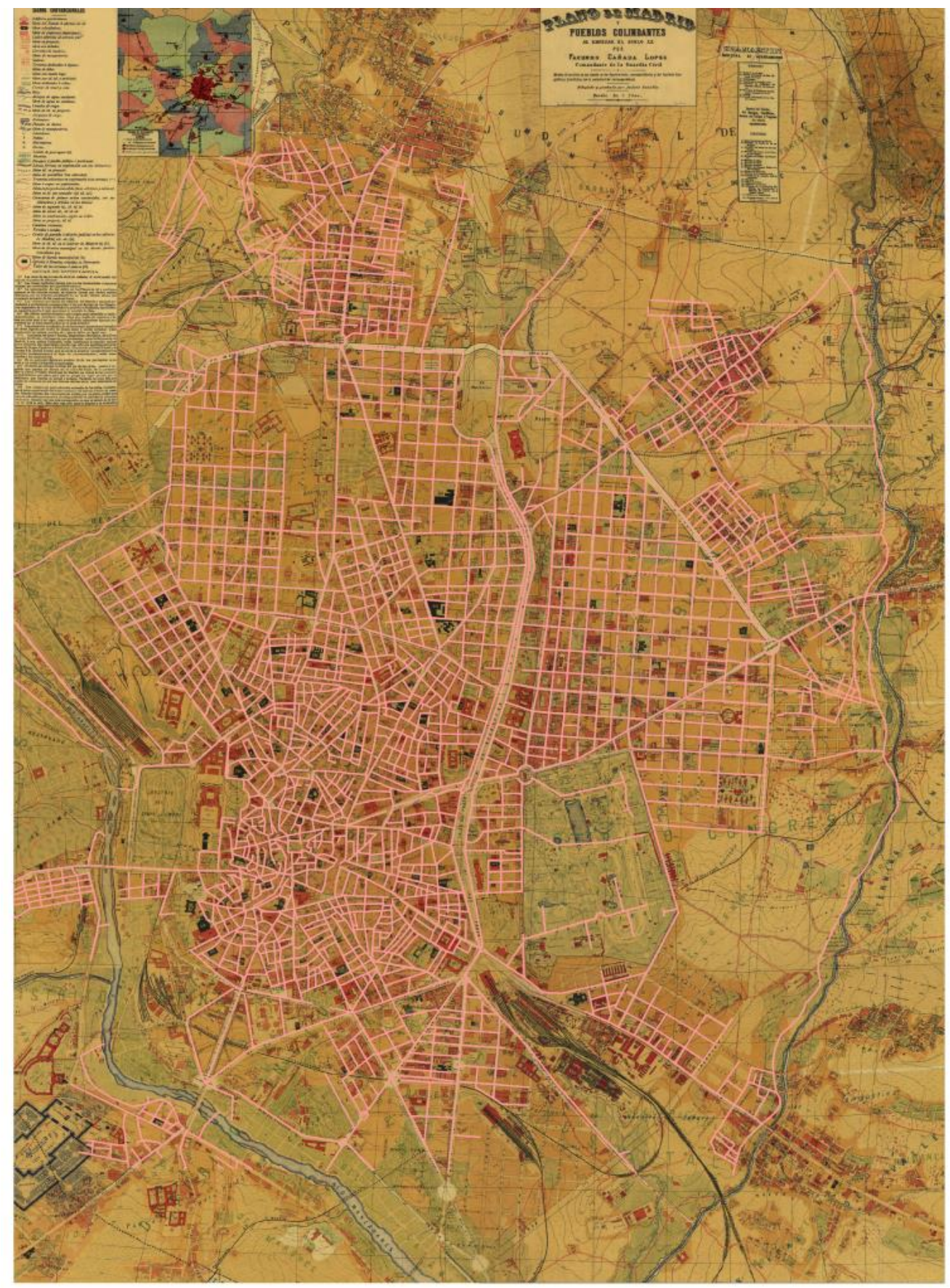

Fuente: Elaboración propia. 
Mapa 2-14. Capa de la red de alcantarillado. 1929

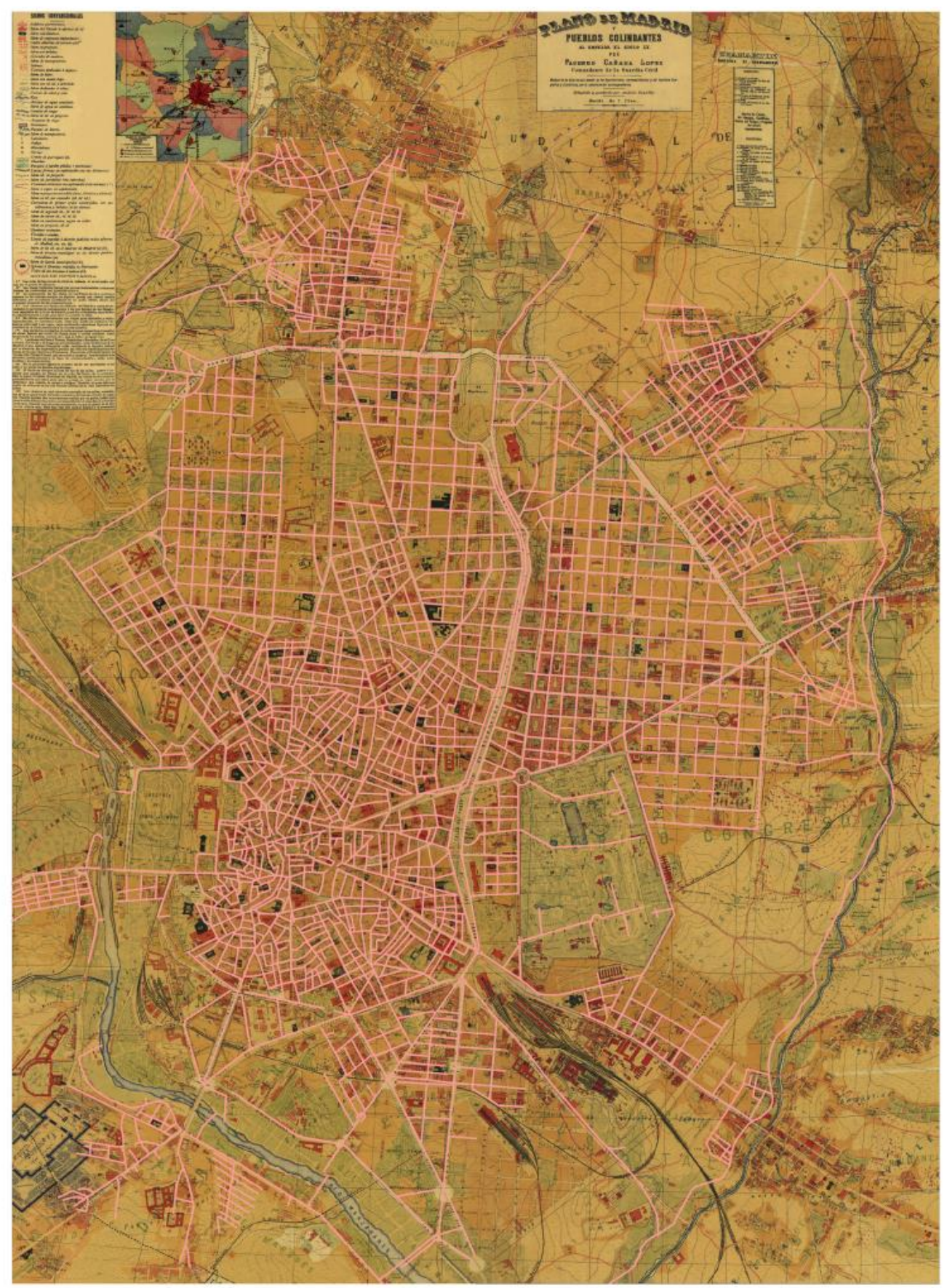

Fuente: Elaboración propia. 
Mapa 2-15. Capa de la red de abastecimiento de agua. Canal de Isabel II. 1929.

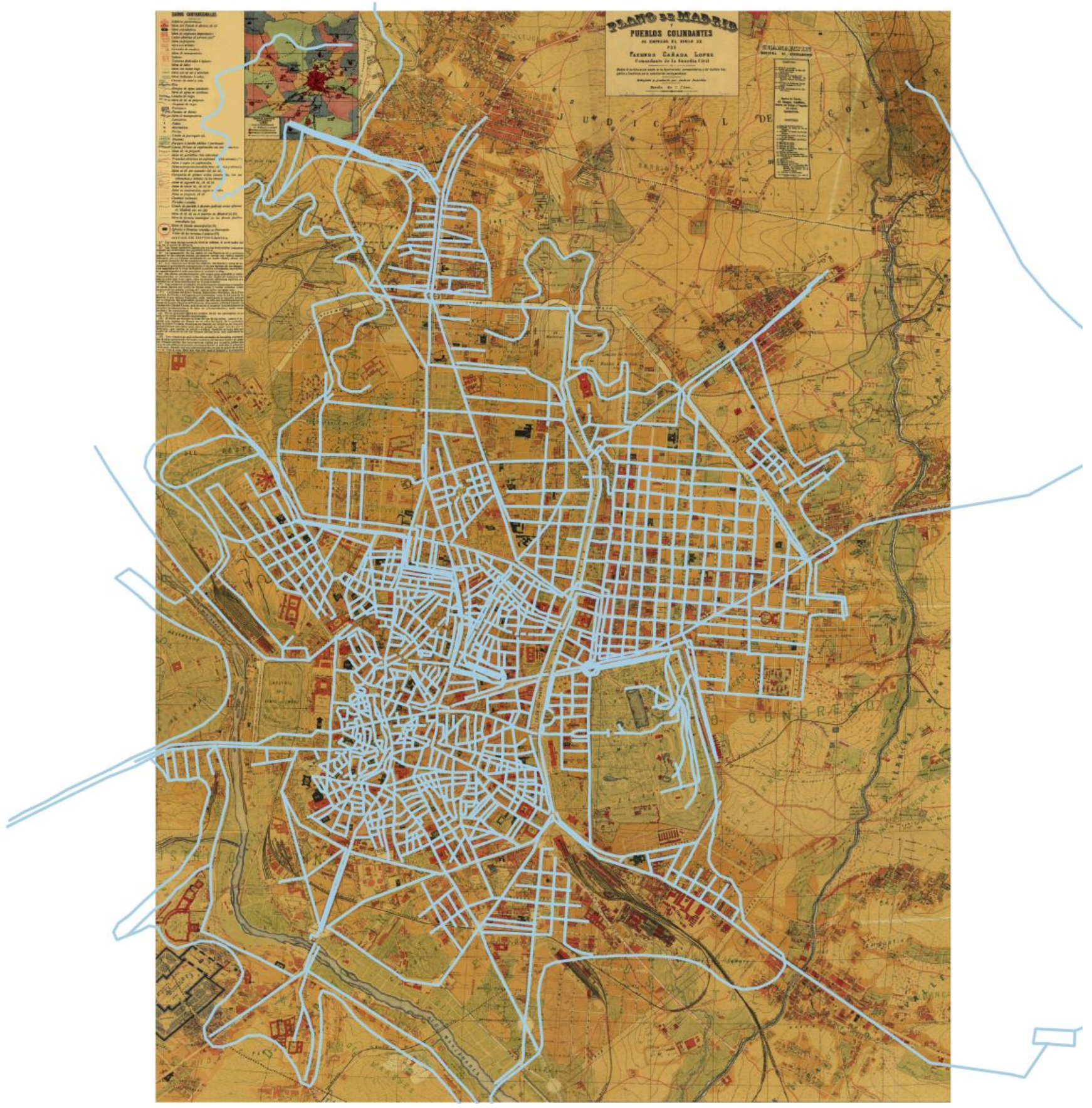

Fuente: Elaboración propia. 
Mapa 2-16. Capa de la red de abastecimiento de agua. Hidráulica Santillana. 1929.

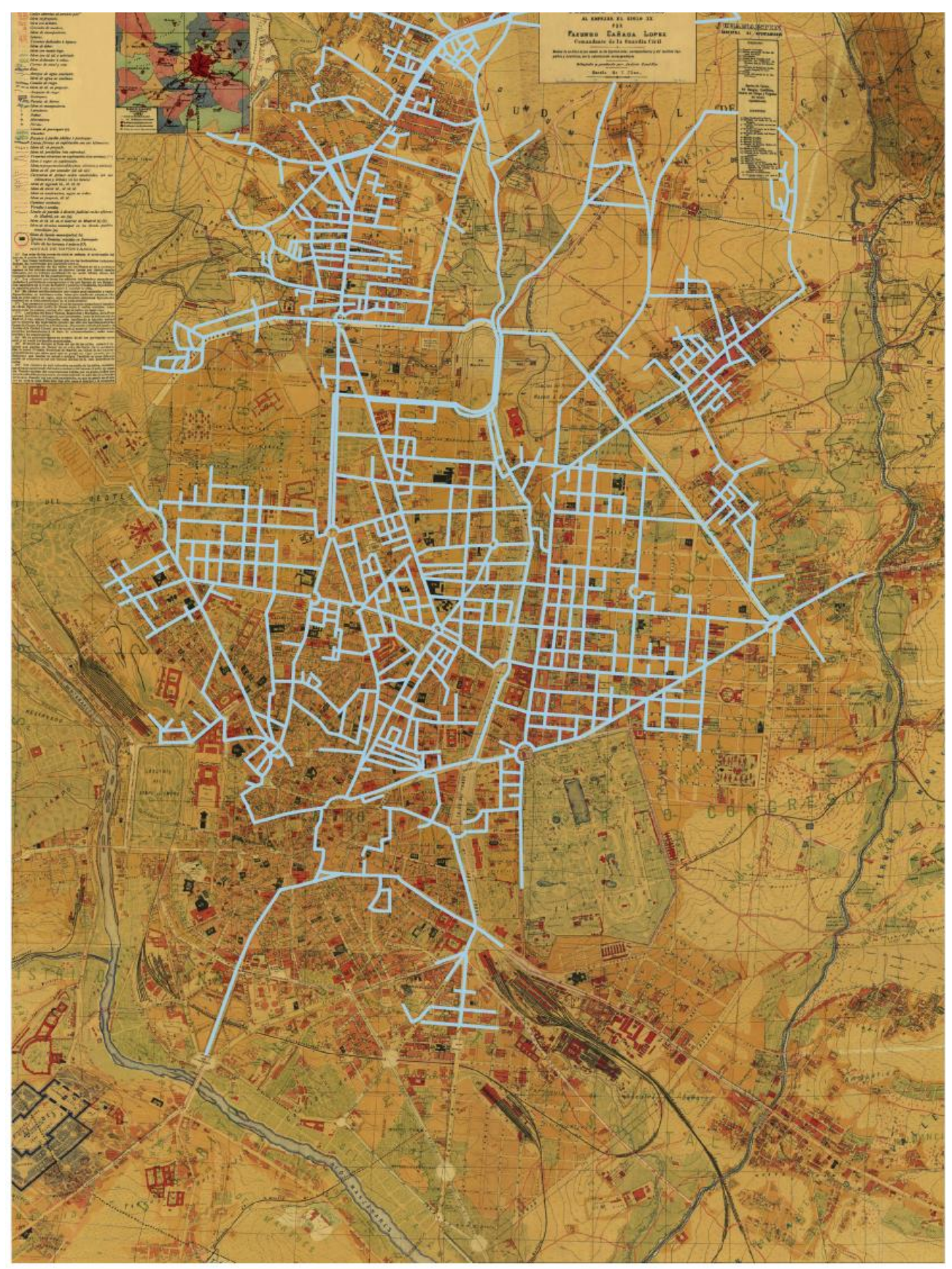

Fuente: Elaboración propia. 
Mapa 2-17. Capa de la red de abastecimiento de agua. Viajes de agua. 1929.

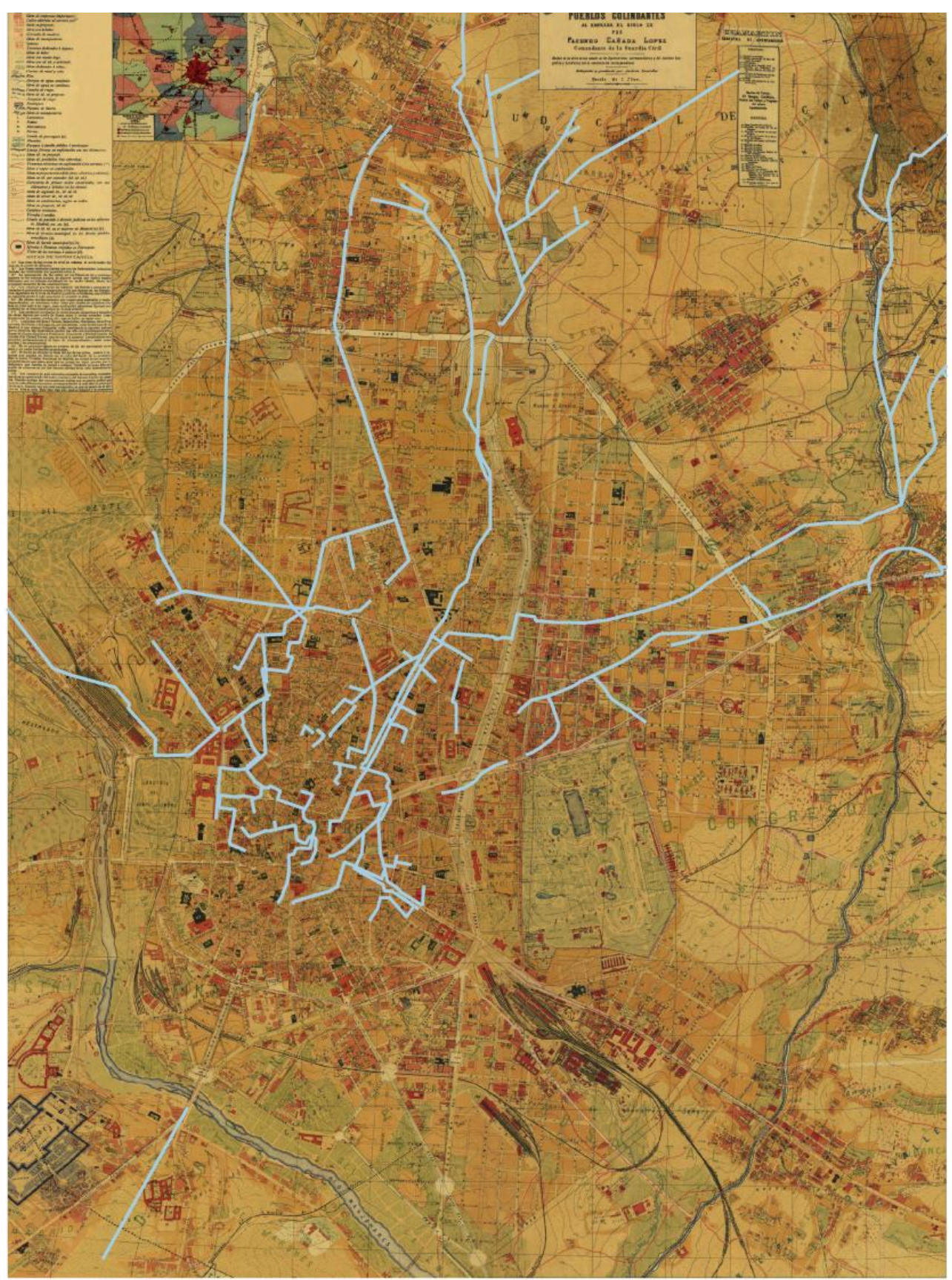

Fuente: Elaboración propia. 
Dado que el interés principal de nuestro estudio es disponer de un valor que nos permitiera conocer la proporción de las redes de distribución de agua y de alcantarillado a nivel de barrio, se han empleado diferentes herramientas de geoproceso. La herramienta de intersección, ha sido empleada con el objetivo de conocer todas las líneas de agua que se intersectaban con cada uno de los barrios.

También se ha empleado al herramienta de buffer, con el objetivo de ser capaces de considerar el radio de influencia de las diferentes líneas de las capas vectoriales de agua y de alcantarillado. Nuestra capa de entrada han sido las capas de líneas de agua y alcantarillado y la distancia elegida respecto a la línea, han sido 20, 25, y 50 metros.

Así se han creado buffers a las distancias descritas, con el objetivo de crear zonas de influencia alrededor de una entidad, que en nuestro caso son las líneas de redes de agua, de redes de alcantarillado y de ejes de calles. En el análisis espacial, las áreas de influencia (buffering), consiste en la generación de buffers o áreas de entorno. Ésta es una operación que permite identificar un área de tamaño predeterminado rodeando alguna entidad geográfica seleccionada. Se construye uno o más polígonos englobando los objetos cartográficos seleccionados ${ }^{15}$.Se utiliza fundamentalmente para determinar proximidad espacial, tomando como referencia cualquier tipo de objeto, punto, línea o polígono.

Estos buffers obtenidos, nos ofrecen un objeto por cada línea de agua o de alcantarillado, por lo que se ha empleado la herramienta "dissolve", tras ser intersectados con la capa de barrios, con el objetivo de para así obtener un valor a nivel de barrio y poder realizar el cálculo de la proporción.

\subsubsection{Cálculo de buffers y problemas asociados}

Una vez creada la capa vectorial de redes de abastecimiento de agua y de redes de evacuación, nos encontramos ante la problemática asociada al modo de plantear la creación y operacionalización de los indicadores de superficie sobre el barrio de cada una de las redes.

\footnotetext{
${ }^{15}$ Para conocer más sobre ésta herramienta de análisis espacial, puede consultarse https://docs.qgis.org/2.14/es/docs/gentle_gis_introduction/vector_spatial_analysis_buffers.html
} 
En este sentido, se procedió a crear tres tipos de indicadores, cada uno de los cuales contempla diferentes escenarios.

El primer indicador que se ha creado permite medir la proporción de la red de agua y la proporción de la red de alcantarillado (por separado) sobre la superficie total del barrio. El problema que nos encontramos es que, en algunos casos, nos hallamos ante la presencia de barrios que disponían de una cobertura baja de redes de calles teniendo en cuenta la superficie del barrio. En este sentido, cabe preguntarse por supuestos tales como si es posible dar por hecho que en los lugares donde no existía red viaria, tampoco cabría esperar que hubiera red de abastecimiento de agua ni red de alcantarillado.

Otro supuesto sería pensar que en estas zonas sin red de calle "oficial" tampoco estaría habitada y realmente lo que estaríamos cometiendo sería un error de subestimación de la red de agua y alcantarillado, al no tener en cuenta la red real por la que estos sistemas discurrían; es decir, las redes de calle.

Sin embargo, finalmente se ha decidido usar este indicador, en la medida en que precisamente, permitiría incluir las zonas más deprimidas de la ciudad, donde no existía ni siquiera una red de calle, pero permanecían habitadas

Teniendo en consideración los supuestos anteriores, se consideró la creación de un indicador adicional, que permitiera medir la proporción de las calles con red de agua y la proporción de las calles con red de alcantarillado sobre la superficie total del barrio. Se ha añadido, por tanto, un nuevo factor al cálculo anterior; la superficie de calle construida en relación al barrio. El objetivo de haber construido este indicador adicional viene dado por la posible subestimación de la proporción de barrio saneada que podamos haber cometido al no tener en consideración las calles. Se ha desechado el uso de este indicador, pues, teniendo en cuenta que se ha usado como capa vectorial base la red de ejes de calle del Mapa de Facundo Cañada de la IDE histórica de la ciudad de Madrid, éste contempla el callejero existente hasta 1902.

En un tercer momento, se ha considerado proceder a un cálculo añadido a los dos anteriores, en el que se ha tenido en consideración el porcentaje de las calles con red de agua/alcantarillado (=proporción de red de agua/ alcantarillado sobre la superficie de calles, asignando este valor a los barrios (sin tener en cuenta la superficie del barrio).

Dado que finalmente se ha usado el primer indicador descrito arriba, sólo atenderemos de manera sintética a la forma de construcción de éste. 
Así, se ha calculado el porcentaje de la superficie cubierta por las Redes de Aguas y Alcantarillado sobre la superficie total de cada barrio. Para ello, con la capa vectorial de líneas de agua y alcantarillado, se han calculado los Buffers de 25 y 50 metros de las capas de agua (Canal de Isabel II, Hidráulica Santillana y Viajes Antiguos, del año 1929) y de alcantarillado para los años 1900, 1923 y 1929. A continuación, estos buffers se han intersectado con la capa de de la IDE histórica de Madrid y se le ha aplicado un 'Dissolve' para obtener así el dato total de superficie por cada barrio. Para finalizar, se ha calculado el porcentaje que ocupará en cada barrio la superficie total de alcantarillado (para cada capa, y para cada Buffer de 25 y 50 de cada una de esas capas). Para poder representar los porcentajes por barrio necesitamos añadir los datos de esta capa a la de polígonos de barrios, y crear así un mapa de coropletas.

Los mapas resultado de la aplicación de buffers se insertan a continuación. 
Mapa 2-18. Proporción de alcantarillado con buffer de 25 metros. Años 1900, 1913-1923 y 1929

1900

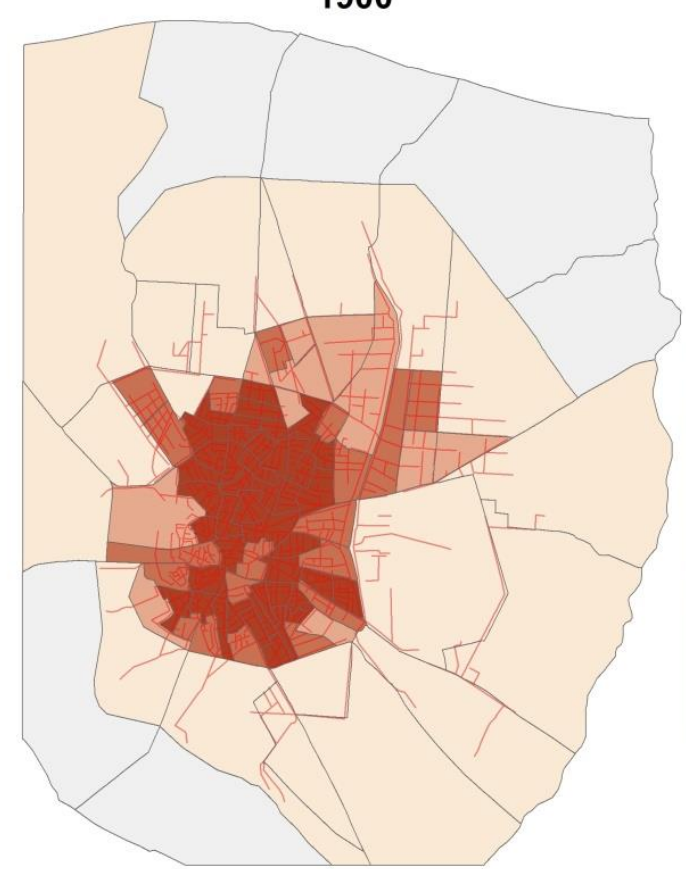

Proportion of sewer network (\%)
1923

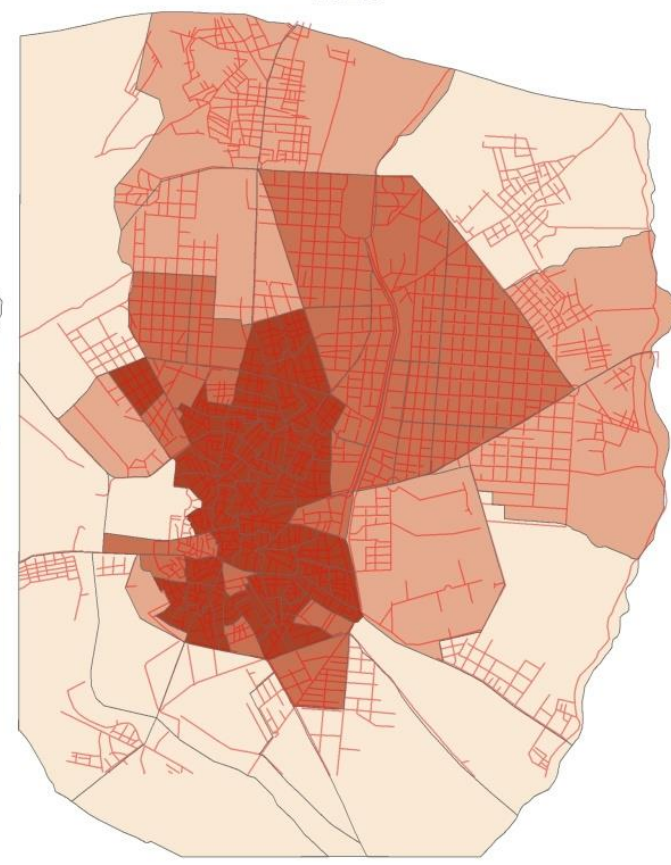

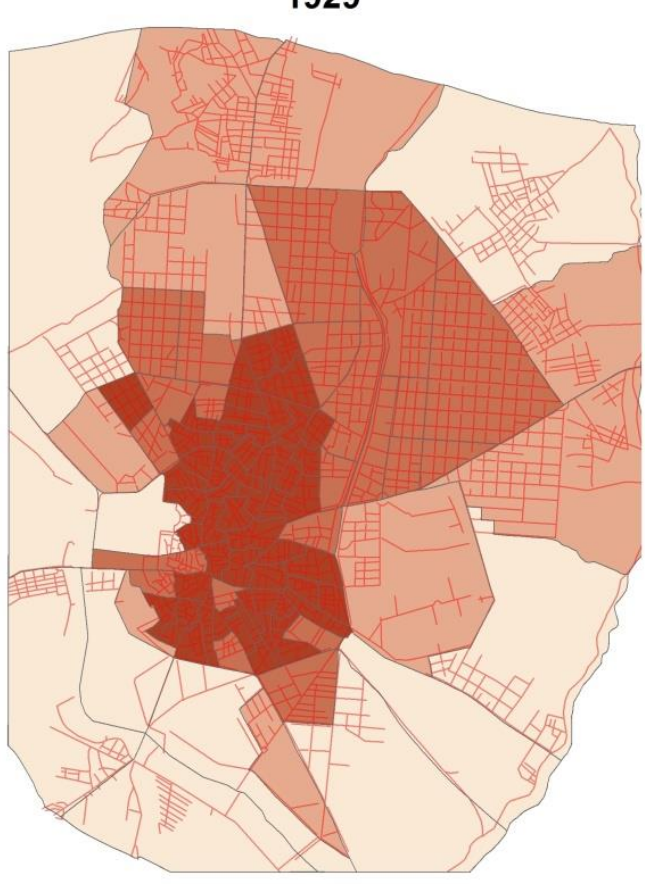

$\begin{array}{lll}0 & 1,25 & 2,5\end{array}$ $5 \mathrm{Km}$

Coordinate System: ETRS 1989 UTM Zone 30N

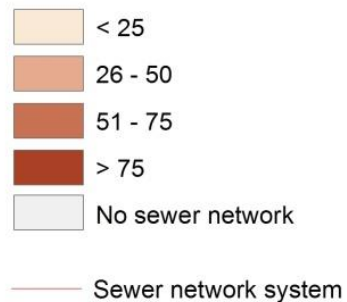


Mapa 2-19. Proporción de alcantarillado con buffer de 50 metros. Años 1900, 1913-1923 y 1929

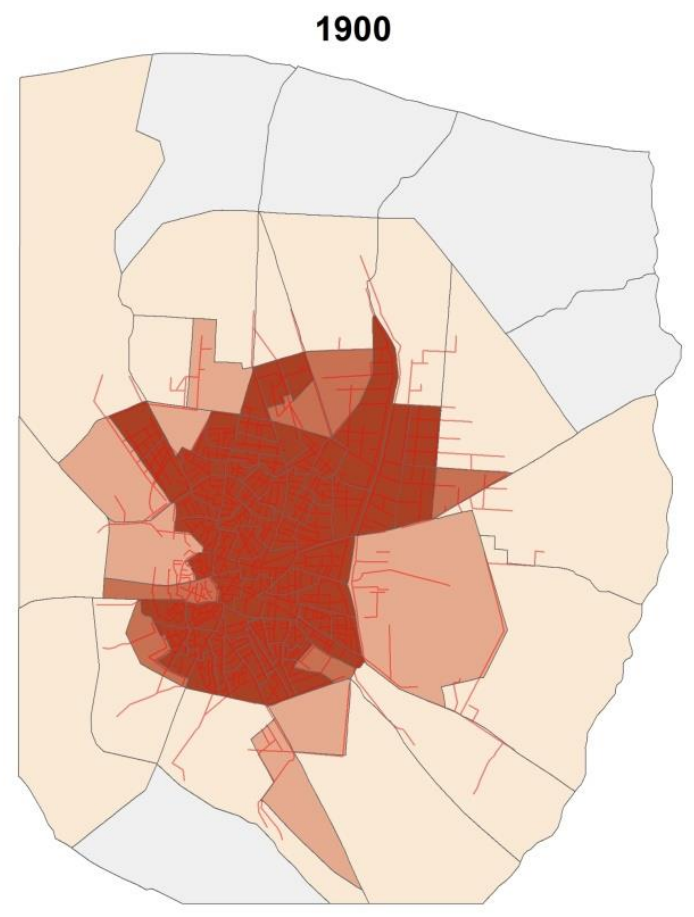

Proportion of sewer network (\%)

\begin{tabular}{|l|l}
\hline & $<25$ \\
$26-50$ \\
$51-75$ \\
& $>75$ \\
& No sewer network \\
& \\
& Sewer network system
\end{tabular}

1923
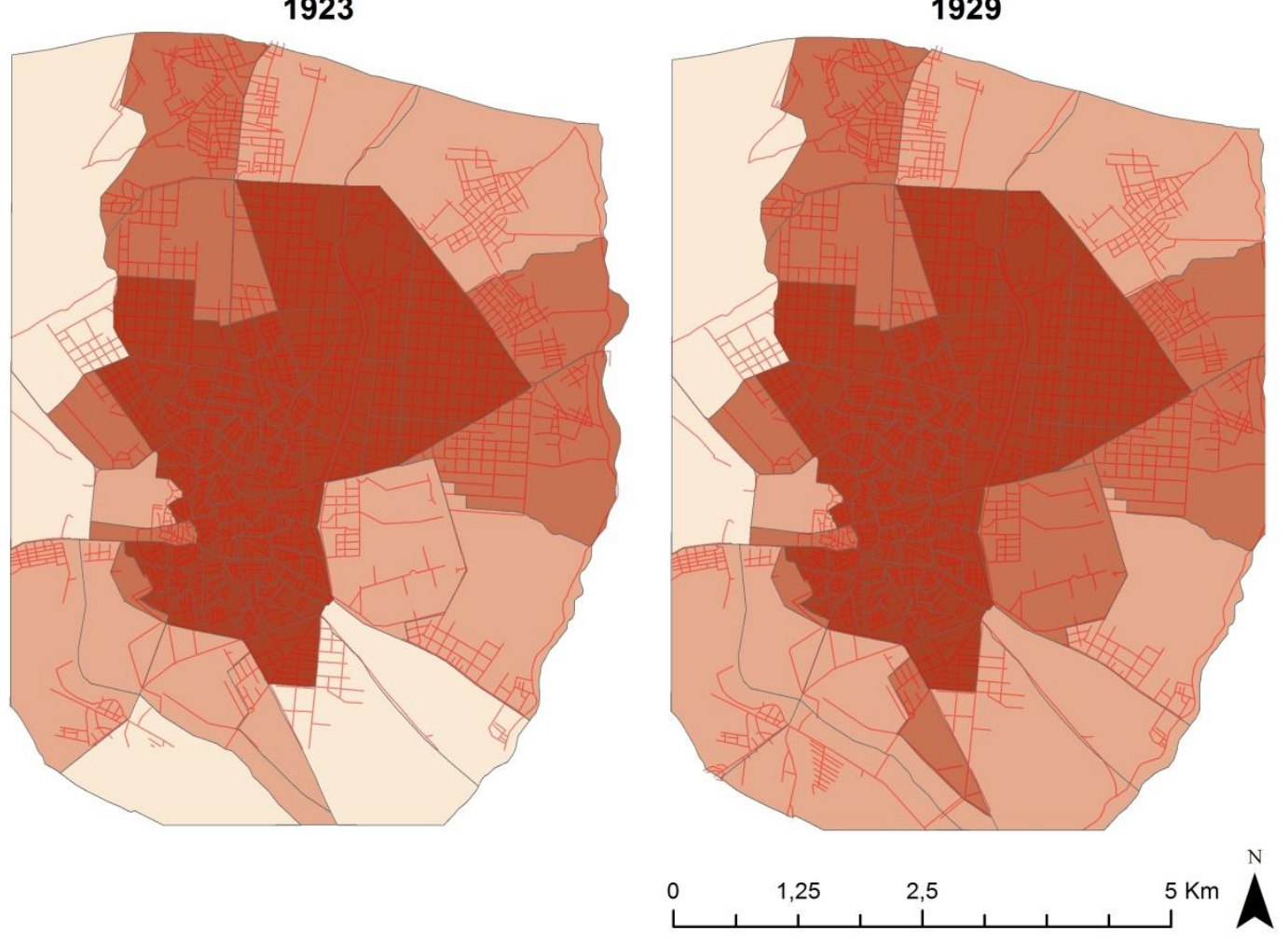

Coordinate System: ETRS 1989 UTM Zone 30N 
Mapa 2-20. Proporción de la red de alcantarillado 1900, 1923 y 1929 teniendo en cuenta la proporción de calles.

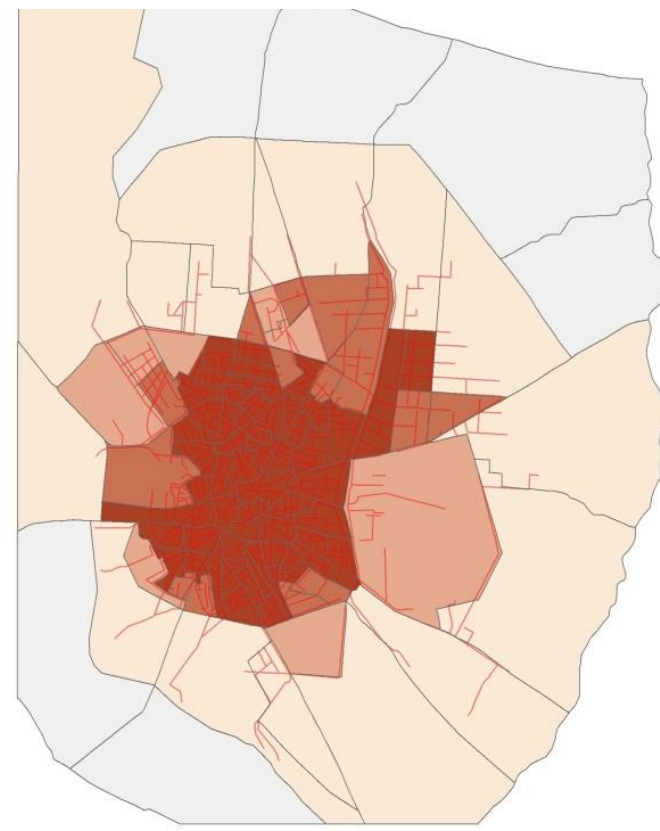

Proportion of sewer network (\%)

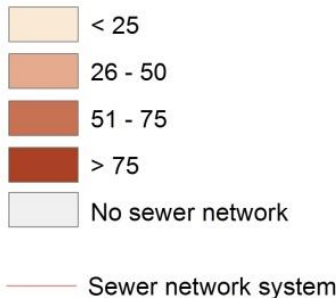

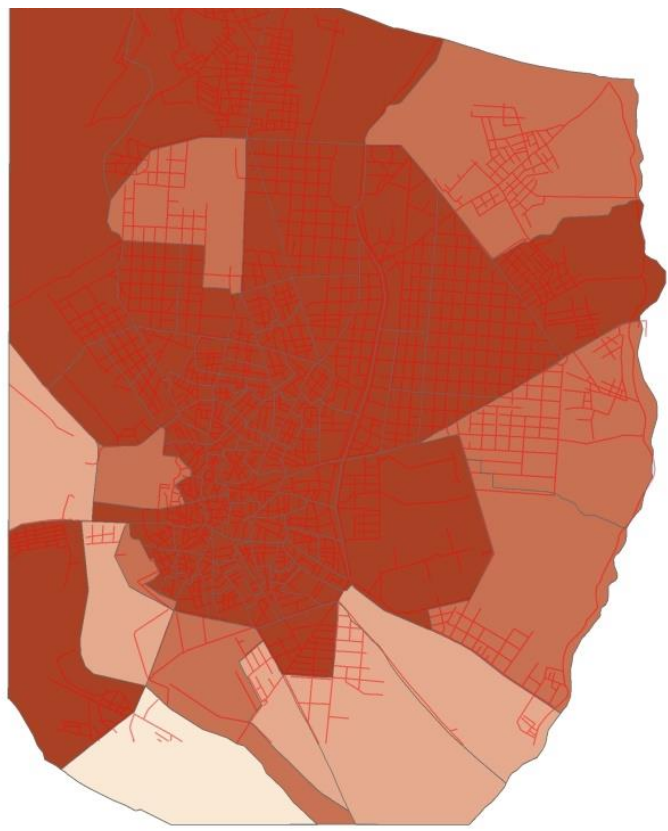

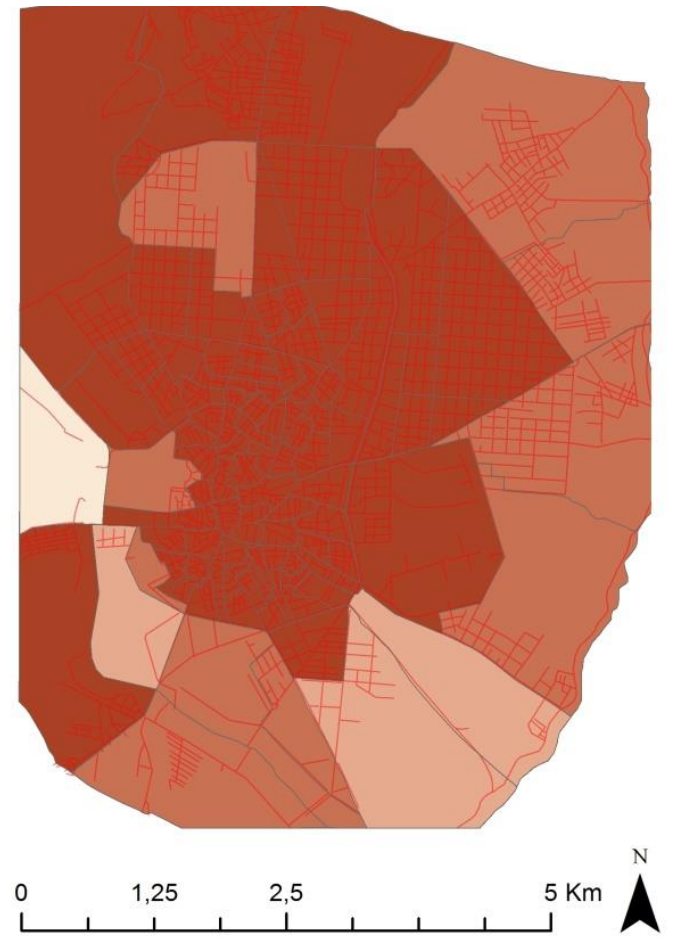

Coordinate System: ETRS 1989 UTM Zone 30N 
Mapa 2-21. Proporción de la red de agua con buffer de 25 metros. Año 1929.

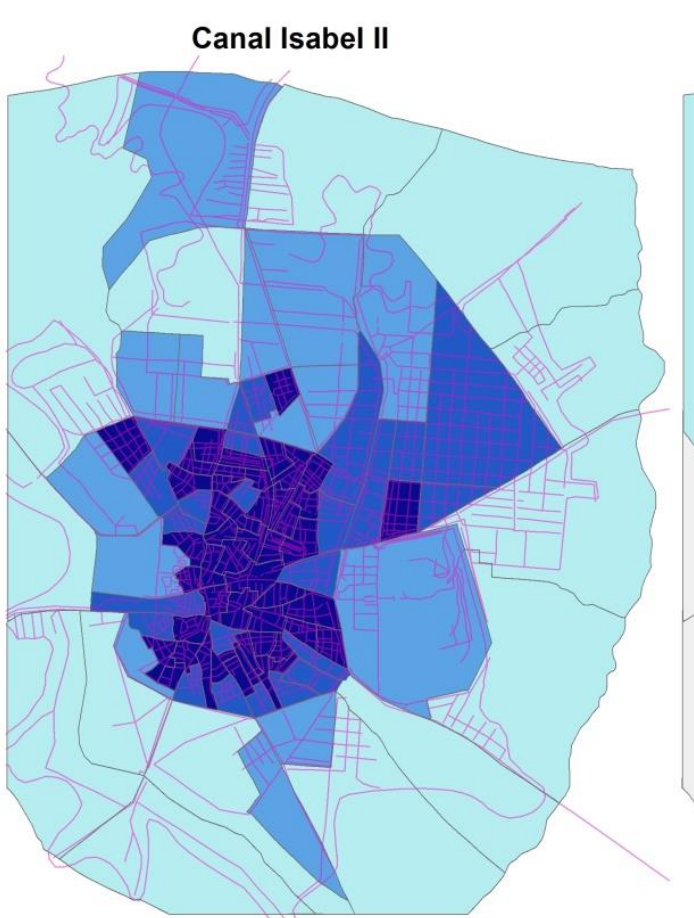

Proportion of water network (\%)
$<25$
$26-50$
$51-75$
$>75$

No water network

Water network system
Hidráulica Santillana

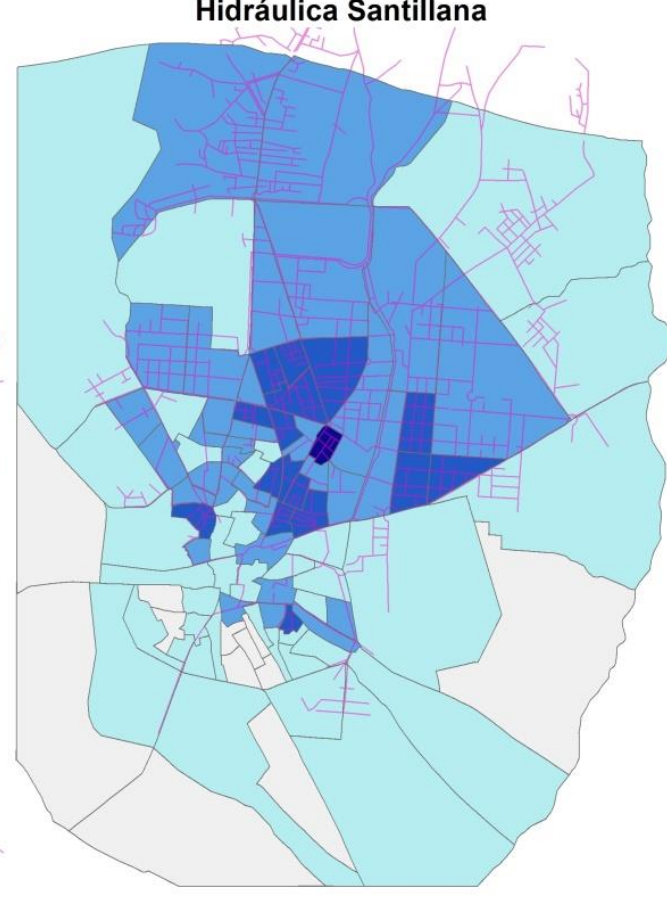

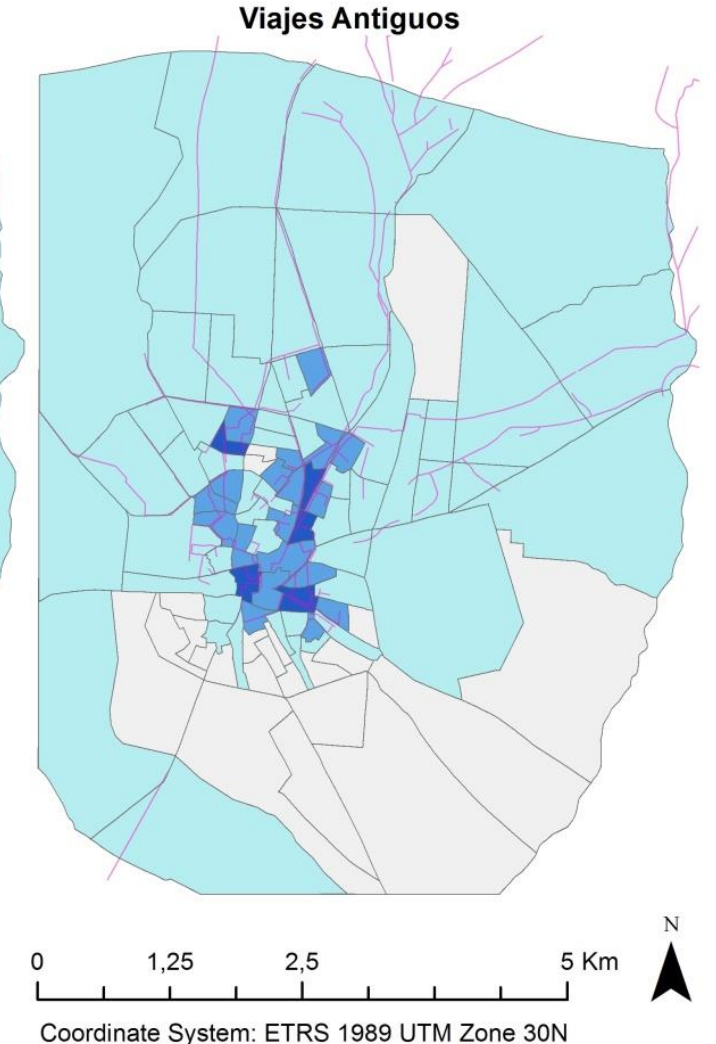

Coordinate System: ETRS 1989 UTM Zone 30N

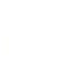


Mapa 2-22. Proporción de la red de agua con buffer de 50 metros. Año 1929.

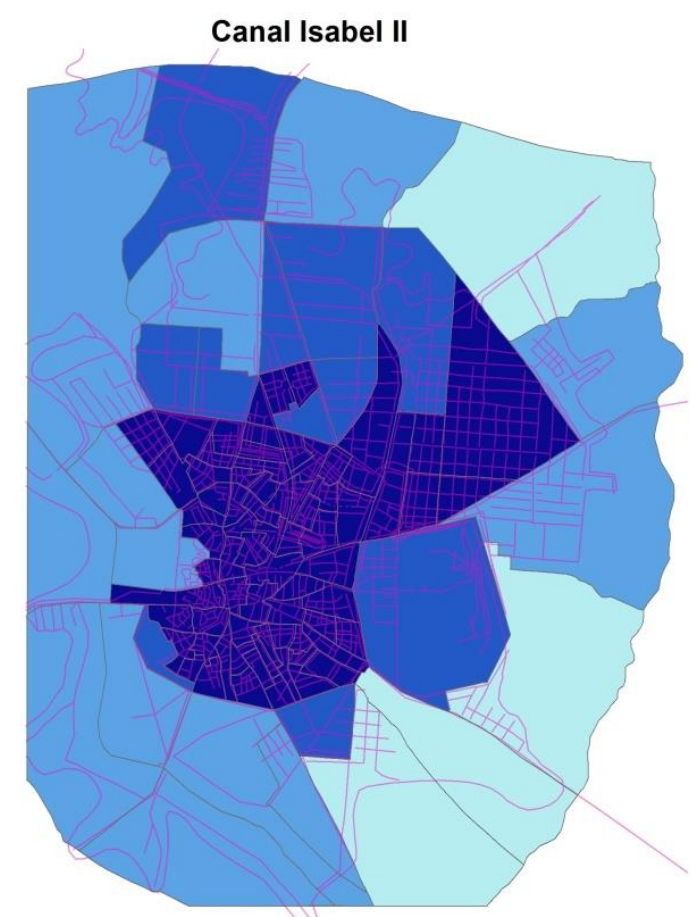

Proportion of water network (\%)

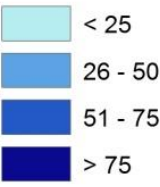

No water network
Hidráulica Santillana

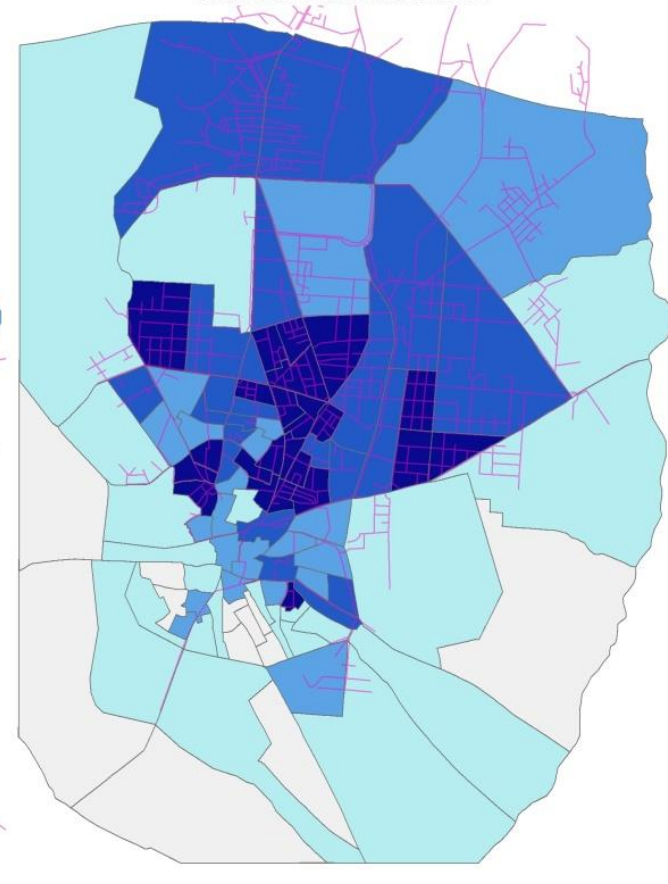

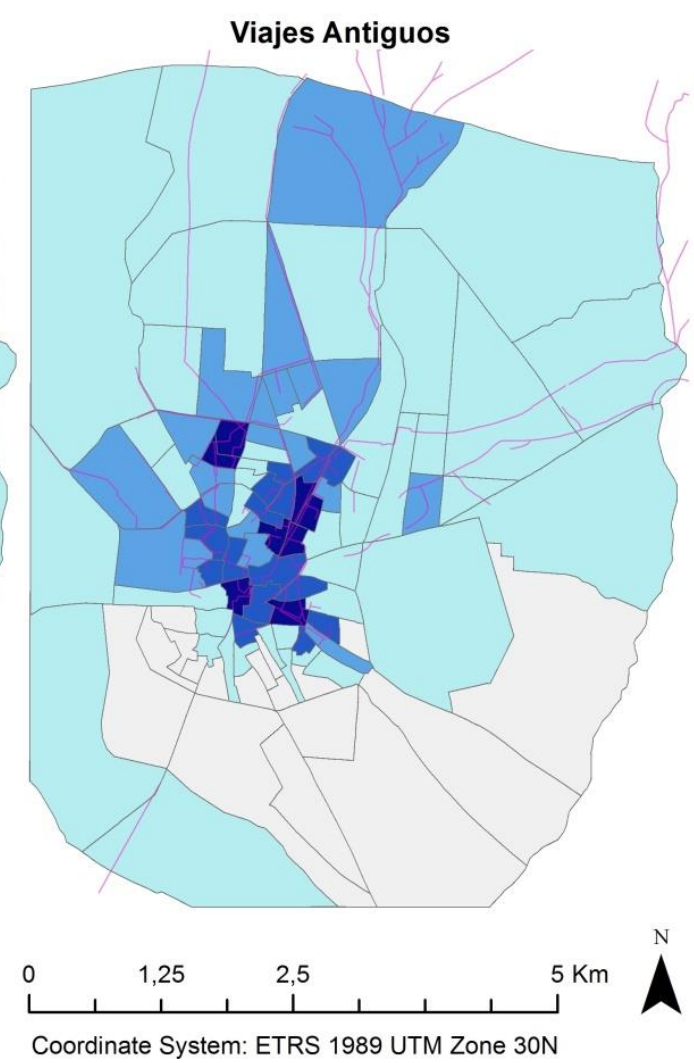

Coordinate System: ETRS 1989 UTM Zone 30N 
Mapa 2-23. Proporción de la red de agua teniendo en cuenta la proporción de calles .Año 1929.

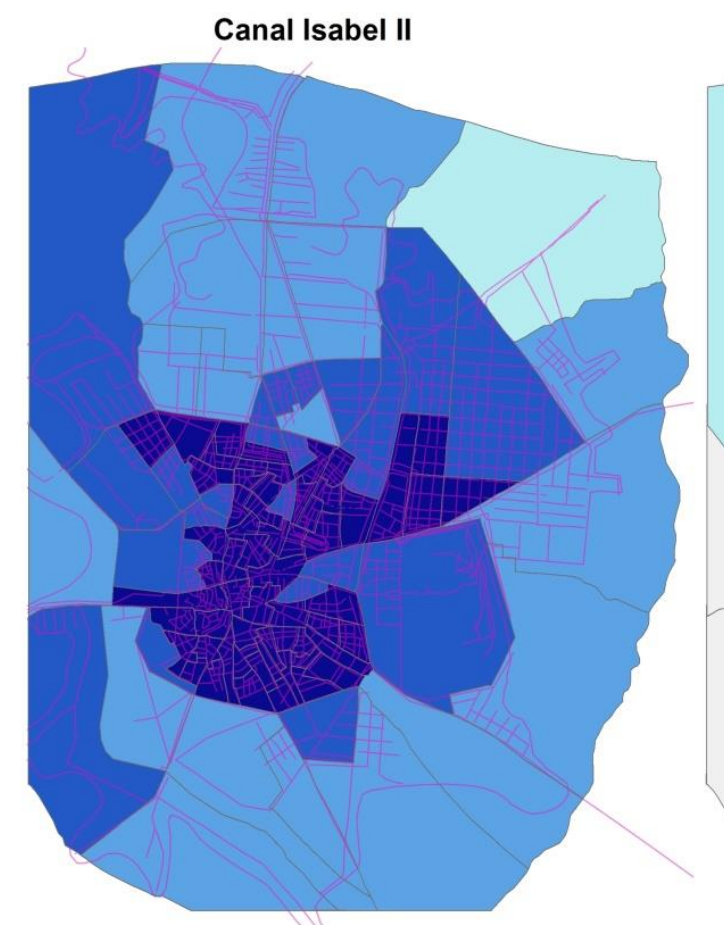

Proportion of water network (\%)

$\longrightarrow<25$

$26-50$

$51-75$

$>75$

No water network

Water network system
Hidráulica Santillana

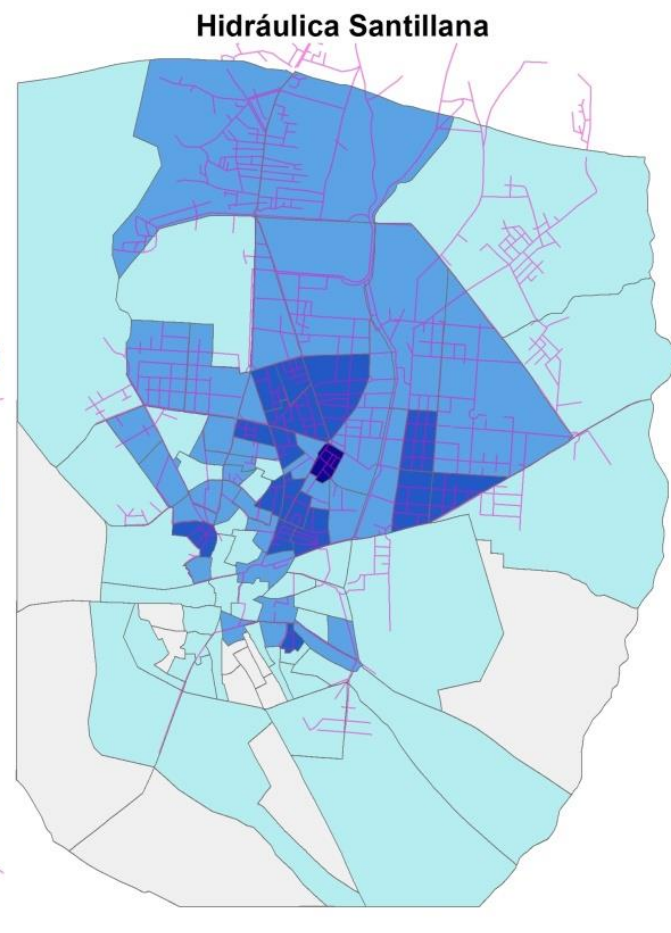

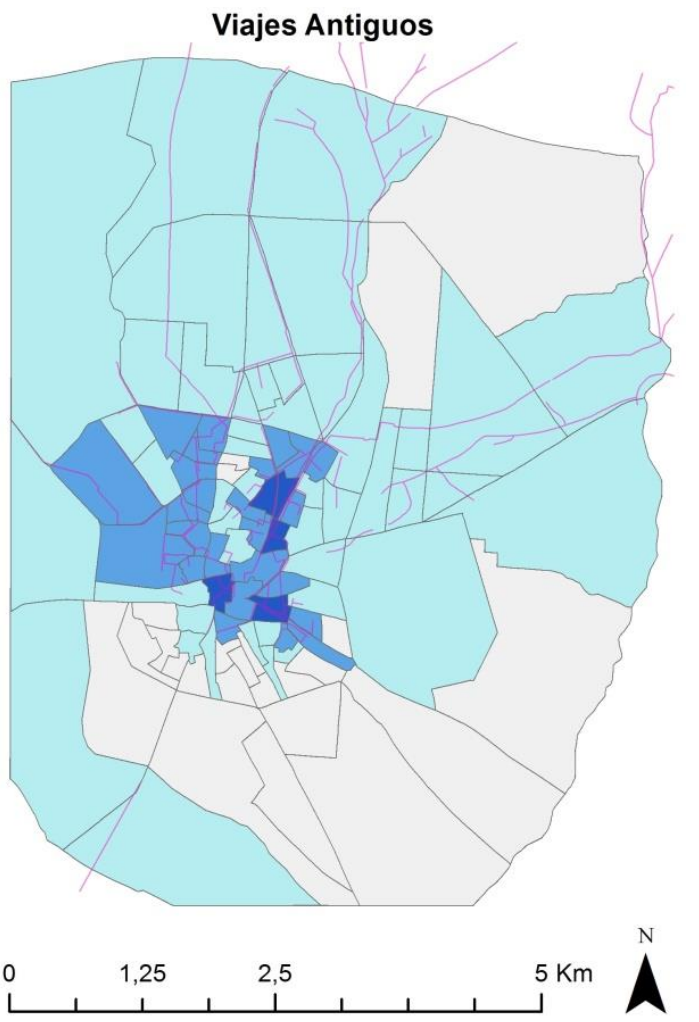

Coordinate System: ETRS 1989 UTM Zone 30N 


\subsubsection{Normalización y codificación de ocupaciones}

Para la normalización y codificación de las ocupaciones registradas en las partidas de defunciones del Registro Civil, se ha tomado como instrumento la clasificación de ocupaciones laborales del Historical International Standard Classification of Occupations (HISCO).

\subsubsection{Historical International Standard Classification of Occupations (HISCO)}

La clasificación de ocupaciones propuesta por el Historical International Standard Classification of Occupations (HISCO) nace en un contexto, a partir de los años setenta del siglo XX, en el que comienzan a desarrollarse los sistemas computacionales, así como el empleo de grandes bases de datos y la necesidad de sistematizar la información masiva en diferentes campos de las Ciencias Sociales. Asimismo, comienzan a desarrollarse modelos de clasificación por parte de organismos nacionales e internacionales con el objetivo de ser capaces de codificar la información laboral, no sólo del mercado laboral actual, sino también la extraída de fuentes de información histórica (Miller, 1980; Treiman, 2013).

En 1997, el grupo de historiadores liderado por M. van Leeuwen, A. Miles e I. Maas, comenzó a trabajar en la creación de un sistema de codificación y clasificación de ocupaciones históricas, basado en números y posiciones. Para ello, se orientaron, principalmente, en los catálogos de la OIT-ILO (Oficina Internacional del Trabajo), con el objetivo principal de solventar la problemática asociada a la dificultad de comparación espacio temporal (Pujadas-Mora, Marín, \& Villar, 2014, p. 183). Su objetivo se basó en ser capaces de crear una codificación y clasificación que pudiera emplearse para análisis de movilidad social y estratificación en contextos históricos diferentes.

Podría decirse que el predecesor de HISCO fue el International Standard Classification of Occupations (ISCO'68), creado por la Oficina Internacional del Trabajo en el año 1968. Hay que tener en consideración que el término "ocupación" no tiene porqué asociarse de manera necesaria a un oficio o profesión, en la medida en que es considerado como "la tarea o conjunto de tareas de un proceso de producción por el 
cual se percibe una remuneración" (Pujadas-Mora et al., 2014, p. 183). La definición de ocupación tampoco hace referencia al estatus, pese a la descripción de la cualificación de las labores. Otro aspecto que hay que destacar es que las ocupaciones laborales se limitan estrictamente a las aparecidas en el propio mercado laboral y, por tanto, todo trabajo no considerado ocupación no forma parte de esta clasificación (tal como pueden ser las labores domésticas). Además, el sistema de clasificación y catalogación de ocupaciones corresponde a un periodo plenamente industrial.

\subsubsection{La clasificación y lectura de HISCO}

HISCO se basa en una clasificación de ocupaciones laborales mediante números y posiciones, con un total de cinco cifras, en la que cada una de ellas tiene un significado. De este modo, se consigue una desagregación de ocupaciones en tres grupos: Major Group, Minor Group y Unit Group.

Comenzando por la lectura de la cifra desde la izquierda, se encuentra el denominado Major Group, que compendia siete grandes grupos bajo los números de 0/1, 2, 3, 4, 5, 6 y 7/8/9 y, en términos generales, atiende al grado de especialización o cualificación de la ocupación en cuestión. Bajo los números 0/1 se encuentran incluidas las ocupaciones con preparación reglada, gestión de negocios privados y agentes de la Administración del Estado. Los siguientes números van correlativos de la especialización no manual a la manual, de modo que los números 7/8 y 9 se insertan aquellas ocupaciones de menor cualificación y especialización; tal como los trabajadores de la producción, peones, jornaleros, entre otros.

El Minor Group atiende a las especializaciones presentes en un grupo de ocupación y el Unit Group distingue los sectores laborales. Los dos últimos dígitos se corresponden con especificaciones concretas de las tareas realizadas en la ocupación en cuestión.

A modo de ejemplo, vamos a ver la clasificación en HISCO de la ocupación laboral de "curtidor de cuero". 
Clasificación HISCO para "curtidor de cuero"

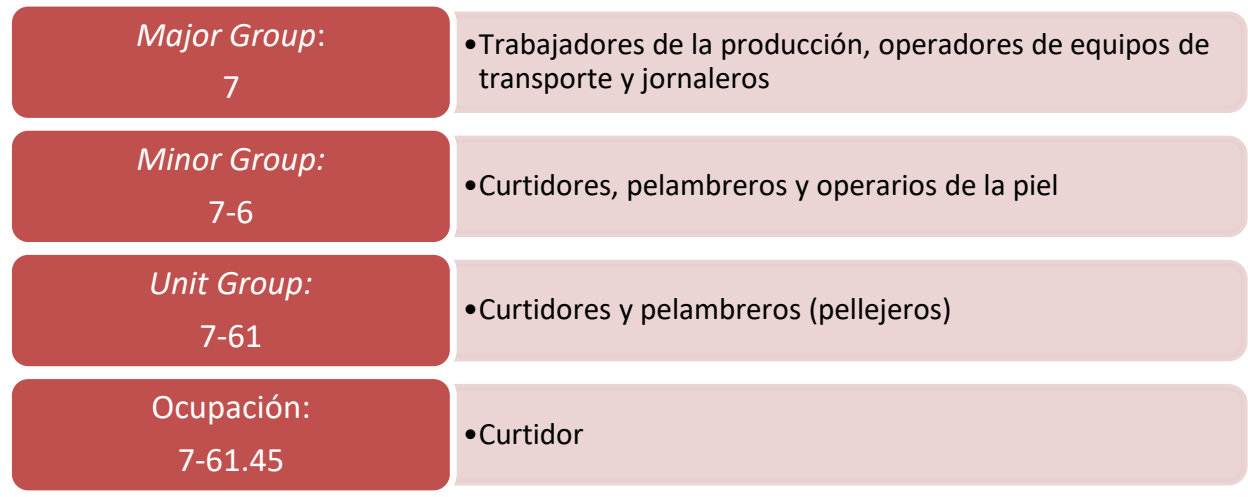

HISCO también incluye una serie de códigos añadidos a los anteriores, en aras a poder abarcar otros elementos importantes a la hora de clasificar las ocupaciones laborales en entornos históricos. Estos se refieren al estatus de la persona ("Status"), los vínculos existentes con el cabeza de familia generalmente ("Relation") o el sector de actividad basado en el empleo de determinadas materias primas ("Product").

Es necesario mencionar que, desde la creación del Historical International Standard Classification of Occupations en 1997, han surgido clasificaciones adicionales asociadas, con el objetivo principal de atender no sólo a la ocupación laboral, sino también a la posición social. Entre éstas clasificaciones cabe destacar SOCPO (Dribe, Helgertz, \& Van de Putte, 2015; Van de Putte \& Miles, 2005), HISCLASS (Van Leeuwen \& Maas, 2005) o HISCAM (Lambert, Zijdeman, Van Leeuwen, Maas, \& Prandy, 2013).

\subsubsection{El proceso de codificación de las ocupaciones de los partes de defunción del Registro Civil}

El proceso de catalogación y clasificación a HISCO resulta una tarea compleja. Comenzando por el vaciado y catalogación de las ocupaciones que aparecen en las fuentes demográficas de orden primario (en nuestro caso, el Registro Civil de defunciones de la ciudad de Madrid), le sigue un proceso de cuantificación de datos, compilación y tratamiento y conversión a códigos HISCO, así como tareas de gestión y control de los datos compilados ${ }^{16}$.

\footnotetext{
${ }^{16}$ Me gustaría agradecer al profesor Richard L. Zijdeman, miembro del International Institute of Social History y de la University of Stirling, quien tuvo la cortesía de compartir sus impresiones conmigo, de manera personal, en su visita al Departamento de Población del CCHS-CSIC, fruto de la conferencia
} 


\subsubsection{1.4. La corrección ortográfica de las ocupaciones}

El paso previo ante cualquier proceso de codificación requiere la limpieza y depuración ortográfica, con el objetivo de sistematizar el paso posterior. En este sentido, se ha procedido a crear una matriz de datos, de manera que se recoja la transcripción de la información ocupacional de manera literal y la normativizada. Asimismo, en este paso previo, se ha incluido en la matriz abreviaturas recurrentes, tales como "sl", que corresponde a la referencia de "sus labores" y la eliminación de acentos y guiones, con el objetivo de facilitar la codificación posterior. Una vez creada la matriz con las ocupaciones normativizadas, se ha creado otra adicional, en la que se ha incluido el código HISCO asociado a la ocupación.

\subsubsection{Recursos adicionales y diccionarios de ocupaciones}

Para la realización de la codificación de las ocupaciones laborales de los partes de defunción del Registro Civil ha sido de gran ayuda recurrir al trabajo desarrollado bajo las directrices de la profesora Enriqueta Camps (Universitat Pompeu Fabra, UPF) y la coordinación de la profesora Cristina Borderias (Universitat de Barcelona, UB) acerca de la catalogación y clasificación de las ocupaciones registradas en Cataluña en los siglos XIX y XX y su posterior clasificación a HISCO. Fruto del trabajo coordinado de especialistas en Demografía Histórica y en Historia Social del Trabajo ${ }^{17}$, dio lugar a un extenso informe sobre las ocupaciones laborales en Cataluña. El tesaurus creado a partir de las clasificaciones de las ocupaciones laborales registradas en diversas fuentes entre los años 1852 y 1936 es de gran utilidad. Posteriormente, como complemento del anterior y bajo el proyecto titulado "La reconstrucción de la actividad económica en la

impartida bajo el título Historical occupational classi cation and stratication schemes: HISCO, HISCAM, HISCLASS, celebrada en marzo de 2017. Dicha conferencia formó parte de la serie Demography Today lecture series, convocadas bajo el convenio de colaboración existente en el momento entre la Fundación BBVA y el Grupo de investigación dirigido por Diego Ramiro Fariñas. Asimismo, debo agradecer la colaboración de mi compañera Belén Castillo Belmonte, pues la realización de estas tareas hubieran sido imposibles sin su ayuda.

${ }^{17}$ Llorenç Ferrer (UB), Pilar López, Montserrat Llonch (Universitat Autònoma de Barcelona), Albert García (UPF), Socorro Sancho (Centre d'Estudis Demogràfics de Catalunya), Enriqueta Camps, Cristina Borderías, Juanjo Romero (UB) y Conchi G. Villar (UB). 
Cataluña Contemporánea" de la Doctora Cristina Borderías de la Universidad de Barcelona, se ha completado y ampliado el anterior ${ }^{18}$.

También se ha requerido de la consulta de otras fuentes de información bibliográfica acerca de la historia del trabajo, así como diccionarios específicos sobre oficios antiguos y definiciones de la Real Academia de la Lengua Española. Mención especial merece el proyecto HISPA_HISCO ${ }^{* 19}$ y su herramienta de búsqueda de ocupaciones laborales, bajo el diseño de modelo online, que ha servido de recurso indiscutiblemente valioso ante la dificultad de asociar de manera manual determinadas ocupaciones.

\subsubsection{1.6. La codificación basada en el contexto}

Las tareas de gestión y control de los datos han estado centrados, especialmente, en atender a calidad del registro del campo edades, con el objetivo de poder asociar las mismas a una ocupación laboral de manera coherente y fiable. En este sentido, se ha procedido a la comprobación de los ítems correspondientes a la edad aparecida en los partes de defunciones del registro civil en conjunción con las ocupaciones laborales.

Para comprobar la codificación correcta de algunas ocupaciones, tales como escolapio, hemos tenido que recurrir al fichero original y mirar las características del individuo en cuestión y, en función de éstas, codificarlo de manera adecuada. Esto sucede en el caso de ocupaciones que pueden corresponder a oficios distintos llamados igual pero que en función del contexto es posible deducir a qué se asocia. En este caso concreto de escolapio, para no llegar a posibles equívocos, hemos nombrado la ocupación como "clérigo escolapio", ya que la denominación escolapio, según la rae, puede referirse a escolapio

2. Estudiante que recibía enseñanza en las Escuelas Pías.

3. m. Clérigo regular de las Escuelas Pías.

4. f. Religiosa de las Escuelas Pías.

\footnotetext{
${ }^{18}$ El informe completo puede consultarse en: https://hicodigos.files.wordpress.com/2012/07/informehisco.pdf

${ }^{19}$ Toda la información relativa a Hispa_Hisco* puede consultarse en : https://hicodigos.wordpress.com/
} 


\subsubsection{Problemas de la aplicación práctica de HISCO}

Algunas problemáticas que nos hemos encontrado, tomando como base la clasificación propuesta para las ocupaciones laborales catalanas y HISCO se han basado en la imprecisión para clasificar algunas categorías profesionales encontradas en los partes de defunciones de la ciudad de Madrid. Asimismo, la falta de especificidad que se recogen en algunas de las ocupaciones que aparecen en los partes de defunción y la información extensamente detallada en otros casos, produce que HISCO no sea aplicable de manera automática a las ocupaciones encontradas en nuestra fuente primaria de información.

Además, hay que tener en cuenta problemas asociados a la codificación de HISCO, especialmente asociadas al Major Group y su catalogación de la cualificación laboral. Un ejemplo de ello es el referente a los comerciantes u otras ocupaciones laborales vinculadas al comercio. Todos ellos aparecen bajo el dígito 4, siendo indiferente si se trata de un gran comerciante o de un tendero o vendedor de la calle.

Si bien hay que tener en cuenta que la codificación a HISCO a partir de las ocupaciones laborales que aparecen en los partes de defunciones no permite realmente un análisis del mercado laboral madrileño, fruto del propio sesgo de la base de datos empleada, pues no se trata de una fuente de información que contenga toda la población, sino exclusivamente las personas fallecidas. La fuente de información demográfica que mejor se adapta al objetivo del estudio y clasificación del mercado laboral histórico, son los datos individuales de los Padrones Municipales de Habitantes.

Sin embargo, la codificación de las ocupaciones laborales de los partes de defunción a HISCO nos permitirá realizar análisis que serán descritos posteriormente, y que nos permitirán tomar como variable explicativa la ocupación de las personas fallecidas. Es pues, una forma de poder operacionalizar el campo relativo a la ocupación.

Teniendo en cuenta lo anterior y, en aras de poder ampliar la perspectiva acerca de la distribución espacial de las ocupaciones profesionales en la ciudad de Madrid, se realizará la codificación al Major Group de HISCO de la información sobre ocupaciones laborales a nivel de barrio que aparece en el resumen del empadronamiento del año 1915 (Ayuntamiento de Madrid, 1917). Si bien, hay que reiterar que el ideal sería basarse en la información primaria obtenida de las hojas individuales del Padrón Municipal de Habitantes de la ciudad, dado que la falta de especificidad aparecida en 
los datos agregados, no nos permite realizar una clasificación más allá de la codificación atendiendo a los códigos de Major Group ${ }^{20}$.

\subsubsection{Normalización y codificación de causas de muerte.}

\subsubsection{2. Las expresiones diagnósticas. Codificación y clasificación de causas de muerte}

Atendiendo a la operacionalización de causas de muerte, tal y como mantienen algunos autores (Bernabeu-Mestre, Ramiro Fariñas, Sanz Gimeno, \& Robles González, 2003; Bernabeu Mestre, 1993), existen dificultades en los análisis de mortalidad en lo que atañe a las expresiones diagnósticas. A ello hay que añadir el gran volumen de diagnósticos de muerte registrados en el periodo de estudio, lo que dificulta cualquier análisis de mortalidad por causas. Se necesitaba recurrir a una clasificación que permitiera un objetivo doble; la clasificación de enfermedades y el análisis por diagnóstico/ causa de mortalidad principal.

Por ello, para el tratamiento de las causas de muerte procedentes del Registro Civil de defunciones, hemos empleado la clasificación proporcionada por Bernabeu et al. (Bernabeu-Mestre et al., 2003; D Ramiro Fariñas, Sanz Gimeno, Bernabeu Mestre, \& Robles González, 2002), quienes elaboraron una propuesta metodológica para abordar los principales problemas que plantea el análisis de la mortalidad a partir de las expresiones diagnósticas que se recogen en las partidas de defunción de los registros parroquiales y civiles ${ }^{21}$. La clasificación propuesta por estos autores, permite la agrupación de las enfermedades, así como analizar diagnósticos o principales causas de muerte partiendo de criterios etiológicos y anatómicos, basándose en la Clasificación de Enfermedades propuesta por McKeown en su obra El crecimiento moderno de la población (McKeown, 1976).

Se ha procedido a una doble clasificación y codificación; primeramente se ha operacionalizado el diagnóstico de causas de muertes siguiendo la Primera Clasificación Internacional de Causas de Muerte de Bertillon y, posteriormente, por la Clasificación diseñada por Bernabeu et al. (2003)

\footnotetext{
${ }^{20}$ Ver capítulo ocho sobre las ocupaciones laborales de Madrid.

21 La agrupación de las diversas causas de muerte propuesta por los autores se basa en la utilización simultánea de la Segunda Nomenclatura de la Primera Clasificación de Causas de Muerte propuesta por Jacques Bertillon en 1899, y una modificación de la clasificación propuesta por Thomas McKeown en su conocida monografía sobre "El crecimiento moderno de la población".
} 
Tabla 2-3. Capítulos Generales de la Nomenclatura Internacional de Enfermedades y Causas de Muerte de J. Bertillon

\begin{tabular}{l}
\hline 1. Enfermedades Generales. \\
\hline 2. Enfermedades del Sistema Nervioso y de los Órganos de los Sentidos. \\
\hline 3. Enfermedades del Aparato Circulatorio. \\
\hline 4. Enfermedades del Aparato Respiratorio. \\
\hline 5. Enfermedades del Aparato Digestivo. \\
\hline 6. Enfermedades del Aparato Genito-urinario y de sus Anexos. \\
\hline 7. Estado Puerperal. \\
\hline 8. Enfermedades de la Piel y del Tejido Celular. \\
\hline 9. Enfermedades de los Órganos de Locomoción. \\
10. Vicios de Conformación. \\
\hline 11. Primera Infancia. \\
\hline 12. Vejez. \\
\hline 13. Afecciones producidas por Causas Exteriores. \\
\hline 14. Enfermedades Mal Definidas. Otras Enfermedades.
\end{tabular}

Fuente: (Bernabeu-Mestre et al., 2003).

La clasificación de causas de muerte de Bertillon tiene algunas limitaciones, al estar basada en un criterio anatómico en detrimento del etiológico, lo que supone una limitación a la hora de determinar la causalidad del fallecimiento (D Ramiro Fariñas et al., 2002).

La clasificación de Bernabeu et al. (2003), permite salvaguardar los problemas de la clasificación de Bertillon. Asimismo, se supera la posible confusión fruto de la agrupación de procesos que pudieran parecer similares pero que, realmente, pudieran tener una etiología diferente o corresponderse a una naturaleza médica, social o de orden cultural diversa (D Ramiro Fariñas et al., 2002).

Como ya se ha mencionado, para la creación de su propuesta metodológica acerca de los diagnósticos y causas de muerte, se apoyan en la clasificación de McKeown (1976). En términos generales, toman de ésta la clasificación en dos grandes grupos de enfermedades así como algunos de los subgrupos en los que McKeown divida éstas. Las dos grandes divisiones son las enfermedades infecciosas y las enfermedades no infecciosas. Dentro de las primeras, McKeown las subdivide atendiendo al modo de transmisión; enfermedades transmitidas por el agua y los alimentos, enfermedades transmitidas por el aire y las enfermedades con transmisión por otras vías. En la clasificación propuesta por Bernabeu et al, es añadido el grupo de enfermedades 
trasmitidas por vectores. Si bien las enfermedades infecciosas eran, en el proceso de transición demográfica, las causantes de la mayor parte de las defunciones sucedidas en el periodo, las enfermedades no infecciosas también fueron intensamente clasificadas. Éstas se subdividían en grupos tales como "enfermedades de patología perinatal", "vicios de conformación”, “enfermedades carenciales", entre otras. 
Tabla 2-4. Clasificación de causas de mortalidad modificada a partir de la propuesta por Thomas McKeown.

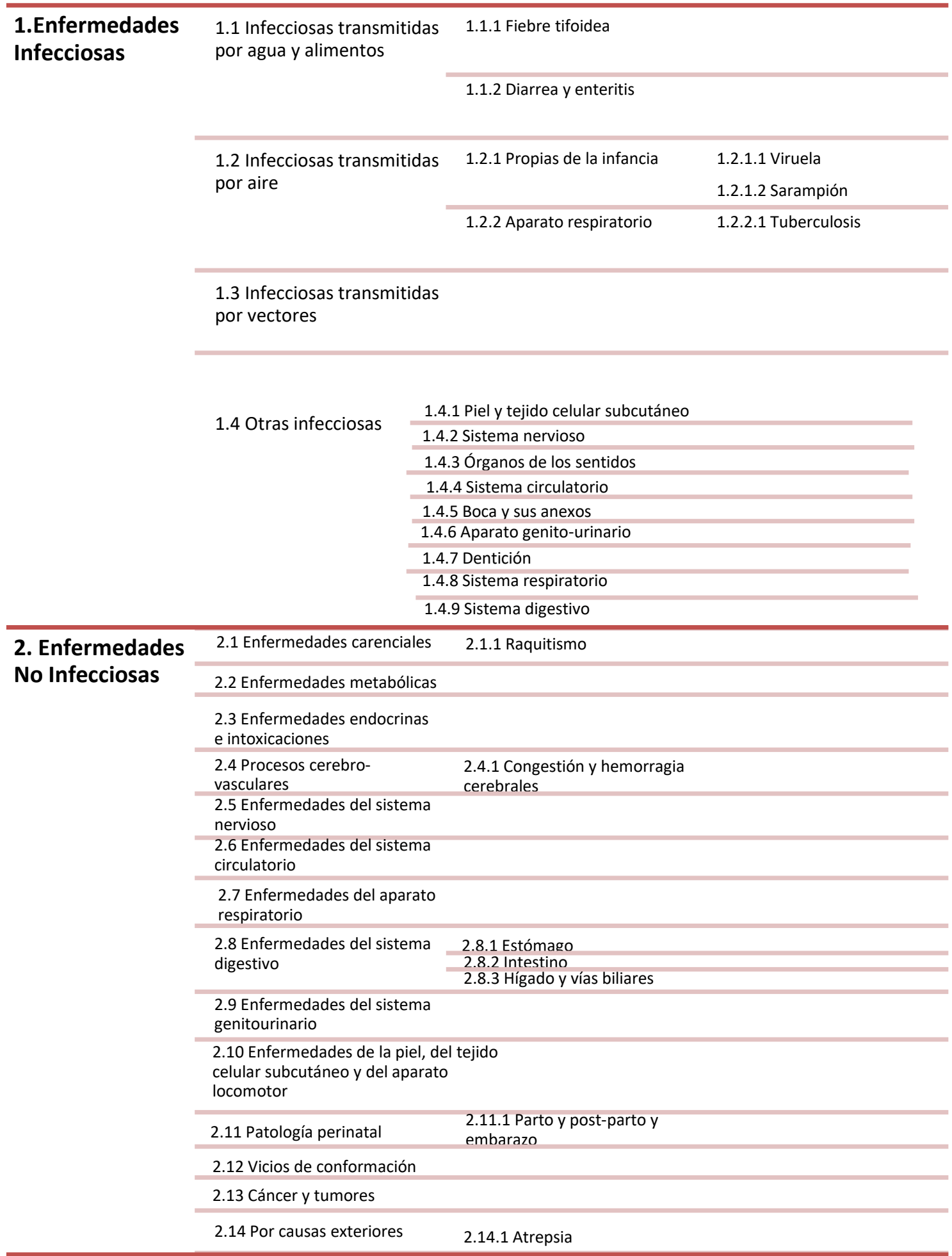

\section{Enfermedades}

Mal Definidas

Fuente: (Bernabeu-Mestre et al., 2003). 


\section{El abastecimiento de agua en Madrid}

\subsection{Introducción}

En este capítulo se ahondará en la evolución de los modelos de organización, gestión y distribución del servicio de abastecimiento de agua entre la segunda mitad del siglo XIX y principios del XX, tomando como caso de estudio la ciudad de Madrid.

Primeramente, se hará alusión al marco legal relativo al abastecimiento de agua en España para, posteriormente, poder enmarcar en el mismo la creación del Canal de Isabel II en una época en la que el auge de la municipalización de los servicios urbanos cobró especial relevancia. Asimismo, se realizará un pequeño bosquejo histórico sobre la situación previa a la modernización del servicio de abastecimiento de agua en la ciudad de Madrid, con alusión explícita al antiguo sistema empleado, los Viajes de Agua, con el objetivo de manifestar que, fruto de la ineficiencia para hacer frente al crecimiento poblacional y de expansión de la ciudad experimentado, se tomaron alternativas a éstos para surtir de agua a la población. Así, la creación del Canal de Isabel II y, posteriormente, la Hidráulica Santillana, serán objeto de atención en el presente capítulo. Especialmente, se atenderá de manera pormenorizada a la evolución histórica del Canal de Isabel II, desde sus reglamentos y su personalidad jurídica a las características económicas, entre otras, como entidad ineludible a la hora de tratar la temática del abastecimiento de agua en la ciudad de Madrid.

Cabe destacar, primeramente, que en Madrid, a diferencia de otras ciudades españolas, el servicio fue explotado por una entidad pública hasta bien entrado el siglo XX. Si bien, la incapacidad técnica y financiera de las administraciones locales para acometer la modernización de los sistemas de suministro de aguas provocó el surgimiento de una empresa privada, la Hidráulica Santillana, y la concesión de parte del servicio de suministro de aguas en la capital. A lo largo del periodo estudiado, tuvieron lugar amplias modificaciones y renovaciones del servicio de aguas, con nuevos modelos de gestión, y cuya traducción se orientó a una modernización (parcial) del sistema, pero que fue de facto insuficiente para satisfacer la demanda de agua de una ciudad como Madrid, que crecía tanto demográfica como territorialmente. 
“(...) La primera, la más urgente necesidad material del pueblo de Madrid es el abastecimiento de aguas, necesidad que todos sus habitantes sienten y deploran.... "(Bravo Murillo, 1851, p. 1)

\subsection{El marco legal.}

Un aspecto a tener en consideración es que la temática relativa al abastecimiento de aguas en las poblaciones puede ser enmarcada en Leyes que recogen amplias esferas de la actuación y responsabilidad gubernamental; desde Leyes de Saneamiento de las ciudades hasta Leyes de Obras Públicas, entre otras. Es por ello, que resulta complejo hacer referencia a todos y cada uno de los asuntos, en materia de aguas potables, que fueron despachados desde la creación del Canal de Isabel II hasta 1930. Por ello, se seleccionarán las disposiciones legislativas que tuvieron mayor relevancia institucional en materia de aguas y, más concretamente, aquellas que regulaban el suministro de aguas para usos públicos, entendido como (...) un derecho exclusivo de las municipalidades, superior a todos los demás usos de las aguas por ser para la salubridad pública (Garrido Lopera, 1973, pp. 124-125).

\subsubsection{Las leyes de aguas}

Atendiendo al marco legal relativo al suministro de agua a las poblaciones en el caso de España, las Leyes de Aguas de 1866 y 1879 constituyeron el nacimiento del marco legal en esta materia. En estas leyes se plasma de manera tácita el carácter general del recurso como "bien público", y, por excepción, de su carácter de "bien privado" (Rueda Laffond, 1998, p. 6).

En estas Leyes de Aguas se reconoce la utilidad pública de las aguas terrestres, así como la necesidad de disponer de autorización para el aprovechamiento de las mismas. No podemos olvidarnos de que el uso de agua no sólo viene de manos de particulares, sino también de empresas. Por ello, estas disposiciones legislativas fueron las primeras en otorgar un orden de preferencia en el aprovechamiento dirigido al abastecimiento de poblaciones, así es como comienzan a delimitarse los plazos de caducidad de 
concesiones, como los derechos y obligaciones de las personas concesionarias, asunto que trataremos más adelante.

Podría decirse que las Leyes de Aguas de 1866 y 1879 plasman de manera perfecta lo que Jordi Maluquer (Maluquer de Motes i Berner, 1983) definió como "despatrimonialización del agua" en referencia a las pautas de propiedad del agua, rompiendo con las existentes en el Antiguo Régimen. Los objetivos de estas normativas estaban enmarcados en un contexto de la desamortización, en el que la movilización de un recurso económico básico bajo una (...) "regulación capaz de ratificar la titularidad pública, los derechos privados y comunes y la personalidad legal de propietarios y concesionarios” (Rueda Laffond, 1994, p. 7).

\subsubsection{La Ley de aguas de 1866}

La Ley de Aguas de 1866 es el culmen legal de una serie de disposiciones legales dictadas anteriormente que tuvieron por objeto la regulación del alcance de la titularidad del Estado, así como la racionalización del aprovechamiento de los abastecimientos de agua. Particularmente, podemos citar la Real Orden de 15 de agosto de 1855 sobre utilidad pública de los abastecimientos de agua y el Real Decreto de 29 de abril de 1860 en el que se establece el orden preferente en los aprovechamientos de las aguas públicas.

Según autores como Retortillo (1960), la relevancia de la Ley General de 1866 radica en su sentido institucional y unificador, no meramente ejecutivo o administrativo, capaz de emplazar una sistematización que no va a verse sino puntualmente ampliada con la de 1879 (Martín-Retortillo Baquer, 1960). Además, en la Ley de Aguas de 1866 se parte de la defensa de la expropiación forzosa en pro de cualquier aprovechamiento de aguas públicas para el suministro de agua a las poblaciones, siendo el abastecimiento a núcleos tanto rurales como urbanos una parte elemental de dicho aprovechamiento.

La ley de Aguas de 1866 regulaba elementos tales como la dotación mínima, los supuestos de expropiación o enajenación y las pautas de la concesión del abastecimiento. La potestad de los dos últimos son responsabilidad del Gobernador o Gobierno, relegando a las corporaciones locales la potestad para formar Reglamentos 
relativos al régimen y distribución de aguas, pero sin dejar éstos de estar condicionados por disposiciones administrativas y la aprobación definitiva del poder Ejecutivo.

\subsubsection{La Ley de aguas de 1879.}

El contenido de la de Ley de Aguas de 1879, realmente, no introdujo modificaciones sustanciales respecto a la Ley de 1866.

Algunos de los aspectos que no sufrieron ningún tipo de modificación respecto a la Ley de 1866 fueron los supuestos de enajenación y expropiación, la dotación mínima de abastecimiento de agua, así como los plazos de concesiones $^{22}$. Respecto al caudal mínimo de abastecimiento, aparece regulado en el artículo 164: "únicamente cuando el caudal normal de agua que disfrute una población no llegase a 50 litros al día por habitante, de ellos 20 potables, podrá concedérsele de la destinada a otros aprovechamientos, y previa la correspondiente indemnización, la cantidad que falte para completar aquella dotación". En cuanto al tema de las concesiones, aparece reflejado el artículo 171: "A los Ayuntamientos corresponde formar los reglamentos para el régimen y distribución de las aguas en el interior de las poblaciones, con sujeción a las disposiciones generales administrativas. La formación de estos reglamentos debe ser siempre anterior al otorgamiento de las concesiones... Una vez. hecha la concesión, sólo podrán alterarse los reglamentos de común acuerdo entre el Ayuntamiento y el concesionario. Cuando no hubiere acuerdo, resolverá el Ministro de Fomento".

Una de las aportaciones más importantes de la Ley de 1879 fue el establecer la obligación, a las entidades concesionarias del servicio, de fijar una tabla de tarifas en el caso en que el caudal de abastecimiento a la población dispusiera de menos de veinte litros por habitante (Carmona Hernández, 1966).

\subsubsection{La progresiva municipalización del servicio de aguas potables}

\footnotetext{
${ }^{22}$ Los requisitos que debían cumplirse para que las concesiones de agua fueran otorgadas, se revisaron más tarde y será objeto de estudio de manera detallada en el presente estudio, ya que estuvo ligado a criterios de evaluación del saneamiento de las viviendas.
} 
El contexto de estudio en el que nos enmarcamos en el presente trabajo estuvo caracterizado por una atribución de nuevos contenidos, organización y atribuciones a los gobiernos municipales, que se dio entre 1823 y $1877^{23}$, con un reforzamiento del centralismo del poder ejecutivo y otorgando al nivel local prácticas en ámbitos tales como las elecciones y decisiones de política municipal, pero que debían proceder de instancias superiores al nivel local (El Gobierno, Gobernadores o las Diputaciones Provinciales).

La necesidad de que las municipalidades controlasen las condiciones de salubridad de sus territorios conllevó a que el carácter de servicio público municipal se viera reflejado en las disposiciones legislativas, tal como aparece en la Ley de Obras Públicas de 13 de abril de 1877, y se mantendrá hasta mediados de Siglo XX.

La confluencia entre intereses públicos y privados en el servicio público de agua potable ha sido una dinámica continua en el caso español. Las empresas de carácter privado fueron las gestoras del servicio en el siglo XIX y los primeros años del siglo XX, comenzando un cambio de tendencia hacia la municipalización a partir del Estatuto de $1924^{24}$.

La Ley Municipal de 1877 estableció, de manera obligatoria, la existencia de servicios de abastecimiento de aguas, pero considerando al Ayuntamiento como mero ejecutor de las decisiones del poder central. El carácter económico administrativo de los Ayuntamientos se reflejó en el artículo 71 de la Ley y la competencia exclusiva en el mantenimiento de servicios urbanos en el artículo 72, donde se recogieron aspectos importantes considerando el objeto de la presente tesis, ya que se otorgaba competencia exclusiva al ayuntamiento en lo que tuviera que ver con el arreglo y ornato de la vía pública e higiene del municipio o de los habitantes del mismo. Así, los consistorios municipales sólo tenían la potestad para firmar Ordenanzas Municipales, estando subrogados a lo que dispusiera el Gobierno y los gobernadores civiles, respecto a la explotación o gestión de tales servicios (Rueda Laffond, 1994, p. 11).

A las anteriores legislaciones hay que sumar otras disposiciones generales que trataban el tema del abastecimiento de aguas; tales como las leyes de obras públicas y obras

\footnotetext{
${ }^{23}$ Especial mención merece el Decreto sobre Competencia Municipal de 20- III-1873, puesto que pone de manifiesto los preceptos de la Revolución Liberal y el papel de los municipios españoles.

${ }^{24}$ Será a partir del año 1939 cuando el proceso de municipalización del servicio de aguas llegue a su culmen.
} 
hidráulicas $^{25}$ o los decretos sobre salubridad de aguas potables ${ }^{26}$ (dentro de la corriente higienista de la época).

\subsubsection{El Estatuto Municipal de 1924 y el Reglamento de Obras, Servicios y Bienes Municipales}

La serie de normas enfocadas en el abastecimiento urbano de aguas y el papel de los municipios, como gestores del servicio, tuvieron su punto culmen con la aprobación del Estatuto Municipal de 1924, y con reajuste consiguiente de la orientación de la política municipal. Con las nuevas reglamentaciones el papel de los Municipios y sus competencias en materia de servicios urbanos se vio extensamente ampliado.

Así, el papel de los municipios y la potestad de los mismos en materia de distribución de agua de consumo, se vio modificado por el Reglamento de Obras, Servicios y Bienes Municipales, de julio de 1924, surgido al amparo del Estatuto Municipal.

En sus artículos 77 y 79 se introdujo que serían las corporaciones locales quienes resolverían las peticiones de concesión, y la prohibición de que concediese el monopolio del agua a una entidad particular. Las solicitudes de concesión debían aludir también a las tablas de tarifas y presión del líquido para el servicio público y privado (Rueda Laffond, 1994, p. 12). Además, como efecto de la autonomía municipal y de su autoridad sobre el interior de la ciudad, se obligaba a señalar de manera explícita, para

\footnotetext{
${ }^{25}$ Una manifestación de las principales disposiciones de obras públicas e hidráulicas fueron la Ley de Obras Públicas de 13 de abril de 1877 y la Ley de obras Hidráulicas de 7 de julio de 1911. Además, no podemos pasar por alto los Reales Decretos de 27 de marzo de 1914 y el del 9 de junio de 1925, ya que regularon que el Estado salvaguardaría " a los pueblos necesitados de abastecimiento de agua potable", mediante la dotación de subvenciones para la realización de obras de captación, conducción y toma de agua. La dotación media de agua se estableció en ambos reales decretos en 50 litros por habitante y día.

${ }_{26}$ Tales como el Real Decreto sobre sanidad de las aguas de 16 de noviembre de 1900; la Real Orden sobre sanidad de las aguas de ríos y arroyos de 19 de octubre de 1910; el Real Decreto de 25 de noviembre de 1910 sobre sanidad de las aguas y el Reglamento del Servicio de Inspección de Sanidad del campo; Real Orden sobre sanidad de las aguas en Comarcas Rurales de 14 de julio de 1911; las Reales Ordenes sobre sanidad de las aguas de 28 de julio de 1911 y 4 de agosto de 1911; la Orden sobre normativas sanitarias del 5 de marzo de 1912; la Real Decreto que aprueba el Reglamento organizando los servicios de Sanidad del campo de 18 de octubre de 1913; Real Orden sobre análisis de las aguas destinadas al abastecimiento de poblaciones de 30 de mayo de 1914; Reglamento reculando la vigilancia y custodia sanitaria de las aguas de 11 de septiembre de 1919; y la Real Orden sobre normas técnico sanitarias para pequeños municipios.
} 
cualquier proyecto de urbanización, las redes de distribución ${ }^{27}$ y de establecer el enlace entre las redes en caso de que existieran canalizaciones de empresas independientes.

Otro aspecto relevante del Estatuto Municipal de 1924 y del Reglamento de Obras, Servicios y Bienes Municipales fue la imposición de abastecimiento de un caudal mínimo de 200 litros por persona y día para los municipios con una población superior a quince mil habitantes. También el papel del Municipio como garante de la calidad química y bacteriológica de las aguas comienza a ser una obligación para estos entes administrativos, en aras de mejorar la higiene pública y reducir la mortalidad y enfermedades transmitidas a través del agua.

Sin embargo, para algunos, estas herramientas jurídicas empleadas por el Estado Liberal fueron soluciones circunstanciales y provisionales (Cosculluela Montaner \& Orduña Rebollo, 1983; Gallego Anabitarte, Menéndez Rexach, \& Díaz Lema, 1986; Matés Barco, 2017). "La competencia sobre el agua era una competencia fundamentalmente de policía: cuidar la observancia de las disposiciones sobre obras públicas y distribución de riegos o establecimiento de molinos, cuando es un hecho que en muchas de estas materias no existía ninguna disposición sino una solemne declaración de libertad, o un confuso derecho común dominado por el sistema ribereño de las Partidas, y solamente en determinadas zonas de España, fundamentalmente Levante, se podía encontrar un articulado sistema de usos y ordenanzas de aprovechamientos comunes de aguas” (Matés Barco, 2017, p. 48).

\subsubsection{El Canal de Isabel II como ejemplo de Empresa Pública.}

Es necesario esbozar, de manera muy sucinta y genérica, el papel del Estado a mediados del siglo XIX, para poder comprender el contexto en el que se creó el Canal de Isabel II como empresa pública. "La imagen del Estado como agente económico es coetánea al proceso de articulación de las entidades nacionales. No es casual que la formulación histórica de los estados europeos coincida con un reforzamiento de la intervención sobre los mecanismos que rigen la circulación monetaria o con un decidido impulso

\footnotetext{
${ }^{27}$ Estatuto Municipal de 8 de marzo de 1924, extensamente anotado, comentado y concordado con los Reglamentos complementarios y con el Estatuto Provincial por la redacción de " El consultor de los Ayuntamientos y de los Juzgados Municopales”, Madrid (3ª ed.), 1927, pp.669-670
} 
oficial respecto a las actividades manufactureras y comerciales" (Rueda Laffond, 1994, p. 20). La política económica y el papel del Estado como agente económico regulador, como garante de determinados derechos, así como de proveedor de bienes y servicios frente a condiciones "no naturales” de la oferta (Aceña \& Comín, 1992).

Es en este contexto en el que se debe enmarcar la creación del Canal como empresa pública, dentro del intervencionismo y participación estatal creciente $^{28}$, fruto del proceso de modernización de los servicios urbanos que tuvo lugar a partir del mediados del siglo XIX. No sólo se trató del abastecimiento del agua, sino de la transformación en el fomento y gestión de los servicios desde la esfera municipal; transportes, alumbrado público, construcción de necrópolis, instituciones de salud, entre otros.

Si bien, en el caso del Canal de Isabel II, constituye, en cierta medida, un caso anómalo en lo referente a la gestión, explotación y propiedad, si se compara con la de otros servicios públicos. Tal y como veremos en líneas posteriores, el Canal de Isabel II sufrió a lo largo de los años una suerte de diferentes modos de organización (como el arrendamiento o iniciativas privadas). Sin embargo, la dependencia respecto a la financiación pública fue palpable, pese a disponer de autonomía desde 1851 a 1867 y a partir del año 1907, con su nuevo Reglamento. "Entre 1867 y 1907 esta vinculación resultó orgánica, en tanto que se mantuvo como sección administrativa dentro del Presupuesto de Fomento. En las etapas en las que se estableció el régimen de Comisaría Regia y Consejo de Administración, todas las necesidades financieras referidas a la ampliación de su infraestructura debían cubrirse en forma de empréstito con el respaldo y aprobación del Estado, constituyendo, en definitiva, endeudamientos del propio Ministerio de Fomento" (Rueda Laffond, 1994, p. 26).

\subsection{Los Viajes de Agua}

\subsubsection{Los viajes de agua en Madrid hasta mediados del siglo XIX.}

Para poder comprender, en buena medida, las deficiencias existentes en lo que se refiere a las infraestructuras y abastecimiento de agua en la ciudad de Madrid (tanto su alcance como su calidad), es necesario que nos remontemos al siglo XVII. Esto es así debido a

\footnotetext{
${ }^{28}$ Para atender de manera más específica a la gestación del sector público empresarial en el contexto español, consultar (Comín \& Díaz, 2005).
} 
que el sistema de conducción y abastecimiento de agua, que se mantuvo hasta el siglo XX, data de esa época. Son los denominados viajes de agua ${ }^{29}$. Se trataba de conducciones subterráneas, formadas por minas y cañerías, usadas para transportar, mediante gravedad, el agua de capas freáticas alejadas de la villa, a distintos lugares de la misma.

En la Memoria de la ciudad de 1929 aparece la siguiente definición para referirse a los viajes de agua, viajes antiguos o antiguos viajes: "Los llamado antiguos viajes eran minas hechas sobre una capa de arcilla en la que se recogían las aguas meteóricas, que llegan a ella pro filtración de las capas arenosas que tiene el terreno con bastante uniformidad" (Ciudad, 1929, p. 109).

Los viajes de agua constituyeron el sistema de abastecimiento de la ciudad de Madrid que existía con anterioridad al Canal de Isabel II. Bien es cierto que los viajes siguieron siendo fuente de abastecimiento con posterioridad a la construcción del Canal de Isabel II, pero su importancia iría cayendo al tiempo que el protagonismo del Canal de Isabel II aumentaba.

La red de abastecimiento de agua de los viajes antiguos era propiedad del Ayuntamiento. A través de éstos, se había abastecido de agua a la ciudad de Madrid tradicionalmente. Estas aguas provenían de filtraciones de agua de lluvia, almacenadas, en parte en pozos y norias, tratándose de galerías excavadas en la zona alta de Madrid, en los términos de Fuencarral y Chamartín de la Rosa.

\subsubsection{Descripción de los viajes de agua}

El primer viaje de agua que se construyó en la villa de Madrid en el siglo XVII fue el Viaje del Buen Suceso (entre los años 1612-1618), cuya función fue surtir una fuente ubicada en la Puerta del Sol. Si bien, los principales viajes fueron otros cuatro; el Viaje de Amaniel (1610-1621), que era de la Corona, y los tres de la villa; el Viaje de la Fuente Castellana (1613-1620), el Viaje del Abroñigal Alto y el Viaje del Abroñigal Bajo (1617-1630). En los siguientes años tuvo lugar la construcción de los viajes de

\footnotetext{
${ }^{29}$ Para un análisis pormenorizado de los Viajes de agua, consultar Hausser (Hauser, 1902a, pp. 219-226), así como el libro titulado Los viajes de agua de Madrid durante el Antiguo Régimen (V. d. Pinto Crespo, Labrador Arroyo, \& Gili Ruiz, 2010).
} 
Contreras (1637-1645) y Alcubilla (1688-1692). Además, teniendo como necesidad el abastecimiento del Real Sitio del Buen Retiro se construyeron los viajes Alto (16321636) y Bajo (1636-1640) del Buen Retiro (Hauser, 1902b; V. d. Pinto Crespo et al., 2010).

A modo ilustrativo, se adjunta una imagen del mapa de distribución de los viajes de agua en Madrid en el año 1750 (Mapa 3-1). 


\section{Mapa 3-1. Los Viajes de Agua en Madrid, año 1750}

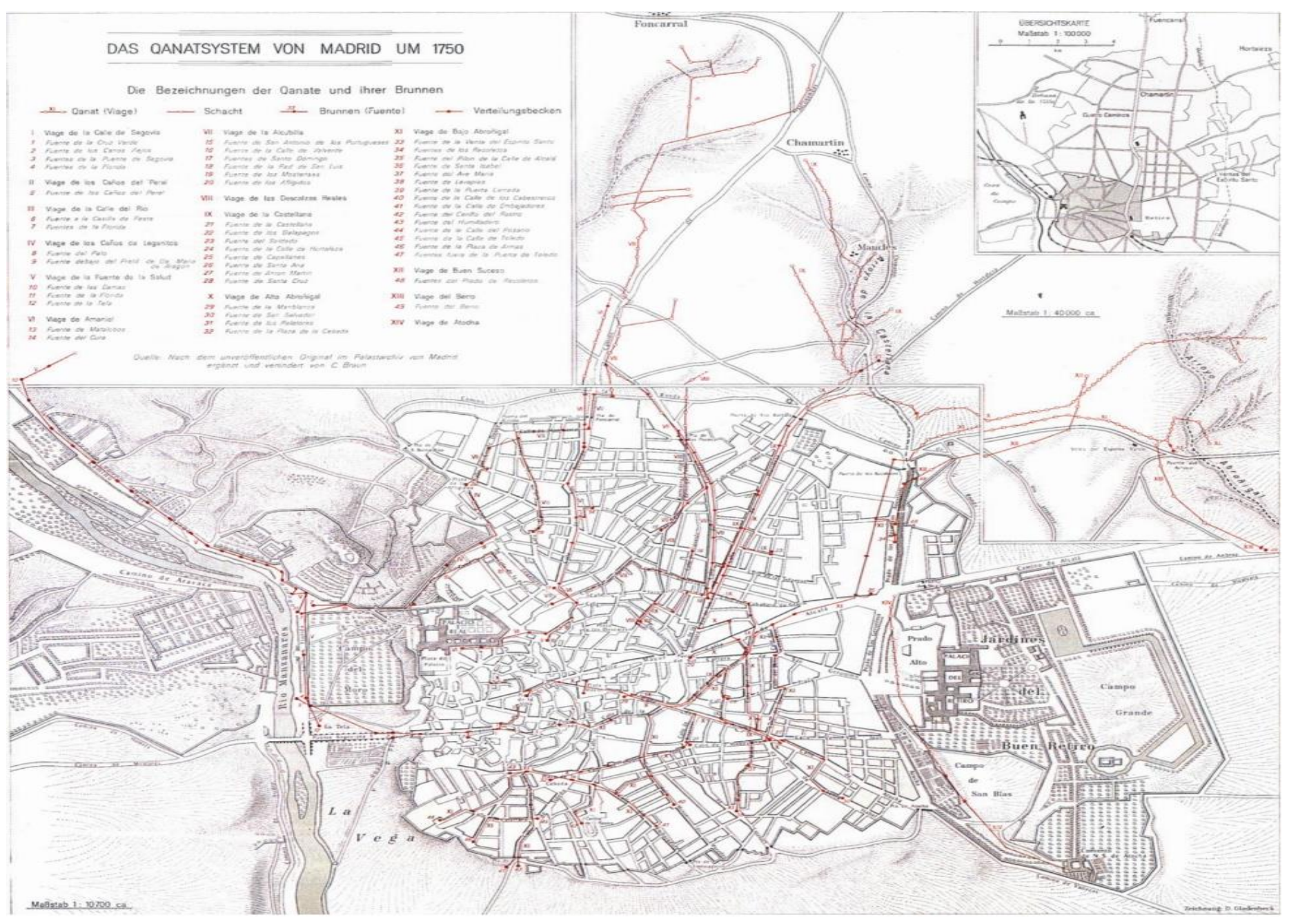

Fuente: Portal Web del Ayuntamiento de Madrid. 
Hasta que no se produjo la modernización del servicio de abastecimiento de aguas, que comenzó entre los años 1851 (con la creación del Canal de Isabel II) y 1858 (con la llegada real de la traída de aguas a Madrid), el suministro se regulaba a través del servicio particular por medio de los aguadores. Respecto a la repartición del agua de los Viajes Antiguos, a mediados del siglo XVIII, con la excepción del viaje de agua del Abroñigal Bajo, en el que se repartía el agua por mitades entre usos públicos y privados, en los otros grandes viajes los usos privados acaparaban en torno al 70 por cien del agua y más del 90 por cien de la población se tenía abastecer básicamente de las 34 fuentes públicas de los cinco principales viajes de agua. Las pautas en cuanto al consumo de agua y el modo de acceso a un bien tan necesario son, sin duda, el fiel reflejo de una sociedad estamental, jerarquizada y profundamente desigual.

De este modo, la forma en que el vecindario se surtía de agua hasta mediados del siglo XIX, en su gran mayoría, era mediante el trabajo de los aguadores, oficio que, a mediados del siglo XIX, desempeñaban aproximadamente 1000 personas en la capital, abastecidos de las 77 fuentes públicas existentes dentro del perímetro urbano. Respecto a la cantidad de agua transportada por los aguadores, tampoco se han encontrado cifras exactas. En la memoria del Canal de Isabel II de 1907, se señala que los aguadores transportaban cerca de 36.000 cubas, con capacidad aproximada de 360 reales fontaneros, equivalente a 1.168 metros cúbicos de agua (Canal de Isabel II, 1907). Sin embargo, otros autores mantienen que la dotación de agua estimada para aquellos años sería de 2000 a 2500 metros cúbicos diarios para una población de 235.000 personas (Rueda Laffond, 1994, p. 27). 


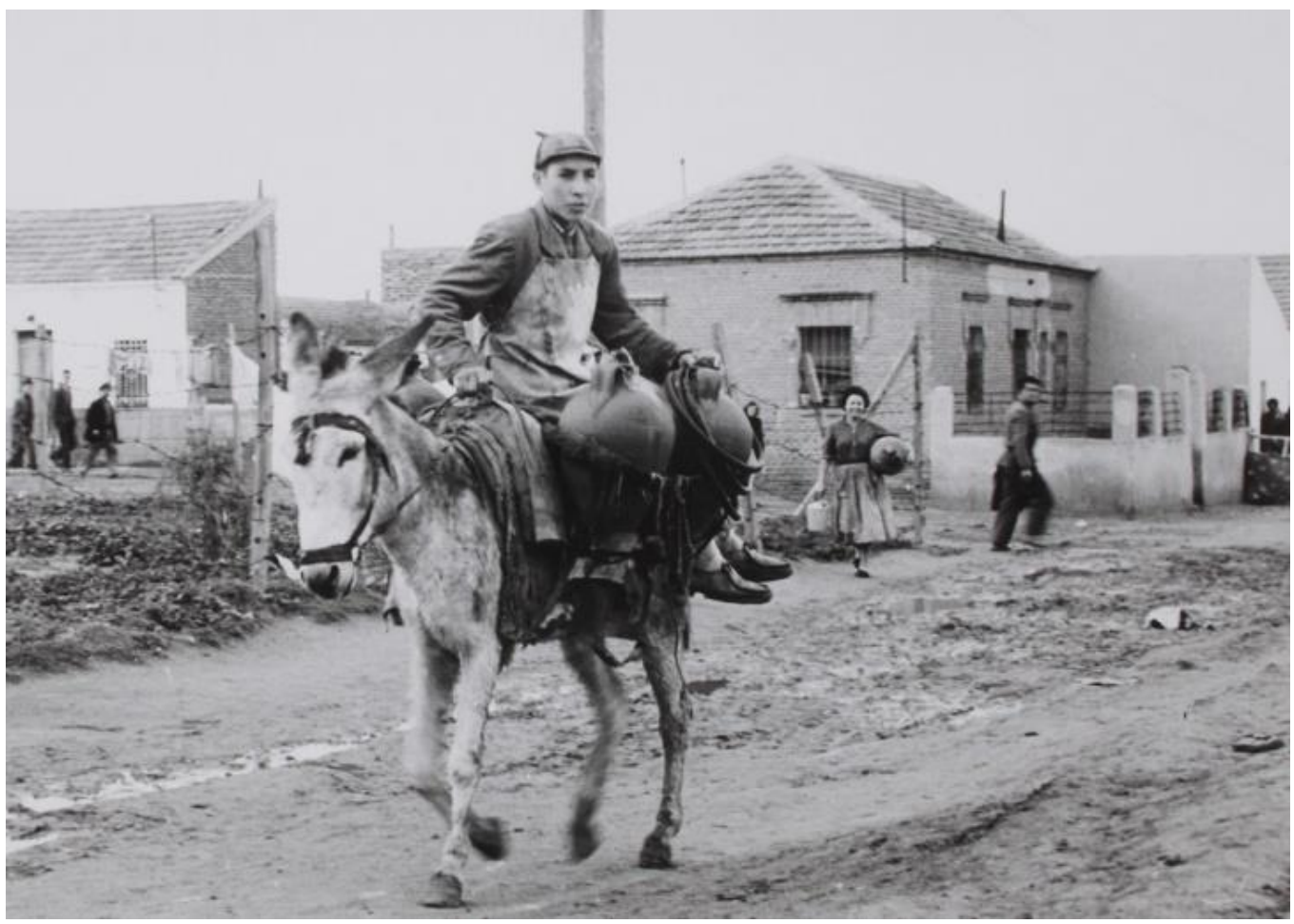

Fuente: Museo de Historia de Madrid.

En cuanto al oficio de los aguadores en la capital, estaba dominado por personas de origen gallego. Dado el esfuerzo que debían desempeñar, algunos calificaban este trabajo como penoso, teniendo en consideración el jornal percibido por el mismo, que no ascendía de 2,75 pesetas al día. Las plazas de aguador se consideraban como oficio público, poseído por juro de heredad, cuyo valor en venta alcanzaba a mediados del siglo XIX 1.500 pesetas. Esta cantidad que, a priori, puede parecer excesiva, no lo era tanto teniendo en consideración que en las épocas de estiaje los aguadores cobraban una peseta por cuba las personas que no figuraban en la lista de habituales. Cada cuba tenía una capacidad de 32'45 litros, por lo que el coste de cada metro cúbico de agua que era transportada desde la fuente pública al domicilio del comprador, alcanzaba cifra de 30'81 pesetas (Melgosa Olaechea, 1912, p. 94).

El Servicio de fuentes públicas ${ }^{30}$, aparecía regulado en las Ordenanzas Municipales, concretamente en los capítulos XII y XIII. Entre los artículos que regulaban el servicio

\footnotetext{
${ }^{30}$ No se atenderá a las fuentes ornamentales o monumentales que servían para embellecimiento de la ciudad, sino a aquellas destinadas al surtimiento de agua destinada al consumo. Para un estudio detallado de las fuentes de ornato de la ciudad, consultar Rincón Lazcano, J. (2001). Historia de los monumentos de la Villa de Madrid: Asociación de Libreros de Lance de Madrid. (Rincón Lazcano, 2001)
} 
de fuentes públicas, aguadores y abrevaderos, cabe destacar el artículo 41, en el que se señala la división de los tipos de fuentes existentes en la Villa de Madrid; las fuentes vecinales, las fuentes de vecindad, fuentes de aguadores, las fuentes volantes, fuentes monumentales y de adorno. En el artículo 42 se regula para quién estaban destinadas cada clase de fuente descrita en el artículo anterior. Los siguientes artículos versan sobre el número de licencias de aguadores, la dotación de caños y aforos, la preferencia del uso de los vecinos de las fuentes ante el uso de los aguadores, entre otros asuntos.

También existían algunas fuentes ubicadas en casas de particulares y pozos antiguos que permanecían inutilizados. Estas fuentes particulares, solían ser propiedad de la nobleza. De entre ellas, cabe destacar la denominada Fuente del Berro, ubicada en la Huerta del Berro desde tiempos de Felipe IV, que, si bien era propiedad del Real Patrimonio, se empleaba el agua principal del manantial para el uso de la casa cerrada allí situada, pero el agua sobrante se destinaba para uso público.

\subsubsection{La insuficiencia del servicio. La necesidad de mejora del abastecimiento de agua de los viajes antiguos}

En enero de 1855, nombrado Alcalde de Madrid Don Valentín Ferraz, se dispusieron varias máquinas elevadoras en el viaje de La Fuente de la Reina. Además, dotadas de las aguas de este viaje se colocaron distintas fuentes teniendo emplazamientos en las de las plazas de la Encarnación, Sacramento, Celenque, San Marcial y Capuchinas. El consumo medio de agua en 1855 era de 2.000 metros cúbicos cada veinticuatro horas (Melgosa Olaechea, 1912, p. 94).

Atendiendo a la información mostrada por Hauser (1902a), ya en el año 1828 el caudal proveniente de los Viajes de agua más importantes sufría una tendencia a la disminución (Gráficos 3-1 y 3-2). Las medidas de los aforos de las aguas mostraban un decrecimiento, lo que dio origen al planteamiento de diferentes proyectos cuya finalizad fue la traída de aguas a la ciudad de Madrid. 
Gráfico 3-1. Medidas de agua de los cuatro principales Viajes, en reales fontaneros. Años 1699-1828 ${ }^{31}$

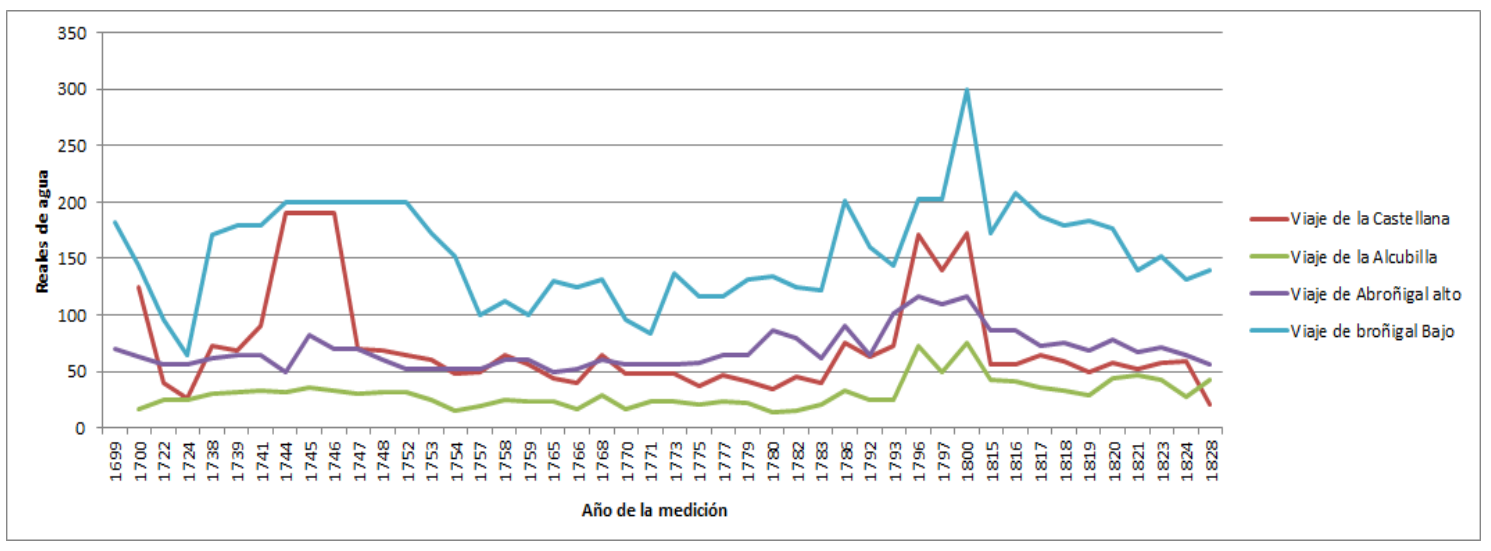

Fuente: Elaboración propia. Datos obtenidos de (Hauser, 1902a, p. 221)

Gráfico 3-2. Reales Fontaneros de agua de los cuatro viajes de agua principales en reales fontaneros. Años 16991828

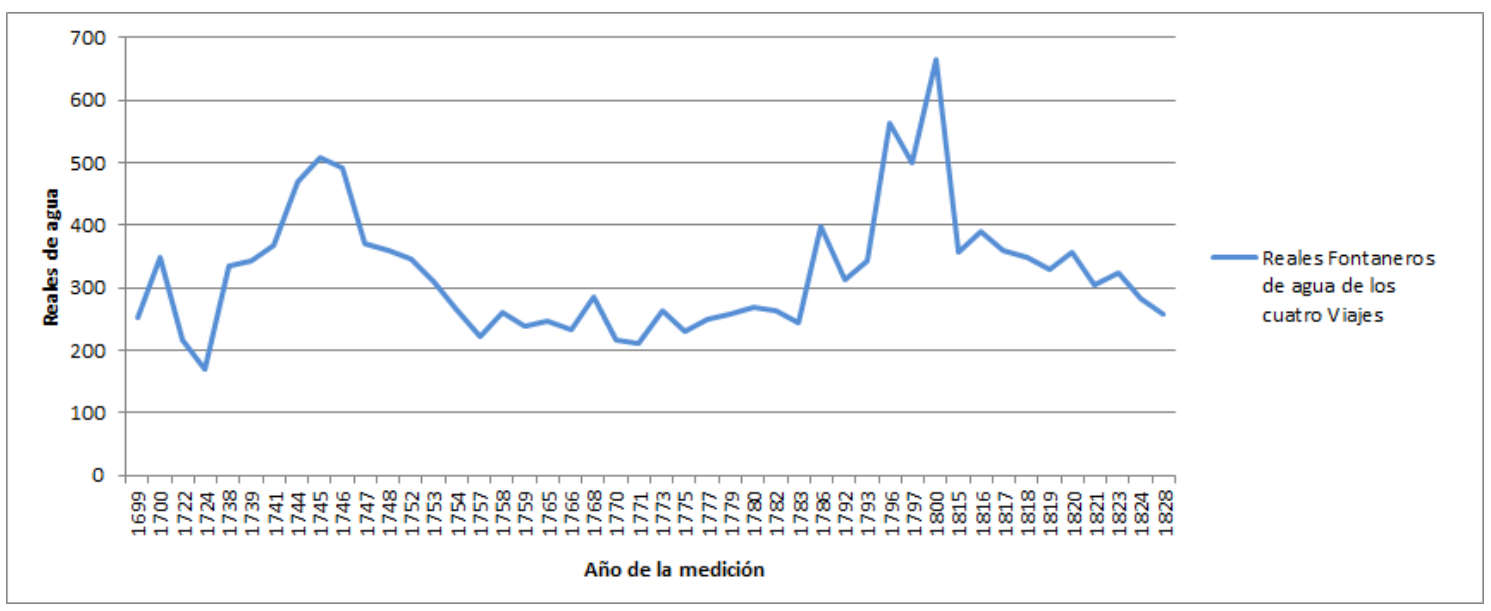

Fuente: Elaboración propia. Datos obtenidos de (Hauser, 1902a, p. 221)

En años posteriores a 1828, no se ha conseguido encontrar información homogénea en torno a la cantidad de agua que era transportada por los viajes antiguos

En el estudio sobre Las subsistencias en Madrid (1912) se registra que en 1848, las fuentes públicas tenían capacidad para suministrar tan solo 1.100 metros cúbicos cada veinticuatro horas. Otros autores estiman una cantidad superior, manteniendo que a mediados del siglo XIX se transportaban en la ciudad de unos 2.000 a (5000?)25000 metros cúbicos diarios de agua, lo que suponía un consumo aproximado de entre cinco a

\footnotetext{
${ }^{31}$ Un Real de Fontanero equivalía a 3,245 metros cúbicos de agua
} 
diez litros por habitante y día (Rueda Laffond, 1994, p. 34). Según Hausser, a comienzos del siglo $\mathrm{XX}$, la cantidad estimada de litros diarios que recibían los vecinos de la ciudad de Madrid eran 2.990.562 (Hauser, 1902a, p. 222).

En cualquier caso, las cantidades de agua que recibían los vecinos de Madrid eran claramente insuficiente para hacer frente a la demanda, dado que el crecimiento poblacional experimentado en la capital, debido, en parte, a familias que emigraron a Madrid fruto de la conflictividad política y social existente (Melgosa Olaechea, 1912, p. 94).

Y fue este el motivo principal por el que surgieron Proyectos que tuvieron por objetivo la traída de agua a la ciudad de Madrid.

\subsubsection{Proyectos anteriores al Canal de Isabel II y los viajes de agua}

La reunión celebrada en el Municipio de Madrid el día 10 de Febrero de 1818, puede ser considerada como la primera en que se plantearon las pretensiones de elaboración de un proyecto para la traída a Madrid de aguas procedentes del Río Jarama o del Guadalix.

Posteriormente, el día 11 de Enero de 1828, Don Antonio Galindo, primer Teniente de Corregidor, ejerciendo de Corregidor por fallecimiento del que lo era, manifestó su preocupación acerca de la escasez de agua en la ciudad. Reunido con otros representantes del Ayuntamiento, ante el temor de que la escasez pudiera ir en aumento, realizó una petición para realizar una visita de reconocimiento y medida a todos los viajes de agua en sus arcas principales, con el objeto de saber la cantidad exacta que contienen y así poder tomar las medidas oportunas (Melgosa Olaechea, 1912, p. 92). Dos días después de la citada petición, el Consejo del Ayuntamiento de 14 de febrero de 1828, presentó un Informe con el resultado de la medición de la disponibilidad de agua procedente de los cuatro Viajes de agua y un Ramal secundario, indicando que El Viaje del Abroñigal Bajo disponía de 140 reales fontaneros, el del Abroñigal Alto de 56, El Viaje de la Castellana de 42, el Viaje de la Alcubilla de 15 y, por último, el Ramal de Afligidos de tan sólo seis.

La consecuencia inmediata de los datos del Informe se tradujo en la inversión del Ayuntamiento para la realización de algunas obras para mejorar los Viajes de Agua. Se pretendía "excitar el celo de los Arquitectos municipales a fin de que estudiaran la 
manera de traer a Madrid mayor cantidad de aquel líquido, aunque fuera a costa de los mayores sacrificios, antes de que llegasen los meses de verano y con ellos el conflicto que se temía (Melgosa Olaechea, 1912, p. 93).

En 1844, los viajes de agua abastecían a Madrid de 1.251.200 litros cada día, cantidad que cada vez se plasmaba más insuficiente para una población en crecimiento. Así, era indispensable que la ciudad comenzara a dotarse de aguas potables procedentes de origen distinto al de los Viajes de Agua.

Si bien, hasta la llegada del Canal, hubo algunos intentos fallidos que tuvieron por objetivo la traída de aguas; tales como los de Don Jorge Sicré, Don Juan Villanueva, Don Mariano Vallejo, Don Francisco J Barra o el de Don Pedro Cortijo.

El Proyecto de los ingenieros Jorge Sicré y Manuel Navacerrada se planteó como medio “(...) para construir un canal desde el Jarama y el Lozoya, con el objetivo de aumentar el suministro y la calidad del recurso frente a los brotes e fiebres tifoideas y de canalizar nuevas dotaciones para su uso agrícola” (Rueda Laffond, 1994, p. 36).

Respecto al proyecto de Francisco Javier Barra, titulado Proyecto y Memoria sobre Conducción de aguas a Madrid, de 1834 (Barra, 1834), pretendía, grosso modo, construir un canal que consiguiera suministrar agua a los particulares y abastecer a las fuentes públicas, así como disponer el mismo para la navegación o el riego. De la lectura del Apéndice del Proyecto, se criticó que Barra abogase por una titularidad municipal. Pese a que fue aprobado por la Comisión Municipal, no se avanzó en el mismo, aunque, para algunos autores, este proyecto (...) supuso el esfuerzo municipal más significativo que antecede al Canal de Isabel II (Rueda Laffond, 1994, p. 38)

(...) " Desde el establecimiento de la Corte en Madrid se ha tratado en repetidas ocasiones de traer a esta Villa abundancia de aguas para aumentar su frondosidad y hermosura; pero en estos últimos tiempos, sea por causas físicas, sea por el mayor consumo que resulta del aumento de la población, se ha notado falta de aguas potables, y el Ayuntamiento no ha personado gasto ni fatiga para ocurrir a este mal, y proporcionar con abundancia este elemento indispensable de la subsistencia”. "Era, pues, cosa natural la división de este problema en aguas potables y de riego: las primeras son de una urgencia del momento para remediar la situación penosa en que se hallan, a lo menos por los 
cuatro meses de verano, todos los habitantes, y con especialidad la clase pobre, siempre más numerosa...”(Barra, 1834, p. 1)

Imagen 3-2. Portada del proyecto de Francisco Javier Barra. "Proyecto y Memoria sobre Conducción de aguas a Madrid". Año 1834

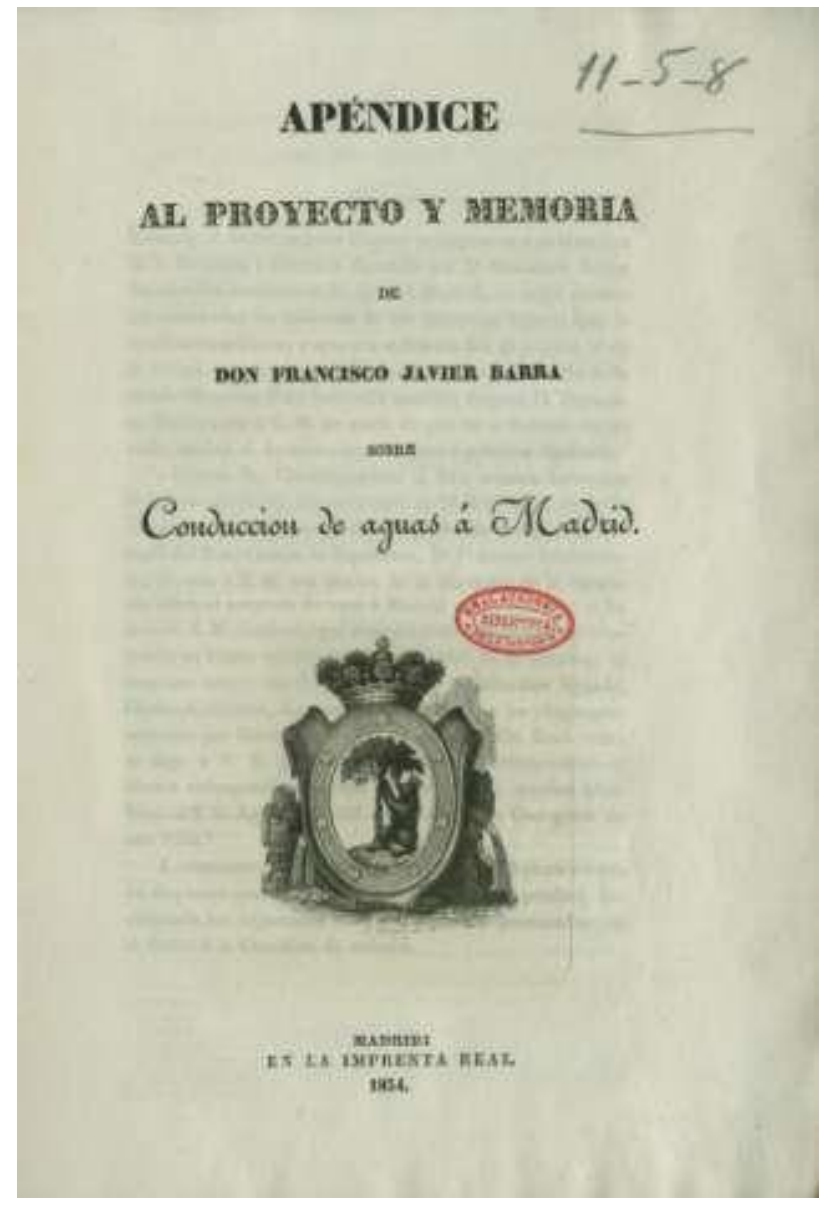

Fuente: Biblioteca Digital Real Academia de la Historia. Apéndice al proyecto y memoria de Don Francisco Javier Barra sobre conducción de aguas á Madrid. 1834. (Barra, 1834)

Sin que ninguno de los anteriores llegase a ser aplicado, el 30 de mayo de 1846, el Ayuntamiento de Madrid sacó a subasta la traída de aguas a Madrid, otorgándose a la compañía anónima La Aurora. La compañía, si bien no se comprometió a poner en práctica ninguno de los proyectos anteriormente citados, sí afirmó que dotaría a Madrid de diez mil reales de agua (equivalentes a 32.450 metros cúbicos al día) (Melgosa Olaechea, 1912, p. 93). No hubo de pasar ni siquiera un año, para que el contrato suscrito entre la compañía La Aurora y el Ayuntamiento se diera por rescindido.

En el año 1846 tuvo lugar la redacción de otro proyecto con similares objetivos, pero diferentes mecanismos. Este estudio, realizado por Manuel Cortijo, plasmó la idea de la traída de aguas desde un canal único desde el Río Lozoya. Pese a resultar aprobado por 
el Ministerio de la Gobernación, salir a subasta y adjudicarse a la empresa llamada "La Aurora", el contrato se anuló porque a la altura de 1847 no habían comenzado las obras. Destacar también la creación de la "Sociedad Anónima para el Aumento de Aguas a Madrid" cuya intención fue la apertura de nuevos viajes de agua (Rueda Laffond, 1994, p. 39).

Ante estos continuos fracasos, con el Marqués de Santa Cruz como alcalde del Ayuntamiento de Madrid, se optó por la colocación de tres fuentes vecinales (en el inicio del Puente de Toledo, en la Plaza de Herradores y en Puerta Cerrada), así como por la apertura de quince pozos dotados de bombas de mano, con el objetivo de que pudieran destinarse al servicio de limpiezas y riegos de la ciudad y otros de mayor caudal, ubicados en las afueras de la ciudad, para que sirvieran de medios auxiliares de los Viajes de agua.

Imagen 3-3. Litografía de la Fuente de Puerta Cerrada.

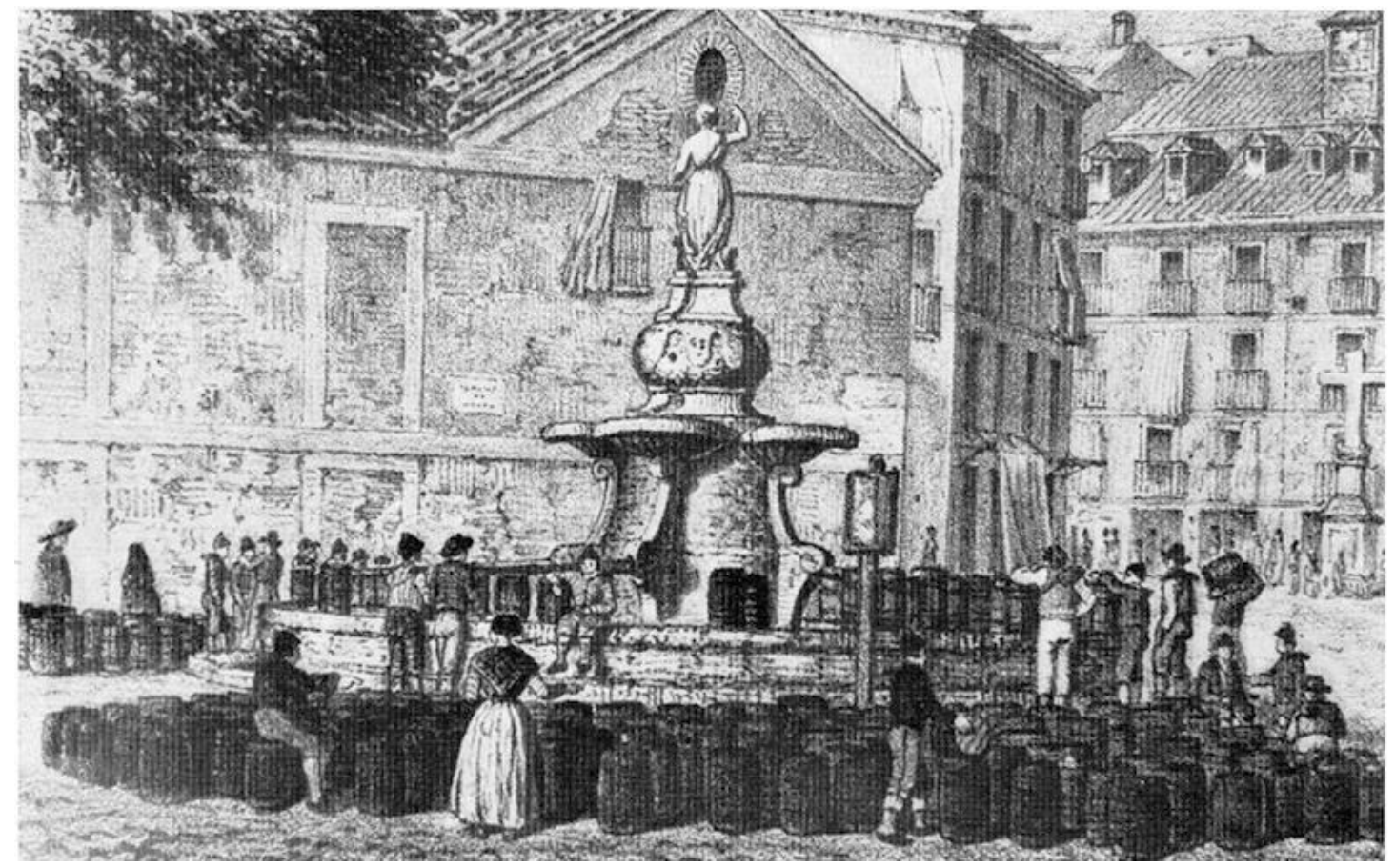

Fuente: Litografía de la serie del Madrid artístico. Museo Municipal de Madrid 


\subsubsection{El proyecto de Rafo y Rivera}

Entre los años 1848 y 1849 fueron elaborados, por Rafo y Rivera, los primeros proyectos que proponían la construcción de un único canal elevado del Río Lozoya, que sería regularizado con la presa del Pontón de la Oliva.

Mapa 3-2. Plano del Proyecto de Conducción de aguas a Madrid de Rafo y Rivera. Año 1848.

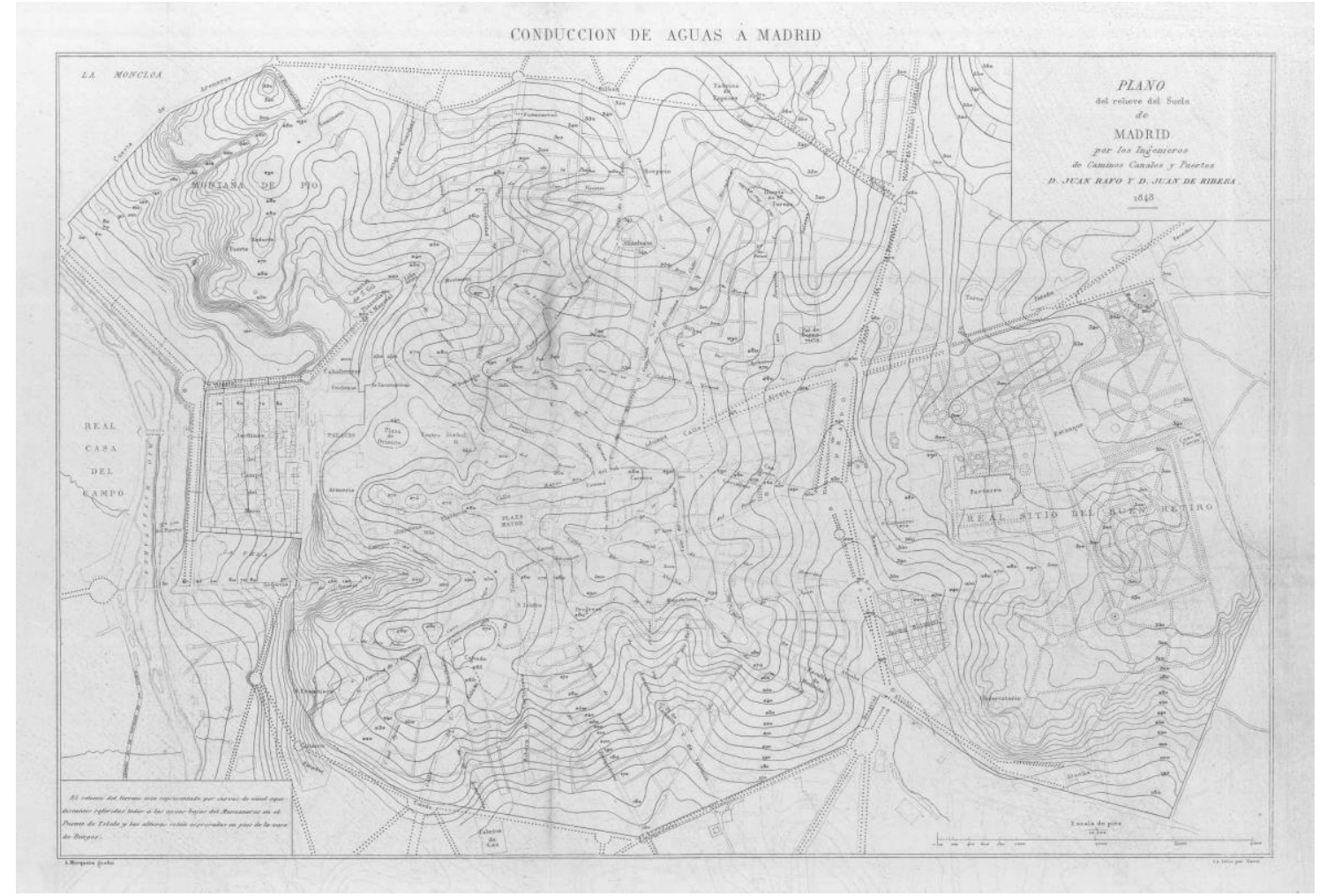

Fuente: Biblioteca Digital de la Comunidad de Madrid

De este modo, la modernización del servicio de agua vino dada, principalmente, por la insuficiencia del suministro, potenciado por el incremento poblacional experimentado, así como por el aumento de la extensión de la capital (con el Ensanche y el Extrarradio) más allá de los límites históricos de la ciudad. Temporalmente, el Proyecto de Castro ${ }^{32}$ fue contemporáneo a la primera llegada de aguas del Lozoya a la capital, en 1858. En el proyecto del Ensanche se señala de manera explícita la necesidad de la extensión de la distribución de agua domiciliaria a los nuevos barrios de la ciudad. Asimismo, las necesidades de higiene de la ciudad se acrecentaban al compás que lo hacía el crecimiento de su población.

\footnotetext{
${ }^{32}$ Para conocer las especificidades del Plan Castro, consultar: (Carballo, Pallol, \& Vicente, 2008)
} 
Hauser, retrataba así la situación de Madrid refiriéndose a los datos de abastecimiento del agua a principios del siglo $\mathrm{XX}$ en la capital “(...) este es el resultado de los múltiples esfuerzos hechos por el Gobierno y Municipio durante más de dos siglos para el abastecimiento de la capital con aguas potables. ¡Triste resultado de una experiencia tan larga!” (Hauser, 1902a, p. 227).

\subsection{La génesis del Canal de Isabel II.}

\subsubsection{La primera etapa del Canal de Isabel II (1851-1865).}

Como se ha visto en líneas precedentes, hubo iniciativas anteriores a la creación del Canal de Isabel II que tuvieron por objetivo la traída de aguas a la ciudad de Madrid, pero fracasaron. Estas iniciativas se redactaron al amparo de la Real Cédula de 8 de marzo de 1829, que establecía la obligatoriedad de que el Ayuntamiento de Madrid redactase un proyecto para la explotación de canales de abastecimiento de agua potable. Dirigidas a garantizar la construcción y gestión del servicio, todas las iniciativas tuvieron un elemento común que fomentaba la figura del Ayuntamiento y del sector privado como entes titulares del abastecimiento del agua. Sin embargo, la crisis económica, principalmente, dio como resultado la creación del Canal bajo titularidad estatal. Podría decirse que la figura que adoptó finalmente la administración del Canal de Isabel II fue fruto de una conjunción de "fracasos" previos ${ }^{33}$. Hasta ese momento, tal y como se ha descrito en líneas precedentes, el suministro de agua potable se hacía por el servicio de los aguadores o por fuentes públicas con agua proveniente de los Viajes Antiguos. La manifestación de la insuficiencia de la dotación de agua para una ciudad en crecimiento, así como la influencia del discurso higienista de la época en pro de la higiene pública, dio origen a la modernización del servicio de abastecimiento de aguas con la creación del Canal de Isabel II, teniendo por objetivo la consecución de una dotación abundante y regular de agua.

Es en este contexto en que, mediante Real Decreto el 18 de junio de 1851 (publicado en la Gaceta de Madrid de 20 de junio de 1851), se creó el Canal de Isabel II, como

\footnotetext{
${ }^{33}$ Por ejemplo, en 1846 se adjudicó a una compañía particular la realización de trabajos del Canal, fruto de la aprobación de un proyecto para la construcción de un canal de abastecimiento de aguas del Rio Lozoya, pero el contrato finalmente se rescindió puesto que se agotó el plazo de inicio de las obras sin que se hubiera avanzado en la realización de las mismas.
} 
empresa pública, con el objetivo de la gestión y explotación del servicio de abastecimiento de agua potable del río Lozoya a la Madrid, mediante un canal de superficie. El Estado fue el encargado de acometer la obra de abastecer de agua a la ciudad de Madrid, bajo iniciativa de Bravo Murillo como Presidente del Consejo de Ministros.

En el Real Decreto, se estipuló que la construcción como la red de distribución dentro del perímetro urbano sería de competencia municipal exclusiva, así como la propiedad del caudal sería municipal. Real decreto procediendo á la ejecución de las obras necesarias para abastecer á Madrid de aguas saludables por medio de un canal derivado del río Lozoya, que se denominará Canal de Isabel II, admitiendo la participación del Ayuntamiento y de los particulares en los términos que se determinarán en este decreto. (Bravo Murillo, 1851, pp. 1-2).

El presidente del Consejo de Ministros en el reinado de Isabel II, Juan Bravo Murillo encargó el proyecto para traer las aguas a Madrid a los ingenieros Juan Rafo y Juan de Rivera, creando la llamada Comisión Especial de traída de aguas. En el Real Decreto, se especificaba la intención de que las obras abarcasen la construcción de un embalse y de un canal que superaba los 70 kilómetros, con el objetico de la traída de aguas del Río Lozoya a Madrid. El Consejo de 1851 estuvo formado por representantes del Estado, del Ayuntamiento de Madrid y particulares. Dependía de la inspección del Gobierno y estuvo presidido por un Comisario delegado de la Corona.

La llegada de aguas a la capital tuvo lugar el 24 de junio de $1858^{34}$.

\footnotetext{
${ }^{34}$ El acta de la solemne inauguración del Canal de Isabel II puede consultarse en el ejemplar de Prado, C. (1858). Calidad de las aguas del Lozoya. El Mundo pintoresco, ilustración española, 13, 103.
} 
Imagen 3-4. Colocación de la primera piedra en el Pontón de la Oliva

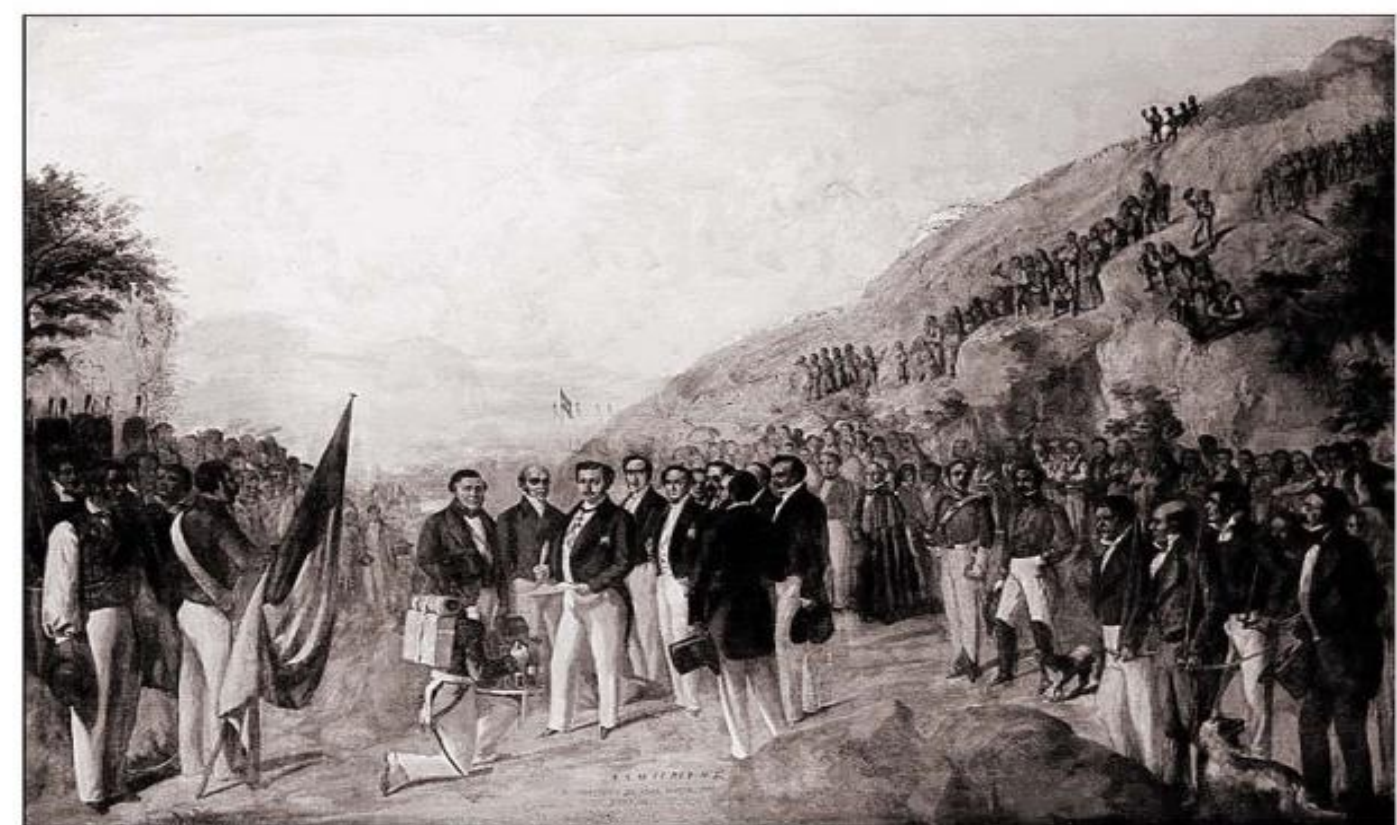

La primera piedra de las obras del Pontón de la Oliva; José Carol. Patrimonio Nacional

Imagen 3-5. Inauguración del Canal de Isabel II.

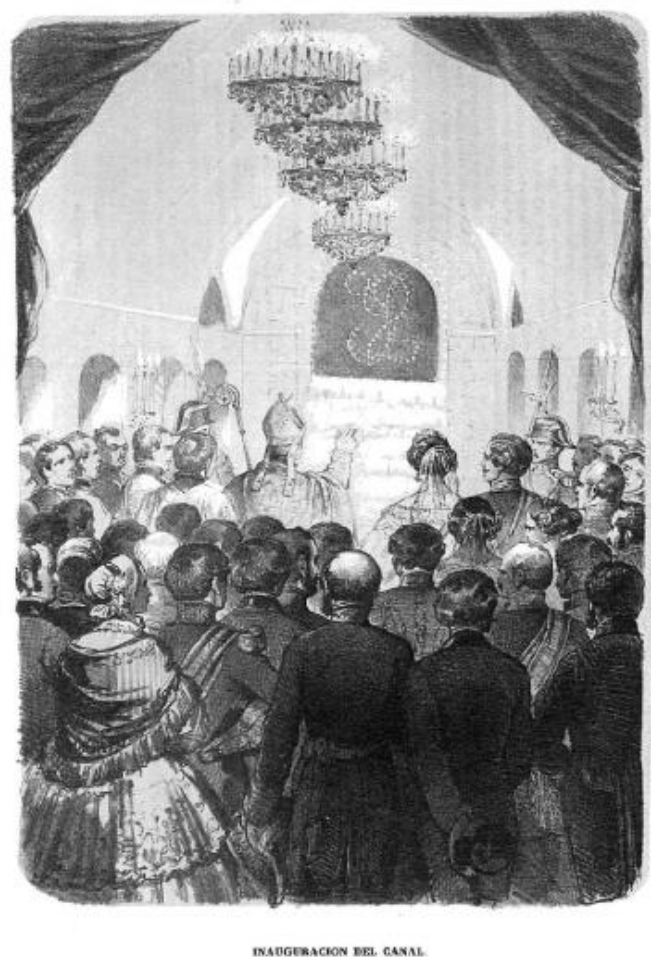

Fuente: (de Prado, 1858, p. 101) 


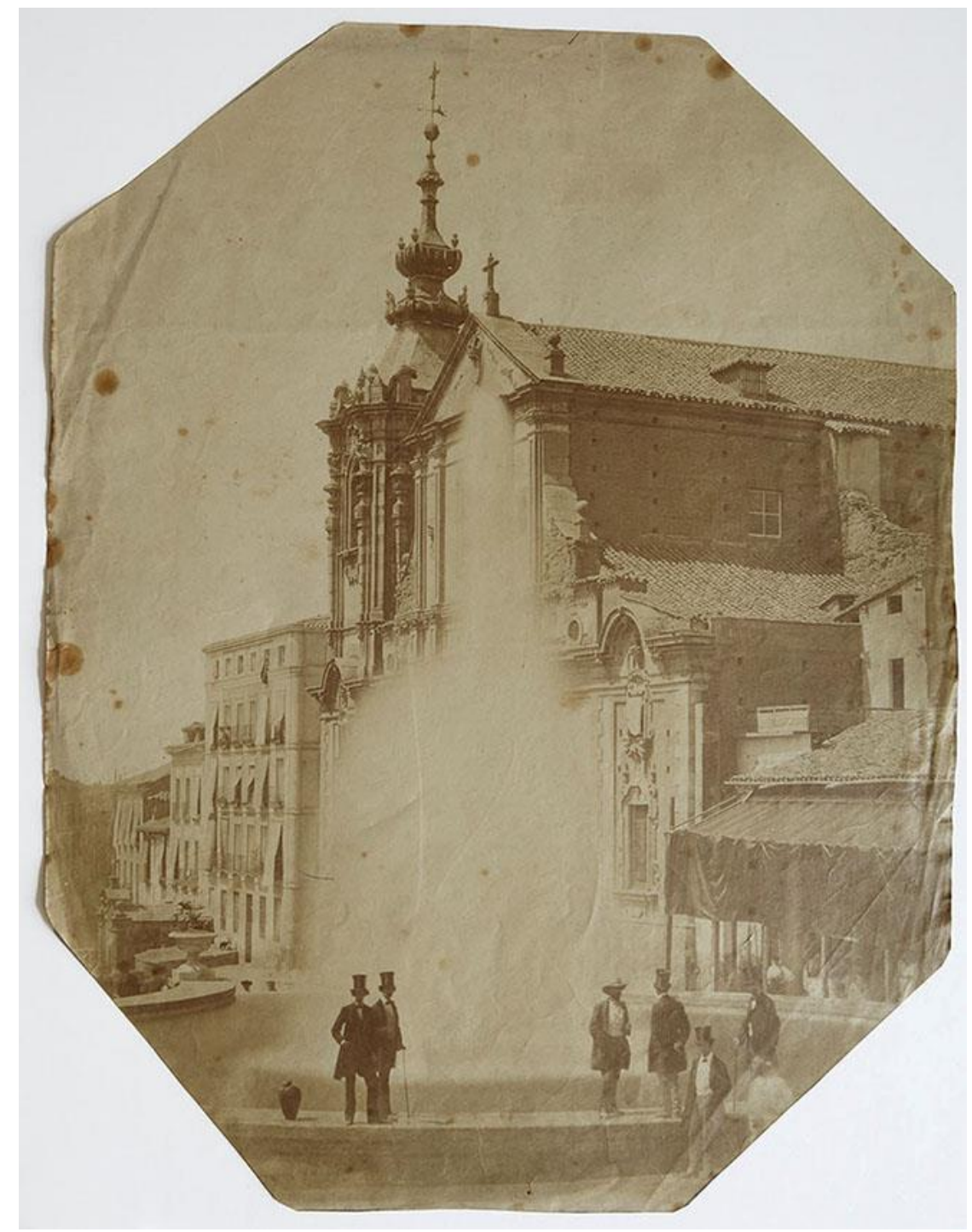

Fuente: Charles Clifford. Madrid, inauguración de la primera fuente del Canal de Isabel II en la calle de San Bernardo. 24/6/1858. Albúmina. (Col. Familia Fierros)

El Canal de Isabel II tenía potestad para captar agua de las cuencas de los Ríos Lozoya, Guadalix, Jarama y Sorbe. En las primera obras, la presa se situó para el embalse en la desembocadmra del río Lozoya en el Jarama, en el denominado Pontón de la Oliva, pero fue modificada a la Parra. Para la traída de aguas a Madrid, se construyó un canal de conducción, que tiene una longitud de 77 kilómetros contados desde la presa anterior hasta el partidor en la ciudad.

En el primer período de obras, que dura quince años, se llevan a cabo importantes obras de ingeniería; tales como la construcción del canal de conducción, la red arterial, y se 
construyen dos canalillos o acequias del Norte y Este-Sur (con un total de 17 kilómetros), que se utilizaban para el riego con el sobrante de agua que no consumía el vecindario. (Ayuntamiento de Madrid, 1929, p. 112)

La figura administrativa del Canal de Isabel II como empresa pública duró apenas unos años. Una vez finalizó la primera infraestructura del Canal, en 1867, se decide que la empresa pase a ser dependencia del Régimen de Jefaturas de Obras Públicas del Ministerio de Fomento, en contra de lo firmado en el Real Decreto de 1851, que establecía que la gestión del Canal estuviera en manos de representantes municipales, tres comisarios regios y un Sindicato de abonados. A su vez tal y como señala Rueda Laffond (Rueda Laffond, 1994, p. 24)" Atrás quedaba un nuevo fracaso por arrendar el servicio de distribución a la sociedad "La Lozoyana", promovida con capital francés. Concluía así la autonomía administrativa de la empresa, a la vez que las tareas de mantenimiento quedaban cubiertas desde esa fecha por el presupuesto ordinario del Ministerio”.

\subsubsection{Problemas económicos iniciales}

Los problemas iniciales del Canal de Isabel II tuvieron que ver con la incapacidad económica de la entidad municipal para llevar a cabo los proyectos de obras dictados en el Reglamento para la construcción del Canal. Pese a que se llevaron a cabo diversas modificaciones en el Reglamento inicial relativa a la financiación, se puso de manifiesto la necesidad de que el Estado debía colaborar en el empréstito de las obras.

En el Real Decreto para la construcción del Canal de Isabel II, publicado en la Gaceta de Madrid el día 20 de junio de $1851^{35}$, se estipuló un capital de 80 millones de reales de vellón y la dotación prevista fue de 10.000 reales fontaneros diarios, lo que suponía cerca de 33.000 metros cúbicos de agua diarios. El Estado aportó cerca de dos millones y medio de reales de vellón y otros 45,5 millones serían fruto de las cantidades presupuestadas en los presupuestos generales. El Ayuntamiento otorgaría 16 millones de reales de vellón, reintegrados con la adquisición de 2000 reales fontaneros de agua. Por su parte, los particulares también contribuirían mediante la figura de abonados a la entidad.

\footnotetext{
${ }^{35}$ El Real Decreto puede consultarse en: https://www.boe.es/datos/pdfs/BOE//1851/6185/A0000100002.pdf
} 
Sin embargo, desde el mes de agosto en que se colocó la primera piedra en el Pontón de la Oliva., al tiempo que las obras comenzaban a avanzar, con el consiguiente gasto que suponía, se incrementaban las dificultades. De este modo, cuatro años más tarde, en 1855, los problemas comenzaron a manifestarse. Por un lado, el Ayuntamiento de Madrid todavía no había cumplido con el pago de la cantidad que aparecía estipulada por Real Decreto y, por otro, buena parte de los trabajadores en la construcción de la infraestructura acusaron ausencias en sus puestos de trabajo fruto de la epidemia de cólera (Rueda Laffond, 1994, p. 44), lo que supuso una ralentización de los trabajos.

Imagen 3-7. Obras de la Presa del Pontón de la Oliva.

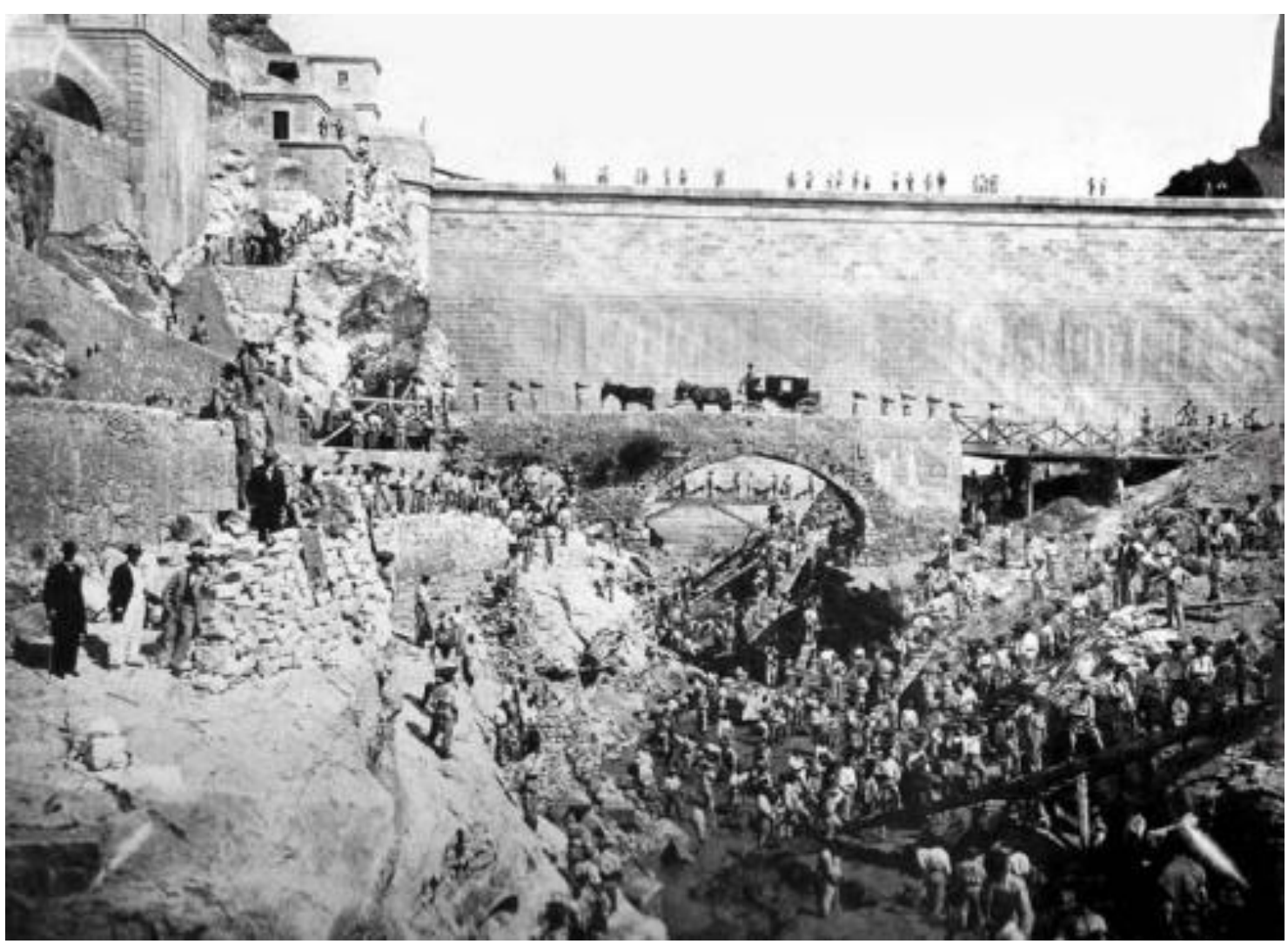

Fuente: Album Vistas de la presa y demás obras del Canal de Isabel II de Charles Clifford (1819-1863), publicado en 1858 (BNE).

Esta situación provocó que, en los años siguientes, hubiera que ampliarse la legislación para solventar los problemas económicos. En junio del mismo año se dictó una Ley mediante la cual se autorizaba "al Ministerio de Fomento la emisión de obligaciones del Canal por un capital nominal de 50 millones de reales, al 8 por ciento de interés, para la financiación de las obras de conducción dentro de la ciudad. Como garantía se 
consignarla un crédito de cuatro millones de reales anuales del presupuesto ordinario del Ministerio así como un recargo transitorio en los derechos de puertas" (Rueda Laffond, 1994, p. 44). La figura del Estado, como garante de los servicios municipales, se puso de manifiesto de manera palpable.

\subsubsection{La segunda etapa del Canal de Isabel II (1865-1907)}

Es en estos años cuando el Canal de Isabel II pasó a ser dirigida por la Dirección de Obras Públicas del Ministerio de Fomento, de manera que sus cuentas dependían del Ministerio. Si bien en el Reglamento de 1851 se establecía que una vez finalizada la primera infraestructura se constituiría un "Sindicato" que gestionaría el Canal, esto no se produjo. En su lugar, se creó una sociedad privada para arrendar el servicio, llamada "La Lozoyana", que entró en quiebra.

El Canal dependerá del Ministerio de Fomento hasta el año 1907, con la firma del nuevo reglamento (González Besada, 1907) que supuso la reorganización del servicio. Esta reorganización fue consecuencia de varios frentes y desafíos a los que se enfrentaba el Canal; desde el aumento de la población madrileña con el consiguiente incremento de la demanda de agua, hasta la competitividad que marcó la puesta en marcha de la Hidráulica Santillana. Es por ello que, desde 1907, el Canal de Isabel II pasó a ser figura autónoma respecto al Ministerio de Fomento, tal y como se verá en la siguiente sección de este capítulo. Con figura adoptada en 1907, la dirección vendría de manos de un Comisario nombrado por el Gobierno, y el sistema estaría formado por representantes municipales y personal técnico.

En líneas generales, puede decirse que en esta segunda etapa (de 1866 a 1907) se produjo un descenso en las cantidades invertidas para la financiación respecto a los primeros años de vida del Canal (1851-1865). En estos años se realizaron labores de mantenimiento, obras para construir un segundo embalse y la construcción de la Presa del Villar, entre 1869-1882, con el objetivo de regularizar el Lozoya. Además, en 1876, se concluye la construcción del segundo depósito y comienza a plantearse la construcción del tercero. La extensión de la red de distribución llegó a 90 kilómetros y se amplió el alcantarillado. 
Como consecuencia de las deficiencias relativas a la insuficiencia de abastecimiento, deficiencias en infraestructuras y el mal estado higiénico de la ciudad, desde 1889 se redactaron diversos proyectos que pretendieron acotar los problemas, teniendo por objetivo la ampliación del abastecimiento de agua en la ciudad y que puso de manifiesto la necesidad de construir un depósito elevado, con el objetivo de llegar a las zonas más altas de la ciudad (Ensanche Norte). Asimismo, se aprobó en 1902 la creación de un acueducto nuevo, El canal Transversal (García Agustín, 1971)

Otro de los problemas del agua en Madrid era el provocado por la escasez en meses de estiaje. Esto suponía, atendido a los datos ofrecidos por las Memorias del Canal de Isabel II en varios años, una reducción de su aforo importante.

Respecto a los Reglamentos del servicio de distribución entre 1870 y 1903, fueron cinco los aprobados en este periodo de tiempo, teniendo por objetivo de regularizar la distribución del servicio de aguas del Lozoya a la capital madrileña. (Canal de Isabel II, $1873,1886,1908 a)$.

Del Reglamento de 1873, cabe destacar que los particulares abonados podrían suscribir concesiones por llave de aforo, caño libre y se añadió la modalidad de una suscripción por contador. En el correspondiente al año 1886, se recoge y amplían los requisitos para usos industriales, que anteriormente se habían regulado supeditados a las concesiones para usos domésticos. El correspondiente a 1903, podría decirse que es el reglamento que reviste mayor importancia de los mencionados hasta el momento, ya que introduce que las concesiones urbanas se debían suscribir a caño libre con verificador, limitándose la suscripción por aforo. Además, se produjo la caducidad de las concesiones a caño libre, que ascendían a 5250 (Canal de Isabel II, 1908a). También se reguló el tema de las tarifas, de manera que ya no dependía de la renta de alquiler de los abonados, sino que se estableció una tarifa general en proporción al agua consumida. De esta forma, se produjo una cierta racionalización tanto en el consumo de agua como en el reporte económico para el Canal de Isabel II.

En definitiva, los últimos años del siglo XIX y los principios del $\mathrm{XX}$ estuvieron marcados, principalmente por tres retos a los que se debía hacer frente en cuanto al abastecimiento del agua. Por un lado, cubrir las necesidades no satisfechas en cuanto a suministro, especialmente en las zonas del Ensanche norte y este de la ciudad. En relación a lo anterior, las insuficientes infraestructuras existentes y, fruto de todo ello, el 
consecuente ambiente de malestar sanitario e higiénico que todo ello provocaba. Siendo los barrios de estas zonas de la ciudad los que estuvieron más desabastecidos.

La salubridad del agua del Lozoya fue también un tema relevante en la época. El afloramiento de las campañas higienistas fomentaron tal preocupación, centrándose ya no sólo en la cantidad de agua, sino en su calidad (Úbeda y Correal, 1900). Las aguas turbias del Río Lozoya fueron objeto de preocupación. Así lo manifestó Aguinaga, Director del Canal de Isabel II, años más tarde en su análisis sobre este tema (de Aguinaga, 1916), proponiendo, para su solución, desde el revestimiento de cañerías a la ampliación de la Presa del Villar. Realmente, no será hasta 1912 cuando comienzan a tomarse en valor los beneficios de la ozonificación del agua como medidas de saneamiento y depuración ${ }^{36}$.

\subsubsection{La creación de una nueva empresa. La hidráulica Santillana.}

El periodo temporal que va desde 1898 a 1910 supuso una modificación de las condiciones de suministro de agua a la capital, fruto de la creación de la compañía privada Hidráulica Santillana, que rompió con el monopolio del agua de manos del Canal de Isabel II. Otros acontecimientos importantes que produjeron la alteración de las condiciones anteriores fueron, como ya se ha señalado anteriormente, la reorganización del Canal en 1907, de modo que la antigua administración ministerial se adaptó a un modelo de sociedad industrial, pero bajo una figura especial que no dejaba de corresponder a la titularidad estatal de la que disfrutaba. La nueva administración, bajo la denominada Comisaría Regia, efectuó un plan de obras extraordinario, del que cabe destacar la planificación de construcción del Canal Transversal (localizado entre las Presas del Portón y del Villar), la finalización del Tercer Depósito de agua y el aprovechamiento eléctrico de un salto de agua (Rueda Laffond, 1994, p. 57). A raíz de estas decisiones comenzó un periodo de conflictos con las sociedades eléctricas que distribuían en la capital al tiempo que se incrementó el malestar entre el Canal y la Hidráulica Santillana, ya que esta segunda había recibido autorización para abastecer agua a las zonas a las que no llegaba el Canal o que éste abastecía de manera

\footnotetext{
${ }^{36}$ La temática relativa a la calidad y medios de purificación de las aguas será tratada en el capítulo siguiente.
} 
insuficiente (autorizado por el Ministerio de Fomento y el consistorio municipal). El punto álgido de las disputas se produjo en 1909, cuando el Canal de Isabel II promovió constituir la Cooperativa Eléctrica y logró un acuerdo con el Ayuntamiento para abastecer el alumbrado público. Sin embargo, estos planes orientados a diversificar las actividades económicas de Canal no llegaron demasiado lejos, tras la cesión de Sánchez de Toca en el puesto de Comisario Regio.

Mientras tanto, las disputas con la Hidráulica Santillana se sucedieron hasta la segunda década del Siglo XX.

La constitución de la Hidráulica Santillana, de manos de Joaquín de Arteaga y Echagüe Silva y Méndez de Vigo, Marqués de Santillana y XVII Duque del Infantado ${ }^{37}$, constituyó el primer intento real de emplear la energía hidráulica del noroeste de la provincia de Madrid para abastecer agua y energía. Anteriormente se habían propuesto algunos otros proyectos con este cometido. En la última década del siglo XIX, cabe destacar el propuesto por Salvador Peydró y el planteado por Felipe Mora.

El Marqués de Santillana comenzó sus gestiones al respecto desde 1897, con la compra de algunas concesiones del Río Manzanares, el Guadalix, el Guadarrama y el Lozoya Pese a que no fue hasta 1902 cuando sus proyectos se llevarán a cabo. En 1900 el Ministerio de Fomento le otorga un caudal medio de tres metros cúbicos por segundo que podrá conducirse a la capital, teniendo como objetivo llevar las aguas a las zonas donde el Canal de Isabel II aún no había llegado; Ensanche y el Extrarradio en su parte norte y este. (Rueda Laffond, 1994, p. 62).

El plan de obras del Marqués de Santillana fue bastante ambicioso, teniendo en consideración todas las problemáticas que quiso abarcar; por un lado, el abastecimiento de agua las zonas de la ciudad no abastecidas por el Canal; por otro, el saneamiento y la regularización del caudal del Río Manzanares y, por último, la instalación de centrales hidroeléctricas. Si bien no será objeto de estudio pormenorizado, merece la pena destacar que a partir de ese momento Madrid contará con energía eléctrica proporcionada por un salto hidráulico, que se irán ampliando a lo largo de los años junto

\footnotetext{
${ }^{37}$ Para conocer más, consultar biografía en la página web de la Real Academia de la Historia. http://dbe.rah.es/biografias/8178/joaquin-ignacio-de-arteaga-y-echague-silva-y-mendez-de-vigo.
} 
con otras distribuidoras de electricidad ${ }^{38}$ (Otero Carvajal \& Rodríguez Martín, 2019, pp. $36-43)$.

A partir de 1904, por Real Orden, se autorizan las obras destinadas al abastecimiento de agua siguiendo lo dispuesto en 1900, pero una petición de ratificación del proyecto ralentizó su aprobación definitiva hasta 1906. Así el 20 de octubre de 1906 se aprobó por la Dirección General de Obras Públicas, dependiente del Ministerio de Fomento, el proyecto de conducción de aguas presentado por el Sr. Marqués de Santillana, en cumplimiento de lo dispuesto en la condición 3. a de la Real orden de 10 de Febrero de 1904, por la que se le otorgó la concesión del aprovechamiento de tres metros cúbicos por segundo de agua del río Manzanares, con destino al abastecimiento de la zona alta de Madrid y usos industriales (Fernández Latorre, 1906, p. 420). El siguiente año, el 22 de abril de 1907, se concede a la Hidráulica autorización para distribuir agua en los denominados "barrios altos de Madrid", para aquellas zonas que no estaban cubiertas por el Canal de Isabel II. Sin embargo, el Canal de Isabel II "contraatacó”, proponiendo su Plan extraordinario de obras basadas en la necesidad de instaurar un sistema de agua elevada con el objetivo de que el abastecimiento llegara a las zonas más altas de la ciudad (J. J. González Reglero, 2014). Esto supuso la paralización de las obras de la Hidráulica Santillana.

En enero de 1911 llegaron por primera vez aguas del Manzanares a la capital, concretamente a las barriadas de Cuatro Caminos y Bellas Vistas. Al año siguiente hubo un buen número de solicitudes para proceder a canalizaciones nuevas, para los distritos de Congreso y Buenavista.

Las aguas de las que se abastecía la Hidráulica Santillana eran captadas al pie de la Pedriza de Manzanares, situándose el embalse próximo a Manzanares el Real, con una cuenca de 250 kilómetros cuadrados.

Pese a que la concesión otorgada era de un metro cúbico, el volumen de agua conducida a Madrid es de 600 litros por segundo, lo que da una cantidad que oscila entre los 40.000 y los 60.000 metros cúbicos por día, inferior a los 86.000 metros cúbicos por día que correspondería a la concesión (Ayuntamiento de Madrid, 1929, p. 111).

\footnotetext{
${ }^{38}$ Para conocer más sobre el abastecimiento de energía eléctrica en Madrid, consultar (Otero Carvajal \& Rodríguez Martín, 2019, pp. 36-43)
} 


\subsubsection{La tercera etapa del Canal de Isabel II (1907-1930)}

\subsubsection{Reorganización administrativa}

En el año 1907, por Ley de 8 de Febrero de 1907 y Reglamento de 20 de mayo de 1907 (González Besada, 1907, pp. 239-242), el Canal de Isabel II vuelve a la situación administrativa de su génesis.

En buena medida, la reforma administrativa del Canal estuvo influenciada por la autorización a la Hidráulica Santillana para comenzar las obras con el objetivo de transportar agua a Madrid. La importancia de este hecho radica en que fue un elemento que forzó el cambio de régimen de la estructura de autonomía administrativa del Canal, ya que se rompía con el monopolio que tuvo el Canal hasta ese momento (pese a que la Ley General de Aguas y las Ordenanzas Municipales de 1892 desestimaban la posibilidad de dicha autonomía). Así, desde 1905 tuvo lugar una situación de competencia entre el Canal de Isabel II y la empresa privada Hidráulica Santillana por el control del abastecimiento y suministro de aguas a los "barrios altos" de la ciudad de Madrid, más concretamente, a la zona norte y este del Ensanche y el Extrarradio.

Tras unos años en los que hubo discusiones sobre la forma administrativa que debía adoptar el Canal de Isabel II, finalmente, por Decreto de ocho de febrero de 1907 se aprueba la reorganización administrativa. Se decide constituir un consejo de administración que, por delegación del Estado y a las órdenes de Ministerio de Fomento, tendría por objeto el mantenimiento y gestión del servicio. La presidencia del mismo fue ocupada por un Comisario Regio, elegido por el Gobierno, y debía ser un ex ministro (González Besada, 1907). El Cargo de Comisario Regio fue otorgado, a partir de abril de 1907, por el Alcalde de Madrid Joaquín Sánchez de Toca.

En líneas generales, el nuevo Reglamento de 1907 dispuso que, pese a que la autorización de nuevas obras debían contar previamente con autorización del Gobierno, el nuevo Consejo de Administración tendría potestad para "intervenir la gerencia, administración e inversión de los recursos del Canal y la ejecución de las respectivas obras de mejora, conservación, reparación, organización y dirección de todos sus servicios" (Reglamento del Canal de Isabel II, 1907. Capítulo primero, respectivo al Objeto y organización del Consejo de Administración. Artículo 1. (González Besada, 1907, p. 239). 


\subsubsection{Planes de obras del Canal}

Por Real Orden de 13 de junio de 1907, se aprobó el presupuesto general de las obras para llevar a cabo el Plan General del Canal de Isabel II (de Aguinaga, 1907). Atendiendo a las obras planificadas, éstas estuvieron encaminadas a la ampliación de la infraestructura existente, así como a la finalización de las no terminadas (como las referidas al Tercer Depósito o la de las Presas del Villar).

Con Aguinaga en la Comisaría Regia, hasta marzo de 1909, el Canal orientó sus esfuerzos a constituir una empresa que fuera rentable. El Plan General de las Obras de 1907 esbozaba el presupuesto para la finalización de, entre otras cosas, la distribución de aguas a los barrios altos de la ciudad ${ }^{39}$. Para la financiación de las obras, especialmente la del Canal Transversal, el Consejo de Administración del Canal aprobó en estos años diferentes suscripciones en cédulas garantizadas. También se llevaron a cabo negociaciones con el Banco de España, con el objetivo de que los valores anteriores quedaran catalogados como efectos públicos, y que el Banco de España fuera el encargado de los servicios bancarios de la suscripción. Así aparece en los Informes y documentos relativos a las operaciones del empréstito : empréstito de veinte millones de pesetas en cédulas garantizadas, conforme al Real Decreto acordado en Consejo de Ministros, en 20 de diciembre de 1907 (Sánchez de Toca, 1908).

A la altura de 1907, los metros cúbicos consumidos eran en torno a $140.000 \mathrm{y}$, con el nuevo Plan, se esperaba que esta cifra llegase a los 300.000 metros cúbicos en tres años (Rueda Laffond, 1994, p. 73). En cuanto a los ingresos, fruto de la variación en el sistema de concesiones por contador, se estimaba que mejorasen.

\subsubsection{Los planes de obras del Canal de Isabel II entre 1910 y 1930}

En términos generales, podemos decir que las obras ejecutadas por el Canal de Isabel II no pudieron hacer frente al reto que suponía el incremento de la población de la ciudad. Entre otros factores, las pugnas con la Hidráulica Santillana fueron un obstáculo

\footnotetext{
39 Hay que reseñar, también, los esfuerzos por la promoción de energía eléctrica de manos del Canal, que, si bien no serán objeto del presente trabajo, también supuso un aspecto importante en la orientación y vida del Canal de Isabel II.
} 
importante ante la consecución de objetivos reales planteados en los Planes de Obras del Canal. Y esto no sucedió hasta el momento en que el Ministerio de Fomento no dio por desestimadas todas las propuestas de la Hidráulica Santillana para abastecer de agua a los barrios del Ensanche y Extrarradio. De este modo, hasta casi llegados los años treinta del siglo $\mathrm{XX}$, no se finalizaron los programas propuestos por el Canal, especialmente lo relacionado con la extensión de la red de abastecimiento a toda la ciudad, así como las obras del segundo canal de abastecimiento.

Previo a comenzarse en los años veinte del siglo pasado, consiguieron finalizarse los trabajos que tuvieron que ver con el Canal Transversal, las obras del Tercer Depósito de aguas, los planes relacionados con la diversificación vinculados a la producción de energía eléctrica, y la ampliación de la red de abastecimiento a parte de la zona norte del Ensanche. Todos ellos, proyectos aprobados con Sánchez de Toca en la Comisaria Regia. A las disputas con la Hidráulica Santillana, hay que unir diversas modificaciones en los presupuestos aprobados, que supusieron la ralentización en las obras. Un ejemplo de ello fue la reducción en 1911 del presupuesto que fue aprobado en 1908, para llevarse hasta 1913. Este presupuesto, fue modificado seguidamente para los años 19131917 y, por Real Orden de diciembre de 1917, para los años 1918-1922.

En relación a los presupuestos y a la financiación con la que contaba el Canal, hay que tener en cuenta que, dadas las pretensiones de las obras a llevar a cabo, las arcas económicas del Canal necesitaban mayor volumen. Sin embargo, en el año 1909, el Gobierno suspendió la contratación del Empréstito acordado y el Canal tuvo que financiarse con sus beneficios propios y con un crédito del Banco de España. También fueron revisados los presupuestos de 1908, ya que había algunas obras que requerían un aumento de mano de obra, como lo era la red de abastecimiento a los Barrios Altos y las obras del ya mencionado Canal Transversal, así como la finalización del Pantano de Puentes Viejas (de Aguinaga, 1911).

Atendiendo al estado de las obras en estos años, las obras se centraron, especialmente, en el abastecimiento a toda la ciudad a través de la extensión del canal de distribución, la finalización de la Presa de Puentes Viejas o la construcción de un nuevo Canal (Real Orden de 28 de marzo de 1922) mediante el cual garantizar el suministro con una longitud de 55 kilómetros y con una capacidad máxima de conducción de 6.000 litros por segundo. Sin embargo, teniendo en cuenta las cantidades invertidas entre los años 
1921-1929, cabe destacar que realmente se produjo un descenso en el gasto destinado a la red de distribución.

Gráfico 3-3. Diferencia del gasto en obras del Canal de Isabel II. Años 1921 y 1929

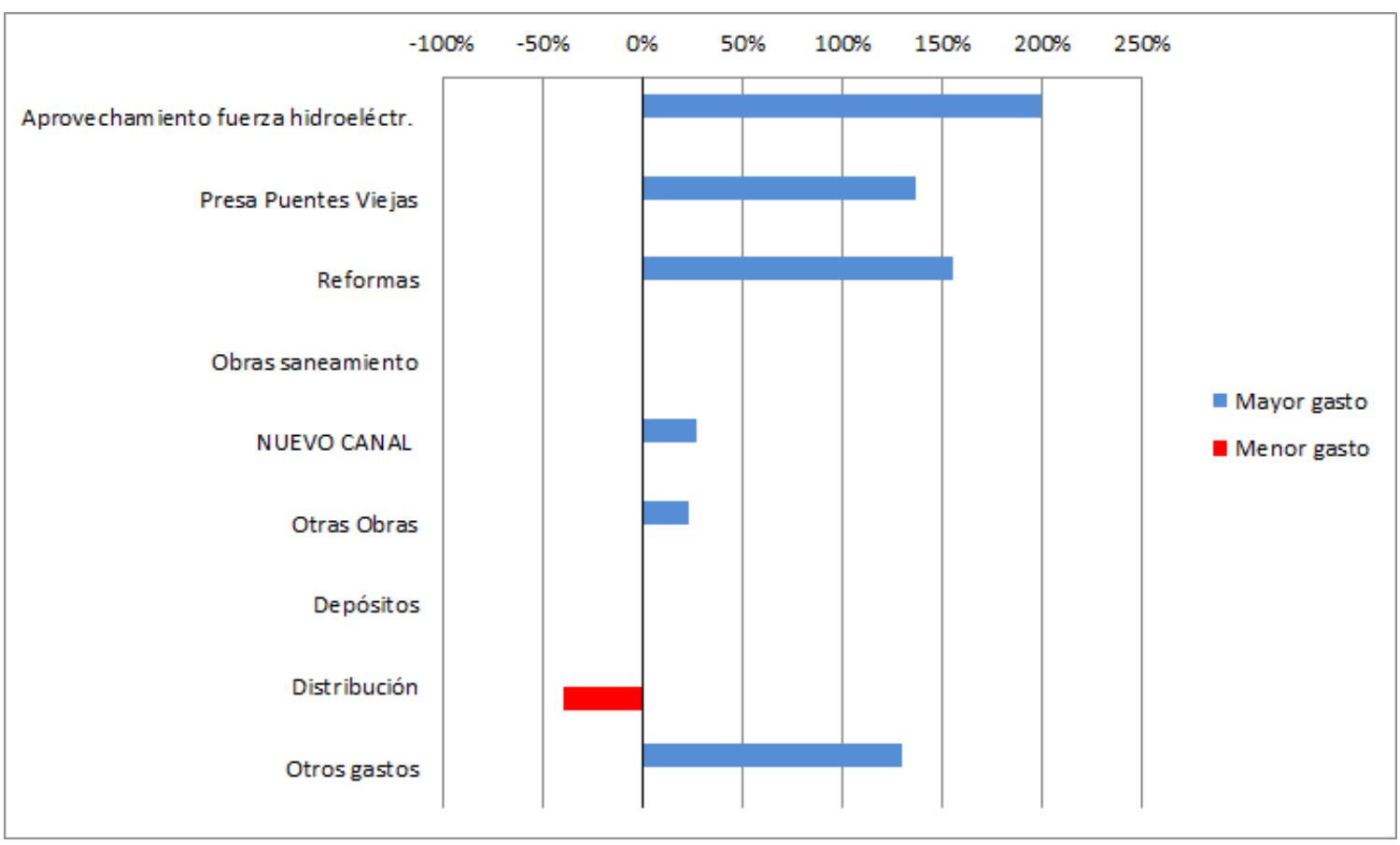

Fuente: Elaboración propia. Memorias del Canal de Isabel II para los años citados.

Los problemas para la financiación del Canal continuaron. En la Ley de presupuestos de 1922, se (...) había autorizado al Gobierno a garantizar el servicio de intereses y amortización de la deuda ofertada por el Canal, En el mes de octubre la sociedad pidió autorización para emitir la deuda calculada el año anterior. sin embargo, a pesar del dictamen favorable del Consejo de Estado, el Banco de España se opuso a respaldar más allá del 60 por ciento de las obligaciones previstas (Rueda Laffond, 1994, p. 103).

Ante tales problemáticas, el Canal en 1924 decide revisar los Planes de Obras, reduciendo los presupuestos para el quinquenio 1925-1929. (Bello Poeyusan, 1929, pp. 18-19).

A partir de febrero 1926, el Canal del Lozoya comenzó la etapa que denominaron "Nuevo Régimen" (de Zaracondegui, 1929), con Juan de Zaracondegui en el puesto de la Comisaría Regia. Los cambios se habían basado en la suspensión del artículo 22 de la Ley de febrero de 1907, de modo que, con el Real Decreto de 6 de febrero de 1926 (y hasta el nuevo Decreto de marzo de 1930) el personal del Canal dependía del 
nombramiento por parte del Ministerio de Fomento (ya no había representantes del Ayuntamiento en el Consejo). En los años de Zaracondegui como Comisario Regio, de 1926 a 1928, se centraron los esfuerzos en realizar obras menores.

Respecto a las cantidades invertidas en 1921 y 1929, se observó un claro cambio de tendencia en este último año, coincidente con la autorización del Gobierno a lanzar un empréstito sin una cifra fijada, sino que dependería de las necesidades de las obras y que podría llegar a los sesenta millones de pesetas.

\subsubsection{Situación a la altura de 1929}

En 1929, atendiento a los datos que aparecen en la imagen siguiente (imagen 3.10), llegaban a la ciudad de Madrid 233.000 metros cúbicos de agua por día, de los que el Ayuntamiento tenía en su propiedad 6400 metros cúbicos diarios. Se preveía que el nuevo Canal de Madrid permitiría la llegada de 752.000 metros cúbicos diarios. Los cálculos del Canal insinuaban una capacidad de abastecimiento de 300 litros por

persona y día, y terminadas las obras se tendrá caudal para una población de 2,5 millones de habitantes. Pasada esta cifra, se preveía poder contar con las cuencas del Jarama y Sorbe, teniendo en cuenta que, por Real orden de 1921 y mayo de 1925, el Estado se reservó estas cuencas con el objetivo de disponer de un mayor volumen de agua, para la estimación de los años en los que alcanzasen los 5 millones de habitantes en la ciudad.

La Memoria del Canal de Isabel II correspondiente al año hidráulico 1926-1927, publicada en 1928, calculó que el consumo en Madrid ascensió a un total de 72.650.000 metros cúbicos. Esto suponía 199.041 metros cúbicos por día y un promedio de 288 litros por habitante y día.

Respecto a los aspectos técnicos de la red de distribución de Madrid, existían tuberías instaladas por el Ayutamiento y otras por el Canal, con diámetros diferenciados unas de otras (entre 55 y 400 milímetros las primeras y entre 50 y 1.250 las del Canal). En cuanto a los metros de tubería de la red de distribución instalada por el Ayuntamiento, era de $121.539,24$ metros a los que hay que sumar 28.000 colocados en 1928. En cuanto a la red de distribución del Canal, ascendía a 243.418,60 metros de tubería. Esto supone que, a la altura de 1929, el total de metros de tubería de la red de distribución de la 
ciudad de Madrid era de 392.957,84 metros. Además, eran abastecidas por el Canal 6.000 bocas de riego de todos los sistemas, 500 fuentes, 52 urinarios, 17 evacuatorios y cuatro abrevaderos (Ciudad, 1929, p. 114).

Gráfico 3-4. Representación gráfica de la población y abastecimiento de agua con cálculos futuros

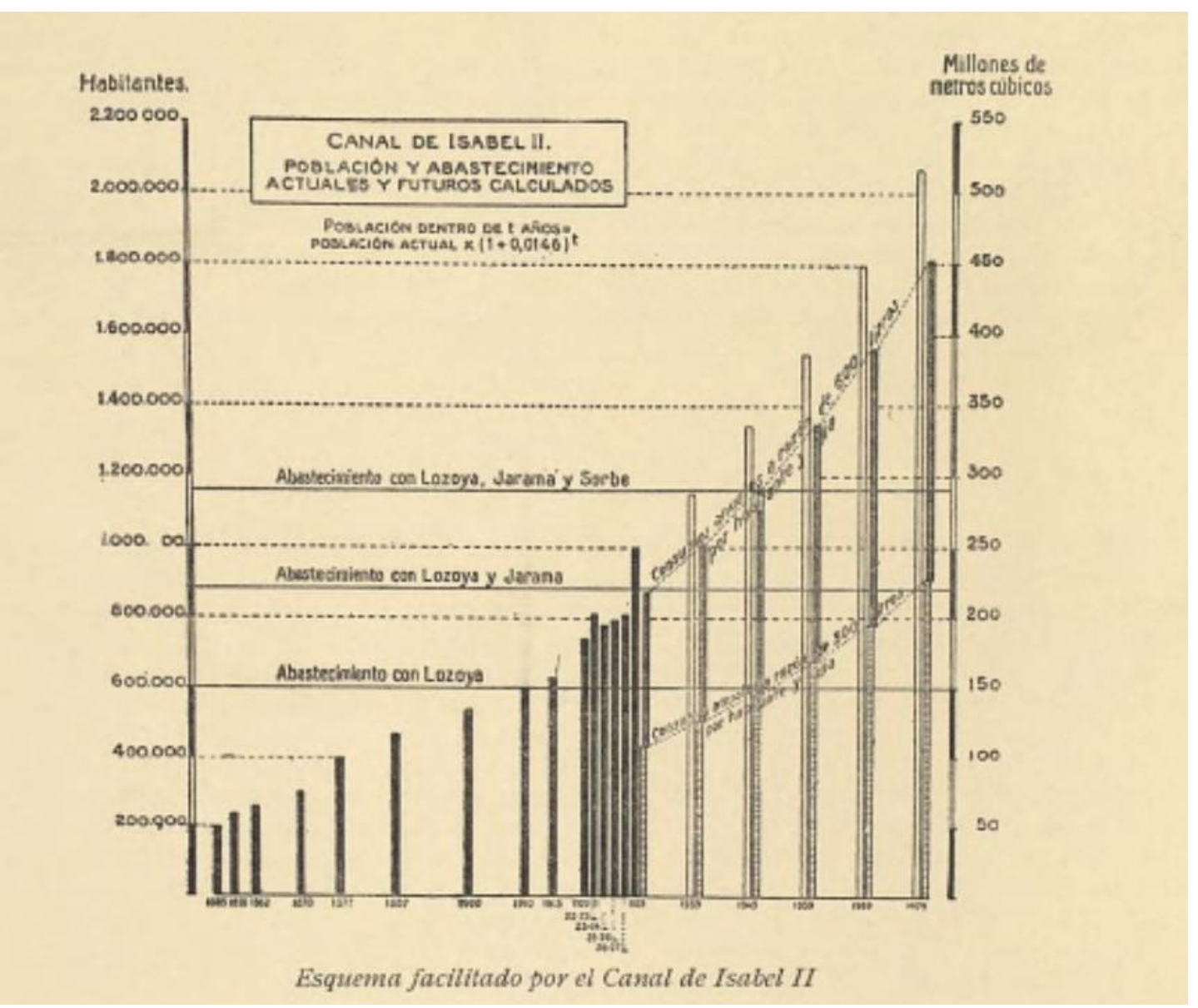

Fuente: (Ayuntamiento de Madrid, 1929)

Atendiendo a la imagen en la que aparece representado el Plano General del Canal y los perfiles de las presas (Mapa 3-3), se indica que las presas de El Villar y la de Puentes Viejas eran capaces de albergar 22 y 23 millones de metros cúbicos. Desde la Presa de El Villar hasta los depósitos de la ciudad de Madrid, transcurrían 91 kilómetros, delimitados en zonas; el transversal, de 24 kilómetros de longitud y una capacidad de 8 metros cúbicos; y el antiguo, con 67 kilómetros de longitud y 2,7 metros cúbicos de capacidad. 
Respecto a las acequias, éstas eran capaces de derivar un metro cúbico por segundo. El suministro de éstas se producía en los Parques de Madrid y del Oeste, con 20.000 metros cúbicos por día, Moncloa, Dehesa de la Villa y Viveros (con una media de 10.000 metros cúbicos). El sobrante del abastecimiento de la red de distribución de la capital, también se distribuía, suministrando aprximadamente 77.000 metros cúbicos por día. Los depóstitos de los que disponía el Canal a la altura de 1929 eran tres, con una capacidad de 58.000, de 181.925 y de 447.622 metros cúbicos. En cuanto al depósito elevado, tenía capacidad de 1.500 metros cúbicos de cabida. La central elevadora disponía de electrobombas capaces de elevar 1,4 metros cúbicos por segundo a 35 metros de altura. (Ayuntamiento de Madrid, 1929)

Mapa 3-3. Plano general del Canal de Isabel II y perfiles de las presas

CANal de IsABel II.

ABASTECIMIENTO DE AGUA DE MADRIO

PLANO GENERAL

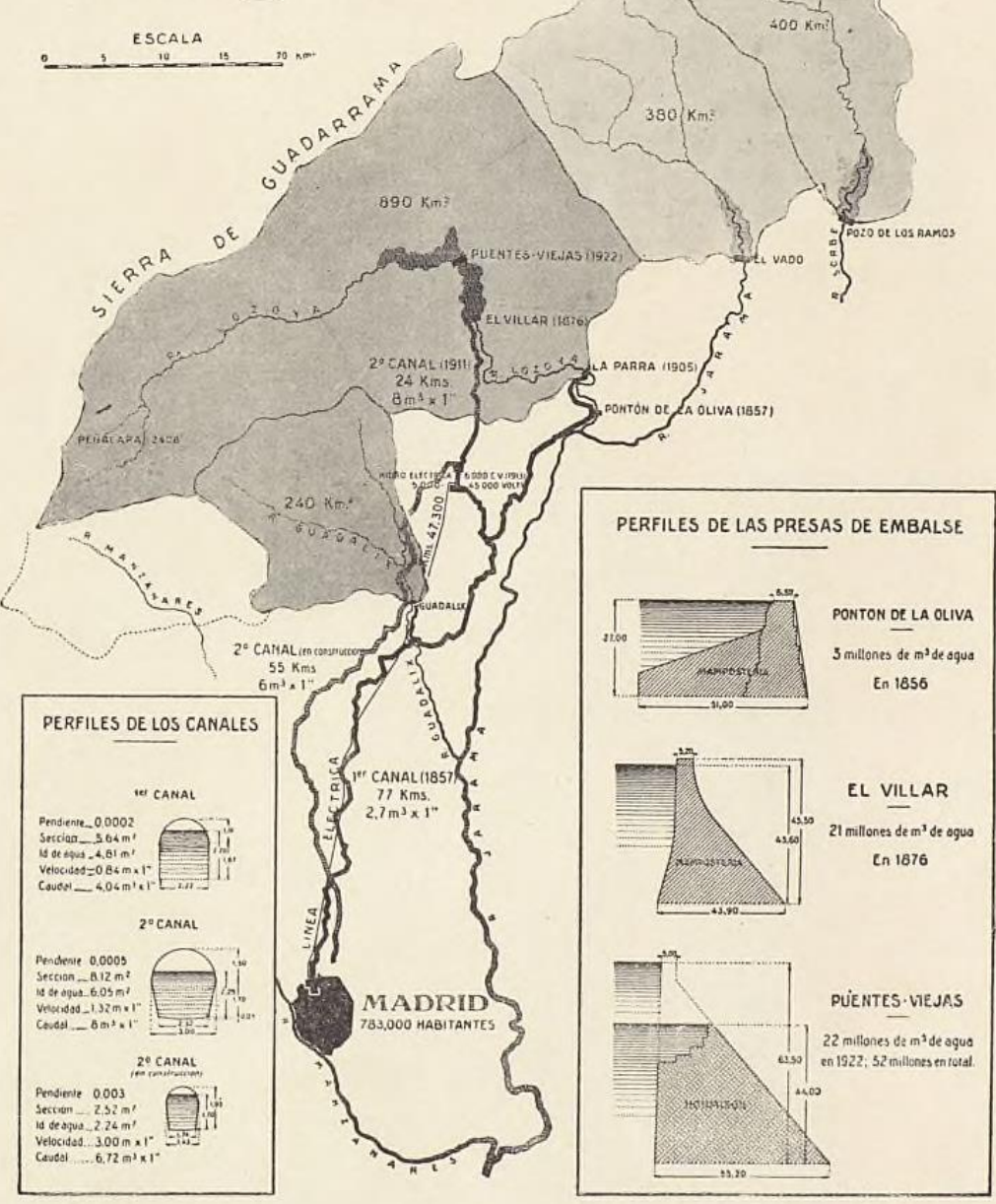

Fuente: (Ayuntamiento de Madrid, 1929, p. 113) 


\subsection{4. ¿Municipalización del Servicio de agua en Madrid?}

El conflicto existente entre el Canal de Isabel II y la Sociedad Hidráulica Santillana tuvo una de sus manifestaciones en el debate acerca de la posible municipalización del servicio de agua.

La municipalización del servicio de agua en Madrid resultó particular, si nos ceñimos a lo que el propio término de municipalización. En este sentido, hay que tener en consideración diferentes factores que nos permitan entender las prácticas que se llevaron a cabo de manera fáctica. La responsabilidad que tuvieron y el papel que jugaron las instituciones, por ejemplo, en lo que respecta a la financiación de las obras para extender la red de distribución. Por sentencia del Tribunal Supremo dictada en diciembre de 1915 se confirmó que el coste de las acometidas de las arterias principales para el abastecimiento de los Barrios Altos derivadas del nuevo depósito "eran de cuenta y cargo del Ayuntamiento de Madrid y los propietarios interesados" y no del Canal de Isabel II (Rueda Laffond, 1994, p. 110). Con Sánchez de Toca, en 1907, se barajó la idea del cooperativismo como modo de organización y gestión, no sin

críticas desde algunos sectores, “(...) El Sr. Sánchez de Toca entiende que las cooperaciones de tipo democrático son las más á propósito para habituar á las ciudadanías á la administración directa de sus intereses colectivos, pues se teme que la nacionalización y municipalización de la economía, sin estar preparados los espíritus, son ocasionadas á fracasos, incluso, el descrédito" (Grael, 1909, pp. 891-892).

El conflicto con la empresa Hidráulica Santillana promovió nuevamente las tesis a favor de la municipalización del servicio. Por Real Orden de 25 de diciembre de 1925, se intentó dar solución al problema desde el Ayuntamiento de Madrid, entendiendo como conveniente la municipalización del Canal. Se estableció una Comisión y se estudió el asunto dando por resultado el Proyecto de municipalización del Canal de Isabel II, en 1926, con el Informe del arquitecto Manuel Martínez Ángel y el ingeniero de caminos Pedro González Quijano. Las críticas desde varios sectores fueron palpables. Así se referían al proyecto en la Revista de Obras Públicas en 1927; (...) sentar la urgencia de traer aguas a Madrid en cantidad suficiente; se hace notar que el Canal tiene plan de obras y medios de ejecutarlo, y que, por tanto debe realizarlo; se establece lo inadmisible de la injerencia de una Empresa particular estorbando el servicio público del Estado, y se termina haciendo notar que la municipalización es a todas luces 
extemporánea y en contraposición con el sentir general del vecindario, y que es una nueva complicación y una traba más que ha surgido, retrasando de nuevo las obras del Canal, que son las que resuelven el problema sin perjuicio de que se deje la mayor libertad de concurrencia al suministro público. Continúa, (...)es verdaderamente absurdo que existiendo una entidad modelo en su género, que dispone de todos los elementos para llegar a resolver por completo el problema del abastecimiento de la Corte sin más que realizar unas obras de relativa poca importancia, y para lo cual cuenta con recursos propios suficientes, esté la capital de la Nación expuesta al gravísimo conflicto de quedar sin agua por la injerencia de un interés particular opuesto al del vecindario, complicado con la inoportuna idea de la municipalización, que viene a poner nuevas dificultades a un problema cuya resolución no exige sino una ínfima cantidad de sentido común y la energía necesaria para sostener el interés público por encima de todo (J.L.U, 1927, p. 298). Finalmente, la municipalización del Canal como modo de organización quedó desestimada, promovido, en buena medida, por la incapacidad del Consistorio madrileño para abonar al Estado la tasación del Canal.

Las disputas con la Hidráulica Santillana influyeron en la ralentización en las obras de distribución de agua. Del todo importante para continuar con las obras de nueva planta, que se habían paralizado, fue la autorización del empréstito del Canal que podía llegar hasta los sesenta millones de pesetas Real Orden de abril de 1928. En esta Real Orden, también se reiteraba el derecho a la Hidráulica Santillana a seguir con la distribución del agua en la ciudad. Las pugnas entre las dos compañías (véase como ejemplo de la pésima relación, la respuesta de Sánchez de Toca al Marqués de Santillana en 1908 (Sánchez de Toca, 1925, pp. 20-23)), no finalizaron hasta 1930, momento en que se adquirieron las acciones de la Hidráulica por la Unión Eléctrica Madrileña (Cayón García, 2002).

\subsection{Las cuentas económicas del Canal de Isabel II}


En este apartado, se tratará de describir la evolución a lo largo de los años de las cuentas del Canal de Isabel II.

Primeramente, cabe destacar que la relación que se mantenía entre las condiciones higiénicas del agua y la importancia del estado y progreso de las obras del Canal de Isabel II (o Canales del Lozoya desde la instauración de la II República), se manifestaba, también, en la obligatoriedad de que el ingeniero director que ocupase la Dirección Técnica, presentase anualmente una memoria en la que no sólo debían verse recogidos estos aspectos, sino también su vinculación con el estado de la salubridad de la población madrileña. Así pues, el valor documental de estas Memorias es de suma importancia, en la medida en que se refleja la marcha de dicha entidad desde diferentes aspectos. Por el contrario, hay que destacar la inexistente presencia de una memoria económica anual, que permita realizar un estudio económico continuo del Canal. Si bien, en las Memorias anuales sí se hacen alusiones a algunos aspectos económicos, dado que no es el objetivo central de las mismas, no son exhaustivos ni sistemáticos ${ }^{40}$. Pese a lo anterior, dado que el objeto preferente de la presente investigación no es realizar un análisis económico de las cuentas del Canal, disponemos de información extraída de las Memorias anuales (a sabiendas de las limitaciones expuestas arriba), así como de un interesante artículo del Ingeniero de Caminos Don Ramón Sánchez Moreno, publicado en 1933 en la Revista de Obras Públicas (Sánchez Moreno, 1933).

Hay que considerar que el cambio de los propios reglamentos de la entidad tiene influencia en la realización de cualquier análisis sistemático y continuo en el tiempo. Por ello, el presente trabajo se centrará en mayor medida en los datos de situación entre $1907^{41}$ y 1933, dado que el último reglamento hasta el estallido de la Guerra Civil Española permaneció inamovible entre los años citados. El último anuncio de Plan de obras que trataremos será el correspondiente al empréstito autorizado por el Gobierno, por el que se destinaron cuarenta y cinco millones de pesetas para las obras destinadas a tratar la insuficiencia de la capacidad de los embalses, conducción y distribución, datado en 1933.

\footnotetext{
${ }^{40}$ En una línea de investigación futura se plantea la ampliación de realizar un estudio económico del Canal de Isabel II- Canales del Lozoya, recurriendo al análisis de los documentos originales de contabilidad.

${ }^{41}$ Hay que tener en consideración en el periodo marcado entre 1867 a 1907, fruto del Reglamento aprobado del momento y sus consecuente dependencia del Ministerio de Fomento, las cuentas del Canal de Isabel II se veían insertadas en los Presupuestos Generales del Estado, por lo que resultaría difícilmente comparable a las del régimen posterior, que permaneció inamovible desde 1907 hasta el final de nuestro objeto de estudio, con comienzo de la Guerra Civil Española.
} 


\subsubsection{Ingresos y Gastos del Canal}

Como puede verse en los gráficos adjuntos, en términos generales, entre 1908 y 1929 el Canal mantuvo sus cuentas en valores positivos. El superávit fue manifiesto. Gracias, en buena medida, a esta buena solvencia, el Canal pudo llevar a cabo las obras de mantenimiento y reparación. Pese a la tendencia al alza, también, de su cuenta de gastos, en especial a partir de 1918, los ingresos también se incrementaron.

Gráfico 3-5. Cuenta de ingresos del Canal de Isabel II entre los años 1908-1929

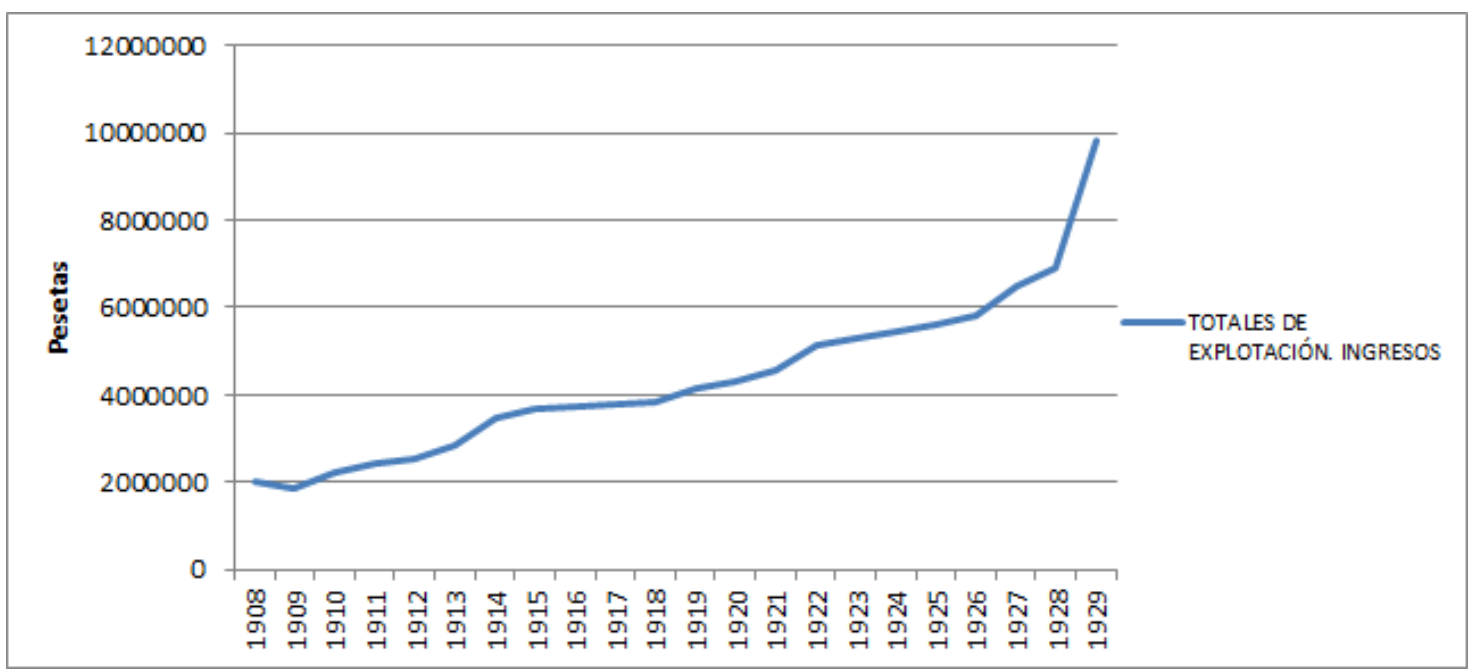

Fuente: Memorias del Canal de Isabel II para los citados años y (Sánchez Moreno, 1933) 
Gráfico 3-6. Cuenta de gastos del Canal entre 1907-1929.

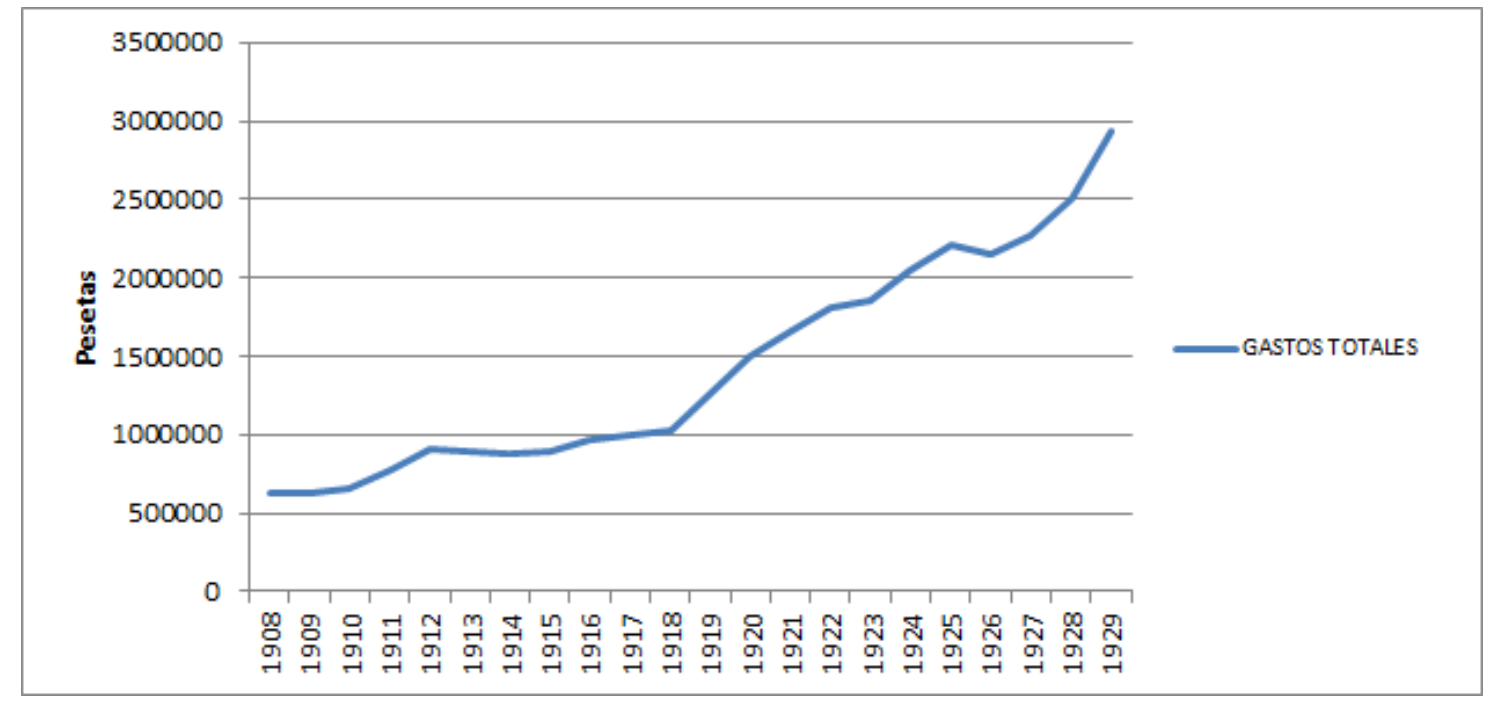

Fuente: Memorias del Canal de Isabel II para los citados años y (Sánchez Moreno, 1933)

\subsubsection{La cuenta de explotación: ingresos.}

La vida económica de cualquier entidad puede estudiarse desde diferentes perspectivas. Una de ellas es mediante el análisis de la cuenta de explotación, que como herramienta de análisis, permite, entre otras cosas, obtener una panorámica de la realidad financiera. Como ya ha sido mencionado, el Canal de Isabel II-Canales del Lozoya, se forjó en 1851 por Bravo Murillo, con una fórmula que podría denominarse como industrial, al estar bajo la gestión económica de un Consejo de Administración, delegada por el Estado $^{42}$.

En 1867, se produjo un modificación, de modo que la organización del Canal de Isabel II pasó a formar parte del Ministerio de Fomento, como un servicio más ofrecido por el Ministerio, lo que conllevó a que los beneficios económicos se recaudasen a favor del Tesoro Público y los créditos y gastos de explotación de las obras quedaran inmersos en los Presupuestos Generales del Estado. Hubo muchas voces discordantes con esta modificación sufrida en 1867 y la consecuente dependencia estatal del Canal de Isabel II, pero hubo que esperar a 1907 para que se produjera un cambio de régimen de la entidad, volviéndose al anterior sistema de los Consejos de Administración de los orígenes, en los tiempos de Bravo Murillo. Entre otros aspectos, en 1907 el Canal

\footnotetext{
${ }^{42}$ Se trataría de una fórmula estatal usada posteriormente para la organización de otros servicios públicos estratificados, como la llevada a cabo en el sector del ferrocarril.
} 
vuelve a ser administrador de sus propias cuentas, especificando de manera explícita los ingresos por venta de agua y energía eléctrica que paraban al Tesoro Público.

En el gráfico sobre los ingresos de explotación. 1907-1933. Aparecen representados los ingresos anuales del Canal de Isabel II- Canales del Lozoya, con el concepto desglosado en función de los ingresos por venta de energía eléctrica, a partir de 1913, y por venta de agua.

Gráfico 3-7. Evolución de los ingresos anuales por venta de agua, venta de energía eléctrica y totales del Canal de Isabel II . Años 1907-1932

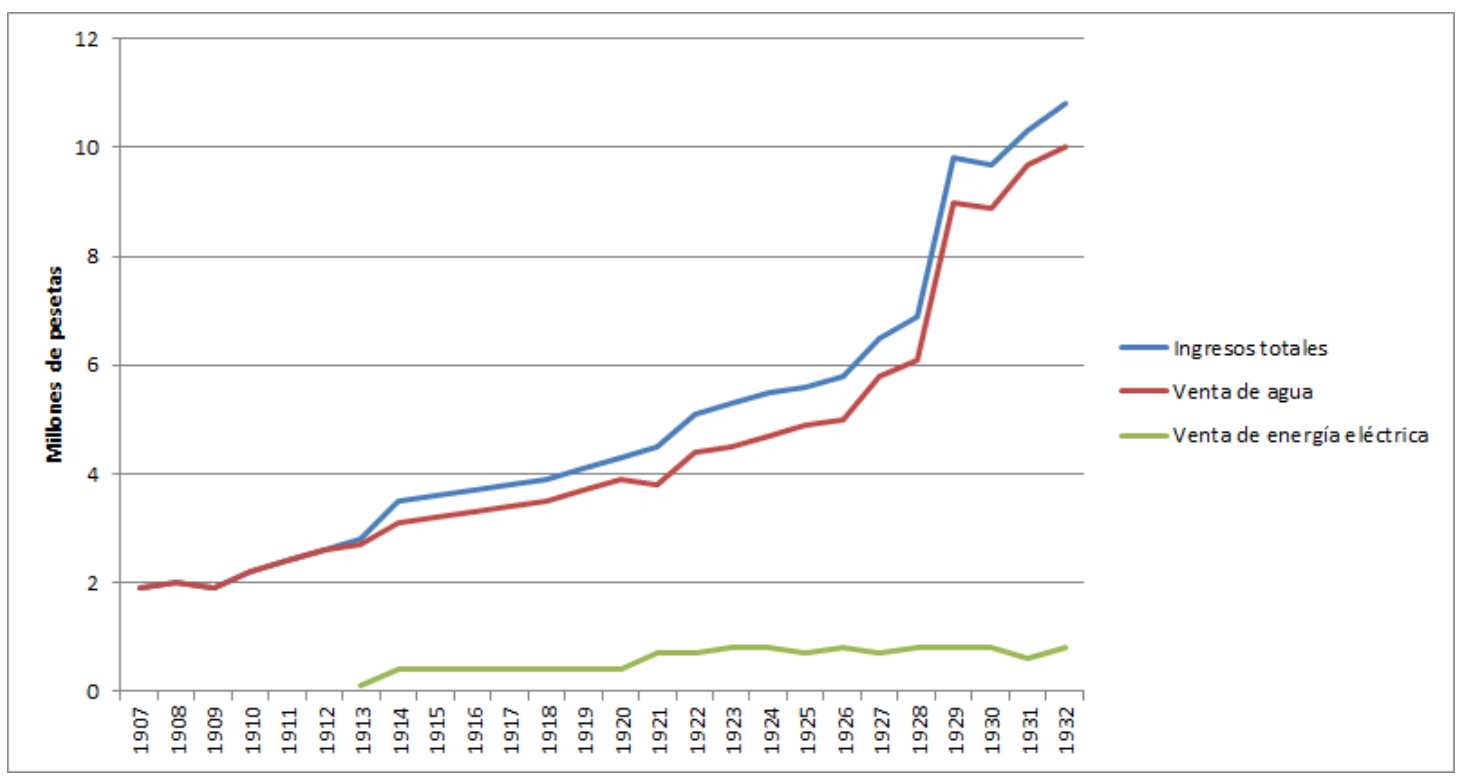

Fuente: (Sánchez Moreno, 1933, pp. 511-516)

La venta de energía eléctrica procedía de la central eléctrica de Torrelaguna, que fue establecida como medio para aprovechar el salto de agua del desnivel entre el Canal Transversal (de la Presa del Villar) y el Canal de conducción antiguo. La producción de energía eléctrica fue aprovechada para accionar las bombas situadas en el depósito elevado de la capital y para la venta a diferentes compañías distribuidoras de energía eléctrica (Sánchez Moreno, 1933, p. 512). Tal y como puede verse en el gráfico, la mayor parte de los ingresos del Canal de Isabel II- Canales del Lozoya, procedía de la venta de agua. Este reporte de ingresos, mantuvo un aumento continuado durante todo el periodo de estudio, incrementándose notoriamente en 1929, fruto, principalmente, del procedimiento de reorganización de los sistemas de facturación que conllevaron el ingreso de numerosos cobros atrasados. Así, en términos generales, el continuado aumento de ingresos por venta de agua en la ciudad de Madrid se debió al aumento del 
consumo de este bien, teniendo en consideración que las tarifas generales que se pagaron por consumo de agua, no experimentaron cambios desde 1906, tal y como veremos más adelante. Además, las tarifas que se pagaban por adquisición de agua de consumo, fueron siempre consideradas como bajas, en comparación con el precio pagado en otras capitales. Por vivienda y día en la ciudad de Madrid se pagaban entre 0.005 a 0.30 pesetas, de manera que el tramo entre 0.20 y 0.30 pesetas se aplicaba al consumo del primero y segundo metro cúbico de agua, respectivamente. Además, es necesario tener en consideración, tal y como ya se ha mencionado en líneas precedentes, que el agua consumida por los servicios públicos municipales (ya fuera el destinado al riego de parques, abastecimiento de fuentes, limpieza de calles, o el consumo de locales institucionales, tales como hospitales e instituciones de beneficencia, entre otros) era dispensado de manera gratuita y el conjunto del volumen para estos cometidos suponía, junto a las pérdidas de la propia red de abastecimiento, un 31,2 por ciento del total de agua que era consumida en la capital (Sánchez Moreno, 1933, p. 512).

Gráfico 3-8. Precio del metro cúbico de agua en domicilios para varias ciudades.

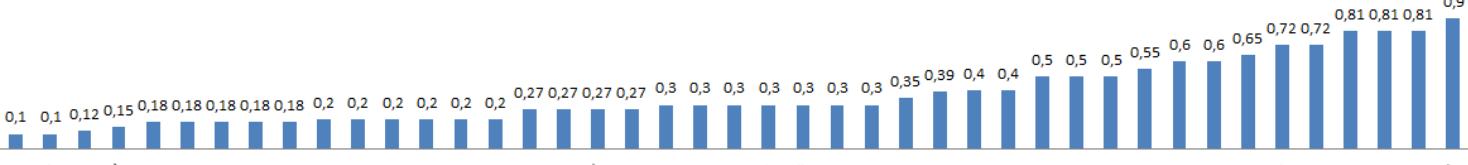

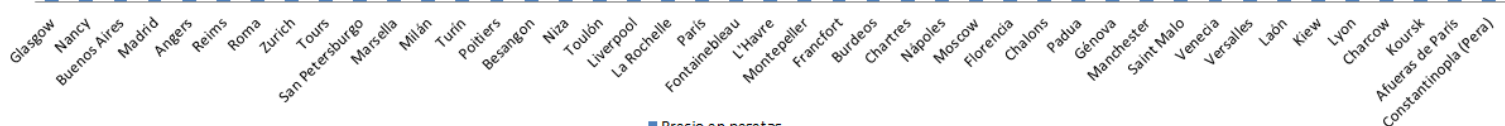

Fuente: elaboración propia. Datos obtenidos de (Melgosa Olaechea, 1912, p. 131)

\subsubsection{La cuenta de explotación: gastos.}

En el gráfico, pueden verse representados los datos correspondientes a los gastos de explotación del Canal de Isabel II- Canales del Lozoya, en los conceptos de gastos de administración, por un lado, y de explotación, conservación y reparación, por otro, así como los totales. Si bien, en términos generales, los gastos experimentaron un aumento continuado, éste fue más acusado a partir del año 1926. La explicación se hallaba, principalmente, en el aumento de gasto en personal, fruto de las modificaciones sufridas en las bases de trabajo del personal de oficinas y de los obreros, y, en menor medida, al incremento en el número de servicios ofertado. 
Gráfico 3-9. Evolución de los gastos del Canal de Isabel II, por tipo de gasto. Años 1907-1932

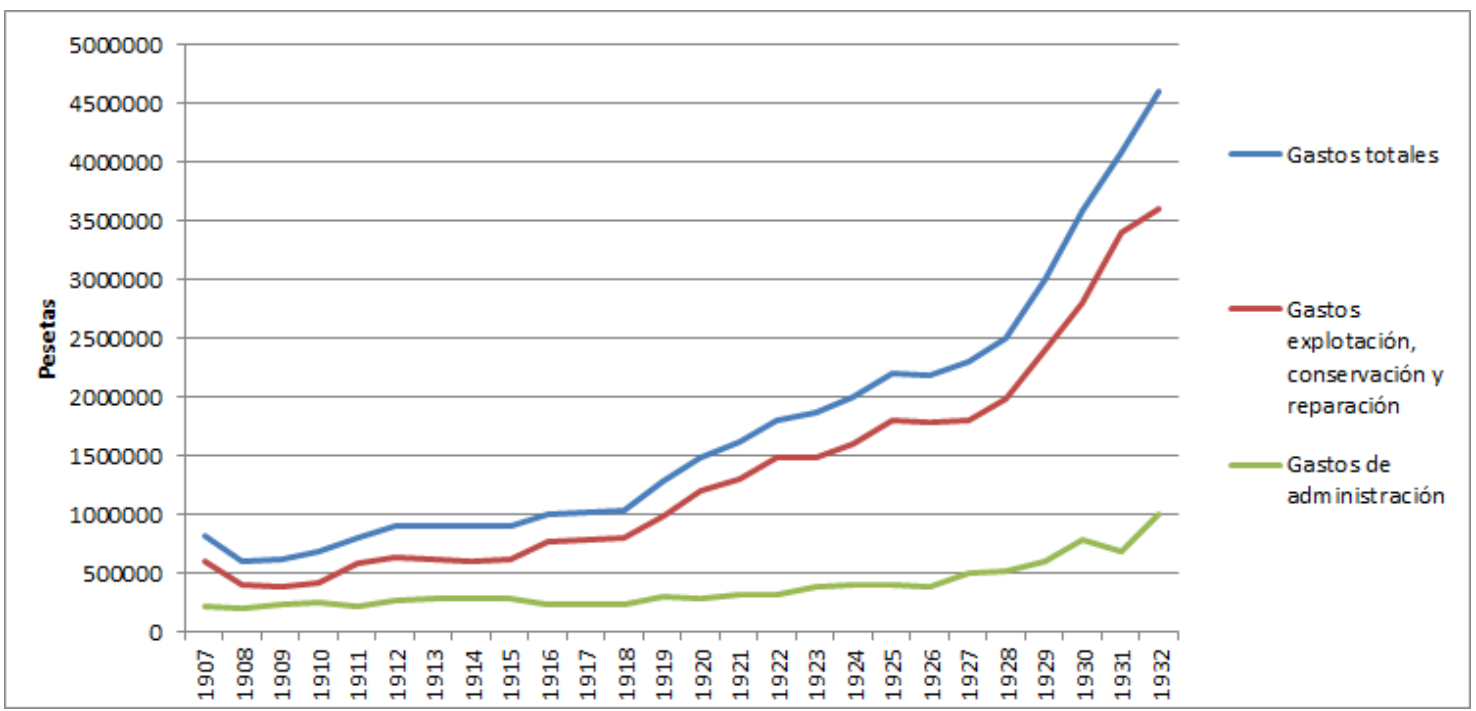

Fuente: Elaboración propia. Datos obtenidos de (Sánchez Moreno, 1933, pp. 511-516)

\subsubsection{Beneficio de explotación-}

En el gráfico siguiente, pueden verse representado los datos correspondientes a los beneficios obtenidos por el Canal de Isabel II- Canales del Lozoya, como diferencia de los ingresos y gastos correspondientes a cada año. Para cada valor representado, se ha calculado y representado la curva de tendencia exponencial, con el objetivo de ilustrar y poder comparar cómo fueron las fluctuaciones de gastos e ingresos en relación a las mismas. Como puede verse a partir del gráfico, se observa que el beneficio de explotación permaneció en continuo incremento, a excepción del último periodo analizado, fruto del incremento en los gastos, tal y como se señaló en el apartado anterior correspondiente al gasto de explotación. 


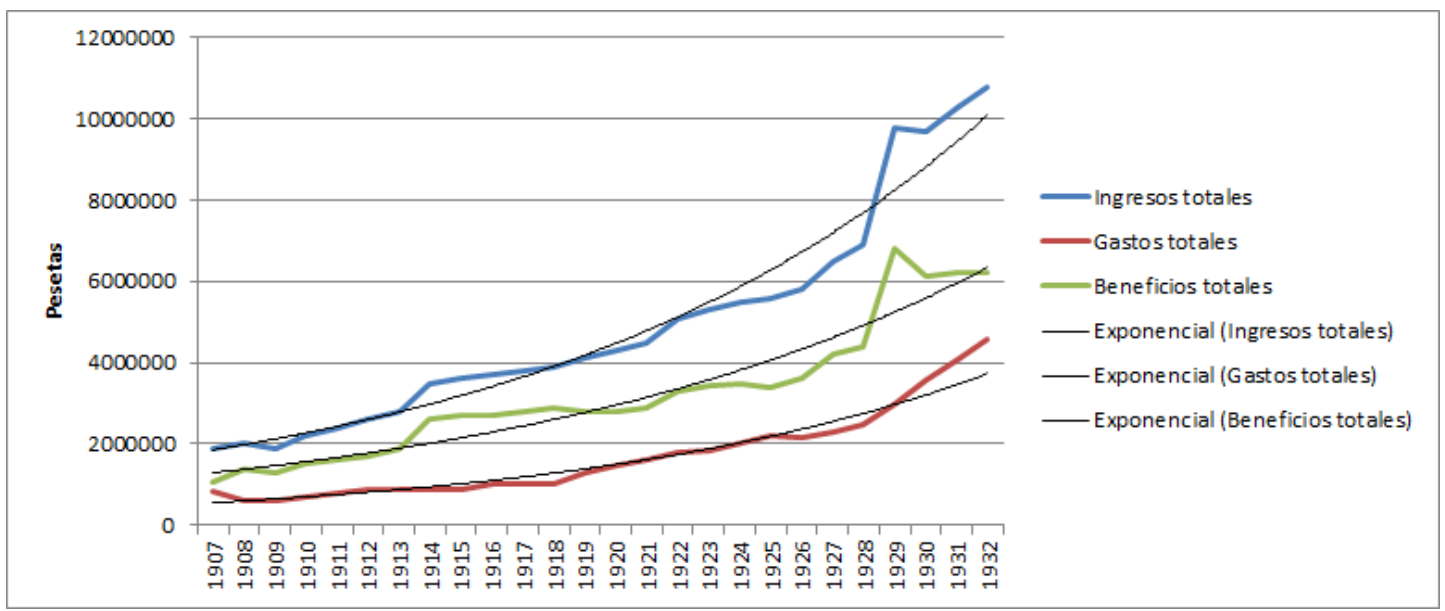

Fuente: Elaboración propia. Datos obtenidos de (Sánchez Moreno, 1933, pp. 511-516)

Respecto a la variación del Coeficiente de explotación ${ }^{43}$, el promedio, teniendo en cuenta el periodo completo de estudio, de 1907 a 1932, fue de 0.349. Las fluctuaciones sufridas en el mismo fueron notables, alcanzando el máximo en el año 1907 con un valor de 0.451 y con mínimos de 0.243 en el año 1915. Una posible explicación, puede radicar en la nueva organización del Canal de Isabel II en 1907 y los efectos del cambio de una organización claramente burocratizada a una de tipo industrial. Respecto al segundo periodo de bruscos cambios, acaecido a partir de 1929, podría explicarse por la mejora sucedida en 1929, con un aumento brusco de los ingresos, fruto del nuevo sistema de facturación implantado, que, como ya se citó anteriormente, conllevó a un cobro de recibos atrasados. Asimismo, desde ese mismo año, los gastos derivados del pago de los salarios del personal que prestaba servicios en el Canal aumentaron notablemente.

\footnotetext{
${ }^{43}$ Para una interpretación sintética del coeficiente de explotación hay que tener en consideración que, dado que este indicador relaciona los ingresos obtenidos con los gastos necesarios para conseguir dichos ingresos durante un período de tiempo determinado, el ratio del cálculo expresado en porcentaje, es lo que representa. En este sentido, una entidad es más eficiente a menor valor del coeficiente se experimente. Por poner un ejemplo tomando el caso de estudio que nos compete, en el año 1907 el Canal de Isabel II para ingresar 100 pesetas, necesitaba gastar 45.
} 


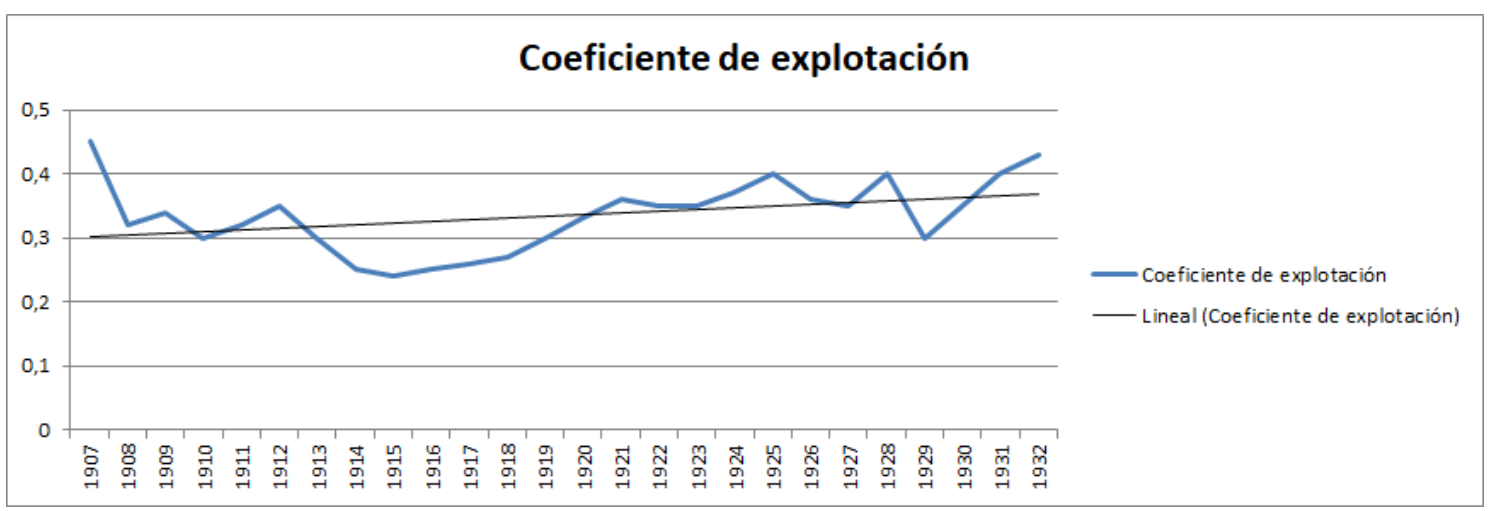

Fuente: Elaboración propia. Datos obtenidos de (Sánchez Moreno, 1933, pp. 511-516)

Si comparamos el crecimiento de la población junto a los gastos, ingresos y beneficios medios por habitante y año, puede observarse en el gráfico 3.11, que se produjo un aumento casi constante a lo largo de todo el periodo de estudio del beneficio medio por habitante hasta llegado el año 1929, momento en que se asiste a una reducción del mismo. Entre los factores explicativos, puede aludirse el incremento de los gastos sufridos por el aumento de los jornales de los trabajadores dependientes del Canal y, especialmente, el hecho de que a partir de 1929 comenzó a sufrirse una importante insuficiencia de abastecimiento fruto de la constante demanda de abonos de agua que no podían ser satisfechos. Este es un asunto muy importante, que nos pone en la antesala de situación real del abastecimiento de agua en la ciudad de Madrid, marcada por la insuficiencia de oferta de agua ante una población en constante crecimiento. Así, a la par que se producía un aumento constante de petición de abonados, existía una insuficiencia de abastecimiento y una paralización de la extensión de la red, que conllevó a la restricción de nuevos abonos. 
Gráfico 3-12. Evolución del gasto, ingreso y beneficio por habitante y año del Canal de Isabel II. Años 1910-1932

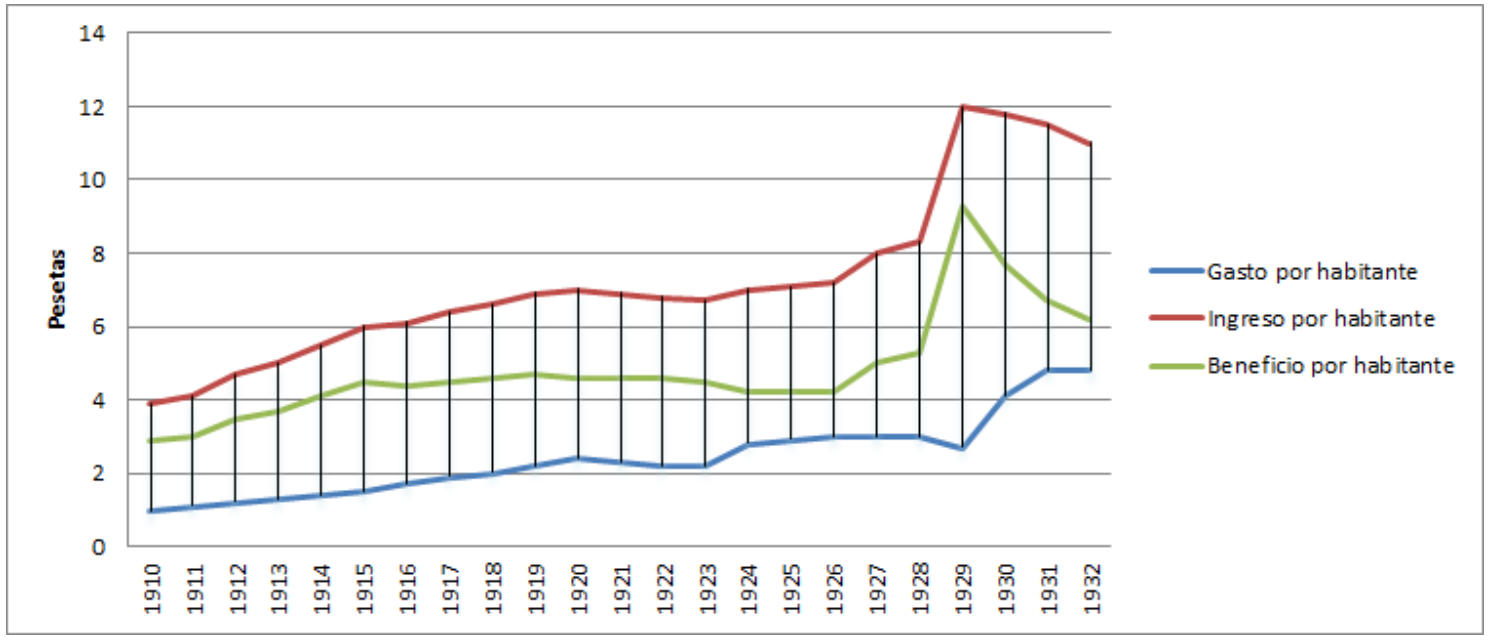

Fuente: Elaboración propia. Datos obtenidos de (Sánchez Moreno, 1933, pp. 511-516)

Asimismo, como complemento del anterior análisis descriptivo sobre el beneficio por habitante y su obvia relación con los gastos e ingresos, resulta interesante la realización de una representación gráfica acerca del agua vendida, las tarifas medias y los gastos y beneficios por metro cúbico de agua. Figura 6. Sobre tarifas. Aparece representada la variación de la tarifa media de agua experimentadas entre 1921 a 1932, obtenida mediante la relación entre el ingreso por venta de agua y el número de metros cúbicos facturados. (Sánchez Moreno, 1933, p. 514).

Gráfico 3-13. Evolución del agua vendida por el Canal de Isabel II. Años 1921-1932

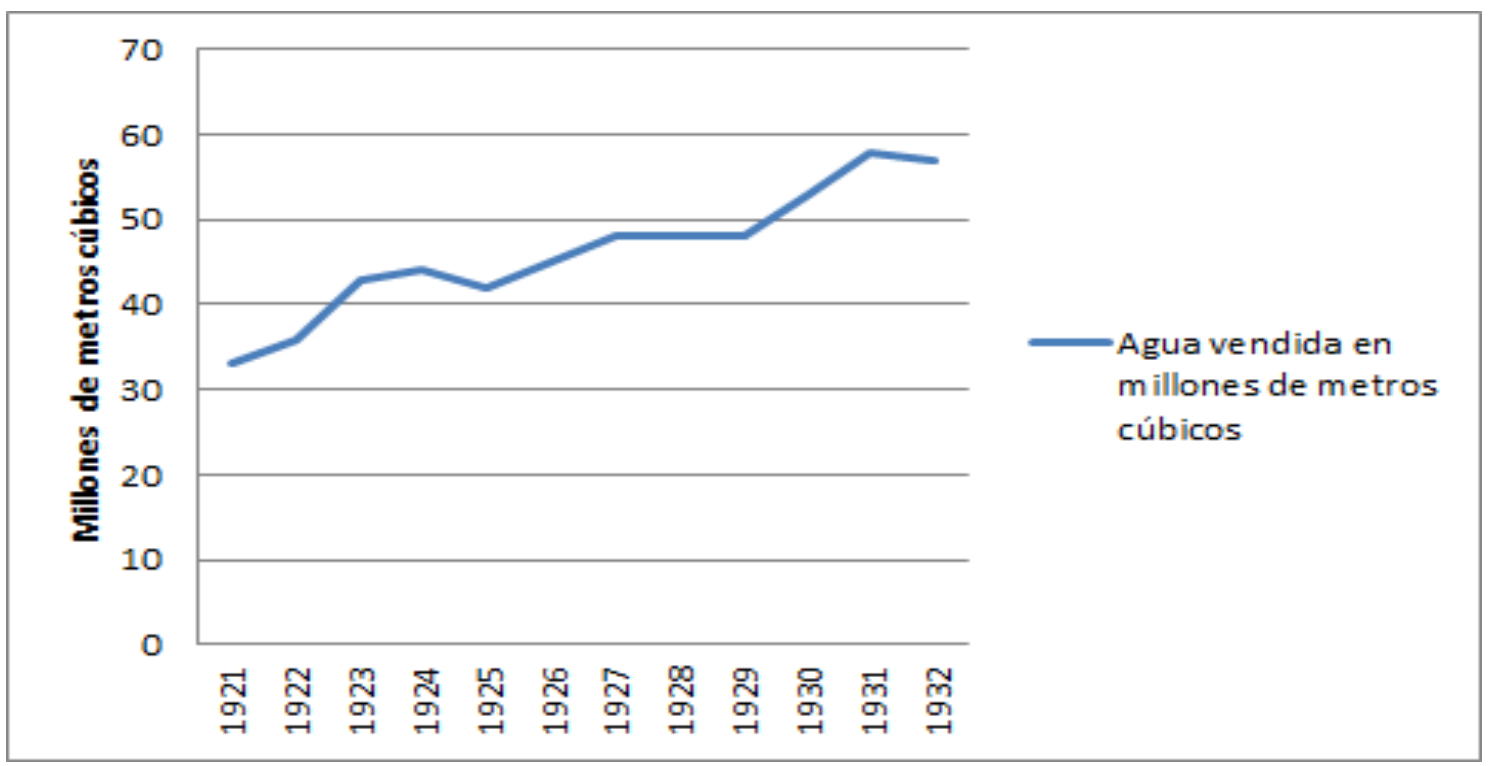

Fuente: Elaboración propia. Datos obtenidos de (Sánchez Moreno, 1933, pp. 511-516) 


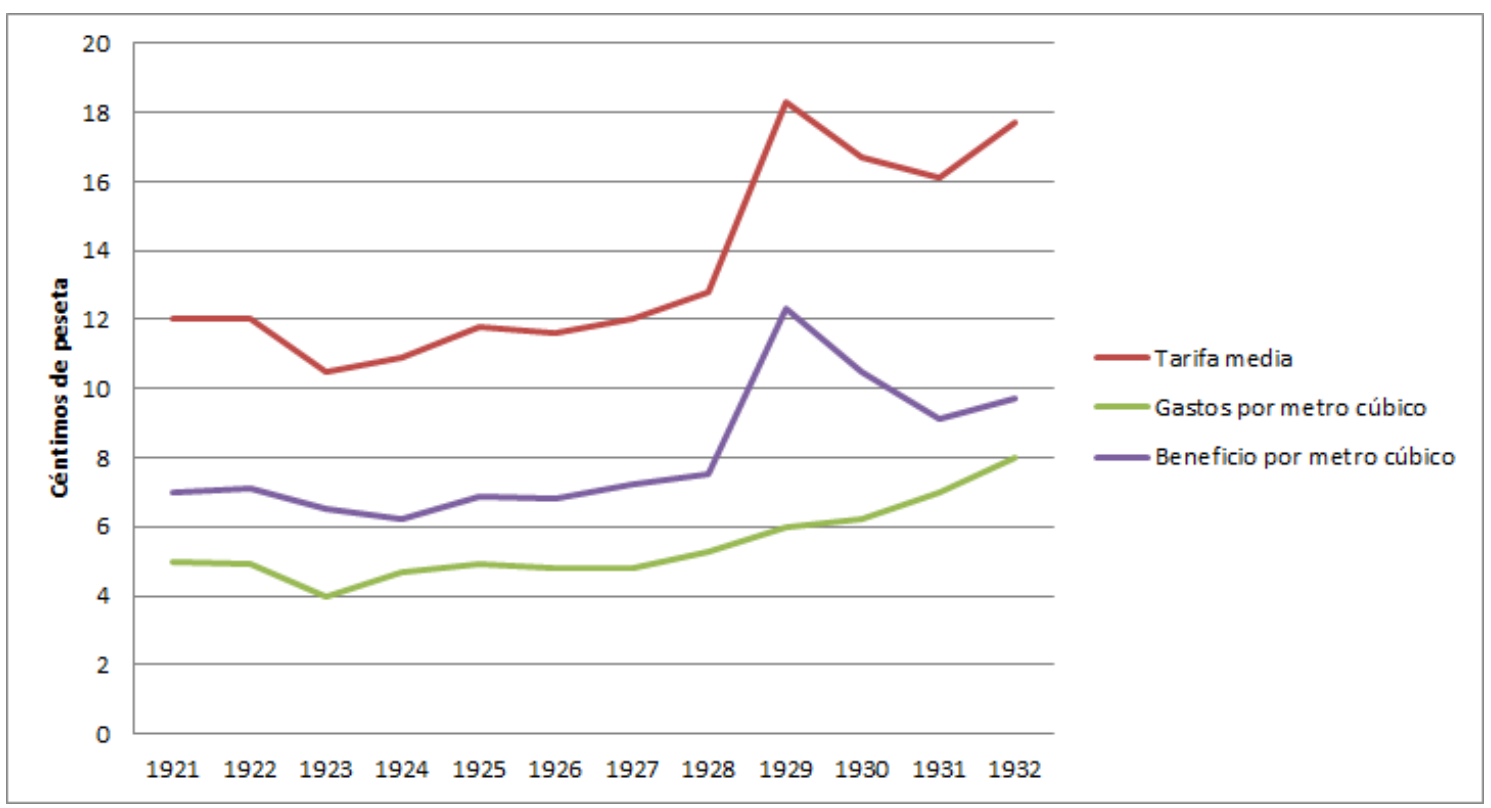

Fuente: Elaboración propia. Datos obtenidos de (Sánchez Moreno, 1933, pp. 511-516)

\subsubsection{La cuenta de capital.}

Las aportaciones estatales al Canal de Isabel II-Canales del Lozoya, podrían dividirse, en términos generales, en la inversión destinada a la construcción de las obras que constituyeron su génesis y por los beneficios netos de la entidad, que estuvieron destinados a la implementación de obras e instalaciones nuevas, en vez de ser retirados los fondos de manera anual. En este sentido, siguiendo la lógica anterior, se realizará un análisis descriptivo de las cuentas de capital a partir de 1907, momento en que el Canal se reorganizó en Consejo de Administración. Para poder emitir datos sobre este primer año, tomaremos de ejemplo el análisis realizado por Sánchez Moreno (Sánchez Moreno, 1933), que toma como valor aproximado el valor de instalaciones y obras de periodos anteriores para poder obtener una estimación del capital estatal en 1907.

Tal y como ha sido apuntado en líneas precedentes, a lo largo de lo que puede considerarse como el primer periodo del Canal, datado entre los años 1851-1865, se llevaron a cabo las siguientes obras de construcción: las presas del Pontón de la Oliva, de Navarejos y la de Guadalix; la construcción del denominado Canal Antiguo; el primer y segundo depósitos; diversas tuberías de distribución, galerías, alcantarillas y riegos. Todo ello, con un valor de 52.903 .397 pesetas (Sánchez Moreno, 1933, p. 514). 
La Presa del Villar, canales y presas de la Parra y del Mesto; el Canal Transversal; diversas acequias; la construcción del tercer depósito y la ampliación de la red de distribución comenzada en el periodo anterior, fueron obras llevadas a cabo en el segundo periodo (ente los años 1865-1907). El valor de estas obras fue de 18.173.921 pesetas (Sánchez Moreno, 1933, p. 514).

Atendiendo al valor de las obras en los dos periodos previos a 1907, éste ascendió a 71.077.318 pesetas, por lo que va a considerarse esta cifra como el valor inicial respectivo a la aportación de capital estatal. A partir de este año, para el cálculo de capital, se considerará a partir del aumento del beneficio líquido obtenido por el Canal de Isabel II- Canales del Lozoya correspondiente al ejercicio anterior. El beneficio líquido es obtenido como resultado de la suma y la resta del importe de los intereses de los valores (que eran propiedad del Canal) junto a sus cargas financieras, al beneficio de explotación.

Gráfico 3-15. Capital, beneficios líquidos y rentabilidad del Canal de Isabel II

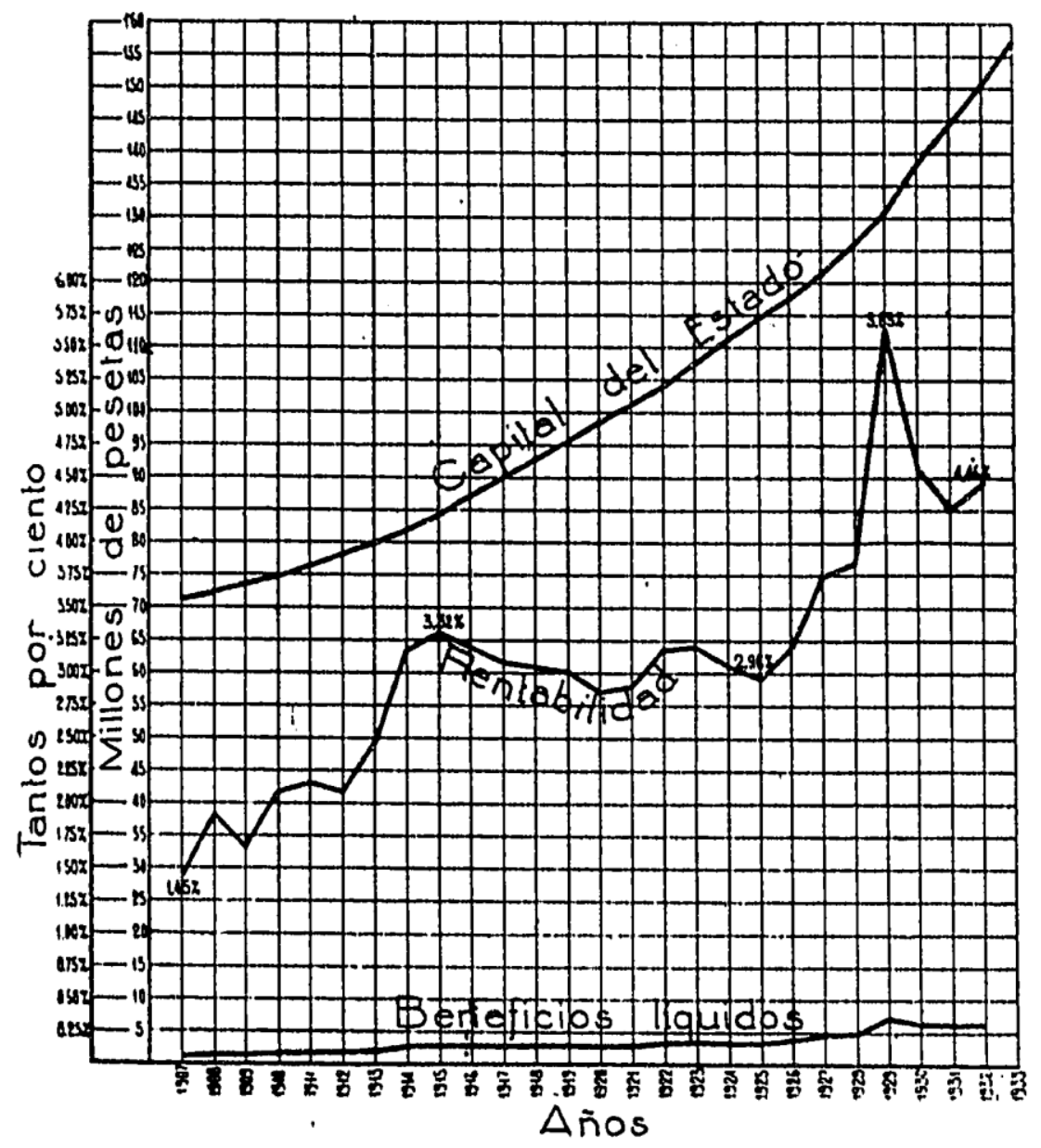

Fuente: (Sánchez Moreno, 1933, p. 515) 
A través del gráfico, podemos ver que a partir de 1925 los intereses de los valores propiedad del Canal gozaron de importancia, fruto, en buena medida, del hecho de que no se invirtió todo el capital estatal destinado a obras urgentes a estos cometidos, resultando como sobrantes. En 1931, esta cantidad ascendió a 509.861 pesetas.

Respecto a las cargas financieras, éstas no revistieron demasiada importancia. Siguiendo la explicación de Sánchez Moreno (Sánchez Moreno, 1933, p. 515), esto fue debido a que las anualidades destinadas al pago de intereses y amortización del único empréstito que tuvo lugar, en 1908, aparecen incluidos en los gastos de explotación de los años 1908-1924, ante la imposibilidad de ser separados, a sabiendas del error. Sin embargo, según el autor, este hecho no influye en los cálculos, debido a que, de facto, sólo se pusieron en circulación ocho millones y medio de pesetas, de los veinte millones emitidos. Atendiendo a estas explicaciones, Sánchez Moreno obtiene los valores de representación de la figura, en la que puede verse la curva superior correspondiente al capital aportado por el Estado. Tal y como ha sido explicado, el valor para el año inicial, corresponde al capital resultado del sumatorio de la inversión estatal para los dos primeros periodos (1851-1865 y 1865-1907), observándose un incremento del beneficio líquido que corresponde al año anterior al representado. Asimismo, puede verse que en 1932, se alcanzó el de 157.000.000 pesetas, capital destinado a instalaciones y obras, entre otros conceptos. A su vez, los beneficios líquidos de la entidad aparecen representados en la curva inferior de la figura.

Atendiendo al importe del beneficio líquido del Canal y del capital estatal, se obtiene el porcentaje de este capital que representan los beneficios líquidos. A partir de esta serie de valores, se obtiene la curva de rentabilidad, que aparece en la figura anterior. El punto máximo se encuentra en el año 1929, fruto, en buena medida, del reporte de ganancias obtenidas de la reorganización en el sistema de facturación ya mencionado. Para el último año de estudio, 1932, el valor del interés fue de un 4.46 por ciento. Teniendo en cuenta el valor del tipo de interés normal de la época, esté resultaba escaso, además debe tenerse en cuenta que para 1932 "hay muchas obras en construcción y, por tanto, no produce todavía beneficio, no obstante lo cual, se ha considerado capital rentable. Esto, que indudablemente es causa de disminución de la rentabilidad de la empresa, contribuye al saneamiento del activo, por la supresión del importante capítulo 
de intereses intercalarios, que tanto aumenta el coste de las obras" (Sánchez Moreno, 1933, p. 515).

\subsubsection{Consideraciones finales sobre las Cuentas del Canal de Isabel II}

El Canal de Isabel II- Canales del Lozoya gozó de una solidez económica palpable a lo largo del primer tercio del siglo XX.

A partir del año 1930, tal y como pude apreciarse en el gráfico, en el que aparece representado el beneficio por habitante, el servicio de distribución de agua era insuficiente para atender a una demanda en constante crecimiento. Sabedores del problema, el Estado aprobó un plan de obras, con una dotación de cien millones de pesetas, y que debían finalizarse antes de 1941. Asimismo, se aprobó un empréstito por valor de cuarenta y cinco millones de pesetas (Sánchez Moreno, 1933, p. 515).

Las tarifas del Canal fueron consideradas como asequibles, en comparativa con el coste de otras capitales. Asimismo, hay que tener en cuenta que permanecieron prácticamente constantes desde el año 1906. Además, teniendo en consideración que el valor adquisitivo de la peseta disminuyó de 1906 a 1932, algunos autores manifestaban que era una situación que merecía revisión, ya que en valor adquisitivo éstas habrían disminuido.

El hecho de que el Ayuntamiento de Madrid concediese agua gratuita para abastecer los servicios públicos y aplicase tarifas muy reducidas para otros, fue un triunfo. Atendiendo a los datos de la Dirección Técnica del Canal, en 1929 el consumo de agua destinado a estos menesteres suponía un 31.2 por ciento del total de agua. Para el año 1932, si el total de metros cúbicos consumidos fue de 86.399.139, el 31.2 corresponde a 26.956.531 metros cúbicos de agua que consumirían los servicios públicos del Ayuntamiento. La tarifa media era de 0.175 , por lo que el valor total del consumo municipal ascendía a 4.680 .000 de pesetas, “aun afectándole de un prudencial coeficiente de reducción, por pérdidas en la red, todavía resta una importante subvención que el Estado viene otorgando anualmente al Ayuntamiento, con cargo a la economía de Canales del Lozoya” (Sánchez Moreno, 1933, p. 516). 


\subsection{Conclusiones}

Este capítulo ha pretendido mostrar los acontecimientos más relevantes vinculados a la gestión del agua en la capital. Indudablemente, el Canal de Isabel II fue el protagonista en la serie de acciones llevadas a cabo.

El fracaso de las iniciativas públicas y privadas llevadas a cabo durante el siglo XIX llevó a que, en 1851, el Canal de Isabel II se instaurase como entidad pública para suministrar el agua potable en la ciudad de Madrid. Desde 1867 hasta 1907, el Canal pasó a formar parte del Departamento de Obras Públicas del Ministerio de Fomento, ante la incapacidad del Ayuntamiento para atender a los cometidos. La titularidad estatal y el establecimiento de la Comisaria Regia y el Consejo de Administración del Canal, fueron los elementos definitorios administrativos y de gestión. Si bien, las figuras de Comisaria Regia y el Consejo de Administración afirmaban cierta autonomía respecto al Ministerio de Fomento, en los ámbitos técnicos, contables y administrativos. Así, las vías alternativas propuestas, como fue el arrendamiento a particulares y la municipalización del servicio, se desestimaron.

Pese a la importancia ineludible de la creación del Canal de Isabel, dada su relevancia en lo que respecta a la modernización y extensión del servicio de abastecimiento de agua en la ciudad de Madrid, la realidad es que ni con su evolución, ni con la creación de la Sociedad Hidráulica Santillana, fue suficiente para hacer frente a la demanda de una urbe caracterizada, en el periodo de estudio, por un crecimiento poblacional sin precedentes ${ }^{44}$.

\footnotetext{
${ }^{44}$ Esta temática será abordada de manera pormenorizada en el capítulo número cinco de la presente tesis
} 


\section{La calidad de las aguas de abastecimiento.}

Teniendo en cuenta que los mecanismos de tratamiento de las aguas de consumo, tales como la filtración y la cloración, fueron los principales mecanismos de que se dispuso para mejorar la calidad de las aguas (D. Cutler \& Miller, 2005) en el presente capítulo se hará alusión a la evolución de los sistemas de análisis del agua, en aras de remarcar la importancia que en la misma tuvo el tránsito de la realización de análisis puntuales a la implantación de los análisis sistemáticos de las mismas, tomando como caso de estudio la ciudad de Madrid. Estos análisis supusieron el paso previo ante la puesta en práctica y el establecimiento de proyectos que tuvieron por objetivo los tratamientos de depuración mediante la construcción de estaciones depuradoras, a los que también dedicaremos una parte de esta sección.

\subsection{Los primeros análisis de las aguas de consumo. Los análisis no sistemáticos.}

La importancia de la depuración o purificación de aguas negras fue considerada, especialmente desde los años veinte del siglo XX, un bastión ineludible a la hora de atender a los problemas de saneamiento acaecidos en toda España. "Las tendencias de la higiene en los tiempos modernos han venido a plantear en España, aunque con un retraso de consideración, el problema de la purificación de las aguas negras, como complemento esencial, indispensable de una red perfecta de saneamiento" continúa "poco se ha hecho aún, nada, puede decirse, si comparamos el saneamiento de nuestras poblaciones con el establecido en los países que marchan a la cabeza del progreso; pero ya se habla de la necesidad de acometer el problema, reconociendo su importancia, y esto es algo, si se tiene en cuenta que su resolución racional afecta directamente a la salud pública y que hay multitud de enfermedades que pueden evitarse, y se evitan en gran parte, con el establecimiento de sistemas perfectos". (Herrán Rucabado \& Escario Núñez del Pino, 1926, p. 39).

El ideal de sistema de saneamiento se basaba, en términos generales, en la recogida de aguas negras que se producen en un núcleo urbano de forma que éstas se hallen completamente aisladas en los colectores de la red y sean conducidas fuera de los 
límites de la población en cuestión. El problema principal era que, si bien esto se había conseguido realizar en algunas poblaciones, en mayor o menor medida, el sistema continuaba estando caracterizado por tener importantes fallas relativas al destino final de las aguas negras de manera que "no se completa el sistema, no se hace perfecto, si las aguas negras que con tanto cuidado hemos conducido fuera de la población a pocos metros de las últimas casas las dejamos en libertad, sin precaución alguna, arrojándolas al curso de agua más próximo” (Herrán Rucabado \& Escario Núñez del Pino, 1926, p. 39).

El problema del abastecimiento de agua en la ciudad de Madrid no sólo radicaba en los medios de distribución y la cantidad necesaria, sino también en la calidad de la misma. Hay que tener en consideración que desde 1858, año en que las aguas del Canal de Isabel II llegan al depósito del Campo de Guardias, hasta 1907, momento en que, tal y como se ha tratado en línea precedentes, el régimen administrativo del Canal de Isabel II sufre importantes modificaciones, no existe constancia de la realización de estudios periódicos de carácter bacteriológico para la medición de la calidad del agua que llegaba a Madrid (J. J. González Reglero, 2002, p. 917). De este modo, la preocupación por la calidad de las aguas de abastecimiento y los mecanismos para mejorarla, fue un problema que comenzó a tratarse como tal de manera posterior a los planteamientos sobre distribución y cantidades necesarias de abastecimiento.

Bien es cierto que hubo experiencias previas a 1907 en torno al estudio de la calidad de las aguas. Un ejemplo de ello lo constituye el contenido de la memoria de Rafo y Rivera, de 1848 (Rafo \& Rivera, 1848), formada en cumplimiento de la Real Orden de 10 de marzo de 1848 con arreglo a las instrucciones dadas por la Dirección General de Obras Públicas. En dicha memoria, aparece una sección dedicada al análisis de las aguas del Río Lozoya, verificadas en la Facultad de Farmacia de la Universidad de Madrid (Rafo \& Rivera, 1848, pp. 93-98). Los análisis llevados a cabo, se centraron en dos puntos: el Pontón de la Oliva y el Canal de Cabarrus (frente a Torremocha). De entre los resultados obtenidos, cabe citar que "aunque no esté todavía decidido cuál debe ser la composición de las aguas cuyo uso convenga más al hombre para bebida habitual, puede afirmarse sin embargo, siguiendo la opinión más generalmente adoptada, que las del río Lozoya por sus propiedades físicas, por su composición y por la calidad del aire que contiene, son de la mejor calidad como potables, y para todos 
los demás usos económicos e industriales que exigen aguas de las más puras" (Rafo \& Rivera, 1848, p. 97).

En 1852, se realizaron análisis bacteriológicos a las aguas de algunos de los Viajes Antiguos. Más concretamente a los viajes del Alto Abroñigal, Bajo Abroñigal, Viaje de la Castellana y Viaje de la Alcubilla. Los resultados de estos análisis químicos biológicos dieron como resultado que, en el mejor de los viajes, se encontró 0,223 g/l de materias fijas, lo que suponía una cantidad mayor que la que encontraba en el abastecimiento de París y muy por encima de la del Lozoya (de Prado, 1858, p. 103)

Los análisis siguientes se realizan con la llegada del agua del Lozoya a la ciudad de Madrid, en 1858. Casiano de Prado realiza un interesante artículo en la Revista El Mundo Pintoresco, que puede consultarse en la Hemeroteca de la Biblioteca Nacional de España. (de Prado, 1858, p. 103). El autor realiza una síntesis de los análisis de las aguas del río Lozoya llevados a cabo hasta ese momento, en comparativa con resultados obtenidos en capitales como Nueva York o París. Además, afirma que, atendiendo a los resultados, el agua del Río Lozoya es de una pureza y calidad superior a las de las otras ciudades mencionadas, en comparativa.

Estudios posteriores estuvieron muy influenciados por la epidemia de cólera que sufrió Madrid en 1885. En el Bando del ayuntamiento de Madrid del 18 de junio de 1885 se establecieron medidas que tuvieron por objetivo intentar evitar un agravamiento de la epidemia, prohibiendo el consumo de agua de la mayoría de los Viajes de Agua, a excepción del Viaje de la Fuente de Reina y del Canal del Lozoya. Asimismo, se procedió a la realización de análisis del agua de los viajes, encargados al Laboratorio Municipal, que por esa época estaba dirigido por el Doctor Fausto Garagarza, puesto que ocupó durante 16 años, hasta 1896. A lo largo de este periodo emprendió el estudio y vigilancia de las aguas de abastecimiento de Madrid (Martín, 2012, pp. 197-211).

\subsection{La sistematización de los análisis del agua de consumo}

Hasta el año 1907 no se contaba con un sistema regular de medición de calidad de las aguas del Río Lozoya que abastecía de agua a la ciudad de Madrid. En este sentido, fue clave el cambio de régimen administrativo del Canal, que este año dejó de ser una 
oficina de pertenencia del Negociado de Aguas del Ministerio de Fomento, para formar un Consejo de Administración especial, delegado por el Estado, que tenía por encargo su gobierno y estaba presidido por un Comisario Regio que era delegado del ministerio, quedando bajo las órdenes del mismo.

La Organización de inspección sanitaria de las aguas del Canal de Isabel II, aparece anunciada en el Boletín del Canal de Isabel II el 11 de mayo de 1908 (Canal de Isabel II, 1908b, pp. 59-60), con el objetivo de conformar una organización de carácter permanente que se encargase de la Inspección Sanitaria de las aguas del Canal, que permitiera una verificación de una manera continuada los ensayos y análisis necesarios, y publicarlos en forma de partes quincenales que se insertaran en este mismo Boletín. "Desde el momento en que se instituyó el nuevo régimen que figura al frente del Canal de Isabel II, el Consejo de Administración y la Comisaria Regia, han dedicado atención muy preferente a las condiciones sanitarias de las aguas de aquel, preocupándose de organizar un servicio de laboratorio que en todo momento que se desee, permita conocer el estado de pureza de las aguas de que se surte la casi totalidad del vecindario de Madrid”. (Canal de Isabel II, 1908b, p. 59)

\subsection{Las condiciones higiénicas de las aguas de consumo y su composición química.}

Uno de los primeros aspectos que hubieron de tomarse en consideración a la hora de tratar el estado real de la calidad de las aguas, fue atender al conocimiento de sus condiciones higiénicas. Sánchez de Toca, Comisario Regio del Canal en 1907, encargó a César Chicote, quien a partir del 24 de octubre de 1898 se traslada de San Sebastián a Madrid para comenzar su función como director del Laboratorio Municipal de Madrid (cargo que ocupará hasta su jubilación en 1932), ${ }^{45}$ la redacción de una Memoria sobre las condiciones higiénicas del agua del Lozoya (Chicote del Riego, 1907). En el Boletín del Canal de Isabel II del 16 de septiembre de 1907 (Chicote del Riego, 1907, pp. 24-26) aparecen sintetizados los resultados más relevantes de los análisis llevados a cabo por el Doctor Chicote, recogidos, también, en una Memoria de 27 de agosto de 1907.

\footnotetext{
${ }^{45}$ Para conocer más sobre la biografía de César Chicote y del Riego, consultar en la Real Academia de la Historia. http://dbe.rah.es/biografias/12122/cesar-chicote-y-del-riego
} 
El Doctor Chicote, en una visita que duró dos días, visitó diversas zonas del Río con el objetivo de recoger muestras en seis puntos de parada, con el objetivo de realizar análisis químicos y biológicos de las aguas. Las zonas donde se recogieron las muestras fueron el Paular (que corresponde con el inicio del Río Lozoya), los arroyos de desagüe del pueblo de Lozoya y del pueblo de Canencia, cerca de Buitrago, en el embalse del Villar y en la presa de la Parra. La visita por estos lugares fue realizada junto a Ramón Aguinaga (como Director), Vicente Valcárcel (ingeniero de la sección primera del Canal de Isabel II) y Carlos Varela (ayudante de laboratorio del Canal de Isabel II) (J. J. González Reglero, 2002, p. 921). Entre los resultados obtenidos, cabe destacar el problema de las turbias y del sabor del agua que, en algunas ocasiones, se presentaba como “(...)mohoso, por sus analogías con el que se produce en los espacios confinados donde se desarrolla vegetación criptogámica, siendo su intensidad, a veces, de tal índole, que se hace sensible también al olfato" (Chicote del Riego, 1907, p. 24) . Respecto a las aguas turbias, “ (...) débense a una tierra arcillo ferruginosa que lleva el agua en suspensión, de color pardo algo ocráceo, adherente a los labios y dotada del sabor peculiar de las arcillas. Ofrece la particularidad de presentarse en un estado de división tal, que es suficiente una cantidad muy pequeña para producir el enturbiamiento de las aguas, A las que comunica su color más o menos intenso, según la cantidad de arcilla que arrastran. A partir de diez miligramos por litro, el agua se presenta ya opaca y de color pardo obscuro, siendo completamente inservible para todos los usos domésticos” (Chicote del Riego, 1907, p. 24).

Además, en los informes realizados por el Doctor Chicote, se destaca la importancia de la contaminación sufrida en el pueblo de Buitrago, dada su situación de cercanía al río, proponiendo como soluciones la expropiación del pueblo entero. 
Gráfico 4-1. Contaminación del Río Lozoya en su transcurso desde el Paular hasta la Presa de la Parra. Paular, Lozoya, Cruce, Buitrago, Embalse, Presa del Villar, Presa de la Parra ${ }^{46}$.

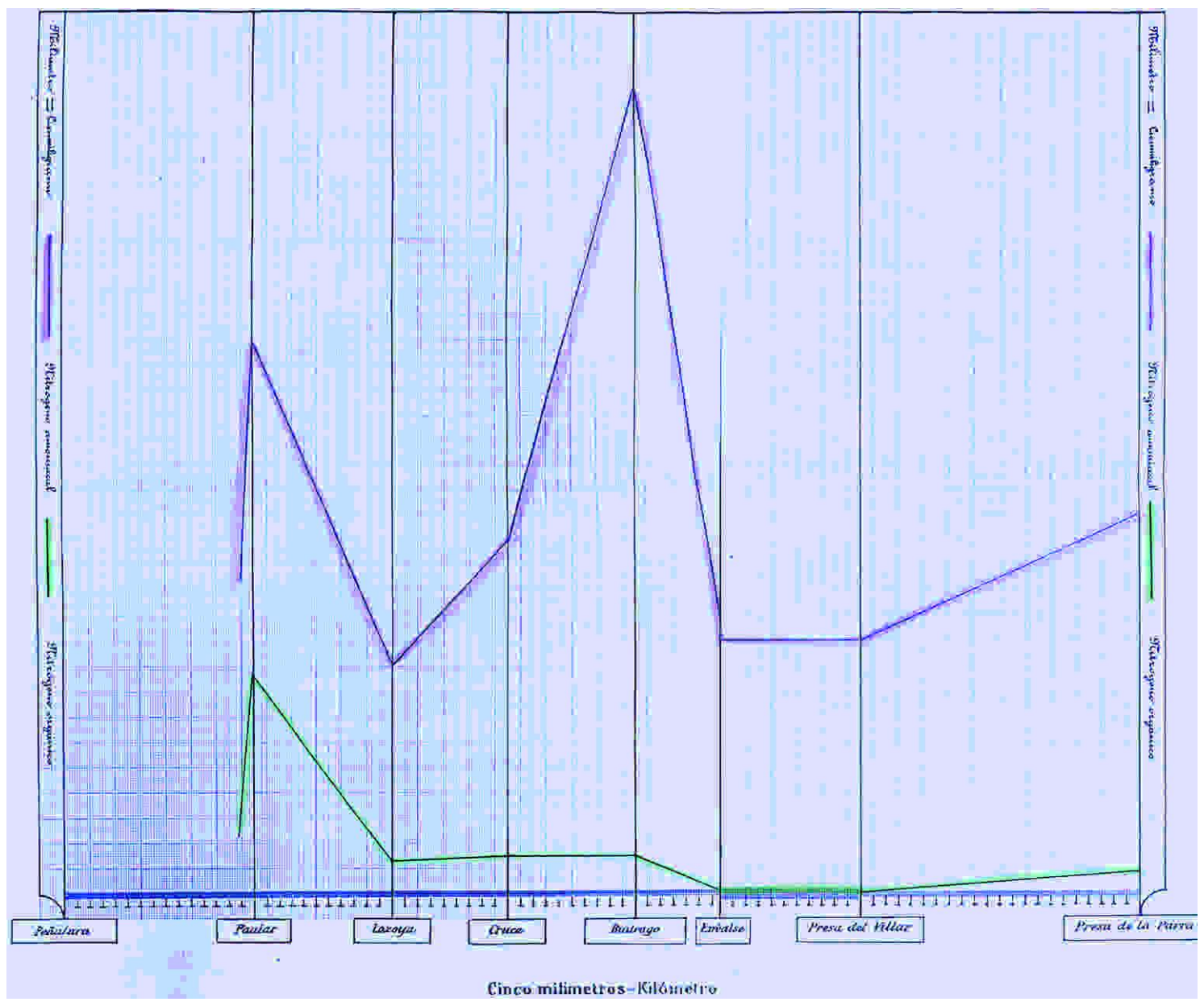

Fuente: CHICOTE, C. (1907). Memoria sobre las condiciones higiénicas del agua del Lozoya, Madrid. Obtenido de (J. J. González Reglero, 2002, p. 923).

\subsubsection{Los análisis químicos}

La importancia del estudio de la composición química de las aguas ha llegado hasta nuestros días. En este sentido, numerosos autores (Ávila, 1984; Christophersen y Seijo, 1982; Likens et al., 1977; Vertraten, 1977; Vitousek, 1977) señalan que la composición química de las aguas sirve para dar explicación a los procesos que ocurren tanto en la propia cuenca hidrográfica a la que pertenecen, como a lo largo de su recorrido. El agua, por su transporte y almacenamiento, sufre modificaciones en sus características físicas y químicas. Además, hay que tener en consideración que, la composición química de las aguas sufre variaciones en función de la época del año en que se realizan los análisis.

\footnotetext{
${ }^{46}$ Aparece la medición de nitrógeno amoniacal (azul) y de nitrógeno orgánico (verde)
} 
Respecto al tema de la calidad de las aguas, hay que tener en cuenta que no pueden ser tratadas por igual todas las aguas que llegaban a la capital destinadas al consumo. Esto viene dado porque su origen es bastante dispar, tal y como se ha tratado en el capítulo anterior, ya que el agua que provenía de los viajes antiguos podía proceder, en función del viaje de agua al que nos refiramos, bien de filtraciones naturales a través de capas permeables del suelo y o bien de alguna vena líquida existente en el terreno terciario que, debajo de una capa de cuaternario muy extensa, que constituye el subsuelo de Madrid. En este sentido, la variabilidad en lo que se refiere a la problemática en la calidad de las aguas será diferente atendiendo, entre otras cosas, a su génesis. En lo que respecta a los viajes antiguos, era común que las aguas que distribuían se mezclasen con partículas ricas en yeso (selenitosas), dando como resultado esta mezcla tan característica de la composición de esas aguas (Úbeda y Correal, 1900, p. 11). Además, la permeabilidad de los terrenos que los viajes de agua atravesaban influían de manera necesaria en la pureza de las mismas, en la medida en que algunos de los mismos discurrían por debajo de, por ejemplo, el Cementerio de Nuestra Señora de la Almudena, así como de otras zonas destinadas a colectar residuos orgánicos humanos, como era la zona del Arroyo Abroñigal. Como cabe esperar, estas aguas podían ser contaminadas con facilidad en el caso en que se produjesen filtraciones de estos lugares y se mezclasen con las aguas de abastecimiento. Según Úbeda y Correal, esta contaminación era poco probable, ya que la acción filtrante que las capas de terreno eran capaces de ejercer sobre los líquidos que contienen bacterias, cuya acción llega, en determinadas condiciones de espesor y naturaleza del terreno, a retener por completo esos organismos, verificando así una verdadera purificación mecánica del líquido filtrado (Úbeda y Correal, 1900, p. 11).

El mayor problema radicaba en la composición química de las aguas, ya que el agua de los viajes, especialmente en el interior de la ciudad, se mezclaba con las filtraciones que procedían del alcantarillado y las tuberías de gas, fruto del mal estado en el que se encontraban las cañerías empleadas para la distribución del agua. Esta situación tuvo lugar, por ejemplo, en el invierno de 1900, llegándose incluso a prohibir el consumo de agua de algunas fuentes públicas de manera temporal por el mal estado de las canalizaciones. Hasta entonces, la averiguación de estas deficiencias venía dada por situaciones que podríamos calificar de fortuitas o bien cuando el mal estado de las aguas manifestase de facto un trastorno en los consumidores. Un ejemplo de la primera 
situación lo tenemos en los ocurrido en el verano de 1899 cuando se inundaron los sótanos de las viviendas del cruce de la calle Lagasca y Goya, y gracias a ello las autoridades municipales se percataron de la mezcla de las aguas de un viaje antiguo con las aguas de un lavadero (Úbeda y Correal, 1900, p. 13).

Una vez hemos puesto de manifiesto, de manera sucinta, la situación de los viajes de agua, procedemos a hablar sobre las aguas del Lozoya. A diferencia de los viajes antiguos, las aguas del Lozoya tienen que hacer un largo recorrido antes de llegar a la capital. Éste, al menos hasta que se introdujeron mejoras en la canalización del trasvase de agua, se producía (...) al aire libre y sin protección contra las transgresiones higiénicas de los vecinos de los pueblos por cuya proximidad pasan, están expuestas á todas las causas de contaminación procedentes de la atmósfera y de esos mismos vecinos, que dejan que sus ganados atraviesen el río, que se abreven en él, y menos mal si no hicieran nada más que esto, que tal vez utilicen su corriente para el lavado y limpieza de las ropas, y, por último, que no respetan, como sería de desear, el caudal del río, que hasta ha servido, en ocasiones, como medio de arrastre de los productos residuarios de algunas fábricas (Úbeda y Correal, 1900, p. 13).

La proporción de ácido sulfúrico que contengan las aguas, así como su combinación con el nivel de cloro y de dureza total y permanente es importante para tratar la calidad de potabilidad de las mismas. Asimismo, factores como la lluvia y la estación del año en la que nos encontremos, influyen en los niveles de filtración de agua a través del terreno y, consecuentemente, en el caudal de los viajes.

En lo que respecta a las aguas del Lozoya, el agua permanecía en los depósitos durante unos días, antes de que fuera distribuida, por lo que cuantos más días permaneciese, esto conllevaba que aumentase la proporción de materia orgánica que el agua contenía, disminuyendo el oxígeno libre a su salida para ser distribuido a la población (que era bastante elevado una vez llegaban las aguas al depósito).

A su vez, no podemos olvidar que tanto en las aguas de los viajes antiguos como en las aguas del Canal se producían empeoramientos en la composición de las aguas fruto de actuaciones de los habitantes de la ciudad y, como ya hemos señalado anteriormente, de la influencia que producen las deficiencias en las canalizaciones de gas y del alcantarillado. 
Así pues, para autores como Úbeda y Correal (Úbeda y Correal, 1900) atendiendo a los análisis realizados por él mismo en 1898, las aguas con un mayor grado de pureza desde el punto de vista químico eran las del Lozoya, seguida de la calidad de los distintos viajes de agua que hemos apuntado más arriba. El problema con las aguas del Lozoya residía, en buena medida, en su camino hasta la capital y una vez allí, en el camino recorrido hasta su distribución. En este sentido, una de las razones más importantes de plantear la construcción de los siguientes depósitos fue precisamente conseguir evitar que las aguas del Lozoya llegasen turbias. La protección eficaz del Canal de Isabel II en toda su extensión fue una tarea ardua, que no llegó a conseguirse al término del marco temporal que abarca el presente trabajo.

\subsubsection{Las condiciones del agua destinada a la alimentación. Características mínimas del agua destinado al consumo}

Primeramente, cabe pensar en las causas por las que las aguas potables puedan ser impuras, que no necesariamente es sinónimo de no aptas para el consumo. Pudiera ser por contener substancias minerales distintas de las que constituyen su composición ordinaria, o que éstas estuvieran presentes en mayor proporción de la que normalmente suelen llevar, o bien por arrastrar, como consecuencia de una contaminación accidental, microorganismos diversos o los productos solubles de su vida orgánica, capaces de producir y transmitir diversas enfermedades, algunas de ellas de muy graves consecuencias (Úbeda y Correal, 1900, p. 19). Tal y como hemos señalado más arriba, los análisis de aguas realizados atienden a dos componentes; los químicos y los bacteriológicos. Por ello, los medios de purificación se orientaron a resolver los posibles problemas existentes que tenían que ver con esos dos componentes.

"Es evidente que la mayor parte de los trastornos gastrointestinales que todos los veranos sufren los habitantes de Madrid, debe atribuirse á que en esta época se hace, sin duda, más intensa la infección que padecen, por diferentes conceptos, así las aguas de Lozoya, como las de los viajes antiguos, sometidas unas y otras á las poluciones más peligrosas que se pueden presentar en una ciudad. Es de gran importancia para la integración de la salud durante el verano adoptar una rigurosa regimentación higiénica con las bebidas que se ingieren con exceso en la época de grandes calores, 
exceso que es el origen de los frecuentes cólicos, diarreas y otras alteraciones del aparato digestivo”.(Melgosa Olaechea, 1912, p. 121).

Según las reglas y preceptos, del Doctor Manuel Corral y Maira, médico que orientó su corriente investigadora en la vertiente del higienismo (Melgosa Olaechea, 1912, p. 121; Moral Jimeno, 2011), se señalan a continuación las consideraciones principales respecto a las condiciones de consumo del agua y otros líquidos:

$1^{\circ}$. El agua, que, para bebida se utilice en las refacciones alimenticias, deberá esterilizarse previamente hirviéndola, enfriándola y filtrándola.

$2^{\circ}$. La temperatura del agua que se ingiera durante las comidas deberá ser fría, pero no helada ó enfriada con hielo; el vino tampoco se enfriará con hielo, y es preciso beberlo mezclado con agua esterilizada ó agua de Seltz.

$3^{\circ}$. Hasta que no hayan transcurrido tres horas después de las comidas, no se ingerirá cantidad alguna de agua ni líquidos de ninguna clase, excepto la cerveza.

$4^{\circ}$. Únicamente al terminar de comer serán permitidos los helados; á cualquier otra hora resultarán nocivos.

$5^{\circ}$. Si durante las tres horas subsiguientes á las comidas abrumase la imperiosidad de la sed estival, basta para aplacarla hacer gargarismos y enjuagues con buchadas de agua fresca ligeramente acidulada con limón ó vinagre.

$6^{\circ}$. Las horchatas, refrescos fríos, gaseosos ó naturales, pueden ingerirse dos horas antes ó tres después de las refacciones alimenticias.

$7^{\circ}$. Deben escogerse durante el estío las bebidas refrescantes diuréticas, es decir, aquellas que sean capaces de disminuir la secreción de la orina, y para ello basta hacer uso del agua esterilizada, fría, teñida con jarabe de café y acidulada con limón (masagrán).

$8^{\circ}$. De todos los refrescos ácidos, el mejor es el de agraz.

$9^{\circ}$. La cantidad máxima total de líquidos que debe ingerirse cada veinticuatro horas durante el estío, no debe pasar de 1.200 á 1.500 gramos.

Atendiendo a la información de Melgosa Olaechea, para 1912, sobre las consideraciones del agua como elemento del subsuelo, se mantiene la necesidad de 
prohibir el consumo de agua de los pozos situados a una distancia menor de diez metros de los pozos negros, y cinco metros de separación respecto de las bajadas pluviales.

\subsection{Los medios de tratamiento y purificación de las aguas}

Atendiendo a la temática relativa a los medios de tratamiento y purificación de las aguas, es necesario tener en consideración que los estudios que tratan el tema de la depuración de las aguas residuales en el contexto español y desde una perspectiva histórica, son escasos. Si bien, desde finales del siglo XIX, los higienistas focalizaron este asunto como problemática a tratar, manifestado en la redacción de proyectos con los que se consiguiera atajar el problema.

En el caso de Madrid, no es hasta 1907 cuando se comienzan a tratar de manera sistemática el tema de la calidad de las aguas, de los problemas derivados de los vertidos incontrolados a los ríos y de la necesidad de tratamiento de las mismas.

Bien es cierto que, en años anteriores, desde la esfera científica ya se plasmaba la necesidad de atender a los medios de purificación de las aguas de consumo como elemento higiénico y vinculado a la salud de las poblaciones. Un ejemplo de ello fue el concurso de premios convocado por la Sociedad Española de Higiene, en 1900, con la propuesta temática de una serie de trabajos sobre el estudio de los «Procedimientos domésticos de purificación de las aguas potables que utiliza Madrid», que debería ir precedido de algunas noticias acerca de las condiciones higiénicas de estas mismas aguas. El ganador de citado concurso fue José Ubeda y Correal ${ }^{47}$, con su trabajo acerca del "Estudio higiénico de las aguas de que se sirve Madrid y procedimientos domésticos de purificación de estas aguas: cartilla premiada en el concurso público de 1900 "

\footnotetext{
${ }^{47}$ El Doctor José Úbeda y Correal fue Farmacéutico Primero del Cuerpo de Sanidad Militar, Doctor por oposición en la Facultad de Farmacia graduado en la de Medicina y Cirugía, premiado por la Real Academia de Ciencias Físicas y Naturales por la Excma. Diputación provincial de Logroño, por el Colegio de Farmacéuticos do Madrid, etc. Otros de sus trabajos más destacados son: Acciones químicas de las bacterias: discursos leídos ante la Real Academia de Medicina en la recepción pública del Ilmo. Señor Doctor D. José Ubeda y Correal el día 7 de junio de 1914, contestación del Excmo. Sr. Doctor Don Ángel Fernández-Caro y Nouvilas. Publicación Madrid : R. Velasco, 1914. // Análisis químico (cualitativo y cuantitativo), micrográfico y bacteriológico de las aguas minero-medicinales de la Hermida (Santander) / practicado por José Ubeda y Correal y Rosendo Castells y Ballespi Publicación: [S.I.] : [s.n], 1908 (Madrid : Imp. de Ricardo Rojas), Dictamen referente a una información acerca de laanquilostomiasis : efectuada por acuerdo del Instituto, fecha 6 de febrero de 1917, en La Carolina(Jaén) Publicación: [S.I.] : [s.n.], 1917 (Madrid : Sobrinos de la Suc. de M. Minuesa de los Ríos)
} 
(Úbeda y Correal, 1900). El Doctor Úbeda y Correal realizó un estudio sobre la calidad de las aguas para consumo que llegaban a la ciudad de Madrid y los medios domésticos destinados a la purificación de las mismas. El planteamiento general del trabajo se basaba en la importancia de atender a la localización de la problemática (la mala calidad de las aguas "potables"48) que llegaban a la capital, para lo que se revestía como necesario la realización de un estudio higiénico de las mismas y, en segundo lugar, tratar de descubrir e implantar los procedimientos de purificación.

En otros países, los estudios que en Madrid comenzaron en 1907, se venían realizando desde años antes. Un ejemplo de ello lo constituye la experiencia francesa en sus estudios sobre las aguas del extrarradio de París. Las conclusiones más relevantes giraban en torno a la manifestación de lo nefasto que suponía la toma de agua directa sin tratamiento de por medio. Asimismo, con la introducción de mecanismos de filtración de las aguas, se había logrado reducir la mortalidad por fiebre tifoidea en un $70 \%$. Se proponía el sistema de ozonización como mecanismo complementario a la filtración, con el objetivo de reducir las bacterias presentes en el agua a menos de $200 \mathrm{~cm} 3$ (J. J. González Reglero, 2002, p. 921).

En el caso de Madrid, no es hasta 1907, ante el problema derivado del vertido incontrolado a las aguas del río Lozoya, cuando una compañía francesa ("Compagnie del Ozone") se postuló ante el Consejo del Canal de Isabel II y el Ayuntamiento de Madrid con el objeto de llevar a cabo mecanismos de esterilización y filtración de las aguas. Una comisión mixta fue formada para debatir la concesión, finalizando con el resultado de denegar la concesión de los servicios anteriormente descritos. Si bien, las reuniones establecieron que era necesario fomentar la organización de una policía sanitaria realmente efectiva, con el objetivo de establecer una vigilancia intensiva que terminara con la problemática de los vertidos al agua del Lozoya, que servía para el consumo de aguas de la ciudad de Madrid. El municipio de Buitrago quedó en entredicho en estos asuntos, en tanto en cuanto se estableció que el grueso del problema derivado de los vertidos incontrolados al río Lozoya, provenían de las aguas residuales de citado municipio.

\footnotetext{
${ }^{48}$ En este caso, he creído oportuno entrecomillar la palabra potable, ya que se trata de un adjetivo que en el presente caso desconocemos hasta qué punto puede tomar la acepción que tenemos actualmente por potable.
} 
El agua que llegaba a Madrid para consumo humano poseía un estado, al menos a simple vista, que no infería al propio consumo. En palabras del Doctor Úbeda, a la altura de 1900, no sólo las aguas procedentes de los viajes de agua llegaban a las fuentes públicas en malas condiciones, sino también las del Canal de Isabel II: “Las repetidas ocasiones, sobre todo en estos últimos tiempos, en que el agua del Lozoya, la más extendida y la más empleada en Madrid, ha llegado á las fuentes públicas en un estado verdaderamente deplorable por su aspecto y por la cantidad de arcilla finamente dividida que acarrea en suspensión (...) (Úbeda y Correal, 1898).

Es necesario advertir que el estudio de los procedimientos para obtener mayor calidad de las aguas comenzó en los primeros años con un sentido más orientado a la clarificación que a la purificación total de las mismas, por lo que el problema real de la potabilidad de las aguas continuó existiendo años más tarde, hasta que el Laboratorio Municipal de Higiene se encargó de realizar estudios exhaustivos de la calidad de las aguas, que, dada su relevancia, trataremos más delante de manera específica en el capítulo número siete.

Así, en 1907, momento en que el Canal de Isabel II se constituye bajo la administración de la Comisaría Regia y del Consejo de Administración, comienzan a focalizarse verdaderos esfuerzos en torno a la mejora de las condiciones sanitarias de las aguas del Lozoya. En este sentido, como se ha indicado en líneas precedentes, se crea una Comisión Mixta, con el objetivo de valorar la propuesta de la empresa francesa “Compagnie del Ozone" encaminada a la cesión de las labores de filtración y esterilización, mediante el procedimiento del Doctor Otto, del agua del río Lozoya (J. J. González Reglero, 2002, p. 921).

En el caso del agua de abastecimiento de Madrid, procedente del Río Lozoya, las medidas llevadas a cabo en el municipio de Buitrago, se pueden considerar como una de las experiencias pioneras de depuración de las aguas residuales en el contexto español, y la primera llevada a cabo por el Canal de Isabel II, datándose entre los años 1911 y 1912. 


\subsubsection{Las estaciones depuradoras en la ciudad de Madrid.}

No sólo el volumen de abastecimiento de aguas era importante, también había que atender a la calidad de las mismas. En el ya mencionado Reglamento del Canal de Isabel II de 1907 (González Besada, 1907), se establece en el Artículo 46. (...) organizar y dirigir la policía y vigilancia de las aguas y aprovechamiento de los ríos que abastecen á Madrid, proponiendo al Comisario las determinaciones que convenga adoptar relativas á este punto.

Uno de los problemas más acuciantes era el que denominaban las turbias, aguas que llegaban en mal estado a la ciudad. En 1913, para solucionar este problema, se abrió la primera planta depuradora, llegando a instalarse tres más a la altura de 1929, con el objetivo de la depuración del agua de los viajes antiguos. Si bien, no es hasta enero de 1927 cuando el Ayuntamiento de la ciudad elaboró un nuevo y ambicioso plan para la depuración de aguas residuales, elaborado por José de Lorite y Kramer, ArquitectoDirector de Obras Sanitarias del Ayuntamiento de Madrid.

La figura de José de Lorite fue destacable, como precursor de la construcción de una pequeña instalación de cienos activos, antesala de la que sería construida posteriormente en la Calle Méndez Álvaro, con capacidad para someter a tratamiento aproximadamente 250 metros cúbicos diarios de agua. El proyecto de Lorite planteó un sistema de depuración basado en tomar las aguas del colector general y separadas en compartimientos de las materias en suspensión. Un segundo depósito, provisto de válvulas Clifford, sedimenta las aguas resultantes del primero. Las aguas, desprovistas de elementos sólidos, pasan a los tanques de sedimentación y activación de lodos. En estos tanques están los difusores para la mezcla íntima del aire y la materia orgánica. La obtención de los lodos activos dura un período que oscila entre quince y veinte días. Después de este tratamiento de las aguas se pasa al período de aireación, que se hace por medio de difusores. Verificada la mezcla íntima de las aguas con los lodos activos entra en los tanques de sedimentación. Las válvulas antes citadas favorecen la sedimentación y se obtiene una clarificación perfecta. Las aguas son depuradas en un 90 por 100, quedando sólo elementos minerales que no perjudican el cauce público. El exceso de lodos activos se lleva extendido a terrenos apropiados para su desecación y luego poder ser retirado por aquellos a quienes interese su aprovechamiento. (Ayuntamiento de Madrid, 1929, p. 111) 
Posteriormente, en la calle Méndez Álvaro, se construyó una estación depuradora para someter a tratamiento las aguas. En ésta se realizaban ensayos mediante un sistema de depuración basado en lodos activos, insuflando aire por medio de difusores. Desde un punto del colector del Carcabón, se conducían las aguas fecales por conducción de agua rodada y, una vez terminado el circuito de la instalación, se volvían a verter al mismo colector. Las características de la estación de depuración de Méndez Álvaro eran: un depósito de decantación de gruesos, depósitos de aireación y depósito final de sedimentación, con válvulas Clifford. El flujo de las aguas fecales era permanente, y el volumen depurado era de 9 metros cúbicos a las 24 horas (Ciudad, 1929, p. 110). Además, Existía otra pequeña instalación, cercana a la anterior, basada en mismo mecanismo de lodos activos, pero con un sistema de aireación por turbinas Simplex, que permitía depurar 5 metros cúbicos a las 24 horas.

Estos dos proyectos experimentales y sus resultados satisfactorios respecto a la depuración de las aguas, sirvieron de revulsivo ante la decisión y necesidad de redactar un verdadero proyecto para la depuración de las aguas de Madrid. Así, bajo la alcaldía del Conde de Vallellano, en 1927 se aprobó dicho proyecto, aprobándose un presupuesto extraordinario para iniciarse la construcción de la estación de depuración. Sin embargo, los costes derivados del establecimiento y explotación fueron considerados como muy elevados para ser asumidos por el consistorio madrileño.

Por ello, desde la Dirección de Obras Sanitarias, se encargó a José Luis Escario Núñez del Pino el estudio de la problemática y la formulación de un proyecto definitivo. El ingeniero consideraba que la principal problemática sanitaria de la ciudad radicaba en la inexistencia de sistemas de depuración de las aguas: "El alcantarillado de Madrid, obra muy completa, verdadero modelo, con el único defecto de ser excesivamente lujoso, pues es todo visitable, con una longitud total de colectores de $400 \mathrm{~km}$, está de hecho anulado, desde el punto de vista higiénico, por el destino final de las aguas que recoge" (Escario Núñez del Pino, 1931a, p. 112).

Hay que tener en consideración que también existía un debate paralelo sobre los métodos más óptimos a emplear para la depuración de las aguas ${ }^{49}$. Si bien no será

\footnotetext{
${ }^{49}$ En el Proyecto de estación depuradora de las aguas residuarias de Madrid se realiza un análisis completo sobre los cuatro posibles sistemas de depuración de las aguas y sus características asociadas (Escario Núñez del Pino, 1931a, 1931b, 1931c)
} 
objeto del presente estudio presentar de manera exhaustiva cuáles fueron estos, sí cabe la señalización de algunos de los elementos más destacables y que fueron tenidos en cuenta a la hora de elaborar el proyecto de depuración de las aguas para la ciudad de Madrid.

José Luis Escario Núñez del Pino, para la elaboración del proyecto, recorrió diferentes instalaciones en diversas localizaciones, decantándose por enfatizar las bondades de las alemanas, por su innovación técnica y efectividad. Cabe destacar que el ingeniero adaptó los mecanismos que consideró óptimos a la propia realidad local de la ciudad. De este modo, se tuvieron en consideración elementos tales como la capacidad máxima que podía soportar el colector del Manzanares, por lo que sus cálculos estaban basados en una población de un millón doscientos mil habitantes. Asimismo, el sistema debía compasarse con el sistema de alcantarillado existente en Madrid, que era unitario y la dotación de agua diaria por habitante, que era elevada, así como la composición de las aguas negras, que fueron calificadas como débiles. A su vez, la concentración industrial en la ciudad con una producción de grandes masas de residuos biológicos perjudiciales era baja. Teniendo en consideración estas características locales, se calculó para la estación depuradora un caudal medio diario de 350.000 de m3, calculándose ésta para un máximo horario de $350.000:(14$ X 3600$)=6,94$ metros cúbicos por segundo por 7 metros cúbicos por segundo, que correspondía al diario repartido en 14 horas. Así, la dotación media diaria de 350.000 corresponde a 291 litros por habitante y día, para una población de 1.200.000 habitantes, cantidad de agua que resultaba en sintonía teniendo en cuenta los planes futuros del Canal de Isabel II (Escario Núñez del Pino, 1931a, p. 114). 


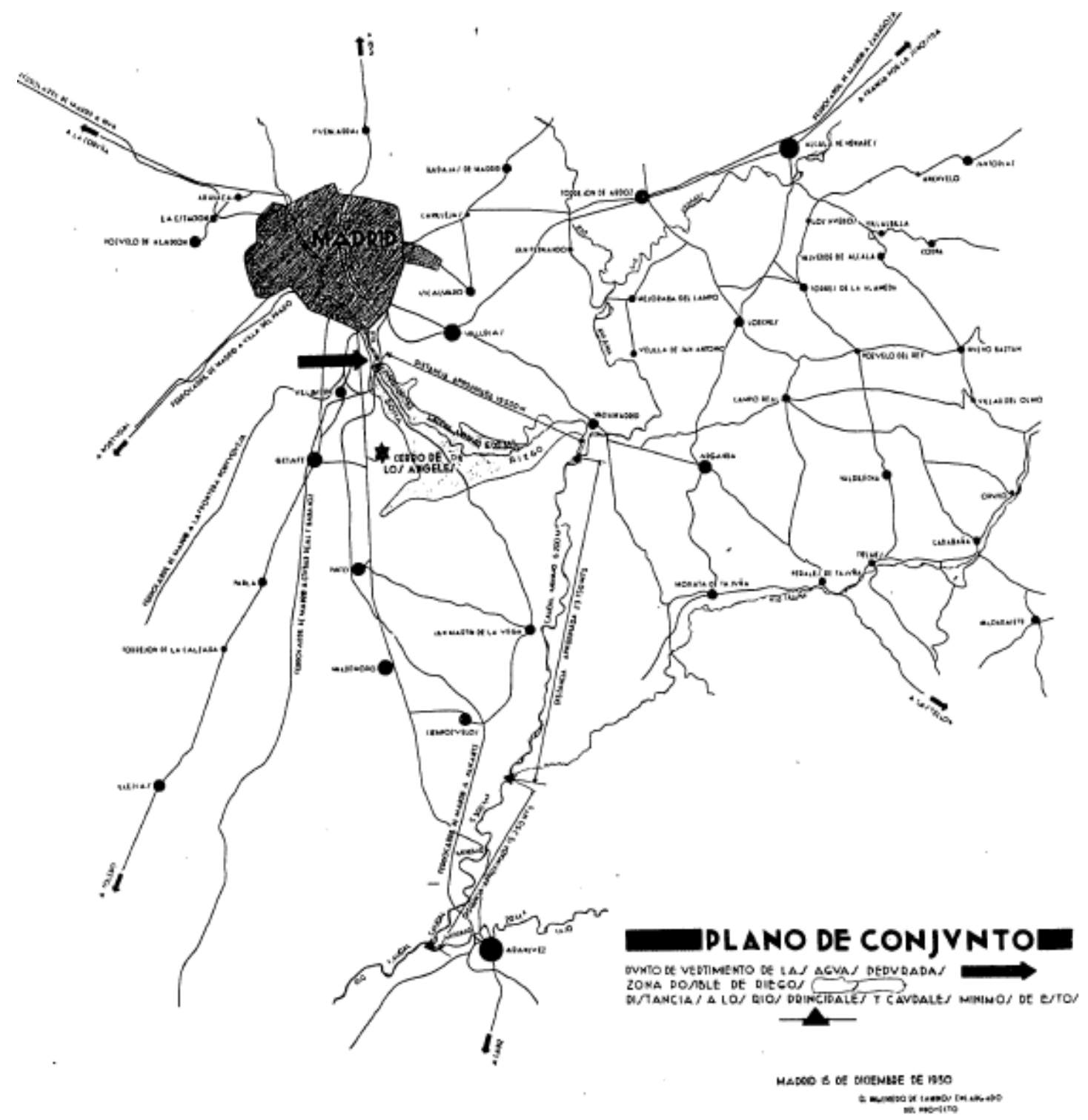

Fuente: (Escario Núñez del Pino, 1931a, p. 112)

El presupuesto del proyecto, bajo contrata, ascendía a 18.399.300,72 pesetas, con unos gastos de explotación calculados en 225.800 pesetas al año. Además, había que tener en consideración que si se llevaba a cabo el proyecto de riego con aguas depuradas, se verían compensados los anteriores costes (Escario Núñez del Pino, 1931a, p. 113)

"El problema higiénico, que de todas maneras se resolvería, es de importancia capital. La forma en que hoy día se vierten las aguas negras de Madrid a la vista del Ministerio de la Gobernación, donde residen las más altas autoridades sanitarias del Estado, es una verdadera vergüenza y un crimen contra la salud pública. Acometer el problema, 
desde el punto de vista financiero, es perfectamente realizable, y bajo el aspecto técnico no presenta la menor dificultad, dado el perfeccionamiento a que ha llegado la Ingeniería Sanitaria”. (Escario Núñez del Pino, 1931c, p. 150).

\subsubsection{Estaciones de depuración de aguas por ozono.}

A finales de la segunda década del siglo XX, el Ayuntamiento de Madrid contaba con cuatro estaciones depuradoras por ozonación, que fueron construidas con el objetivo de depurar las aguas procedentes de los viajes antiguos. Atendiendo a la información de la Memoria de la ciudad de 1929, si bien estas estaciones depuradoras cumplían su función, existía un problema vinculado a que las conducciones de salida de las mismas estaban en mal estado, dada la antigüedad y falta de reparacion de los propios Viajes de agua, por lo que “(...) si el Ayuntamiento de Madrid está decidido a conservar las aguas de los viajes antiguos para el consumo en fuentes públicas, no podrán ser útiles estas estaciones sin la reforma previa de todos los viajes”. (Ayuntamiento de Madrid, 1929, p. 123).

A la altura de 1929, existían cuatro depuradoras que trataban el agua de los Viajes antiguos, propiedad del consistorio municipal de Madrid, que son ilustradas en el gráfico 4-2..

Gráfico 4-2. Estaciones depuradoras del Ayuntamiento de Madrid. Año 1929

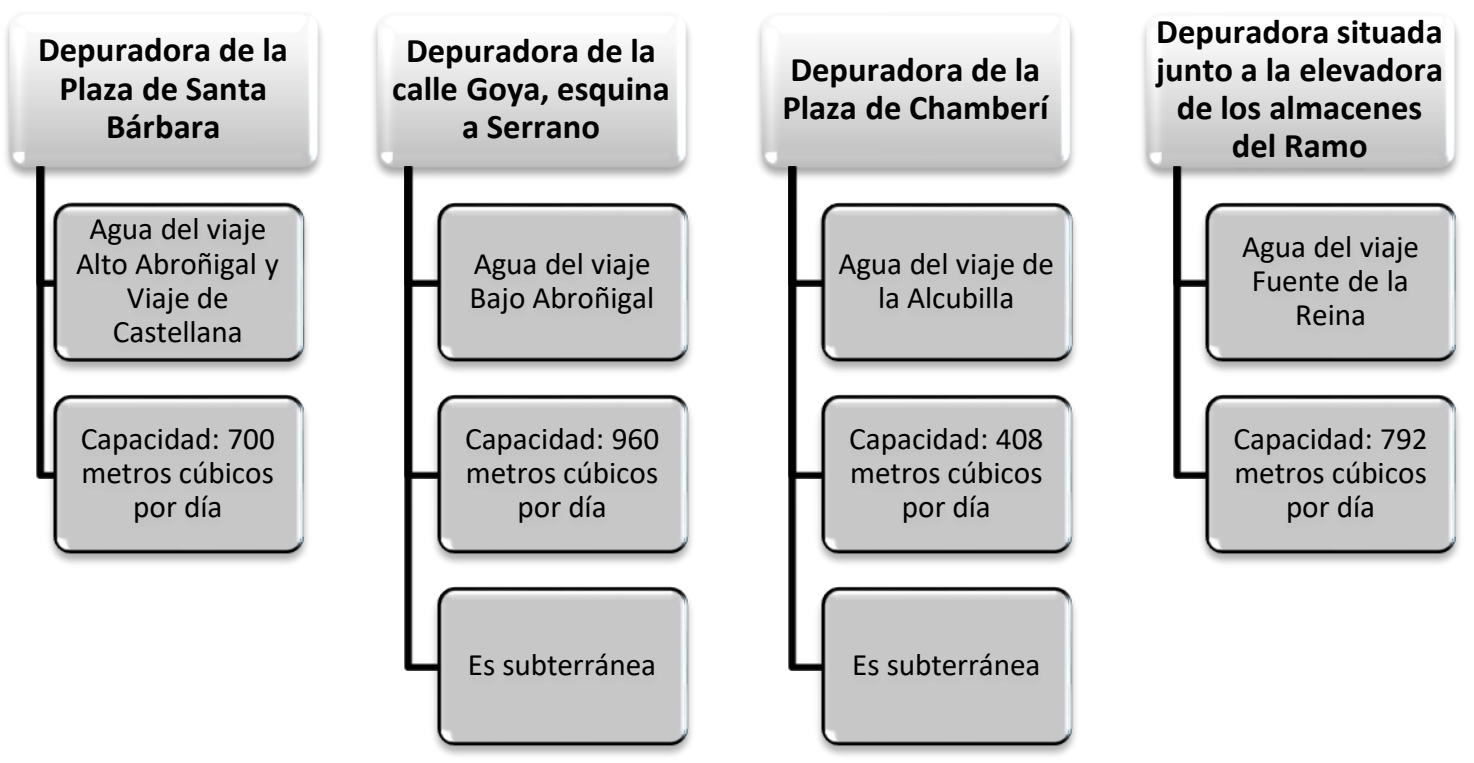

Fuente: Elaboración propia. Datos obtenidos de (Ciudad, 1929, p. 123) 
Otras actuaciones destinadas a la mejora de la higiene pública por parte del consistorio municipal fue la construcción de evacuatorios públicos y casas de baño o baño municipales en diferentes lugares de la ciudad. Hasta el año 1929, el Servicio de Aguas potables y residuarias del ayuntamiento había procedido a la construcción de evacuatorios en la plaza de Castelar, Puerta del Sol, Parque del Oeste, calle de Goya, plaza de España, plaza de Lavapiés, plaza de la Constitución, glorieta de Bilbao, Avenida de Raimundo Fernández Villaverde, calle de Toledo, Retiro y paseo de Atocha. De ellos son subtemineos y mixtos todos, menos los del Retiro y Parque del Oeste. Éstos estaban separados por el servicio para hombres y el servicio para mujeres, de manera que el primero estaba compuesto por W. C, lavavos y urinarios y los destinados al uso por parte de mujeres contenian W.C y lavavos. (Ayuntamiento de Madrid, 1929, p. 123)

En lo relativo a los baños municipales, existía la Casa de Baños situada en la Glorieta de Embajadores, inaugurada en 1928. El edificio constaba de ocho cuartos de baño, trece duchas y los servicios de salas de espera, para hombres y mujeres, conserjería, W. C., calderas, carbonera, etc. En la Memoria de la ciudad de 1929 se resalta la buena acogida por parte de la población en el uso de ésta: "Esta Casa de Baños, hecha como ensayo, ha tenido un éxito grande, especialmente en los meses de verano, teniendo el Ayuntamiento el proyecto de construir otras dos análogas”. (Ayuntamiento de Madrid, 1929, p. 124)

Sin embargo, el asunto de las aguas residuales continuaba siendo un problema que parecía no solucionarse, así se manifestaba en la prensa y revistas especializadas de ingeniería de la época: "Resolver este problema ha sido el afán de muchos Municipios madrileños; pero no se ha logrado, algo por las vicisitudes y cambios políticos, y mucho porque el problema técnico presentaba dificultades no fáciles de vencer" (Escario Núñez del Pino, 1931a, p. 113).

Así pues, la altura de los años treinta, el problema de la gestión de las aguas residuales de la capital seguía configurándose como una deuda pendiente. Las aguas negras continuaban desaguando desde las alcantarillas al río Manzanares, sin ningún tipo de 
tratamiento, lo que conllevaba que, especialmente en las épocas de estiaje, el caudal de éstas aguas fuera incluso superior a las del propio río, resultado un ambiente insalubre "a las puertas mismas de Madrid, un emisario descubierto; en sus márgenes y meandros se detiene la materia orgánica que transporta, formando depósitos en activísima putrefacción, cuyos olores hacen imposible la vida en las proximidades y constituyen focos de contagio de importancia grande, por su situación en las cercanías de núcleos de población considerables" (Escario Núñez del Pino, 1931a, pp. 112-113).

A la altura de $1931^{50}$, tanto el Ministro de la Gobernación, el Marqués de Hoyos, como el alcalde de la ciudad de Madrid, Joaquín Ruiz Jiménez, fueron fervientes defensores de la puesta en práctica del Proyecto de estación depuradora de las aguas residuales de Madrid. Ésta se publicitaba como una de "las mayores el mundo y sus construcción colocaría a Madrid a la cabeza de las capitales europeas por lo que a servicio tan esencial como el saneamiento se refiere” (Escario Núñez del Pino, 1931c, p. 150).

\footnotetext{
${ }^{50}$ La construcción de la primera gran depuradora que se instaló en Madrid se inició en el año 1934, pero, a causa de la guerra civil y las dificultades del periodo posterior, su finalización no se produjo hasta el año 1950. El nombre coloquial con el que se conoce es "la China". La denominada China, era una zona situada en la margen izquierda del Río Manzanares en la confluencia del Abroñigal con el río, contando con el colector general del Manzanares y la proximidad de la desembocadura del arroyo de la Gabia. (González Reglero, 2015)
} 
Imagen 4-2. Plano del anteproyecto de riego con las aguas depuradas. Año 1930

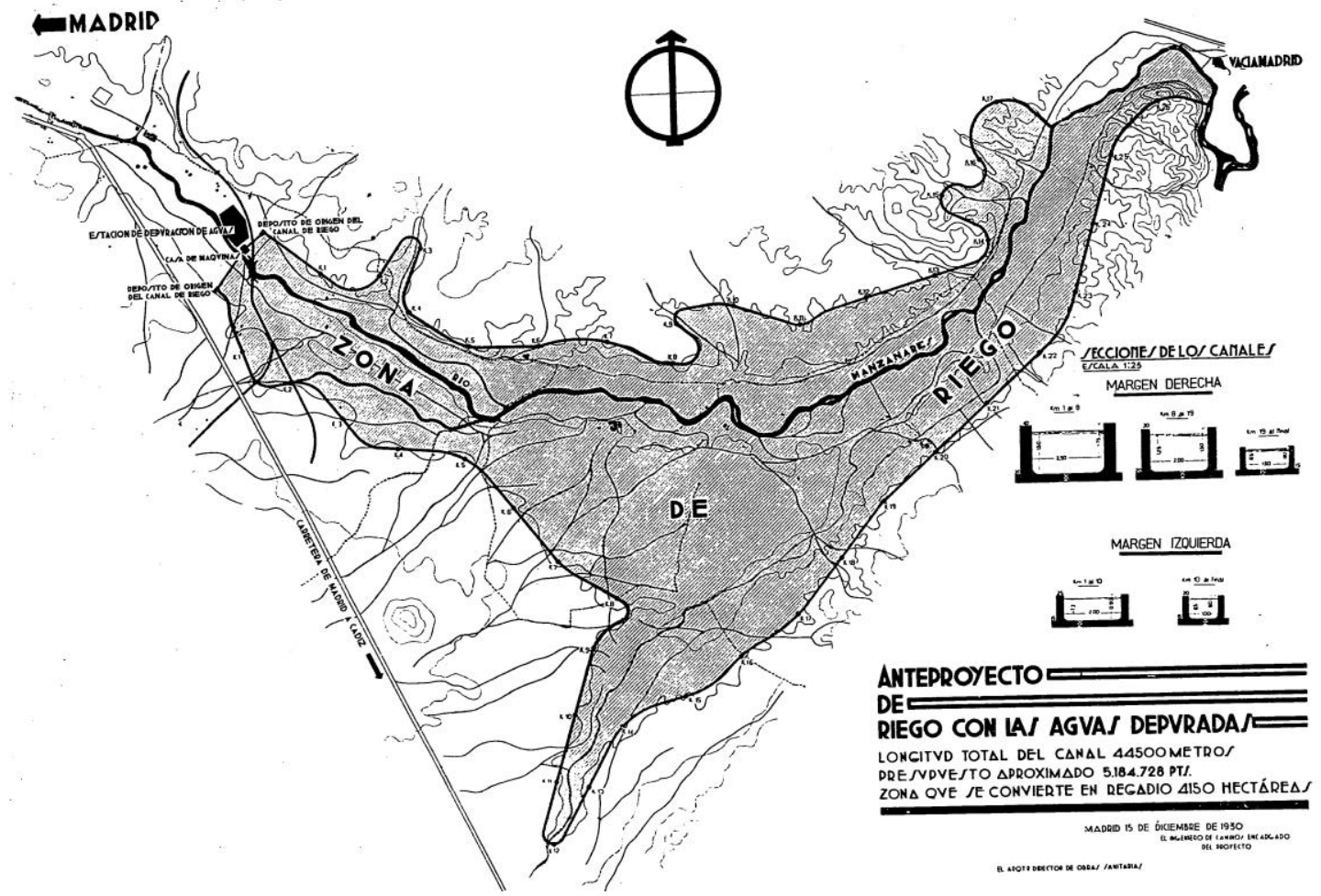

Fuente: (Escario Núñez del Pino, 1931c, p. 148). 


\section{El consumo de agua en una ciudad en crecimiento}

\subsection{Introducción}

La construcción de infraestructuras para el abastecimiento de agua potable y la gestión de residuos acompañó al proceso de crecimiento de las ciudades occidentales desde el siglo XIX. En la ciudad de Madrid, el crecimiento en extensión y en población experimentado, también vino acompañado de la necesidad de introducir estas mejoras de infraestructura urbana. En este sentido, el presente capítulo será un reflejo de cómo las condiciones del suministro de agua estuvieron determinadas por el crecimiento poblacional y, a su vez, este crecimiento de población se vio reflejado en la expansión territorial de la ciudad, lo que conllevó a una agudización de las diferencias sociales, especialmente a nivel de barrio.

\subsection{El abastecimiento de agua en una ciudad en crecimiento}

\subsubsection{El crecimiento poblacional de la ciudad}

El Canal de Isabel II se creó como empresa pública en $1851^{51}$, con el objetivo de la gestión y explotación del servicio de abastecimiento de agua potable del río Lozoya a la ciudad de Madrid, mediante un canal de superficie. Hasta la creación del Canal de Isabel II el suministro de agua potable se hacía por el servicio de los aguadores o por fuentes públicas y el sistema de abastecimiento de agua potable empleado hasta esa fecha seguía siendo el mismo que se había empleado desde el siglo XVI, mediante los llamados viajes de agua ${ }^{52}$.

Debe considerarse, a este respecto, que el Canal se construyó en 1851 para abastecer a una población que no llegaba a los 250.000 habitantes, y a finales de los años veinte

51 Antes de la creación del Canal de Isabel II la ciudad contaba con 77 fuentes públicas dentro de su perímetro urbano y con un servicio de alrededor de 1000 aguadores. La dotación de agua estimada para aquellos años sería de 2000 a 2500 metros cúbicos diarios para una población de 235.000 personas (Rueda Laffond 1994:27).

52 Básicamente se trata de unas conducciones subterráneas, formadas por minas y cañerías, usadas para transportar, mediante gravedad, el agua de capas freáticas alejadas de la villa, a distintos lugares de la misma. Para saber más acerca de la historia y evolución de los viajes de agua ver Pinto Crespo, V.d., F. Labrador Arroyo, and R. Gili Ruiz. 2010. Los viajes de agua de Madrid durante el Antiguo Régimen. . Madrid: Fundación Canal. 
debía abastecer a una ciudad con una población cuatro veces mayor, lo que, como veremos más adelante adquirirá importancia suma en la medida en demográficamente la ciudad crecía a un ritmo mayor de lo que lo hacía la distribución del suministro de agua. Atendiendo, de manera sintética a las características demográficas de la ciudad de Madrid de los primeros años de 1900, cabe destacar que fue una ciudad caracterizada por la pervivencia de un crecimiento vegetativo negativo y una elevada llegada masiva de inmigrantes, que será característica clave para comprender las dinámicas demográficas que caracterizaron la ciudad (hasta 1935 en nuestro caso), fruto, en buena medida, del espectacular incremento de su población, que duplicará su volumen, y alcanzará el millón de personas en 1930 (Ver gráfico 5.1) .

El flujo migratorio fue una característica de importancia ineludible y explicativa del incremento de población en la ciudad de Madrid. En estos años, además, se mantienen las características tradicionales asociadas a los procesos migratorios, caracterizados, grosso modo, por una población rural y cohortes dirigidas al servicio doméstico o a la construcción, que procedían de las provincias limítrofes a Madrid. La repercusión de que esta migración esté caracterizada, en su mayoría, por estas características sociales, tendrá importancia suma a la hora de entender los procesos de urbanización y su vinculación con la mortalidad, dado que aporta, en buena medida, el componente humano que se concentrará en las barriadas de la periferia, desprovistas de cualquier servicio e infraestructura de saneamiento urbano.

En términos generales, entre 1900 y 1930 asistimos a un cambio en las tendencias demográficas, caracterizadas por un crecimiento vegetativo negativo, tasas de mortalidad elevadas (especialmente la mortalidad infantil) y las crisis epidémicas, especialmente la Gripe Española de 1918 (Bahamonde Magro \& Otero Carvajal, 1989; de Miguel, 1982; Fernández, 1989; Otero Carvajal, 2016; Ringrose, 1985) 
Gráfico 5-1. Evolución del número de habitantes de la ciudad de Madrid. Años 1857-1930

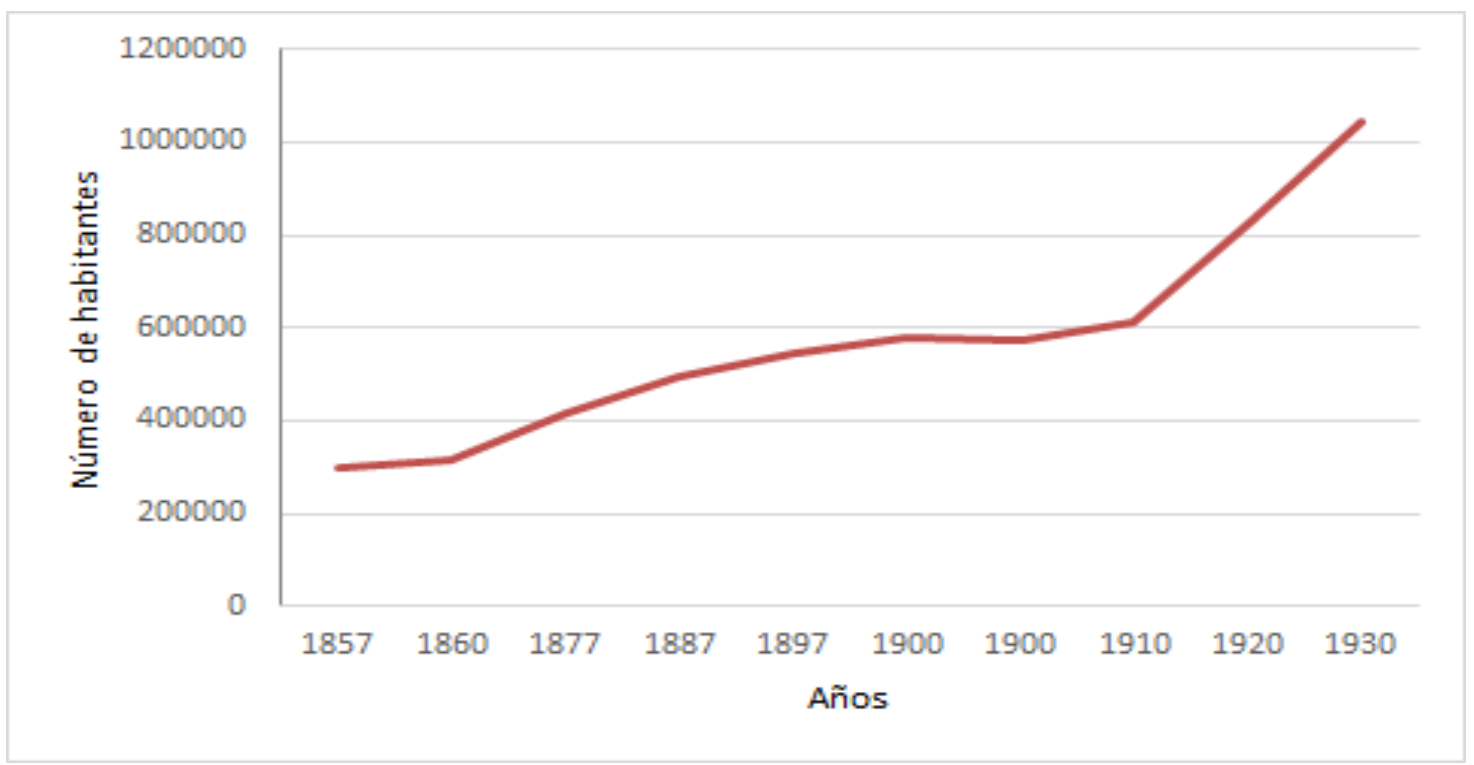

Fuente: Elaboración propia. Censos de población para los años correspondientes.

Nota: el número de habitantes se refiere a población de derecho

\subsubsection{El agua de consumo}

Desde la constitución del Canal de Isabel II hasta los años treinta del siglo XX, fue estimable el aumento en el abastecimiento de agua en Madrid. Asimismo, las pretensiones sobre el aumento de la disponibilidad de agua fue un continuo esfuerzo desde mitad del siglo XIX hasta la década de los años treinta. En el año 1879, regulado por la Ley de aguas, se estableció que la dotación mínima por habitante al día debía ser de 50 litros. En 1911, el Director del Canal, Ramón de Aguinaga, mantuvo que en 1911 esta cifra debía ascender a 171 litros, pero que el Canal estaba en disposición de llegar hasta los 287 litros por habitante (de Aguinaga, 1911). Años más tarde, desde la Dirección del Canal de Isabel II, se aseguraba que la disposición de agua había aumentado hasta 298 litros por habitante y día (Bello Poeyusan 1929).

La cantidad de agua necesaria para diferentes actividades, sufría cambios a medida que la sociedad se modernizaba. Resulta interesante remarcar el enfoque tomado por algunos autores, quienes hablan de "los usos sociales" del agua (V. d. Pinto Crespo et al., 2010), entendiendo que es necesario tener en cuenta que los usos sociales del agua en aquel momento dependían mucho del origen social de las personas, así "para la gran mayoría de esta población la necesidad más perentoria era tener agua para beber y 
poco más, que podía ser satisfecha mediante las fuentes públicas. Para un grupo mucho más reducido -comerciantes y artesanos-el agua era un complemento fundamental de su actividad productiva. Para los privilegiados -donde incluimos personas, pero también instituciones-, hablamos de un consumo mucho más diversificado en consonancia con sus estándares de vida: criados, cocinas, caballerías, huertas y jardines, por mencionar sólo los factores más importantes a satisfacer con importantes cantidades de agua"(V. d. Pinto Crespo et al., 2010). Pp6

Como ejemplo, podemos tomar el cálculo realizado por Melgosa Olaechea (Melgosa Olaechea, 1912) sobre el mínimo de litros necesarios para el abastecimiento de las poblaciones para diferentes ámbitos, reflejado en el gráfico 5-2..

Gráfico 5-2. Mínimo de litros d agua necesarios para el abastecimiento de las poblaciones para diferentes ámbitos.

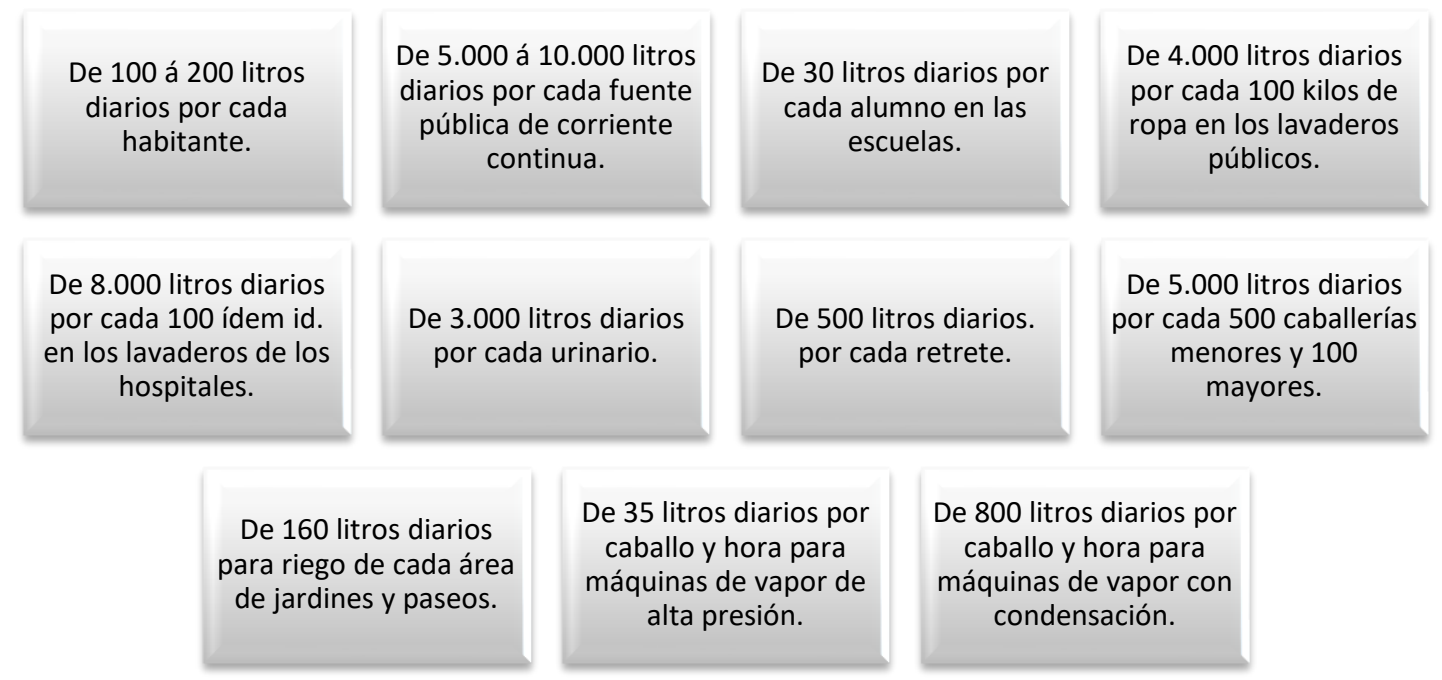

Fuente: Elaboración propia. Información extraída de (Melgosa Olaechea, 1912, p. 96)

Un aspecto importante a tener en cuenta, en lo que respecta a los usos del agua, es el de los hábitos de higiene de la población (Martínez, Garcia, \& Susarte, 2016). La mayor disponibilidad fue causa y efecto de la transformación de los hábitos de higiene en las zonas urbanas (Rodríguez Martín, 2013, p. 279). A principios de siglo XX, la mayoría de domicilios no contaban con wc o grifos en las cocinas. Solamente los habitantes más ricos disponían de tales comodidades en sus domicilios. Pero la mejora de los niveles de vida, particularmente en los años posteriores al fin de la Primera Guerra Mundial, incluyeron también la aspiración de que toda familia pudiera contar en su casa con un 
grifo de cocina y un inodoro. Una aspiración que progresivamente se fue transformando en realidad para un número creciente de habitantes de la ciudad (Rodríguez Martín, 2013, p. 279).

Imagen 5-1. Fotografía de anuncio de prensa del jabón Heno de Pravia

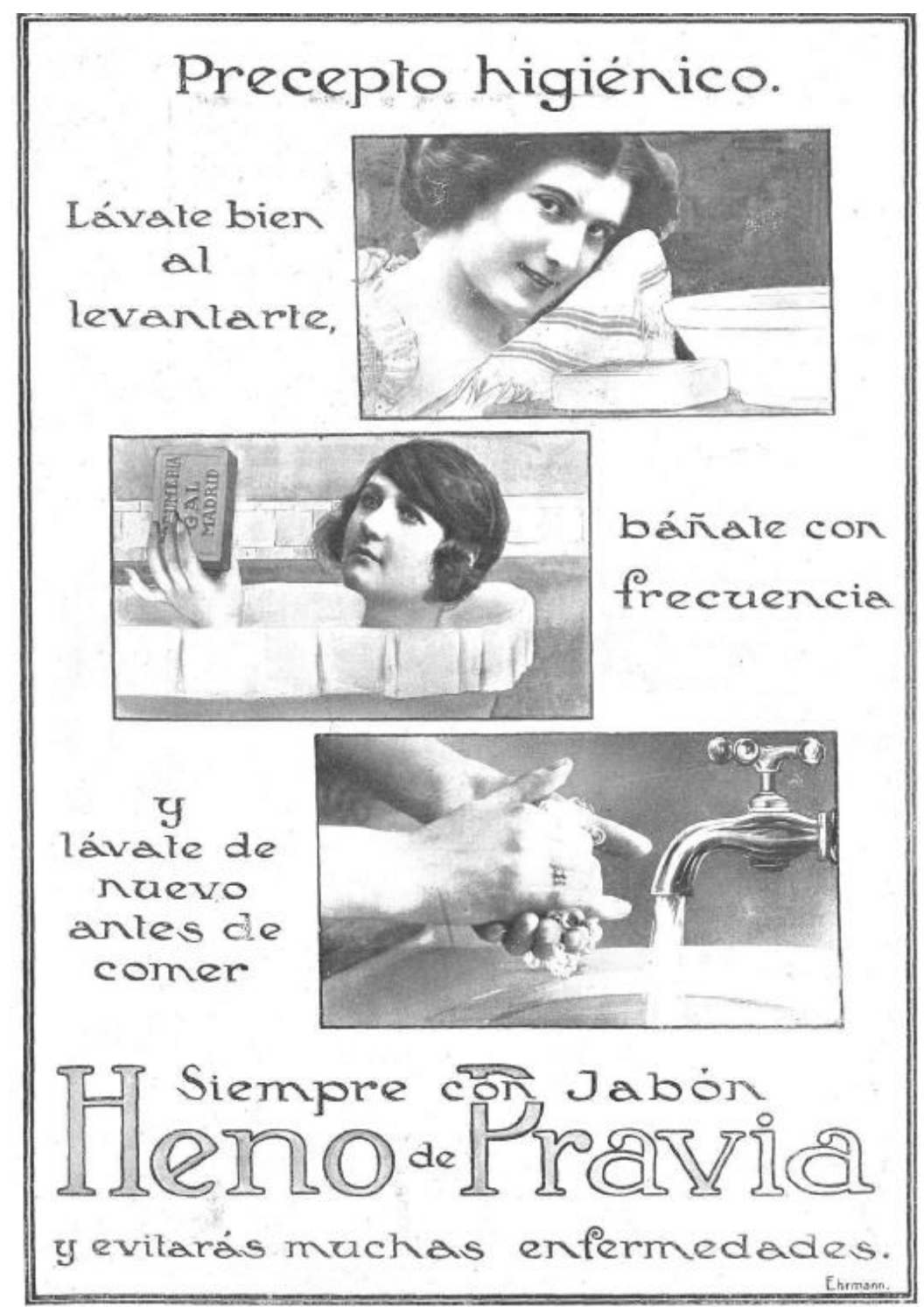

Fuente: El Mundo Gráfico. 11 de febrero de 1914. Pp. 24 
Imagen 5-2. Caricatura del siglo XVIII mostrando diferentes aseos según el país

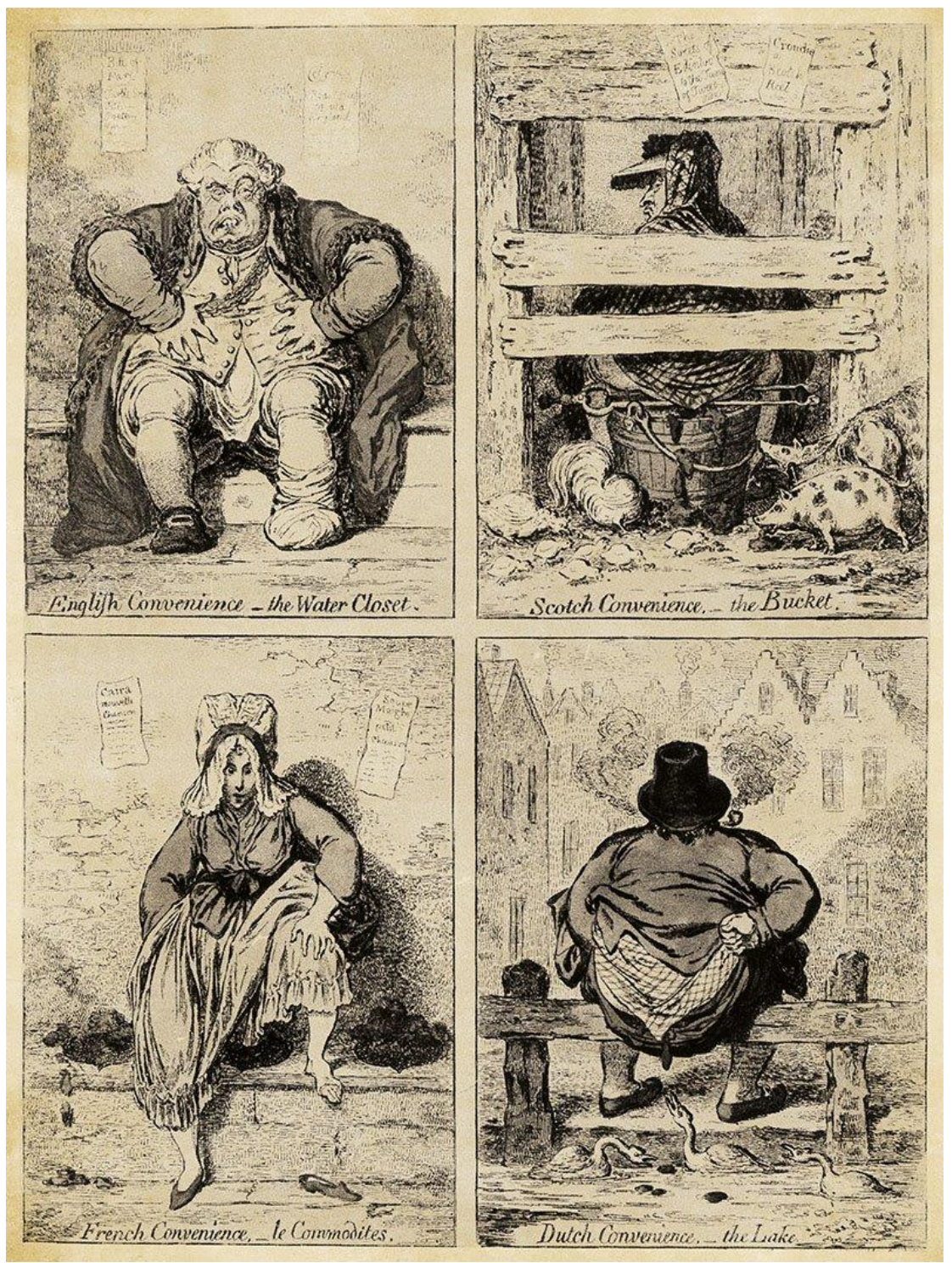

Fuente: https://historia.nationalgeographic.com.es/a/nacimiento-inodoro_14927

\subsubsection{La cantidad de agua consumida}

Atendiendo a los datos disponibles sobre la evolución del consumo máximo por habitante de agua del Canal de Isabel II, el consumo diario por persona en la ciudad de Madrid aumentó de 5-10 litros diarios por habitante en 1850, a superar los 200 litros en 1905 y a 263 en 1930. 
Gráfico 5-3. Evolución del consumo máximo de agua por habitante y día (1858-1930)

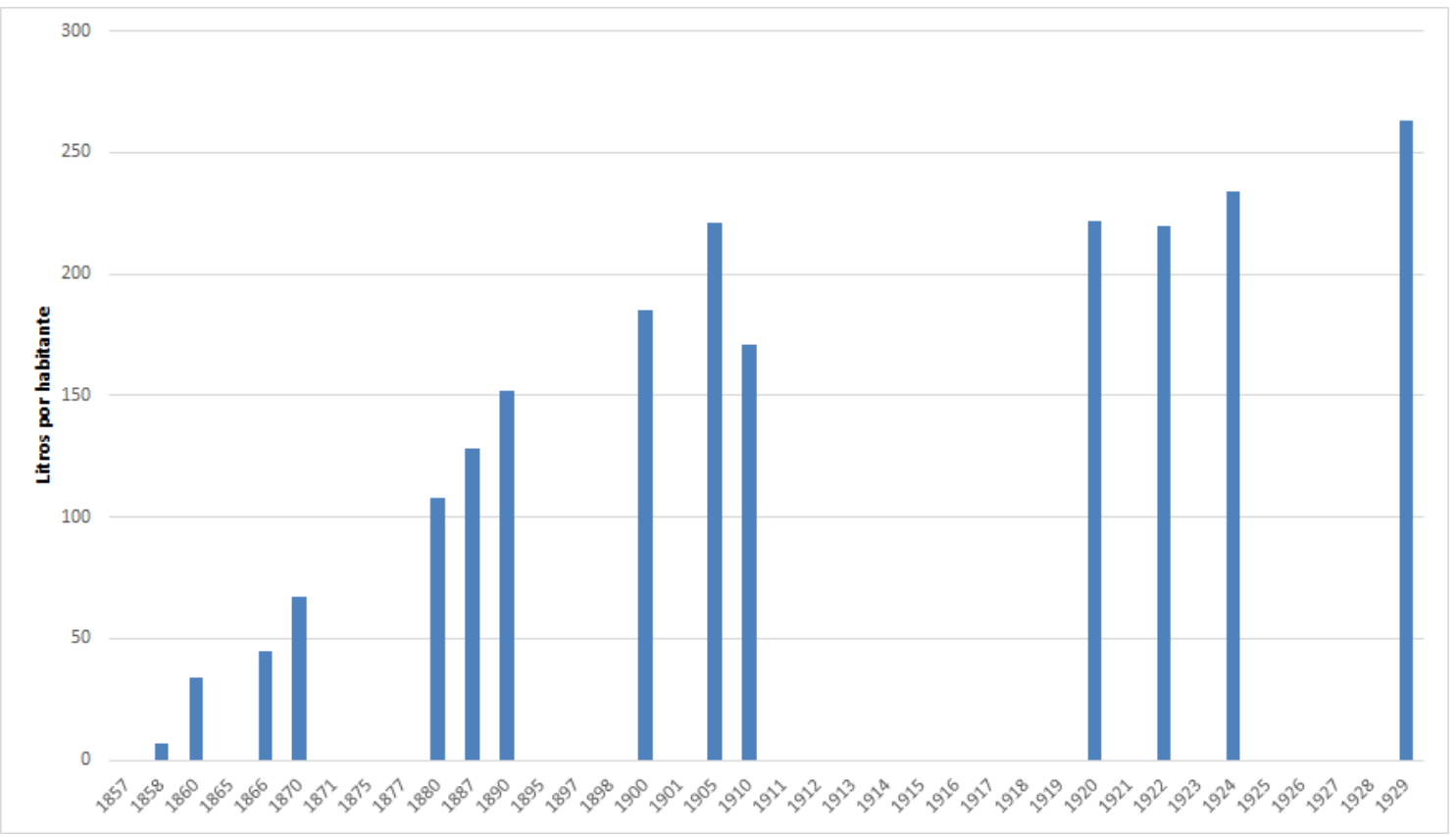

Fuente: Elaboración propia. Datos de las Memorias del Canal de Isabel II, varios años.

Además, como ya señalamos más arriba, el monopolio del servicio de aguas por parte del Canal de Isabel II dejó de estar vigente con la creación de la compañía privada Hidráulica Santillana. Este hecho contribuyó a que se produjeran modificaciones en las condiciones de suministro de agua ${ }^{53}$, pero el Canal de Isabel II siguió siendo el principal

53 Otros acontecimientos importantes que produjeron la alteración de las condiciones de suministro de agua a la capital por el Canal de Isabel II fue la reorganización del Canal en 1907 , de modo que la antigua administración ministerial se adaptó a un modelo de sociedad industrial, pero bajo una figura especial que no dejaba de corresponder a la titularidad estatal de la que disfrutaba.

La nueva administración (Comisaría Regia) efectuó un plan de obras extraordinario, del que cabe destacar la planificación de construcción del Canal Transversal (localizado entre las Presas del Portón y del Villar), la finalización del Tercer Depósito de agua y el aprovechamiento eléctrico de un salto de agua A raíz de estas decisiones comenzó un periodo de conflictos con las sociedades eléctricas que distribuían en la capital al tiempo que se incrementó el malestar entre el Canal y la Hidráulica Santillana, ya que esta segunda había recibido autorización para abastecer agua a las zonas a las que no llegaba el Canal o que éste abastecía de manera insuficiente (autorizado por el Ministerio de Fomento y el consistorio municipal). El punto álgido de las disputas se produjo en 1909, cuando el Canal de Isabel II promovió constituir la Cooperativa Eléctrica y logró un acuerdo con el Ayuntamiento para abastecer el alumbrado público. (seguir pp58 y explicar el papel que jugó la cesión de Sánchez de Toca en la limitación de las perspectivas de diversificación de la Compañía). Finalmente, por Decreto de ocho de febrero de 1907 se aprueba la reorganización administrativa, de manera que se decide constituir un consejo de administración que, por delegación del Estado y a las órdenes de Ministerio de Fomento, tendría por objeto el mantenimiento y gestión del servicio. La presidencia del mismo fue ocupada por un Comisario Regio, elegido por el Gobierno, y debía ser un ex ministro. (para más información al respecto, ver: Rueda Laffond, J.C. 1994. El agua en Madrid: Datos para la historia del Canal de Isabel II, 1851-1930: Fundación Empresa Pública.). 
distribuidor de agua a la ciudad de Madrid, atendiendo al volumen de agua distribuido. A la altura de los años treinta, los litros de agua en media diaria por habitante de manos el Canal de Isabel II ascendían a casi 241 litros y la Hidráulica Santillana 39,5 litros

Tabla 5-1. Consumo de agua procedente del Canal de Isabel II. 1920-1932 ${ }^{54}$

\begin{tabular}{|c|c|c|c|c|c|c|c|c|}
\hline \multirow[b]{2}{*}{ Años } & \multirow{2}{*}{$\begin{array}{l}\text { Número de } \\
\text { habitantes }\end{array}$} & \multicolumn{7}{|c|}{ Conducción ${ }^{(22)}$} \\
\hline & & $\begin{array}{c}\text { Total anual } \\
\text { (metros cúbicos) }\end{array}$ & $\begin{array}{c}\text { Medio diario } \\
\text { (metros cúbicos) }\end{array}$ & $\begin{array}{c}\text { Medio diario } \\
\text { por habitante } \\
\text { (Litros) }\end{array}$ & $\begin{array}{c}\text { Máximo diario } \\
\text { (metros cúbicos) }\end{array}$ & & $\begin{array}{l}\text { Mínimo diario } \\
\text { (metros cúbicos) }\end{array}$ & \\
\hline $1920-1921^{(1)}$ & 750.896 & 49.240 .524 & 134.906 & 179,6 & 212.000 & (4) & 133.000 & (13) \\
\hline $1921-1922^{(2)}$ & 756.611 & 54.846 .906 & 150.265 & 198,6 & 220.000 & $(5)$ & 136.000 & (14) \\
\hline $1922-1923^{(2)}$ & 764.139 & 65.266 .000 & 178.800 & 234,0 & 229.000 & (6) & 137.000 & (15) \\
\hline $1923-1924^{(3)}$ & 765.484 & 66.092 .000 & 181.100 & 236,6 & 233.000 & (7) & 102.000 & (16) \\
\hline $1924-1925^{(3)}$ & 773.318 & 64.288 .000 & 175.705 & 227,2 & 227.000 & $(8)$ & 80.000 & (17) \\
\hline $1925-1926^{(3)}$ & 782.860 & 68.835 .000 & 187.357 & 239,3 & 238.000 & $(9)$ & 150.000 & (18) \\
\hline $1926-1927^{(3)}$ & 794.924 & 72.650 .000 & 199.041 & 250,4 & 233.000 & (10) & 163.000 & (19) \\
\hline $1927-1928^{(3)}$ & 809.400 & 72.136 .000 & 197.633 & 244,2 & 242.000 & (11) & 154.000 & (20) \\
\hline $1928-1929^{(3)}$ & 824.927 & 73.882 .080 & 199.451 & 241,8 & 259.763 & (12) & 152.630 & (21) \\
\hline $1929-1930$ & - & - & 229.263 & - & - & & - & \\
\hline $1930-1931$ & - & - & 235.304 & - & - & & - & \\
\hline $1931-1932$ & - & - & 242.976 & - & - & & - & \\
\hline
\end{tabular}

Fuente: Anuario estadístico de España. Años 1928 a 1932-1933. Instituto Nacional de Estadística.

\footnotetext{
54 (1) Número de habitantes según el Censo de 1920. (2) Número de habitantes calculado. (3) Número de habitantes según el Padrón municipal. (4) Fecha: 12 julio. (5) Fecha: 2 agosto. (6) Fecha: 15 agosto. (7) Fecha: 16 julio. (8) Fecha: 7 agosto. (9) Fecha: 26 julio. (10) Fecha: 29 julio. (11) Fecha: 18 julio. (12) Fecha: 22 julio. (13) Fecha: 5 marzo. (14) Fecha: 15 octubre. (15) Fecha: 23 diciembre. (16) Fecha: 25 octubre. Con restricciones por sequía. (17) Fecha: 18 marzo. Con restricciones fuertes por la avería del acueducto del Sotillo. (18) Fecha: 16 mayo. (19) Fecha: 29 enero. (20) Fecha: 25 diciembre. (21) Fecha: 15 enero. (22) Total, incluida el agua que al fin del Canal se emplea para riegos agrícolas.
} 
Tabla 5-2. Consumo de agua procedente de la Sociedad Hidráulica Santillana. $1920-1932^{55}$

\begin{tabular}{|c|c|c|c|c|c|c|}
\hline \multirow[b]{2}{*}{ Años } & \multirow[b]{2}{*}{$\begin{array}{l}\text { Número de } \\
\text { habitates }\end{array}$} & \multicolumn{5}{|c|}{ Conducción } \\
\hline & & \begin{tabular}{|c|} 
Total anual \\
(metros cúbicos)
\end{tabular} & $\begin{array}{c}\text { Medio diario } \\
\text { (metros cúbicos) }\end{array}$ & $\begin{array}{c}\text { Medio diario } \\
\text { por habitante } \\
\text { (Litros) }\end{array}$ & $\begin{array}{c}\text { Máximo diario } \\
\text { (metros cúbicos) }\end{array}$ & \begin{tabular}{|c} 
Mínimo diario \\
(metros cúbicos)
\end{tabular} \\
\hline $1920-1921^{(1)}$ & 750.896 & 6.424 .600 & 17.601 & 23,4 & $23.500^{(4)}$ & $11.300^{(13)}$ \\
\hline $1921-1922^{(2)}$ & 756.611 & 6.535 .300 & 17.904 & 23,7 & $24.300^{(5)}$ & $11.800^{(14)}$ \\
\hline $1922-1923^{(2)}$ & 764.139 & 8.510 .700 & 23.316 & 30,5 & $29.200^{(6)}$ & $14.100^{(15)}$ \\
\hline $1923-1924^{(3)}$ & 765.484 & 8.838 .000 & 24.213 & 31,6 & $31.400^{(7)}$ & $19.600^{(16)}$ \\
\hline $1924-1925^{(3)}$ & 773.318 & 9.589 .000 & 26.271 & 34,0 & $35.200^{(8)}$ & $20.100^{(17)}$ \\
\hline $1925-1926^{(3)}$ & 782.860 & 11.675 .700 & 31.988 & 40,9 & $37.000^{(9)}$ & $27.800^{(18)}$ \\
\hline $1926-1927^{(3)}$ & 794.924 & 11.253 .558 & 30.831 & 38,8 & $35.400^{(10)}$ & $25.200^{(19)}$ \\
\hline $1927-1928^{(3)}$ & 809.400 & 11.563 .000 & 31.679 & 39,1 & $36.300^{(11)}$ & $23.400^{(20)}$ \\
\hline $1928-1929^{(3)}$ & 824.927 & 11.881 .481 & 32.552 & 39,5 & $40.000^{(12)}$ & $31.000^{(21)}$ \\
\hline $1929-1930$ & - & - & 29.578 & - & - & - \\
\hline $1930-1931$ & - & - & 29.330 & - & - & - \\
\hline $1931-1932$ & - & - & 31.300 & - & - & - \\
\hline
\end{tabular}

Fuente: Anuario estadístico de España. Años 1928 a 1932-1933. Instituto Nacional de Estadística.

Otros indicadores que nos ponen en la antesala de la evolución que sufrió el suministro de agua hasta la década de los años treinta del siglo XX, es el número de abonados de agua del Canal de Isabel II desde 1903 a 1933 (con algunas interrupciones en los datos disponibles) y el nivel de conducción máxima de agua.

Atendiendo al nivel de conducción de agua, el incremento experimentado refleja una mejora sustancial en lo concerniente a la mejora del servicio. El aumento del número de abonados, refleja que la ampliación del servicio tuvo lugar en este periodo.

Sin embargo, la realidad es que, pese a la extensión indudable del servicio de distribución de aguas, todavía en 1930 autores como Chicote consideraban que las condiciones del servicio no eran suficientes, de forma que, de cara a mejorar las condiciones de salubridad de Madrid, las actuaciones municipales deberían tener como principales objetivos, entre otros, ampliar la dotación de agua, cuidando de su abundancia y pureza y continuar la obra del alcantarillado.

\footnotetext{
55 (1) Número de habitantes según el Censo de 1920. (2) Número de habitantes calculado. (3) Número de habitantes según el Padrón municipal. (4) Fecha: 18 agosto. (5) Fecha: 20 agosto. (6) Fecha: 6 agosto. (7) Fecha: 25 julio. (8) Fecha: 13 agosto. (9) Fecha: 4 agosto. (10) Fecha: 19 julio. (11) Fecha: 13 agosto. (12) Fecha: 25 julio. (13) Fecha: 21 febrero. (14) Fecha: 7 enero. (15) Fecha: 12 febrero. (16) Fecha: 7 febrero. (17) Fecha: 17 febrero. (18) Fecha: 23 noviembre. (19) Fecha: 14 febrero. (20) Fecha: 7 diciembre. (21) Fecha: 9 febrero.
} 
Gráfico 5-4. Evolución anual de la conducción máxima de agua del Canal de Isabel II (1858-1930).

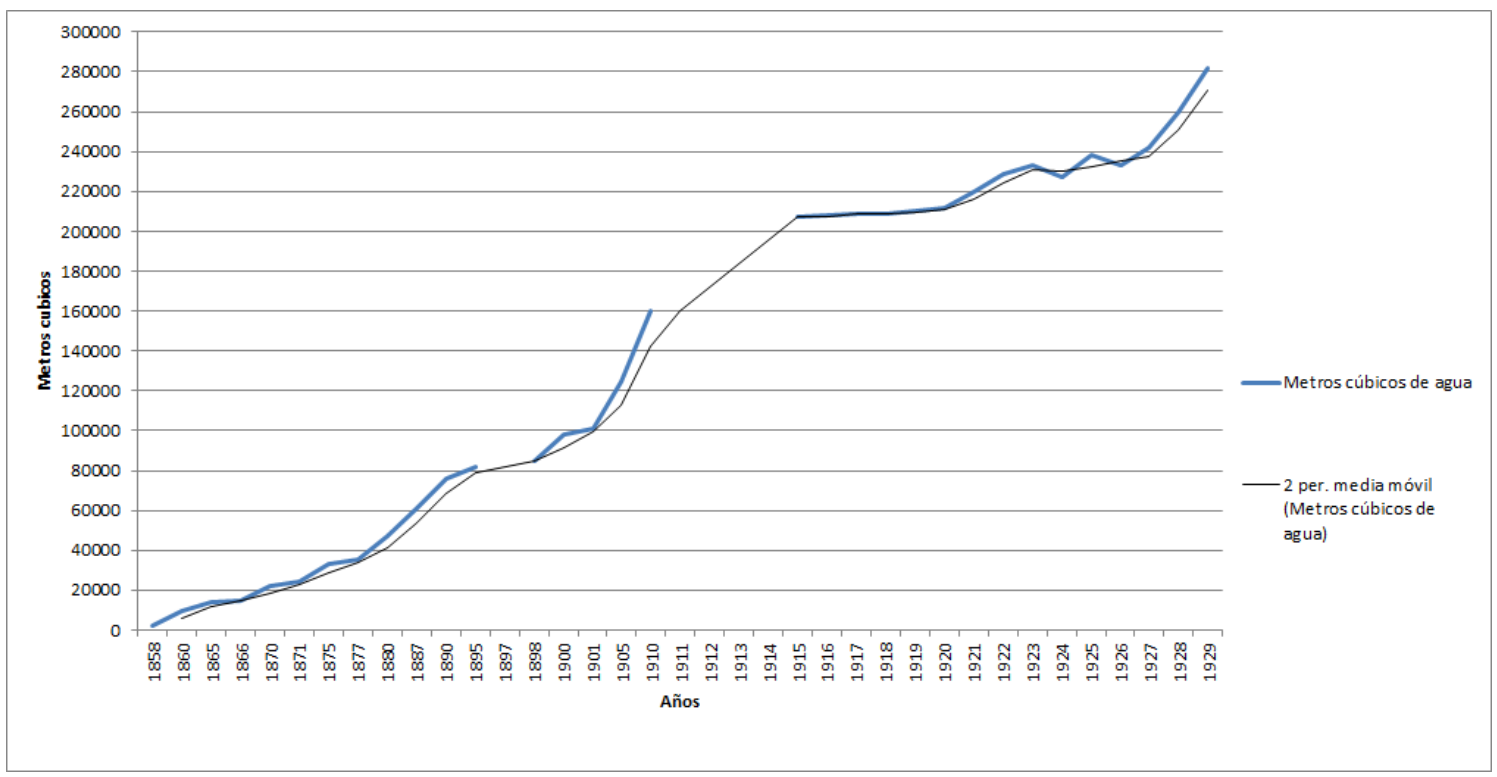

FUENTE: Elaboración propia. Canal de Isabel II. Exposición de la ciudad y de la vivienda modernas. Madrid, marzo de 1927. Información del Canal de Isabel II que abastece de agua a Madrid, de 1927 y Memorias del Canal de Isabel II para varios años. Con línea de tendencia de media móvil entre periodos. Total anual en metros cúbicos, mediante el aforo máximo registrado en las jornadas de mayor consumo.

Gráfico 5-5. Evolución anual de los abonados del Canal de Isabel II (1903-1933)

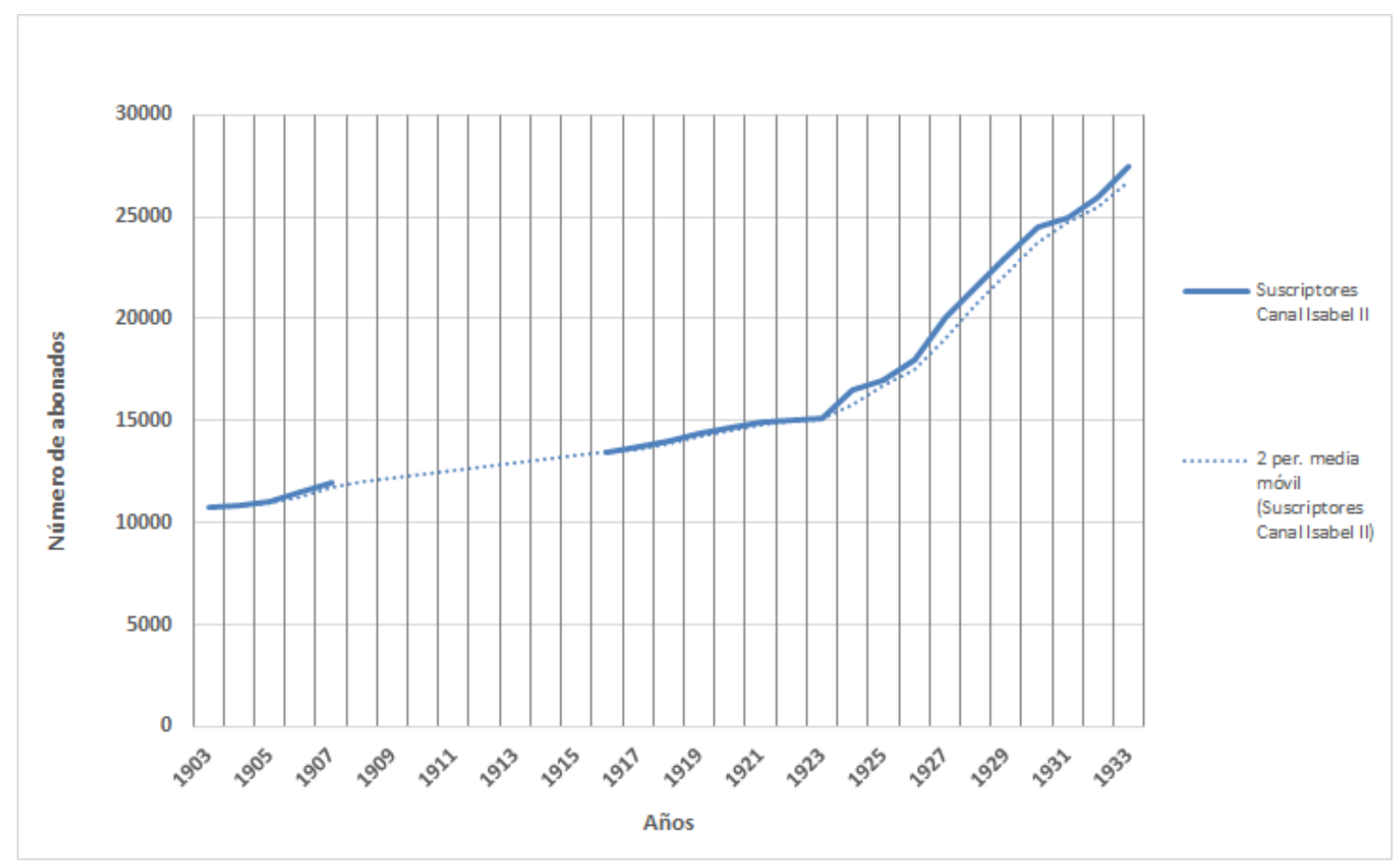

Fuente: Elaboración propia. Datos de las Memorias del Canal de Isabel II, varios años. 
En el contexto internacional, Madrid contaba con una dotación de agua potable que se encontraba entre las mayores, en comparación con otras capitales europeas (Gráfico 56). Atendiendo a los datos ofrecidos por los técnicos del Canal de Isabel II, en los primeros años del siglo XX, le correspondía a cada habitante por día aproximadamente 250 litros diarios, por encima de los 216 litros por habitante y día que correspondían a los parisinos y de los 80 litros diarios por habitante en caso de Berlín (Canal de Isabel II, 1907). En 1929, la dotación de agua potable a la ciudad de Madrid ascendía a 298 litros por habitante y día (Bello Poeyusan, 1929). En definitiva, el problema del agua en Madrid respondía más bien a problemas derivados de su distribución, y no del suministro de agua como tal, en tanto en cuanto se disponía de dotación suficiente. 
Gráfico 5-6. Consumo de agua por persona y día en litros para varias ciudades del mundo (1900)

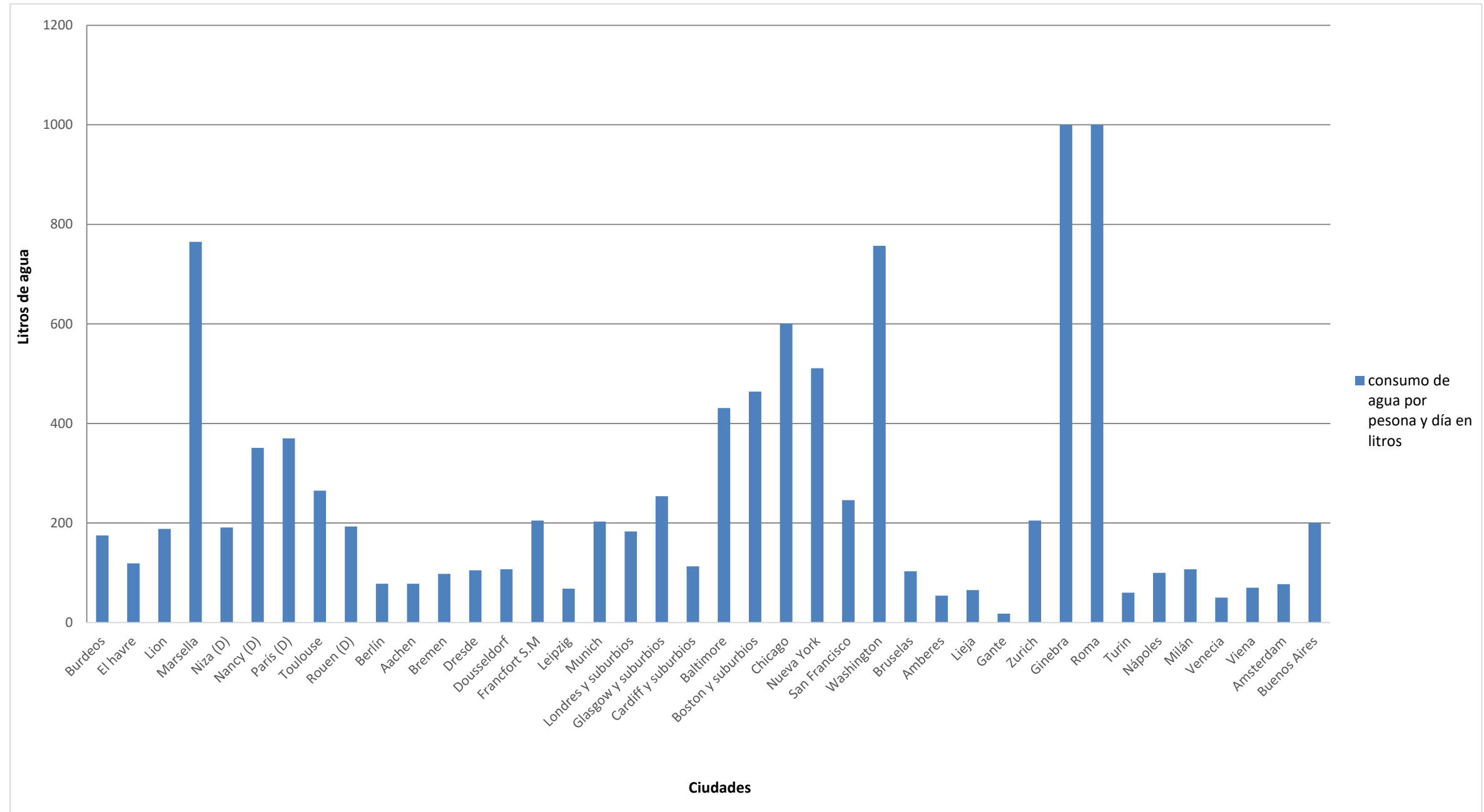

Fuente: Elaboración propia. Revista obras públicas. Varios números 1920. (Ricart Gualdo 1920). Nota: la (D) indica doble distribución. 
Otro de los aspectos que estuvo presente a lo largo de todo el periodo de estudio fue el miedo al desabastecimiento de agua durante las épocas de estiaje, en los que se abogaba por la racionalización del agua, tanto por parte de particulares como del agua consumida destinada a servicios públicos.

Respecto a los consumidores particulares, como objeto de atención respecto a la necesidad de racionalizar el agua que se consumía, cabe destacar que, en los momentos de estiaje, cuando el caudal del Lozoya era menor, se recurría a anuncios en la prensa para alentar a los habitantes de la ciudad a que moderasen el gasto de agua. Los mecanismos empleados para la regulación en épocas de sequía, solían ser restricciones basadas en la disminución de la presión del agua o el corte de la misma a determinadas horas (Rodríguez Martín, 2013, p. 274). Los usuarios, mostraban sus quejas ante estas situaciones, tal y como se refleja en los diarios de la época. "Escenas un tanto violentas $y$ un mucho pintorescas ocurren en las casas entre inquilinos y porteros, administradores, propietarios y vecinos, porque los consumidores de agua advierten la falta y la atribuyen, por el momento, a una malquerencia de los porteros cuando no a una excesiva economía de los propietarios. Cuatro días hace que ya se van dando cuenta los vecinos madrileños de que ni son los porteros ni son los caseros los que los tasan y les quitan el agua. Es la Dirección del Canal, que, al mediar la noche, corta en absoluto y deja a los madrileños en seco". "La realidad es que la mayoría de los vecinos de Madrid carecen actualmente de agua, incluso para beber y lavarse. Hay miles de retretes estos días sin agua corriente. Y puede desarrollarse una epidemia". ("Madrid, sediento. De día poca agua y de noche ninguna," 1924).

Realmente, el mecanismo que en mayor medida consiguió una racionalización del consumo del agua por parte de los particulares fue el cambio en los sistemas de contadores.

En cuanto a la estacionalidad del consumo de agua, disponemos de información acerca de la cantidad de agua tomada del río Lozoya y del río Guadalix por meses a lo largo de un año. Atendiendo a los datos proporcionados, no se refleja la disminución de agua llegada a la ciudad fruto del verano, siendo, realmente, a partir del mes de octubre, cuando se produce una considerable disminución, tal y como puede verse en los gráficos $5-7$ y $5-8$. 
Gráfico 5-7. Consumo de agua del Canal de Isabel II, tomado por meses, en el espacio de un año

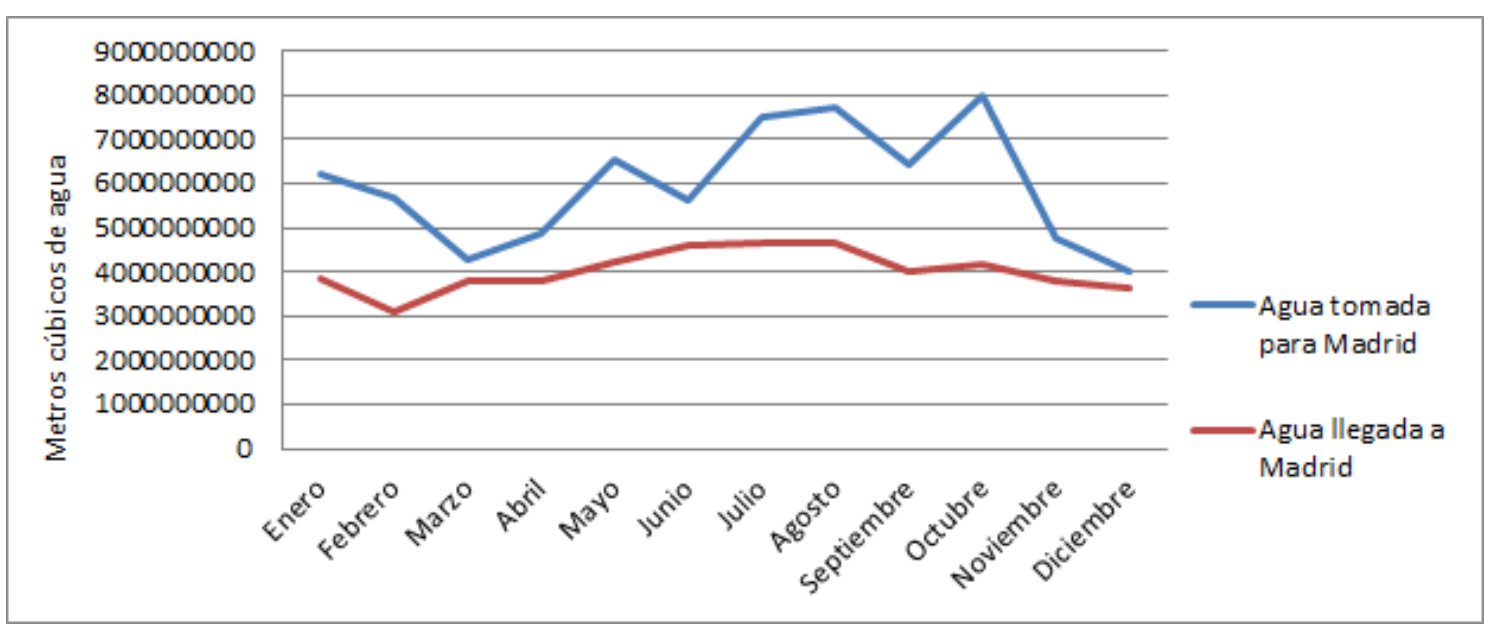

Fuente: Elaboración propia. Información obtenida de (Melgosa Olaechea, 1912, pp. 122-123)

Gráfico 5-8. Metros cúbicos de agua según río de abastecimiento

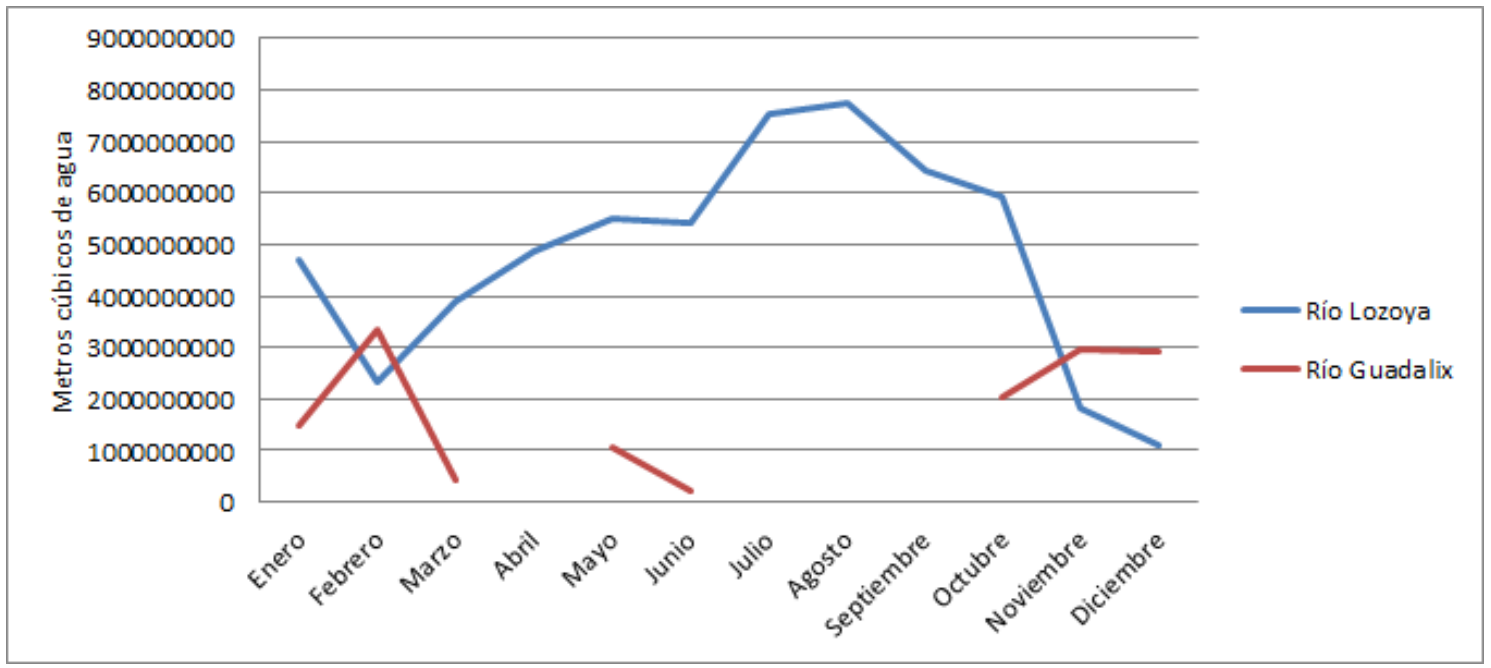

Fuente: Elaboración propia. Información obtenida de (Melgosa Olaechea, 1912, pp. 122-123)

Respecto al agua proveniente de los Viajes Antiguos, propiedad del Ayuntamiento, disponemos de información, para el año 1912, sobre las concesiones realizadas por el Ayuntamiento de Madrid sobre el agua de los Viajes antiguos a fincas particulares, así como de las concesiones de agua sobrante de abrevaderos, fuentes públicas y arroyos de la Villa de Madrid. 
Respecto a primeras, se trata de un total de 60 concesiones a fincas particulares, que correspondían a un total de 17.143,63 pesetas de recaudación y un 4.462,62 de canon en pesetas. (Melgosa Olaechea, 1912, pp. 129-130). 
Tabla 5-3. Concesiones de agua de los Viajes Antiguos realizadas por el Ayuntamiento de Madrid a fincas particulares. Año 1912

\begin{tabular}{|c|c|c|c|}
\hline Nombre de calle & Número & Capital en pesetas & Canon en pesetas \\
\hline Abada & 11 & 515,63 & 15,48 \\
\hline Aguas & 4 & 490,50 & 14,72 \\
\hline Alcalá & 36 & 2.750 & 82,50 \\
\hline Alcalá & 52 dup & & 93,76 \\
\hline Alcalá & 74 & 2.750 & 82,50 \\
\hline Alcalá & 23 & & 187,50 \\
\hline Almendro & 6 & 687,50 & 20,64 \\
\hline Angel (plaza del) & 7 & 687,50 & 20,64 \\
\hline Atocha & 18 & 687,50 & 20,64 \\
\hline Atocha & 20 & 687,50 & 20,64 \\
\hline Atocha & 34 & 2750,00 & 82,50 \\
\hline Atocha & 141 & 687,50 & 20,64 \\
\hline Atocha & 65 & & 20,64 \\
\hline Ave María & 45 & 1875,00 & 56,26 \\
\hline Castellana (paseo de la) & 37 & 1.100 & 33,00 \\
\hline Carrera de San Jerónimo & 15 & 1.375 & 41,26 \\
\hline Carrera de San Jerónimo & 42 & 3.750 & 112,50 \\
\hline Cervantes & 34 & $1.237,50$ & 37,14 \\
\hline Concepción Jerónima & 29 & 1.375 & 41,26 \\
\hline Conde de Rom anones & 5 & 687,50 & 20,64 \\
\hline Cruzada & 3 & 6.250 & 187,50 \\
\hline Desengaño & 25 & $1.562,50$ & 48,88 \\
\hline Duque de Alba & 5 & 618,75 & 18,58 \\
\hline Echegaray & 21 & 2.750 & 82,50 \\
\hline Embajadores & 41 & $2.052,50$ & 61,88 \\
\hline lístudios & 5 & 927,25 & 27,64 \\
\hline Horno de la Mata & 10 & 1.375 & 41,26 \\
\hline Hortaleza & 122 & 687,50 & 20,64 \\
\hline Hortaleza & 81 y 83 & 6.250 & 187,50 \\
\hline Leganitos & 44 & 12.500 & 375,00 \\
\hline Libertad & 4 & 257,75 & 7,66 \\
\hline Mayor & 6 & 9.900 & 297,00 \\
\hline Mayor & 131 & 2.750 & 82,50 \\
\hline Mesón de Paredes & 74 & 25.000 & 750,00 \\
\hline Nicolás María Rivero & 13 & 687,50 & 20,64 \\
\hline Nuncio & 6 y 8 & 1.375 & 41,26 \\
\hline Nuncio & 13 & 2.750 & 82,50 \\
\hline Olmo & 14 & 346,25 & 10,36 \\
\hline Peligros & 4 & 343,75 & 10,32 \\
\hline Peñón & 40 & $1.037,50$ & 32,22 \\
\hline Piamonte & 2 & 3.125 & 93,76 \\
\hline Prado & 24 & 1.237 & 37,14 \\
\hline Preciados & 44 & 343,75 & 10,32 \\
\hline Prim & 1 y 3 & $7.812,20$ & 234,38 \\
\hline Recoletos (paseo de) & 8 & 2.475 & 74,46 \\
\hline Ribera de Curtidores & 5 & $1.031,25$ & 30,94 \\
\hline Ribera de Curtidores & 15 & $1.031,25$ & 30,94 \\
\hline Rodas & 15 & $1.031,25$ & 30,94 \\
\hline San Bernabé & 13 & 172,25 & 5,18 \\
\hline San Bernardo & 28 & 687,50 & 20,64 \\
\hline San Francisco (plaza de) & 2 & 2.750 & 82,50 \\
\hline \multicolumn{4}{|l|}{ San Juan (Platería de } \\
\hline Martínez). & 2 & $2.062,50$ & 61,88 \\
\hline San Lorenzo & 15 & 3.750 & 112,50 \\
\hline San Mateo & 17 & 1.375 & 41,26 \\
\hline Santa María (Plaza de) & 2 & $2.401,62$ & 74,46 \\
\hline Toledo & 96 & 682,50 & 20,64 \\
\hline Tres Cruces & 4 & 257,75 & 7,74 \\
\hline Tres Cruces & 4 & 687,50 & 20,64 \\
\hline Villa (plaza de la) & 4 & 1.375 & 41,26 \\
\hline Zorrilla & 6 & 687,50 & 20,34 \\
\hline
\end{tabular}

Fuente: Elaboración propia. Información obtenida de (Melgosa Olaechea, 1912, pp. 129-130) 
En cuanto a la concesión de aguas sobrantes, hasta el año 1912, se produjo la concesión de aguas sobrantes proveniente de un total de diez arroyos, abrevaderos y fuentes, que suponía un canon anual de 775 pesetas.

Tabla 5-4. Concesiones de las aguas sobrantes realizadas por el Ayuntamiento de Madrid hasta 1912.

\begin{tabular}{|ccccc|}
$\begin{array}{c}\text { Nombre de Fuentes, Arroyos } \\
\text { y Abrevaderos }\end{array}$ & Calles & Numero & $\begin{array}{c}\text { Canon } \\
\text { anual (en } \\
\text { pesetas) }\end{array}$ & Fecha de la concesión \\
\hline Peñuelas & Quinta de la Esperanza & & 25 & 13 de noviembre de 1861 \\
Portillo de Embajadores & Martín de Vargas & 3 & 25 & 5 de noviembre de 1861 \\
Puerta de Toledo & Ronda de Segovia & 18 y 20 & 25 & 5 de noviembre de 1864 \\
Abrevadero, Puerta de Segovia & Huerta de Villatoyas & & 25 & 25 de agosto de 1865 \\
Antonio López & Antonio López & 58 & 70 & 6 de abril de 1901 \\
Alcantarilla del Águila & Paseo de los Pontones & 14 & 70 & 14 de abril de 1901 \\
Paseo de los Pontones & Huerta & & 210 & 4 de mayo de 1904 \\
Fuente de Santa Isabel & Fábrica de electricidad del Sur & & 150 & 15 de octubre de 1900 \\
Alcantarilla del Águila & Paseo Melancólicos & & 35 & 31 de diciembre de 1906 \\
Alcantarilla del Águila & Huerta & & 140 & 8 de junio de 1907 \\
\hline
\end{tabular}

Fuente: Elaboración propia. Información obtenida de (Melgosa Olaechea, 1912, pp. 129-130)

Además del canon señalado en los cuadros, el coste anual por consumo de agua sobrante de cada fuente, era de 150 pesetas, y del agua sobrante de las alcantarillas destinado al riego de tierras y/o huertas, era de 70 pesetas por hectárea ${ }^{56}$ (Melgosa Olaechea, 1912, p. 130)

Como ya se ha citado más arriba, el Ayuntamiento hacía cesión de agua a los aguadores, mediante la expedición de licencias para la venta de agua de las fuentes públicas, mediante el cobro de un arbitrio municipal anual, que debía efectuarse en el mes de enero de cada año. De lo contrario, se declaraba desierta la vacante de la plaza en cuestión.

\footnotetext{
${ }^{56} \mathrm{La}$ estimación de riego por hectárea para la época, era que un litro de agua por segundo, da lo suficiente para regar una hectárea de terreno veinte veces en seis meses, a razón de 777 metros cúbicos de agua por cada riego y ocho fanegas de tierra de regadío producen lo suficiente para mantener una familia compuesta de siete personas (Melgosa Olaechea, 1912, p. 130)
} 
Tabla 5-5. Coste de la licencia de aguador en la ciudad de Madrid.

\begin{tabular}{|c|c|}
\hline Tipos de licencias para el servicio de los aguadores & Pesetas \\
\hline Nueva & 16 \\
\hline Renovación & 11 \\
\hline Sustitución & 5 \\
\hline Duplicada & 2 \\
\hline Llenado en fuentes vecinales & 10 \\
\hline
\end{tabular}

Fuente: elaboración propia. Información recogida de (Melgosa Olaechea, 1912, p. 131)

Sin embargo, pese a que señala que Madrid poseía una posición envidiable en lo que respecta al consumo de agua respecto a las capitales de provincia del resto de España (Melgosa Olaechea, 1912), así como en el contexto internacional, el Jefe del Negociado de Consumos del Ayuntamiento de Madrid, en su artículo titulado Las subsistencias en Madrid, mantiene su preocupación acerca de que Madrid pudiera encontrarse de manera repentina sin suministro de agua (Melgosa Olaechea, 1912, pp. 96-98).

Y es realmente importante tener esto en cuenta, ya que de ahí se derivan dos posibles explicaciones; bien porque el Canal de Isabel II no poseía la capacidad suficiente como para dotar de abastecimiento a una población en constante crecimiento, o por los peligros derivados de la antigua infraestructura utilizada, ya que se basada en una sola red de distribución y ésta estaba incompleta.

\subsection{La expansión de la ciudad y los problemas de distribución.}

Un elemento ineludible a tener en cuenta para entender la vinculación entre las características demográficas y de saneamiento urbano que tuvieron lugar en la ciudad de Madrid, es el correspondiente al proceso de expansión espacial que sufrió la ciudad en los años que son objeto de estudio y su supeditación a la disponibilidad de redes de saneamiento en los barrios que se extendieron más allá de las fronteras históricas de la ciudad (la zona del Casco Antiguo de la capital). Así, al igual que en otras ciudades europeas, el crecimiento de población de las ciudades vino acompañado de la necesidad de construcción de infraestructuras de abastecimiento diseñadas para la dotación de agua y sistemas de eliminación de residuos. 
En la ciudad de Madrid, el debate sobre la conveniencia de aprobar un Plan de Ensanche (el Proyecto de Castro $^{57}$ ), estuvo condicionado, en gran medida, por la insuficiencia de agua disponible. De facto, el Consistorio Madrileño manifestó su incapacidad para suministrar el agua en relación a las necesidades reales de la población requiriéndose la intervención del Gobierno, de forma que el 18 de junio de 1851, la reina Isabel II firmó el Real Decreto que aprobó el proyecto de conducción de las aguas del río Lozoya, un afluente del Jarama, a la ciudad.

El Proyecto de Castro fue contemporáneo a la primera llegada de aguas del Lozoya a la capital, en 1858, y en el mismo se señala de manera explícita la necesidad de la extensión de la distribución de agua domiciliaria a los nuevos barrios de la ciudad. Asimismo, cuando se verificó la traída de aguas a la ciudad, las acometidas directas a la red para proveer directamente a los domicilios particulares se consideraban "un lujo", pero ya en 1909 el Ingeniero-director del Canal de Isabel II reconocía que (...) un abastecimiento que no lleve los grifos del agua a todas las casas y a cada piso, se califica con razón como organización de servicios incompatible con las necesidades de la vida urbana contemporánea (Canal de Isabel II, 1909: 66).

Pronto comenzó a ponerse de manifiesto la insuficiencia de abastecimiento para una ciudad en constante crecimiento demográfico. La incapacidad técnica y financiera de las administraciones locales para acometer la modernización de los sistemas de suministro de aguas provocó el surgimiento de una empresa privada, la Hidráulica Santillana, en 1898, y la concesión de parte del servicio de suministro de aguas de la ciudad. Además, a lo largo del periodo estudiado, tuvieron lugar amplias modificaciones y renovaciones del servicio de aguas, con nuevos modelos de gestión, y cuya traducción se orientó a una modernización (parcial) del sistema, pero que fue de facto insuficiente para satisfacer a la demanda social de una ciudad como Madrid, que crecía tanto demográfica como territorialmente.

57 Pese a que no sea objeto de análisis exhaustivo en el capítulo aludir de manera detallada a la forma en que se conformó el Ensanche de la ciudad, sí consideramos oportuno apuntar que el Proyecto original sufrió un continuo proceso de modificaciones, tanto desde el punto de vista normativo como de su ordenación originaria. Uno de los factores más importantes fue que el Anteproyecto del Ensanche de Madrid comenzó a redactarse en 1857, cuando Madrid contaba con 271.254 habitantes, con una proyección prolongada a los 100 años, momento en que Castro estimaba que Madrid contaría con 450.000 habitantes. Sin embargo, el rápido crecimiento poblacional hizo que los planes originales se vieran desbordados, en la medida en 30 años después de la redacción del proyecto, Madrid ya había superado el número de habitantes que Castro estimó para 1857. Para un análisis detallado del proceso de nacimiento y evolución del ensanche consultar (Carballo Barral, Pallol Trigueros, \& Vicente, 2008) 
Si bien, en 1909, el Director de Vías públicas, Fontanería Alcantarillas y Servicios Eléctricos del Ayuntamiento, Núñez Granés en su Proyecto para la Urbanización del Extrarradio (Núñez Granés, 1910) ya intentó abordar estas cuestiones, no fue hasta el año 1918 cuando fue sancionado por el Ministerio de la Gobernación. Además, este Plan fue desestimado cuando en 1924 se acuerda por la Junta Consultiva Municipal de Obras aprobar el Plan general de extensión de Madrid y su distribución en Zonas, de los arquitectos López Sallaberry, Aranda, Lorite y García Cascales (Sallaberry, Sánchez, Lorite, \& Cáscales, 1924).

Desde las esferas política y médica hubo preocupación por el incremento de población "descontrolado", especialmente en las zonas del Extrarradio de la ciudad. Esta zona, careció de cualquier tipo de plan de urbanización, ni de saneamiento hasta casi la segunda década del siglo XX.

Atendiendo a una comparativa a nivel de distrito, entre 1905 y 1920, vemos que el comportamiento no es símil entre éstos (gráfico 5-9). Todos los distritos experimentaron un incremento en su población, a excepción del distrito Hospicio y, especialmente, el distrito Centro. Los distritos del Extrarradio y del Ensanche de la ciudad son los que experimentan un crecimiento poblacional más acusado, especialmente Universidad, Buenavista y Chamberí. Como se verá en el capítulo ocho, el componente humano de los barrios que componen estos distritos estará caracterizado por ser población de condiciones económicas, sociales y comportamientos diferenciados (Brandis, 1983) 
Gráfico 5-9. Número de habitantes por distritos. Años 1905, 1915 y 1920.

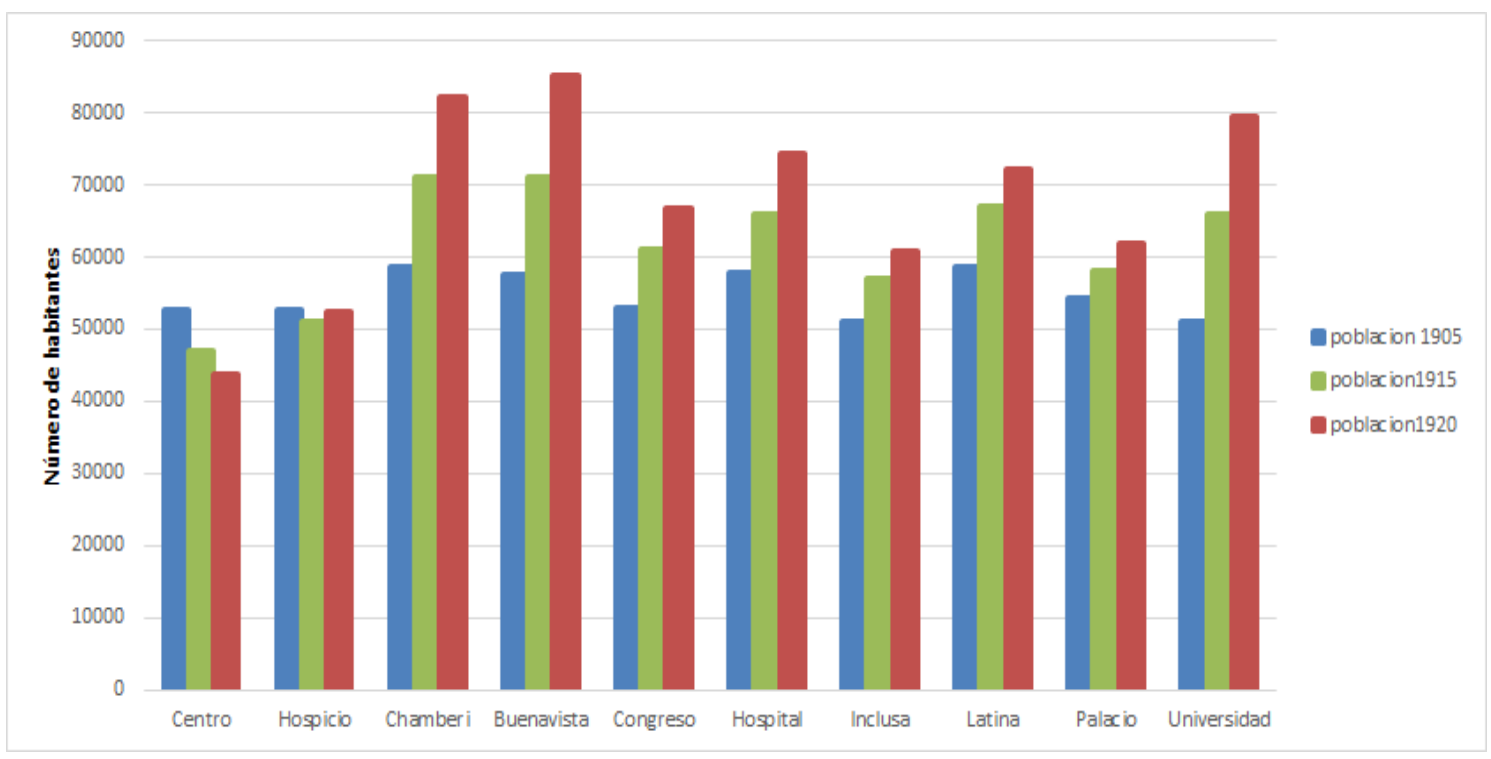

Fuente: Elaboración propia. Datos obtenidos de (León Peralta, 1926)

Gráfico 5-10. Variación en el número de habitantes por distrito. Años 1905 y 1920.

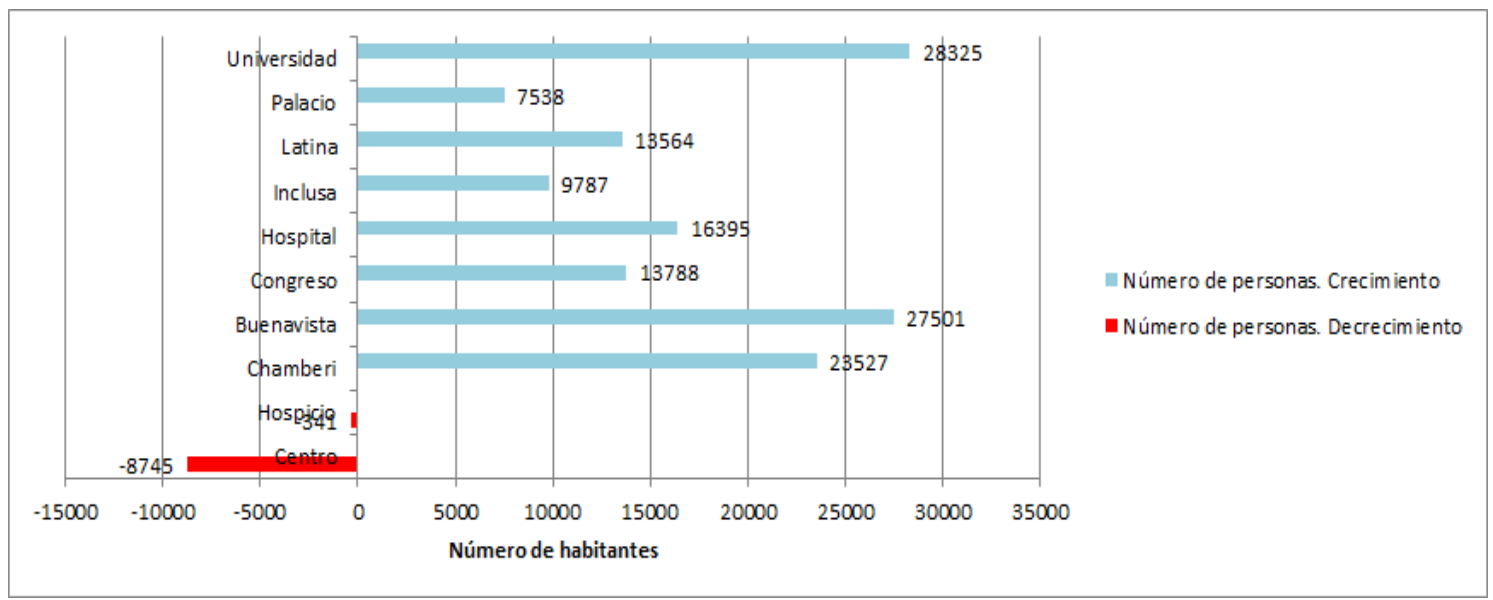

Fuente: Elaboración propia. Datos obtenidos de (León Peralta, 1926)

\subsubsection{El problema de la distribución de agua de consumo}

Teniendo en consideración que el consumo diario de agua en la ciudad aumentó considerablemente a lo largo del periodo de estudio (tal y como hemos visto en el apartado anterior), los problemas relativos al abastecimiento del agua de consumo no radicaban en torno a la cantidad, sino en su calidad y, sobre todo, en su irregular e ineficiente distribución. Si bien el primero de los aspectos, logró mejorarse parcialmente con la instalación de plantas depuradoras y con la finalización del Canal Transversal, 
que paliaba los efectos de "las turbias", el problema de la distribución fue un problema sólo parcialmente resuelto a la altura de los años treinta del siglo XX.

Si bien se consiguieron avances en la ampliación de la red de distribución, estos no se consiguieron hasta la aprobación del trazado subterráneo siguiendo las cuatro zonas principales de expansión de la capital, en 1929. El aumento en la demanda de agua, forzado por el crecimiento de la población de la ciudad y la ampliación de su extensión, no fue al mismo compás que lo hacían las obras de abastecimiento, existiendo zonas de la ciudad, especialmente en el Ensanche (norte y este) y el Extrarradio en su plenitud, desabastecidas del servicio de agua potable.

Ante esta circunstancia, la Hidráulica Santillana, creada en 1898, actuó como revulsivo, fomentando la necesidad de reorganización del Canal en el periodo de 1907. El Canal de Isabel II, desde el nombramiento de Sánchez de Toca, comenzó a plantearse la necesidad de aumentar su financiación y rentabilidad, para poder hacer frente a los afanosos proyectos que plantearon. 


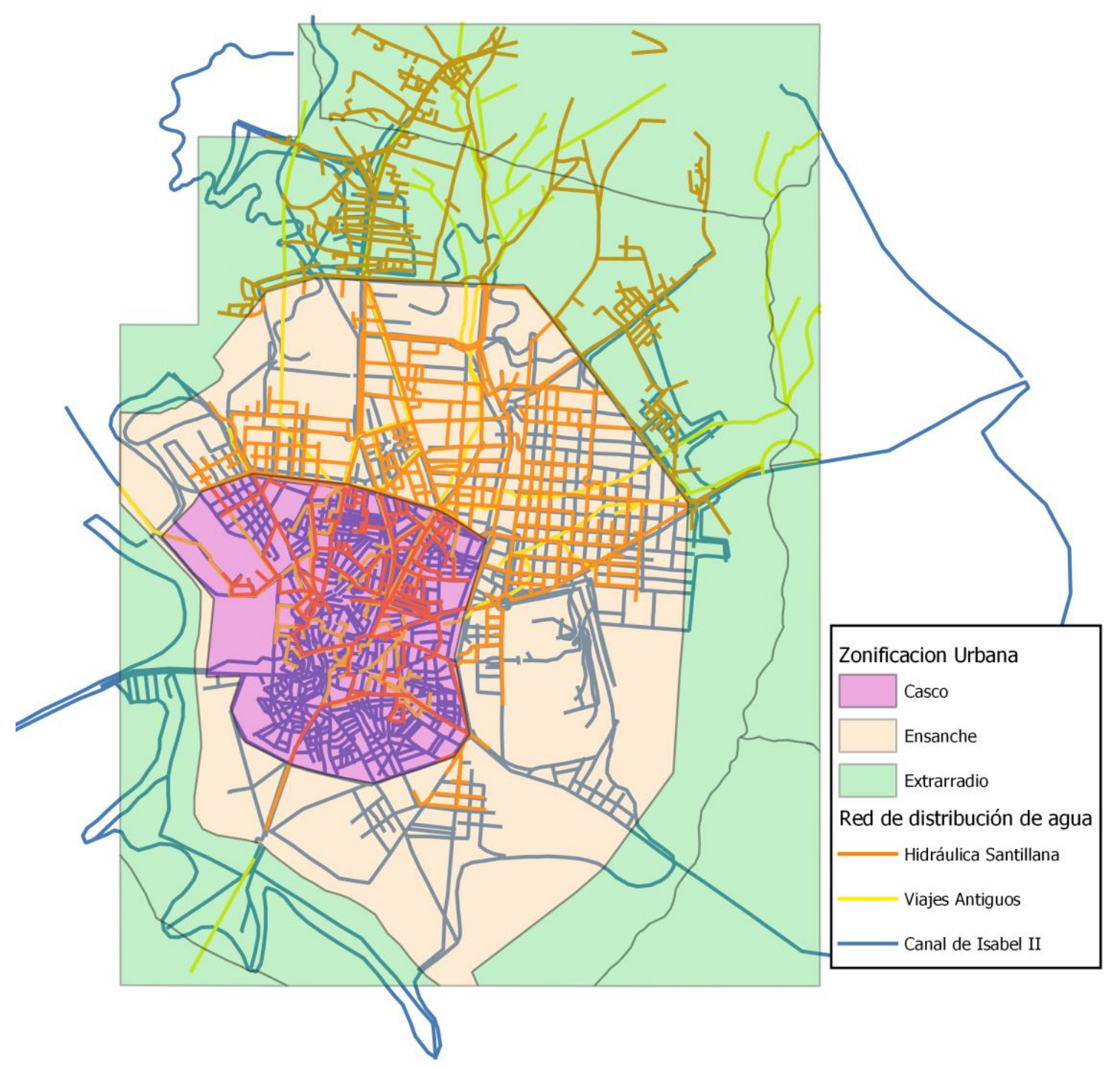

Fuente: Elaboración propia a partir de la vectorización de las redes de agua existentes en 1929.

Como puede verse a través del mapa de la red de distribución de agua (Mapa 5-1), a la altura de 1929 el abastecimiento de agua potable se realizaba bajo tres entidades; el Ayuntamiento, a través de los Viajes de agua (también llamados Viajes antiguos), el Canal de Isabel II y la Sociedad Hidráulica Santillana. El Canal de Isabel II era el que revestía mayor importancia, si atendemos a la cantidad de agua que trasportaba. Los viajes antiguos, en continuo declive a lo largo del siglo XX, siguieron explotándose hasta los años treinta del siglo pasado.

Atendiendo a los datos proporcionados por la Memoria de Información sobre la ciudad (1929), a finales de la década de los años veinte aún seguían en funcionamiento seis 
viajes de aguas, siendo el Viaje del Bajo Abroñigal el más importante de éstos por su mayor caudal, con una dotación de, aproximadamente, un millón y medio de litros de agua por día. La susceptibilidad ante las filtraciones, especialmente procedentes de los pozos negros, hicieron que estuvieran en progresivo desuso, pese a la insistencia en mantenerlos en activo, especialmente por el miedo al desabastecimiento que podía producirse en épocas de sequía (Lopez Baeza, 1931, p. 3).

En lo que respecta al Canal de Isabel II y la dotación de agua disponible, los avances logrados fueron innegables. La problemática con la situación de Madrid y el agua del Lozoya no era el volumen o cantidad de agua, sino que estaban derivados de las deficiencias existentes en cuanto a las conducciones, los sistemas de almacenamiento y, especialmente, los mecanismos y la red de distribución (Rodríguez Martín, 2013, p. 262).

Un estudio publicado en 1903 por el médico de la Beneficencia Municipal Emilio Loza Collado, resumía el problema: La distribución del agua es enormemente defectuosa por insuficiencia de la red repartidora, poca elevación de los depósitos y por haberse hecho muchas concesiones a caño libre. 200.000 habitantes y 4.000 edificios carecen, por estas causas de un abastecimiento regular, y más del 50 por 100 del agua suministrada se desperdicia lastimosamente. (Rodríguez Martín, 2013, pp. 262-263).

Los problemas de distribución de agua, no sólo pueden denotarse mediante la falta de cobertura de la red, tal y como puede verse en los mapas de la red de distribución para varios años, sino que estaban asociados, también, a elementos tales como la insuficiencia de conducción de agua por parte del Canal de Isabel II a los pisos más altos de los edificios. Es decir, incluso los pisos de edificios elevados que estaban ubicados en zonas que sí estaban abastecidas, como las del casco antiguo de la ciudad, también se encontraban con cantidad de agua insuficiente a principios del siglo XX (Rodríguez Martín, 2013, p. 263). 


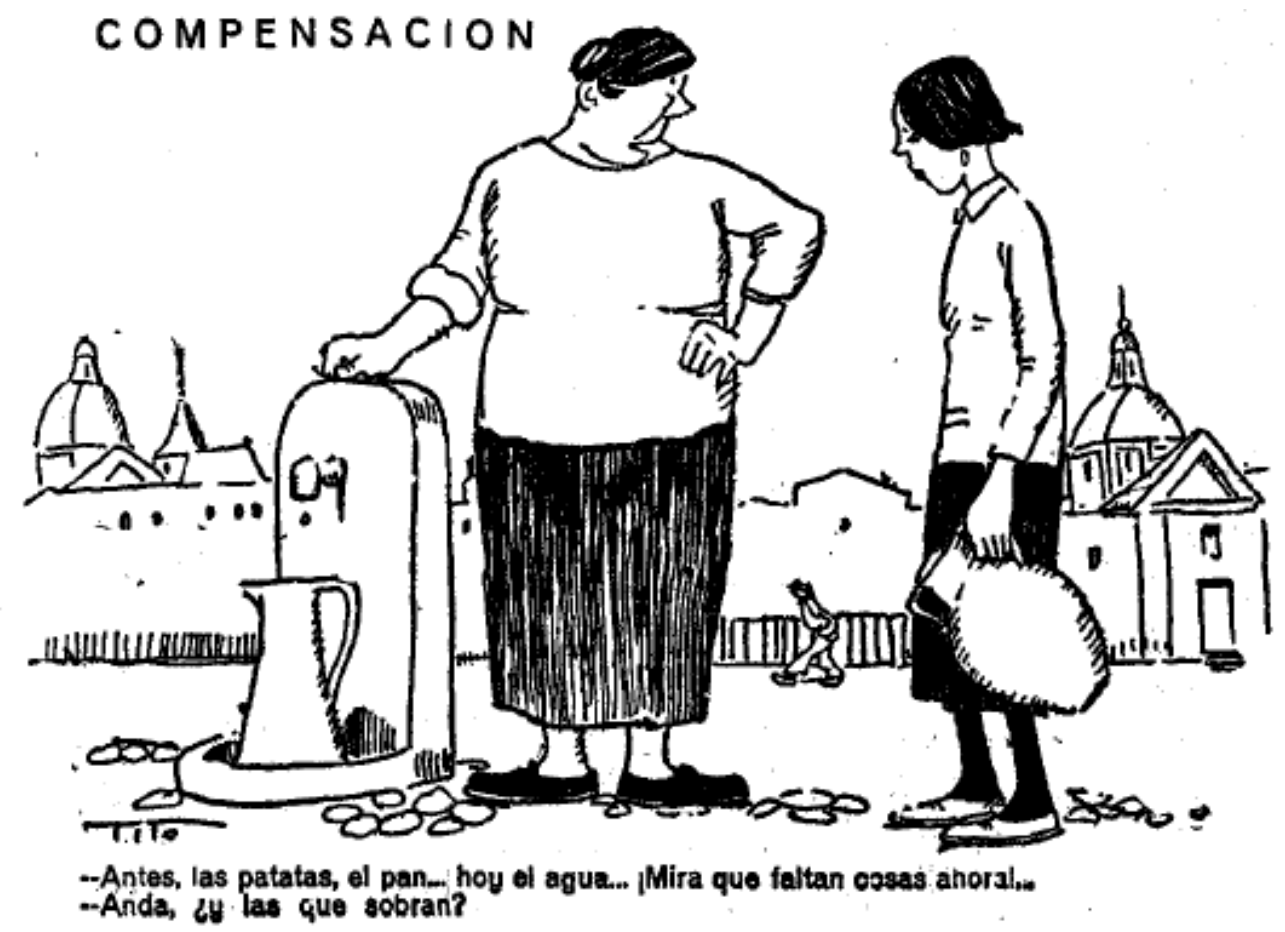

Fuente: La Libertad. ("El Extrarradio, la extensión de Madrid y el problema del agua. Una nota explicando las causas de que no haya suficiente agua en Madrid," 1928). Obtenido de la Hemeroteca de la BNE.

El propio Canal de Isabel II, en la Memoria de 1911 (de Aguinaga, 1911), reconoce la importancia de atender a la insuficiente distribución de agua en las zonas elevadas de la ciudad y que, dados los desniveles que existen en Madrid, "en algunos pisos altos de las casas no tenía el agua presión suficiente para llegar á ellos” (de Aguinaga, 1911, p. 44). Asimismo, años antes, en la Memoria publicada en 1909, aparecen alusiones del vecindario de la ciudad, que mostraba su descontento en torno a la impresión del ineficiente servicio de abastecimiento de agua, destacando los hundimientos producidos en el terreno, las interrupciones del servicio, el mal estado de las bocas de riego o la irregularidad de la presión del suministro de agua en los domicilios (Canal de Isabel II, 1909, pp. 50-51).

La solución a la problemática giró en torno a la construcción de depósitos elevados y la instalación de máquinas elevadoras. Además, se atendió a la necesidad de mejora y extensión de la red de distribución, mediante la construcción no sólo de un mayor número de tuberías de distribución de agua sino también con una infraestructura de mayor calibre. Otro de los puntos a los que atendieron fue la reparación y/o sustitución 
de la red existente, dado el deterioro de la misma en algunos puntos. Los aspectos anteriormente descritos fueron el eje central de los planes de obras a partir de 1907.

Como se ha mencionado en líneas precedentes, Madrid contaba con un sistema de distribución de agua deficiente. La conducción de agua se producía mediante cañerías de diferente titularidad y con distintos diámetros. Una parte de la red pertenecía al Ayuntamiento de Madrid, otras eran propiedad de particulares y, la mayor parte, fueron construidas de manos del Canal de Isabel II, por lo que su propiedad correspondía al Estado (Rodríguez Martín, 2013, p. 268).

Atendiendo a la red de tuberías para diferentes años, el Canal de Isabel II amplió su red de conducción de tuberías de manera excepcional. A principios del siglo XX, el Canal disponía de cerca de $130 \mathrm{~km}$ de cañerías de distribución y en 1930 superaba los 321 kilómetros. Las que dependían del Ayuntamiento se incrementaron de manera mucho más leve, de cerca de $110 \mathrm{~km}$ en 1920 a $128 \mathrm{~km}$ en 1930. En lo que respecta a la titularidad de particulares, en 1920 suponían 61 km de tubería de la red de distribución y en 1930 alcanzaron los 93 km (Memorias del Canal y (Rodríguez Martín, 2013). En resumen, a la altura de los años treinta, Madrid disponía de un total de más de $540 \mathrm{~km}$ de redes de tuberías de abastecimiento de agua.

Sin embargo, el crecimiento poblacional era muy superior al ritmo de construcción de tuberías de distribución.

\subsubsection{La cobertura de agua a nivel de barrio}

La repartición del agua a Madrid se hacía desde los depósitos ubicados en la ciudad, surtiendo también a las acequias de riego del Norte, Sur y Este. Si bien estas conducciones estuvieron en un principio orientadas al regadío de terrenos y de parques, tales como el Parque del Oeste o el Parque del Retiro, también surtían a las cañerías propiedad del Ayuntamiento, de particulares y del Estado, que repartían agua a zonas ubicadas en los barrios extremos de la ciudad, tales como Pacífico, Plaza de Toros, el Madrid Moderno, y los Carabancheles (Canal de Isabel II, 1907). 
Fruto del crecimiento experimentado en la ciudad, los años veinte fueron fiel reflejo de la creciente demanda de agua, mostrándose la incapacidad por parte del Canal de hacer frente a las necesidades reales.

Como ya hemos citado en líneas precedentes, los planes de obras quedaron paralizados por esta época, de manera que los problemas en la distribución de agua se vieron acrecentados. Así se reflejaba en la Memoria del Canal de Isabel II del año 1920 (Canal de Isabel II, 1920), la situación de la red de distribución revela una deficiencia grande enfrente de las necesidades sentidas. En la antigua, las presiones son cada día menores, efecto del aumento incesante en el consumo, a que contribuye la densidad, cada vez mayor, de la población con relación al área edificada, [...]. Por otra parte, el ensanche de Madrid no cesa, y a medida que la distribución avanza surgen nuevas casas, calles y barrios, que motivan a su vez mayores ampliaciones y engendran la necesidad de nuevas extensiones de la red. Resulta, pues, que actualmente la deficiencia de ésta es notoria, y la conveniencia de mejorarla y de complementarla, verdaderamente apremiante (Canal de Isabel II, 1920, p. 29).

Respecto a los servicios públicos, de gestión municipal, que eran abastecidos por el Ayuntamiento de la capital, pueden destacarse el abastecimiento de agua para instituciones de beneficencia, hospitales o escuelas públicas así como los servicios de limpieza de la vía púbica y el riego de jardines y parques. Desde el Canal de Isabel II se criticó duramente la gestión de estos servicios, en la medida en que los técnicos del Canal entendían que se producía un derroche de agua por parte del consistorio madrileño (Rodríguez Martín, 2013, p. 272). En la Memoria del Canal de 1904, se estimaba que el Ayuntamiento de Madrid empleaba 40.000 metros cúbicos de agua por día (Canal de Isabel II, 1907). Asimismo, se consideraba que la limpieza de calles era ineficiente, empleándose grandes cantidades de agua sin un resultado óptimo.

Además, las bocas de riego, las fuentes, los urinarios, los evacuatorios y los abrevaderos también eran elementos de gestión municipal, que empleaba agua del Canal para su funcionamiento. En 1907, dentro del plan de reformas del Canal, se firmó un convenio entre el Canal y el Municipio para la instalación y conservación de bocas de riego. Así, el Ayuntamiento de Madrid, en la sesión celebrada el 27 de julio de 1907, aprobó las bases de un convenio en el que se contemplaba la concesión al Canal del servicio de renovación, suministro y conservación de todas las bocas de riego, excepto las situadas en los parques y locales cerrados (Rueda Laffond, 2002, pp. 301-302). 
El periódico La libertad, en su tirada del 6 de julio de 1928, se hace eco del contenido de una circular enviada por el Canal, en la que se refleja el malestar respecto al uso del agua por parte del Ayuntamiento. "El Canal de Isabel II hace notar que durante los últimos veranos ha tenido siempre repletos todos sus depósitos situados en la capital, que no ha cortado ni una sola vez la comunicación de sus depósitos con la red general de distribución, y que, por tanto, su servicio básico de agua se hace sin interrupción alguna, tanto de día como de noche, sin que haya corrido en ningún momento peligro el abastecimiento Integral de la población, ni aun en los casos de Incendio, y que sólo se hacen cortas en determinados y limitados servicios cuando hay que hacer alguna reparación por averías locales, paradas que siempre duran muy poco tiempo.

La causa principal de la falta de presión en los domicilios la ocasiona, según dice la nota, el empleo constante de las bocas de riego, y sobre este punto se ha requerido, como en años anteriores, el concurso del señor alcalde, para que sean respetadas por los servicios de riego, del Ayuntamiento las horas de mayor consumo del vecindario. La importancia de esta medida queda demostrada con sólo decir que el Ayuntamiento tiene establecidas más de 6.000 bocas de riego, qué en un momento pueden dejar prácticamente impotentes las tuberías de las casas afectas a su recorrido.

Otra de las causas que originan falta de agua en los domicilios es la insuficiencia de las instalaciones domésticas, cuyas cañerías, capaces en las demás épocas del año, son insuficientes en el estío, en que aumenta el consumo. Por esta razón, existiendo presiones regulares al pie de las tuberías, no llega el agua más que a cierta altura porque, antes se ha consumido toda la que la tubería ha podido conducir.

El Canal, que todo lo concerniente a precios y condiciones lo tenía de antemano previsto, tan pronto como ha obtenido la autorización que con carácter urgente tenía solicitada del Gobierno, ha contratado con las industrias nacionales las tuberías necesarias para las obras de ampliación y mejora de la red actual, y comenzará las obras, sin dilación alguna, en cuanto reciba los materiales encargados, para lo cual tiene ya organizados los servicios".("El Extrarradio, la extensión de Madrid y el problema del agua. Una nota explicando las causas de que no haya suficiente agua en Madrid," 1928, p. 3).

Atendiendo a la cobertura de la red de abastecimiento de agua en el año 1929, se ha obtenido la proporción de ésta a nivel de barrio, teniendo en cuenta la superficie de cada 
uno de los barrios (gráficos 5-11 al 5-20). Se ha empleado, para ello, la vectorización de las líneas de red de agua obtenidas de los mapas de la Memoria sobre la ciudad de 1929 (Ayuntamiento de Madrid, 1929), para la red del Canal de Isabel II, Hidráulica Santillana y Viajes Antiguos ${ }^{58}$.

Teniendo en cuenta que la mayor dotación de agua de consumo venía de manos del Canal de Isabel II, a continuación se tendrá en cuenta aquellos barrios que, la altura del año 1929, disponían de menos de un $25 \%$ de su superficie con cobertura de abastecimiento del Canal de Isabel II. Éstos corresponden a barrios de los distritos Buenavista (Guindalera y Prosperidad), Cuatro Caminos (Chamberí), Congreso (Gutenberg y Plaza de Toros), Hospital (Pacifico, Delicias), Inclusa (Gasómetro y Marqués de Comillas), Latina (Imperial y San Isidro), Palacio (Moncloa y Casa de Campo) y Universidad (Lozoya).

Además, resulta interesante tener en consideración que, de éstos barrios con menos de un $25 \%$ de su superficie abastecida por el Canal de Isabel II, tampoco superan el $25 \%$ de superficie con red de abastecimiento de agua por las otras compañías de distribución, a excepción de Cuatro Caminos, que aparece abastecida en un $31 \%$ de su superficie por la Hidráulica Santillana.

Todos ellos, a excepción de los barrios del distrito de Inclusa y los de Latina, son barrios de las zonas del Ensanche y el Extrarradio de la ciudad. Esta situación nos pone en la tesitura de pensar sobre dos cuestiones principales. La primera de ellas es la deficiente distribución del servicio en las zonas que fueron fruto de la expansión de la ciudad (Ensanche y Extrarradio) y también en el abandono de aquellos barrios caracterizados por ser los más pobres de la ciudad, los situados en el distrito de Inclusa y de Latina.

\footnotetext{
${ }^{58}$ Para una atención pormenorizada de la obtención de la superficie de abastecimiento de agua, consultar capítulo sobre metodología.
} 
Tabla 5-6. Barrios con una superficie de cobertura de red de agua por el Canal de Isabel II inferior al 25\%. Año 1929.

\begin{tabular}{|r|c|c|c|}
\hline \multicolumn{1}{|c|}{ Barrio y distrito } & $\begin{array}{c}\text { Superficie con } \\
\text { agua del Canal de } \\
\text { Isabel II }\end{array}$ & $\begin{array}{c}\text { Superficie con } \\
\text { agua de la } \\
\text { Hidráulica } \\
\text { Santillana }\end{array}$ & $\begin{array}{c}\text { Superficie con agua } \\
\text { de Viajes Antiguos }\end{array}$ \\
\hline Prosperidad - Buenavista & 6 & 15 & 10 \\
\hline Guindalera - Buenavista & 20 & 13 & 14 \\
\hline Cuatro Caminos - Chamberí & 16 & 31 & 0 \\
\hline Gutenberg - Congreso & 13 & 0 & 0 \\
\hline Plaza de Toros - Congreso & 25 & 8 & 0 \\
\hline Pacifico - Hospital & 10 & 0 & 3 \\
\hline Delicias - Hospital & 14 & 2 & 0 \\
\hline Gasómetro - Inclusa & 16 & 1 & 0 \\
\hline Marqués de Comillas - Inclusa & 21 & 0 & 1 \\
\hline Imperial - Latina & 19 & 3 & 4 \\
\hline San Isidro - Latina & 22 & 0 & 3 \\
\hline Moncloa - Palacio & 18 & 0 & 0 \\
\hline Casa de Campo - Palacio & 19 & 10 & 0 \\
\hline Lozoya - Universidad & 24 & & 0 \\
\hline
\end{tabular}

Fuente: Elaboración propia.

Respecto a cuáles eran los barrios de los distritos más favorecidos en cuanto a la cobertura de red de agua, corresponden a los del distrito Centro. Con todos ellos abastecidos en más de un 75\% por parte del Canal de Isabel II. Asimismo, estos barrios estaban cubiertos por la red de agua de la Hidráulica Santillana y por los Viajes antiguos, en proporción variable. Nueve de los barrios del distrito Hospicio también disponían de una superficie de red de agua cubierta por el Canal de Isabel II en más de un $75 \%$. Hay que tener en cuenta que, siendo éstos los distritos mejor abastecidos por la red de agua, también son los distritos que, tal y como vimos en líneas precedentes (Gráficos 5-9 y 5-10, sobre el crecimiento de la población a nivel de distrito), también son los que experimentaron pérdidas de población entre 1905 y 1920. Como veremos en el capítulo número ocho de la presente tesis, son, también, los distritos caracterizados por disponer, en líneas generales, de un contingente poblacional con una posición socioeconómica más elevada, en comparación con el resto. 
Otros de los barrios con una buena dotación de abastecimiento de la red de agua correspondían a los barrios de Conde de Aranda, del distrito de Buenavista; Cardenal Cisneros, Trafalgar y Dos de Mayo, del distrito de Chamberí; Príncipe, Cervantes, Cañizares, Santa María y Alameda, del distrito de Congreso; Lavapiés, Jesús y María, Ministriles, Torrecilla y Primavera, del distrito de Hospital; Cabestreros, Amazonas, Rastro y Caravaca, del distrito de Inclusa; Calatrava, Aguas, Cava y Humilladero, del distrito de Latina; Quintana, Isabel II y Espejo, del distrito de Palacio y Quiñones, Conde Toreno, Amaniel, Minas y Santa Lucía, del distrito de Universidad.

Tabla 5-7. Barrios con una superficie de cobertura de red de agua por el Canal de Isabel II superior al 75\%. Año 1929.

\begin{tabular}{|c|c|c|c|}
\hline Barrio y distrito & $\begin{array}{c}\text { Superficie con } \\
\text { agua del Canal de } \\
\text { Isabel II }\end{array}$ & $\begin{array}{l}\text { Superficie con } \\
\text { agua de la } \\
\text { Hidráulica } \\
\text { Santillana }\end{array}$ & $\begin{array}{l}\text { Superficie con } \\
\text { agua de Viajes } \\
\text { Antiguos }\end{array}$ \\
\hline $\begin{array}{r}\text { Conde de Aranda - } \\
\text { Buenavista }\end{array}$ & 82 & 51 & 24 \\
\hline Correos - Centro & 80 & 22 & 27 \\
\hline Carmen - Centro & 82 & 5 & 20 \\
\hline Puerta del Sol - Centro & 83 & 38 & 38 \\
\hline Muñoz Torrero - Centro & 86 & 43 & 24 \\
\hline San Martin - Centro & 87 & 17 & 28 \\
\hline Estrella - Centro & 88 & 34 & 11 \\
\hline Jardines - Centro & 90 & 70 & 55 \\
\hline San Luis - Centro & 93 & 47 & 42 \\
\hline Tudescos - Centro & 93 & 17 & 15 \\
\hline Constitución - Centro & 94 & 14 & 52 \\
\hline $\begin{array}{r}\text { Cardenal Cisneros - } \\
\text { Chamberí }\end{array}$ & 75 & 56 & 12 \\
\hline Trafalgar - Chamberí & 82 & 60 & 26 \\
\hline Dos de Mayo - Chamberí & 98 & 39 & 8 \\
\hline Principe - Congreso & 77 & 25 & 29 \\
\hline Cervantes - Congreso & 81 & 23 & 8 \\
\hline Cañizares - Congreso & 83 & 35 & 51 \\
\hline Santa Maria - Congreso & 88 & 10 & 26 \\
\hline
\end{tabular}




\begin{tabular}{|c|c|c|c|}
\hline Alameda - Congreso & 96 & 29 & 0 \\
\hline Apodaca - Hospicio & 81 & 55 & 8 \\
\hline Las Torres - Hospicio & 84 & 69 & 4 \\
\hline Colon - Hospicio & 89 & 58 & 43 \\
\hline Gongora - Hospicio & 89 & 50 & 20 \\
\hline San Opropio - Hospicio & 90 & 45 & 45 \\
\hline San Pablo - Hospicio & 92 & 24 & 32 \\
\hline Bilbao - Hospicio & 94 & 75 & 47 \\
\hline Campoamor - Hospicio & 96 & 77 & 36 \\
\hline Hernán Cortés - Hospicio & 97 & 62 & 52 \\
\hline Lavapies - Hospital & 86 & 2 & 1 \\
\hline Jesus y Maria - Hospital & 92 & 7 & 9 \\
\hline Ministriles - Hospital & 92 & 26 & 10 \\
\hline Torrecilla - Hospital & 93 & 54 & 36 \\
\hline Primavera - Hospital & 98 & 5 & 4 \\
\hline Cabestreros - Inclusa & 77 & 0 & 0 \\
\hline Amazonas - Inclusa & 85 & 9 & 6 \\
\hline Rastro - Inclusa & 87 & 0 & 0 \\
\hline Caravaca - Inclusa & 91 & 0 & 0 \\
\hline Calatrava - Latina & 77 & 17 & 0 \\
\hline Aguas - Latina & 87 & 0 & 0 \\
\hline Cava - Latina & 89 & 2 & 9 \\
\hline Humilladero - Latina & 93 & 23 & 0 \\
\hline Quintana - Palacio & 79 & 29 & 9 \\
\hline Isabel II - Palacio & 80 & 52 & 36 \\
\hline Espejo - Palacio & 96 & 27 & 25 \\
\hline Quiñones - Universidad & 77 & 26 & 48 \\
\hline Conde Duque - Universidad & 81 & 22 & 25 \\
\hline Amaniel - Universidad & 95 & 35 & 54 \\
\hline Minas - Universidad & 96 & 50 & 0 \\
\hline Santa Lucia - Universidad & 98 & 35 & 0 \\
\hline
\end{tabular}

Fuente: Elaboración propia. 
Gráfico 5-11. Superficie abastecida por redes de agua en función de la superficie del barrio. Barrios del Distrito de Centro. Año 1929.

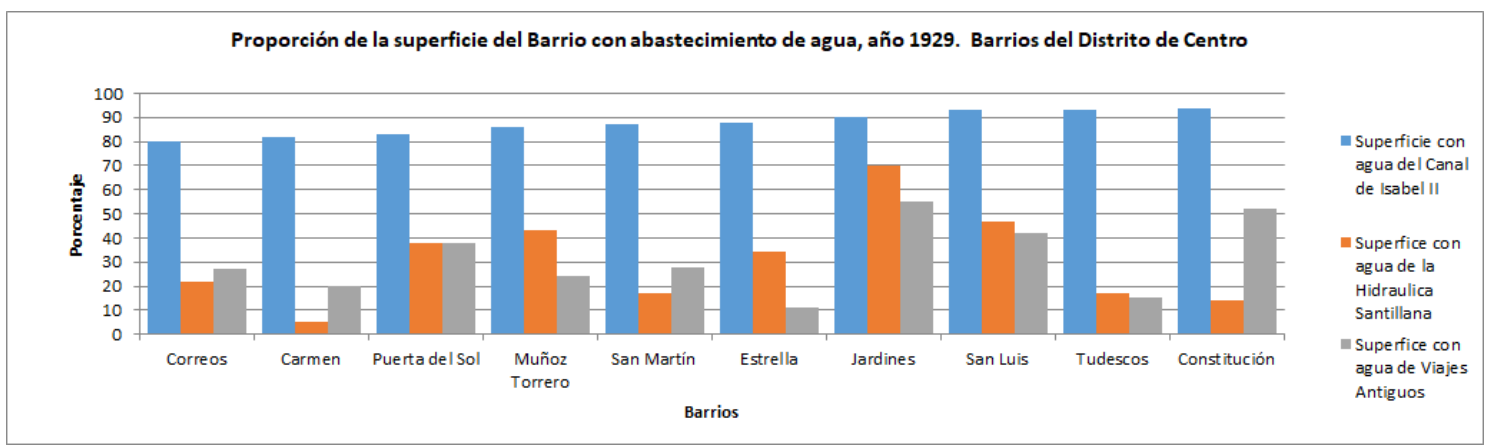

Fuente: elaboración propia

Gráfico 5-12. Superficie abastecida por redes de agua en función de la superficie del barrio. Barrios del Distrito de Buenavista. Año 1929.

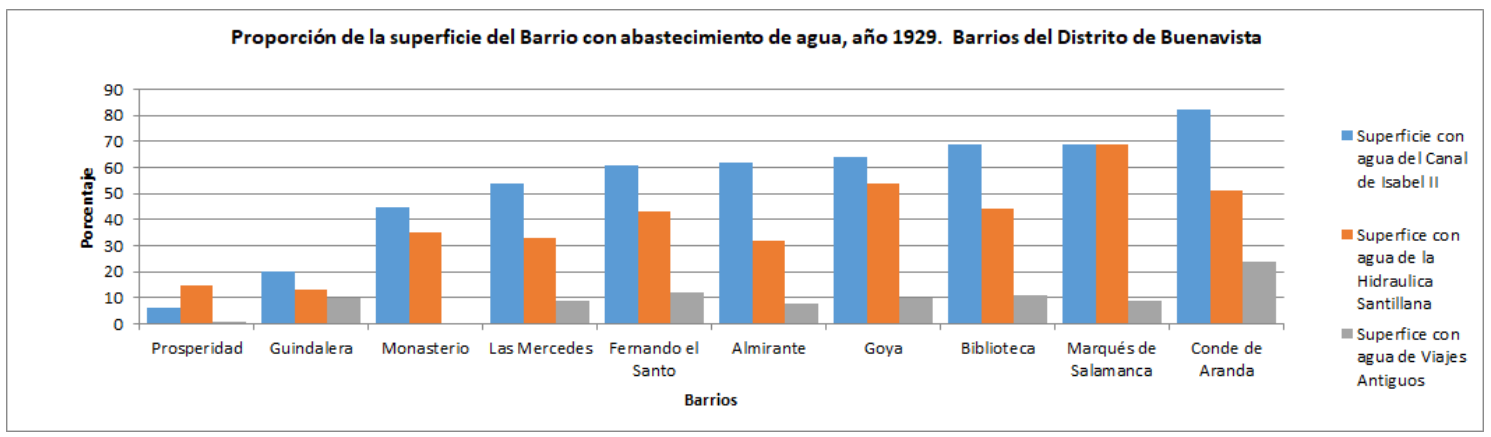

Fuente: elaboración propia

Gráfico 5-13. Superficie abastecida por redes de agua en función de la superficie del barrio. Barrios del Distrito de Chamberí. Año 1929.

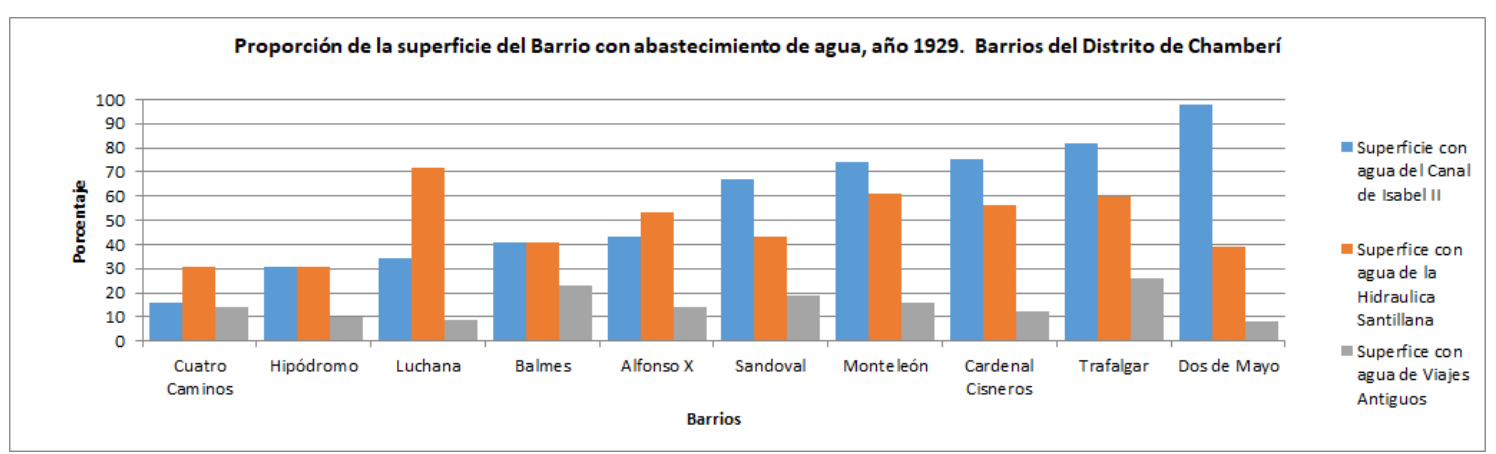

Fuente: elaboración propia 
Gráfico 5-14. Superficie abastecida por redes de agua en función de la superficie del barrio. Barrios del Distrito de Congreso. Año 1929.

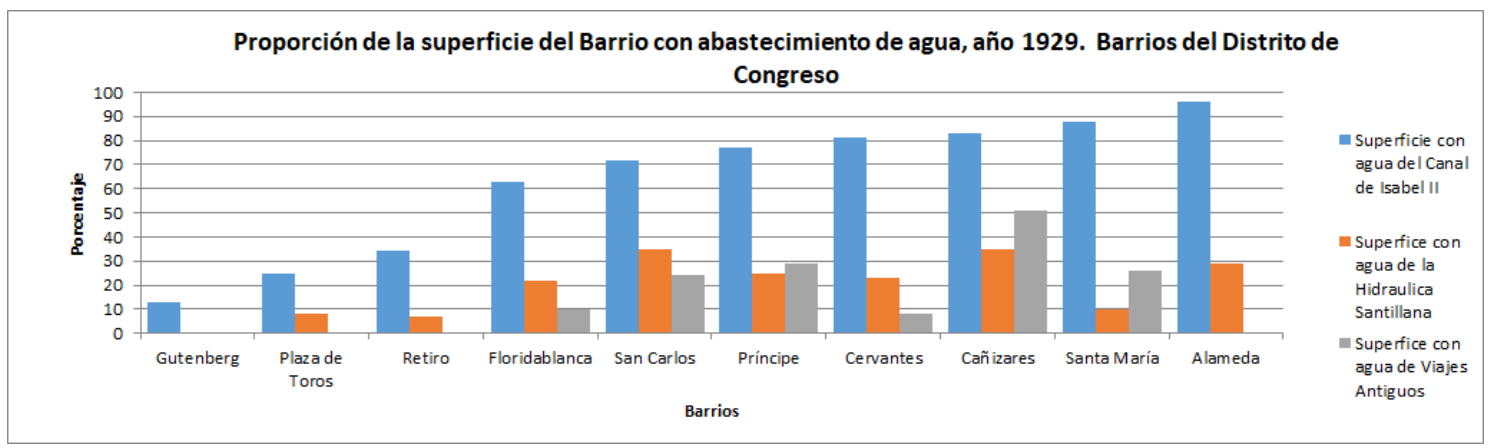

Fuente: elaboración propia

Gráfico 5-15. Superficie abastecida por redes de agua en función de la superficie del barrio. Barrios del Distrito de Hospicio. Año 1929.

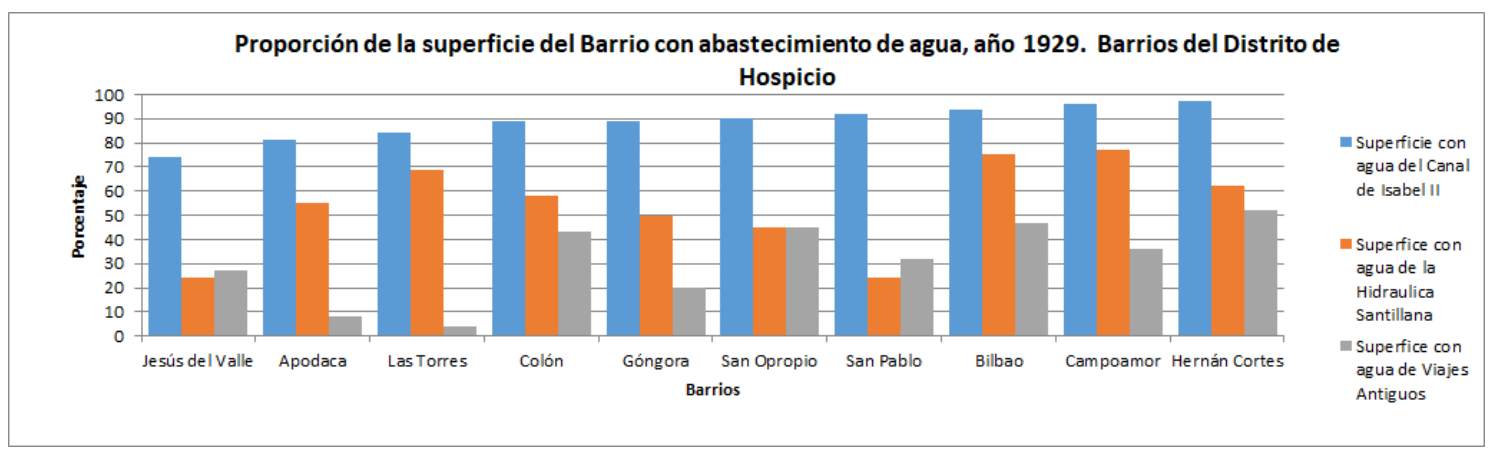

Fuente: elaboración propia

Gráfico 5-16. Superficie abastecida por redes de agua en función de la superficie del barrio. Barrios del Distrito de Hospital. Año 1929.

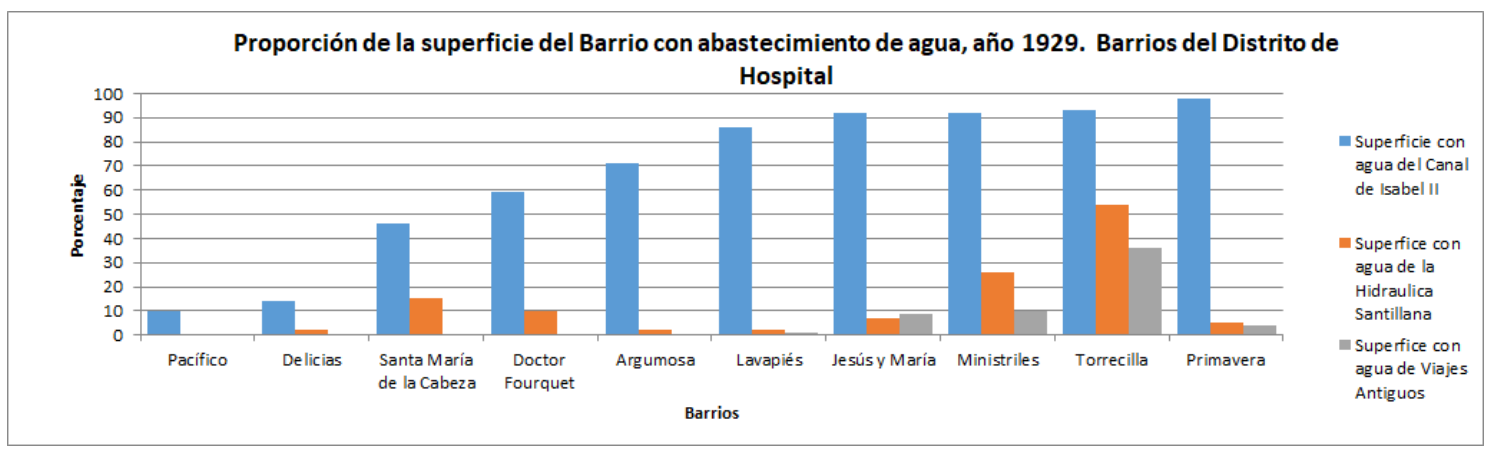

Fuente: elaboración propia 
Gráfico 5-17. Superficie abastecida por redes de agua en función de la superficie del barrio. Barrios del Distrito de Inclusa. Año 1929.

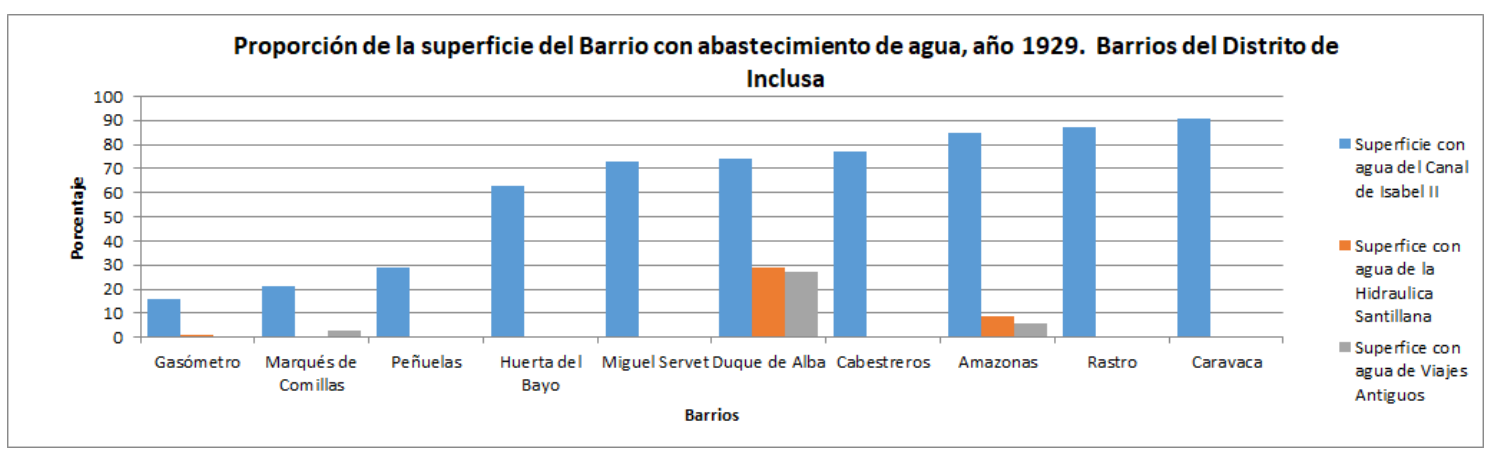

Fuente: elaboración propia

Gráfico 5-18. Superficie abastecida por redes de agua en función de la superficie del barrio. Barrios del Distrito de Latina. Año 1929.

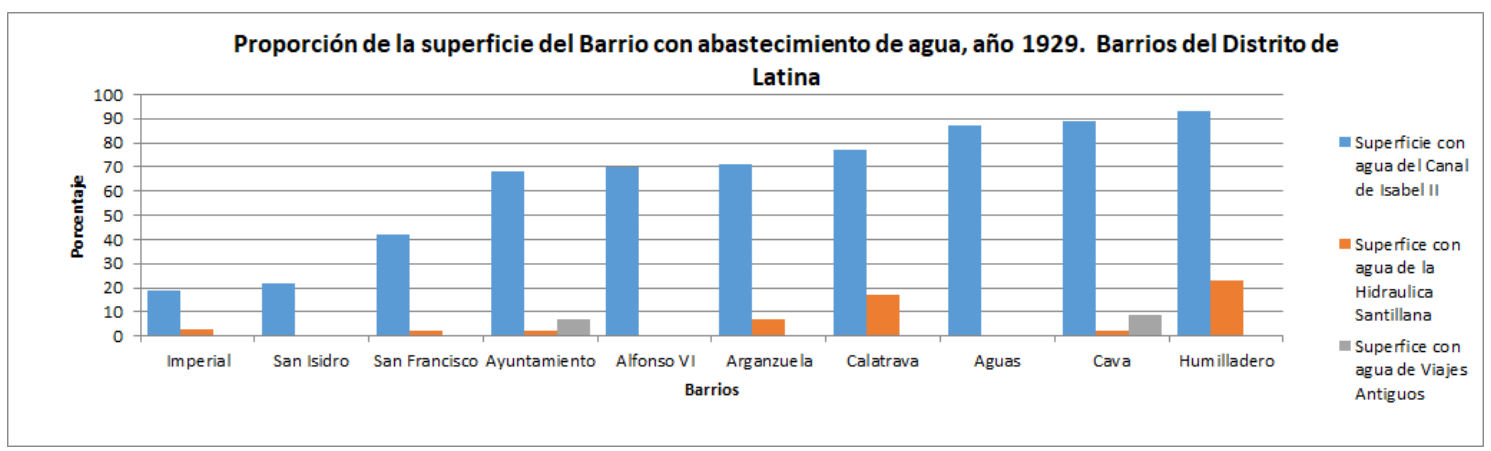

Fuente: elaboración propia

Gráfico 5-19. Superficie abastecida por redes de agua en función de la superficie del barrio. Barrios del Distrito de Palacio. Año 1929.

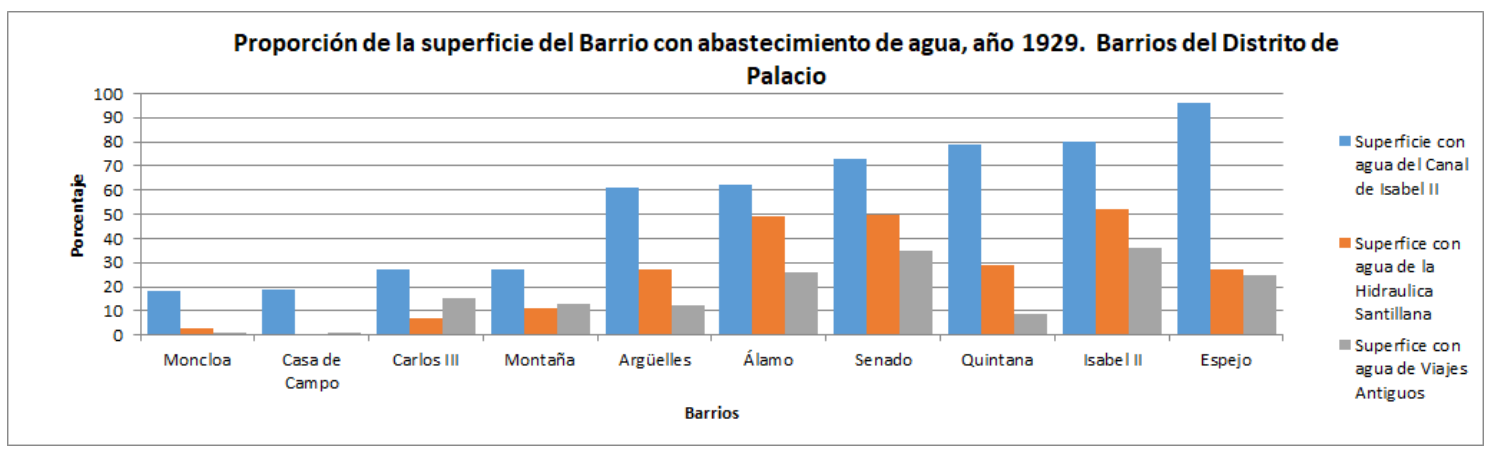

Fuente: elaboración propia 
Gráfico 5-20. Superficie abastecida por redes de agua en función de la superficie del barrio. Barrios del Distrito de Universidad. Año 1929.

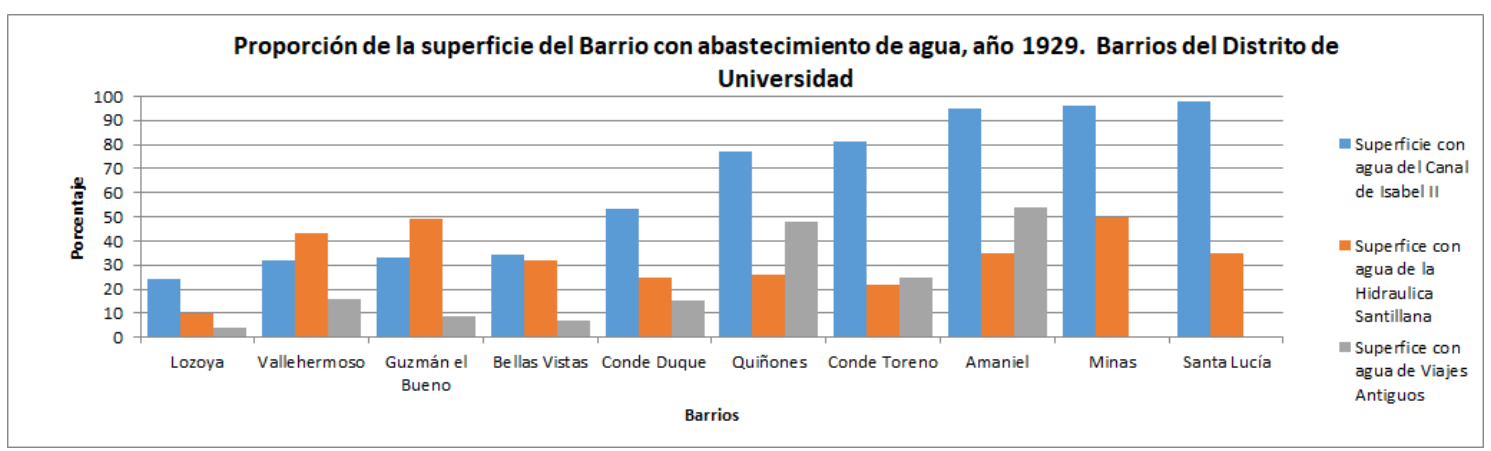

Fuente: elaboración propia

\subsection{Conclusiones}

Tal y como se ha podido ver a lo largo del capítulo, sería imposible poder hacer alusión a la expansión de la ciudad y el incremento poblacional sin tratar la importancia del Canal de Isabel II como elemento de mejora urbana.

Del mismo modo, ya en 1912 se consideraba la relación anterior de manera inversa; es decir, se destacó el papel del Canal de Isabel II como "órgano principal” para el avance y la expansión urbana. No es posible entender estos dos elementos por si solos, sino que es necesario tratarlos de manera conjunta. Esta es una de las razones que justifican la importancia de la temática del presente capítulo, ya que el desarrollo y modernización de los servicios urbanos, no sólo a principios del siglo XX ya que se trata de características que pueden ser extrapoladas a la actualidad, estuvo al servicio de la mejora de las condiciones de vida de poblaciones que, en su momento, experimentaron un cambio en los patrones demográficos inéditos hasta la época, y, a su vez, esta mejora en los servicios contribuyó a mejorar la salud y bienestar de los habitantes.

La necesidad de propuestas de mejora y expansión de la cobertura de redes de abastecimiento de agua fue fruto no sólo del incremento de demanda de los servicios por parte de la población debido al aumento de la misma y de la extensión territorial de la ciudad, sino también de la detección de problemas de salubridad en un momento en que las tesis higienistas cobraron importancia. 
Sin embargo, las diferencias existentes en torno a la distribución del servicio de agua fue un problema sólo parcialmente resuelto a la altura de los años treinta del siglo XX. Esta no es más que una manifestación añadida a las muchas que configuraron un panorama marcado por escenario residencial muy desigual dentro de la ciudad. Los problemas de insalubridad, los procesos de la segregación residencial, el hacinamiento, y otros derivados, serán tratados en el capítulo número ocho. 


\section{La red de alcantarillado y el sistema de evacuación de aguas}

\subsection{Introducción}

El presente capítulo tratará la temática relativa al sistema de evacuación de aguas en la ciudad de Madrid. Para ello, primeramente se hará alusión a la situación del alcantarillado madrileño en el periodo previo a la construcción del primer alcantarillado moderno, de manos del Canal de Isabel II. Posteriormente, se atenderá a la evolución del sistema de saneamiento, haciendo alusión a los planes más relevantes en esta materia, destacando el Plan General de Saneamiento del Subsuelo y el Proyecto de obras de saneamiento del subsuelo de los barrios extremos. Para concluir, se hará mención explícita al Proyecto sobre la Canalización y Saneamiento del Río Manzanares.

Hay que tener en cuenta que, junto a las redes de distribución de agua potable, las redes de evacuación de aguas configuran un elemento imprescindible de la infraestructura urbana destinada al saneamiento de las poblaciones, tal y como pusieron de manifiesto los preceptos de ingeniería sanitaria, y su visión sanitaria del urbanismo, que comenzaron a mostrar un incipiente auge desde finales del siglo XIX y fueron consolidados en el siglo XX.

En el caso de la ciudad de Madrid, el enfoque higienista y la necesidad tácita del saneamiento de las poblaciones prevalecerá de manera clara en el periodo estudiado, en tanto en cuanto comenzará a tratarse de manera conjunta el problema de la gestión de los residuos urbanos y el estado en que se encontraba el Río Manzanares, como lugar al que desaguaban las aguas negras con procedencia del casco histórico de la ciudad. Así, durante este periodo, de manera muy paulatina, se pasará de una simple red de evacuación a otra más desarrollada de saneamiento, lo que implicó la realización de complejas y costosas obras de ingeniería que contribuyeron a dotar a la capital de España de una nueva escala urbana, propia ya, no de una simple ciudad, sino de una incipiente metrópoli (Pinto Crespo 2015:211). 


\subsection{Las alcantarillas antiguas. Breve bosquejo histórico}

Buena parte de la historiografía considera que la construcción de los primeros ramales de alcantarillado en la ciudad de Madrid data de la primera mitad del siglo XVIII. Si bien, no existe un consenso absoluto al respecto, en la medida en que algunos historiadores consideran que la construcción de las primeras alcantarillas en la urbe tuvo lugar en el siglo XVII y que, incluso, es posible afirmar que ya se ejecutase la construcción de algunas al asentarse la Corte en Madrid, en la segunda mitad del siglo XVI (Pinto Crespo 2015:44).

En cualquier caso, estas construcciones iniciales no tuvieron la vocación de formar parte de una red integrada (no eran en sí mismas alcantarillas, aunque se denominasen como tal), sino que se trataba de construcciones aisladas, cuyo objetivo era paliar los efectos antihigiénicos producidos por los lodazales y otro tipo de concentraciones de agua en algunas zonas de la ciudad.

No es hasta la puesta en marcha de la Instrucción para el nuevo empedrado y limpieza de las calles de Madrid ${ }^{59}$, redactado por Francisco Sabatini y aprobada por Carlos III por Real Orden de 1761, cuando realmente puede hablarse de una vinculación entre la limpieza de la ciudad con la infraestructura de saneamiento, destacando pozos negros y alcantarillas. El texto de Sabatini puede considerarse pionero en cuanto a la pretensión de la implementación de un verdadero sistema integrado destinado a la limpieza urbana.

\footnotetext{
${ }^{59}$ El proyecto completo puede consultarse en el Repositorio Institucional del Banco de España: https://repositorio.bde.es/handle/123456789/4672
} 


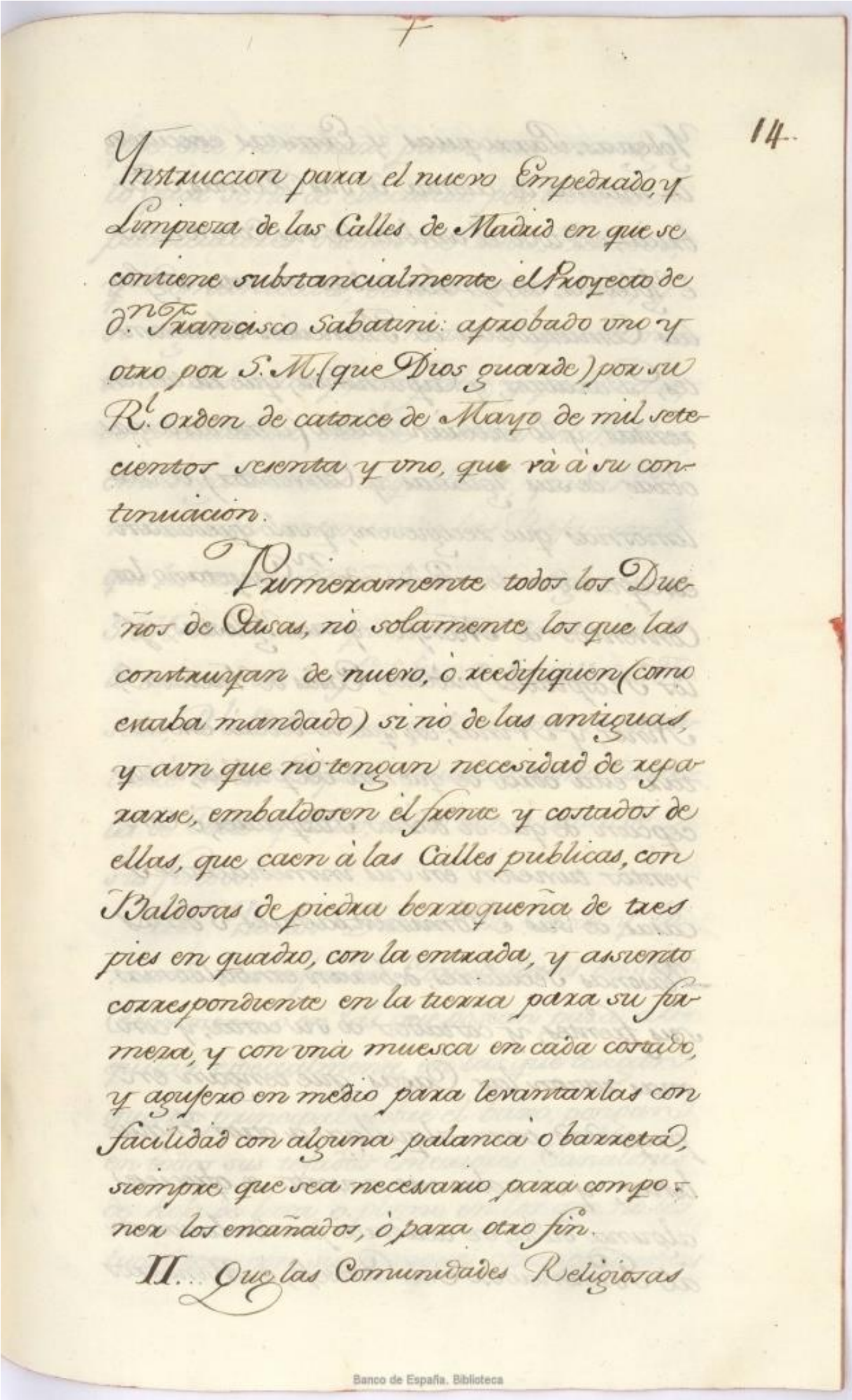

Fuente: Repositorio Institucional del Banco de España 
En los albores de mediados del siglo XIX, la situación del alcantarillado madrileño se caracterizaba por ser antiguo, deficiente desde el punto de vista técnico y con una limitada capacidad de desagüe, fruto de la insuficiente pendiente de las conducciones. En palabras de José Morer, a la altura de 1855 “(...) en Madrid no se han construido todavía más que las alcantarillas de una tercera parte de la población; y a menos que la Municipalidad no trate de dar un gran impulso a este importante ramo de policía urbana, es muy probable que esta sola causa retarde largos años la colocación de la tubería en la totalidad de las calles de la corte” (Morer Abril, 1855a)

Así pues, se puso de manifiesto la ineficacia e incapacidad por parte del consistorio municipal de la gestión del sistema de evacuación, de manera que el Ministerio de Fomento encargó la construcción del alcantarillado al Canal de Isabel II.

En este sentido, la falta de presupuesto municipal repercutió en el proceso de construcción de alcantarillas desde 1845, hasta el punto que en 1849 quedaron prácticamente paralizadas las obras (V. G. R. Pinto Crespo, Rafael; Velasco Medina, Fernando, 2015, p. 181). En 1851, momento en que el Canal de Isabel II comenzó sus trabajos para llevar el agua del Lozoya a Madrid, el Ayuntamiento pareció entender que era necesaria la reactivación de la construcción de alcantarillas, de manera que realizó algunas tareas entre 1850 y 1855. Sin embargo, éstas no estuvieron planificadas teniendo en consideración la futura traída de aguas a la ciudad, sino que respondieron más bien a protestas vecinales o a soluciones puntuales que requerían de urgencia.

\subsection{La primera construcción del alcantarillado moderno en Madrid. 1856 y 1865}

Por Real decreto de 15 de agosto de 1854, se encomendó al Canal de Isabel II que fuera el encargado del proyecto del sistema de distribución de agua en Madrid. Se incluía, además, la necesidad de atender a la red general de alcantarillado con el objetivo de que el servicio de abastecimiento funcionara de manera óptima.

Por aquel entonces, Lucio del Valle, Director de las obras del Canal, dirigió las mismas bajo la convicción de que era necesario construir la red de alcantarillado al tiempo que se construía la de abastecimiento de aguas. 
“(...) es forzoso haber planteado con anterioridad otro servicio importante, y que forma el complemento obligado, o por mejor decir la mitad del problema de la distribución: nos referimos al sistema general de alcantarillas o desagües subterráneos. Inútil es haber llevado á todas las casas un caudal de agua suficiente para cubrir ampliamente todas las necesidades domésticas, si después de ensuciadas y aun corrompidas estas aguas por el uso no tienen una fácil y pronta salida, no solo de las casas sino también de la población" (Canal de Isabel II, 1856, p. 41)

En cuando al orden en que debían realizarse la ejecución de las obras de la red de alcantarillado, mantenía que “(...) seguirá la misma marcha y orden que las de distribución, si bien la construcción de las galerías subterráneas de cada calle precederá á la colocación de la tubería correspondiente”. El Director de las obras expresó también su preocupación acerca del estado de las aguas residuales y la forma de abordar este problema, manteniendo que “(...)en rigor, queda todavía una parte del problema por estudiar: el aprovechamiento de las aguas sucias á su salida de la población. Por desgracia la agricultura no está tan desarrollada en los alrededores de la Capital que se haya hecho sentir la necesidad de emprender la resolución de tan importante problema; mas sin embargo, abrigamos la esperanza que no ha de transcurrir mucho tiempo antes de que empiece á hacerse sentir esta necesidad, y por lo mismo pensamos emprender el estudio de esta capital cuestión, tan luego como los mayores progresos en las obras de conducción y en los proyectos de la distribución nos permitan dedicarnos á tan importantes trabajos" (Canal de Isabel II, 1856, p. 41)

Mediante el Real Decreto de 15 de agosto de 1854, bajo firma de Francisco Luxan como ministro, se regulaba en el artículo dos que como complemento al proyecto de distribución de las aguas “(...) se formará el de las alcantarillas, procurando aprovechar las existentes, haciendo en ellas las modificaciones indispensables".

Lucio del Valle nombró a José Morer, ingeniero de caminos, para llevar a cabo el Proyecto de las redes de distribución de agua y alcantarillado. De este modo, un año más tarde, el 20 de abril de 1855, fue presentado el Anteproyecto de la Distribución, en el que se reiteró la necesaria conexión de la construcción entre una red y otra. Así lo manifestó el propio Morer en las últimas palabras que aparecen en el Anteproyecto: "Finalmente, no es posible desconocer la íntima relación que existe entre el sistema de 
distribución y el de desagües subterráneos, llegando hasta el punto de ser imposible la completa conclusión del primero sin que se halle terminado el segundo”.(Morer Abril, $1855 \mathrm{a}, 1855 \mathrm{~b})$

En el Anteproyecto se reseñaron las características de la red que era necesario implementar, que pueden ser resumidas en tres: la construcción de un alcantarillado con pendiente suficiente para solventar los problemas de acumulación de residuos de la red existente, la construcción de galerías subterráneas independientes respecto de la red de abastecimiento de agua y un sistema que permitiera la evacuación vinculada de aguas negras y aguas de lluvia.

Mediante el sistema de gran pendiente, se pretendía que las aguas atravesaran las tuberías a una velocidad suficiente como para arrastrar cualquier material que estuviera alojado en su interior. Asimismo, Morer tuvo en consideración los costes de la construcción, de manera que mantuvo que con este sistema se pudiera aprovechar alguna de las alcantarillas ya construidas, aun cuando su forma, pendientes y dimensiones no fueran las más a propósito para el servicio a que se las destina" (Canal de Isabel II, 1856, p. 25)

Como se ha señalado, la necesidad de independencia de las redes de distribución de agua y la red de alcantarillado también quedó patente en el Anteproyecto de 1855. Así, se estableció que no sólo se debía cumplir entre las redes de agua potable y alcantarillado, sino que, también, debían ser independientes de otras como las de gas. La solución adoptada fue la construcción de alcantarillas a una profundidad mínima de seis metros y máxima de diecisiete, ubicadas por debajo de las tuberías de agua potable, con una profundidad de éstas últimas de uno metro a un metro y medio. La amplitud de los metros de profundidad dependerían de elementos como la pendiente, la profundidad de los sótanos de las casas y de la altura de los acometimientos particulares (Hauser, 1902a, p. 227).

La última de las características versaba en torno a la evacuación conjunta de aguas pluviales y negras. Morer defendió que con la red de alcantarillado se debería ser capaz de “(...) llevar fuera de la población no sólo el agua de lluvias y riegos, sino también todas las de las cloacas de las casas particulares” (Morer Abril, 1855a, 1855b) 
Para la elección del sistema de evacuación, Morer se basó en el sistema británico, que evacuaba dentro de una misma red las aguas negras y la de lluvia (Tout a L'égout). Alternativamente, había otros modelos que se basaban en la separación de unas aguas y otras, como el sistema holandés (Liermur), o el francés (Berlier), empleado en algunas zonas de París y en otras ciudades francesas (Hauser, 1902a, pp. 186-208).

Si bien el sistema británico era menos higiénico que los modelos que separaban las aguas, también era menos costoso y más rápido de construir. Y, de ahí, la decisión de Morer de optar por éste.

La aprobación de este anteproyecto, por parte de la dirección del Canal de Isabel II, se hizo oficial con el Real Decreto de 19 de mayo de 1855. A su vez, mediante la promulgación de la Ley 19 de junio de 1855 (Ley de 19 de junio de 1855, en Gaceta de Madrid, $\mathrm{n}^{\circ} 899$, 19/6/1855, pp.3-4), se traspasaron las competencias para ejecutar las obras de alcantarillado al Canal de Isabel II. Una consideración importante a tener en cuenta es que, atendiendo a lo dictado en el Real Decreto de 19 de junio de 1855, las competencias del Canal se limitaban solamente a la zona que comprendía el Anteproyecto de distribución de agua; esto es, a la zona del interior de Madrid. Esto pone en la antesala de suponer que, aquellas zonas que no estuvieran comprendidas en la zona interior quedaban bajo manos de la competencia municipal, por lo que cabría esperar que fuera el Ayuntamiento el encargado de la construcción de las alcantarillas.

\subsection{La red de saneamiento. 1866-1939}

Entre los años 1856 y 1865 el Canal de Isabel II construyó la primera red de alcantarillado moderno en Madrid, constituyendo un reto, único hasta entonces, desde el punto de vista higiénico y técnico. Si bien, a partir de 1866 es el momento en que comienza a considerarse de manera paralela el problema de la gestión de residuos y la necesidad de canalización del Río Manzanares, lugar donde desaguaban las aguas negras de la zona del interior de la ciudad.

Tal y como señala Pinto (V. G. R. Pinto Crespo, Rafael; Velasco Medina, Fernando, 2015), durante este periodo poco a poco se irá pasando de una simple red de evacuación a otra más desarrollada de saneamiento. Bajo la nueva gestión municipal, elementos 
característicos de esta nueva etapa fueron los esfuerzos para consolidar la red de alcantarillado, así como su ampliación a otras zonas de la ciudad (los barrios del Ensanche y del Extrarradio) que, hasta el momento, tenían deficiencias severas en cuanto a la cobertura de alcantarillado.

\subsubsection{La reorganización del ramo de alcantarillas de Madrid (1866-1885).}

Tras la gestión por parte del Canal de Isabel II del sistema de evacuación entre los años 1856 y 1865, el Ayuntamiento volvió a ser titular de estas competencias. Fue necesario organizar y actualizar todo el ramo de alcantarillado de Madrid, en la medida en que tanto los reglamentos como las ordenanzas municipales habían quedado arcaicos.

La sección de alcantarillas, que había formado parte del ramo de Fontanería del Ayuntamiento (que tenía por función todo lo relacionado con el agua potable), se reorganizó como sección independiente. Sin embargo, las deficiencias en materia económica y de personal, quedaron patentes, tal y como puso de manifiesto el arquitecto mayor del ramo Martín López Aguado, “(...) imposibilidad de tener limpias las nuevas alcantarillas con únicamente una cuadrilla de diez hombres" (V. G. R. Pinto Crespo, Rafael; Velasco Medina, Fernando, 2015, p. 212).

A partir de 1865 se produjo una reorganización del denominado Ramo de Alcantarillas, la sección del Ayuntamiento de Madrid encargada de gestionar la nueva red de alcantarillas. Pero, de facto, no tuvo un resultado demasiado satisfactorio, ya que la operatividad del alcantarillado no conjugaba con las necesidades de una ciudad en crecimiento tanto territorial como demográfico. Esto tuvo consecuencias importantes, la más palpable fue el hecho de que en veinte años las actuaciones se limitasen casi en exclusiva al mantenimiento de la red original que, como hemos señalado más arriba, sólo ocupaba parte del casco histórico, y la construcción de algunos tramos en la parte del Enchanche de la ciudad, lo que contribuyó a que durante décadas esta zona quedase desprovista de este tipo de infraestructuras hasta los primeros años del siglo XX, cuando se abordó su ejecución; en cincuenta años apenas se construyeron alcantarillas en los barrios del Ensanche que cada vez estaban más poblados. 


\subsubsection{La integración al saneamiento. $1885-1930$}

La epidemia de cólera de 1885 supuso el punto de inflexión definitivo para la implantación de los preceptos higienistas en materia de suministro de aguas y de alcantarillado. Así lo puso de manifiesto el alcalde de la ciudad de Madrid, Alberto Boch en su Memoria de las medidas adoptadas para contener la invasión del cólera en 1885, donde resaltó la importancia y necesidad de llevar a cabo “(...) una verdadera campaña a favor de la higiene” (Bosch, 1885).

En lo relativo a las alcantarillas de la ciudad, Bosch expuso las graves deficiencias de la red, así como la no disposición de planos mediante los que fuera posible entender por dónde circulaba. Otras de las quejas expuestas giraban en torno al tema de los pozos negros que afloraban por toda la ciudad, así como el estado del Río Manzanares. Ya no bastaba con evacuar las aguas negras de la ciudad, con lo que hubiera bastado simplemente con extender el alcantarillado a los barrios del Ensanche y Extrarradio que todavía carecían de estas infraestructuras, sino que se pretendía sanear, es decir, depurar los residuos urbanos para evitar que el río, u otra parte de la ciudad o sus alrededores, se acabaran convirtiendo en un peligroso foco de infección (V. G. R. Pinto Crespo, Rafael; Velasco Medina, Fernando, 2015, p. 229)

Como ya hemos señalado más arriba, la problemática de las alcantarillas de dentro y fuera de la ciudad vino abordándose de maneca más acuciante desde 1885 con la epidemia de cólera, ya que puso de manifiesto la deplorable situación del alcantarillado madrileño. Era necesario el planteamiento de un plan general que dotara de alcantarillado a los barrios del ensanche y extrarradio y se modificasen los que estaban inoperativos en el interior, pero, como ya dijimos en líneas precedentes, el problema se agravaba en tanto en cuanto ni siquiera estas zonas eran suficientemente abastecidas por agua potable del Canal de Isabel II, y este problema no se solucionó, parcialmente, hasta principios del siglo XX.

Hasta esos años, por tanto, las alcantarillas que se construyeron en Madrid fueron muy pocas, y sin ningún tipo de orden ni plan establecido, pues su iniciativa seguía dependiendo mayoritariamente de la voluntad de los propietarios de las casas. Sólo en casos muy puntuales, y de urgente necesidad, el Ayuntamiento actuaba de oficio. 
Según el resumen de las actuaciones municipales que en 1898 hizo el ramo de fontanería y alcantarillado del Ayuntamiento de Madrid, se indica que, de las 3.100 obras ejecutadas, 3.069 fueron de conservación y reparación, y únicamente 31 lo fueron de obra nueva (Ruano y Carriedo 1898:82).

\subsubsection{El problema de las acometidas de agua}

Tras la epidemia de cólera, el consistorio madrileño concentró sus esfuerzos en disponer de una regulación para el alcantarillado y el saneamiento de la ciudad. La nueva normativa municipal fue todo un reto, en la medida en que para dotar de alcantarillado a los nuevos barrios de las zonas del Ensanche y del Extrarradio se necesitaba que, primeramente, estuvieran abastecidos de agua potable suficiente, y esto era competencia del Canal de Isabel II. Tal y como veremos más adelante, esta problemática no comenzó a solucionarse hasta entrado el siglo XX.

Teniendo en consideración lo anterior, el Ayuntamiento de Madrid consideró que había que abordar el problema de las acometidas de alcantarillado. En 1889, mediante el Bando de don José Abascal y Carredaño, Alcalde Presidente del Ayuntamiento de Madrid, sobre Sanidad e Higiene. 30 de Enero de 1889. Madrid, Imprenta Municipal, 1889. AVM, Secretaría, 13-107-6, (V. G. R. Pinto Crespo, Rafael; Velasco Medina, Fernando, 2015, p. 230), se obligaba a colocar sifones a todos los propietarios que quisieran realizar las acometidas desde sus casas a las alcantarillas, pues consideraba "que la mala comunicación entre éstas y las viviendas era una de las principales causas que producían gran número de enfermedades y contribuía a propagar las epidemias". De esta manera, al disponer la colocación de sifones, se oponía un cierre hidráulico a la entrada de los gases provenientes del alcantarillado, lo que suponía una mejora evidente respecto a la etapa anterior (Pinto Crespo, 2015, p. 230).

Además, el consistorio madrileño aprobó el 16 de abril de 1892 unas nuevas Ordenanzas para regular el tema de las acometidas, así como la construcción de pozos negros o el mantenimiento de las alcantarillas (Ayuntamiento, 1892b). Si bien, en sus 22 artículos, apenas se trata el tema de la construcción de alcantarillas nuevas.

Respecto a las acometidas, las Ordenanzas de 1892 sí tuvieron una regulación bastante exhaustiva. Así, se establecía la obligación para los constructores y promotores a 
ejecutar una acometida para las aguas sucias y pluviales. En el artículo 169 se indica que, en el caso que no hubiera alcantarilla previa, como sucedía en buena parte de las zonas del Ensanche y del Extrarradio, el propietario tenía la obligación de construir un pozo negro que recogiera únicamente las aguas fecales, y que debía mantener hasta que se construyera la alcantarilla nueva. Por su parte, en el artículo 173 se recoje el supuesto bajo el que, en caso de sí existir una alcantarilla previa, los propietarios estaban obligados a realizar las acometidas a la alcantarilla y cegar el pozo negro en la calle donde construían la casa, sin cuyo requisito no se le daría posteriormente licencia al propietario para alquilarla.

Los resultados que se tuvieron con la puesta en marcha de estas Ordenanzas fueron, en gran medida, contraproducentes. La falta de obligatoriedad de construir alcantarillas nuevas a los propietarios dejando en sus manos la iniciativa de comenzar el procedimiento, la mayoría no las ejecutaron, con lo que entre 1892 y 1910, esta nueva normativa produjo una construcción masiva de pozos negros tanto en el Ensanche como en el Extrarradio de la ciudad (V. G. R. Pinto Crespo, Rafael; Velasco Medina, Fernando, 2015, p. 230).

La construcción y conservación de pozos negros quedó reglamentada bajo las Ordenanzas de 1892. En el artículo 169 se establecen las caracteristicas de que debían estar dispuestos, tales como su impermeabilidad y su longitud de apertura (un metro y medio alejados de cualquier depósito, conducto de agua potable o cañería, así como de las propiedades vecinas).

En lo que respecta a la limpieza de los pozos negros, vino regulado por los artículos 171 y 172. Se establecieron medidas de seguridad para los operarios, así como el procedimiento a seguir para cegar un pozo; proceder primero al limpiado, la posterior desinfección y, por último, su llenado.

También se reguló la temática relativa a la vigilancia y seguridad de las alcantarillas (Artículos 167 y 168). El artículo 176 resulta interesante, pues establece que en las calles donde hubiera alcantarilla nueva y vieja -todavía seguían funcionando algunas alcantarillas anteriores a las ejecutadas por el Canal de Isabel II-, los propietarios debían obligatoriamente construir la acometida a la nueva alcantarilla, macizando las acometidas antiguas, a fin de que poco a poco fueran quedando sin servicio para que el 
Ayuntamiento pudiera inutilizar y anular las alcantarillas viejas (V. G. R. Pinto Crespo, Rafael; Velasco Medina, Fernando, 2015, p. 234).

También se dispuso que, para la construcción de las acometidas, solamente podían llevarse a cabo aquellas que tuvieran una licencia municipal. Las dimensiones y tamaño vinieron regulados por el artículo 179.

Tal y como aparece recogido en los Comentarios a las ordenanzas municipales de Madrid / publicados por la Gaceta de Obras Públicas (Ayuntamiento, 1892a, p. 49), las regulaciones contenidas en las Ordenanzas de 1892 recibieron críticas; unas enfatizando sus deficiencias, otras, sus excesos.

Un aspecto muy importante en cuando a la regulación de las acometidas a las viviendas, fue el hecho de la incipiente industria que, por aquel entonces, comenzó a desarrollarse en algunas zonas de Madrid, especialmente en los barrios del Sur del Ensanche. La justificación de la exhaustiva regulación de las acometidas en las Ordenanzas de 1892 venía dada, en buena medida, por la necesidad de dar salida a los residuos de las fábricas. En este orden de cosas, en los artículos 183 y 184, se estableció la forma, y materiales, en que debían construirse los pozos colectores. Se estableció una diferenciación de la forma en que debían ser depositados los residuos, atendiendo a si éstos eran peligrosos por su elevada temperatura o eran peligrosos por el tipo de sustancia. En el primer caso, los vertidos debían ser depositados en los colectores hasta su enfriamiento y, posteriormente, depositarse en la alcantarilla. En el segundo caso, los vertidos debían ser depositados en los colectores hasta que fuera inactivada la peligrosidad de la sustancia, mediante el uso de desinfectantes o reactivos. En la citada regulación, se mantenía que los daños causados caían bajo responsabilidad de la persona responsable de la fábrica.

En el artículo 177 se establecía que los gastos ocasionados por la construcción, conservación y limpieza de las acometidas recaían bajo cuenta de los propietarios.

Si bien las Ordenanzas de 1892 marcaron un punto importante, en lo que respecta a la instauración de medidas, por parte del Ayuntamiento de la capital, en torno a la regulación de todo lo relacionado con el problema de las acometidas a las alcantarillas desde las edificaciones y los desagües, durante los últimos años del siglo XIX se dictaron Bandos adicionales que sirvieron para completar la regulación. De este modo, 
el 5 de diciembre de 1898 el Ayuntamiento, siendo alcalde Álvaro de Figueroa y Torres (conde de Romanones), dictó el Bando sobre saneamiento e higiene de las casas de Madrid ("Bando de la Alcaldía de Presidencia de 5 de octubre de 1898 sobre saneamiento e higiene de las casas de Madrid," 1898). Una de las medidas más destacables de este Bando, fue la obligación a los propietarios en su totalidad (no sólo a los de construcciones o edificaciones nuevas) a la adopción de medidas integrales, con el objetivo de que todas las redes de desagüe de los edificios fueran trasformadas.

El Bando sobre saneamiento e higiene de las casas de Madrid constaba de 12 artículos. Se indicaba minuciosamente los elementos de la red de desagüe que debía contener cada edificio. Debían constar de cañerías verticales a las cuales tenían que afluir otras inclinadas, partiendo de los retretes, baños y sumideros; y que, a su vez, debían acometer a un colector en cada casa que desaguara en la alcantarilla general, o, en su defecto, en un pozo negro. Además, estableció que las cañerías fueran de plomo, gres o hierro, teniendo en este último caso que estar revestidas en su interior de un baño anticorrosivo; y en cuanto a los depósitos de descarga y sifones, podían ser de cualquier sistema (V. G. R. Pinto Crespo, Rafael; Velasco Medina, Fernando, 2015, p. 233) siempre que cumplieran su cometido" ("Bando de la Alcaldía de Presidencia de 5 de octubre de 1898 sobre saneamiento e higiene de las casas de Madrid," 1898).

Tal y como se ha indicado más arriba, uno de los aspectos más importantes fue que el Bando del Conde de Romanones debía ser adoptado por todos los propietarios sin excepción. Así pues, se estipuló un plazo de cinco años para el cumplimiento de sus características. En el artículo 3, se establecieron las condiciones temporales en que deberían ejecutarse las obras necesarias por parte de los propietarios; en el transcurso del primer año, se debía establecer, por lo menos, el colector de cada casa y las acometidas de la planta baja; en el segundo las del primer piso; el tercer año, las del segundo piso; durante el cuarto año, las del tercero, y durante el quinto año, las restantes.

La Junta técnica municipal de salubridad e higiene, de carácter municipal, debía ser quien aprobara las obras, y un arquitecto debía supervisarlas. La Junta técnica municipal de salubridad e higiene también se encargaba de repartir una certificación y una placa, que el propietario tenía la obligación de colocar en la fachada del edificio, con inscripción siguiente; Aprobada por la Junta técnica municipal de salubridad e higiene 
("Bando de la Alcaldía de Presidencia de 5 de octubre de 1898 sobre saneamiento e higiene de las casas de Madrid," 1898, p. Artículo 7.). Con un objetivo divulgativo y educativo se creó dentro de la Casa Ayuntamiento un Museo de Higiene Urbana, donde se pudieron ver durante meses ejemplos prácticos de sistemas y procedimientos relacionados con la problemática de las acometidas y los desagües (V. G. R. Pinto Crespo, Rafael; Velasco Medina, Fernando, 2015, p. 234).

A principios del siglo $\mathrm{XX}$, la reglamentación que tuvo por objetivo la mejora de la higiene y salubridad de los edificios de Madrid, se fue ampliando notoriamente, desde su espectro de influencia de los edificios privado a los de uso público. Así, el 13 de julio de 1901, el Ministerio de la Gobernación dictó la Real Orden sobre el saneamiento de Edificios públicos y de uso público ${ }^{60}$ (Ministerio de la Gobernación, 1901). Se indican las malas condiciones higiénicas y sanitarias de casi la totalidad de los establecimientos públicos del país, "que desatendían las más mínimas exigencias de la higiene, las del decoro y las del respeto a sexos y personas”. Asimismo, se enfatiza que “(...) En España todavía, no ya en las pequeñas y anticuadas poblaciones, sino hasta en las de primer orden, y dentro de éstas, no solamente en los albergues modestos, sino también aun en aquellos establecimientos públicos afamados, donde los refinamientos del decorado han hecho costosos alardes para atraer una concurrencia elegante y exigente, como en los teatros, cafés y restaurants lujosos, por ejemplo, se observan gravísimas infracciones de la higiene y menosprecios del decoro público, que convierten á dichos lugares en focos hediondos y peligrosos que urge remediar" (Ministerio de la Gobernación, 1901, p. 4).

Respecto al articulado, en el primer artículo de la Real Orden se establecía la obligatoriedad de que antes del 1 de julio de 1902, (...) todos los edificios públicos ó de uso público deberán tener, los sitios designados á desagües en perfectas condiciones sanitarias.

Para cumplir con lo dictado la Real Orden, las Juntas municipales de Sanidad eran las encargadas de realizar un catastro de todos los edificios públicos o de uso público, para

\footnotetext{
${ }^{60}$ En el Artículo $2^{\circ}$ de esta R.O., se hace una relación de aquellos edificios que debían considerarse públicos o de uso público, siéndolo a todos los efectos los teatros, estaciones, mercados, cafés, restaurantes, hoteles, casas de viajeros y de dormir, posadas, cervecerías, colegios, oficinas del Estado, Provincia o Municipio; casinos, centros sociales de cualquier naturaleza, establecimientos de enseñanza, colegios particulares, institutos, Sociedades de instrucción o recreo, fábricas, talleres, hospitales, balnearios, y en general, todo lugar donde el público tiene derecho a penetrar o permanecer.
} 
posteriormente incluirlos en dos listas, dependiendo si tenían buenas o malas condiciones higiénicas. La lista con los edificios que no cumplían sería remitida inmediatamente a la Junta provincial de Sanidad, y periódicamente serían visitados por los inspectores de la Junta que verían si se habían subsanado sus deficiencias (V. G. R. Pinto Crespo, Rafael; Velasco Medina, Fernando, 2015, p. 234)

En el artículo 4 de esta Real Orden, se establecen los elementos de que debe constar un edificio o establecimiento para ser caracterizado de gozar de buenas condiciones higiénicas.

A. Los lugares destinados a desagüe, ya sean sumideros, urinarios, retretes, baños, fregaderos, etc., cuando estén situados en piezas que den directamente a patios o a la vía pública, se hallen muy bien alumbrados, tengan absoluta ventilación, no ofrezcan malos olores, estén completamente exentos de humedad y haya en ellos constante limpieza esmeradísima.

B. Los sumideros de patios, fregaderos, urinarios, retretes y cualquier otro género de puntos de desagüe, cuanto estén absolutamente aislados con la red de desagüe o depósitos de aguas sucias o materias fecales, por medio de sifones $u$ otro medio, en tanto perfecto estado de funcionamiento que impidan la salida del más insignificante olor.

C. La red de desagües cuando sea completamente impermeable en todo su trayecto.

D. Los depósitos de materiales fecales o de aguas sucias cuando estén completamente cerrados para evitar el paso de gases a los lugares donde se hallen y estén bien ventilados por tubos que alcancen mayor altura que los tejados de las casas en que se hallen de las inmediatas.

En el artículo 7 se estipula que "Los establecimientos públicos que en la citada fecha de $1 .^{\circ}$ de Julio de 1902 no hubieren cumplido con las disposiciones sanitarias de esta Real orden, quedarán sometidos durante una año á una inspección quincenal, con aplicación cada vez de la multa de 50 pesetas que autoriza á los Ayuntamientos el art. 77 de la ley Municipal, cuyo producto ingresará en las arca s municipales. Si el $1 .^{\circ}$ de Julio de 1903 no se hubiese hecho la reforma, se procederá á su clausura. (artículo 7) ("Saneamiento de edificios públicos. Real orden de 13 de julio de 1901," 1901). 
Un ejemplo de otra serie de medidas destinadas a la mejora de las condiciones higiénicas por parte de los particulares en la ciudad de Madrid fue el Acuerdo del Excmo. Ayuntamiento de Madrid de 13 de diciembre de 1901, instituyendo un premio en metálico para la casa de nueva construcción que reúna las mejores condiciones de salubridad, higiene y ornato. Mediante éste se premiaba con 5.000 pesetas a la casa de nueva construcción que mejor cumpliera con lo estipulado en el del Bando de 5 de octubre de 1898 y la Real Orden de 13 de julio de 1901.

\subsubsection{El problema de las alcantarillas}

El punto de inflexión marcado por la epidemia de cólera en 1885 influyó, también, en la consideración del problema del alcantarillado en la ciudad de Madrid. Así, el Alcalde Alberto Bosch, planteó la necesidad de realizar un plan general que incluyera a los nuevos barrios del Ensanche y Extrarradio, así como la reparación y modificara de los ramales de la zona del Interior que estaban inservibles. Sin embargo, como ya se ha señalado más arriba, la realización de este plan estaba condicionada a que los barrios del Ensanche y del Extrarradio estuvieran dotados de agua potable en cantidad suficiente. Por ello, no se pudo llevar a cabo hasta comienzos del siglo XX.

A la altura de 1901, el escenario del alcantarillado madrileño no varió demasiado. El problema más palpable fue que se llevaban a cabo obras parciales, sin ninguna clase de conexión entre las mismas. Un ejemplo de ello, fue la construcción de alcantarillas en algunas calles de la ciudad: en la zona del interior, se alcantarillaron las calles de Sombrerería y Argumosa; en la zona del Ensanche las calles de Génova, Sagasta, Carranza, Marqués de Riscal, Zurbano, Españoleto, Calvo Asensio, Ronda de Toledo, Sebastián Herrera, y partes de la de Monte Esquinza, Jenner, Alcalá, Hermosilla, Príncipe de Vergara, don Ramón de la Cruz, Villanueva, Lagasca, Velázquez, y Claudio Coello (Aguilera y Velasco, 1902, pp. 27-28)

Esta situación queda atestiguada por Hausser (Hauser and del Moral 1979) en su Plano Sanitario Demográfico que realizó sobre la ciudad en 1902, quien refleja que en alcantarillado de la ciudad en 1900 había cambiado poco respecto al ejecutado por el Canal de Isabel II entre 1856 y 1865. En el plano se aprecia que el casco histórico era la única parte de la ciudad que estaba bien abastecida de alcantarillas, aunque todavía 
había algunas zonas sin alcantarillar. Respecto al Ensanche y Extrarradio, en el plano se aprecia que a comienzos del siglo XX la falta de alcantarillado era casi total, sobre todo en los terrenos del término municipal madrileño que estaban fuera del foso del Ensanche, pues en sus barrios no se aprecia ninguna alcantarilla, a pesar de que alguno de ellos, como la Prosperidad, Guindalera, Madrid Moderno y parte de Tetuán estaban consolidados. (Ver mapa 2-7, en el capítulo sobre Fuentes y Metodología).

La preocupación por estos asuntos era manifiesta. Así lo declaró el Alcalde de la ciudad Alberto Aguilera y Velasco en la Moción presentada al Ayuntamiento en enero de 1902 sometiendo á estudio de las distintas Comisiones proyectos de obras y reformas para la mejora y ornato de la Capital, en los servicios que les están encomendados, así como también el de los económicos, para la realización de dichas mejoras, y el nombramiento de una Comisión técnica que formule los planes para el arreglo de la vía pública y del subsuelo. (...) No está completa la red de alcantarillas, se encuentran en deplorable estado las tuberías de los antiguos viajes de aguas potables, es el río Manzanares un foco perenne de infección que á toda costa conviene extirpar, el agua del Lozoya no llega pura á los que la han de consumir" (Aguilera y Velasco, 1902, p. 3)

En esta Moción, también mostró sus ideas sobre la necesidad de pasar de obras parciales a un plan general, bajo el reconocimiento de que el saneamiento de la ciudad sólo podía lograrse de este modo.

(...) al saneamiento y ensanche total de la población no cabe llegar con las reformas y obras parciales que hasta aquí se han venido haciendo en Madrid, obras y reformas mezquinas, y á veces incongruentes, casi limitadas á la superficie del suelo, en el que se teje y desteje sin cesar; que por su pequeñez no disminuyen la densidad de la población, cada día mayor por la desaparición de los grandes espacios no edificados que tenían las fincas antiguas y el aumento de pisos en las nuevas, lo cual demanda, en compensación, grandísimos ensanches de la vía pública, y que, en virtud de la falta de plan general, no pueden ofrecer la unidad, la grandeza, la hermosura, ni, sobre todo, el resultado útil para la salubridad y la longevidad ofrecido por las reformas hechas en los grandes pueblos, que, gracias á la formación de planes generales previos, han visto descender su mortalidad, barómetro de la vida urbana, desde cifra análoga á la que nosotros tenemos hoy, hasta la muchísimo menor que 
actualmente acusan sus respectivas estadísticas (Aguilera y Velasco, 1902, p.

$6)$.

En resumen, hasta comienzos del siglo XX, el desarrollo de las redes de alcantarillado en la zona del Ensanche fue deficiente, e incluso inexistente en algunos de sus barrios, en buena medida motivado por la falta de agua corriente en determinadas zonas. Y es que, como en otras zonas de la ciudad, también en el Ensanche el Ayuntamiento de Madrid había dejado a la iniciativa privada la construcción de las alcantarillas. Así, al particular que quisiera construir un inmueble en estos barrios sólo se le obligaba a realizar un pozo negro, siendo la construcción de la alcantarilla opcional. Un buen ejemplo de ello es que en 1914, 1917 y 1920, del total de licencias para la construcción de pozos negros $(14,24$ y 14, correspondientemente) ninguna se otorgó para la zona del interior, correspondiendo todas ellas a la zona del extrarradio de la ciudad (Resúmenes sobre la Gestión del Ayuntamiento, varios años). Y como además de ser más cara la construcción de la alcantarilla, y se carecía del agua suficiente para hacerla funcionar, lo normal fue que se optara por no ejecutarla. Por esta razón, la mayoría de las alcantarillas construidas durante estos años en el Ensanche fueron únicamente actuaciones puntuales, realizadas sin planificación alguna, y ejecutadas fundamentalmente en aquellos barrios que estaban mejor dotados de agua, aunque fuera de los viajes antiguos, y cuyos propietarios se lo pudieran permitir.

Durante los siguientes años, se producen algunos avances en la construcción del alcantarillado, especialmente en la zona del Ensanche y algunas zonas del Interior de la ciudad. Tal y como aparece en el artículo sobre el Alcantarillado moderno de Madrid, publicado por el arquitecto Gabriel Aguado, desde Agosto de 1903 hasta Junio del 1906, se construyeron un total de 12.346 metros de alcantarillas nuevas, correspondiendo próximamente 10 kilómetros al Ensanche y el resto al Interior (Aguado y Aguado, 1907, p. 21).

Un aspecto que es imprescindible tener en consideración a la hora de abordar la posibilidad de construcción del alcantarillado, es la disposición de agua en la zona a alcantarillar en cuestión. Hay que tener en consideración la importancia que tuvo la competencia directa que, fruto de la creación de Hidráulica Santillana por Orden de 13 de febrero de 1904, hubo entre ésta empresa y la del Canal de Isabel II. A su vez, a 
finales de ese año fue aprobado por el Canal de Isabel II el trabajo realizado por el ingeniero de caminos Diego Martín Montalvo, redactor, además de la Revista de Obras Públicas durante los años 1881 y $1893^{61}$; el Anteproyecto de distribución de agua en el Ensanche de Madrid (J. González Reglero, 2008, p. 12). La empresa Hidráulica Santillana en su pretensión de abastecer de agua a aquellos barrios que no estaban cubiertos por las actividades del Canal de Isabel II, hizo que en 1907, cuando éste vuelve a adquirir autonomía respecto al Ministerio a Fomento formándose un Consejo de Administración, impulsara de una manera decidida su actividad constructiva para hacer frente a su nuevo competidor (V. G. R. Pinto Crespo, Rafael; Velasco Medina, Fernando, 2015, p. 239).

Nuñez Granés, en su Memoria sobre los trabajos realizados entre los años 1906, 1907 y 1908 (Núñez Granés, 1909), muestra alguna información de los trabajos efectuados en Fontanería y Alcantarillas, desde el 22 de Noviembre de 1907 (momento en que se hace cargo de la Dirección de este ramo del ayuntamiento), hasta el 31 de diciembre de 1908. Entre éstos, se encuentran la instalación de tuberías, la construcción de alcantarillado y la colocación de absorvederos y urinarios en diferentes calles de la ciudad.

Así, señala que en el lapso de poco más de un año se instalaron tuberías para la conducción de aguas y servicio de bocas de riego, en las siguientes calles: Calle de Alcalá (en su tramo final), Alarcón, Mendizábal, Padilla, Zurbano, Velázquez, Toledo, Prado, Paseo de la Castellana, plaza de Cánovas, Montalbán, Conde de Aranda, paseo de Ronda y carretera de la Coruña.

Asimismo, se dotó de Alcantarillado a las calles de Mártires de Alcalá y algunos trayectos de las de Alberto Aguilera, López de Hoyos, Diego de León, Meléndez Valdés Mendizábal en la parte que ocupaba el cuartel de San Gil; Alfonso XI, Alarcón, Almagro, Pozano, Serrano, Lagasca, Conde de Aranda, Padilla, Ayala, Ferraz, Moret, Marqués de Urquijo, Viriato, Prim, Argensola, Apodaca, Larra, Churruca, Canarias y Californias, estando en construcción la tubular del Parque del Oeste y la de la calle de Hermosilla, y se colocaron diferentes absorbederos en las calles de Andrés Mellado, Canarias, Cava de San Miguel, Cuchilleros, Mártires de Alcalá, Mayor, plaza de Olavide, Peñuelas, Pizarra, Reyes, Cuesta de la Vega, Ferraz y plaza de los Ministerios, así como la colocación de urinarios situados en la Puerta de Atocha, calles del Cuervo,

\footnotetext{
${ }^{61}$ http://dbe.rah.es/biografias/21281/diego-martin-montalvo
} 
Farmacia, Barceló, San Jerónimo, Santa Brígida y en la plaza del Carmen. (Núñez Granés, 1909, p. 8).

\subsubsection{Los nuevos planes de obras. El Plan general de saneamiento del subsuelo de Madrid.}

Pese a la evolución del alcantarillado descrita en líneas precedentes, la ciudad de Madrid aún no disponía de un plan director que consiguiera ser realmente integral. Hubo que esperar a 1909 para la redacción del mismo, denominado Plan general de saneamiento del subsuelo de Madrid, dirigido por el ingeniero Pedro Núñez Granés. El proyecto se fue gestando en tiempos del entonces Alcalde de Madrid, Joaquín Sánchez de Toca Calvo que, en 1907, nombró a Núñez Granés, que ya era Director de Vías Públicas, como Director del Servicio de Fontanería y Alcantarillas. En aras de establecer una coordinación de servicios, Núñez Granés, desde un primer momento, abogó por unificar en una misma dirección los servicios de Vías Públicas (del Interior, Ensanche y Extrarradio), los de Fontanería y Alcantarillas, Servicios Eléctricos, Pozos negros, y obras de alumbrado (V. G. R. Pinto Crespo, Rafael; Velasco Medina, Fernando, 2015, p. 241).

Núñez Granés consiguió su objetivo, de manera que en 1908, el sucesor a la Alcaldía de Sánchez de Toca, Nicolás de Peñalver y Zamora (conde de Peñalver) unificó los servicios bajo una única oficina municipal que se encargase de los servicios del Suelo y Subsuelo de la capital, así como de la ejecución del Plan general de saneamiento del subsuelo de Madrid, bajo la Dirección de Núñez Granés. Esta oficina municipal quedó dividida en cuatro direcciones técnicas, entre las que cabe destacar la de Fontanería y Alcantarillas, que quedó en manos del ingeniero Julián Gil Clemente, y en su ayudante, el arquitecto José de Lorite Kramer y la Sección especial encargada de la redacción de proyectos de carácter general de vías públicas y de alcantarillado, bajo cargo de Mauricio Jalvo.

El 13 de agosto de 1908 se dictó la Ley que abordaba, entre otras cuestiones (como fue la canalización del Manzanares y de sus caudales) el tema del alcantarillado de Madrid. Grosso modo, bajo la Ley se amparaba la financiación de la mitad de los costes de la 
nueva red de alcantarillado así como de las obras relativas a la canalización del Manzanares y la regularización de su caudal (Paz Maroto, 1945).

“(...) pero Madrid siguió creciendo; y como "el traje sanitario” hecho por el Canal se quedó estrecho; y, como ha pasado siempre, pasa ahora, y pasará, que este crecimiento de Madrid (reflejo del aumento de potencialidad del país) no puede atenderse exclusivamente con los recursos de una Corporación, llegó un momento en que el Estado se dio cuenta de la necesidad de prestar esta ayuda económica y técnica, y con la Ley de 13 de agosto de 1908 dio el empujón decisivo, en forma de subvención del 50 por 100, para las obras de saneamiento de subsuelo de Madrid y canalización del Manzanares”. (Paz Maroto, 1945, p. $38)$.

$\mathrm{Y}$ es en este contexto en el que el proyecto del alcantarillado de la ciudad fue encomendado a Mauricio Jalvo, Director de la Sección especial (encargada de la redacción de proyectos de carácter general de vías públicas y de alcantarillado), que formaba parte de la Dirección única. Fruto de la dimisión de Jalvo, Núñez Granés, encargó definitivamente el proyecto al ingeniero Julián Gil Clemente, cabeza de la dirección técnica de Fontanería y Alcantarillas. El Proyecto General de saneamiento del subsuelo de Madrid terminó de redactarse el 25 de julio de 1909, y en el mismo colaboraron, bajo dirección de Núñez Granés, algunos ingenieros del Ministerio de Fomento (V. G. R. Pinto Crespo, Rafael; Velasco Medina, Fernando, 2015, p. 242).

El Plan General debía ejecutarse en nueve años, y tuvo un presupuesto de 37.849.313,88 pesetas.

Gil Clemente manifestaba que “(...) el alcantarillado actual no responde a plan alguno ni a idea fija determinada de conjunto; las aguas sucias se vierten directamente al río, convirtiéndole en constante depósito de inmundicias, estando surcada la parte baja de la población por arroyos de deyecciones, en cuyas proximidades se albergan millares de personas ... constituyendo todo ello un estado higiénico de la población absolutamente inadmisible, y contra el cual no es posible lucha alguna, con buenos resultados, en el caso desgraciado de una epidemia o de infecciones de la población, de carácter general”. (Corona., 1910b, p. 144).

Tal y como apareció reflejado en dos artículos publicados en la Revista La Construcción Moderna, (Corona., 1910a, 1910b), las personas que conformaban la Subcomisión de 
obras del Ayuntamiento de Madrid formalizaron el Informe de la Subcomisión de obras del Ayuntamiento de esta corte al Proyecto General de Saneamiento del subsuelo de Madrid. En el mismo, explicitaban algunos elementos que, a su juicio, debían insertarse en el Plan (Corona., 1910b, pp. 164-165). Extracto de Proyecto general de saneamiento del subsuelo de Madrid. La Construcción Moderna de 30 de mayo de 1910. Madrid.

$\left.1^{o}\right)$ Se aprueba en todas sus partes, el proyecto presentado por el señor ingeniero jefe de Fontanería y Alcantarillado en cuanto al sistema unitario se refiere, recomendando se tenga en cuenta, en su ejecución, la posibilidad de transformarlo en el porvenir, adoptando de un modo general ó parcial el sistema Duplex, o separado en la forma que propone el mismo proyecto, obligando desde luego, á construir las casas de nueva planta con doble red de alcantarillado, que ha de ser precisamente visitable ó tubular en todas sus partes.

$\left.2^{o}\right)$ Se estudiará un tipo de sección visitable mínima, ovoide, tubular, para reemplazar el tubo en los sitios en que la profundidad del cauce y longitud consiguiente de los pozos de registro, exija hacer un gasto igual ó mayor, si se empleara el sistema tubular no visitable, y para los colectores principales de las cuencas menos importantes.

$\left.3^{\circ}\right)$ Se admitirá el gres barnizado, el hierro ú otro material conveniente a juicio de los técnicos en el sistema tubular, en los sitios en que su permeabilidad absoluta y su mayor resistencia sean necesarias, y aun en la red general, sí la contrata con estos materiales no aumentara sensiblemente las cifras del presupuesto.

$\left.4^{\circ}\right)$ Se aumentará hasta 12 centímetros el diámetro de las más pequeñas chimeneas de ventilación y á un metro por segundo la velocidad mínima de las aguas.

$\left.5^{\circ}\right)$ Se declarará urgente la tramitación de este expediente y se sacará á subasta o concurso la totalidad o parte de los proyectos en que se divide este estudio, á la mayor brevedad posible, sin necesidad de esperar el auxilio del Gobierno, introduciendo durante la ejecución de las obras las modificaciones anteriores, y las que convenga que no alteren el presupuesto y mejoren la obra.

$\left.6^{\circ}\right)$ Al desglosar de este estudio las canalizaciones de agua, gas, luz eléctrica, teléfonos, etcétera, por ser más urgente cuanto á las aguas sucias se refiere, y al 
no ocuparse la Comisión en este documento, de la depuración y aprovechamiento de estas últimas que es cuanto constituye el saneamiento del subsuelo de una población, entiende llevar a cabo una parte de lo que se obliga á hacer el Ayuntamiento y á subvencionar el Estado, por la ley de 13 de Agosto y Reales órdenes de 8 y 14 de Septiembre de 1908, y acuerda examinar estos estudios complementarios, ya hechos en parte por los técnicos del Ayuntamiento, y puestos á examen de la Comisión de Obras, con la mayor ce9leridad.

$7^{\circ}$ El importe total del presupuesto dividido en décimas partes, se incluirá en los presupuestos municipales de diez años sucesivos, á contar desde el actual, y se redactarán los pliegos de condiciones administrativas, en forma que el total del pago de las obras so haga en quince días hábiles, pero con la obligación por parte del contratista, de entregar concluida la totalidad de la obra en un plazo improrrogable de diez años, y

8.^ Se solicitará del Estado la más pronta subasta y ejecución del colector de la margen izquierda del Manzanares, desglosándolo para mayor rapidez, del proyecto de canalización del mismo, en cumplimiento de la ley y Reales órdenes antes citadas.

Es cuanto los firmantes, tienen el honor de someter al examen y aprobación de sus dignos compañeros de Comisión.

Madrid, 5 de Marzo de 1910- Marqués de Mordía. —Luis Sainz de los Terreros.-Félix de la Torre y José Corona

En abril de 1910, el Ayuntamiento de Madrid aprobó el proyecto. Asimismo, mediante Reales Órdenes de 12 y 16 de septiembre de 1910, el Estado hizo lo propio. Cabe destacar, que fueron incorporadas algunas de las anotaciones anteriores, realizadas por la Subcomisión de obras del Ayuntamiento de Madrid, tales como optar por el alcantarillado unitario de evacuación como sistema más óptimo, frente al sistema separado $^{62}$, así como optar por dar prioridad a secciones visitables. En lo que respecta a los materiales a emplear, se aprobó que, cuando su precio no resultara demasiado elevado, se emplearan tubos de gres o porcelana en las secciones circulares con

\footnotetext{
62 Para consultar un examen exhaustivo de los beneficios e inconvenientes de este tipo de sistema, (Corona., 1910a, pp. 161-161)
} 
diámetros pequeños y, en caso de tubos de grandes diámetros con coste elevado, usar tubos de hormigón comprimido con cemento portland. Respecto a los plazos, se produjo la ampliación del periodo de garantía de las obras a un año y el plazo de ejecución a diez años. Otros asuntos importantes fueron la eliminación de los proyectos parciales que se estaban encargando de la temática de los colectores del Río Manzanares (que serán objeto de estudio en la siguiente sección de este capítulo), en tanto en cuanto, con la aplicación de la Ley de 13 de agosto de 1908, el Estado se encargaría de la construcción de éstos.

También se redactaron los plazos y algunas de las características que debían contener las bases del concurso público del Proyecto. Éste debería publicitarse en el plazo de dos meses y contemplaría que el Ayuntamiento se reservaría la posibilidad de ejecutar por administración las obras proyectadas con aplicación del alcantarillado existente (V. G. R. Pinto Crespo, Rafael; Velasco Medina, Fernando, 2015, p. 250).

Atendiendo al documento oficial sobre el Concurso Celebrado para la adjudicación de las obras de saneamiento del subsuelo de Madrid (1911), los licitadores fueron cinco, cada uno de los cuales aportaba un presupuesto y una memoria explicativa conforme a cada una de las bases del concurso. José Luis Oriol y Urigüen con un presupuesto de 35.162.012,60 pesetas; la Sociedad General de Obras y Construcciones, 37.716.841,28 pesetas; la Sociedad Anónima Fomento de Obras y Construcciones 35.845.848 pesetas; Sociedad Ibáñez y Cía, 37.849.313,88 pesetas y Eugenio Grasset y Echevarría, 29.860.000 pesetas.

En el documento de resolución señalado, se realiza una valoración pormenorizada de las propuestas, así como el dictamen de adjudicación sobre las proposiciones presentadas, en el que se señaló lo siguiente:

Reunidos en diez y nueve de Junio de mil novecientos once, á las once de la mañana, bajo la presidencia del Excmo. Sr. Ministro de Fomento, los señores que componen el Jurado, se dió lectura por el Sr. Ingeniero Jefe del servicio de Fontanería Alcantarillas del informe, que se une á este acta, complementario del emitido en la sesión anterior, proponiendo, en definitiva la adjudicación á la proposición presentada por D. Recaredo de Uhagón en representación de D. José Luis de Oriol y Urigüen. (Madrid, 1911, p. 43). 
Si bien, hubo que esperar a 1912 para que se otorgase la adjudicación de las obras, debido a que, finalmente, el primer concurso público para llevar a cabo las obras del Proyecto General de Saneamiento del Subsuelo de Madrid fue declarado desierto. Así, se celebró nuevamente el Concurso para las obras del Proyecto General de Saneamiento del subsuelo de Madrid, con arreglo a las Reales órdenes de fecha 12 y 16 de septiembre y 22 de diciembre de 1910, y según lo preceptuado en la Real orden comunicada de fecha 25 de septiembre de 1912 (Madrid, 1912). En este nuevo concurso, sólo hubo un proyecto licitador, de manos de la Sociedad Fomento de Obras y Construcciones de Barcelona, que ya participó en el anterior concurso (...) comprometiéndose a realizar todas las obras generales, además de sustituir todos los colectores parciales de cuencas o vertientes, por colectores visitables; y sustituir por alcantarillas tubulares de gres las alcantarillas visitables no tubulares de cemento armado (V. G. R. Pinto Crespo, Rafael; Velasco Medina, Fernando, 2015, p. 251).

Imagen 6-2. Fotografía de la firma de la escritura de adjudicación de las Obras de saneamiento del subsuelo de Madrid.

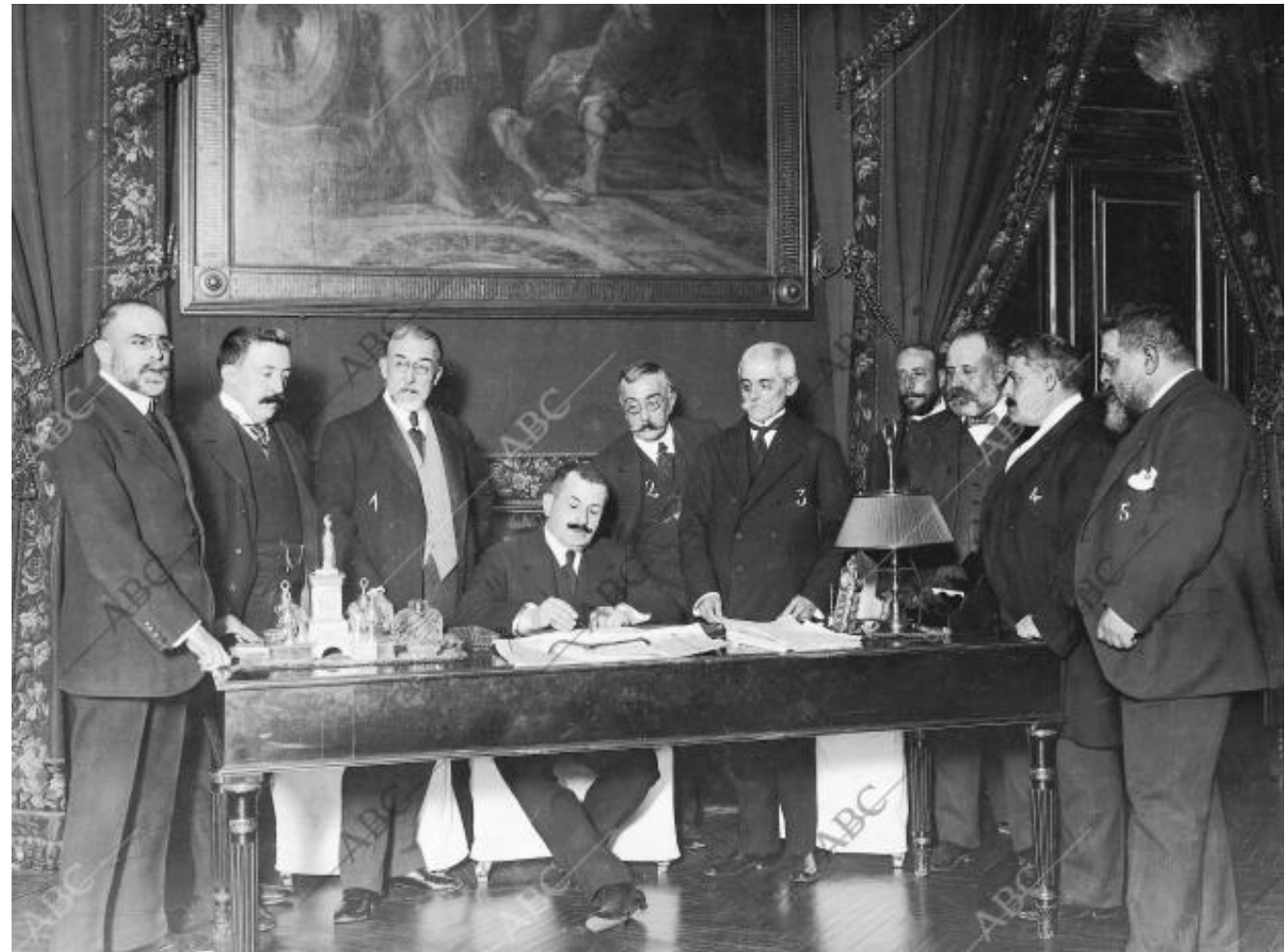

Fuente: archivo ABC. Fecha31/03/1913. 


\subsubsection{El Plan General de Saneamiento del Subsuelo a la altura de 1923 y el Proyecto de obras de saneamiento del subsuelo de los barrios extremos de Madrid de 1924.}

Atendiendo a la ejecución de las obras, en lo que respecta a la construcción de la nueva red, fue llevada a cabo sin demasiados incidentes, de modo que se cumplió con los plazos de ejecución del plan. En el año 1923, se finalizó la nueva red, resultando un nuevo y flamante alcantarillado de 395 kilómetros, que incluía 170 kilómetros de alcantarillado antiguo (hasta 1913) y 225 de nuevo (desde 1913 a 1924) (V. G. R. Pinto Crespo, Rafael; Velasco Medina, Fernando, 2015, p. 251).

En lo que atiende al alcantarillado antiguo, éste fue remodelado prácticamente por entero. Las secciones visitables fueron unificadas resultando una red de solera horizontal, sin andén, y con pendientes que oscilaban entre el 1 y el 5\%. De los 170 kilómetros de alcantarillado antiguo, 8 acabaron siendo de red tubular, de tres secciones con diámetros de entre 3 y 15 centímetros y pendientes del 2 al 4\%. También se establecieron cámaras de limpia y depósitos de descarga automática (Ayuntamiento de Madrid, 1929, p. 110). Los 225 kilómetros de alcantarillado de nueva planta, fueron realizados según las bases establecidas en el proyecto general. Formado por alcantarillas visitables y tubulares, sus pendientes oscilaron entre el 0,07 y el 3\%; estableciéndose muy diversas secciones según las necesidades de cada alcantarilla.

La regularización del alcantarillado de la ciudad se produjo con la finalización del proyecto. Hay que mencionar que la Gran Vía no se enmarcó en las bases, sino que su alcantarillado se realizó mediante planes parciales. Francisco López de Sallaberry y Francisco Andrés Octavio fueron los arquitectos encargados de llevarlo a cabo. 


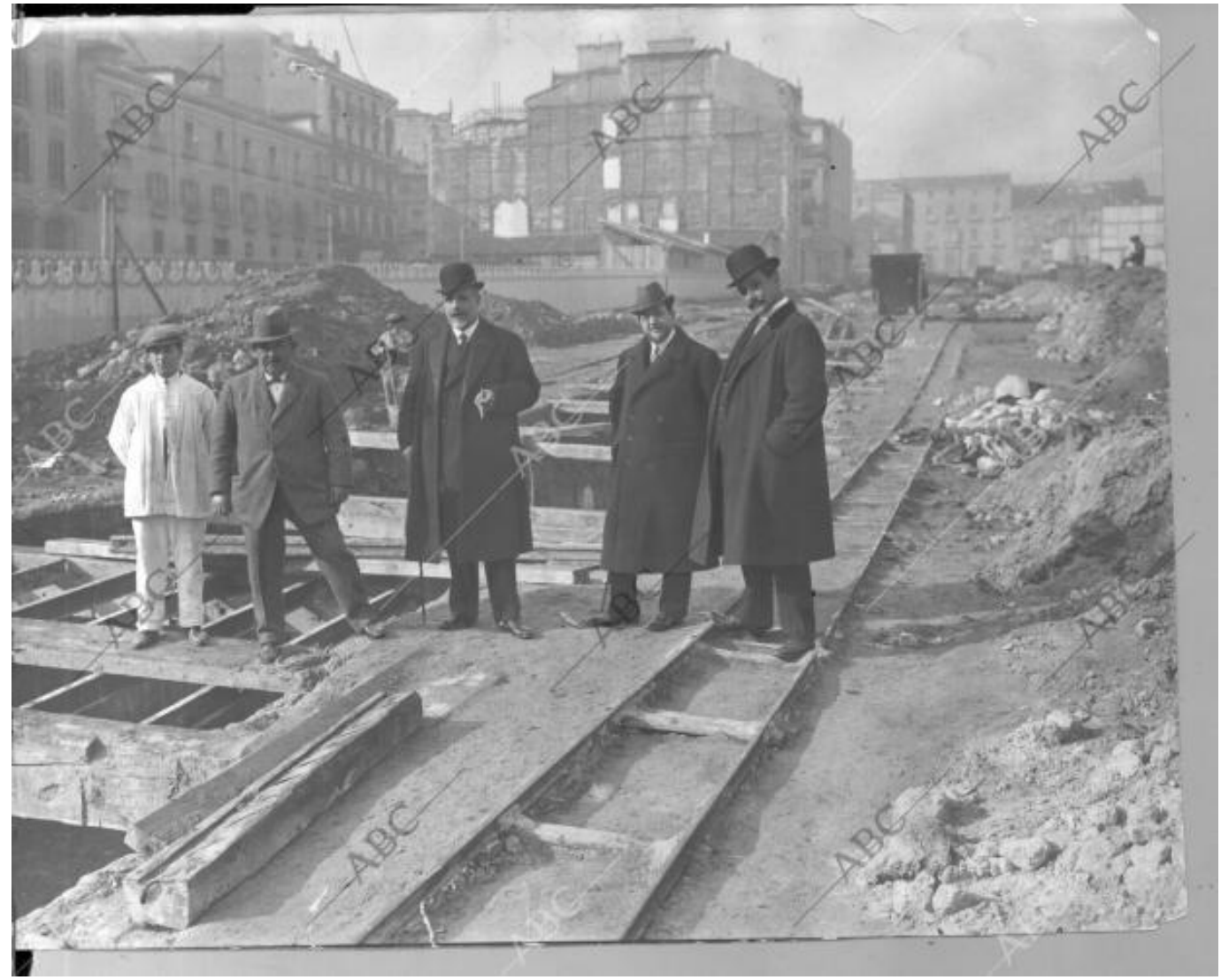

Fuente: Archivo ABC. Madrid, 03/01/1912. Autor: Ramón Alba.

Pese a las buenas pretensiones del Proyecto, a la altura de 1923 el dimensionamiento del alcantarillado en la ciudad de Madrid siguió siendo un problema acuciante. Esta circunstancia tiene una explicación, que no es otra que la de que el Proyecto terminó de redactarse a la altura de 1910 y, llegados los años 20, Madrid se había expandido mucho más allá de lo que representaba en la primera década del siglo XX. Tanto su población como su extensión sufrieron un desarrollo que no fue previsto. En 1910, cuando se acabó de redactar el proyecto, Madrid tenía 599.807 habitantes; en 1920 ya había llegado a los 750.896, y en 1930 a los 952.832 habitantes.

“El plan general de saneamiento de Madrid, redactado en el año 1909, no puedo prever ni sospechar que en un periodo de tiempo tan corto como el transcurrido desde aquella fecha tuviera Madrid un desarrollo tan rápido y un aumento de la población tan considerable, que cuando se creía solucionada la cuestión, y que todos los pozos negros del término municipal de Madrid habrían de desaparecer, no quedando calle en que no existiese alcantarilla, nos 
encontramos con que existen zonas extensas donde se han formado verdaderos núcleos de población, que han determinado un hacinamiento de seres humanos, y que obliga a poner sobre el tapete otra vez la misma cuestión que en 1909.

A medida que se ha ido construyendo el alcantarillado en las calles del interior $y$ del ensanche y parte del extrarradio, la capital aumentaba, formándose barriadas que, como único medio de desagüe, tienen el pozo negro. Desgraciadamente, Madrid tiene el sino fatal de llevar todas sus obras de urbanización a la zaga del movimiento de expansión de las construcciones, y por esta causa la construcción del alcantarillado se hace a posteriori. Pero ese es asunto que viene debatiéndose constantemente, sin que sobre él recaiga una solución acertada, quizá porque no la tenga o quizá porque no se busca y, entre tanto, Madrid aumenta y no pueden dejarse abandonadas todas aquellas fincas que están constituyendo verdaderos focos de infección con su sistema de desagüe”. ("Informaciones Municipales," 1924, p. 10)

Además, los pozos negros volvieron a ser el recurso más habitual en algunos barrios, especialmente en los ubicados en algunas de las zonas del Ensanche y del Extrarradio. El Ayuntamiento de Madrid actuó con bastante celeridad, de modo que en 1924, sólo un año después de que finalizara el Proyecto General de Saneamiento del Subsuelo de Madrid, se elaboró uno nuevo; el Proyecto de obras de saneamiento del subsuelo de los barrios extremos de Madrid. José de Lorite, Director de Fontanería y Alcantarillas en este periodo, presentó el mismo el 8 de agosto de 1924 ("Informaciones Municipales," 1924, p. 10).

Sin embargo, a la altura de 1929, los distritos con un mayor número de fosas y pozos negros eran el de la Inclusa y la Latina (Gráfico 6-1).

$\mathrm{Y}$ es que las casas que en el tiempo no hubieran podido acometer su red de desagüe a la del alcantarillado, contaban para la evacuación con dos posibles medios, que son los pozos negros y las fosas sépticas. Tal y como se describe en la memoria de 1929, los distritos que tradicionalmente han sido caracterizados como más pobres, son los que en mayor número cuentan con este tipo de medios de evacuación; especialmente latina e inclusa. El 27 de enero de 1922 se aprobó un reglamento por parte del ayuntamiento con la finalidad de regular la recogida de aguas fecales en los edificios donde no existiera alcantarillado en la calle, y, además, se hizo obligatoria la construcción de fosas sépticas para acabar con los pozos negros y se finalizó con la posibilidad de conceder licencias 
para la construcción de pozos negros, con el objetivo de acabar con ellos. Atendiendo a los datos ofrecidos por la Memoria de la ciudad en 1929, con datos de la Dirección de Fontanería y Alcantarillas, el número de fosas sépticas ascendía a 240 en toda la ciudad, mientras que todavía existían 981 pozos negros.

Gráfico 6-1. Número de fosas y pozos negros por distritos, año 1929.

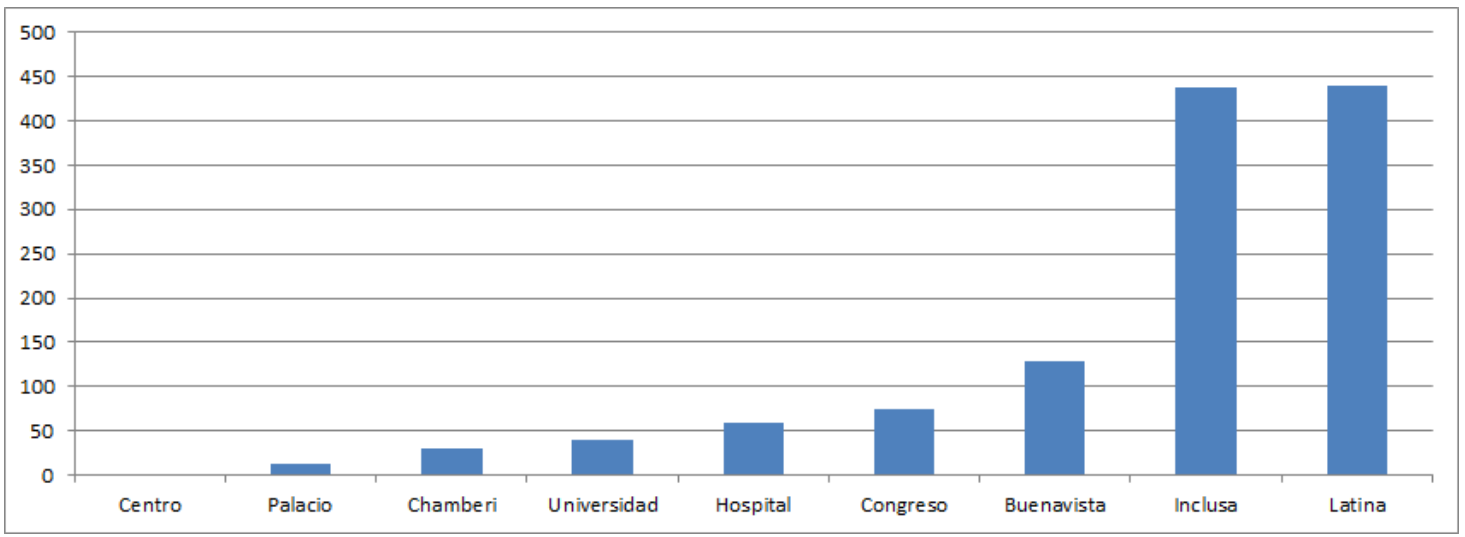

Fuente: elaboración propia. datos obtenidos de (Ayuntamiento de Madrid, 1929)

Este nuevo Proyecto, el Proyecto de obras de saneamiento del subsuelo de los barrios extremos de Madrid, tuvo similitudes con el Proyecto de 1909, especialmente en lo que respecta a materiales a emplear y elementos técnicos. Sin embargo, hay que tener en consideración que, si bien para llevar a cabo el Proyecto General de Saneamiento del Subsuelo de Madrid se contó con financiación y respaldo del Ministerio de Fomento, en el Proyecto de obras de saneamiento del subsuelo de los barrios extremos de Madrid, sólo se contó con las partidas presupuestarias del Ayuntamiento (Paz Maroto, 1945, p. 41). El importe de las obras de saneamiento de los barrios extremos, en el que se incluían las obras auxiliares y complementarias, fue de 18.970.614,05 pesetas, con un plazo de ejecución de cuatro años ("Informaciones Municipales," 1924, p. 10). Los metros de alcantarillado nuevo ascendían a 22.459,17, distribuidos de manera desigual entre las Zonas. 
Gráfico 6-2. Zonas a alcantarillar según el Proyecto de obras de saneamiento del subsuelo de los barrios extremos de Madrid.

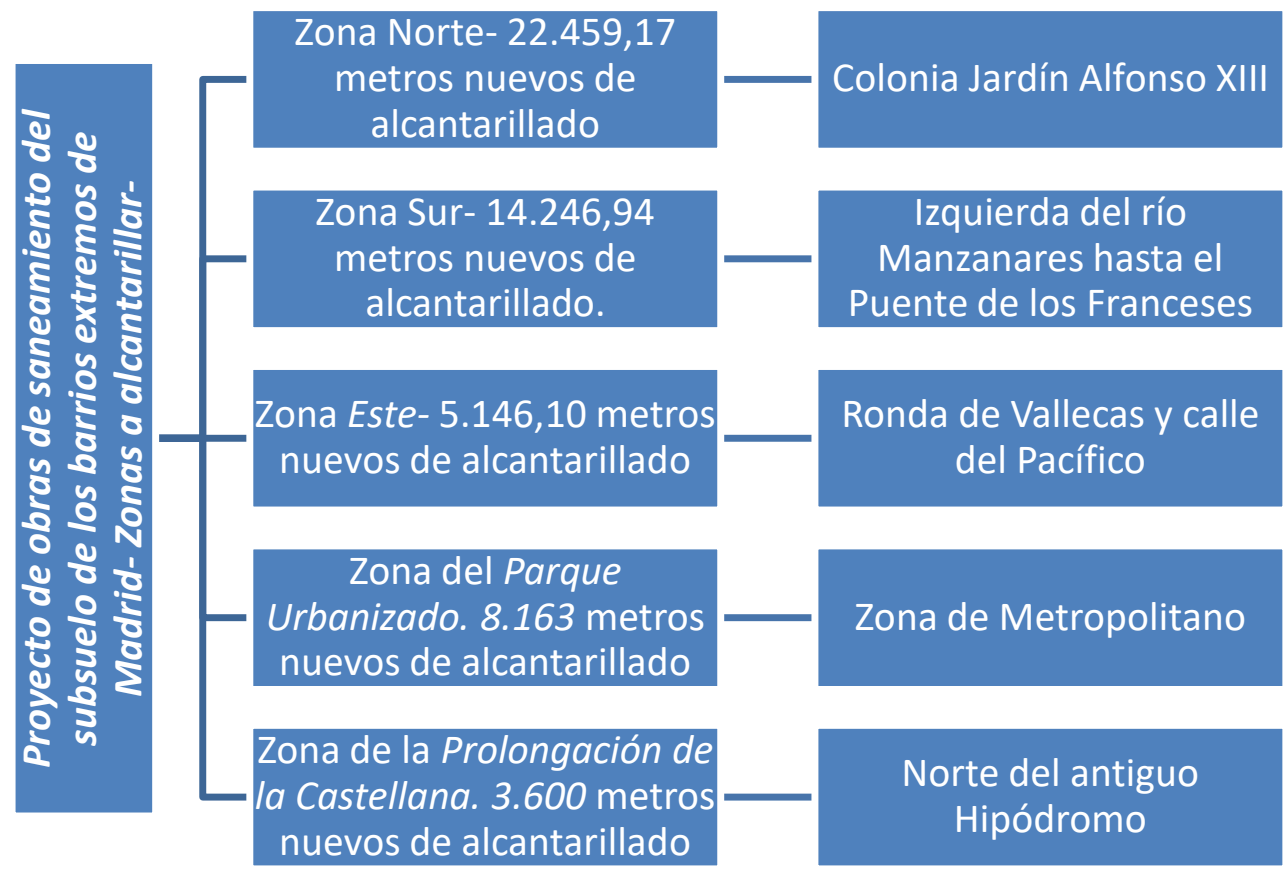

Fuente: elaboración propia. Datos obtenidos de ABC y Pinto ("Informaciones Municipales," 1924, pp. 253-254; V. G. R. Pinto Crespo, Rafael; Velasco Medina, Fernando, 2015).

"Sería un ideal que se aprovechasen estos cuatro años para que los estudios de urbanización de Madrid y de extensión de la capital llegaran a una situación de realidad tal que permitiera que, por una vez, la urbanización de Madrid fuera delate del capricho y de la anarquía que hasta ahora ha reinado en materia de distribución de construcciones"” ("Informaciones Municipales," 1924, p. 10)

La adjudicación de las obras del Proyecto de Saneamiento del Subsuelo de los Barrios Extremos de Madrid fueron para la Sociedad Fomento de Obras y Construcciones, la misma que ganó la licitación para la realización de las obras del anterior plan (Proyecto Obras de saneamiento del subsuelo de Madrid ), con un presupuesto de 18.333.106,81 pesetas ("Informaciones Municipales. Las obras del subsuelo," 1925, p. 13)

"Las obras de saneamiento del subsuelo en los barrios extremos de Madrid, por las que hace años se viene abogando por cuantos conocen la importancia que encierra el problema para el extrarradio especialmente, fueron ayer adjudicadas en subasta a la Sociedad Fomento de Obras y Construcciones. El 
tipo de adjudicación asciende a pesetas: 18.333.106,81" ("Informaciones Municipales. Las obras del subsuelo," 1925, p. 13).

En el Boletín Oficial de la Provincia de Madrid, a fecha de 18 de mayo de 1925 se indicaba que: "La Comisión Municipal Permanente de esta Excma. Corporación de 11 del pasado Marzo, con sesión del Pleno en la de 4 de Abril siguiente, ha acordado anunciar subasta pública, para contratar obras de saneamiento del subsuelo de los barrios extremos de esta Capital" (1925, p. 2). Asimismo, se explicita el anuncio de licitación completo, firmado por José de Lorite a fecha 8 de agosto de 1924. Está compuesto por 49 artículos seccionados en cinco capítulos. En el capítulo I se indican los pliegos de condiciones del mismo (Artículo 1); en el capítulo II, las condiciones que deben satisfacer los materiales a emplear y la mano de obra (Artículos del 2 al 16); en el Capítulo III, el proceso de ejecución de las obras (Artículos 17 al 39); en el Capítulo IV, la medición y el abono de las obras y, por último, el $\mathrm{V}$ capítulo versa sobre las Disposiciones Generales que han de cumplirse.

\subsubsection{La red de evacuación de aguas a la altura de 1929}

Tal y como se ha señalado en el capítulo sobre fuentes y metodología, la Memoria de la ciudad de 1929 (Ayuntamiento de Madrid, 1929) nos permite obtener información de importancia ineludible a la hora de poder comprender cómo era la ciudad, desde información sobre el estado meteorológico hasta información sobre la instrucción de los habitantes en la época.

Ante la ya citada dificultad para acceder a mapas que nos permitan conocer cómo eran las redes de abastecimiento de agua y de evacuación, la Memoria de 1929 nos ofrece la posibilidad de hacerlo. Se dispone de un plano (plano número 9 de la Memoria), con la

red general de evacuación existente perteneciente al término municipal de Madrid a fecha de 1929 (Mapa 2-9, capítulo de Fuentes y Metodología).

Para contemplar la información sobre el alcantarillado a la altura de 1929, en aras de una mejor comprensión, consideramos que es más operativo dividir la relación de alcantarillado entre "alcantarillado antiguo" y "alcantarillado nuevo". 
En este sentido, en relación al alcantarillado antiguo, éste constaba, en el año 1929, de 96 kilómetros. Las características de esta red, grosso modo, pueden resumirse en que las secciones visitables constaban de una solera horizontal, sin andén y con pendientes que oscilaban entre el uno y el cinco por ciento y que, por razones higiénicas, había sufrido remodelaciones con el objetivo de impermeabilizarla. En cuanto a la red tubular, ésta disponía de tres secciones, con una longitud aproximada de 8 kilómetros, diámetros de 15 a 3 centímetros y pendientes del 2 al 4 por 100. Existían cámaras de limpia y depósitos de descarga automática. (Ciudad, 1929, p. 110)

Respecto al alcantarillado nuevo, éste estaba dispuesto en las tres vaguadas en que se puede dividir a la ciudad; la del Manzanares, Carcabón y Abroñigal. Constaba de tres grandes colectores visitables, con andén central y bóveda parabólica. A estos tres principales colectores acometían 36 secundarios de sección, de canal y andén, y pendientes entre el 0,07 y el 3 por 100. Estos secundarios formaban una red total de 425 kilómetros, completada con absorbederos, ventilaciones, registros y cámaras de limpia.

Las obras de saneamiento de los barrios extremos finalizaron en el año 1930. Pese a lograrse los objetivos marcados en el Proyecto, la situación anterior al inicio del mismo, pareció repetirse. Fruto del crecimiento continuado de la ciudad, en términos poblacionales y territoriales, hubo que ampliarse el Proyecto de saneamiento del subsuelo de los barrios extremos. Desde $1931 \mathrm{y}$, paralizado por el inicio de la Guerra Civil $^{63}$, consiguieron construirse 41,4 kilómetros de alcantarillas más, con financiación por parte del Estado (V. G. R. Pinto Crespo, Rafael; Velasco Medina, Fernando, 2015, p. 254).

Por tanto, hasta el año 1936, en Madrid había alcantarillados un total de 490 kilómetros.

\footnotetext{
${ }^{63}$ En 1946 entró en vigor el denominado Plan Bigador. Desde el estallido de la Guerra Civil hasta ese año, no se llevó a cabo ningún Plan para el alcantarillado de la ciudad. Si bien, en 1935 se planteó un plan para modernizar el alcantarillado antiguo de Madrid, pero no se llevó a cabo. Asimismo, (...) en 1939, en plena Guerra Civil, el Comité de Reforma, Reconstrucción y Saneamiento de Madrid, presidido por Julián Besteiro, elaboró un Plan Regional que, si bien tampoco se llegó a realizar, marcó las bases de la política que se siguió a partir de 1946, extendiendo el saneamiento, en primer lugar a los pueblos que rodeaban la Capital, y más tarde al resto de la Región (V. G. R. Pinto Crespo, Rafael; Velasco Medina, Fernando, 2015, p. 254)
} 


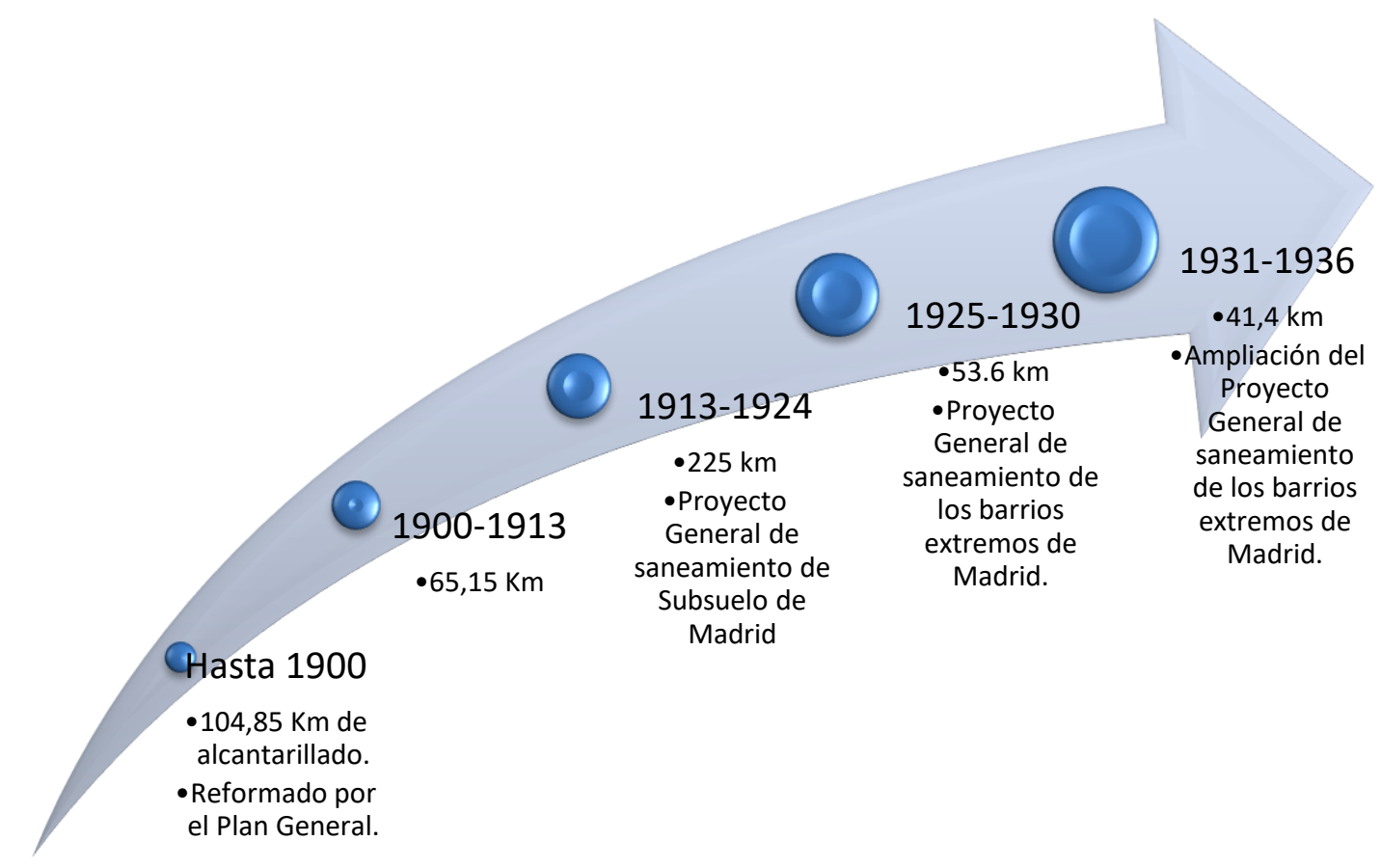

Fuente: Elaboración propia. Datos de los diferentes Planes de alcantarillado de la ciudad.

\subsection{Canalización y saneamiento del Río Manzanares}

Otro de los elementos vinculados al saneamiento, fue el deplorable estado en que se encontraba el Río Manzanares, siendo foco de atención a comienzos del siglo XX. La consecuencia de que las alcantarillas de la ciudad, durante todo el siglo XIX, hubieran desaguado las aguas negras al río fue la de que produjo que (...) las riberas del Manzanares, especialmente el tramo que discurría entre el Puente del Rey y el Puente de Toledo, se habían convertido en un lugar pútrido y maloliente, muy distinto a esos paisajes oníricos y bucólicos que magistralmente mostró Goya a finales del siglo XVIII (V. G. R. Pinto Crespo, Rafael; Velasco Medina, Fernando, 2015, p. 254). Desde el punto de vista gubernamental, este asunto fue prioritario a principios del siglo $\mathrm{XX}$, pues fruto del vertido de las aguas fecales al río Manzanares, éste pasó a ser un foco de infección. 


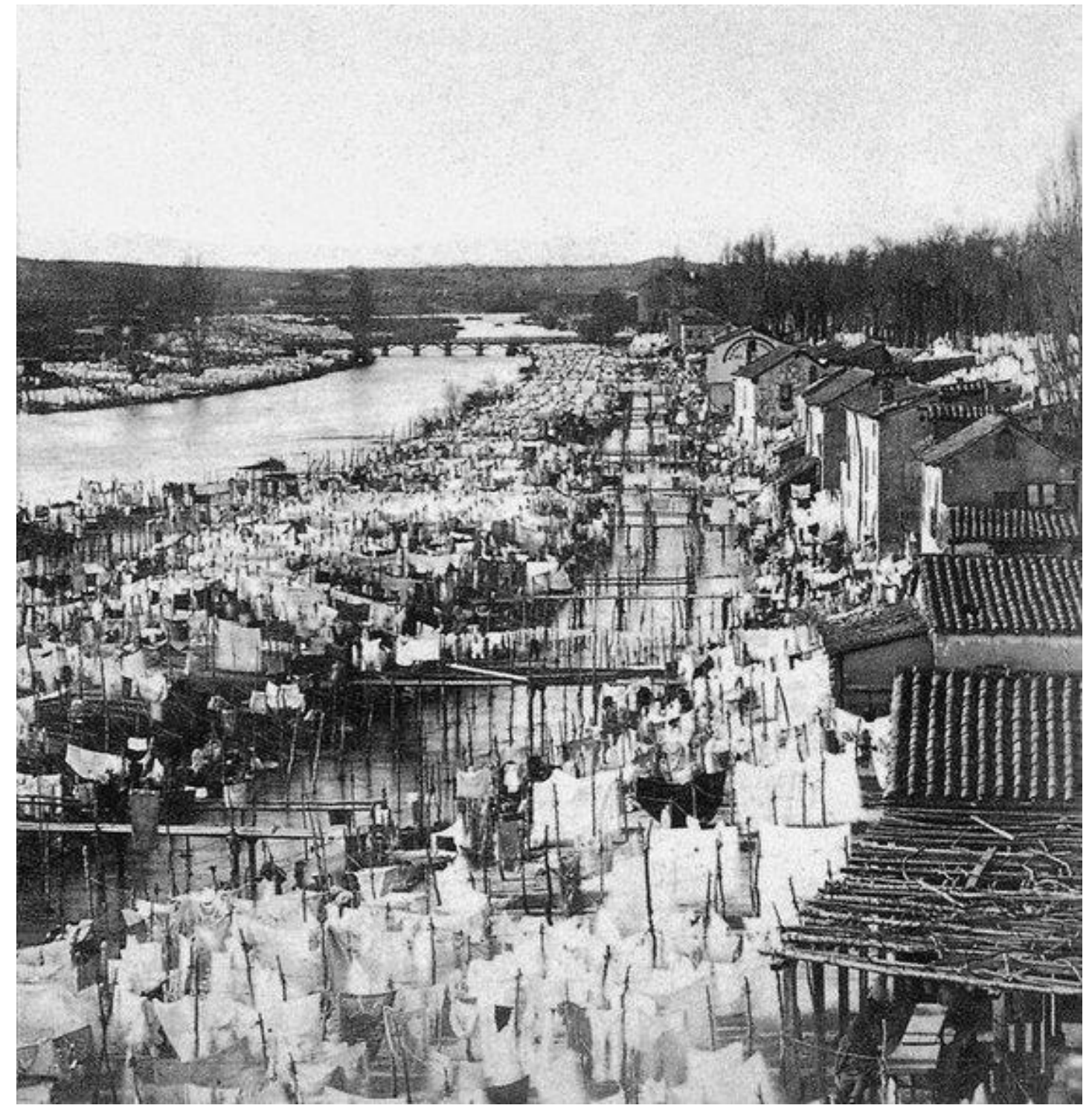

Quince eran las cuencas hidrográficas, con origen en el casco histórico de la ciudad, que vertían aguas fecales al río, desembocando en siete alcantarillas, tal y como puede verse especificado en la tabla 6-1.

Tabla 6-1. Alcantarillas y cuencas que desembocaban en el río Manzanares.

\begin{tabular}{|c|c|c|c|c|c|c|c|}
\hline Alcantarillas & $\begin{array}{l}\text { Puente } \\
\text { del Rey }\end{array}$ & Segovia & $\begin{array}{l}\text { San } \\
\text { Francisco }\end{array}$ & Águila & Gas & Embajadores & Atocha \\
\hline Cuencas & $\begin{array}{l}\text { Reyes, } \\
\text { Flor y } \\
\text { Arenal }\end{array}$ & Segovia & $\begin{array}{l}\text { San } \\
\text { Francisco }\end{array}$ & $\begin{array}{l}\text { Toledo y } \\
\text { Curtidores }\end{array}$ & Curtidores & $\begin{array}{l}\text { Embajadores } \\
\text { y Valencia; }\end{array}$ & $\begin{array}{l}\text { Barquillo, } \\
\text { Infantas, } \\
\text { Prado, } \\
\text { Huertas y } \\
\text { Atocha }\end{array}$ \\
\hline
\end{tabular}

Fuente: Elaboración propia 
De las siete alcantarillas, seis de ellas vertían sus residuos al río Manzanares, excepto la alcantarilla de Atocha que tenía su desagüe en un punto existente entre la Estación de Atocha y la de Méndez Álvaro, concretamente en un arroyo llamado del Hospital que acababa vertiendo en el arroyo Abroñigal (Novales Sáinz, 1895, p. 31). Si bien, sólo las alcantarillas de Gas y Embajadores desaguaban directamente en el Río. Las alcantarillas restantes (la del Puente del Rey, Puente de Segovia, San Francisco y Águila) desaguaban en un canal paralelo a la orilla del Río, que se unía con las aguas del río poco antes de llegar al Puente de Toledo (V. G. R. Pinto Crespo, Rafael; Velasco Medina, Fernando, 2015, p. 255).

En cuanto a las cantidades de aguas negras que eran desaguadas al río desde las alcantarillas descritas arriba, no se disponen de datos que nos permitan ofrecer una estimación. Si bien, Pinto (V. G. R. Pinto Crespo, Rafael; Velasco Medina, Fernando, 2015, p. 256) señala que el estudio realizado por el catedrático de la Escuela de Ingenieros Industriales de Barcelona, Luis Justo y Villanueva en la Tercera memoria que contiene los trabajos hechos acerca del aprovechamiento de las aguas que discurren por las alcantarillas de Madrid, puede ofrecernos datos aproximados para finales del siglo XIX (...)un aforo de 12.410.426 litros de aguas fecales por cada 24 horas, siendo la que más aforo llevaba la alcantarilla del Puente del Rey, con 3.206.105 litros por cada 24 horas .

\subsubsection{Proyectos de Canalización del Rio}

Pese a que hasta llegado el siglo XX no se comenzó con los trabajos de canalización y saneamiento del río Manzanares, a finales del siglo XIX se propusieron algunos proyectos que tuvieron por objeto su canalización.

Cabe destacar el llevado a cabo por Sergio de Novales y Sáinz (Novales Sáinz, 1895), que, basándose en las teorías Congreso Internacional de Higiene de 1878 por Schlaesing Proust y Durand-Claye, consideraba que el propio suelo era un elemento capaz de purificar las aguas fecales. Su proyecto abogaba por la construcción de dos canales, que funcionarían como elementos colectores de las alcantarillas, y, a través de éstos, se aprovecharían las aguas para regar las huertas colindantes con la ciudad de Madrid. El aprovechamiento de las aguas negras para el riego de huertas ya venía haciéndose 
durante el siglo XIX (y no será hasta después de 1939 cuando estas medidas quedaron prohibidas) y comenzaba a ponerse en cuestión, por los peligros que estas prácticas pudieran tener en la salud. El proyecto de Novales y Sáinz no fue aprobado.

En el año 1900, el Ayuntamiento de Madrid convocó un concurso público para presentar proyectos sobre la canalización y saneamiento del río Manzanares. El arquitecto Mauricio Jalvo fue la única persona que se presentó. En un primer momento, el concurso se declaró desierto, pero en el mes de febrero de 1902 el Ayuntamiento de Madrid retomó el proyecto de Jalvo, creó un negociado especial y le nombró, Arquitecto Director de la Canalización del Manzanares y del Colector General.

Mapa 6-1. Plano General de la Cuenca del río Manzanares.

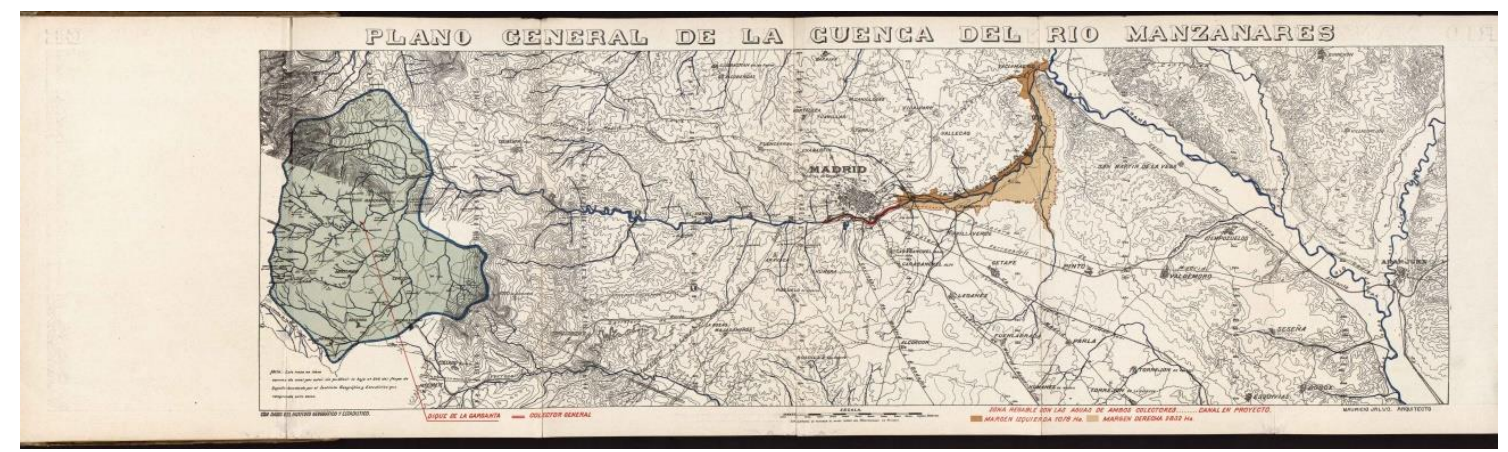

Fuente: Biblioteca Regional de Madrid.

Otro ejemplo de proyecto que fue desestimado por el Ayuntamiento, fue el presentado por el Director de la Hidráulica Santillana, Antonio González Echarte, junto con Mauricio Jalvo ("Canalización del río Manzanares," 1906, pp. 304-305) quienes concurrieron a la convocatoria del Ayuntamiento el 13 de enero de 1906. El consistorio convocó citado concurso con el objetivo de realizar obras para lograr la limpieza de las aguas y la regularización de su caudal y corriente, así como para construir un colector general en la ribera del Manzanares. El proyecto pretendía, además de la canalización y saneamiento de la margen derecha del río, construir un colector que iba desde el Puente de los Franceses al Puente de la Princesa (Jalvo, 1906, pp. 112-121).

De este modo, llegado el año 1908, la solución vino de manos del Gobierno. El 13 de agosto de 1908, el Congreso de los Diputados dictó la Ley mediante la cual se otorgaba legitimidad al Estado a que se encargase de las obras necesarias para la canalización del río Manzanares, así como otra serie de obras que fueran necesarias. La denominada 
"Ley básica del Manzanares". Para su ejecución, primeramente se convocó un concurso público publicado en la Gazeta de Madrid el 8 de septiembre de 1908 (Fungairiño, 1915).

Con el objetivo de analizar los proyectos que se presentasen en los concursos y los informes de adjudicación de los mismos, en 1909 se crea la denominada Jefatura del Canal de Castilla y sus pantanos y canalización del Manzanares. Tras varios proyectos declarados como no aptos y, por tanto, declarando desiertos los concursos, finalmente se decidió, en 1910, adjudicar la realización del proyecto a la Jefatura del Canal de Castilla y Canalización del Manzanares. Éste fue elaborado por el ingeniero de la Dirección General de Obras Públicas del Ministerio de Fomento de aquel momento, Eduardo Fungairiño. El proyecto del ingeniero Fungairiño se aprobó mediante Real Orden el 5 de septiembre de 1910, con un presupuesto de 6.925.411,86 pesetas (Fungairiño, 1915). Éste comprendía las obras correspondientes al colector de la margen izquierda del Río, así como el encauzamiento del mismo. Por otro lado, (....) “se encomendó a la misma Jefatura (la Jefatura del Canal de Castilla y Canalización del Manzanares), la redacción del proyecto de colector de la margen derecha, y llevada a efecto a la información pública en 24 e junio de 1912 se aprobaron definitivamente ambos trabajos" (Fungairiño, 1915, p. 14).

En 1914 se produjo la adjudicación de las obras, por periodo de seis años, al arquitecto José López de Coca, con un presupuesto de 7.168.994,17 pesetas, tras autorizarse al Ministerio de Fomento a licitar las obrar mediante subasta (Fungairiño, 1919). El 18 de julio de 1914, en presencia de destacadas autoridades, entre las que cabe destacar el Ministro de Fomento, el Gobernador Civil, el Alcalde de Madrid y el Director General de Obras Públicas, tuvo lugar la inauguración de las obras de encauzamiento y saneamiento del río Manzanares. En el acto, el Ministro de Fomento, a modo de inauguración, colocó la primera piedra del colector de la margen izquierda, con asistencia del alcalde, Sr. Prast, y el Gobernador Civil, Sr. Sanz Escartín, tal y como puede verse reflejado en la fotografía adjunta. 


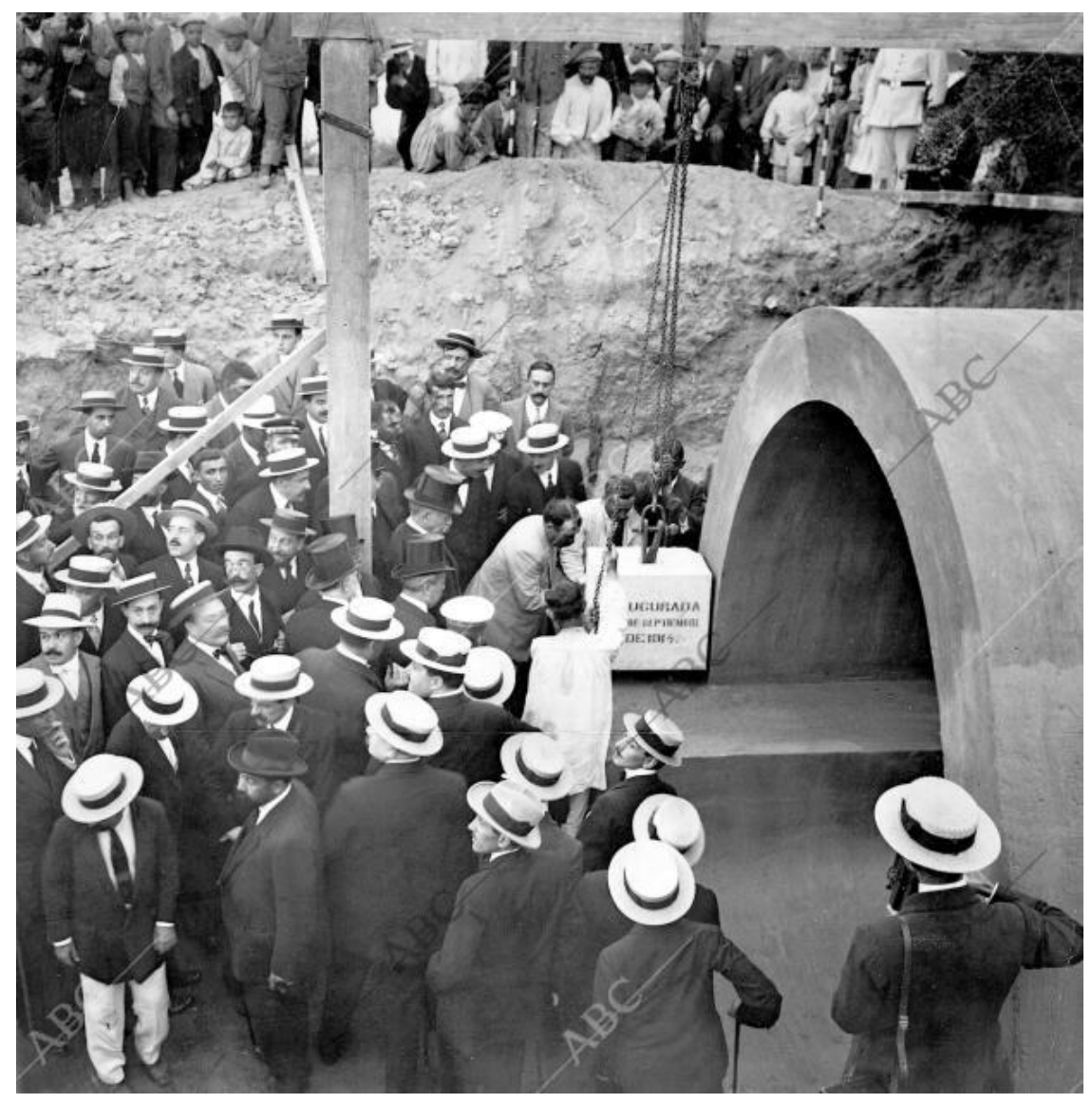

Fuente: Archivo ABC. Autor: José Zegri. Madrid, 12/09/1914.

Tal y como se ha señalado más arriba, el plazo de ejecución de las obras era de seis años, por lo que se estimó que debían ser finalizadas en julio de 1920. Pese a ello, las obras duraron hasta el año 1926. Una de las razones por las cuales se dilataron en el tiempo, fue por el problema de las expropiaciones de las zonas colindantes respecto a las que se ejecutaba el proyecto. Así, en mayo de 1918, desde el Ministerio de Fomento se tuvo que consignar un crédito extraordinario de un millón y medio de pesetas.

Desde 1914, cuando se inauguraron las obras, a 1926 el proyecto inicial se vio parcialmente modificado en algunas partes, y ampliado en otras. (...) básicamente se refieren a las obras de saneamiento -es decir, los colectores-, a las de encauzamiento y a las de urbanización, contando entre éstas los medios de cruce sobre el nuevo cauce (V. G. R. Pinto Crespo, Rafael; Velasco Medina, Fernando, 2015, p. 262). 
Atendiendo a las modificaciones relacionadas con el saneamiento, cabe destacar la introducción de alumbrado eléctrico en la margen izquierda así como la ventilación de los colectores de ésta y de la derecha se consiguió por medio de columnas jónicas de 6,70 metros de altura, construidas de fábrica artificial separadas 300 metros. (V. G. R. Pinto Crespo, Rafael; Velasco Medina, Fernando, 2015, p. 262).

El desarrollo y progreso que la ciudad sufrió en estos años hizo que se pusieran de manifiesto las deficiencias del proyecto inicial. En 1919, Fungairiño, en su Exposición de un plan para completar las obras actuales (Fungairiño, 1919) así lo reflejó. Sus preocupaciones atañían, principalmente, al tema de la urbanización de las riberas del Río, la reforma del cauce y su posible navegación y el aprovechamiento de las aguas residuales. Por una parte, se consideraba que el problema del saneamiento del río quedaría solucionado, en la medida en que las aguas que iban abajo hasta la confluencia con el arroyo Abroñigal (situado a 200 metros aguas abajo del puente del ferrocarril Madrid a Cáceres y Portugal) no estarían contaminadas. Sin embargo, se debía tener en consideración que (...)previendo el crecimiento que se produciría con la llamada del nuevo Matadero, el río ya estaría contaminado, especialmente en el entorno del puente del ferrocarril de la línea Madrid a Zaragoza, situado a unos 2 kilómetros de la confluencia con el Abroñigal.(V. G. R. Pinto Crespo, Rafael; Velasco Medina, Fernando, 2015, p. 262).

Otro aspecto importante fue la regulación de los niveles de agua. La solución propuesta fue la instalación de presas con elementos que fueran capaces de facilitar el arrastre de depósitos y el paso de crecidas (V. G. R. Pinto Crespo, Rafael; Velasco Medina, Fernando, 2015, p. 262). En julio de 1924, el Ministerio de Fomento adjudicó a la Sociedad Construcción de Obras Públicas y Urbanas las obras para la cimentación y estribo de dos presas para encauzar el Río (1924). El plazo de ejecución de las obras se estimó en cinco meses por la cantidad de 68.500 pesetas y el presupuesto de contrata de 71.409,20 pesetas. (V. G. R. Pinto Crespo, Rafael; Velasco Medina, Fernando, 2015, p. 263).

Una vez finalizadas las obras de encauzamiento y saneamiento del Río Manzanares en 1925, aún existía otro problema relativo a la calidad de las aguas que desaguaban en el mismo que no era otro sino el de la necesidad de depuración y tratamiento de las mismas. Tuvieron que transcurrir dos años más para que tuviera lugar el primer 
proyecto que trató el tema del tratamiento y depuración de las aguas fecales y se diera la construcción de la primera estación depuradora, situada en la Calle Méndez Álvaro, tal y como ha podido verse en el capítulo número cuatro del presente estudio. 


\section{El Laboratorio Municipal de Madrid}

Una de las manifestaciones más importantes de los preceptos higienistas en las instituciones de la capital, fue la creación de un organismo cuya finalidad expresa fue contribuir, mediante sus actuaciones, a la mejora de la higiene pública madrileña: el Laboratorio Municipal de Higiene. Las actuaciones gubernamentales llevadas hasta la creación del mismo, en materia de higiene y salubridad, estuvieron caracterizadas por su eventualidad, ligadas especialmente a la irrupción de enfermedades epidémicas que forzaban, de algún modo, a la adopción de medidas gubernamentales en materia de salud, pero sin una planificación y proyección continuada.

A nivel estatal, es importante prestar atención a la influencia que tuvieron las dos invasiones de cólera de la primera mitad del siglo XIX en la medida en que fue el revulsivo necesario para que se dictase la Ley Orgánica de Sanidad de 28/XI/1855 ${ }^{64}$. A nivel municipal, en Madrid desde 1847 existían unas Ordenanzas municipales que regulaban aspectos varios relacionados con la higiene pública, desde la limpieza de calles hasta la traída de aguas a la capital, o el control alimenticio (competencias que serán propias del Laboratorio Municipal con su fundación en 1877). Sin embargo, esta serie de ordenanzas se fueron modificando con asiduidad, además de venir acompañadas de medidas urgentes de lucha antiepidémica cuando en la capital irrumpía el cólera. En 1892 se promulgaron nuevas Ordenanzas municipales, más completas que las anteriores en lo que respectaba al contenido y forma de enfrentar los problemas. Además, en esta Ley quedaron tácitamente institucionalizadas las funciones del Laboratorio Municipal, que no eran otras que asesorar en materia de salubridad e higiene y de inspección de alimentos.

\subsection{La creación de los Laboratorios Municipales de Higiene.}

El control de la calidad de las sustancias alimenticias fue un asunto de salud pública que acrecentó su importancia al tiempo que se estaba produciendo un aumento poblacional acusado en las ciudades españolas desde el siglo XVIII. La aparición de los laboratorios de higiene y salubridad, como instituciones especializadas, encargadas del control

64 Ley que fue modificada posteriormente con la Ley de 24/V/1866 
exhaustivo de las propiedades de los alimentos y las bebidas basados en métodos de análisis químicos, fue una manifestación clara de que los antiguos métodos empleados para el control de las subsistencias, ya no respondían a las necesidades reales. " $A l$ principio eran solamente las mismas autoridades locales (alcaldes, corregidores, ó sus delegados inmediatos), quienes auxiliadas de individuos de policía, giraban de cuando en cuando visitas por los sitios que estimaban conveniente: mercados, puestos ambulantes, tiendas fijas, etc., y sin más examen que la simple inspección, hecha las más veces con más buen deseo que conocimientos apropiados, decomisaban ó inutilizaban en el acto lo que les parecía nocivo á la salubridad por cualquier concepto, y aplicaban al ipso fado reputado delincuente, las penas de pérdida de sustancia, multa, etc., en grado correspondiente á la supuesta falta y dentro de los límites jurisdiccionales en que las autoridades locales administrativas pueden obrar". (Vera y López, 1885, p. 15).

La adulteración de los alimentos y bebidas fue un problema bastante común en el entorno europeo, siendo a partir de 1850 cuando comienza a dársele verdadera importancia (Phillips \& Smith, 2013). En este tiempo, también se fue profundizando sobre la transmisión de enfermedades fruto del consumo de animales enfermos. La química y la microbiología sufrieron importantes avances, dando fruto a una etapa sanitaria centrada en el control de los alimentos (De Miguel Salanova, 2018, p. 167). La bromatología estaba en auge, con la colaboración indispensable de químicos, médicos, veterinarios y farmacéuticos como profesionales al frente de tales cometidos. La seguridad alimentaria, bromalotología y la microbiología de los alimentos fueron indispensables como mecanismo de control ante la falsificación y adulteración de los alimentos.

Es en este contexto en que la relevancia de los laboratorios municipales de salubridad e higiene, creados en el contexto europeo desde el siglo XIX, cobran especial importancia como instituciones con el objetivo de velar por la salud pública. 
Imagen 7-1. Fotografía de un funcionario de la Food and Drugs Administration inspeccionando una fábrica de dulces en 1911

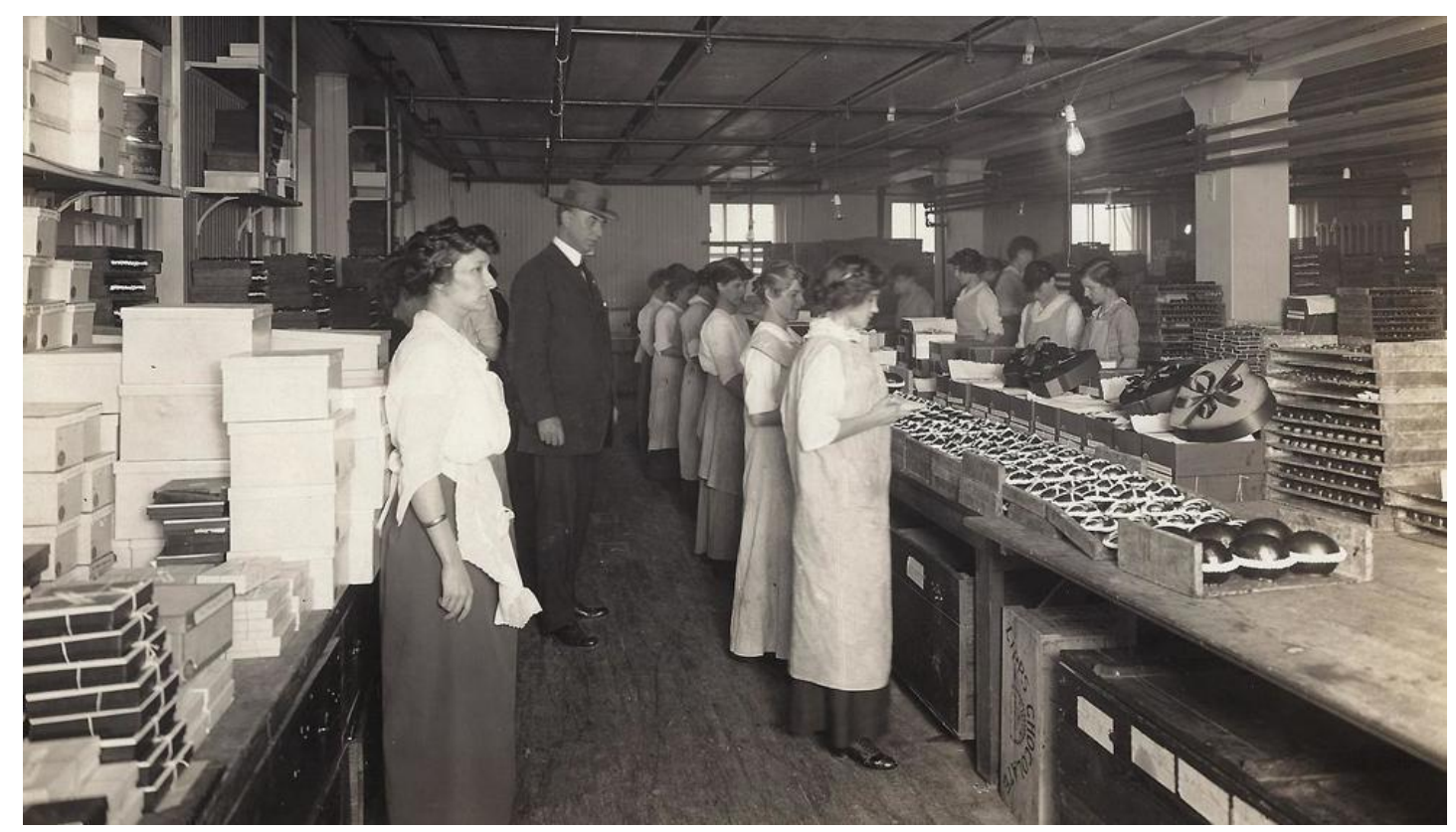

Fuente: Dominio público

Imagen 7-2. Fotografía de una laboratorio de inspección de alimentos adulterados.

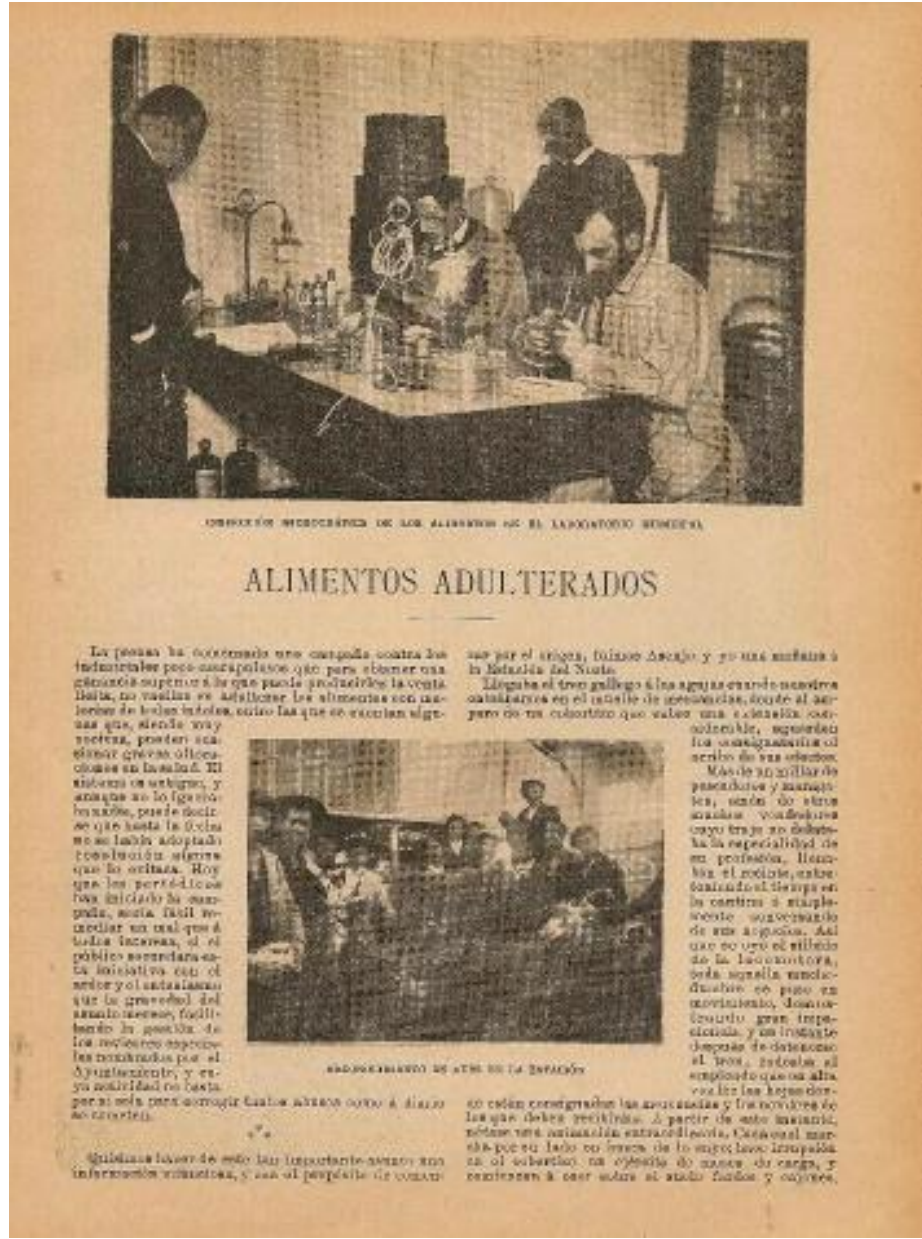

Fuente: E. Contreras y Camargo - 1899. Procedente de antigua revista Blanco y Negro. 
El desarrollo que sufrieron, tanto por el concepto como por la praxis de la higiene pública, especialmente desde mediados del siglo XIX, es clave para enmarcar el contexto en que son creados los Laboratorios Químicos Municipales. Desde este momento, la higiene pública pasó a formar parte de una disciplina experimental, basada en los métodos estadísticos y en el desarrollo de la Bacteriología, nueva ciencia que arranca de la obra de Pasteur y Koch; en definitiva, de la doctrina etiopatogénica de la enfermedad que, junto a la mentalidad anatomoclínica y fisiopatológica, cambian por completo el quehacer médico, alumbrando un nuevo estilo en el tratamiento de las enfermedades, basado en criterios científicos (Etxaniz Makazaga, 1998, pp. 1-2)

En la memoria sobre los Laboratorios Municipales de Salubridad, premiada por la Sociedad Española de Higiene, redactada por el Doctor Vicente de Vera y López en 1885 (Vera y López, 1885), se atiende a la génesis de estos Laboratorios. En dicha memoria, aparecen alusiones no sólo al contexto español, sino que también se dedica un capítulo completo (el capítulo IV) a la organización de los laboratorios de salubridad e higiene de Alemania e Inglaterra (Vera y López, 1885, pp. 29-47).

Vera destaca la creación de un cuerpo de agentes de policía especial, que tenía el cometido de vigilar la inspección, tanto de sustancias alimenticias como de otra clase de elementos que pudieran influir en la salubridad pública, tales como juguetes, tapices, vajillas, entre otros. Asimismo, se destaca la labor de los laboratorios, sostenidos con autoridades locales, creadas para el análisis de los anteriores elementos y con la potestad para enviar el certificado, fruto del resultado de los análisis, a la autoridad correspondiente. "La autoridad apoyada en este certificado obra, advirtiendo que las leyes del imperio prescriben una prisión que puede durar hasta seis meses y una multa que puede elevarse hasta 1.500 marcos (1.875 pesetas.) a todo el que "para engañar en el comercio o tráfico imite o falsifique los objetos de alimentación y consumo”, y también al quien "venda a sabiendas objetos de alimentación y consumo alterados, adulterados o falsificados, ocultando estas circunstancias o poniéndolos a la venta bajo una denominación a propósito para engañar” (Vera y López, 1885, pp. 29-30).

Respecto a los laboratorios municipales en Inglaterra, se destaca que estas instituciones desempeñaban un "servicio muy activo en la inspección de las sustancias alimenticias y en la corrección de las adulteraciones de éstas últimas" (Vera y López, 1885, p. 31). Además, se disponía de un servicio mediante el cual, cualquier comprador, podía 
solicitar el análisis de la sustancia alimenticia o producto farmacéutico comprado, previo pago de una cantidad que oscilaba entre las doce pesetas a los doce céntimos.

Si bien en Alemania se creó un cuerpo especial de policía, en Inglaterra se optó por el nombramiento de un oficial de sanidad, inspector de pesas y medidas o un agente de policía para llevar a cabo la recogida de las muestras de alimentos o sustancias farmacéuticas. Posteriormente, dichas muestras serían analizadas por el laboratorio municipal correspondiente para prescribir el certificado del resultado de las muestras.

Pese a la importancia de los Laboratorios municipales de salubridad e higiene ingleses y alemanes, por servir de ejemplos como pioneros en su instauración, fueron los Laboratorios franceses los que sirvieron de ejemplo para su instauración en España (De Miguel Salanova, 2018, pp. 167-168).

En este sentido, fue el Laboratorio de París, (Laboratoire central de la préfecture de pólice, $L C P P$ ) creado en 1878 por Charles Girard, el que gozó de mayor relevancia (Alary, 2007; Etxaniz Makazaga, 1998). Si bien, en sus inicios, fue una institución al servicio del consistorio parisino, en 1881, se produjo una reorganización de sus servicios, de manera que sus funciones se extendieron al público general. Así, la inspección de alimentos y bebidas y de establecimientos de diversa tipología (industriales y de naturaleza pública como cafés, cervecerías, fondas...) se extendió al vecindario. Los análisis llevados a cabo por el Laboratorio Municipal de París se dividían en cualitativos y cuantitativos. Los primeros, que eran gratuitos, se limitaban a otorgar un calificativo a la sustancia analizada, mientras que los análisis cuantitativos atendían a las características químicas de la misma y, para su empleo, se aplicaban diferentes tarifas en función de la clase de estudio a llevar a cabo (De Miguel Salanova, 2018, p. 168). El ejemplo del Laboratorio Municipal parisino fue aplicado en ciudades como Madrid, dada la evolución del primero hasta llegar a convertirse en inspector, no solo de sustancias alimenticias y bebidas, sino también de viviendas así como organizador de otra serie de servicios sanitarios en pro de la reducción de la mortalidad urbana. 


\subsection{Las normativas comunes en el contexto español}

Entre los Reglamentos que se dictaron en torno a la necesidad de homogeneizar algunos aspectos de los Laboratorios Municipales en España, así como establecer unos mínimos respecto a su funcionamiento, cabe destacar la Real Orden de Gobernación de 12 de mayo de 1909, mediante la que se aprobó el catálogo o lista de aparatos de que deben estar dotados los laboratorios municipales, y se dictaban las reglas acerca de las condiciones que debía reunir el personal técnico de estos Laboratorios, publicada en la Gaceta de Madrid de 15 de mayo de 1909.

Esta normativa supone un ejemplo más de la importancia que fue adquiriendo la mejora de la dotación de los Laboratorios municipales en toda España, así como la descripción de competencias, unificadas para España en su conjunto, de los trabajadores de los mismos. La Real Orden de Gobernación de 12 de mayo de 1909 se dictó por iniciación de una Consulta planteada por el gobernador de Córdoba, bajo el discurso de la protección de la salud pública y de la necesidad de que se cumplieran los preceptos del Real decreto de 22 de Diciembre de 1908, concernientes al establecimiento de Laboratorios de Higiene en todas las capitales de provincia y en los pueblos o agrupaciones de pueblos mayores de 10.000 habitantes. (Melgosa Olaechea, 1912, p. $65)$.

Previo a dictarse la obligación de instalar Laboratorios Municipales por Real decreto de 22 de Diciembre de 1908, las labores de inspección de alimentos y bebidas y de los servicios sanitarios en el ámbito municipal, se llevaban a cabo por médicos y veterinarios del municipio. Regulado por los Reales decretos de 14 de Junio de 1891 y de 12 de Enero de 1904 se imponía al médico municipal o Inspector municipal de Sanidad la obligación de practicar e inspeccionar todos los servicios sanitarios de interés general en el término municipal. Asimismo, el Real decreto de 14 de Febrero de 1905 decretaba que el farmacéutico municipal tenía el deber de practicar los análisis necesarios en alimentos y bebidas, y que los Reales decretos de 12 de Enero de 1904 y 22 de Marzo de 1906, obligaban al veterinario municipal a la inspección de carnes, de pescados y de todo alimento de procedencia animal, así como a la de verduras y frutas (Melgosa Olaechea, 1912, p. 71) .

"Los servicios que se hallan encomendados a los Laboratorios municipales son de investigación, mediante el análisis, de las alteraciones, adulteraciones, etc., 
de las substancias alimenticias en general, bebidas y condimentos, todas aquéllas que tengan más o menos relación con aquéllos; perfumería, juguetes, investigación de venenos en determinados casos, o sea análisis toxicológico, todas, en una palabra, que tengan relación directa o indirecta con la higiene y salubridad públicas, teniendo como complemento un servicio de inspección técnica, alimenticia y de higiene en relación con los Laboratorios, dentro, dicha inspección, naturalmente, de la legítima competencia, indiscutible para dicho fin, y á la vez, única de las profesiones sanitarias.

Es también función de estos Laboratorios el servicio municipal público de la desinfección con todo lo que en sí lleva adherente de saneamiento, cuya dirección y aplicación exige conocimientos que sólo existen dentro de la cultura de las profesiones sanitarias. En dos grandes y por igual importantes secciones, se dividen estos Laboratorios municipales para su mejor funcionamiento en toda su parte técnica: uno, representa el análisis químico; otro, la bacteriología; ambas la general y la especial. Y, últimamente, el servicio de desinfección que constituye por su naturaleza, sección especial, atendida y dirigida por el mismo Laboratorio".

Extraído del Informe del Real Consejo de Sanidad en pleno, Madrid, 11 de octubre de 1909, en respuesta a la instancia presentada por la Asociación de Ingenieros Industriales bajo petición de que se modificase el artículo 9 del Real Decreto de 22 de Diciembre de 1908 (Gaceta de Madrid de 19 de octubre de 1909).

\subsection{La génesis del Laboratorio Municipal de Madrid}

El Laboratorio Municipal de Higiene de Madrid (denominado primeramente Laboratorio Químico de Higiene) fue creado a finales del año $1877^{65}$, de manos de Luis Justo Villanueva, Catedrático de la Escuela de Ingenieros Industriales de Barcelona. Pionero en el estudio y práctica del aprovechamiento de las aguas residuales en España, fue contratado por el Ayuntamiento de Madrid para la realización de estudios sobre esta

\footnotetext{
${ }^{65}$ Lo que hoy día es el Laboratorio de Salud Pública, tuvo su origen en el Laboratorio Municipal de Higiene de Madrid.
} 
temática, así como el análisis químico de las aguas de la capital (J. J. González Reglero \& Pernaute Monreal, 2017).

La idea de Villanueva de establecer un Laboratorio Químico en la ciudad de Madrid, vino influenciada por la elevada cantidad de casos, que fueron publicados en los diarios madrileños, que presentaban la adulteración de alimentos de primera necesidad. Asimismo, cabe destacar que, fruto del nivel de casos de fraude y adulteración que eran registrados, se generó un malestar entre los vecinos de Madrid, solicitando responsabilidades a las autoridades encargadas de la inspección de ciertos establecimientos, como las tiendas de ultramarinos y comestibles. Es en este contexto y, siguiendo el ejemplo de los laboratorios franceses y del de Barcelona (creado en 1864), en que se propuso la creación del laboratorio en la ciudad de Madrid, con un presupuesto de cerca de cuatro mil pesetas (De Miguel Salanova, 2018, p. 169).

Si bien los Laboratorios de Barcelona y Madrid fueron los primeros creados en España, poco tiempo después también fueron instalados en otras ciudades como Valencia (1881), Sevilla (1883), Bilbao (1885) o San Sebastián (1886), entre otras (Etxaniz Makazaga, 1998; Guillem-Llobat \& Perdiguero-Gil, 2014; Puerto Sarmiento \& Cobo Cobo, 1983; Toro Mérida \& Bahamonde Magro, 1980).

Pese a la creación del Laboratorio Químico de Madrid en 1877, lo cierto es que los primeros años de su actividad estuvieron dedicados a una mera labor administrativa y de peritaje entre instituciones de diferente nivel administrativo (Puerto Sarmiento \& Cobo Cobo, 1983; Vera y López, 1885), tal como puede verse en la figura adjunta relativa a los servicios del Laboratorio de Madrid en su fundación (Gráfico 7-1, sobre los servicios del Laboratorio de Madrid en los primeros años su funcionamiento). 


\section{Gráfico 7-1. Servicios del Laboratorio de Madrid en su fundación}

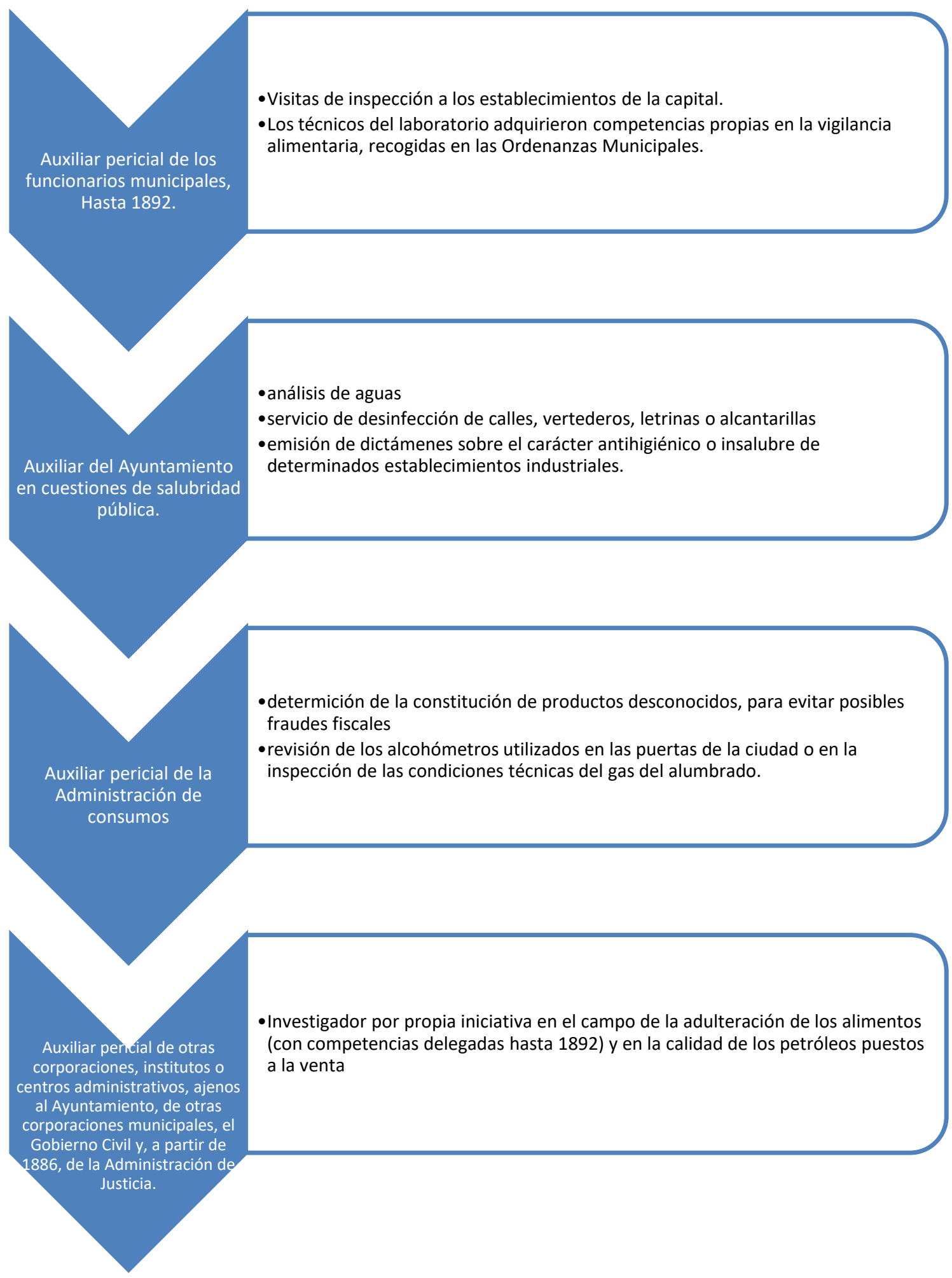

Fuente: Esquema elaborado con información recogida de (Puerto Sarmiento \& Cobo Cobo, 1983, p. 157). 
La "apertura" al público general tuvo lugar en 1881, con Fausto Garagarza en la dirección del Laboratorio, momento en que se firmó el Reglamento para el servicio público del Laboratorio Químico Municipal (Vera y López, 1885, pp. 37-38). Mediante el citado reglamento, se regulaba la posibilidad de que los ciudadanos pudieran solicitar los servicios del Laboratorio, bajo el pago de la correspondiente tarifa. A partir del 15 de diciembre de 1882, comenzó a establecerse el servicio gratuito de análisis de carne de cerdo, embutido y pescado para el público en general. De este modo, Laboratorio de Madrid se convirtió en la primera institución que prestó servicio al público gratuitamente, y no sólo al Ayuntamiento, tal y como venía haciéndose hasta entonces. (Puerto Sarmiento \& Cobo Cobo, 1983, pp. 156-157)

Sin embargo, el número de análisis practicados seguían siendo escasos, al tiempo que la falsificación y adulteración alimentaria seguía creciendo. Los factores que influyeron en la ineficiencia del servicio radicaban en el bajo presupuesto dedicado a su funcionamiento y modernización, así como por la no aplicación de sanciones acordes a los fraudes llevados a cabo (De Miguel Salanova, 2018, p. 170). Sin embargo, cabe destacar las actuaciones llevadas a cabo por el Laboratorio de Madrid durante la invasión de la epidemia de cólera de 1885, especialmente con la actuación de las brigadas sanitarias en diferentes mercados de la ciudad (Díaz Simón, 2014).

La propia organización del Laboratorio Químico tampoco favorecía un correcto funcionamiento, en buena medida, por la falta de centralización de servicios. A la par de las labores llevadas a cabo por el Laboratorio, existía el denominado Gabinete Micrográfico, creado en 1881, encargado del reconocimiento diario de embutidos, jamones, tocinos y carne fresca y como apoyo a los revisores veterinarios (Puerto Sarmiento \& Cobo Cobo, 1983, p. 156).

En este sentido, pese al dictamen de diferentes Reales Órdenes y Ordenanzas Municipales que tuvieron por objetivo la persecución del fraude alimenticio, tales como la Real Orden de 1 de noviembre de 1887, mediante la que se daba instrucciones de carácter científico para el reconocimiento de los alcoholes de las Aduanas y desnaturalización de los industriales; la Real Orden de 4 de enero de 1887, que se remite a toda la legislación anterior represiva respecto a la adulteración de alimentos y fomentaba que los alcaldes y gobernadores hicieran cumplir la ley; la Real Orden de 21 de octubre de 1887, mediante la que se fijaron las directrices bajo las cuales se debía 
proceder a la fabricación de embutidos, se dictaminaban las fechas de matanza, se establecía que los inspectores veterinarios debían realizar visitas al menos dos veces al año a las grandes fábricas, así como las reglas sobre la toma de muestras de las grandes fábricas de embutidos y su examen microscópico; la Real Orden de 31 de diciembre de 1887, que fijaba las condiciones de entrada en el país de ganado vivo o muerto, entre otras. También fueron destacables las Ordenanzas Municipales de Madrid de 1892, que contemplaban la actividad del laboratorio, de manera que ésta quedaba bajo inspección del alcalde y se otorgaba, por primera vez, una serie de competencias propias a los peritos del Laboratorio en asuntos relacionados con la represión del fraude alimentario. Toda esta serie de medidas estuvieron encaminadas contra el fraude alimentario, pues "lo cierto es que en España el fraude alimenticio ha tomado proporciones aterradoras y los medios que se usan para reprimirle son ineficaces casi siempre” (Solá Esprín, 1926, p. 46).

Sin embargo, no se observó una verdadera tendencia de cambio en los servicios hasta casi entrado el siglo XX. De facto, la modernización de Laboratorio se inició en el momento en que quedó bajo la dirección de Cesar Chicote, en 1898.

\subsubsection{La reorganización del Laboratorio Químico de Madrid desde 1898}

César Chicote puede considerarse como una de las figuras más relevantes en cuanto a la modernización, reorganización de los servicios y actuaciones llevadas a cabo por el Laboratorio Químico de Higiene de Madrid. Previo a su llegada a Madrid, como Director de este Laboratorio en 1898, Chicote había desempeñado importantes empresas como Director del Laboratorio Municipal de San Sebastián, entre 1887 y 1897, donde realizó una importante labor sanitaria. La detección de adulteraciones y falsificaciones en productos tales como vinos, sidras, cervezas, aguas, leches, derivados lácteos, carnes, chocolates, aceites, sebos, petróleos, azúcares, harinas, entre otros, mediante su análisis en profundidad, fueron algunos de sus cometidos (Etxaniz Makazaga, 1998, p. 4). También, bajo su dirección, se implantaron medidas orientadas a la desinfección de viviendas y se creó una oficina central que ofrecía un servicio de visitas a domicilios donde hubiera personas con enfermedades infectocontagiosas, servicio que podía ser utilizado tanto por las autoridades como por particulares (De Miguel Salanova, 2018, p. 171). 
El tiempo que Chicote permaneció como Director en San Sebastián influyó en su posterior cargo en Madrid, en la medida que intentó implantar el mismo modelo de funcionamiento y organización para la capital madrileña. Durante el tiempo que permaneció en el cargo como Director del Laboratorio Municipal de Madrid se ocupó de los más diversos temas relacionados con la sanidad y la higiene de la capital, lo que abarcaba desde la calidad del agua hasta la higiene de los transportes, la lucha contra las enfermedades transmisibles o las pompas fúnebres ${ }^{66}$.

La estructura organizativa implantada, siguió el ejemplo de la llevada a cabo en San Sebastián que, a su vez, estuvo basada en el modelo parisino. Los análisis fueron divididos en cualitativos y cuantitativos, otorgando, también, la potestad a los vecinos para poder solicitarlos.

En cuanto a las tarifas del servicio, se estableció la gratuidad para la calificación cualitativa de alimentos y bebidas. Asimismo, también eran gratuitos los análisis solicitados por autoridades y establecimientos caritativos y de beneficencia, así como los de las instituciones sanitarias. En cuanto a las tarifas de pago, quedaban sujetas a la petición fundamentalmente por parte de comerciantes, que usaban posteriormente la credencial otorgada por el laboratorio como mecanismo de propaganda de las industrias o comercios en cuestión. En estos casos, el interesado abonaría el doble de los precios de tarifa, debiéndose hacer constar que la certificación expedida no responde más que al resultado obtenido por el producto presentado en el Laboratorio (De Miguel Salanova, 2018, p. 127; Melgosa Olaechea, 1912, p. 46).

Respecto a la composición del personal del laboratorio, se produjeron cambios orientados a la ratio de especialización. Un ejemplo de ello fue la imperiosa necesidad, mostrada por Chicote, de aumentar el personal encargado de la inspección química. Hasta su llegada como Director, éstos profesionales escaseaban en la institución, frente al número, elevado en proporción, de peritos veterinarios.

En cuanto a las funciones del personal del laboratorio, se abogó por una delimitación de competencias más estructurada, con la que se consiguiera una nitidez funcional de los inspectores químicos respecto a los peritos veterinarios. Respecto a los primeros, se encargarían de la inspección de industrias y fábricas de alimentos y bebidas, así como de la vigilancia y análisis de las aguas. Por su parte, los peritos veterinarios tuvieron como cometidos la inspección y supervisión de mataderos, fielatos, fábricas de

\footnotetext{
${ }^{66}$ Para conocer más acerca de la biografía de César Chicote y del Riego, consultar http://dbe.rah.es/biografias/12122/cesar-chicote-y-del-riego
} 
embutidos, mercados, puesto fijos y ambulantes de venta de carnes, pescados, frutas y verduras, así como de la fiscalización de vaquerías, cabrerías, ganaderías, fondas, restaurantes y casas de comidas (De Miguel Salanova, 2018, p. 173).

Adicionales a los cuerpos de inspectores químicos y peritos veterinarios, fue creado un cuerpo de inspectores de subsistencias, cuyas labores se centraban en la recogida de muestras de alimentos, bebidas, petróleos y condimentos, previa solicitud por parte del Laboratorio.

Otro de los cambios relevantes, acaecidos tras la llegada de César Chicote al Laboratorio Municipal de Madrid, fue la variación en el sistema de calificación de los análisis cualitativos. Hasta ese momento, los análisis cualitativos realizados se dividían bajo el resultado de bueno o malo, lo que podía dar origen a confusiones y/o multas que podían calificarse como laxas. En este sentido, se consideró apropiado acompañar a la categoría de malo con el adjetivo de "nocivo" o "no nocivo", y, en función de ello, aplicar una sanción económica, de decomiso de sustancias o de cierre del comercio en cuestión (De Miguel Salanova, 2018, p. 174).

En cuanto a la modernización del servicio del Laboratorio Químico de Higiene de Madrid, el aumento del presupuesto destinado a la institución influyó de manera importante. La falta de recursos suficientes repercutía en la imposibilidad de llevar a cabo tareas de manera estructurada y progresiva, fruto de la presencia de personal insuficiente y de la indisposición de materiales necesarios para la limpieza de calles, desinfecciones de vías públicas, domicilios o alcantarillas. A partir de 1899, los presupuestos se ampliaron, lo que conllevó a su modernización y una mejor y mayor eficiencia del servicio.

Como ya se ha mencionado más arriba, se creó una oficina central, encargada de recibir llamadas a cualquier hora, tanto de particulares como de las autoridades. Se dotaron de brigadas de desinfección, que tenían por objetivo el transporte en furgones de material contaminado (ropas u otros objetos). Además, se estableció un cuerpo especial de actuación para tiempos de epidemias. 


\subsection{Las funciones y servicios del Laboratorio}

\subsubsection{El funcionamiento del laboratorio y sus dependencias}

El Laboratorio Municipal fue construido ad hoc, disponiendo de un edificio propio ubicado en la Calle Bailén, número 43 y dotado de dependencias anexas.

Funcionaba en horario de ocho de la mañana a ocho de la noche, mediante el relevo de personal para el cumplimiento de la jornada. De ocho de la noche a las ocho de la mañana permanecía operativo, mediante guardia, el servicio de Desinfección y el de conducción de enfermos, con el objetivo de atender las llamadas de urgencia.

\subsubsection{Las dependencias del Laboratorio.}

En el Edificio del Laboratorio, se encontraban instalados los servicios de química y de bacteriología, los de preparación de vacunas, excepto la antivariólica y el servicio antirrábico, el servicio de aplicación gratuita de vacuna antivariólica, así como todas las oficinas centrales.

Imagen 7-3. Fotografía de la fachada principal del Laboratorio Municipal de Madrid.

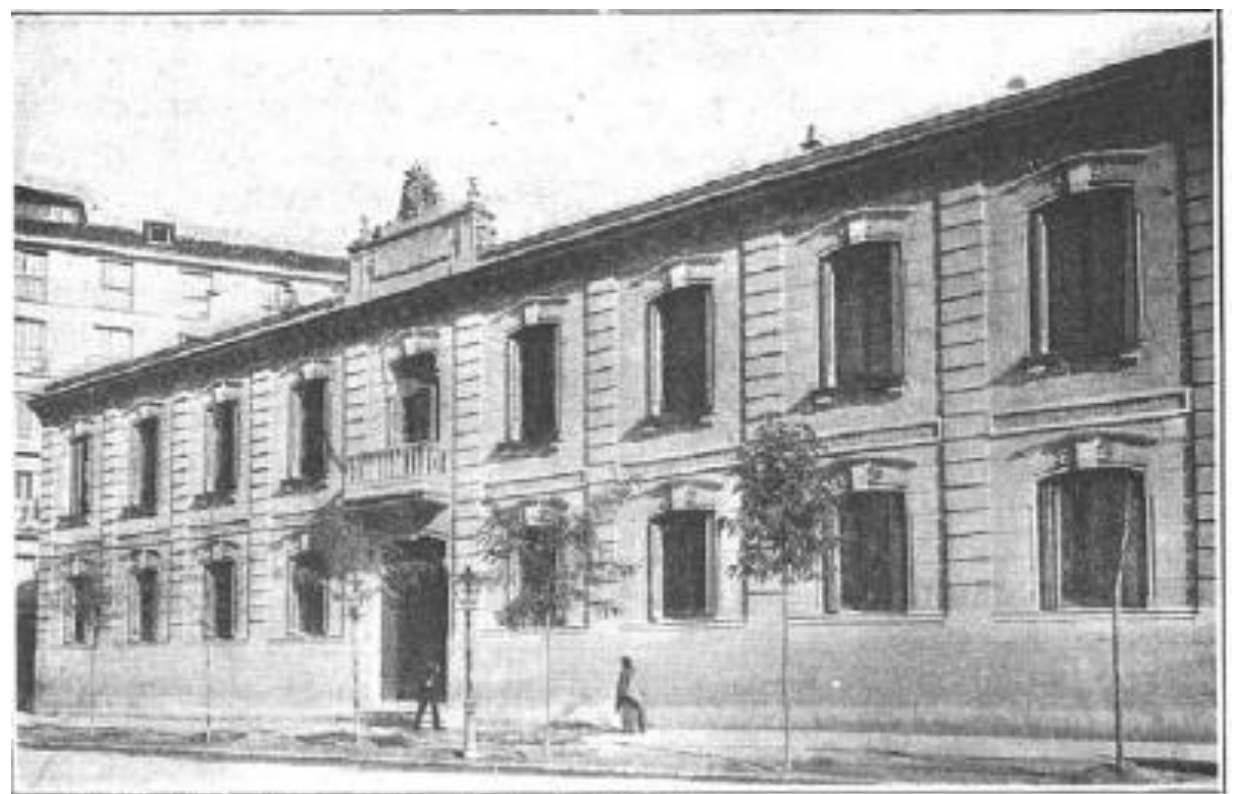

FUENTE: (Chicote del Riego, 1918, p. 12) 
Otra de las dependencias de las que disponía el Laboratorio, era el Parque o puesto de desinfección de la plaza de San Francisco. Este edificio disponía de una instalación destinada a la desinfección de ropas y efectos contaminados. También estaba en sus inmediaciones el cuartel general de desinfectores de viviendas con las dependencias adecuadas, la oficina de la inspección del servicio de desinfección y la Academia de desinfectores con un pequeño museo (Chicote del Riego, 1918, p. 13).

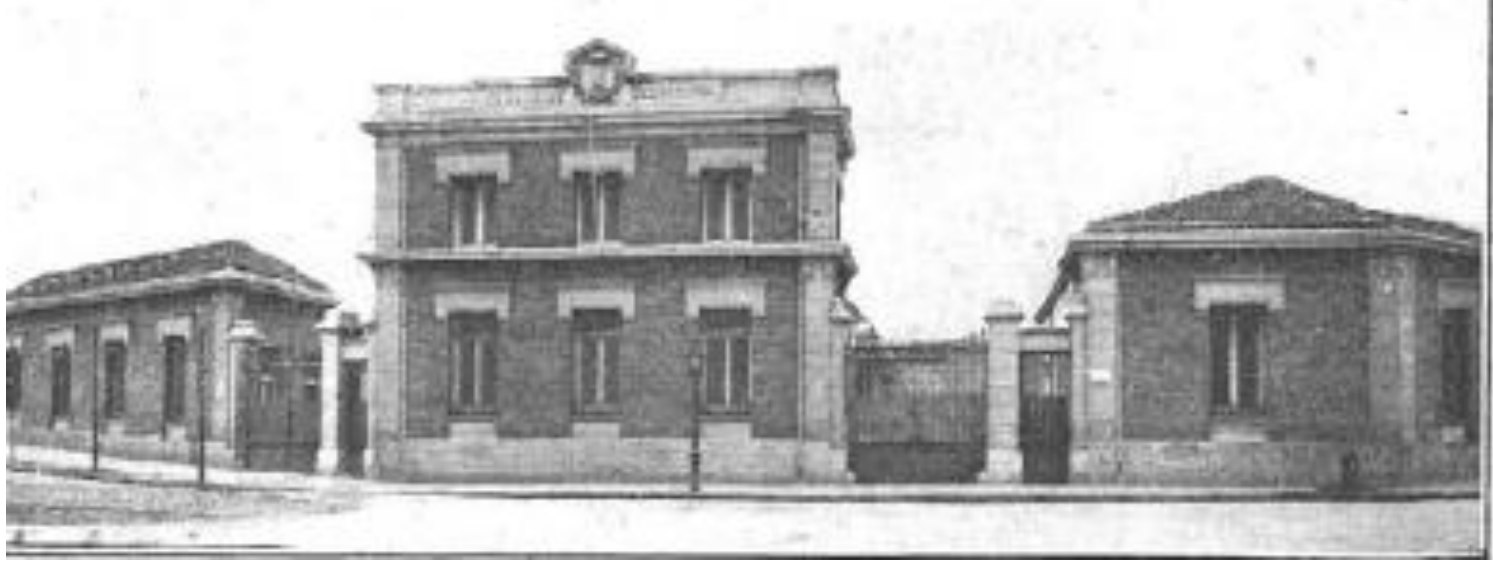

FUENTE: (Chicote del Riego, 1918, p. 13)

Situado en la Avenida Menéndez Pelayo, número 11, se encontraba el llamado Parque de desinfección de Huerta Segura. Éste, al igual que Parque de desinfección de la plaza de San Francisco, también disponía de una instalación para la desinfección de ropas y efectos contaminados, siendo ésta la primera que adquirió el Laboratorio. También se encontraban aquí las cuadras del ganado de arrastre y la cochera con el material en uso de coches a disposición del Laboratorio. 
Imagen 7-5. Fotografía del Parque de desinfección de Huerta Segura.

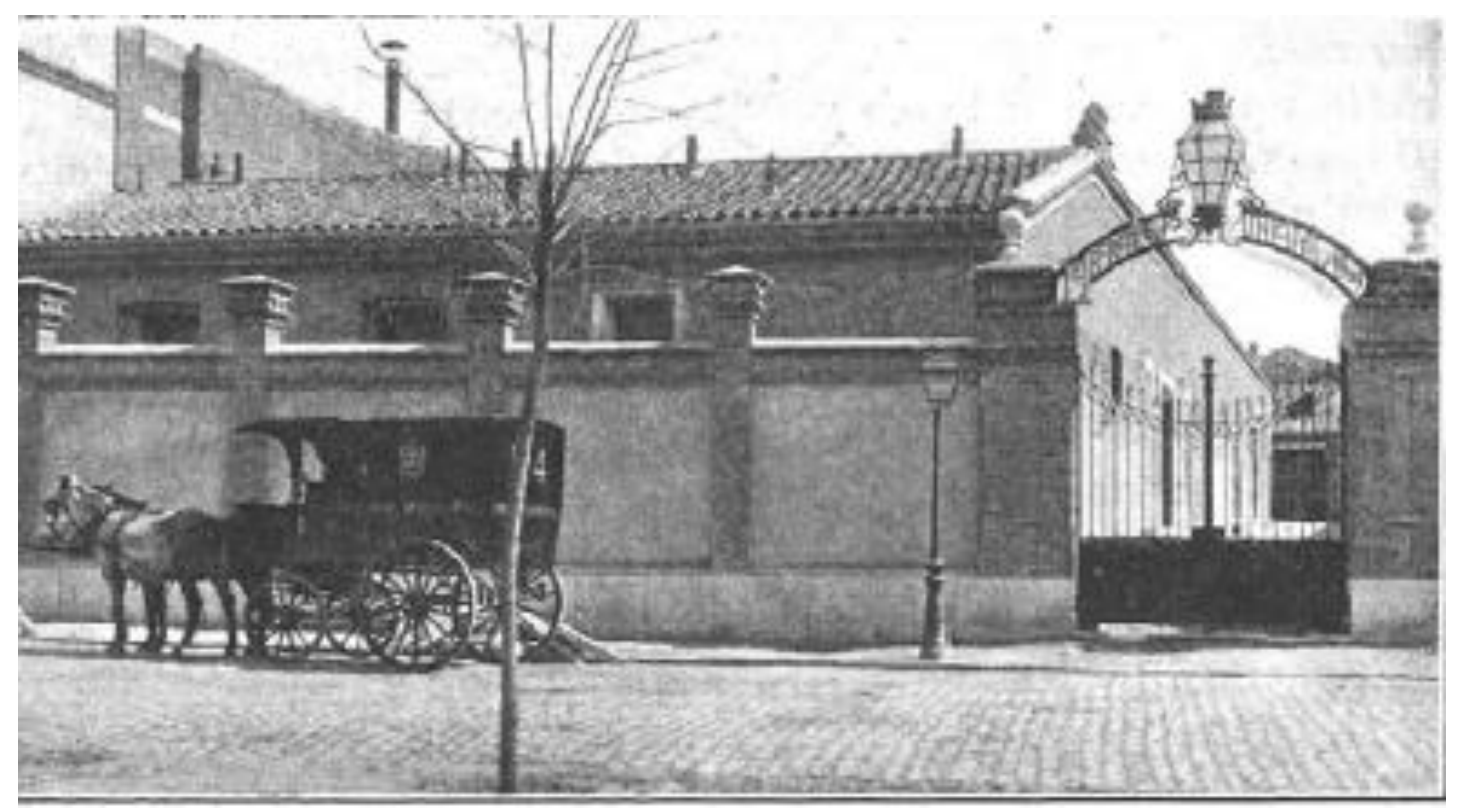

FUENTE: (Chicote del Riego, 1918, p. 13)

En el Barrio de la Guindalera, concretamente en la Calle de Ferrer del Río, número 21, se encontraba la Sucursal encargada de la producción de sueros y vacunas contra la viruela. Por sus condiciones de amplitud, era idónea para estar dotada de cuadras y establos donde permanecían los animales productores de sueros y los destinados a la investigación. También servía de depósito de diverso material sanitario y de desinfección, dividido en tres departamentos: los laboratorios de sueros y de vacuna antivariólica y el departamento de envases, la sección de los animales mordidos en observación, las conejeras y una oficina de vacunación antivariólica destinada a la vacunación de los vecinos de los alrededores. También disponía de un taller de reparaciones de material (Chicote del Riego, 1918, p. 14). 
Imagen 7-6. . Fotografía de Sucursal de la calle de Ferrer del Río.

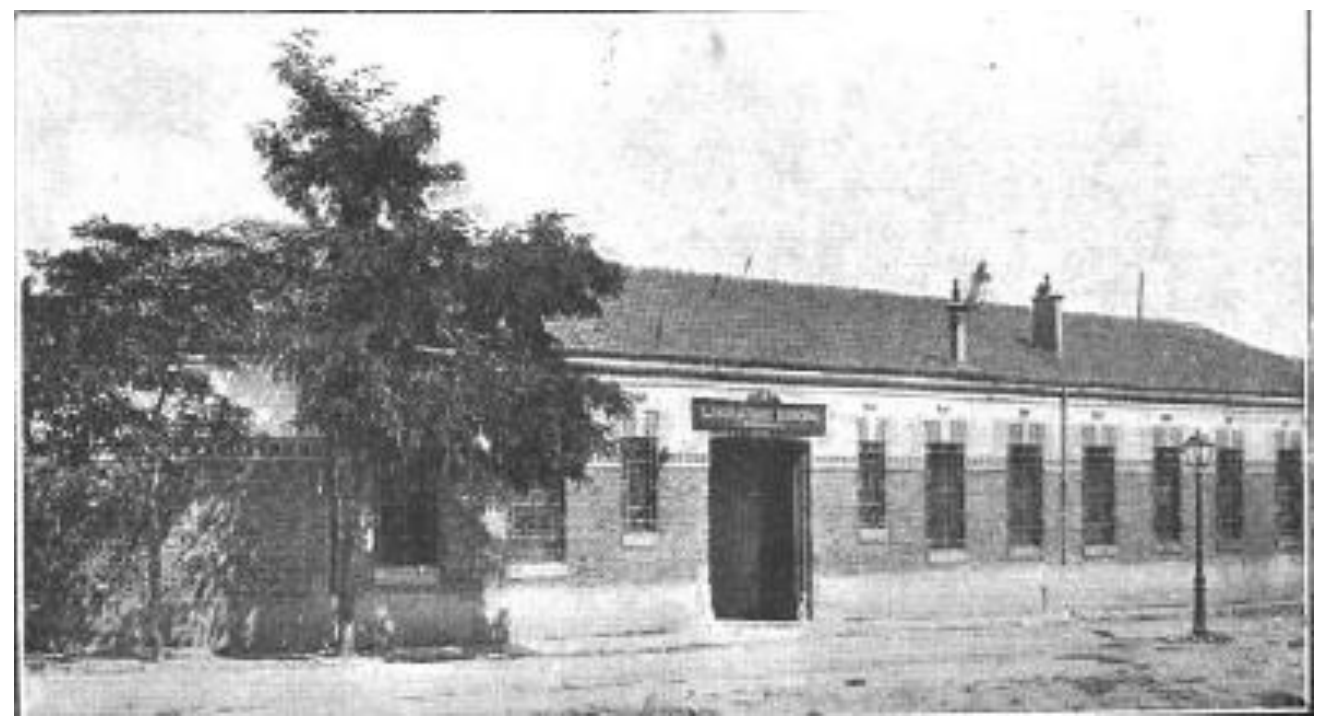

FUENTE: (Chicote del Riego, 1918, p. 14)

El Campamento de desinfección, ubicado en el Paseo de las Yeserías, números 13 y 15, estaba dividido en varias naves en relación a las funciones para las que estaban dispuestas. Así, había una nave con de baños y duchas para hombres, dos naves con 150 camas, comedores, salas de aseo, oficina, ropero, inspección médica, retretes y un servicio completo y modernísimo de desinfección. Los pabellones están edificados en un extenso parque perfectamente cuidado. (Chicote del Riego, 1918, p. 14).

Imagen 7-7. Fotografía del Campamento de desinfección. Paseo de las Yeserías, números 13 y 15

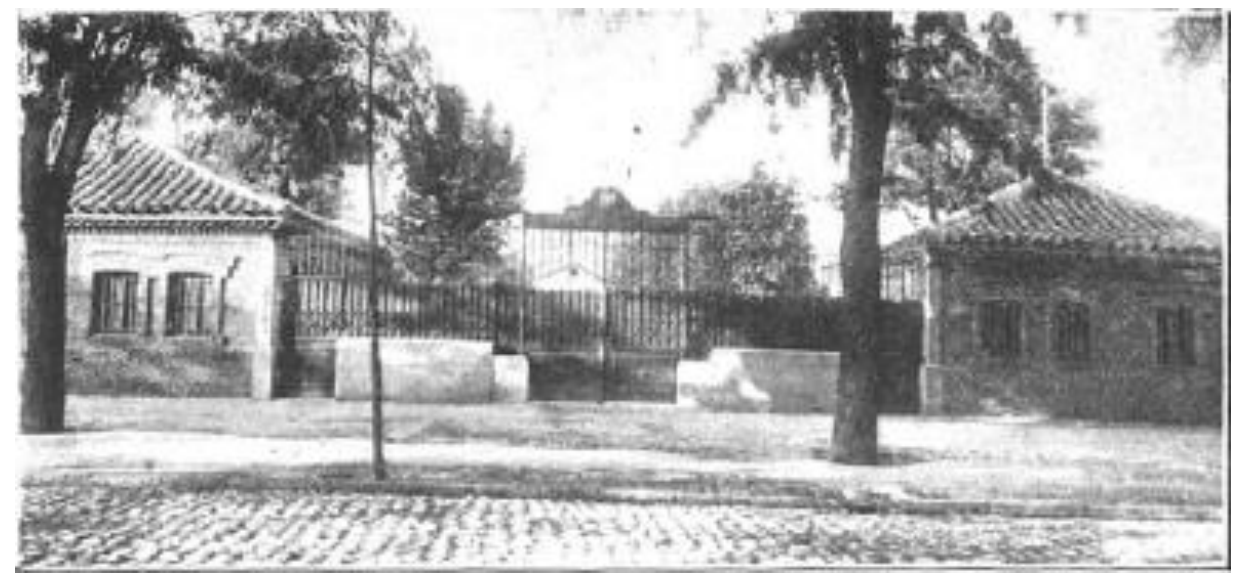

FUENTE: (Chicote del Riego, 1918, p. 14) 
Imagen 7-8. Fotografía de los Golfillos ${ }^{67}$ recogidos en el Campamento de Desinfección.

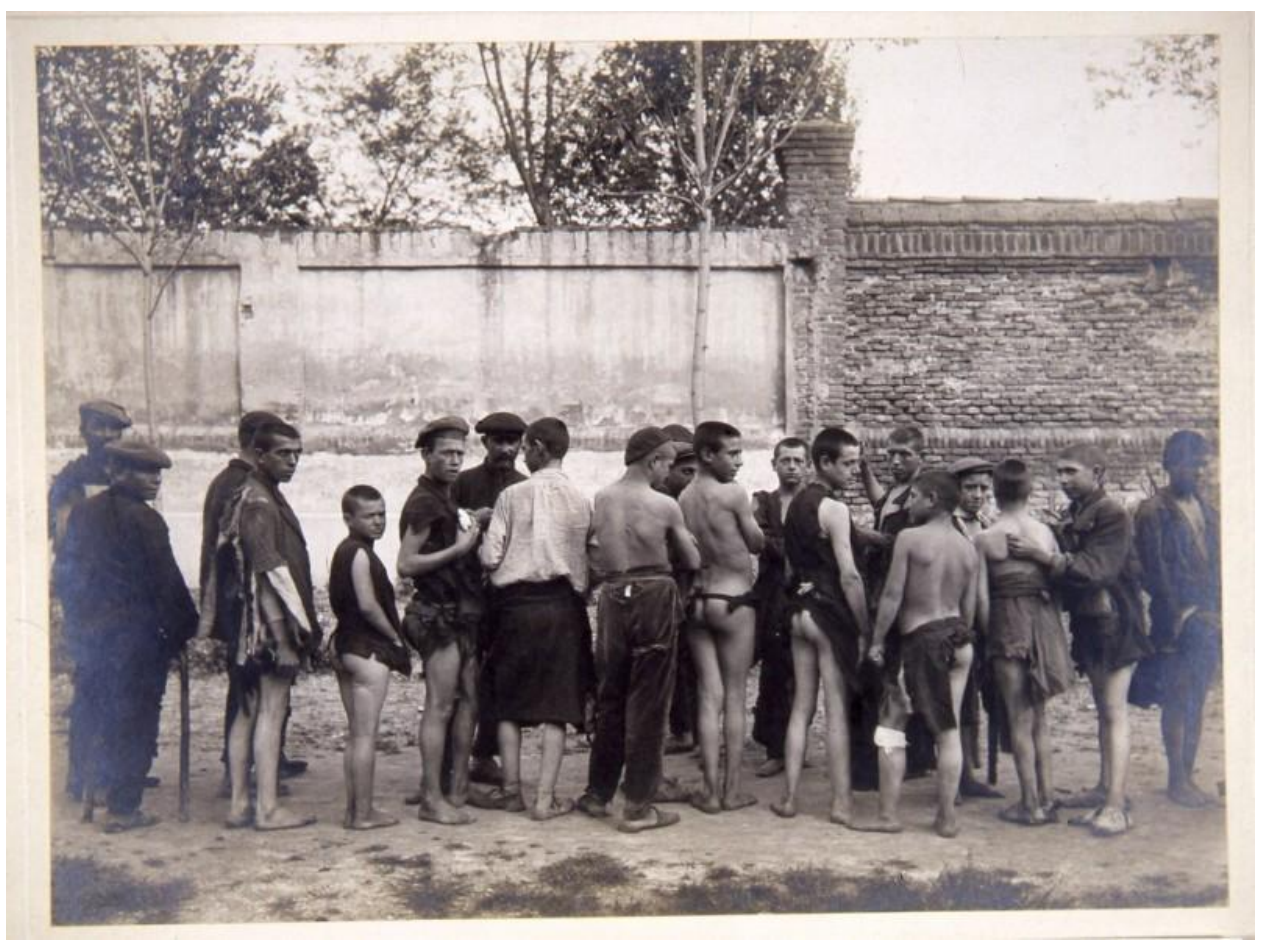

Fuente: Museo de Historia. Obtenido de la Biblioteca digital Memoria de Madrid. Fecha: Entre 1091 y 1910. Lugar: Madrid. Descripción: Papel fotográfico blanco y negro 28 x 34 cm. Inv. 21569

\subsubsection{La estructura organizativa del Laboratorio}

La práctica del servicio técnico del Laboratorio se llevaba a cabo en el Interior del Laboratorio y en el exterior, mediante visitas a tiendas, fielatos, mercados y estaciones, entre otros establecimientos. Además, como se ha señalado, la inspección se llevaba a cabo por dos grupos de profesionales, con competencias reguladas en los artículos $10 \mathrm{y}$ 11 del Real decreto de 22 de Diciembre de 1908, dictado previo informe del Real Consejo de Sanidad (Melgosa Olaechea, 1912, p. 41), los Inspectores Veterinarios y los Inspectores Químicos.

\footnotetext{
${ }^{67}$ Los golfillos eran niños vagabundos, abandonados o delincuentes, que vivían en las calles de la ciudad. Tras comenzar a verse como un peligro público, el Gobernador civil Sr, Ruiz Jiménez en 1905 ordena que sean recogidos de las calles, con el objetivo de que se les prestase atención benéfica en los Asilos y otras dependencias Municipales. Para más información sobre este tema, puede consultarse el artículo publicado el 6 de julio de 1905 en la Revista Nuevo Mundo ("La recogida de los golfos," 1905).
} 
Gráfico 7-2. Funciones de los Inspectores veterinarios y los Inspectores químicos

\begin{tabular}{|c|c|}
\hline $\begin{array}{l}\text { Funciones de } \\
\text { los }\end{array}$ & La inspección en los mataderos. \\
\hline \multirow[t]{5}{*}{$\begin{array}{l}\text { Inspectores } \\
\text { Veterinarios }\end{array}$} & $\begin{array}{l}\text { La inspección en fielatos, estaciones y mercados de toda clase de carnes, pescados y demás } \\
\text { alimentos de origen animal, así como de las frutas, verduras y de la leche. }\end{array}$ \\
\hline & $\begin{array}{l}\text { La inspección de las carnes, caza, aves, pescados, embutidos y leche expendidas en toda clase de } \\
\text { establecimientos y puestos, así como de las verduras y frutas. }\end{array}$ \\
\hline & $\begin{array}{l}\text { La inspección de las mondonguerías, casquerías, fábricas de escabeche y de embutidos y de } \\
\text { establecimientos ó casas que, sin ser fábricas, se dedican á la elaboración y comercio de éstos. }\end{array}$ \\
\hline & La inspección de cabrerías, encierros de ovejas y cuadras de burras de leche. \\
\hline & $\begin{array}{l}\text { La inspección de vaquerías, comprendiendo: } \\
\text { 1) El reconocimiento, reseña y contraseñado de las reses que se encuentren estabuladas en todos los } \\
\text { establecimientos y de las que se trate de estabular. } \\
\text { 2) La vigilancia de las condiciones de los alimentos que se empleen en cada vaquería para la nutrición de las } \\
\text { reses, así como sobre el cumplimiento de la higiene en los establos. } \\
\text { 3) La aplicación de los medios de diagnóstico que la ciencia aconseje para comprobar el estado de sanidad de las } \\
\text { reses. } \\
\text { 4) El estudio de la normalidad en la producción de la leche. }\end{array}$ \\
\hline
\end{tabular}

La inspección de paradores donde se albergue ganado de matadero ó productor de leche.

La inspección en las fondas, casas de comidas, bodegones, cafés, etc., de las carnes, aves, pescados, caza, embutidos; de las frutas y verduras.

La inspección en los desolladeros y fábricas de aprovechamiento de animales muertos.

\section{Funciones de La inspección y vigilancia en las fábricas de alimentos y bebidas, en cuanto concierneá éstos. \\ los \\ Inspectores \\ químicos}

La inspección y vigilancia en los almacenes, tiendas y puestos donde se venda toda clase de productos alimenticios, excepto las carnes, aves, pescados y demás alimentos procedentes del reino animal, de las frutas y de las verduras.

La inspección y vigilancia de las fondas, cafés, cafetines, cervecerías, horchaterías, establecimientos de gaseosas y de bebidas refrescantes.

La inspección de la fabricación y venta de utensilios de cocina, por lo que respecta á los barnices y esmaltes, así como de las fábricas de papel de estaño, cápsulas metálicas, utensilios, vasijas y envases metálicos.

La vigilancia de la potabilidad y pureza de las aguas en las fuentes públicas.

Dispone, además, de un gabinete de inspección en el mercado de los Mostenses, de otro en cada una de las estaciones de ferrocarriles, y de otro en cada uno de los Mataderos.

Fuente: Elaboración propia. Información de Las subsistencias en Madrid (Melgosa Olaechea, 1912, pp. 41-42). 
En el transcurso de la Dirección del Laboratorio Municipal con el Doctor Chicote a la cabeza, se logró una modernización de los servicios y una eficiencia ineludible en su funcionamiento. Hay que tener en cuenta la importancia que, en la consagración de las actividades del Laboratorio Municipal de Madrid, tuvieron las visitas y el estudio de otros Laboratorios municipales, incluidos los extranjeros, así como la asistencia a Congresos Internacionales que tuvieron por temáticas la alimentación, la vivienda y/o la higiene general.

El Laboratorio Municipal consiguió a lo largo de los años una especialización sin precedentes, teniendo en consideración, entre otras cosas, la división del trabajo que allí se desempeñaba. De este modo, a la altura de 1917, el Laboratorio Municipal de Madrid estaba dividido en cuatro agrupaciones: el Servicio analítico, el Servicio de inspección de subsistencias, el Servicio de defensa contra las enfermedades infecciosas y el Servicio Administrativo. Las funciones de cada uno de los servicios estaban claramente definidas "dentro de la esfera de acción que reclaman las modernas orientaciones de la higiene: el alimento puro y la defensa contra las infecciones" (Chicote del Riego, 1918, p. 5).

Siguiendo con la organización de los servicios, por acuerdo de 20 de noviembre de 1931, se produjeron modificaciones sustanciales respecto a los años anteriores, de manera que se dividió en cuatro secciones; la Sección de Química, la Sección de Microbiología, la Sección de Veterinaria, la Sección de Epidemiología. La importancia de la nueva distribución del Laboratorio Municipal radicaba en la importancia otorgada al Servicio de Epidemiología, pues, si bien existía una distribución del trabajo bien definida entre cada una de las secciones, Revenga destacaba la "necesaria relación, especialmente por cuanto se refiere a la de Epidemiología, necesitada, como base fundamental, de las informaciones de las demás”. (García Revenga, 1933, p. 6). 


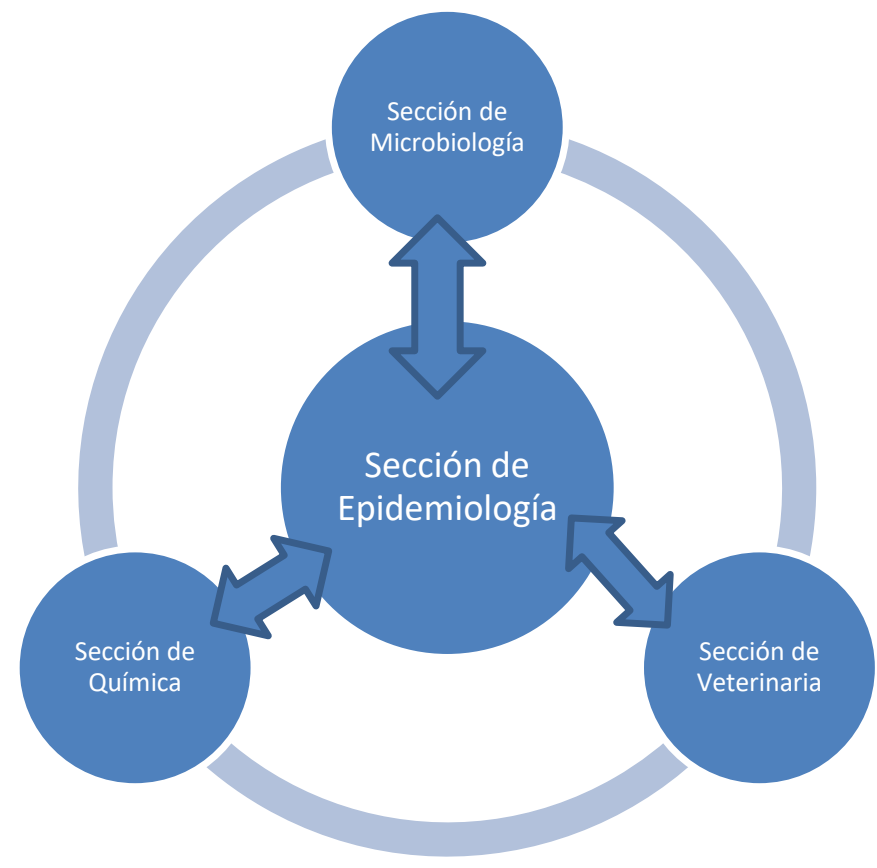

Fuente: Elaboración propia. Información extraída de (García Revenga, 1933, p. 6)

Respecto a la opinión sobre el funcionamiento y las necesidades de los servicios del Laboratorio, ésta era positiva, en términos generales. Así lo manifestaba César Chicote, como Director del Laboratorio: "Los servicios se encuentran bien instalados y dotados de material moderno de investigación en forma que pueden competir con los de laboratorios más renombrados del extranjero. Debo decir, sin embargo, que los locales son ya notoriamente insuficientes para el desenvolvimiento que han adquirido los servicios en estos últimos años, muy a pesar de cuantos esfuerzos se han hecho para aprovechar todo el terreno y de haberse reconcentrado todas las oficinas aun con perjuicio de su organización” (Chicote del Riego, 1918, p. 12). Sin embargo, las instalaciones del Laboratorio, a la altura de 1917, habían quedado pequeñas para el desarrollo de la incesante labor desempeñada. Ya en 1906 y el 1914, el propio Chicote lo manifestó en un comunicado dirigido a la Alcaldía de la Presidencia, con el objetivo de lograr una ampliación del edificio donde estaba instalado el Laboratorio. Asimismo, se consideraba que la descentralización de los servicios en las dependencias varias existentes (ya descritas anteriormente) perjudicaba la marcha de los mismos, abogando por una centralización: "Refiriéndome a los locales, considero que sería conveniente en extremo acometer la empresa de construir un nuevo Laboratorio con diversos pabellones en los que, excepto el Campamento, deberían centralizarse todos los 
servicios. Esto sería muy beneficioso, primero porque la vigilancia de aquéllos sería más eficaz por parte de la Dirección, y después porque habría facilidad para ampliarlos en consonancia con las necesidades de la capital y los progresos de la ciencia; tendrían más cohesión y acaso se proporcionaría un beneficio económico”. (Chicote del Riego, 1918, p. 15).

Respecto a los materiales de los que estaba dotado el Laboratorio, pese a la tónica general de la sensación de suficiencia de los mismos, la insatisfacción se mostraba respecto a los coches empleados para el servicio de desinfección. Hay que tener en cuenta que, a la altura de 1917, seguían funcionando los mismos coches que fueron comprados entre los años 1904 y 1905, momento en que se organizó el servicio de desinfección y comenzaron a funcionar los coches de ropas. Estos coches permanecían en funcionamiento prácticamente todo el día, prestando sus servicios tanto dentro de la ciudad como en los pueblos aledaños y eran empleados, además, como medio de transporte auxiliar de los Hospitales, tanto de la provincia de Madrid como del Estado. Asimismo, se abogaba por la sustitución de los coches actuales, que eran de arrastre animal, por automóviles "ya que éstos afortunadamente han dejado de ser exclusivamente de lujo para satisfacer cumplidamente todo género de necesidades incluso las sanitarias. Así se dispondría de un servicio modernizado cuya primera ventaja sería la de economizar tiempo" (Chicote del Riego, 1918, p. 16).

Las necesidades mostradas, surtieron efecto en 1922, momento en que se produce la Adquisición por concurso de cuatro automóviles sanitarios con destino a los servicios de transporte de enfermos infecciosos y de desinfección del Laboratorio Municipal de Madrid $^{68}$.

\footnotetext{
${ }^{68}$ En el siguiente enlace pueden consultarse el Pliego de condiciones, dictámenes, enmiendas y aprobación del concurso; la Publicación de concurso en la Gaceta de Madrid, Boletín Oficial de la Provincia de Madrid, y Boletín del Ayuntamiento; las Ofertas de empresas concurrentes al concurso y la Resolución de adjudicación de concurso y documentación complementaria. http://www. memoriademadrid.es/buscador . php?accion=VerFicha\&id=128220\&num id=34\&num total $=44$.
} 
Imagen 7-9. Expediente relativo al concurso de cuatro automóviles sanitarios con destino a los servicios de transporte de enfermos infecciosos y de desinfección, 1922.

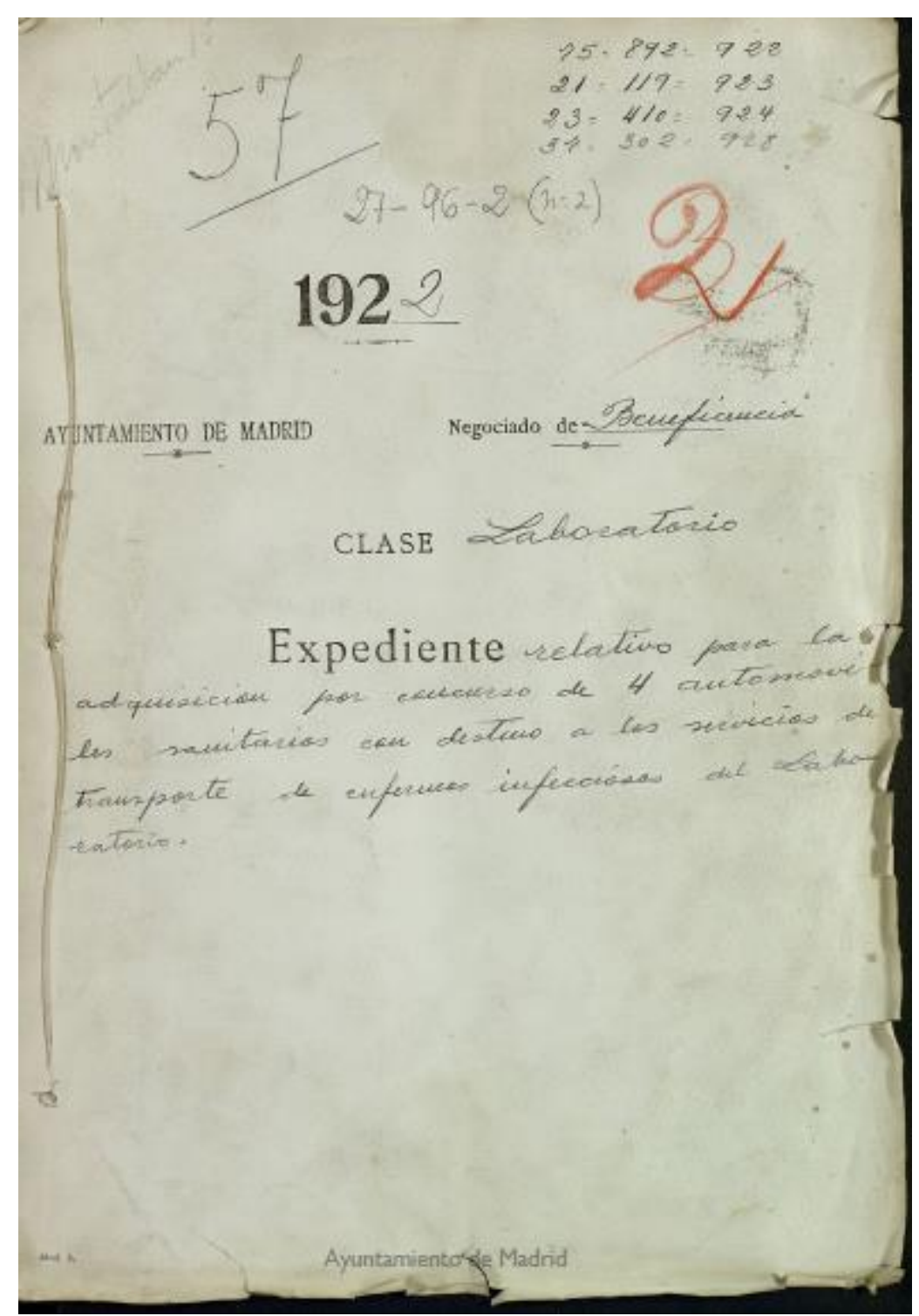

Fuente: Memoria de Madrid 


\subsubsection{Los servicios a la ciudadanía. Servicio de de pago y los servicios gratuitos. Las tarifas del Laboratorio}

Una de las potencialidades más relevantes del Laboratorio Municipal de Madrid era que ofrecía sus servicios no sólo a las autoridades, sino también a los vecinos de la ciudad. Los primeros, eran denominados servicios de carácter oficial, y, los segundos servicios de carácter particular.

Los servicios oficiales tenían la consideración de ser preferentes y ejecutivos, además de ser gratuitos. En cuanto a la procedencia de su solicitud, podían ser ordenados por la Alcaldía Presidencia, Tenientes de Alcalde, Concejales, Autoridades y Centros oficiales, consultivos y administrativos. También eran considerados como servicios oficiales aquellos solicitados por los establecimientos sanitarios de beneficencia y caridad, así como aquellos practicados por el servicio de Inspección de subsistencias del Laboratorio Municipal.

Gráfico 7-4. Servicios del Laboratorio Municipal de Madrid.

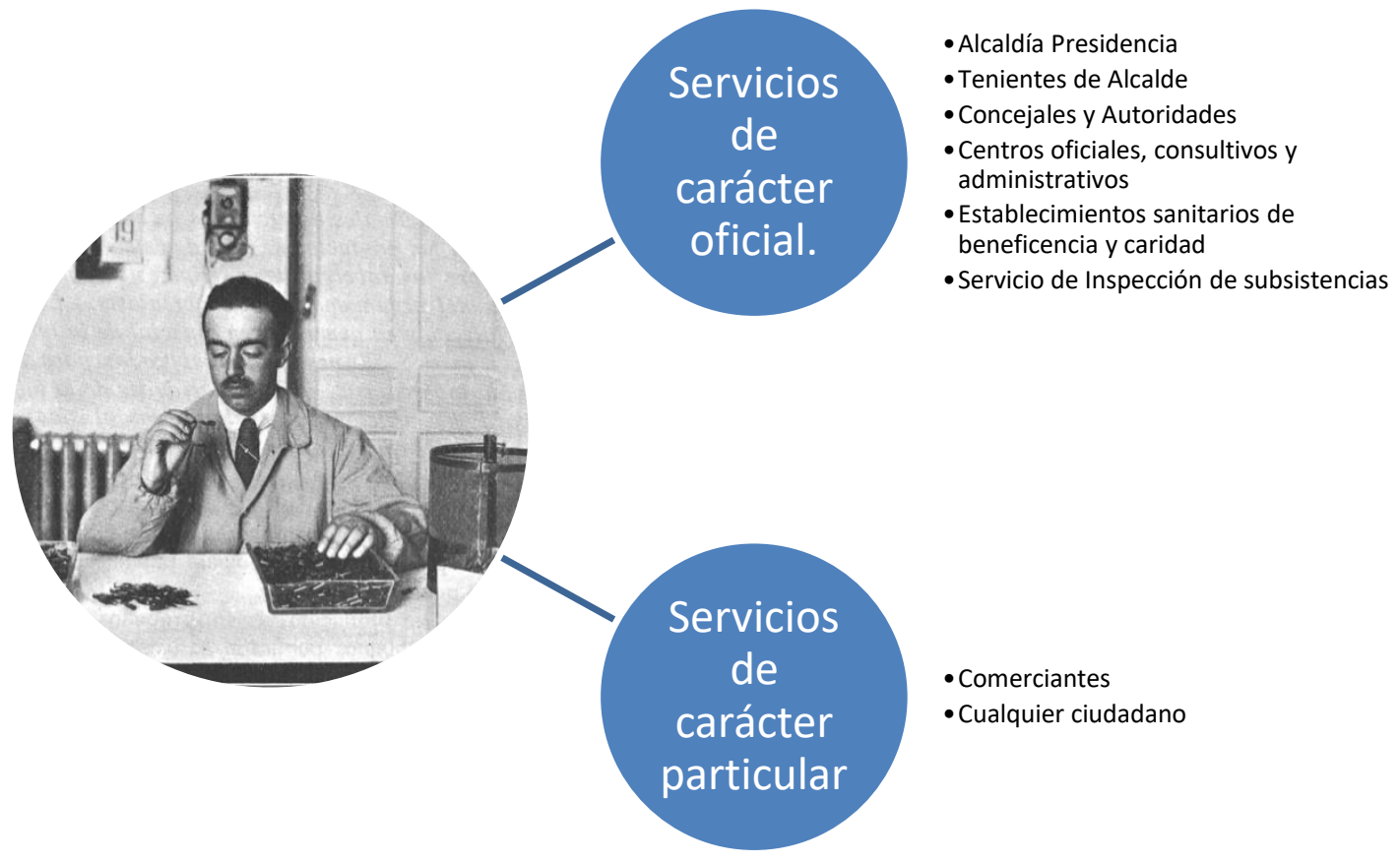

Fotografía: El Sr. Chicote haciendo la separación de las ampollas de vacuna no utilizables, 1916. (Chicote del Riego, 1916)

En cuanto a los servicios de carácter particular, podían ser solicitados por cualquier vecino de Madrid. En este caso, existían algunos servicios que eran gratuitos, mientas que otros tenían una tarifa variable en función del servicio solicitado en cuestión. Los 
análisis que no requerían de certificación, sino sólo una mera calificación de la sustancia que se presentase, eran gratuitos. Por el contrario, aquellos análisis, tanto cualitativos como cuantitativos para los que se requería una certificación por parte del Laboratorio, requerían de una tarifa. "los cualitativos y cuantitativos que pida el comercio con fines de propaganda, y los reconocimientos y análisis de toda clase pedidos por personas, Centros y Corporaciones residentes fuera de la Corte. Además serán siempre de pago los informes acerca de los aparatos aplicados a la higiene" (Chicote del Riego, 1918, p. 129). Para poder proceder a una certificación de los análisis cualitativos, éstos se cuantificaban, de manera que se les otorgaba una calificación. Los análisis cualitativos podían solicitarse sobre cualquier tipo de alimentos, bebidas, condimentos..., con carácter de gratuidad en caso de entregarse una calificación. Para la solicitud de certificación del análisis cualitativo, debía pagarse cinco pesetas por análisis, en concepto de derechos. Tanto en la calificación como en la certificación, se entregaba una hoja en la que aparecía si la muestra analizada era buena o mala. En caso de ser mala, se consignaba también si estaba alterada o adulterada, así como si era nociva o no a la salud (Chicote del Riego, 1918, p. 130).

Para los análisis cuantitativos, además de la certificación con la calificación en cuestión, se entregaban los datos obtenidos en el análisis practicado sobre la muestra presentada para el reconocimiento y el análisis por parte del Laboratorio Municipal de Madrid.

Los análisis podrían practicarse sobre las siguientes sustancias:

Gráfico 7-5. Sustancias susceptibles de análisis por el Laboratorio Municipal.
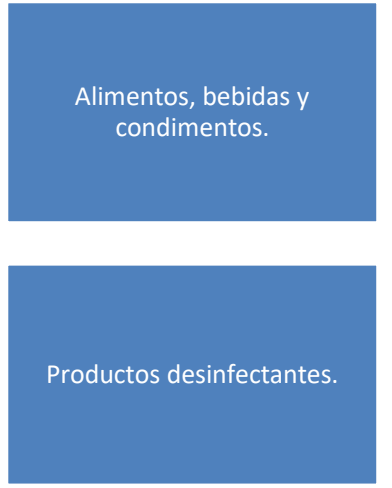

Objetos que pudieran tener acción sobre la salud pública por su coloración, presencia de metales tóxicos u otra causa (papeles, telas, juguetes, aleaciones, entre otros)

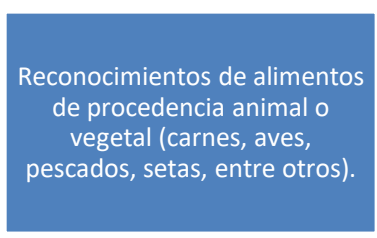

Cualquier análisis y reconocimiento que disponga la Alcaldía Presidencia para la resolución de problemas

relacionados con la higiene y seguridad personal.
Otras materias que pudieran ser peligrosas para la seguridad personal (como los petróleos).
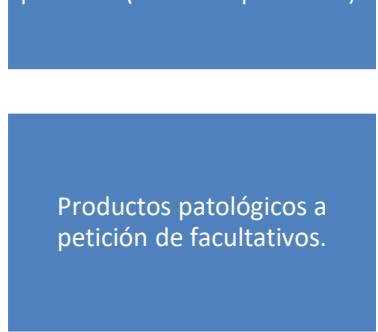

Fuente: Elaboración propia 
Las tarifas de los análisis cuantitativos se expresan en el cuadro siguiente:

Tabla 7-1. Las tarifas de los análisis cuantitativos del Laboratorio Municipal de Madrid,

\section{Aguas}

○ Análisis ponderal completo del agua potable: 100 pesetas

○ Análisis desde el punto de vista de sus condiciones de potabilidad y pureza: 50 pesetas

- Investigación de bacilos patógenos: 25 pesetas

○ Aparatos para la purificación del agua (ensayo) : 100 pesetas

Hielo.

○ Análisis desde el punto de vista de sus condiciones para el consumo: 25 pesetas

Aguas y bebidas refrescantes

○ Análisis desde el punto de vista de sus condiciones para el consumo: 20 pesetas

- Determinaciones aisladas(cada una): 4 pesetas

Vinos, cervezas y sidras.

○ Análisis desde el punto de vista de su pureza y condiciones para el consumo: 25 pesetas

$\bigcirc$ Determinaciones aisladas(cada una): 4 pesetas

\section{Alcoholes}

○ Determinación de su pureza y grado alcohólico: 15 pesetas

\section{Aguardientes y licores.}

○ Análisis desde el punto de vista de su pureza y condiciones para el consumo: 20 pesetas

$\circ$ Determinaciones aisladas(cada una): 4 pesetas

Harinas, pan, pastas para sopa y pastelería.

- Análisis desde el punto de vista de su pureza y condiciones para el consumo: 15 pesetas

- Determinaciones aisladas(cada una): 4 pesetas

\section{Leches.}

○ Análisis desde el punto de vista de su pureza y condiciones para el consumo: 15 pesetas 
$\circ$ Determinaciones aisladas: cada una: 4 pesetas

\section{Leche de nodriza.}

○ Análisis desde el punto de vista de sus condiciones nutritivas: 5 pesetas

Quesos y requesón.

○ Análisis desde el punto de vista de su pureza y condiciones para el consumo: 15 pesetas

Manteca de vaca y grasa de cerdo.

- Análisis desde el punto de vista de su pureza y condiciones para el consumo: 15 pesetas

Aceite de oliva.

○ Análisis desde el punto de vista de su pureza y condiciones para el consumo: 15 pesetas

Azúcares y miel.

- Análisis desde el punto de vista de su pureza y condiciones para el consumo: 15 pesetas

$\circ$ Determinaciones aisladas(cada una): 4 pesetas

Café verde y tostado.

○ Investigación de su pureza y condiciones para el consumo: 10 pesetas

Te.

- Investigación de su pureza y condiciones para el consumo: 10 pesetas

Sucedáneos del café y del te

○ Análisis desde el punto de vista de su pureza y condiciones para el consumo: 15 pesetas

Infusión de café y de te.

- Investigación de sus condiciones y presencia de sacarina: 10 pesetas

Chocolate y cacao en polvo.

- Análisis desde el punto de vista de su pureza y condiciones para el consumo: 20 pesetas

Azafrán, pimienta, pimentón, etc., y demás especias y condimentos.

○ Análisis desde el punto de vista de su pureza y condiciones para el consumo: 10 pesetas

Sal de cocina.

○ Análisis desde el punto de vista de su pureza y condiciones para el consumo: 10 pesetas 
Vinagres.

○ Análisis desde el punto de vista de su pureza y condiciones para el consumo: 20 pesetas

$\circ$ Determinaciones aisladas(cada una): 4 pesetas

Conservas de todas clases.

○ Análisis desde el punto de vista de sus condiciones para el consumo: 15 pesetas

Carnes de todas clases, aves, pescados, crustáceos y mariscos al estado fresco, embutidos, hortalizas, verduras, frutas, semillas alimenticias, garbanzos, etc.

- Apreciación de sus condiciones para el consumo determinando la naturaleza de sus alteraciones: 10 pesetas

\section{Metales tóxicos.}

○ Determinación de su presencia en los alimentos, bebidas, conservas, condimentos, vasijas, estaño de soldaduras, papeles metálicos, cabezas de sifón, utensilios de metal y barro(cada uno): 6 pesetas

Papeles, juguetes y telas.

○ Determinación de los colores perjudiciales: 6 pesetas

\section{Materias colorantes para alimentos.}

○ Análisis desde el punto de vista de su pureza y condiciones para el consumo: 15 pesetas

\section{Petróleos.}

○ Densidad e inflamabilidad: 2 pesetas

\section{Jabones.}

- Análisis desde el punto de vista de sus condiciones generales: 11 pesetas

\section{Productos de perfumería.}

○ Determinación de sus condiciones higiénicas: 50 pesetas

\section{Productos desinfectantes.}

○ Poder bactericida: 100 pesetas

Fuente: Elaboración propia con información extraída de (Chicote del Riego, 1918, pp. 130-131)

Además, cualquier otra sustancia o producto que se solicitase ser analizada y no estuviera incluida en la tabla de tarifas, así como los informes y reconocimientos requeridos para aparatos de aplicación a la higiene, sería cobrada con una tarifa a juicio 
del Jefe del Laboratorio. Otra serie de análisis o reconocimiento de sustancias y productos que estaban fuera de la tarifa de la tabla anteriormente indicada, eran los correspondientes a aquellos que eran solicitados por los comerciantes con el objetivo de ejercer un uso propagandístico del certificado obtenido por el Laboratorio Municipal. En este caso, el particular debería abonar el doble de la tarifa indicada en la tabla. En la época, era usual que los comerciantes e industriales usaran los certificados emitidos por el Laboratorio para fines comerciales y propagandísticos, como seña de "higiene" del comercio en cuestión. Es por ello que, desde el Laboratorio Municipal se reiterase el hecho de que el resultado mostrado en el certificado no era más que el propio del producto presentado. Atendiendo a las muestras de productos cuyos resultados fueran buenos, éstos eran devueltos al particular en el momento en que se le entregase el certificado. Para aquellas sustancias en que el resultado del análisis fuera de regulares o malas condiciones, éstas quedaban custodiadas en el depósito del Laboratorio durante el plazo de un mes, el mismo otorgado para cualquier tipo de reclamación. Otra tarifa adicional era la correspondiente a la solicitud de copias de certificaciones, por las cuales se debía reintegrar, en concepto de derecho de copia, 3.50 pesetas por copia (Chicote del Riego, 1918, p. 132)

Como se ha señalado más arriba, en la descripción y listado de las sustancias posibles que podían ser analizadas, los productos patológicos sólo serían analizados por el Laboratorio cuando éstos vinieran solicitados por facultativos. Además de los señalados en el listado, con su correspondiente tarifa, el Director del Laboratorio tenía potestad para analizar cualquier otro producto patológico que considerase. 
Tabla 7-2. Las tarifas de los análisis cuantitativos sobre productos patológicos del Laboratorio Municipal de Madrid,

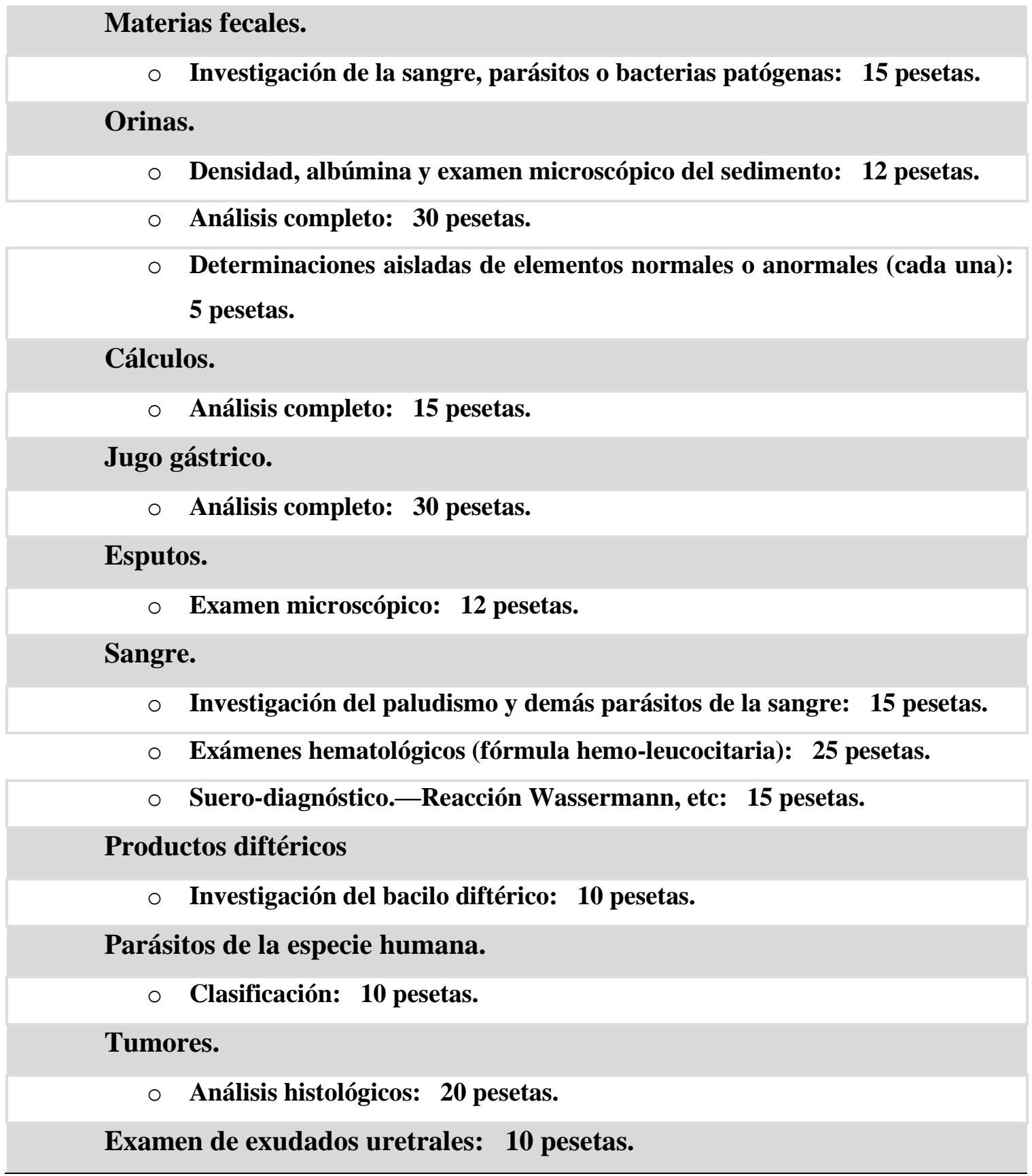

Fuente: Elaboración propia con información extraída de (Chicote del Riego, 1918, p. 132)

Un servicio que revestía de especial importancia era el servicio de vacunas y sueros del Laboratorio. Éstas tenían una tarifa base, que debía abonarse de manera íntegra, a excepción de aquellas dispensadas para las personas de escasos recursos económicos, así como las destinadas para el abastecimiento de instituciones de caridad y beneficencia, que eran totalmente gratuitas. Asimismo, los farmacéuticos y los 
depósitos de especialidad que comprasen vacunas y sueros, sólo debían abonar el ochenta y cinco por ciento de la tarifa para el público general.

Tabla 7-3. Las tarifas de vacunas y sueros del Laboratorio Municipal de Madrid,

\section{Vacuna de ternera contra la viruela:}

$\bigcirc \quad$ Tubos para una a tres personas: 1 pesetas

$\circ \quad$ Viales para diez personas: 5 pesetas

Vacuna tuberculosa:

$\circ \quad$ Caja de una ampolla: 1 pesetas

Vacuna contra el cólera:

○ Caja de tres ampollas: 5 pesetas

Vacuna gonocócica polivalente.

$\bigcirc \quad$ Caja de tres ampollas: 5 pesetas

Vacuna contra el ocena:

$\bigcirc \quad$ Caja de tres ampollas: 3 pesetas

Vacuna de bacilos coli y lactis aerógenes:

○ Caja de tres ampollas:3 pesetas

Vacuna pneumocócica:

$\circ \quad$ Caja de tres ampollas: 3 pesetas

Vacuna estreptocócica.

○ Caja de tres ampollas:3 pesetas

Vacuna estafilocócica polivalente:

$\circ \quad$ Caja de tres ampollas:3 pesetas

Vacuna antitífica polivalente:

○ Caja de tres ampollas: 3 pesetas

Vacuna contra las periodontitis y sus complicaciones:

○ Caja de tres ampollas: 3 pesetas

Vacunas autógenas: 50 pesetas

Suero antidiftérico:

○ Frasco de 10 centímetros cúbicos: 3 pesetas

Suero antitetánico:

○ Frasco de 10 centímetros cúbicos: 5 pesetas

Suero antimeningocócico:

○ Frasco de 10 centímetros cúbicos: 5 pesetas

Fuente: Elaboración propia con información extraída de (Chicote del Riego, 1918, p. 133) 
Respecto al servicio antirrábico, el coste de los servicios era gratuito para las personas pobres o de escasos recursos y aquellos que fueran solicitados de oficio por las Autoridades. Para el resto, se aplicaba una tarifa de 10 pesetas para el servicio de comprobación de la rabia y de 50 pesetas en caso de que se requiriera un tratamiento antirrábico. Además, se disponía de un servicio de vigilancia de animales mordidos, que quedarían custodiados en el Laboratorio. La alimentación de éstos podía correr a cargo del particular que solicitase el servicio de observación de animales o quedar de manos del Laboratorio, con el pago de 0.50 pesetas diarias en caso de que se tratara de un perro o gato, encontrándose el resto de animales bajo convenio particular.

Imagen 7-10. Fotografía de la vacunación de unas niñas mordidas por un animal rabioso, 1916

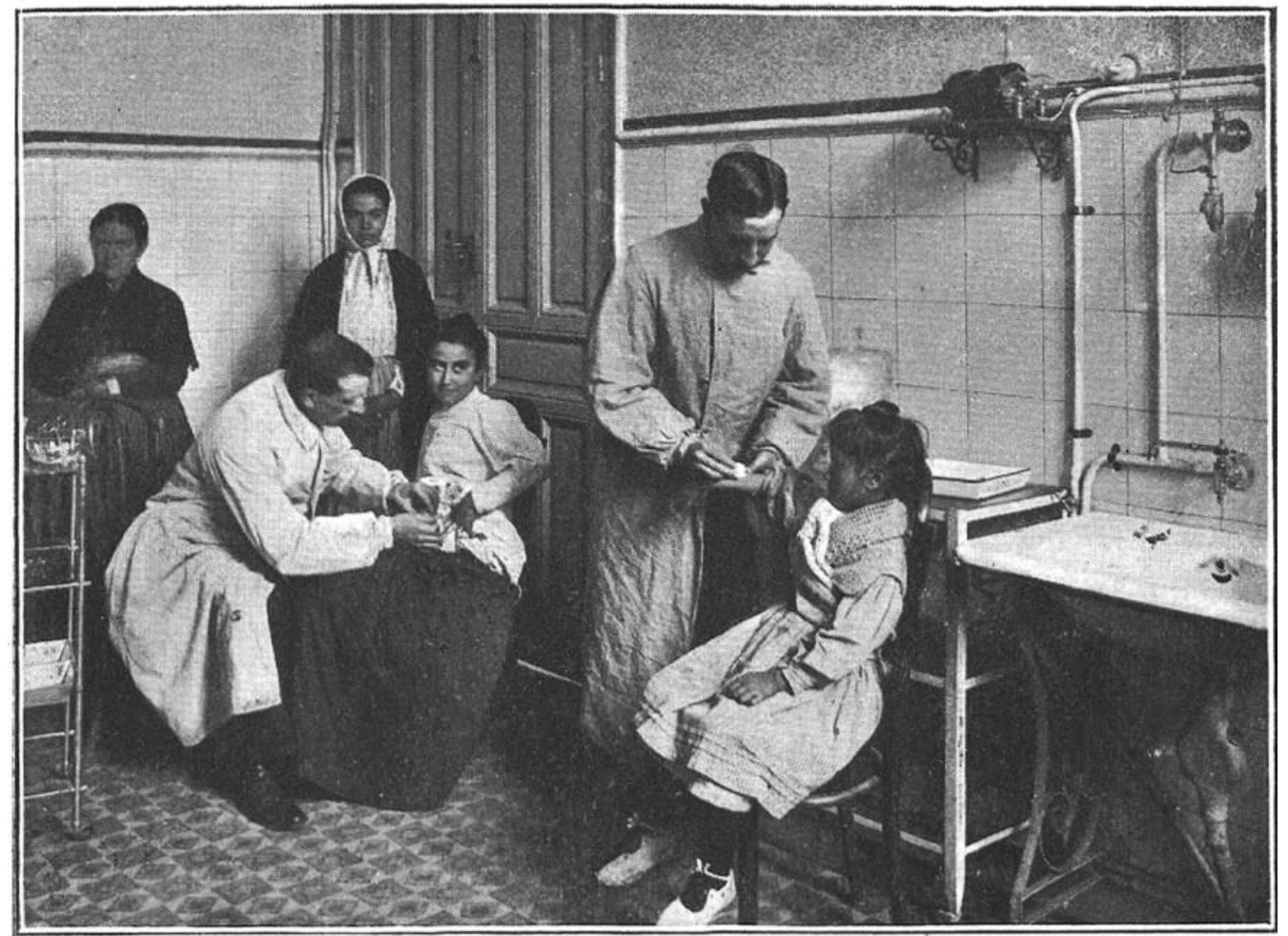

El Dr. Román. y el Dr. Olano tratando a unas niñas mordidas por un animal rabioso, 1916.

Fuente: (Chicote del Riego, 1916, p. 116)

En lo que respecta al servicio de Desinfección y sus tarifas asociadas, era de coste gratuito para personas que estuvieran en el curso y terminación de enfermedades que eran de declaración obligatoria y exigían, atendiendo a las disposiciones legales en materia de sanidad vigentes en la época y por la Real Academia de Medicina, el aislamiento y la desinfección. Así, las enfermedades para las cuales el servicio de 
desinfección era gratuito eran las siguientes: cólera, fiebre amarilla, tifus exantemático, disentería, fiebre tifoidea, peste bubónica, viruela, varioloide y varicela, difteria, escarlatina, sarampión, meningitis cerebro-espinal, septicemia, tos ferina, grippe y tuberculosis, además de la poliomelitis o parálisis infantil (Chicote del Riego, 1918, p. 134).

Para el resto de enfermedades no incluidas en la relación anterior, el servicio de desinfección era de pago siempre y cuando el alquiler pagado por la persona interesada superase las 75 pesetas mensuales. Las tarifas dependían, a su vez de si la desinfección se realizaba en el domicilio del interesado o en los puestos de desinfección, tal y como se señala en la siguiente tabla. Hay que reseñar que el Laboratorio disponía también de un servicio que podía ser solicitado por localidades con cercanía a la Capital, que no dispusieran de este servicio sanitario. En estos casos, debían abonarse tarifas variables, en los conceptos indicados en la tabla adjunta (Tabla 7-4). 
Tabla 7-4. Tarifas del Servicio de desinfección del Laboratorio Municipal de Madrid.

- Desinfección a domicilio

○ Por cada diez metros cúbicos de local desinfectado: 0'50 pesetas

- Servicio en los puestos.

○ Desinfección aislada de ropas y efectos de uso

- Cuando ocupen media estufa: 5 pesetas

- Cuando ocupen una estufa: 10 pesetas

- Desinfección de edificios públicos de toda clase, excepto los oficiales con carácter preventivo, por cada desinfección que se solicite y con exclusión de ropas, cada diez metros cúbicos de local desinfectado: 0'25 pesetas

- Desinfección de cuadras y establos, por cada diez metros cúbicos de local desinfectado: 1 peseta

- La desinfección de edificios oficiales y de establecimientos sanitarios de beneficencia o caridad, así como la de cuartos desalquilados y ropas usadas destinadas a la venta, será gratuita.

- Servicio de desinfección fuera del término municipal.

- El transporte de ida y vuelta del personal y material necesario: Tarifa variable.

- El precio que se fije previamente, según la importancia de los trabajos que deban realizarse, y que ingresará íntegro en la Caja municipal: Tarifa variable.

○ La estancia completa del personal: Tarifa variable.

- El importe del haber que perciba el personal con arreglo a los días que sea utilizado en concepto de gratificación al mismo, como servicio extraordinario: Tarifa variable.

- Siempre que la presencia del servicio se haga necesaria por causa de epidemia, la Alcaldía Presidencia resolverá lo que proceda en cada caso: Tarifa variable. 


\subsection{El servicio de inspección de subsistencias del laboratorio}

\subsubsection{La seguridad alimentaria}

Desde los primeros años del siglo XX, comienzan a proliferar algunos Reales Decretos y Ordenanzas Municipales encaminadas a la persecución del fraude y adulteración alimentaria. Cabe destacar el Real Decreto de Gobernación de 22 de diciembre de 1908 (Melgosa Olaechea, 1912, pp. 48-55), mediante el cual se reguló el servicio de inspección de sustancias alimenticias y bebidas (Real decreto de 22 de Diciembre de 1908, regulando el servicio de inspección de sustancias alimenticias y bebidas, 1909) así como el Real Decreto de 14 de septiembre de 1920, mediante el que se organizaban los servicios de inspección de los alimentos y se dictaron las instrucciones técnicas sobre las condiciones que debían reunir los papeles, aparatos, utensilios y vasijas que se relacionasen con la alimentación. Respecto a la regulación municipal de Madrid en torno a la inspección de sustancias alimenticias, cabe destacar la Ordenanza Municipal que, en su capítulo II, reglamenta de manera exhaustiva este asunto. Se señalan a continuación los artículos que se consideran de mayor relevancia:

Art. 201. La inspección y vigilancia de las substancias alimenticias compete al Alcalde y a sus delegados, Jefe del Laboratorio Químico municipal, Comisión de Higiene y Salubridad y peritos encargados, en su esfera y funciones respectivas, del reconocimiento y análisis.

Art. 202. El Laboratorio Químico municipal es la oficina de comprobación que debe determinar el estado y condiciones de los alimentos y bebidas. El Jefe del Laboratorio certificará clara y concretamente acerca de la bondad, adulteración ó alteración de los mismos.

Art. 203. Los Tenientes de Alcalde, así como las Comisiones de Higiene y de Salubridad, girarán las visitas que consideren oportunas a los establecimientos públicos, fondas, cafés, tabernas, casas de comer, tiendas de comestibles, almacenes, panaderías, pescaderías, carnicerías, mercados, vaquerías, cabrerías, etc., para que en todo tiempo se observen las prescripciones de esta Ordenanza.

Art. 204. Los funcionarios del Laboratorio y los Revisores veterinarios en su esfera, girarán asimismo las visitas que señalan los reglamentos respectivos, atendiendo constantemente y con regularidad a este servicio, denunciando a la Autoridad municipal las faltas que observen y consignando en los libros respectivos los resultados de sus observaciones. 
Art. 205. Los dueños o representantes de tiendas o almacenes dedicados al comercio de substancias alimenticias, no podrán oponerse a que los delegados de la Autoridad giren visitas de inspección a sus establecimientos, incurriendo en el caso contrario en la pena correspondiente.

Art. 206. Los encargados de esta inspección y vigilancia podrán tomar, previo abono de su valor, las muestras de toda clase de géneros alimenticios que consideren convenientes para el análisis, que se efectuará en el Laboratorio municipal.

Art. 207. El acto de la toma de muestras tendrá efecto ante el dueño o un dependiente del establecimiento. La cantidad de muestras que se tome se dividirá en dos partes; ambas serán lacradas, selladas y rubricadas por el dueño o representante del género y selladas con el de la Autoridad. Una de estas partes quedará en poder del dueño del establecimiento para su garantía y comprobación en caso necesario.

Art. 208. Cualquier particular podrá exigir del expendedor, bajo la pena impuesta por esta Ordenanza, que se divida una muestra de la mercancía en tres partes, que serán lacradas y rubricadas, y una factura en que conste la naturaleza y precio de la misma, manifestando precisamente que su objeto es pedir el análisis del género en el Laboratorio municipal. De las tres muestras quedará una en poder del dueño, otra se reservará el comprador y la tercera será remitida al Laboratorio.

Art. 209. Para efectuarse el análisis deberá el interesado consignar su nombre, profesión y domicilio, así como las señas del establecimiento de donde proceda la muestra, y manifestará á la vez si el análisis que solicita es cualitativo ó cuantitativo. Hecho el análisis, se expedirá al interesado una certificación, en la cual se exprese si la substancia es buena ó mala, y en este último caso, alterada ó adulterada, nociva ó no á la salud.

Art. 210. En el caso de que resultase de malas condiciones la sustancia alimenticia, se dará aviso por el Laboratorio al Teniente de Alcalde del distrito correspondiente antes de expedirse la certificación al interesado, a fin de que se tome oficialmente una muestra igual en el establecimiento de su procedencia para comprobar el hecho.

Art. 211. Si de esta comprobación resultase que la substancia es mala (alterada o adulterada), impondrá la Autoridad al dueño del establecimiento la pena que corresponda, exigiéndosele además el pago de los derechos del análisis, según tarifa municipal, y devolviéndose al comprador la cantidad que hubiere satisfecho en este concepto.

Art. 212. Las certificaciones expedidas por el Laboratorio municipal a los particulares llevarán la numeración correlativa, pero no se consignarán en ellas las señas ni el nombre del dueño del establecimiento. Las certificaciones particulares no podrán en ningún caso utilizarse más que para la reclamación administrativa. 
Art. 213. No se podrá exigir el análisis de substancias alimenticias que, después de adquiridas en establecimientos públicos, hayan sufrido cualquier preparación de parte del comprador, en su domicilio o fuera del establecimiento.

Art. 214. El reconocimiento cualitativo del pan, carne, pescado, leche, aceite, vino y aguardiente, se hará gratis en el Laboratorio municipal a todo particular que presente la muestra en la oficina, debiendo, sin embargo, entenderse que, en caso de que se solicite certificación, deberá ajustarse a las condiciones y pago de los derechos prescriptos anteriormente.

Art. 215. El Laboratorio municipal ejecutará, además, por iniciativa propia y en cuanto lo permita su presupuesto, los reconocimientos que considere oportunos para vigilar las condiciones higiénicas de los alimentos, condimentos, bebidas y cuanto pueda afectar á la salubridad, participando al Alcalde el resultado de todas sus investigaciones, a fin de que adopte las medidas que considere del caso.

Art. 216. Se prohíbe la adulteración de las substancias alimenticias, así como la exposición y venta de las adulteradas, alteradas, corrompidas, y en general, de toda substancia que ofrezca malas condiciones higiénicas.

Art. 217. No podrá emplearse en las pastas, confituras, conservas y otros alimentos, así como en los condimentos y bebidas, materias colorantes o no colorantes, conservativas o de otra índole, que sean nocivas a la salud.

Art. 218. Asimismo se prohíbe la mezcla de substancias inertes que alteren la calidad o naturaleza del alimento o bebida, aun cuando no sean nocivas a la salud. En el caso de que en una pasta, masa o bebida se introduzcan algunas substancias no nocivas, pero que, por la semejanza de su naturaleza con alguna de las componentes, rebaje o altere la cualidad del alimento en su composición, deberá consignarse esta circunstancia, cualquiera que sea el motivo que haya inducido a la introducción de aquellas substancias no comprendidas en el nombre genérico de la pasta o de la bebida

Art. 219. No podrá venderse ninguna substancia alimenticia con nombre que indique origen, naturaleza o calidad diferente a la que en realidad tenga, cuyo nombre pueda inducir a engaño o preparar y realizar un fraude, aun cuando en la mezcla existan algunos principios o productos del origen y naturaleza indicados en la muestra ó rótulo de la mercancía.

Art. 220. Ningún expendedor podrá alegar ignorancia acerca de la calidad de sus géneros, toda vez que puede comprobarla, como todos los habitantes de la Villa, en el Laboratorio Químico-micrográflco de análisis y comprobación que tiene establecido el Ayuntamiento.

Art. 221. Las certificaciones expedidas por el Laboratorio Químico municipal no garantizan la bondad y calidad real de la mercancía expuesta al público, por cuantos 
dichos documentos se refieren única y exclusivamente a las muestras presentadas en el Laboratorio, las que quedarán numeradas, lacradas y selladas en depósito como garantía para su comprobación, en caso necesario.

Art. 222. Toda substancia que haya sido calificada de adulterada, alterada ó mala, en general, sea o no directa o inmediatamente nociva, y la que haya resultado falta del peso correspondiente, será decomisada y retirada de la venta pública por la Autoridad respectiva, destinándola a establecimientos de beneficencia si, previo dictamen pudiera utilizarse, y en otro caso será inutilizada, después de haber oído en ambos casos los descargos o reclamaciones del interesado.

Art. 223. En todo establecimiento público habrá medidas, básculas y pesos contrastados para la venta y para la comprobación que exija cualquier interesado. (Melgosa Olaechea, 1912, pp. 46-48)

Acerca de la necesidad de intervención contra el fraude y adulteraciones alimenticias, se celebró en París el Segundo Congreso internacional para la represión de fraudes alimenticios, que tuvo lugar entre los días 17 al 24 de octubre de 1909. Las repercusiones de las conclusiones a las que llegaron en esta cita, suscitaron preocupación a la vista de algunos, en la medida en que se acusaba de tomar acuerdos contrarios a lo que pudiera considerarse como una buena higiene alimentaria. Así lo describe Melgosa Olaecha en su obra "Las subsistencias en Madrid":

"Se autorizó, como operación regular, el empleo del sulfato de cobre para dar color verde á las conservas y al aceite de oliva, y mezclar éste con el de algodón, sésamo y otros de inferiores calidad y precio, sin más restricción que imponerles á los adulteradores la obligación de denominar á estas mezclas, aceites de mesa. En las confituras se consiente también el empleo de esta sal, así como el de aceites y grasas minerales, ácido acético, bicarbonato de sosa, alumbre; para la mantequilla, el bórax; el empleo de antisépticos en los vinos, sidras, cervezas, vinagres, á pesar de ser sabido que el empleo de los antisépticos en la alimentación ha sido siempre prohibido, por entenderse que aquéllos producían graves perjuicios en los fenómenos de la digestión y asimilación, por oponerse á la acción regular y fisiológica de los fermentos digestivos, retardándolos ó impidiéndolos, dando lugar á dispepsias y alteraciones gastrointestinales. $Y$ no concluiríamos, si continuásemos relatando las infinitas enormidades acordadas en este Congreso, que adquirirá por ello triste fama. (Melgosa Olaechea, 1912, p. 80) 
Las disposiciones descritas en estos párrafos suponen una manifestación palpable de la preocupación y de la necesidad de regulación de la calidad de los alimentos y bebidas desde finales del siglo XIX, con el objetivo de garantizar la salud e higiene públicas.

\subsubsection{Los peritos veterinarios y los peritos químicos del laboratorio}

La práctica del servicio técnico del Laboratorio se llevaba a cabo en el Interior del Laboratorio y en el exterior, mediante visitas a tiendas, fielatos, mercados y estaciones, entre otros establecimientos. Además, como se ha señalado, la inspección se llevaba a cabo por dos grupos de profesionales, con competencias reguladas en los artículos $10 \mathrm{y}$ 11 del Real decreto de 22 de Diciembre de 1908, dictado previo informe del Real Consejo de Sanidad (Melgosa Olaechea, 1912, p. 41), los Inspectores Veterinarios y los Inspectores Químicos. 
Gráfico 7-6. Funciones de los Inspectores veterinarios y los Inspectores químicos.

\begin{tabular}{|c|c|}
\hline \multirow{6}{*}{$\begin{array}{l}\text { Funciones de } \\
\text { los } \\
\text { Inspectores } \\
\text { Veterinarios }\end{array}$} & La inspección en los mataderos. \\
\hline & $\begin{array}{l}\text { La inspección en fielatos, estaciones y mercados de toda clase de carnes, pescados y demás } \\
\text { alimentos de origen animal, así como de las frutas, verduras y de la leche. }\end{array}$ \\
\hline & $\begin{array}{l}\text { La inspección de las carnes, caza, aves, pescados, embutidos y leche expendidas en toda clase de } \\
\text { establecimientos y puestos, así como de las verduras y frutas. }\end{array}$ \\
\hline & $\begin{array}{l}\text { La inspección de las mondonguerías, casquerías, fábricas de escabeche y de embutidos y de } \\
\text { establecimientos ó casas que, sin ser fábricas, se dedican á la elaboración y comercio de éstos. }\end{array}$ \\
\hline & La inspección de cabrerías, encierros de ovejas y cuadras de burras de leche. \\
\hline & $\begin{array}{l}\text { La inspección de vaquerías, comprendiendo: } \\
\text { 1) El reconocimiento, reseña y contraseñado de las reses que se encuentren estabuladas en todos } \\
\text { los establecimientos y de las que se trate de estabular. } \\
\text { 2) La vigilancia de las condiciones de los alimentos que se empleen en cada vaquería para la } \\
\text { nutrición de las reses, así como sobre el cumplimiento de la higiene en los establos. } \\
\text { 3) La aplicación de los medios de diagnóstico que la ciencia aconseje para comprobar el estado de } \\
\text { sanidad de las reses. } \\
\text { 4) El estudio de la normalidad en la producción de la leche. }\end{array}$ \\
\hline
\end{tabular}

La inspección de paradores donde se albergue ganado de matadero ó productor de leche.

La inspección en las fondas, casas de comidas, bodegones, cafés, etc., de las carnes, aves, pescados, caza, embutidos; de las frutas y verduras.

La inspección en los desolladeros y fábricas de aprovechamiento de animales muertos.

\section{Funciones de La inspección y vigilancia en las fábricas de alimentos y bebidas, en cuanto concierneá éstos. \\ los \\ Inspectores \\ químicos}

La inspección y vigilancia en los almacenes, tiendas y puestos donde se venda toda clase de productos alimenticios, excepto las carnes, aves, pescados y demás alimentos procedentes del reino animal, de las frutas y de las verduras.

La inspección y vigilancia de las fondas, cafés, cafetines, cervecerías, horchaterías, establecimientos de gaseosas y de bebidas refrescantes.

La inspección de la fabricación y venta de utensilios de cocina, por lo que respecta á los barnices y esmaltes, así como de las fábricas de papel de estaño, cápsulas metálicas, utensilios, vasijas y envases metálicos.

La vigilancia de la potabilidad y pureza de las aguas en las fuentes públicas.

Dispone, además, de un gabinete de inspección en el mercado de los Mostenses, de otro en cada una de las estaciones de ferrocarriles, y de otro en cada uno de los Mataderos.

Fuente: Elaboración propia. Información de Las subsistencias en Madrid (Melgosa Olaechea, 1912, pp.

41-42). 


\subsubsection{Número de inspección de subsistencias}

Atendiendo a las visitas realizadas en los establecimientos y de los resultados obtenidos, a continuación se muestran las visitas realizadas y las muestras tomadas, así como el número de inutilizaciones y denuncias recibidas por Distritos, para los años 1917 y 1932.

Gráfico 7-7. Visitas realizadas a los establecimientos por los inspectores químicos y veterinarios en los años 1932 y 1917 por Distritos.

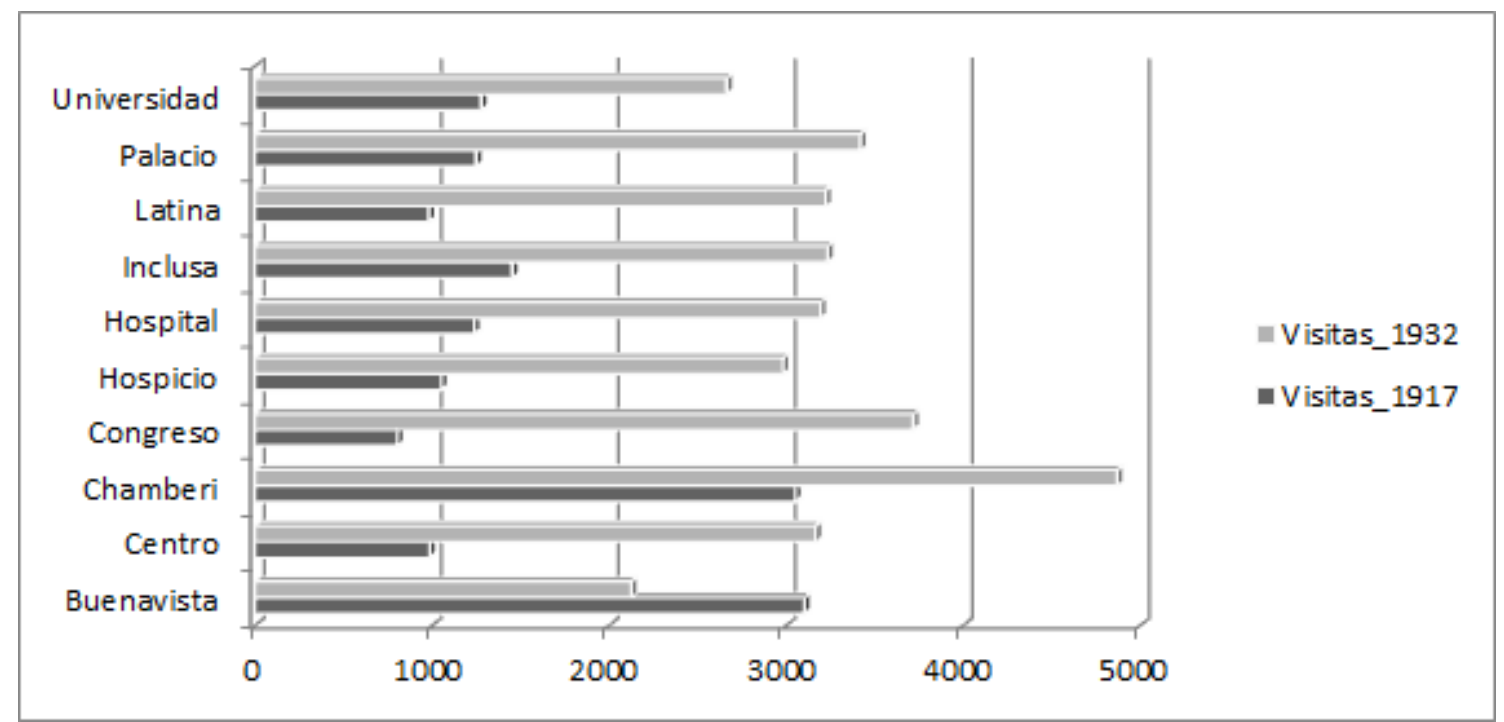

Fuente: elaboración propia (Chicote del Riego, 1918; García Revenga, 1933)

Respecto al número de muestras tomadas en los establecimientos, cabe destacar el incremento de éstas en 1932 respecto al año 1917 en todos los distritos de la ciudad a excepción de Buenavista. Resulta especialmente notorio el incremento de muestras recogidas en los distritos de Universidad y Chamberí durante el año 1932. 
Gráfico 7-8. Muestras tomadas en los establecimientos por los inspectores químicos y veterinarios en los años 1932 y 1917 por Distritos.

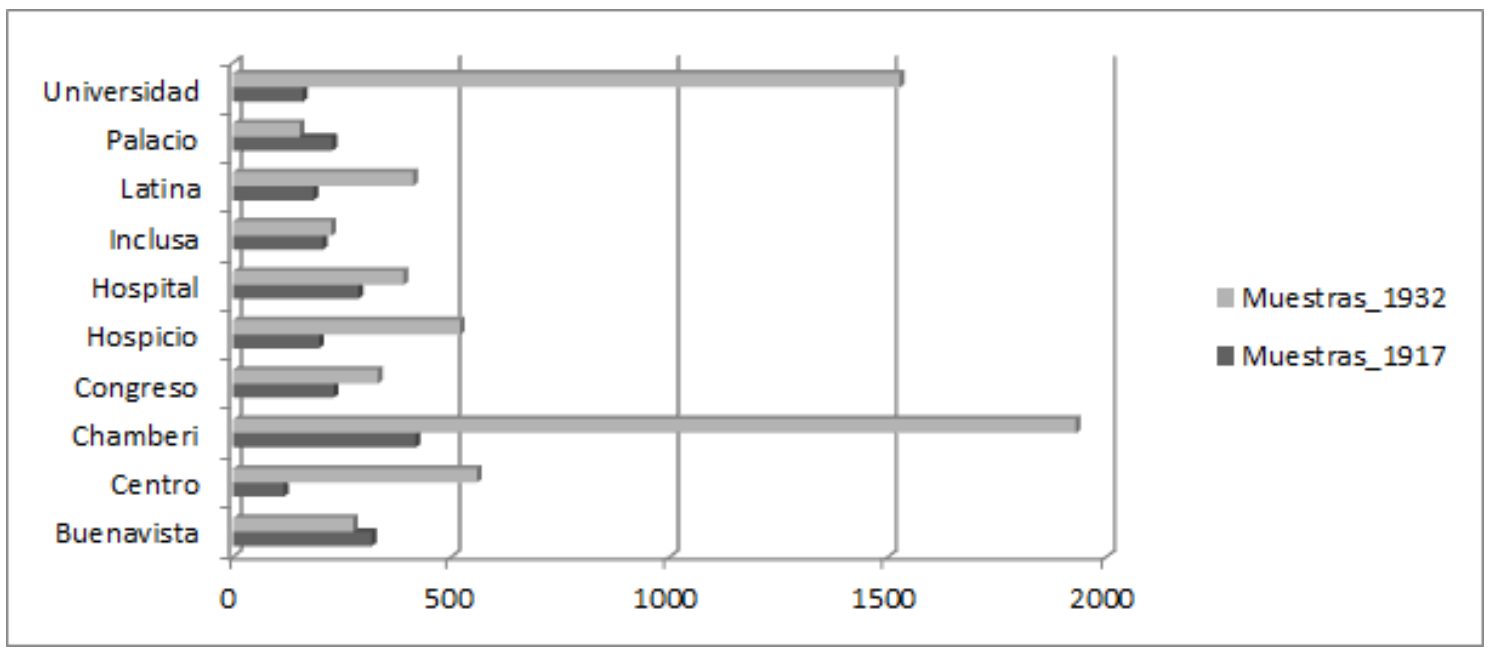

Fuente: elaboración propia (Chicote del Riego, 1918; García Revenga, 1933)

Atendiendo al número de inutilizaciones, la relación es inversa respecto al número de muestras tomadas y el número de visitas realizadas en los distritos, de modo que éstas se ven claramente disminuidas en 1932 respecto a 1917. Este hecho puede corresponderse con la eficacia de las medidas de control de sustancias.

Gráfico 7-9. Inutilizaciones realizadas en los establecimientos en los años 1932 y 1917 por Distritos.

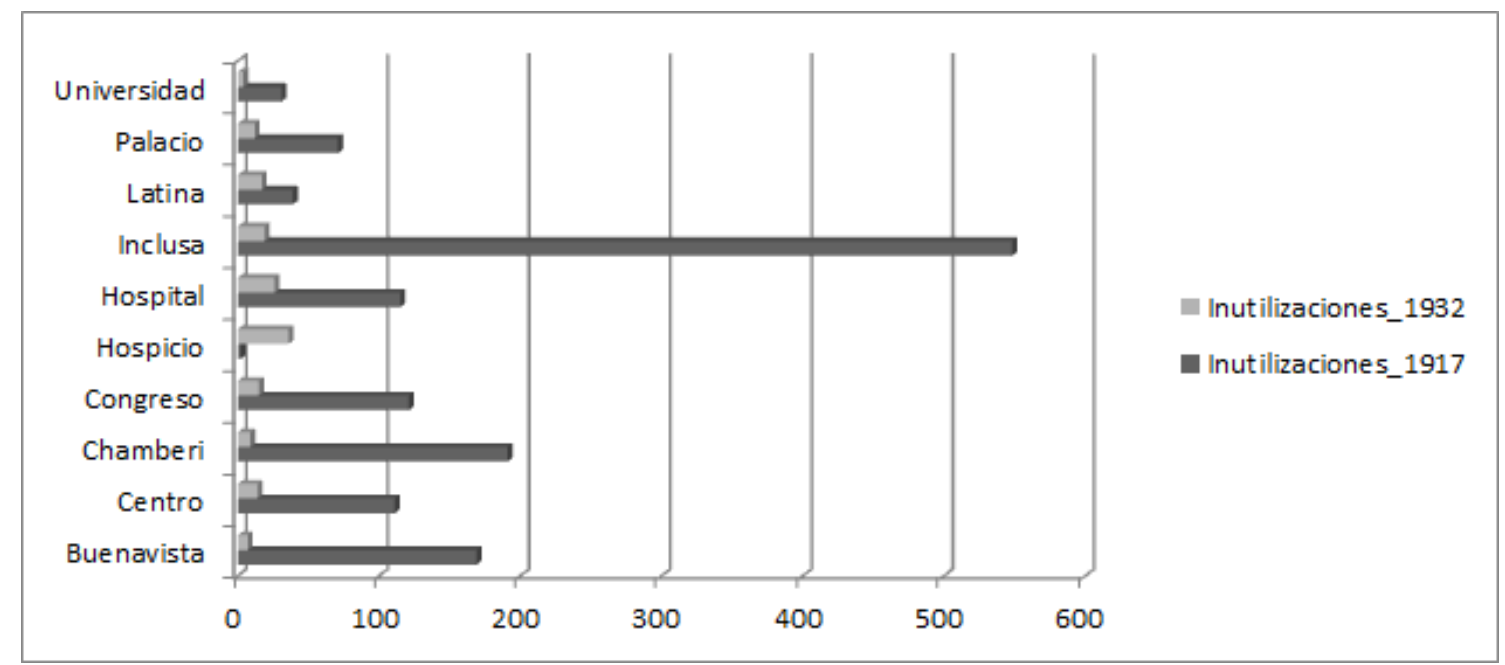

Fuente: elaboración propia (Chicote del Riego, 1918; García Revenga, 1933)

Otro aspecto reseñable es el incremento de denuncias a los establecimientos durante el año 1932. La concienciación general ante la necesidad de que los establecimientos tuvieran unos mínimos de higiene que correspondieran a los preceptos de la seguridad 
alimentaria, puede verse claramente representada por el número aumento de denuncias llevadas a cabo.

Gráfico 7-10. Denuncias realizadas a los establecimientos en los años 1932 y 1917 por Distritos.

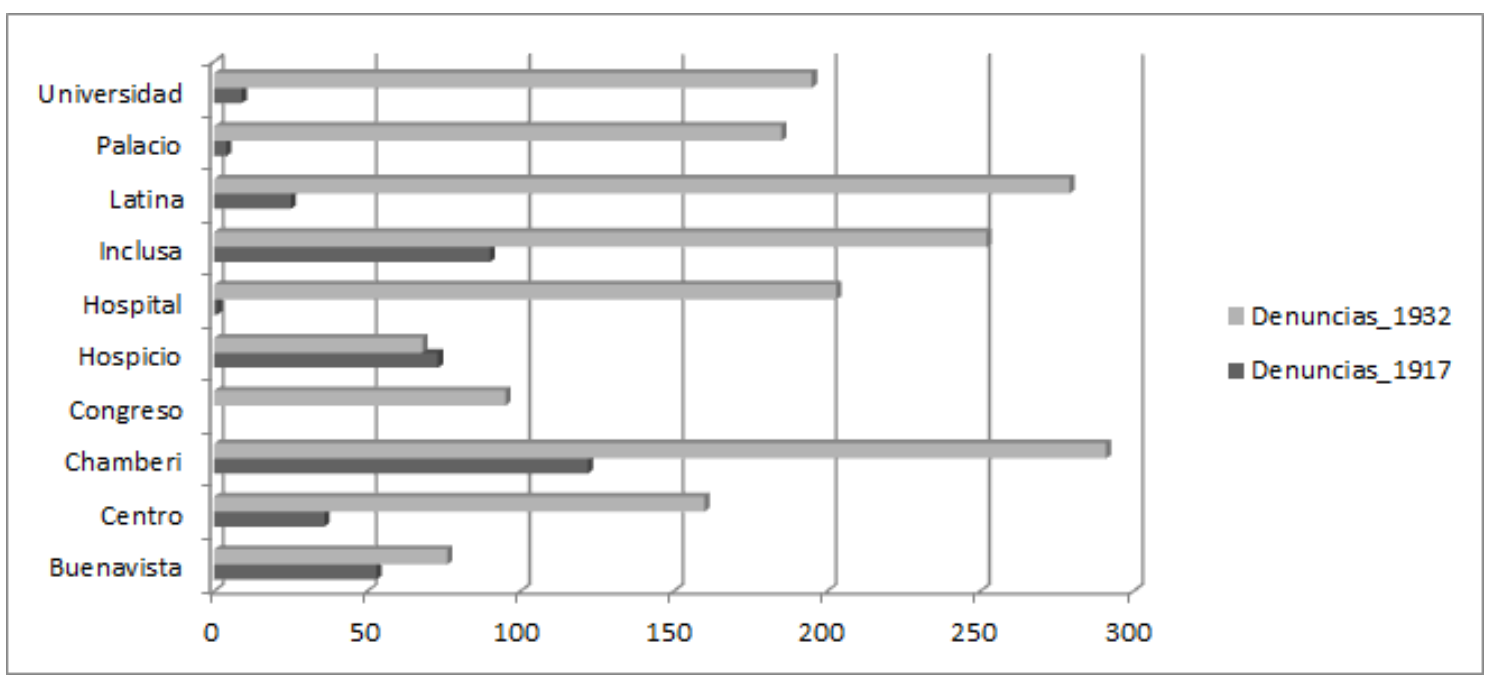

Fuente: elaboración propia (Chicote del Riego, 1918; García Revenga, 1933)

\subsubsection{Mercados de abastos en la ciudad}

En 1929 existían cuatro mercados ubicados en espacios cerrados, cinco en espacios abiertos y un buen número de mercados callejeros en las zonas aledañas a la ubicación de los anteriores.

(...) Todos ellos, insuficientes para el abastecimiento de Madrid, anticuados la mayor parte en su disposición y mal dotados de servicios higiénicos, han dado origen al estado de cosas actual, verdaderamente inadmisible, de los mercados callejeros en las calles de Santa Isabel, Torrecilla del Leal, Ruda, Lavapiés, Vistillas, Corredera de San Pablo e inmediaciones de todos los mercados citados. (Ayuntamiento de Madrid, 1929, p. 124) 
Imagen 7-11. Fotografía de los puestos de venta contiguos al Mercado de Santa Isabel.

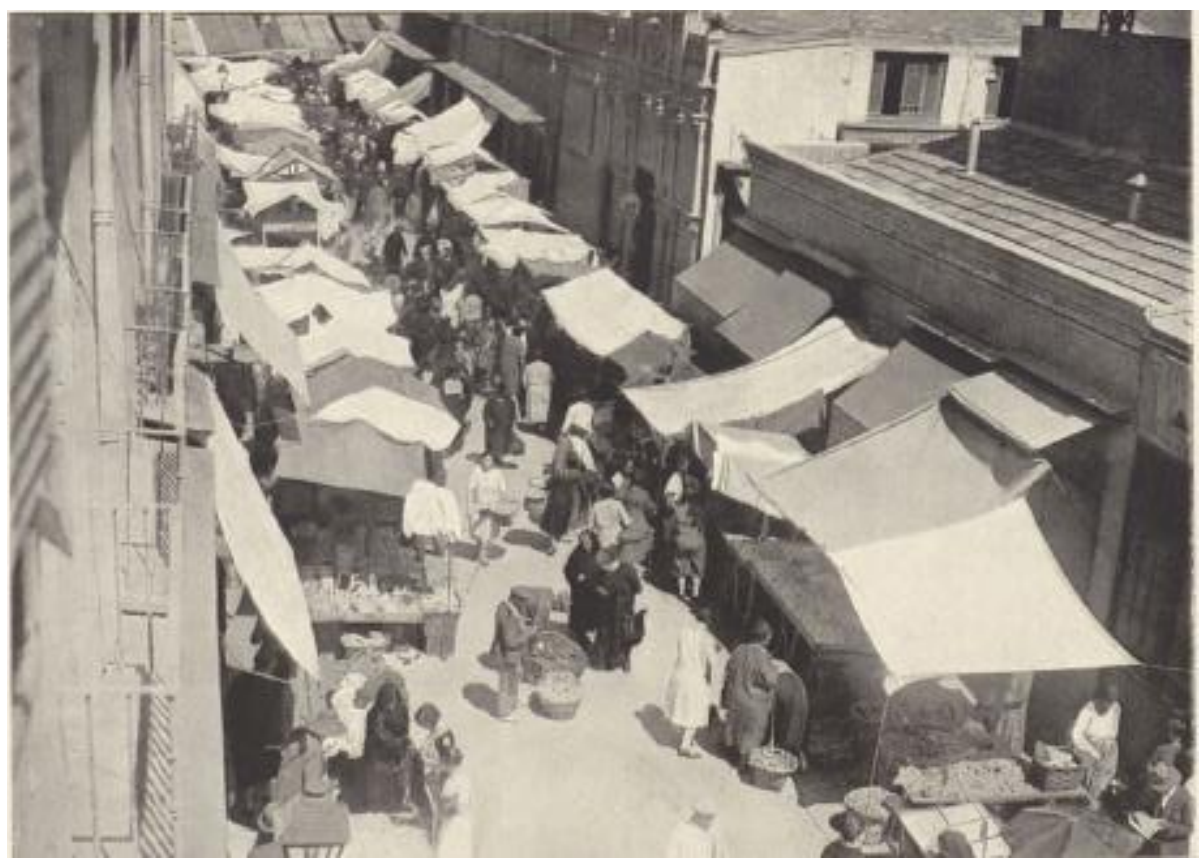

Fuente: (Ayuntamiento de Madrid, 1929, p. 125)

El tema relacionado con los mercados no sólo tuvo que ver con la necesidad de inspección de las sustancias alimenticias, sino también con el abastecimiento en la ciudad, siendo objeto de preocupación y de difícil solución desde el ámbito higiénico.

En el gráfico siguiente, se muestra la relación de mercados que, en 1929, el Ayuntamiento tenía pensado regular en corto espacio de tiempo. Para ello, había aprobado las obras de los mismos y un empréstito para su realización. Con estos nuevos proyectos sobre los mercados se pretendía “(...)dotar a Madrid de diez mercados de distrito, con todas las condiciones exigidas a esta clase de establecimientos y de tipos cerrados, para evitar el estado actual, en que por estar abiertos extienden su radio de acción a las calles a ellos alluentes, entorpeciendo el tráfico y constituyendo un verdadero foco de infección” (Ayuntamiento de Madrid, 1929).

“También queremos consignar aquí, como procedimiento llamado a desaparecer desde el punto de vista higiénico, la venta ambulante, en la que por regla general y en artículos de primera necesidad se venden mercancías averiadas y a bajo precio, procedentes de los mercados y tiendas, cuya inspección se hace difícil "(Ayuntamiento de Madrid, 1929, p. 124). 


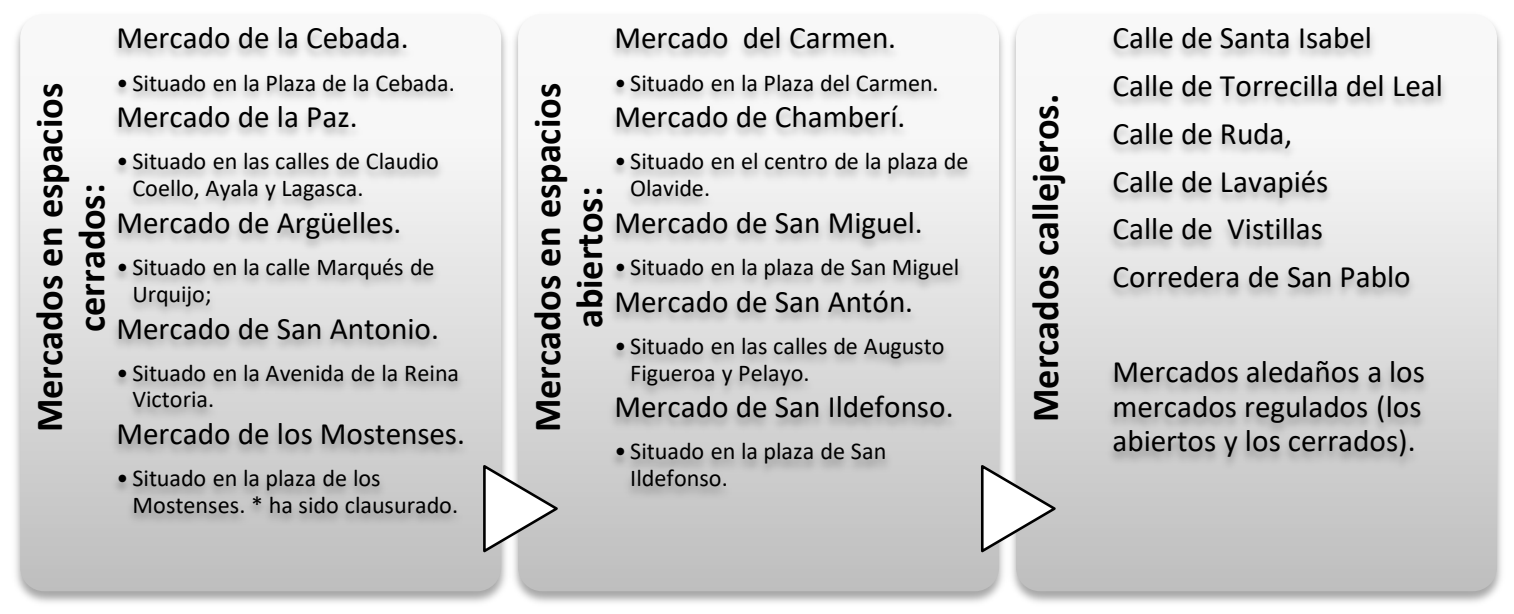

Fuente: elaboración propia. Información obtenida de (Ayuntamiento de Madrid, 1929)

\section{Gráfico 7-12. Mercados en proyección en 1929}

\section{Mercados en proyección. 1929.}

- Mercado de la Guindalera y Prosperidad.

- Situado en la calle de Cartagena

- Mercado delas Ventas

- Situado en el solar de las calles Bocángel y Pedro Heredia

- Mercado de Pardiñas.

- Situado en el solar de las calles de Narváez y Jorge Juan.

- Mercado de Antón Martín.

- Situado en el lugar ocupado hoy por varias construccione

de tipo de mercado rudimentario en las calles de Atocha,

Fernán Núñez y Santa Isabel.

- Mercado de Lavapiés.

- Situado en el solar de la plaza de Lavapiés, Valencia y

Argumosa.

- Mercado del Puente de Segovia.

- Situado en el centro de la plaza de Tirso de Molina.
- Mecado de Vallehermoso.

- Situado en el solar de las calles de Femando el Católico y Vallehermoso.

- Mercado de Chamberí.

- Situado en el solar de las calles de

Viriato y Alonso Cano.

- Mercado de Bravo Murillo.

- Situado en la Calle Bravo Murillo.

- Mercado de Hospicio.

- Situado en solar aún no decidido

- Mercado central de frutas y verduras.

- Situado en el solar municipal de la

izquierda del Puente de la Princesa.

- Mercado y matadero de aves.

- Situado contiguo al nuevo

Matadero.

Fuente: elaboración propia. Información obtenida de (Ayuntamiento de Madrid, 1929) 


\subsection{El servicio de defensa contra las enfermedades infectocontagiosas del laboratorio. Vacunas y servicio de desinfección}

\subsubsection{La vigilancia epidemiológica}

Resulta del todo destacable, especialmente teniendo en cuenta la reciente pandemia de COVID-19, la importancia de la disposición de un servicio de vigilancia epidemiológica, así como de legislación y mecanismo de actuación concernientes. En este sentido, hay que tener en consideración que el control de las enfermedades infecciosas y la vigilancia de enfermedades transmisibles fue materia legislada desde finales del siglo XIX en España. Asimismo, previo a lo que podría denominarse como política de control de las enfermedades, ya se llevaron a cabo mecanismos como el aislamiento, la cuarentena y /o la declaración de muertes y casos patológicos de enfermedad, con el objetivo de control de enfermedades infectocontagiosas.

Las Circulares del Ministerio de Gobernación, de manos de la Dirección General de Sanidad de 10 de octubre de 1900 (Gaceta de Madrid 286, de 13 de octubre de 1900) y la de 11 de mayo de 1901 (Gaceta de Madrid 134, de 14 de mayo de 1901) pueden considerarse como pioneras en cuanto a mecanismos de vigilancia de enfermedades. Mediante éstas, se dispuso que los médicos debieran dar parte a la Autoridad competente en aquellos casos en que tuvieran conocimiento de personas con enfermedades infectocontagiosas. Dichos partes, formarían los datos e información registrada para la elaboración de la Estadística Demográfico Sanitaria ${ }^{69}$.

La obligatoriedad de declaración de enfermedad, tuvo lugar con la Circular de 11 de mayo de 1901 (Gaceta de Madrid 134, de 14 de mayo de 1901), mediante la que se obligó a declarar la enfermedad de meningitis cerebro espinal endémica.

Posteriormente, por Real decreto de 31 de Octubre de 1901, del Ministerio de la Gobernación, se acordaron las medidas y precauciones que debían adoptarse en los casos que pudieran ocurrir enfermedades contagiosas. La importancia de este Real Decreto radica, en buena medida, en que, mediante el mismo, se impone la desinfección con carácter obligatorio. Regulado en el Artículo primero, se establece la obligatoriedad de declaración enfermedades contagiosas a la Autoridad Municipal de los enfermos de

\footnotetext{
${ }^{69}$ Para conocer más acerca de la Estadística Demográfico Sanitaria y otras fuentes en el contexto español, puede consultarse (Bernabeu-Mestre, 2007; RODRíGUEZ-OCAÑA \& Bernabeu-Mestre, 1997)
} 
peste, fiebre amarilla, cólera, lepra, viruela, sarampión, escarlatina, difteria, tifus, fiebre tifoidea y tuberculosis. Además, se señala que la autoridad competente, en caso de necesidad, podría extender la obligatoriedad de la declaración para otras enfermedades. En el artículo dos se señala el proceso a seguir para llevar a cabo la declaración obligatoria de la enfermedad infecciosa.

$1^{\circ} \mathrm{Al}$ Médico que presta la asistencia facultativa.

$2^{\circ} \mathrm{Al}$ jefe de la familia á quien pertenezca el enfermo; al individuo a cuyo nombre figure el empadronamiento de la casa donde éste habita, o al jefe superior del establecimiento, sea cualquiera la clase de éste: religioso, industrial, comercial, etc.

$3^{\circ}$ A la persona que cuide del enfermo.

Cualquiera otra persona puede hacer también esta declaración.

En el artículo 15 del Real decreto de 31 de Octubre de 1901, se especifica que "será obligatoria la desinfección de todos los cuartos desalquilados, los cuales no deben ser alquilados por el público sin que tengan en la puerta un sella municipal que acredite haber sido desinfectados convenientemente. Para cumplir esta desinfección, inmediatamente que se desalquile una vivienda, su propietario ó administrador pasará un oficio al Alcalde participándoselo y solicitando aquélla, la cual se practicará en el plazo más breve posible y que no exceda de cuarenta y ocho horas. Una vez practicada la desinfección, el jefe de ella entregará al interesado un documento que atestigüe haberla practicado y fijará en la puerta principal de entrada un sello que acredite la operación higiénica á que se ha sometida aquel domicilio”.

Otra fecha clave, no solo para el control de las enfermedades infecciosas, sino para el desarrollo de la legislación sanitaria en general, tuvo lugar en enero de 1904, momento en que fue decretada la Instrucción General de Sanidad, por Real Decreto de 12 de enero de 1904, (Gaceta de Madrid números 22 y 23, de 22 y 23 de enero de 1904). Mediante la misma, se estableció la obligatoriedad de declaración de las siguientes enfermedades infectocontagiosas: cólera, fiebre amarilla, tifus exantemático, disentería, fiebre tifoidea, peste bubónica, viruela, varioloide y varicela, difteria, escarlatina, sarampión, meningitis cerebro-espinal, septicemias, y, singularmente la puerperal, coqueluche, gripe y tuberculosis. Asimismo, se dispuso la obligación del inmediato 
aviso escrito de las enfermedades epidémicas, epizootias infecciosas o contagiosas en que interviniese.

\subsubsection{La ampliación de los servicios del laboratorio y la Sección de Epidemiología.}

La ampliación de los servicios del Laboratorio Municipal se produjo con el cambio de Dirección, en 1931. La centralización de los servicios fue una petición notoria durante la época de dirección del Doctor Chicote.

Será a partir del primero de noviembre de 1932, momento en que Juan García Revenga comenzó a ejercer la función de Director interino del Laboratorio, cuando se produce una proliferación de los servicios llevados a cabo, entre los que cabe destacar el traslado del centro de vacunación y profilaxis ubicado en la calle Olózaga número uno a la planta baja del propio Laboratorio, siendo los Médicos de la Sección de Epidemiología quienes, desde este momento, prestarían este servicio.

Como ya se ha citado más arriba, la epidemiología comenzó a tomar una fuerza sin precedentes, de manera que se hizo realmente palpable la necesidad de adoptar dicha ciencia como elemental a la hora de atender a las preocupaciones sobre la salud de la población, especialmente debido a la mortalidad producida por las enfermedades infectocontagiosas. Así lo relataba Revenga en su Memoria sobre los trabajos desempeñados por el Laboratorio Municipal, en referencia a la importancia de disponer de una Sección de Epidemiología dentro del mismo :

"Se ha reorganizado también esta última Sección, pues convencida esta Dirección de que entre las funciones de mayor importancia de los Municipios está la de salvaguardar la salud de los vecinos de su jurisdicción con la adopción de todas cuantas medidas sean conducentes a este fin, y siendo las enfermedades infectocontagiosas uno de los mayores motivos de mortalidad, no tan sólo cuando existen en estado epidémico, sino también en estado endémico, claro está que todo Ayuntamiento cuidadoso de sus funciones ha de considerar como atención primordial -y así lo estima el de Madrid-el establecimiento, dentro de los servicios del Laboratorio, de una Sección de Epidemiología" (García Revenga, 1933, p. 9).

En este sentido, la Sección de Epidemiología, debía disponer de los siguientes elementos para llevar a cabo sus labores, tal y como se refleja en el gráfico 7-13. 


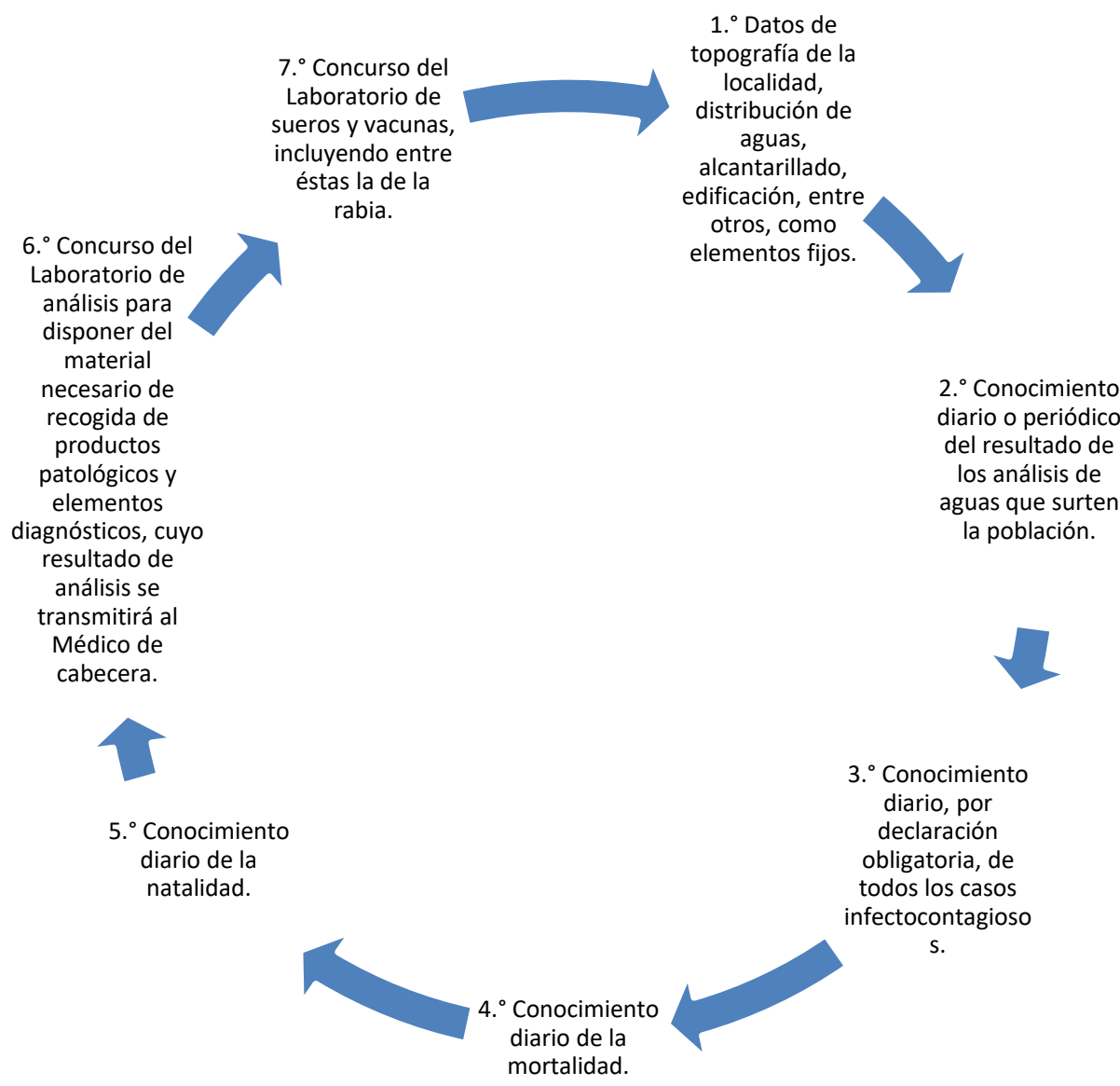

Fuente: Elaboración propia a partir de información extraída de (García Revenga, 1933, p. 13).

Si bien, con anterioridad, el Laboratorio Municipal otorgó importancia a la profilaxis de las enfermedades infectocontagiosas, fue a partir de 1931, con la creación de una sección independiente, cuando la Epidemiología cobró una suma importancia como elemento indispensable a la hora de atender a la salud y al saneamiento de la población madriñeña. La finalidad principal de dicha sección era la atención a la profilaxis de las enfermedades infecciosas, mediante servicios tales como comprobación de las enfermedades infectocontagiosas, mecanismos de desinfección, desinsectación y desratización y el servicio de ambulancias sanitarias. Asimismo, se encargaría de llevar a al día la estadística de morbilidad y mortalidad por enfermedades infectocontagiosas y la puesta en marcha y organización de otras medidas sanitarias profilácticas como la vacunación contra la fiebre tifoidea, la viruela, o la difteria, entre otras enfermedades.

La Sección de Epidemiología estaba compuesta por un Jefe Médico, un Profesor, un Jefe facultativo del Parque, un Auxiliar técnico del Parque, diez Médicos epidemiólogos y Auxiliares de oficina y el servicio de Policía sanitaria. El Jefe Médico era el 
responsable de los servicios de la Sección, bajo órdenes del Director del Laboratorio. Por su parte, el Jefe facultativo del Parque era el encargado de los servicios de desinfección, desinsectación, desratización, y las ambulancias sanitarias, con asistencia técnica del Auxiliar técnico del Parque, bajo mando del Jefe Médico de la Sección de Epidemiología. También se encargaba de la instrucción de nuevo personal de servicios. Por último, pero no menos importante, el cuerpo de Médicos epidemiólogos se encargaban del servicio domiciliario y el de vacunación preventiva infectocontagiosa. Este servicio de Médicos epidemiólogos atendía no sólo las necesidades del momento, sino también recibía preparación técnica específica con el objetivo de prepararse para posibles epidemias, quedando bajo dirigencia del Jefe de Sección (García Revenga, 1933, pp. 13-14).

\subsubsection{El funcionamiento de la Sección de Epidemiología.}

Ante una declaración de caso de enfermedad infectocontagiosa, una vez recibida la notificación de la misma a la Sección de Epidemiología, se ordenaba una visita al domicilio de la persona afectada por parte de un Médico Epidemiólogo, bajo rellenado y firma del formulario que se adjunta (hoja número 1, imagen 7-12). Una vez en el domicilio de la persona enferma, el Médico empleaba los métodos adecuados para cada caso (bien analíticos o de otra clase) con el objetivo de comprobar el diágnostico de enfermedad y adoptar las medidas adecuadas, rellenado nuevamente un formulario adicional al primero (hoja número dos, imagen 7-13), que debía ser aprobado por el Médico de cabecera del enfermo. Una vez realizado este procedimiento, se concertaba un periodo de veinticuatro horas para que el Médico de cabecera remitiera nuevamente a la Sección de Epidemiología del Laboratorio la hoja número tres (Imagen 7-14), debiéndose indicar los ítmes señalados y realizar las vacunaciones requeridad para cada caso particular o, como alternativa, se indicaría si el enfermo debía asistir a vacunarse en el Centro de Vacunación. También se indicaba si era necesario un traslado del enfermo, la desinfección en el Parque u otros servicios. 
Imagen 7-12. Modelo de formulario del Laboratorio Municipal. Sección de Epidemiología (Hoja número uno)

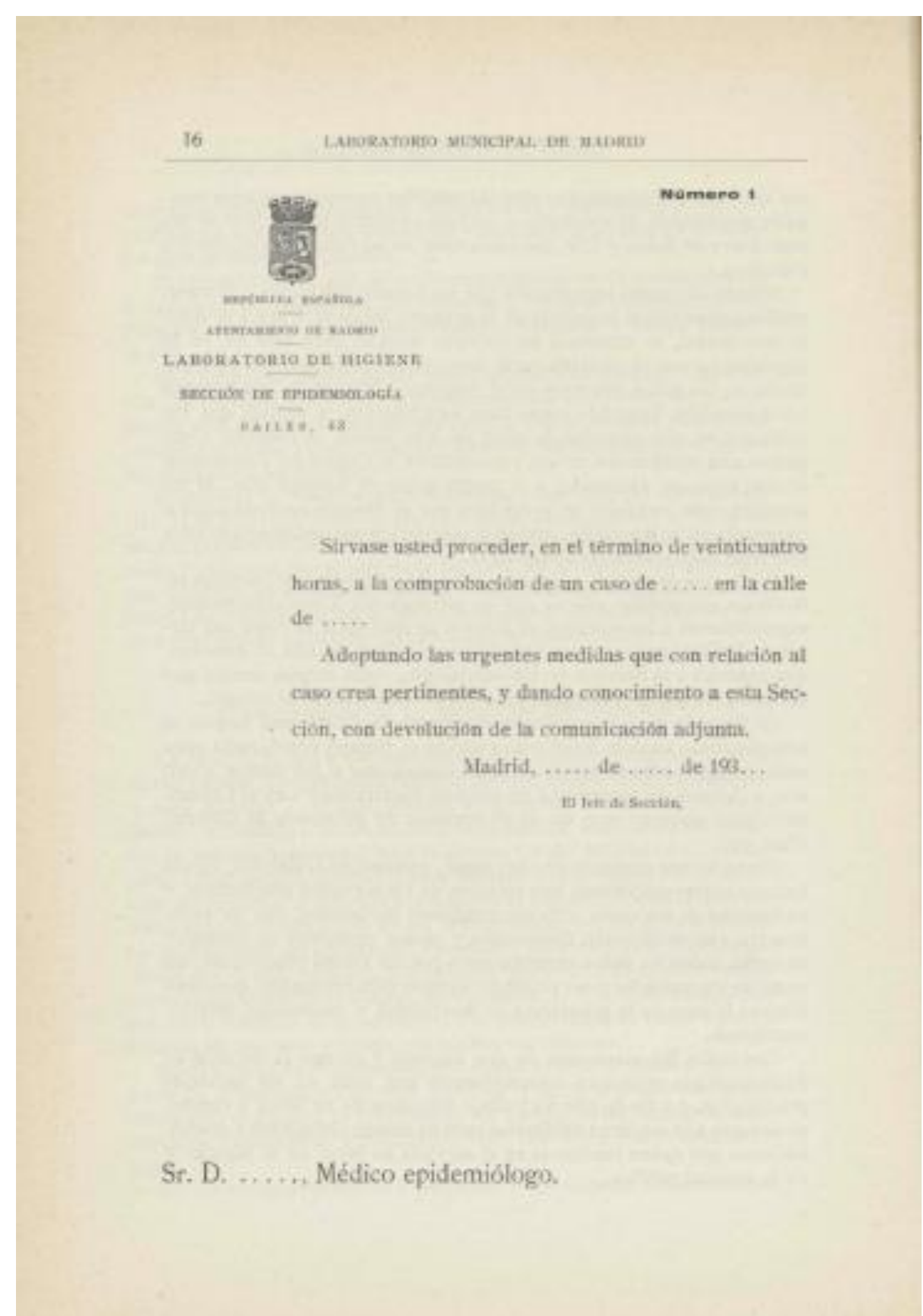

Fuente: (García Revenga, 1933, p. 16) 
Imagen 7-13. Modelo de formulario del Laboratorio Municipal. Sección de Epidemiología (Hoja número dos) ${ }^{70}$

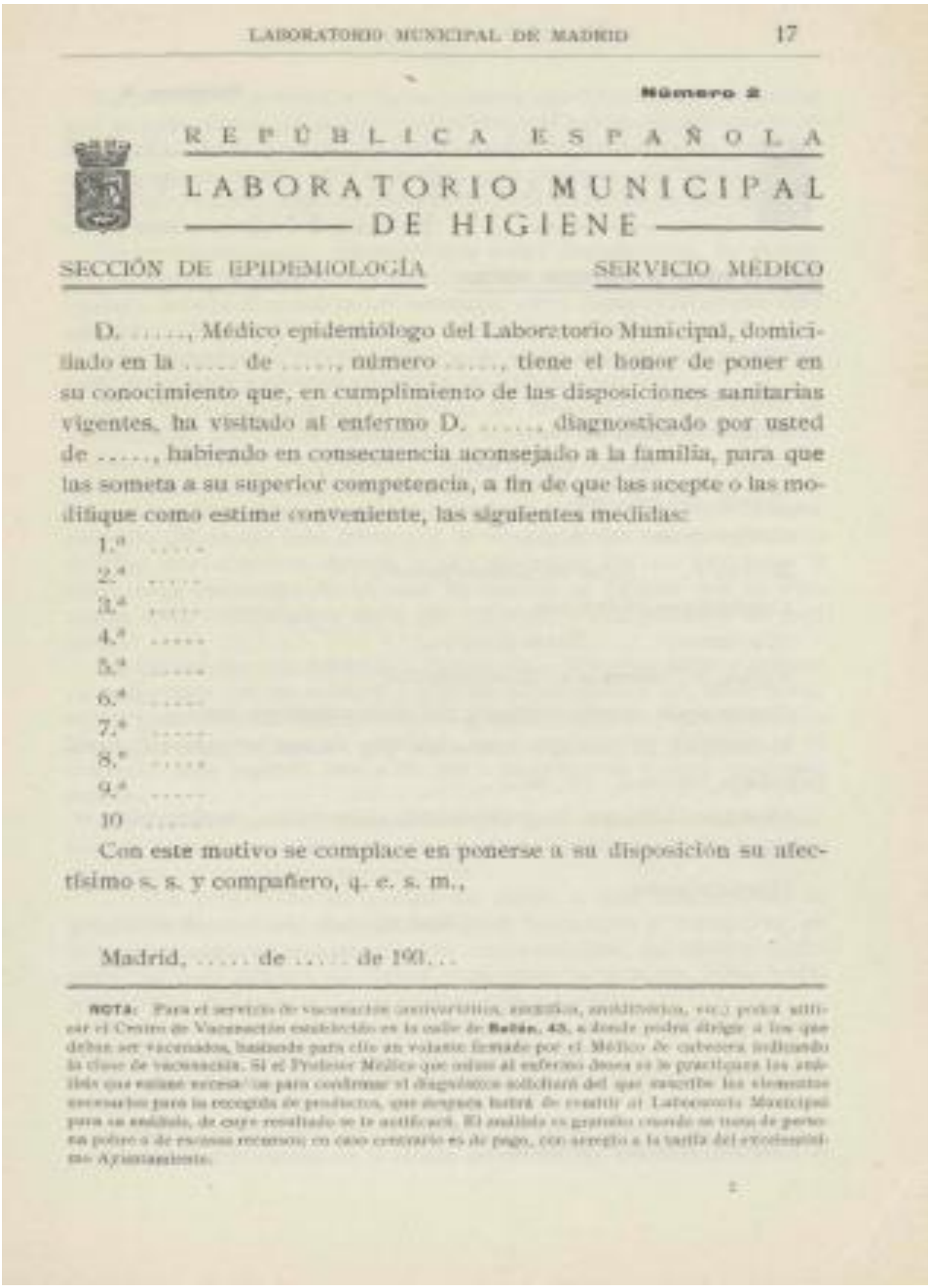

Fuente: (García Revenga, 1933, p. 17)

${ }^{70}$ NOTA: Para el servicio de vacunación antivariólica, antitífica, antidiftérica, etc.) podrá utilizar el Centro de Vacunación establecido en la calle de Bailen, 43, a donde podrá dirigir a los que deban ser vacunados, bastando para ello un volante firmado por el Médico de cabecera indicando la clase de vacunación. Si el Profesor Médico que asiste al enfermo desea se le practiquen los análisis que estime necesarios para confirmar el diagnóstico solicitará del que suscribe los elementos necesarios para la recogida de productos, que después habrá de remitir al Laboratorio Municipal para su análisis, de cuyo resultado se le notificará. El análisis es gratuito cuando se trata de persona pobre o de escasos recursos; en caso contrario es de pago, con arreglo a la tarifa del excelentísimo Ayuntamiento. (García Revenga, 1933, p. 17) 
Imagen 7-14. Modelo de formulario del Laboratorio Municipal. Sección de Epidemiología (Hoja número tres)

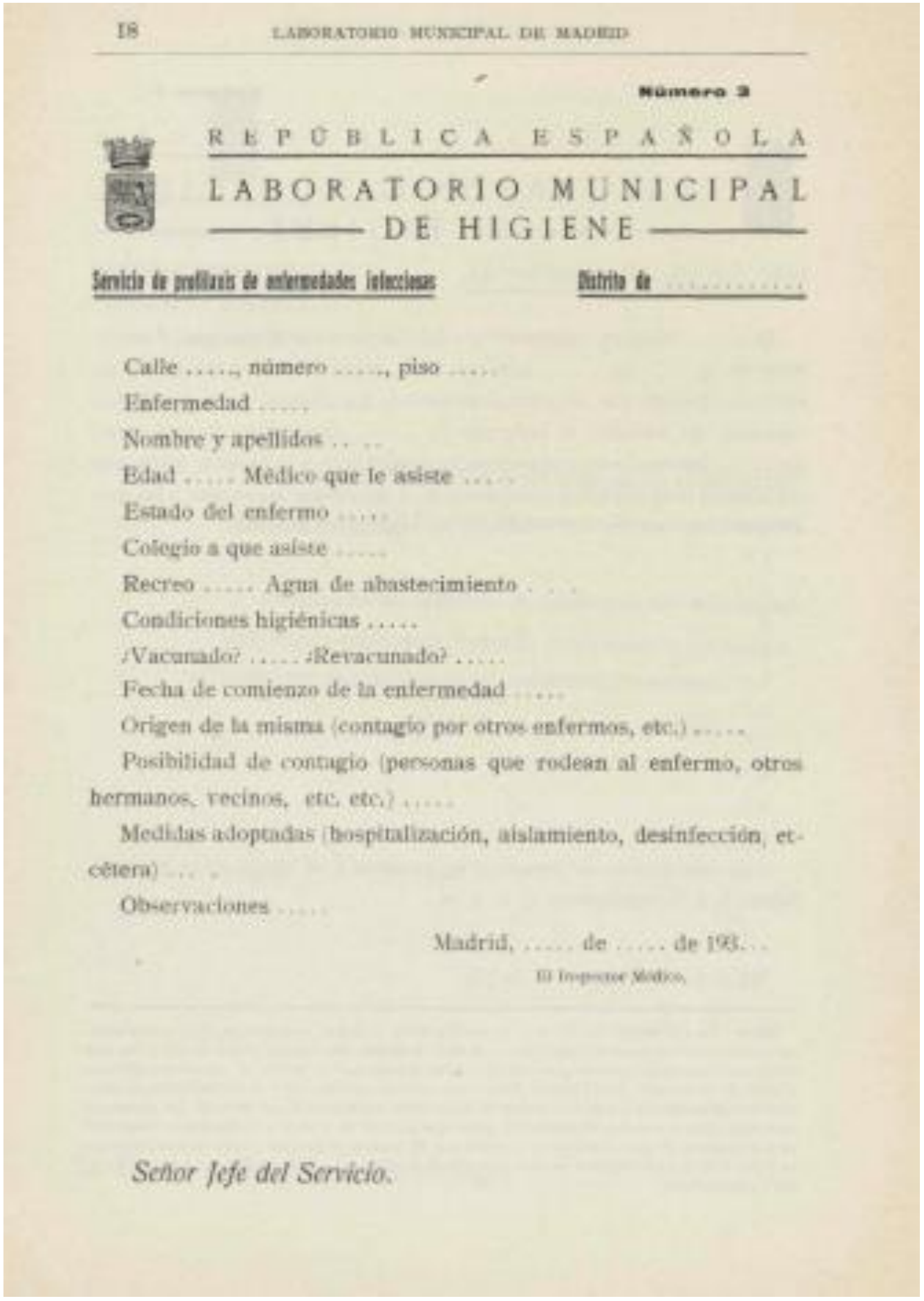

(García Revenga, 1933, p. 18). 


\subsection{El servicio de vacunación como medida profiláctica contra las enfermedades infecciosas}

El Laboratorio Municipal de Madrid, al igual que sus coetáneos en otras ciudades europeas y españolas, no sólo centró sus objetivos en el análisis de las sustancias de consumo de la población. También se erigió como institución clave en la lucha contra distintas enfermedades epidémicas, así como una institución elemental en la organización de servicios de medidas profilácticas contra las enfermedades infecciosas que se sufrían en la capital. Un ejemplo de las primeras, fueron las campañas llevadas a cabo por el Laboratorio Municipal de Madrid cuando, en los años 1903 y 1909, Madrid sufrió un brote de tifus exantemático (De Miguel Salanova, 2017), enfermedad bacteriana propagada por piojos o pulgas (no confundir con la fiebre tifoidea/tifus abdominal). En aquellos años, se producía un desconocimiento de la etiología de la enfermedad, por lo que se abogó por medidas preventivas que se basaron en la desinfección de los focos epidemiológicos y la llevada de enfermos para su aislamiento a los hospitales de la ciudad. Otro episodio destacable de la actividad del Laboratorio fue durante la epidemia de la Gripe española en 1918 (Porras Gallo, 1994; María Isabel Porras Gallo, 2002; Ramiro, Garcia, Casado, Cilek, \& Chowell, 2018). Pese a las labores llevadas a cabo durante la epidemia, los esfuerzos resultaron del todo insuficientes, dada la elevada demanda de los servicios. Sin embargo, las contribuciones del Laboratorio en materia de tratamiento, profilaxis y diagnóstico de la gripe fueron, sin duda, importantes (Porras Gallo, 1997).

Tal y como ha sido mencionado en líneas precedentes, el Laboratorio Municipal de Madrid, también ejerció funciones de ente asistencial en momentos en que, sin existir un embate epidémico, la ciudad sufría brotes importantes de alguna enfermedad infectocontagiosa. La lucha contra las denominadas "enfermedades evitables" fue un continuum durante el primer tercio del siglo $\mathrm{XX}$ en la capital. Por su relevancia posterior, cabe destacar los trabajos de esta institución como pionera en estudios experimentales sobre las vacunas bacterianas contra el cólera, la fiebre tifoidea o la tuberculosis. La vacuna anticolérica comenzó a experimentarse en el Laboratorio desde 1912. A partir de 1911, comenzaron a investigarse los medios profilácticos contra la fiebre tifoidea con la vacuna antitífica, fruto del embate sufrido en la capital en ese mismo año. Respecto a la vacuna contra la tuberculosis, fue dispuesta en 1914, fruto de 
los esfuerzos para paliar el impacto de esta enfermedad, que asolaba con especial fuerza los barrios populosos.

El Laboratorio Municipal de Madrid también se encargó de otra tipología de vacunas, como la antirrábica. Cabe destacar el gran conocimiento del que disponía el Doctor Chicote en esta materia, fruto de sus estancias en el Instituto Pasteur de París (De Miguel Salanova, 2018, p. 179). En esta materia, los veterinarios del laboratorio tuvieron una importancia primordial, en la medida en que eran los encargados de la recogida de muestras y la vigilancia de los animales con indicios de sufrir hidrofobia. El servicio de alertas sobre animales sospechosos de estar infectados, estaba, también, a disposición de los particulares y era gratuito para personas de escasos recursos económicos.

Una de las campañas más importantes llevadas a cabo fue la ejercida contra la difteria, enfermedad que representaba una proporción importante de la mortalidad infantil. El Laboratorio participó como actor activo en diferentes campañas de prevención, la preparación de sueros y, como venía siendo habitual, con labores de desinfección de viviendas, ropas y otros enseres.

Gráfico 7-14. Tasa de mortalidad por difteria (\%०) en Madrid. 1904-1929

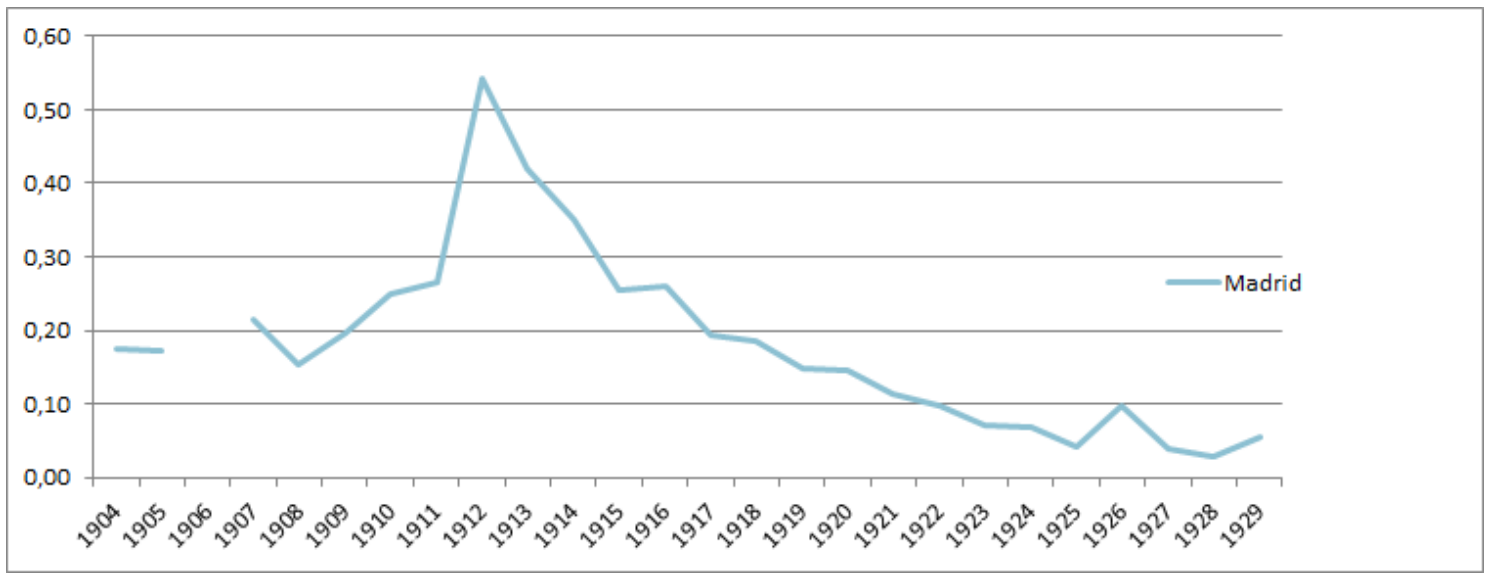

Fuente: Elaboración propia. Datos del Anuario Estadístico de Madrid para los años seleccionados

La viruela fue otra de las enfermedades infectocontagiosas que fueron objeto de estudio, análisis y pugna por el Laboratorio Municipal de Madrid. En 1900, desencadenado por la epidemia de viruela sufrida en la capital, el Doctor Chicote centró sus esfuerzos en 
combatir esta enfermedad, pidiendo al consistorio la aplicación de medidas particulares, con el objetivo de poner en marcha un servicio de vacunación y revacunación domiciliario, llevado a cabo por diez médicos del cuerpo de Beneficencia Municipal con dotación de materiales del Laboratorio. Las peticiones del Doctor Chicote no se llevaron a trámite, fruto de la imposibilidad del consistorio de atenderlas, de modo que se optó por elaborar vacunas de ternera en las dependencias del Laboratorio, servidos de distinto material importando del extranjero (De Miguel Salanova, 2018, p. 179).

Tres años después de esta experiencia, Madrid sufrió otra epidemia de viruela entre 1903 y 1904, momento en que el Laboratorio ya contaba con suficiencia para atender a las demandas requeridas de manera más eficiente. Un ejemplo de ello fue el perfeccionamiento de las vacunas, fruto del mayor conocimiento dado a través de las autopsias realizadas en terneras y diferentes seguimientos realizados con periodicidad.

Gráfico 7-15. Tasa de mortalidad por viruela(\%) en Madrid. 1904-1929.

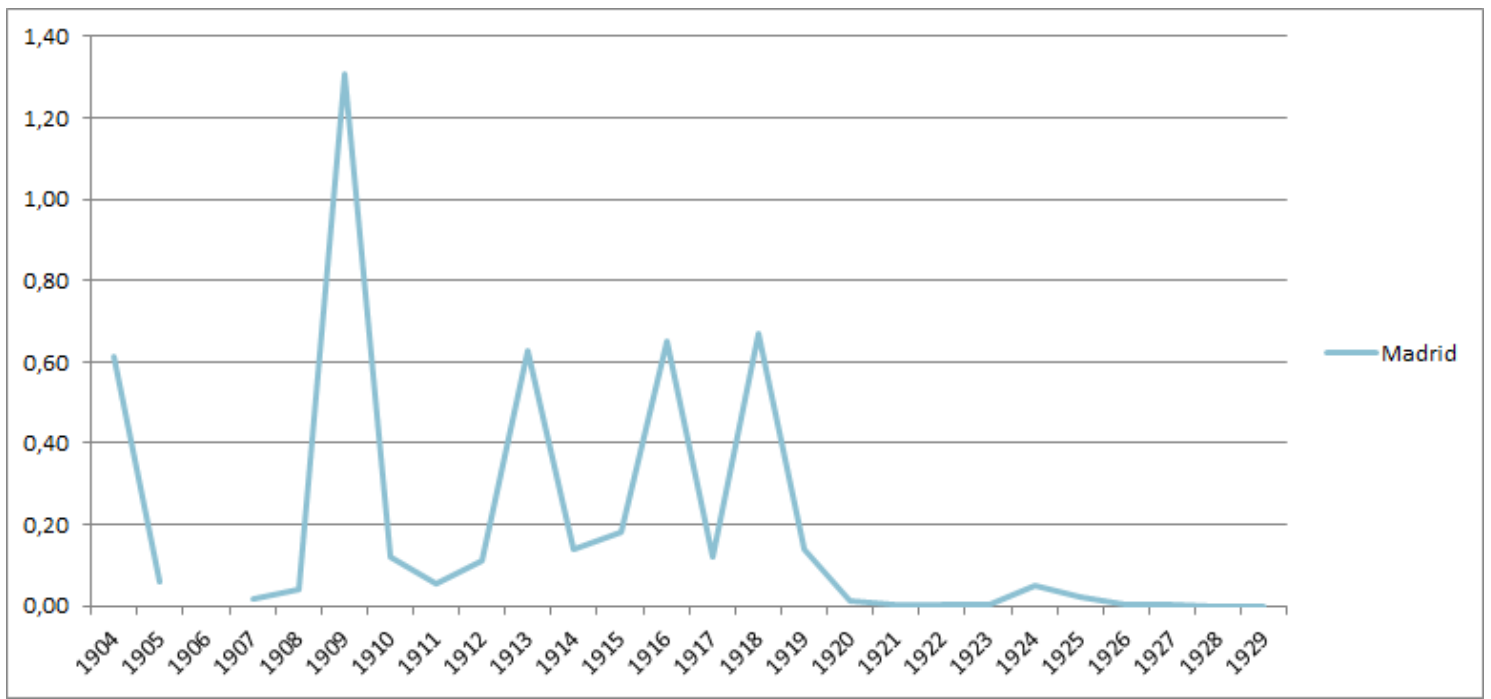

Fuente: Elaboración propia. Datos del Anuario Estadístico de Madrid para los años seleccionados

La coordinación entre el servicio encargado de la elaboración de sueros y vacunas y los destinados a la desinfección fue un aspecto clave para el buen desempeño del Laboratorio Municipal de Madrid en su lucha contra las enfermedades infectocontagiosas. Cabe hacer una mención especial al trabajo realizado por el Doctor Chicote en 1916 (Chicote del Riego, 1916) sobre las Vacunas y sueros del Laboratorio 
Municipal, titulado "Moderna Terapéutica biológica. Las vacunas y sueros del Laboratorio Municipal”.

Imagen 7-15. Portada del libro Moderna Terapéutica biológica. Las vacunas y sueros del Laboratorio Municipal. 1916
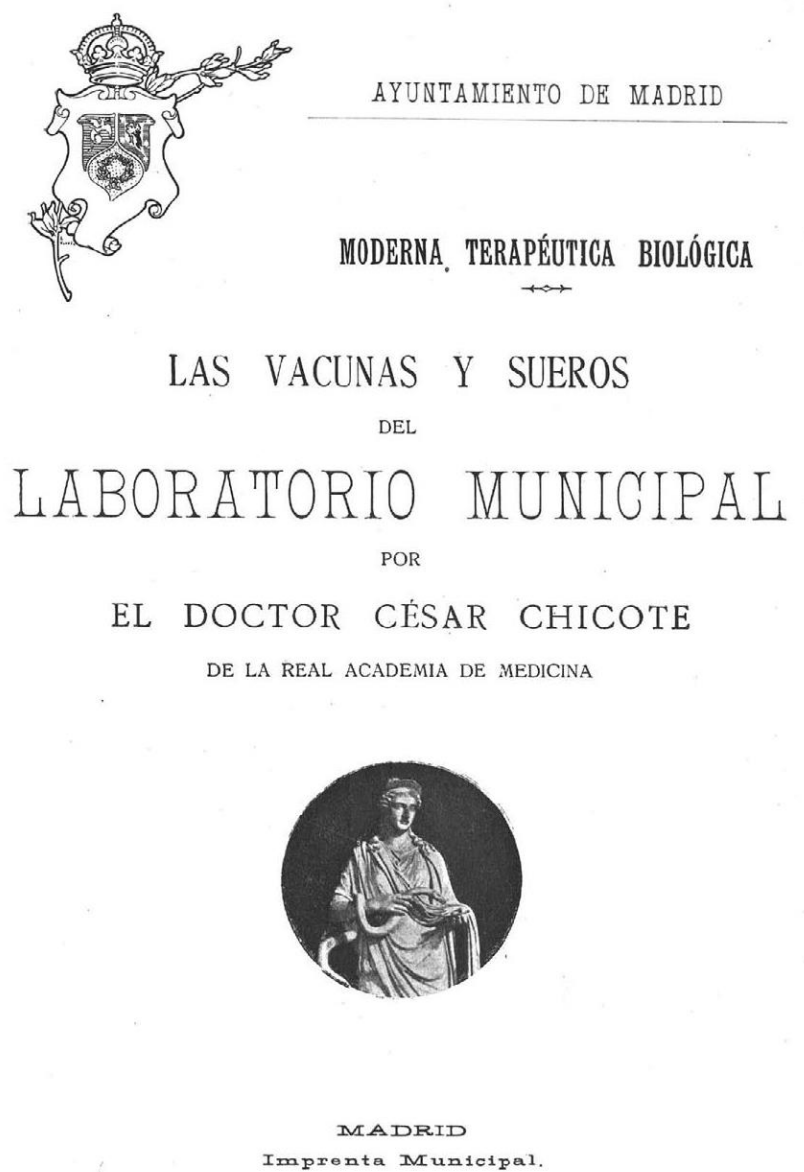

1016

En el trabajo de Chicote se dispone de diversa información sobre diferentes tipologías de vacunas. Dentro de las vacunas bacterianas, se dispone de cierta información sobre la vacuna tífica, polivalente y combinada, y su experimentación en el Laboratorio Municipal de Madrid. Son tratados aspectos tales como las ventajas ofrecidas por la vacuna polivalente y combinada, así como sobre la importancia de la procedencia de los gérmenes y los mecanismos empleados para la preparación de la vacuna.

También se exponen algunos ejemplos, a modo de experiencia profiláctica contra la fiebre tifoidea en diferentes lugares de España; tales como los trabajos del Doctor Gadea en la provincia de Alicante, las experiencia de la vacunación en la Inclusa de Lérida de manos del Doctor Fontanalls, la del Doctor Becares en la provincia de 
Ourense y las efectuadas durante la epidemia de Vigo a manos de los doctores Fandiño, Montes, Rollán, González, Casas, León, Reobo, Lanzas, Padín y Colmeiro. También se hace referencia, de modo bastante general, a la vacunoterapia en Inglaterra. Asimismo, se especifica el papel de la vacuna en la profilaxis y curación de la fiebre tifoidea y las instrucciones necesarias para su aplicación.

Las Vacunas y sueros que se trabajaban en el Laboratorio Municipal, quedan resumidas en el siguiente gráfico.

Gráfico 7-16. Vacunas y sueros del Laboratorio Municipal.
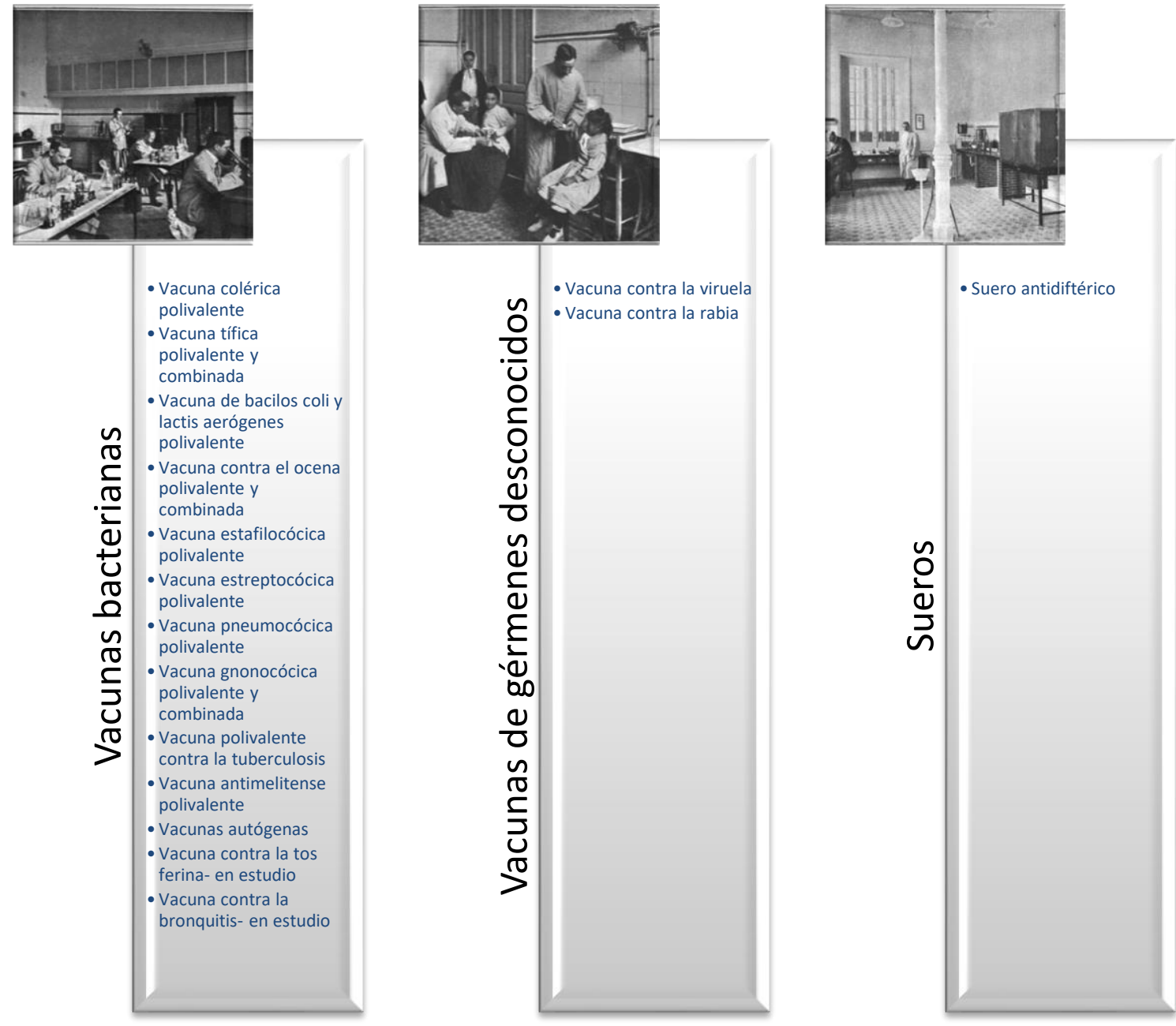

Fuente: elaboración propia. Información obtenida de (Chicote del Riego, 1916).

Desde 1931 se abogó por una vacunación no sólo de lucha contra las enfermedades manifiestas, sino también como medida preventiva ante las mismas. El Centro de Vacunación del Laboratorio Municipal, con los médicos epidemiólogos a su cargo, 
atendía al público en servicio de mañana y tarde (de once a una de la mañana y de cuatro a seis de la tarde), mediante la aplicación de vacunas antitífica, antivariólica, antirrábica, antidiftérica, entre otras. Se preveía la posibilidad de realizar vacunaciones colectivas ante la posibilidad de contagio, especialmente en colegios y otros centros colectivos. Asimimo, se estableció un servicio especial para la vacunación antivariólica, de manera que la Sección de Epidemiología recibía los datos relativos a la inscripción en el Registro Civil de los nacidos, donde se hacía constar el domicilio. Disponiendo de esta información, se realizaba notificación domicliaria a la edad de tres meses del nacido, con el objetivo de que sus padres llevaran al niño al Centro de Vacunación. En caso de no acudir a la citación, se realizaría una vacunación domiciliaria y, en caso de oposición de los padres, se procedería a sancionarlos (García Revenga, 1933).

En cuanto a las personas que fueran portadores de gérmenes, bajo la posibilidad de que puedieran ser foco de contagio de una colectividad, en especial en el caso de niños en edad escolar, sus médicos de cabecera debían rellenar una tarjeta indicando la situación de alta de la enfermedad, que debía ser remitida a la Sección de Epidemiología. Una vez hecho esto, la persona interesada debía recoger dicha tarjeta en la Sección de Epidemiología, bajo la condiciónd de que " solamente facilitará esta tarjeta al convaleciente cuando haya transcurrido el tiempo consignado para cada proceso como necesario para no contaminar a los demás alumnos, o después de sometido a un examen bacteriológico en el Laboratorio para garantir que no es un portador de gérmenes de difteria, tiñas, etc." (García Revenga, 1933, p. 15).

Dichas tarjetas, los casos declarados, así como todos los datos obtenidos fruto de las visitas realizadas, servicios de desinfección practicados, serán la base de las estadísticas de mortalidad y morbilidad por enfermedades infectocontagiosas llevadas a cabo por la Sección de Epidemiología del Laboratorio. 


\subsection{El servicio de desinfección}

Otro de los servicios prestados por el Laboratorio Municipal fue el servicio de desinfección, que consistía en la inspección médica de infecciones, que estuvo desempeñada por los señores Médicos Inspectores municipales de Sanidad, auxiliados por la Policía Sanitaria del Laboratorio ${ }^{71}$.

Las instrucciones que para uso del personal de la sección de Policía Sanitaria se dictaron por la Dirección del Laboratorio. La misión del servicio fue la de "adquirir toda clase de antecedentes de índole sanitaria a partir del momento en que se recibe la denuncia de un caso de enfermedad transmisible, así como durante su curso y terminación. Estos antecedentes son indispensables para la adopción de las medidas que en cada caso se estimen oportunas, encaminadas a evitar la difusión de la enfermedad y la formación de focos epidémicos" (Puerto Sarmiento and Cobo Cobo 1983).

\subsubsection{La cartilla del desinfector}

El doctor Chicote redactó una cartilla destinada a la formación de obreros reclutados para desempeñar los servicios del laboratorio dedicados a la desinfección, bajo el título La cartilla del desinfector (Chicote del Riego, 1903). En esta cartilla se hace alusión a los diferentes ámbitos que abarcaba la desinfección, como medio de lucha contra las enfermedades infecciosas: "he procurado aparezcan tan sólo nociones elementales sobre la desinfección, expresadas en estilo liso y llano, puesto que se dedican á personas que carecen de toda base científica y que no necesitan adquirir conocimientos más elevados para cumplir á conciencia su misión” (Chicote del Riego, 1903, p. 3).

También aparece especificado el objeto de la desinfección de manera explícita, así como la misión social del desinfector. "se comprende cuan delicada es la misión social del desinfectar, cuya más pequeña negligencia puede comprometer no sólo la vida de sus semejantes; sino la suya y la de su misma familia" (Chicote del Riego, 1903, pp. 67).

Respecto al objeto de la desinfección, ésta se basaba en:

71 El servicio de Policía Sanitaria, organizado en 1909, se suspendió al año siguiente por dificultades de orden económico, y en fines de 1918 volvió a dotarse de personal, continuando ya en su funcionamiento regularizado. 
- destruir los microbios e impedir, por tanto, la propagación de las enfermedades que ocasionan, persiguiéndolos en los vómitos, en las orinas, en las deyecciones, en la saliva, en los esputos, en las secreciones de la nariz, en cuantos objetos y ropas puedan éstos manchar, en las costras de la viruela, en las películas de la escarlatina, en las habitaciones, en los coches, en todos los objetos y en todas las partes, en fin, que hayan estado en contacto de un enfermo.

- evitar el contagio de las enfermedades debidas a los microbios, es solicitada en ocasiones para evitar la propagación de enfermedades originadas por parásitos vegetales, como la tina, ó parásitos animales, como la sarna.

- Destrucción: diversas enfermedades, como los mosquitos el paludismo, las chinches la tuberculosis, las pulgas y las ratas la peste, las moscas el cólera, el tifus, la tuberculosis, el carbunclo, etc

El lugar de práctica de estas acciones era tanto a domicilio como en las ya mencionadas estaciones de desinfección. Ésta podía llevarse a cabo durante la enfermedad o cuando se diera por terminada, bien por curación, traslado del enfermo a un hospital o por producirse el fallecimiento.

Las enfermedades objeto de la desinfección pública se clasificaban en tres clases, atendiendo a la necesidad de la desinfección: 
Gráfico 7-17. Clases de desinfección en función de la enfermedad. Servicio de desinfección del Laboratorio Municipal.
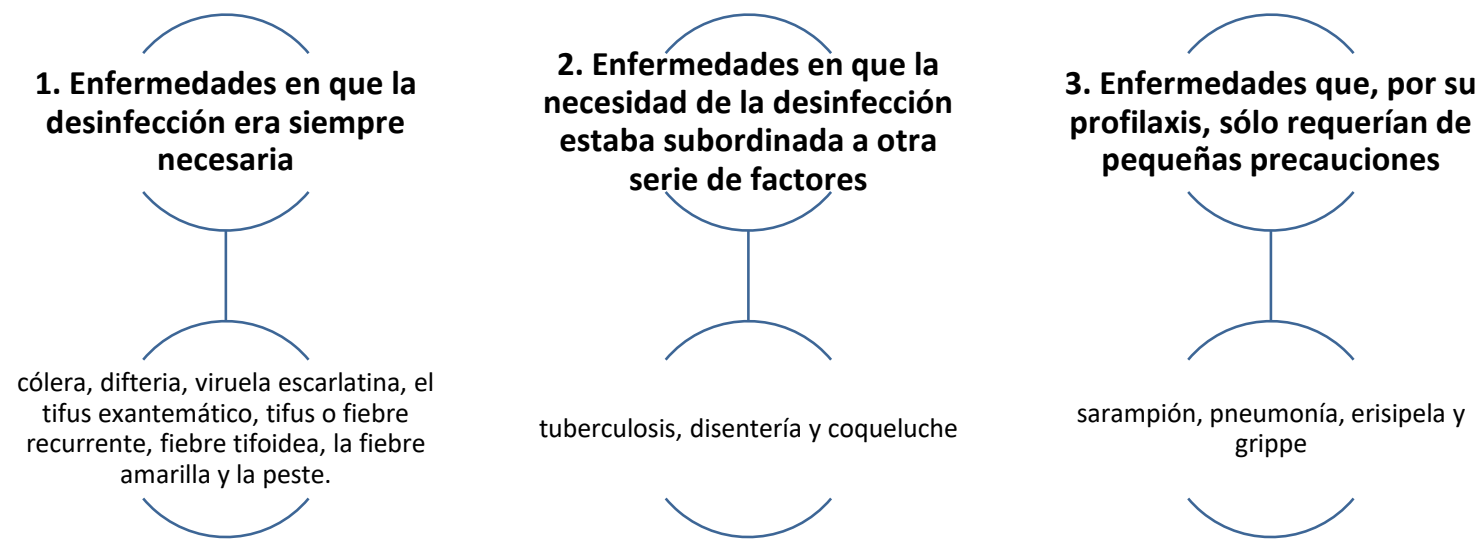

Fuente: elaboración propia, con información de (Chicote del Riego, 1903, p. 7).

Respecto a los medios empleados para la desinfección, aparecen clasificados en dos grupos; los desinfectantes químicos y los desinfectantes físicos.

Gráfico 7-18. Tipos de desinfectantes. Servicio de desinfección del Laboratorio Municipal.

Desinfectantes químicos: Desinfectantes físicos:

$\begin{array}{ll}\square & \square \\ \square \text { Sublimado } & \square \text { Incineración } \\ \square \text { Sulfato de cobre } & \square \text { Agua caliente o hirviendo } \\ \square \text { Lechada de cal } & \square \text { Lejías } \\ \square \text { Creolina, cresilo, lisol y } & \square \text { Vapor bajo presión } \\ & \text { zotal. } \\ \text { Cresol } & \\ \square \text { Acido sulfuroso } \\ \square \text { Formaldehido } \\ \square \text { Hipoclorito de cal }\end{array}$

Fuente: elaboración propia, con información de (Chicote del Riego, 1903, pp. 11-12). 
Otra serie de elementos que se empleaban para la desinfección eran las estufas transportables, como la denominada "locomóvil", empleadas en ocasiones en que era necesaria la movilización de los recursos del Laboratorio para llevar a cabo las desinfecciones, y las estufas fijas, ubicadas en las estaciones sanitarias, así como las lavadoras desinfectantes.

\section{Imagen 7-16. Fotografía de una "locomóvil".}

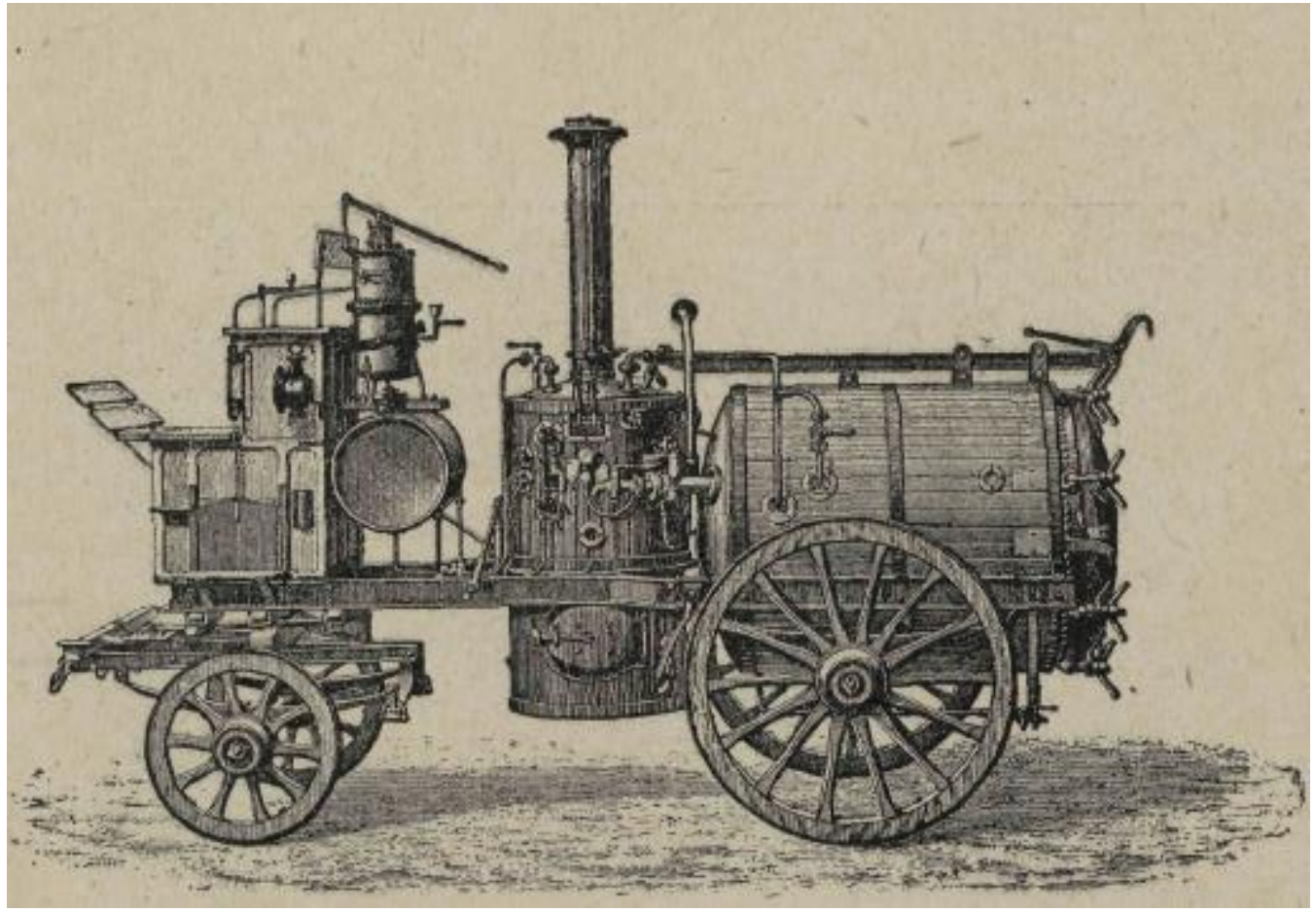

Fuente: (Chicote del Riego, 1903, p. 17) 
Imagen 7-17. Fotografía de una Lavadora desinfectante.

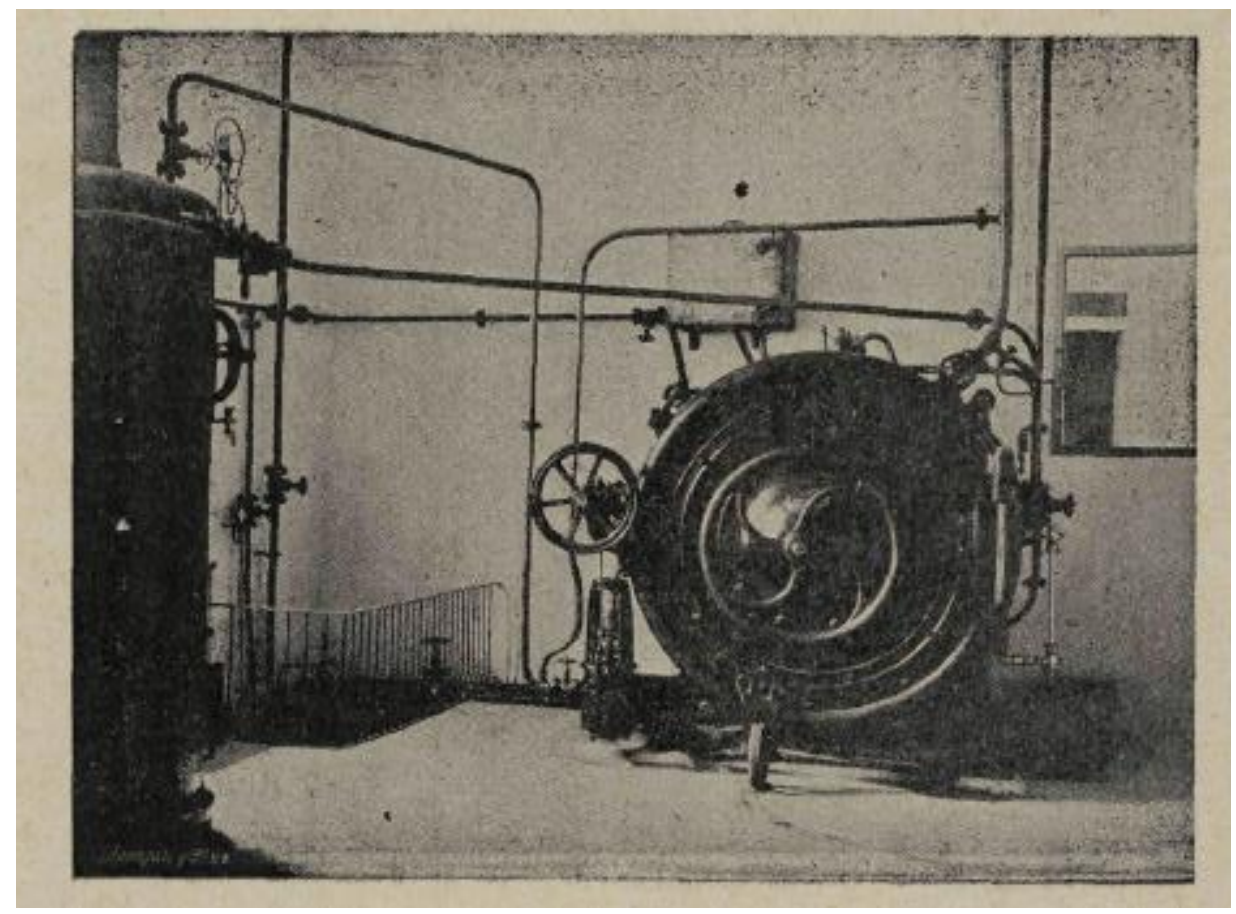

Fuente: (Chicote del Riego, 1903, p. 21)

Para llevar a cabo la desinfección domiciliaria, se empleaban utensilios tales como los aparatos pulverizadores.

Imagen 7-18. Fotografía de aparatos pulverizadores.

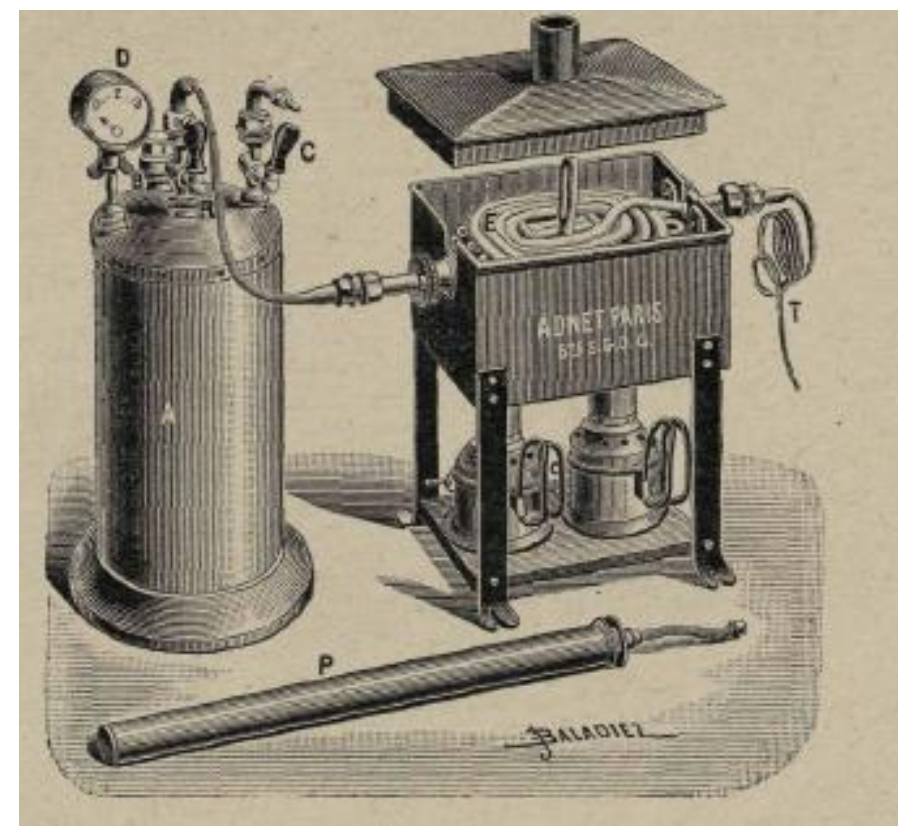

Fuente: (Chicote del Riego, 1903, p. 26) 
Imagen 7-19.Fotografía del personal con la herramienta de desinfección de la vía pública.

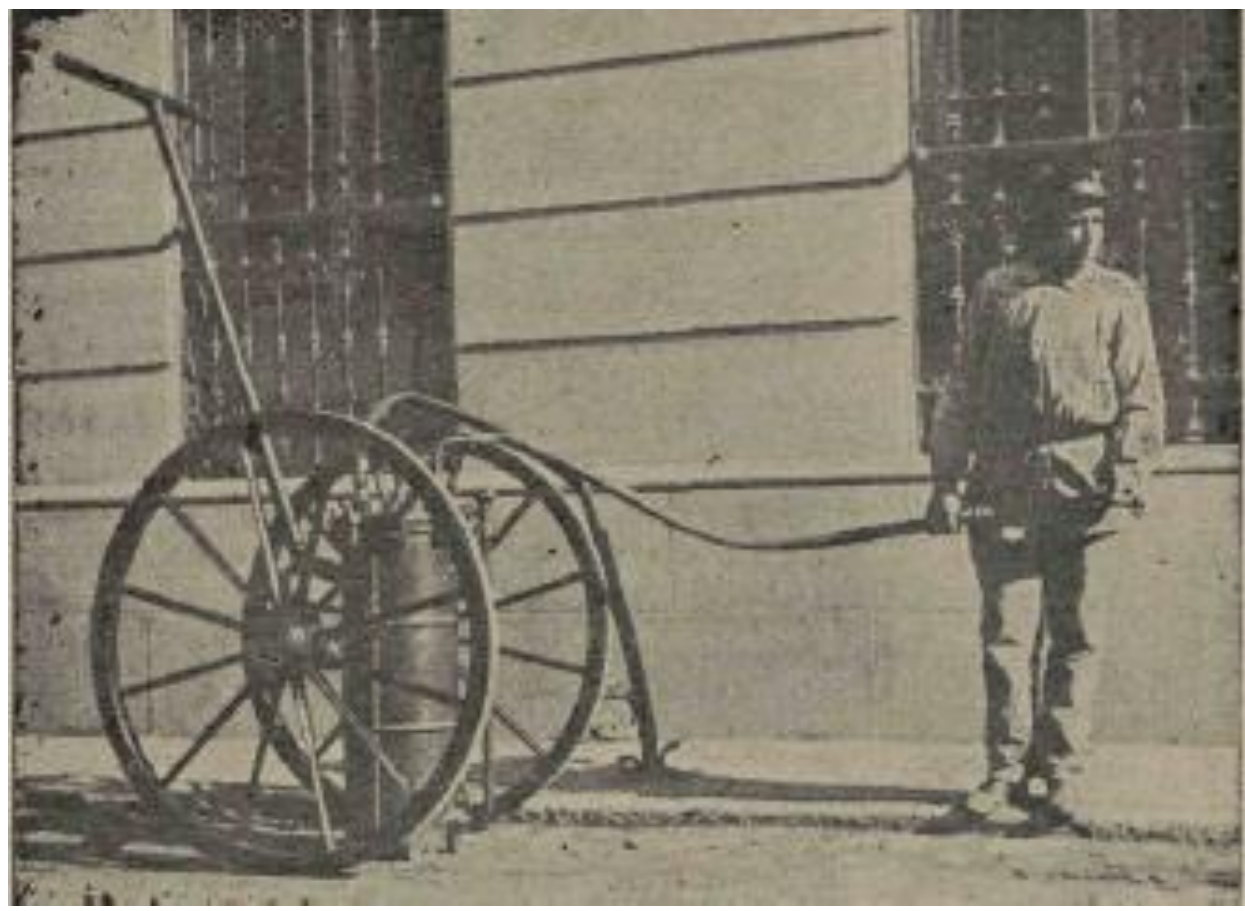

Fuente: (Chicote del Riego, 1903, p. 33)

En el capítulo IV de la cartilla del desinfector se pormenorizan los elementos a ser desinfectados y el mecanismo particular en cada caso, tal y como queda reflejado en el siguiente gráfico elaborado a modo esquemático. 
Vía Pública:

- Subsuelo (alcantarillado, fosas fijas y movibles). Con lechada de cal

- Vía pública (calles, plazas, etc.). Con lavado metódico, La disolución que se emplee con dicho objeto, será la de creolina. cresilo, cresol ó zotal.

- Inmundicias urbanas

- Retretes públicos. Lechadas de cal, lavando las tablas con sublimado y el suelo con creolina

- Urinarios y rinconadas. Riego con creolina

Las viviendas

- Ropas, tejidos de todas clases, cortinas, alfombras, colchones, etc. $-S u$ desinfección debe hacerse en las estufas de vapor, bajo presión.

- Vajilla, tazas de noche, cucharillas y utensilios análogos. Tratamiento con solución fuerte de sulfato de cobre, por inmersión y lavado después con abundante agua.

-Muebles, camas y objetos que constituyen el mobiliario propiamente dicho.-Practíquese el lavado con esponja y pulverizaciones con solución de sublimado ó desinféctense con los aparatos productores de formaldehído.

- Paredes y techos. - Su desinfección se hará con auxilio de la solución de sublimado proyectada metódicamente, con los aparatos pulverizadores de presión, por dos veces con el intervalo de quince minutos.

- Puertas y ventanas. - Los tableros y cristales se desinfectarán lavándolos á la esponja con solución de sublimado.

- Pavimentos. - Deben lavarse repetidamente por medio del riego, con solución de creolina, zotal, etc.

- Retretes. - La desinfección se llevará á cabo: vertiendo por los mismos solución fuerte de sulfato de cobre y lechada de cal, lavando la parte exterior con la de sublimado y el piso con la dé creolina.

- Escalera de la casa. - Para sus paredes y techo empléense las pulverizaciones con solución de sublimado, así como el lavado con la misma del pasamanos y barandilla, y riego abundante de los escalones con la de creolina.

- Patios. - El pavimento de los patios es convenentísimo regarlos con solución de creolina y quemar en el mismo cuanta basura, trapos y papeles contenga.

- Cuadras y establos. - Las paredes y techos se pasarán con lechada de cal. ó se lavarán con solución de creolina en el caso de estar estucados ó pintados, por medio de los pulverizadores de presión; el suelo se regará abundantemente con aquella. Últimamente, las tablas, la paja y las camas de los animales deben quemarse en el mismo local.

- Coches y vagones. - Considerando á éstos como habitaciones temporales infectadas por el hombre y los animales durante su permanencia en ellos, deben desinfectarse siempre por los medios reseñados al tratar de las habitaciones, cuadras y establos, teniendo muy especial cuidado con los pisos. También pueden desinfectarse lavando el piso con solución de creolina, y el resto, bien cerradas las portezuelas y ventanillas, con los vapores de formaldehído.

Fuente: Elaboración propia, a partir de la información de (Chicote del Riego, 1903, p. 33) 
Existía una Oficina Central encargada de recibir avisos a cualquier hora del día y de la noche, permitiéndose la recepción de los mismos vía telefónica, por carta o de palabra. En tiempos de epidemia, se formaba una guardia permanente, con el objetivo de garantizar la asistencia en cualquier momento en que fuera requerida. Asimismo, en los tiempos en que no hubiera epidemia, el Laboratorio disponía de una brigada con un furgón para trasportar objetos y ropas que pudieran estar contaminados. Dado que la notificación acerca de la sospecha de producirse una enfermedad infectocontagiosa se debía realizar primeramente al médico que prestaba la asistencia facultativa (El Real decreto de 31 de Octubre de 1901, articulo 2), éstos fueron dotados de una tarjeta de modelo especial, con el objetivo de facilitar el procedimiento. Una vez fuera recibido el aviso, se anotaba en un libro talonario, que era entregado al cabo de brigada en cuestión para llevar a cabo la desinfección y, una vez llevada a cabo, se devolvía firmada por el cabo de brigada (Chicote del Riego, 1903, pp. 41-42).

El procedimiento llevado a cabo por los desinfectores, previo a la salida para realizar una operación, se basaba en que los desinfectores debían realizar una revisión de todo el material necesario para llevar a cabo el servicio solicitado, cerciorándose de su correcto funcionamiento. En función de cuál fuera la clase de desinfección a llevar a cabo (siguiéndose los procedimientos y material a emplear en función de la naturaleza de la desinfección, tal y como ha sido explicado en líneas precedentes) los desinfectores debían seguir las pautas correspondientes. Por ejemplo, para la desinfección de habitaciones, debían empaquetarse toda clase de elementos que pudieran estar contaminados, tales como ropas, telas y otros objetos, para proceder a su desinfección en las estufas empleadas para ello. Se documentaba el conteo de todos los utensilios confiscados para su desinfección, dejando una copia al dueño de la vivienda, o su representante, bajo firma del cabo de brigada. Por último, los utensilios eran llevados al furgón de transporte, que estaban dotados de telas y sacos: las telas para la envoltura de colchones y alfombras, y los sacos para las ropas. Terminada la visita, se dejaba en los domicilios un modelo de propaganda con instrucciones varias. Una vez realizada la desinfección de todos los utensilios en la estación de desinfección del Laboratorio, éstos eran devueltos al interesado, debiendo éste último de entregar la nota con a relación detallada de la confisca firmada por el cabo de brigada. Esta nota era archivada en las oficinas del servicio de desinfección y servía como garantía ante posibles reclamaciones (Chicote del Riego, 1903, p. 42). 
Del procedimiento anterior, se revela que la desinfección aunaba dos tipos de procedimientos: las operaciones llevadas a cabo en el domicilio de la persona enferma y, otras, en la estación de desinfección. Para las que eran practicadas en los domicilios, la brigada de desinfectores iba dotada de aparatos de pulverización, regaderas, cepillos de baldeo y cubetas con solución de creolina y sublimado, además de sus trajes de trabajo, una bolsa conteniendo esponjas, lámparas para llamear los objetos de hierro, paquetes de sulfato de cobre pulverizado, entre otras herramientas.

Transportados por el furgón, llegaban los objetos y las ropas a la estación de desinfección. Éstos se desembalaban para su clasificación, en función del mecanismo desinfector a emplear:

1ㅇ) los que pueden meterse directamente en las estufas, por no estar manchados con sangre, pus ó materia fecal, ni ser de cuero, piel, cauchú, etc.

$2^{\circ}$ ) está formado por los que aparecen manchados en la forma indicada, que es preciso lavar para que las manchas no se fijen indeleblemente á su paso por la estufa, bien sea parcialmente tratándose de vestidos, alfombras, etc., ó totalmente, siendo sábanas, telas de colchón, pañuelos, tohallas y demás tejidos cuyas condiciones permitan ser sometidos á la acción de la estufa legiadora.

3o) Los objetos de cauchú, cuero, piel, sombreros, calzado y demás que no pueden someterse á la acción del vapor bajo presión ó de la legía, se desinfectan por la acción del formaldehído, para evitar su deterioro.

4ㅇ) Los coches que han transportado los objetos infectados, se desinfectan interior y exteriormente con los aparatos de pulverización

Fuente: Elaboración propia, a partir de la información de (Chicote del Riego, 1903, p. 43)

Un aspecto destacable es que la desinfección también se producía en el transcurso de la enfermedad infectocontagiosa en cuestión, siempre bajo reclamo del servicio. En este sentido, se procedía a dar una serie de instrucciones en el domicilio del enfermo, y se dotaba a los que allí habitaban de recomendaciones y utensilios, tales como sacos y cilindros de metal. Los sacos, para depositar las ropas y, los cilindros de metal, con el objetivo de que depositasen sábanas, fundas de almohada o pañuelos. Cada veinticuatro horas, los recipientes eran trasladados a la estación y se dejaba en el domicilio otros nuevos. Además, se desinfectaban algunas partes de la casa por donde pudiera haber 
estado la persona enferma, tales como la escalera, retretes o pasillos y se ubicaba al enfermo de una habitación a otra, desinfectándose cada vez (Chicote del Riego, 1903, p. 44). Estos procedimientos sistemáticos y bien definidos, nos ponen en la antesala de pensar en la labor de seguimiento epidemiológico de las enfermedades infectocontagiosas que, si bien con algunas deficiencias, ya se estaba produciendo en la ciudad de Madrid desde los primeros años del siglo XX.

En la Cartilla del desinfector (Chicote del Riego, 1903, pp. 45-46), también se describen una serie de precauciones y obligaciones que debían llevar a cabo los desinfectores, en aras de evitar su contagio en el transcurso del desarrollo de sus trabajos.

Gráfico 7-20. Precauciones y obligaciones de los desinfectores.

\begin{tabular}{|l|}
\hline \multicolumn{1}{|c|}{ Precauciones } \\
\hline - Al llegar á la estación de desinfección dejarán sus ropas en el \\
vestuario y se pondrán las de trabajo ó salida. \\
- Ni en la estación de desinfección ni en las casas procederán á \\
operación alguna sin haberse vestido el traje de trabajo. \\
- Deben llevar ropa interior limpia, el pelo cortado al rape y la \\
cara afeitada. Las uñas deberán conservarlas extremadamente \\
cortas. \\
- Teniendo heridas en las manos usarán para las operaciones de \\
desinfección guantes de goma. \\
- Está prohibido comer y beber en las salas de trabajo. Para \\
hacerlo en las otras se lavarán cuidadosámente cara y manos, \\
cepillándose bien las uñas y, por último, enjuagándose la boca. \\
- El fumar está asimismo prohibido por el peligro que supone \\
tocar el cigarro con los dedos sucios por manejar las ropas y \\
objetos, ó dejar las puntas sobre las mesas en que han estado. \\
- Está prohibido á los desinfectores detenerse en ninguna otra \\
casa más que en aquélla á donde van á prestar servicio. \\
- Los que se ocupan en el manejo de los objetos infectados no \\
deben, bajo ningún pretexto, ponerse en relación con los \\
maquinistas de las estufas durante las diversas operaciones \\
que tengan que practicar. \\
- La recogida de colchones, ropas, etc., en las casas, así como su \\
clasificación en la estación de desinfección, debe hacerse con \\
gran precaución por ser operaciones peligrosas, evitando el \\
agitarlas y tocar los sitios manchados. \\
- Una vez terminadas las operaciones, si es en la casa, \\
empaquetarán el traje que han tenido durante la desinfección, \\
para esterilizarle, y si es en la estación, antes de cerrar la \\
estufa, meterán en ella pantalón, blusa y gorra, lavarán el \\
calzado con solución de sublimado y las manos, cara, etc., \\
- Logún se ha dicho anteriormente. \\
duchas antisépticas.
\end{tabular}

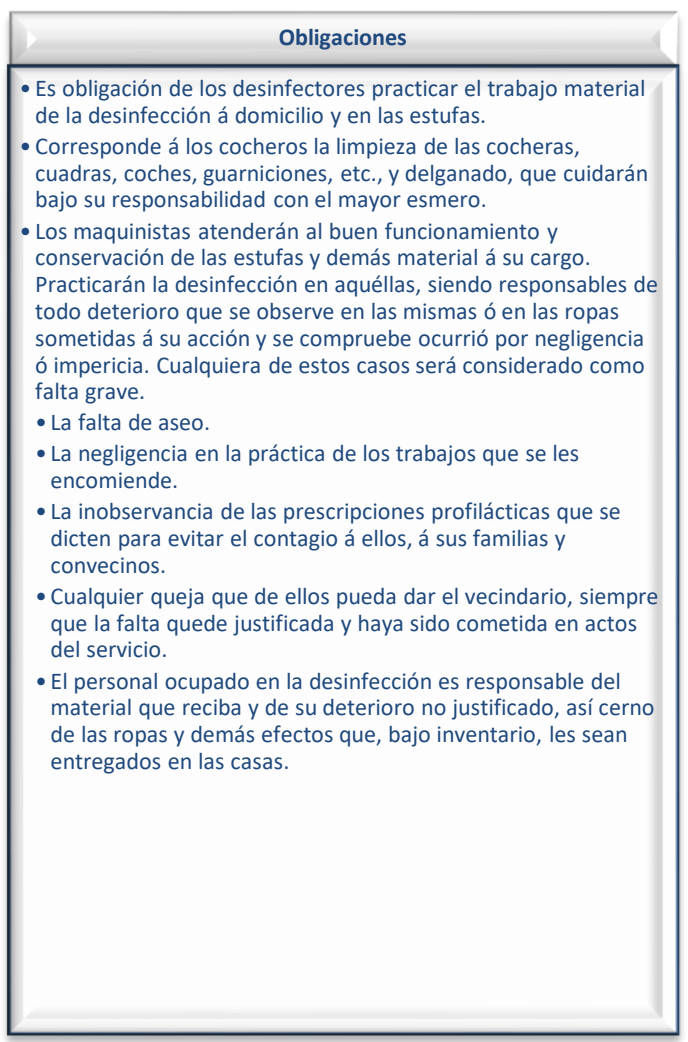

Fuente: Elaboración propia. Información de La Cartilla del desinfector (Chicote del Riego, 1903, pp. 4547) 


\subsubsection{Servicio de desinfección ante las enfermedades infecciosas.}

En la década de los años treinta del siglo veinte, el modelo de desinfección a seguir, estipulado como el más óptimo, era el alemán. Éste se basaba principalmente en dos directrices: la primera radicaba en la importancia de la organización de la desinfección en el curso de la enfermedad y, la segunda, en la práctica de la desinfección, por parte de la familia de la persona contagiada, mediante medios antisépticos ${ }^{72}$, siendo éstos económicos y eficaces. En este segundo caso, se dotaba a los familiares de desinfectantes, enseñando a la familia la manera en que debían ser usados y se les instruía sobre la forma en que debían actuar como medio de evitar contagios. Asimismo, en caso de que el Médico de cabecera lo solicitara, las familias eran asistidas por los desinfectores municipales y por personal de enfermería. Este aspecto es de suma importancia, en la medida en que comienza a otorgarse relevancia al papel del entorno familiar y/ o personal que cuidase al enfermo, como agente activo en el freno de los posibles contagios de enfermedades. "Desde el punto de vista sanitario, forzoso es reconocer que estas instrucciones suponen la organización de una inmensa cruzada para enseñar cómo se contraen las enfermedades contagiosas y cómo pueden evitarse”. “(...) las prácticas de desinfección en curso de enfermedad sean realizadas por la familia o personas que cuiden al enfermo, bajo la dirección del Médico de cabecera y contando con el auxilio del Laboratorio Municipal, única forma en la que puede aquélla ser eficaz y practicable, ofreciendo además tal sistema la enorme ventaja de conseguir que el vecindario adquiera una instrucción en materia de profilaxis que supondría un extraordinario y beneficioso progreso sanitario”. (García Revenga, 1933, p. 20)

Se entendía que, con llevarse a cabo una desinfección bien ejecutada, se lograba la eficiencia y suficiencia de la misma, pero se recomendaba la práctica adicional de una desinfección final sobre objetos que pudieran haber estado expuestos al agente contaminante, tales como ropas, ropa de cama, el suelo de la habitación... Además, para aquellos casos en que pudiera darse el caso de un contagio masivo, se recomendaba la desinfección con estufas para las ropas y el empleo de formol para los locales. (García Revenga, 1933, p. 20)

\footnotetext{
${ }^{72}$ El método antiséptico empleado en Alemania era el sublimado.
} 
Los anteriores fundamentos que giraban en torno a la importancia de "que la profilaxis debe estar fundamentada en un conocimiento perfecto del modo más frecuente de contagio, que es de hombre a hombre por contacto directo o por diseminación de gérmenes a muy corta distancia; de lo cual fácilmente se deduce que la vigilancia debe establecerse cerca del enfermo o del portador de gérmenes. Se estima que los gérmenes depositados sobre los objetos son poco peligrosos por su escasez y por su adherencia a las superficies, sobre todo si están húmedas o son grasas; además, pierden rápidamente su virulencia y su vitalidad, no interviniendo aquéllos en el contagio sino cuando han sido muy manchados y muy recientemente”. (García Revenga, 1933, p. 19).

Así, se establecían como medios posibles de contaminación, para cada enfermedad infectocontagiosa, los reseñados en el siguiente cuadro.

Gráfico 7-21. Mecanismos de contaminación por enfermedades infectocontagiosas ${ }^{73}$.

PROYECCIÓN DE GOTITAS DE

SALIVA, SECRECIONES NASALES

FARINGEAS, TRAQUEALES Y

BRÓNQUICAS. tuberculosis,

- Difteria

-Meningitis cerebroespinal

- Encefalitis epidémica

- Parálisis infantil

- Tos ferina

-Sarampión

- Escarlatina

- Gripe

-Peste neumónica

- Neumonías

- Bronconeumonías

- Viruela

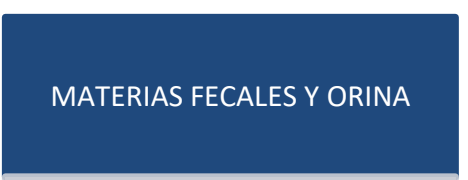

- Fiebre tifoidea

- Fiebres paratíficas

- Cólera

- Disentería

- Fiebre de Malta

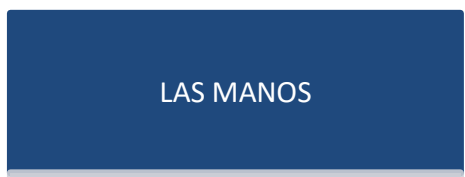

- Tracoma

- Vector en las afecciones precedentes y en otras, como el

FUENTE: Elaboración propia. Información extraída de (García Revenga, 1933, p. 19)

En los años treinta del siglo XX, el laboratorio contaba con un parque central, otro auxiliar, y varias estaciones que tenían por objetivo ser el lugar donde se llevaba a cabo la desinfección de enseres varios. Si bien el objetivo inicial fue el de servir de medio desinfector y destructor de bacterias y gérmenes de diferentes enfermedades infectocontagiosas (viruela, fiebre tifoidea, escarlatina, sarampión, tuberculosis, entre

\footnotetext{
${ }^{73}$ A los orígenes de contagio señalados, se debe sumar el orginen parasitario
} 
otras), la aplicación de medidas orientadas a la prevención fueron adicionadas a las anteriores. Un ejemplo de estas labores preventivas son las desinfecciones llevadas a cabo en las viviendas o locales desalquilados antes de que fueran alquilados, la desinfección de fondas, locales de traperos o los transportes públicos.

Tabla 7-5. Desinfecciones realizadas. 1919-1925

\begin{tabular}{|c|c|c|c|c|c|c|}
\hline & 1919 & 1920 & 1917 & 1915 & 1914 & $1924-1925$ \\
\hline En viviendas & 28437 & 33936 & 50504 & 61686 & 110348 & 38673 \\
\hline En estufas (ropas) & 272105 & 420540 & 196609 & 178894 & 121051 & 318559 \\
\hline En el Campamento de desinfección & & & 77460 & & & \\
\hline Ropas y calzado en el rastro & 123407 & 279283 & & & 68689 & 180884 \\
\hline Pompas funebres & 53001 & 13182 & 14659 & & & 11902 \\
\hline Coches y furgones en el cementerio de la almudena & 14231 & 13358 & 10844 & & & 13918 \\
\hline Viviendas desalquiladas & & & & & & 596 \\
\hline Total de desinfecciones & 491181 & 760299 & 350076 & 240580 & 300088 & 564532 \\
\hline
\end{tabular}

Fuente: "Resumen de los trabajos realizados por las dependencias municipales durante el año económico 1924-1925". El resto de "Resumen de los trabajos realizados por las dependencias municipales para varios años".

Atendiendo al número de desinfecciones realizadas a nivel de distrito, como puede verse a través de los gráficos 7-23 y 7-24, sobre las desinfecciones realizadas por el servicio de desinfección del Laboratorio Municipal por distritos y la proporción de desinfecciones realizadas por el servicio de desinfección del Laboratorio Municipal según el año, respectivamente, puede verse que el Distrito con una mayor proporción de desinfecciones llevadas a cabo fue el de Latina, seguido de el de Inclusa.

Gráfico 7-22. Número de desinfecciones realizadas según la iniciativa ante la desinfección.

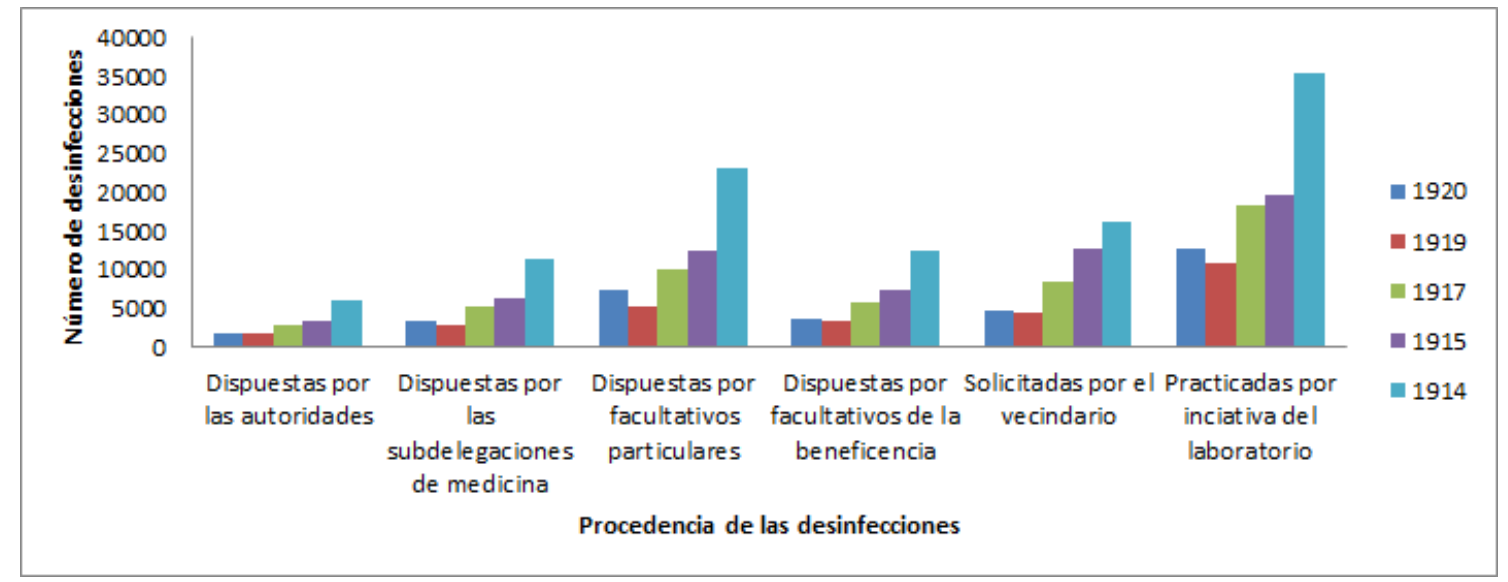

Fuente: Elaboración propia. Resumen de los trabajos realizados por las dependencias municipales para varios años. 
Gráfico 7-23. Desinfecciones realizadas por el servicio de desinfección del Laboratorio Municipal por distritos. Proporción de desinfecciones según el distrito.

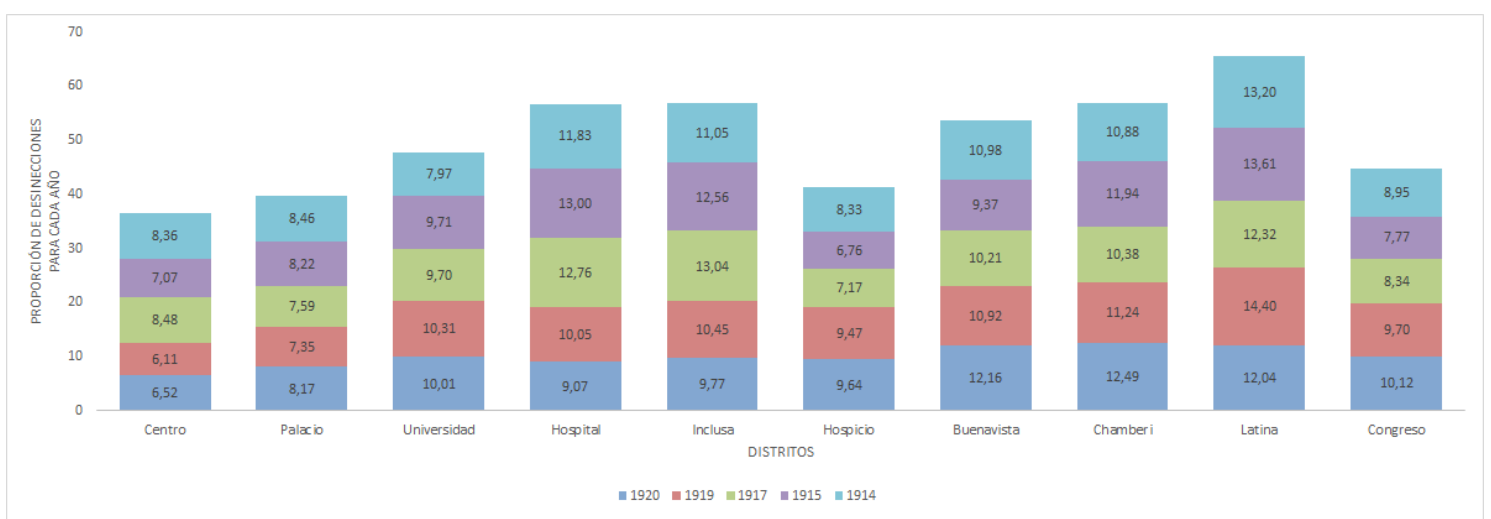

Fuente: Elaboración propia. Resumen de los trabajos realizados por las dependencias municipales para varios años.

Gráfico 7-24. Desinfecciones realizadas por el servicio de desinfección del Laboratorio Municipal por distritos. Proporción de desinfecciones según el año.

\begin{tabular}{|c|c|c|c|c|c|c|}
\hline \multirow{6}{*}{ 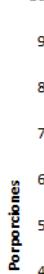 } & 10,12 & 9,70 & 8.34 & 7,77 & 8.95 & \multirow{11}{*}{ 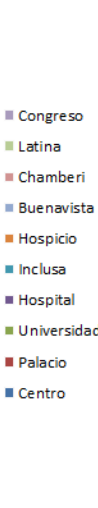 } \\
\hline & 12,04 & 14,40 & 12,32 & 13,61 & 13,20 & \\
\hline & 12,49 & 11,24 & 10,38 & 11,94 & 10,88 & \\
\hline & 12,16 & 10,92 & 10,21 & 9,37 & 10,98 & \\
\hline & 9,64 & 9,47 & & 6,76 & 8,33 & \\
\hline & 9,77 & 10,45 & & & 11,05 & \\
\hline 36 & 9,07 & 10,05 & 12,76 & 13,00 & 11,83 & \\
\hline 2 & 10,01 & 10,31 & 9,70 & 9,71 & 7,97 & \\
\hline $1 c$ & 8,17 & 7,35 & 7,59 & 8,22 & 8,46 & \\
\hline & 6,52 & 6,11 & 8,48 & 7,07 & 8,36 & \\
\hline & 1920 & 1919 & 1917 & 1915 & 1914 & \\
\hline
\end{tabular}

Fuente: Elaboración propia. Resumen de los trabajos realizados por las dependencias municipales para varios años. 
En lo que respecta a las desinfecciones teniendo en consideración el mes de la desinfección y los distritos de la ciudad (Grafico 7-25), los meses comprendidos de enero a abril son los de mayor incidencia en términos generales. Si bien, teniendo en cuenta las desinfecciones realizadas por enfermedad (Gráficos 7-26 al 7-31) puede verse que se producen variaciones en los meses de mayor número de desinfecciones según éstas.

Gráfico 7-25. Desinfecciones totales realizadas en viviendas. Por meses y distritos.

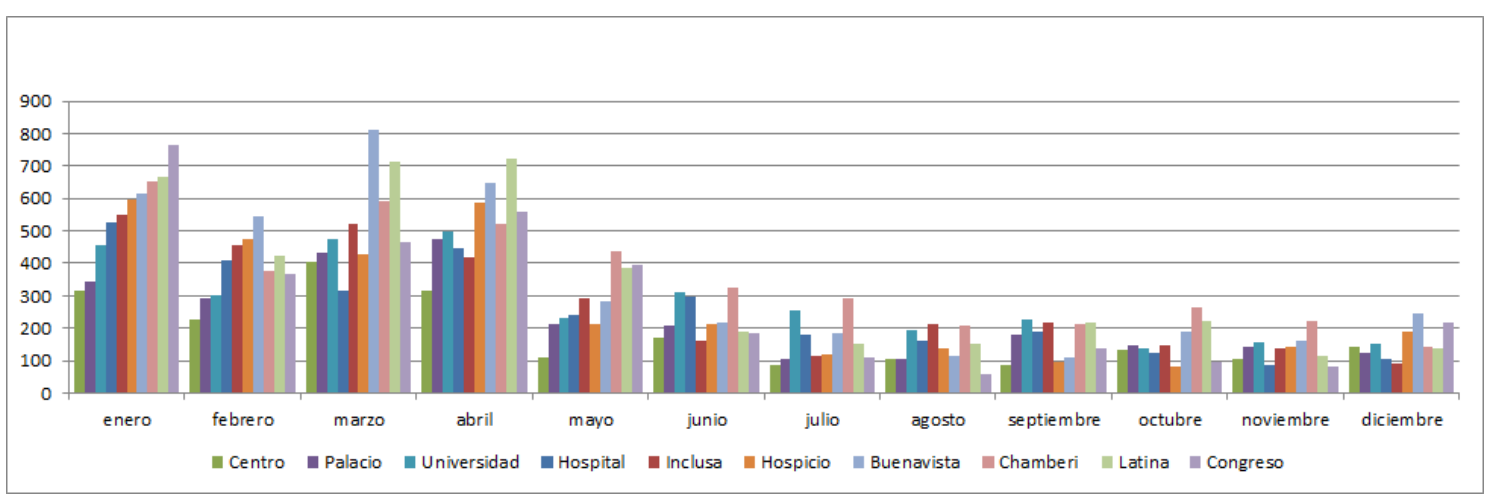

Gráfico 7-26. Desinfecciones realizadas en viviendas por fiebre tifoidea e infecciones intestinales. Por meses. Laboratorio Municipal

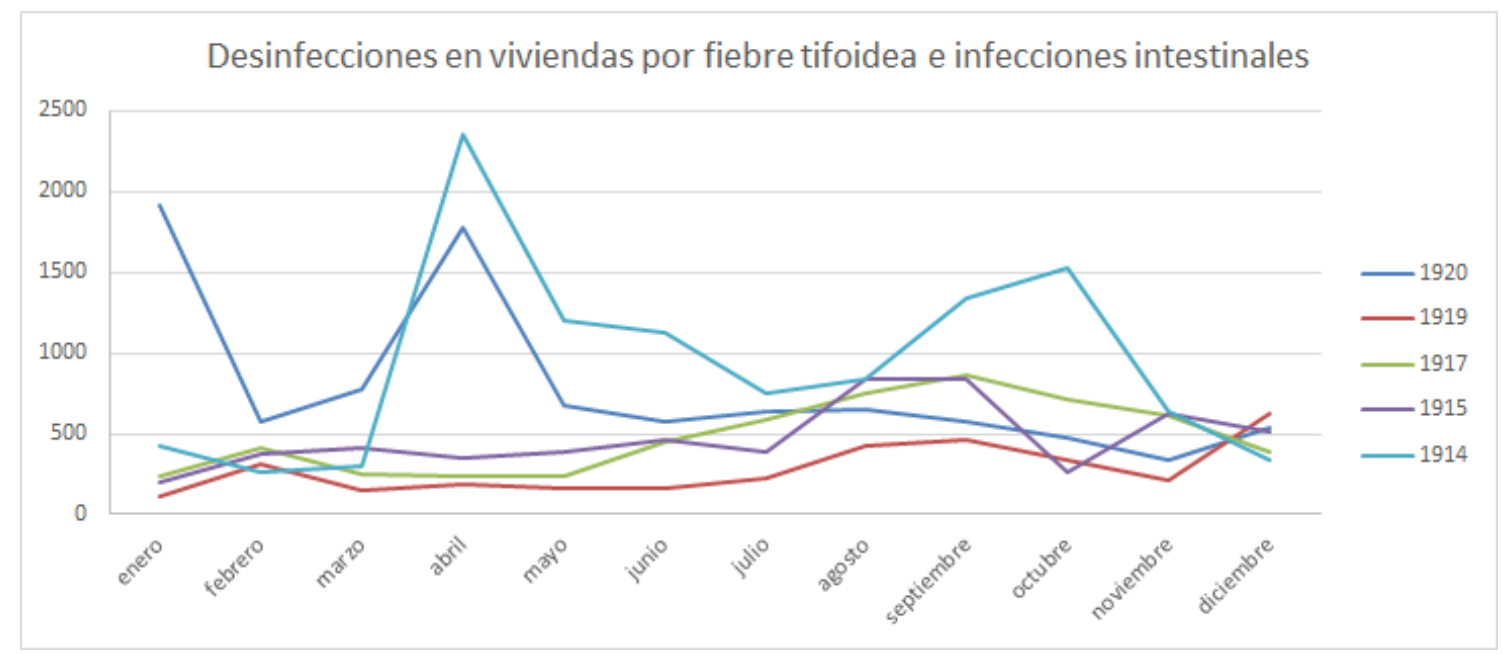

Fuente: Elaboración propia. Resumen de los trabajos realizados por las dependencias municipales para varios años. 
Gráfico 7-27. Desinfecciones realizadas en viviendas por gripe. Por meses. Laboratorio Municipal

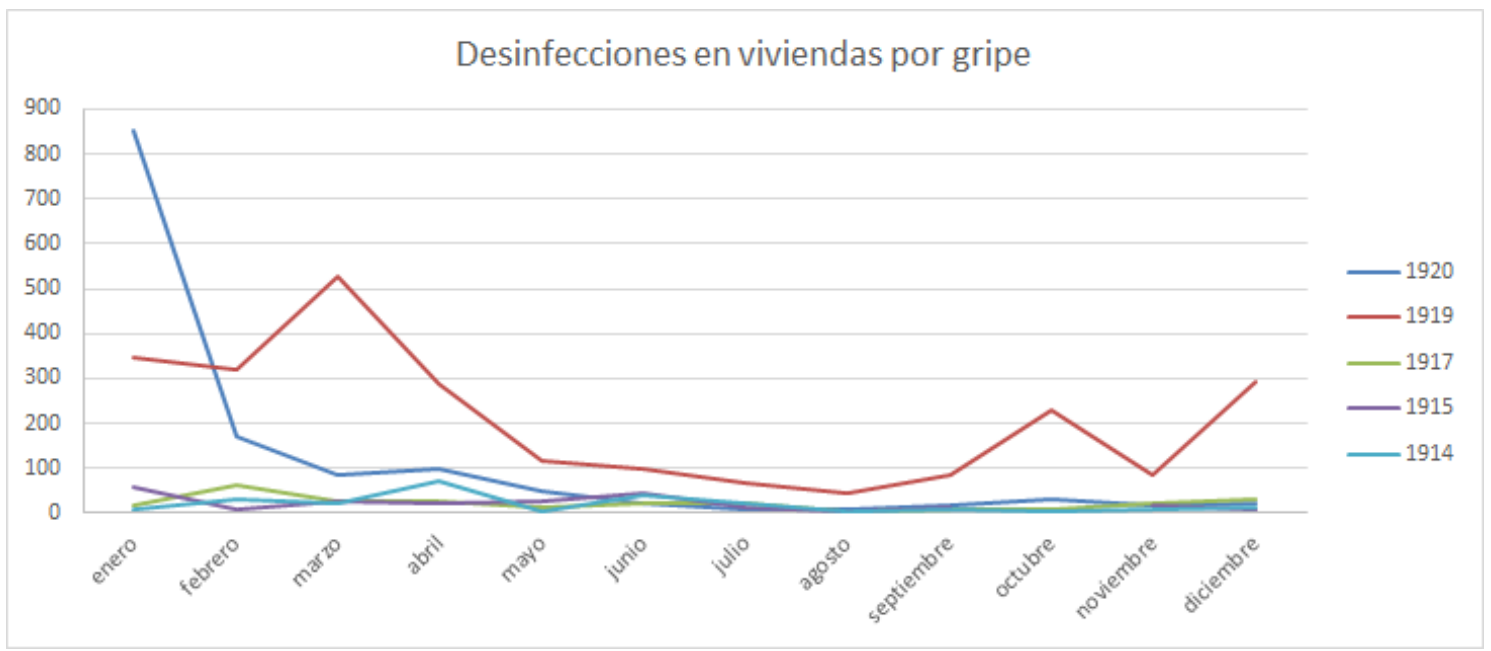

Fuente: Elaboración propia. Resumen de los trabajos realizados por las dependencias municipales para varios años.

Gráfico 7-28. Desinfecciones realizadas en viviendas por difteria. Por meses. Laboratorio Municipal

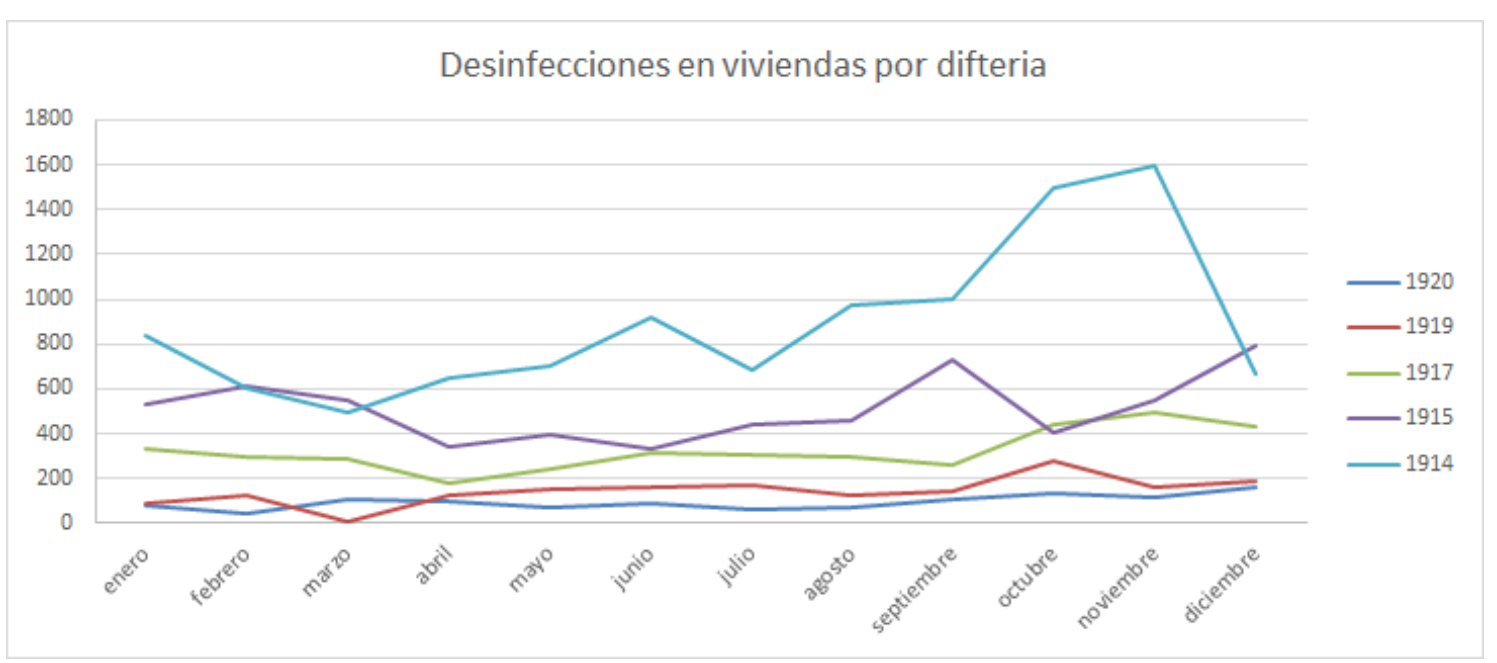

Fuente: Elaboración propia. Resumen de los trabajos realizados por las dependencias municipales para varios años. 
Gráfico 7-29. Desinfecciones realizadas en viviendas por viruela. Por meses. Laboratorio Municipal

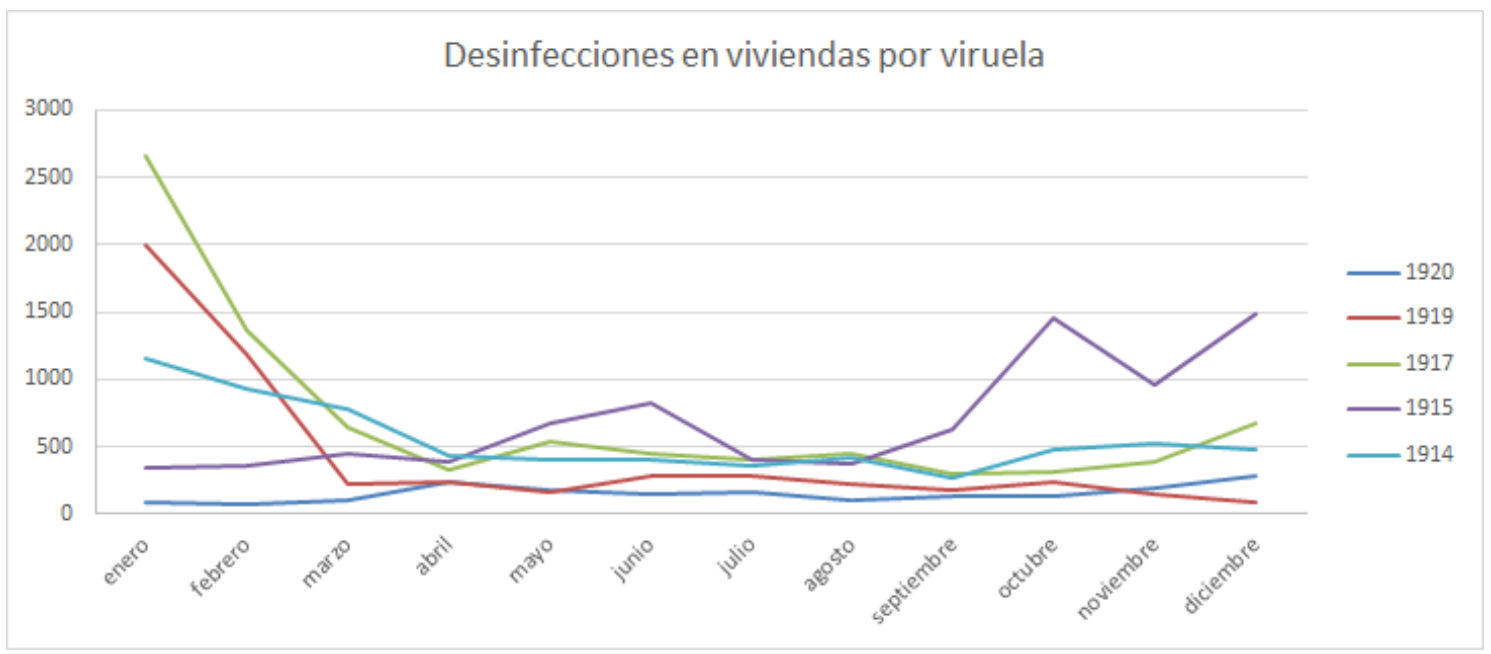

Fuente: Elaboración propia. Resumen de los trabajos realizados por las dependencias municipales para varios años.

Gráfico 7-30. Desinfecciones realizadas en viviendas por tuberculosis. Por meses. Laboratorio Municipal

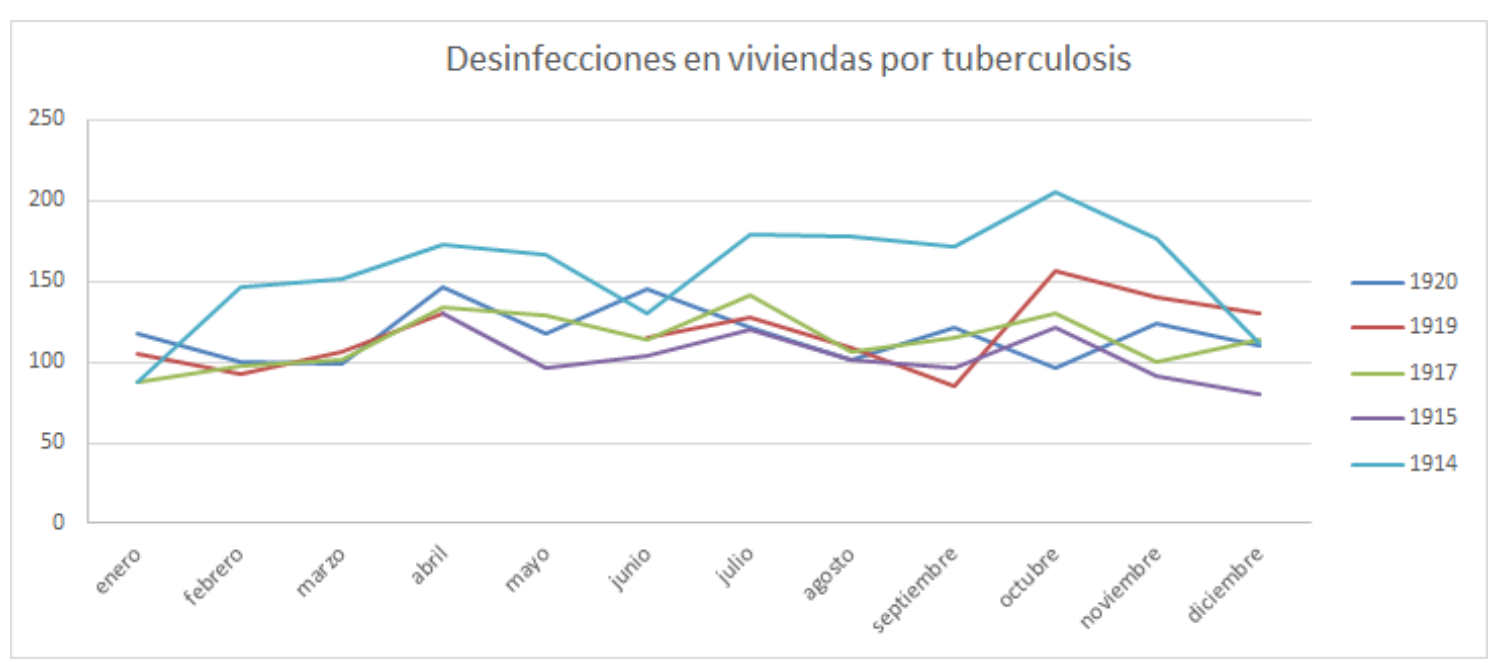

Fuente: Elaboración propia. Resumen de los trabajos realizados por las dependencias municipales para varios años. 


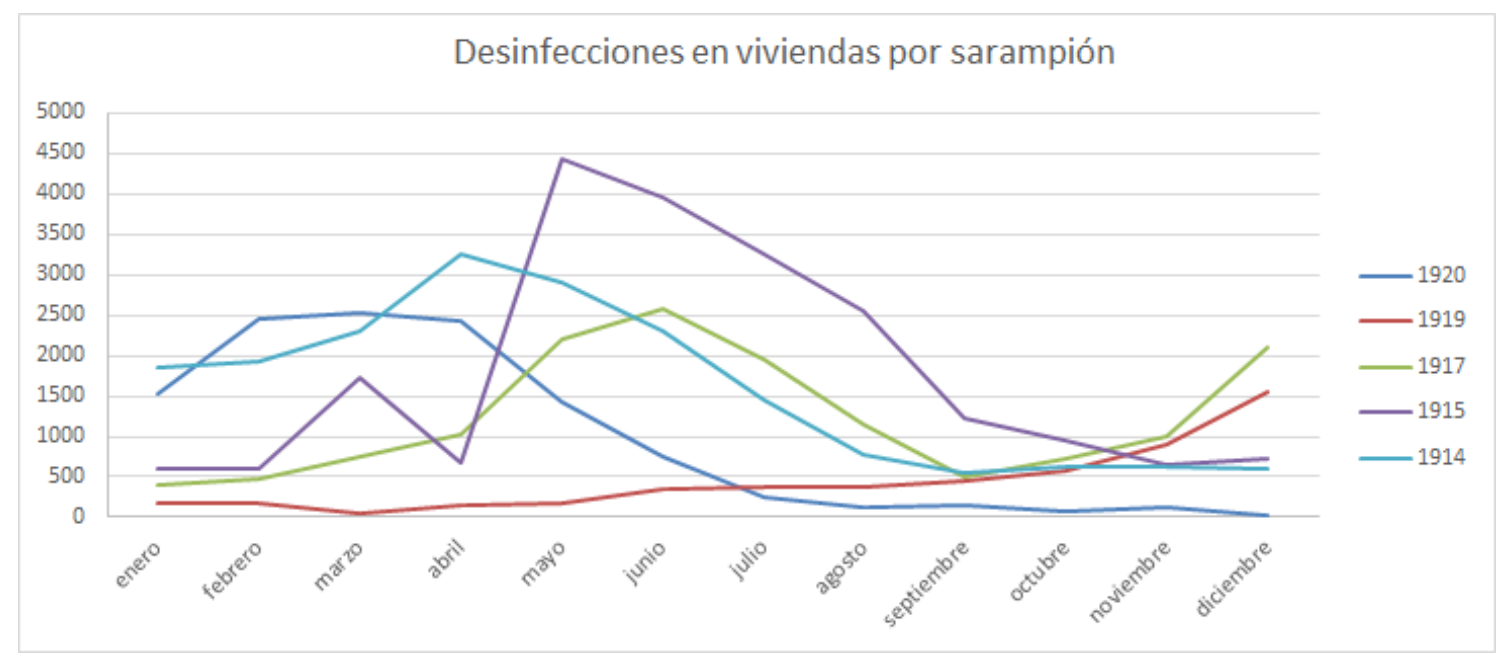

Fuente: Elaboración propia. Resumen de los trabajos realizados por las dependencias municipales para varios años.

\subsubsection{El Campamento de Desinfección}

El Campamento de Desinfección formaba parte del servicio de Defensa contra las enfermedades infecto-contagiosas. Su origen se remonta a 1909, momento en que comienza a repararse en la necesidad de crear un organismo en el que se pudiera albergar a personas convivientes de enfermos con enfermedades infectocontagiosas, fruto de la ineficacia de los servicios de desinfección en casas en las que las condiciones de salubridad eran pésimas. Inspirados en los medios llevados a cabo en Inglaterra, donde existían las denominadas reception house que eran "casas de recepción para las personas expuestas a infectarse por convivencia con algún enfermo y en las que permanecen hasta pasado el período de incubación, mantenidas y atendidas a expensas de la Autoridad local” (Chicote del Riego, 1918, p. 10), se creó el Campamento de Desinfección de Madrid. El objetivo fue tener un lugar donde trasladar a los convivientes de los enfermos, en un momento en que Madrid sufría un brote de tifus exantemático, enfermedad transmitida por los piojos, y así poder realizar una desinfección de los domicilios.

El proceso de atención del servicio, tras el aviso sobre la existencia de un enfermo, era la recogida del mismo por un coche de camillas y su traslado al hospital de epidemias. 
Al mismo tiempo, los convivientes del enfermo eran llevados al Campamento de Desinfección. Allí, tras tomar nota de información tal como su procedencia, edad, sexo, entre otros datos, los hombres eran llevados a una sala y las mujeres y niños a otra, donde se aseaban, abañaban, cambiaban de ropas y eran atendidos por un Médico. El tiempo de permanencia en el Campamento era variable, dependiendo de las necesidades, con la visita de un Médico dos veces al día. En caso de que se dieran casos con síntomas de infecciones, se les trasladaba a los pabellones de observación del hospital de epidemias. Durante su estancia, se les proporcionaba tres comidas diarias, se les renovaba la ropa y se desinfectaba la ropa de cama diariamente.

Al tiempo que los convivientes de la persona enferma estaban en el Campamento y la persona infectada en el Hospital de epidemias, el personal desinfector del Laboratorio procedía a la desinfección del domicilio, desinfección gaseosa con anhídrido sulfuroso y después se blanquean con lechada de cal las paredes y techos y se baldea el suelo con solución de creolina (Chicote del Riego, 1918, p. 11).

El nuevo servicio, contra lo que por muchos se creyó equivocadamente, no suponía la creación de un hospital, ni de un asilo, ni de nada de lo que hasta aquel momento se había pensado ni hecho; ni el Laboratorio al acometer esta empresa por mandato de las autoridades sanitarias, rebasó los límites de su cometido por tratarse exclusivamente de un problema de desinfección (Chicote del Riego, 1918, p. 11).

\subsection{El servicio analítico del laboratorio}

Dada la complejidad intrínseca de las funciones desempeñadas por el Servicio de análisis del Laboratorio Municipal de Madrid (relativos a la estructura prevaleciente hasta la modificación de la organización de los servicios por acuerdo de 20 de noviembre de 1931) se ha optado por la construcción de un esquema con el objetivo de sintetizar cada una de las divisiones del mismo y los servicios asociados a cada una de éstas. 
Gráfico 7-32. El Servicio analítico del Laboratorio Municipal de Higiene de Madrid. 1917.

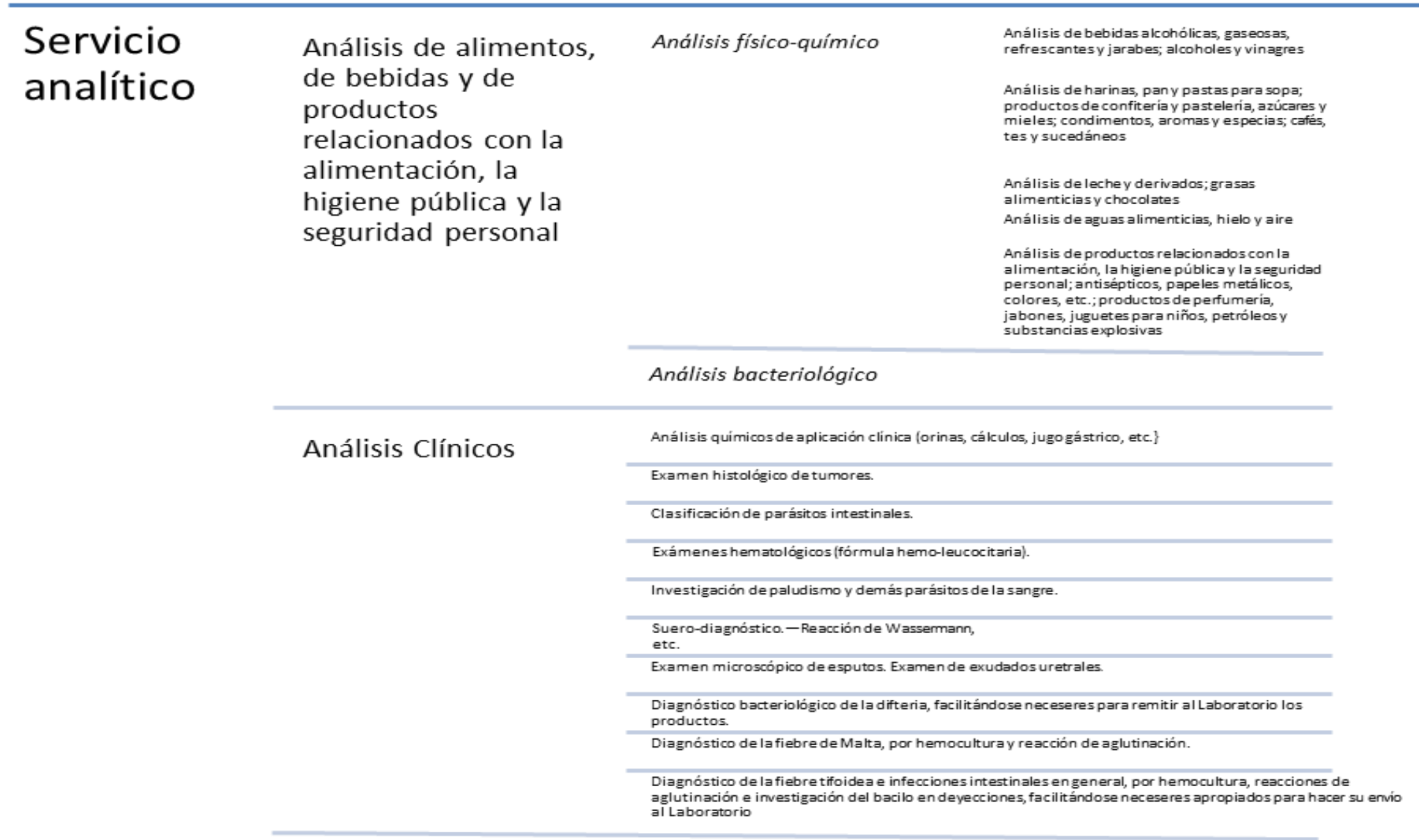

FUENTE: Elaboración propia con información obtenida de (Chicote del Riego, 1918). 
Con las modificaciones sufridas por el citado acuerdo de 1931, se inserta a la estructura organizativa del Laboratorio la Sección de Química. Podríamos decir que, en líneas generales la Sección de Química se correspondía con la antigua subsección del Servicio Analítico, que se encargaba del Análisis de alimentos, de bebidas y de productos relacionados con la alimentación, la higiene pública y la seguridad personal, atendidendo a las funciones desempeñadas. Así, era la sección encargada de llevar a cabo los análisis físicoquímicos y micrográficos, quedando subdividida en seis subsecciones, cada una de las cuales, disponía de un laboratorio independiente, que se recogen el el siguiente cuadro.
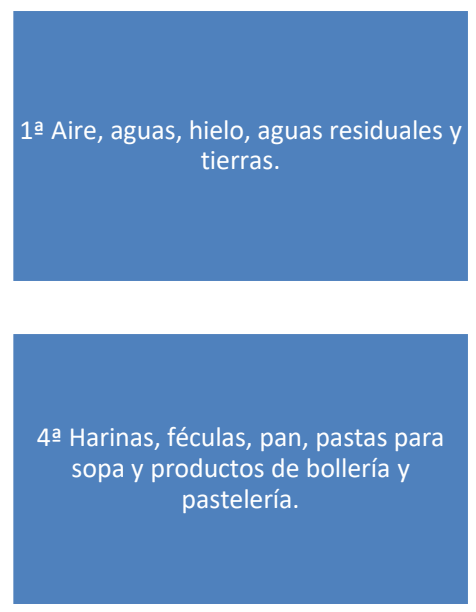
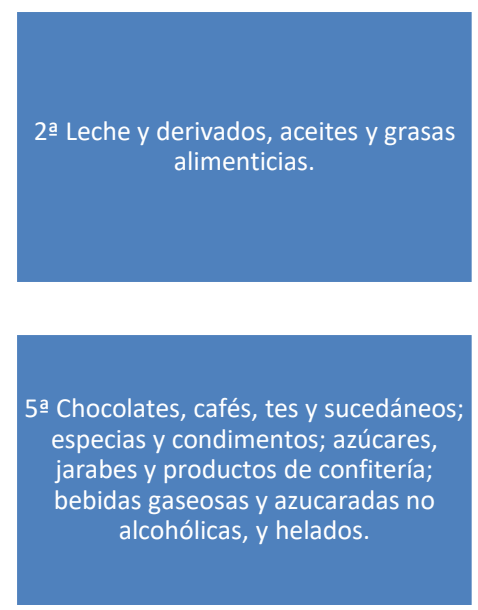

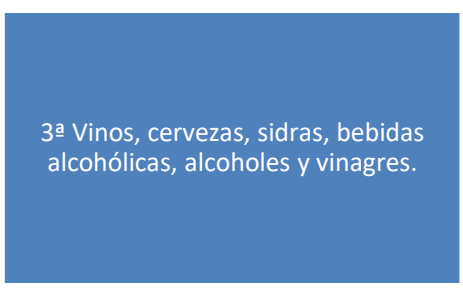

6a Conservas de todas clases; materias colorantes; papeles metálicos y metales aplicados a usos alimenticios; productos de perfumería, jabones y lejías; productos no comprendidos en ninguna de las otras subsecciones, y análisis judiciales.

Por su parte, la Sección de Microbiología, insertada en la estructura organizativa del Laboratorio a partir de 1931, aunaba funciones que años anteriores eran desempeñados por varios departamentos del Laboratorio. Así, podría decirse que esta sección aglutinó tareas que anteriormente se llevaban a cabo por el denominado Servicio Analítico, dentro de la Subsección de Análisis Clínicos, así como funciones anteriormente llevadas a cabo por el Servicio de defensa contra las enfermedades infectocontagiosas. De este modo, la nueva Sección de Microbiología se encargó de llevar a cabo los análisis bacteriológicos (de las aguas, el aire, las tierras, los alimentos y las bebidas), así como el diagnóstico de las enfermedades contagiosas, la preparación de vacunas preventivas y del servicio contra la rabia. Al igual que para la Sección Química, la Sección de Microbiología quedó subidivida en diferentes áreas, con el fin de lograr una eficiente organización y especialización del trabajo desempeñado. Además, cada subsección disponía de un laboratorio independiente con material específico para cada tarea. 
$1^{a}$ Diagnóstico de infecciones y preparación de vacunas bacterianas.

$2^{\text {a }}$ Bacteriología de aguas, alimentos, aire, aguas residuales y tierras.

$3^{\mathrm{a}}$ Preparación de vacuna contra la viruela.

$4^{a}$ Análisis bioquímicos.

- Subsección antirrábica: diagnóstico y tratamiento de la rabia.

- Subsección de preparación de medios de cultivo.

La Sección de Veterinaria comprende la vigilancia de las enfermedades de los animales transmisibles al hombre, los servicios de inspección de alimentos, la preparación de vacuna antivariólica, el servicio antirrábico y trabajos de laboratorio, todo ello en la parte que compete a la Veterinaria.

La Sección de Epidemiología tiene a su cargo la epidemiología del término municipal y su relación con la de los colindantes, más los servicios de desinfección, desinsectación y desratización, ambulancias sanitarias y estadística de morbilidad y mortalidad por enfermedades contagiosas. 
Gráfico 7-33. Secciones y funciones del Laboratorio Municipal. 1932.

\begin{tabular}{|c|c|c|}
\hline \multirow{6}{*}{$\begin{array}{l}\text { Sección de } \\
\text { Química. } \\
\text { Subsecciones }\end{array}$} & \multicolumn{2}{|c|}{ 1르 Aire, aguas, hielo, aguas residuales y tierras. } \\
\hline & \multicolumn{2}{|c|}{ 2aㅡ Leche y derivados, aceites y grasas alimenticias. } \\
\hline & \multicolumn{2}{|c|}{3 a Vinos, cervezas, sidras, bebidas alcohólicas, alcoholes y vinagres. } \\
\hline & \multicolumn{2}{|c|}{ 4a Harinas, féculas, pan, pastas para sopa y productos de bollería y pastelería. } \\
\hline & \multicolumn{2}{|c|}{$\begin{array}{l}\text { 5a Chocolates, cafés, tes y sucedáneos; especias y condimentos; azúcares, jarabes y productos de } \\
\text { confitería; bebidas gaseosas y azucaradas no alcohólicas, y helados. }\end{array}$} \\
\hline & \multicolumn{2}{|c|}{$\begin{array}{l}\text { 6a Conservas de todas clases; materias colorantes; papeles metálicos y metales aplicados a usos alimenticios; } \\
\text { productos de perfumería, jabones y lejías; productos no comprendidos en ninguna de las otras subsecciones, } \\
\text { y análisis judiciales. }\end{array}$} \\
\hline \multirow{5}{*}{$\begin{array}{l}\text { Sección de } \\
\text { Microbiología. } \\
\text { Subsecciones. }\end{array}$} & \multicolumn{2}{|c|}{ 1aㅡ Diagnóstico de infecciones y preparación de vacunas bacterianas. } \\
\hline & \multicolumn{2}{|c|}{$\begin{array}{l}\text { 2a Bacteriología de aguas, alimentos, } \\
\text { aire, aguas residuales y tierras. }\end{array}$} \\
\hline & \multicolumn{2}{|c|}{$\begin{array}{l}3 \text { a Preparación de vacuna contra la } \\
\text { viruela. }\end{array}$} \\
\hline & \multirow[t]{2}{*}{ 4aA Análisis bioquímicos. } & $\begin{array}{l}\text { Subsección antirrábica: diagnóstico y tratamiento de la } \\
\text { rabia. }\end{array}$ \\
\hline & & Subsección de preparación de medios de cultivo. \\
\hline $\begin{array}{l}\text { Sección de } \\
\text { Veterinaria }\end{array}$ & \multicolumn{2}{|c|}{$\begin{array}{l}\text { Vigilancia de las enfermedades de los } \\
\text { animales transmisibles al hombre. }\end{array}$} \\
\hline
\end{tabular}

Servicios de inspección de alimentos.

Preparación de vacuna antivariólica.

Servicio antirrábico y trabajos de laboratorio

\section{Sección de}

Epidemiología

Epidemiología del término municipal y su

relación con la de los colindantes.

Servicios de desinfección, desinsectación y

desratización,

Servicio de ambulancias sanitarias

Estadística de morbilidad y mortalidad por

enfermedades contagiosas.

Fuente: Elaboración propia. Información extraída de (García Revenga, 1933, pp. 5-6) 
Cabe señalar que, dentro del grupo correspondiente a los análisis físico-químicos de productos relacionados con la alimentación, había un grupo que fue considerado como servicio urgente, de manera que los análisis se realizaban ipso facto en el momento en que se recogían las muestras en cuestión, con el objetivo de obtener los resultados de la manera más rápida posible. Este grupo de alimentos estaba compuesto por el reconocimiento de alimentos tales como carnes, aves, pescados, embutidos, crustáceos, mariscos, hortalizas, verduras, frutas, semillas alimenticias, setas, entre otros, caracterizados por la necesidad de su consumo en condiciones de frescura. La urgencia de los análisis radicaba, en buena medida, en que si la calificación por parte del Laboratorio era buena, el género debía ser devuelto. Tanto el servicio de análisis físicoquímico como los análisis clínicos, podían ser solicitados no sólo por los Médicos, sino también por el vecindario en general, siendo éstos de orden gratuito o de pago ${ }^{74}$. En el resultado obtenido de los servicios con tarifa de pago aparecía una certificación acreditativa, mientras que en el servicio gratuito, solamente se hacía constar la calificación obtenida, sin certificado.

En lo que respecta al proceso de admisión de muestras en el servicio de análisis clínico del Laboratorio, era necesario que fueran acompañadas de un documento justificativo, si el análisis había sido solicitado por un organismo o autoridad oficial, o de la presentación de un documento firmado por el interesado, en caso de que el análisis fuera solicitado por un particular, al que se le entregaba un recibo del documento presentado. El servicio para particulares estaba destinado a cualquier ciudadano del vecindario de la ciudad, así como por los Ayuntamientos de provincias.

Las muestras que llegaban al Laboratorio pasaban primeramente por el registro y, posteriormente, los Subjefes (encargados de vigilar el orden y eficacia en el despacho de asuntos) distribuían las mismas a los Jefes de cada uno de los grupos analíticos. Éstos últimos, las entregaban a su personal a cargo en función de la especialización requerida en el análisis, recayendo la responsabilidad de los trabajos llevados a cabo en el Jefe de grupo. Además, los Jefes de grupo tenían potestad para realizar comprobaciones de resultados obtenidos y eran los encargados de firmar las hojas de análisis expedidas por los Profesores antes de que estas fueran entregadas a la Dirección del Laboratorio.

\footnotetext{
${ }^{74}$ En cuanto a los derechos de análisis percibidos, estaba sujetos a tarifas aprobadas por el Excmo. Ayuntamiento de Madrid, de modo que se ingresaban íntegros en la Administración de Propiedades, Rentas y Arbitrios (Chicote del Riego, 1918, p. 6)
} 
El procedimiento general para llevar a cabo los análisis no sufrió modificaciones con los nuevos acuerdos llevados a cabo tras la salida del Doctor Chicote como Director del Laboratorio. Las variaciones acontecidas afectaban al tiempo máximo para llevar a cabo los análisis, el cual no debía exceder los ocho días desde la recepción de las muestras, a excepción de comprobación de aparatos o procedimientos para tratamiento de aguas, desinfectantes y problemas similares, así como los análisis relacionados con el diagnóstico de las enfermedades infecciosas de origen parasitario, que serán hechos dentro del plazo estrictamente necesario . Asímismo, para los análisis de los artículos de consumo, se procedía a hacer lo que se denominaba exámenes rápidos, que debían llevarse a cabo en tres horas. Estos análisis rápidos sólo pueden pedirse para la investigación de aquellas defectuosidades que suponen fraude o alteraciones corrientes a cuyo descubrimiento pueden aplicarse los procedimientos rápidos toda vez que las excepcionales no son demostrables más que por los métodos de análisis completo, que son inevitablemente largos y delicados. (García Revenga, 1933, pp. 7-8).

La inspección química incuía los trabajos desempeñados por los Inspectores químicos e inspectores veterinarios. Las funciones de los Inspectores químicos eran las siguientes:

- La inspección y vigilancia en los almacenes, tiendas y puestos en donde se venda toda clase de productos alimenticios, excepto las carnes, aves, pescados $y$ demás alimentos procedentes del reino animal, de las frutas y de las verduras.

- La inspección y vigilancia en las fondas, cafés, cafetines, cervecerías, horchaterías y establecimientos de bebidas gaseosas y refrescantes.

- La inspección de la fabricación y venta de utensilios de cocina, por lo que respecta a los barnices y esmaltes, así como de las fábricas de papel de estaño, cápsulas, utensilios, vasijas y envases metálicos.

Los Inspectores químicos se encontraban a las inmediatas órdenes de los señores Tenientes de Alcalde, a los que directamente elevaban las denuncias y cuantos partes motivasen las incidencias de los servicios, salvo en el caso de que para resolver sobre las condiciones de un alimento se precise el análisis del mismo en el Laboratorio, el cual da cuenta por oficio a la Tenencia de Alcaldía del resultado obtenido. En la toma de muestras por los Inspectores se utilizan unas actas impresas, en las que aparecen aquellas disposiciones que interesa conocer al comercio para que en ningún caso pueda 
alegar ignorancia y se cumplimenten rigurosamente las prescripciones del real decreto de 22 de diciembre de 1908.

Un cambio significativo, en lo que compete a los inspectores veterinarios, fue que comenzaron a disponer de jefatura propia, dependiendo a su vez, en la esfera administrativa, del excelentísimo señor Alcalde, y en lo técnico, de la Inspección Provincial de Veterinaria, según decreto del Ministerio de Fomento de 7 de diciembre de 1931 (Publicado en la Gaceta de Madrid del día 8 de diciembre de 1931).

\subsubsection{Condiciones mínimas de las sustancias}

Las condiciones e instrucciones técnicas que aparecen en el Real Decreto de Gobernación de 22 de diciembre de 1908, sobre las Condiciones que deben reunir los alimentos, papeles, aparatos, utensilios y vasijas, que ya han sido señalados en líneas precendentes, por la que se regulaban sustancias alimenticias tales como el hielo, la leche y sus derivados (como mantequillas y quesos), aceite, harina, pan, pastas alimenticias, alcoholes, aguardientes y licores (vinos, kirsch, sifras, cognac, cerveza, ginebra, whisky, brandy, ron y ratafia), café, té, cacao y chocolate, jarabes, aguas y bebidas gaseosas, bebidas refrescantes y helados, azúcar refinado, glucosa, azúcar invertido, miel, productos de confiteria y pastelería, vinagres, sal de cocina, azafrán,

pimentón, clavo, pimienta, mostaza, canela, conservas alimenticias, carnes y sus derivados, materias colorantes y materias vegetales, siguieron estando en vigor a la altura de los años treinta del siglo XX.

Atendiendo a las condiciones necesarias correspondiente a las aguas que aparecen en el Real Decreto de 22 de diciembre de 1908, también se señalan las características cualitativas y cuantitativas que eran necesario cumplir todo el agua destinado a la alimentación. Respecto a las primeras, debía ofrecerse transparente, incolora, inodora e insípida.

En cuanto a los componentes cuantitativos, se indica que no debían superar los siguientes límites máximos de cada uno de los factores indicados, medido en miligramos por litro de agua, tal y como se indica en la tabla adjunta. Estos valores sufrieron modificaciones por Real decreto de 14 de septiembre de 1920. 
Tabla 7-6. Niveles máximos permitidos de los componentes del agua destinados al consumo.

\begin{tabular}{|c|c|c|}
\hline Componentes & $\begin{array}{lr}\text { Hasta } 1920 . \\
\text { Miligramos por } \\
\text { litro }\end{array}$ & $\begin{array}{l}\text { A partir de } \\
1920^{75} \text {. } \\
\text { Miligramos por } \\
\text { litro }\end{array}$ \\
\hline $\begin{array}{l}\text { Residuo fijo por evaporación seco } \\
\text { á } 180^{\circ} \text { centígrados, hasta peso } \\
\text { constante }\end{array}$ & 500 & 500 \\
\hline $\begin{array}{l}\text { Residuo fijo por calcinación al rojo } \\
\text { sombra }\end{array}$ & 450 & 450 \\
\hline $\begin{array}{l}\text { Cloro expresado en cloruro de } \\
\text { sodio }\end{array}$ & 70 & 60 \\
\hline Acido sulfúrico & 30 & 50 \\
\hline Cal & 200 & 150 \\
\hline Magnesia & 30 & 50 \\
\hline $\begin{array}{l}\text { Materia orgánica total valorada en } \\
\text { líquido ácido y expresada en } \\
\text { oxigeno }\end{array}$ & 4 & 3 \\
\hline Amoníaco, por reacción directa & 0 & 0 \\
\hline $\begin{array}{l}\text { Amoníaco libre determinado por } \\
\text { destilación }\end{array}$ & 0.02 & 0.02 \\
\hline Amoníaco albuminoide & 0.005 & 0.005 \\
\hline Ácido nitroso & 0 & 0 \\
\hline Ácido nítrico & 20 & 20 \\
\hline
\end{tabular}

Fuente: elaboración propia. Información extraida de Las subsistencias en Madrid (García Revenga, 1933, p. 59; Melgosa Olaechea, 1912, p. 55)

Otras de las condiciones que debían ofrecer las aguas de consumo eran las siguientes:

- Que no contenga en suspensión productos intestinales del hombre o de los animales.

- Que no contenga sino una escasa proporción de gérmenes inofensivos, cuyos cultivos den en la experimentación fisiológica resultados satisfactorios y ninguno procedente del tubo intestinal, ni otros menos frecuentes de carácter patógeno.

\footnotetext{
${ }^{75}$ Condiciones que deben reunir las aguas destinadas a la bebida y usos alimenticios en el aspecto químico, por Real decreto de 14 de septiembre de 1920
} 
- Deberá tenerse en cuenta que Cualquier agua cuyo análisis haya arrojado una vez conclusiones desfavorables, procederá considerarla, por lo menos, como sospechosa; y que, por el contrario, el hecho de que sólo un análisis demuestre su bondad, no debe ser motivo suficiente para poder apreciar en definitiva su valer higiénico.

Atendiendo al número de muestras analizadas por el Laboratorio, según su naturaleza, en los años 1917 y 1932, cabe destacar un aumento de éstas, especialmente en lo respectivo a las realizadas sobre alimentos y bebidas, tal y como puede verse en la tabla 7-7.

En lo que repecta a las muestras analizadas según su procedencia (Tabla 7-8), se produjo un aumento considerable en aquellas socilitadas por los servicios de inspección, pasando de 2250 en 1917 a 15467 en el año 1932, así como las socilicitadas por el vecindario, que superaron en más del doble en los años respectivos. Sin embargo, pese a que en cómputo global las muestras analizadas fueron más del doble en 1932 que en 1917, en lo que respecta a los análisis químicos y bacteriológicos de las aguas alimenticias de Madrid, se produjo un descenso considerabla en la comparativa de éstos dos años.

Tabla 7-7. Muestras analizadas según su naturaleza en los años 1917 y 1932

\begin{tabular}{|c|c|c|}
\hline Muestras analizadas, según su naturaleza & 1917 & 1932 \\
\hline Alimentos y bebidas & 8715 & 20747 \\
\hline Productos que interesan a la higiene & 169 & 373 \\
\hline Productos patológicos & 2502 & 3528 \\
\hline Total de muestras & 11386 & 24648 \\
\hline
\end{tabular}

Fuente: elaboración propia (Chicote del Riego, 1918; García Revenga, 1933) 
Tabla 7-8. Muestras analizadas según su procedencia en los años 1917 y 1932

\begin{tabular}{|rcc|}
\hline Muestras analizadas, según su procedencia & 1917 & 1932 \\
\cline { 2 - 3 } Ordenados por las Autoridades & 246 & 175 \\
Solicitados por diversos pueblos & 44 & \\
Pedidos por el vecindario & 320 & 822 \\
Pedidos por los servicios de Inspección & 2250 & 15467 \\
Pedidos por los facultativos de la Beneficencia municipal & 602 & 840 \\
Pedidos por los facultativos de asistencia al vecindario & 1671 & \\
Pedidos por diversas clínicas & 219 & 477 \\
Vigilancia de las aguas alimenticias de Madrid; análisis & & 1857 \\
químicos y bacteriológicos & 6034 & 2787 \\
Ordenados por la Delegación de Abastos & & \\
Pedidos por la Administración de Rentas y Exacciones & & 2223 \\
Tunicipales & & 24648 \\
\hline
\end{tabular}

Fuente: elaboración propia (Chicote del Riego, 1918; García Revenga, 1933)

\subsubsection{La institucionalización de los análisis de agua.}

La Institucionalización de los análisis de aguas por parte del Laboratorio Municipal es un aspecto clave a la hora de analizar la importancia que fue adquiriendo la necesidad de higienización de las infraestructuras y los productos alimenticios. Ya no sólo se trabajaba de la cantidad de agua, sino de su calidad.

El análisis de las aguas de una localidad, en vista siempre de un conjunto de antecedentes geológicos, locales, físicos, químicos, micrográílcos y bacteriológicos, deberá ser motivo para que los Laboratorios organicen un servicio permanente, por el que diariamente, á ser posible, se hagan las investigaciones necesarias bajo el concepto de una posible contaminación. (Melgosa Olaechea, 1912, p. 55).

Las condiciones higiénicas de las aguas de la ciudad eran atendidas mediante análisis químicos y bacteriológicos que llevaba a cabo el Laboratorio Municipal. En la Memoria de la ciudad de 1929 (Ayuntamiento de Madrid, 1929) se especifica que éstos son llevados a cabo sobre las aguas del Lozolla, Canalillo, Santillana y Manzanares. Sin embargo, atendiendo a diversas memorias publicadas por el Laboratorio, los análisis también comprendían las aguas provenientes de los Viajes antiguos, tal y como se verá a continuación. 


\subsubsection{Los análisis químicos}

Tal y como se ha podido ver en el capítulo relativo a la depuración de las aguas alimenticias de Madrid, éste fue un problema que caracterizó a todo el periodo que comprende el presente estudio.

A la altura de 1917, ya se habían concluido las estaciones de depuración de las aguas del Ayuntamiento, las de los antiguos viajes, mediante sistemas de ozono. Sin embargo, el agua suministrada por éstos era la menor, en comparación con la abastecida por el Canal de Isabel II y por la Sociedad Hidráulica Santillana y éstas dos continuaban sin ser tratadas por sistemas de depuración. La preocupación y el descontento por parte de los higienistas acerca de la falta de mecanismos de depuración del agua era manifiesta, pues tal y como mostraba el Doctor Chicote "continúan constantemente expuestas al peligro de la contaminación, que nada se ha hecho para evitarle, con manifiesto olvido de lo dispuesto en contrario. Un año más que a este efecto ha transcurrido estérilmente" (Chicote del Riego, 1918, p. 53).

Como se ha mencionado, el Laboratorio Municipal de Madrid realizó a lo largo de los años, entre sus servicios, una importantísima labor en referencia al abastecimiento de las aguas y sus condiciones óptimas para el consumo. Sin embargo, el malestar acerca de la gestión, en torno a la depuración biológica del agua, por parte de la Hidráulica Santillana y el Canal de Isabel II se hacía notar en los informes de los técnicos, como el elaborado en 1917 por el Doctor Chicote sobre los trabajos del Laboratorio “(...)si los trabajos del Laboratorio y su constante labor en este sentido no han de ser tomados en consideración para adoptar medidas de defensa contra la contaminación de las aguas, indudablemente se está perdiendo el tiempo de una manera lastimosa. Pero muy a pesar de este convencimiento, seguiremos insistiendo, ahora y siempre, sobre este problema de vida para Madrid, no sólo porque con ello cumplimos un deber, sino porque conviene al Laboratorio no aceptar con su silencio participación en responsabilidades de una gravedad abrumadora. Pretender que las aguas superficiales, de río, que discurren por lugares cercanamente habitados pueden ser bebidas sin previo tratamiento, sea el que fuere y convenga, es sencillamente una peligrosa equivocación”" (Chicote del Riego, 1918, p. 53). 
Pese a que varias de las Memorias del Canal de Isabel II, en términos generales, se "dulcifica", de algún modo, la situación sobre la contaminación de las aguas de abastecimiento a la población, los resultados mostrados por el Laboratorio Municipal son opuestos, manteniendo que sus informes "reflejan la realidad en cuanto se refiere al abastecimiento de aguas, manifestando clara y concretamente que hasta ahora no se han conseguido evitar las contaminaciones; que éstas constituyen una amenaza constante, y que de no corregirse el mal sólo por un milagro de la Providencia nos iremos defendiendo" y, continúa "concédase o no la importancia que se quiera a la presencia en las aguas de los bacilos coli y lactis aerógenes; mas lo cierto es, que procediendo éstas de la flora intestinal, lógico es suponer que de la misma manera que se encuentran en el agua el día que se ponga en su contacto un portador de gérmenes o las deyecciones de un enfermo de fiebre tifoidea o de cólera, de igual manera irán al agua los gérmenes de estas enfermedades, puesto que unos y otros proceden de las materias fecaloideas" (Chicote del Riego, 1918, p. 53).

En el cuadro adjunto, realizado por el Laboratorio Municipal de Madrid para el año 1917, se recogen los valores de medición ${ }^{76}$ correspondientes a la composición química de las aguas alimenticias de Madrid, obtenidos mediante la recogida de numerosas muestras que, tras su análisis, se calculó el valor medio de cada uno de los factores. Los resultados obtenidos se muestran para el estudio de las aguas del Canal de Isabel II y de los viajes de agua del Abroñigal Alto, Abroñigal Bajo, Alcubilla, Amaniel, Berro, Castellana, Reina, Retamar y Retiro.

\footnotetext{
${ }^{76}$ Temperatura (media de las cuatro estaciones de 1 año); densidad referida a 4ํoc; dureza total (Boutron y Boudet); dureza persistente (Boutron y Boudet); coeficiente de alterabilidad (por estaciones del año y Media anual); totalidad de gases en disolución a 0 grados centígrados y $700 \mathrm{~mm}$ : de anhídrido carbónico, de nitrógeno, de oxígeno y la proporcionalidad centesimal de los mismos; nitrógeno combinado al estado nítrico, representado en ácido nítrico; nitrógeno combinado al estado nitroso, representado en ácido nitroso, nitrógeno combinado al estado amoniacal, representado en amoníaco; nitrógeno combinado al estado albuminoide; carbono orgánico; materia orgánica total, representada en oxígeno absorbido (en líquido ácido, a $900^{\circ} \mathrm{c}$ ); materia orgánica total (líquido alcalino, a $90^{\circ} \mathrm{c}$.); materia volátil reducida; anhídrido silícico; anhídrido sulfúrico; cloro; cal total; magnesia total; alúmina; hierro; potasa; sosa; residuo fijo total a 110 grados centígrados.
} 
Tabla 7-9. Composición química de las aguas alimenticias de Madrid, en su estado normal: media de numerosos análisis. 1917

Composición quimica de las aguas alimenticias de Madrid, en su estado normal: media de numerosos análisis.

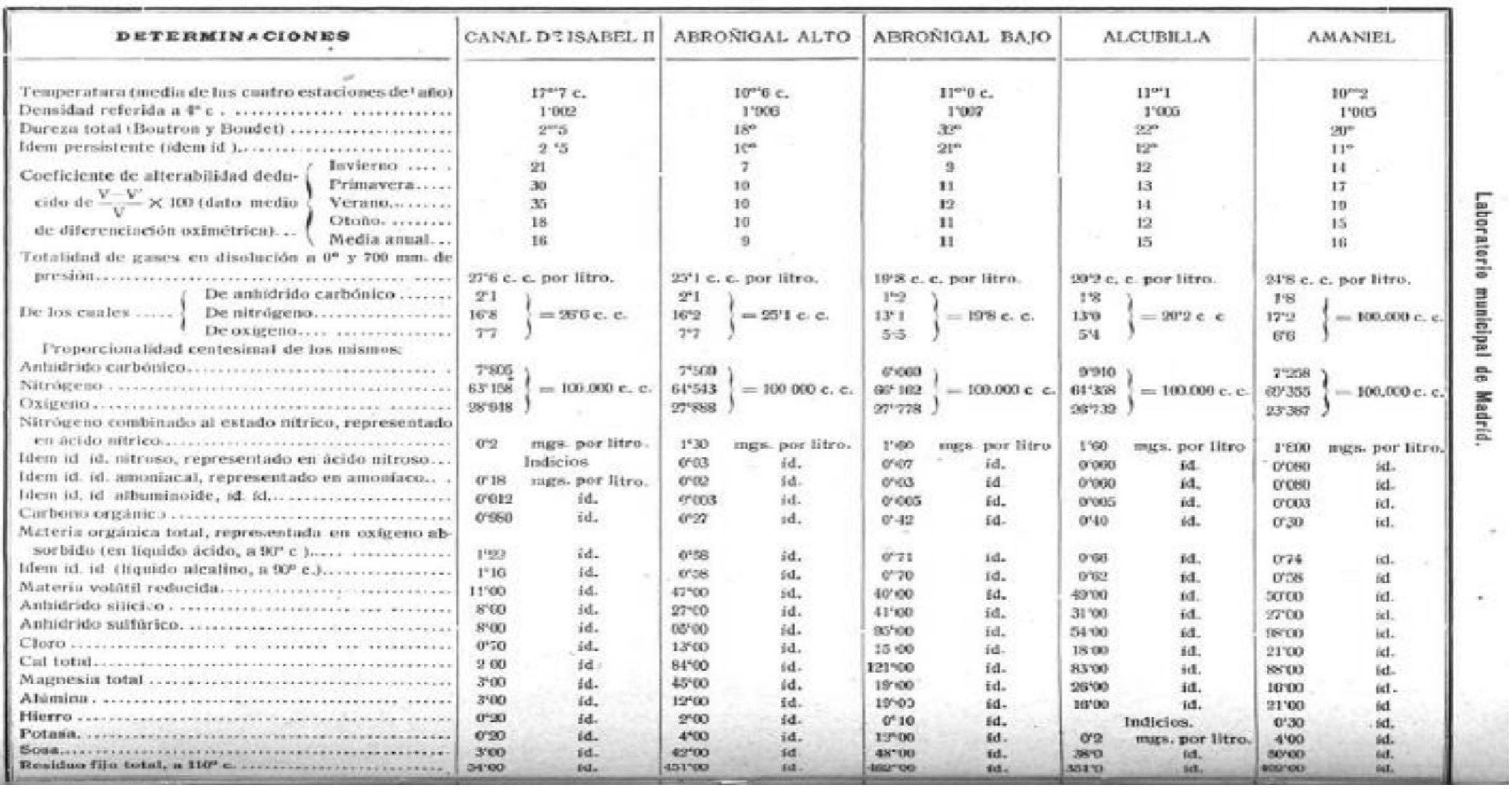




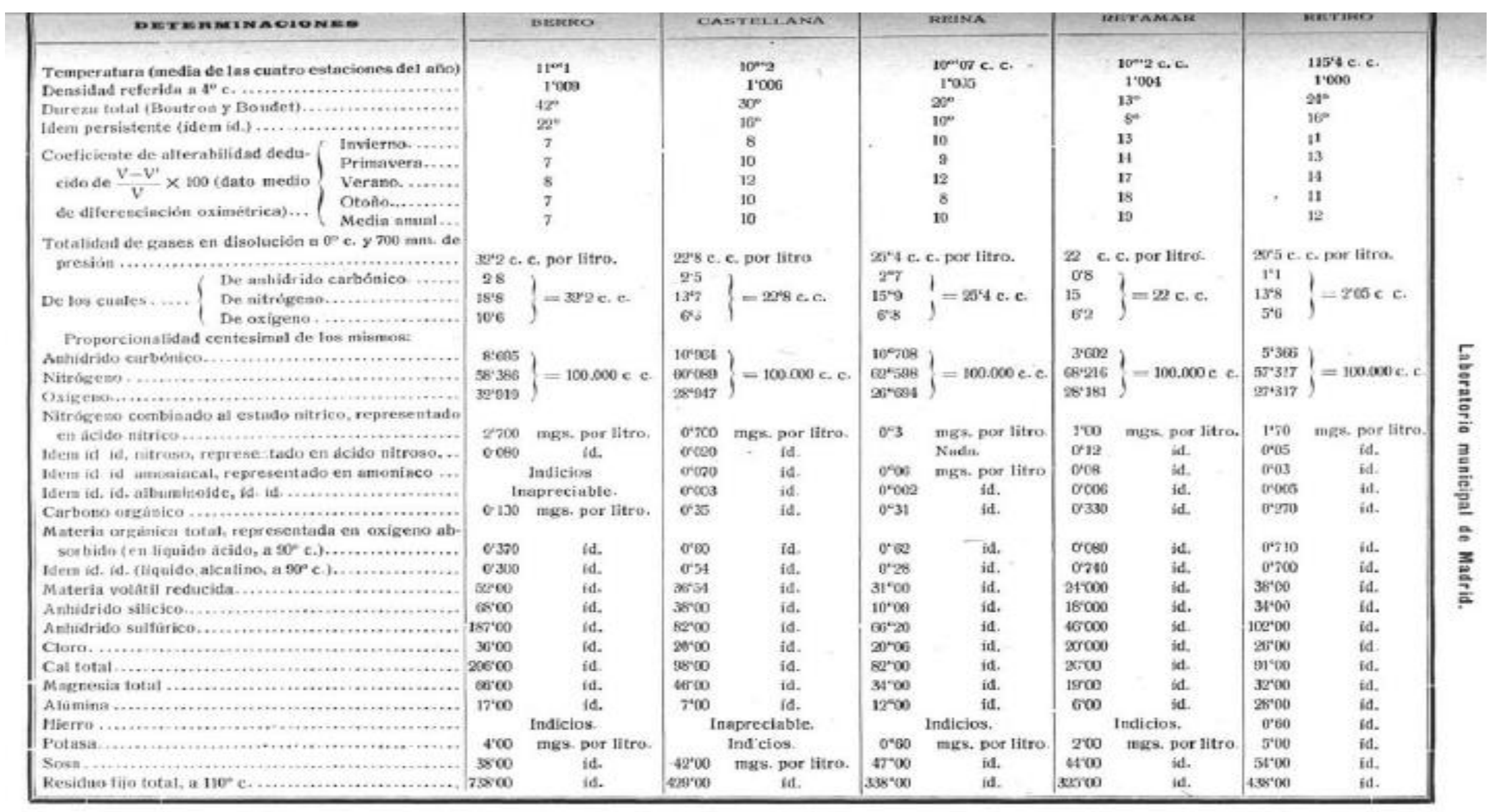

Fuente: (Chicote del Riego, 1918, pp. 54-55) 
Años posteriores, tal y como se muestra en el cuadro adjunto, realizado por el Laboratorio Municipal de Madrid para el año 1932, se recogen los valores de medición ${ }^{77}$ correspondientes a la composición química de las aguas alimenticias de Madrid, obtenidos mediante la recogida de numerosas muestras que, tras su análisis, se calculó el valor medio de cada uno de los factores. Los resultados obtenidos se muestran para el estudio de las aguas de los Canales del Lozoya (tomada de los depósitos y de las fuentes de la población), Agua de la Hidráulica Santillana procedente del río Manzanares ( tomada de fuentes de casas particulares), y de los viajes de agua del Abroñigal Alto, agua del viaje del Retamar, agua del viaje de la Alcubilla, agua del viaje del Abroñigal Bajo, agua del viaje de Amaniel y agua del viaje de la fuente del Berro (el agua tomada de los viajes era de procedencia de fuentes de la población).

\footnotetext{
${ }^{77}$ Temperatura (media de las cuatro estaciones de1 año); densidad referida a 4"c; dureza total (Boutron y Boudet); dureza persistente (Boutron y Boudet); coeficiente de alterabilidad (por estaciones del año y Media anual); totalidad de gases en disolución a 0 grados centígrados y $700 \mathrm{~mm}$ : de anhídrido carbónico, de nitrógeno, de oxígeno y la proporcionalidad centesimal de los mismos; nitrógeno combinado al estado nítrico, representado en ácido nítrico; nitrógeno combinado al estado nitroso, representado en ácido nitroso, nitrógeno combinado al estado amoniacal, representado en amoníaco; nitrógeno combinado al estado albuminoide; carbono orgánico; materia orgánica total, representada en oxígeno absorbido (en líquido ácido, a 90" c ); materia orgánica total (líquido alcalino, a $90^{\circ}$ c.); materia volátil reducida; anhídrido silícico; anhídrido sulfúrico; cloro; cal total; magnesia total; alúmina; hierro; potasa; sosa; residuo fijo total a 110 grados centrígrados.
} 
Tabla 7-10. Composición química normal de las aguas del Lozoya, año 1932.

\title{
Composicion quimica normal de las aguas alimenticias de Madrid
}

\author{
Agua de los Canales del Lozoya

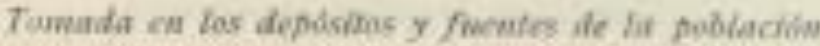

Temperatura invida (en tas cuatro cotactones de! anot

Desisdad referide a $8 \mathrm{c}$.

Dereza tocal (Boudron y Boodet)........................

Idera persistede cidem il. ..........................

Coebciente de alterabilidad deduci- ( Inyierno. de de $v-v^{2}$ tov idaro (Primavera.

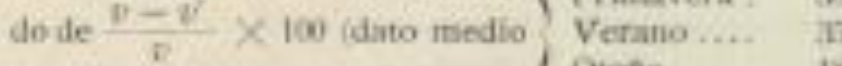
de diferenciacien oximsestica)..... / Otohe ...... is

$17 \% \mathrm{C}$

1,002

$r, 3$

2,3

21

(1)

is

$2 i$

Tocaidad de gasro en disolucide a of c, y $760 \mathrm{~mm}$. de presibón.

De los cuales: de anhideido corbonico.

$$
\text { - de nitrogero ....................... }
$$

Proponcionalidad centegimal de los mistans.

Anhidirido cartumico.

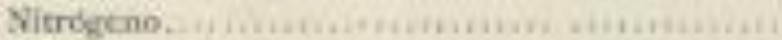

Oxisene.

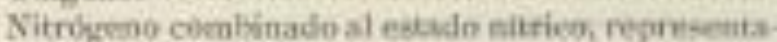
do en beido nitrike

Idem id. id, sitroso, represernado en icidon nitroso. Hem fd. Id, amneiacal, representsdo en amumisco.

Jdem fd. fo, albuminoide, tdem fo

Cirbono oggeinico .....................

Materia anglnika wotal, representads en osfigeoo absorhido ien liquido acido a $90^{\circ}$ e.l twa..........

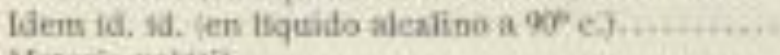

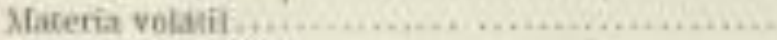

Anhidrido silsciro

INem sutflerico

Clere (chonimo sadico?

Cal ioxióo de calcio

Maqnesia fidem ce magnesio?

Mamina (secgoidosido de aluminio). .................

Hienva tedem de hierro).

Pothea (áxido de potasia) ................... . .........

Sosa (idem de sodio)

Rekidos lifio tocal a $355^{\circ} \mathrm{c}$.

Fuente: (García Revenga, 1933)

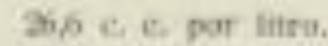

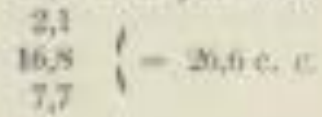

$-3,54$

$6,12 !-100-1$ is,ass

Q.2 men.por litro.

Indicios.

0,015inys. por litno.

1,002

0,500

1,27

1,10

11,09

ri,ai

$x,(0)$

a., 70

$2, \infty$

1,03

3,00

$(6,2)$

0,2 !

300

3,00 
Tabla 7-11. Composición química normal de las aguas del Manzanares, año 1932.

\section{Aqua de fa Hidraiulica Santillana, Manzanares}

\section{Tawuda en foutos pormesians}

Fenteratura imsia (en las cantro estacicaes del ẩ

Densiduif referiula a +t $^{\circ}$

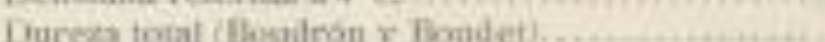

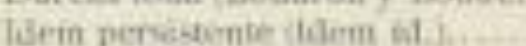

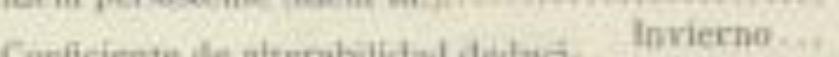

Coeficiente de atterabilidad deduá- Primawira. do de $F-\psi>100$ hituro meatio

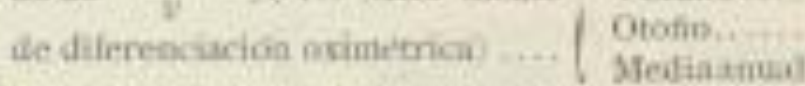

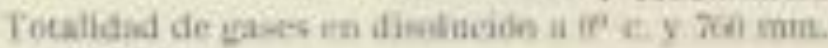
de puraine

De lis canlest de anhidriato carhnico

$$
\text { - de itirguees. }
$$

Pmproncionalifiod centesimal de las minmosc

Aolnktrido carbonic

Nitrugenor

Oxigene

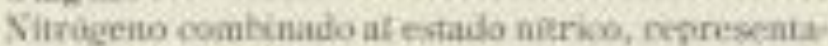
As en acido nitrico

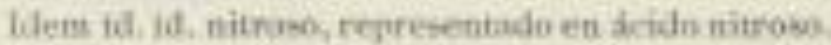

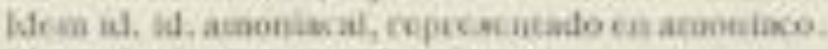

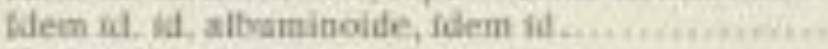
Carboso onsanirco

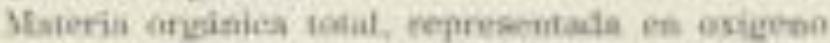

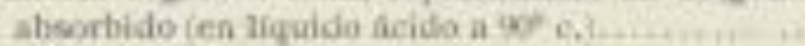

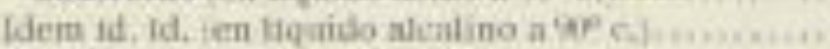
Materï volisil

Ablisterida silicieco.

hem suiforico

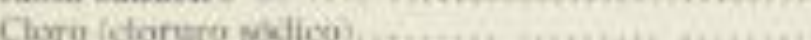

Cal Cisila k cakion.

MLumesia | Idem de magresiol. ......................

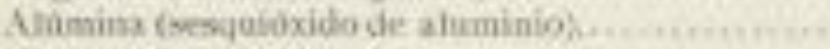

Herm isem de hierrof

Pneara idxide de potacio

Sosn oiden de sortio

$18^{\circ} \mathrm{C}$. t, mik

8

Z⿱乛龰n

20

27

$7 \%$

4.

245

$2 h, 40, e$, pat Titro

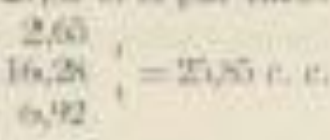

10,22 cons $=10$ lan ere $4 \times 773$

Initicias.

Inspreviabie.

apubiase por titro. 0,012

I.,3li

2,85

2,15

18,00

18;

2,10

1.20

$(x, 4)$

$1,(3)$

1.in

1.,6)

1, in.

4.2

th: 80

Fuente: (García Revenga, 1933) 
Tabla 7-12. Composición química normal de las aguas del viaje del Abroñigal Alto, año 1932.

\section{Agua del vinie del Abroniligal Alto}

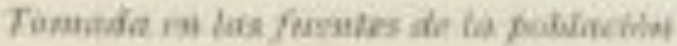

Teaperaura iscdia (en laz cuatri estacionex del inio)

Thentidaul referida at $c$.

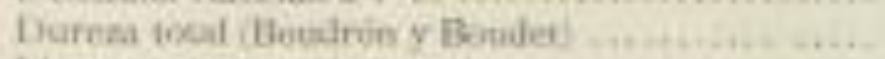

Ideas persistede idern bit.

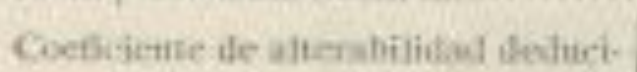

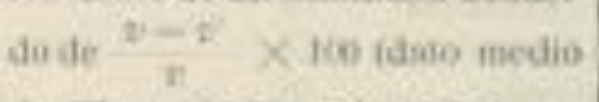
Je difiefericiacian oxizucirical

traterno

Frimares

10

Veranin.... 10

Oennos

Mrsiaiminal

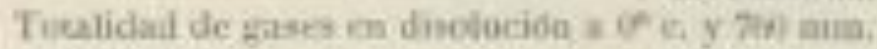

de prestion

De les cuales: de anhatrido siarbentico

$$
\text { - de nitrogene. }
$$

Proporsomatidad centesima! de los misinos:

\section{Anhidride rarzhinios}

\section{Xitrozeno}

Oxilptrosis

Nifrikeno eomìinado at eqado nitrikco, representa:de ca scido nitrice.

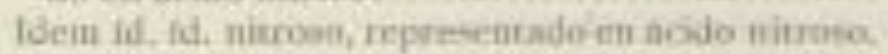

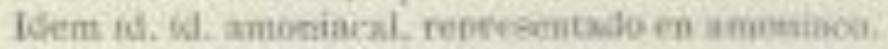

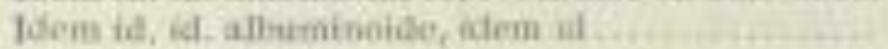
Carbone arguinica.

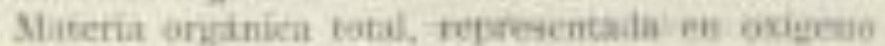

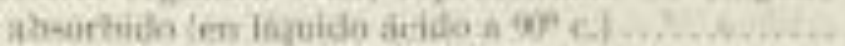

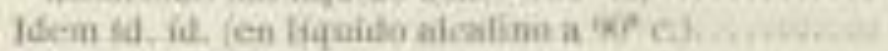
Materia folatil.

Ashuirido wiscrive.

Idem salfarivo

Cloro (cyaruro modico)

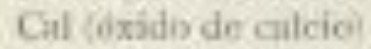

Mhenesia fidena de magnesio?

Alumina (assquioxido de ahrminio)

Ifierno udern de hierno

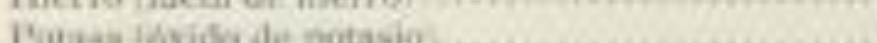

Sosi inere de sodio.

Kesideo njo tntal a Iafe c..........................

lipes $1.0 \mathrm{n}$

(1)

$\mathrm{I}^{2}$

T

10

it

97, e. et par lism

1,9

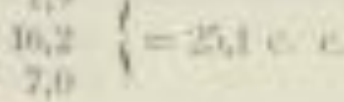

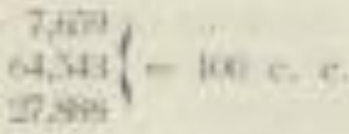

138 anes par litito

avo

ope

wast

wat

aris

otni

47 (x)

270

tisyo

ra만

4.

aving

1200

2,00

4.60

+1200

45t.

Fuente: (García Revenga, 1933) 
Tabla 7-13. Composición química normal de las aguas del viaje del viaje del Retamar, año 1932.

\section{Agua del viaje del Retamar}

\section{Tumade en las faesebs de la poôlacionn}

Temperitura media (en bes natre entaciones del aho

Densidad relerida a tor e

Durea toual (Boudros y Boudet).

Idem persistente indern id. L.

Coefieiente de alterabilidad deduci- Invierno... do de $\frac{D-I f}{D} \times 100$ (dsto modio Primasera te diferendacidn oximierica), | Otoôo....... Medianmual

Totalifad de troses ea disolusion a of c. y fod mm. de preaien

De los cuales de anhiérido carbonius

$$
\begin{aligned}
& \text { - de-nitroneno. } \\
& \text { - dr asigeno. } \\
& \text { dr exieeno: }
\end{aligned}
$$

Preporcionalkad centesimat de los mismos:

Anhidrato carbonien . ...............................

Nitrogeno

Osigeno …

Nitrógeno coubinado al estado nitrico, representa. do en acido nilirico.

Idem id, id, sitroso, representado ea dcido nitruso. Idem id. Id. amoniacal, representalo en amoninoo.

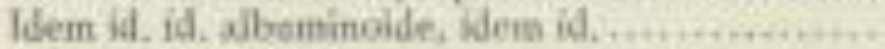
Carbone ergänico. . ...............................

Mtateria orgainiea tetal, representada en oxigeos shsorbido ien tiquido deido a se e. . ................

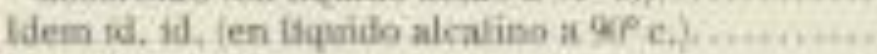
Materis volatil.

Ashidride sticico.

Idem saltarico Clome jetorerar sodico y....................................... Cal (óxide de calrin). Mlannesia (tidem de magnekio) .......................... Alsmina (seceyainxido de aluminio) ................. Hiervo (lden de hierro)

Prosasi (axide de potasin)

sosa didem de soulio?

Reridue fifo total a thet IOP:20, 1.004

t.x

22 c, c. por litro.<smiles>CCCCCCCCCCCCC</smiles>
$\begin{array}{r}3,008 \\ 08,216 \\ 28,291\end{array} \mid=100$ s. 140 ings, por litro. 0,12 $0,58$. 0.000 $0,2 x i$

\section{0,65}

0,74

3,00

18,0

46,00

gowo

texpo

19001

6,00

Indicies.

2,00 mes. por litro. H, 00 3⿻上丨

Fuente: (García Revenga, 1933) 


\section{Agua del viaje de la Alcubilla}

\section{Towada on las faentes de ia fobiborive}

Temperatara media ien las cuatro estaciones de! aho

Eensidad reteride a $4^{\prime \prime}$.

$11 \%, 1$.

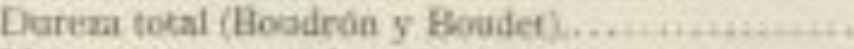

IJem persistente (ddem idt.)

Coeficiente de altrrahilidad fectori | Invierno

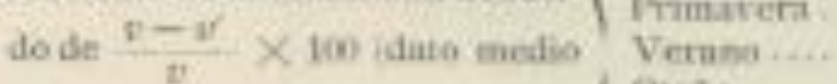
de diferenciacions uximeirical o ( Mtohe......

Totalidad det uaxes en difolucion a of c, y fed mm. de presion

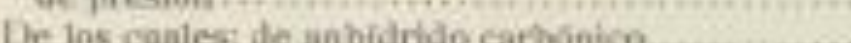

$$
\begin{aligned}
& \text { - de nilmogeno } \\
& \text { - de odigeno }
\end{aligned}
$$

Proporecionalidat contosismal de lith mämos:

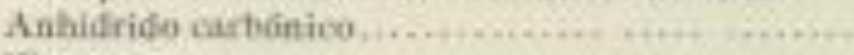

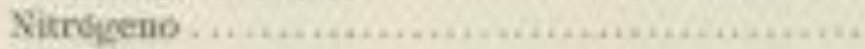

Ostieno:

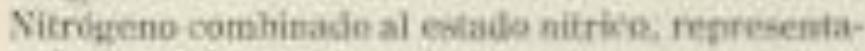
down deiden nitriks.

liem id id. bitroso, mepesentado en arido nirmso. Idem id. id. amoniacal, representado en amontaco.

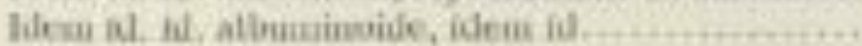

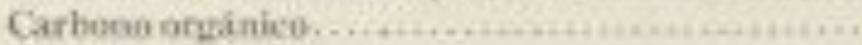

Materia exgátaica tocal, rejresentodia en coxigeno

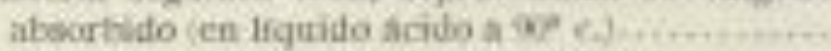

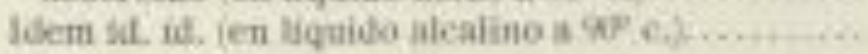
Materia voliarl.......................................

Anhiletido siticico.............

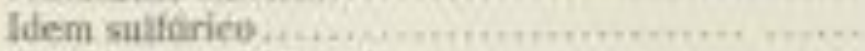

Claro \{clecuro sudico)

342 is r. por litro.
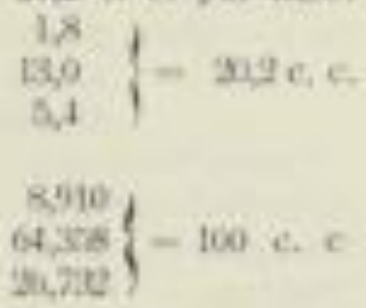

Cal (oxido de rakio)

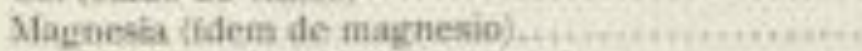

Miemina (aesqubsido de alaminio)

Hermo \{tdern de hiermo).

Precasa (oxido de potasio _..........

Sosa (loem de sodito)

6ol ume por litiro.

$0,0 \times 0$

$0 / m \times$

agan

10,10

0,tos

0.te

$+4,00$

$3 t, 00$

ज4, in

18,50

sisuco

3600

16,00

lndicios.

Qjk mes.per liaro.

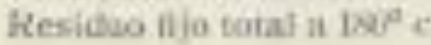

Fuente: (García Revenga, 1933) 


\section{Agun del viaje del Abronigigal Bajo}

- Temudir en fies finevits de ha palviarison

Touperatara media fen lak rasmo estaciones del มกิอ

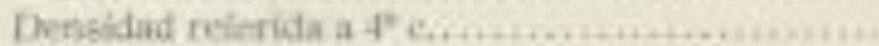

Dorrez total (fheudroin y Hoodec)

tdem persistente (idem fid.).

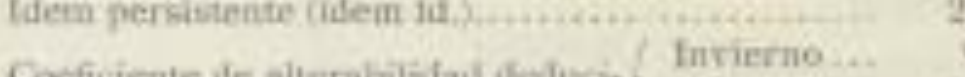

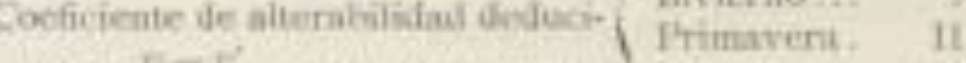

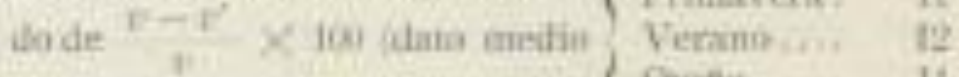

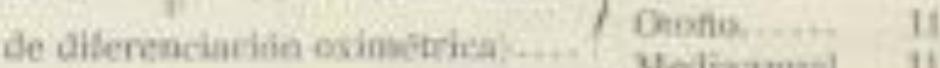

$11^{*} \mathrm{c}$.

1.5e?

논

10

9

It

11

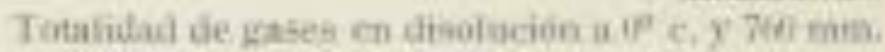

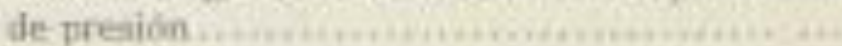

De lus ruales: de anhidrido cathobiso, ...............

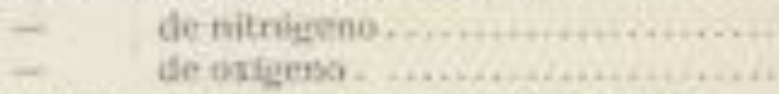

Proporcienalidad centestmal de los mitames:

Anhidrido cartodico

Nituigeans,

Oxipeno.

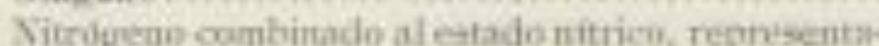

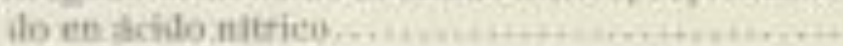

IJern id. id. nitmex, refrewentado en acido nistren.

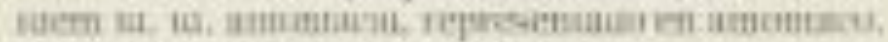

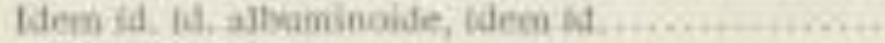

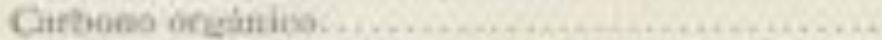

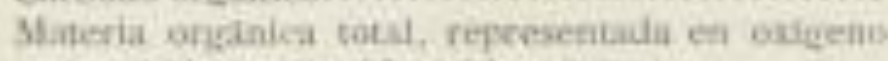

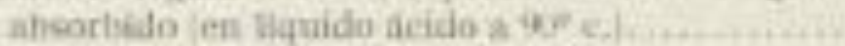

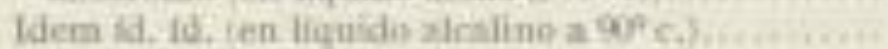

Slatrria vulistil

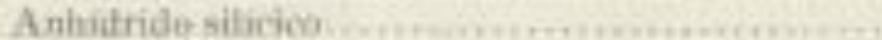

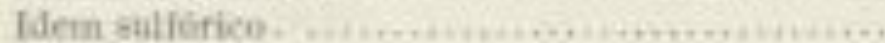

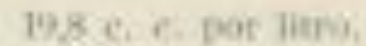

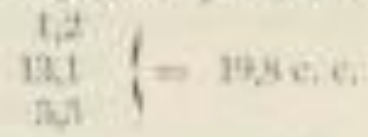

$\frac{6,4 m \mid}{6,162 !}-110<+c$

1,10 mes. pin limi.

$0,0 \%$

1,in

0,006

0,42

$4 \geqslant 1$

0.70

$x,(n)$

41,03

Q5,

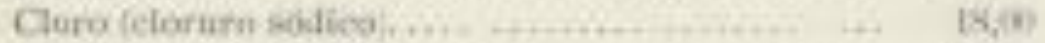

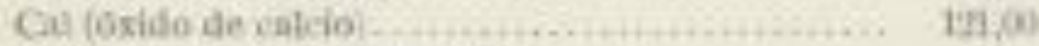

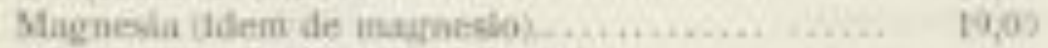

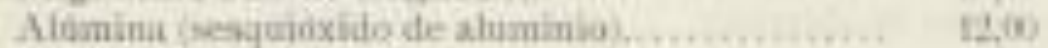

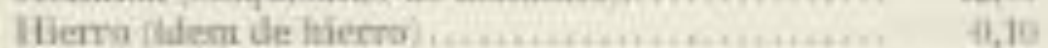

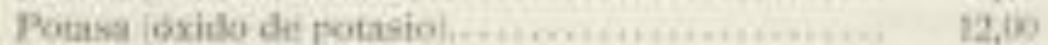

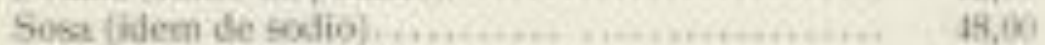

Residue tifo total a terpt

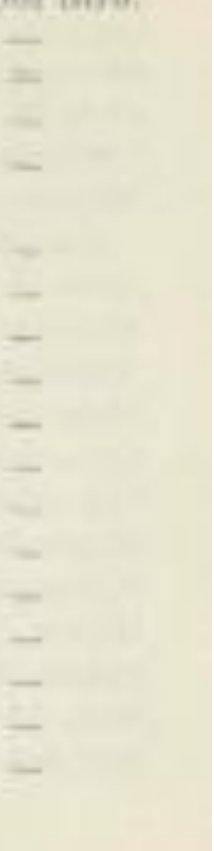

Fuente: (García Revenga, 1933) 


\section{Agraa del viaje de Amaniel}

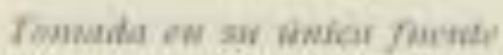

Tenoperasurn metion irn las ruatro estaciones det ลกี่อ)

Denaibad referilia a $4^{\prime \prime}$;

Durene incal Bneatron y Boudect;

Idem peristentet idemi fol.

Cinetickente de alterahitidail dedori:

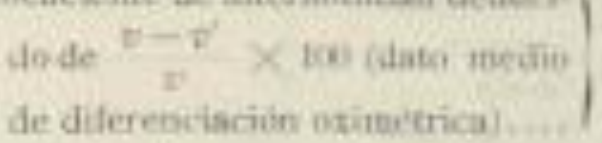

Invieraan... it

Primavera. it

Verane w... 19

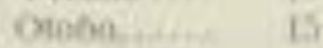

Modiaamuat

Totalifad de gases en dinolncico a of \& $y$ Tw wam. the prewion

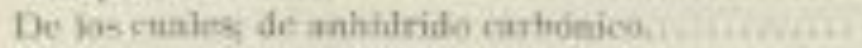
Ac nitrugerea:

de oxigrno

Proporciomiduit centesimat de bé aisinos:

Aahsdridacar konoce.

Nirrikgeno

asiones

Xitonkemo combinado al mitalo natrino, represerita: do ea acidos ziltricos

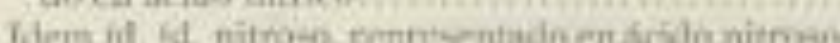

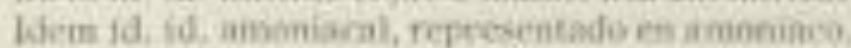

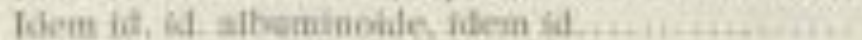
Cartkmo arialnica.

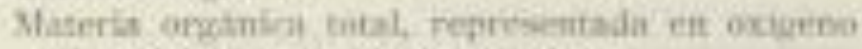

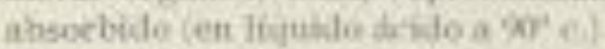

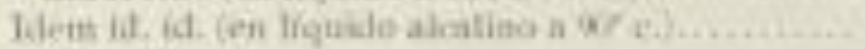

Mlateria vodail.

Anhidrido sialciesh.

Idem sulfírion

Clomo (clintara abidico)

Cal (oxido de caline)

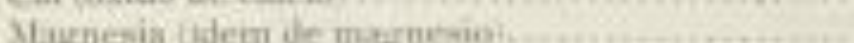

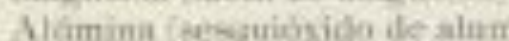

Herro (Jdern de hierno?

Potasa (exido de potasio lis.

Sosul (titero ofe solion?

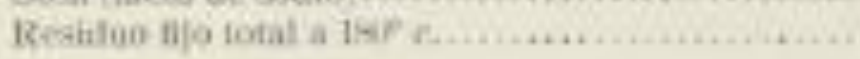

$10 x_{1} \mathbb{2}$,

1 rons

are

$4^{\circ}$

1

4

in

4h eir en par itro.

tis

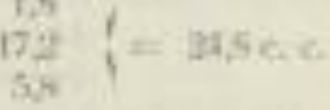

$7,2.18$

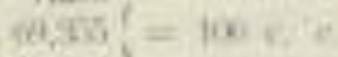

$x \sin 5$

I ket mes por itro

9ก:

QN⿴囗十

D.Mng

0.98

0,7

a,W

Now

$2(2,1)$

usion

21,00

acion

Ifion

His

a,

4,00

Fowo

axton

Fuente: (García Revenga, 1933) 
Tabla 7-17. Composición química normal de las aguas del viaje de la fuente del Berro, año 1932

\section{Agua del viaje de la fuente del Berro}

\section{Foumidr ene su sonce fucwite}

Teraperaum medis en las cuatno estaciones def ane]

Denaidad reircida a $A^{\mathrm{N}} \mathrm{s}$.

$1 \mathrm{r}^{2}, 1 \mathrm{c}$

$\operatorname{lin}(x)$

Dureac sotat / Boudión y Boodet

$+2$

Tetens persistente iddeen id.

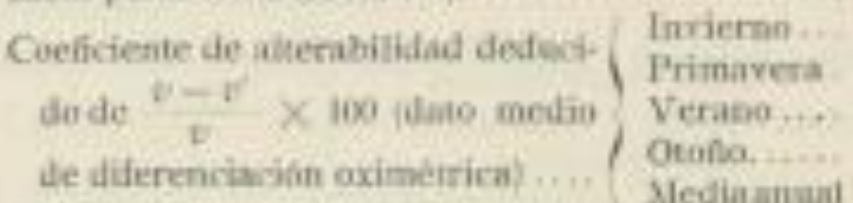

27

7

7

8.

$\overline{7}$

7,25

Totalidad de pases en disoluctón a $\sigma^{\prime} c_{,}, y^{\prime}(\omega) \mathrm{mm}$. de presion.

De loo cuales de anhidrido rarbonico.
- de nisidereno
- de osigeno
(n).....................

Propondomalidad centeritinal de lon mismos:

Anhulrido carhinico.

Nitroggeno,

Oxigeno.

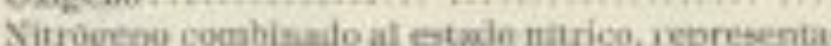

Ge en acide nitriep

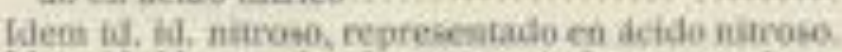

fdem id: id. amomiacal, represeniado en amoalice.

iders id. id. albuminolde, idere fd...................

Cartone aryinice.

Materia oncinicat tesal. representada en exterene

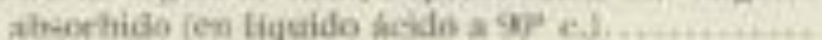

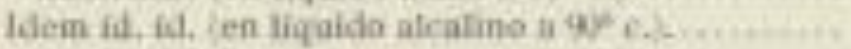

Materia soditil

Anhintrislor sibscico.

Jifem sulfarion

Clnco ulocuro sondiono:

Cal fóxido de cairiola

Sauresica (derts de marnesio).

Alimima (4scyuibside de aluminio)

Herro ibders de hierro)

Pceasa loxido de potasin

Soba ffuem de hodiol ................

Resifan fijo tocal a 18\% of

3,2 e. e por látro.

ㄹ,

$14,8\}=3,2,25,4$

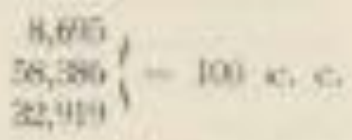

2,700mus, portitro. (0)4

Indleios.

Inaprecinble.

0,19 mas. pos titn.

637

ato

$6 / 12$

60.00

142.00

$x, 00$

200, (x)

in, 100

1700

Indickak

1,00 mes por litina.

3,00

7 ind

Fuente: (García Revenga, 1933) 
Los procedimientos que se llevaban a cabo para comprobar la potabilidad de las aguas que se consumían en Madrid, desde el punto de vista químico, se realizaban en los siguientes puntos:

Viajes modernos
a) Lozoya. (Tomada la muestra en la sala de máquinas de los depósitos.)
b) Canalillo.
c) Santillana.

Viajes antiguos

a) Bajo Abroñigal, con 27 fuentes en la vía pública.

b) Alto Abroñigal, con siete fuentes en la vía pública.

c) Alcubilla, con 15 fuentes en la vía pública.

c) Castellana, con 13 fuentes en la vía pública.

e) Retamar, con tres fuentes en la vía pública.

f) Amaniel, con una fuente en la vía pública.

g) Berro, con una fuente en la vía pública.

El procedimiento que se empleaba para llevar a cabo los análisis de las aguas, comenzaba con la toma de muestras, con una variablidad temporal diferente, dependiendo de la fuente de abastecimiento, de manera que, en conjunto, la Sección de Análisis Químico disponía de un total de seis muestras diarias de agua, recogidas por un Mozo encargado de tal cometido.

En el caso de las aguas del Lozoya, se captaba una muestra diaria tomada de la sala de máquinas de los depósitos, siendo siempre el mismo sitio de recogida. Para el caso de las aguas del Canalillo se tomaba una muestra diaria en ocho sitios diferentes; dos de ellas de manera directa del agua del Canalillo y las seis restantes en diferentes fuentes. De las aguas de Santillana, se procedía a la recogida de muestras en ocho fuentes de casas particulares. Para la toma de muestras del Canalillo y de Santillana, se alternaba la recogida entre las fuentes. Asimismo, en el propio Laboratorio se disponía de una fuente de agua surtida con agua procedente del Lozoya, por lo que diariamente se extraía una muestra de la misma, con el objetivo de compararla con la de los depósitos. 
En lo que respecta a la captación de muestras para el análisis de las aguas de los Viajes Antiguos, se alternaban los sitios de recogida y las fuentes, constituyéndose un total de tres muestras diarias de esta procedencia.

A la hora de llevar a cabo los análisis, para las seis muestras diarias, no se analizaban todos los datos que debían consignarse, atendiendo al Decreto de 17 de septiembre de 1920. Así, a la altura de 1931, no se tenían en consideración los siguientes elementos químicos de las aguas, orientados, en buena medida, a determinar la mineralización de la misma: el residuo fijo por evaporación seco a 180 grados centígrados hasta peso constante; el residuo fijo por calcinación al rojo sombra; el cloro, expresado en cloruro sódico; el ácido sulfúrico; la cal y la magnesia. La justificación del por qué no se analizaban los elementos descritos radicaba en que éstos "permanecen casi constantes, y las variaciones que experimentan se acusan sólo en los miligramos o sus décimas, y son atribuidas generalmente, o a una mala captación de la muestra, o al coeficiente de error personal. Así lo hemos comprobado en las dos o tres veces que lo hacemos anualmente. Consignados se hallan en las Memorias publicadas por el Laboratorio Municipal, y no es de extrañar que así suceda. La mineralización de las aguas es producida por disolución de los gases atmosféricos y de las sustancias que hay en los terrenos por donde ellas circulan, y como estas condiciones son casi constantes, por esta razón no se determinan más que de tarde en tarde” (García Revenga, 1933, p. 47). Precisamente por ser variables, sí se procedía al análisis de los siguientes elementos, dada su característica móvil ${ }^{\mathbf{7 8}}$ ::

\footnotetext{
${ }^{78}$ Hay que tener en consideración que la reacción por ácido nitroso no era habitual en los análisis de las aguas de Madrid. En los casos en que se daba la presencia del mismo, solía estar asociado a la roturas de cañerías o de pozos negros y, por ende, a la consecutiva contaminación de las aguas de viajes antiguos.
} 
Gráfico 7-34. Elementos del agua susceptibles de análisis químicos.

\begin{tabular}{|c|c|c|}
\hline \multirow{3}{*}{$\begin{array}{l}\text { Amoníaco investigado } \\
\text { por reacción directa }\end{array}$} & $\begin{array}{l}\text { Se practicaba de manera diaria en las seis muestras de agua que ingresan en la } \\
\text { Sección. }\end{array}$ & \\
\hline & $\begin{array}{l}\text { Se llevaba a cabo poniendo cierta cantidad de agua con disolución de sosa } \\
\text { cáustica recién hervida, dejándola sedimentar hasta el día siguiente y } \\
\text { decantando la parte líquida transparente. }\end{array}$ & \\
\hline & Se aplicaba el reactivo Nesler & \\
\hline \multirow{2}{*}{$\begin{array}{l}\text { Amoníaco, } \\
\text { determinado } \\
\text { cuantitativamente por } \\
\text { destilación: }\end{array}$} & se practicaba sólo una vez a la semana en cada una de las muestras recibidas. & \\
\hline & $\begin{array}{l}\text { Si el dato obtenido era superior a lo tolerado, se repetían las determinaciones } \\
\text { por destilación en vaias ocasiones. }\end{array}$ & \\
\hline \multirow[t]{2}{*}{ Amoníaco albuminoide: } & Práctica ocasional, bajo dos supuestos; & $\begin{array}{l}\text { que los elementos anteriores dieran } \\
\text { resultado positivo, }\end{array}$ \\
\hline & & $\begin{array}{l}\text { casos en que la materia orgánica } \\
\text { superase a la cifra tolerada. }\end{array}$ \\
\hline \multirow{2}{*}{$\begin{array}{l}\text { Materia orgánica total } \\
\text { del agua, determinada } \\
\text { en líquido ácido y } \\
\text { materia orgánica total } \\
\text { del agua, determinada } \\
\text { en líquido alcalino: }\end{array}$} & $\begin{array}{l}\text { se practicaba de manera diaria en las seis muestras de agua que ingresan en la } \\
\text { Sección. }\end{array}$ & \\
\hline & $\begin{array}{l}\text { Las determinaciones en líquido ácido y en líquido alcalino se llevaban a cabo } \\
\text { mediante el métodod directo, con una disolución valorada de permanganato } \\
\text { potásico en líquido ácido por el ácido sulfúrico, y expresando en oxígeno los } \\
\text { datos obtenidos }\end{array}$ & \\
\hline \multirow[t]{2}{*}{ Ácido nitroso: } & se practicaba de manera diaria mediante el el reactivo de Tromsdorff. & \\
\hline & $\begin{array}{l}\text { En caso de dar como resultado la presencia del ácido nitroso, por mínima que } \\
\text { fuera, se procedía a la repetición de la reacción empleando el reactivo de } \\
\text { Gries, que ya es específica (clorhidrato de metafenilenodiamina). }\end{array}$ & \\
\hline
\end{tabular}

Fuente: elaboración propia. Información obtenida de (García Revenga, 1933, pp. 47-48)

Además de la medición de los seis valores descritos, en el cambio de estación se llevaban a cabo análisis adicionales para medir la cantidad de oxígeno disuelto en el aguas, siendo un elemento que permite conocer el grado de aireación de las mismas, siendo de gran importancia ya que "pues con el batido y aireación de las aguas se quema paulatinamente la materia orgánica de ellas y los gérmenes bacterianos sufren la acción del oxígeno, debilitándose o destruyéndose, haciendo además al agua más impropia como medio de cultivo". Asimismo, también se procedía a medir la determinación del coeficiente de alterabilidad de las aguas deducido de la fórmula ${ }^{79}$ $\frac{\mathrm{v}-\mathrm{v}^{\prime}}{\mathrm{v}} * 100=\mathrm{e} \quad$ (García Revenga, 1933, pp. 48-49).

\footnotetext{
${ }^{79}$ Proporciona el dato medio de diferenciación oximétrica, que permite conocer el consumo de oxígeno que a la temperatura de 37 grados centígrados hacen las sustancias o gérmenes que tenga el agua del que ella llevaba disuelto, proporcionado una idea aproximada de la posible existencia de bacterias anaerobias o de otras sustancias.
} 


\subsubsection{Los análisis bacteriológicos.}

Podría decirse que la génesis de la institucionalización del problema de la higiene de las aguas de consumo madrileño data de 1894, momento en que el Ayuntamiento de Madrid, por acuerdo de 20 de mayo de 1894, creó el Gabinete micrográfico para el estudio diario y constante de las aguas y demás trabajos propios de esta especialidad, bajo la alcaldía del Conde de Romanones y mediante proposición planteada por el Concejal Francos Rodríguez.

Atendiendo a los estatutos de su creación, el primer Doctor que desempeñó el cargo de Director fue el Dr. Madrid Moreno.

Las necesidades del servicios fueron cambiando al tiempo que lo hacía el entorno social y demográfico madrileño, así como el ambiente científico. Respecto a la asistencia y atención en lo relativo al análisis de las aguas del vecindario madrileño, el Dr. Chicote llevo a cabo una organziación del servicio, tal y como ha sido mencionado a lo largo del presente capítulo, diseminado el análisis de las aguas en dos secciones complementarias; la dedicada a los ensayos bacteriológicos y la dedicada a los ensayos físicoquímicos.

Respecto a las labores desempeñadas por las Secciones del anáisis de las aguas, tanto a la fisicoquímica como a la bacteriológica, se ensalzaban las mismas, al tiempo que se establecían críticas por la imposibilidad de alcanzar una mayor precisición y alcance, debido a los déficits presentes en el Laboratorio a la altura de los años treinta, vinculados, entre otras cosas, a la inexistencia de patrones unificados de los servicios : "siempre atentas al movimiento científico mundial, aplican a la resolución de los problemas hígiénico sanitarios de las aguas todo cuanto pueda considerarse como de algún interés y suponga verdadero progreso científico, sobre todo por lo que atañe a la rapidez y exactitud en las determinaciones, cualidades ambas muy lejos todavía de alcanzar con los procedimientos actuales" (García Revenga, 1933, p. 60). En este sentido, una de las imposibilidades de alcanzar la plena eficiencia del servicio de la Sección de Bacteriología de aguas y alimentos radicaba en la organización del servicio. Tal y como ya presentaba Chicote y como fue expuesto en los Congresos de Químicos y Bacteriólogos municipales celebrados en Madrid en octubre de 1913 y mayo de 1924, 
se atendía como necesaria la unificación de servicios de análisis bacteriológicos de aguas y de alimentos.

La justificación de la defensa de las modificaciones propuestas, radicaba en los contratiempos que estaban presentes en el actual servicio. En este sentido, se proponía la necesidad de que se dictaran normas únicas y claras por parte de las autoridades sanitarias, que sirvieran de base y guía procedimental para el especialista bacteriólogo especializado en el examen de aguas, sustituyendo a la Ley presente hasta el momento por ser considerada poco concreta. Se abogaba por una "legislación acabada que comprenda taxativamente no sólo los procedimientos que deban emplearse, detallando hasta los más pequeños pormenores, sino marcando la composición de los medios de cultivo y su preparación y la manera de apreciar e interpretar los resultados analíticos, a fin de que la calificación sea lo más acertada posible. Tampoco debe olvidarse todo lo que afecta a la recogida de las muestras de agua y su transporte al Laboratorio, porque de ello dependen los resultados analíticos” (García Revenga, 1933, pp. 60-61)

Respecto a las bacterias encontradas en el agua, se muestra una síntesis de las encontradas años anteriores en los análisis de las aguas alimenticias de la ciudad de Madrid. Para la interpretación de los cuadros, cabe decir que el signo "—_ " es empleado para la referir la presencia de bacterias saprofitas; la simbología " + " para las bacterias patógenas para el ser humano; y el signo “*” para las bacterias de la putrefacción. 
Respecto al análisis de las bacterias de origen intestinal de las aguas del Manzanares, cabe reseñar que en el resumen del Laboratorio Municipal del año 1915 , se consignó la presencia de B. coli commune. En un principio, se consideró que esta bacteria provenía del intestino de los peces del propio embalse. Desde ese momento, el Laboratorio Municipal de Madrid realizó estudios minuciosos para desentrañar la procedencia de la contaminación de las aguas del Manzanares. Para la interpretación de los cuadros resultados de los análisis realizados para 1917 sobre la presencia de bacterias de origen intestinal en las aguas del Manzanares, se hará del modo siguiente: El signo “+ " indica haber encontrado el B. coli commune, de Escherich; el signo adiccional "+ *" se emplea para representar la existencia de B. lactis aerogenes, de Escherich, y, finalmente, el signo "- "para indicar que no han encontrado bacterias intestinales.

Atendiendo a los resultados de los cuadros, puede verse que en el agua del Manzanares existía la Bacteria coli commune con resultado positivo. Esta bacteria provenía de heces fecales humanas evidenciados por el procedimiento de Eykman. Indudablemente existen un B. coli de origen pisciario que no fermenta la glucosa a $46^{\circ}$; pero también otro B. coli que sí la fermenta, y que, por tanto, tiene una positiva importancia para el juicio higiénico del agua, aceptando el criterio del Laboratorio de la Sociedad (Chicote del Riego, 1918, p. 122) 
Tabla 7-20. Bacterias encontradas en el agua de los Viajes antiguos

\section{Relación de las especies de bacterias encontradas en las aguas de los viajes.}

* + Staphylococcus pyogenes albus. - Rosenbach.-Alcubilla, Alto Abroñigal, Reina y

Castellana.

* - Staphylococcus pyogenes aureus. - Rosenbach._Alcubilla, Alto Abroñigal, Retiro, Casa de Campo, Canalillo y Reina.

- Micrococcus flavus desidens.-Flügge.-Castellana.

- Micrococcus urace.-Pastear.-Bajo Abroñigal.

- Micrococcus flavus liquefaciens. - Flügge. - Reina.

- Micrococcus coronatus. -Flügge. - Retamar y Alcubilla.

- Micrococcus flavus tardigradus. -Flügge.-Alcubilla.

- Micrococcus radiatus. - Flügge. - Retamar y Amaniel.

- Micrococcus citreus conglomeratus.-Brumm.-Bajo Abroñigal.

- Micrococcus concentricus.-Zimmermann.-Castellana.

- Micrococcus cereus albus.-Maschek.-Retiro.

- Micrococcus albus. - Madrid Moreno.-Casa de Campo.

- Micrococcus albinus. - Madrid Moreno.-Berro.

- Micrococcus candicans. - Flügge.-Casi todos los viajes.

- Micrococcus candidus.-Cohn._-Alcubilla y Berro.

- Micrococcus stellatus.-Maschek-Castellana.

- Micrococcus cremoides._Zimmermann.--Alcubilla.

- Micrococcus sulphureus.-Zimmermann.-Castellana y Bajo Abroñigal.

- Micrococcus rosettaceus.-Zimmermann.-Alcubilla.

- Micrococcus roseus. - Flügge. - Casi todos los viajes.

- Micrococcus cinnabareus. -Flügge._Castellana.

- Micrococcus cerasinus siccus. - List. - Berro.

- Diplococcus luteus. -Adametz. - Castellana.

- Sarcina lútea.-Schoter.-Bajo Abroñigal.

- Sarcina luteola.-Gruber.-Castellana.

- Sarcina flava.-De Bary.-Alto Abroñigal.

- Sarcina aurantiaca._Koch._Amaniel y Castellana.

- Bacillus aquatilis sulcatus. - Weichselbauni.-Alcubilla.

* Bacillus fluorescens putidus. -Flügge.-Berro, Castellana, Retamar, Amaniel y Bajo Abroñigal. 
En la Memoria del Laboratorio correspondiente al año 1932, también encontramos los resultados de los análisis químicos realizados sobre la potabilidad de las aguas que se consumen en Madrid

Tendiendo en cuenta el Resumen de los trabajos llevados a cabo por el personal de la Sección de Bacteriología de aguas y alimentos correspondiente al año 1932, hay que tener en considerción que no aparece especificada la relación detallada de los procedimientos analíticos, aspectos que sí aparecían en la Memoria correspondiente al año 1917. Atendiendo a la información proporcionada, que es mensual, solamente aparece la calificación de las muestras tomadas calificandose las mismas como "buenas" o “contaminadas", así como la media aritmética de bacterias aeórbicas encontradas por centímetro cúbico de agar a 37 grados centígrados.

En lo que respecta a los resultados, para una correcta interpretación de los resultados mostrados por el Laboratotio sobre las condiciones de las aguas de Madrid desde el punto de vista bacteriológico, hay que atenerse a lo regulado en el reglamento del Estatuto Municipal vigente, mediante el cual era condierado que las aguas debían calificarse como contaminadas cuando el germen del bacilo coli aprecía presente en un centímetro cúbico de la muestra analiada. Asimismo, se la consideración de agua contaminada se producía cuando el estreptococo, el bacilo piociánico y las bacterias anaerobias esponjadas estaban presentes. A continuación, se muestra un gráfico donde aparece reflejada la proporción de aguas contaminadas y aguas limpias, según los resultados de las muestras analizadas para cada clase de abastecimiento para el año 1932.

Como puede verse a raíz de los datos, las aguas dotadas de condiciones más óptimas para el consumo en la ciudad de Madrid en el año 1932 (Gráfico 7-35, sobre la contaminación de las aguas) eran, de manera clara, las aguas del Lozoya. Atendiendo a la proporción de los días en que estas aguas estuvieron contaminadas, el valor máximo fue de 9.13 días, correspondiendo a las muestras tomadas de las fuentes vecinales abastecidas de las aguas del Río Lozoya. Hay que tener en cuenta que las aguas de las Fuentes vecinales, eran aguas no sometidas a depuración, ya que se trataba de aguas superficiales.

Siguiendo este orden de consideraciones deben colocarse a continuación las aguas procedentes de la Hidráulica Santillana, las cuales tienen un porcentaje de 
contaminación muy superior a las de los Canales del Lozoya, sin llegar, no obstante, al que presentan los llamados viajes antiguos, en los que se registran proporciones verdaderamente altas, como sucede con el del Retamar, que alcanza al 54,90 por 100, según ya hemos apreciado. Resultados análogos a los anteriormente dichos se obtienen, excepto con las aguas de la Hidráulica Santillana.

Gráfico 7-35. Proporción de la contaminación de muestras por fuente de abastecimiento de agua. Año 1932

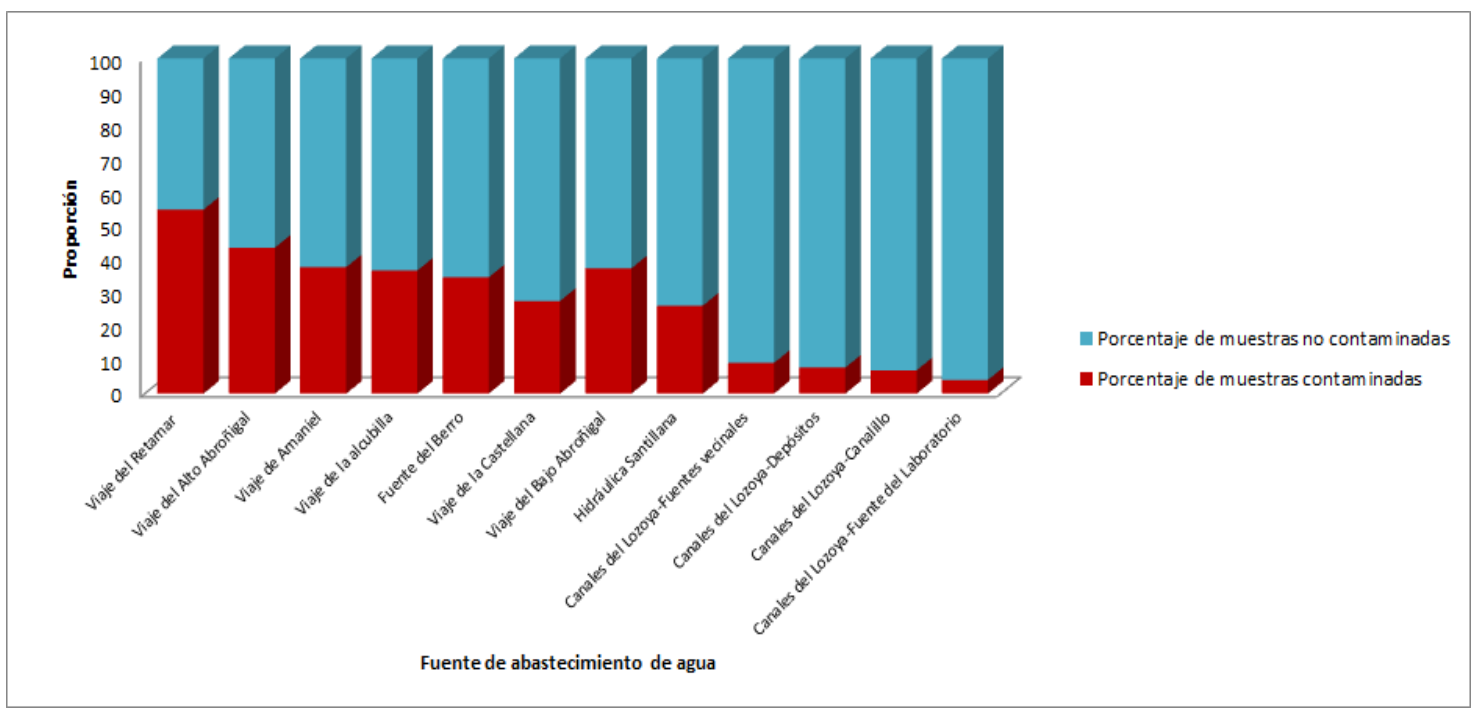

Fuente: Elaboración propia. Información extraída de (García Revenga, 1933, p. 68)

Respecto a las bacterias encontradas en las aguas de consumo por tipo de abastecimiento (Gráfico 7-36), según la información obtenida, de 3.683, 4.089 y 4.600 bacterias por centímetro cúbico que presentan como término medio las aguas procedentes de los Canales del Lozoya, se llega a la cifra de 8.900 en las del Retamar, que es de los viajes antiguos el más abundante en flora bacteriana,y a la cantidad de 11.820, correspondiente a las aguas de la Hidráulica Santillana. Al interpretar estos resultados debe tenerse en cuenta que para las aguas superficiales la tolerancia en la cantidad de bacterias es mayor que cuando se trata de aguas profundas, como son las de los viajes antiguos (García Revenga, 1933). 
Gráfico 7-36. Bacterias encontradas por centrímetro cúbico de agua por fuente de abastecimiento. Año 1932

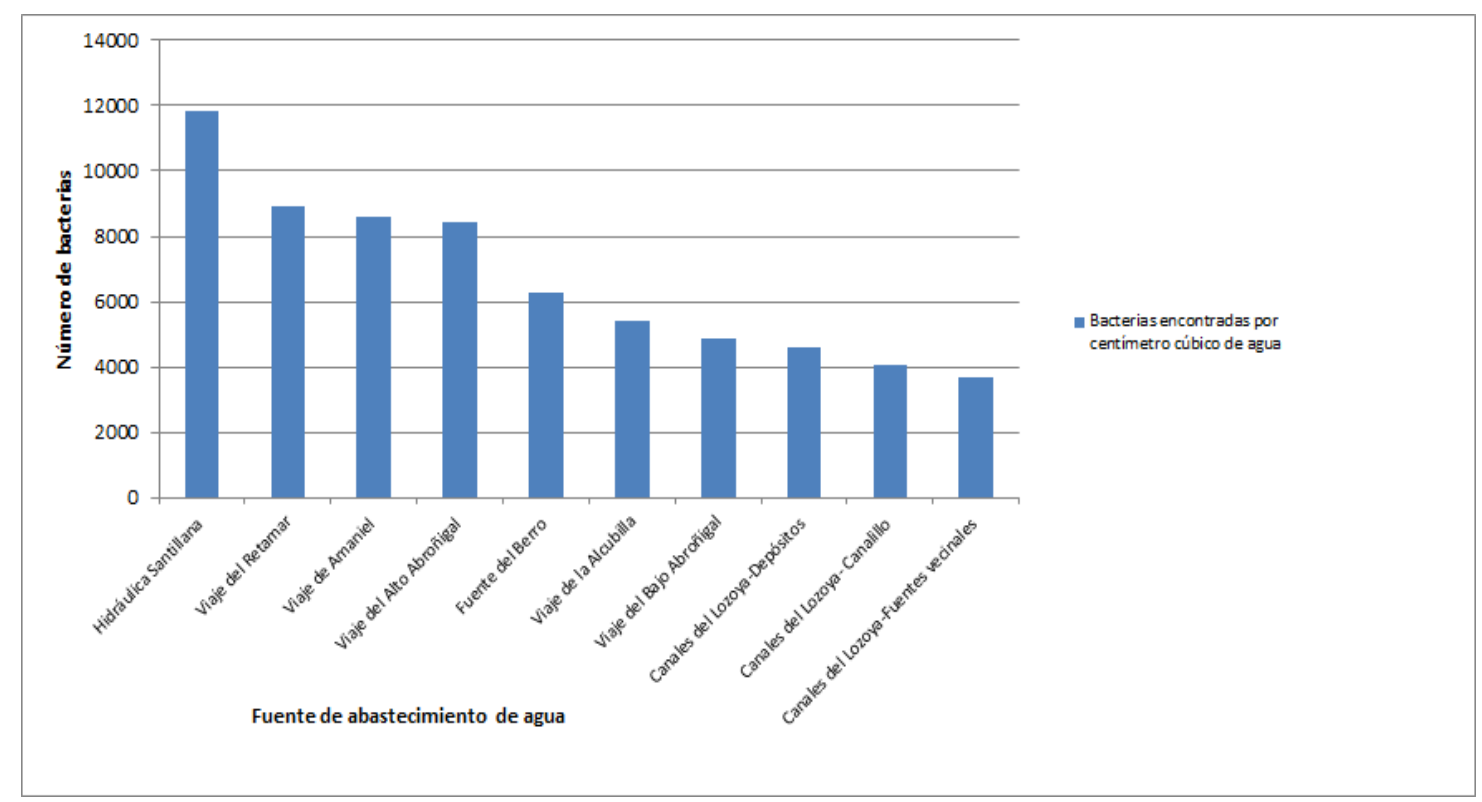

Fuente: Elaboración propia. Información extraída de (García Revenga, 1933, p. 69)

Atendiendo a la pureza de las aguas en la clasificación de éstas como agua clara, agua opalina, turbia y muy turbia, en proporción, el voumen de agua clara representó para todos los años, entre el año 1909 y 1929 , la mayor. Sin embargo, tal y como puede verse en el gráfico adjunto, el agua opalina, turbia o muy turbia se vio incrementada entre los años especialmente entre los años 1918 y 1919. 


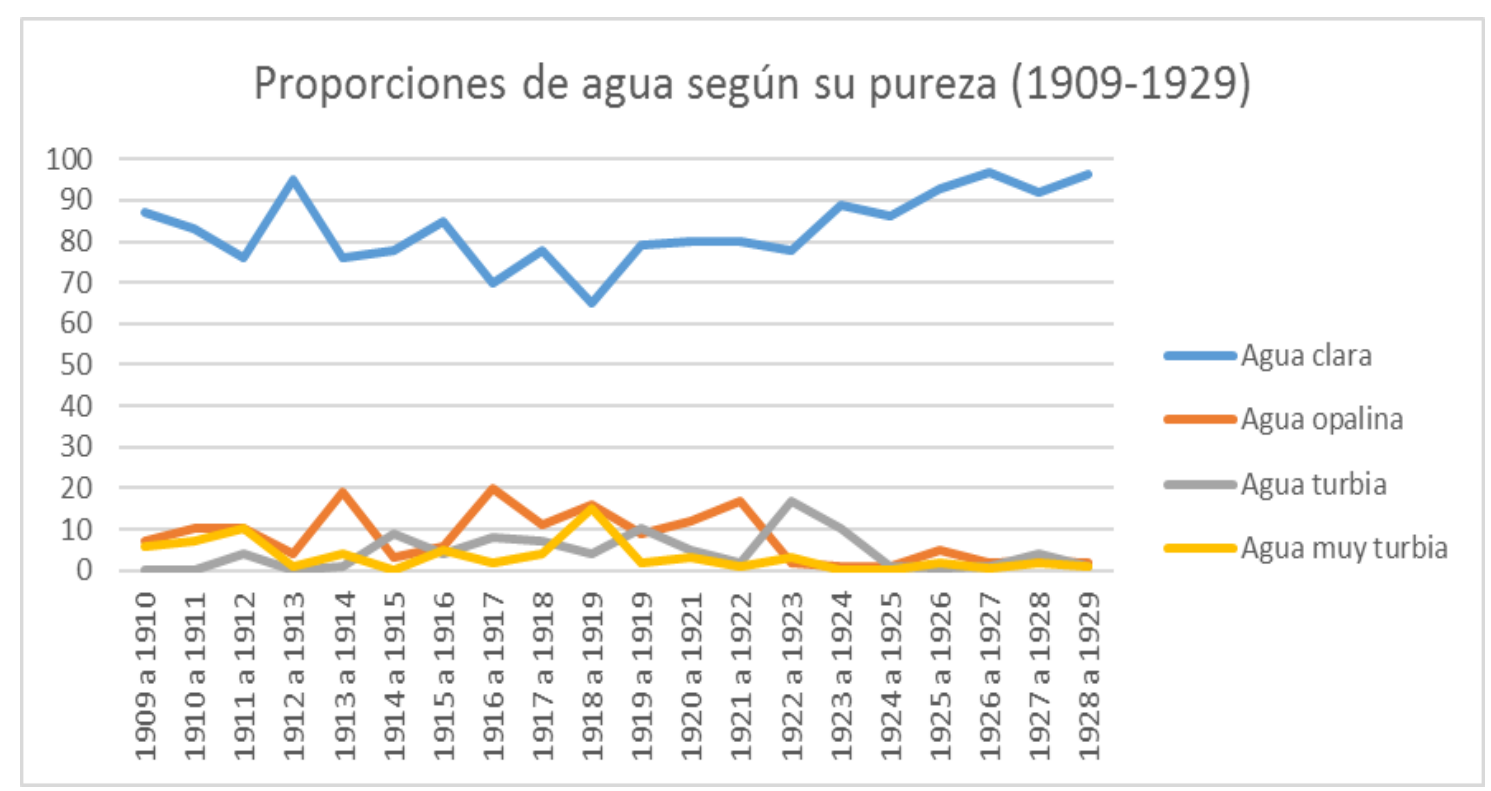

Fuente. Elaboración propia. Datos de las memorias del Laboratorio Municipal para varios años.

Para concluir el presente capítulo, expongo las palabras de García Revenga, como manifestación de que, a la altura de 1932, la regulación existente en cuanto a la vigilancia sustancias reportaba deficiencias: “(...) expresión del deseo de que se haga una verdadera revisión de nuestra legislación sobre alimentos y bebidas, poniéndola al día y desterrando para siempre la autorización de prácticas viciosas, que si en algunas legislaciones extranjeras tienen su explicación por las condiciones naturales de su clima, suelo y cultivos, son radicalmente distintas a las de nuestra patria”. (García Revenga, 1933) 


\section{Características sociales y demográficas del espacio urbano madrileño}

Las primeras décadas del siglo XX constituyeron para la ciudad de Madrid una época de profunda transformación. Esta transformación fue fiel reflejo de una ciudad profundamente desigual, caracterizada por la fragmentación del espacio urbano. Por un lado, las variaciones en la arquitectura de la ciudad, remontan a ejemplos tales como la apertura de la Gran Vía y la caracterización de la modernidad que estuvo asociado a la misma, con la construcción de rascacielos, los cines o los teatros. Por otro, la extensión de la ciudad hacia los barrios del Ensanche, desde el siglo XIX, así como el asentamiento de grandes núcleos de población más allá de las fronteras de éste, en las barriadas del Extrarradio. 
Imagen 8-1. Fotografías del llamado Barrio de las Injurias
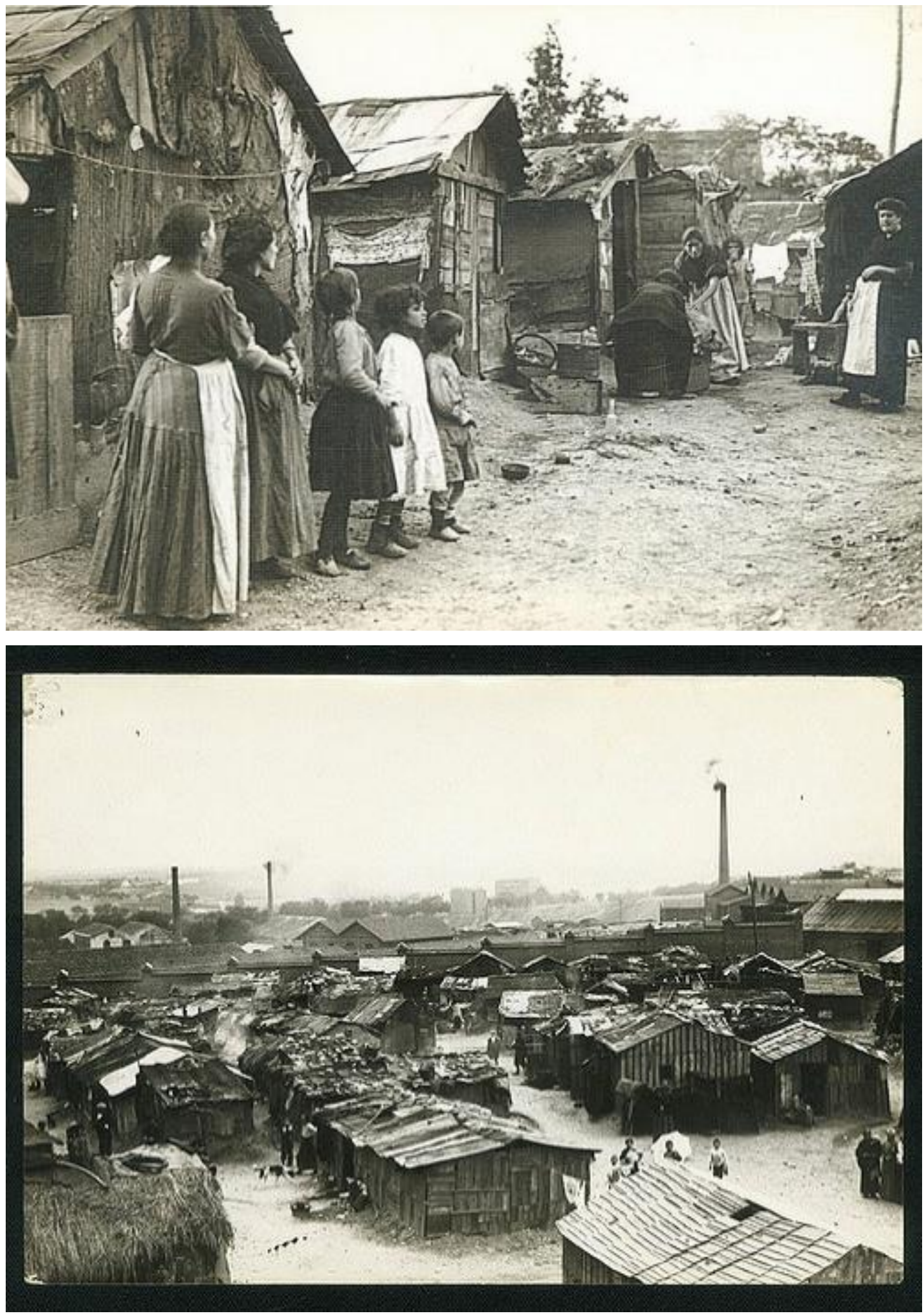

Fuente: Biblioteca Histórica. Ayuntamiento de Madrid 


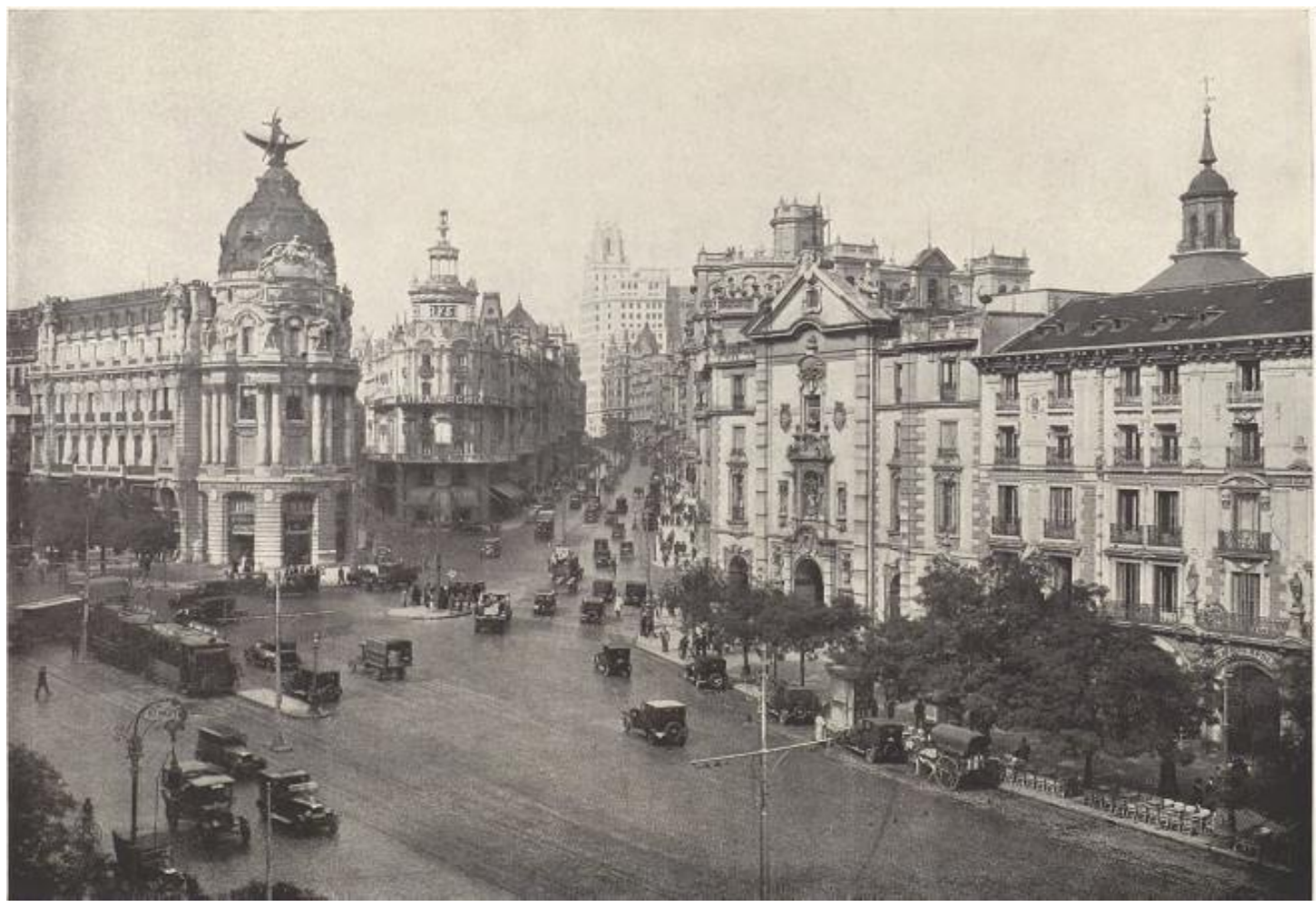

Fuente: Biblioteca Histórica. Ayuntamiento de Madrid

Imagen 8-3. Gran Vía. Año 1924

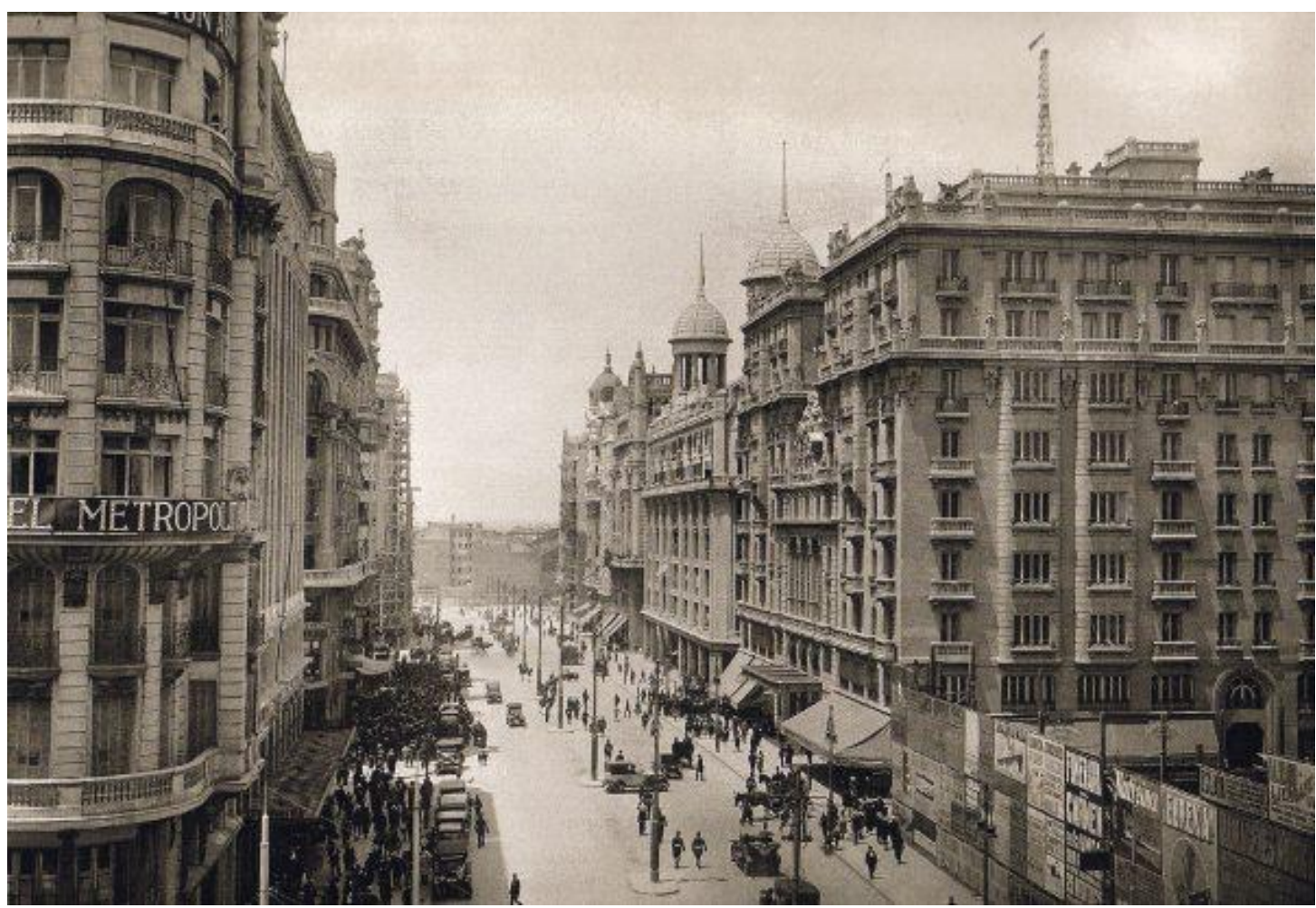

Fuente: Biblioteca Histórica. Ayuntamiento de Madrid. 
Asimismo, al hilo de los procesos de transformación económica, se iba produciendo una reconfiguración de la composición social de la población. Si bien la ciudad de Madrid no llegó a ser una gran ciudad industrial, en comparación con otras como Bilbao o Barcelona (Beascoechea Gangoiti, González Portilla, Pedro, \& López, 2006; Oller, Benaul Berenguer, \& Sudrià Triay, 2003; Tatjer, 2006), a la altura de 1900 Madrid adquirió rasgos fabriles (Otero Carvajal \& Pallol Trigueros, 2009). Estos grupos de población de clase social más baja madrileña se integraban en estos centros de trabajo, así como trabajadores de la construcción, barrenderos y un sinfín de ocupaciones laborales de escasa cualificación.

Por otra parte, el Madrid de la época también estaba caracterizado por ser una economía de servicio. La centralización de grandes empresas y entidades de la Administración en la capital, hicieron que las ocupaciones del sector servicios se vieran incrementadas, fruto del capitalismo industrial. Las nuevas clases medias se irán configurando en torno a estos sectores; banqueros, oficinistas, contables... Además, el desempeño de ocupaciones vinculadas a la oferta de servicios por parte de la Administración (sanidad, educación, entre otros) también se vieron incrementados y, con ello, el funcionariado madrileño (Pallol Trigueros, 2015).

En definitiva, la vinculación a la industrialización y la integración hacia los mercados capitalistas, influyeron ineludiblemente en la disposición de perfiles sociales con rasgos claramente definidos.

\subsection{Operacionalización de las variables}

Con el objeto de conocer la estructura socioprofesional de la ciudad de Madrid y su distribución espacial, se han codificado usando la clasificación HISCO (Leeuwen, Maas, \& Miles, 2002) un total de 410 ocupaciones laborales que aparecen en el Resumen de padrón de 1915 (Ayuntamiento de Madrid, 1917). Se realizarán análisis de la distribución de las ocupaciones laborales a nivel de barrio serán representadas las proporciones de éstas en el mapa Histórico de Madrid.

Dado que los resúmenes de padrón ofrecen la información diseminada por sexo, se ha optado por realizar los cálculos de manera diferenciada, partiendo de la hipótesis de la diferencia en la estructura ocupacional en función del sexo (Borderías Mondejar, 2012; Honeyman \& Goodman, 1991; Pareja Alonso, 2018) 
Algunos de los problemas que han surgido en torno a la codificación a HISCO han girado en torno a que la fuente de datos empleada es una fuente de información con datos agregados. En este sentido, algunas de las ocupaciones referidas venían bajo una denominación ocupacional demasiado general como para poder codificarlo en HISCO. Éste ha sido el caso de los comerciantes. Por ello, se ha tomado la decisión de representarlos de manera independiente. Lo mismo ha sucedido con el término de Jornalero. Dado que representa un grueso de la población importante, se ha decidido representar esta ocupación profesional de manera separada al Major Group 7-8-9, con el objetivo de poder diferenciar esta categoría ocupacional de las otras representadas en el Major Group señalado.

Otra de las problemáticas ha surgido con la denominación de "aprendiz". Propiamente, no se trata de un código HISCO, sino de un código auxiliar que se emplea para matizar la información una vez clasificada, de modo que, tomando nuestro ejemplo, "aprendiz" marcaría el status, no la ocupación laboral, que es imposible conocerla. Por ello, ha sido clasificado de manera independiente, a sabiendas de que no se trata de un código HISCO. Lo mismo ha sucedido con la categoría de "empleadas", por lo que será representada de manera independiente.

Para la representación de la distribución espacial de los mapas referidos a las ocupaciones laborales, se ha optado por el uso del sistema de rupturas naturales de Jenks. La decisión ha venido dada debido a que, en algunos casos, la proporción de algunas de las ocupaciones codificadas en Major Group, representaban un porcentaje muy bajo. En este sentido, dado que el interés es visualizar la representación de valores similares, para conseguir una maximización de las diferencias entre clases, se ha optado por éste método, dado que mediante el mismo se consigue realizar cortes basados en las agrupaciones naturales inherentes a los datos mediante el llamado algoritmo de cortes naturales de Jenks (De Smith, Goodchild, \& Longley, 2007).

Los cálculos de proporciones han sido calculados tomando la población a nivel de barrio, eliminando los menores de diez años por considerarse población no susceptible de desempeñar un oficio.

Respecto a la población mayor de ochenta años, sólo ha sido tomada para el cálculo de la categoría (-), en la medida en que ésta incluye a los jubilados, cesantes y pensionistas. Ésta categoría ha sido utilizada para representar aquellas que no son directamente 
relativas a una actividad laboral. Concretamente, aparecen bajo éste ítem las siguientes: para mujeres: las asiladas, cesantes, colegialas, estudiantes, jubiladas, labores domésticas, pensionistas, propietarias y rentistas. Para los hombres: cesantes, estudiantes, jubilados, pensionistas, propietarios, rentistas, retirados).

\author{
Clasificación Major group de HISCO $^{80}$ \\ 0/1 Profesiones liberales, técnicos y trabajadores similares \\ 2 Trabajadores administrativos y de gestión \\ 3 Trabajadores de oficina, funcionarios y similares \\ 4 Trabajadores de ventas \\ 5 Trabajadores del servicio \\ 6. Trabajadores agropecuarios, forestales, cazadores y pescadores \\ 7/8/9 Trabajadores dela producción, operadores de equipos de transporte y \\ jornaleros. (Sin jornaleros, que han sido calificados aparte)
}

\title{
8.2. La estructura socioprofesional de Madrid y su distribución en la ciudad en el año 1915
}

Partiendo de la estructura socioprofesional de la ciudad en general, representado en el gráfico 8-1, podemos ver que, respecto a los hombres, casi un 35\% eran jornaleros, seguidos de las ocupaciones sin clasificar y de la categoría que inserta a ocupaciones no laborales (-). El siguiente grupo está formado por los trabajadores no cualificados dentro del Major Group correspondiente a los trabajadores de la producción, operadores de equipos de transporte.

Las denominadas nuevas clases medias, estarían representadas por cerca de un 7,5\% por trabajadores de oficina, funcionarios y similares, seguidos de un 5\% de los dedicados a profesiones liberales, técnicos y trabajadores similares y un 3\% de los trabajadores administrativos y de gestión.

Los trabajadores de ventas representaban cerca de un 3\%, seguidos de los comerciantes, con algo más de un $2 \%$. Las categorías residuales las conforman los aprendices, que no es una categoría ocupacional como tal, tal y como se ha explicado en líneas precedentes, y los trabajadores agropecuarios, forestales, cazadores y pescadores.

\footnotetext{
${ }^{80}$ Para más información sobre la clasificación de ocupaciones profesionales de HISCO, consultar apartado de Metodología.
} 
Gráfico 8-1. Estructura socioprofesional de Madrid. Hombres. Año 1915

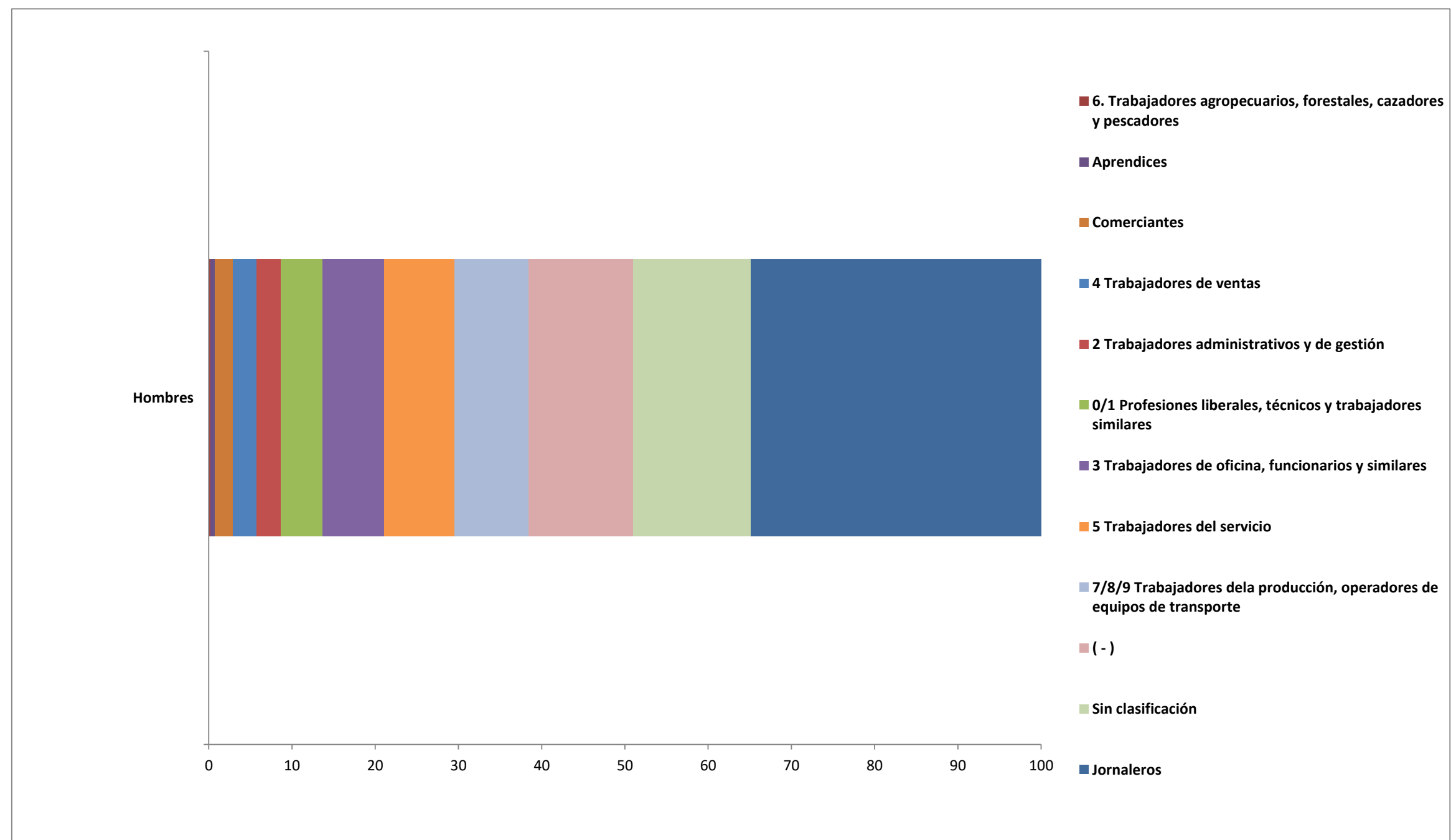

Fuente: Elaboración propia con información obtenida de (Ayuntamiento de Madrid, 1917) 
En lo que respecta a las mujeres, la estructura es considerablemente diferente respecto a la de los hombres, tal y como puede verse en el gráfico $8-2^{81}$.

Cerca de un $68 \%$ de las mujeres pertenecen a la clasificación (-), que, como se ha señalado, corresponde a ocupaciones no laborales. Una de las razones de este elevado valor radica en que en esta categoría aparece representada la situación de "labores domésticas". Teniendo en cuenta que más de un 15\% lo conforma la categoría de "ocupaciones sin clasificar", nos encontramos con que menos de un 19\% aparece conformado por el resto de categorías ocupaciones y, de éste porcentaje, un $11 \%$ lo conforman mujeres trabajadoras del servicio. El siguiente grupo, estaría formado por mujeres jornaleras y trabajadoras de la producción, operadores de equipos de transporte, con un 3\%. Las ocupaciones residuales las conforman las profesiones liberales, técnicos y trabajadores similares, con un uno por ciento, seguido de las empleadas, las trabajadores de oficina, funcionarios y similares, las aprendices, trabajadores administrativos y de gestión y trabajadores de ventas, todas ellas representadas en menos de un 0.5 por mujeres.

\footnotetext{
${ }^{81}$ Para el caso de las mujeres, la categoría correspondiente a los trabajadores agropecuarios, forestales, cazadores y pescadores (Major Group 6) no aparece representada por no aparecer información sobre alguna mujer dedicada a esta clase de ocupaciones.
} 
Gráfico 8-2. Estructura socioprofesional de Madrid. Mujeres. Año 1915

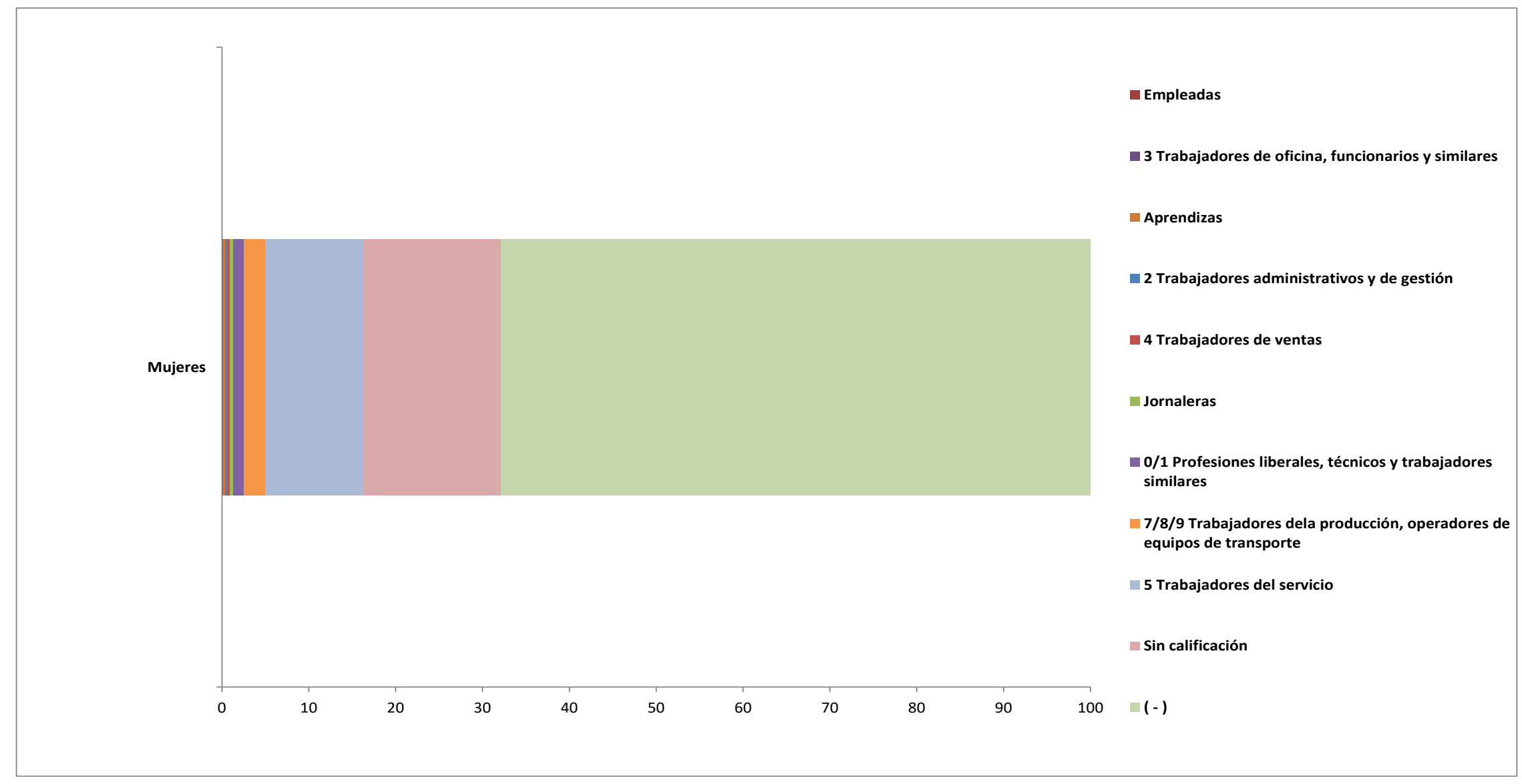

Fuente: Elaboración propia con información obtenida de (Ayuntamiento de Madrid, 1917) 


\subsection{La distribución espacial de las ocupaciones profesionales}

Teniendo en cuenta la distribución espacial según la ocupación profesional de las personas empadronadas en Madrid a la altura de 1915, pueden verse patrones claramente diferenciados en la ciudad, con características de segregación socioespacial acusada. Asimismo, se mantienen patrones diferenciados entre hombres y mujeres.

Los grupos sociales definidos por su ocupación no se distribuían de manera homogénea en la ciudad. La ocupación profesional puede ser un indicador de la renta disponible que, a su vez, tiene íntima relación con el precio de la vivienda .

Algunos autores señalan que antes de iniciarse el siglo XX, en la ciudad de Madrid, las diferencias no podían ser asociadas a la zona donde se residía, sino por la vivienda que se ocupaba. Se trataba de la manifestación de una segregación vertical dentro de los propios edificios: la burguesía y clases acomodadas ocupaban los cuartos (viviendas) principales y las de la planta primera; los segundos y superiores solían ser viviendas de menor calidad, hasta llegar a las buhardillas, ocupadas por las personas de menores recursos y trabajos de escasa cualificación (Otero Carvajal, 2016, pp. 101-102).

Sin embargo, a partir de la urbanización del siglo XIX, se asistirá a una formalización de diferencias en cuanto a la zona de residencia, quedando definidas de manera estructural, tal y como puede verse a partir de los mapas de distribución de las ocupaciones profesionales a nivel de barrio, así como por la de los precios del alquiler.

La homogeneización interna a nivel de barrio respecto a status profesional y económico se materializará conformando una ciudad de grandes contrastes: de los hotelitos habitados por las familias más adineradas a las viviendas obreras, representadas por las casas de corredor, las corralas, dentro de casco urbano y por las casas bajas ubicadas en el Extrarradio y sur del Ensanche.

Las grandes reformas que tuvieron lugar en el casco urbano de Madrid, teniendo como manifestaciones más evidentes la apertura de la Gran Vía, o las remodelaciones de la Puerta del Sol y de la Plaza de Callao, fomentaron una revalorización de estos terrenos. Sin embargo, dentro de la zona antigua de la ciudad no se llevaron a cabo reformas urbanísticas en muchas otras zonas, como las de los barrios de Lavapiés o el Rastro. 
Éstos barrios seguirán disponiendo de una oferta residencial caracterizada por disponer de habitaciones de tamaño ínfimo, escasa ventilación y sin elementos de saneamiento como agua o sistemas de evacuación (Hauser, 1902a; León Peralta, 1926).

Imagen 8-4. Viviendas en el Barrio de Lavapiés.

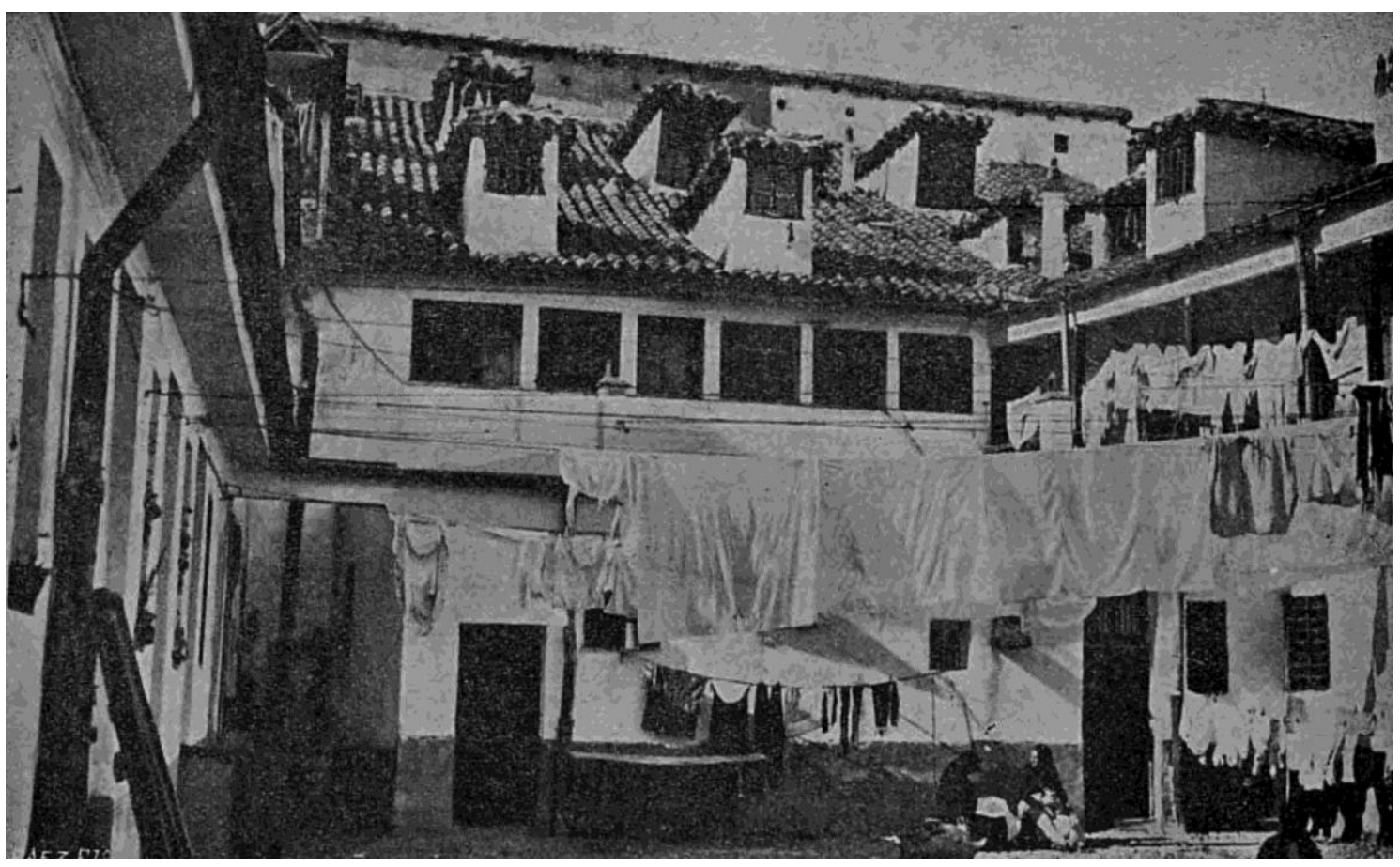

Fuente: Biblioteca Histórica. Ayuntamiento de Madrid

Esta diversidad dentro del casco antiguo de la ciudad puede verse claramente reflejada en la distribución ocupacional de los residentes en los barrios que conformaban dicha zona de la ciudad. Las reformas realizadas, con la apertura de grandes vías y calles, saneamiento de las calles, construcción de grandes edificios, fomentaban que éstas zonas estuvieran habitadas por las nuevas clases medias (representadas por la clasificación Hisco en los Major Group 0-1,2 y 3).

Sin embargo, el casco antiguo también estaba habitado por los trabajadores de más escasa cualificación, como los jornaleros, concentrados, especialmente, en diferentes barrios del Distrito de Latina. 
Imagen 8-5. Viviendas en el Barrio de Arganzuela. Distrito de Latina.

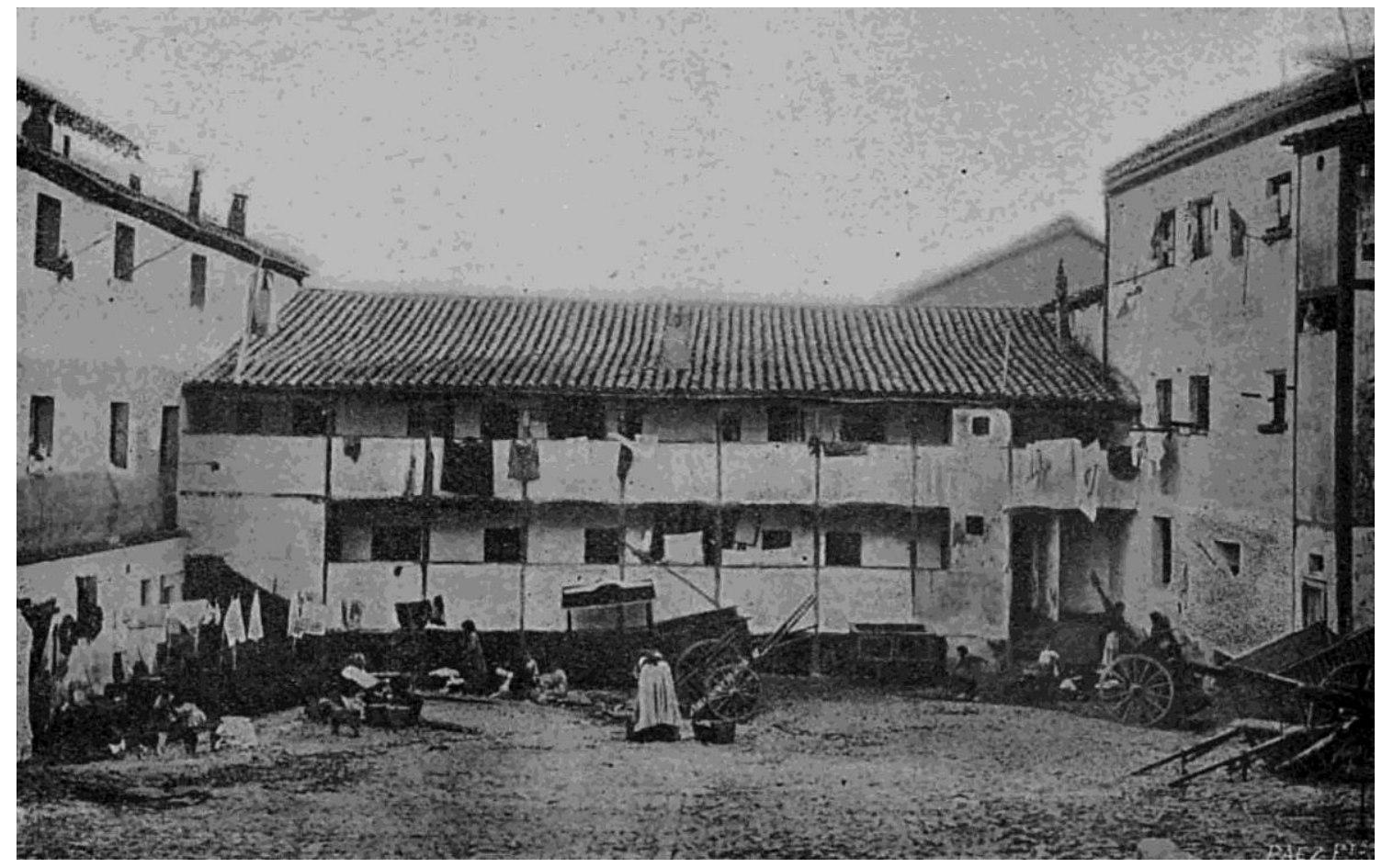

Fuente: Biblioteca Histórica. Ayuntamiento de Madrid

Respecto a las zonas del Ensanche de la ciudad, es necesario señalar que se trató de la manifestación palpable del racionalismo burgués característico de las sociedades industriales y se abogaba por el diseño de espacios urbanos basados en los preceptos de la higiene y la salubridad, tal y como sucedió en otras ciudades españolas, como el caso de Barcelona (Magrinyà, 2009; Núñez Granés, 1909). Sin embargo, los preceptos de estructuración del Ensanche, en el caso de Madrid, no fueron suficientes para limitar el crecimiento poblacional y el asentamiento desestructurado. Los procesos migratorios hacia la ciudad de Madrid tuvieron importancia ineludible en la forma en que, de facto, la ciudad se iba configurando (Bayona-i-Carrasco \& Pujadas-i-Rúbies, 2014).

Estas zonas estaban caracterizadas por un componente social y de tipología de construcción habitacional claramente diferenciado. Así, fueron éstas las zonas elegidas para la ubicación de los hotelitos y las villas de clase media y, a su vez, la localización de las casas de vecindad y los edificios bajos, conformando populares suburbios obreros (Otero Carvajal, 2016). 
La aparición de arrabales, en torno al proyecto del Ensanche, se dio en barrios tales como Chamberí, Peñuelas y Vallehermoso. Asimismo, dentro de la zona del Ensanche, zonas como los barrios anteriores y otros como los de Plaza de Toros, Delicias o Imperial, carecían de servicios tales como adoquinado de calles o redes de evacuación de aguas y por viviendas con características similares a las de los barrios más insalubres del Casco Histórico; poca ventilación y espacio (Hauser, 1902a; León Peralta, 1926) con la diferencia de que solían ser viviendas de planta baja.

Imagen 8-6. Barrio Plaza de Toros. Año 1914.

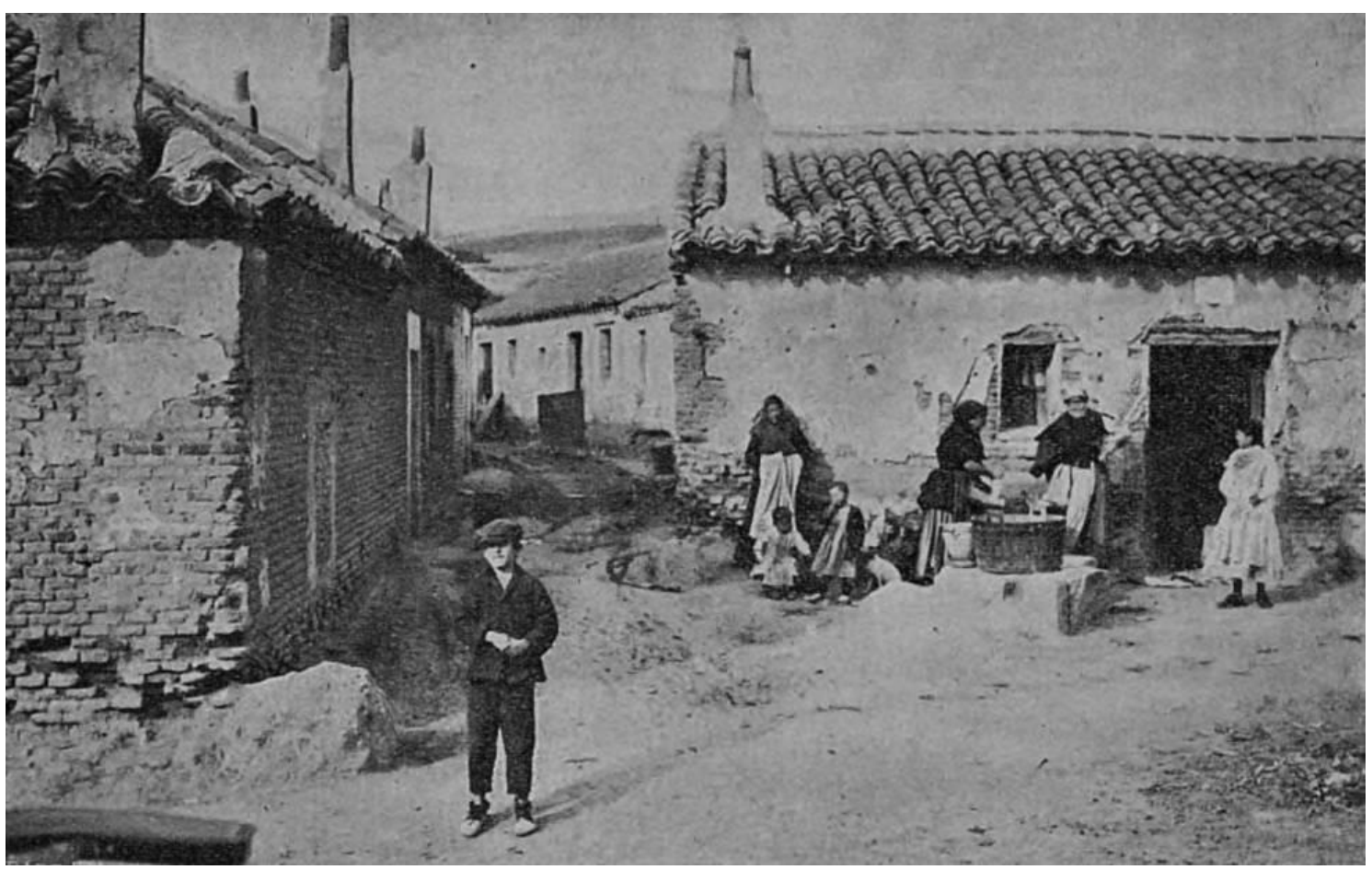

Fuente: Biblioteca Histórica. Ayuntamiento de Madrid 


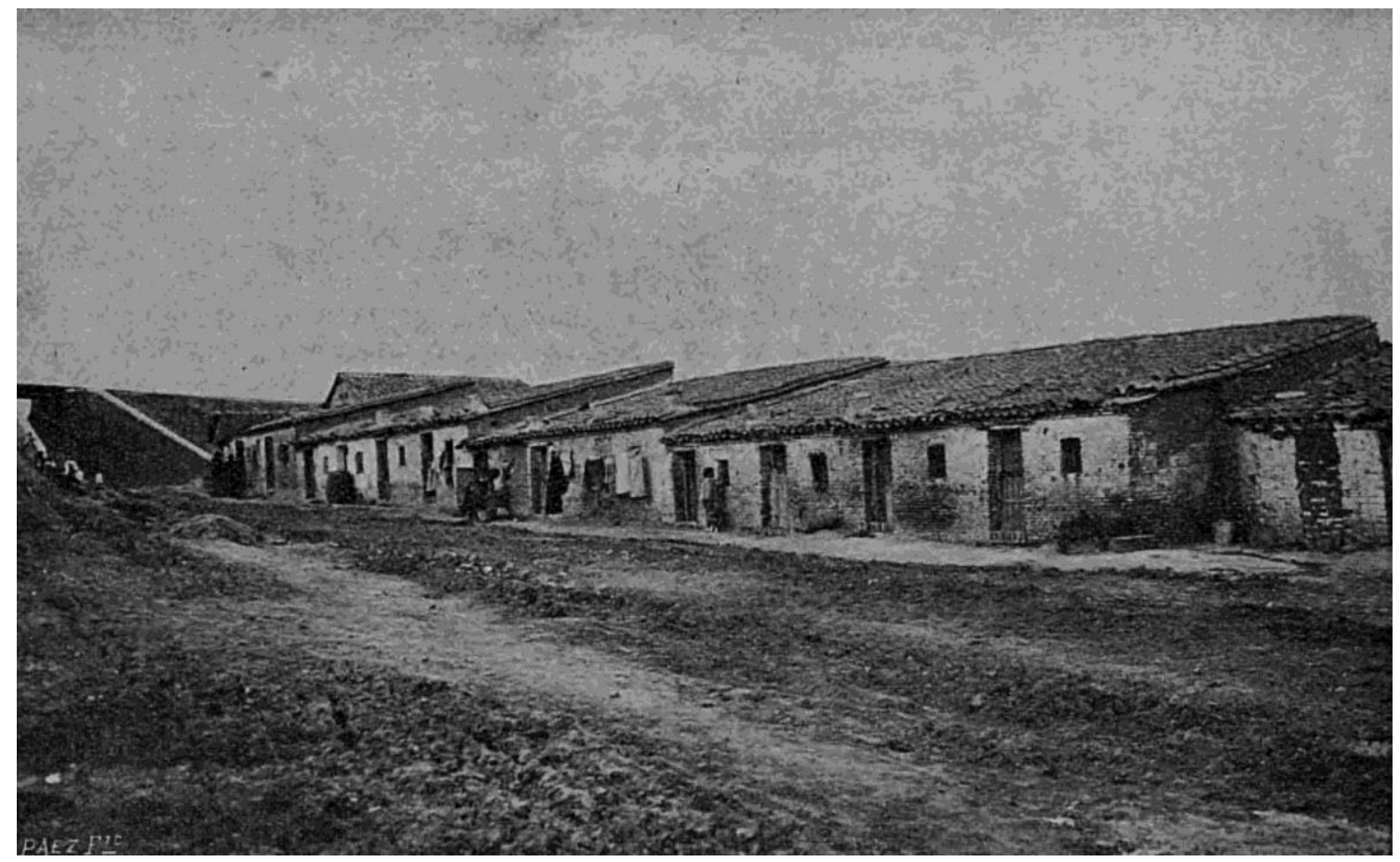

Fuente: Biblioteca Histórica. Ayuntamiento de Madrid

En el lado opuesto se encuentran los barrios del Ensanche que, de facto, se creó para la habitabilidad de las clases acomodadas. Éstos, estaban caracterizados por la limpieza de sus calles, amplias avenidas o bien acondicionadas en cuando infraestructura de saneamiento y con una amplia arquitectura de viviendas conformando hotelitos o palacetes. Estos barrios eran los de Fernando el Santo, Biblioteca, Conde de Aranda o Goya.

El ensanche sur y el ensanche norte, se conformarán como dos zonas diametralmente opuestas en cuanto a la composición social de sus habitantes, así como en torno la calidad de sus calles y viviendas.

Como colofón a la falta de planificación urbana, se encuentran los barrios del Extrarradio de la ciudad. Los barrios que conformaban los suburbios no disponían de ningún tipo de servicio, hasta la puesta en marcha del Plan para Urbanización del extrarradio (Núñez Granés, 1914), aunque el problema derivado de estos asentamientos manifestados sin ninguna clase de diseño institucional, no será resuelto ni siquiera a la altura de los años treinta. 


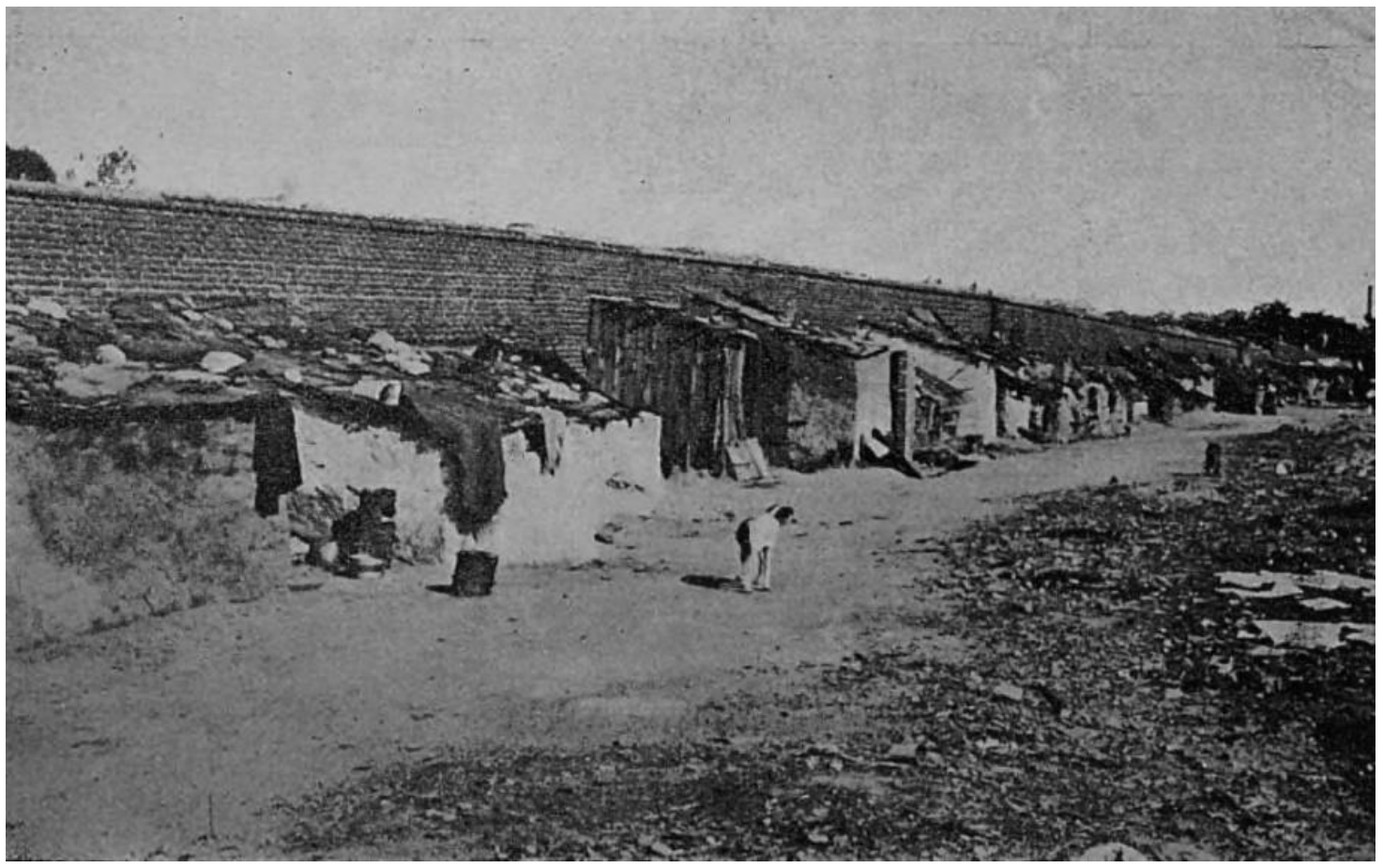

Fuente: Biblioteca Histórica. Ayuntamiento de Madrid

Una vez dispuestas las características generales de los barrios de la ciudad de Madrid, señalaremos a continuación la distribución socioprofesional de hombres y mujeres en el espacio madriñelo. En este sentido, como puede verse a través de los mapas de distribución de las ocupaciones, en relación a los hombres (Mapa 8-1), los dedicados a profesiones liberales, técnicos y trabajadores similares (Major Group 0-1), residían en mayor medida en barrios de los distritos de Buenavista (Conde de Aranda, Fernando el Santo, Biblioteca, Almirante, Goya, Las Mercedes) de Congreso (Príncipe, Floridablanca) de Hospicio (Campoamor, Las Torres, Hernán Cortés) Centro (San Martin, Puerta del Sol, Muñoz Torrero), Chamberí (Alfonso X). Todos ellos con más de un $10 \%$ de su población dedicada a estas profesiones.

Los trabajadores administrativos y de gestión (Major Group 2), tenían su residencia en mayor medida en barrios de los distritos de Congreso (Floridablanca, Príncipe, Cervantes, Santa María, San Carlos, Cañizares, Gutenberg y Almeda, en menor medida éste último), Inclusa ( Duque de Alba), Centro (Jardines, Puerta del Sol, San Luis), Hospicio (Bilbao). 
Los trabajadores de oficina, funcionarios y similares (Major Group 3), se concentraban en los distritos de Congreso (en los barrios e Príncipe, Floridablanca), Centro (en los barrios de Constitución, Puerta del Sol, Jardines, Carmen, Centro, San Martin, Correos), Universidad (en el barrio de Santa Lucía) y el distrito de Hospicio (en el barrio de Colón).

Los trabajadores de ventas (Major Group 4), residían principalmente en los distritos de Congreso (Príncipe, Floridablanca), Centro (Constitución, Puerta del Sol, Jardines, Carmen, San Martín, Correos), Universidad (Santa Lucía) y Hospicio (Colón).

Los trabajadores del servicio (Major Group 5), se concentraban Congreso (Gutenberg, Floridablanca, Príncipe, Cañizares, Cervantes, Alameda, Santa María, San Carlos); Hospital (Pacífico, Las Torres); Latina (San Francisco, Ayuntamiento); Universidad (Conde Duque); Buenavista (Almirante, Goya, Fernando el Santo, Monasterio, Biblioteca, Las Mercedes, Conde de Aranda) ; Palacio (Montaña, Carlos III); Centro (Puerta del Sol); Chamberí (Alfonso X); Hospicio (Las Torres, Campoamor)

Los trabajadores agropecuarios, forestales, cazadores y pescadores (Major Group 6) solo tienen presencia, muy residual además en los siguientes: Palacio (Moncloa, Isabel II, Argüelles), Buenavista (Guindalera), Universidad (Vallehermoso, Lozoya), Latina (San Isidro, Imperial) y Hospital (Delicias).

Los trabajadores de la producción, operadores de equipos de transporte (Major Group 7-8-9): Inclusa (Duque de Alba, Rastro, Caravaca), Palacio (Isabel II, Carlos III, Senado, Quintana, Argüelles), Congreso (Príncipe, Santa María), Chamberí (Cuatro Caminos, Balmes), Universidad (Lozoya, Vallehermoso)

Los comerciantes estaban realmente concentrados residencialmente en Centro (Constitución, Puerta del Sol, Correos, Jardines, Tudescos, Carmen, San Luis, San Martin)

En lo que se refiere a los jornaleros, representaban más del $50 \%$ de la población residente de los siguientes barrios: Latina (San Isidro, Imperial, Aguas, Calatrava, Humilladero, Arganzuela, Alfonso VI); Inclusa (Huerta del Bayo, Gasómetro, Cabestreros, Miguel Servet, Marqués de Comillas, Amazonas, Peñuelas, Caravaca); 
Palacio (Casa de Campo, Espejo); Hospital (Santa María de la Cabeza, Ministriles, Torrecilla, Primavera, Lavapiés)

Aquellas ocupaciones que no son directamente relativas a una actividad laboral (Cesantes, Estudiantes, Jubilados, Pensionistas, Propietarios, Rentistas, Retirados), representan más de un $20 \%$ en proporción a nivel de barrio en los siguientes: Hospicio (Apodaca, Campoamor); Palacio (Moncloa, Quintana, Argüelles); Universidad (Conde de Toreno); Congreso (San Carlos); Buenavista (Conde de Aranda); Chamberí (Alfonso $\mathrm{X})$; Centro (Muñoz Torrero). 
Mapa 8-1. Mapas de la distribución ocupacional de los hombres. 1915.
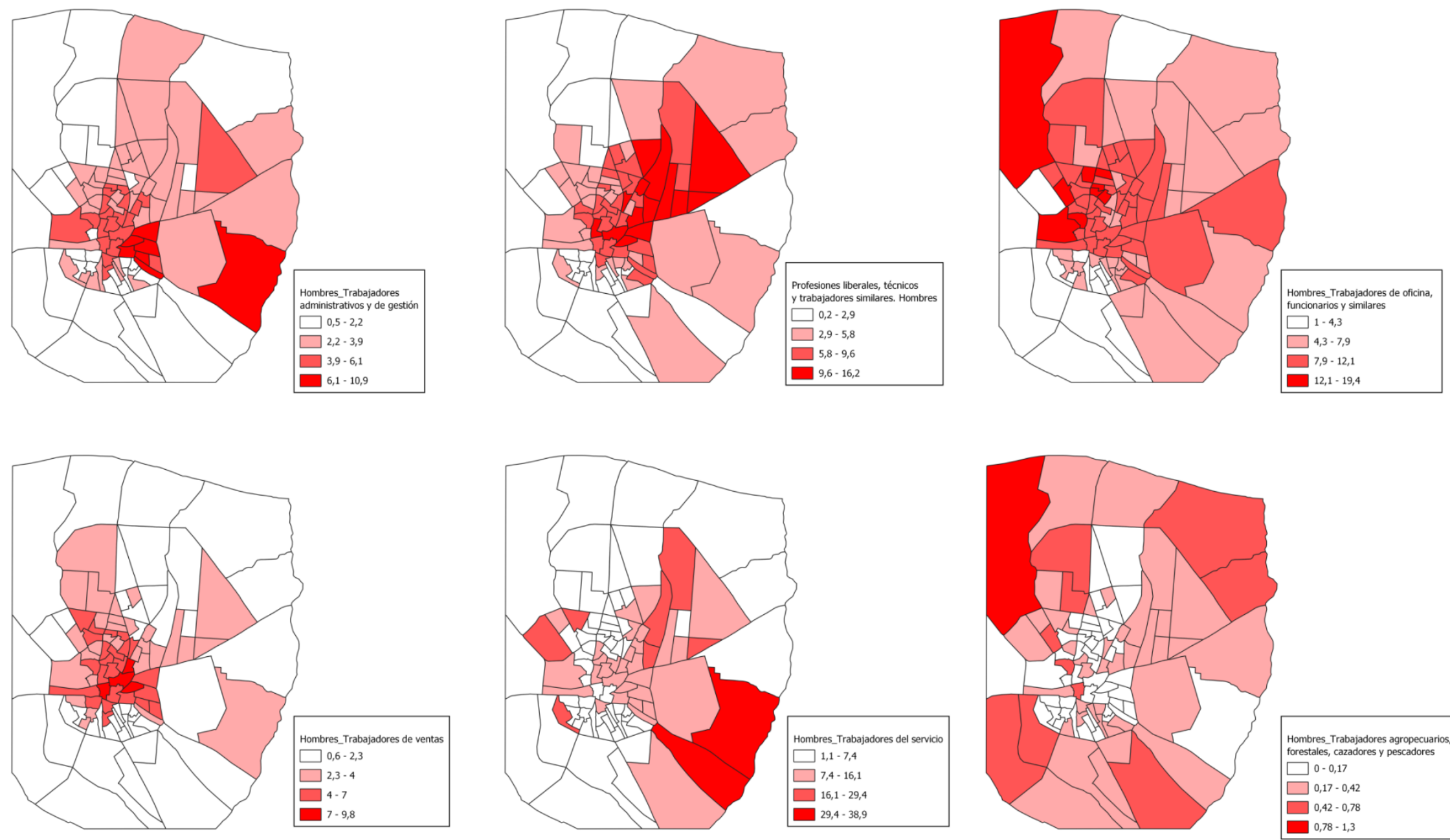

Hombres_Trabajadores agropecuarios forestales, cazadores
$\square 0-0,17$ $\square \quad 0,17-0,42$ $0,42 \cdot 0,7$, 

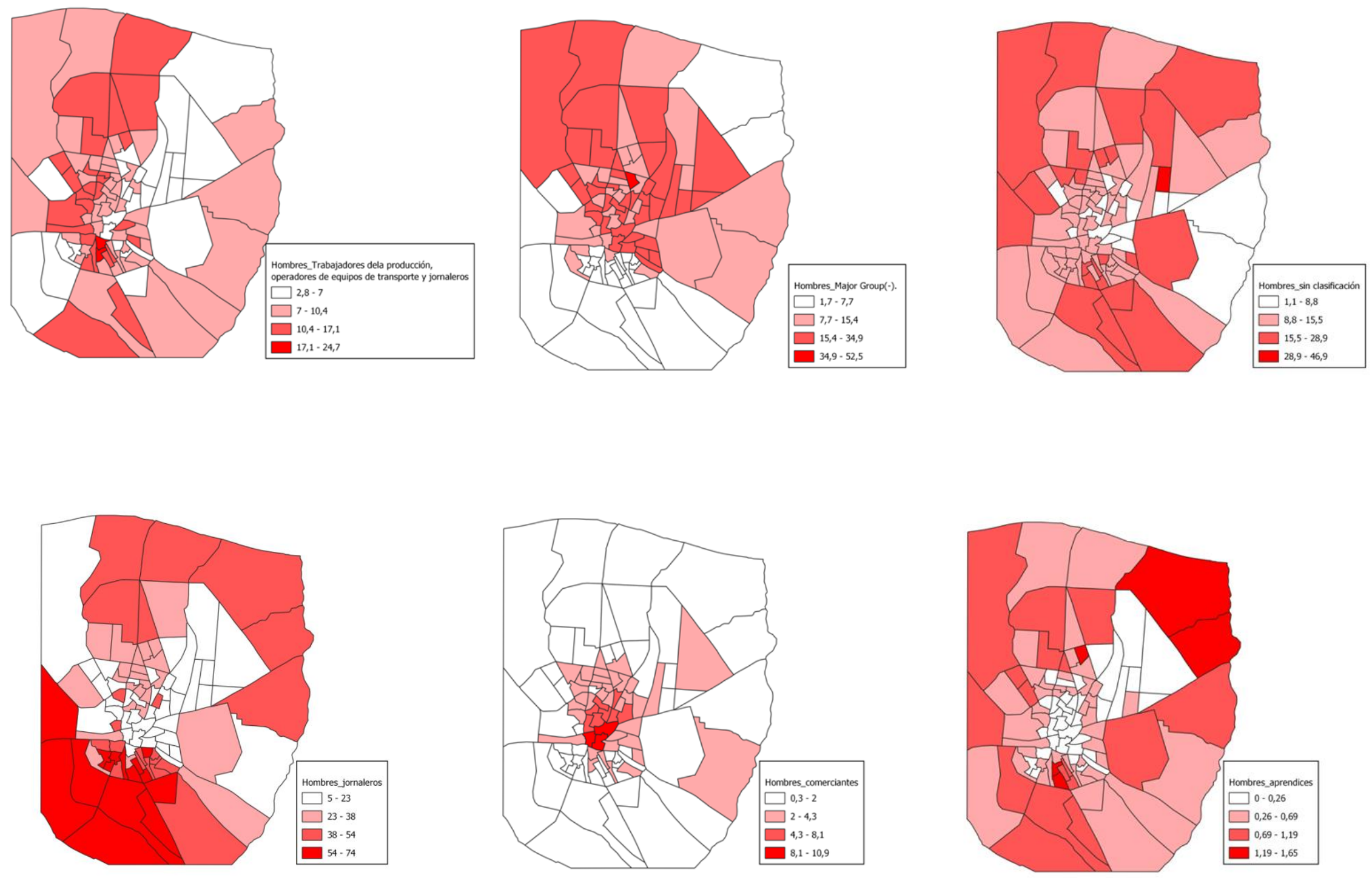
Respecto a la distribución ocupacional de las mujeres a nivel de barrio ${ }^{82}$ (Mapa 8-2), las dedicadas a profesiones liberales, técnicos y trabajadores similares (Major Group 0-1), tenían una presencia especialmente destacable en el Barrio de Alfonso X, del distrito de Chamberí (15\%), seguido de los de Conde Duque y Vallehermoso (Universidad), Argüelles y Quintana y Álamo (Palacio), Dos de Mayo (Chamberí) y Doctor Fourquet (Hospital).

Las trabajadoras administrativas y de gestión (Major Group 2), tenían una presencia muy residual en todos los barrios de la ciudad. Solo la tienen en los siguientes, con un 1\%. Palacio (Espejo, Carlos III, Quintana, Isabel II, Argüelles, Senado, Montaña); Centro (Tudescos, Puerta del Sol, Carmen, Jardines, San Luís); Congreso (Príncipe); Hospicio (Bilbao, Colón, San Pablo); Chamberí (Trafalgar, Monteleón); Latina (San Francisco) y Buenavista (Goya)

Las trabajadoras de oficina, funcionarias y similares (Major Group 3), al igual que sucede con el Major Group 2, tenían una presencia muy residual en todos los barrios de la ciudad. Solo la tienen en los siguientes, con un 1\%: Príncipe (distrito Congreso) y Argüelles (distrito Palacio).

Las trabajadoras de ventas (Major Group 4), tienen una presencia muy residual en todos los barrios de la ciudad. Sólo la tienen en los siguientes, con un 2 y 1\%: Inclusa (Rastro, Duque de Alba, Cabestreros, Gasómetro, Marqués de Comillas, Amazonas, Peñuelas); Latina (Cava, Ayuntamiento, San Francisco, Humilladero, Arganzuela, Calatrava, Alfonso VI, San Isidro); Congreso (Príncipe, Alameda); Centro(Constitución, Carmen, Puerta del Sol) y Palacio(Senado, Álamo, Espejo)

Las trabajadoras del servicio (Major Group 5), sí configuraban un grueso importante en algunos barrios de Madrid. De este modo, representan más de un 20\% en los siguientes: Buenavista (Conde de Aranda, Las Mercedes, Goya, Almirante, Biblioteca, Monasterio, Fernando el Santo, Guindalera); Hospicio (Las Torres, Campoamor, Apodaca); Centro (Puerta del Sol, San Martín); Congreso (Cervantes, Cañizares, Floridablanca). Una explicación posible ante esta concentración en estos barrios, radica en que residían en los hogares donde desempeñaban su trabajo del servicio.

\footnotetext{
${ }^{82}$ Cabe señalar que no se han encontrado en los Resúmenes de padrón ninguna mujer dentro del Major Group 6, por lo que, en consecuencia, no han sido incluidas en los mapas de distribución.
} 
Las trabajadoras de la producción, operadores de equipos de transporte (Major Group 78-9), residían más de un $10 \%$ en los barrios de Duque de Alba y Rastro (del distrito Inclusa), seguido de otros como Carlos III, Isabel II, Senado y Espejo (Palacio), Peñuelas, Miguel Servet, Gasómetro, Cabestreros (Distrito Inclusa, nuevamente), Conde Duque en Universidad, Príncipe, Cervantes y Floridablanca (Congreso); Jesús y María y Lavapiés (Hospital)

Las aprendizas, sólo tenían presencia en los distritos de Universidad (Vallehermoso, Conde Duque, Lozoya, Bellas Vistas y Minas), Congreso (Príncipe, Cervantes, Floridablanca) y Palacio, (Senado, Carlos II, Moncloa, Casa de Campo).

Frente al número elevado de hombres Jornaleros declarados, en el caso de las mujeres representan proporciones muy bajas. Solo tenían presencia en las siguientes zonas de la ciudad, representando menos de un 2\% a nivel de barrio: Universidad (Vallehermoso, Lozoya); Latina (Arganzuela, Humilladero, Cava, Calatrava, Imperial, Alfonso VI, Ayuntamiento); Congreso (Plaza de Toros, Cañizares); Hospital (Pacífico); Inclusa (Rastro, Duque de Alba, Cabestreros, Marqués de Comillas) y Palacio (Casa de Campo, Argüelles).

Aquellas ocupaciones que no son directamente relativas a una actividad laboral (asiladas, cesantes, colegialas, estudiantes, jubiladas, labores domésticas, pensionistas, propietarias y rentistas), aparecen en proporciones muy elevadas en todos los barrios de la ciudad. A excepción de los barrios de Las Mercedes y Almirante del distrito de Buenavista), todos los demás barrios muestran esta categoría en más de un $50 \%$. Especialmente destacable en los siguientes barrios, con un porcentaje superior al $75 \%$ : Hospicio (San Pablo, Bilbao, Jesús del Valle); Buenavista (Prosperidad, Marqués de Salamanca); Centro (Muñoz Torrero, Tudescos); Inclusa(Marqués de Comillas, Caravaca, Peñuelas, Huerta el Bayo, Miguel Servet, Gasómetro); Latina (Imperial, Alfonso VI, Arganzuela) y Universidad (Quiñones, Lozoya). 
Mapa 8-2. Mapas de la distribución ocupacional de las mujeres. 1915
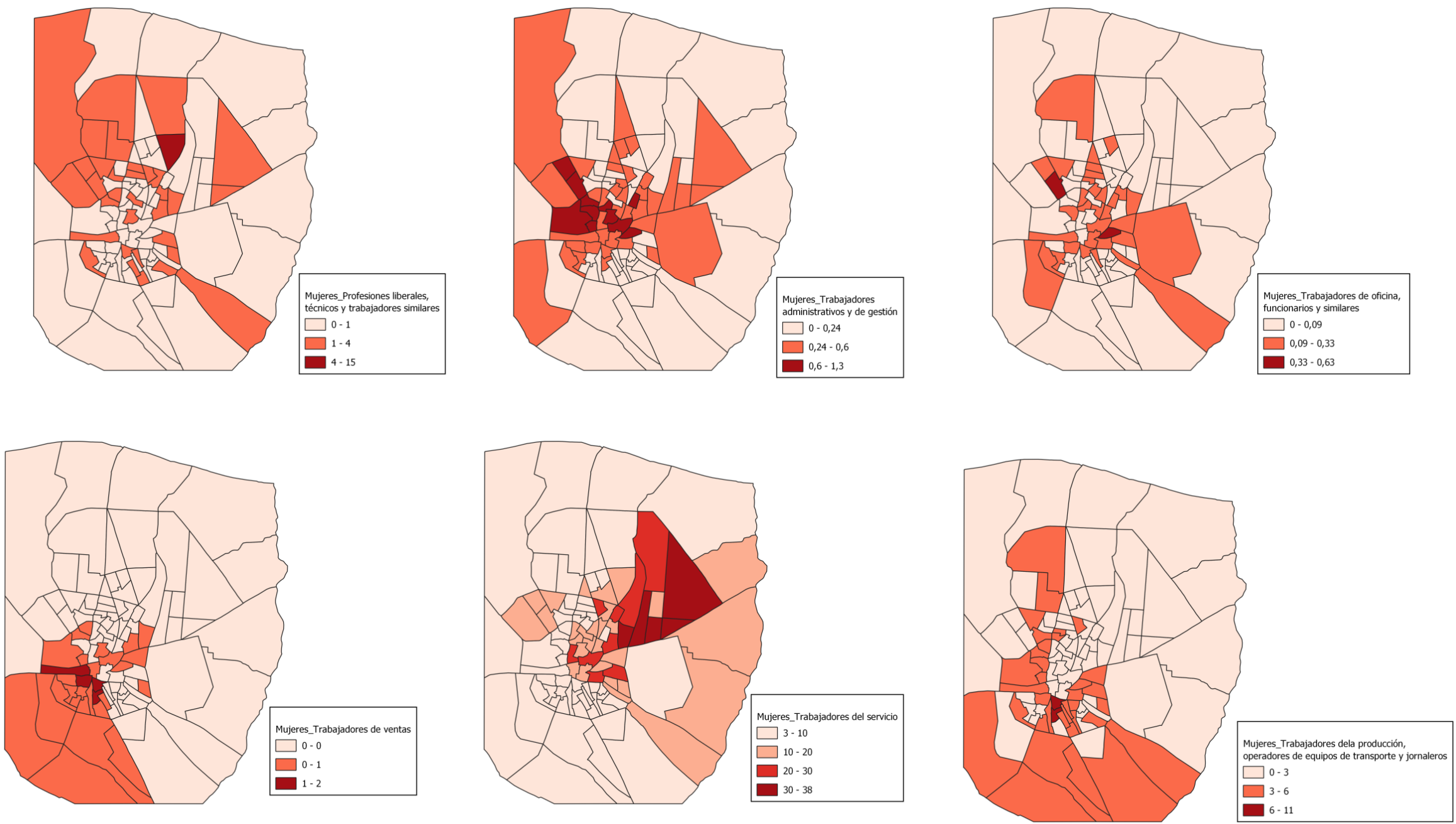

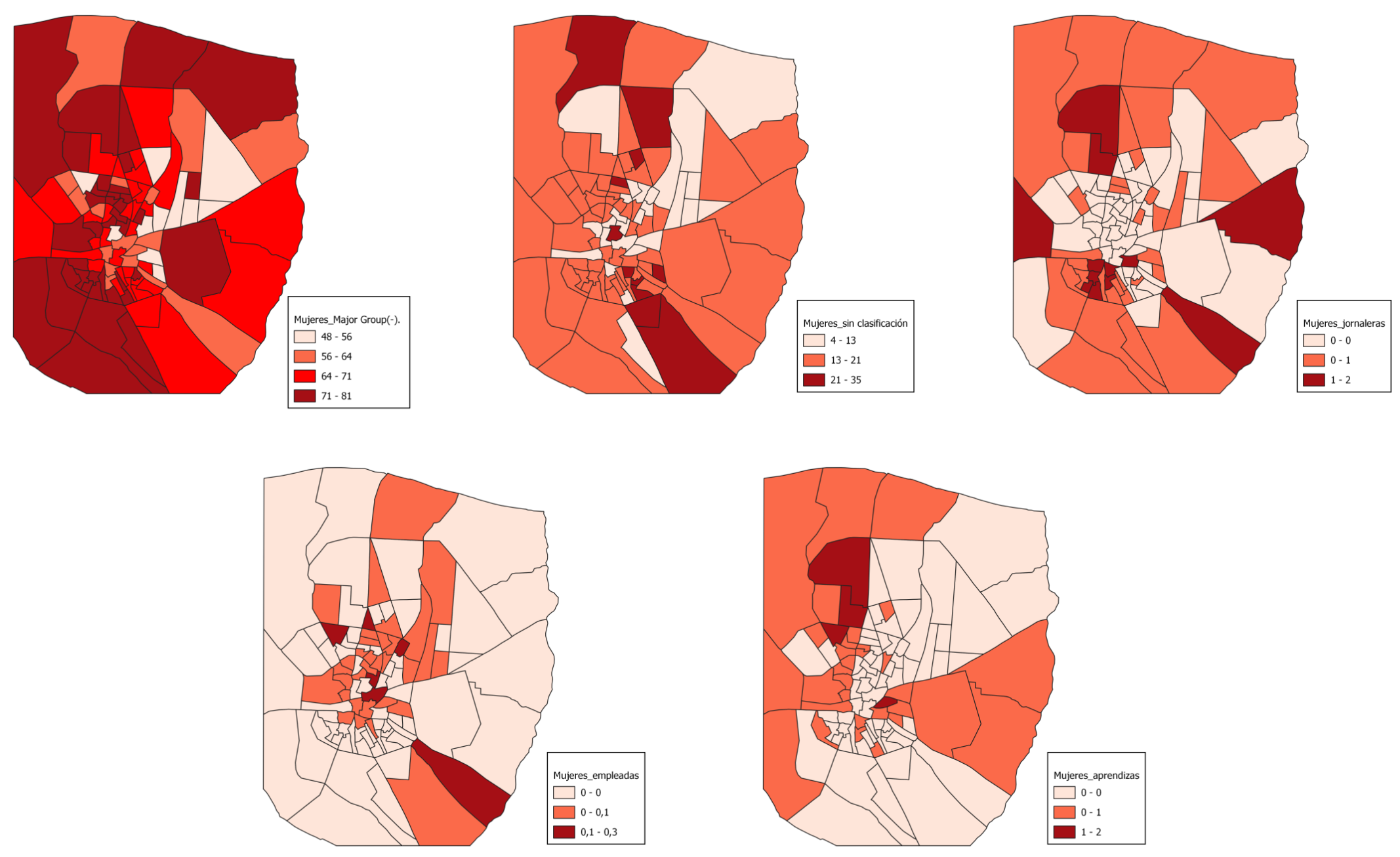
Con el objetivo de completar el análisis anterior, se ha optado por tomar el nivel de analfabetismo, como variable explicativa de la fragmentación y segregación residencial a nivel de barrio (Ramsey-Kurz, 2007)

Para la operacionalización de la variable, se ha optado por tomar como personas analfabetas todas aquellas que hubieran declarado que no saben leer ni escribir o cualquiera de las dos anteriores. Han sido representados los mapas en tres grupos, diferenciado por sexo en cada uno de los mismos, por considerarse una variable significativa a la hora de tratar el nivel de instrucción en el periodo de estudio (García Abad, Pareja Alonso, \& Zarraga Sangroniz, 2007)

Además, se ha tenido en consideración naturaleza de nacimiento: oriundos de Madrid, de fuera de la ciudad, y la población en su conjunto. Los cálculos han sido realizados tomando la población mayor de 9 años.

En términos generales, cabe destacar una mayor presencia de mujeres que no sabían leer ni escribir en comparación con los hombres. Asimismo, esta proporción se ve claramente incrementada si se toma en consideración las mujeres no nativas de la ciudad.

La proporción de personas analfabetas, en el caso de los hombres tanto para los nacidos en Madrid como para los que no lo eran, tenían una menor presencia muy acusada en los barrios de Congreso, Hospicio, Centro y algunos de Buenavista (como Biblioteca o Conde de Aranda).

En términos generales, el mismo patrón anterior es el experimentado para las mujeres nacidas en Madrid. Sin embargo, si se toman las mujeres de fuera de Madrid, la proporción de éstas que declaraban que no sabían leer ni escribir, se incrementa respecto a las nacidas en la ciudad y se concentraban en los siguientes barrios, representando más de un $30 \%$ respecto al total por barrio: Cuatro Caminos, Hipódromo y Balmes (distrito de Chamberí); Almirante, Monasterio, Guindalera, Prosperidad (distrito de Buenavista), Gasómetro y Marqués de Comillas (distrito de Inclusa).

Teniendo en consideración el conjunto de los habitantes de Madrid, la menor presencia de personas analfabetas (menos de un 10\%) se concentraban en Congreso (Alameda, Retiro, Floridablanca, Cervantes), Hospital (Argumosa, Las Torres); Hospicio 
(Apodaca, Campoamor, Hernán Cortés, Bilbao); Centro (Puerta del Sol, San Martín, Muñoz Torrero, Carmen, Correos, San Luís, Jardines, Constitución); Buenavista(Biblioteca).

Por el contrario, las personas que no sabían leer ni escribir del conjunto de empadronados en Madrid, residían en los siguientes distritos y barrios (con más de un 20\%): Chamberí (Cuatro Caminos); Hospital (Delicias, Jesús y María, Doctor Fourquet); Inclusa (Gasómetro, Marqués de Comillas, Rastro, Cabestreros): Palacio (Álamo); Buenavista (Guindalera, Prosperidad); Congreso (San Carlos, Santa María); Latina(Humilladero) 
Mapa 8-3. Mapas de analfabetismo. Nacidos en Madrid
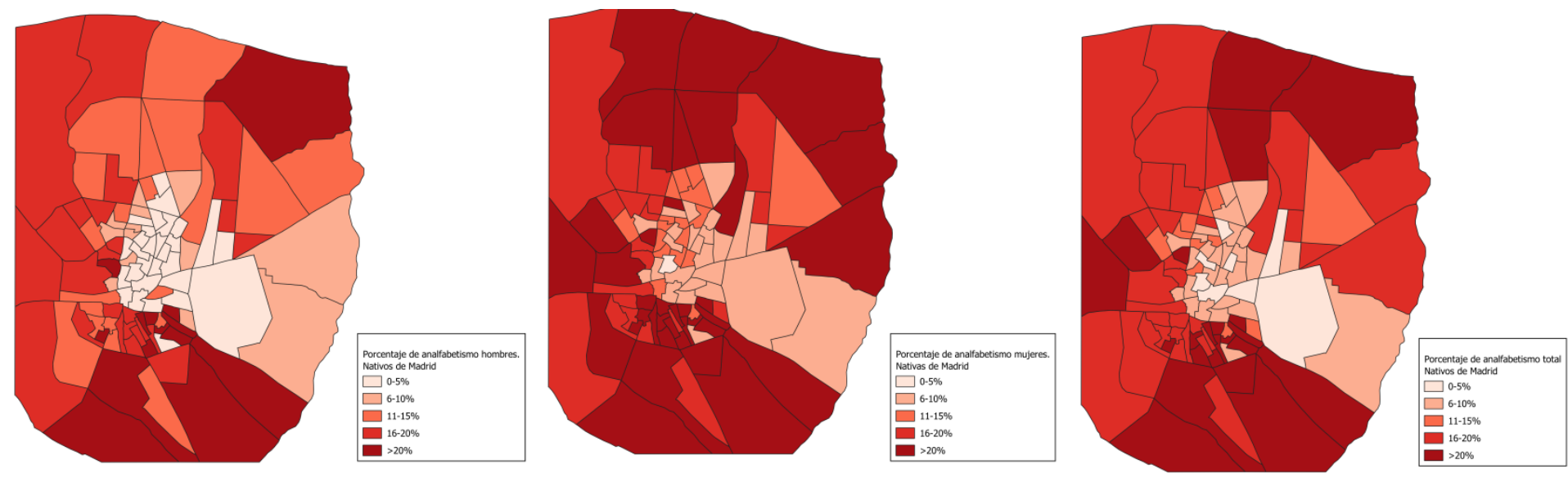
Mapa 8-4. Mapas de analfabetismo. No nacidos en Madrid
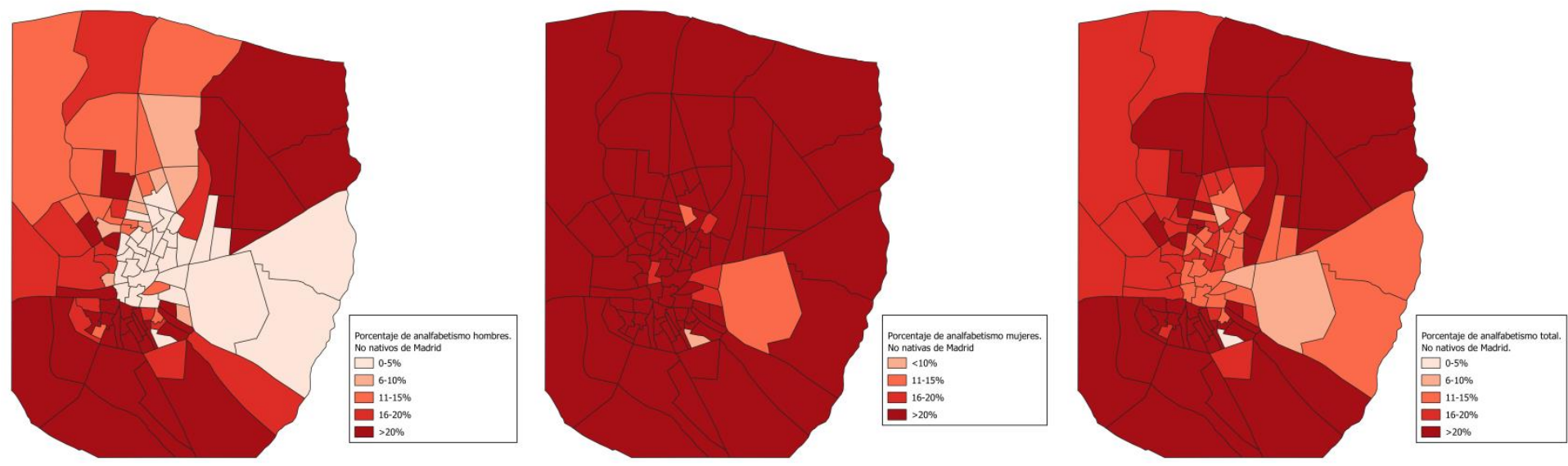
Mapa 8-5. Mapas de analfabetismo. Conjunto de Madrid
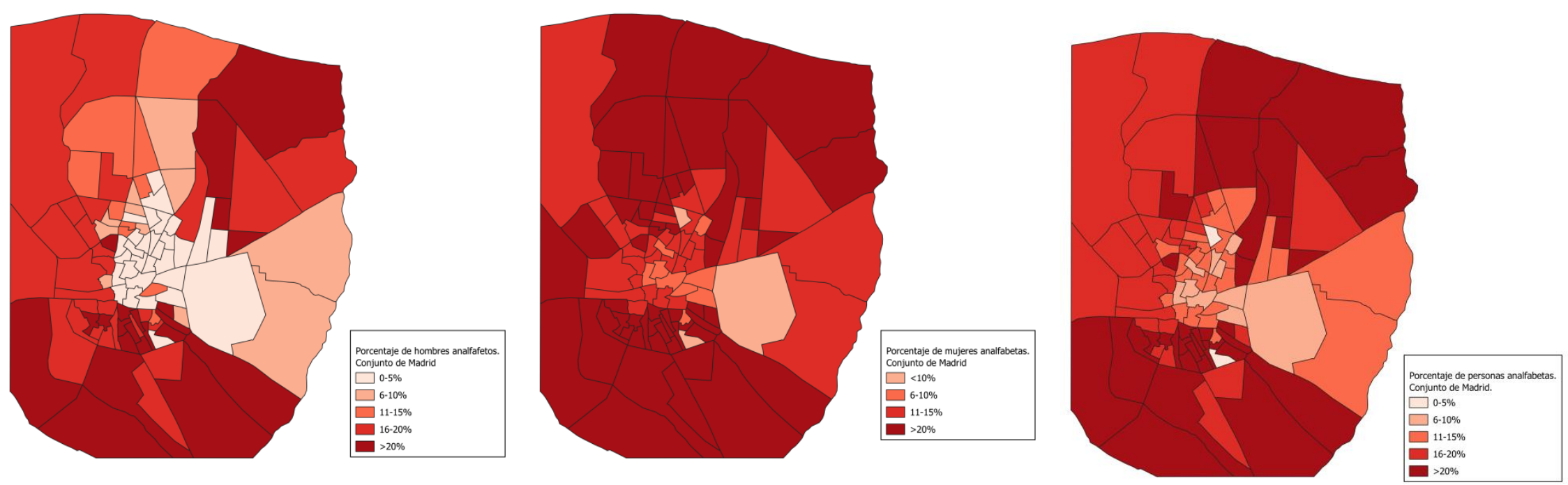


\subsection{La vivienda en Madrid}

Es necesario partir del hecho de que el problema de la vivienda, tanto su alto precio, como su escasez y características habitacionales, no era exclusivo de la ciudad de Madrid, sino que acuciaba a la mayoría de las urbes en el contexto español.

En líneas generales, tres problemas eran los que adolecían la situación de la vivienda en Madrid; la carestía y elevación de precio a lo largo del periodo estudiado; la escasez y la insalubridad de las mismas, tratándose de aspectos que no pueden ser tratados de manera aislada, en tanto en cuanto se hallan intrínsecamente relacionados. Así lo reflejan en su estudio sobre la situación de la vivienda autores como León Peralta:

La escasez es compañera inseparable de la carestía, a pesar de todas las tasas y de todas las trabas que se imaginen para limitar la codicia del que ofrece cuando éste dispone de un arma tan excelente para sus fines como la necesidad del que demanda.

Y la carestía, en un problema tan esencialmente vital para la sociedad como lo es el de la casa, cuando no va seguida del correspondiente aumento en los ingresos, sólo puede contrarrestarse de dos maneras: una, restando de otras atenciones (y la principal para las familias modestas es la comida) la cantidad necesaria hasta completar la que absorbe el alquiler, y otra reduciendo el costo del alquiler, bien habitando dos familias juntas, o ya realquilando habitaciones. Cualquiera de las dos soluciones es perjudicial para la familia. Por la primera se tiene casa pero no alimentación suficiente, y entonces pronto aparecen enfermedades como la anemia y la tuberculosis.

Por la segunda se tiene alimentación y vivienda; pero en ésta el aire respirable habrá de repartirse entre más personas de las que consiente la cubicación de las habitaciones, ya de suyo precaria, y en este caso también aparecerán pronto enfermedades que son inherentes a la falta de higiene y salubridad.(León Peralta, 1926, p. 27).

La necesidad de extensión urbana y de los problemas existentes relacionados con la situación de la vivienda, llevó incluso al Ayuntamiento de Madrid a convocar concursos y premios en relación a esta temática, para que los expertos pudieran realizar estudios sobre la ciudad y planteasen soluciones posibles. De especial importancia fue la memoria que ganó el concurso celebrado en 1926, realizada por Alberto León Peralta y José Bravo Ramírez, bajo el título de Escasez, carestía e higiene de la vivienda en 
Madrid. Creo conveniente transcribir un fragmento que aparece en el prólogo de dicho estudio, de manos de Salvador Crespo, pues considero que refleja de manera bastante clara los problemas de la época, sus causas y la razón por la cual era necesario que se solucionaran.

La solución del problema de la vivienda constituye una de las mayores preocupaciones de los pueblos cultos, ya que ello representa la defensa del orden social al crear nuevas masas de propietarios; la conservación de la raza que se depaupera en viviendas insalubres, que por ser demasiado caras no dejan margen para una alimentación suficiente; el fundamento esencial de la vida de familia, ya que el hogar inhospitalario aleja y disgrega a sus habitantes; el cumplimiento de los esenciales preceptos de la higiene; la lucha más adecuada y eficaz contra la tuberculosis, terrible tara de la humanidad que causa anualmente más víctimas que la guerra más cruenta; la desaparición de las enfermedades evitables, que siegan en flor cientos de miles de vidas; la disminución del alcoholismo, con todas las innumerables ventajas que ello representa para la sociedad y la familia; el estímulo del ahorro y de la previsión, virtudes que engrandecen a los pueblos y redimen de la miseria a los humildes; el decrecimiento de la criminalidad; la elevación del sentido moral, evitando las terribles promiscuidades de sexos en los tugurios, que producen repetidamente hechos que mi pluma se avergonzaría de relatar; la constitución de un patrimonio familiar inalienable e inembargable, que es la mayor parte de las veces fruto de una colaboración de los esfuerzos y del trabajo de todos los individuos que constituyen la familia, y, por último, la alegría, el bienestar y la felicidad. (León Peralta, 1926, p. 9).

(...)la solución del problema, con lo cual no sólo se salvarían muchos miles de vidas, sino que los habitantes de Madrid tendrían una vida más cómoda y feliz y en consonancia con las exigencias del progreso, y ello podría convertir la capital de España en una de las más hermosas poblaciones del mundo(León Peralta, 1926, p. 13).

Como ya hemos dicho anteriormente, cuando nos hemos referido a la municipalización de los servicios, ya había comenzado a implantarse una "conciencia" por parte de los entes gubernamentales de la necesidad de intervención pública en algunas ocasiones; tal como la que en este momento nos ocupa, el problema de la vivienda. Y si bien, se 
consideró un problema municipal, se requería la intervención del estado en cuanto a la dirección, coordinación, inspección y auxilio. Se consideraba que los órganos municipales llevaban a cabo labores que no le eran propias realmente, al igual que el Estado no cumplía las propias, y que estas actuaciones habían venido derivadas del incorrecto funcionamiento de los órganos que tienen estas competencias; por ejemplo, dictando leyes de expropiación, concediendo exenciones tributarias, otorgando el aval en los empréstitos y dictando normas generales para la extensión y urbanización de ciudades (León Peralta, 1926, p. 10). Las Corporaciones Municipales serían las encargadas de llevar a cabo los dictámenes estatales y desde el Estado dirigir, coordinar, inspeccionar y aportar auxilio en caso de necesidad. Un ejemplo bastante clarificador de esta situación es la que se daba con la construcción de las casas baratas (vivienda pública y social) y la adquisición del suelo. El proceso es el siguiente: para poder adquirir el suelo, el Ayuntamiento, con su poder interventor otorgado por el estado, adquiere el suelo, bien por compra directa o por expropiación. El problema aparece en el momento en que se convierte en una actividad especulativa, ya que el enorme agio que se realiza con los terrenos hace se vendan a elevados precios, y con más motivo si han de ser adquiridos a plazos por personas que no poseen recursos para satisfacer el precio de una vez (León Peralta, 1926, p. 11). Como solución al obstáculo principal que se opone a la edificación, se propone la cesión a los particulares o cooperativas constructoras de casas baratas del suelo parcelado. Respecto a la urbanización, resulta siempre muy costosa si se trata de pequeños grupos de casas, y suele realizarse deficientemente; en cambio, realizada en una extensión de terreno, el coste será menor y se facilitará extraordinariamente la disminución del precio de la edificación (León Peralta, 1926, p. 11).

El problema de la vivienda, tanto por su escasez como por motivos higiénicos y económicos, no sólo era objeto de problemas en España, sino también en otros países del entorno europeo en general y se agravó como problema urbano con la I guerra Mundial. Grosso modo, las medidas adoptadas por los Gobiernos de los países, radicaron en disponer dictámenes con el objetivo de normalizar el mercado de la vivienda, prestación de auxilios económicos y otras intervenciones de iniciativa patronal y privada. Si bien en algunos países lograron ser eficaces, para el caso español ni los auxilios acordados por el Estado, ni la legislación promulgada sobre el particular, han dejado sentir sus efectos por falta de orientación unas veces y otras de efectividad (León Peralta, 1926, p. 14). 
Respecto al tema de la vivienda, en España se llevaron a cabo actuaciones tales como la formación de la liga del inquilino, la celebración de un Congreso de edificación, la promulgación de una tercera ley de Casas Baratas, la concesión de exenciones tributarias especiales, la publicación de recientes disposiciones sobre ampliación de pisos, construcción de viviendas económicas, autorizaciones especiales a los Ayuntamientos, concesión de créditos por valor de 180 millones de pesetas con destino al préstamo, la subvención y el abono de intereses, estudio de Bancos de crédito inmobiliario con destino de sus capitales al préstamo para la construcción y mociones y acuerdos municipales que tendrán o no realidad, pero que demuestran cumplidamente que el problema ha llegado a interesar a la opinión y a los poderes públicos.

En este sentido, la primera iniciativa gubernamental que tuvo por objetivo la mejora de la situación de la vivienda en España fue la Ley de 12 de junio de 1911 sobre Casas Baratas. Los principios en los que se basó fueron tres: establecer un régimen de exención tributaria, fomentar el crédito y subvencionar de manera directa.

Además, la Ley de Casas Baratas de 1911, para logar incentivar a los constructores a embarcarse en la edificación de este tipo de viviendas, creó las denominadas Juntas para el fomento y mejora de casas baratas. Se estableció un régimen de autorizaciones al Estado, la Provincia o el Municipio para la cesión gratuita de solares o terrenos de su pertenencia, así como la expropiación de solares o terrenos improductivos, dentro de determinadas condiciones. También se establecieron reglas especiales respecto a la sucesión hereditaria de las casas baratas y se autorizó a las Sociedades constructoras y a las Cooperativas para que pudieran emitir Obligaciones, dentro de ciertos límites, y la determinación de la forma en que hubieran de substanciarse las cuestiones judiciales que se promovieran por la adquisición de solares y terrenos y los litigios, con motivo de los contratos de alquiler o de venta a plazos de las casas baratas. Especial atención merece, teniendo en cuenta el objetivo de este trabajo, la imposición de deberes a los Ayuntamientos en cuanto al saneamiento de habitaciones insalubres. Bien es cierto que esta ley no tuvo la acogida esperada y el fomento del crédito, recogido en la Ley, no obtuvo la eficacia que se pretendía. Consideraba la ley de 1911 a las Cooperativas de construcción de casas con destino a la propiedad de sus socios principal instrumento para la solución del problema de la vivienda, y, sin embargo, por no haber hecho uso las Cajas de Ahorros y Montes de Piedad, igual que el Banco Hipotecario, de las autorizaciones de la ley para invertir parte de sus fondos en la concesión de préstamos a 
Sociedades o particulares ni para construir directamente, el resultado fue que, a pesar de haberse modificado la ley por Real decreto de 3 de julio de 1917 haciendo extensivo el concepto de prestamista a los particulares y entidades, a principios de 1920 apenas sumarían unas 2.000 las edificaciones hechas en toda España al amparo de la ley y de sus modificaciones (León Peralta, 1926, p. 45)

A la luz del fracaso de la Ley de 1911, el 10 de diciembre de 1921, se dictó una nueva Ley, teniendo el mismo objetivo que la anterior, que no fue otro sino el fomento de la construcción de Casas Baratas. La promulgación de esta Ley estuvo muy influenciada por el Congreso internacional de la vivienda y el urbanismo, que tuvo lugar en Londres en 1920.

La importancia de la Ley de Casas Baratas de 1921 radicó en que se otorgó mayor potestad a los Ayuntamientos en materia de vivienda (Rubio, 1978, p. 11). Se les otorgó derechos y deberes y, más concretamente, la obligatoriedad de construir ellos mismos las Casas Baratas.

Como medidas para lograrlo, se ampliaron los principios instrumentales en los que la Ley anterior se basaba, de modo que:

- Se otorgaron autorizaciones al Estado y organismos locales en lo que respecta a la cesión gratuita de terrenos (medida ya existente en la Ley de 1911 pero con ampliaciones, ya que se les facultaba también para arrendar, dar a censo o vender).

- Se continuó con la medida de Exenciones tributarias y, además, se consignaron en ésta otras como la exención de impuestos de derechos reales y transmisión de bienes y del Timbre del Estado para las instituciones testamentarias, donativos y legados destinados a la construcción de casas baratas y la exención del impuesto de pagos al Estado para las subvenciones, préstamos y entrega de cantidades por parte del mismo Estado.

- Se mantenía también en la ley del 21 el abono de intereses de préstamos y subvención directa, si bien elevando a 1.000 .000 de pesetas la cantidad destinada a dichas atenciones, que en 1911 fue de 470.000 y en 1920 se amplió a 950.000 pesetas.

Como innovaciones de la Ley de 1921 respecto a la de 1911, cabe destacar las siguientes; 
- Se estableció un régimen de préstamos por parte del Estado, y, además, se consignaron en ésta otras como la exención de impuestos de derechos reales y transmisión de bienes y del Timbre del Estado para las instituciones testamentarias, donativos y legados destinados a la construcción de casas baratas y la exención del impuesto de pagos al Estado para las subvenciones, préstamos y entrega de cantidades por parte del mismo Estado.

- Se propuso una garantía de renta a los propietarios de casas edificadas para alquilarlas, que se establecía con la concesión de 3.000.000 de pesetas anuales para el abono por parte del Estado a los propietarios de casas (calificadas legalmente de baratas y dedicadas a alquiler) de la diferencia que existiese entre el producto de las mismas, deducidos los gastos que se calculasen para su conservación, y el tanto por ciento que se fijase por el Ministerio del Trabajo. Esta diferencia no podría exceder en ningún caso de la mitad del tanto por ciento de garantía concedida.

- el bono de intereses, de préstamos y Obligaciones y subvención directa. Se mantenía también en la ley del 21 el abono de intereses de préstamos y subvención directa, si bien elevando a 1.000.000 de pesetas la cantidad destinada a dichas atenciones, que en 1911 fue de 470.000 y en 1920 se amplió a 950.000 pesetas.

\subsubsection{El precio de la vivienda}

Como se ha señalado anteriormente, el precio del alquiler de la vivienda puede tomarse como un factor explicativo de la distribución desigual de la población en el espacio urbano madrileño, muy relacionado con el nivel de renta medido a través de la ocupación profesional (Bar \& Leukhina, 2010; Barral, Trigueros, \& Albarrán, 2013). 


\begin{tabular}{|c|c|c|c|c|c|}
\hline $\begin{array}{c}\text { ALQETLERES ANUALES } \\
\text { EN PESETAS }\end{array}$ & 1916 & 1915 & 1020 & 1925 & 1930 \\
\hline 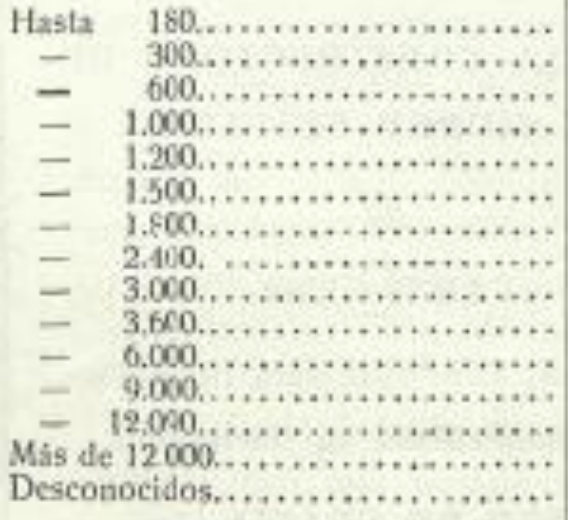 & $\begin{array}{r}44.511 \\
22.808 \\
23.186 \\
11.811 \\
6.900 \\
4.102 \\
2.521 \\
2.721 \\
1.796 \\
697 \\
1.390 \\
384 \\
167 \\
181 \\
20.776\end{array}$ & $\begin{array}{r}35.222 \\
33.590 \\
32.412 \\
1 \times .745 \\
11.358 \\
6.869 \\
4.507 \\
4.184 \\
2.730 \\
1.753 \\
1.839 \\
781 \\
409 \\
356 \\
4.048\end{array}$ & $\begin{array}{r}13.004 \\
25.357 \\
43150 \\
27.400 \\
18.964 \\
7.580 \\
5.423 \\
5.968 \\
3.671 \\
2.485 \\
2.778 \\
1.445 \\
682 \\
619 \\
2.781\end{array}$ & $\begin{array}{r}8.964 \\
17.139 \\
30.290 \\
31.311 \\
27.368 \\
14.214 \\
10.774 \\
7.652 \\
4.227 \\
3.339 \\
3.300 \\
1.786 \\
897 \\
763 \\
2254\end{array}$ & $\begin{array}{r}5.352 \\
8735 \\
45.362 \\
33.456 \\
32.691 \\
19.566 \\
17.672 \\
17.395 \\
7.417 \\
4.916 \\
4.990 \\
1.697 \\
1.083 \\
1.450 \\
1.017\end{array}$ \\
\hline TorALES,.............. & 146041 & 158.813 & 162.218 & 173.273 & 201.626 \\
\hline
\end{tabular}

Fuente: (León Peralta, 1926)

Atendiendo a las variaciones quinquenales de los precios de alquiler de la vivienda en Madrid, el porcentaje de cuartos más baratos (de 0 a 180 pesetas), se redujo desde 1910 a 1915 de un $36 \%$ a un $22 \%$, respectivamente y a tan solo un $8 \%$ en el año 1920. Hay dos posibles razones por las que suceda esto: bien porque esos cuartos hubieran desaparecido o porque hubieran elevado su precio. Si atendemos al segundo grupo de alquileres más bajos, vemos que aumenta si tomamos el conjunto de los 3 años . Teniendo en cuenta que a partir del tercer grupo de alquiler (de 601 a 1200) todos se incrementan, cabe pensar que los aumentos de cada grupo de alquileres van engrosando a medida que disminuyen los más bajos, por lo que la hipótesis de una subida en los precios del alquiler de los cuartos se puede ver reflejada en este hecho. Es decir, que los cuartos que desaparecieron del grupo primero, tienen que aparecer en el siguiente que es más caro, si es que hubo elevación de precios. Y si hubo elevación exagerada de alquileres en este grupo en el período de 1915-1920, el porcentaje de este período ha de disminuir engrosando, en cambio, el grupo siguiente de alquileres más elevados, como en efecto ocurre, pues su porcentaje se incrementa en 7,8 puntos (León Peralta, 1926, p. 27).

Un elemento adicional a tener en consideración es la proporción de los ingresos de una familia que representaba el alquiler. Autores como Juderías, en su libro Los hombres 
inferiores (Juderías, 1909, p. 61), realiza una comparación de los alquileres pagados en Madrid, bajo la idea de que el alquiler representa la quinta parte de los ingresos de una familia, lo que era cierto sólo para clases bajas y medias pero no para la clase más rica.

En líneas generales, entre las causas de lo que los autores de la época denominaron "crisis de la vivienda" responden en buena medida al encarecimiento de los materiales y la mano de obra y, sobre todo, del precio del suelo. También por la situación de escasez de capital disponible, así como por las políticas de construcción y alquileres que no favorecían la disponibilidad de los constructores a embaucarse en nuevas construcciones $\mathrm{y}$, especialmente, aquellas que menos beneficios les reportarían, que no son otras sino las vinculadas a las "casas para obreros", de las que hemos hablado anteriormente. Otras causas señaladas por diversos autores fueron (...) la dificultad y carestía de los transportes, el régimen proteccionista arancelario establecido en nuestro país, la duración de la jornada, la unificación de aptitudes y salarios, la falta de rendimiento en la mano de obra (...)(León Peralta, 1926, p. 28).

\subsubsection{Los precios del alquiler a la altura de 1915}

A la altura de 1915, los alquileres más elevados se pagaban en los barrios de Puerta del Sol y el Carmen (distrito Centro), Floridablanca, Retiro, Príncipe, Cañizares (distrito Congreso), Biblioteca, Conde de Aranda, Monasterio y Fernando el Santo (distrito de Buenavista). Se trata de barrios que mantienen una correspondencia con los habitados por las denominadas nuevas clases medias (Major Group 01, 2 y 3 de la clasificación HISCO), ubicados, en mayor medida, en la zona este del Ensanche Madrileño.

En el lado opuesto, encontramos los Barrios de Gasómetro, Marqués de Comillas, Peñuelas, Huerta del Bajo, Miguel Servet y Cabestreros (distrito de Inclusa); San Francisco, Imperial, Arganzuela, San Isidro y Calatrava (distrito de Latina); Argumosa, Delicias, Primavera y Doctor Fourquet (distrito de Hospital); Casa de Campo (distrito de Palacio). A excepción de la Casa de Campo, el resto de barrios corresponden a las zonas del Sur del Ensanche y zonas del Extrarradio de la ciudad y las zonas más pobres del casco. Todas ellas caracterizadas por ser habitadas por personas que desempeñaban ocupaciones laborales de escasa cualificación profesional. 
Mapa 8-6. Precio medio del alquiler por Barrios. 1915

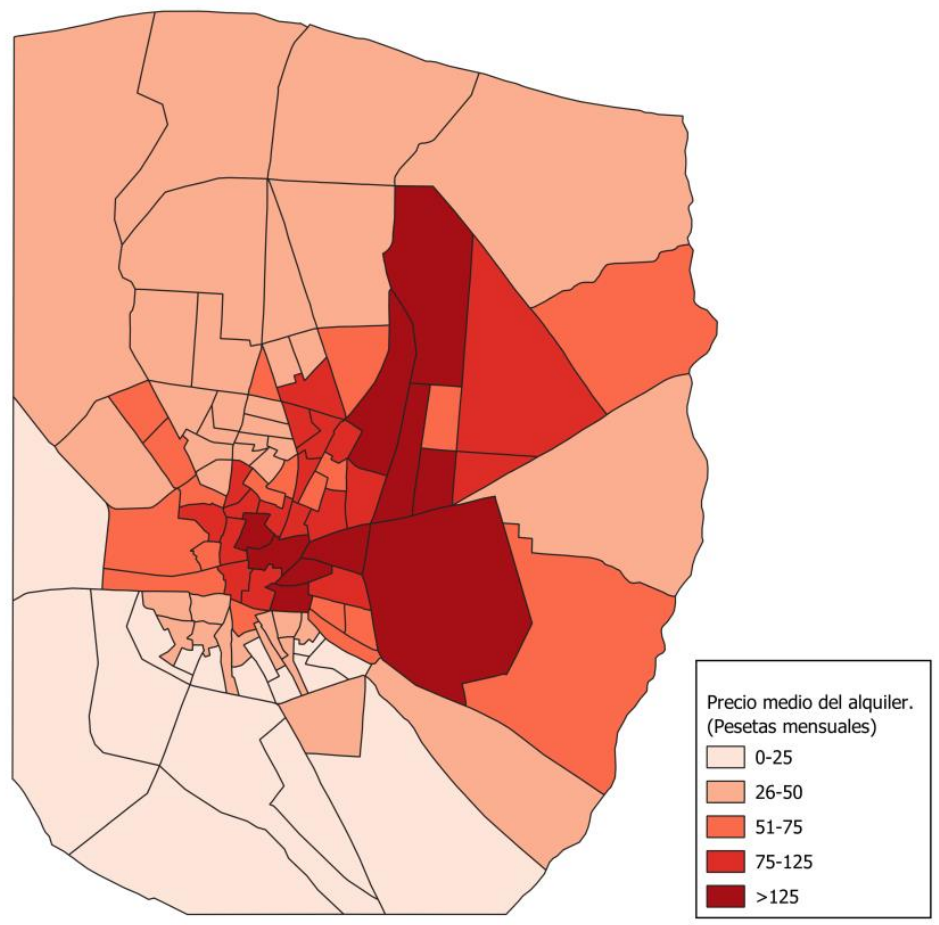


Proporción de los precios del alquiler en la ciudad de Madrid en el año 1915. Obtenido de los resúmenes del padrón de 1915 a nivel de barrio y distrito.

Gráfico 8-3. Proporción de los precios del alquiler en la ciudad de Madrid en el año 1915. Distritos de Madrid

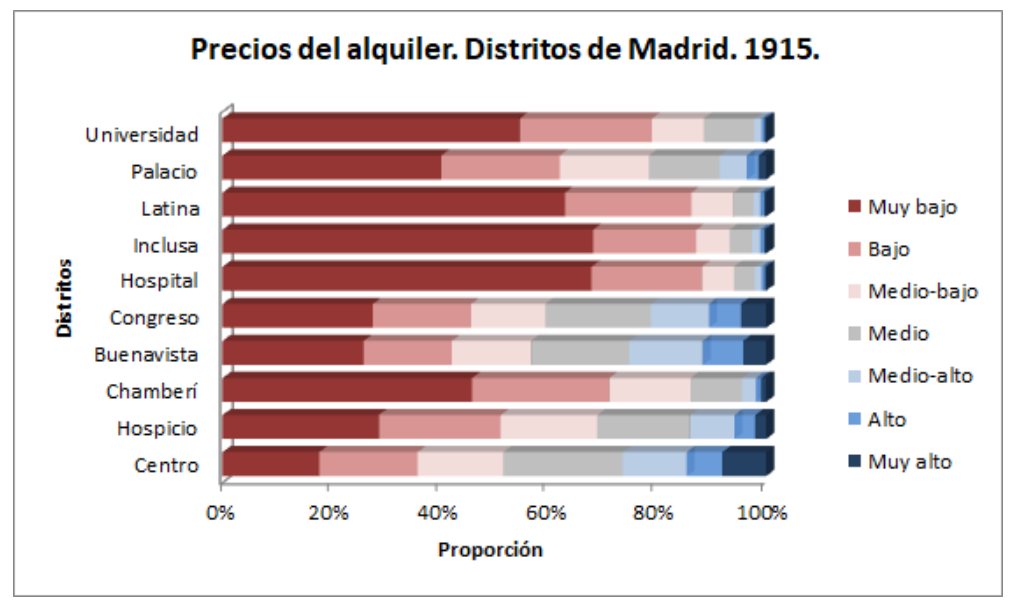

Fuente: Elaboración propia. Datos obtenidos de (Ayuntamiento de Madrid, 1917) 


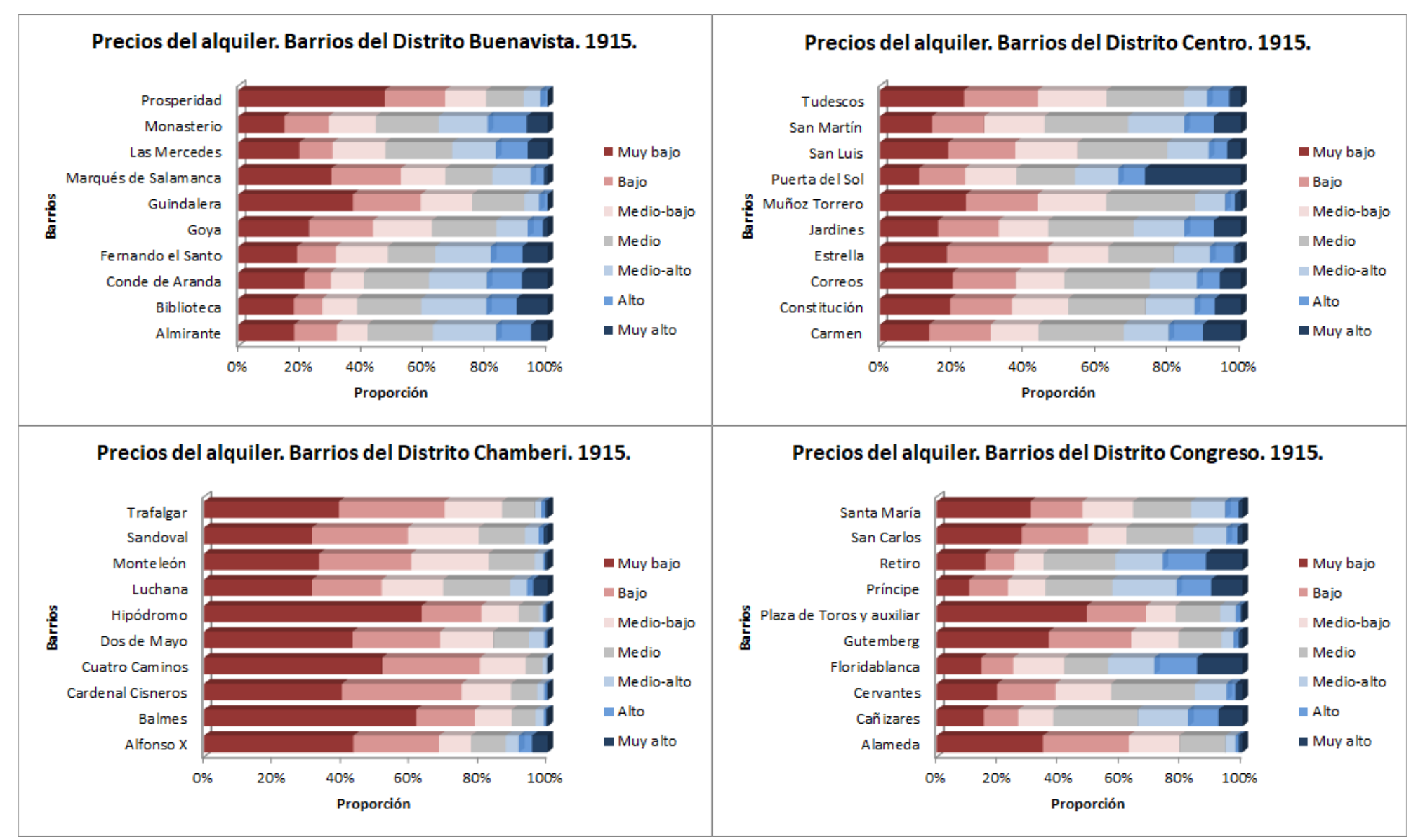



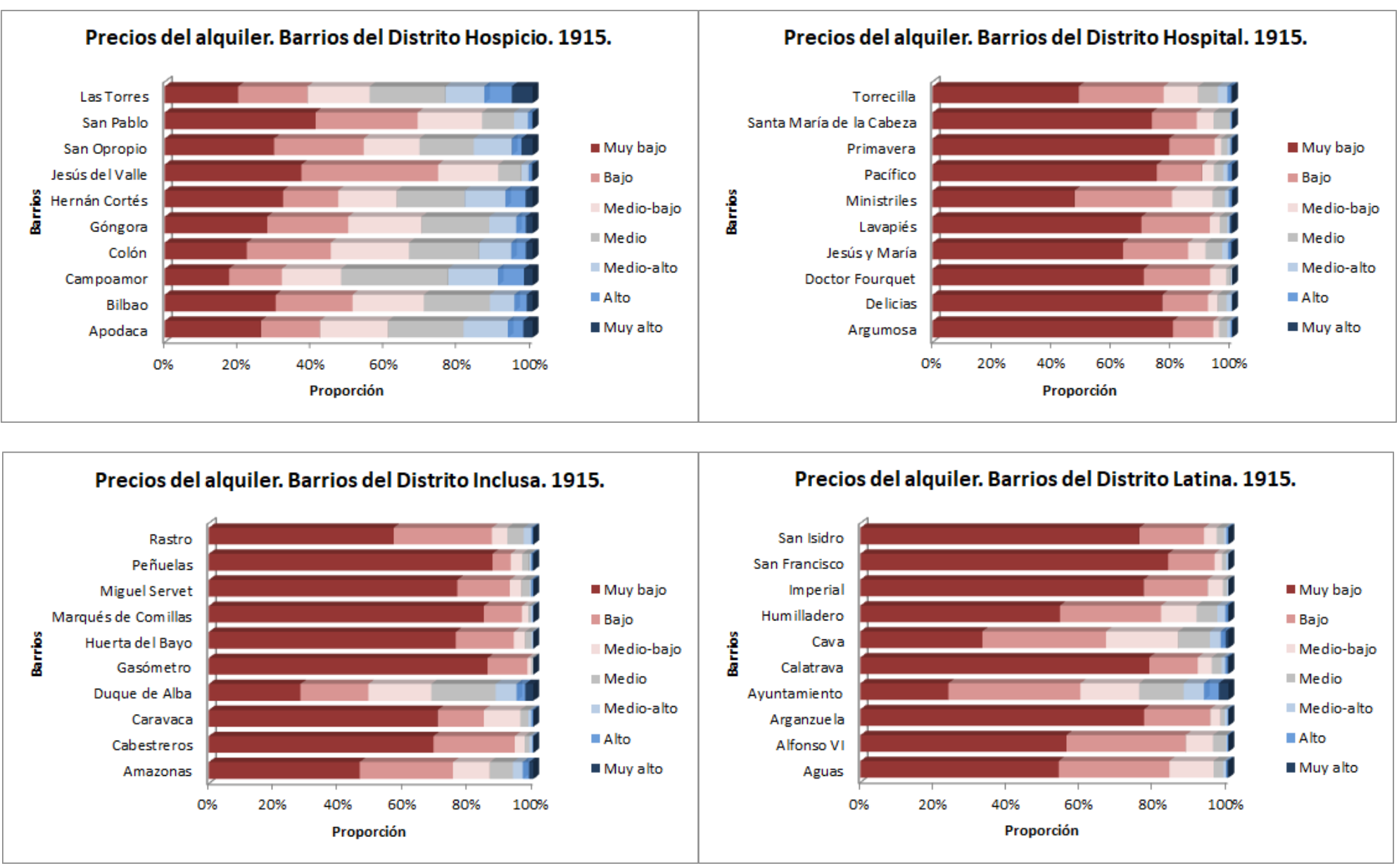


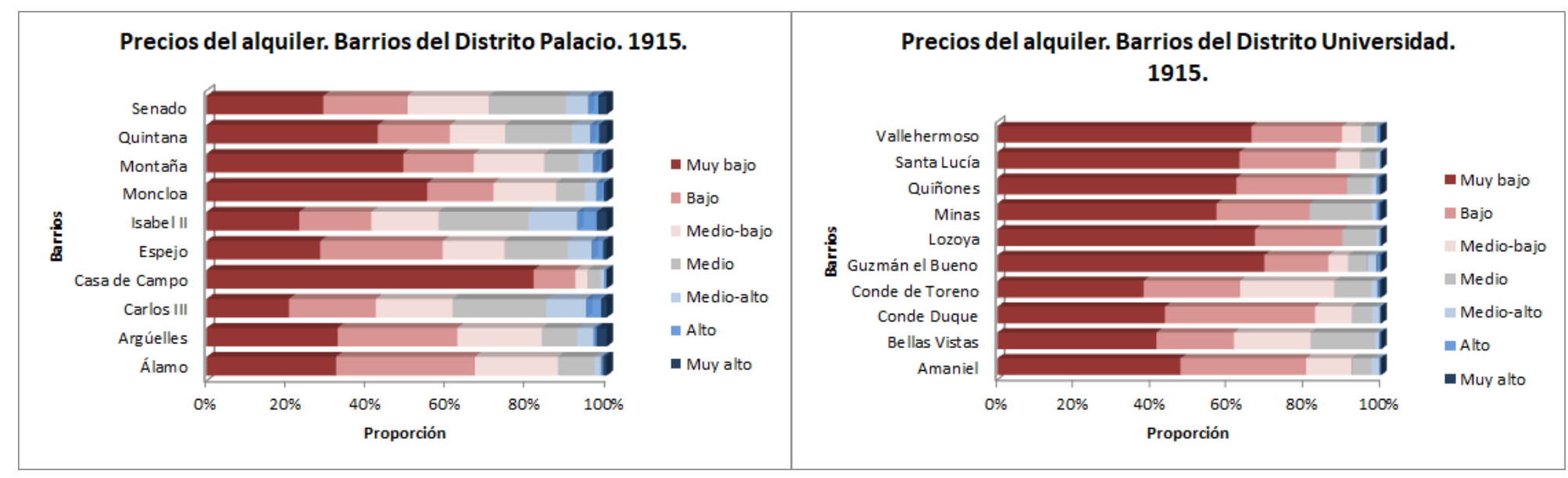




\subsubsection{El problema de la habitación: el hacinamiento.}

A partir del proceso de urbanización, comenzado a mediados del siglo XIX, en la ciudad de Madrid se llevarán a cabo proyectos de reforma del Casco Antiguo (como la apertura de la Gran Vía o la reforma de la Puerta del Sol) que conllevará una disminución de los edificios residenciales en pro de la ubicación de comercios, oficinas o edificios de carácter institucional y administrativo (Otero Carvajal \& Rodríguez Martín, 2019).

En el caso de Madrid, el crecimiento poblacional no fue homogéneo espacialmente. La mayoría de los distritos que formaban parte de la periferia de Madrid, fueron los que experimentaron un mayor crecimiento poblacional. Esto tiene su explicación en que los inmigrantes, procedentes en su mayoría de otros lugares de España, terminaban residiendo en los barrios de la periferia, debido al menor coste de las viviendas.

En el lado opuesto, se encontraban otras barriadas menos céntricas, ocupadas en su mayor parte por las clases aristocráticas y acomodadas que por su posición económica no sentían la presión de la escasez y carestía de las viviendas como las demás clases sociales (León Peralta 1926:22)

Pese a que el crecimiento de la población fue de la mano del crecimiento de la ciudad, tal y como señalan algunos autores (Gómez Mendoza, 1986), entre 1900 y 1935 no se experimentaron diferencias significativas en la ratio de habitantes por vivienda, encontrándose entre 4,6 y 4,2 respectivamente, así como señala un crecimiento parejo entre habitantes y viviendas por inmueble. Sin embargo, otros autores han señalado la presencia de determinados puntos en la ciudad en la que se dibuja un panorama caracterizado por el hacinamiento (Hauser, 1902a).

Atendiendo al número de habitaciones existentes, con los datos de los que disponemos, vemos que entre los años 1905 y 1920, en el Distrito Centro, se produjo una reducción del número de viviendas, de 13.089 a 12.453 y de sus habitantes. Por el contrario, en otros distritos "más pobres", como Latina, aumentaron significativamente el número de personas (en más de 20.000 personas) pero, respecto a las viviendas, lo hizo en una proporción ínfima (de 15.105 a 15.865) (Rueda Laffond, 1994, p. 90) . 
Gráfico 8-4. Número de habitantes por distritos. Años 1905, 1915 y 1920

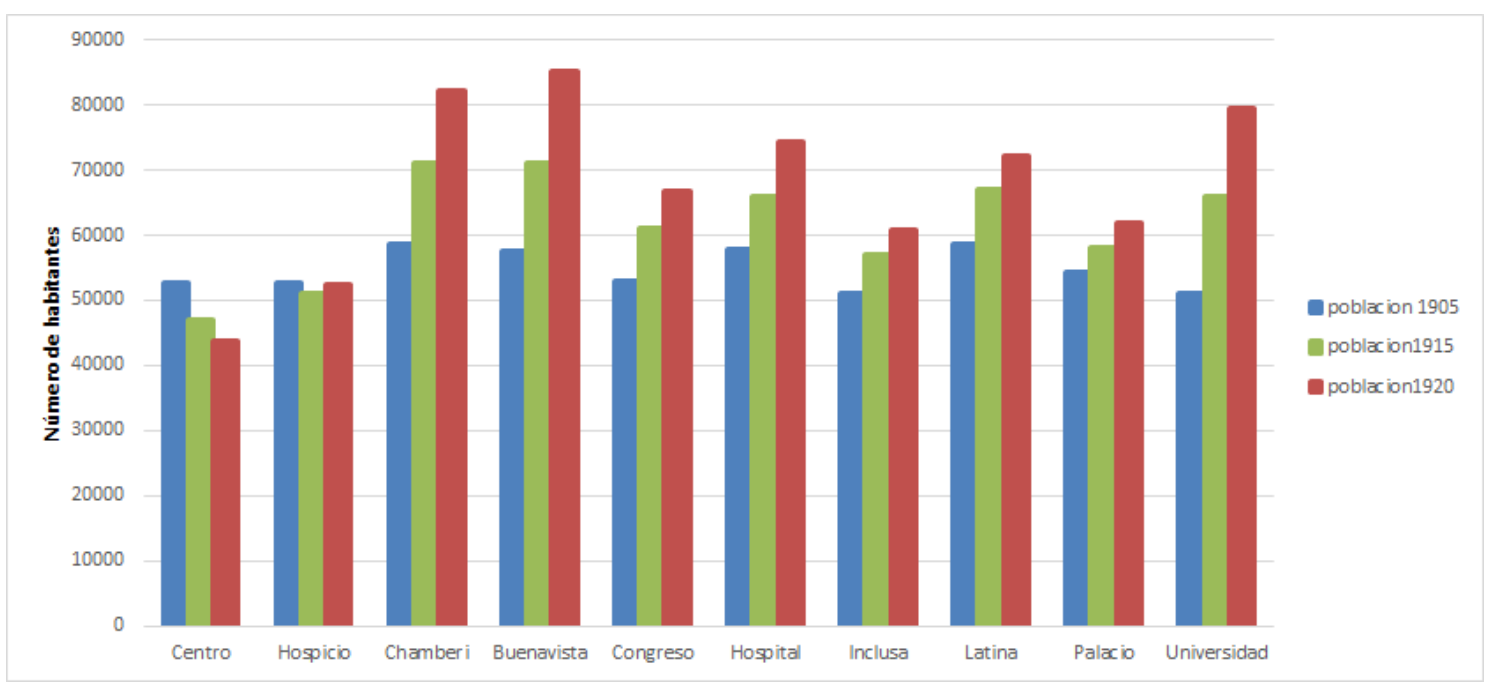

Fuente: datos obtenidos de (León Peralta, 1926)

Gráfico 8-5. Número de viviendas por distritos. Años 1915 y 1920

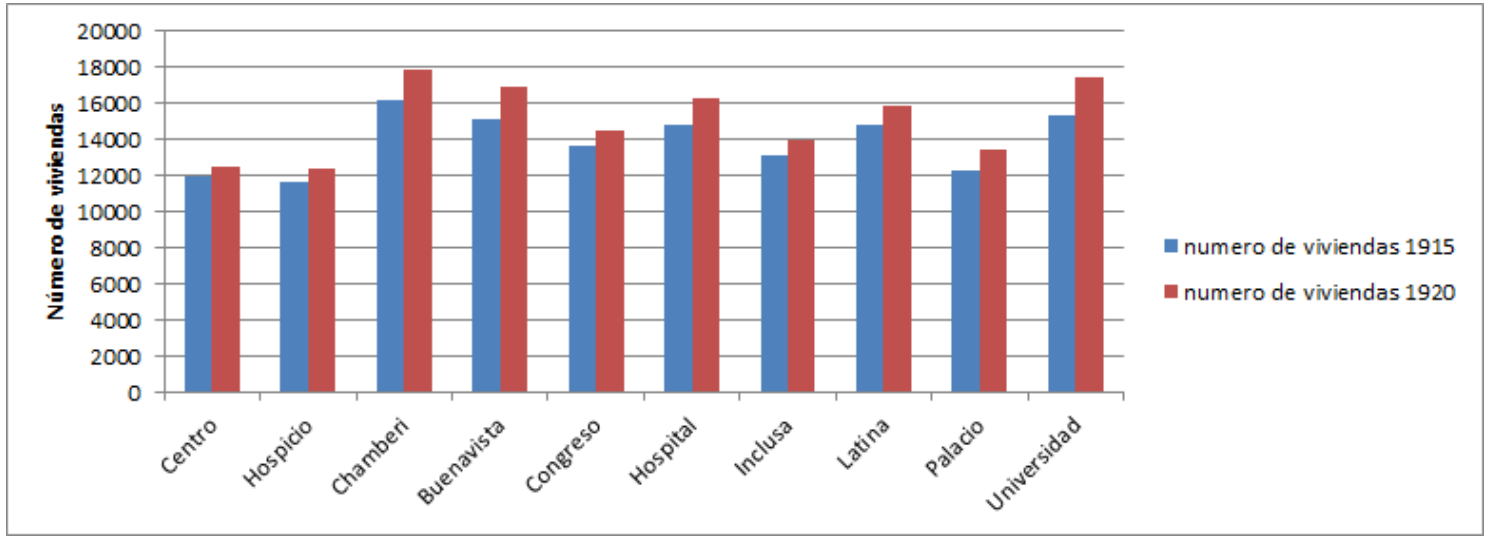

Fuente: datos obtenidos de (León Peralta, 1926)

Gráfico 8-6. Número de habitantes por vivienda, según distritos. Años 1915 y 1920

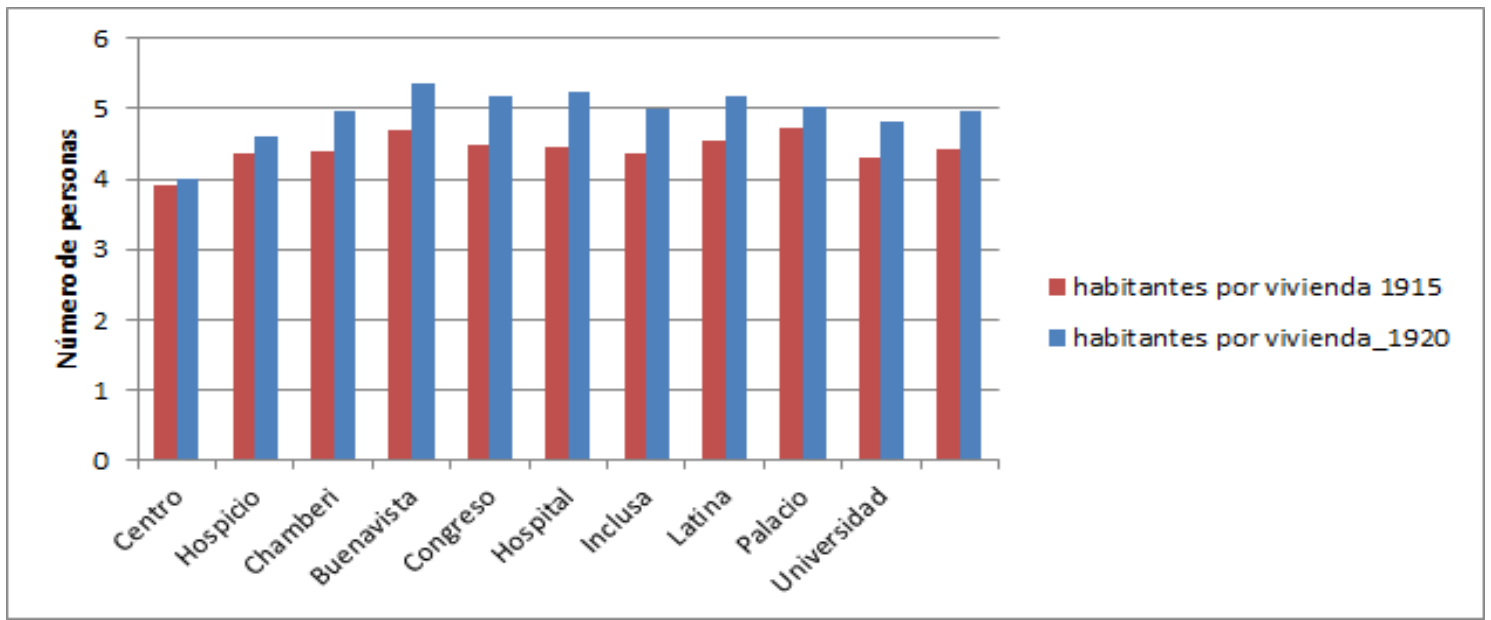

Fuente: elaboración propia. Datos obtenidos de (León Peralta, 1926) 


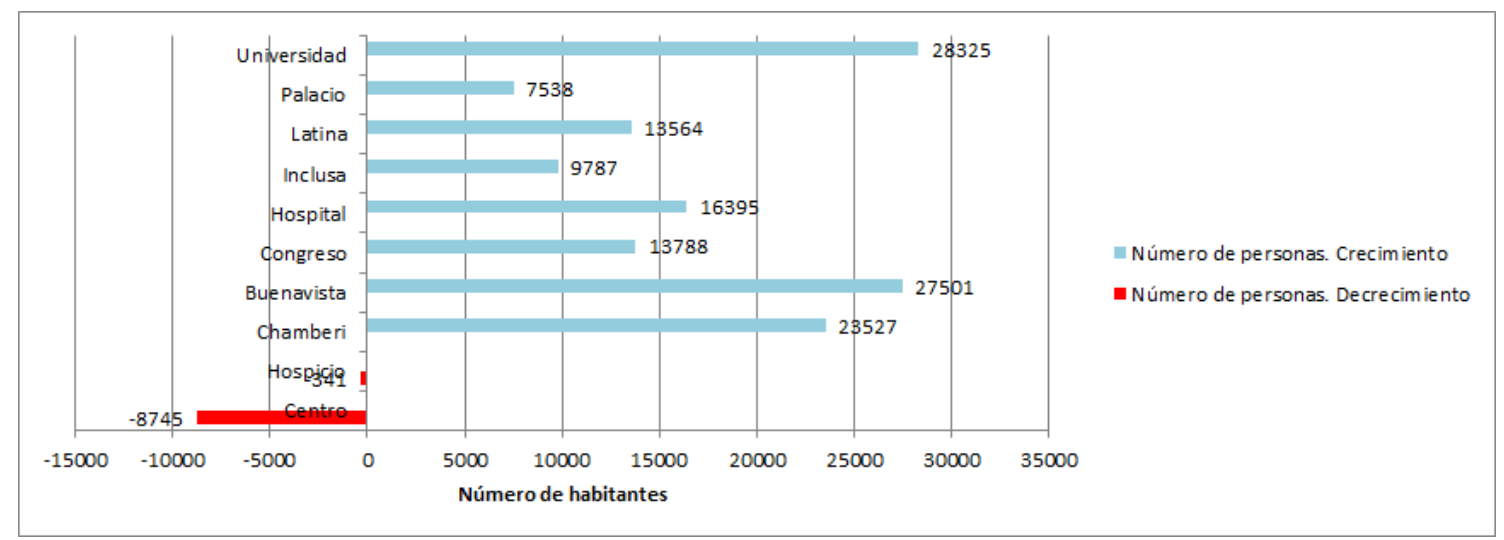

Fuente: elaboración propia.

Tres son los distritos con mayor número de habitantes por vivienda entre 1915 y 1920: Hospital, Congreso y Latina, tal y como puede verse en el gráfico 8-6. Se trata de 3 distritos bastante parecidos en lo que respecta a la posición socioeconómica de sus habitantes, siendo, principalmente, jornaleros y otras ocupaciones laborales de escasa cualificación. Cabe destacar que se trata de tres distritos que tienen entre sus edificios casas de corredor, corralas, de modo que (...) sólo entre los tres cuentan con 102 casas de más de 200 habitantes y con 26 de más de 300, es decir, casi el doble de las que en iguales condiciones suman los siete distritos restantes (León Peralta 1926:24). Además, las condiciones de luz y aire eran deficientes. Si bien, es necesario señalar que el Distrito Congreso, el que tiene mayor número de habitantes por vivienda, es el que presenta más diferencias de entre los tres, ya que la composición social de sus barrios es desigual. La explicación del volumen de individuos por vivienda radica en dos explicaciones principalmente: el gran número de hoteles y pensiones familiares y también a contar entre sus barrios algunos como los de Floridablanca y Retiro, que son barrios de casas espaciosas en las que se alberga a la servidumbre. Pero también en la aglomeración de habitantes por vivienda influye en este distrito la existencia de barrios como los de Gutenberg, donde la presencia de tejares era palpable (como los tejares de Molina y las casas del camino de Vicálvaro) y Plaza de Toros, con las casas de los tejares de Sixto y de la Elipa. Los restantes distritos acusan también una gran proporción de habitantes por vivienda, y ello comprueba que en el quinquenio de 1915 a 1920, época en que el problema de la vivienda empezó a adquirir graves proporciones, el hacinamiento, la aglomeración de habitantes por vivienda se manifestaba en todos los 
distritos, siendo para el aumento de habitantes y viviendas la proporción que señala las cifras indicadas.

Gráfico 8-8. Evolución del número de habitantes y del número de viviendas por distritos. Años 1905, 1915 y 1920

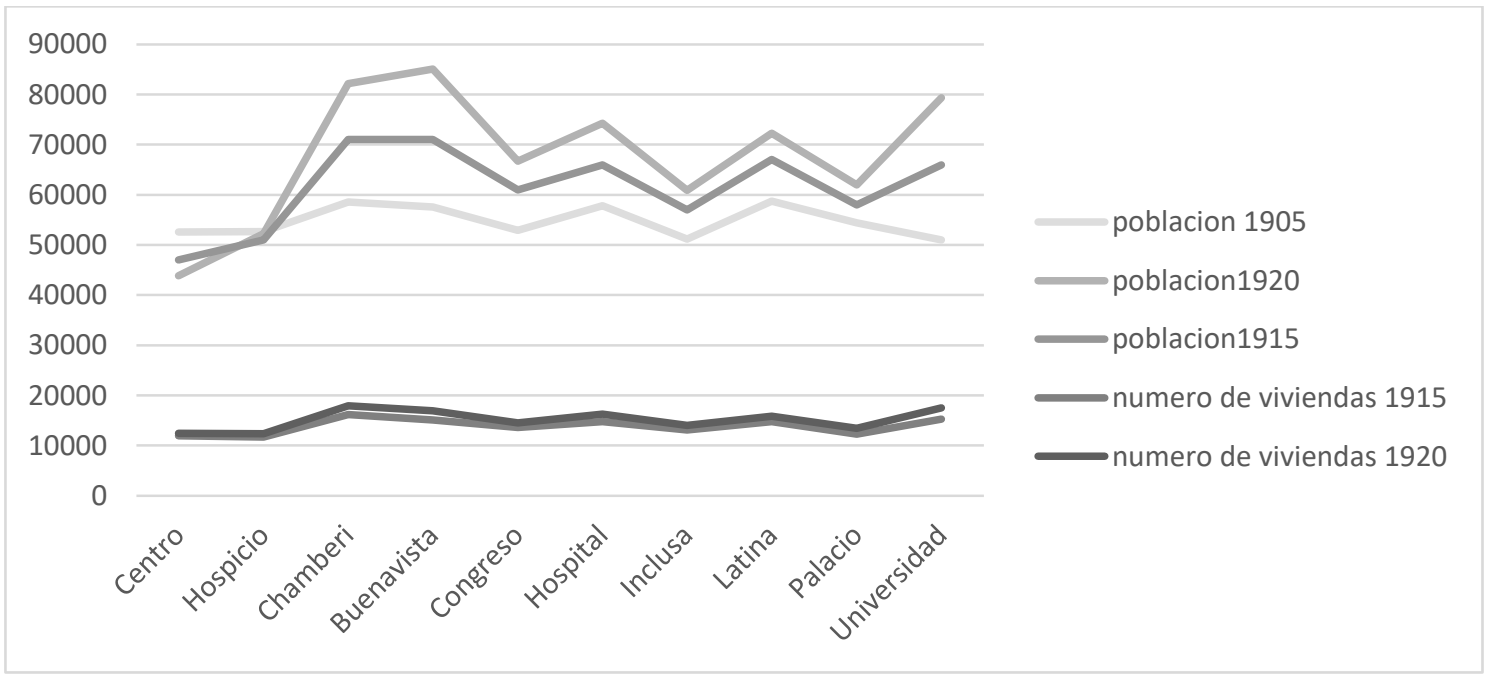

Fuente: Elaboración propia. datos obtenidos de (León Peralta, 1926, p. 23)

Mapa 8-7. Distribución del número de personas por edificio. Barrios de Madrid, año 1915.

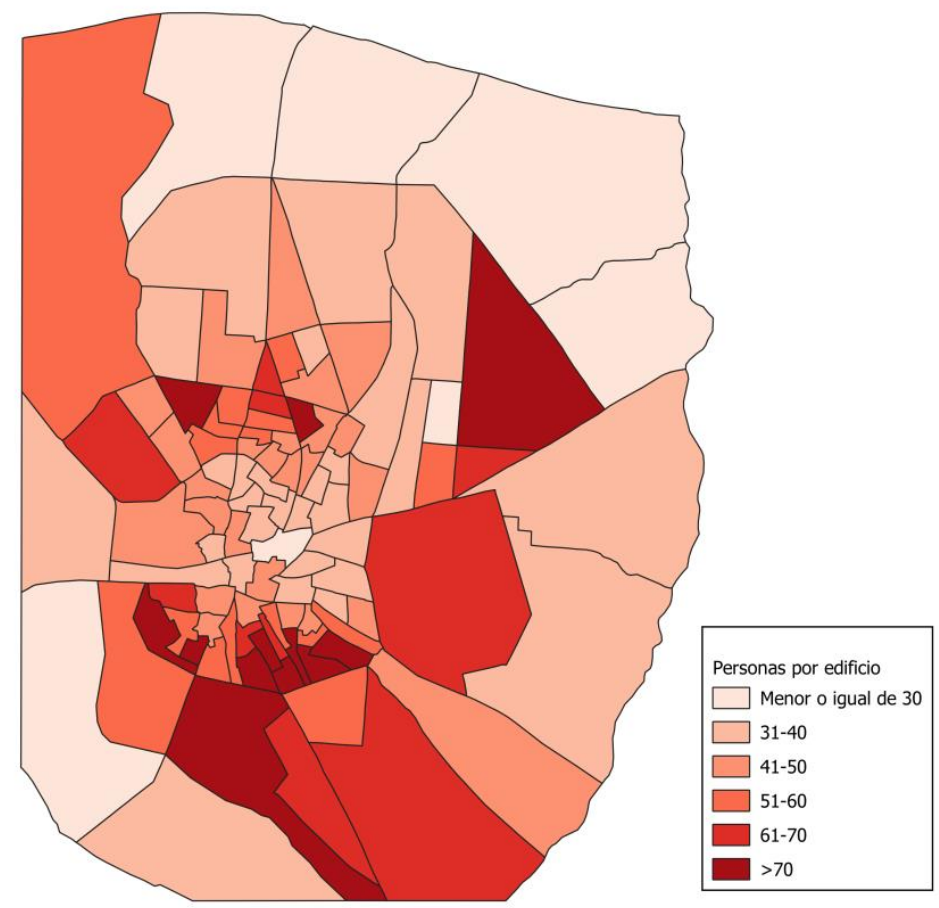


Otro de los elementos a tener en cuenta para analizar las posibles limitaciones espaciales existentes, en cualquier contexto caracterizado por un crecimiento poblacional como el Madrid de la época, es si el aumento de la población estuvo acompañado de un crecimiento de la superficie de la capital. Como ya se ha señalado en otro capítulo, la expansión de la ciudad de Madrid, que tuvo su elemento fundamental en el Plan Castro, se basó en el principio de necesidad de expandir la ciudad por temas tanto de funcionalidad como de saneamiento. Para descubrir lo anterior, puede parecer, a priori, que basta con establecer una relación superficie-población y en relación a esto valorar si realmente la extensión territorial de la ciudad fue o no suficiente como para albergar al contingente poblacional de la ciudad. Sin embargo, también es necesario preguntarse acerca de cuánta superficie estaba ocupada por elementos no habitables, Es decir, vías públicas, parques, jardines... Según León Peralta, más de la mitad del territorio del término municipal de Madrid se hallaba ocupado por estos elementos, concretamente 36.395.448 metros cuadrados, ocupando 30.361 .034 metros cuadrados las fincas construidas, solares y terrenos destinados al cultivo.

Así resulta que, en realidad, en 1915 correspondía a cada habitante 49,20 metros cuadrados de superficie construida, y en 1920 sólo 40,42, siendo, por tanto, el descenso de 8,48 metros cuadrados por habitante en el tiempo indicado. Si bien la relación de la superficie del término municipal con el número de habitantes no es un indicador que de manera única e independiente pueda ayudarnos a determinar si existía aglomeración de viviendas, sí que puede usarse como proxi ya que existe una relación entre el hacinamiento de viviendas y el número de habitantes por metro cuadrado. Por ello, conocer la densidad de población por barrios será una tarea útil, que nos permita conocer posibles diferencias socio espaciales relacionadas con la salud de los habitantes.

Atendiendo a la densidad de población en la relación correspondiente entre el tamaño del barrio y la población en dicha unidad, han sido representados a nivel de barrio, con el objetivo de conocer su distribución en la ciudad. Se observa una mayor densidad de población en los barrios del casco antiguo de la ciudad, así como de algunas zonas del ensanche sur (Mapa 8-8). 


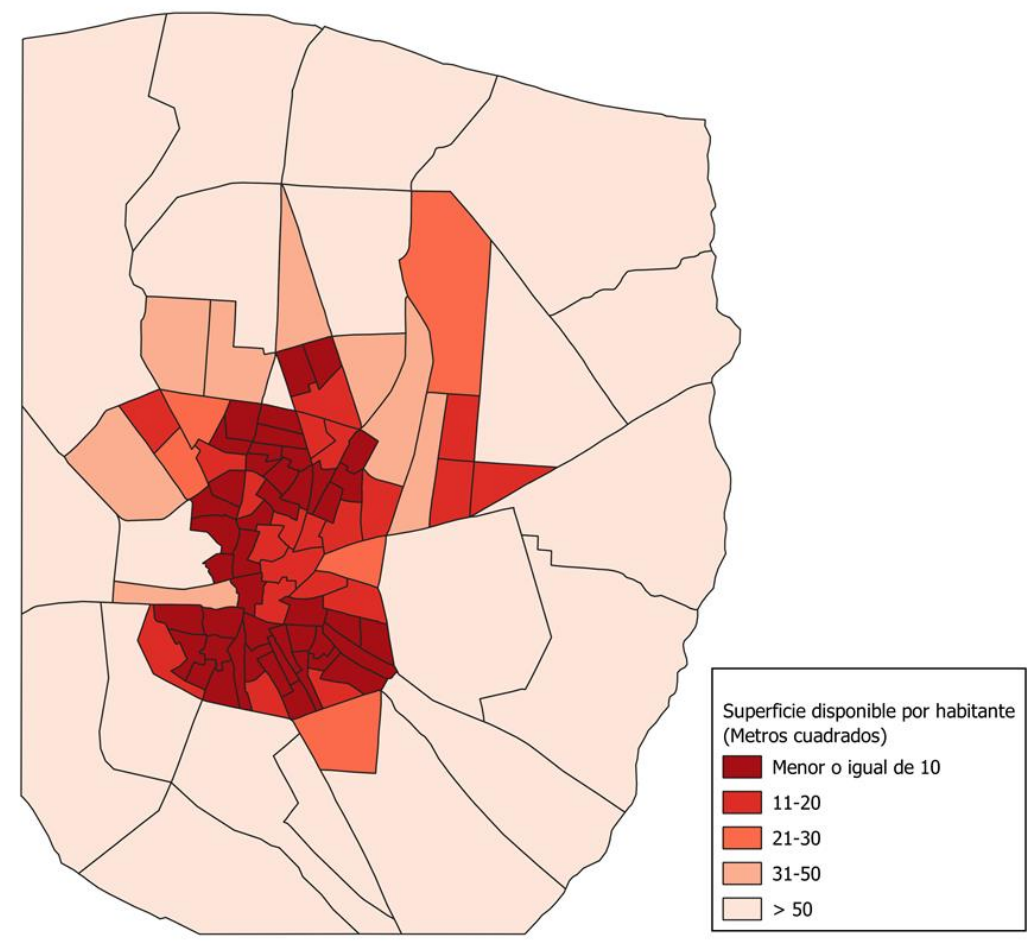

\subsubsection{La salubridad de la vivienda}

El último punto a tratar en relación a la vivienda es el referido a la salubridad de la misma, en relación a la presencia o ausencia de higiene en la misma, si bien se trata de un aspecto íntimamente relacionado con las características de carestía y escasez.

Pese a las medidas tomadas por el Ayuntamiento de Madrid respecto a la cuestión higiénica de las viviendas, el problema de la insalubridad de las viviendas no se solucionó, principalmente porque no sólo existían viviendas aisladas caracterizadas por su insalubridad y falta de acondicionamiento, sino que se trataba también de barriadas enteras. En este sentido, hubiera sido necesario derruir dichos barrios de manera completa y otorgar nuevas viviendas a los individuos que habitaban en las derruidas. Citando literalmente al doctor César Chicote, las causas de la insalubridad de las viviendas radicaba en (...) la disposición arquitectural, defectuosa por estrechez de calles y excesiva elevación de las casas; su mala orientación y situación; el estar edificadas sobre terrenos saturados de humedad, sin sótanos que las defiendan de ella, o por estar construidas con materiales que la retienen; el débil espesor de los muros que no pueden proteger contra las variaciones de la temperatura; la escasa altura de 
los techos y reducidas dimensiones de los cuartos, que así arrojan una cubicación insuficiente; la mala disposición interior de las habitaciones que, con lamentable frecuencia, carecen de luz solar y conveniente aireación, y, finalmente, la falta de aislamiento con las atarjeas que provoca la impureza del aire con gases malolientes y tóxicos. A estas esenciales causas de insalubridad-dice-, deben agregarse las que suponen la suciedad y abandono del inquilino y el hacinamiento, aun cuando en realidad se trata de defectuosidades que, hasta cierto punto, serían ajenas a las condiciones de las viviendas si éstas se ofreciesen por la propiedad en aquéllas que reclama un local destinado a que lo habiten personas"(Chicote \& Eza, 1915).

Al problema de la falta de higiene de las viviendas se unía el del hacinamiento. En este sentido, ya los médicos de la época pusieron su foco de atención en las consecuencias inmediatas de la situación de hacinamiento de algunas casas, como la transmisión de enfermedades infecciosas, transmitidas por el aire especialmente, como la tuberculosis $\mathrm{u}$ otras como el tifus.

No es posible entender la situación de hacinamiento en que se encontraban muchos de los individuos de Madrid sin hacer alusión a la arquitectura y disposición de las casas. Especial mención merecen las casas de corredor o de vecindad, ya que llegaban a albergar entre 200 y 300 personas en un mismo edificio, con servicios sanitarios deficitarios y compartidos por los vecinos de la vivienda en cuestión. Atendiendo a los datos proporcionados por León Peralta (1926), recogidos del Instituto Geográfico y Estadístico para la ciudad de Madrid, los distritos con un mayor número de casas de vecindad en el municipio de Madrid eran Inclusa, Latina y Hospital y los que menos eran Palacio, Centro y Hospicio.

Según datos ofrecidos por León Peralta, el hacinamiento era tal en algunas localizaciones de la ciudad que en tan solo en 231 edificios habitaban una media de 66.500 personas (León Peralta, 1926, p. 37) 


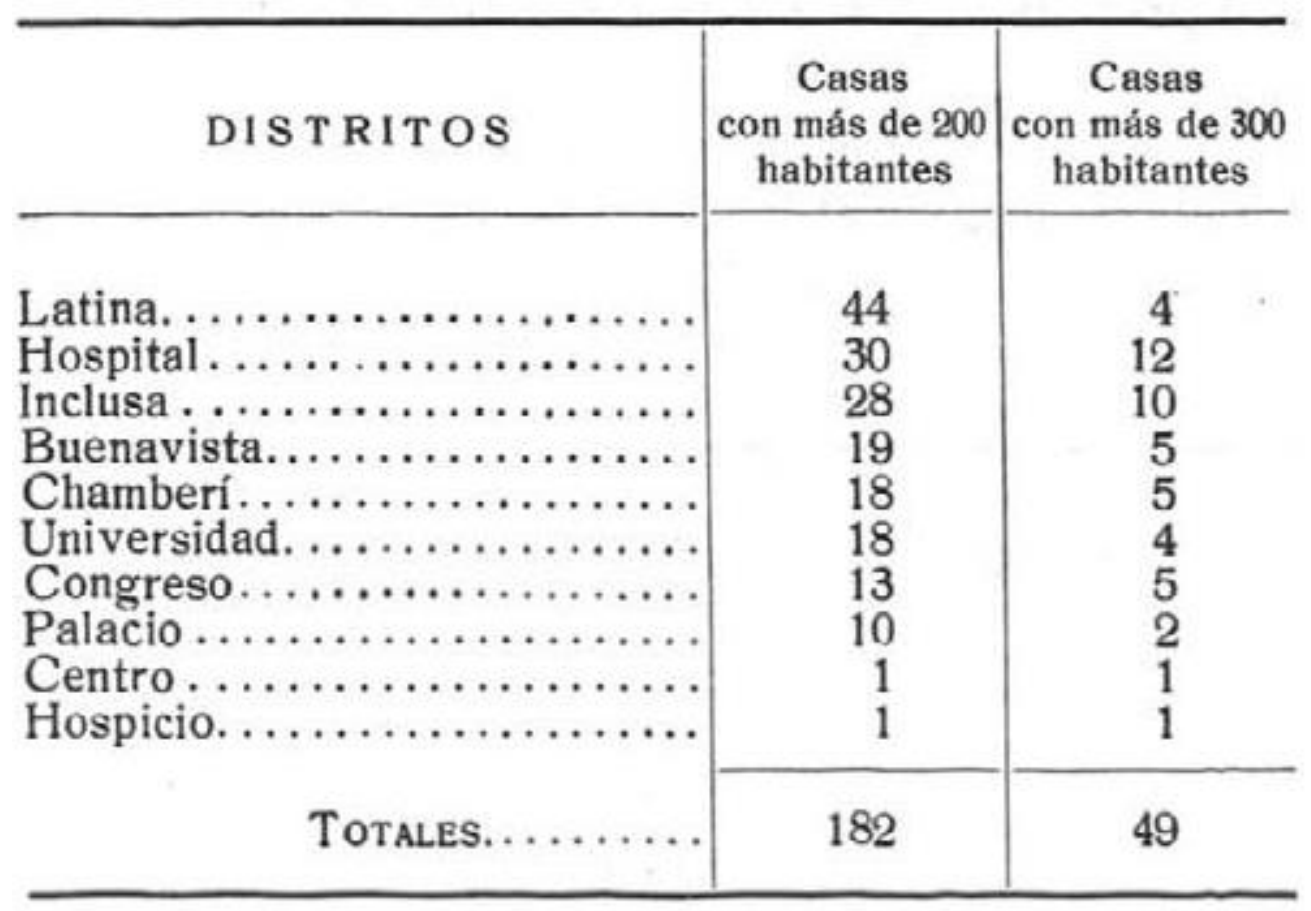

Fuente: (León Peralta, 1926).

Si bien no sólo las casas de vecindad eran las viviendas insalubres en la ciudad de Madrid, en éstas (...) la insalubridad se manifiesta en todo. En la falta de agua, que a ello conduce el disponer sólo de una fuente para toda la casa. El dedicar un solo retrete para todo un piso, corriendo alternativamente su limpieza a cargo de los vecinos. En la falta de sol y de aire, que nunca puede llegar a las habitaciones a través de los inmundos patios. En la falta de limpieza, originada en muchos casos más que por incuria del vecino, por no permitir la escasez de luz darse cuenta de la suciedad que se acumula en escaleras y patios y en las viviendas mismas. En la disposición e insuficiencia de las habitaciones, que hace difícil la renovación del aire y da lugar a hedores insoportables; y, en una palabra: en todo.(León Peralta, 1926, p. 38).

Otras de las viviendas insalubres de la ciudad eran aquellas que por su disposición dentro del edificio carecían de ventilación y luz, tales como los sótanos y buhardillas destinadas a viviendas.

Cabría esperar que en aquellas zonas de la ciudad con peores índices de salubridad de sus viviendas, la mortalidad será más elevada que en aquellas zonas con viviendas higiénicas, temática que será tratada en el capítulo número diez. 
Se ha representado la densidad de población en la relación correspondiente entre el número de domicilios (denominadas "habitaciones" o "cuartos") por barrio y la población a nivel de barrio, para conocer la distribución en la ciudad teniendo en cuenta el número de personas residentes por domicilio (Mapa 8-9).

Mapa 8-9. Distribución del número de personas por vivienda. Barrios de Madrid, año 1915

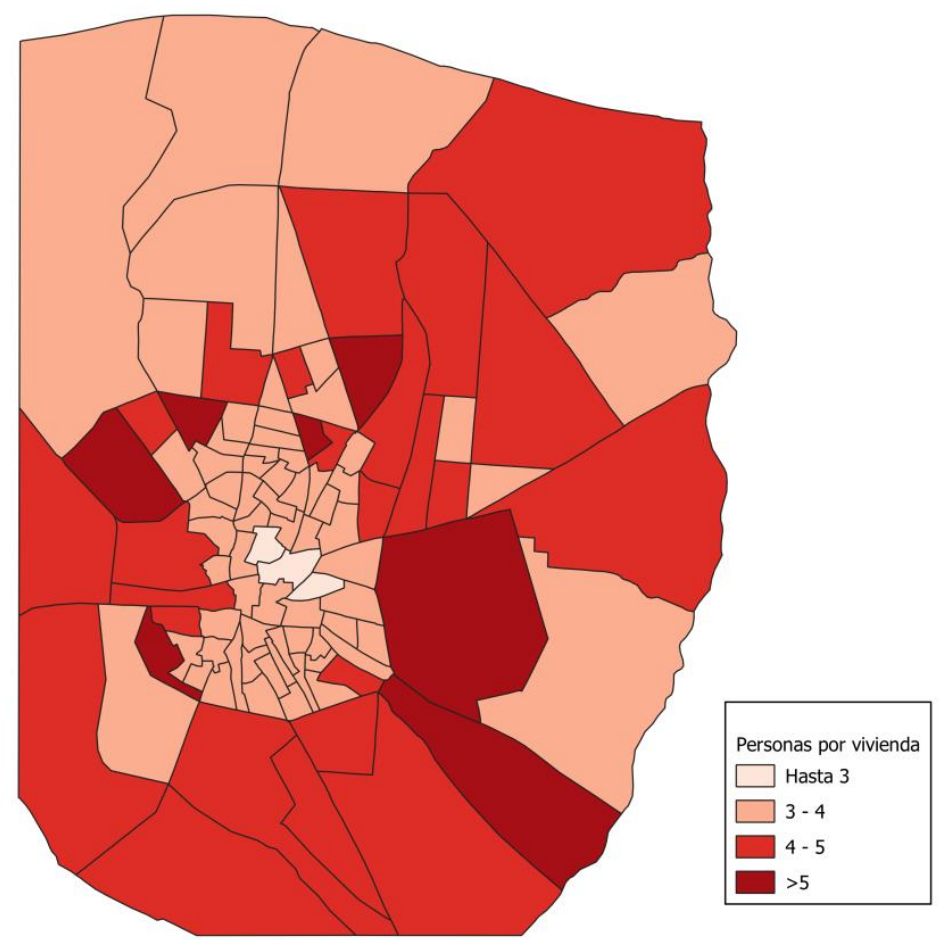

Como complemento al anterior, es interesante conocer el número de cuartos que hay por edificio, de media, a nivel de barrio. Para ello, se ha tomado la relación correspondiente entre el número de domicilios (denominadas "habitaciones" o "cuartos") por barrio y el total de edificios por barrios. 
Mapa 8-10. Distribución del número de cuartos por edificio. Barrios de Madrid, año 1915.

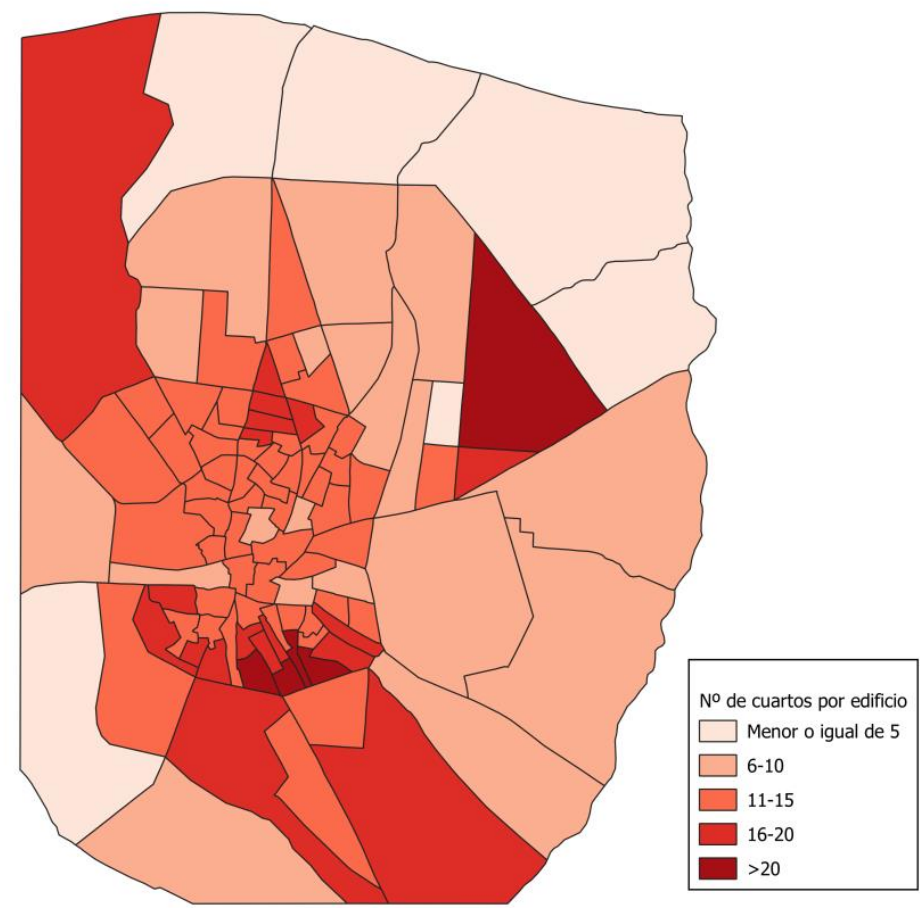




\section{La Fiebre tifoidea}

La fiebre tifoidea fue considerada una de las enfermedades infectocontagiosas de mayor relevancia (junto al cólera) cuya transmisión se produce a través del agua y alimentos. En este sentido, en el presente capítulo se hará alusión a la misma teniendo en cuenta sus principales características clínicas, su descripción y epidemiología. Se realizará un pequeño bosquejo histórico de la enfermedad, haciendo alusión explícita a algunos estudios históricos sobre ésta. Posteriormente, atenderemos a la relación existente entre la calidad de las aguas y la transmisión de la fiebre tifoidea, tomando como marco el denominado Teorema de Hazen y su aplicación histórica ante las epidemias tíficas en el contexto español y mundial. Por último, se hará alusión a la epidemia de fiebre tifoidea acaecida en Madrid en 1920; a su posible origen y a las medidas profilácticas llevadas a cabo, todo ello vinculado con el estado sanitario del Madrid de 1920.

\subsection{La Fiebre tifoidea como enfermedad endémica.}

\subsubsection{Aspectos clínicos de la fiebre tifoidea}

"No es el peligro de las aguas negras su mal olor, aunque por ser lo que molesta es lo único que produce la pública censura; el peligro está inmerso en el inmenso número de bacterias, órganos de vida o muerte, aliados o enemigos del hombre que las pueblan. El número de ellas es muy variable de unas a otras ciudades, de unas a otras épocas y aun de unas a otras horas". "Entre este inmenso número de bacterias existen como las más temibles, por encerrar inmediato peligro para la salud humana y ser causa de enfermedades las del cólera, el tifus, la enteritis, etc” (Herrán Rucabado \& Escario Núñez del Pino, 1926, p. 39).

La causa de la fiebre tifoidea es el bacilo de Eberth, nombre adoptado por el apellido del Patólogo Alemán Karl Joseph, descubridor del mismo. Más adelante, y tal y como se conoce hoy día de manera general, será denominado 'Salmonella' 'typhi'. Respecto a la fecha de su descubrimiento, si bien la mayoría de la literatura muestra que fue descubierto en 1880, otros autores lo sitúan en1872 (Moreno Blasco, 1933, p. 7). Cabe destacar las figuras de Koch y Gaffki, como investigadores que continuaron con los estudios del bacilo, así como la figura de Almroth Edward Wright, que en 1897 desarrolló la primera vacuna. 
La vida del bacilo tífico fuera del organismo humano, se caracteriza por su resistencia al frío y al calor seco-moderado, si bien, la acción solar directa lo destruye, así como también lo hacen los mecanismos antisépticos ordinarios (Moreno Blasco, 1933, p. 7).

\subsubsection{Pequeño bosquejo histórico de la fiebre tifoidea}

Varios historiadores señalan la prevalencia de la fiebre tifoidea desde la época de Hipócrates, señalando que la epidemia que dio muerte a un tercio de la población de Atenas puede atribuirse a la fiebre tifoidea, atendiendo a la detección de secuencias de ADN similares a las de las bacterias que causan esta enfermedad (Papagrigorakis, Yapijakis, Synodinos, \& Baziotopoulou-Valavani, 2006).

Es interesante advertir que con anterioridad al siglo XIX la fiebre tifoidea no era reconocida como enfermedad independiente, en el sentido en que se solía confundir con otras, como el tifus. Si bien, en 1739, John Huxham escribió acerca de las dos manifestaciones entéricas a las que denominó fiebre pútrida maligna (lo que hoy llamamos tifus) y fiebre tifoidea (Antonio \& Daniel, 2015).

A finales del siglo XIX se producen las aportaciones más relevantes acerca del estudio de la fiebre tifoidea. Los estudios epidemiológicos de Budd, en 1873, demostraron que el agua, los alimentos y los fómites eran causas posibles de la fiebre tifoidea. (Budd, 1873). El alemán Karl Joseph Eberth, en el año 1880, observó el agente causal, los bacilos en secciones de nódulos linfáticos y del bazo en pacientes fallecidos por la enfermedad (Eberth, 1880, pp. 58-74).

Otros ejemplo del avance del estudio de la fiebre tifoidea, fue el aislamiento del agente causante, de manos de un médico de la Armada prusiana llamado Georg Gaffky (Gaffky, 1884, pp. 372-420). En 1896, Ferran Widal realizó ensayos a partir de suero de pacientes sospechosos de padecer la enfermedad. En la misma fecha, Pfeiffer y Kolle, en Alemania (Pfeiffer \& Kolle, 1896, pp. 735-737), lograron la primera vacuna contra la fiebre tifoidea con microorganismos destruidos por calor y Wright, en Inglaterra, logró el desarrollo de una segunda vacuna en ese mismo año (Wright, 1896, pp. 807-809).

\subsubsection{Descripción y epidemiología de la fiebre tifoidea}


La fiebre tifoidea (entérica) es una enfermedad infecciosa producida por el bacilo Eberth o Salmonella Typhi, o por la Salmonella paratyphi A, B o C. El mecanismo de contagio es fecal-oral y el hombre es quien puede ser contagiado, por medio del agua y los alimentos contaminados por heces y orina de pacientes portadores. Los alimentos involucrados pueden ser verduras que se consumen crudas, frutas crudas, leche o productos lácteos (contaminados por lo común por las manos de portadores) y mariscos contaminados. Las moscas pueden actuar como vehículo de transmisión infectando los alimentos (Antonio \& Daniel, 2015, p. 102).

La salmonella typhi invade las placas de Peyer situadas en el íleon terminal tras su ingestión. Posteriormente, las bacterias comienzan a proliferar en el tejido linfoide y se propagan hasta los ganglios linfáticos del intestino, hígado y bazo, acompañado de lesiones granulomatosas (Baquero, Nombela, Cassell, \& Fuentes, 2008). Una vez llegado el bacilo a la sangre, produce una bacteriemia y, posteriormente, fenómenos inflamatorios y necróticos en diversos órganos.

Finalmente, las salmonellas se excretan al exterior. La enfermedad puede evolucionar a la curación o prolongarse con localizaciones focales. Sin un tratamiento adecuado pueden presentarse complicaciones graves como hemorragias, perforación intestinal o shock séptico. El estado de portador puede llegar a ser transitorio o crónico (Antonio \& Daniel, 2015, p. 103).

La fiebre tifoidea es un tipo de infección mortal potencialmente. En la actualidad, la tasa media de mortalidad es inferior al $1 \%$ de los casos totales, en países en desarrollo de los continentes asiático y africano se ha llegado al 30-50\%, fruto de la infección por cepas resistentes a los fármacos y al retraso de los tratamientos antimicrobianos. Según la OMS, la incidencia anual de fiebre tifoidea es de aproximadamente 22 millones de casos en el mundo y cerca de 200.000 defunciones. La mejora de las estructuras y las políticas de salud pública, especialmente las vinculadas a la gestión de residuos y calidad de las aguas son condiciones indispensables para la disminución de las enfermedades producidas a través del agua.

El acceso al agua potable y un saneamiento adecuado, junto a una manipulación de los alimentos de manera controlada y limpia, el aislamiento de enfermos y la detección de los portadores, son las medidas que se han de tomar para prevenir la enfermedad. 


\subsubsection{Clínica de la fiebre tifoidea}

El periodo de incubación de la fiebre tifoidea, fiebre entérica o fiebre tifoparatífica es de 8 a 14 días, pero puede tener una variación de 3 a más de 60 en función del tamaño del inóculo ingerido y del estado de salud inmunitario de la persona (de 1 a 10 en la fiebre paratifoidea) en que se dé la enfermedad (Antonio \& Daniel, 2015, p. 103).

Las características clínicas de la enfermedad producidas por la S. entérica serovariedad Typhi y S. entérica serovariedad Paratyphi son indistinguibles, y ambas están incluidas dentro del término fiebre entérica, fiebre tifoidea o fiebre tifoparatífica (Crump, Luby, \& Mintz, 2004).

Las manifestaciones de la enfermedad se han dividido de manera clásica por semanas, en la medida en que, si no es tratada, la fiebre tifoidea se desarrolla a lo largo de cuatro semanas. El periodo temporal en que se basa el presente estudio data de unas fechas en que la infección se desarrollaba sin interferencia de antibióticos, por lo que en la descripción de las situaciones se ha de tener en cuenta este elemento.

Después de la ingestión del microorganismo, las personas potencialmente pueden desarrollar enterocolitis con diarrea que dura varios días y que suele desaparecer antes del inicio de la fiebre.

\subsection{Estudios históricos sobre la fiebre tifoidea}

Whipple en su estudio sobre la fiebre tifoidea en los Estados Unidos (Whipple, 1908), estudió de manera exhaustiva, entre otros aspectos, la relación entre la bacteria patógena de la fiebre tifoidea y el agua. A partir del análisis de la supervivencia del bacilo de Eberth en el agua, realiza un gráfico que será reproducido al español y publicado en la obra, acerca de los problemas sanitarios y la purificación de aguas negras, de los ingenieros Herrán Rucabado y Escario Núñez del Pino. 


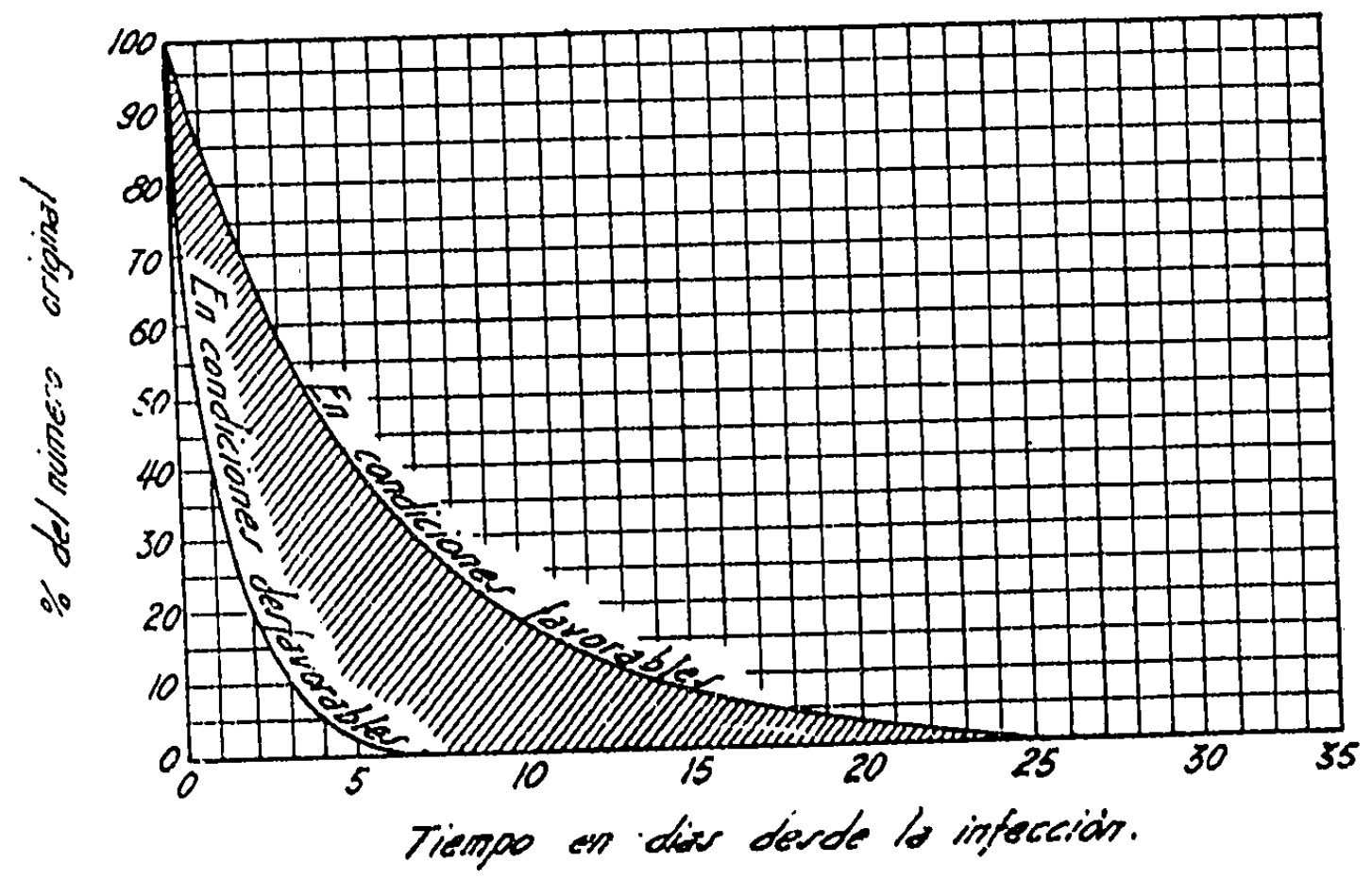

Vitalidad del hacilo tifico en el agua, en condiciones maturales (De la uhra de Whipple Typhoid Fever)

Fuente: (Herrán Rucabado \& Escario Núñez del Pino, 1926, p. 39)

Años atrás, la comisión Sanitaria de Nueva York, mediante los estudios de Royce y Heman, declaraba que el bacilo era capaz de sobrevivir en el agua salada hasta un mes. Los primeros estudios en agua dulce, fueron realizados en aguas del Jordán y en la ciudad de Chicago, concluyendo que la supervivencia del bacilo se reducía a una semana. Whipple mantenía que la rapidez de la mortalidad del bacilo Eberth, en condiciones naturales, es mayor en aguas frías, poco oxigenadas, estancadas y pobres en materia orgánica.

Respecto a los medios de transmisión de la fiebre tifoidea, merece la pena recurrir, nuevamente, a la obra de Whipple sobre la fiebre tifoidea y, de manera concreta, al gráfico que el autor elabora sobre los medios de transmisión y mecanismos de defensa de la enfermedad, por resultar del todo ilustrativo. 


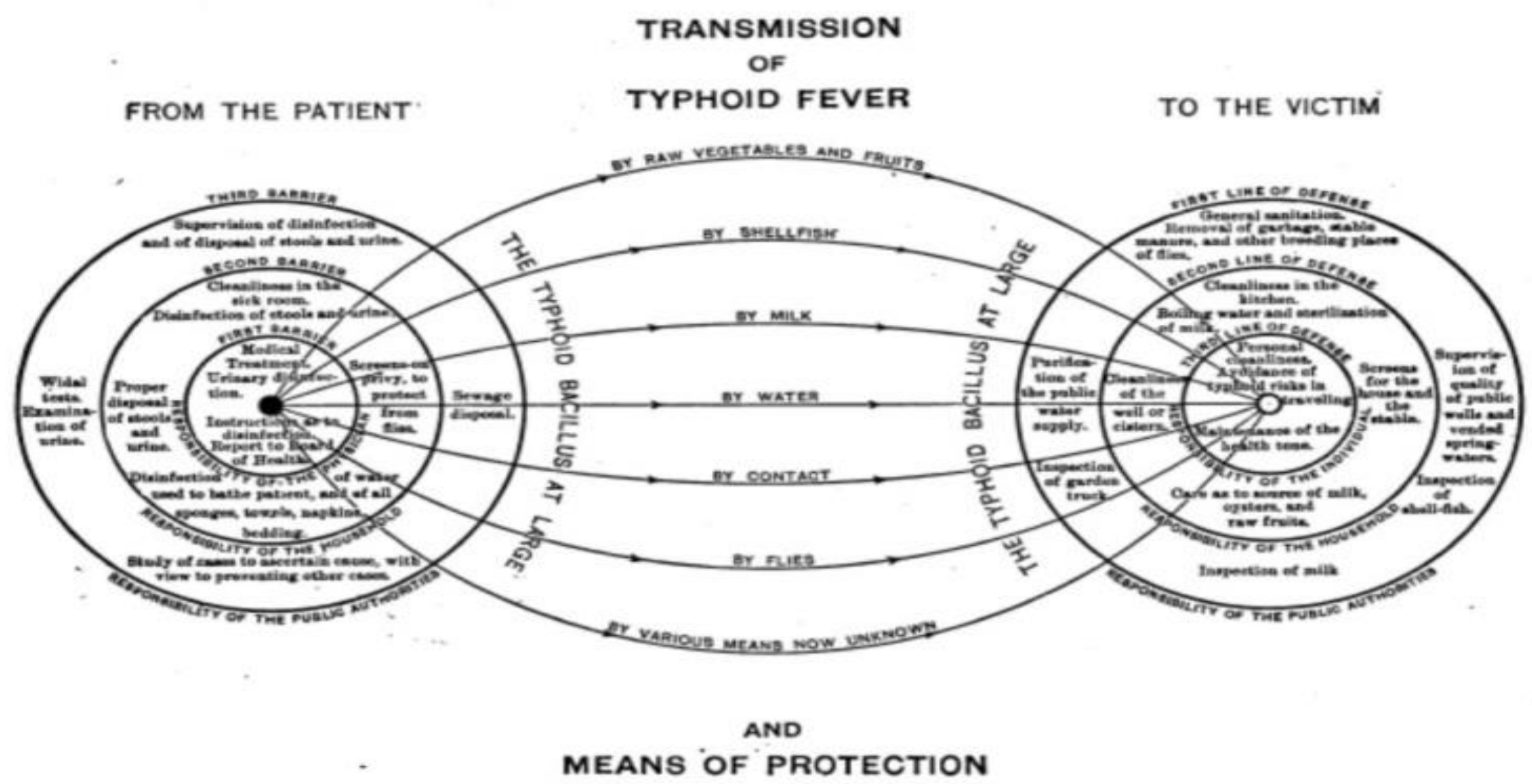

Fuente: (Whipple, 1908). 
A través del gráfico de Whipple (Gráfico 9-2), puede verse como principal barrera contra la epidemia de fiebre tifoidea, el papel de las autoridades públicas. Como línea de defensa principal que a éstas corresponde, aparecen como medios elementales el tratamiento de aguas del alcantarillado, así como el tratamiento depurativo de las aguas destinadas al consumo.

A la altura de los años treinta del siglo veinte, ya se perfilaba el perfil de pacientes que, en mayor medida, se contagiaban de fiebre tifoidea. Así, se consideraba que, tratándose de una infección general aguda, de carácter endémico más que epidémico, atacaba de manera leve a los niños menores de cinco años y a los ancianos de más de setenta. Por el contrario, afectaba de manera preferente y más violenta a los que tienen desde diez a treinta años, por lo cual es ya bien sabido que es la enfermedad que mata a jóvenes robustos y que es más frecuente en el hombre que en la mujer (Moreno Blasco, 1933, p. 7).

\subsection{La calidad de las aguas y la transmisión de fiebre tifoidea}

Muy relacionado con la calidad de las aguas está la transmisión de enfermedades a través de ésta y de los alimentos. A la altura de los años treinta, el problema de la gestión de las aguas residuales de la capital seguía configurándose como una deuda pendiente.

Asimismo, las aguas del alcantarillado que eran derivadas de manera directa desde los colectores y cogidas del río, se empleaban para el riego de huertas aledañas a la ciudad. La vigilancia respecto al cultivo de las verduras crecidas en estas huertas era nula, por lo que algunos autores consideraban que una razón por la que la fiebre tifoidea era endémica en la ciudad de Madrid podía ser explicada por este factor, vinculado al consumo de verduras regadas con aguas no tratadas (Escario Núñez del Pino, 1931a, p. 113). El debate sobre si la fiebre tifoidea en la capital se producía por las aguas de abastecimiento o por la influencia del riego de huertas con aguas residuales, fue un continuo disenso entre los higienistas de la época.

"Hay la idea popular de que el tifus en Madrid está causado por sus aguas de abastecimiento. Nada más lejos de la realidad. Es cierto que tanto los viajes antiguos como el abastecimiento de Santillana, son deficientes y peligrosos; pero la población 
que de ellos se sirve es sólo una pequeña parte de la total. Las otras aguas, las que Madrid recibe del Canal de Isabel II, reúnen las máximas garantías higiénicas" (Escario Núñez del Pino, 1931a, p. 113). En un intento de corroborar esta hipótesis, el ingeniero de caminos y abogado José Luis Escario Núñez del Pino, profesor de ingeniería sanitaria en la Escuela Nacional de Sanidad y redactor del proyecto de depuración de aguas residuales de Madrid y otros proyectos de abastecimiento de aguas y saneamiento ${ }^{83}$, realizó un interesante análisis sobre la relación establecida entre los máximos de bacilus coli encontrados en las aguas del Canal, los máximos de defunciones por fiebre tifoidea y el máximo de consumo de verduras crudas a lo largo

\footnotetext{
${ }^{83}$ Una breve biografía del autor está disponible en la página web de la Real Academia de la Historia: https://dbe.rah.es/biografias/21168/jose-luis-escario-nunez-del-pino.
} 
Gráfico 9-3. Término medio de defunciones por fiebres tifoideas por distritos y meses, en relación con los máximos de bacilus coli encontrados en los depósitos del Canal y el consumo mensual de verduras crudas, entre los años 1919-1931
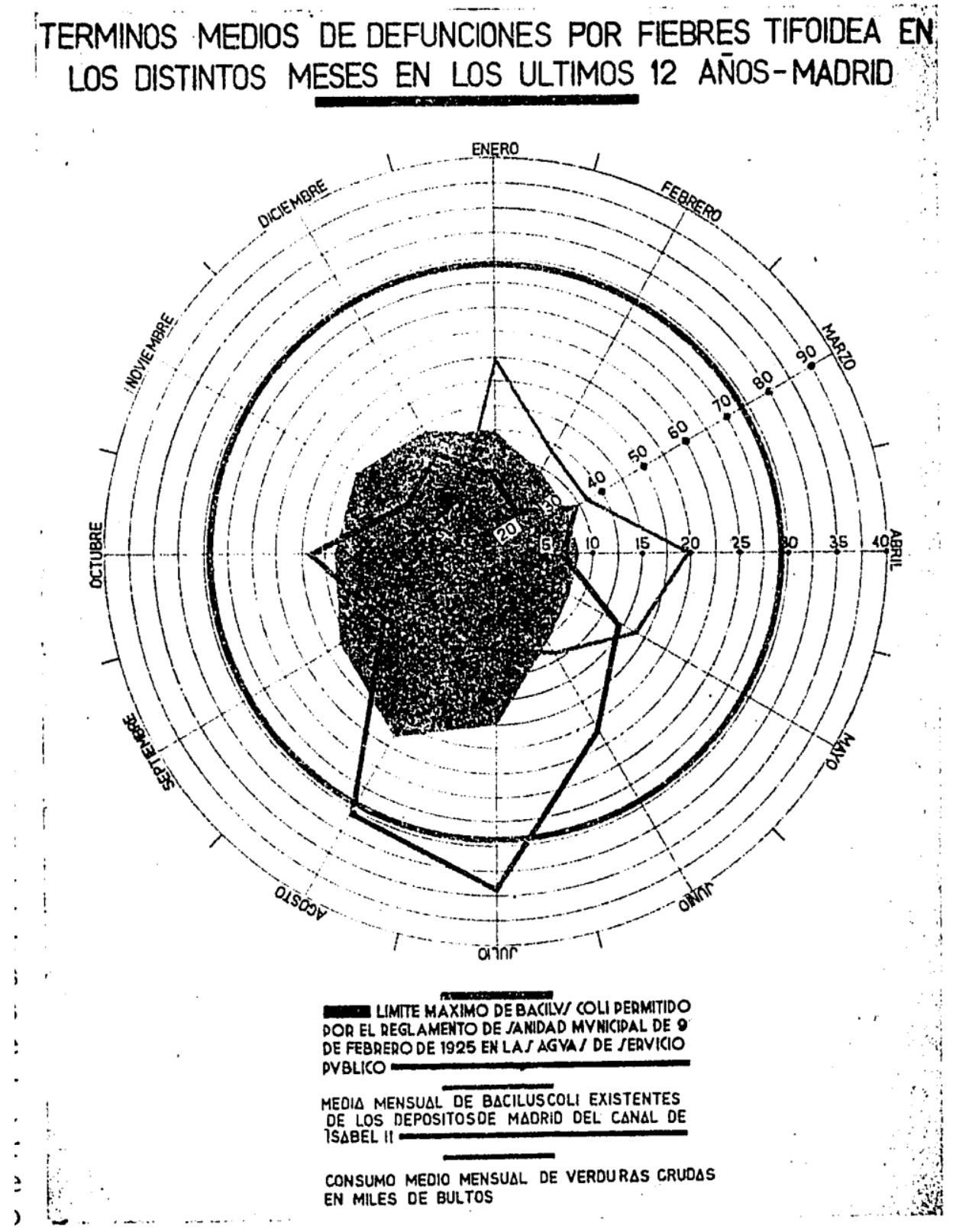

Fuente: (Escario Núñez del Pino, 1931a, p. 113)

Asimismo, pueden verse representados los máximos de bacilo coli encontrados en los depósitos del Canal, la curva de defunciones por fiebres tifoideas y el máximo de consumo de verduras crudas consumidas, representado por meses entre los años 19191931. Escario Núñez del Pino mantiene que, dado que las curvas de los máximos encontrados de bacilus coli y la mortalidad por fiebres tifoideas no coinciden, su 
hipótesis sobre la falta de influencia de las aguas del Canal en la mortalidad por fiebre tifoidea, se corrobora. Sin embargo, sucede lo contrario respecto a la variable sobre el máximo de consumo de verduras crudas, que coincide con la curva de mortalidad por fiebre tifoidea. Así, la conclusión del autor es que “(...)esta coincidencia no es, claro está, para fundar en ella una afirmación categórica, máxime existiendo otros abastecimientos que no reúnen las garantías higiénicas del Canal de Isabel II, pero de todas maneras es muy significativa, especialmente teniendo en cuenta el destino de las aguas residuarias de la capital” (Escario Núñez del Pino, 1931a, p. 113).

Gráfico 9-4. Mortalidad por fiebre tifoidea en Madrid.

137

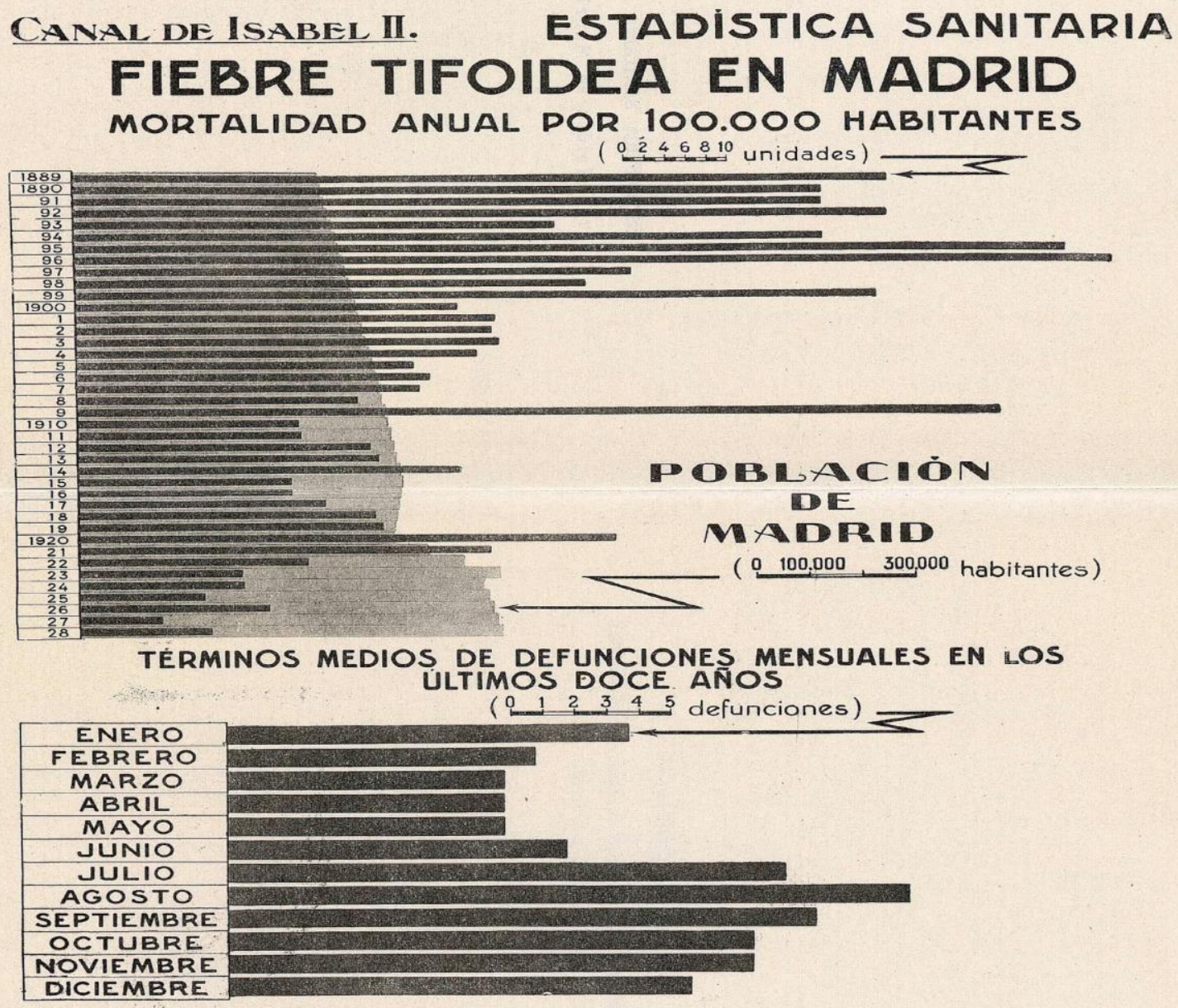

Fuente: (Bello Poeyusan, 1929, p. 137) 


\subsubsection{Epidemias tíficas y el teorema de Hazen. Contexto español y mundial}

El interés y preocupación por las epidemias de fiebre tifoidea en España, se manifestaba en los círculos médicos. Cabe destacar, a modo de ejemplo, el discurso del Doctor Francisco Murillo y Palacio, que desde 1911 ostentó el cargo de Subdirector del Instituto Nacional de Higiene de Alfonso XIII y Jefe de la Sección de Sueros y Vacunas del mismo y en 1923 fue nombrado Director General de Sanidad (Campo Urbano \& Ramírez Jerez, 2005), en una de las conferencias de la Real Academia de Medicina ${ }^{84}$, acerca de las epidemias de fiebre tifoidea en España. El Doctor Murillo ensalzaba la importancia del acometimiento de mecanismos de purificación de las aguas como elemento clave a la hora de prevenir y disminuir la transmisión de enfermedades transmitidas a través del agua, especialmente de la fiebre tifoidea. " Una experiencia abrumadora por las proporciones e incontestable por las pruebas, demuestra que la fiebre tifoidea disminuye el 60 o 70 por 100 con sólo someter a eficaz depuración de los abastecimientos de agua" (Martínez Vargas, 1921, p. 1). Como ejemplificación ante su hipótesis, tomaba el caso de Estados Unidos, manteniendo que en el lapso de veinticinco años, se había logrado reducir a la mitad las enfermedades de orden eberthiano, fruto de la implementación de mecanismos de purificación de agua de consumo. Teniendo por bandera este elemento explicativo de la reducción de la mortalidad por fiebre tifoidea, defendido tanto por médicos, como por ingenieros y autoridades administrativas, les llevó a tomar "como conclusión, hoy aceptada como regla, de que toda urbe cuya mortalidad por infecciones tíficas excede de 20 por 100. 000, es que consume aguas polucionadas, aguas impuras" (Martínez Vargas, 1921, p. $1)$.

El Doctor Murillo mantuvo un discurso bastante crítico respecto a algunas de las informaciones proporcionadas por el Canal de Isabel II, declarando las mismas de "paladinas, pero infundadas declaraciones de las más ilustres capacidades del Canal, que niegan la existencia del daño" (Martínez Vargas, 1921, p. 1). Sirva como ejemplo el contenido de la Memoria del Canal de Isabel II del año 1921, donde se manifestaba que "en el transcurso de los sesenta años que las aguas del Lozoya vienen utilizándose en Madrid, no se ha producido ninguna epidemia que haya reconocido como causa su

\footnotetext{
${ }^{84}$ Conferencia publicada en (Martínez Vargas, 1921)
} 
contaminación", así como que las epidemias de origen hídrico que hubieran podido suceder en Madrid "se ha comprobado que procedían de aguas distintas de las del Lozoya", "también puede afirmarse que el cólera, las fiebres tíficas y paratíficas y ciertas diarreas, que son las únicas enfermedades susceptibles en nuestro clima de transmitirse mediante el agua en bebida, en caso alguno producido en Madrid, bajo forma epidémica que racionalmente pueda achacarse a las del Lozoya. Y aun los casos de fiebres tifoideas que se registran, en que la importación, el contagio y otros orígenes de invasión distintos del agua tienen participación acaso exclusiva, o, por lo menos, preponderante, y no dan lugar a índices de mortalidad más elevados, y, generalmente, ni siquiera tan altos como los que se registran ordinariamente en las capitales más sanas del resto de España". (Memoria del Canal de Isabel II, 1921)

En la génesis de las infecciones, la importancia del agua era reconocida en la medida en que servía de vehículo de las tíficas, el cólera y la disentería. Sin embargo, comenzó a ponerse de manifiesto que las condiciones biológicas del agua también podían influir, de manera variable, en otra serie de enfermedades infecciosas para las que no se conocía su origen hídrico. Se trataba de enfermedades infecciosas que, hasta el momento, no habían surtido sospecha de su relación etiológica con el agua y que iban más allá de los denominados catarros gastrointestinales. El estudio de esta relación, será conocido como el Teorema de Hazen.

Respecto a las ventajas de la depuración de las aguas como elemento clave para luchar contra determinadas enfermedades de origen hídrico, diversos autores toman como paradigma demostrativo de la propagación hídrica, el caso de la epidemia de cólera acaecida en Hamburgo en el año 1892. En este año, ya se había comenzado en la ciudad la construcción de mecanismos de filtrado, destinados a la depuración del agua del río Elba. Una vez finalizados los trabajos, dos años más tarde, el inspector de higiene de Hamburgo, el Doctor Reincke, realizó un estudio con el objetivo de investigar los resultados de la implementación de los sistemas de depuración. Para ello, comparó los datos de mortalidad entre el año 1894 (año en que finalizaron las obras) y los años anteriores a $1892^{85}$, obteniendo como resultado principal un descenso considerable en la

\footnotetext{
${ }^{85}$ La justificación ofrecida por el Doctor Reincke acerca de los años de su estudio y, más concretamente, de la eliminación de los años 1892 y 1893, radicaba en que, para 1892, las epidemias exóticas ofrecen perturbaciones en las estadísticas de mortalidad para años normales. Para el año 1893, la justificación de la exclusión de este año en su análisis, se basaba en que el sistema de filtrado de las aguas del Elba no estaba finalizado, por lo que en la ciudad de Hamburgo todavía había zonas con agua sin filtrar.
} 
mortalidad por fiebre tifoidea; de 47 a 7 por cien mil (Martínez Vargas, 1921, p. 2). Cabe destacar el estudio de Evans, Richard (Evans, 2005), y su estudio centrado en la ciudad de Hamburgo entre 1830 y 1910 y la importancia otorgada a la implementación de medidas de tratamiento de las aguas en la mortalidad por cólera. Otro ejemplo de la influencia otorgada a los sistemas de tratamiento de las aguas en la mortalidad por enfermedades hídricas, fue el de Zurich, considerado por algunos como uno los más exitosos del mundo en cuanto a su influencia en la mortalidad por fiebre tifoidea, con un descenso de la mortalidad por esta causa de 76 a 10 por cien mil (Martínez Vargas, 1921, p. 2) desde la implantación de grandes filtros para la depuración del agua.

Lo realmente novedoso del estudio de Reincke, fue el hallazgo en relación a la mortalidad general: "Mayor o menor, de todas suertes era cosa esperada y sabida la reducción de la mortalidad tífica. Lo inesperado, lo imprevisto para Reincke fue encontrar que la cifra de la mortalidad general no guardaba proporción con el descenso obtenido en el epígrafe de la fiebre tifoidea”. (Martínez Vargas, 1921, p. 2)

"La mortalidad general de Hamburgo alcanzaba, desde años atrás, la media de 24: 1.000, y frente a esta cifra, la general e 1894 no excedía de 17: 1 000. Como la reducción de óbitos a cargo de la fiebre tifoidea (de 47 a 7) representan un descenso de 0,4; 1000 la repercusión sobre la mortalidad general debía ser mucho menor, porque sustrayendo 0,4 de 24 enteros quedan 23,6, pero de ninguna manera 17. En una palabra: a la disminución de 0,4 por fiebre tifoidea respondió la general con la reducción de 6,6, es decir, una ganancia 14 veces superior a la calculada” (Martínez Vargas, 1921, p. 2). Estos hallazgos, revestían su importancia en la medida en que no se realizaron otras medidas de carácter sanitario en la ciudad de Hamburgo, así como porque las divergencias entre las cifras se mantuvieron a lo largo del tiempo. Otro ejemplo del mismo tipo de análisis tuvo lugar en la ciudad de Lawrence, con el estudio de Mills, ingeniero norteamericano. Éste estudió la mortalidad antes y después de la instalación de filtros depuradores de agua, observando divergencias similares en lo que refiere a la mortalidad por fiebre tifoidea y la mortalidad general. Previo a la instalación de filtros, la mortalidad por fiebre tifoidea era de 121 por cien mil y la mortalidad general de 24.4 por mil, reduciéndose, en el periodo de cinco años, a 26 por cien mil y a 20 por mil, respectivamente. En este sentido, se consideraba que, teniendo en cuenta la influencia de la mortalidad por fiebre tifoidea en la mortalidad general, ésta debía haber sido aproximadamente de uno, pero no de cuatro, como realmente fue (Martínez 
Vargas, 1921, p. 2). Los resultados de estas y otras investigaciones basadas en el mismo objeto dieron lugar a lo que se denominó, desde la corriente higienista de la época, como fenómeno de Reincke o de Mills-Reincke ${ }^{86}$, sustentado en las divergencias existentes entre la curva de mortalidad específica por las tíficas y la mortalidad general, en beneficio de la general. En sus investigaciones, Reincke trató de encontrar cuales eran las causas y mecanismos del fenómeno en cuestión, centrándose, especialmente, en el origen de la discrepancia en la disminución de mortalidad por otras causas de muerte. Su idea se basaba en que si la implementación de mecanismos de depuración de las aguas eran factores influyentes en la mortalidad por fiebre tifoidea de manera que "rebaja, por ejemplo, en cincuenta la mortalidad de una población, y esa cantidad transportada al resumen general, se convierte en doscientos, no cabe duda que la diferencia, el exceso de ciento cincuenta vidas ahorradas, debe figurar, en menos, dentro de otros grupos nosológicos” (Martínez Vargas, 1921, p. 2). Es entonces cuando Reincke comienza a estudiar otro grupo de enfermedades, encontrando que, en paralelo a la reducción de la mortalidad por fiebre tifoidea, se produjo una disminución de la gastroenteritis infantil tras la instalación de filtros de depuración hídrica; de 300 a 150 por cien mil. No sólo enfermedades infecciosas relacionadas con el aparato digestivo sufrieron variaciones. Reincke también encontró que algunas enfermedades infecciosas del aparato respiratorio sufrieron un descenso; tales como las pulmonías y bronquitis (de 228 a 188 por cien mil entre 1901 y 1904). Pese a esto, atendiendo a las ganancias por la reducción de la mortalidad por las causas descritas, éstas constituían el sesenta por ciento de la mortalidad general.

En esta misma línea de investigación, cabe destacar el estudio de los higienistas Segwick y MacNutt (Sedgwick \& MacNutt, 1910), quienes realizan un interesante y completo estudio sobre el fenómeno de Mills- Reincke y el teorema de Hazen, con el objetivo principal de comprobar las hipótesis que estas teorías defendían.

Asimismo, si bien en Europa no se llevaron a cabo, por aquella época, demasiados estudios adicionales con el objetivo de comprobar el fenómeno de Mills-Reincke, la experiencia norteamericana sí nos ofrece algunos ejemplos de comprobaciones realizadas a medida que se iban implantando sistemas de tratamiento de las aguas de

\footnotetext{
${ }^{86}$ Según la Real Academia de Ingeniería, el fenómeno de Mills-Reincke guarda la siguiente definición: Experiencia que determinó la importancia de realizar la desinfección de las aguas para evitar la propagación de las enfermedades y así disminuir la mortalidad de la población.
} 
consumo; tales como en las ciudades de Albany (Nueva York), Lowell (Massachusetts), San Luis (Misuri), Paterson (Nueva Jersey), Yakima (Washington), Newark (Nueva Jersey), entre otras. El denominador común de estas investigaciones fue que en todas las ciudades se apreciaba el fenómeno Mills-Reincke aunque en algunas con mayor incidencia que en otras. Hay ciudades "donde la ganancia en favor de la mortalidad general, es diez o doce veces superior a la correspondiente por diminución de la fiebre tifoidea; en otras, el múltiplo es de dos, tres o cuatro" (Martínez Vargas, 1921, p. 2). A raíz del hallazgo de estas disimilitudes en lo que respecta a la influencia de las hipótesis de Mills- Reincke, el ingeniero Hazen formuló sus hipótesis basadas en la fórmula siguiente y que darán origen al denominado Teorema de Hazen:

“ (...) por cada óbito de fiebre tifoidea que la depuración hídrica suprime, evítase al mismo tiempo, dos o tres defunciones debidas a otras causas morbosas".

La influencia positiva de la depuración de aguas en enfermedades que no son consideradas de origen hídrico, comienza a ser el foco de estudio de estas investigaciones. Si bien en algunas, como era la gastroenteritis infantil, se comprendía que la supresión de impurezas biológicas del agua repercutía en un doble sentido; el más obvio, en el agua bebida y, el menos, por la costumbre generalizada de mezclar la leche con el agua, de manera que, en términos finales, la propia leche se convertía en vehículo de la enfermedad. Las dificultades se encontraban en otra serie de enfermedades infecciosas, tales como la bronquitis, tuberculosis y pulmonía, bajo la pregunta de si éstas tenían algo que ver con las mejoras hídricas. Una posible hipótesis, podría ser el diagnóstico erróneo de la causa de muerte, de modo que ante casos reales de, por ejemplo, fiebre tifoidea atípica, se diagnosticaba otra causa de muerte, de modo que las estadísticas necrológicas y sus causas asociadas, sobreestimaban unas causas en detrimento de otras. Si bien esta serie de explicaciones fueron calificadas de insuficientes a la hora de dar una verdadera respuesta al fenómeno.

Otra serie de investigaciones, basaron sus hipótesis en que el neumococo ${ }^{87}$, el bacilo de Koch $^{88}$ y otra serie de bacterias productoras de malestares en las vías respiratorias altas, se introducían en el cuerpo teniendo por mecanismo el agua.

\footnotetext{
${ }^{87}$ El neumococo es una bacteria que puede causar desde infecciones leves (otitis media y sinusitis) e infecciones graves como la neumonía, bacteriemias, sepsis y meningitis.
} 
Las comprobaciones del teorema de Hazen fue, de facto, una suerte de prueba- error, dada su inadaptabilidad en algunos casos particulares y su triunfo en otros. Este hecho ponía, y sigue poniendo, de relieve la importancia de tener en consideración una multiplicidad de factores a la hora de poder atender de manera holística a los elementos a tener en cuenta a la hora de comprender el predominio y frecuencia de las distintas causas de enfermedad, su influencia intrínseca entre unas y otras, así como factores tanto sanitarios como sociales de una colectividad en el recuento de la mortalidad general. Asimismo, hay que tener en consideración que, en algunos casos, la mala gestión de los mecanismos de depuración implantados influyeron de manera negativa en la mortalidad. Así lo manifestaba el doctor Martínez Vargas (1921), quien afirmaba que "en algunas ciudades, el remedio de la depuración, por mal entendido y mal administrado, fué peor que la enfermedad, y de que, en fin de cuentas, el teorema de Hazen no tiene la pretensión de ser una ley numérica -exacta e inflexible, sino la fórmula 6 expresión de un lecho biológico sujeto a multitud de contingencias y variables condiciones" (Martínez Vargas, 1921, p. 3).

Entre otros trabajos, cabe destacar el discurso leído en la Real Academia de Medicina en 1929 por el Doctor José A. Palanca (Palanca \& Martínez-Fortún, 1929), para su recepción como Académico electo en sustitución del Doctor Fernández Caro, que trató de la problemática de la fiebre tifoidea en España. En el mismo se ofrecen datos representativos del descenso de la mortalidad por fiebre tifoidea y el origen de las aguas destinadas para el consumo en algunas ciudades norteamericanas y europeas, así como el descenso producido por la introducción de mecanismos de cloración.

\footnotetext{
${ }^{88}$ El bacilo de Koch, también denominado 'Mycobacterium tuberculosis', es una bacteria que afecta al sistema respiratorio afectando a los pulmones y productora de la infección por tuberculosis.
} 
Gráfico 9-5. Mortalidad por fiebre tifoidea por $\mathbf{1 0 0 . 0 0 0 ~ h a b i t a n t e s ~ e n ~ r e l a c i o ́ n ~ c o n ~ e l ~ s i s t e m a ~ d e ~ a b a s t e c i m i e n t o ~}$ de agua en algunas ciudades europeas y norteamericanas

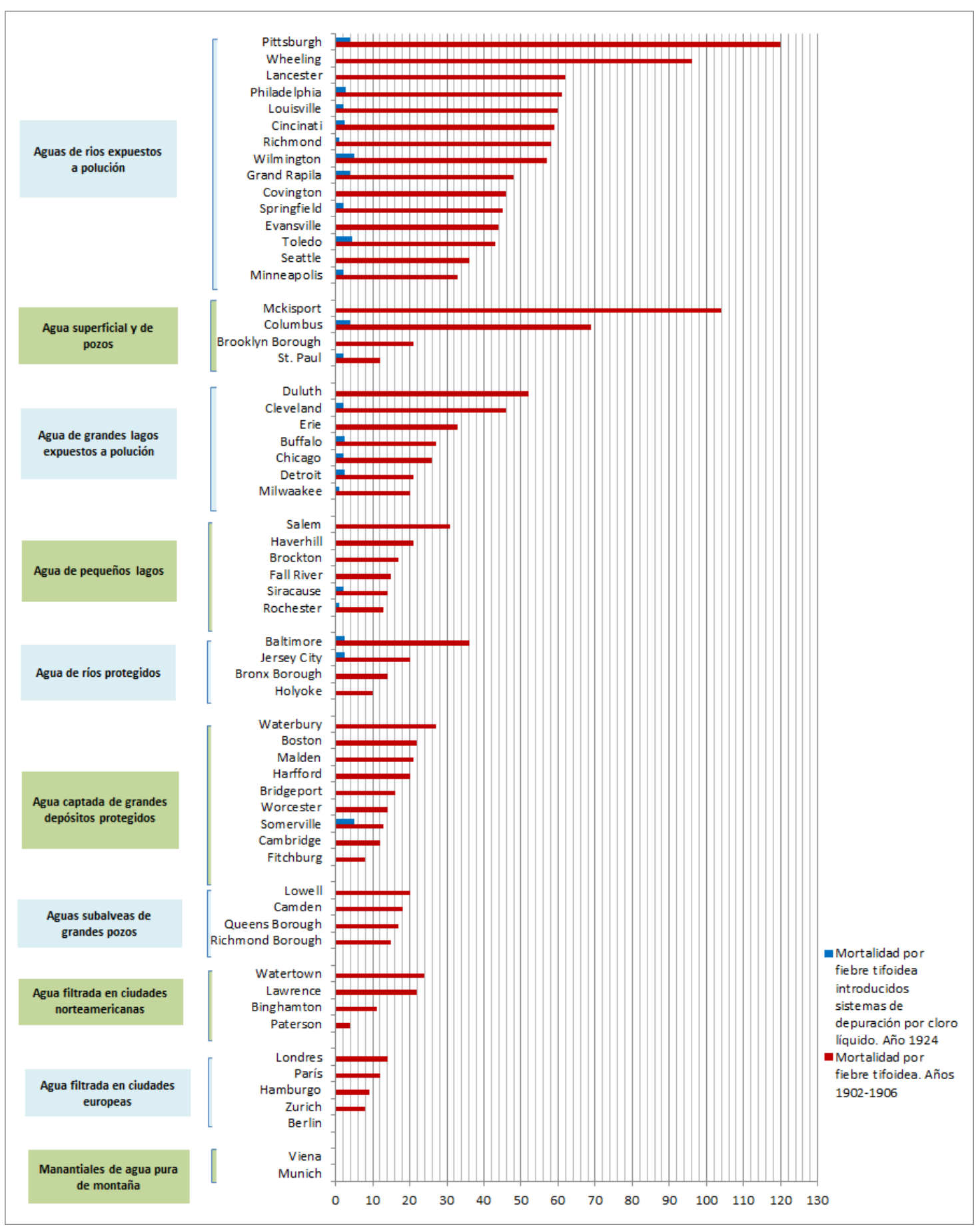

Fuente: Elaboración propia, basado en información proporcionado por (Moreno Blasco, 1933, p. 1; Palanca \& Martínez-Fortún, 1929, p. 20).

La importancia otorgada a la higiene, desde el punto de vista médico, fue tomando cada vez mayor relevancia a lo largo del primer tercio del siglo $\mathrm{XX}$, al tiempo que se iba labrando una nueva corriente médica, que unía la higiene a la bacteriología práctica. 
Respecto a la denominada política sanitaria, cada vez fue tomando mayor protagonismo. Si bien, a la altura de los años treinta, todavía con importantes deficiencias en su implantación. Así lo recogía el Doctor Benito Moreno Blasco, en la Conferencia pronunciada en el Ateneo Riojano el día uno de diciembre de 1932 acerca de las epidemias tíficas y su profilaxis "La política sanitaria, que hasta hace muy poco tiempo ha sido un tópico, una palabra casi vacía de sentido para los gobernantes y aún lo es para gran parte del país, empieza a ser objeto de alguna atención para los actuales gobernantes, que, con excesiva timidez y parsimonia, están haciendo algunos pinitos de imitación a los países más adelantados que nosotros en cultura sanitaria, siendo así que nosotros creemos que debían dar un tremendo salto" (Moreno Blasco, 1933, p. 4). El discurso del Doctor Moreno Blasco continuaba con una descafeinada pero directa crítica hacia la falta de atención por parte de la República en relación a los asuntos de política sanitaria en España, manteniendo que “(...)al cabo de año y medio de Parlamento, de discursos, de Constitución y de una legislación copiosa, aún no ha habido un momento para dedicarlo a garantizar el primero de los derechos del hombre: el derecho a la salud" (Moreno Blasco, 1933, pp. 4-5). La invectiva del autor, finaliza con una petición acerca una la necesidad imperante "más unánime, más sentida y más pensada del Cuerpo sanitario español: Creación de un ministerio de Sanidad, de Salud pública, de Higiene y asistencia social, como le quieran llamar, y aprobación urgente por el Parlamento de una ley de Sanidad moderna y viable ” (Moreno Blasco, 1933, p. 5). Esta realidad no será tal hasta los años de la Guerra Civil española, momento en que se crea el Ministerio de Sanidad y Asistencia Social, el 4 de noviembre de 1936, ocupando la cartera Federica Montseny, que será la primera mujer en ostentar este cargo en la historia de España.

También se abogaba por una mejor gestión de los asuntos sanitarios por parte de los entes públicos, con una mejor repartición de las competencias entre el Estado, las Diputaciones y los Municipios. Las garantías sanitarias respecto a determinadas enfermedades infecciosas, en los años previos a la guerra civil, continuaban siendo una batalla sin resolver. Haciendo alusión a las epidemias de cólera del siglo XIX, de 1834, 1855 y 1885, el Doctor Moreno Blasco mantenía que, si bien la atención a la fiebre tifoidea desde las autoridades públicas no podía ser caracterizada del abandono que caracterizó a las mencionadas epidemias, existían importantes deficiencias. Así lo manifestó en el discurso ofrecido en el Ateneo Riojano en 1932 "si el huésped del 
Ganges o viajero hindú ya no nos visita, es porque no le dejan pasar; pero, en cambio, el bacilo de Eberth y el de Koch y los productores de las enfermedades venéreas y los de la infancia enferman y matan millares y millares de españoles que debían vivir, y vivir sanos, si tomáramos con la mitad del calor que las cosas políticas, los asuntos sanitarios” (Moreno Blasco, 1933, p. 7)

\subsection{El problema de la fiebre tifoidea en España}

Para comprender de manera óptima la situación de en relación a la fiebre tifoidea en España, es necesario atener, aunque sea de manera sintética, a la realidad de la Salud Pública, así como hacer alusión al contexto social y político que se vivía desde finales del siglo XIX.

En este sentido, desde finales del siglo XIX hasta los años treinta del siglo XX, en el entorno español se acude a un periodo de modernización en varias esferas de la vida. Un ejemplo de ello es la modernización de la Administración del Estado, mediante la creación de una nueva legislación y administración sanitaria. La Dirección General de Sanidad fue creada en 1899, asentándose en 1922 con su reinstalación, acompañado de la promulgación del Reglamento de Sanidad Provincial en 1925 que, a su vez, promulgó la creación de los Institutos provinciales de Higiene, como centros que funcionaban con competencia de administración sanitaria periférica (E. Rodríguez Ocaña, 2001)

Sin lugar a duda, la Salud Pública española estaba marcada por la preocupante crisis económica, política y social que azotaba a la España de finales del siglo XIX. Uno de los revulsivos que contribuyeron a mostrar este malestar, fue la situación vivida en 1898, cuando, fruto de la derrota frente a los Estados Unidos, se acabó con las últimas colonias transoceánicas de la monarquía hispana. Manuel Tuñón de Lara, señalaba que el comienzo del siglo XX venía marcado por muchas de las propuestas levantadas en el XIX (Tuñon De Lara, 2000). De forma genérica, se empleó el término "regeneracionismo" para referirse al intento de modificar todas las facetas de la vida social y la acción del Estado, con un sentido modernizador. La modernización, como programa, consistía en adaptar las condiciones españolas a las pautas y estructuras vigentes en los países que se consideraban, ejemplarmente, "civilizados", como eran los europeos occidentales (Esteban Rodríguez Ocaña, 1994, p. 11). 
El componente sanitario estaba claro en esta alusión a la necesidad de civilización. Entre otros elementos, las deficiencias en cuanto a los servicios de suministro de agua y alcantarillado, así como la ausencia de una eficiente organización de servicios de estadística sanitaria o la elevada mortalidad española eran características que se establecían en contraposición a la situación española vs europea.

Cabe preguntarse cuáles son las causas que provocaban este atraso de España en materia sanitaria en comparación con otros países del entorno europeo. Según autores como Martín Salazar (1913), éstas causas englobaban elementos políticos, médicos y culturales. La persistente creencia popular en la "acción fatalista de la providencia", reflejo de la importancia de la religión en la conformación de la mentalidad popular, y la consideración excesivamente individualista del derecho, personificada en el "derecho de propiedad", que se oponía a cualquier atisbo de "derecho sanitario”(Esteban Rodríguez Ocaña, 1994, p. 12). Además, se apuntaba a la escasa presencia de médicos entre los legisladores, y la poca relevancia de las ciencias básicas en el currículum médico, como la química biológica y la microbiología.

Atendiendo a las condiciones de salubridad de las ciudades, el relato de Hauser (1902b) sobre el Madrid de principio de siglo, ponía de manifiesto las graves deficiencias existentes en varias materias vinculadas con el saneamiento de la capital. Así lo era la presencia de más de 3000 pozos negros, las 4000 casas sin acceso directo al agua o la carencia de sifones en los sumideros de las zonas del ensanche y en buena parte del casco antiguo. Si bien, esta situación no era exclusiva de la capital, sino que en otras ciudades españolas acontecían situaciones similares; así sucedía en Barcelona o Sevilla. Barcelona, por ejemplo, acometió un plan de saneamiento a ejecutar hasta 1913, mediante el que se debían construir depósitos de descarga de agua para la correcta circulación de las alcantarillas (Capel \& Tatjer, 1991). En Sevilla, un conflicto entre el Ayuntamiento de la ciudad y la Liga de Propietarios estuvo a punto de impedir la construcción del nuevo alcantarillado para la ciudad (Pulido Fernández, 1902).

Cabe destacar el interesante estudio realizado por Membrillera (Gómez de Membrillera, 1921) sobre el problema sanitario de España y sobre el saneamiento e higienización de España (Gómez de Membrillera, 1920), que otros estudios han recogido para adaptarlos al estudio de diferentes contextos, tanto urbano como rural (Galiana \& BernabeuMestre, 2006). 
"El problema de la fiebre tifoidea en España está aún y estará muchos años sobre el tapete, porque la enfermedad es endémica en todo el país, y de cuando en cuando, casi siempre a fines de verano, en los otoños, hace su aparición una epidemia más o menos duradera y de variable morbilidad y mortalidad, pero que siempre, siempre, produce sobre los pueblos el mismo efecto de terror momentáneo, siendo también siempre el pretexto para que las viejas brujas con que con el tiempo han de representarse plásticamente en sociedades más avanzadas la ignorancia y la simplicidad, hagan su aparición, y con mayor velocidad que el germen productor crece y corre a través de las vías de propagación, propaguen las consejas, los cuentos, las exageraciones y los errores” (Moreno Blasco, 1933, p. 6). En el siglo XIX, existía la creencia popular de que, si bien se sabía que las fiebres tifoideas y el cólera se transmitían a través del agua, la enfermedad y la muerte producidas eran atribuidas al arrojamiento de un veneno en las fuentes públicas.

A la altura de los años treinta, uno de los problemas de los que sufría la España del momento era la insuficiencia de cantidad de agua disponible. Así, debían batallarse dos guerras respecto al agua; su cantidad y su calidad. Así lo mantenían autores como el Doctor Moreno cuando, para referirse a la situación del agua en España las rotulaba bajo frases tales como “Poca agua, pero además mala”(Moreno Blasco, 1933, p. 18) o el Doctor Palanca, acerca de la calidad de las mismas "Yo no creo pecar de exagerado si os digo que más del ochenta por ciento de los abastecimientos de aguas de España están contaminadas o son susceptibles de contaminarse" (Palanca \& Martínez-Fortún, 1929).

Atendiendo a los datos sobre la Mortalidad por fiebre tifoidea registradas en capitales de provincia y provincias de España en el decenio de 1910-1919, cabe destacar que se producían en mayor medida en las capitales de provincia. Otro aspecto a considerar es el repunte producido en 1914 teniendo en cuenta las capitales de provincia.

Los datos ofrecidos en este grafico nos ponen en la tesitura de pensar la relación existente entre la mejora de los servicios de abastecimiento de agua y el alcantarillado en la mortalidad por fiebre tifoidea, en la medida en que éstos se produjeron antes y en mayor proporción en los entornos urbanos respecto a los rurales y, atendiendo a los datos, precisamente fueron las capitales de provincia las que más mortalidad acusaron por fiebre tifoidea. 
Gráfico 9-6. Mortalidad por fiebre tifoidea (\%०) registradas en capitales de provincia y provincias de España en el decenio de 1910-1919.

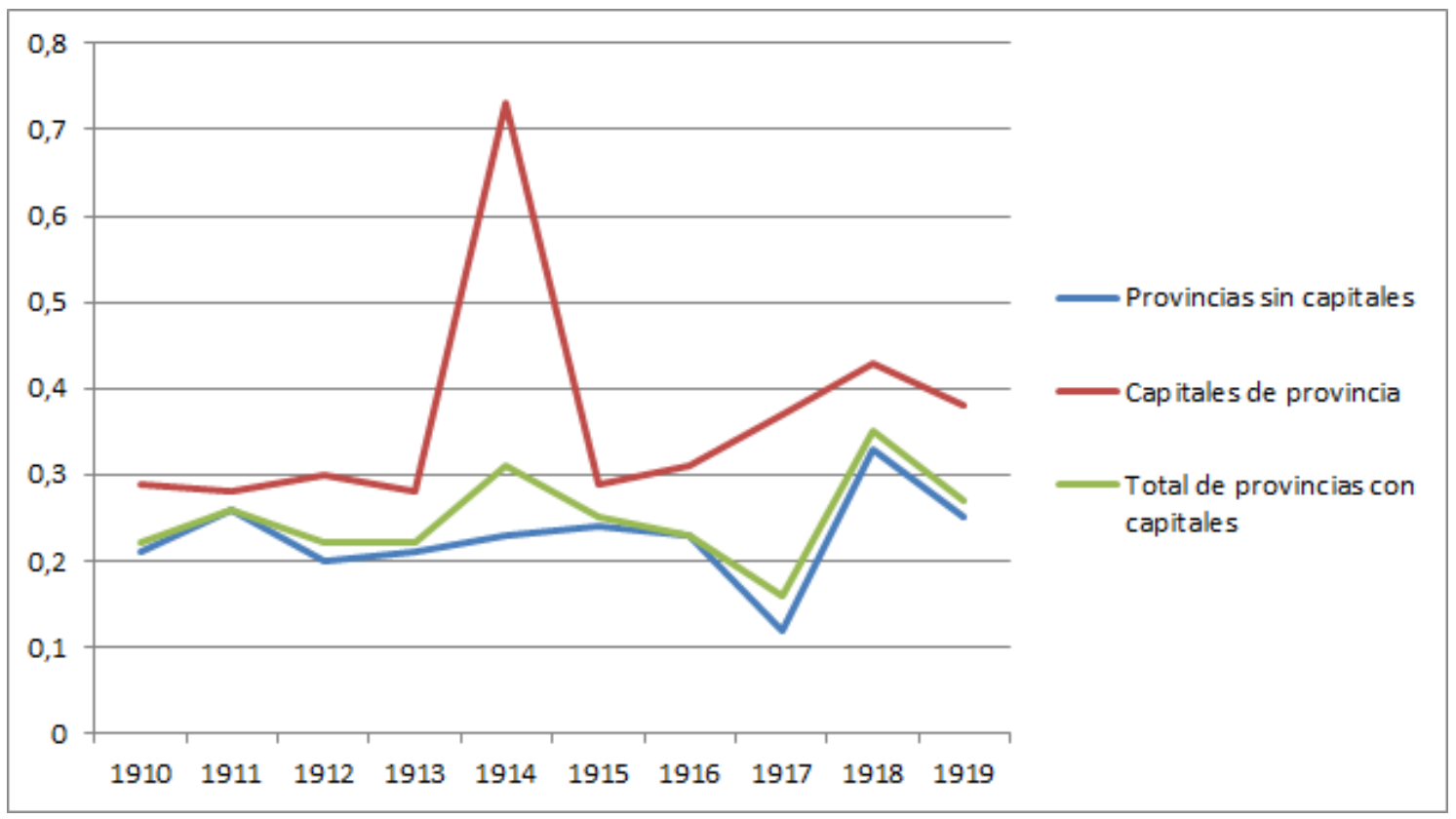

Fuente: Elaboración propia con datos obtenidos de (Martínez Vargas, 1921)

Gráfico 9-7. Las ocho capitales de mayor y menor mortalidad por 100000 habitantes, entre 1917-1919.

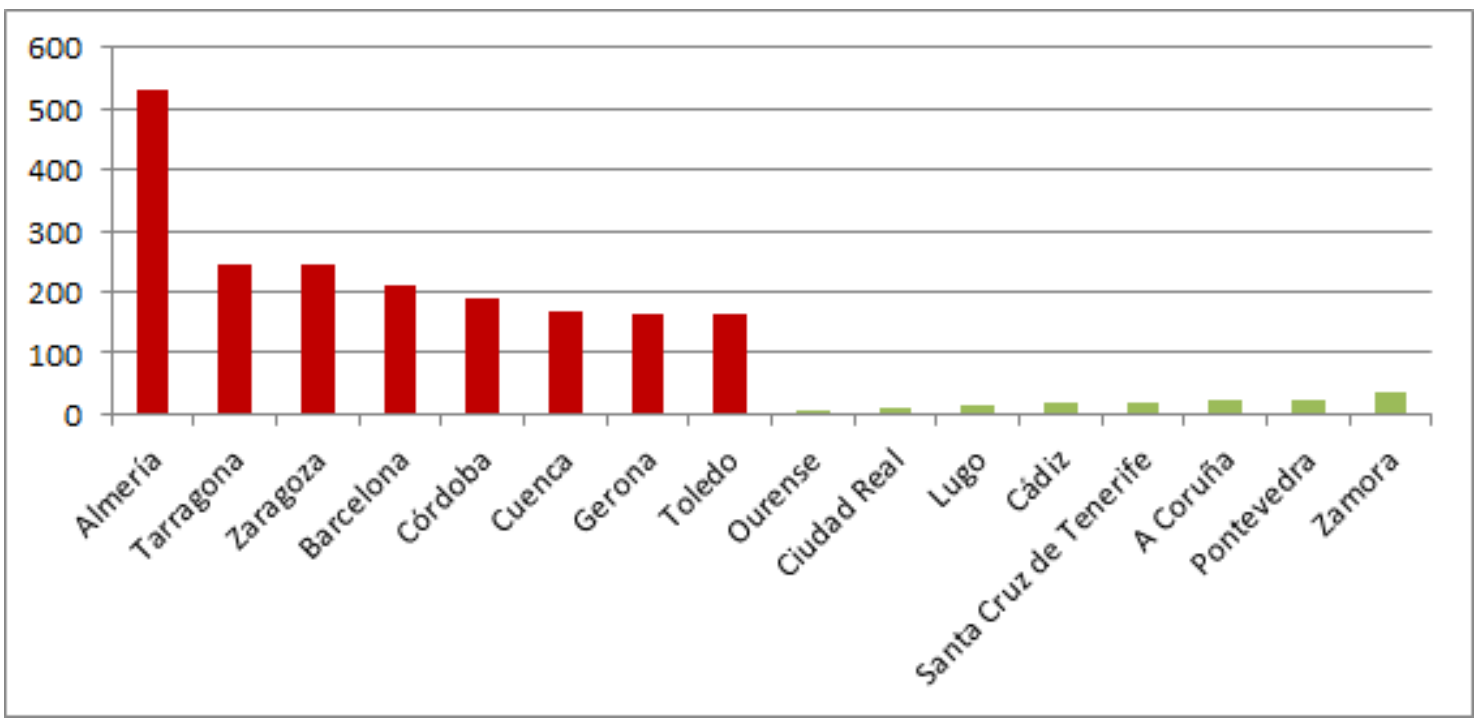

Fuente: Elaboración propia con datos obtenidos de (Martínez Vargas, 1921)

Respecto a la disposición de redes de alcantarillado y de agua en las capitales de provincia, la situación general, a la altura de los años veinte, era nefasta, atendiendo a la información recogida por Gómez de Membrillera sobre la situación higiénica de España (Gómez de Membrillera, 1920, 1921). Así, en lo que respecta al alcantarillado, pese a 
que todas las capitales disponían de alcantarillado, no todas tenían instalado en toda la población el alcantarillado moderno (Gómez de Membrillera, 1921, p. 353), siendo sólo once capitales las que disponían del mismo.

Además, las que Membrillera y su equipo califican como alcantarillado regular, se refiere a las que sí disponen de cloacas con secciones suficientes para la evacuación de las aguas de lluvia y residuales, pero carecen de disposición adecuada para la limpieza y ventilación (17 capitales se hayan en esta situación).

Por último, 19 de las capitales españolas están caracterizadas por tener secciones insuficientes, poca pendiente y materiales no impermeables, por lo que son clasificadas con ciudades con malas cloacas.

En cuanto a la capacidad del abastecimiento de aguas, hay que tener en cuenta la disposición de la cantidad de la misma para cubrir las necesidades privadas de los habitantes, así como para atender a los servicios públicos de riego de calles y paseos y de alcantarillado. Según la información proporcionada por Gómez de Membrillera, sólo 11 capitales cumplían con los requisitos de abastecimiento suficiente en los ámbitos descritos.

Otro punto importante responde a la calidad de las aguas, se considera que, en general, son buenas las aguas procedentes de manantiales, así como aquellas aguas procedentes de ríos que tienen un caudal regular.

En los siguientes mapas y gráficos se puede observar la evolución de la mortalidad por fiebre tifoidea en España en las capitales de provincia en el período que abarca el presente trabajo. 
Imagen. Mortalidad por fiebre tifoidea (\%o) en algunas capitales de provincia. Años 1906-1910

Mortalidad por fiebre tifoidea en las capitales de provincia de España. 1906-1910

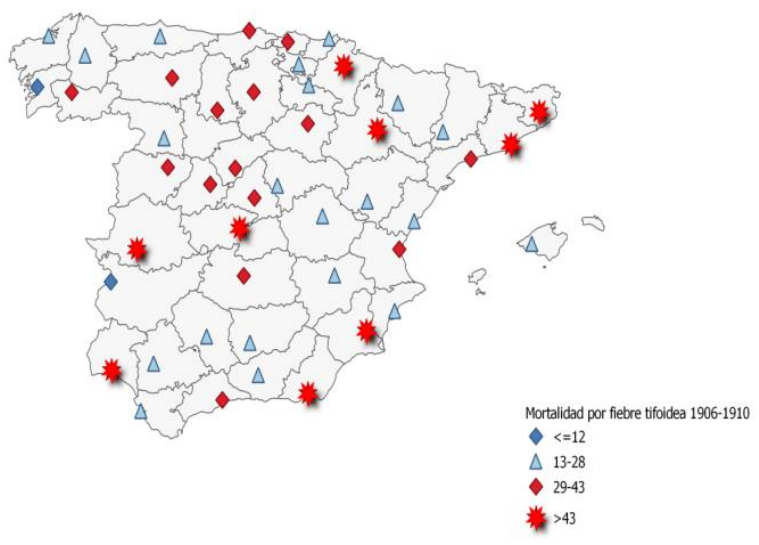

Fuente: Elaboración propia. Datos obtenidos de (Moreno Blasco, 1933; Palanca \& Martínez-Fortún, 1929)

Imagen. Mortalidad por fiebre tifoidea (\%) en algunas capitales de provincia. Años 1911-1915.

Mortalidad por fiebre tifoidea en las capitales de provincia de España. 1911-1915

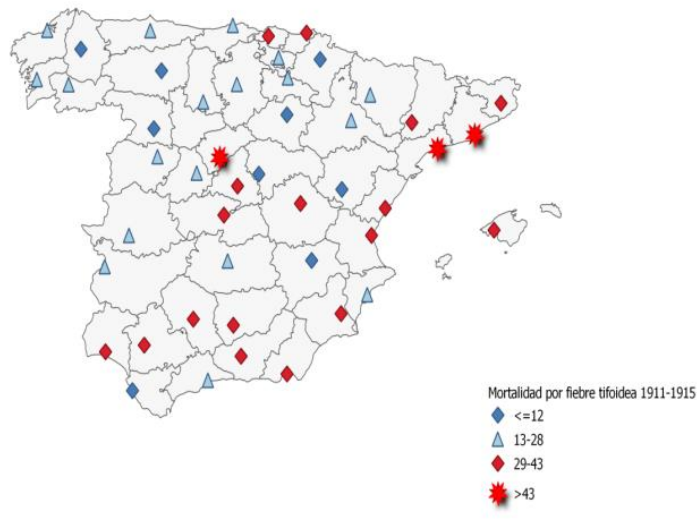

Fuente: Elaboración propia. Datos obtenidos de (Moreno Blasco, 1933; Palanca \& Martínez-Fortún, 1929) 
Imagen. Mortalidad por fiebre tifoidea (\%o) en algunas capitales de provincia. Años 1916-1920

Mortalidad por fiebre tifoidea en las capitales de provincia de España. 1916-1920

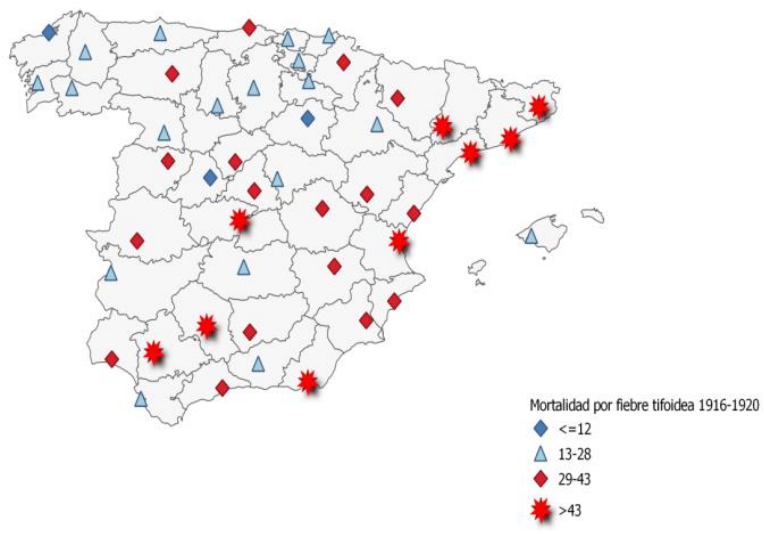

Fuente: Elaboración propia. Datos obtenidos de (Moreno Blasco, 1933; Palanca \& Martínez-Fortún, 1929)

Imagen. Mortalidad por fiebre tifoidea (\%o) en algunas capitales de provincia. Años 1921-1925

Mortalidad por fiebre tifoidea en las capitales de provincia de España. 1921-1925

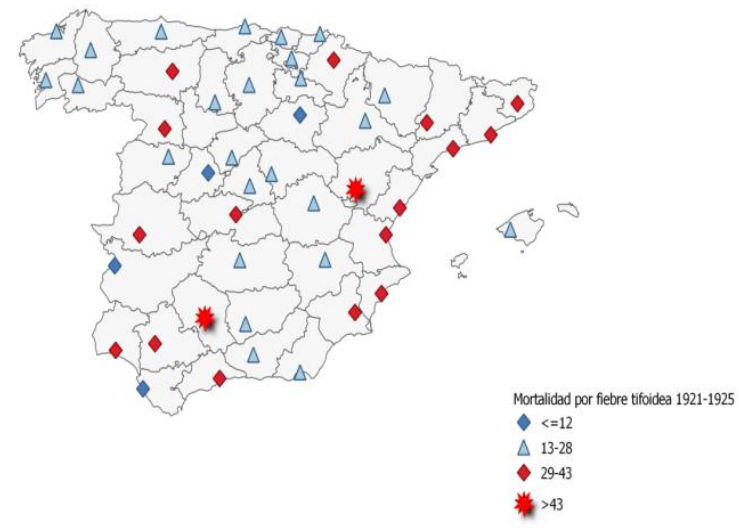

Fuente: Elaboración propia. Datos obtenidos de (Moreno Blasco, 1933; Palanca \& Martínez-Fortún, 1929) 
Imagen. Mortalidad por fiebre tifoidea (\%o) en algunas capitales de provincia. Año 1926.

Mortalidad por fiebre tifoidea en las capitales de provincia de España. 1926

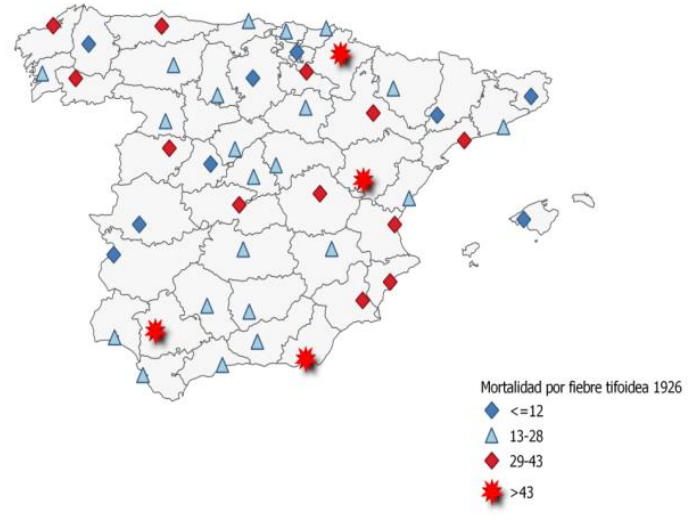

Fuente: Elaboración propia. Datos obtenidos de (Moreno Blasco, 1933; Palanca \& Martínez-Fortún, 1929)

Imagen. Mortalidad por fiebre tifoidea (\%) en algunas capitales de provincia. Año 1927.

Mortalidad por fiebre tifoidea en las capitales de provincia de España. 1927.

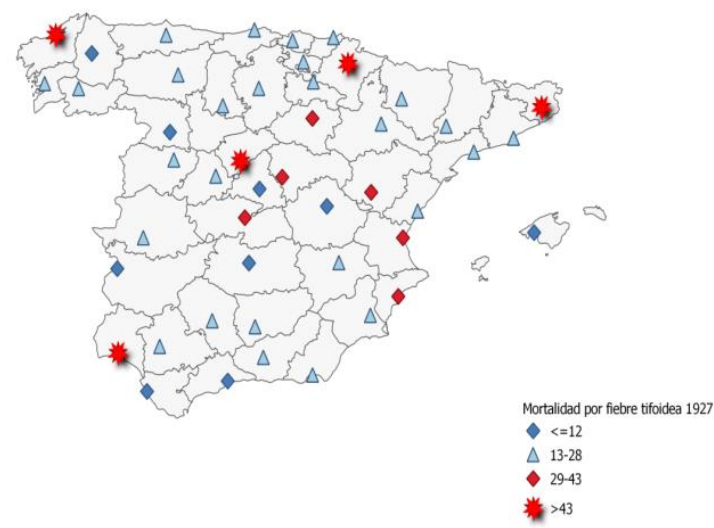

Fuente: Elaboración propia. Datos obtenidos de (Moreno Blasco, 1933; Palanca \& Martínez-Fortún, 1929) 
Atendiendo a la calidad de las aguas y el tipo de abastecimiento por provincias, no podemos extraer un patrón que asocie estas dos variables, en la medida que se presenta variabilidad en la interrelación entre aguas buenas o aguas malas y el abastecimiento de agua por medio de agua de manantiales, agua de pozos y profundas, aguas superficiales o aguas de origen mixto.

Imagen. Imagen de España por provincias según la calidad de las aguas. Año 1929

Calidad de las aguas de las provincias de España. Año 1929.

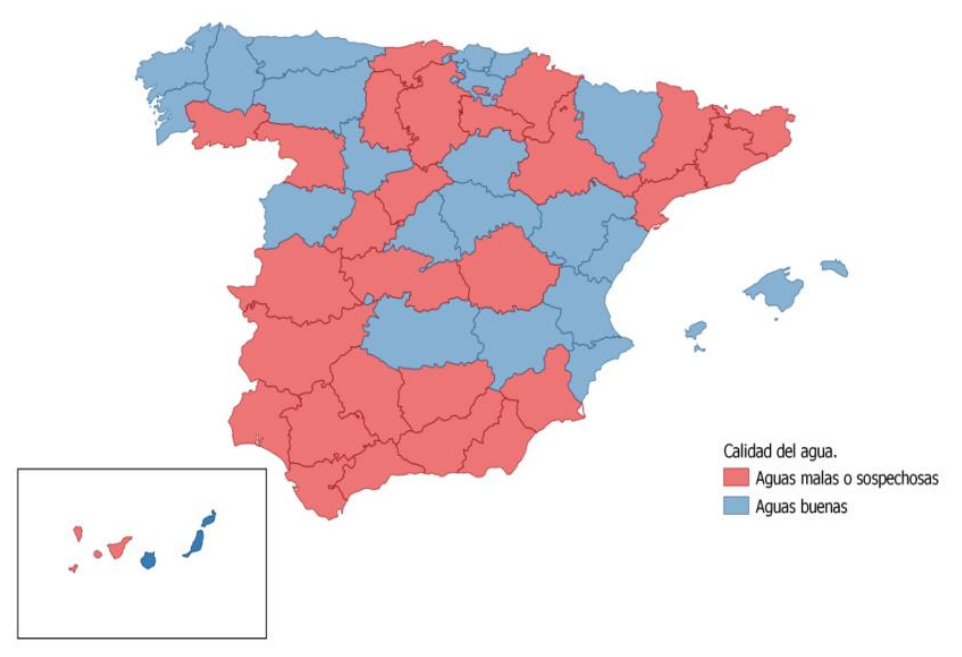

Fuente: Elaboración propia. Datos obtenidos de (Moreno Blasco, 1933; Palanca \& Martínez-Fortún, 1929) 
Sistema de abastecimiento de las aguas de las provincias de España. Año 1929.

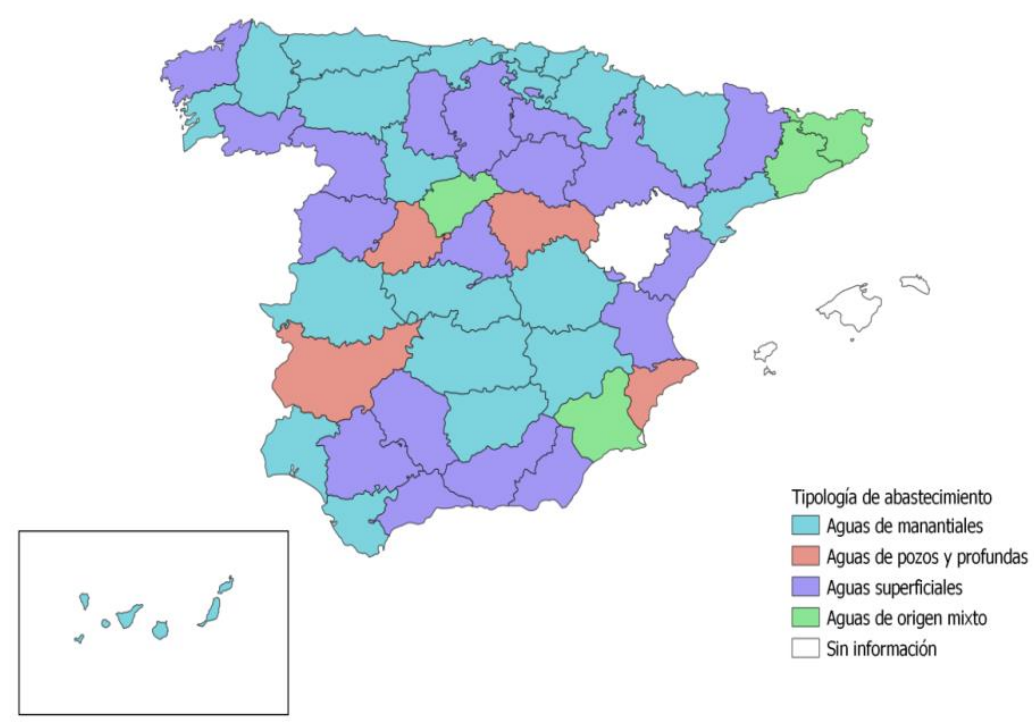

Fuente: Elaboración propia. Datos obtenidos de (Moreno Blasco, 1933; Palanca \& Martínez-Fortún, 1929)

En lo que respecta a los medios de tratamiento de las aguas a nivel provincial, la mayoría de las provincias empleaba agua de consumo sin ningún tipo de tratamiento. En este caso, teniendo en cuenta el gráfico correspondiente a la calidad de las aguas, parece existir una relación entre las provincias con agua sin tratar y por sedimentación y una calidad mala o sospechosa de las aguas. 


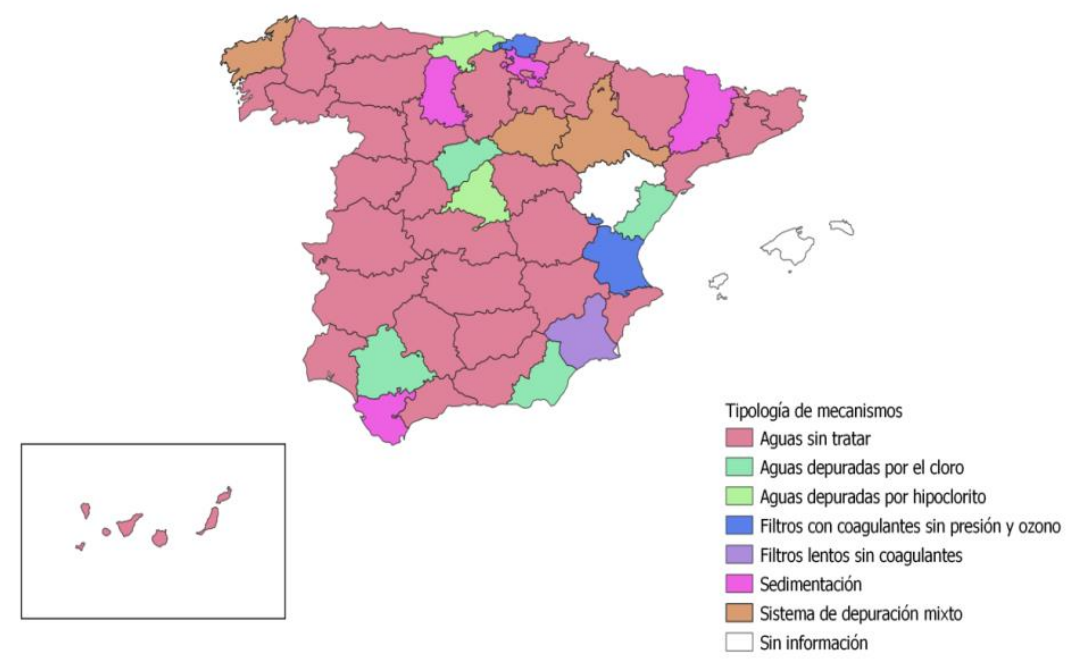

Fuente: Elaboración propia. Datos obtenidos de (Moreno Blasco, 1933; Palanca \& Martínez-Fortún, 1929)

Lo que parece quedar palpable es que, a la altura de 1930, existían importantes deficiencias en lo que respecta al suministro de agua y su tratamiento en el contexto español. Por poner un ejemplo, de las 7 ciudades con más de 100000 habitantes en España, solamente Zaragoza y Sevilla contaban con una amplia y moderna red de alcantarillado, aunque con una deficiente suministración de agua. Madrid, Valencia y Málaga, se caracterizaban por disponer de una buena dotación de agua potable, pero una muy deficiente red de evacuación. Las 2 ciudades restantes, Barcelona y Murcia, disponían de un equipamiento de red de agua y de alcantarillado deficiente (Gómez de Membrillera, 1921). 


\subsection{Estado sanitario de Madrid y las fiebres tifoideas. Epidemia de}

1920.

El aumento de los casos de fiebre tifoidea acaecidos en 1920 en la ciudad de Madrid, fue objeto de preocupación por parte del vecindario. Así lo recogían diversos noticiarios y revistas de la época "existe en Madrid un estado de alarma con motivo del aumento de casos de fiebre tifoidea que se registra en el vecindario. El hecho es cierto, resultando inútil toda ocultación. Ahora bien; no constituye una situación grave, ni verdadera epidemia, sino un crecimiento en la enfermería, suficiente para llamar la atención de las autoridades y poner en práctica toda aquella serie de medidas que garanticen un dominio del mal, evitando posibles diseminaciones" (Aguado Marinoni, 1920, p. 6). Algunas de las medidas tomadas para solventar la situación fueron una pequeña dotación económica a la Diputación Provincial de Madrid por parte del Ministerio de la Gobernación y la colocación de barracas Docker desde el Hospital San Juan de Dios al Hospital Provincial, con el objetivo de una posible atención al exceso de población enferma.

Gráfico 9-8. Evolución de la mortalidad por fiebre tifoidea en Madrid. 1904-1929

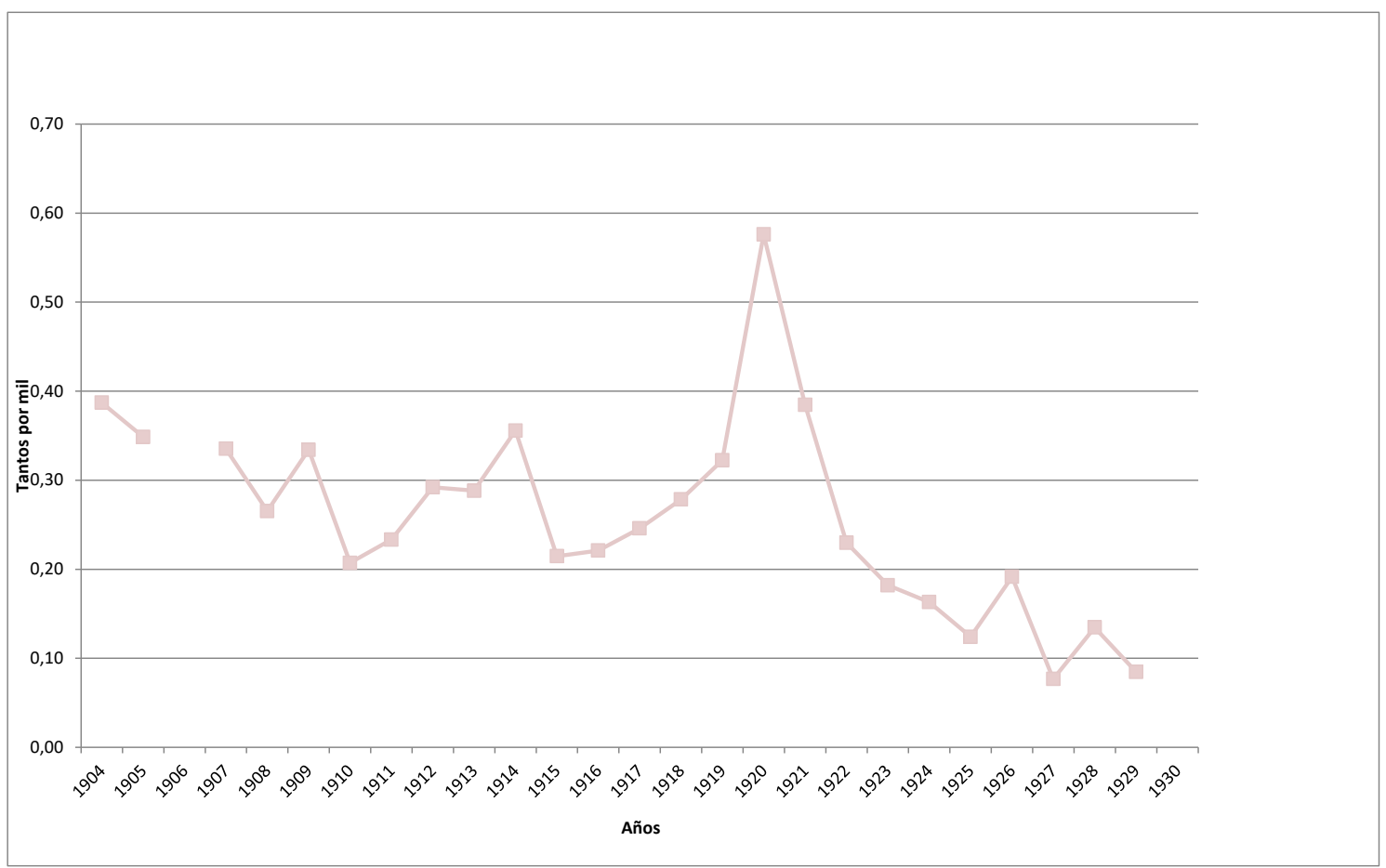

Fuente: Elaboración propia. Datos obtenidos de los Anuarios Estadísticos de la ciudad para los años señalados. 
El Doctor Martín Salazar, que ostentaba el cargo de inspector general de Sanidad en 1920, mantuvo una seria preocupación por el incremento de casos de enfermos de fiebre tifoidea en Madrid. Asimismo, señalaba que los casos diagnosticados eran inferiores a los casos reales, culpando a los médicos de cabecera de no cumplir la instrucción sobre declaración obligatoria de la enfermedad. Respecto a la distribución de casos en el vecindario de Madrid, mantenía que "solamente tenemos a impresión de que hay numerosos casos repartidos por toda la población, aunque con más intensidad en el barrio de Buenavista. El número de enfermos que actualmente hay en el Hospital General ascendía a unos cincuenta, y todos los días entran tres o cuatro, que, como usted ve, para una población de cerca de un millón de habitantes no es para producir verdadera alarma en la opinión” (Aguado Marinoni, 1920, p. 6). En este sentido, el Doctor Chicote, Director del Laboratorio Municipal, mantenía que "la opinión médica más generalizada es que la infección se ha presentado con benignidad, debida a la escasa cantidad de gérmenes, y como a esto parece oponerse la cifra de mortalidad, no cabe duda que el número de invasiones ha sido muchísimo mayor; pero los médicos siguen con su censurable conducta de no dar parte a las autoridades sanitarias" (Aguado Marinoni, 1920, p. 7).

\subsubsection{Origen de la epidemia.}

En lo que respecta al origen de la epidemia, las opiniones no eran unívocas. Así lo manifestaba el Inspector General de Sanidad en 1920, el Doctor Martínez Salazar, en una entrevista para la revista España Médica ante una pregunta formulada sobre el origen de la epidemia "Hay opiniones contradictorias, sin que se pueda afirmar de una manera rotunda cuál haya sido la causa de la epidemia. La mayor parte de los médicos se inclinan a creer en la posible contaminación de las aguas de la bebida, singularmente del Lozoya; pero de los análisis microbiológicos, que se hacen diariamente no se ha podido comprobar la existencia del bacilo Eberth" (Aguado Marinoni, 1920, p. 6). Las divergentes opiniones sobre el origen de la misma radicaba, en buena medida, en el hecho de que los análisis bacteriológicos de las aguas realizados por el Laboratorio Municipal no encontraron la presencia del bacilo Eberth, germen específico de la fiebre tifoidea. Esta ausencia se dio en los análisis de las aguas de abastecimiento de la ciudad de Madrid, así como en las visitas realizadas por el personal 
del Laboratorio a Buitrago y otros pueblos como Manzanares y Colmenar, si bien en Miraflores se estaba padeciendo afecciones de tifoidea desde el mes de octubre de 1919. Se realizaron, también, viajes de investigación a las cuencas del Lozoya, en la que se tomaron muestras en diferentes embalses y de los ríos Manzanares y Guadalix, pero tampoco encontraron indicios del bacilo Eberth. En este sentido, el origen hídrico del aumento de casos de fiebre tifoidea en 1920 quedaba en entredicho, de manera que se barajaron otros posibles focos de contaminación, como determinados alimentos. Entre éstos, destacaba la leche ${ }^{89}$ como medio transmisor de la enfermedad por ser considerado como "un alimento peligrosísimo para el contagio de la fiebre tifoidea, porque en ella se cultiva el germen de una manera prodigiosa, sin coagularla y sin alterar el aspecto externo de la misma" (Aguado Marinoni, 1920, p. 6).

Por su parte, el Doctor Chicote, mantenía como hipótesis la contaminación de las aguas con origen en la obra de la presa de Puentes Viejas. Si bien destacaba que el Canal de Isabel II había dotado de retretes las inmediaciones de las obras, para uso de la colonia de obreros y se castigaba con la expulsión a quien no los usara, el Doctor Chicote consideraba como plausible la contaminación por micción. "Esta acción del portador de gérmenes en una masa de agua, como la del embalse, ha podido ocasionar una contaminación extraordinariamente diluida, que por su escasísima cantidad de gérmenes muy atenuados, ha provocado una pequeña explosión de fiebre tifoidea, ciertamente muy alejada por su importancia de cuanto se conoce sobre infecciones provocadas por las aguas alimenticias" (Aguado Marinoni, 1920, p. 7). Asimismo, su hipótesis se sustentaba en que una parte de los trabajadores procedían de Miraflores, pueblo con una alta incidencia de fiebre tifoidea, y se comprobó que estaban contagiados de fiebre tifoidea, por lo que podría tratarse, además, de un caso de portadores de gérmenes.

El hecho de que la contaminación fuera muy diluida, dado el tamaño del embalse, se mantenía como elemento explicativo de la falta de resultados positivos del bacilo Eberth en las investigaciones analíticas de las aguas realizadas por el Laboratorio Municipal. Hay que tener en consideración, tal y como se explica en el capítulo número siete sobre los análisis realizados por el Laboratorio Municipal, que la necesidad de completar los análisis diarios de las aguas fue una constante petición por parte de los técnicos del

\footnotetext{
${ }^{89}$ Había antecedentes de que las epidemias de fiebre tifoidea acaecidas en Miraflores de la Sierra fueron debidas a la contaminación de la leche y sus derivados, ya que era un lugar de producción de leche, quesos frescos, requesón... y otros derivados frescos de la leche.
} 
Laboratorio. El Doctor Chicote mantuvo una preocupación sobre este asunto, reclamando medios con los que fueran capaces de realizar estudios sobre la pureza de las aguas desde el nacimiento hasta los embalses, que era el proceder de los trabajos de vigilancia sanitaria de las aguas de consumo en otros lugares.

El Inspector Provincial de Sanidad, el Doctor Call, ante el aumento de mortalidad experimentado en Madrid en 1920, mantenía que se debía, principalmente, al recrudecimiento de la gripe y a los procesos concomitantes asociados, que producían una gravedad especial en las personas con gripe. Respecto a la fiebre tifoidea, el doctor Call mantenía que los casos no eran preocupantes, y que "se lucha con ella con más seguridad de éxito, y, sobre todo, se puede evitar su propagación acudiendo a la vacuna de la enfermedad, sobre todo a la preparada con los mismos gérmenes de los enfermos de la actual etapa (vacuna autógena)”. (Aguado Marinoni, 1920, p. 6).

\subsubsection{Las medidas defensivas contra la fiebre tifoidea: medidas higiénicas dirigidas a la población y la vacunación antitífica}

Ya en 1920, el Inspector General de Sanidad en 1920, el Doctor Martínez Salazar, ante el incremento de casos de fiebre tifoidea en su visita a Miraflores de la Sierra propuso "proceder a la vacunación antitífica de todo el pueblo, así como de las demás poblaciones da la provincia de Madrid donde haya casos de fiebre tifoidea y sostengan algún comercio de alimentos con la capital” (Aguado Marinoni, 1920, p. 6).

Entre las medidas dirigidas a la población ante el incremento de casos de fiebre tifoidea en 1920, se realizaban recomendaciones a través de la prensa y desde el Gobierno Civil que versaban en torno a la necesidad de hervir la leche y el agua antes de ser consumidas, así como cocer los mariscos y verduras y no tomarlos en crudo. Otras de las medidas higiénicas fueron las recomendaciones en torno al aislamiento de los enfermos y la desinfección de los productos patológicos que pudieran contener gérmenes. Si bien, la escasez de alojamiento en la capital era un elemento que jugaba en contra del asilamiento de enfermos de manera fáctica. También la importancia del aseo personal, especialmente centrado en el lavado de manos antes de comer. 
Respecto a la vacuna antitífica, se presumía como la medida más eficaz. Martínez Salazar, Inspector General de Sanidad, declaraba lo siguiente sobre la vacuna contra la fiebre tifoidea: "Mi opinión, que es absolutamente preventiva. Las experiencias de todo el mundo y, sobre todo, las de la guerra última, vienen a darle tanta fuerza de convicción, que no creo que haya hoy nadie que se oponga a vacunar cuando menos a las personas que rodean los enfermos o que por cualquier circunstancia se encuentran más expuestas al contagio” (Aguado Marinoni, 1920, p. 6).

\subsubsection{Las medidas defensivas contra la fiebre tifoidea: el estudio de las aguas de abastecimiento}

Se criticaba la falta de tutela por parte del Estado para la lucha contra las enfermedades evitables. En palabras del Doctor Call, Inspector Provincial de Sanidad de Madrid: "El Estado en nuestro país no cotiza la vida de los ciudadanos en su verdadero valor. Si lo hiciera así, se asustaría de ver los millones que se pierden en España cada año a consecuencia de fallecidos por procesos infecciosos, por enfermedades específicas, por tuberculosis y por otras muchas causas y concausas que horroriza analizar".(Aguado Marinoni, 1920, p. 7).

En torno a la lucha contra las enfermedades evitables: "para luchar se necesitan armas, y los sanitarios disponemos sólo de promesas. No hay Gobierno que, lleno de buena intención, no hable de reformas sanitarias e intente acometerlas. No hay tampoco Gobierno que, al llegar el momento de consignar en presupuestos lo necesario para la sanidad, no empiece a cortar y a recortar sin compasión de ninguna especie. Liberales, conservadores, republicanos, socialistas..., todos, absolutamente todos, convienen en la necesidad de emprender una campaña sanitaria valiente; pero todos se quedan con la intención de hacerlo, y es lo cierto que en la capital de España no existe ni un hospital de epidemias, no existen los campamentos de aislamiento y desinfección necesarios, no existen parques ni institutos en número adecuado, y lo que hay, se ha hecho todo gracias a la perseverancia y la fe de esta clase de médicos, tan sufrida que asocia a todas sus empresas de corazón, y que lucha con armas y sin armas y hasta pegando puñetazos al viento. Para todo es posible la discusión, menos para la defensa de la vida, y lo que para esto se necesita, se discute y se regatea siempre de la manera más despiadada, más inconsciente y más suicida” (Aguado Marinoni, 1920, p. 7). 


\section{La mortalidad en Madrid durante el primer tercio del siglo XX}

El capítulo que aquí se presenta aborda el estudio de la mortalidad en la ciudad de Madrid durante el primer tercio del siglo XX.

Para atender de forma óptima a los patrones de mortalidad y obtener una visión temporal y espacial del fenómeno, se analiza la evolución de la mortalidad en la ciudad de Madrid desde dos perspectivas y a través de dos tipos de fuentes. Por un lado, se procede a la reconstrucción de series anuales con datos individuales agregados para el análisis de la mortalidad general y por causas transmitidas a través del agua y alimentos y, además, se realiza una comparativa entre dos periodos (1905-1907 y 1920-1922) para el análisis de la mortalidad de niños menores de cinco años mediante datos individuales procedentes del Registro Civil de Nacimientos y del Registro Civil de Defunciones de la ciudad que serán representados en la Infraestructura de Datos Espaciales histórica de la ciudad de Madrid (HISDI-MAD ${ }^{90}$ ). Con el enfoque espacial, no solo se pretende identificar la presencia de focos de mortalidad en la ciudad de Madrid, sino también analizar las condiciones de saneamiento de los barrios como determinantes del estado de salud de los individuos y, por lo tanto, como estos pueden ayudarnos a explicar la diferenciación de la mortalidad a nivel espacial. Esto permitirá obtener una visión completa de cómo fue el proceso de transición de la mortalidad en la capital.

Asimismo, trataremos de ver si las mejoras implementadas en la infraestructura urbana de saneamiento de la ciudad de Madrid, influyeron en la probabilidad de morir por enfermedades transmitidas a través del agua y alimentos en dos periodos temporales, empleando, para ello, los datos individuales recogidos del registro civil de defunciones: 1905-1906-1907 y 1918-1919-1920-1921-1922.

\footnotetext{
${ }^{90}$ HISDIMAD fue un producto del proyecto dirigido por Diego Ramiro Fariñas titulado, "Creación de una infraestructura de datos espaciales urbanos como plataforma de información geoespacial y sociodemográfica (IDE-URBANA)" (CSO2010-11485-E) y la información de base de los proyectos de investigación CSO2008-06130/SOCI y CSO2011-29970 del Plan Nacional (I+D) del Ministerio de Economía Competitividad. Se trata de un geoportal de cartografía y demografía histórica para la ciudad de Madrid realizado siguiendo los estándares y normativa de interoperabilidad del Open Geospatial Consortium (OGC). Esta Infraestructura de Datos Espaciales utiliza como cartografía histórica el "Plano de Madrid y pueblos colindantes" de 1900 del cartógrafo español Facundo Cañada López, y acompaña cartografía, fotografía aérea y ortofotografías para el período 1860-2012.Para el acceso a la plataforma, consultar el siguiente enlace. http://www.sdihistoricalmadrid.org/hisdimad/index.htm
} 


\subsection{El contexto}

Desde finales del siglo XIX la mala situación higiénico-sanitaria de la ciudad de Madrid fue objeto de preocupación, debido a las elevadas cifras de mortalidad, especialmente de la mortalidad en la infancia, que se experimentaron en la capital. En este sentido, desde mediados de los años setenta del siglo XIX, la prensa científico profesional, tanto en las Academias como en la Sociedad Española de Higiene, comenzaron a poner de manifiesto la importancia y urgencia de implantar medidas higienistas higiénicas? vinculadas al saneamiento urbano. Comienzan, de este modo, a realizarse estudios con el objetivo de conocer y analizar los posibles factores que influían en la alta mortalidad de la capital, valorando desde las condiciones topográficas, climatológicas y urbanas, hasta la situación en la que se encontraban las viviendas, hospitales y el sistema de evacuación de aguas fecales (Maria Isabel Porras Gallo, 2002, pp. 219-250). Cabe destacar que estos debates tuvieron suma importancia, especialmente en el momento en que la mejora de la higiene pública se tradujo en objeto de actuación de las autoridades municipales $^{91}$, poniendo en práctica toda una serie de mejoras higiénico-sanitarias que contribuyeron a atenuar enfermedades infecciosas, así como disminuir paulatinamente la mortalidad catastrófica ${ }^{92}$.

Los testimonios médicos de la época ponen de manifiesto una visión generalizada acerca de la situación de la ciudad de Madrid, con una elevada mortalidad infantil como rasgo característico de la capital. Esta sobremortalidad, especialmente infantil, se ha explicado por la influencia de factores asociados al proceso de industrialización, tales como el hacinamiento, la densidad de población, las pésimas condiciones higiénicas en la ciudad, la elevada frecuencia y variedad de las comunicaciones interpersonales, el uso común de los recursos, especialmente agua y alimentos, etc (David S Reher, 2001). Ante estos problemas, surge la necesidad de implementar medidas institucionales que permitieran reducir los niveles de mortalidad y mejorar las condiciones de vida en las

\footnotetext{
${ }^{91}$ Se puso de manifiesto la necesidad de llevar a cabo estudios de epidemiología, demografía, estadística, climatología y geografía médica, de manos del Ayuntamiento de Madrid, que reflejasen la realidad de la ciudad en las materias descritas. Especialmente relevante es el estudio llevado a cabo por Hauser en 1902 en el que llevó a cabo un estudio pormenorizado de la ciudad. HAUSER, Ph. (1902), Madrid bajo el punto de vista médico-social, Madrid, Sucs. Rivadeneyra, 2 vols

${ }^{92}$ Para ver más acerca de la política de protección de la salud pública tanto en España como en el resto de países europeos consultar Hauser, P., Madrid bajo el punto de vista médico - social, Madrid, 1902, pp. 319-371).
} 
ciudades, de manos de la corriente higienista por parte de médicos, políticos y reformistas en general (Alvaro, 1853; Chicote \& Eza, 1915; Hauser, 1902a; Ocaña, 2005).

Conocida es la expresión de Revenga (Revenga, 1904), en referencia a la ciudad de Madrid como la "ciudad de la muerte". Esta percepción de la ciudad, como lugar insalubre para vivir, lejos de ser exclusiva para el ámbito madrileño, fue captada por igual para buena parte de las ciudades europeas. El denominado urban penalty ha sido estudiado por la historiografía a nivel internacional para explicar la sobremortalidad urbana que tuvo lugar en las ciudades desde el siglo XIX y parte del siglo XX, tomando como factores explicativos principales el proceso de urbanización e industrialización característico de las ciudades en crecimiento (Kearns, 1988; Preston \& Van de Walle, 1978; Ramiro-Fariñas \& Sanz-Gimeno, 2000). La influencia de los efectos de la industrialización sobre el estado de salud de la población urbana ha sido históricamente documentada como factores determinantes del estado de salud de las poblaciones (Alvaro, 1853; Gorostiza, 2014).

Sin embargo, para el caso español, existen evidencias que permiten pensar que el "urban penalty" o castigo urbano, no se experimentó como tal, sino que los procesos de baja inscripción y producción de los datos, unidos a los efectos de composición, influyeron en parte en el exceso de mortalidad registrado en las ciudades (Eugercios \& Fariñas, 2016; Fariñas \& Oris, 2016; Woods, 2003). Además, el exceso de mortalidad urbana estaba sobredimensionado por el asentamiento de instituciones sanitarias que acogían a población no nativa de la ciudad (Diego Ramiro Fariñas, 2007). Este hecho, unido a la tradicional manera de tomar indicadores para medir las dinámicas poblacionales, como por ejemplo el crecimiento vegetativo, puede llevar a una idea de la ciudad menos dinámica de lo que en realidad fue.

Para el contexto madrileño de principio del siglo $\mathrm{XX}$, ambas perspectivas nos muestran un enfoque que nos permitirá profundizar en el estudio de la mortalidad sucedida en la ciudad de Madrid desde un doble enfoque, temporal y espacial. Atenderemos a las características vinculadas a la habitabilidad de la ciudad (relacionadas con la infraestructura de saneamiento urbano) y de mortalidad.

En España, los estudios de carácter histórico sobre la reducción de la mortalidad y sus causas asociadas, se han centrado en la descripción del fenómeno de manera agregada. 
Sin embargo, la mayoría de estos han tomado como casos de análisis la dimensión estatal o regional, o en algún caso la agregación de municipios, siguiendo el modelo del Cambridge Group for the History of Population tanto en la agregación de registros, como en las tradicionales reconstrucciones de familias de Louis Henry y el propio Cambridge Group. de manera que apenas encontramos estudios que hayan tomado como fuente de análisis datos individuales o tomando como unidades de estudio elementos menores dentro de una propia ciudad.

Con el objetivo de tener una panorámica general del fenómeno, primeramente, recurriremos al análisis de la distribución de la mortalidad general y la mortalidad por causas de muerte trasmitidas a través del agua y alimentos de carácter infeccioso mediante datos agregados.

En un segundo lugar, nos centraremos en el análisis de la distribución de la mortalidad de niños menores de cinco años, por causas de muerte por enfermedades transmitidas a través del agua y alimentos. Para este segundo proceso, emplearemos datos individuales, que serán posteriormente agregados para realizar un análisis de distribución espacial a nivel de barrio.

Asimismo, el capítulo finalizará con el análisis de la posible influencia que tuvieron las mejoras en el saneamiento urbano en la salud de los madrileños, mediante modelos de regresión logística binaria realizados con datos individuales del Registro Civil de defunciones de la ciudad de Madrid para los periodos 1905-1906-1907 y 1918-19191920-1921-1922.

La complementariedad entre el análisis de la mortalidad general junto con el análisis de la mortalidad en la infancia tiene su explicación en que ésta segunda constituye uno de los componentes básicos dentro de la mortalidad general durante el proceso de la transición demográfica (Pérez Moreda et al., 2015, p. 147). Con la disminución de la mortalidad en este periodo de la vida se produjeron ganancias en la esperanza de vida y un crecimiento de la población más rápido. Si bien la tasa de mortalidad infantil ha sido utilizada tradicionalmente como indicador para medir las condiciones generales de la salud de las poblaciones, en la actualidad se considera que la mortalidad juvenil se comporta como un mejor indicador (Palloni, Milesi, White, \& Turner, 2009). 


\subsection{La evolución de la mortalidad general en la ciudad de Madrid}

Uno de los cambios más importantes que se han producido en las poblaciones humanas en los dos últimos siglos ha sido, sin lugar a dudas, el descenso de la mortalidad. Numerosas investigaciones se han realizado en España en torno al tema de la transición de la mortalidad. Pioneros en este ámbito fueron los trabajos de Marcelino Pascua en 1934, con su obra La mortalidad infantil en España (Pascua, 1934).

El periodo de estudio que aquí se contempla, se enmarca dentro del contexto demográfico del declive de la mortalidad a nivel europeo. Europa comienza a experimentar un descenso sostenido de la mortalidad durante la segunda mitad del siglo XIX (Schofield \& Reher, 1991). En el contexto español, el proceso de transición demográfica que propició el descenso de la mortalidad infecciosa (Dopico \& Reher, 1998), tuvo su inicio en la último tercio del siglo XIX, acelerándose a principios del siglo XX (Dopico \& Reher, 1998; Pérez Moreda et al., 2015; D. a. A. S. G. Ramiro Fariñas, 2002; D. y. A. S. G. Ramiro Fariñas, 1997).

El descenso de la mortalidad por enfermedades infecciosas se asocia a la mejora de infraestructuras de higiene urbana, como los sistemas de distribución y evacuación de aguas, en especial en la mortalidad juvenil por ser más perceptivo a la influencia que el ambiente higiénico y familiar (Preston \& Van de Walle, 1978; Woods, 2003).

La primera de las tres fases que caracterizan el declive de la mortalidad en España, tuvo lugar entre finales de 1870 y 1910, periodo en el cual se produce "más de la cuarta parte del referido descenso" (Dopico \& Reher, 1998). Fue durante estos años cuando Madrid experimenta una serie de cambios, cuya dinámica se perfila muy similar a la ocurrida en el conjunto de España (Sanz Gimeno, 1999).

Durante el periodo 1904-1930 la tasa bruta de mortalidad en la ciudad de Madrid, según datos del Anuario de la ciudad de Madrid, pasó de representar cerca de un 28 \% a un 17 \%o. Si tenemos en cuenta la proporción de las enfermedades infecciosas, que constituyeron la mayor parte de la mortalidad por este tipo de causas, la mortalidad por enfermedades transmitidas a través del agua y alimentos junto a las transmitidas a través del aire son las que mayor proporción representan. A excepción de los años epidémicos donde el peso de la infecciones transmitidas por aire sobre la mortalidad general se 
incrementaba notoriamente, como fue en el caso de la epidemia de gripe de 1918 (Chowell, Erkoreka, Viboud, \& Echeverri-Dávila, 2014; Ramiro et al., 2018).

Gráfico 10-1. Tasa Bruta de Mortalidad en Madrid (1904-1930)

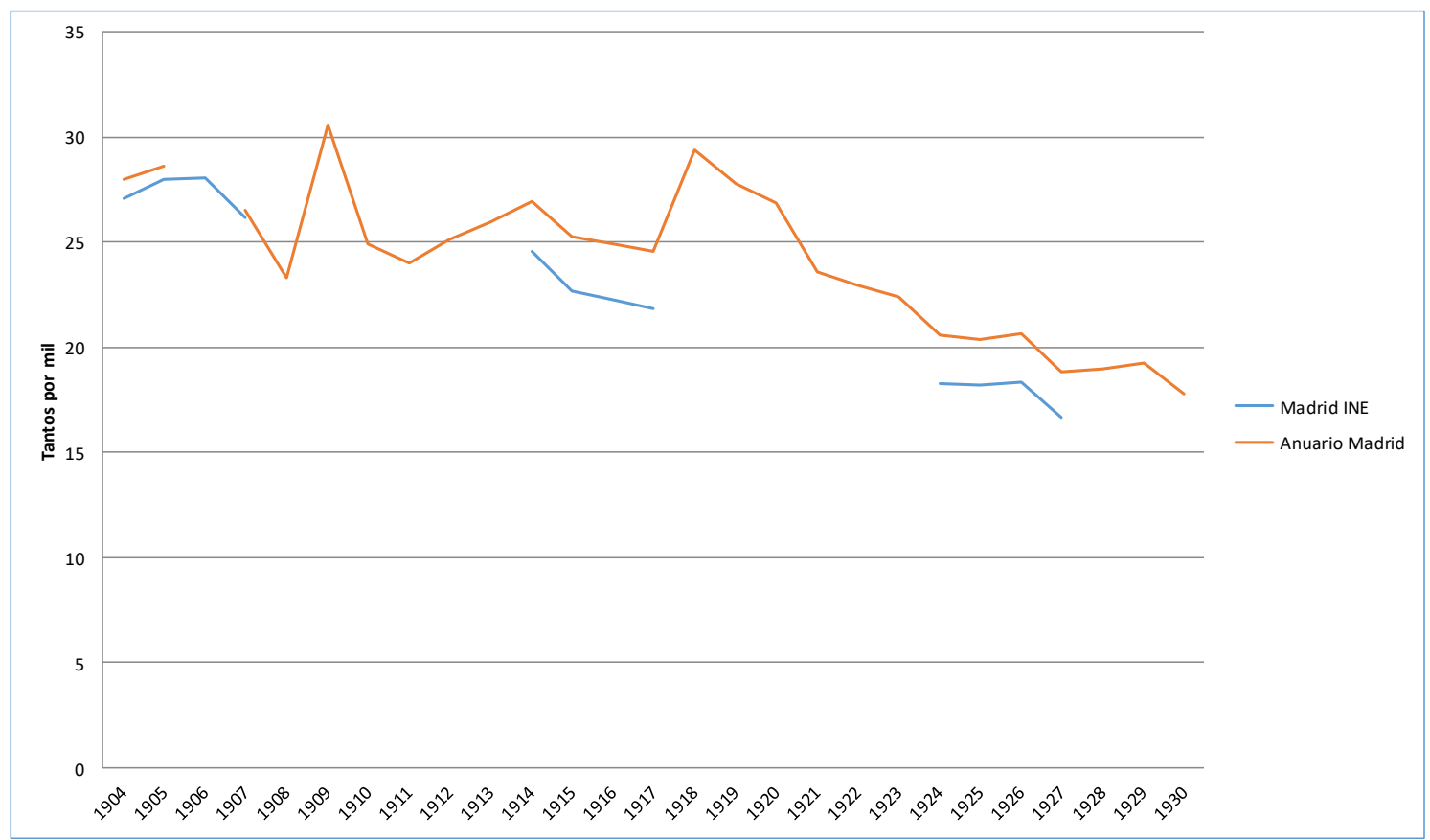

Fuente: elaboración propia

Atendiendo a la evolución de la mortalidad general en la ciudad de Madrid en el primer tercio del siglo XX a nivel de distrito, podemos ver de manera clara que existen diferencias en los niveles de mortalidad y su evolución. En términos generales, podríamos agrupar los distritos en tres grandes grupos, en relación a su tasa bruta de mortalidad a lo largo del periodo. Los distritos de Chamberí, Latina y Universidad tuvieron unas tasas de mortalidad cercanas a las de la media de Madrid en conjunto. Los grupos extremos corresponden a los distritos de Buenavista, Centro, Hospicio y Palacio por un lado, representando valores menores, e Inclusa y el distrito Hospital, por otro, con las mayores tasas de mortalidad. El distrito Congreso es un caso "especial", en tanto en cuanto parte a inicio del periodo con una tasa de mortalidad de $23 \%$, por debajo de la media madrileña, y finaliza la década de los 20’s con una tasa de mortalidad superior al $26 \%$ o. El cambio de tendencia de la mortalidad en este distrito comenzó a suceder unos años antes de 1925, momento en que la institución de la Inclusa de Madrid se 
traslada de manera oficial de la Calle Mesón de Pareces, situada en el barrio de Cabestreros, a la Maternidad de O’Donnel, en el barrio de Plaza de Toros, perteneciente al distrito de Congreso.

En términos generales, puede afirmarse que aquellos distritos que presentaban mayor mortalidad eran los mismos en los que existían peores condiciones sanitarias e higiénicas y en ellos se concentraban la mayor parte de las viviendas y barrios insalubres, careciendo de alcantarillado, suministro de agua corriente, con habitáculos carentes de luz y aire. Además, allí vivían los jornaleros y clases menesterosas (Maria Isabel Porras Gallo, 2002). Sin embargo, pese a que resulta indudable que las diferencias higiénico-sanitarias presentes entre los distritos de la ciudad de Madrid fueron factores influyentes en la mortalidad, no se debe pasar por alto que un componente de la sobremortalidad existente tiene como determinante la presencia de instituciones de beneficencia y/o sanitarias en determinadas zonas de la ciudad.

Gráfico 10-2. Tasa Bruta de Mortalidad de Madrid a nivel de distrito (1904-1929)

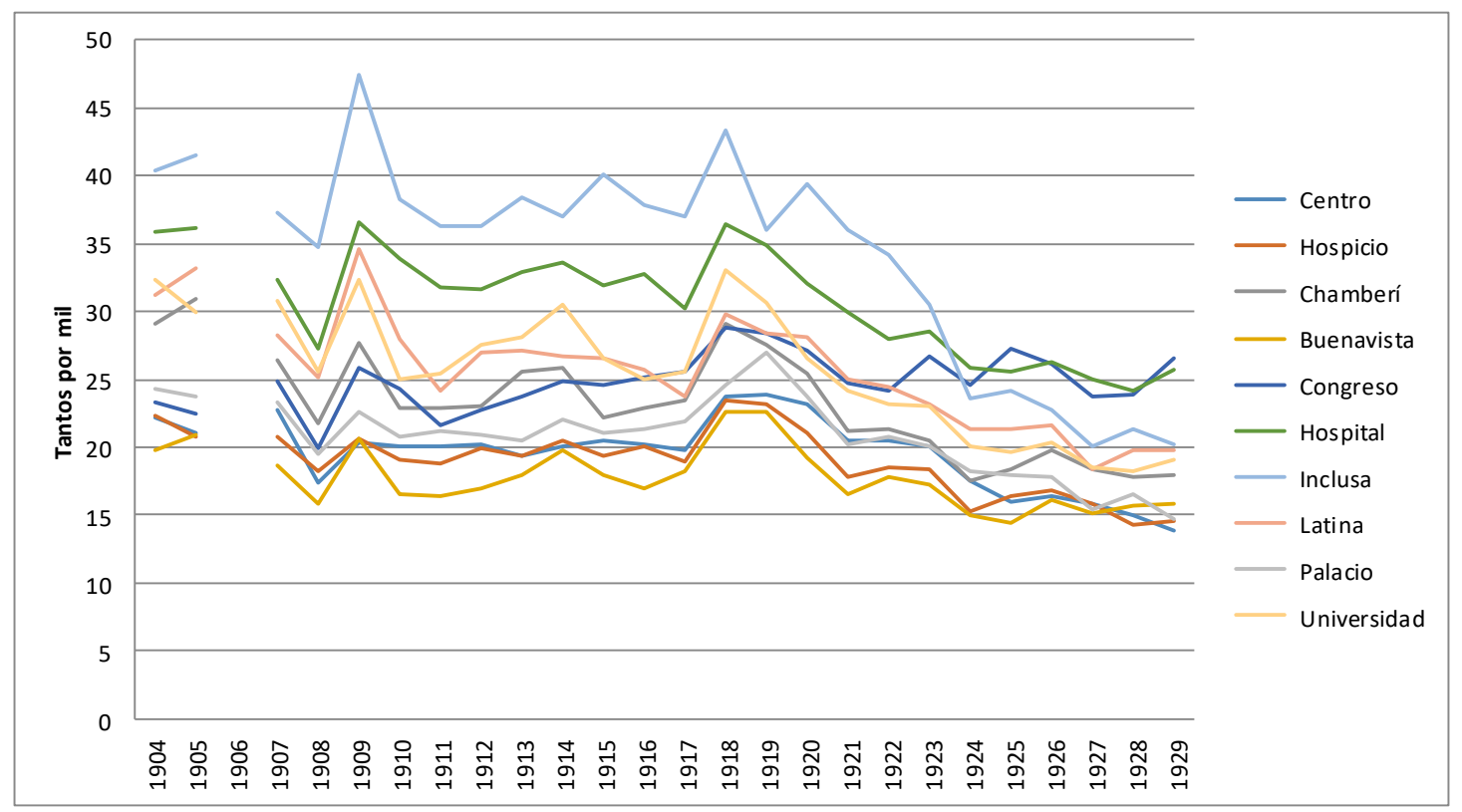

Fuente: Elaboración propia

Para poder vislumbrar este efecto podemos hacerlo de mejor manera atendiendo a la distribución de la mortalidad y su evolución a nivel de barrio. Una buena manera de hacerlo es mediante la creación de mapas de calor, dada la magnitud temporal (desde 1904 a 1930) y espacial (100 barrios de la ciudad) para poder realizar una comparativa teniendo en cuenta las dos dimensiones.(Gráfico 10-3). 
Atendiendo a la distribución de la mortalidad teniendo en cuenta el componente geográfico a nivel de barrio, podemos observar, de manera clara, que existían patrones diferenciados, persistiendo a lo largo del primer tercio del siglo $\mathrm{XX}$ una tendencia de concentración en determinadas zonas de la ciudad. Como podemos ver a partir de la representación gráfica, destacan sobremanera dos barrios; Doctor Fourquet, perteneciente al distrito Hospital, y el barrio de Cabestreros, del distrito Inclusa. Para el primer caso, las altas tasas de mortalidad se producen durante todo el periodo de estudio, pero para el caso del barrio de Cabestreros, vemos que sólo lo hace hasta llegada la segunda década del siglo XX. La explicación a este hecho no la encontramos en elementos de mejora de la higiene e infraestructura urbana, ya que, si fuera el caso, estaríamos ante un descenso paulatino, imposible de explicar con un corte anual como es el presente. El año en que se produce el descenso en la mortalidad en el barrio de cabestreros coincide con el momento en que se produce el traslado de la Inclusa. Podemos afirmar que la mortalidad infantil que se registra para Madrid está seriamente afectada por la mortalidad expósita (Revuelta, 2011, p. 166), de manera que, al menos en principio, la ubicación de la casa de expósitos en la ciudad de Madrid influyó en la evolución de la mortalidad a nivel de barrio. 
Gráfico 10-3. Tasa Bruta de Mortalidad de los Barrios de Madrid (1904-1930).

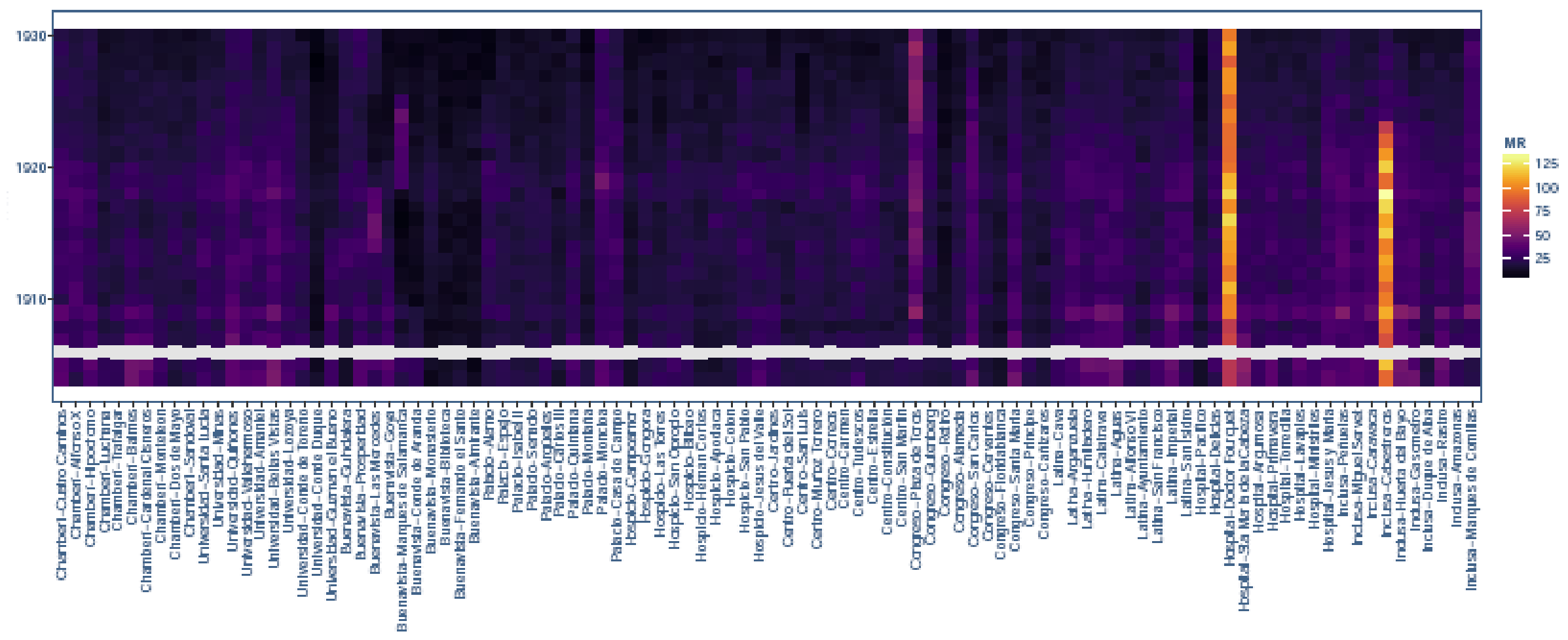

Fuente: Elaboración propia. Datos obtenidos de los Anuarios Estadísticos de la ciudad de Madrid para los años señalados 
Para conocer más sobre la dinámica de la influencia de la mortalidad institucional en los cálculos de mortalidad, partiendo de la hipótesis de la sobrestimación en determinadas zonas de la ciudad por el componente de la mortalidad institucional (Revuelta Eugercios \& Ramiro Fariñas, 2016), se ha procedido a realizar un análisis descriptivo comparado, teniendo en cuenta la mortalidad total a nivel de barrio por causas de muerte por enfermedades infecciosas transmitidas por el agua y alimentos y la mortalidad total por estas causas con la exclusión de la mortalidad institucional ${ }^{93}$. Como puede verse a través de los gráficos, la variación se produce, especialmente, por las defunciones de niños producidos en la institución de la Inclusa de Madrid $^{94}$, teniendo en cuenta las disimilitudes en la comparativa realizada para la mortalidad por diarrea y enteritis que era la que más afectaba a la mortalidad en la infancia.

En lo que respecta a la distribución por edad de la mortalidad por diarrea y enteritis, se observa que afecta, en mayor medida a los niños menores de un año.

Gráfico 10-4. Distribución por edades de la mortalidad por diarrea y enteritis en Madrid, 1905-1921.

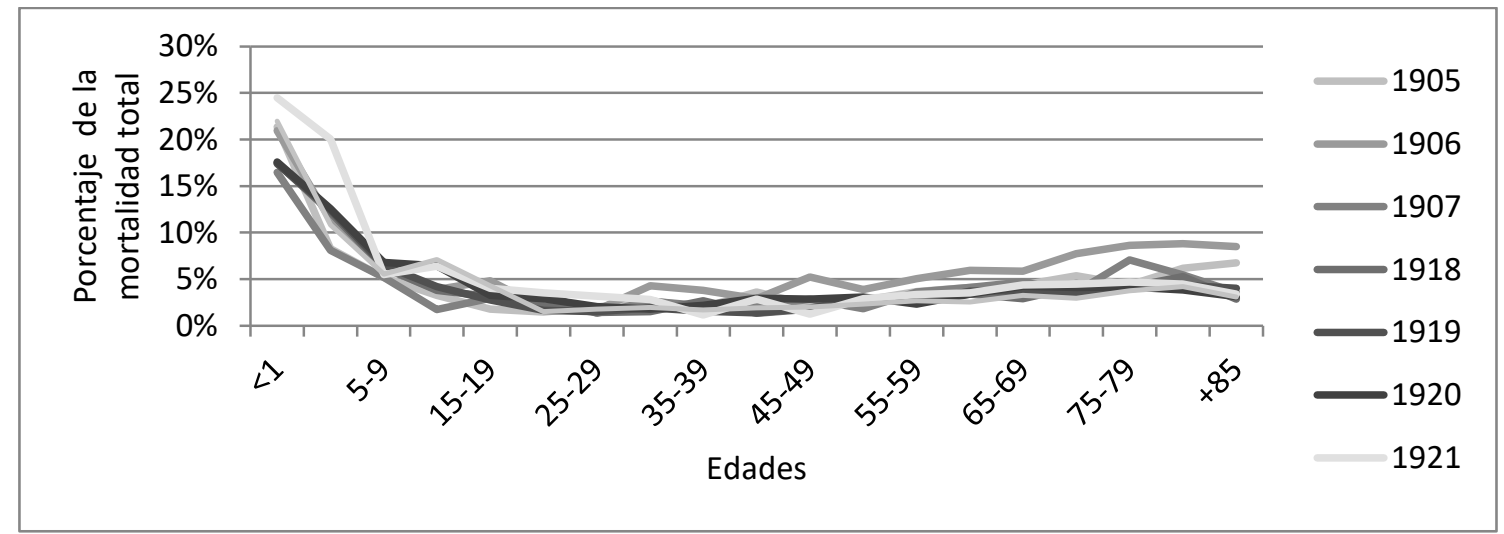

Fuente: elaboración propia. Datos individuales del registro civil de defunciones para los años seleccionados.

\footnotetext{
${ }^{93}$ Como ya se ha apuntado en el apartado del presente trabajo correspondiente a la metodología, la mortalidad institucional se ha detectado en los partes de defunciones teniendo en consideración los siguientes aspectos; En el campo dirección o en el campo cuarto o en el campo observación: la mención explícita del nombre de una institución, asociando la dirección completa y el barrio correspondiente; la identificación de una dirección que se corresponde con una institución, asociando el nombre de la institución y el barrio correspondiente.

${ }^{94}$ Para conocer de manera detallada más aspectos sobre la mortalidad en la Inclusa de Madrid, así como otra información pormenorizada acerca de esta Institución, consultar (Revuelta Eugercios, 2011)
} 
Atendiendo a la distribución de la mortalidad a nivel de barrio por enfermedades infecciosas transmitida por agua y alimentos (gráfico 10-6), que tiene en consideración la mortalidad por las causas señaladas diferenciando la mortalidad total (es decir, la mortalidad institucional y la no institucional) y la mortalidad que tiene sólo en consideración la mortalidad no institucional (gráfico 10-7), puede verse claramente una dispersión de casos obtenida en éste segundo gráfico respecto al primero.

Atendiendo a la distribución por edades de la mortalidad por enfermedades transmitidas por agua y alimentos en la ciudad de Madrid, podemos observar que afectaban en mayor medida a los menores de un año y al grupo de edad de 10 a 14 años.

Gráfico 10-5. Distribución por edades de la mortalidad por agua y alimentos como proporción del grupo de edad. Madrid (1905-1907 Y 1918-1922).

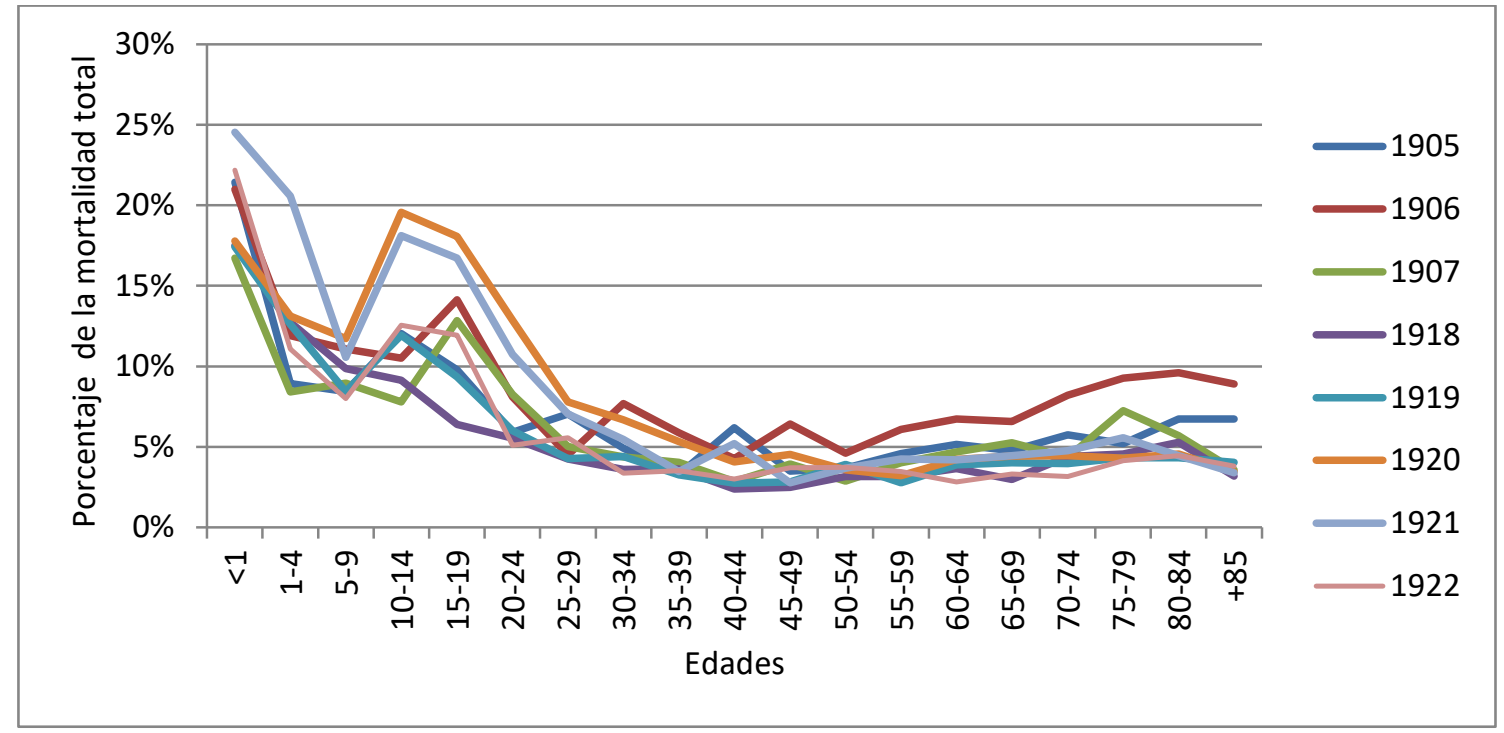

Fuente: elaboración propia. Datos individuales del registro civil de defunciones para los años seleccionados.

Sin embargo, teniendo en consideración las causas incluidas en la clasificación seguida para clasificar las causas de muerte (ver apartado de metodología), es decir, la diarrea y la enteritis (gráficos 10-10 y 10-11), por un lado y la fiebre tifoidea (Gráficos 10-8 y 109), por otro, el comportamiento de la distribución es claramente disímil entre estas dos enfermedades si se tiene en consideración la mortalidad total por causa (mortalidad institucional y no institucional) respecto a si se toma la mortalidad institucional.

Así, en el caso de la fiebre tifoidea, el resultado de la comparativa entre los gráficos nos muestra que no existen demasiadas diferencias. Sin embargo, tomando la distribución 
de la mortalidad a nivel de barrio por diarrea y enteritis, la dispersión de los casos se ve muy acentuada si se atiende a la mortalidad total por estas causas (mortalidad institucional y no institucional) respecto a la mortalidad no institucional. Tomando el primer caso, la mortalidad por diarrea y enteritis (al igual que sucedía en caso de tomar el conjunto de la mortalidad por enfermedades transmitidas a través del agua y alimentos) la mortalidad se concentra en el barrio de Cabestreros. La explicación ante este hecho radica en la mortalidad institucional que tenía lugar, concretamente, en la inclusa de la ciudad, ubicada en dicho barrio, caracterizándose por una exposición al riesgo a morir extraordinaria (Revuelta, 2011).

Además, hay que tener en cuenta que el componente predominante de la distribución por causas de muerte por causas transmitidas a través del agua y alimentos lo sustenta la mortalidad por diarrea y enteritis, afectando, en su mayoría, a la mortalidad en la infancia y, especialmente, a la mortalidad infantil. 
Gráfico 10-6. Proporción de las defunciones por enfermedades transmitidas por agua y alimentos por barrio. Como porcentaje de las muertes totales de cada barrio, por años. Mortalidad institucional y no institucional

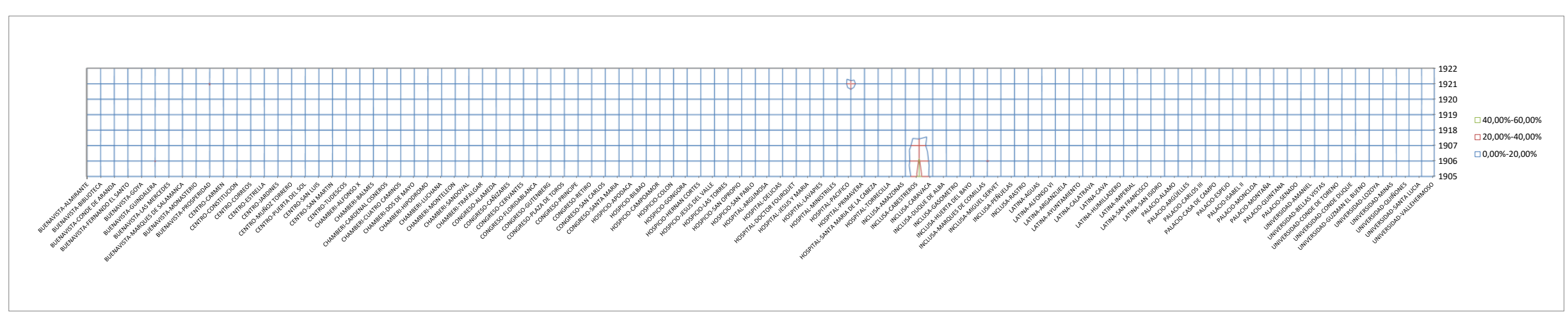

Gráfico 10-7. Proporción de las defunciones por enfermedades transmitidas por agua y alimentos por barrio. Como porcentaje de las muertes totales de cada barrio, por años. Mortalidad no institucional

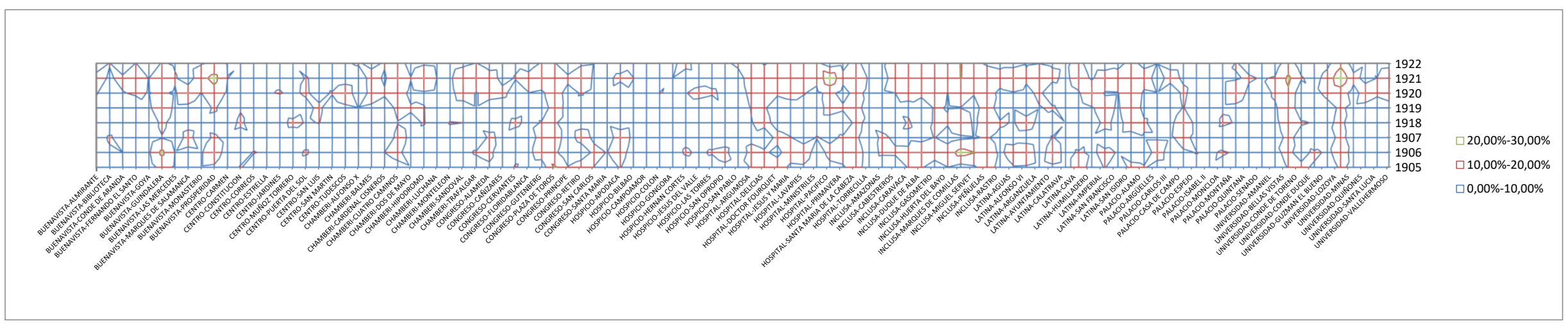

Fuente: elaboración propia. Datos individuales del registro civil de defunciones para los años seleccionados. 
Gráfico 10-8. Proporción de las defunciones por fiebre tifoidea por barrio. Como porcentaje de las muertes totales de cada barrio, por años. Mortalidad institucional y no institucional.

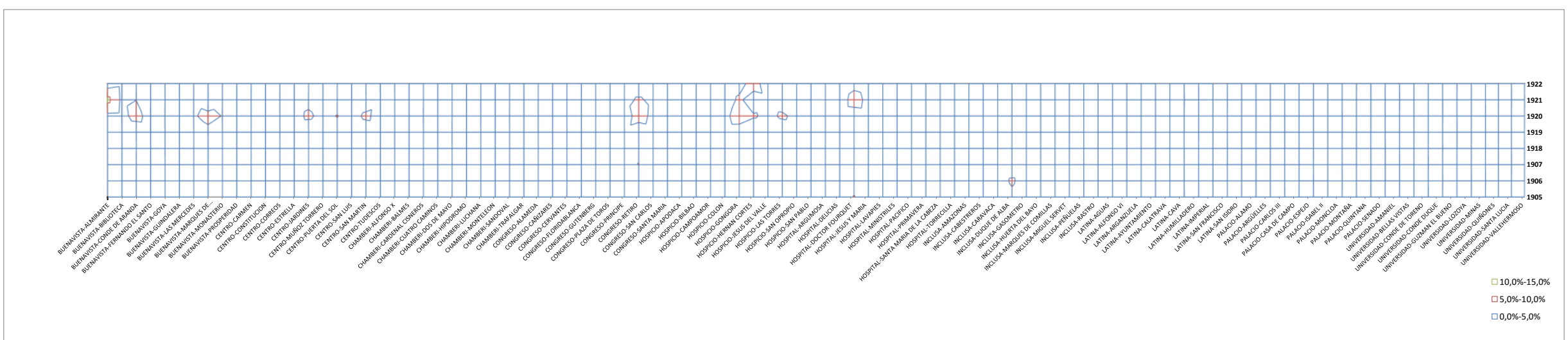

Gráfico 10-9. Proporción de las defunciones por fiebre tifoidea por barrio. Como porcentaje de las muertes totales de cada barrio, por años. Mortalidad no institucional.

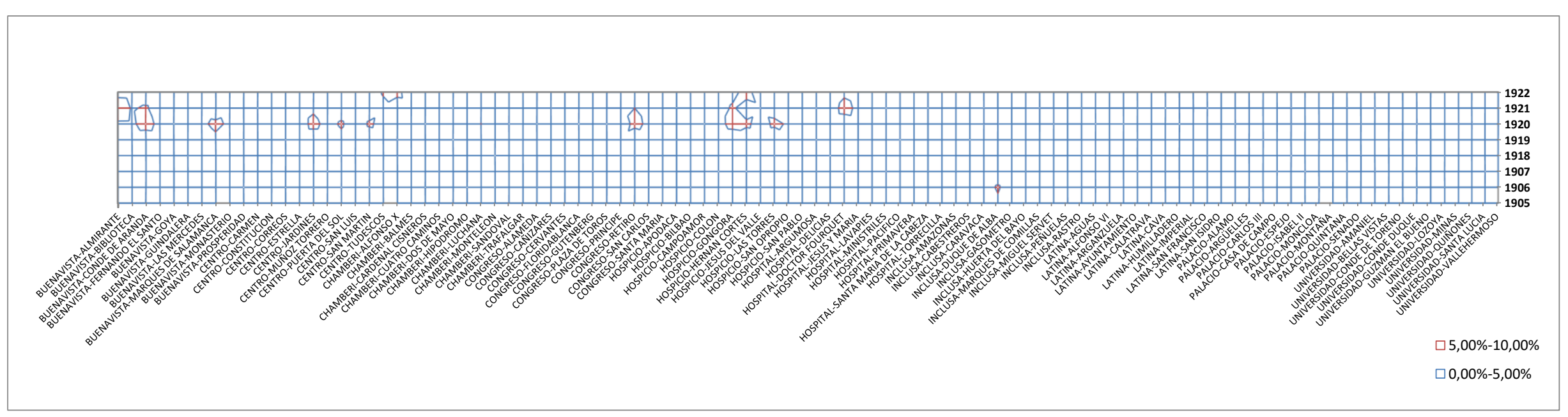

Fuente: elaboración propia. Datos individuales del registro civil de defunciones para los años seleccionados. 
Gráfico 10-10. Proporción de las defunciones por diarrea y enteritis por barrio. Como porcentaje de las muertes totales de cada barrio, por años. Mortalidad institucional y no institucional.

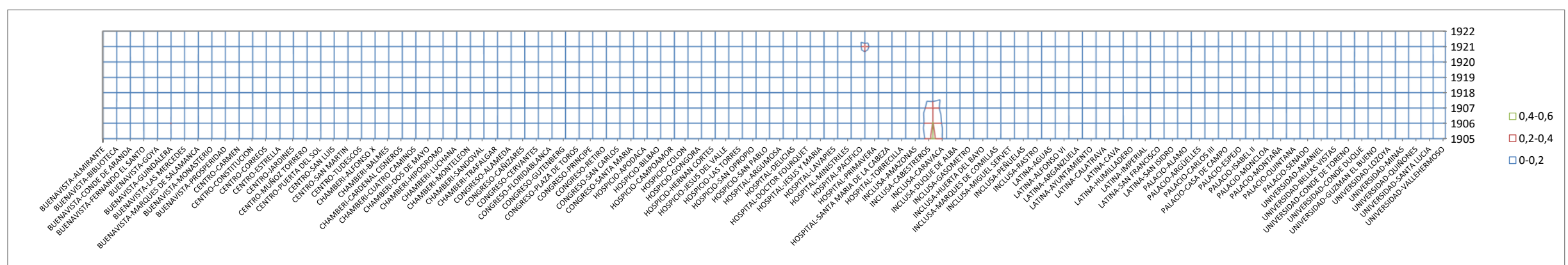

Gráfico 10-11. Proporción de las defunciones por diarrea y enteritis por barrio. Como porcentaje de las muertes totales de cada barrio, por años. Mortalidad no institucional

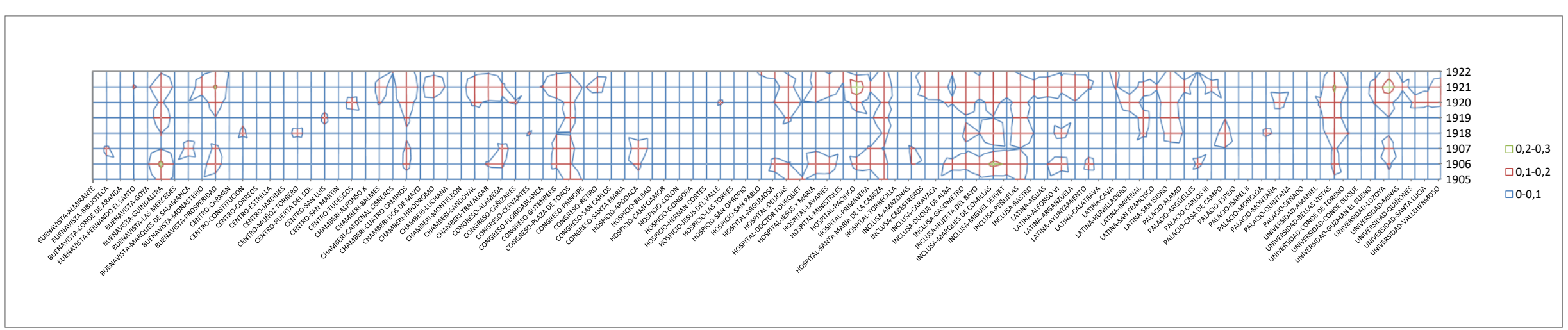

Fuente: elaboración propia. Datos individuales del registro civil de defunciones para los años seleccionados. 


\subsection{La mortalidad de niños menores de cinco años a nivel de barrio.}

Teniendo en cuenta que hay una larga tradición de utilizar estimaciones de salud para la identificación de áreas de privación en los asentamientos urbanos y que dentro de esas estimaciones de la salud la mortalidad en la infancia ha sido uno de los más utilizados en el pasado (debido al papel crucial dentro de las estimaciones de la esperanza de vida en general), trataremos de conocer, primeramente, las diferencias existentes en la mortalidad de niños menores de cinco años en los diferentes barrios de la ciudad de Madrid.

En los siguientes mapas (Mapas 10-1 y 10-2) hemos representado la probabilidad de morir antes de los 5 años (Early Chilhood Mortality Rate ECMR, en inglés) estandarizada para ambos períodos de tiempo (1905-1907 y 1920-1922) con respecto a cada distrito de la ciudad de Madrid, constituyendo un total de 100 barrios. Para el cálculo, se han usado los datos del Registro Civil de Defunciones y del Registro Civil de Nacimientos para los años señalados. Los cálculos se han representado a nivel de barrio usando la IDE Histórica de Madrid.

Atendiendo al análisis de la distribución por barrios, podemos ver que para el período 1905-1907 (Mapa 10-1), el ECMR (5q q $_{0}$ fue bastante alto, 384 por mil, pero con niveles muy desiguales dependiendo de las áreas de la ciudad, que van desde 109 por mil a niveles de mortalidad extrema en el área donde se encontraba la inclusa de Madrid. En 1920-1922 (Mapa 10-2), los niveles de ECMR disminuyeron sustancialmente, con un promedio de 279 por mil para la ciudad y con extremos que pasaron de 55 por mil en áreas de la ciudad, como el barrio Senado, a niveles elevados en los distritos del sur, especialmente los correspondientes al distrito de Inclusa (mortalidad "distorsionada" principalmente por la inclusión en el numerador de muchos niños del resto de la ciudad y colindantes que nacían en la Casa de Maternidad o que eran abandonados en la Inclusa de la ciudad).

Precisamente vemos que las zonas con menor ECMR $\left.{ }_{5} q_{0}\right)$ corresponden a algunos de los barrios menos céntricos del noreste de la ciudad, que estaban ocupados en su mayor parte por las clases aristocráticas y acomodadas que por su posición económica no sienten la presión de la escasez y carestía de las viviendas como las demás clases 
sociales (León Peralta 1926:22). Por el contrario, aquellos barrios con mayor número de viviendas pobres y con la mayor parte de los bajos precios de alquiler fueron habitados por buena parte del contingente inmigrante de la ciudad.

La distribución geográfica de la mortalidad de niños menores de cinco años en la ciudad sigue gran parte de la literatura y está más presente en las zonas más pobres y más densamente pobladas, las áreas con mayor porcentaje de población analfabeta y las zonas de la ciudad donde se asentaron los migrantes recientes. Atendiendo a los datos ofrecidos por León Peralta (1926) en su estudio sobre Madrid y la vivienda, tres son los distritos con mayor número de habitantes por vivienda entre 1915 y 1920: Hospital, Congreso y Latina. Se trata de 3 distritos bastante parecidos en lo que respecta a la posición socioeconómica de sus habitantes, siendo, principalmente, empleados y obreros. Cabe destacar que se trata de tres distritos que tienen entre sus edificios casas de corredor, corralas, de modo que (...) sólo entre los tres cuentan con 102 casas de más de 200 habitantes y con 26 de más de 300, es decir, casi el doble de las que en iguales condiciones suman los siete distritos restantes (León Peralta 1926:24). Además, las condiciones de luz y aire eras deficientes. Si bien, es necesario señalar que el distrito Congreso, el que tiene mayor número de habitantes por vivienda, es el que presenta más diferencias de entre los tres, ya que la composición social de sus barrios es desigual. La explicación del volumen de individuos por vivienda radica en dos razones principalmente: el gran número de hoteles y pensiones familiares y también a contar entre sus barrios, algunos como los de Floridablanca y Retiro, que son barrios de casas espaciosas en las que se alberga a la servidumbre. Pero también en la aglomeración de habitantes por vivienda influye en este distrito la existencia de barrios como los de Gutenberg, donde la presencia de tejares era palpable (como los tejares de Molina y las casas del camino de Vicálvaro) y Plaza de Toros, con las casas de los tejares de Sixto y de la Elipa. Los restantes distritos acusan también una gran proporción de habitantes por vivienda, y ello hace que en el quinquenio de 1915 a 1920, época en que el problema de la vivienda empezó a adquirir graves proporciones, el hacinamiento, la aglomeración de habitantes por vivienda se manifestaba en todos los distritos (León Peralta 1926:22) como ya se ha visto en otros capítulos. 


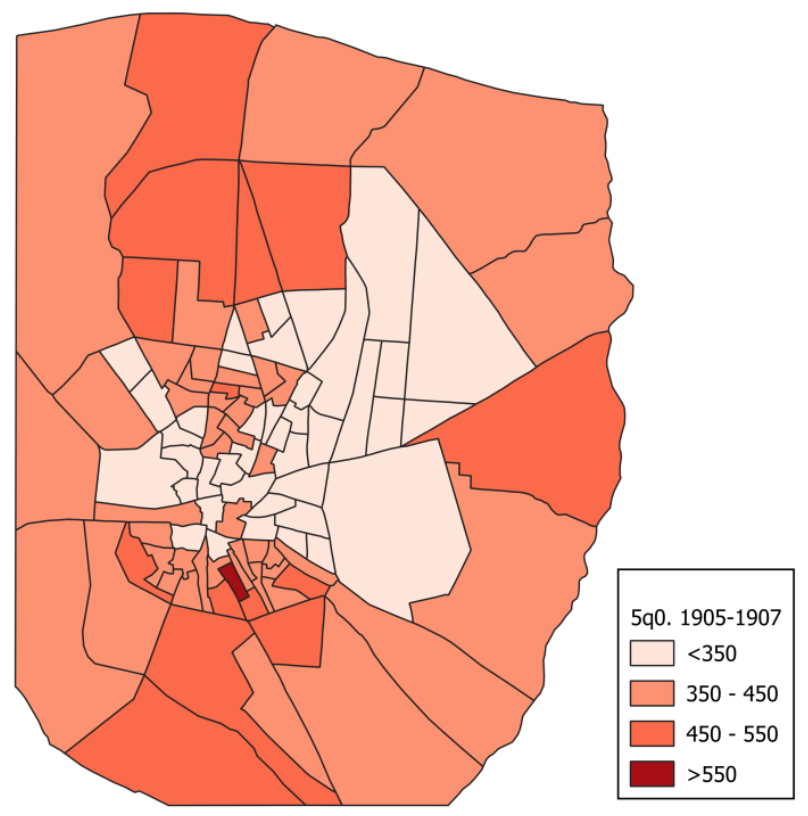

Mapa 10-2. ECMR (5q0) estandarizado para la ciudad de Madrid. 1920-1922

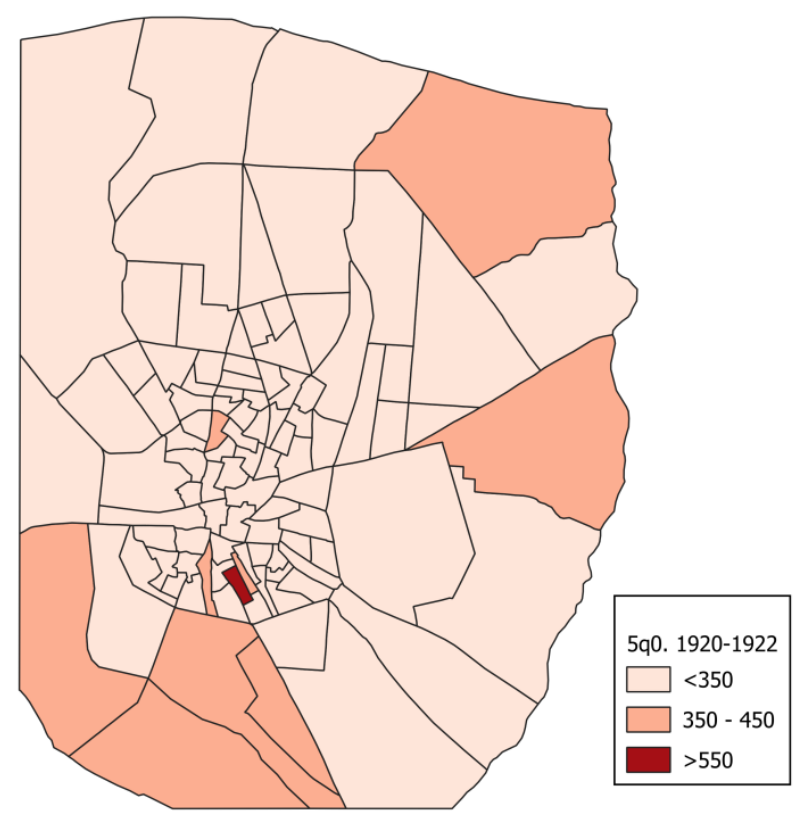

Fuente: elaboración propia. Datos individuales del registro civil de defunciones para los años seleccionados. 
A luz de los resultados de la representación espacial existen marcadas diferencias en la de niños menores de cinco años dentro de la ciudad. Las tasas de mortalidad más altas se encuentran en áreas ubicadas en el sur y noreste de la ciudad. Estas áreas fueron las receptoras de los migrantes que llegaron a Madrid en un período en que la ciudad casi duplicó su población. Además, debe tenerse en cuenta que el crecimiento de la población de la ciudad de Madrid no fue espacialmente homogéneo. La mayoría de los distritos que formaban parte de la periferia de Madrid, fueron los que experimentaron un mayor crecimiento. Esto tiene su explicación de que los inmigrantes, en su mayoría de otras partes de España, terminaron residiendo en los suburbios de la periferia, debido al menor coste de la vivienda (León Peralta, 1926, p. 22). Sin embargo, se aprecia una sustancial disminución de ECMR $\left({ }_{5} \mathrm{q}_{0}\right)$ entre los dos periodos, en la mayoría de los barrios.

Para estudiar con más detalle las características de la mortalidad en la ciudad, decidimos utilizar la información sobre la causa de muerte, codificada, como ya hemos indicado anteriormente, atendiendo a la primera clasificación internacional de causas de muerte de Bertillon y la clasificación diseñado por Bernabeu et al. (2003). En respuesta a la distribución de ECMR $\left({ }_{5} \mathrm{q}_{0}\right)$ para enfermedades infecciosas en la ciudad de Madrid, vemos que es muy similar al descrito anteriormente en el patrón espacial de niños menores de cinco años en general.

\subsubsection{Distribución de mortalidad por causas y factores explicativos}

A la hora de determinar la importancia de los distintos elementos sobre el declive de la mortalidad, el análisis de la estructura de mortalidad por causas ${ }^{95}$ puede ser un buen indicador (Bernabeu Mestre, 1993; Caselli, 1991; Pérez Moreda et al., 2015). Por ello, y a modo de contextualización de la evolución de la mortalidad durante el primer tercio del siglo XX, el análisis que se pretende llevar a cabo intenta examinar la implicación de determinadas causas de muerte en el proceso de transición de la mortalidad.

El análisis de la mortalidad por causas, nos permitirá conocer de mejor manera los elementos y mecanismos que explican la evolución de la mortalidad. Los niveles y la estructura de la mortalidad en cada momento vienen condicionados por una serie de circunstancias. Los marcos explicativos de la mortalidad (transición epidemiológica, la

\footnotetext{
${ }^{95}$ Ver capítulo sobre metodología
} 
transición sanitaria o las formulaciones de Thomas McKeown), a grandes rasgos, se han basado precisamente en las causas de muerte para sustentar sus explicaciones, enfatizando la importancia de unos u otros factores para poder dar explicación a la caída de la mortalidad.

Entre los grupos de factores que han sido utilizados para dar explicación a la transición de la mortalidad, cabe destacar aquellos que atañen al nivel de vida y el estatus nutritivo de la población, el papel de las madres y su capacidad para llevar adecuadamente la crianza de sus hijos, las medidas de salud pública destinadas a limitar el contagio y/o la extensión de las enfermedades, los avances de la ciencia médica y de la práctica sanitaria (Pérez Moreda, Reher, \& Sanz Gimeno, 2015, p. 80).

Teniendo en consideración que el descenso de la mortalidad por enfermedades infecciosas se asocia a la mejora de infraestructuras de higiene urbana, como los sistemas de distribución y evacuación de aguas, en especial en la mortalidad juvenil por ser más sensible a la influencia del ambiente higiénico y familiar (Preston \& Van de Walle, 1978; Woods, 2003), nos centraremos en la distribución de la mortalidad por enfermedades infecciosas en niños menores de 5 años, tomando como factor explicativo la distribución del alcantarillado a nivel de barrio en la ciudad de Madrid. Para ello, hemos calculado la ECMR ( $\left.{ }_{5} \mathrm{q}_{0}\right)$ estandarizada para los años 1905-1907 y 1920-1922 (Figura $\mathrm{x}$ ). Se observa que, en términos generales, existe una relación entre la menor cobertura de alcantarillado y una mayor mortalidad por enfermedades infecciosas a nivel de barrio. 
Mapa 10-3. ECMR (5q0) Estandarizada por enfermedades infecciosas y cobertura del sistema de alcantarillado en la ciudad de Madrid, 1905-1907 y 1920-1922.
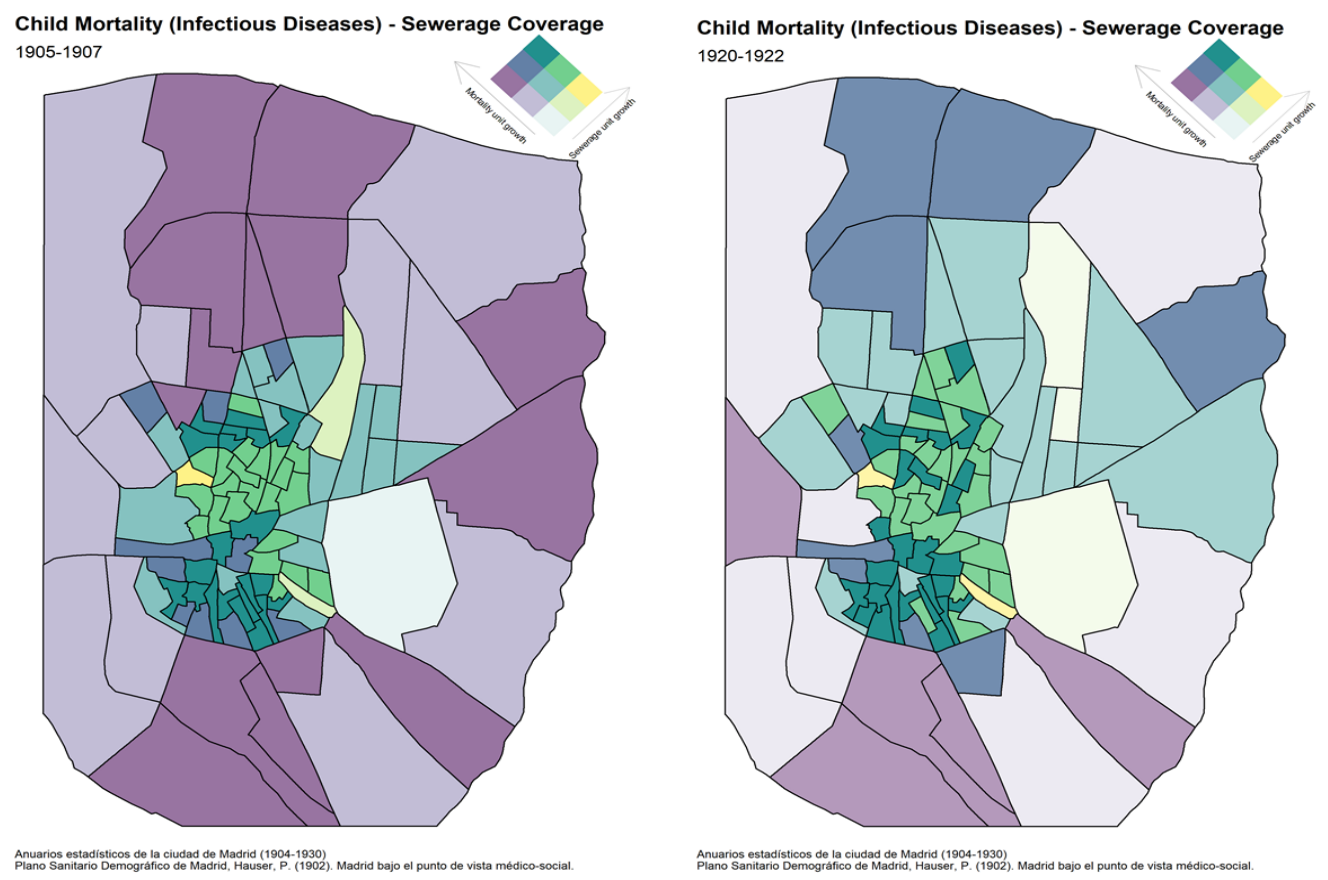

Fuente: elaboración propia. Datos individuales del registro civil de defunciones para los años seleccionados.

Dentro de las enfermedades infecciosas, en el descenso de la mortalidad tuvieron especial relevancia las enfermedades respiratorias (enfermedades transmitidas por aire) y las gastrointestinales (enfermedades transmitidas por agua y alimentos), con una incidencia especial en la reducción de los niveles de mortalidad en la infancia (Caselli, 1991; D. a. A. S. G. Ramiro Fariñas, 2002; Schofield \& Reher, 1991). Las deficiencias higiénico-sanitarias en el hogar, tales como el hacinamiento en las viviendas o la falta de ventilación y la densidad de población tuvieron importancia suma en la propagación e incidencia y letalidad de las enfermedades (Barnes, 1995), especialmente de las de carácter respiratorio como la tuberculosis, bronquitis, neumonía y gripe. En el caso de las enfermedades trasmitidas a través del agua y alimentos, como la difteria, el cólera y las diarreas infantiles, la ausencia de una adecuada red de alcantarillado y suministro de agua potable jugaron un papel importante.

En esta sección, nos centraremos en este último grupo de causas de muerte, mediante el análisis de la evolución de la mortalidad por causas infecciosas transmitidas por agua y alimentos seleccionadas (1900-1930), así como la distribución de la mortalidad de niños 
menores de cinco años por enfermedades transmitidas a través del agua y alimentos (tomando como caso de análisis la ciudad de Madrid a nivel de distrito y de barrio).

Para ello, nos centraremos en dos periodos de estudio, 1905-1907 y 1920-1922, realizando una comparación tanto temporal como espacial. La justificación de haber tomado los años señalados viene dada porque se trata de dos periodos diferenciados de manera clara por alcance de la red de alcantarillado; el primero de ellos claramente deficiente, y el segundo con la mayor parte de la zona urbanizada de Madrid con acceso a la red. De este modo, cabría esperar que en aquellos barrios en los que en 1905-1907 no estaban todavía construida la red de alcantarillado y que sí lo estuviera en 19201922, las tasas de mortalidad de menores de 5 años por enteritis y diarrea y fiebres tifoideas se deberían haber visto reducidas. Se pretende, por un lado, conocer posibles diferencias en los patrones de mortalidad de menores de 5 años en los barrios de Madrid $y$, por otro, ver si la extensión en la red de alcantarillado, como mejora higiénico sanitaria llevada a cabo por el ayuntamiento de Madrid, se tradujo en una mejora de los patrones de mortalidad de los niños menores de cinco años por causas específicas (diarrea, enteritis y fiebres tifoideas).

\subsubsection{Mortalidad por enfermedades transmitidas a través del agua y alimentos y evolución de la infraestructura de saneamiento ${ }^{96}$}

La relación entre las peores condiciones de habitabilidad y saneamiento con una mayor mortalidad, ya fue advertida por los contemporáneos de la época (Chicote, 1930; Hauser, 1902a). Bien es cierto que se llevaron a cabo intervenciones puntuales orientadas a la mejora de la higiene de la ciudad, pero no fue hasta pasada la epidemia de gripe española cuando comienza la puesta en marcha de un plan de saneamiento para la ciudad: comienza la prohibición de fosas sépticas, se produce la reorganización de los servicios de limpieza, se moderniza el laboratorio municipal, se construyen baños y servicios públicos, se produce la extensión de la distribución de aguas, entre otras medidas (Huertas, 2002, p. 272; Maria Isabel Porras Gallo, 2002).

\footnotetext{
${ }^{96}$ Dado que ya se ha tratado en los capítulos iniciales del presente trabajo, no nos centraremos, en el presente capítulo en la historia del abastecimiento de agua ni del sistema de evacuación de aguas.
} 
Las causas de mortalidad de enfermedades transmitidas por agua y alimentos representaron, junto a las enfermedades transmitidas por aire, el grupo de enfermedades con mayor presencia sobre la mortalidad de Madrid. Su incidencia se presenta tanto sobre la mortalidad infecciosa como sobre la mortalidad general.

Atendiendo a la distribución de la mortalidad de niños menores de cinco años por enfermedades trasmitidas a través del agua y alimentos, se observa un patrón desigual para los dos periodos de estudio. Atendiendo al periodo 1905-1907 (Mapa 10-4), puede observarse que la mortalidad se concentra en los barrios del Extrarradio noreste y sur. El mayor valor, tal y como cabía esperar, corresponde al barrio de Cabestreros, lugar donde se ubicaba la Inclusa de la ciudad.

Teniendo en cuenta el periodo correspondiente a 1920-1922 (Mapa 10-5), la mortalidad por enfermedades transmitidas a través del agua y alimentos sigue concentrándose en los mismos barrios que lo hacía en el periodo de 1905-1907, hay que señalar que en el periodo de 1920-1922 se incrementa el número de barrios con mayor mortalidad. En este sentido, en 1905-1907 un total de treinta y ocho barrios aparecen representados por una ECMR $\left({ }_{5} q_{0}\right)$ superior al 40, incrementándose a cincuenta y tres en el periodo de 1920-1922. Especialmente, la situación empeora en este último periodo en el barrio de Santa María de la Cabeza. Atendiendo de manera particular a éste caso, en el año 1900 disponía de una cobertura de red de alcantarillado de cerca de un 13\%, mientras que, a la altura de 1929, ésta era de un $63 \%{ }^{97}$. Respecto a la cobertura de redes de agua, atendiendo a los indicadores sobre éstas fuentes, en el año 1929, estaba abastecido por el Canal de Isabel II en un $46 \%$ de la superficie del barrio y un $15 \%$ por la Hidráulica Santillana. A priori, al menos en lo que atiende a la cobertura de alcantarillado (dado que no disponemos información que nos permitan conocer la evolución del sistema de abastecimiento de agua, sino sólo sobre 1929), la situación del barrio a este aspecto mejoró, por lo que cabría esperar que la incidencia de la mortalidad por enfermedades transmitidas a través del agua y alimentos también lo hiciera. Sin embargo, atendiendo a los valores de la proporción de abastecimiento de agua y de red de evacuación descritos, nos pone en la antesala de comenzar a pensar sobre la importancia de la secuencia de la implementación de éstas medidas de higiene en infraestructura urbana, así como en los posibles efectos de la parcialidad del sistema.

\footnotetext{
${ }^{97}$ Según el Plan de Obras de 1913-1923, éste debería haber llegado al 64\%
} 
Mapa 10-4. ECMR (5q0) estandarizado por enfermedades transmitidas por agua y alimentos para la ciudad de Madrid. 1905-1907

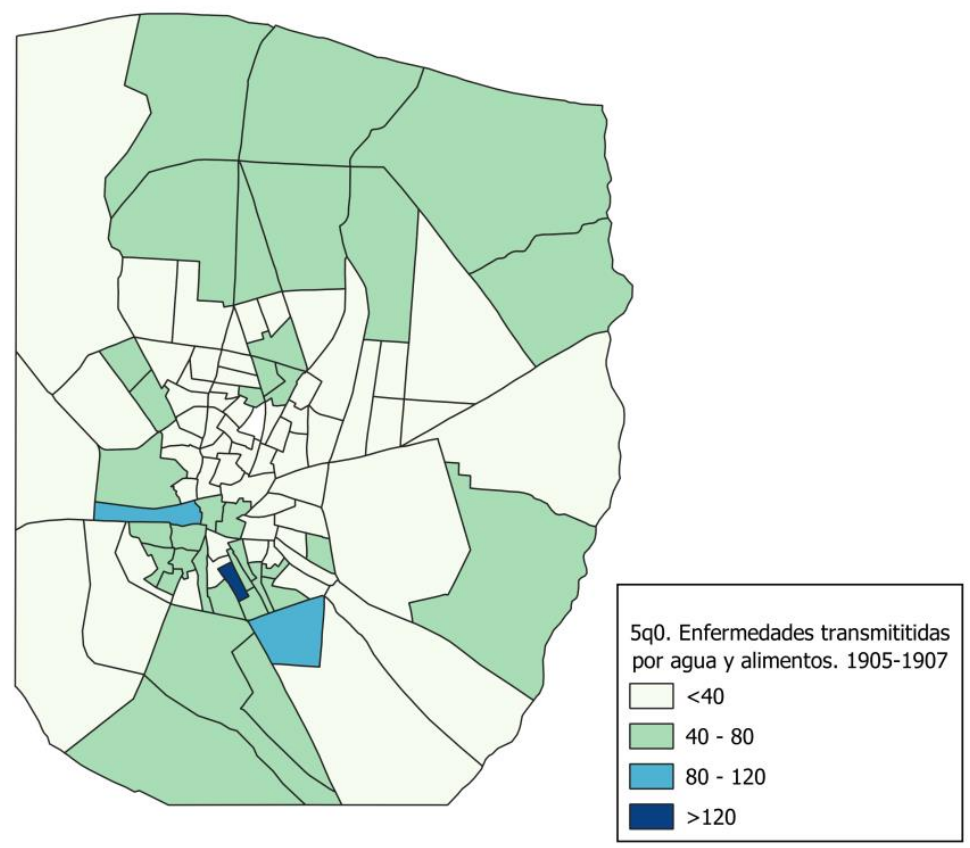

Mapa 10-5. ECMR (5q0) estandarizado por enfermedades transmitidas por agua y alimentos para la ciudad de Madrid. 1920-1922

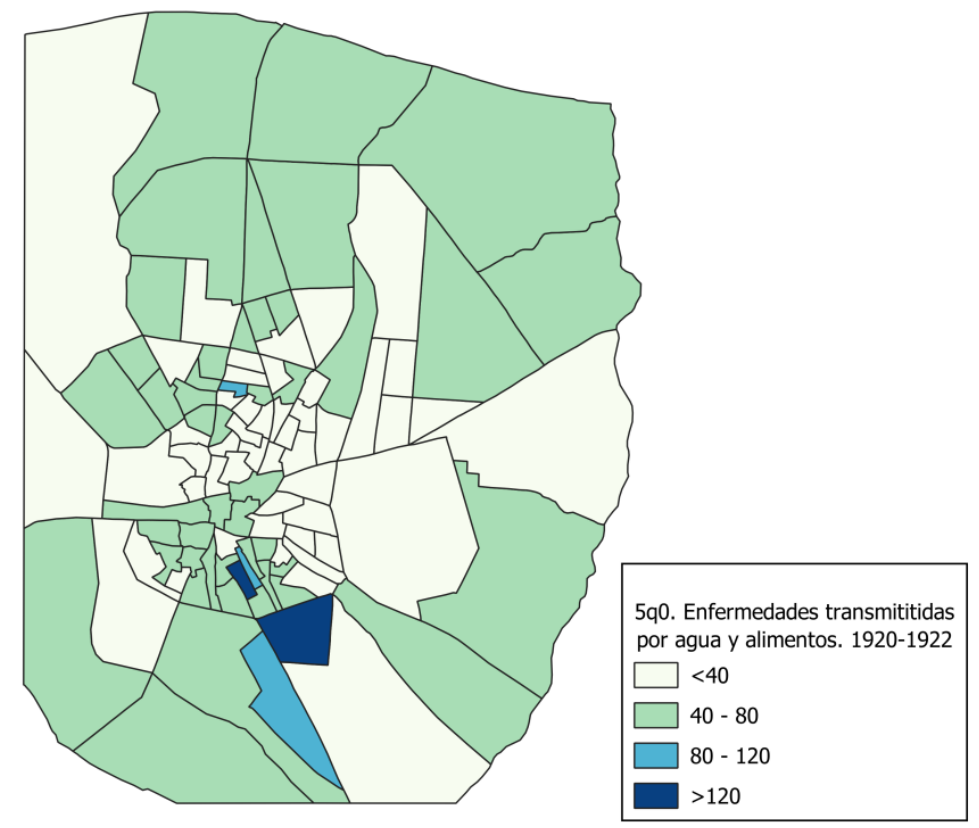

Fuente: elaboración propia. Datos individuales del registro civil de defunciones para los años seleccionados. 
En este sentido, una de las razones que, muy probablemente, podrían estar detrás de estas diferencias espaciales es la disímil distribución de los sistemas de red de alcantarillado y red de distribución de agua de la Ciudad de Madrid y su implementación, que no fue realizada de manera conjunta.

Asimismo, hay que tener en consideración que todavía en 1929, los sistemas de alcantarillado y de agua abastecían, principalmente, la zona del interior la ciudad, mientras que otras partes, en especial la parte el sur y el norte del Ensanche y Extrarradio no tenían una red de distribución de agua y de evacuación suficiente. Así lo atestiguaban autores como Chicote (director del Laboratorio Municipal de 1898 a 1932) que en 1930, en su reporte sobre las actuaciones anuales del Laboratorio Municipal, consideraba que las condiciones del servicio no eran suficientes, de forma que, de cara a mejorar las condiciones de salubridad de Madrid, las actuaciones municipales deberían tener como principales objetivos, entre otros, ampliar la dotación de agua, cuidando de su abundancia y pureza y continuar la obra del alcantarillado.

La combinación de malas condiciones de vivienda, zonas densamente pobladas y la ausencia de instalaciones sanitarias mínimas podrían facilitar la propagación de enfermedades infecciosas en esas zonas, en este caso principalmente enfermedades gastrointestinales infecciosas. 

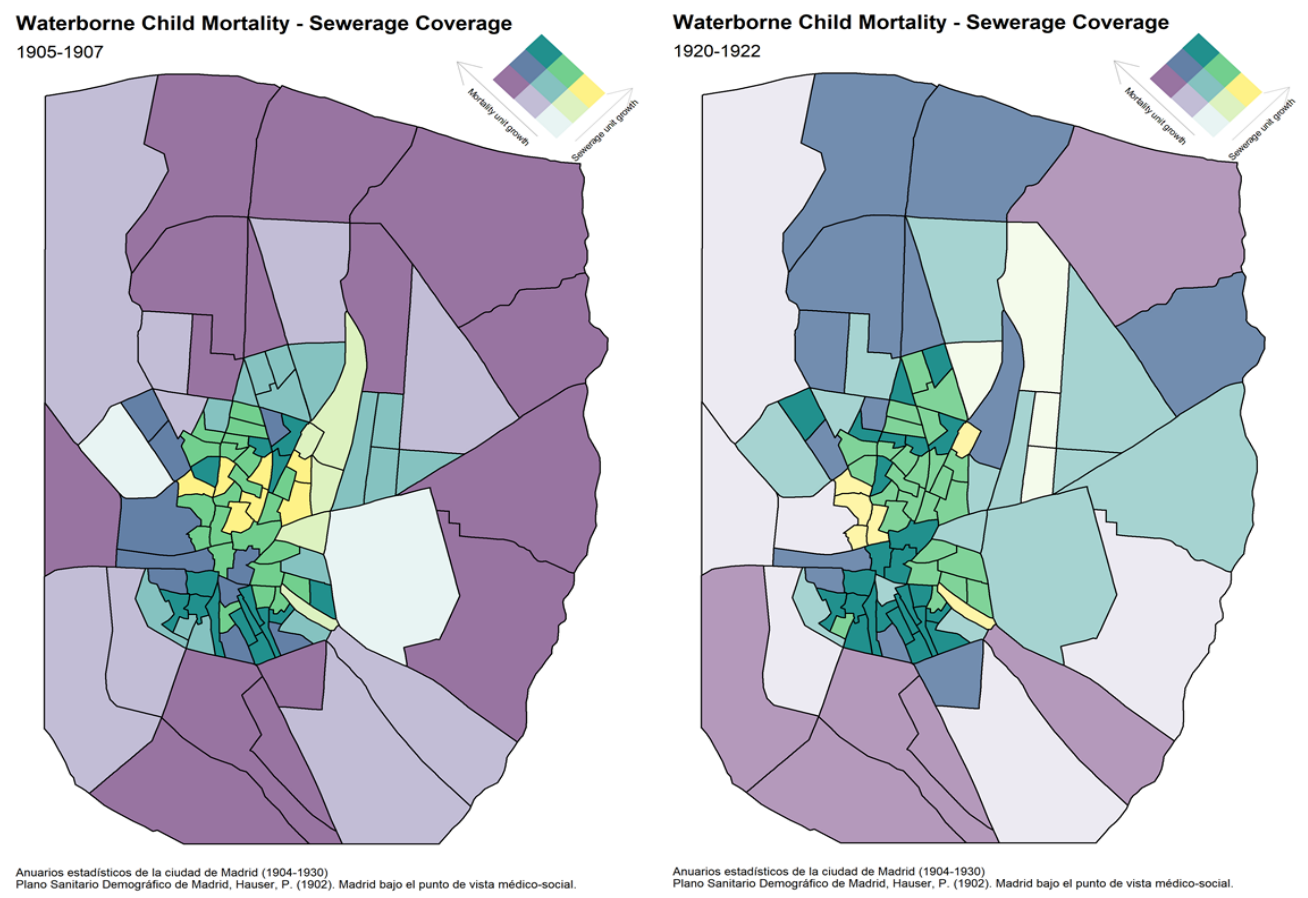

Fuente: elaboración propia. Datos individuales del registro civil de defunciones para los años seleccionados.

Atendiendo a la mortalidad por causas de muerte relacionadas con agua y alimentos de menores de cinco años y su asociación espacial con la cobertura de alcantarillado, se encuentra que, en la comparación entre periodos, podemos ver que en 1920-1922 toda la zona correspondiente al noreste y sureste de la ciudad (a excepción del barrio de Pacífico), muestra una tendencia clara de disminución de la mortalidad de menores de cinco años por enfermedades transmitidas a través del agua y alimentos. Precisamente, aquellas zonas de la ciudad que experimentaron un mejor acondicionamiento de la infraestructura de alcantarillado. Las zonas del extrarradio, tanto norte como sureste, experimentan las mayores tasas estandarizadas de mortalidad de menores de cinco años por enfermedades transmitidas a través del agua y alimentos en ambos periodos (barrios del norte como Bellas Vistas y Cuatro Caminos o Marqués de Comillas en el sur), así como los barrios de Gasómetro, Peñuelas y Santa María de la Cabeza. El hecho de que la consolidación y ampliación de la red moderna de alcantarillado comenzase en 1866 y no finalizase hasta a 1939, con el abastecimiento a los barrios del ensanche y del extrarradio de la ciudad, en la medida en que, por primera vez, se estableció un Plan coordinado de alcantarillado para la ciudad -Plan general de saneamiento del subsuelo de Madrid, 1909-, provocó que las diferencias entre barrios permaneciesen. 
La asociación entre zonas de la ciudad que estuvieron provistas de una buena red de alcantarillado pero que muestran a la altura de los primeros años de la segunda década del siglo XX una alta mortalidad ECMR $\left({ }_{5} \mathrm{q}_{0}\right)$, corresponden a los barrios del interior de la ciudad que estaban cercanos a los barrios del ensanche y algunos de los que compusieron el mismo donde se localizaban zonas de desagüe de las alcantarillas. Esto nos anima a pensar que el hecho de que meramente existiera una conducción de evacuación sin que, a la par, lo hiciera una red de agua, podría estar detrás de la explicación de parte de los resultados que mostraremos posteriormente. En estos casos, la red de alcantarillas funcionaba más bien como red de depósitos, funcionando como red de evacuación solamente con la ayuda del agua de lluvia.

Sin embargo, a priori, se pone de manifiesto que las mejoras higiénico urbanísticas que se pusieron en práctica en la ciudad y, especialmente, la mejora y extensión del abastecimiento de agua a los barrios altos de la capital y el aumento de la red de alcantarillado, se tradujo en una reducción de la mortalidad de niños menores de cinco años en Madrid a principios de siglo XX.

En términos generales, se observa una relación existente entre la mortalidad diferencial vinculada a la estructuración social, económica, higiénica y urbana, así como la importancia de la presencia en la capital de algunas instituciones benéfico-asistenciales en las tasas de mortalidad.

Atendiendo a la mortalidad por diarrea para niños menores de dos años a nivel de distrito para el periodo de 1904 a 1929 (Gráfico 10-12), se observa una tendencia descendente en todos los distritos de Madrid, a excepción del distrito Congreso, y coincidente temporalmente con el traslado de la Inclusa de su local de Mesón de Paredes a la Maternidad de O'Donnell (Alvarez-Sierra, 1952).

En un primer periodo, los distritos de Buenavista, Centro, Congreso, Hospicio y Palacio se caracterizaron por tener cifras más bajas de mortalidad. Las tasas de mortalidad por diarrea para menores de dos años caracterizaron la alta mortalidad de los distritos de Inclusa (hasta mitad de los años 20) y más tarde a Congreso. Los distritos restantes, tuvieron valores parecidos a los de la media de Madrid en conjunto. 


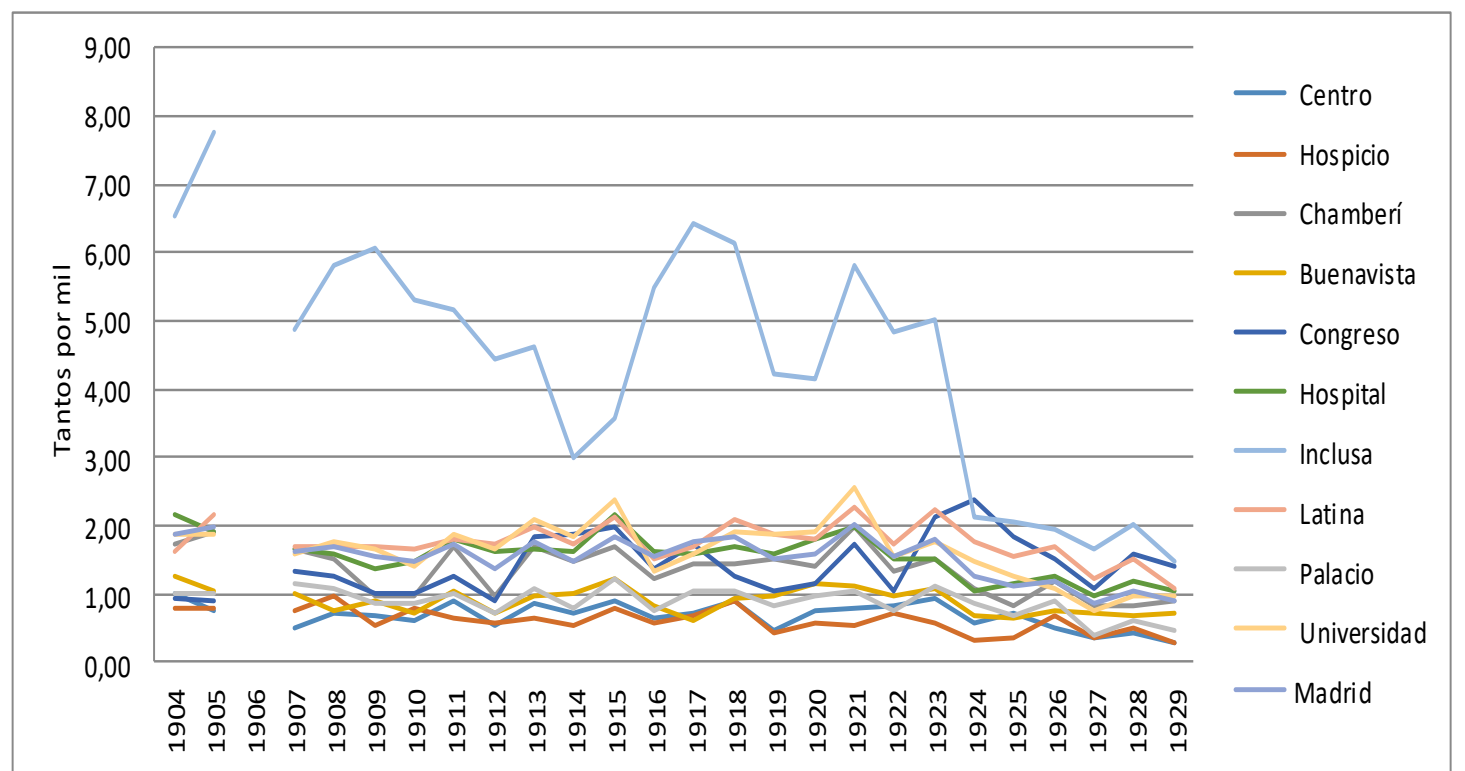

Fuente: Elaboración propia. Datos obtenidos de los Anurarios Estadísticos de la ciudad de Madrid para los años seleccionados.

Respecto a los barrios que entre el periodo 1904 y 1930 mostraron una mayor tasa de mortalidad fueron Gasómetro, Las Mercedes, Senado, Álamo, Retiro, Jardines, Santa Lucía, Delicias, Vallehermoso, Gutenberg, Alameda, Prosperidad, Marques de Comillas, Cuatro Caminos, Plaza de Toros.. Sin embargo, esto no significó necesariamente que tuvieran una mayor mortalidad que la media general de la ciudad de Madrid en el año fin de nuestro periodo de estudio. Así sucede con barrios como Senado, Álamo, Retiro y Jardines, que pese a que haber sufrido un aumento general de la mortalidad por diarrea en menores de dos años, en 1930 tenían una tasa bruta de mortalidad por esta causa de muerte por debajo de 0,9, que era la media de la ciudad de Madrid. Muy por encima estaban los barrios de Prosperidad (4,15) Marqués de Comillas $(7,36)$, Cuatro Caminos $(9,66)$ o Plaza de toros $(13,82)$. 


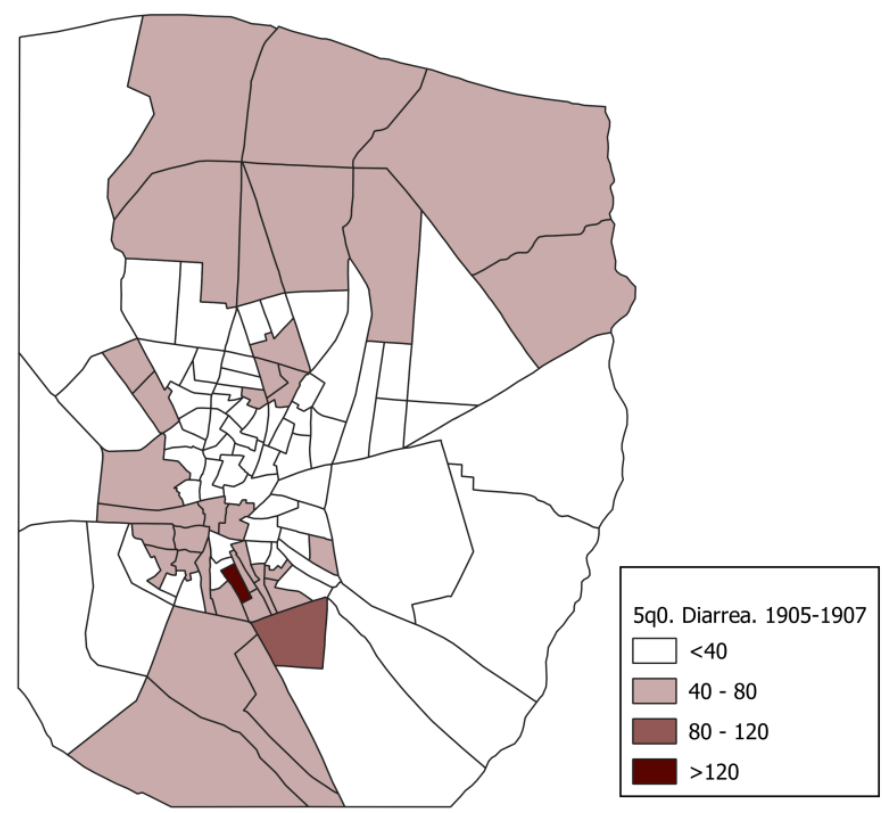

Mapa 10-8. ECMR (5q0) estandarizado por diarrea y enteritis para la ciudad de Madrid. 1920-1922.

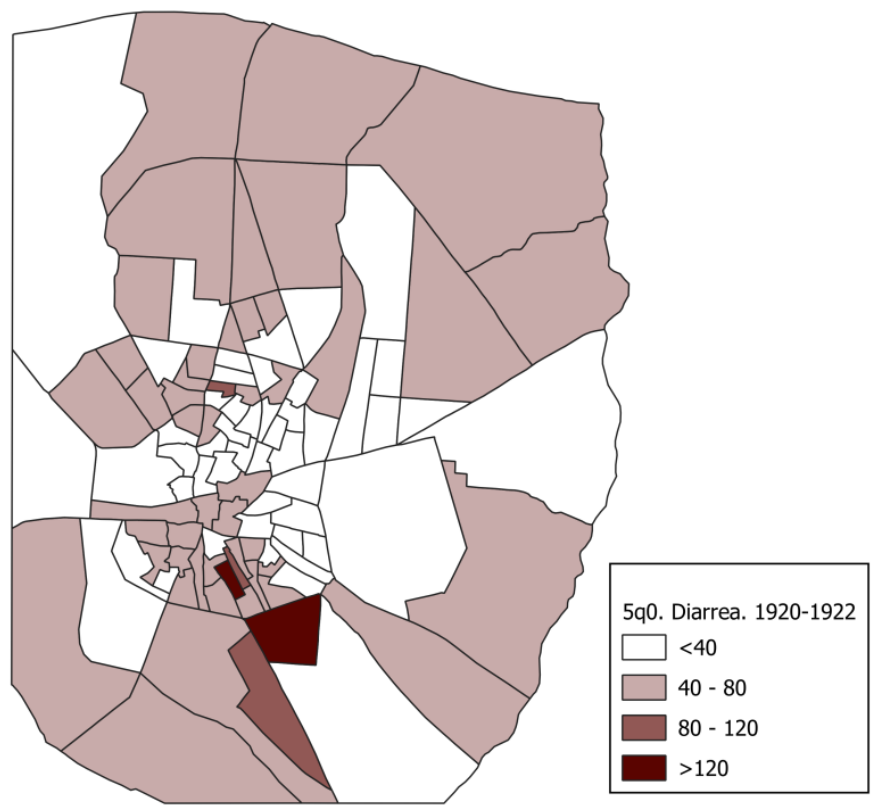

Fuente: elaboración propia. Datos individuales del registro civil de defunciones para los años seleccionados. 
Atendiendo a la mortalidad por diarrea y enteritis de menores de cinco años, encontramos que, en la comparación entre periodos, podemos ver que en 1920-1922, al igual que sucede con el caso de haber tomado las enfermedades transmitidas a través del agua y alimentos de manera general, algunos barrios de la ciudad empeoran su situación respecto al periodo 1905-1907, incluso siendo barrios en los que se habían acometido mejoras en el alcantarillado y el abastecimiento de agua. Asimismo, las zonas del extrarradio, tanto norte como sureste, experimentan las mayores tasas de mortalidad de niños menores de cinco años por enfermedades transmitidas a través del agua $\mathrm{y}$ alimentos en ambos periodos (barrios del norte como Bellas Vista y Cuatro Caminos o Marqués de Comillas en el sur), así como los barrios de Gasómetro, Peñuelas y Santa María de la Cabeza.

Mapa 10-9. ECMR (5q0) Estandarizada por diarrea y enteritis y cobertura del sistema de alcantarillado en la ciudad de Madrid, 1905-1907 y 1920-1922.
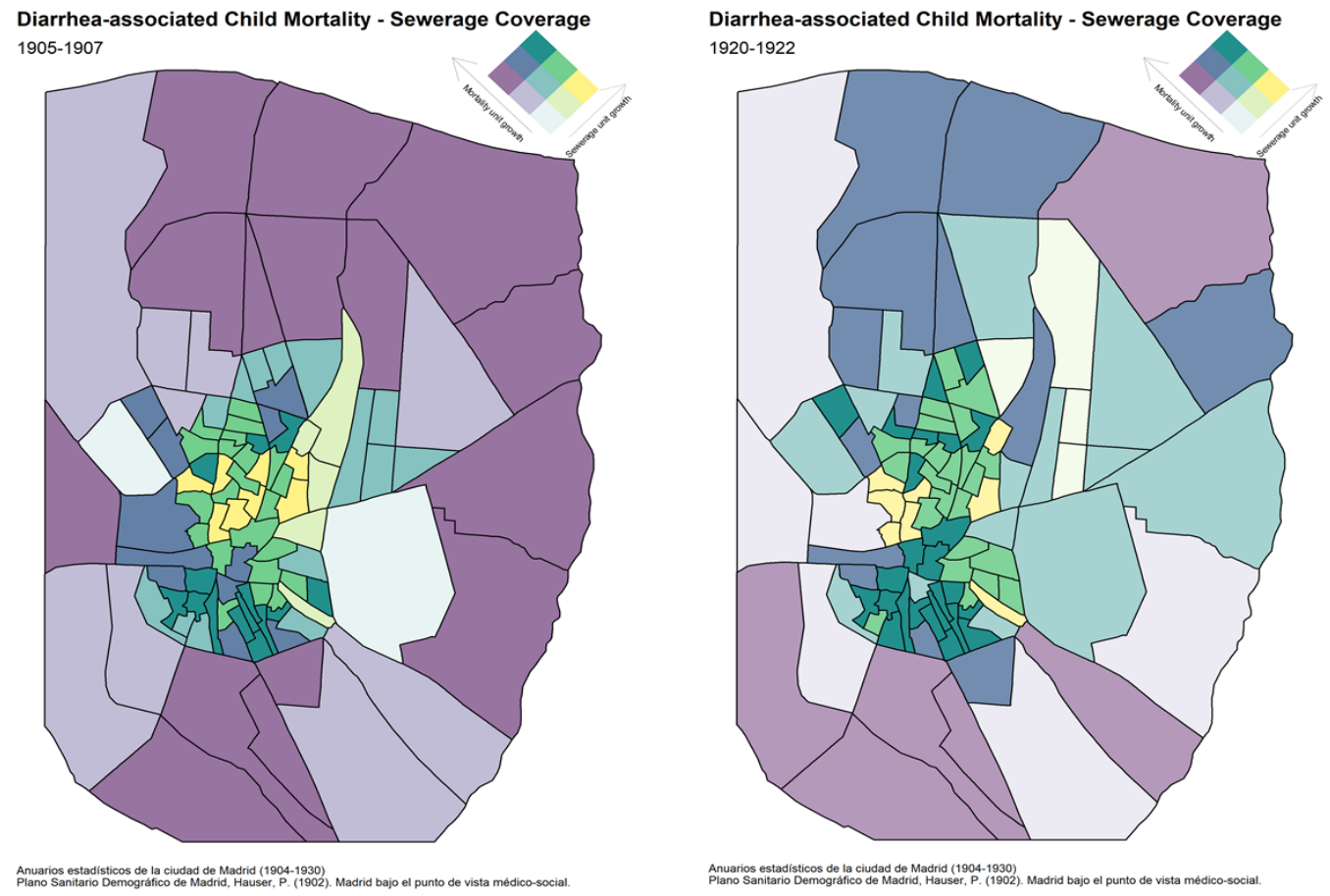

Fuente: elaboración propia. Datos individuales del registro civil de defunciones para los años seleccionados. 
Mapa 10-10. ECMR (5q0) Estandarizada por diarrea 1905-1907 y 1920-1922 y cobertura del sistema de alcantarillado y de agua en 1929 en la ciudad de Madrid

SMR*: 1920-1922

Alcantarillado: 1929

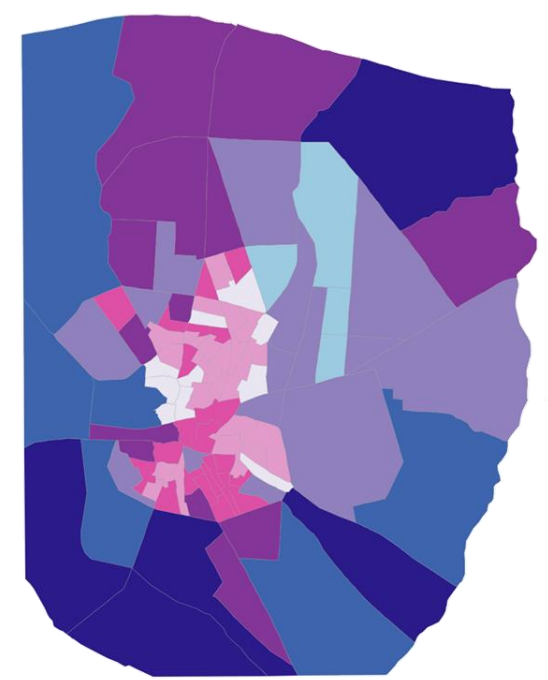

SMR*: 1920- 1922 .

Red de agua: 1929

Fuente: elaboración propia. Datos individuales del registro civil de defunciones para los años seleccionados.

Una vez más, observamos una relación existente entre la mortalidad diferencial vinculada a la estructura social, económica, higiénica y urbana. También observamos la importancia de la presencia en la capital de algunas instituciones benéfico-asistenciales en las tasas de mortalidad.

Atendiendo a la mortalidad por fiebre tifoidea, presentó también una tendencia al descenso a lo largo del presente siglo, interrumpida por las epidemias de 1909 y de 1920, tal y como puede verse en el gráfico 10-13 sobre la evolución de la mortalidad por fiebre tifoidea en el periodo 1904-1929.

En cuanto a la distribución de las tasas por distritos, cabe señalar que, en el primer tercio del siglo XX, la mortalidad diferencial de la fiebre tifoidea no sigue el mismo patrón que la diarrea y enteritis, no observándose diferencias tan acusadas entre zonas de la ciudad. 
Gráfico 10-13. Mortalidad por fiebre tifoidea en Madrid por distrito entre 1904-1929

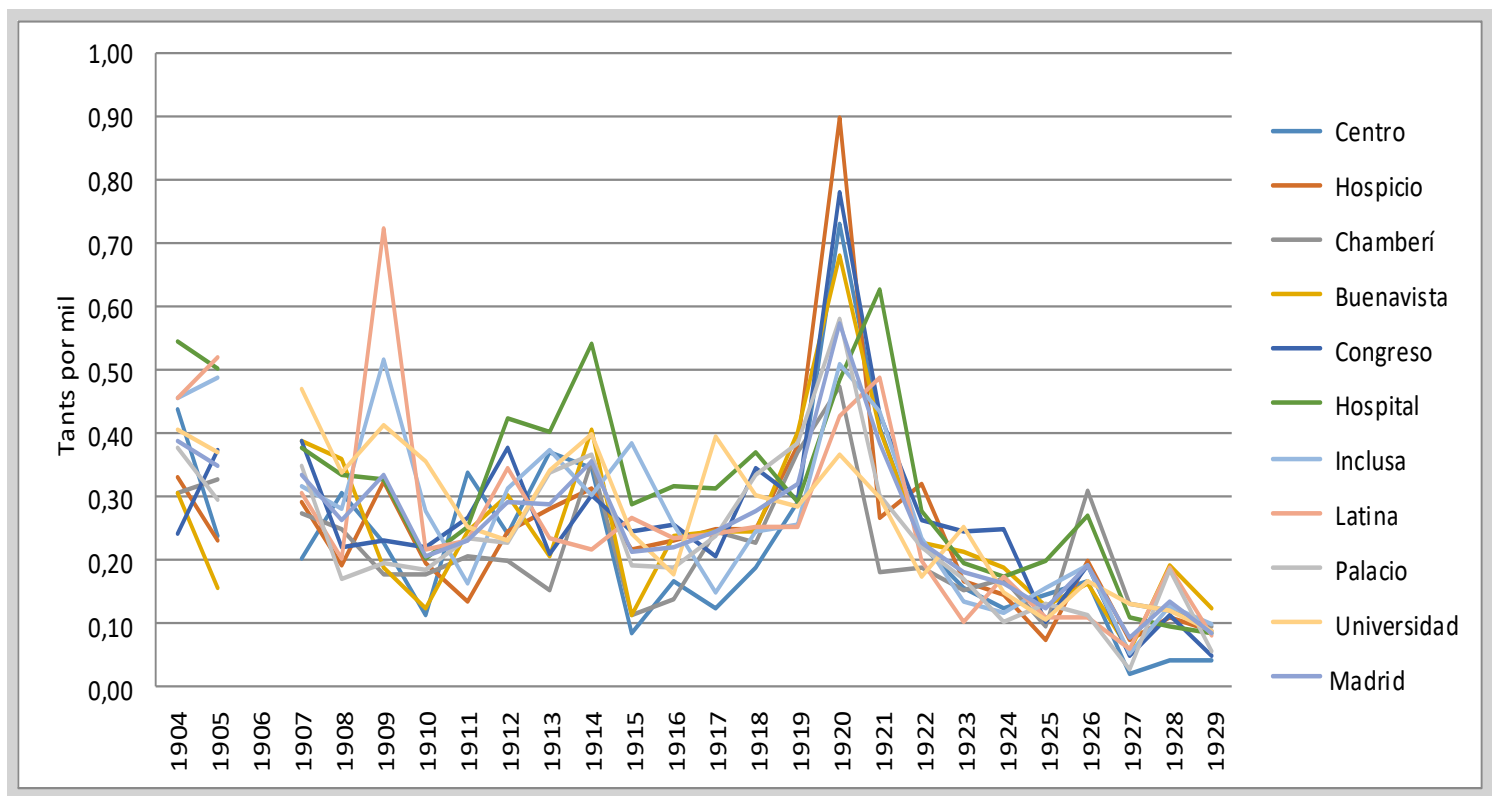

Fuente: Elaboración propia. Datos obtenidos de los Anurarios Estadísticos de la ciudad de Madrid para los años seleccionados.

Atendiendo a tasa de mortalidad por fiebre tifoidea a nivel de barrio, la concentración mayor se producía en el barrio de Doctor Fourquet, del distrito Hospital, que era el lugar donde se encontraba el Hospital Provincial, tal y como se muestra en el gráfico 10-14. 
Gráfico 10-14. Tasa de mortalidad por fiebre tifoidea, nivel de barrio. (1904-1930).

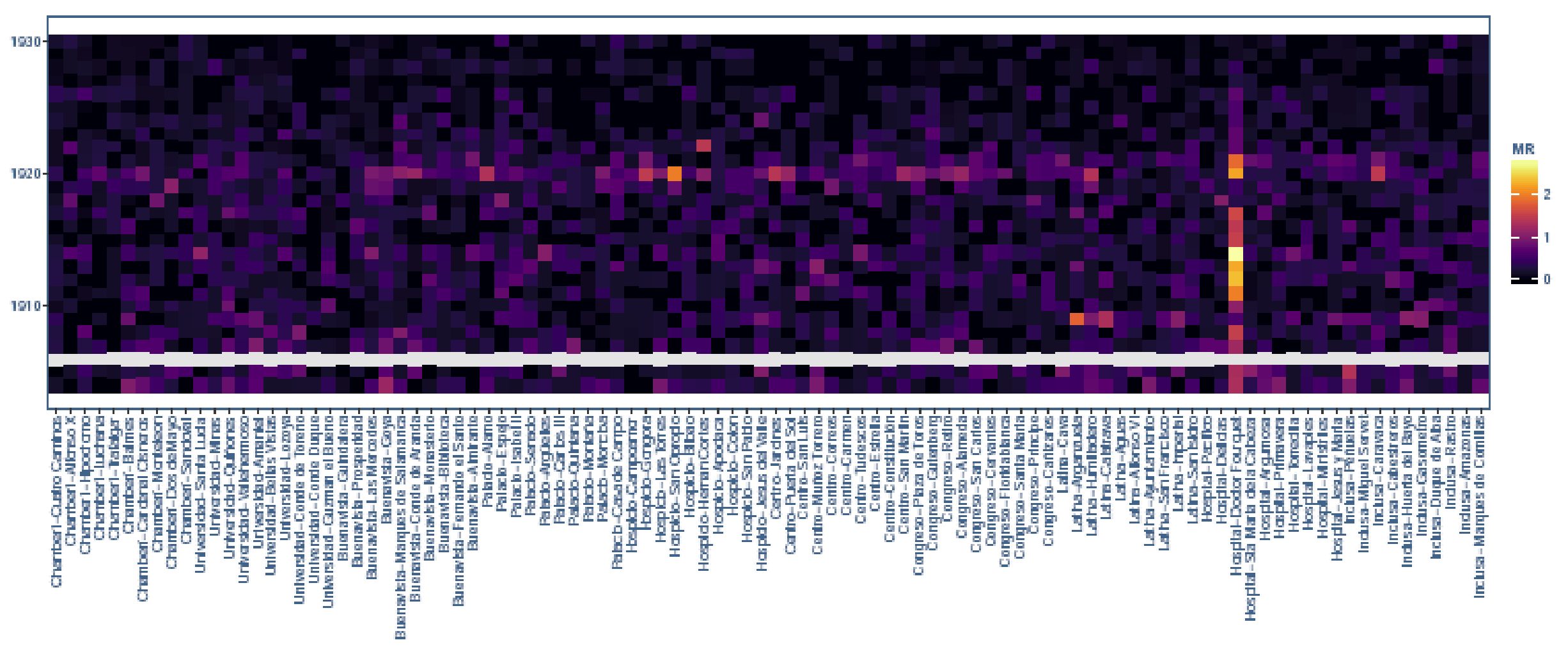

Fuente: Elaboración propia. Datos obtenidos de los Anuarios Estadísticos de la ciudad de Madrid para los años señalados 
En cuanto a la distribución por edad de la mortalidad por fiebre tifoidea, es a partir del grupo de edad de los 5-9 años cuando comienza a incrementarse, hasta llegar al punto álgido en el correspondiente al de los 10-14 años y 15-19, especialmente afectado este último grupo de edad por la epidemia sufrida en la ciudad de Madrid en 1920.

Gráfico 10-15. Distribución por edades de la mortalidad por fiebre tifoidea

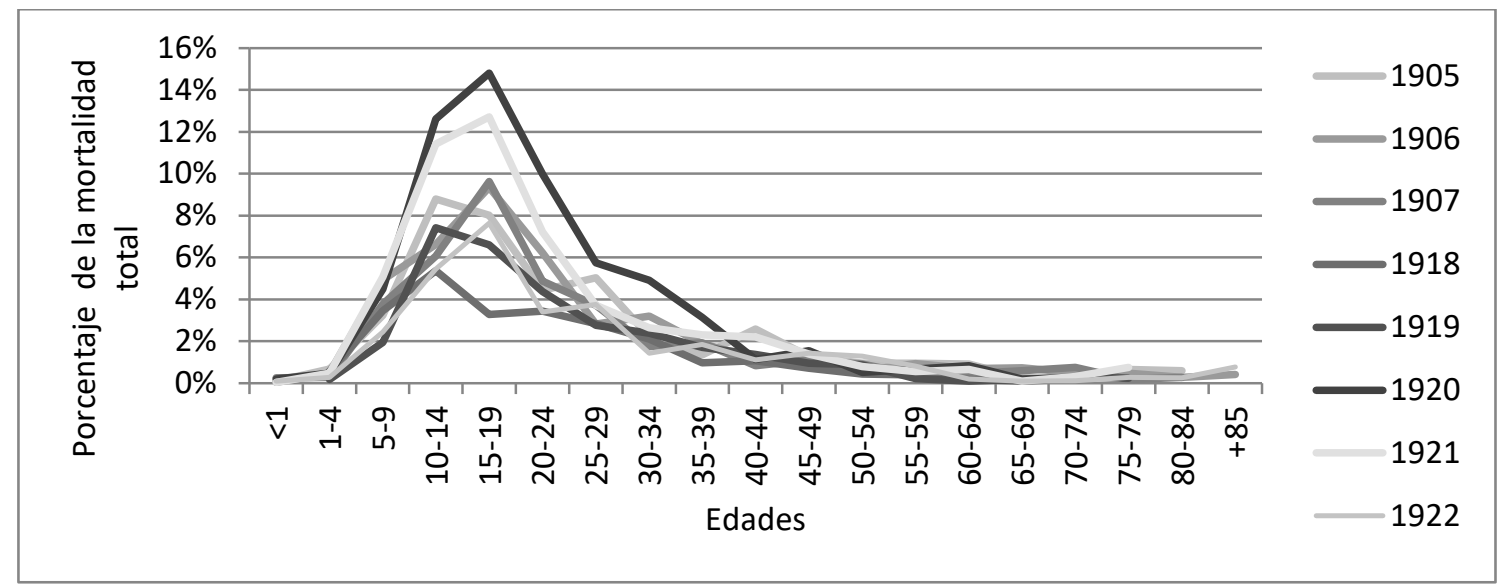

Fuente: Elaboración propia. Datos obtenidos de los Anurarios Estadísticos de la ciudad de Madrid para los años seleccionados.

\subsection{Las mejoras en la infraestructura urbana de saneamiento como elementos explicativos de la mortalidad por enfermedades transmitidas a través del agua y alimentos.}

Se procederá a continuación a analizar la posible influencia que tuvieron las mejoras en el saneamiento urbano en la salud de los madrileños. Para ello, se han aplicado modelos estadísticos que nos permiten conocer si la presencia de mejoras en la infraestructura urbana de la ciudad influyó en la mortalidad. Concretamente, se han realizado análisis de regresión logística binaria con el objetivo de conocer la probabilidad de morir por enfermedades transmitidas a través del agua y alimentos, y, dentro de estas, por diarreaenteritis y por fiebre tifoidea.

Los análisis se han realizado para los dos grupos temporales de los que hemos recogido información a través de los partes de defunciones del Registro Civil. Los periodos corresponden a los años 1905-1906-1907, 1918-1919 y 1920-1921-1922. Se tratará de 
medir la probabilidad de morir por diarrea y enteritis y por fiebre tifoidea para los dos periodos temporales especificados. Las covariables empleadas son la proporción de la cobertura del sistema de abastecimiento de agua y la proporción de la cobertura de red de evacuación en la ciudad a nivel de barrio, como elementos representativos de la situación de la infraestructura urbana.

La justificación de la elección de estas enfermedades como variables dependientes asociadas con el impacto de la intervención sanitaria en la mortalidad por enfermedades transmitidas a través del agua y alimentos, viene dada por la literatura que ha tratado el tema del impacto del saneamiento en infraestructuras sanitarias en la mortalidad.

Bien es cierto que, algunos autores, ofrecen resultados que mantienen que la mortalidad por diarrea no es un buen indicador por ofrecer resultados contradictorios a la hora de relacionarse con la calidad del agua (Davenport et al., 2019). Sin embargo, otros estudios sí mantienen esta relación (Harris \& Hinde, 2019; Helgertz \& Önnerfors, 2019; Hinde \& Harris, 2019). La mortalidad por fiebre tifoidea y su relación con las mejoras en infraestructura urbana también ha sido demostrada por algunos autores (de Looper et al., 2019; Floris \& Staub, 2019; Helgertz \& Önnerfors, 2019; Hinde \& Harris, 2019).

Se tiene en cuenta también la diferente exposición a morir, especialmente en el caso de niños menores de cinco años, atendiendo a la institucionalización o no del fallecimiento. Por ello, se han realizado modelos diferenciados para la mortalidad de menores de un año y de menores de cinco años por diarrea-enteritis, teniendo en cuenta el total de estas defunciones, por un lado $\mathrm{y}$, por otro, suprimiendo la mortalidad institucional. Asimismo, se han realizado modelos atendiendo a la probabilidad de morir por diarreaenteritis y por fiebre tifoidea teniendo en cuenta todas las edades.

\subsubsection{Modelos explicativos de la mortalidad por enfermedades transmitidas a través del agua y alimentos.}

Es necesario señalar que para el periodo 1905-1907 se emplearán como variables explicativas la proporción del alcantarillado correspondiente a 1900. Respecto a la distribución de redes de abastecimiento de agua para este primer grupo de años, no hemos encontrado información. Sin embargo, se ha usado como proxi la 
correspondiente a los viajes de agua datados en el año 1929, en la medida en que éstos no variaron su extensión. En cuanto al tratamiento, la variable de alcantarillado ha sido tomada como variable categórica y la correspondiente a los Viajes de Agua como variable continua.

Para realizar los análisis del periodo comprendido entre 1918-1922 las variables independientes empleadas han sido la proporción del alcantarillado correspondiente al año 1929 y la proporción de redes de agua existente del Canal de Isabel II, los Viajes Antiguos y la Hidráulica Santillana también para año 1929. La primera de ellas, al igual que el alcantarillado, como variable categórica y el resto como variables continuas.

\subsubsection{La probabilidad de morir de menores de un año por diarrea y enteritis.}

Atendiendo a los resultados de los modelos de regresión logística binaria para los niños menores de un año, se han realizado dos modelos para cada uno de los periodos, teniendo en cuenta la totalidad de muertes, por un lado, y discriminando la mortalidad institucional. La decisión de implementar modelos diferenciados ha venido dada por la mortalidad diferencial experimentada por estas causas en lo que respecta la mortalidad en la infancia, tal y como hemos visto en líneas precedentes, cuya explicación radica en la sobremortalidad experimentada en la Inclusa de Madrid.

En el periodo correspondiente a 1905-1907 (Tabla 10-1), teniendo en consideración el total de defunciones por diarrea y enteritis de menores de un año y atendiendo a las asociaciones estadísticamente significativas, puede verse que se experimenta un efecto protector del alcantarillado experimentado solamente cuando la cobertura se ve extendida entre un $70-80 \%$. Sin embargo Pero existe una mayor probabilidad de morir por diarrea y enteritis cuando ésta se extiende entre el $80-90 \%$, respecto a disponer de menos de un $10 \%$. La mayor presencia de la cobertura de red de agua de los viajes antiguos, contribuye significativamente a una menor probabilidad de morir.

En lo que atiende a la mortalidad por diarrea y enteritis de niños menores de un año teniendo en cuenta sólo la mortalidad no producida en instituciones, vemos que los resultados varían respecto al anterior modelo. Si bien, el hecho de disponer de un 70$80 \%$ de red cubierta de alcantarillado en el barrio donde se produce el fallecimiento, se 
asocia significativamente con una disminución de la probabilidad de muerte, tal y como sucedía tomando la mortalidad institucional y no institucional, aunque no exista una significación estadística, se puede apreciar que el alcantarillado actúa como elemento protector de la mortalidad a partir de disponer de un $70 \%$ de cobertura de red de alcantarillado para el resto de valores hasta el 100\%, a diferencia de lo que muestra el modelo que toma en consideración la mortalidad institucional y no institucional. En cuanto a la proporción de cobertura de red de agua por los viajes antiguos, no existen diferencias significativas.

Las divergencias apreciadas en los modelos, nos ponen en la tesitura de pensar sobre las variables a emplear a la hora de medir la influencia del alcantarillado y del abastecimiento de agua en la mortalidad, en la medida en que, teniendo en cuenta que la mortalidad por diarrea y enteritis se producía en la Institución de la Inclusa en una proporción elevada, la influencia de las redes de saneamiento y agua podrían tener un efecto confuso si se tiene en cuenta la mortalidad incluyendo la sucedida en instituciones de salud. Para el caso concreto de Madrid, la Inclusa de la ciudad estaba establecida en un barrio con un alto porcentaje de superficie alcantarillada desde el año 1900 (un 78\%, concretamente) y, sin embargo, con una red de cobertura de los viajes de agua nula. Es por ello, que, posiblemente, al tomar la mortalidad institucional y no institucional ésta última variable ejerza un efecto protector frente a la mortalidad por diarrea y enteritis de los menores de un año.

Tabla 10-1. Probabilidad de morir por diarrea y enteritis. Mortalidad infantil. 1905-1907

\begin{tabular}{|c|c|c|c|c|c|c|c|c|}
\hline & \multicolumn{4}{|c|}{ Diarrea y enteritis. $<1$ año } & \multicolumn{4}{|c|}{ Diarrea y enteritis. $<1$ año. Sin mortalidad instituciona } \\
\hline & B & & Error estándar & OR & B & & $\begin{array}{c}\text { Error } \\
\text { estándar }\end{array}$ & OR \\
\hline \multicolumn{9}{|l|}{$\begin{array}{l}\text { Proporción de superficie con } \\
\text { alcantarillado } \\
\qquad(\text { Ref: }<10 \% \text { a l canta rilla do) }\end{array}$} \\
\hline & $-0,159$ & & 0,138 & 0,853 & $-0,106$ & & 0,139 & 0,900 \\
\hline Alcantarillado $20-30 \%$ & $-0,139$ & & 0,145 & 0,870 & $-0,125$ & & 0,146 & 0,882 \\
\hline Alcantarillado $30-40$ & 0,246 & & 0,320 & 1,279 & 0,068 & & 0,320 & 1,071 \\
\hline Alcantarillado $40-50 \%$ & 0,007 & & 0,238 & 1,007 & 0,074 & & 0,238 & 1,077 \\
\hline Alcantarillado $50-60 \%$ & 0,242 & & 0,176 & 1,274 & 0,104 & & 0,177 & 1,109 \\
\hline Alcantarillado $60-70 \%$ & 0,255 & & 0,192 & 1,290 & 0,193 & & 0,193 & 1,213 \\
\hline Alcantarillado $70-80 \%$ & $-0,387$ & $*$ & 0,158 & 0,679 & $-0,345$ & $* *$ & 0,158 & 0,708 \\
\hline Alcantarillado $80-90 \%$ & 1,241 & $* * *$ & 0,113 & 3,458 & $-0,175$ & & 0,142 & 0,839 \\
\hline Alcantarillado $90-100 \%$ & 0,083 & & 0,132 & 1,086 & $-0,164$ & & 0,135 & 0,849 \\
\hline \multicolumn{9}{|l|}{$\begin{array}{l}\text { Proporción de superficie con agua- } \\
\text { Viajes de agua }\end{array}$} \\
\hline Viajes de agua & $-0,023$ & $* * *$ & 0,002 & 0,978 & $-0,002$ & & 0,003 & 0,998 \\
\hline
\end{tabular}


Tomando como objeto el periodo comprendido entre 1918-1922 (Tabla 10-2), para el total de defunciones por diarrea y enteritis de menores de un año (mortalidad institucional y no institucional), se produce un efecto significativo y protector a partir de la disposición de una cobertura de agua por parte del Canal de Isabel II a partir del 70\% respeto a existir solo un $10 \%$. Respecto a las otras dos clases de abastecimiento de agua, una mayor distribución ofrecida por la Hidráulica Santillana, se asocia significativamente con una mayor mortalidad. Respecto a los viajes de agua, no ofrecen diferencias significativas en cuanto a una mayor o menor cobertura.

En lo que respecta al alcantarillado, se muestran resultados a priori, algo confusos, en la medida en que una mayor cobertura de red de alcantarillado se relaciona significativamente con una mayor probabilidad de morir por diarrea y enteritis en los menores de un año tomando el conjunto de datos.

Teniendo en cuenta la mortalidad no institucional, el modelo nos ofrece resultados similares al anterior. Las variaciones más relevantes radican en que el efecto protector de la disposición de agua del Canal de Isabel II se experimenta desde la disposición de ésta red en un $40 \%$ en adelante, respecto a disponer de menos de un $10 \%$. El efecto significativo de la cobertura de agua por parte de la Hidráulica Santillana deja de ser tal, a diferencia del modelo anterior.

El modelo nos ofrece que una mayor cobertura de alcantarillado se asocia significativamente con una mayor probabilidad de morir. 
Tabla 10-2. Probabilidad de morir por diarrea y enteritis. Mortalidad infantil. 1918-1922

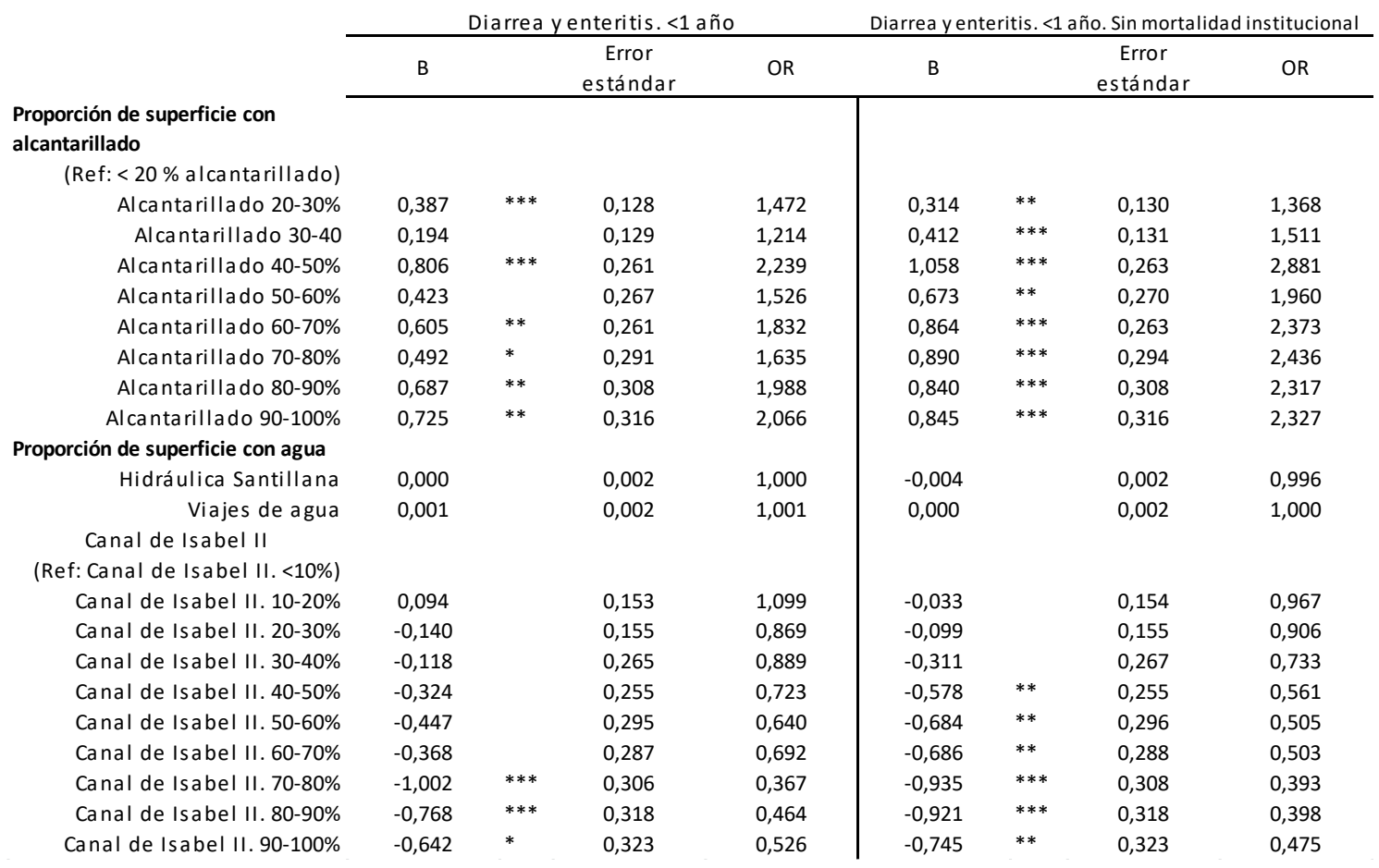

El modelo incluye variables de control. * $\mathrm{p}<0: 10, * * \mathrm{p}<0: 05, * * * \mathrm{p}<0: 01$.

\subsubsection{La probabilidad de morir de menores de cinco años por diarrea y enteritis.}

En el periodo correspondiente a 1905-1907, representado en la tabla 10-3, teniendo en consideración el total de defunciones por diarrea y enteritis de menores de un cinco años $\mathrm{y}$ atendiendo a las asociaciones estadísticamente significativas, se aprecia un efecto protector del alcantarillado sobre la mortalidad muy acusado así como de los viajes de agua.

Para la mortalidad de menores de cinco años sin tener en cuenta la mortalidad institucional, una mayor cobertura de red de alcantarillado se asocia, también, significativamente con una menor probabilidad de morir por estas causas. La cobertura de red de agua por los viajes antiguos, ejerce el mismo efecto que la red de evacuación. 
Tabla 10-3. Probabilidad de morir por diarrea y enteritis. Menores de cinco años. 1905-1907

\begin{tabular}{|c|c|c|c|c|c|c|c|c|}
\hline & \multicolumn{4}{|c|}{ Diarrea y enteritis. $<5$ año. Total } & \multicolumn{4}{|c|}{ Diarrea y enteritis. $<5$ años. Sin mortalidad institucional } \\
\hline & B & & Error estándar & OR & B & & $\begin{array}{c}\text { Error } \\
\text { estándar }\end{array}$ & OR \\
\hline \multirow{2}{*}{\multicolumn{9}{|c|}{$\begin{array}{l}\text { Proporción de superficie con } \\
\text { alcantarillado } \\
\qquad(\text { Ref: }<10 \% \text { alcantarillado) }\end{array}$}} \\
\hline & & & & & & & & \\
\hline Alcantarillado $10-20 \%$ & $-0,348$ & $* * *$ & 0,098 & 0,706 & $-0,315$ & $* * *$ & 0,100 & 0,730 \\
\hline Alcantarillado $20-30 \%$ & $-0,362$ & $* * *$ & 0,103 & 0,696 & $-0,347$ & $* * *$ & 0,104 & 0,707 \\
\hline Alcantarillado $30-40$ & $-0,191$ & & 0,229 & 0,826 & $-0,325$ & $*$ & 0,229 & 0,722 \\
\hline Alcantarillado $40-50 \%$ & $-0,641$ & $* * *$ & 0,190 & 0,527 & $-0,579$ & $* * *$ & 0,190 & 0,560 \\
\hline Alcantarillado $50-60 \%$ & $-0,141$ & & 0,132 & 0,869 & $-0,253$ & $* *$ & 0,133 & 0,776 \\
\hline Alcantarillado $60-70 \%$ & $-0,119$ & & 0,137 & 0,888 & $-0,161$ & & 0,138 & 0,851 \\
\hline Alcantarillado $70-80 \%$ & $-0,703$ & $* * *$ & 0,114 & 0,495 & $-0,654$ & $* * *$ & 0,114 & 0,520 \\
\hline Alcantarillado $80-90 \%$ & 0,740 & $* * *$ & 0,082 & 2,095 & $-0,509$ & $* * *$ & 0,103 & 0,601 \\
\hline Alcantarillado $90-100 \%$ & $-0,271$ & $* * *$ & 0,094 & 0,762 & $-0,460$ & $* * *$ & 0,097 & 0,631 \\
\hline \multicolumn{9}{|l|}{$\begin{array}{l}\text { Proporción de superficie con agua- } \\
\text { Viajes de agua }\end{array}$} \\
\hline Viajes de agua & $-0,023$ & $* * *$ & 0,002 & 0,977 & $-0,006$ & $* * *$ & 0,002 & 0,994 \\
\hline
\end{tabular}

El modelo incluye variables de control. * $\mathrm{p}<0: 10, * * \mathrm{p}<0: 05, * * * \mathrm{p}<0: 01$.

Tomando como objeto el periodo comprendido entre 1918-1922, tal y como puede verse en la tabla 10-4, para el total de defunciones por diarrea y enteritis de menores de cinco años (mortalidad institucional y no institucional), se produce un efecto significativo y protector a partir de la disposición de una cobertura de agua por parte del Canal de Isabel II a partir del $70 \%$ y hasta el $100 \%$ respeto a disponer de un $10 \%$ de superficie con red de agua del Canal de Isabel II. Respecto a las otras dos clases de abastecimiento de agua, una mayor distribución ofrecida por los viajes de agua o por la Hidráulica Santillana, no ofrecen diferencias significativas en cuanto a una mayor o menor cobertura.

En lo que respecta al alcantarillado, se muestran resultados a priori, algo confusos, en la medida en que una mayor cobertura de red de alcantarillado se relaciona significativamente con una mayor probabilidad de morir por diarrea y enteritis en los menores de un cinco tomando el conjunto de datos, con una asociación más fuerte a medida que se incrementa la disposición de alcantarillado.

Teniendo en cuenta la mortalidad no institucional, el modelo nos ofrece resultados similares al anterior. Las variaciones más relevantes radican en que el efecto protector de la disposición de agua del Canal de Isabel II se experimenta desde la disposición de ésta red en un $40 \%$ en adelante, respecto a disponer de menos de un $10 \%$. Además, se produce un efecto significativo protector de la mortalidad de la cobertura de agua por 
parte de la Hidráulica Santillana, a diferencia del modelo anterior, en la que no establecía diferencias significativas.

En términos generales, nuevamente, los modelos nos ofrecen que una mayor cobertura de alcantarillado se asocia significativamente con una mayor probabilidad de morir.

Tabla 10-4. Probabilidad de morir por diarrea y enteritis. Menores de cinco años. 1918-1922

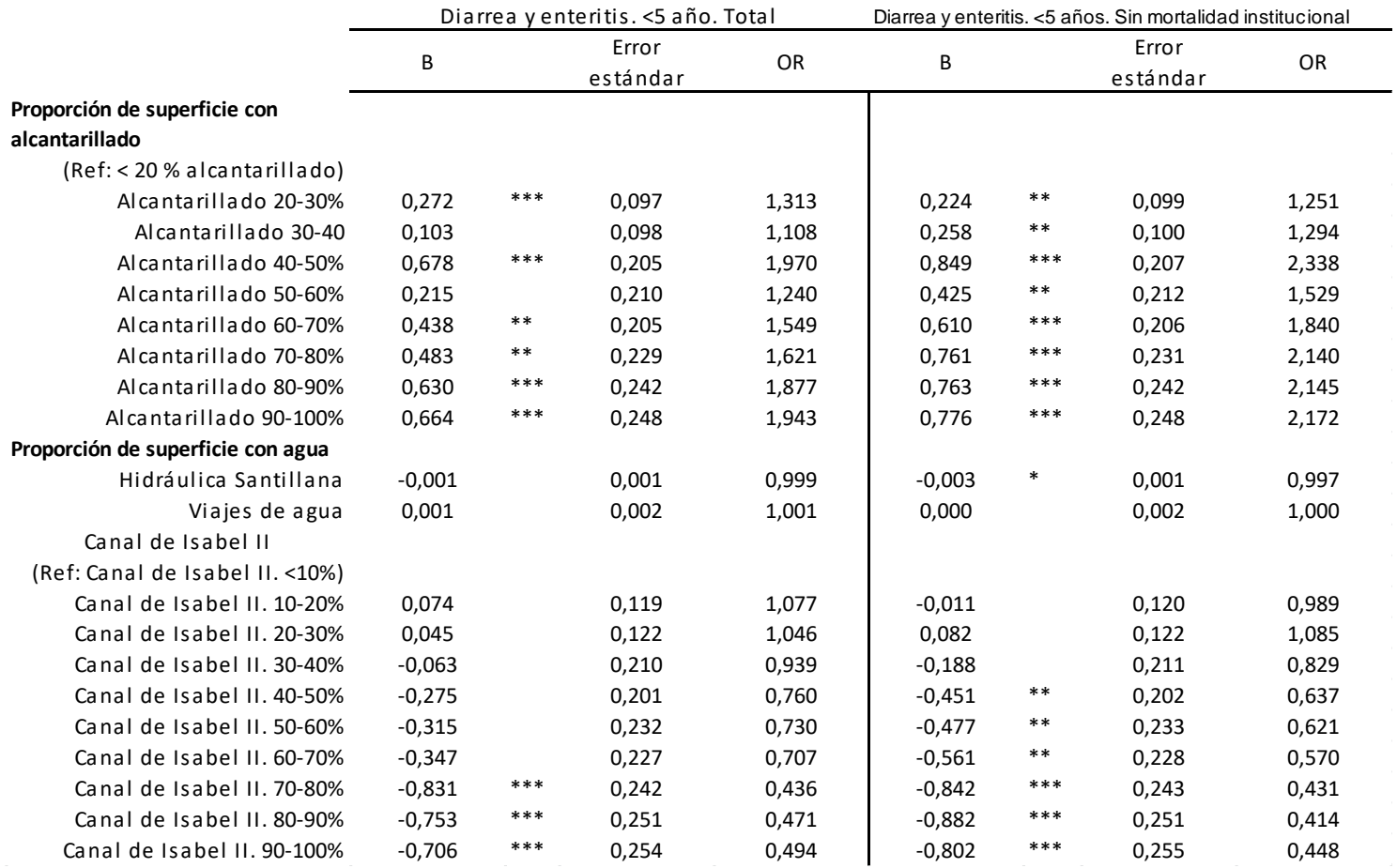

El modelo incluye variables de control. * $\mathrm{p}<0: 10, * * \mathrm{p}<0: 05, * * * \mathrm{p}<0: 01$

\subsubsection{Modelos mortalidad por diarrea y enteritis. Conjunto de la base de datos.}

A continuación, realizamos modelos de regresión logística binaria teniendo en cuenta el conjunto de la base de datos, sin realizar discriminación por edad, para medir la probabilidad de muerte por diarrea y enteritis.

Para los años 1905-1907 (Tabla 10-5), se observa un patrón muy similar al experimentado en los modelos arriba especificados para este periodo. A mayor cobertura de alcantarillado, menor probabilidad de morir por diarrea y enteritis. Igual situación corresponde a los viajes de agua. Es necesario señalar que se han realizado modelos crudos de asociación binaria (tanto en el caso de la covariable alcantarillado, 
como en el caso de los viajes) y la asociación protectora de la mortalidad se ve incrementada respecto a si se toman estas variables en el modelo ajustado.

Tabla 10-5. Probabilidad de morir por diarrea y enteritis. 1905-1907. (Conjunto de la base de datos).

\begin{tabular}{|c|c|c|c|c|}
\hline & \multicolumn{4}{|c|}{ Diarrea y enteritis } \\
\hline & B & & $\begin{array}{l}\text { Error } \\
\text { están }\end{array}$ & OR \\
\hline \\
\hline \multicolumn{5}{|l|}{ alcantarillado } \\
\hline \multicolumn{5}{|l|}{ (Ref: $<10 \%$ alcantarillado) } \\
\hline Alcantarillado $10-20 \%$ & $-0,163$ & $*$ & 0,087 & 0,850 \\
\hline Alcantarillado $20-30 \%$ & $-0,377$ & $* * *$ & 0,090 & 0,686 \\
\hline Alcantarillado $30-40$ & $-0,241$ & & 0,180 & 0,786 \\
\hline Alcantarillado $40-50 \%$ & $-0,460$ & $* * *$ & 0,160 & 0,631 \\
\hline Alcantarillado $50-60 \%$ & $-0,247$ & $* *$ & 0,110 & 0,781 \\
\hline Alcantarillado $60-70 \%$ & $-0,099$ & & 0,114 & 0,905 \\
\hline Alcantarillado $70-80 \%$ & $-0,583$ & $* * *$ & 0,097 & 0,558 \\
\hline Alcantarillado $80-90 \%$ & 0,277 & $* * *$ & 0,079 & 1,319 \\
\hline Alcantarillado $90-100 \%$ & $-0,485$ & $* * *$ & 0,089 & 0,616 \\
\hline \multicolumn{5}{|l|}{$\begin{array}{l}\text { Proporción de superficie con } \\
\text { agua- Viajes de agua }\end{array}$} \\
\hline Viajes de agua & $-0,007$ & $* * *$ & 0,002 & 0,993 \\
\hline
\end{tabular}

El modelo incluye variables de control. * $\mathrm{p}<0: 10, * * \mathrm{p}<0: 05, * * * \mathrm{p}<0: 01$

Tomando en consideración el periodo comprendido entre 1918-1922 (Tabla 10-6), se observa que una mayor cobertura de alcantarillado, reporta una mayor probabilidad de morir por diarrea y enteritis. La cobertura de agua potable por parte del Canal de Isabel II y de la Hidráulica Santillana, ejerce el efecto contrario; un mayor aporte de cobertura del sistema de agua por parte de estas dos clases de abastecimiento, se relaciona significativamente con una menor probabilidad de morir por diarrea y enteritis respecto a hacerlo por otras causas de muerte. Los viajes de agua no muestran diferencias significativas en lo que atiende a su cobertura de distribución. 
Tabla 10-6. Probabilidad de morir por diarrea y enteritis. 1918-1922. (Conjunto de la base de datos).

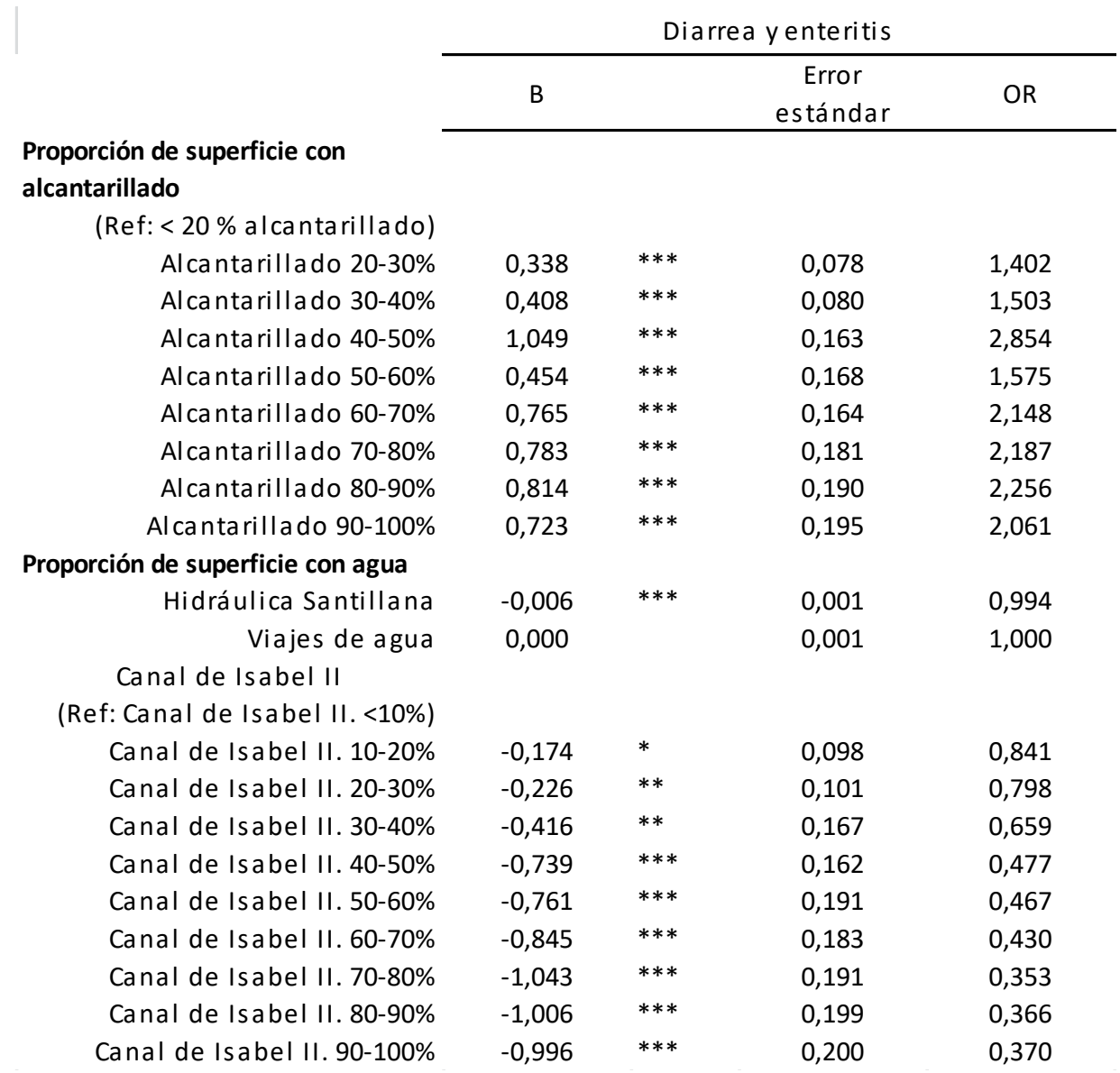

El modelo incluye variables de control. * $\mathrm{p}<0: 10, * * \mathrm{p}<0: 05, * * * \mathrm{p}<0: 01$.

\subsubsection{Modelos mortalidad por Fiebre tifoidea. Conjunto de la base de datos.}

En esta sección nos centraremos en el análisis de la mortalidad por fiebre tifoidea teniendo en cuenta el conjunto de la base de datos, sin realizar discriminación por edad, para medir la probabilidad de muerte por esta causa y la influencia de los sistemas de cobertura de agua y de alcantarillado para los dos periodos diferenciados especificados.

En el periodo 1905-1907 (Tabla 10-7), observamos en el modelo de regresión que a partir de disponer en el barrio de una cobertura de alcantarillado cubierta en un $60 \%$, la probabilidad de morir por fiebre tifoidea es mayor respecto a disponer de una menor cobertura de ésta. La proporción de la disposición de agua por parte de los Viajes Antiguos, no aporta diferencias significativas. 
Tabla 10-7. Probabilidad de morir por fiebre tifoidea. 1905-1907. (Conjunto de la base de datos).

\begin{tabular}{|c|c|c|c|c|}
\hline & \multicolumn{4}{|c|}{ Fiebre tifoidea } \\
\hline & B & & $\begin{array}{l}\text { Error } \\
\text { estándar }\end{array}$ & OR \\
\hline \multicolumn{5}{|l|}{$\begin{array}{l}\text { Proporción de superficie con } \\
\text { alcantarillado }\end{array}$} \\
\hline \multicolumn{5}{|l|}{ (Ref: $<10 \%$ alcantarillado) } \\
\hline Alcantarillado $10-20 \%$ & 0,358 & & 0,259 & 1,431 \\
\hline Alcantarillado $20-30 \%$ & 0,514 & $*$ & 0,263 & 1,672 \\
\hline Alcantarillado $30-40$ & $-0,039$ & & 0,470 & 0,962 \\
\hline Alcantarillado $40-50 \%$ & 0,047 & & 0,422 & 1,048 \\
\hline Alcantarillado $50-60 \%$ & 0,368 & & 0,285 & 1,444 \\
\hline Alcantarillado $60-70 \%$ & 0,591 & $* *$ & 0,297 & 1,807 \\
\hline Alcantarillado $70-80 \%$ & 0,622 & $* *$ & 0,260 & 1,862 \\
\hline Alcantarillado $80-90 \%$ & 0,457 & $* *$ & 0,249 & 1,580 \\
\hline Alcanta rillado $90-100 \%$ & 0,568 & $* *$ & 0,245 & 1,764 \\
\hline \multicolumn{5}{|l|}{$\begin{array}{l}\text { Proporción de superficie con } \\
\text { agua- Viajes de agua }\end{array}$} \\
\hline Viajes de agua & 0,000 & & 0,003 & 1,000 \\
\hline
\end{tabular}

Teniendo en cuenta los años comprendidos entre 1918-1922, correspondiente a la tabla 10-8, se observan diferencias respecto al modelo anterior. En este sentido, a partir de disponerse en el barrio de una cobertura de red de alcantarillado de un $30 \%$, esta variable actúa con una menor probabilidad de muerte por fiebre tifoidea de manera significativa. Sin embargo, la cobertura de red de agua ofrece el resultado contrario, tanto para el Canal de Isabel II como para la Hidráulica Santillana. Sin embargo, a mayor cobertura de agua de los Viajes Antiguos, existe una menor probabilidad de muerte por fiebre tifoidea. 
Tabla 10-8. Probabilidad de morir por fiebre tifoidea. 1922-1918. (Conjunto de la base de datos).

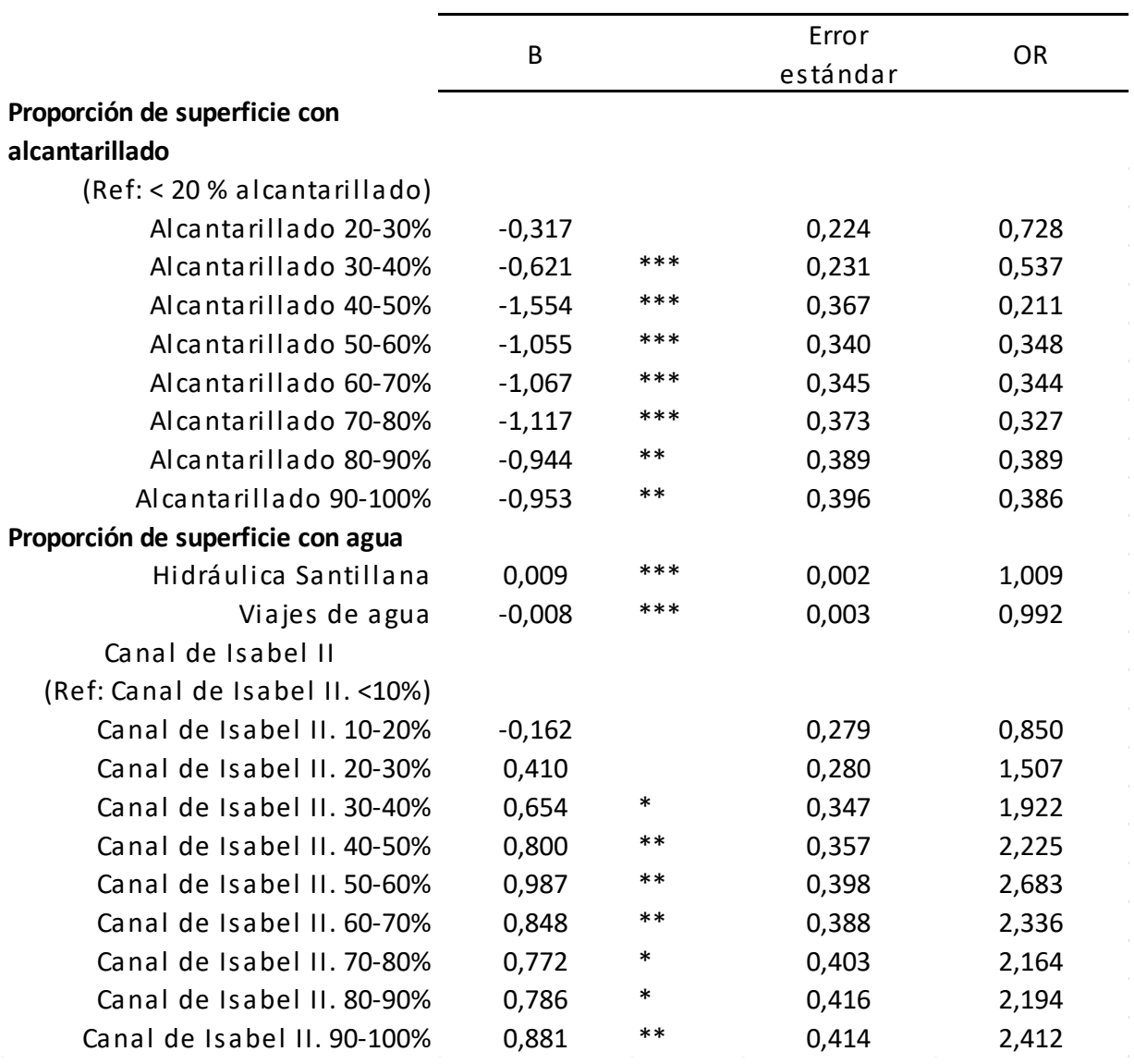

El modelo incluye variables de control. * $\mathrm{p}<0: 10, * * \mathrm{p}<0: 05, * * * \mathrm{p}<0: 01$.

Tomando el valor los resultados de los modelos, respecto a los casos en que las probabilidades de mortalidad disminuyen a medida que la cobertura de agua en el barrio es mayor y al considerar la influencia de variable que mide la proporción de alcantarillado en el barrio se establece una relación positiva (como es el caso de la probabilidad de morir por diarrea y enteritis para el periodo 1918-1922) es decir, que el aumento en la cobertura de alcantarillado influye en una mayor mortalidad por enfermedades transmitidas a través del agua y alimentos, con el objetivo de ampliar nuestro conocimiento sobre estos resultados, hemos realizado modelos crudos; primero teniendo en cuenta de manera aislada la variable de red de agua $y$, posteriormente, de alcantarillado. Al llevar a cabo un modelo crudo, comprobamos que la proporción de alcantarillado sobre la superficie del barrio también actúa como elemento protector de la mortalidad, al igual que sucede con el caso de la red de agua. Esto nos lleva a pensar que la influencia del alcantarillado como elemento protector se vea revocada para 
aquellos casos en los que sí existía red de alcantarillado pero no red de agua de manera conjunta. Esto sucedía en gran medida en las zonas de la ciudad que permanecían en construcción bajo los planes de saneamiento y de modernización del sistema de abastecimiento de agua a la ciudad. El gran problema era que, en aquellos lugares donde la red de alcantarillado existía sin un flujo de agua que discurriese por las mismas, se creaban focos de infección por la no confluencia de desechos sólidos. Por lo que, pensamos que la variable relativa al alcantarillado actúa como una variable de confusión y la incluimos en el modelo ajustado con el objetivo de controlar su influencia.

El mismo patrón pero diametralmente opuesto se observa para el modelo ajustado en el que analizamos la influencia de las variables explicativas descritas y su influencia en la mortalidad por fiebre tifoidea.

En síntesis, realizando una valoración global de los modelos obtenidos para analizar la influencia de la red de distribución de agua y la red de alcantarillado como factores explicativos de la mortalidad por causas relacionadas con la transmisión de enfermedades a través del agua, podemos afirmar que, en términos generales, la mayor disposición por barrio de red de agua actuó favoreciendo una menor mortalidad, excepto para la mortalidad por fiebre tifoidea.

Sin embargo, para el caso del alcantarillado, los resultados obtenidos en los modelos ajustados son más difíciles de interpretar. Resulta llamativo que el hecho de disponer de una proporción mayor de alcantarillado en la superficie del barrio aumenta la probabilidad de muerte por diarrea y enteritis cuando el modelo se realiza en conjunción con la covariable de la red de agua.

Esto puede deberse a que aquellas zonas en las que el alcantarillado aún no estaba completado y que, a priori, esto induciría a pensar en que representa una carestía de infraestructura urbana, no sería tal, ya que esta parcialidad en la red se debía, en algunos casos, a que la red permanecía en construcción y, podemos afirmar que se trataba, con bastante seguridad, de un alcantarillado nuevo que se estaba completando. Sin embargo, aquellas zonas totalmente alcantarilladas, que eran las del interior de la ciudad, tenían un alcantarillado antiguo y, en ocasiones, las obras de reforma se habían basado en la construcción de una doble alcantarilla de forma que se daba una confluencia de la evacuación de aguas residuales con la de distribución de agua potable, lo que conllevaba a que, en vez de un mayor saneamiento, desembocara en ser un foco de infección 
mayor, de manera que en vez de resultar un elemento de saneamiento podría convertirse en un foco infeccioso por las basuras y otros elementos que allí se almacenaban, pues al existir ésta y no pasar el agua, los objetos tanto líquidos como sólidos quedaban almacenados en las mismas. Además, hay que tener en cuenta que, tal y como se ha descrito en el capítulo sobre la evolución histórica de la red de alcantarillado en la ciudad, algunos particulares realizaban las acometidas directamente desde sus casas a la alcantarilla general, de manera que no se tenía en cuenta ningún criterio técnico, lo que ocasionaba desperfectos y roturas. En estos casos, una disposición de la red general de evacuación podría suponer mayor daño ante la propagación de enfermedades que el hecho de no disponer de ésta.

El hecho de que el Ayuntamiento de Madrid diera la iniciativa a los propietarios de las casas a la hora de construir nuevas alcantarillas así como dejar la misma libertad a los propietarios a la hora de hacer las acometidas particulares desde sus casas a las nuevas alcantarillas puede ser una explicación al hecho de que, tal y como reflejan nuestros análisis, la mayor presencia de alcantarillado en las zonas de la ciudad no actúa como elemento protector de la mortalidad. Esta situación nos pone en la tesitura de pensar en que el hecho de que se hubiera construido una alcantarilla por una calle no significaba que todos los edificios de la misma estuvieran conectados pues el propietario no tenía la obligación de hacerlo. A esto hay que sumarle que el hecho de que un edificio estuviera conectado a una alcantarilla no implicaba que todos los pisos del inmueble vertieran sus residuos a la misma, pues la mayoría de los pisos altos carecían de agua corriente, bien por falta de presión, o simplemente porque los propietarios no la querían.

También es necesario considerar, atendiendo a los resultados penalizadores, para algunos casos, que ejerció en la mortalidad una mayor extensión de red de abastecimiento de agua, pueden explicarse, en buena medida, porque había zonas con red de agua de consumo pero sin sistema de evacuación o con éste en construcción.

También hemos de tener en cuenta que nuestros datos sólo pueden ofrecernos una información aproximada a la realidad, al no disponer de información individual sobre la disponibilidad de acometida de agua de consumo y a la red de evacuación de aguas residuales a nivel de vivienda. Por ejemplo, podría darse la circunstancia de que exista una falta de conexión de las casas a las alcantarillas, aunque la red existiera en la calle en cuestión e igualmente sucede con la red de abastecimiento de agua. 


\subsection{Conclusiones}

El presente capítulo ha tenido como pretensión principal mostrar la evolución de la mortalidad en la ciudad de Madrid durante el primer tercio del siglo XX. Hemos podido observar una tendencia clara de disminución de la misma, reflejo de los elementos característicos de la transición de la mortalidad.

Tal y como se defiende desde la perspectiva epidemiológica, el ritmo e intensidad de las tendencias de mortalidad vienen explicadas desde tres grandes grupos de factores: los socioeconómicos, políticos y culturales (que engloba desde los niveles de vida, a los hábitos de salud, higiene y nutrición), los ecobiológicos (relacionados con los agentes patógenos causantes de la enfermedad, las posibilidad de contagio e infección) y los elementos vinculados a la salud pública (que engloba medidas relacionadas con mejoras de saneamiento público, inmunización de la población, entre otros) (Omran, 2005).

Uno de los potenciales del presente estudio reside en la estructura y en la riqueza de los datos demográficos y la vinculación de estos a una infraestructura de datos espaciales que permite la realización de análisis espacial a través de la Infraestructura de Datos Espaciales Histórica de Madrid (HISDI-MAD), tal y como ha podido verse.

A través del análisis de distribución de la mortalidad por causas infecciosas transmitidas a través del agua y alimentos para los niños menores de cinco años y su representación a nivel de barrio se manifiesta que, fruto de la elevada presencia y persistencia de este tipo de causas a lo largo de periodo de estudio, el estado higiénico sanitario de la ciudad de Madrid a finales del siglo y en estos años del siglo XX previos a la Guerra Civil no era ideal. Si bien la ciudad de Madrid comenzaba la evolución a un sistema de infraestructura urbana de saneamiento más moderna y de mayor amplitud territorial, todavía podía caracterizarse como un sistema que no es que no fuera totalmente eficiente, sino que su repercusión en la salud de la población no abarcaba a todos por igual. Continuando, de este modo, a perpetuarse desigualdades vinculadas a la diferente estructura social y económica de las diferentes zonas de la capital.

Además, se ha tenido en cuenta el estado de las infraestructuras de higiene pública urbana en la ciudad de Madrid a principio del siglo XX como factor clave en la explicación de la mortalidad y el análisis explicativo realizado sobre la influencia de 
indicadores de oferta de infraestructuras de salud pública y los servicios urbanos como variables explicativas de la mortalidad urbana, tomando como factores los referidos a la dotación de agua potable y el alcantarillado. En cuanto a los resultados, cabe decir que, si bien sí podemos hablar de que desde finales del siglo XIX hasta el primer tercio del siglo XX se produjo una evolución en los servicios públicos de abastecimiento en la ciudad de Madrid, la interrelación entre el sistema de abastecimiento de aguas y la red de alcantarillado no se forjó de manera unívoca.

A lo largo del periodo de estudio, se produjo una modernización de los sistemas de distribución de agua y de la red de evacuación, pero no se ha podido demostrar de manera fehaciente que la amplitud de la red de distribución de agua y alcantarillado se materializase en un acceso más equitativo al servicio, de manera que en la década de los años 30 del siglo XX los servicios de abastecimiento de agua seguían aún sin atender a la demanda social de una ciudad en crecimiento, como fue Madrid.

Los resultados de los modelos sobre la influencia de la red de alcantarillado y de la red de distribución de agua en las tasas de mortalidad nos han ofrecido resultados un tanto contradictorios. Por una parte, nuestros resultados nos alientan a afirmar que la extensión de la red de distribución de agua sí influyó en la mejora de la mortalidad por causas de muerte relacionadas con enfermedades transmitidas a través del agua y alimentos. Pero, por otro, una mayor presencia de la red de alcantarillado y de una mayor red de agua ejerció, en algunos casos, un efecto negativo en las tasas de mortalidad, lo que puede venir explicado porque en buena parte de las zonas de la ciudad donde la red de agua existía pero no estaba abastecida de agua potable, y al contrario, por lo que podría ser más un foco de infecciones que un elemento de salubridad.

Los resultados obtenidos abren un camino importante en el debate acerca del impacto real que el desarrollo de las infraestructuras de saneamiento tienen en la salud y la mortalidad. Esto nos alienta a abrir una línea de investigación que nos permita ampliar y hacer más exhaustivo el análisis presente, para lo que será necesario disponer datos individuales sobre la presencia o ausencia de alcantarillado en cada casa o, al menos, por edificio.

Asimismo, sería necesario conocer la disponibilidad particular de agua corriente en las viviendas, mediante análisis a nivel individual, que nos permitan acercarnos de manera 
pormenorizada al fenómeno de estudio, que permitirán ampliar el espectro de estudio acerca de los factores influyentes en el proceso de transición sanitaria y epidemiológica. 


\section{Conclusiones}

Pese a que el estudio sobre las causas del descenso de la mortalidad urbana en perspectiva histórica ha sido objeto de investigación desde tiempo atrás, en los últimos años, han cobrado un destacable interés las investigaciones centradas en aspectos como la influencia de la contaminación, así como la influencia de la mejora en la nutrición, y la interacción entre ambas, en especial en el efecto, en épocas históricas, de la contaminación de agua, alimentos y medioambiente en la situación nutricional y en la salud general de la población, y dentro de este último aspecto las mejoras en el saneamiento, alcantarillado y el abastecimiento de agua potable, sobre todo en grandes poblaciones, las pioneras en esa transformación, jugó un papel crucial. En este sentido, estudios recientes han tratado de desentrañar la importancia de éstas en la mortalidad desde mediados del siglo XIX en distintos contextos, países y continentes.

Tal y como se defiende desde la perspectiva epidemiológica, el ritmo e intensidad de las tendencias de mortalidad vienen explicadas desde tres grandes grupos de factores: los socioeconómicos, políticos y culturales (que engloba desde los niveles de vida, a los hábitos de salud, higiene y nutrición); los ecobiológicos, relacionados con los agentes patógenos causantes de la enfermedad, las posibilidad de contagio e infección; y los elementos vinculados a la salud pública, que engloba medidas relacionadas con mejoras de saneamiento público, inmunización de la población, entre otros. En este sentido, si bien se considera que las mejoras en infraestructura urbana de saneamiento, comenzadas en el entorno europeo y Estados Unidos desde finales del siglo XIX, contribuyeron al descenso de las tasas de mortalidad, se trata de factores que se deben tomar en cuenta junto con otros que también contribuyeron a tal descenso; tales como la mayor atención a las prácticas higiénicas, el descubrimiento de gérmenes patógenos y el avance en el conocimiento médico en general, la mejora de la dieta o el crecimiento económico.

Las mejoras en infraestructura sanitaria, experimentada en las ciudades principalmente desde el siglo XIX, fueron una clara manifestación de la preocupación desde las esferas médicas e higienistas acerca de la alta mortalidad experimentada, de manera que la intervención administrativa en pro de una política sanitaria se convirtió en una necesidad acuciante. 
Esta situación puede extrapolarse al momento presente, en la medida en que en 2020, cerca de una de cada cuatro personas seguía careciendo de agua potable y casi la mitad de la población mundial no tenía acceso a servicios de saneamiento gestionados de manera segura. Asimismo, la COVID-19 ha puesto de manifiesto la necesidad de garantizar que todo el mundo tenga acceso a una higiene de manos adecuada. Según datos del informe Progress on household drinking water, sanitation and hygiene 2000 , de 2020, que presenta las estimaciones relativas al acceso de los hogares a servicios de agua potable para 2030, cuando comenzó la pandemia, tres de cada 10 personas del mundo no podían lavarse las manos con agua y jabón en sus hogares $\left(\mathrm{OMS}^{98}\right)$. Por ello, el interés de estudiar el impacto de la infraestructura de saneamiento en la salud de las poblaciones sigue siendo un tema plena actualidad.

Este trabajo, con una mirada retrospectiva, ha descrito el periodo en el que se lograron avances importantes en cuanto a la disposición al acceso a servicios mejorados en torno al agua de consumo y saneamiento de las ciudades, tomando como caso de estudio la ciudad de Madrid.

Si bien, tal y como se ha señalado, existen investigaciones centradas en el estudio de las mejoras en infraestructura urbana en la mortalidad, en el caso español no abundan. Asimismo, éstos se han centrado en la descripción de la evolución del fenómeno, sin atender de manera exhaustiva a la influencia de éstos en la salud y condiciones de vida. Buena parte de la explicación ante la deficiencia de esta clase de estudios, radica en la dificultad para obtener indicadores adecuados que permitan conocer el impacto que tuvieron éstas mejoras de higiene pública en la población en contextos históricos.

Por todo ello, el estudio de la implementación de mejoras en el sistema de abastecimiento de aguas y en las redes de evacuación en la ciudad de Madrid en el primer tercio del siglo XX y su impacto en la mortalidad, supone una contribución relevante al estudio de los factores explicativos del descenso de la mortalidad.

La hipótesis de investigación gira en torno al conocimiento sobre si una mayor cobertura de los sistemas de agua y de alcantarillado contribuyeron a una menor probabilidad de morir por enfermedades transmitidas a través del agua y alimentos. De

\footnotetext{
${ }^{98}$ https://www.who.int/es/news/item/01-07-2021-billions-of-people-will-lack-access-to-safe-watersanitation-and-hygiene-in-2030-unless-progress-quadruples-warn-who-unicef
} 
ello se desprende la necesidad de aplicar un enfoque tanto demográfico-histórico como espacial.

De este modo, desde la descripción de los objetivos específicos, se ha desarrollado un estudio histórico acerca de la evolución e implementación de los elementos de infraestructura urbana de saneamiento tratados; primeramente, sobre el abastecimiento de agua en la ciudad desde mediados del siglo XIX y, en segundo lugar, sobre la construcción y evolución del sistema de alcantarillado madrileño.

Estos capítulos son de suma relevancia en la medida en que, de ellos se deriva el conocimiento sobre la situación real que se vivía en Madrid y su infraestructura urbana a principios del siglo $\mathrm{XX}$.

La construcción de infraestructuras para el abastecimiento de agua potable y la gestión de residuos acompañó al proceso de crecimiento de las ciudades occidentales desde el siglo XIX. En la ciudad de Madrid, el crecimiento en extensión y en población experimentado, también vino acompañado de la necesidad de introducir estas mejoras. En este sentido, las condiciones del suministro de agua estuvieron determinadas por el crecimiento poblacional y, a su vez, este crecimiento de la población se vio reflejado en la expansión territorial de la ciudad, lo que conllevó a una agudización de las diferencias sociales, especialmente a nivel de barrio. De facto, el Plan del Ensanche de la ciudad estuvo muy condicionado a la disponibilidad de agua potable dado que el sistema de distribución de agua utilizado tradicionalmente, los Viajes de Agua, se tornó claramente insuficiente.

La transformación que sufrió la ciudad de Madrid y sus habitantes en el primer tercio del siglo XX también se vio reflejada en el consumo de agua. Este asunto no puede entenderse si no es en el contexto de crecimiento urbano que sufrió la ciudad. Desde que se ordenó la construcción del Canal de Isabel II, en 1851, por orden del Gobierno, dados los graves problemas de abastecimiento que sufría la ciudad de Madrid, las dificultades de diversa índole (económicas, judiciales...) fueron las acompañantes de las diversas actuaciones.

Teniendo en cuenta los acontecimientos más relevantes vinculados a los modelos de organización, gestión y distribución del servicio de abastecimiento de agua entre la 
segunda mitad del siglo XIX y principios del XX, de manera indudable, el Canal de Isabel II fue el protagonista en la serie de acciones llevadas a cabo.

Si bien, la incapacidad técnica y financiera de las administraciones locales para acometer la modernización de los sistemas de suministro de aguas provocó el surgimiento de una empresa privada, la Hidráulica Santillana, y la concesión de parte del servicio de suministro de aguas en la capital. A lo largo del periodo estudiado tuvieron lugar amplias modificaciones y renovaciones del servicio de aguas, con nuevos modelos de gestión, y cuya traducción se orientó a una modernización (parcial) del sistema, pero que fue de facto insuficiente para satisfacer a la demanda social de una ciudad como Madrid, que crecía tanto demográfica como territorialmente. Las necesidades de higiene de la ciudad se acrecentaban al compás que lo hacía el crecimiento de su población.

Junto a las redes de distribución de agua potable, las redes de evacuación de aguas configuran un elemento imprescindible de la infraestructura urbana destinada al saneamiento de las poblaciones, tal y como pusieron de manifiesto los preceptos de ingeniería sanitaria, y su visión sanitaria del urbanismo, que comenzaron a mostrar un incipiente auge desde finales del siglo XIX y fueron consolidados en el siglo XX.

En el caso de la ciudad de Madrid, el enfoque higienista y la necesidad tácita del saneamiento de las poblaciones prevalecerá de manera clara en el periodo estudiado, en tanto en cuanto comenzará a tratarse de manera conjunta el problema de la gestión de los residuos urbanos y el estado en que se encontraba en río Manzanares, como lugar al que desaguaban las aguas negras con procedencia del casco histórico de la ciudad. Así, durante este periodo, de manera muy paulatina, se pasará de una simple red de evacuación a otra más desarrollada de saneamiento, lo que implicó la realización de complejas y costosas obras de ingeniería.

En este sentido, si bien podemos hablar de que desde finales del siglo XIX hasta el primer tercio del siglo $\mathrm{XX}$ se produjo una evolución en los servicios públicos de abastecimiento de agua y del sistema de alcantarillado en la ciudad de Madrid, la interrelación entre estos dos elementos no se forjó de manera unívoca.

Las diferencias espaciales, así como la ineficiencia y falta de planificación de los servicios fue manifiesta. Además, resulta importante destacar que la secuencia de la construcción de las redes, fruto de la ausencia de planes técnicos conjuntos, puede ser 
uno de los elementos explicativos de nuestros resultados, en la medida en que la efectividad de la infraestructura de saneamiento radica, entre otros factores, en la interrelación en la construcción de redes de abastecimiento de agua y de redes de evacuación de manera pareja, temporalmente hablando, y de manera separada en lo que respecta a la conducción de aguas de consumo y de aguas residuales o fecales.

Además, la amplitud de la red de distribución de agua y de alcantarillado no se materializó en un acceso más equitativo al servicio, de manera que en la década de los años 30 del siglo XX seguían aún sin atender a la demanda social de una ciudad en crecimiento, como fue Madrid. En síntesis, podría considerarse que la tónica general del periodo de estudio estuvo marcada por la manifestación de necesidades, quedando por delante de los recursos económicos, materiales y técnicos disponibles. Además, el conflicto existente entre medios y necesidades de los ciudadanos se vio acrecentado con el crecimiento urbano experimentado.

Hay que tener en cuenta, también, que el problema del abastecimiento de agua en la ciudad de Madrid no sólo radicaba en los medios de distribución y la cantidad necesaria, sino también en la calidad de la misma. Si bien, en términos generales, ésta era abundante y se asistió a un crecimiento en lo que respecta a su cantidad, las necesidades en torno a su potabilidad no fueron solucionadas.

Junto con el del destino de las aguas residuales y fecales, es necesario atender a los mecanismos para mejorar la calidad del agua. La importancia de la depuración o purificación de aguas negras fue considerada, especialmente desde los años veinte del siglo veinte, un bastión ineludible a la hora de atender a los problemas de saneamiento acaecidos en toda España. Sin embargo, a la altura de los años treinta, el problema de la gestión de las aguas residuales de la capital siguió configurándose como una deuda pendiente. Las aguas negras continuaban desaguando desde las alcantarillas al río Manzanares, sin ningún tipo de tratamiento, lo que conllevaba que, especialmente en las épocas de estiaje, incluso se diera el caso de que el caudal de éstas aguas fuera superior a las del propio río, resultado un ambiente de indudable insalubridad.

Sin duda alguna, la vigilancia del agua y la conservación de su pureza para el consumo era un asunto importante, no lo era menos la detección de otras posibles causas de peligro, tales como lo era el consumo de verduras para su ingesta cruda que eran regadas con aguas procedentes de la evacuación de aguas residuales del alcantarillado. 
Sin embargo, la actividad gubernamental para combatir este hecho no fue nunca prioritaria, si nos remitimos a que, a la altura de los años treinta, la depuración de las aguas seguía siendo un problema sin resolver, pese a que las entidades municipales tenían obligaciones en torno a estas materias relacionadas con la higiene y sanidad públicas.

Si bien, hay que destacar que una de las manifestaciones más importantes de los preceptos higienistas en las instituciones de la capital, fue la creación de un organismo cuya finalidad expresa era contribuir mediante sus actuaciones a la mejora de la higiene pública madrileña: el Laboratorio Municipal de Higiene. Las actuaciones gubernamentales llevadas hasta la creación del mismo, en materia de higiene y salubridad, estuvieron caracterizadas por su eventualidad, ligadas especialmente a la irrupción de enfermedades epidémicas que forzaban, de algún modo, a la adopción de medidas gubernamentales en materia de salud, pero sin una planificación y proyección continuada. Con su creación se contribuyó de manera impensable hasta el momento en diversos aspectos relacionados con la higiene pública; desde la vigilancia epidemiológica, la puesta en marcha de desinfecciones o la vigilancia alimenticia hasta la creación y dispensación de vacunas. Asimismo, la sistematización de los análisis químicos y bacteriológicos de las aguas de consumo supusieron un avance sin precedentes en la preservación de unos mínimos de calidad del agua y su vinculación con la sanidad pública.

Uno de los potenciales del presente estudio reside en la estructura y en la riqueza de los datos demográficos y la vinculación de estos a una infraestructura de datos espaciales que permite la realización de análisis de espacial a través de la Infraestructura de Datos Espaciales Histórica de Madrid (HISDI-MAD), tal y como ha podido verse.

En este sentido, tras la descripción y contextualización de los temas anteriores, con el objetivo de comprender de una forma holística las diferencias espaciales a nivel de barrio en la ciudad de Madrid, en el capítulo ocho se ha tratado de dibujar una panorámica sobre elementos que constituyen la estructura social de la ciudad. De este modo, se ha constatado que la distribución poblacional en la ciudad de Madrid no se producía de manera aleatoria; las desigualdades sociales delimitan tal distribución, produciéndose una fragmentación del espacio urbano y una segregación socioespacial comprobada a nivel de barrio. 
Asimismo, mediante el cálculo de indicadores de mortalidad de niños menores de cinco años y su representación espacial, los patrones de distribución atendiendo a características sociales se vislumbran también en estos mapas.

Lo mismo sucede teniendo en cuenta el análisis de distribución de la mortalidad por causas infecciosas transmitidas a través del agua y alimentos para los niños menores de cinco años y su representación a nivel de barrio. De este modo, se manifiesta que, fruto de la elevada presencia y persistencia de este tipo de causas a lo largo de periodo de estudio, el estado higiénico sanitario de la ciudad de Madrid a finales del siglo en estos años del siglo XX previos a la Guerra Civil no era ideal. Partiendo de la hipótesis general de este trabajo de que las mejoras en infraestructura urbana de saneamiento contribuyeron a un descenso de la mortalidad por causas de muerte transmitidas a través del agua y alimentos, esto contribuye a pensar que, si bien la ciudad de Madrid caminaba a principios de siglo XX hacia la evolución de un sistema de infraestructura urbana de saneamiento más moderna y de mayor amplitud territorial, todavía podía caracterizarse como un sistema que no es que no fuera totalmente eficiente, sino que su repercusión en la salud de la población no abarcaba a todos por igual. Continuando, de este modo, a perpetuarse desigualdades vinculadas a la desigualdad social y económica de las diferentes zonas de la capital.

Así, no hemos podido demostrar de manera fehaciente que la amplitud de la red de distribución de agua y alcantarillado se materializase en un acceso más equitativo al servicio, de manera que se puede afirmar que en la década de los años 30 del siglo XX los servicios de abastecimiento de agua seguían aún sin atender a la demanda social de una ciudad en crecimiento, como fue Madrid.

Hay que tener en cuenta que el impacto de la provisión de agua potable en el riesgo de mortalidad es un tema de estudio controvertido en los estudios históricos, en la medida en que algunos estudios han evidenciado tal impacto, mientras que otros no han reportado un efecto unívoco. Y es en esta segunda línea donde se ubican los resultados de nuestros análisis.

En relación a la pregunta de investigación planteada en la presente tesis doctoral, que no es otra sino si las reformas sanitarias afectaron la mortalidad urbana, hay que tener en cuenta que el análisis bibliográfico sobre esta temática nos ofrece resultados bastante disímiles unos de otros. Algunos autores llegan a la conclusión del efecto de la 
inversión en saneamiento en la disminución de la mortalidad y la introducción de nuevos suministros de agua en la mortalidad por enfermedades trasmitidas a través del agua así como el impacto de las reformas sanitarias en la disminución de la mortalidad infantil. Pero otros autores no encuentran evidencias significativas, o llegan a resultados bastante más modestos a la hora de establecer una relación explicativa entre las reformas sanitarias y la disminución de la mortalidad.

Partiendo del hecho que la propagación de las enfermedades infectocontagiosas está estrechamente relacionado con la inversión en sanidad y en higiene pública y, entre éstas, la implementación de sistemas de saneamiento, con el suministro de agua de consumo independiente de las residuales y fecales, han sido consideradas como las más relevantes, cabe considerar que, dada la modernización del sistema ocurrida en la ciudad de Madrid, a priori sí se encuentra una influencia en la mortalidad por causas de muerte transmitidas a través del agua y alimentos.

Sin embargo, los resultados de los modelos sobre la influencia de la red de alcantarillado y de la red de distribución de agua en la mortalidad nos han ofrecido resultados un tanto contradictorios. Por una parte, nuestros resultados nos alientan a afirmar que la extensión de la red de distribución de agua sí influyó en la mejora de la mortalidad por causas de muerte relacionadas con enfermedades transmitidas a través del agua y alimentos. Pero, por otro, una mayor presencia de la red de alcantarillado y de una mayor red de agua ejerció, en algunos casos, un efecto negativo en la mortalidad, lo que puede venir explicado porque en buena parte de las zonas de la ciudad donde la red de agua existía pero no estaba abastecida de agua potable, o al contrario, podría convertirse más en un foco de infecciones que en un elemento de salubridad.

Nuestros resultados nos llevan a mantener que la implementación de mejoras en el sistema de abastecimiento de aguas no condujo de forma necesaria a ganancias sustanciales en salud pública, dado que las implicaciones higiénicas y los factores medioambientales resultantes han de verse en conjunto con la modernización de los servicios de tratamiento de las aguas. En este sentido, podría suceder que el efecto producido en la salud de los ciudadanos fruto de la modernización del sistema de aguas no sería tan acusado como lo fue el de la construcción de los sistemas de alcantarillado.

Asimismo, tal y como se ha demostrado en otros estudios, hay que tener en consideración las diferencias entre obras vinculadas al abastecimiento de agua, obras 
relativas al sistema de evacuación de residuos y las referentes a la calidad de las aguas. En este sentido, es de suma importancia conocer la sucesión de las diferentes obras implementadas en el caso de la ciudad de Madrid. Este trabajo ha tratado de mostrar que la secuencia en la implementación de medidas tuvo una influencia significativa en la mortalidad, de manera que pudo ser perjudicial en algunos casos. En el caso de la ciudad de Madrid, la primera inversión en abastecimiento de agua no se acompañó de la correspondiente en el sistema de evacuación, lo que conllevó a que algunas zonas se vieran perjudicadas, o expuestas a un mayor riesgo.

También hay que tener en cuenta que el hecho de que existiera una red de alcantarillado no significaba necesariamente que por ella discurriera agua para el arrastre, de manera que, en vez de resultar un elemento de saneamiento podría convertirse en un foco infeccioso por las basuras y otros elementos que allí se almacenaban, pues los objetos tanto líquidos como sólidos quedaban almacenados en las mismas. El hecho de que el Ayuntamiento de Madrid diera la iniciativa a los propietarios de las casas a la hora de construir nuevas alcantarillas así como dejar la misma libertad a los propietarios a la hora de hacer las acometidas particulares desde sus casas a las nuevas alcantarillas puede ser una explicación al hecho de que, tal y como reflejan nuestros análisis, la mayor presencia de alcantarillado en las zonas de la ciudad no actúa como elemento protector de la mortalidad. Además, una limitación de nuestro análisis es que no somos capaces de conocer realmente qué hogares tenían conexión a la misma, de modo que el hecho de que se hubiera construido una alcantarilla en una calle no significaba que todos los edificios de la misma estuvieran conectados pues los propietarios no tenían la obligación de hacerlo. A esto hay que sumarle que el hecho de que un edificio estuviera conectado a una alcantarilla no implicaba que todos los pisos del inmueble vertieran sus residuos a la misma, pues la mayoría de los pisos altos carecían de agua corriente, bien por falta de presión, o simplemente porque los propietarios no la querían. El ideal sería disponer de datos individuales sobre la conexión de los hogares a la red de alcantarillado, así como los abonos y suscripciones para el abastecimiento de agua, que permitiría acercarnos de manera más pormenorizada al fenómeno de estudio.

Como puede verse, los resultados de este estudio, alientan a la necesidad de incorporar aspectos y variables adicionales a las consideradas en aras de lograr una mayor y más completa comprensión del problema. Asimismo, la amplitud del periodo de estudio 
considerado, permitiría captar de una manera más óptima la influencia de las mejoras en la extensión de las redes de agua y alcantarillado en la mortalidad.

Pese a las limitaciones descritas, la presente tesis doctoral ha tratado de contribuir al debate sobre el impacto real que el desarrollo de las infraestructuras de saneamiento tuvo en la salud y la mortalidad. Asimismo, contribuye a la discusión existente acerca de la falta de una respuesta unánime sobre de la identificación de variables de resultado apropiadas sobre qué mortalidad explicar; mortalidad por causas específicas y/o mortalidad general y/o mortalidad infantil. Todo ello, en aras de ampliar el espectro de estudio acerca de los factores influyentes en el proceso de transición sanitaria y epidemiológica. 


\section{Anexos}

Tabla Anexos -1. Relación de los barrios y su numeración.

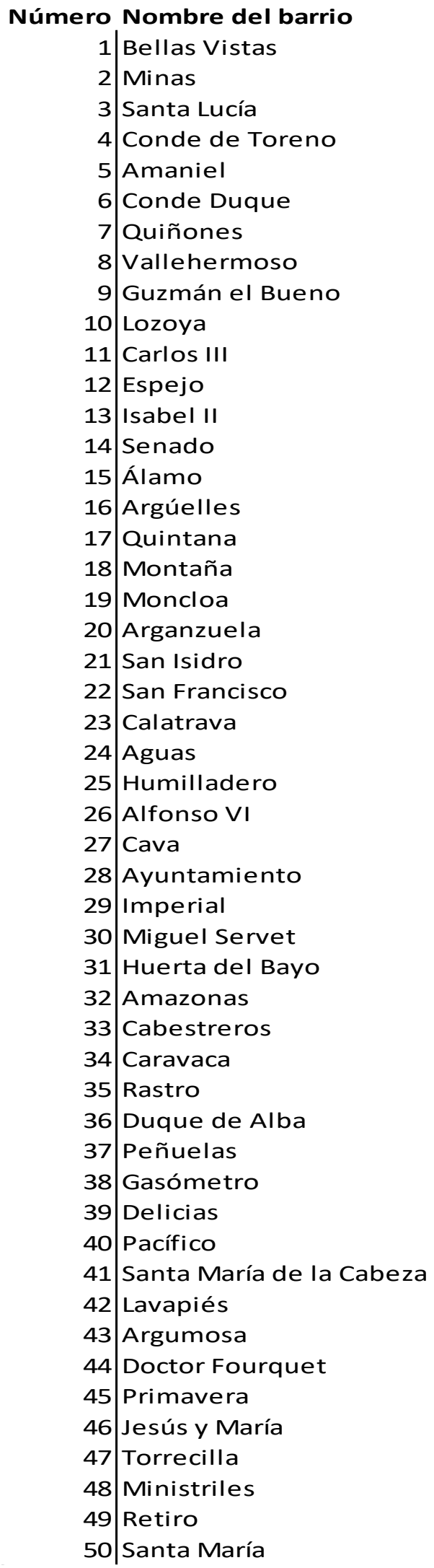

Número Nombre del barrio

$51 \mid$ Alameda

52 Cervantes

53 Cañizares

54 Príncipe

55 Floridablanca

56 San Carlos

57 Gutemberg

58 Fernando el Santo

59 Almirante

60 Conde de Aranda

61 Goya

62 Marqués de Salamanca

63 Las Mercedes

64 Biblioteca

65 Monasterio

66 Alfonso $X$

67 Balmes

68 Dos de Mayo

69 Hipódromo

70 Luchana

71 Monteleón

72 Trafalgar

73 Cuatro Caminos

74 Hernán Cortés

75 Las Torres

76 Colón

77 Bilbao

78 Góngora

79 Jesús del Valle

80 Campoamor

81 San Pablo

82 San Opropio

83 Apodaca

84 Puerta del Sol

85 Constitución

86 San Martin

87 Carmen

88 Jardines

89 San Luis

90 Tudescos

91 Muñoz Torrero

92 Estrella

93 Sandoval

94 Cardenal Cisneros

95 Plaza de Toros

96 Guindalera

97 Prosperidad

98 Marqués de Comillas

99 Correos

100 Casa de Campo 
Gráfico Anexos -1. Compilación del mapa del Distrito Buenavista y sus barrios

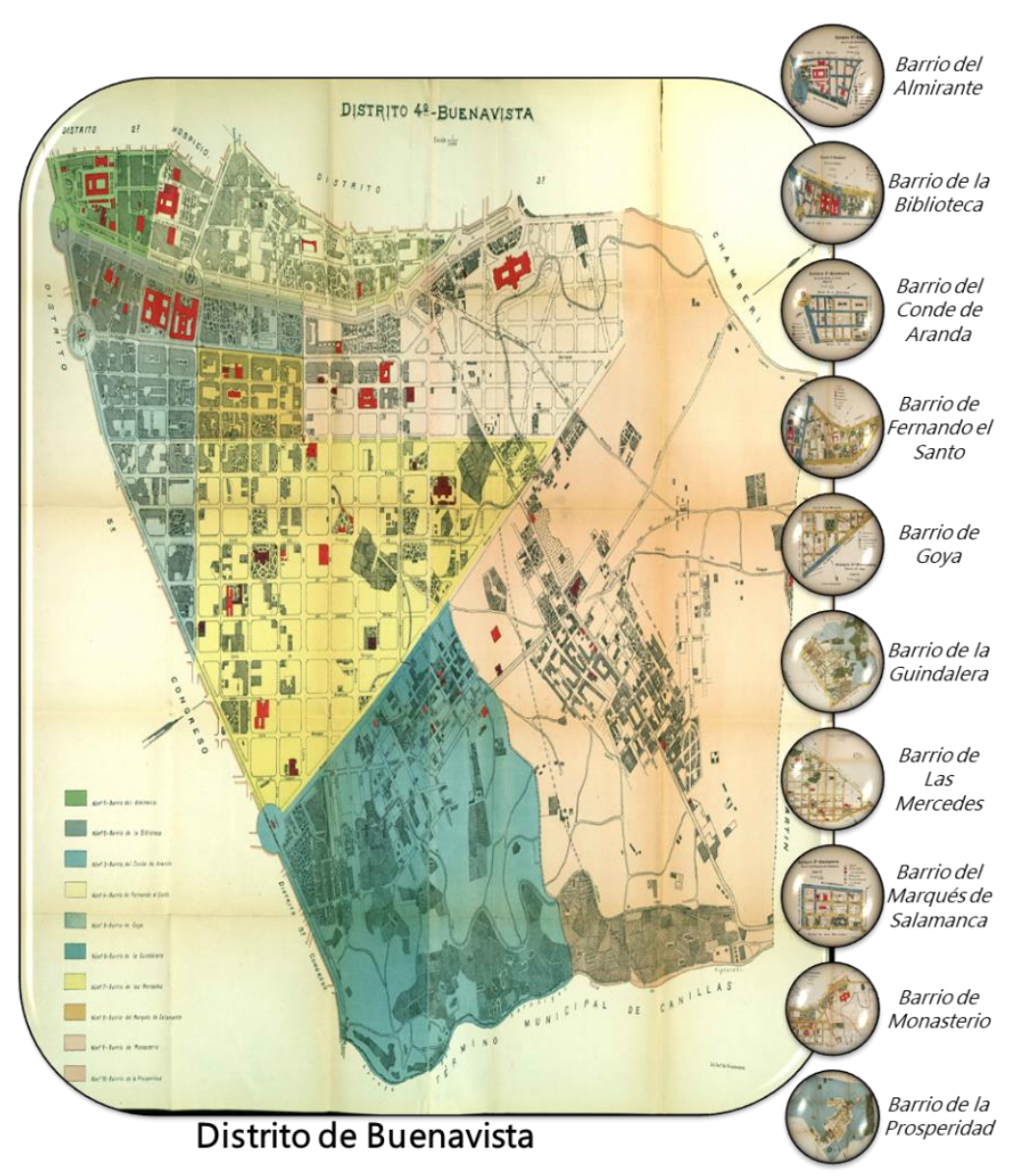

Fuente: Elaboración propia. Imágenes obtenidas de (González e Iribas, 1906) 
Gráfico Anexos -2. Compilación de los mapas de los barrios del distrito Buenavista.

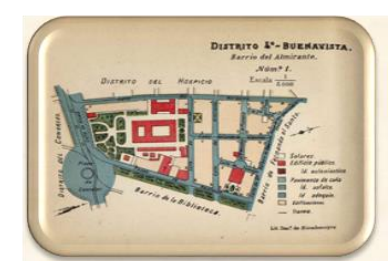

Barrio del Almirante

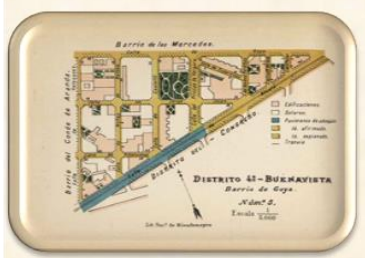

Barrio de Goya

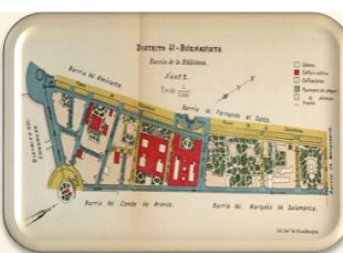

Barrio de la Biblioteca

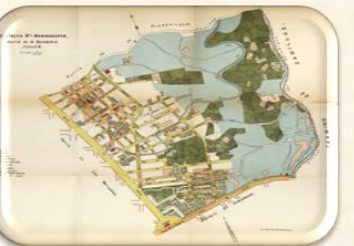

Barrio de la Guindalera

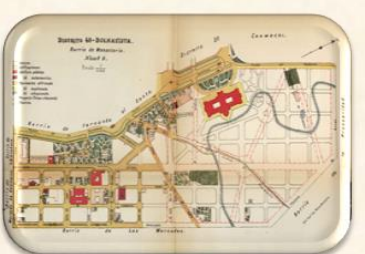

Barrio de Monasterio

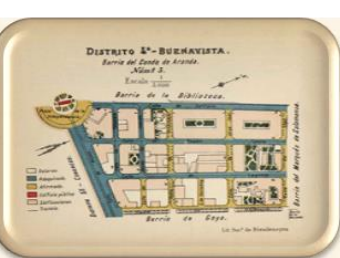

Barrio del Conde de Aranda

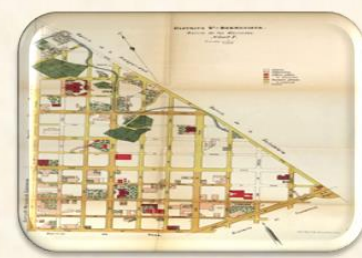

Barrio de Las

Mercedes

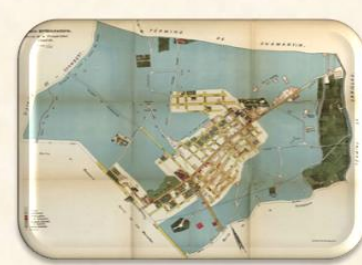

Barrio de la Prosperidad

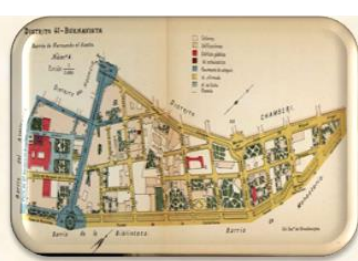

Barrio de Fernando el Santo

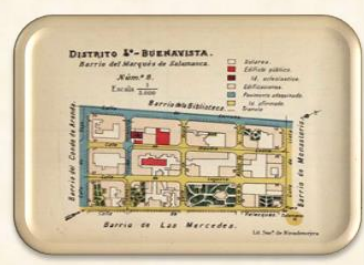

Barrio del Marqués de Salamanca

Fuente: Elaboración propia. Imágenes obtenidas de (González e Iribas, 196) 
Gráfico Anexos -3. Compilación del mapa del Distrito Centro y sus barrios

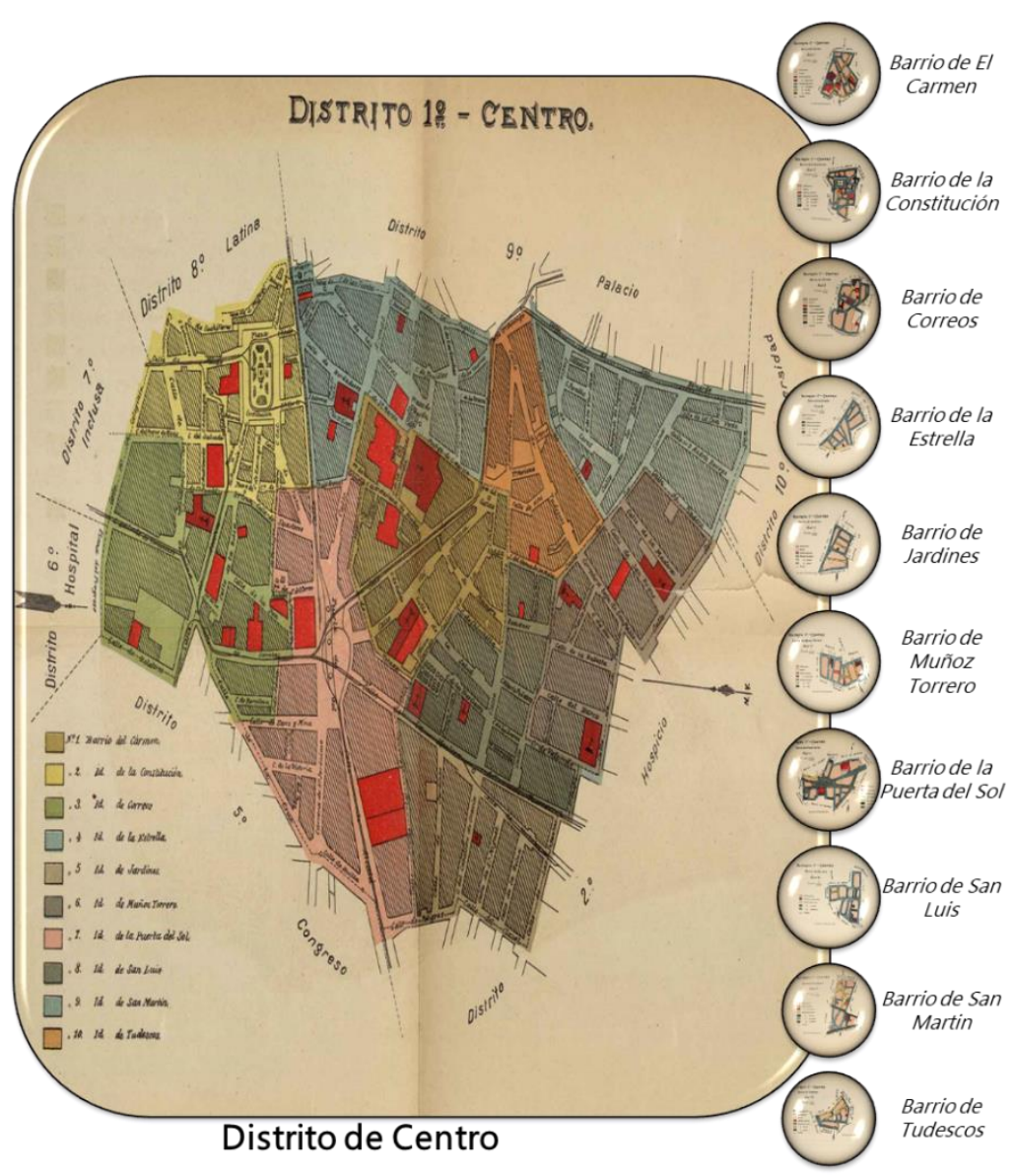

Fuente: Elaboración propia. Imágenes obtenidas de (González e Iribas, 1906) 
Gráfico Anexos -4. Compilación de los mapas de los barrios del distrito Centro.

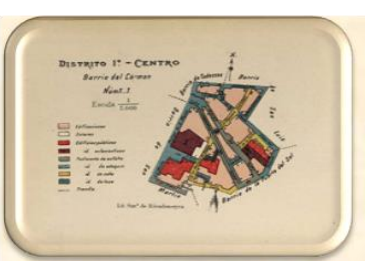

Barrio de El Carmen

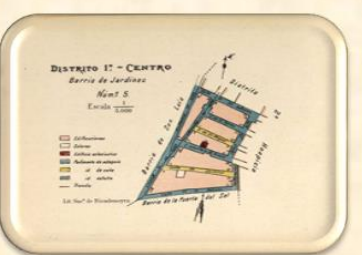

Barrio de Jardines

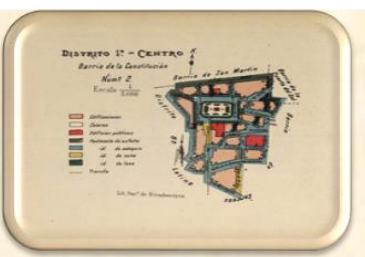

Barrio de la Constitución

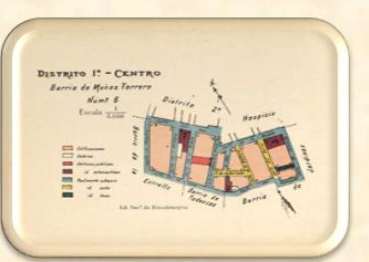

Barrio de Muñoz Torrero

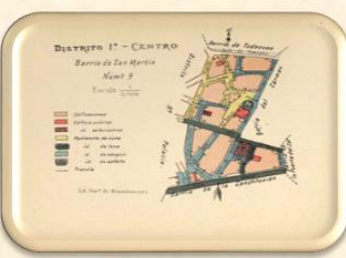

Barrio de San Martín

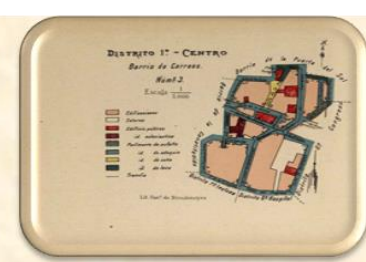

Barrio de Correos

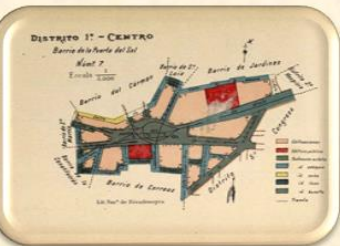

Barrio de Puerta del Sol

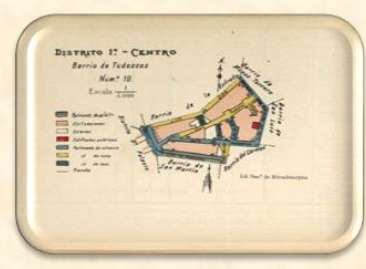

Barrio de Tudescos

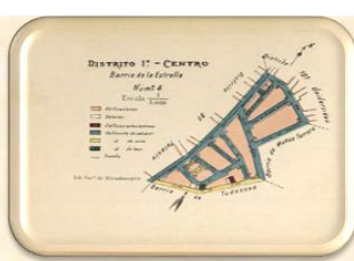

Barrio de la Estrella

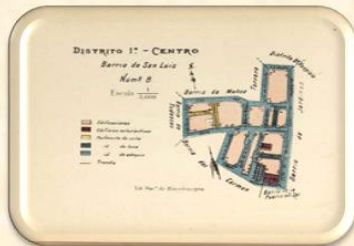

Barrio de San Luis

Fuente: Elaboración propia. Imágenes obtenidas de (González e Iribas, 1906) 
Gráfico Anexos -5. Compilación del mapa del Distrito Chamberi y sus barrios

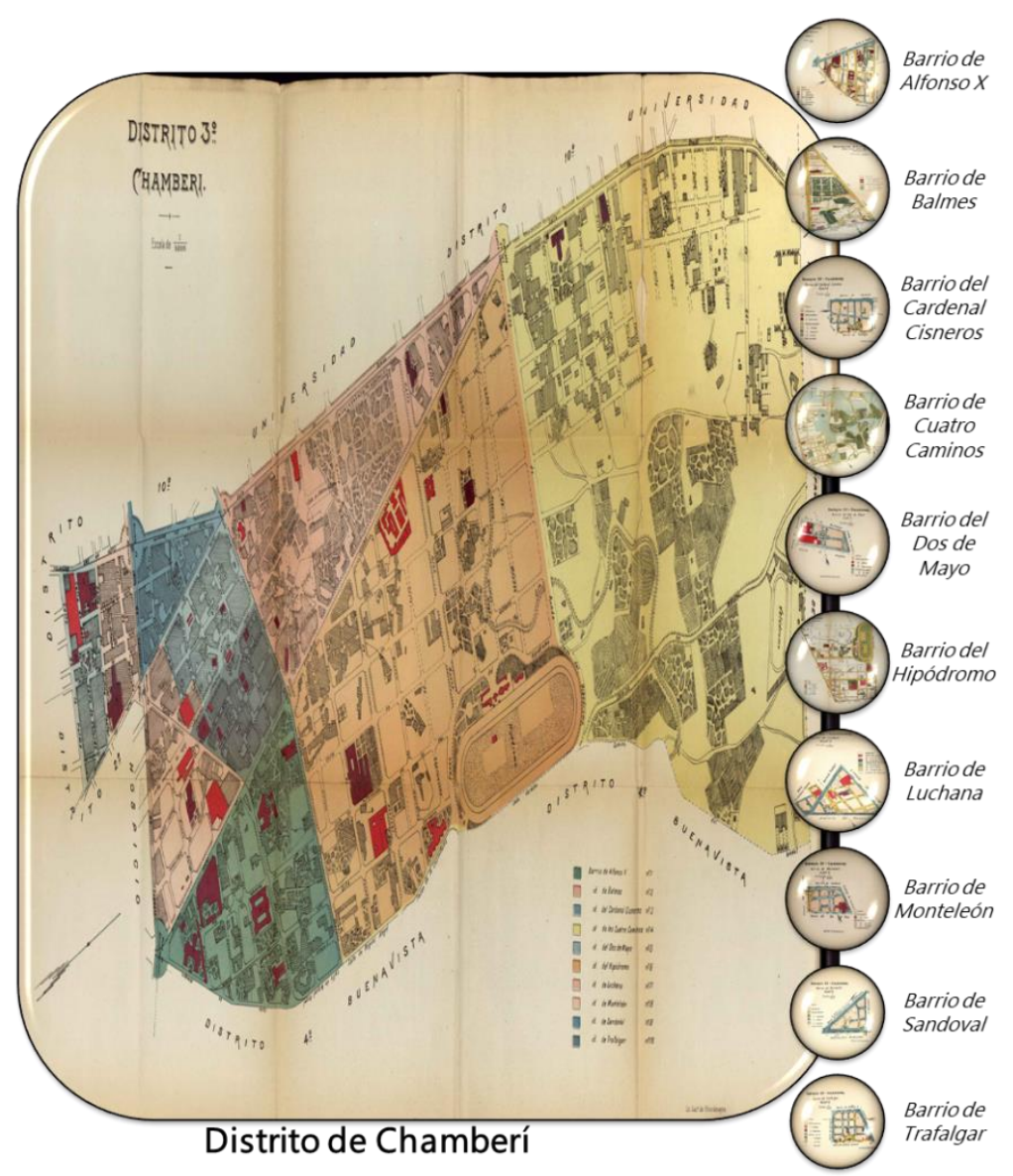

Fuente: Elaboración propia. Imágenes obtenidas de (González e Iribas, 1906) 
Gráfico Anexos -6. Compilación de los mapas de los barrios del distrito Chamberi

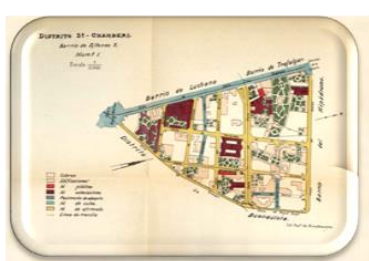

Barrio de Alfonso X

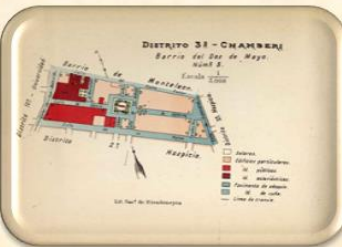

Barrio del Dos de Mayo

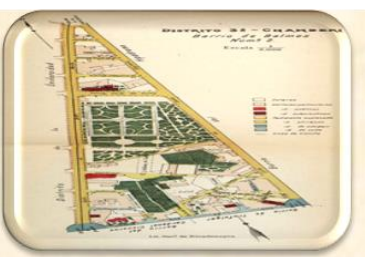

Barrio de Balmes

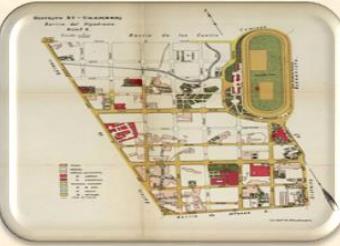

Barrio del Hipódromo

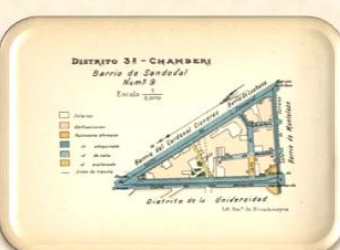

Barrio de Sandoval

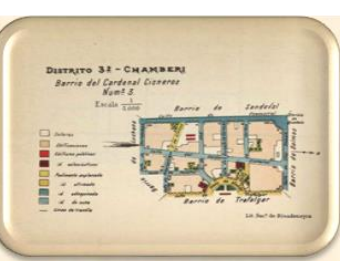

Barrio del Cardenal Cisneros

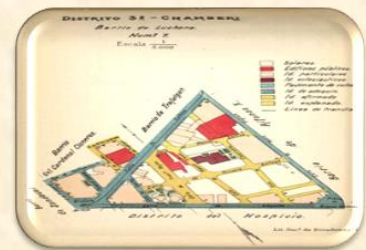

Barrio de Luchana

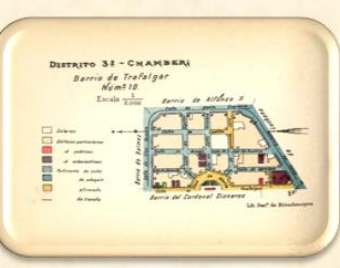

Barrio de Trafalgar

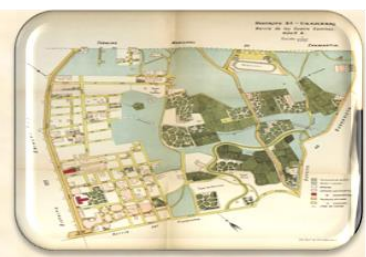

Barrio de Cuatro Caminos

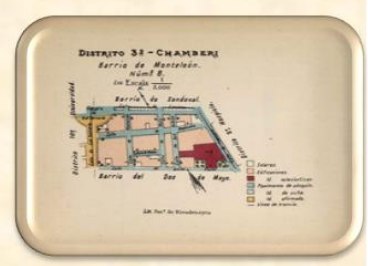

Barrio de Monteleón

Fuente: Elaboración propia. Imágenes obtenidas de (González e Iribas, 1906) 
Gráfico Anexos -7. Compilación del mapa del Distrito Hospicio y sus barrios

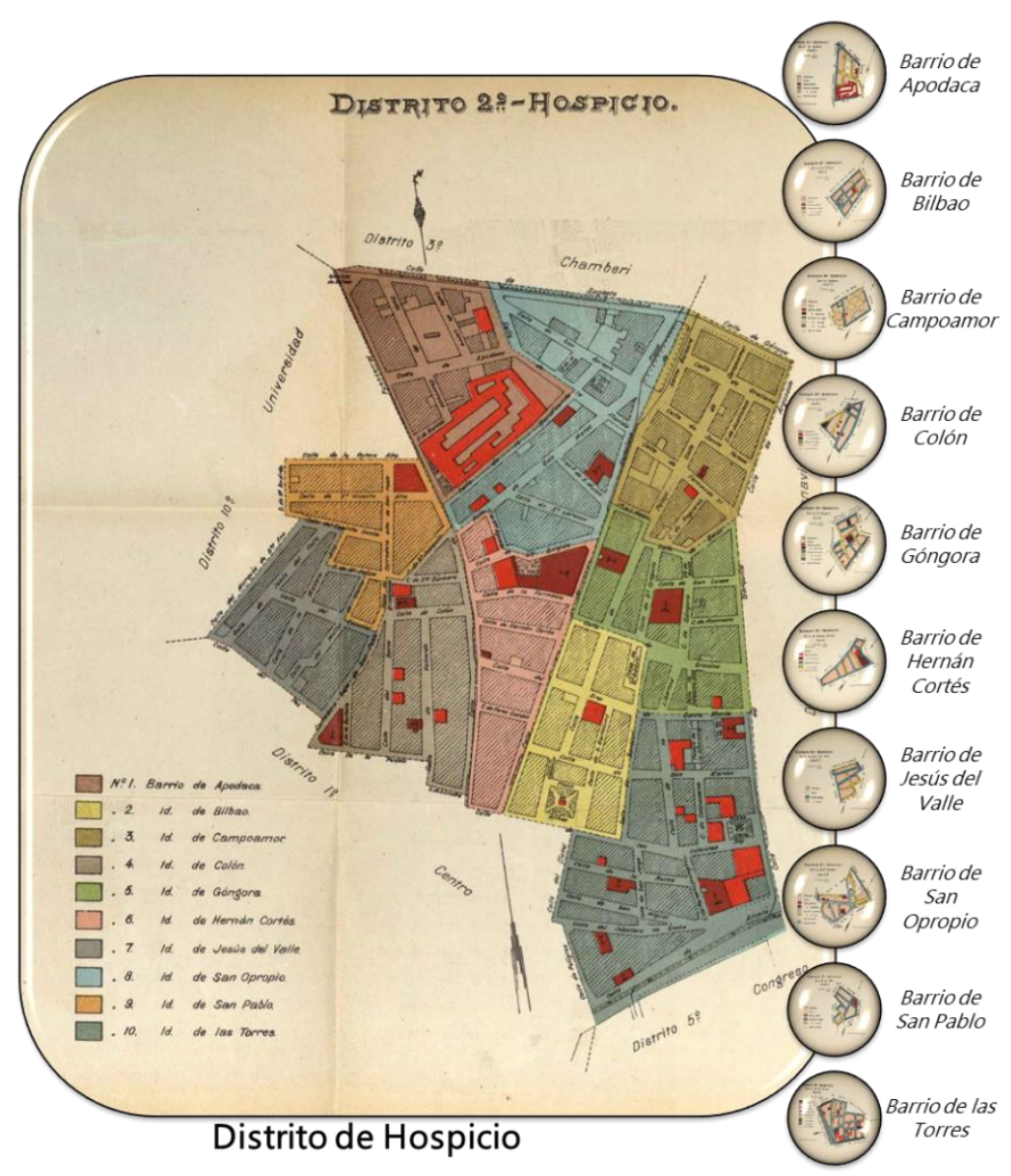

Fuente: Elaboración propia. Imágenes obtenidas de (González e Iribas, 1906) 
Gráfico Anexos -8. Compilación de los mapas de los barrios del distrito Hospicio

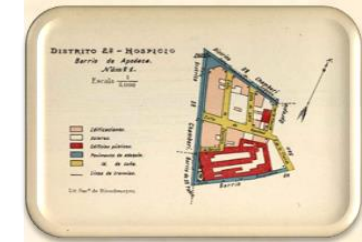

Barrio de Apodaca

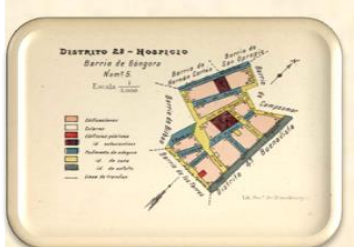

Barrio de Góngora

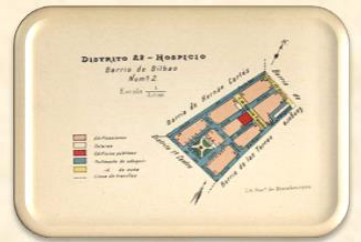

Barrio de Bilbao

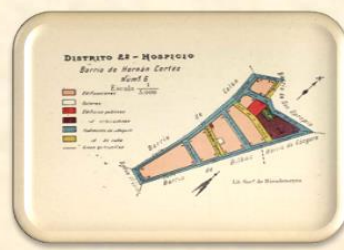

Barrio de Hernán Cortés

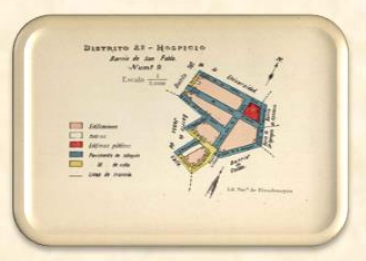

Barrio de San Pablo

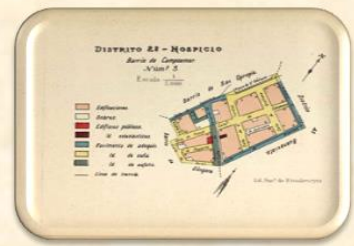

Barrio de Campoamor

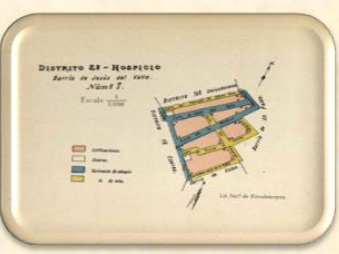

Barrio de Jesús del Valle

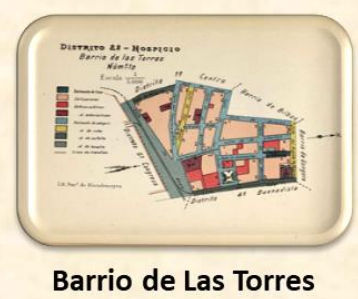

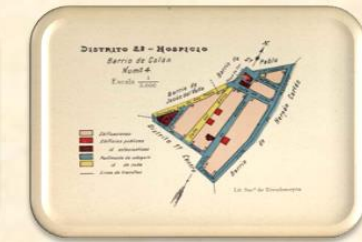

Barrio de Colón

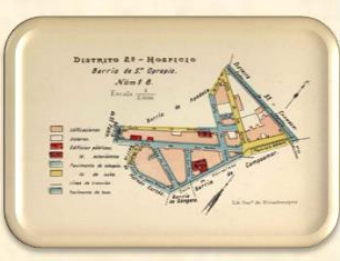

Barrio de San Opropio

Fuente: Elaboración propia. Imágenes obtenidas de (González e Iribas, 1906) 
Gráfico Anexos -9. Compilación del mapa del Distrito Hospital y sus barrios

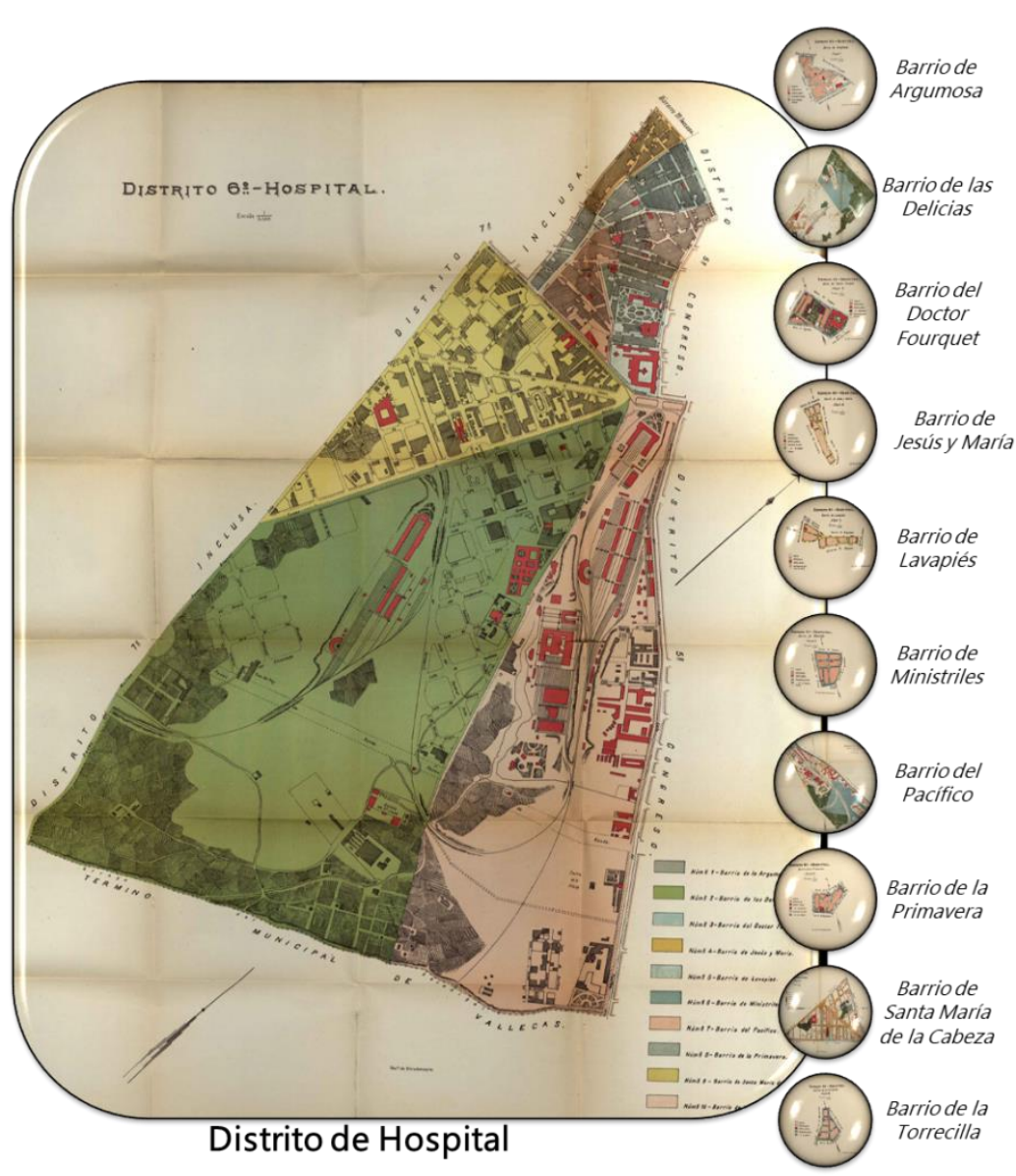

Fuente: Elaboración propia. Imágenes obtenidas de (González e Iribas, 1906) 
Gráfico Anexos -10. Compilación de los mapas de los barrios del distrito Hospital

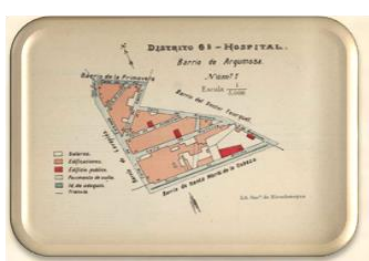

Barrio de Argumosa

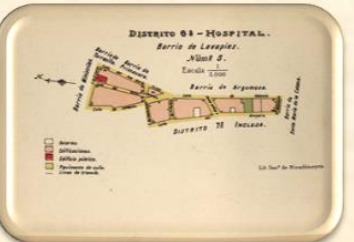

Barrio de Lavapiés

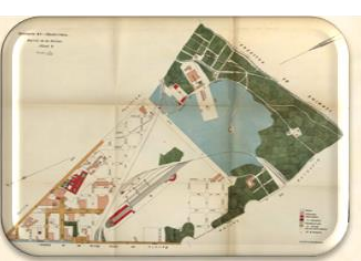

Barrio de las Delicias

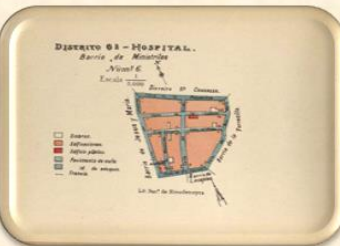

Barrio de Ministriles

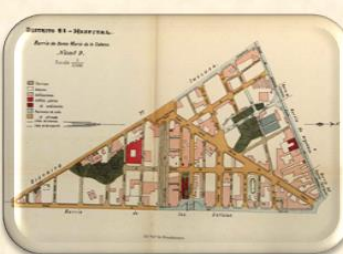

Barrio de Santa María de la Cabeza

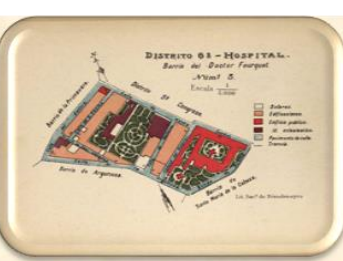

Barrio del Doctor Fourquet

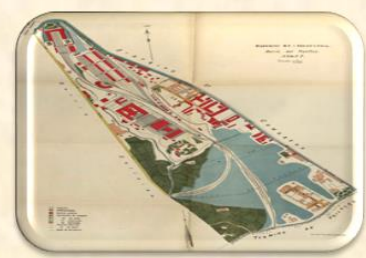

Barrio del Pacífico

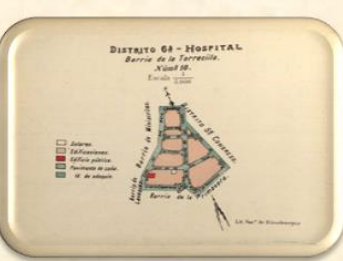

Barrio de la Torrecilla

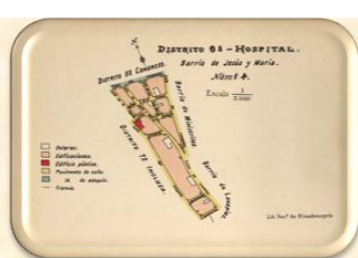

Barrio de Jesús y María

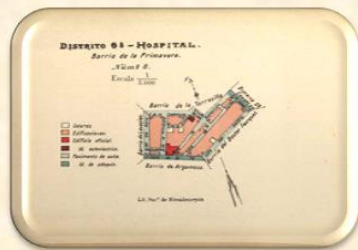

Barrio de la Primavera

Fuente: Elaboración propia. Imágenes obtenidas de (González e Iribas, 1906) 
Gráfico Anexos -11. Compilación del mapa del Distrito Inclusa y sus barrios

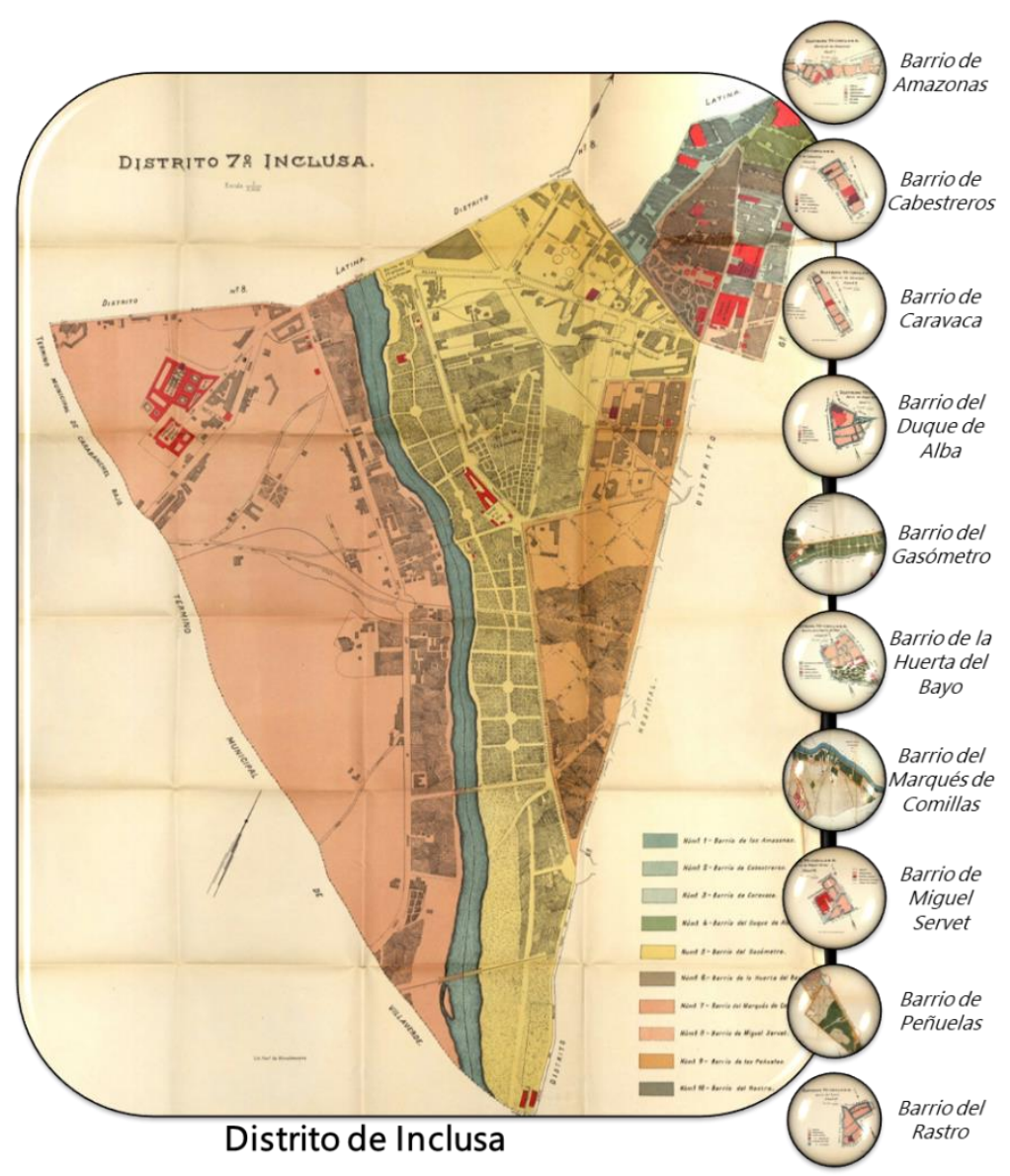

Fuente: Elaboración propia. Imágenes obtenidas de (González e Iribas, 1906) 
Gráfico Anexos -12. Compilación de los mapas de los barrios del distrito Inclusa.

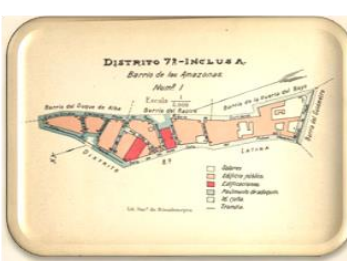

Barrio de Amazonas

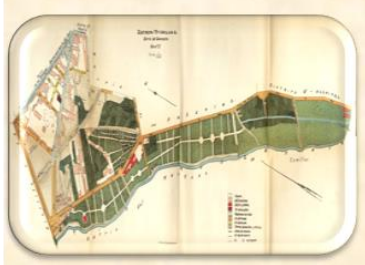

Barrio del Gasómetro

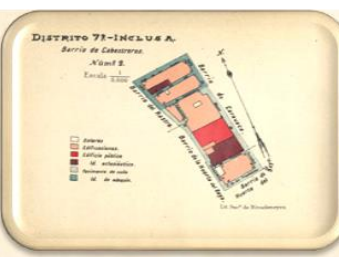

Barrio de Cabestreros

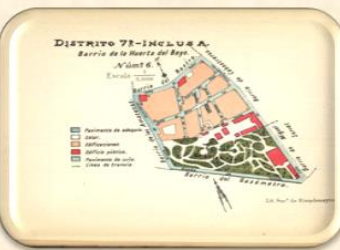

Barrio de la Huerta del

Bayo

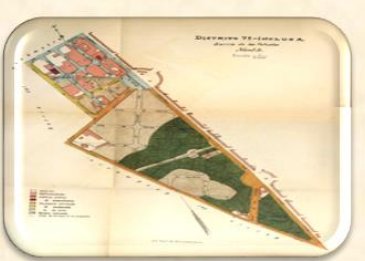

Barrio de Peñuelas

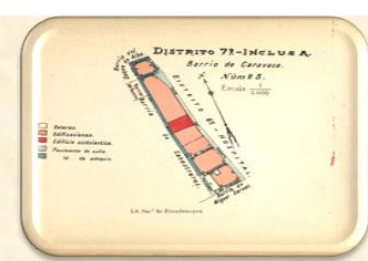

Barrio de Caravaca

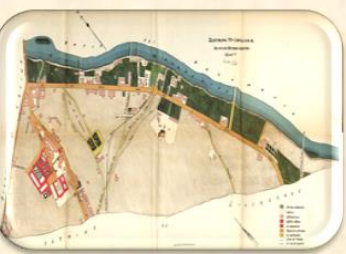

Barrio del Marqués de Comillas

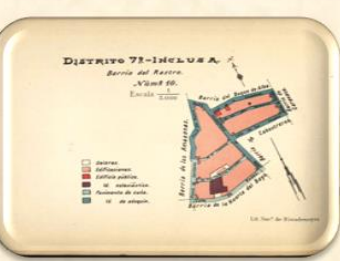

Barrio del Rastro

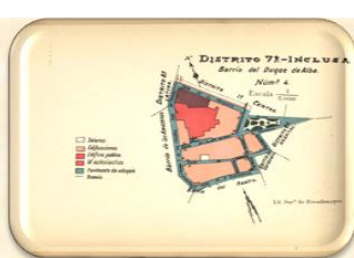

Barrio del Duque de Alba

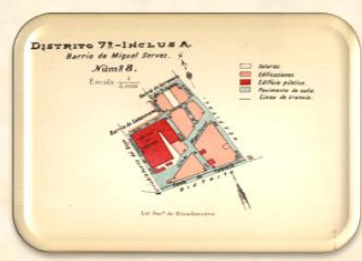

Barrio de Miguel Servet

Fuente: Elaboración propia. Imágenes obtenidas de (González e Iribas, 1906) 
Gráfico Anexos -13. Compilación del mapa del Distrito Latina y sus barrios

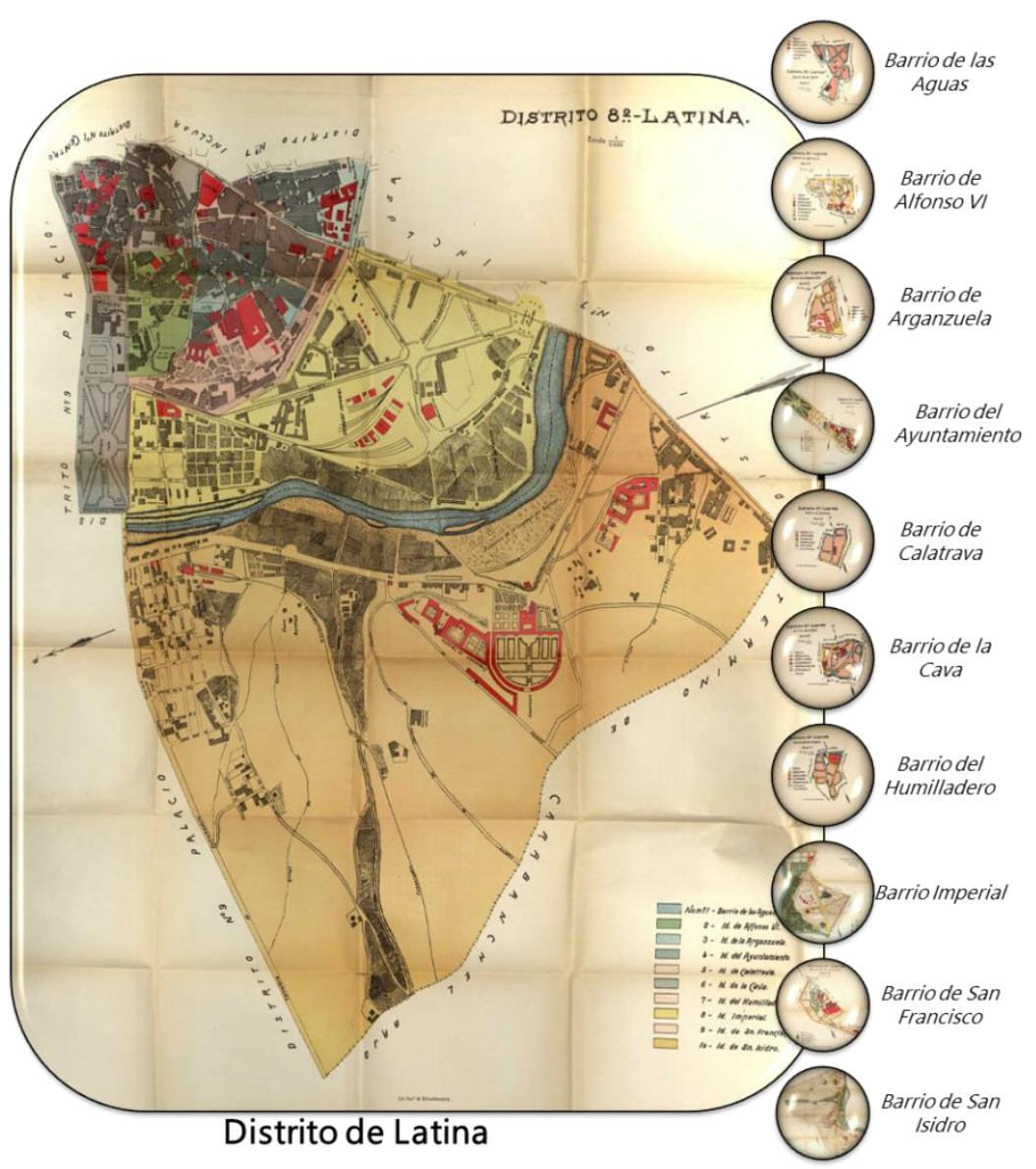

Fuente: Elaboración propia. Imágenes obtenidas de (González e Iribas, 1906) 
Gráfico Anexos -14. Compilación de los mapas de los barrios del distrito Latina

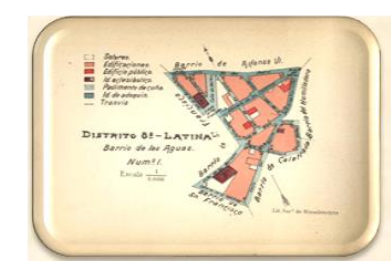

Barrio de las Aguas

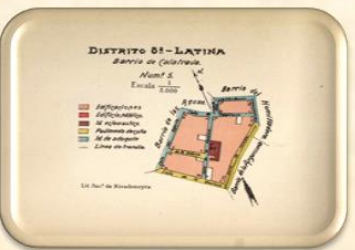

Barrio de Calatrava

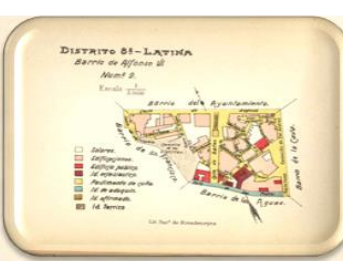

Barrio de Alfonso $\mathrm{VI}$

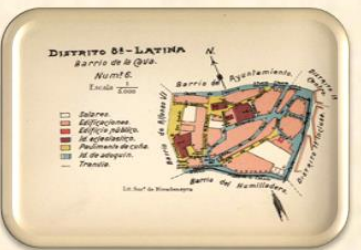

Barrio de la Cava

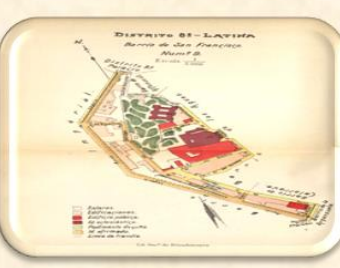

Barrio de San Francisco

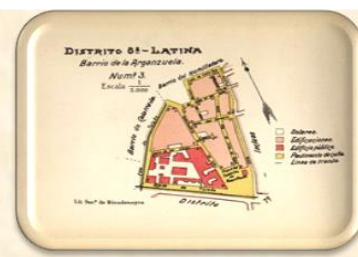

Barrio de Arganzuela

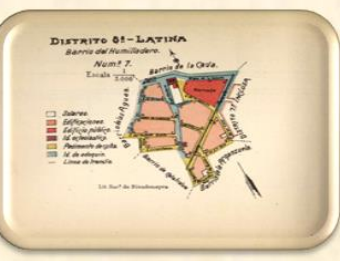

Barrio del Humilladero

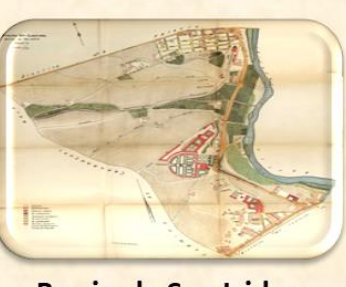

Barrio de San Isidro

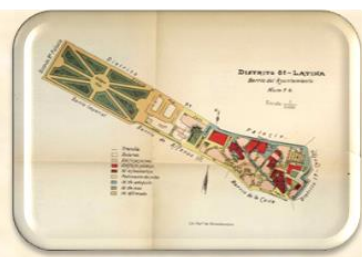

Barrio del Ayuntamiento

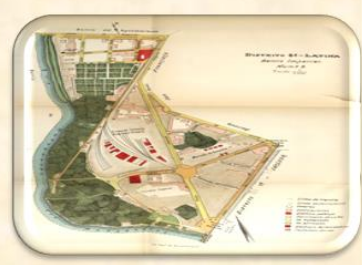

Barrio Imperial

Fuente: Elaboración propia. Imágenes obtenidas de (González e Iribas, 1906) 
Gráfico Anexos -15. Compilación del mapa del Distrito Palacio y sus barrios

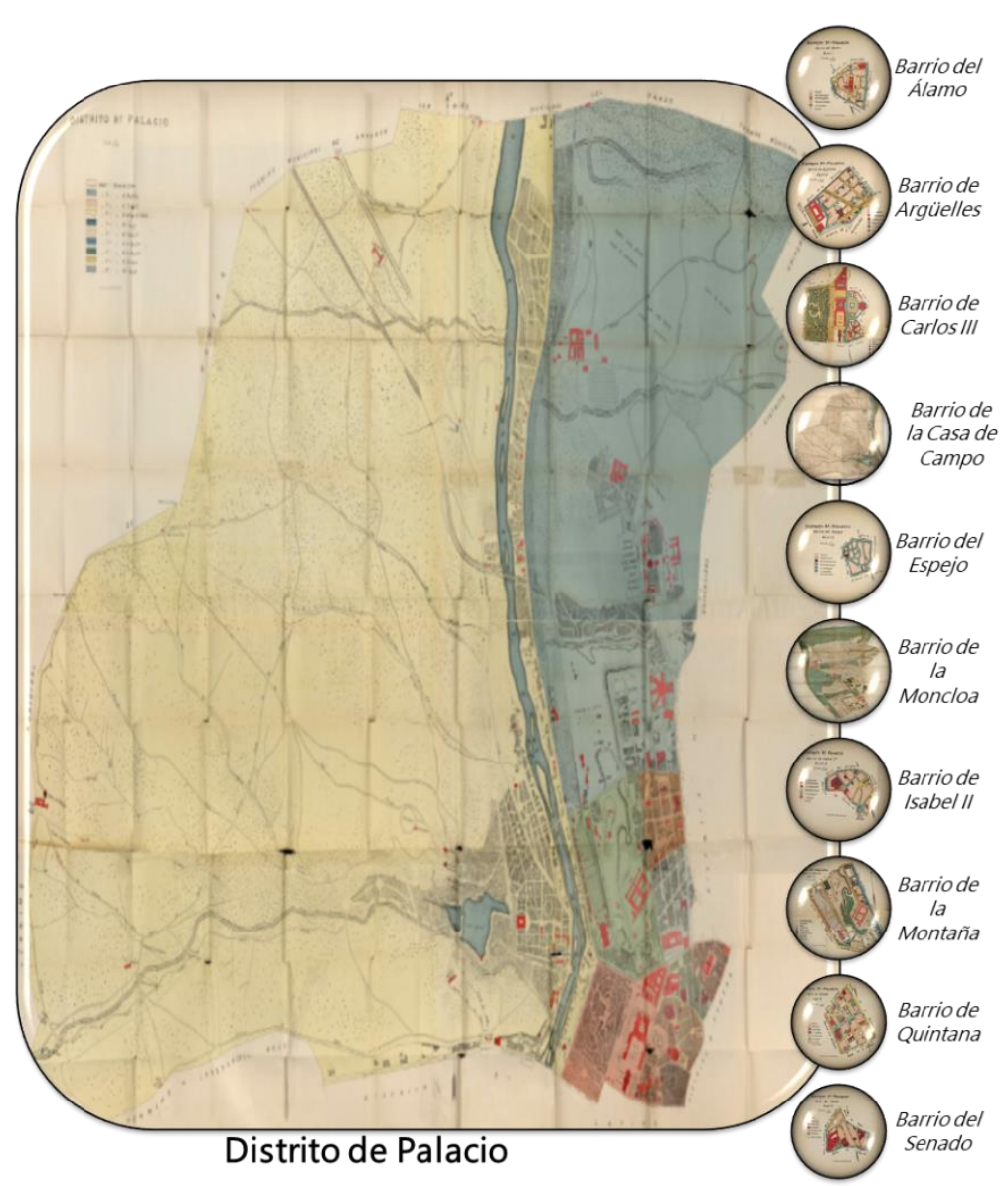

Fuente: Elaboración propia. Imágenes obtenidas de (González e Iribas, 1906) 
Gráfico Anexos -16. Compilación de los mapas de los barrios del distrito Palacio

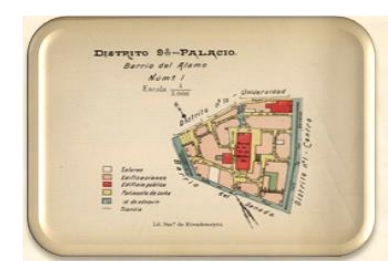

Barrio del Álamo

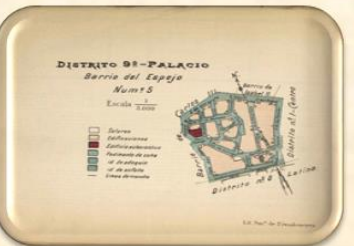

Barrio del Espejo

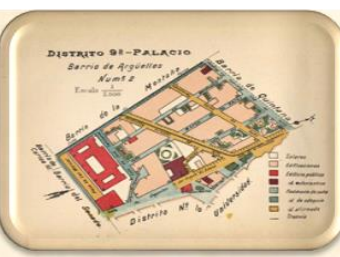

Barrio de Argüelles

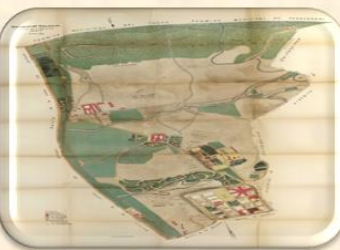

Barrio de la Moncloa

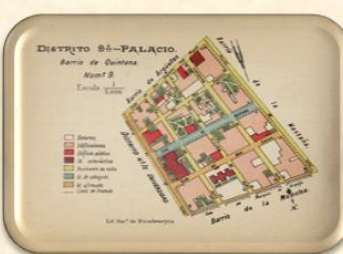

Barrio de Quintana

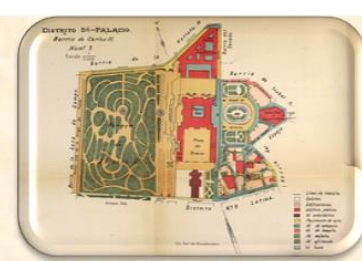

Barrio de Carlos III

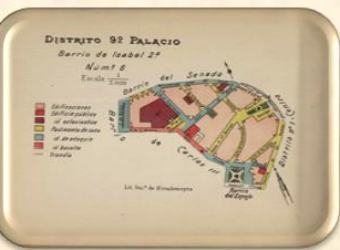

Barrio de Isabel II

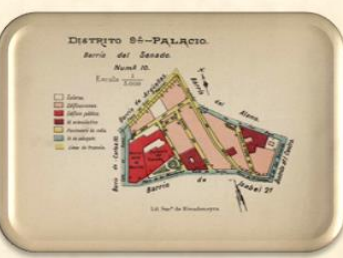

Barrio del Senado

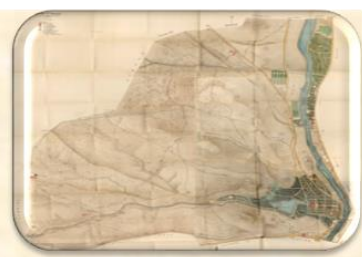

Barrio de la Casa de Campo

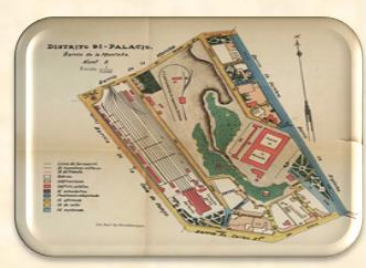

Barrio de la Montaña

Fuente: Elaboración propia. Imágenes obtenidas de (González e Iribas, 1906) 
Gráfico Anexos -17. Compilación del mapa del Distrito Universidad y sus barrios

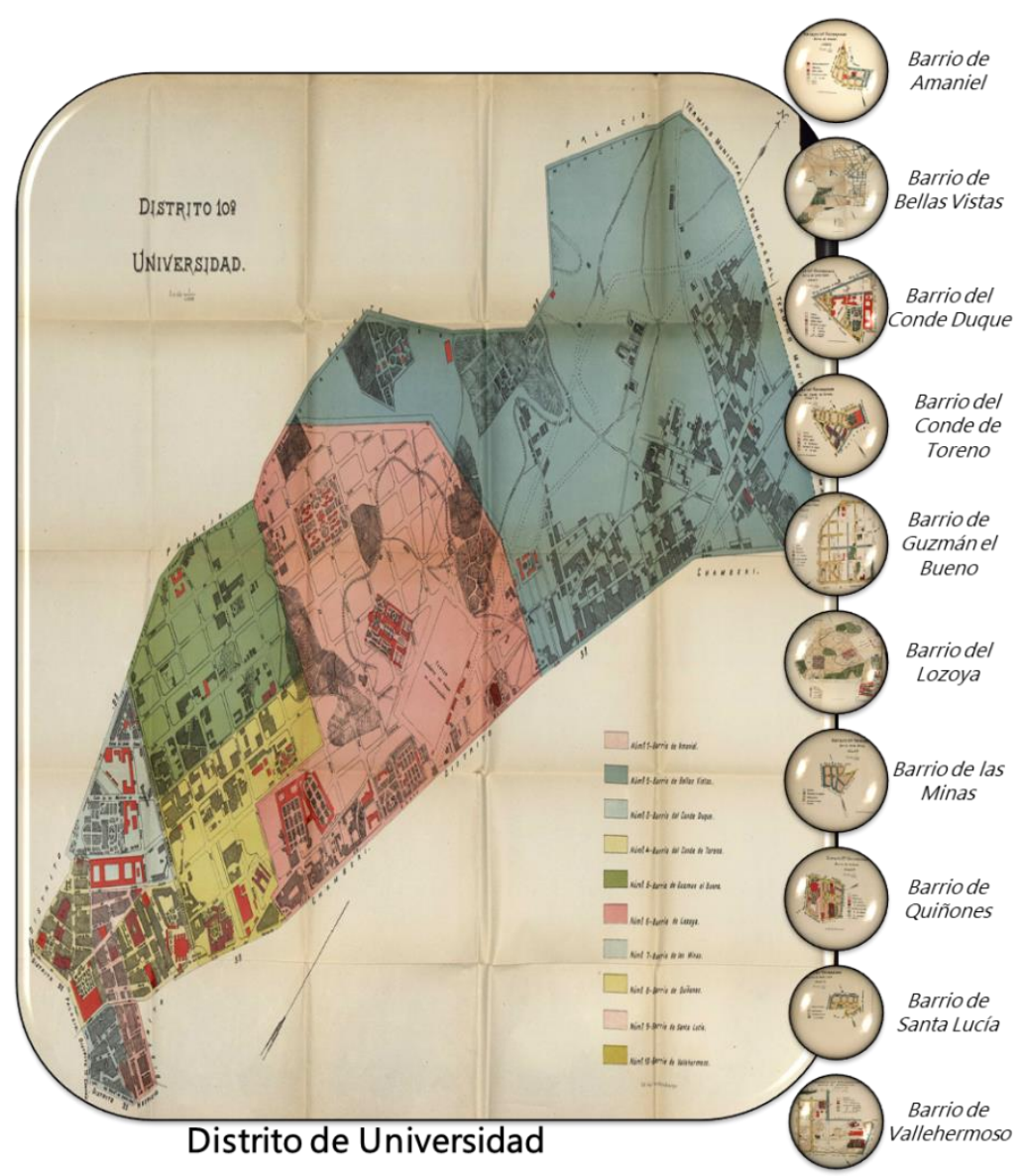

Fuente: Elaboración propia. Imágenes obtenidas de (González e Iribas, 1906) 
Gráfico Anexos -18. Compilación de los mapas de los barrios del distrito Universidad.

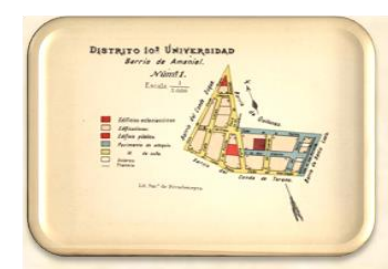

Barrio de Amaniel

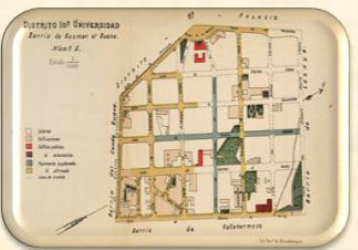

Barrio de Guzmán el Bueno

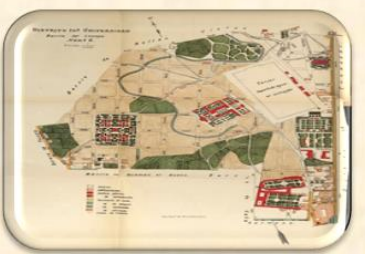

Barrio del Lozoya

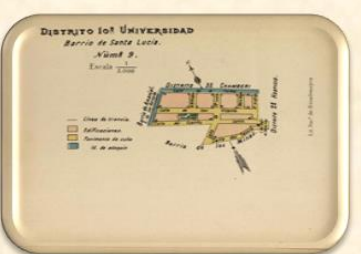

Barrio de Santa Lucía

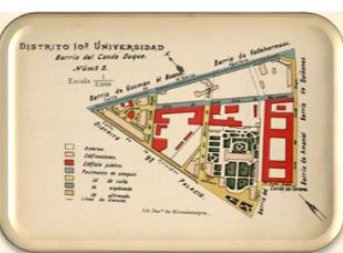

Barrio del Conde Duque

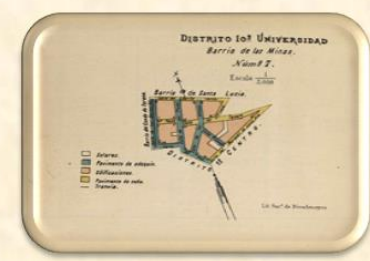

Barrio de las Minas

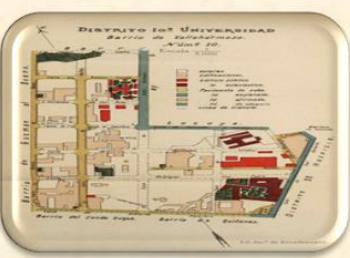

Barrio de Vallehermoso

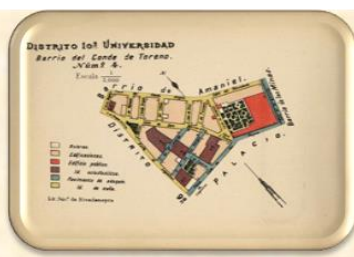

Barrio del Conde de Toreno

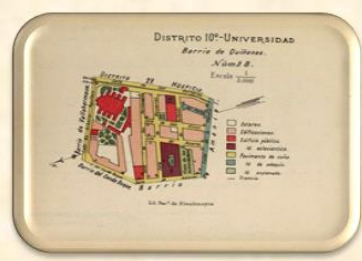

Barrio de Quiñones

Fuente: Elaboración propia. Imágenes obtenidas de (González e Iribas, 1906 


\section{Bibliografía}

Aceña, P. M., \& Comín, F. (1992). La inevitabilidad histórica de la empresa pública. Paper presented at the Economía española, cultura y sociedad: homenaje a Juan Velarde Fuertes ofrecido por la Universidad Complutense.

Aguado Marinoni, A. (1920). El estado sanitario de Madrid. España Médica, 322, 6-7.

Aguado y Aguado, G. J. (1907). Alcantarillado moderno de Madrid. La construcción moderna, $n=2,21-23$.

Aguilera y Velasco, A. (1902). Moción presentada al Excmo. Ayuntamiento por el Alcalde Presidente don Alberto Aguilera y Velasco en sesión de 8 de enero de 1902. Madrid: Imprenta Municipal.

Alary, R. (2007). Le Laboratoire central de la préfecture de police (LCPP). Environnement, Risques \& Santé, 6(4), 303-306.

Alsan, M., \& Goldin, C. (2015). Watersheds in infant mortality: The role of effective water and sewerage infrastructure, 1880 to 1915: National Bureau of Economic Research.

Alvarez-Sierra, J. (1952). Los hospitales de Madrid de ayer y de hoy (Madrid : [s.n.], 1952. ed.).

Alvaro, F. M. (1853). Consideraciones sobre la Higiene Pública y mejoras que reclama en España la Higiene Municipal.

Anderson, D. M., Charles, K. K., \& Rees, D. I. (2018). Public health efforts and the decline in urban mortality: National Bureau of Economic Research.

Antonio, T. S. J., \& Daniel, C. P. (2015). Brote de fiebre tifoidea en la Campaña de Melilla (1909).

Ayuntamiento de Madrid, M. (1916). Guía de las vías públicas de Madrid. Madrid: Imprenta Municipal.

Ayuntamiento de Madrid, M. (1917). Datos obtenidos del empadronamiento general de habitantes de 1915. Madrid: Imprenta Municipal.

Ayuntamiento de Madrid, M. (1929). Memoria : información sobre la ciudad, año 1929. Madrid.

Ayuntamiento, M. (1892a). Comentarios a las ordenanzas municipales de Madrid: Gaceta de Obras Públicas.

Ayuntamiento, M. (1892b). Ordenanzas municipales de la Villa de Madrid: Imprenta Municipal.

Bahamonde Magro, Á., \& Otero Carvajal, L. E. (1989). La sociedad madrileña durante la Restauración 1876-1931. Vol. I: población y territorio. Madrid, centro económico. Burguesía y nobleza en la Restauración (Vol. 3): Comunidad de Madrid-Alfoz-UCM.

Bailey, R. E., Hatton, T. J., \& Inwood, K. (2018). Atmospheric Pollution, Health and Height in Late Nineteenth Century Britain. Journal of Economic History, 78(4), 1210-1247.

Bando de la Alcaldía de Presidencia de 5 de octubre de 1898 sobre saneamiento e higiene de las casas de Madrid (1898).

Baquero, F., Nombela, C., Cassell, G. H., \& Fuentes, J. A. G. (2008). Evolutionary biology of bacterial and fungal pathogens: ASM press Washington, DC, USA.

Bar, M., \& Leukhina, O. (2010). Demographic transition and industrial revolution: A macroeconomic investigation. Review of Economic Dynamics, 13(2), 424-451.

Barra, F. X. (1834). Proyecto y memoria de Francisco Xavier Barra, sobre la conduccion de Aguas a Madrid, mandado imprimir con aprobacion de SM por el Excelentisimo Ayuntamiento de esta MH Villa: Impr. Real.

Barral, B. C., Trigueros, R. P., \& Albarrán, F. V. (2013). Oferta de vivienda de alquiler en Madrid del primer tercio del Siglo XX. Paper presented at the Ciudad y modernización en España y México. 
Bayona-i-Carrasco, J., \& Pujadas-i-Rúbies, I. (2014). Movilidad residencial y redistribución de la población metropolitana: los casos de Madrid y Barcelona. EURE (Santiago), 40(119), 261-287.

Beach, B., \& Hanlon, W. W. (2018). Coal smoke and mortality in an early industrial economy. The Economic Journal, 128(615), 2652-2675.

Beascoechea Gangoiti, J. M., González Portilla, M., Pedro, A., \& López, N. (2006). La ciudad contemporánea, espacio y sociedad (Vol. 28): Universidad del País Vasco, Servicio Editorial.

Bell, F., \& Millward, R. (1998). Public health expenditures and mortality in England and Wales, 1870-1914. Continuity and Change, 13(2), 221-249.

Bello Poeyusan, S. (1929). Información del Canal de Isabel II que abastece de agua a Madrid.

Bernabeu-Mestre, J. (2007). Estadística y salud pública: el argumento del método numérico. Gaceta Sanitaria, 21, 416-417.

Bernabeu-Mestre, J., Ramiro Fariñas, D., Sanz Gimeno, A., \& Robles González, E. (2003). El análisis histórico de la mortalidad por causas: problemas y soluciones.

Bernabeu Mestre, J. (1993). Expresiones diagnósticas y causas de muerte: Algunas reflexiones sobre su utilización en el análisis demográfico de la mortalidad. Revista de Demografía Histórica, 11(3), 11-22.

Borderías Mondejar, C. (2012). La reconstrucción de la actividad femenina en Cataluña circa 1920.

Bosch, A. (1885). Memoria de las medidas adoptadas para contener la invasión del cólera en 1885. Madrid: Imprenta y Litografía Municipal.

Brandis, D. (1983). El paisaje residencial en Madrid: Ministerio de Obras Públicas y Urbanismo.

Bravo Murillo, J. (1851). Presidencia del Consejo de Ministros. Gazeta de Madrid, 6185, 1-2.

Budd, W. (1873). Typhoid fever: its nature, mode of spreading, and prevention: Longmans, Green.

Cain, L., \& Rotella, E. (2001). Death and spending: Urban mortality and municipal expenditure on sanitation. Paper presented at the Annales de démographie historique.

Cairncross, S., Hunt, C., Boisson, S., Bostoen, K., Curtis, V., Fung, I. C., \& Schmidt, W.-P. (2010). Water, sanitation and hygiene for the prevention of diarrhoea. International journal of epidemiology, 39(suppl_1), i193-i205.

Campo Urbano, S. d., \& Ramírez Jerez, J. M. (2005). Académicos numerarios del Instituto de España:(1938-2004): Instituto de España.

Canal de Isabel II, C. (1856). Canal de Isabel II. Memoria sobre la situación económica de la empresa y el estado de las obras en 31 de diciembre de 1855. Madrid: Imprenta de D. Eusebio Aguado.

Canal de Isabel II. Reglamento para el servicio y distribución de las aguas del Canal del Lozoya (1873).

Canal de Isabel II. Reglamento para el servicio y distribución de las aguas del Canal del Lozoya, en los usos urbanos, domésticos e insdustriales que pueden tener lugar en Madrid (1886).

Canal de Isabel II, C. (1907). Memoria sobre el estado de los diferentes servicios en 31 de diciembre de 1904. Madrid: Imprenta de los hijos de M. G. Hernández.

Canal de Isabel II. Reglamento para el servicio y distribución de las aguas del Canal del Canal de Isabel II (1908a).

Canal de Isabel II, C. (1908b). Organización de la Inspección sanitaria de las aguas. Boletín Oficial del Canal de Isabel II, 19.

Canal de Isabel II, C. (1909). Memoria sobre el estado de los diferentes servicios en 31 de diciembre de 1908. Madrid: Imprenta municipal.

Canal de Isabel II, C. (1920). Memoria sobre el estado de los diferentes servicios en 10 de octubre de 1921. Madrid: Sucesores de Rivadeneyra.

Canalización del río Manzanares. (1906). Revista de obras públicas, 1604. 54, tomo I, 304-330. 
Cañada López, F. (1902). Guía de Madrid y pueblos colindantes. S.N: S.L.

Capel, H., \& Tatjer, M. (1991). Reforma social, serveis assistencials i higienisme a la Barcelona de final del segle XIX (1876-1900). Paper presented at the Cent anys de salut pùblica a Barcelona.

Carballo, B., Pallol, R., \& Vicente, F. (2008). El ensanche de Madrid: historia de una capital: Universidad Complutense.

Carballo Barral, B., Pallol Trigueros, R., \& Vicente, F. (2008). El ensanche de Madrid: historia de una capital: Editorial Complutense.

Carmona Hernández, A. (1966). Manual de aguas: Barcelona: Bayer.

Caselli, G. (1991). Health transition and cause-specific mortality.

Cayón García, F. (2002). Hidroeléctrica Española: un análisis de sus primeros años de actividad (1907-1936).

Ciudad, A. d. M. O. M. d. I. s. I. (1929). Memoria : información sobre la ciudad, año 1929. Madrid.

Comín, F., \& Díaz, D. (2005). Sector público administrativo y estado del bienestar. Estadísticas Históricas de España: Siglos XIX y XX, 2nd edition edn, Fundación BBVA, Bilbao, Spain, 873-964.

Corona., M. d. M. L. S. d. I. T. F. d. I. T. J. (1910a). Proyecto general de Saneamiento del subsuelo de Madrid. Informe de la Subcomisión de obras del Ayuntamiento de esta corte. . La construcción moderna, no10, 159-165.

Corona., M. d. M. L. S. d. I. T. F. d. I. T. J. (1910b). Proyecto general de Saneamiento del subsuelo de Madrid. Informe de la Subcomisión de obras del Ayuntamiento de esta corte. . La construcción moderna, no9, 143-147.

Cosculluela Montaner, L., \& Orduña Rebollo, E. (1983). Legislación de administración local: 1900-1975: Instituto de Estudios de Administración Local.

Crump, J. A., Luby, S. P., \& Mintz, E. D. (2004). The global burden of typhoid fever. Bulletin of the World Health Organization, 82, 346-353.

Cutler, D., \& Miller, G. (2005). The role of public health improvements in health advances: the twentieth-century United States. Demography, 42(1), 1-22.

Cutler, D. M., \& Miller, G. (2019). Comment on'Pubic Health Efforts and the Decline in Urban Mortality'. Available at SSRN 3312834.

Chapman, J. (2019). The contribution of infrastructure investment to Britain's urban mortality decline, 1861-1900. The Economic History Review, 72(1), 233-259.

Chicote, C. (1930). El progreso sanitario de Madrid. Paper presented at the Conferencia dada en el Museo.

Chicote, C., \& Eza, L. M. M. y. O. d. Z. (1915). La vivienda insalubre en Madrid.

Chicote del Riego, C. (1903). La cartilla del desinfector. Madrid: Imprenta Municipal. Ayuntamiento de Madrid. Laboratorio.

Chicote del Riego, C. (1907). Condiciones higiénicas del agua del Lozoya. Análisis del Dr. Chicote. Boletín Oficial del Canal de Isabel II, 4.

Chicote del Riego, C. (1916). Moderna Terapeutica Biológica: Las Vacunas y Sueros de Laboratorio Municipal. Madrid: Imprenta Municipal.

Chicote del Riego, C. (1918). Resumen de los trabajos efectuados por el laboratorio durante el año 1917 redactado por el director jefe Doctor Cesar Chicote. Madrid: Imprenta Municipal.

Chowell, G., Erkoreka, A., Viboud, C., \& Echeverri-Dávila, B. (2014). Spatial-temporal excess mortality patterns of the 1918-1919 influenza pandemic in Spain. BMC infectious diseases, 14(1), 1-12.

Davenport, R. J., Satchell, M., \& Shaw-Taylor, L. M. W. (2019). Cholera as a 'sanitary test' of British cities, 1831-1866. The History of the Family, 24(2), 404-438. doi: 10.1080/1081602X.2018.1525755

de Aguinaga, R. (1907). Boletín del Canal de Isabel II. Boletín del Canal de Isabel II, no3. 
de Aguinaga, R. (1911). Memoria sobre el estado de los diferentes servicios en 31 de diciembre de 1911. Madrid: Canal de Isabel II.

de Aguinaga, R. (1916). Las turbias del Lozoya. Revista de obras públicas, 64, tomo I (2132), 385-389.

de Looper, M. W., Booth, H., \& Baffour, B. (2019). Sanitary improvement and mortality decline in Sydney, New South Wales, 1857-1906: drinking water and dunnies as determinants. The History of the Family, 24(2), 227-248. doi: 10.1080/1081602X.2018.1550725

de Miguel, A. (1982). La población en Madrid en los primeros años del siglo. Reis: Revista Española de Investigaciones Sociológicas(19), 55-71.

De Miguel Salanova, S. (2017). La ciudad frente a la epidemia. el tifus exantemático en Madrid a principios del siglo XX. Studia Historica. Historia Contemporánea, 35, 405-444.

De Miguel Salanova, S. (2018). Mejoras alimenticias y sanitarias en la España urbana del primer tercio del siglo XX. El Laboratorio Municipal de Higiene y su contribución a la modernización sociodemográfica de Madrid. 1877-1932. In L. E. y. D. M. S. Otero Carvajal, Santiago (Ed.), La escuela y la despensa. Indicadores de modernidad. España, 1900-1936. (pp. 166-182). Madrid: La Catarata.

de Prado, C. (1858). Calidad de las aguas del Lozoya. El Mundo pintoresco, ilustración española, 13, 103.

De Smith, M. J., Goodchild, M. F., \& Longley, P. (2007). Geospatial analysis: a comprehensive guide to principles, techniques and software tools: Troubador publishing Itd.

de Zaracondegui, J. (1929). El régimen y el Canal de Isabel II : tres años y medio de gestión del comisario regio. Madrid: Diana, artes gráficas.

del Bosque González, I., García Ferrero, S., Gómez Nieto, I., Martín-Forero Morente, L., \& Ramiro Fariñas, D. (2010a). Cartografía y demografía histórica en una IDE. WMS del plano de Madrid de "Facundo Cañada". Revista Catalana de Geografia. Revista digital de geografia, cartografia i ciències de la Terra.

del Bosque González, I., García Ferrero, S., Gómez Nieto, I., Martín-Forero Morente, L., \& Ramiro Fariñas, D. (2010b). Cartografía y demografía histórica en una IDE. WMS del plano de Madrid de "Facundo Cañada".

Díaz Simón, L. (2014). El cólera de 1885 en Madrid: catástrofe sanitaria y conflicto social en la ciudad epidemiada. Paper presented at the Veinticinco años después: Avances en la Historia Social y Económica de Madrid.

Dopico, F. (1985). Desarrollo económico y social y mortalidad infantil. Diferencias regionales (1860-1950). Dynamis: Acta Hispanica ad Medicinae Scientiarumque Historiam Illustrandam, 5, 381-395.

Dopico, F., \& Reher, D. S. (1998). El declive de la mortalidad en España, 1860-1930 (Vol. 1): Asociación de Demografía Histórica.

Dribe, M., Helgertz, J., \& Van de Putte, B. (2015). Did social mobility increase during the industrialization process? A micro-level study of a transforming community in southern Sweden 1828-1968. Research in Social Stratification and Mobility, 41, 25-39.

Eberth, C. J. (1880). Die Organismen in den Organen bei Typhus abdominalis. Archiv für pathologische Anatomie und Physiologie und für klinische Medicin, 81(1), 58-74.

El Extrarradio, la extensión de Madrid y el problema del agua. Una nota explicando las causas de que no haya suficiente agua en Madrid. (1928). La Libertad, № 2588, 3.

Escario Núñez del Pino, J. L. (1931a). Proyecto de estación depuradora de las aguas residuarias de Madrid. Revista de Obras Públicas, 79. Tomo I (2569), 112-118.

Escario Núñez del Pino, J. L. (1931b). Proyecto de estación depuradora de las aguas residuarias de Madrid. Revista de Obras Públicas, 79. Tomo I (2570), 128-132.

Escario Núñez del Pino, J. L. (1931c). Proyecto de estación depuradora de las aguas residuarias de Madrid. Revista de Obras Públicas, 79. Tomo I (2571), 145-150. .

Esteve Palos, A., \& Recaño Valverde, J. (2006). (Re-) visitando García Faria: Un estudio de los factores espaciales y medioambientales de la mortalidad en la Barcelona de finales del 
siglo XIX. Revista de Demografía Histórica-Journal of Iberoamerican Population Studies, 24(1), 121-180.

Etxaniz Makazaga, J. M. (1998). Del Laboratorio Químico Municipal al Instituto Municipal de Higiene. Boletín de la Real Sociedad Bascongada de Amigos del País, 54(1).

Eugercios, B. A. R., \& Fariñas, D. R. (2016). Understanding Infant Mortality in the City: Exploring Registration and Compositional Effects. Madrid, 1905-1906 New Approaches to Death in Cities during the Health Transition (pp. 19-42): Springer.

Evans, R. J. (2005). Death in Hamburg: society and politics in the cholera years: Penguin Group USA.

Ewald, P. (1991). Waterborne transmission and the evolution of virulence among gastrointestinal bacteria. Epidemiology \& Infection, 106(1), 83-119.

Fariñas, D. R., \& Oris, M. (2016). New Approaches to Death in Cities During the Health Transition: Springer.

Fernández, A. (1989). La Sociedad Madrileña Entre 1876 Y 1931. El Cambio De Modelo Demográfico. In Á. B. M. a. L. E. O. Carvajal (Ed.), La Sociedad Madrileña Durante La Restauración (Vol. 23(4)): Alfoz.

Fernández Latorre, J. (1906). Dirección general de Obras públicas. Concediendo al Sr. Marqués de Santillana el aprovechamiento de tres metros cúbicos de agua por segundo del río Manzanares para el abastecimiento de la zona alta de Madrid. . Gazeta de Madrid, 303, 240.

Flinn, M. W. (1965). Report on the sanitary condition of the labouring population of Great Britain by Edwin Chadwick 1842: Edinburgh, Scotland: Edinburgh University Press.

Floris, J., \& Staub, K. (2019). Water, sanitation and mortality in Swiss towns in the context of urban renewal in the late nineteenth century. The History of the Family, 24(2), 249276. doi: $10.1080 / 1081602 X .2019 .1598460$

Floud, R., Fogel, R. W., Harris, B., \& Hong, S. C. (2011). The changing body: health, nutrition, and human development in the western world since 1700: Cambridge University Press.

Fogel, R. W. (2004). The escape from hunger and premature death, 1700-2100: Europe, America, and the Third World: Cambridge University Press.

Fogel, R. W., \& Lindert, P. H. (2007). 9. Nutrition and the Decline in Mortality since 1700: Some Preliminary Findings: University of Chicago Press.

Fungairiño, E. (1915). Encauzamiento y Saneamiento del río Manzanares. Revista de obras públicas, 2051, 13-19.

Fungairiño, E. (1919). Encauzamiento y Saneamiento del río Manzanares. Revista de obras públicas, 67, tomo I (2268), 121-127.

Gaffky, G. (1884). Zur Aetiologie des abdominaltyphus: Mittheilungen aus dem kaiserlichen Gesundheitsamtes. Reichsgesundheitsamt, Berlin.

Galiana, M., \& Bernabeu-Mestre, J. (2006). El problema sanitario de España: saneamiento y medio rural en los primeros decenios del siglo XX. Asclepio, 58(2), 139-164.

Gallardo Albarrán, D. G. (2018). Sanitary infrastructures and the decline of mortality in Germany, 1877-1913.

Gallego Anabitarte, A., Menéndez Rexach, Á., \& Díaz Lema, J. M. (1986). El derecho de aguas en España. Madrid: mopu, 1.

García Abad, R., Pareja Alonso, A., \& Zarraga Sangroniz, K. (2007). ¿ Sabes leer?,¿ Sabes escribir?: El proceso de alfabetización en el País Vasco (1860-1930). Revista de Demografía Histórica, 25(1), 23-58.

García Agustín, J. (1971). EL CANAL DE ISABEL II EN LOS ULTIMOS VEINTE AÑOS, Y ESPECIALMENTE, EN EL ULTIMO QUINQUENIO. Revista de obras públicas, 249-270.

García Ferrero, S. (2018). La gripe de 1889-1890 en Madrid. Universidad Complutense de Madrid, Madrid. 
García Revenga, J. (1933). Organización y resumen de los trabajos realizados durante el año 1932 redactado por el director interino Juan García Revenga. Madrid: Artes gráficas municipales.

Garrido Lopera, J. M. (1973). El servicio público de abastecimiento de agua a poblaciones: Instituto de Estudios de Administración Local.

Gómez de Membrillera, F. (1920). Saneamiento e higienización de España. Revista de Obras Públicas, 68, tomo I (2337), 329-333.

Gómez de Membrillera, F. (1921). El problema sanitario de España. Sarriá, J. Viñals editor.

Gómez Mendoza, A. (1986). La industria de la construcción residencial: Madrid, 1820/1935. Moneda y crédito(177), 53-81.

González Besada, A. (1907). Reglamento del Canal de Isabel II. Revista de obras públicas, 55, tomo II (1655), 239-242.

González e Iribas, A. (1906). Guía práctica de Madrid. Madrid: R. Velasco.

González e Iribas, A. (1907). Guía práctica de Madrid con arreglo a la nueva división administrativa y judicial. 2a edición. . Madrid: R. Velasco.

González Reglero, J. (2008). 1907, el Canal de Isabel II vuelve a ser empresa. Paper presented at the IX Congreso Asociación Española de Historia Económica.

González Reglero, J. J. (2002). Los inicios de la preocupación por la calidad de las aguas de abastecimiento y por la depuración de las aguas residuales en el Canal de Isabel II. I Congreso de Ingeniería Civil, Territorio y Medio Ambiente.

González Reglero, J. J. (2014). El sistema de agua elevada del Canal de Isabel II: 1907-1911. Tst: Transportes, Servicios y telecomunicaciones(26), 12-35.

González Reglero, J. J., \& Pernaute Monreal, C. (2017). El ingeniero Luis Justo y Villanueva: su relación con Tarragona. Paper presented at the XXXIV Jornadas Técnicas de AEAS.

Gorostiza, J. L. R. (2014). Edwin Chadwick, el movimiento británico de salud pública y el higienismo español. Revista de historia industrial(55), 11-38.

Grael, G. (1909). Cooperativa eléctrica de Madrid. El Financiero Hispano-Americano, Madrid, $n$ ㅇ43, 891-892.

Guillem-Llobat, X., \& Perdiguero-Gil, E. (2014). Control de la calidad de los alimentos y urban penalty: a propósito del caso valenciano (1881-1915). Historia Social, 113-131.

Harris, B. (2004). Public health, nutrition, and the decline of mortality: The McKeown thesis revisited. Social history of medicine, 17(3), 379-407.

Harris, B., Floud, R., \& Hong, S. C. (2015). How many calories? Food availability in England and Wales in the eighteenth and nineteenth centuries Research in economic history: Emerald Group Publishing Limited.

Harris, B., \& Helgertz, J. (2019). Urban sanitation and the decline of mortality. The History of the Family, 24(2), 207-226. doi: 10.1080/1081602X.2019.1605923

Harris, B., \& Hinde, A. (2019). Sanitary investment and the decline of urban mortality in England and Wales, 1817-1914. The History of the Family, 24(2), 339-376. doi: 10.1080/1081602X.2018.1556722

Hassan, J. A. (1985). The growth and impact of the British water industry in the nineteenth century. Economic History Review, 531-547.

Hauser, P. (1902a). Madrid bajo el punto de vista médico-social (Vol. 1).

Hauser, P. (1902b). Madrid bajo el punto de vista médico-social (Vol. 2).

Helgertz, J., \& Önnerfors, M. (2019). Public water and sewerage investments and the urban mortality decline in Sweden 1875-1930. The History of the Family, 24(2), 307-338. doi: 10.1080/1081602X.2018.1558411

Herrán Rucabado, E., \& Escario Núñez del Pino, J. L. (1926). Problemas sanitarios: purificación de aguas negras. Revista de Obras Públicas, 74. Tomo I (2445), 39-46.

Hinde, A., \& Harris, B. (2019). Mortality decline by cause in urban and rural England and Wales, 1851-1910. The History of the Family, 24(2), 377-403. doi: 10.1080/1081602X.2019.1598463 
Honeyman, K., \& Goodman, J. (1991). Women's work, gender conflict, and labour markets in Europe, 1500-1900. Economic History Review, 608-628.

Hubbard, W. H. (2000). The urban penalty: towns and mortality in nineteenth-century Norway. Continuity and Change, 15(2), 331-350.

Huertas, R. (2002). Vivir y morir en Madrid: la vivienda como factor determinante del estado de salud de la población madrileña (1874-1923). Asclepio, 54(2), 253-276.

Informaciones Municipales. (1924). ABC, 10.

Informaciones Municipales. Las obras del subsuelo. (1925). ABC, 13.

J.L.U. (1927). Proyecto de municipalización del Canal de Isabel II. Revista de obras públicas, 75, tomo I (2482), 298.

Jaadla, H., \& Puur, A. (2016). The impact of water supply and sanitation on infant mortality: Individual-level evidence from Tartu, Estonia, 1897-1900. Population Studies, 70(2), 163-179.

Jalvo, M. (1906). Saneamiento y regularización del río Manzanares en Madrid. Complemento

al Plan General de obras hidráulicas del Excmo. Sr. Marqués de Santillana. Madrid.

Juderías, J. (1909). Los Hombres inferiores:estudios a cerca del pauperismo en los grandes centros de población.

Kearns, G. (1988). The urban penalty and the population history of England.

Kesztenbaum, L., \& Rosenthal, J.-L. (2014). Income versus sanitation; mortality decline in Paris, 1880-1914.

Kesztenbaum, L., \& Rosenthal, J.-L. (2017). Sewers' diffusion and the decline of mortality: The case of Paris, 1880-1914. Journal of Urban Economics, 98, 174-186.

La recogida de los golfos. (1905). Nuevo Mundo, Año XIII. Número 600.

Lambert, P. S., Zijdeman, R. L., Van Leeuwen, M. H., Maas, I., \& Prandy, K. (2013). The construction of HISCAM: A stratification scale based on social interactions for historical comparative research. Historical methods: a journal of quantitative and interdisciplinary history, 46(2), 77-89.

Lee, R. (2003). The demographic transition: three centuries of fundamental change. The journal of economic perspectives, 17(4), 167-190.

Leeuwen, M., Maas, I., \& Miles, A. (2002). HISCO: Historical international standard classification of occupations: Leuven: Leuven University Press.

León Peralta, A. B. R., José (1926). Escasez, carestía e higiene de la vivienda en Madrid. Madrid.

Lopez Baeza, A. (1931). La utilidad que ofrecería la reparación y saneamiento de los viajes antiguos. El Sol, Aüo XV. Núm. 4.430, 3.

Madrid, A. d. (1911). Concurso celebrado para la adjudicación de las obras de Saneamiento del subsuelo de Madrid. Imprenta Municial.

Madrid, A. d. (1912). Concurso para las obras del Proyecto General de Saneamiento del subsuelo de Madrid. Bases del Concurso y Pliego de Condiciones. Madrid: Imprenta municipal.

Madrid, A. d. (1925). Boletín Oficial de la Provincia de Madrid, 2.

Madrid, sediento. De día poca agua y de noche ninguna. (1924). La Voz. Madrid, Año V. Núm. $1.345,3$.

Magrinyà, F. (2009). El ensanche y la reforma de Ildefons Cerdà como instrumento urbanístico de referencia en la modernización urbana de Barcelona. Scripta Nova: revista electrónica de geografía y ciencias sociales.

Maluquer de Motes i Berner, J. (1983). La despatrimonialización del agua: movilización de un recurso natural fundamental. Revista de Historia Económica / Journal of Iberian and Latin American Economic History, Volume 1(Issue 2 ), 79-96.

Martín-Retortillo Baquer, S. (1960). La elaboración de la ley de aguas de 1866. Revista de administración pública(32), 11-54. 
Martín, I. C. (2012). Cien años de análisis de las aguas mineromedicinales. Paper presented at the Anales de Hidrología Médica.

Martín Salazar, M. (1913). La sanidad en España. Discursos leídos ante la Real Academia de Medicina en la recepción pública del Ilmo. Sr. Doctor... el día, 8.

Martínez, F. J. M., Garcia, C. I. G., \& Susarte, A. M. H. (2016). Evolución histórica de la higiene corporal: desde la edad antigua a las sociedades modernas actuales. Cultura de los cuidados: Revista de enfermería y humanidades(46), 11.

Martínez Vargas, A. (1921). Las epidemias tíficas y el teorema de Hazen. España Médica, 374, 1-5.

Matés Barco, J. M. (2017). El servicio público de abastecimiento de agua en España (siglos XIX y $\mathrm{XX)}$ : El proceso de acumulación de competencias de los ayuntamientos. Revista Brasileira de História \& Ciências Sociais, 9(18), 36-57.

McKeown, T. (1976). The rise of modern population. Edward Arnold, London.

Mckeown, T., Brown, R., \& Record, R. (1972). An interpretation of the modern rise of population in Europe. Population Studies, 26(3), 345-382.

Mckeown, T., \& Record, R. (1962). Reasons for the decline of mortality in England and Wales during the nineteenth century. Population Studies, 16(2), 94-122.

Melgosa Olaechea, M. (1912). Las subsistencias en Madrid. Madrid, Imprenta Municipal.

Miller, A. R. (1980). Work, Jobs, and Occupations: A Critical Review of the" Dictionary of Occupational Titles.": ERIC.

Real Orden de 13 de julio de 1901 sobre saneamiento de Edificios Públicos y de uso público (1901).

Moral Jimeno, M. F. (2011). Manuel Corral y Mairá (1862-1926). Semblanza de un médicohumanista en el Linares de principios del siglo XX. Siete esquinas(3), 7-14.

Moreno Blasco, B. (1933). Algunos aspectos de las epidemias tíficas, el teorema de Hazem y la profilaxis de las mismas. Burgos: Imprenta Aldecoa.

Morer Abril, J. (1855a). Canal de Isabel II: Memoria del anteproyecto de la distribución. Revista de Obras Públicas, 3, tomo I (13), 146-150.

Morer Abril, J. (1855b). Canal de Isabel II: Memoria del anteproyecto de la distribución. Revista de Obras Públicas, 3, tomo I (14), 157-160.

Novales Sáinz, S. d. (1895). Purificación y aprovechamiento de las aguas fecales de Madrid. Madrid.

Núñez Granés, P. (1909). Vías Públicas del Interior, Ensanche y Extrarradio, Memoria relativa a los trabajos efectuados en dichas vías en los años 1906,1907 y 1908, con indicación de lo que precisa hacer para mejorar su pavimentación. Madrid: Imprenta Municipal.

Núñez Granés, P. (1910). Proyecto para la urbanización del Extrarradio. Ayuntamiento de Madrid.

Núñez Granés, P. (1914). Urbanización del extrarradio. Inaplazable necesidad de realizar dicha mejora urbana; forma de llevarla a cabo y beneficios que se obtendrán con su ejecución. . Imprenta Municipal. Ayuntamiento de Madrid.

Ocaña, E. R. (2005). Salud pública en España: ciencia, profesión y política, siglos XVIII-XX: Universidad de Granada.

Ogasawara, K., \& Inoue, T. (2015). Public health improvements and mortality in early twentieth-century Japan. Tokyo: Tokyo Institute of Technology.

Oller, N., Benaul Berenguer, J. M., \& Sudrià Triay, C. (2003). Atlas de la industrialización de España (1750-2000): Fundacion BBVA/BBVA Foundation.

Omran, A. R. (2005). The epidemiologic transition: a theory of the epidemiology of population change. The Milbank Quarterly, 83(4), 731-757.

Otero Carvajal, L. E. (2016). La sociedad urbana y la irrupción de la Modernidad en España, 1900-1936. Cuadernos de Historia Contemporánea, 38, 255.

Otero Carvajal, L. E., \& Pallol Trigueros, R. (2009). El Madrid moderno, capital de una España urbana en transformación, 1860-1931. Historia contemporánea(39). 
Otero Carvajal, L. E., \& Rodríguez Martín, N. (2019). infraestructuras urbanas y modernidad. madrid, nuevas necesidades y nuevos servicios de una metrópoLi moderna, 19001936.

Palanca, J. A., \& Martínez-Fortún, N. M. (1929). El problema de la fiebre tifoidea en España: Real Academia Nac. Medicina.

Pallol Trigueros, R. (2015). Las clases medias madrileñas en el primer tercio del siglo XX: un retrato socioprofesional. Paper presented at the Las nuevas clases medias urbanas: transformación y cambio social en España, 1900-1936.

Palloni, A., Milesi, C., White, R. G., \& Turner, A. (2009). Early childhood health, reproduction of economic inequalities and the persistence of health and mortality differentials. Social Science \& Medicine, 68(9), 1574-1582.

Papagrigorakis, M. J., Yapijakis, C., Synodinos, P. N., \& Baziotopoulou-Valavani, E. (2006). DNA examination of ancient dental pulp incriminates typhoid fever as a probable cause of the Plague of Athens. International Journal of Infectious Diseases, 10(3), 206-214.

Pareja Alonso, A. (2018). La actividad laboral y productiva de las mujeres bilbaínas en 1900. Una propuesta metodológica para su recuperación. Vasconia. Cuadernos de HistoriaGeografía(35).

Pascua, M. (1934). La mortalidad infantil en España: Departamento de Estadísticas sanitarias de la Dirección General de Sanidad.

Paz Maroto, J. (1945). Alcantarillado de Madrid. Revista de obras públicas.

Peltola, J., \& Saaritsa, S. (2019). Later, smaller, better? Water infrastructure and infant mortality in Finnish cities and towns, 1870-1938. The History of the Family, 24(2), 277306. doi: 10.1080/1081602X.2019.1598462

Pérez Moreda, V., Reher, D., \& Sanz Gimeno, A. (2015). La conquista de la salud. Mortalidad y modernización en la España contemporánea. Madrid: Marcial Pons.

Pfeiffer, R., \& Kolle, W. (1896). Experimentelle Untersuchungen zur Frage der Schutzimpfung des Menschen gegen typhus abdominalis. DMW-Deutsche Medizinische Wochenschrift, 22(46), 735-737.

Phillips, J., \& Smith, D. F. (2013). Food, science, policy and regulation in the twentieth century: international and comparative perspectives: Routledge.

Pinto Crespo, V. d., Labrador Arroyo, F., \& Gili Ruiz, R. (2010). Los viajes de agua de Madrid durante el Antiguo Régimen. . Madrid: Fundación Canal.

Pinto Crespo, V. G. R., Rafael; Velasco Medina, Fernando. (2015). Historia del saneamiento de Madrid. Madrid: Fundación Canal. Canal de Isabel II.

Porras Gallo, M. I. (1994). La lucha contra las enfermedades" evitables" en España y la pandemia de la gripe de 1918-19. Dynamis: Acta Hispanica ad Medicinae Scientiarumque Historiam Illustrandam, 14, 159-183.

Porras Gallo, M. I. (1997). El Laboratorio Municipal de Madrid y la epidemia de gripe de 191819. Paper presented at the Anales del Instituto de Estudios Madrileños.

Porras Gallo, M. I. (2002). Un acercamiento a la situación higiénico-sanitaria de los distritos de Madrid en el tránsito del siglo XIX al XX. Asclepio, 54(1), 219-250.

Porras Gallo, M. I. (2002). Una ciudad en crisis: la epidemia de gripe de 1918-1919 en Madrid: Universidad Complutense de Madrid, Servicio de Publicaciones.

Preston, S. H., \& Van de Walle, E. (1978). Urban French mortality in the nineteenth century. Population Studies, 32(2), 275-297.

Puerto Sarmiento, F. J., \& Cobo Cobo, J. (1983). El Laboratorio Municipal de Madrid en el último tercio del siglo XIX. Dynamis: Acta Hispanica ad Medicinae Scientiarumque. Historiam Illustrandam, 3, 149-172.

Pujadas-Mora, J.-M., Marín, J. R., \& Villar, C. (2014). Propuestas metodológicas para la aplicación de HISCO en el caso de Cataluña, siglos XV-XX. Revista de Demografía Histórica-Journal of Iberoamerican Population Studies, 32(1), 181-220.

Pulido Fernández, A. (1902). Saneamiento de poblaciones españolas: Sevilla. 
Rafo, J., \& Rivera, J. (1848). Memoria sobre la conducción de aguas a Madrid. . Madrid: Imprenta Nacional.

Ramiro-Fariñas, D., \& Sanz-Gimeno, A. (2000). Structural changes in childhood mortality in Spain, 1860-1990. International Journal of Population Geography, 6(1), 61-82.

Ramiro, D., Garcia, S., Casado, Y., Cilek, L., \& Chowell, G. (2018). Age-specific excess mortality patterns and transmissibility during the 1889-1890 influenza pandemic in Madrid, Spain. Annals of epidemiology, 28(5), 267-272.

Ramiro Fariñas, D. (2007). Mortality in hospitals and mortality in the city in the nineteenth-and twentieth century Spain: The effect on the measurement of urban mortality rates of the mortality outsiders in urban health institutions. The impact of hospitals, 300-2000.

Ramiro Fariñas, D., Sanz Gimeno, A., Bernabeu Mestre, J., \& Robles González, E. (2002). De expresiones diagnósticas a causas de muerte: Una propuesta metodológica para el análisis de la mortalidad. España: Instituto de Economía y Geografía, CSIC. Serie Cuadernos de Trabajo.

Ramiro Fariñas, D. a. A. S. G. (2002). La caída de la mortalidad en la infancia en la España interior, 1860-1960. Un análisis de las causas de muerte. Cuadernos de Historia Contemporánea, 24, 151-188.

Ramiro Fariñas, D. y. A. S. G. (1997). Estructuras internas de la mortalidad de la infancia (0-4 años) en la España del siglo XX. Política y sociedad, 26, 125-142.

Ramsey-Kurz, H. (2007). The Non-Literate Other: Readings of Illiteracy in Twentieth-Century Novels in English (Vol. 171): Rodopi.

Real decreto de 22 de Diciembre de 1908, regulando el servicio de inspección de sustancias alimenticias y bebidas. (1909). Victoriano Giral Sastre.

Reher, D. S. (2001). In search of the 'urban penalty': exploring urban and rural mortality patterns in Spain during the demographic transition. Population, Space and Place, 7(2), 105-127.

Reher, D. S., Lobo, A. V., \& Sestafe, J. V. G. (1995). Fuentes de información demográfica en España (Vol. 13): CIS.

Revenga, R. (1904). La muerte en España: estudio estadístico sobre la mortalidad: Prensa de Madrid.

Revuelta, B. (2011). Los usos de la inclusa de Madrid, mortalidad y retorno a principios del siglo XX (1890-1935): Tesis Doctoral. Universidad Complutense de Madrid. España.

Revuelta Eugercios, B. A. (2011). Los usos de la Inclusa de Madrid, mortalidad y retorno a principios del siglo XX (1890-1935). Tese de doutoramento, Universidad Complutense de Madrid, Faculdad de Geografía e Historia, Departamento de Historia Contemporánea, Madrid.

Revuelta Eugercios, B. A., \& Ramiro Fariñas, D. (2016). Understanding infant mortality in the city: Exploring registration and compositional effects. Madrid, 1905-1906 New approaches to death in cities during the health transition (pp. 19-42): Springer.

Rincón Lazcano, J. (2001). Historia de los monumentos de la Villa de Madrid: Asociación de Libreros de Lance de Madrid.

Ringrose, D. R. (1985). Madrid y la economía española, 1560-1850: ciudad, corte y país en el antiguo régimen: Alianza editorial.

RODRÍGUEZ-OCAÑA, E., \& Bernabeu-Mestre, J. (1997). Physicians and statisticians: two ways of creating demographic health statistics in Spain, 1841-1936. Continuity and Change, 12(2), 247-264.

Rodríguez Martín, N. (2013). La capital de un sueño: Madrid 1900-1936: la formación de una metrópoli europea. Universidad Complutense de Madrid.

Rodríguez Ocaña, E. (1994). La salud pública en España en el contexto europeo, 1890-1925. Revista de sanidad e higiene pública(gráf), 11-27. 
Rodríguez Ocaña, E. (2001). La salud pública en la España de la primera mitad del siglo XX. In J. A. F. a. J. M. Perez (Ed.), El centro secundario de Higiene Rural de Talavera de la Reina y la Sanidad española de su tiempo. (pp. 215-233): Comunidades de Castilla La Mancha.

Rubio, M. V. (1978). Ciudad y acción municipal, la política de vivienda del Ayuntamiento de Madrid (1868-1978). Paper presented at the Anales del Instituto de Estudios Madrileños.

Rueda Laffond, J. C. (1994). El agua en Madrid: Datos para la historia del Canal de Isabel II, 1851-1930: Fundación Empresa Pública.

Rueda Laffond, J. C. (1998). Madrid en torno a 1898: información y gestión urbana (higienismo y reforma municipal). Historia y comunicación social(3), 177-194.

Rueda Laffond, J. C. (2002). Madrid, 1900; proyectos de reforma y debate sobre la ciudad; 1898-1914.

Sallaberry, J. L., Sánchez, P. A., Lorite, J., \& Cáscales, J. G. (1924). Plan general de extensión de Madrid y su distribución en zonas: Ampliación y modificaciones a establecer en el proyecto para urbanización del Extrarradio. Arquitectura: órgano de la Sociedad Central de Arquitectos(58), 44-69.

Sánchez de Toca, J. (1908). Canal de Isabe II. Informes y documentos relativos a las operaciones del emprésito : emprésito de veinte millones de pesetas en cédulas garantizadas, conforme al Real Decreto acordado en Consejo de Ministros, en 20 de diciembre de 1907. Canal de Isabe II, 120.

Sánchez de Toca, J. (1925). Juicios del Señor Sánchez de Toca. Revista de obras públicas, 73, tomo I (2420), 20-23.

Sánchez Moreno, R. (1933). Notas para un estudio económico de Canales del Lozoya. Revista de Obras Públicas, 81. Tomo I (2634), 511-516.

Saneamiento de edificios públicos. Real orden de 13 de julio de 1901 (1901).

Sanz Gimeno, A. (1999). La mortalidad de la infancia en Madrid. Cambios DemográficosSanitarios en los siglos XIX y XX. Madrid: Edita Dirección General de Salud Pública. Consejería de Sanidad y Servicios Sociales.

Sanz Gimeno, A. (2001). Infancia, mortalidad y causas de muerte en España en el primer tercio del siglo XX (1906-1932). Reis, 129-154.

Scrimshaw, N. S., \& SanGiovanni, J. P. (1997). Synergism of nutrition, infection, and immunity: an overview. The American journal of clinical nutrition, 66(2), 464S-477S.

Schofield, R., \& Reher, D. (1991). The decline of mortality in Europe.

Sebastián, M.-R. (1960). La elaboración de la ley de aguas de 1866. Revista de administración pública(32), 11-54.

Sedgwick, W. T., \& MacNutt, J. S. (1910). On the Mills-Reincke phenomenon and Hazen's theorem concerning the decrease in mortality from diseases other than typhoid fever following the purification of public water-supplies. The Journal of Infectious Diseases, 489-564.

Szreter, S. (1988). The importance of social intervention in Britain's mortality decline c. 18501914: a re-interpretation of the role of public health. Social history of medicine, 1(1), 138.

Tatjer, M. (2006). La industria en Barcelona (1832-1992). Factores de localización y transformación en las áreas fabriles: del centro histórico a la región metropolitana. Scripta Nova: revista electrónica de geografía y ciencias sociales.

Toro Mérida, J., \& Bahamonde Magro, Á. (1980). El fraude alimentario en el Madrid del siglo XiX: estudio preliminar. Estudios de historia social(15), 285-296.

Treiman, D. J. (2013). Occupational prestige in comparative perspective: Elsevier.

Troesken, W. (2004). Water, race, and disease: MIT Press.

Tuñon De Lara, M. (2000). La España del siglo XX (3 volúmenes) (Vol. 45): Ediciones Akal.

Úbeda y Correal, J. (1898). Manual de análisis y purificación de las aguas potables. Madrid. 
Úbeda y Correal, J. (1900). Estudio higiénico de las aguas de que se sirve Madrid y procedimientos domésticos de purificación de estas aguas: cartilla premiada en el concurso público de 1900 (XII Concurso de premios). Biblioteca Nacional de España, Madrid.

Van de Putte, B., \& Miles, A. (2005). A social classification scheme for historical occupational data: partner selection and industrialism in Belgium and England, 1800-1918. Historical Methods, 38(2), 61.

Van Leeuwen, M. H., \& Maas, I. (2005). A short note on HISCLASS. History of Work Information System.

Vera y López, V. d. (1885). Laboratorios municipales de salubridad: F. Maroto e hijos.

Whipple, G. C. (1908). Typhoid fever: J. Wiley \& sons.

Wohl, A. S. (1983). Endangered lives: public health in Victorian Britain: JM Dent and Sons Ltd.

Woods, R. (2003). Urban-Rural Mortality Differentials: An Unresolved Debate. Population and development review, 29(1), 29-46.

Wright, A. (1896). On the assocociation of serous haemorrhages with conditions of defective blood-coagulability. The Lancet, 148(3812), 807-809. 
